\title{
Hydrological, Geological, and Biological Site Characterization of Breccia Pipe Uranium Deposits in Northern Arizona
}
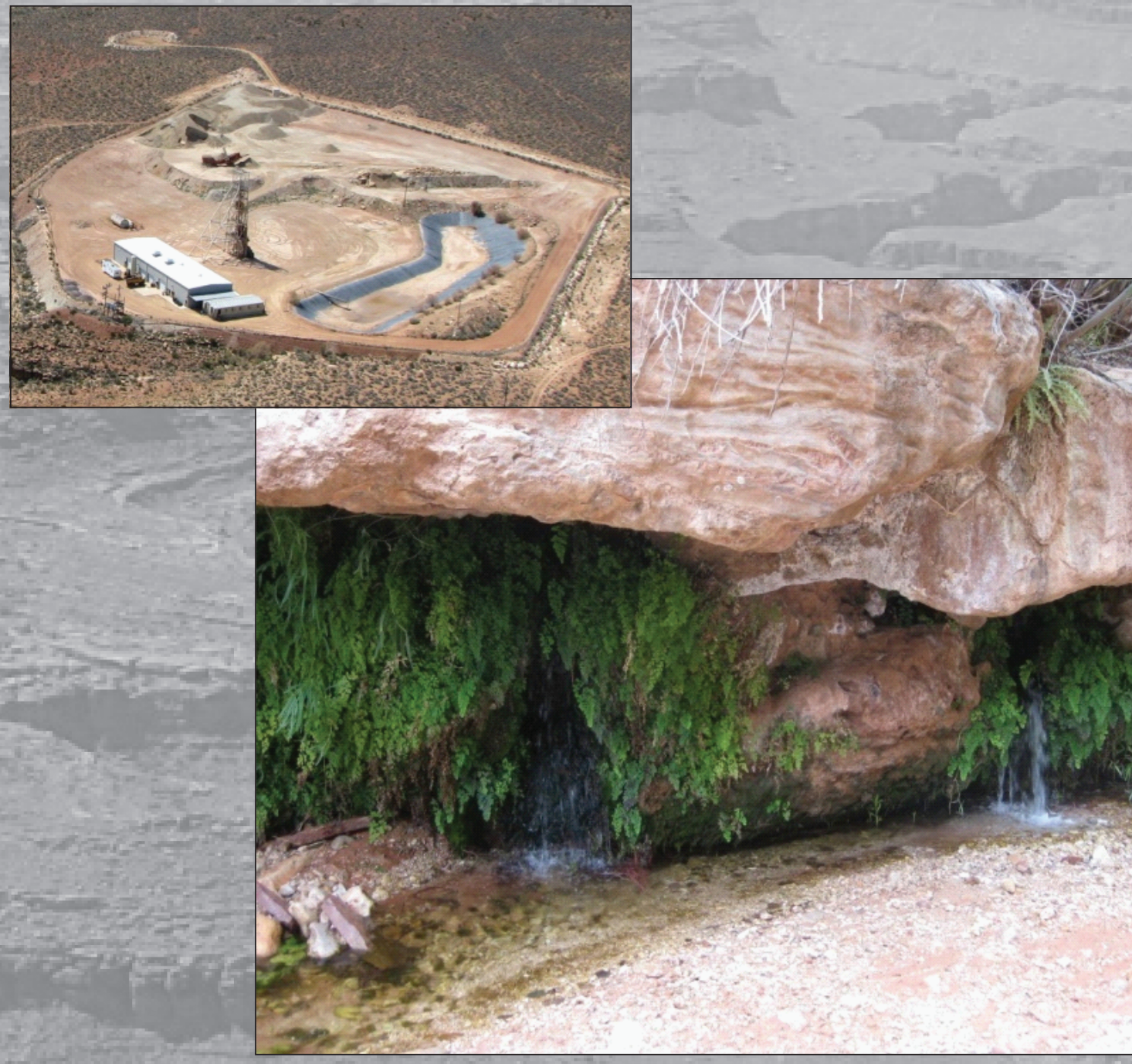

Scientific Investigations Report 2010 -5025

U.S. Department of the Interior U.S. Geological Survey

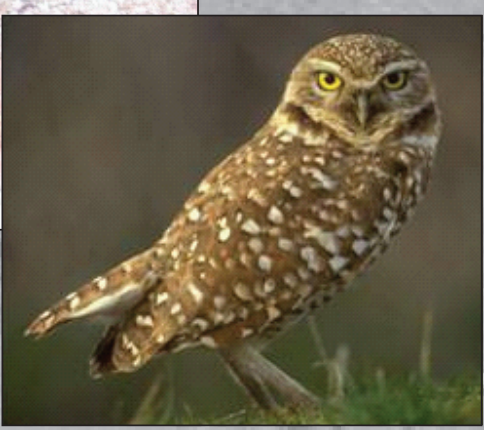

प्र 


\section{Hydrological, Geological, and Biological Site Characterization of Breccia Pipe Uranium Deposits in Northern Arizona}

By Andrea E. Alpine, editor

Scientific Investigations Report 2010-5025 


\section{U.S. Department of the Interior \\ KEN SALAZAR, Secretary \\ U.S. Geological Survey \\ Marcia K. McNutt, Director}

\section{U.S. Geological Survey, Reston, Virginia: 2010}

For more information on the USGS - the Federal source for science about the Earth, its natural and living resources, natural hazards, and the environment, visit http://www.usgs.gov or call 1-888-ASK-USGS

For an overview of USGS information products, including maps, imagery, and publications, visit http://www.usgs.gov/pubprod

To order this and other USGS information products, visit http://store.usgs.gov

Any use of trade, product, or firm names is for descriptive purposes only and does not imply endorsement by the U.S. Government.

Although this report is in the public domain, permission must be secured from the individual copyright owners to reproduce any copyrighted materials contained within this report.

Plate and maps:

Private inholdings may exist in National or State reservations. Not all boundaries have been placed on the maps due to limitations of scale and complexity of land ownership and status. Segregation area boundaries are current as of October 2009. Segregation area boundaries are approximate.

Suggested citation:

Alpine, Andrea E., ed., 2010, Hydrological, geological, and biological site characterization of breccia pipe uranium deposits in northern Arizona: U.S. Geological Survey Scientific Investigations Report 2010-5025, 354 p., 1 pl., scale 1:375,000 


\section{Contents}

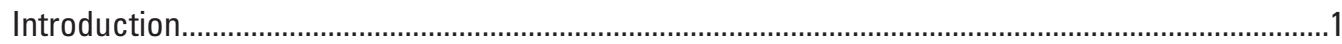

By Andrea E. Alpine and Kristin M. Brown

A. Uranium Resource Availability in Breccia Pipes in Northern Arizona ...................................19

By James K. Otton and Bradley S. Van Gosen

B. Effects of 1980s Uranium Mining in the Kanab Creek Area of Northern Arizona .................... 43

By James K. Otton, Tanya J. Gallegos, Bradley S. Van Gosen, Robert A. Zielinski, Ray H. Johnson, Susan M. Hall, L. Rick Arnold, and Douglas B. Yager

C. Historical and 2009 Water Chemistry of Wells, Perennial and Intermittent

Streams, and Springs in Northern Arizona...

By Donald J. Bills, Fred D Tillman, David W. Anning,

Ronald C. Antweiler, and Thomas F. Kraemer

D. Biological Pathways of Exposure and Ecotoxicity Values for Uranium

and Associated Radionuclides .283

By Jo Ellen Hinck, Greg Linder, Susan Finger, Edward Little,

Donald Tillitt, and Wendy Kuhne

\section{Plate}

[In pocket]

1. Map Showing Geologic Structure, Cultural and Geographic Features, and Geologic Cross Sections of Northwestern Arizona

By Kristin M. Brown and George H. Billingsley 



\section{Introduction}

By Andrea E. Alpine and Kristin M. Brown

Introduction to

Hydrological, Geological, and Biological Site Characterization

of Breccia Pipe Uranium Deposits in Northern Arizona

Edited by Andrea E. Alpine

Scientific Investigations Report 2010-5025

U.S. Department of the Interior

U.S. Geological Survey 


\section{Contents}

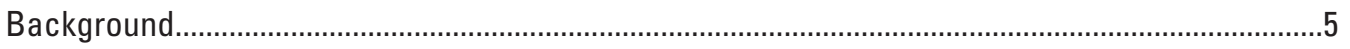

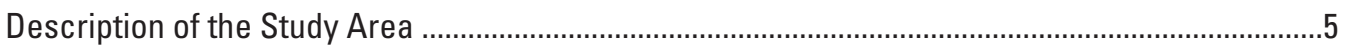

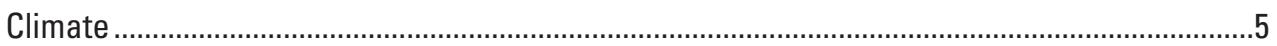

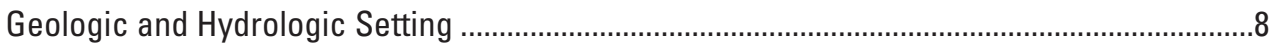

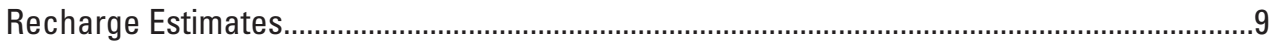

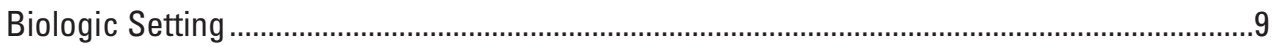

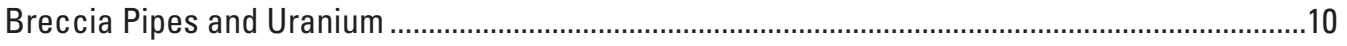

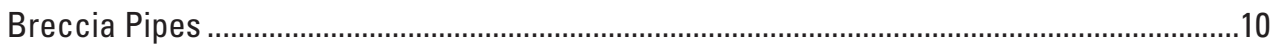

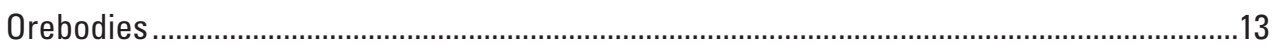

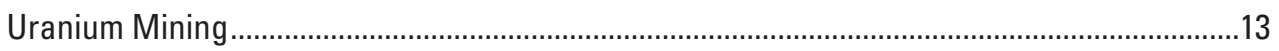

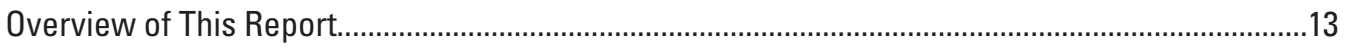

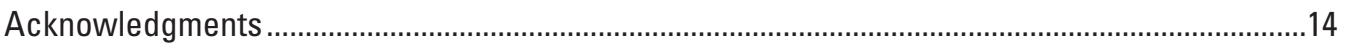

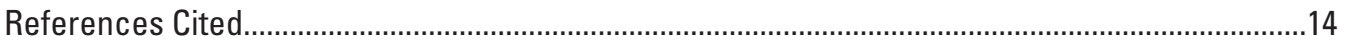

Appendix 1. Scientific Names of Plant and Animal Species Included in the Text........................17

\section{Plate}

[In pocket]

1. Map Showing Geologic Structure, Cultural and Geographic Features, and Geologic Cross Sections of Northwestern Arizona

\section{Figures}

1. Map showing study area, segregation areas, and land ownership...................................

2. Map showing mean annual average precipitation and evaporation for

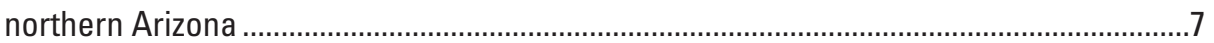

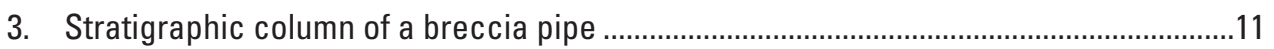

4. Photo showing an exposed breccia pipe column in the Grand Canyon area ..................12

5. Photo showing the surface expression of a collapse structure......................................12 


\section{Conversion Factors}

Inch/Pound to SI

\begin{tabular}{lcl}
\hline Multiply & By & To obtain \\
\hline inch (in.) & Length & \\
inch (in.) & 2.54 & centimeter $(\mathrm{cm})$ \\
foot (ft) & 25.4 & millimeter $(\mathrm{mm})$ \\
\hline \multicolumn{3}{c}{ meter $(\mathrm{m})$} \\
\hline acre & 0.3048 & Area \\
\hline mile per hour (mi/h) & 4,047 & square meter $\left(\mathrm{m}^{2}\right)$ \\
\hline & Flow rate \\
\hline pound, avoirdupois (lb) & 1.609 \\
ton, short $(2,000 \mathrm{lb})$ & Mass & kilometer per hour $(\mathrm{km} / \mathrm{h})$ \\
\hline
\end{tabular}

Temperature in degrees Celsius $\left({ }^{\circ} \mathrm{C}\right)$ may be converted to degrees Fahrenheit $\left({ }^{\circ} \mathrm{F}\right)$ as follows:

${ }^{\circ} \mathrm{F}=\left(1.8 \mathrm{x}^{\circ} \mathrm{C}\right)+32$

Temperature in degrees Fahrenheit $\left({ }^{\circ} \mathrm{F}\right)$ may be converted to degrees Celsius $\left({ }^{\circ} \mathrm{C}\right)$ as follows:

${ }^{\circ} \mathrm{C}=\left({ }^{\circ} \mathrm{F}-32\right) / 1.8$ 



\title{
Introduction
}

\author{
By Andrea E. Alpine and Kristin M. Brown
}

\section{Background}

In the late 1940 s and early $1950 \mathrm{~s}$, uranium was discovered in association with many of the old copper mines in the Grand Canyon region, hosted by geologic features called breccia pipes. Discovery of high-grade uranium ore in the Orphan Lode (breccia pipe) deposit led to uranium mining on patented claims within the Grand Canyon National Park from 1956 to 1969 (plate 1). In the 1970s, breccia pipes became the subject of intense exploration in the Grand Canyon region, sought for their uranium ore potential; several were found exposed in the plateaus and the walls of the Grand Canyon and its tributaries. In the 1980s and early 1990s, uranium was mined from seven breccia pipes in the northern Grand Canyon region. Today, some of the highest grade uranium ore in this country is believed to be located in the many mineralized breccia pipes scattered across the Grand Canyon region.

On July 21, 2009, U.S. Secretary of the Interior Ken Salazar proposed a two-year withdrawal of about 1 million acres of Federal land near the Grand Canyon from future mineral entry. These lands are contained in three parcels: two parcels on Bureau of Land Management (BLM) land to the north of the Grand Canyon (North and East Segregation Areas) and one on the Kaibab National Forest south of the Grand Canyon (South Segregation Area) (fig. 1). The purpose of the two-year withdrawal is to examine the potential effects of restricting these areas from new mine development for the next 20 years, "to protect the Grand Canyon watershed from adverse effects of locatable mineral exploration and mining, except for those effects stemming from valid existing rights" (U.S. Bureau of Land Management, 2009, p. 43152). Dissolved uranium and other major, minor, and trace elements occur naturally in groundwater as the result of precipitation infiltrating from the surface to water-bearing zones and, presumably, to underlying regional aquifers. Discharges from these aquifers occur as seeps and springs throughout the region and provide valuable habitat and water sources for plants and animals. Uranium mining within the watershed may increase the amount of radioactive materials and heavy metals in the surface water and groundwater flowing into Grand Canyon National Park and the Colorado River, and deep mining activities may increase mobilization of uranium through the rock strata into the aquifers. In addition, waste rock and ore from mined areas may be transported away from the mines by wind and runoff.

This proposed withdrawal initiated a period of study during which the effects of the withdrawal must be evaluated. At the direction of the Secretary, the U.S. Geological Survey (USGS) began a series of short-term studies designed to develop additional information about the possible effects of uranium mining on the natural resources of the region. These studies include:

1. Estimation of the amount of uranium resources within the proposed withdrawal areas and previously withdrawn areas,

2. Investigation of the effects of the 1980s uranium mine development and extraction operations to determine if mining operations affected local environments,

3. Examination of whether these previous operations were detrimental to the water quality of surface water and groundwater and estimation of the potential effect of future mining operations,

4. Compilation of the available toxicological information on exposure pathways and biological effects of uranium and associated decay products relevant to species occurring in the region, and

5. Completion of a geologic map of the House Rock Valley area (East Segregation Area), Coconino County, Ariz., providing detailed strata and structural information (published separately as SIM 3108 [Billingsley and Priest, 2010]).

\section{Description of the Study Area}

The study area is larger than the proposed withdrawal areas and is bounded on the north by the Arizona-Utah border, on the south by Valle, Ariz., on the east by Lees Ferry, and on the west by Iceberg Canyon at Lake Mead (fig. 1). The Secretary of Interior's proposed withdrawal area includes three segregation areas north, east, and south of the Colorado River and encompasses about 1 million acres of BLM, National Forest, State, and private lands; all are contained within the study area (fig. 1).

\section{Climate}

The climate of northern Arizona is semiarid to arid with spatial and temporal extremes of temperature and precipitation. The broad range of climate is strongly correlated with altitude resulting in moderate summers and severe winters at higher altitudes and intense summer heat and mild winters at lower altitudes (fig. 2). Microclimates are common to northern Arizona, especially along the Colorado River and at high elevation uplands, as the slope and exposure of mountains and 


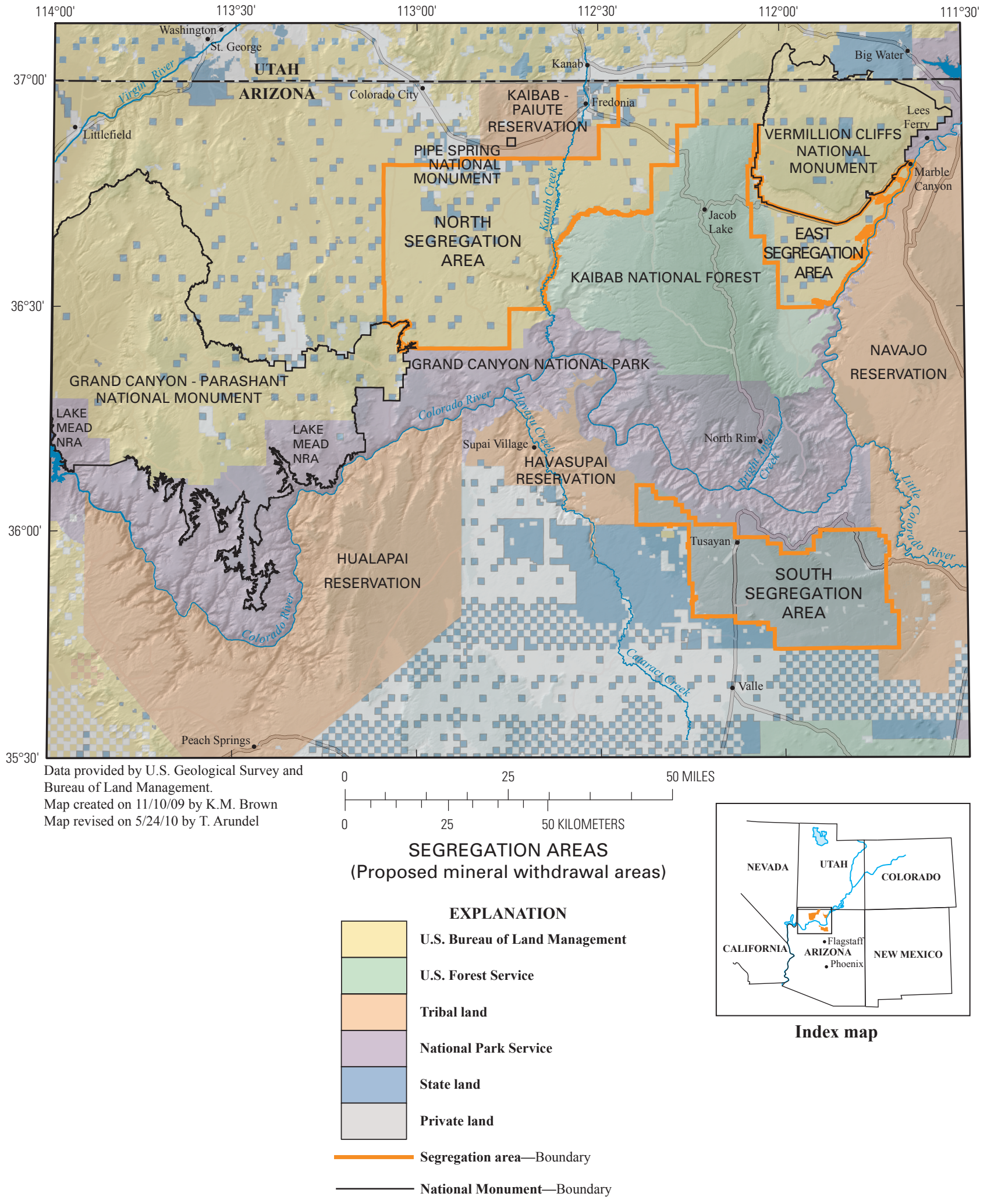

Figure 1. Map showing study area, segregation areas, and land ownership. NRA, National Recreation Area. 


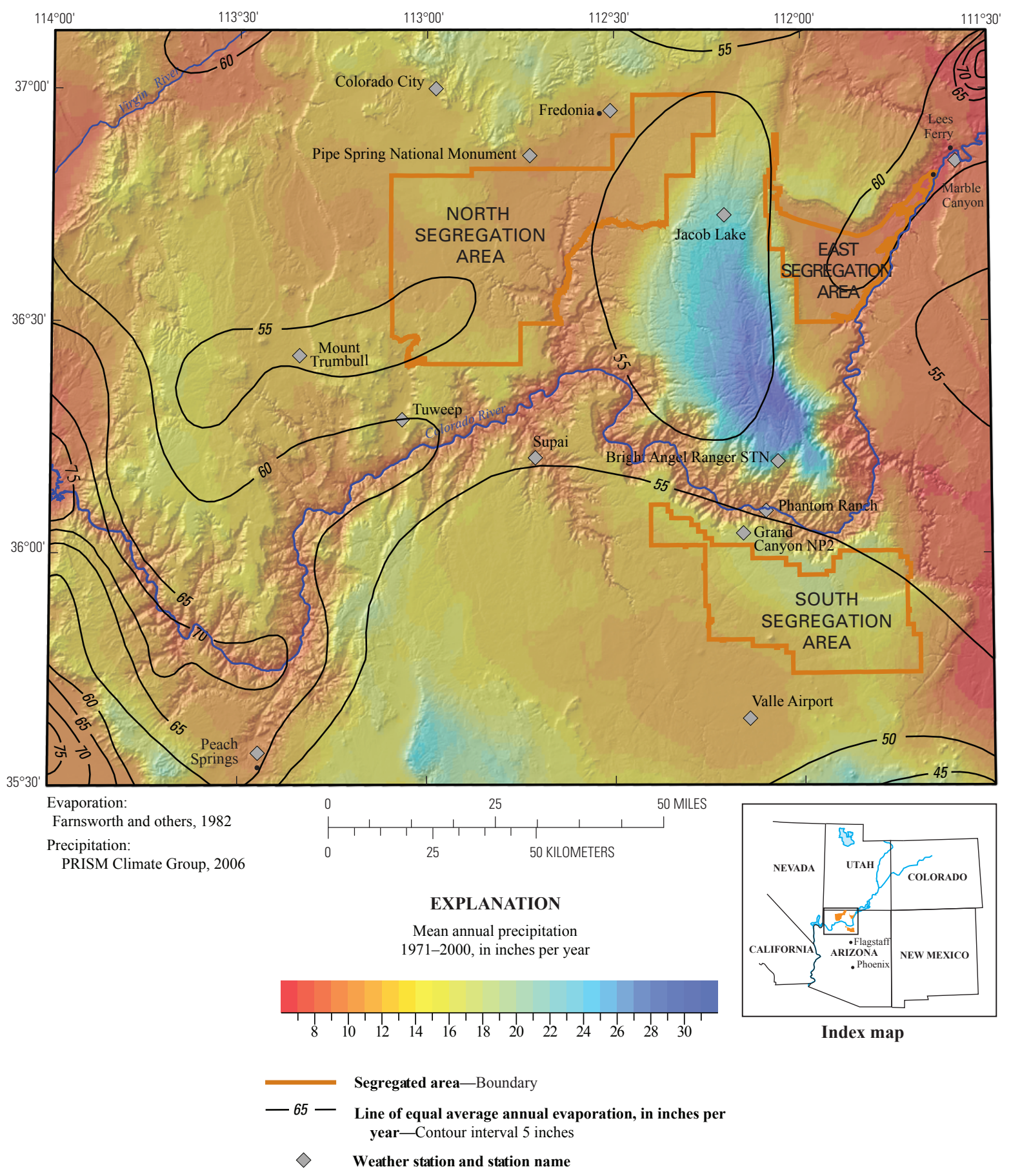

Figure 2. Map showing mean annual average precipitation and evaporation for northern Arizona. 
deep canyons control circulating air masses and the amount of solar radiation that reaches land surface. Average annual evaporation rates are large, more than 20 times the average annual precipitation for much of the area (fig. 2), creating a net annual water deficit for most of northern Arizona. However, water is available on the landscape because most of the precipitation falls in the winter months when evaporation processes are at their lowest.

Winter storms (those occurring from October through April) provide about 60 percent of precipitation to the study area, with summer storms providing about 40 percent (Western Regional Climate Center, 2004). This bimodal precipitation pattern is characteristic of Arizona. The winter and summer wet periods have different effects on the occurrence and availability of water in northern Arizona. In winter, large storm systems that originate in the Pacific Ocean pass over the state bringing rain and heavy snows to higher altitudes and less frequent rain and snow to lower altitudes. Deep snow accumulations in the mountains and on the Kaibab anticline can result in significant spring runoff to lower elevations. Because of low evapotranspiration in winter, a greater portion of winter precipitation is available for runoff and infiltration than summer precipitation. Summer rainfall is controlled by moistureladen air masses that move into Arizona from the Gulf of Mexico and the Gulf of California. In middle to late summer, regionally called the monsoon season, the orographic effect of the high altitude areas of northern Arizona results in frequent, intense, short-duration thunderstorms. The amount of precipitation derived from these thunderstorms is sporadic both spatially and temporally, but intense downpours can produce flash flooding and debris flows. The high summer temperatures also result in evaporation far in excess of precipitation. The ratio of annual evaporation to precipitation is about 2:1 at higher altitudes on the Kaibab anticline and mountains to the south. It ranges from about $6: 1$ at lower altitudes in western and northwestern parts of northern Arizona to more than 8:1 in eastern and northeastern parts of northern Arizona.

The average annual temperature ranges from about $60^{\circ} \mathrm{F}$ on the rim of the Grand Canyon to about $80^{\circ} \mathrm{F}$ at the canyon's bottom (Western Regional Climate Center, 2004), with average annual temperatures about $5^{\circ} \mathrm{F}$ lower on the higher North Rim. Winter extremes of subzero temperatures can occur in deep canyons and the plateaus to the east and west but are more common at higher altitude areas of the Kaibab anticline. Summer temperatures commonly exceed $100^{\circ} \mathrm{F}$ on the east and west plateau north of the Colorado River and reach $110-120^{\circ} \mathrm{F}$ in the inner canyons.

Average annual precipitation ranges from 6 in along the river in the eastern edge of the area to 21 in at Jacob Lake on the Kaibab anticline and 16 in at the South Rim of the Grand Canyon. Some of the largest precipitation events north of the Colorado River have occurred as local summer thunderstorms (Webb, 2002). Extreme runoff events are most often driven by rain-on-snow during the early and late winter. The maximum annual precipitation was recorded at the Bright Angel Ranger Station at the North Rim of the Grand Canyon at 45 in (fig. 2).
Over 60 percent of that total fell as snow in the winter months. As with areas to the north of the Colorado River, precipitation south of the Colorado River is strongly correlated with altitude. Generally less than $15 \mathrm{in} / \mathrm{yr}$ fall on higher altitude areas and $10 \mathrm{in} / \mathrm{yr}$ or less fall on the lower elevation plateaus and inner canyon areas; more than $25 \mathrm{in} / \mathrm{yr}$ fall on elevations above 7,000 ft (fig. 2) (Bills and others, 2007). In general, climate south of the Colorado River is more arid owing to the generally lower elevations.

Data from the National Weather Station (NWS) at Flagstaff, Ariz., show that the prevailing wind direction is bimodal from the south-southwest for February to September and from the north-northwest for October to January (http://www.wrcc.dri.edu/ summary/lcd.html, accessed December 2009). The average annual wind speed is $6.4 \mathrm{mph}$ and varies little from month to month. The Grand Canyon National Park Airport reports similar trends (http://www.wrcc.dri.edu/htmlfiles/westwind.final.html, accessed December 2009). None of the NWS sites north of the Colorado River consistently reports wind speed and direction, but extreme weather data reported by the U.S. Forest Service and NWS in support of fire condition reports suggest that wind patterns are similar in this area (http://www.spc.noaa.gov/products/ fire_wx/, accessed December 2009).

\section{Geologic and Hydrologic Setting}

The study area is located within the southwest portion of the Colorado Plateau, a unique physiographic province roughly centered on the Four Corners region of the southwestern United States (plate 1). This portion of the Colorado Plateau is characterized by nearly flat lying sedimentary rock layers that are exposed in canyons and by a series of high plateaus (Bues and Morales, 2003); the highest plateau in the study area is the Kaibab Plateau north of the Colorado River between the North and East Segregation Areas. The study area has seven major structural trends that significantly affect the regional geology and hydrology. The western part of the study area has several north-south trending major faults: the Grandwash fault on the west, the Dellenbaugh fault, the Hurricane fault, and the Toroweap fault with offsets down to the west (plate 1). The structural features dominating the eastern portion of the study area are the Kaibab anticline (bordered on the east by the East Kaibab monocline, distinguished by east-dipping sedimentary rocks responding to movement of reactivated basement faults), the Mesa Butte fault, and the Havasu-Cataract Basin south of the Colorado River, northeast and northwest trending with westerly dips. Tectonic features such as faults, folds, fractures, and dip angles of sedimentary layers affect the subsurface groundwater flow.

The primary hydrologic feature found in the study area is the Colorado River that flows from the northeast end of the study area winding westward into Lake Mead (plate 1). The flow of the Colorado River today is primarily controlled by the operation of Glen Canyon Dam and is supplemented with unregulated surface flows from tributaries draining higher 
elevations of the Grand Canyon region. Elevations north of the Colorado River reach over 9,200 ft on the Kaibab Plateau; the high elevations and steep gradient of streams facilitate rapid surface runoff with high sediment loads toward the Colorado River. Elevations south of the Colorado River reach over 7,000 ft along the South Rim of the Grand Canyon. The south-sloping topography of this area causes surface water to flow away from the South Rim; it is eventually captured by the larger north-flowing drainages of the Little Colorado River and Cataract Canyon and returned to the Colorado River. The Little Colorado River also drains the surface flows southeast of the Grand Canyon into the Colorado River in the eastern Grand Canyon (plate 1).

Springs located throughout the study area support some of the most diverse habitat on this part of the Colorado Plateau and are a critical source of water for humans, fish, and wildlife. Geologic structures such as joints, fractures, faults, folds, and bedding planes control and direct groundwater movement toward spring discharge areas. Fine-grained sedimentary rocks, such as the Hermit Formation and the lower part of the Supai Group, can prevent the downward movement of groundwater, resulting in locally perched water-bearing zones. Perched water-bearing zones can occur from several hundred to more than 2,000 feet above the underlying regional aquifers. Fractures and faults in the fine-grained rock units provide pathways for vertical movement of groundwater from the perched water-bearing zones deeper into the subsurface. Dissolution of the Redwall and Muav Limestones from groundwater flow through joints and fractures causes caves, caverns, and solution channels to form within these rock layers. The collapse of some of these caves and caverns over time has led to the formation of breccia pipes, some of which host uranium ore deposits. Many of the seeps and springs in the Grand Canyon region emerge from the base of these rock layers. Joints and fractures associated with the caves and solution channels in these rock layers provide pathways that preferentially direct groundwater flow to these discharge areas.

\section{Recharge Estimates}

Water migrating from the surface to the subsurface is an important transport mechanism for the remobilization of trace and radiochemical elements. Since most of the orebodies associated with breccia pipes are located several hundred to more than $1,000 \mathrm{ft}$ above the regional groundwater flow systems of northern Arizona, natural recharge of water from the surface through these orebodies is one of the few ways of naturally adding to the radiochemistry of the regional groundwater flow systems. Estimated recharge potential for the Desert Southwest has been determined based on temporal and spatial variations in precipitation, air temperature, root zone and soil properties and thickness, faults and fractures, and hydrologic properties of geologic strata in the unsaturated

${ }^{1}$ See appendix 1 of the Introduction for a list of scientific names. zone (Flint and others, 2004; Flint and Flint, 2007). The most significant recharge potential occurs on the Kaibab anticline with significant secondary areas of recharge occurring along the South Rim and at areas of structural weakness through the northern Arizona area. Breccia pipes in these areas would have the greatest potential for remobilization of radiochemical elements found in the subsurface.

\section{Biologic Setting}

Habitats in the Grand Canyon and its environs support a diverse flora and fauna including culturally significant, threatened, and endangered species. Three main ecosystems occur in the study area: Great Basin grassland, Great Basin woodland, and Great Basin desert scrubland (Brown and Lowe, 1982; Olson and others, 2001). High elevation areas of the Kaibab anticline are a mix of Rocky Mountain subalpine conifer forest, montane conifer forest, and subalpine grassland. The canyon lands in the region consist almost entirely of Mohave desert scrub with isolated areas of riparian habitat that support most of the species diversity in the region (Brown and Lowe, 1982; Olson and others, 2001; Grand Canyon Wildlands Council, 2004). Vegetation has a significant effect on the occurrence and flow of water both on the surface and in the subsurface. Plants can intercept and store precipitation and thus delay and (or) prevent overland flow that would lead to runoff. They also transpire moisture that has seeped into the soil and deeper root zones as it becomes available and before it has an opportunity to seep deeper into the subsurface to become part of a groundwater flow system.

In general, the ecosystems and habitats of this area are primarily influenced by precipitation, slope, and elevation. Elevations below about 4,900 ft generally support sparse sagebrush and other desert bushes, grasses, and cactus. Elevations between 4,900 and 6,900 ft support thicker brush and grasslands transitioning into pinyon pine, ${ }^{1}$ juniper, and Gambel oak stands on hills and higher elevation areas. While most of these vegetation types require little water, they exist primarily in fracture zones and depressions where water accumulates. Elevations above $6,900 \mathrm{ft}$ are dominated by dense ponderosa pine forest and smaller stands of aspen, firs, spruce, and juniper. Native hardwoods can be found in riparian areas of drainages and include cottonwood, oak, willow, and ash. These species have always been excellent markers on the landscape for locations of water sources. Invasive species such as tamarisk, Russian olive, and Siberian elm have come to dominate and crowd out native species in some drainages and riparian areas where water is available. Land management practices have affected both the vegetation coverage diversity and geomorphic characteristics of drainages north of the Grand Canyon since the early 20th century, changing runoff and recharge patterns (Webb and others, 1991).

In the study area, desert grassland is found on northfacing slopes within the Grand Canyon but is rare, whereas intermediate grassland found at a higher elevation is more 
common in the study area, specifically in the western Grand Canyon, as well as on the North Rim in the Arizona Strip area. Typical animal species in these grasslands include herbivorous rodents, insects, elk, mule deer, and antelope and predatory golden eagles, red-tail hawks, and coyotes.

Shrubland is characterized by open areas where shrubs are dominant or co-dominant with grasses (Brown and Lowe, 1982). Unique steppe habitat on the Colorado Plateau includes low desert bajadas, slope failure fans, bedrock canyons and fans on the Arizona Strip, inner canyon terraces, Marble and Coconino Plateau steppe habitats, riparian terraces, and chaparral vegetation on steep slopes (Nabhan, 2002). Common plant species in shrubland include banana yucca and snakeweed at high elevations, blackbush and mormon tea at middle elevations, creosotebush and white bursage at low elevations, and snakeweed, rabbitbrush, and big sagebrush in the plateau. Ants, prairie dogs, gophers, raptors, and coyotes are common fauna in the shrublands.

Desert woodland is distinct depending on elevation, with mesquite, catclaw, and netleaf hackberry along stream channels at low elevations. Intermediate woodland is dominated by the pinyon pine, juniper, rabbitbrush, and sagebrush throughout the study area at middle elevations.

Predominant species in the ponderosa pine forest include squirrels, mule deer, and elk. Goshawk and Mexican spotted owls can be found nesting in the ponderosa pine and higher elevation forest. Other common vertebrates found in desert woodland include raccoon, skunk, long-tailed weasel, raven, and several species of owls and other birds (jays, nuthatches, chickadees, warblers, woodpeckers, etc.) Old growth ponderosa pine forest is found in the North Kaibab National Forest and can be identified by yellowed bark and large red-yellow bark plates.

The barrenland ecosystem has been identified as a unique habitat characterized by bare bedrock or soil common of the badlands, canyon country, and alpine habitats (Grand Canyon Wildlands Council, 2004). Barrenland ecosystems are abundant within the segregation areas and are typified by cactus and sparse desert bushes or grasses. Common cliff dwelling vertebrates of the barrenlands include chuckwallas, a variety of other lizards, canyon wrens, raptors, ravens, and swallows.

Areas of riparian habitat occur within each of the above areas around lakes, ponds, springs, seeps, streams, and rivers. These riparian habitats have exceptional biodiversity and are critical for the plants and animals that live in the area. Several springs have National significance and are linked to important components of Native American culture. Many of the springs originate in water-bearing zones in the Redwall and Muav Limestones and flow into canyons of the greater Grand Canyon area. These spring habitats support a species diversity that is 100 to 500 times greater than that of the surrounding landscape (Grand Canyon Wildlands Council, 2004). Common vegetation includes monkey flower, redbud, willow, cottonwood, and maidenhair fern. Spring habitats can also host frogs and invertebrates, such as the endangered Kanab ambersnail. Many bird species, both native and migratory, nest and feed along riparian areas of the Colorado River. Common birds found in the Colorado River riparian zone include finches, hummingbird, swifts, swallows, warblers, phoebe, flycatchers, and wrens. Predatory birds include the great blue heron, red-tail hawk, osprey, kestrel, Peregrine falcon, raven, golden eagle, and bald eagle. Other common vertebrate fauna found along the Colorado River include snakes, lizards, frogs, salamanders, rodents, ringtail cat, skunk, coyote, and fox. Raccoons, bobcat, mountain lion, bats, mule deer, and bighorn sheep occur but are rarer in the riparian corridor of the Colorado River. Multiple species of fish utilize the flowing water of the Colorado River. Current fish populations are dominated by introduced species including carp, rainbow trout, brown trout, and catfish. Native species including bluehead suckers and flannelmouth suckers, speckled dace, and the endangered humpback chub are still present, but many are listed as Federal or State species of concern (Grand Canyon Wildlands Council, 2004). Invertebrates are important components to the aquatic food chain of the Colorado River. Descriptions of important species in the mainstem have been documented (for example, Blinn and Cole, 1991; Stevens and others, 1997, 1998). However, aquatic invertebrates in the tributary streams of the Grand Canyon region have not been studied to the same extent (Oberlin and others, 1999).

Mining activity can result in changes to these habitats that may increase exposure of the biological resources to chemical elements including uranium, radium, and other radioactive decay products. Uranium and other radionuclides can affect the survival, growth, and reproduction of plants and animals. The identification of biological pathways of exposure and the compilation of the chemical and radiological hazards for these radionuclides are important for understanding potential effects of uranium mining on the northern Arizona ecosystem.

\section{Breccia Pipes and Uranium}

\section{Breccia Pipes}

The uranium deposits of northwestern Arizona are hosted by geologic features described as "solution-collapse breccia pipes," or simply "breccia pipes." The features, formed by solution and collapse, are named for their vertical, pipe-like shape and the broken rock, or breccia, that fills them (fig. 3). Breccia pipes generally form through a sequence of steps: (1) dissolution and karst (cave) development in the Redwall Limestone rock unit; (2) collapse of the cavern ceiling (which forms the broken rock rubble); and (3) progressive collapse moving upward into overlying formations through time, forming a broken rock or rubble-filled column. The region surrounding the Grand Canyon hosts hundreds, possibly thousands, of breccia pipes, some of which contain concentrated deposits of uranium, copper, silver, lead, zinc, cobalt, and nickel minerals (Wenrich, 1985; Wenrich and others, 1989; Finch and others, 1992). Exploration in the region has shown 


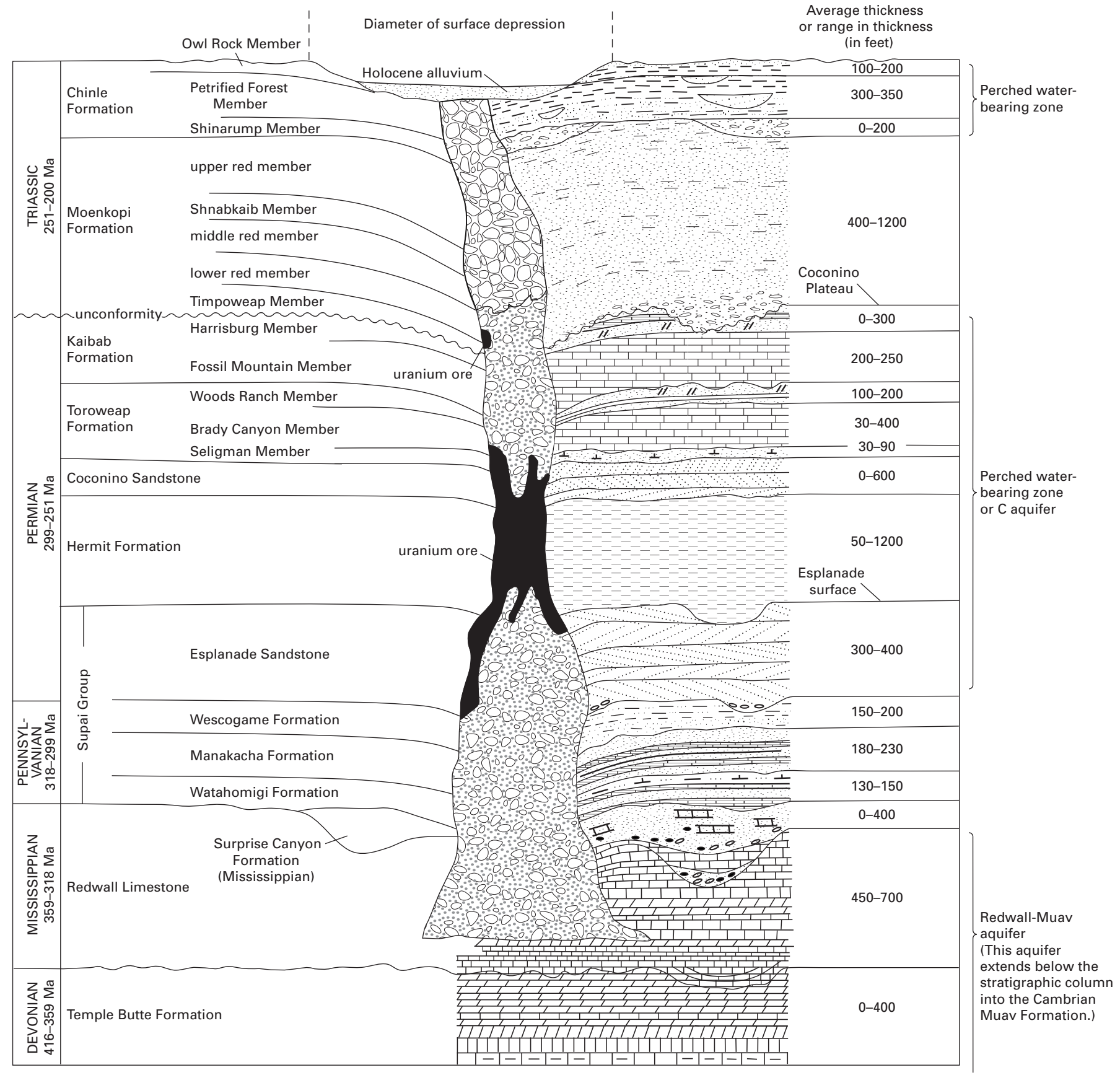

Figure 3. Stratigraphic column of a breccia pipe showing relation of breccia pipe to surrounding rock, orebodies, and perched waterbearing zones and aquifers. 
that a small percentage of the identified breccia pipes do contain an economic uranium deposit. The USGS has mapped more than 1,200 possible solution-collapse breccia pipes in the northern Arizona region.

Breccia pipes have not been observed in rock units younger than about 200 million years old (Triassic age). The breccia fragments that form the pipes are consistently blocks and pieces of rock units found below their normal position in the wall rock; that is, all rocks within the breccia column (pipe) have fallen downward and are never found above their original level. In contrast to many other types of breccia pipes, no igneous rocks are associated with the northern Arizona breccia pipes and no igneous processes have contributed to their formation.

The pipe-shaped structures average about 300 feet in diameter and can vertically extend from the Redwall Limestone to the Chinle Formation. Because the thickness of the host sedimentary strata varies across the Grand Canyon region, the depth to an orebody within a breccia pipe varies from area to area. The upper part of the uranium orebody in breccia pipes often occurs within the horizon of the Coconino Sandstone or the Hermit Formation, with the ore often extending down into the Esplanade Sandstone (fig. 3). The three segregated areas are located in the central and eastern areas of the Grand Canyon region, which are mostly capped by the Kaibab Formation. Thus, the uranium orebody in a breccia pipe within the three areas is typically $900-1,000 \mathrm{ft}$ (or more) below the plateau surface (capped by the Kaibab Formation).

Some breccia pipes are exposed in the canyon walls within the Grand Canyon and its tributaries (fig. 4), but because they are exposed to erosion and weathering processes, much of the uranium ore material has dissipated. Although no single exposure in the Grand Canyon region exposes an entire breccia pipe from bottom to top, exposures of many hundreds of feet appear at several locations and encompass various stratigraphic formations. These exposures illustrate that an individual breccia pipe can cover a vertical range of at least $3,000 \mathrm{ft}$, from the Redwall Limestone through the Chinle Formation.

The breccia pipe column abuts against sedimentary rocks. The plane of contact between the breccia column and the surrounding flat-lying rock is formed by a zone of concentric, circular, near vertical fractures ("ring fractures") and inward-dipping strata. The mineral deposits, including uranium, occur in the fracture zone and in the brecciated column; the mineral deposits do not generally extend into the surrounding sedimentary wall rocks. An orebody, if present, is typically located several hundred to more than a thousand feet $(150-350 \mathrm{~m})$ above the regional water table in brecciated sandstones and siltstones in the pipes. It is possible, however, that a number of orebodies may be in contact with perched groundwater above the Redwall-Muav aquifer.

While the breccia pipe column is typically only a few hundred feet in diameter, its expression on the plateau surface is often a shallow structural basin (fig. 5) that can be as much as a half mile in diameter. Some pipes form a prominent circular depression with inward-dipping strata (Wenrich and Sutphin, 1988), but others are difficult to decipher and show little surface

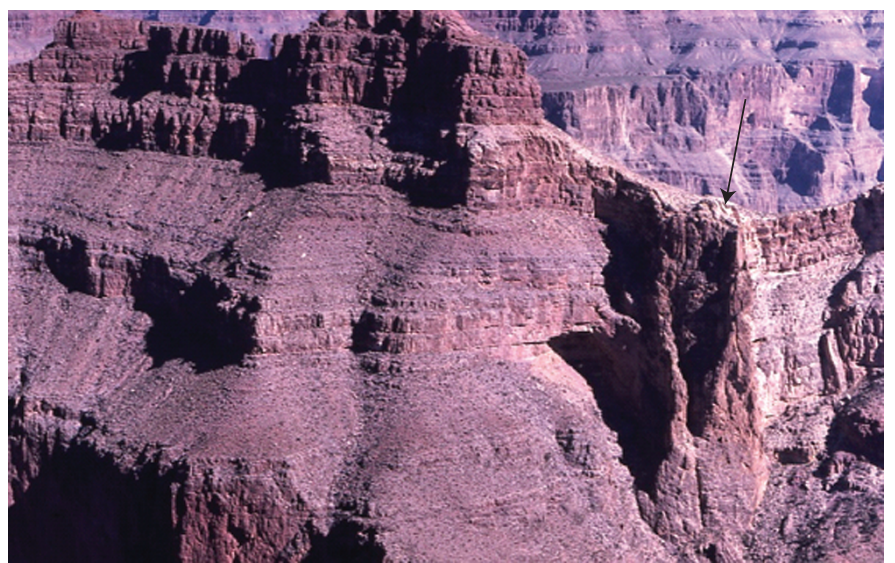

Figure 4. Photo showing an exposed breccia pipe column (indicated by arrow) in the Grand Canyon area. Note the bending of strata toward the breccia pipe. (Photo by George Billingsley, U.S. Geological Survey.)

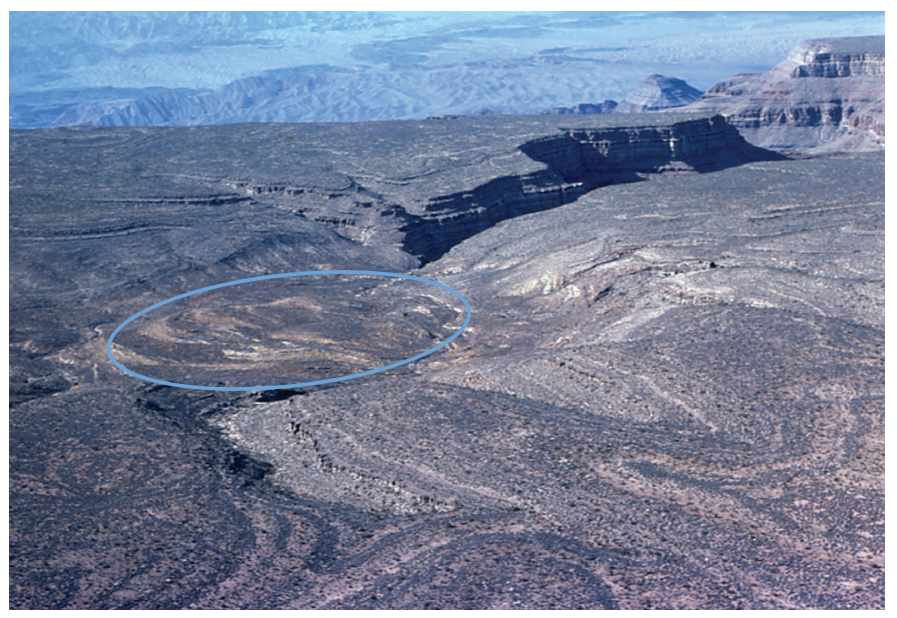

Figure 5. Photo showing the surface expression of a collapse structure, specifically the Grand Pipe in the western Grand Canyon near the Colorado River and Grand Wash Cliffs. The structure measures approximately 2,500 feet in diameter. Note circular inward dipping strata with no breccia exposed at the center. (Photo by George Billingsley, U.S. Geological Survey.)

expression on the plateau surface. Buried, "blind" breccia pipes also exist; these pipes have their roots in the Redwall Limestone and do not extend to the plateau surface. Some geophysical techniques, such as airborne vertical time-domain electromagnetic surveys (Spiering, 2009), have shown promise in locating buried breccia pipes, which have then become potential drilling targets. Once geologic, geochemical, and (or) geophysical indicators suggest that a breccia pipe structure exists at a site, exploratory drilling is conducted to test for uranium deposits at depth. At this time, because the uranium deposits occur deep inside the pipe, usually several hundred feet below the plateau surface, only drilling and sampling of the drilled material can determine if a collapse feature is mineralized at depth. 


\section{Orebodies}

Most of the uranium deposits in the northern Arizona breccia pipes are high grade by U.S. standards. Breccia pipe deposits in this region that were mined or thoroughly drilled during the 1980s revealed average grades of 0.42 to 1.08 percent uranium oxide $\left(\mathrm{U}_{3} \mathrm{O}_{8}\right)$ (Pool and Ross, 2007; Moreton and Ross, 2009) in ore bodies containing about 430,000 pounds to 7 million pounds $\mathrm{U}_{3} \mathrm{O}_{8}$. From breccia pipes of this region, combined uranium production has totaled 23.3 million pounds of ore (to November 2009); this includes past production from the Orphan Mine and the Hack 1, Hack 2, Hack 3, Pigeon, Hermit, Kanab North, and Pinenut pipes/mines in the North Segregation Area.

The primary uranium ore mineral in the breccia pipe deposits is uraninite $\left(\mathrm{UO}_{2}\right)$. It is complexly intergrown with numerous sulfide and oxide minerals (Wenrich, 1985; Wenrich and others, 1989). The ore minerals are confined to the breccia pipe column (fig. 3) and the enclosing fracture zone (ring fractures). The principal form of alteration in the rocks surrounding the deposits is nearby bleaching of iron-oxide minerals, thereby turning red sandstones and siltstone to a bleached white color. The uraninite and associated ore minerals are generally fine grained in size, less than 1/32 of an inch across.

\section{Uranium Mining}

Mining in breccia pipes of the Grand Canyon region began in the 1860s. Prior to 1940, all of the mineral production was for copper, lead, zinc, and silver. The discovery of high-grade uranium deposits in the Orphan Lode (breccia) pipe led to uranium production at this site in 1956, about two miles west of Grand Canyon Village on the South Rim of Grand Canyon National Park. Though the Orphan Lode deposit seemed to be unique (an "orphan"), discovery of uranium there led to the discovery of uranium in breccia pipes in the region. The Orphan Mine produced 4.3 million pounds of $\mathrm{U}_{3} \mathrm{O}_{8}$ from 1956 to 1969 (Chenoweth, 1986) and was by far the largest uranium producer in this region during the early era of uranium production of the 1950s and 1960s. Modest uranium production came from a few other breccia pipe mines during this period, including the Hacks (or Hack Canyon), Ridenour, and Chapel Mines (Chenoweth, 1988). The Hack Canyon Mine produced only about 5,000 pounds of $\mathrm{U}_{3} \mathrm{O}_{8}$ from 1951 to 1954 and in 1961. Mining is no longer permitted within the national park, nearby national monuments, or protected areas of Kaibab National Forest on the North Rim.

Exploration for these kinds of deposits occurred throughout the 1970s, and uranium mining resumed in 1980. During the 1980s and early 1990s, nine pipes were mined or developed, including eight in the North Segregation Area (Kanab Creek area)—-the Hack 1, Hack 2, Hack 3, Pigeon, Hermit, Kanab North, Arizona 1, and Pinenut pipes - and one in the South Segregation Area (Kaibab National Forest) - the Canyon pipe. Mining at the Hack 1, Hack 2, Hack 3, Pigeon, and Hermit pipes was completed by 1989 and the sites were then reclaimed. All of the modern breccia pipe mines (1980s forward) in northern Arizona have been underground operations. Auxiliary surface operations at these kinds of sites typically occupy about $15-20$ acres. The uranium ore is not milled on site; since 1980, uranium ore from these mines has been shipped to a mill near Blanding, Utah, for processing.

Sulfide minerals associated with orebodies have the potential to produce acidic waters. However, the rock fragments (breccias) that host the orebodies, as well as the sedimentary rock units that surround the breccia pipes, include limestone and calcareous sandstone that have a high capacity to buffer acid waters (Wenrich and others, 1995). The breccia pipe mineral deposits are porous and weather rapidly. Based on experiences with newly mined deposits in the region, the uranium ores can oxidize within six months when exposed to surface conditions (Wenrich and others, 1995), indicating rapid leaching and chemical reaction of these materials, even in the arid environment of northern Arizona.

\section{Overview of This Report}

Chapters in this report provide an overview of geological, geochemical, hydrological, and biological issues related to uranium mining and natural resources of the designated segregation areas in the Grand Canyon region. Each chapter provides a detailed discussion of the focus area and, where relevant, identifies additional scientific research that would increase understanding and reduce uncertainty for the issues. The summaries that follow provide a general description of the contents of each chapter.

Chapter A, "Uranium Resource Availability in Breccia Pipes in Northern Arizona," estimates the amount of available uranium resources in the segregation areas. The authors compare uranium endowments from these segregation areas with endowments from other favorable uranium mining areas in northern Arizona.

Chapter B, "Effects of 1980s Uranium Mining in the Kanab Creek Area of Northern Arizona," provides a summary of the geochemistry of surface soils and sediments from a 2009 field assessment of several reclaimed and inactive breccia pipe uranium mines on the plateau north of the Grand Canyon. Stream sediments were also evaluated at a site with no mining history and no known uranium deposits. Chemical analysis for uranium and co-occurring trace metals and measurements of gamma radiation were completed at each site. Samples from breccia pipe sites were analyzed to determine historic wind and water dispersion, and some mine waste samples were evaluated for effects of weathering.

Chapter C, "Historical and 2009 Water Chemistry of Wells, Perennial and Intermittent Streams, and Springs in Northern Arizona," provides an evaluation of available historic water-chemistry data and water-chemistry data collected in 2009 for wells, springs, and streams in the Grand Canyon 
region. Historical data were used to evaluate effects of legacy mining and provide a baseline concentration for dissolved uranium in water in northern Arizona. New data were collected in the three segregation areas.

Chapter D, "Biological Pathways of Exposure and Ecotoxicity Values for Uranium and Associated Radionuclides," compiles available chemical and radiation toxicity information for plants and animals from the scientific literature on naturally occurring uranium and associated radionuclides. Exposure pathways are described and a food web specific to the segregation areas is developed. This chapter summarizes pertinent information that will aid in the development of an ecological risk assessment, but it does not estimate or derive guidance thresholds for uranium or radionuclides associated with uranium.

\section{Acknowledgments}

The tireless efforts of the chapter authors are commendable for completing their research and chapter in the extremely short timeframe given. The assistance of support staff was integral in the production of this document, from overseeing administrative tasks to creating figures. The staff of the U.S. Geological Survey Enterprise Publishing Network was instrumental in finalizing the text, graphics, and layout. And finally, the Bureau Approving Official was remarkable for his swift reviews and approval.

Of course, none of this would have been possible without the funding support provided by the leaders of U.S. Geological Survey and the Bureau of Land Management. Special thanks go to Suzette Kimball and Anne Kinsinger who provided the executive guidance and leadership for the project.

\section{USGS Flagstaff Science Campus}

Serena Mankiller, Biology, administrative and publication support Kristin Brown, Biology, GIS and editing support Marilyn Flynn, Hydrology, GIS and illustration support George Billingsley, Geology, geologic mapping support

\section{USGS Enterprise Publishing Network}

Ed Swibas, Publishing Science Center Chief

Melanie Parker, Editor

Mary Margaret Coates, Editor

Loretta Ulibarri, Visual Information Specialist

Joy Monson, Visual Information Specialist

Mari Kauffman, Visual Information Specialist

Lisa Binder, Map Editor

USGS Bureau Approving Official

Ron Kirby, Biology Discipline-Western Region

\section{References Cited}

Beus, S.S., and Morales, M., 2003, Grand Canyon geology (2d ed.): New York, Oxford University Press, 432 p.

Billingsley, G.H., 2000, Geologic map of the Grand Canyon $30^{\prime} \times 60^{\prime}$ quadrangle, Coconino and Mohave Counties, northwestern Arizona: U.S. Geological Survey Geologic Investigations Series I-2688, version 1.0, 15 p., scale $1: 100,000$.

Billingsley, G.H., Block, D.L., Dyer, H.C., 2006, Geologic map of the Peach Springs 30' $\times 60^{\prime}$ quadrangle, Mohave and Coconino Counties, northwestern Arizona: U.S. Geological Survey, Scientific Investigations Map 2900, 17 p., scale 1:100,000.

Billingsley, G.H., Felger, T.L., and Priest, S.S., 2006, Geologic map of the Valle 30' x 60' quadrangle, Coconino County, northern Arizona: U.S. Geological Survey Geologic Scientific Investigations Map 2895, 27 p., scale 1:100,000.

Billingsley, G.H., and Priest, S.S., 2010, Geologic map of the House Rock Valley area, Coconino County, northern Arizona: U.S. Geological Survey Scientific Investigations Map 3108, 26 p., scale 1:50,000.

Billingsley, G.H., Priest, S.S., and Felger, T.H., 2007, Geologic map of the Cameron 30' $\times 60^{\prime}$ quadrangle, Coconino County, northern Arizona: U.S. Geological Survey, Scientific Investigations Map 2977, 33 p., scale 1:100,000.

Billingsley, G.H., Priest, S.S., and Felger, T.H., 2008, Geologic map of the Fredonia 30' $\times 60^{\prime}$ quadrangle, Mohave and Coconino Counties, northern Arizona: U.S. Geological Survey, Scientific Investigations Map 3035, 25 p., scale 1:100,000.

Billingsley, G.H., Spamer, E.E., and Menkes, Dove, 1997, Quest for the pillar of gold-The mines and miners of the Grand Canyon: Grand Canyon, Ariz., Grand Canyon Association Monograph 10, 112 p.

Billingsley, G.H., and Wellmeyer, J.L., 2006, Geologic map of the Mount Trumbull 30' x 60' quadrangle, Mohave and Coconino Counties, northwestern Arizona, version 1.1: U.S. Geological Survey, Geologic Investigations Series I-2766, 36 p., scale 1:100,000. [Version 1.0 published 2003.]

Billingsley, G.H., and Workman, J.B., 2000, Geologic map of the Littlefield 30' × 60' quadrangle, Mohave County, northwestern Arizona: U.S. Geological Survey, Geologic Investigations Series I-2628, 25 p., scale 1:100,000. 
Bills, D.J., Flynn, M.E., and Monroe, S.A., 2007, Hydrogeology of the Coconino Plateau and adjacent areas, Coconino and Yavapai Counties, Arizona: U.S. Geological Survey Scientific Investigations Report 2005-5222, 101 p., 4 plates.

Blinn, D.W., and Cole, G.A., 1991, Algal and invertebrate biota in the Colorado River-Comparison of pre- and postdam conditions, in Colorado River ecology and dam management, Santa Fe, N. Mex., 24-25 May 1990, Proceedings: Washington, DC, National Academy Press, p. 102-123.

Brown, D., and Lowe, C., 1982, Biotic communities of the southwest United States and Mexico: Desert Plants [University of Arizona], v. 4, no. 1-4, special issue.

Chenoweth, W.L., 1986, The Orphan Lode Mine, Grand Canyon, Arizona-A case history of a mineralized, collapse-breccia pipe: U.S. Geological Survey Open-File Report 86-510, 91 p., 35 p. appendix.

Chenoweth, W.L., 1988, The production history and geology of the Hacks, Ridenour, Riverview, and Chapel breccia pipes, northwestern Arizona: U.S. Geological Survey OpenFile Report 88-648, 60 p.

Farnsworth, R.K., Thompson, E.S., and Peck, E.L., 1982, Evaporation atlas for the contiguous 48 United States: National Oceanographic and Atmospheric Administration Technical Report NWS 33, 26 p.

Finch, W.I., Pierson, C.T., and Sutphin, H.B., 1992, Grade and tonnage model of solution collapse breccia pipe uranium deposits, in Bliss, J.D., ed., Developments in mineral deposit modeling: U.S. Geological Survey Bulletin 2004, p. $36-38$.

Flint, A.L., and Flint, L.E., 2007, Application of the basin characterization model to estimate in-place recharge and runoff potential in the Basin and Range carbonate-rock aquifer system, White Pine County, Nevada, and adjacent areas in Nevada and Utah: U.S. Geological Survey Scientific Investigations Report 2007-5099, 20 p.

Flint, A.L., Flint, L.E., Hevesi, J.A., and Blainey, J.B., 2004, Fundamental concepts of recharge in the desert southwestA regional modeling perspective, in Hogan, J.F., Phillips, F.M., and Scanlon, B.R., eds., Groundwater recharge in a desert environment_- The southwestern United States: American Geophysical Union, Water Science and Applications Series, v. 9, p. 159-184.

Grand Canyon Wildlands Council, 2004, Biological inventory and assessment of ten South Rim springs in Grand Canyon National Park-Revised final report, 21 July 2004: Flagstaff, Ariz., Grand Canyon Wildlands Council Inc., National Park Service Contract WPF-230, 62 p.
Ludington, S. Moring, B.C., Miller, R.J., Stone, P.A., Bookstrom, A.A., Bedford, D.R., Evans, J.G., Haxel, G.A., Nutt, C.J., Flyn, K.S., and Hopkins, M.J., 2007, Preliminary integrated geologic map databases for the United States. Western states - California, Nevada, Arizona, Washington, Oregon, Idaho, and Utah (ver. 1.3): U.S. Geological Survey Open-File Report 2005-1305, variously paged.

Moreton, Christopher, and Ross, David, 2009, Technical report on the EZ1 and EZ2 breccia pipes, Arizona Strip District, U.S.A.: Scott Wilson Roscoe Postle Associates Inc., prepared for Denison Mines Corp. [variously paged], accessed November 3, 2009, at http://sec.edgar-online.com/denison-mines-corp/ 6-k-report-of-foreign-issuer/2009/08/18/section24.aspx.

Nabhan, G.P., ed., 2002, Safeguarding the uniqueness of the Colorado Plateau-An ecoregional assessment of biocultural diversity: Flagstaff, Ariz., Center for Sustainable Environments, Grand Canyon Wildlands Council, 97 p.

Oberlin, G.E., Shannon, J.P., and Blinn, D.W., 1999, Watershed influences on the macroinvertebrate fauna of ten major tributaries of the Colorado River through Grand Canyon, Arizona: Southwestern Naturalist, v. 22, p. 17-30.

Olson, D.M, Dinerstiene, E., Wikramanayake, E.D., Burgress, N.D., Powell, G.V.N., Underwood, E.C., D’Amico, J.A., Itoua, I., Strand, H.E., Morrison, J.C., Loucks, C.J., Allnutt, T.F., Ricketts, T.H., Kura, Y., Lamoreux, J.F., Wettengel, W.W., Hedeo, P., and Kassem, K.R., 2001, Terrestrial ecoregions of the world-A new map of life on Earth: Bio Science, v. 51, p. 933-938.

Pool, T.C., and Ross, D.A., 2007, Technical report on the Arizona strip uranium project, U.S.A.: Scott Wilson Roscoe Postle Associates Inc., prepared for Denison Mines Corp., $116 \mathrm{p}$.

PRISM Climate Group, 2006, United States monthly or annual precipitation, 1971-2000: Oregon State University, PRISM Climate Group, accessed May 29, 2008, at http://www.prism.oregonstate.edu.

Spiering, E.D., 2009, Exploration and discovery of blind breccia pipess - The potential significance to the uranium endowment of the Arizona Strip District, northern Arizona [presentation]: U2009 Globel Uranium Symposium, Keystone, Colo., May 9-13, 2009, accessed November 2, 2009, at http://www.quaterraresources.com/uploads/projects/ presentation_global_uranium_symposium_09_05.pdf.

Stevens, L.E., Shannon, J.P., and Blinn, D.W., 1997, Colorado River benthic ecology in Grand Canyon, Arizona, USA - Dam, tributary, and geomorphological influences: Regulated Rivers-Research and Management, v. 13, no. 2, p. 129-149. 
Stevens, L.E., Sublette, J.E., and Shannon, J.P., 1998, Chironomidae (Diptera) of the Colorado River, Grand Canyon, Arizona, USA - II. Factors influencing distribution: Great Basin Naturalist, v. 58, no. 2, p. 147-155.

U.S. Bureau of Land Management, 2009, Notice of intent to prepare an environmental impact statement for a proposed withdrawal in the vicinity of the Grand Canyon, Arizona: Federal Register, v. 74, no. 164, August 26, 2009, p. 43152-43153.

Webb, Bob, 2002, 2002 debris flows and floods in Grand Canyon: Grand Canyon River Guides-Boatmans Quarterly Review, v. 15, no. 4, accessed October 22, 2009, at http://www.gcrg.org/bqr/15-4/debris.html.

Webb, R.H., Smith, S.S., and McCord, V.A.S., 1991, Historic channel change of Kanab Creek, southern Utah and northern Arizona: Grand Canyon Natural History Association monograph no. 9, $91 \mathrm{p}$.

Wenrich, K.J., 1985, Mineralization of breccia pipes in northern Arizona: Economic Geology, v. 80, p. 1722-1735.
Wenrich, K.J., Chenoweth, W.L., Finch, W.I., and Scarborough, R.B., 1989, Uranium in Arizona, in Jenney, J.P., and Reynolds, S.J., eds., Geologic evolution of Arizona: Arizona Geological Society Digest 17, p. 759-794.

Wenrich, K.J., and Sutphin, H.B., 1988, Recognition of breccia pipes in northern Arizona: Fieldnotes [Arizona Bureau of Geology and Mineral Technology], v. 18, no. 1, p. $1-5,11$.

Wenrich, K.J., Van Gosen, B.S., and Finch, W.I., 1995, Solutioncollapse breccia pipe U deposits (Model 32e; Finch, 1992), in du Bray, E.A., ed., Preliminary compilation of descriptive geoenvironmental mineral deposit models: U.S. Geological Survey Open-File Report 95-831, p. 244-251.

Western Regional Climate Center, 2004, SOD USA climate archive-Arizona: Western Regional Climate Center, accessed November 2, 2009, at http://www.wrcc.dri.edu/ summary/Climsmaz.html. 


\section{Appendix 1. Scientific Names of Plant and Animal Species Included in the Text}

Within major groups, species are listed alphabetically by common name. Scientific names are accurate according to the Integrated Taxonomic Information System, http://www.itis.gov/, last updated December 24, 2009.

\begin{tabular}{|c|c|}
\hline \multicolumn{2}{|c|}{ Vascular plants } \\
\hline Ash & Fraxinus spp. \\
\hline Aspen & Populus tremuloides \\
\hline Banana yucca & Yucca baccata \\
\hline Big sagebrush & Artemisia tridentata \\
\hline Blackbrush & Coleogyne ramosissima \\
\hline Catclaw & Acacia greggii \\
\hline Cottonwood & Populus fremontii \\
\hline Creosotebush & Larrea tridentata \\
\hline Fir & Abies spp. \\
\hline Gambel oak & Quercus gambelii \\
\hline Juniper & Juniperus spp. \\
\hline Maidenhair fern & Adiantum capillus-veneris \\
\hline Mesquite & Prosopis spp. \\
\hline Monkey flower & Mimulus spp. \\
\hline Mormon tea & Ephedra spp. \\
\hline Netleaf hackberry & Celtis laevigata \\
\hline Oak & Quercus spp. \\
\hline Pinyon pine & Pinus edulis \\
\hline Ponderosa pine & Pinus ponderosa \\
\hline Rabbitbrush & Chrysothamnus spp. \\
\hline Redbud & Cercis canadensis \\
\hline Russian olive & Elaeagnus angustifolia \\
\hline Siberian elm & Ulmus pumila \\
\hline Snakeweed & Gutierrezia spp. \\
\hline Spruce & Picea spp. \\
\hline Tamarisk & Tamarix spp. \\
\hline White bursage & Ambrosia dumosa \\
\hline Willow & Salix spp. \\
\hline \multicolumn{2}{|c|}{ Invertebrates } \\
\hline Kanab ambersnail & Oxyloma haydeni kanabensis \\
\hline \multicolumn{2}{|r|}{ Fish } \\
\hline Bluehead sucker & Catostomus discobolus \\
\hline Brown trout & Salmo trutta \\
\hline Carp & Cyprinus carpio \\
\hline
\end{tabular}

\begin{tabular}{lc}
\hline & Fish-Continued \\
\hline Flannelmouth sucker & Catostomus latipinnis \\
Humpback chub & Gila cypha \\
Rainbow trout & Oncorhynchus mykiss \\
Speckled dace & Rhinichthys osculus \\
\hline & Reptiles \\
\hline Chuckwalla & Sauromalus ater \\
\hline & Birds \\
\hline Bald eagle & Haliaeetus leucocephalus \\
Canyon wren & Catherpes mexicanus \\
Golden eagle & Aquila chrysaetos \\
Goshawk & Accipiter gentilis \\
Great blue heron & Ardea herodias \\
Kestrel & Falco sparverius \\
Mexican spotted owl & Strix occidentalis lucida \\
Nuthatch & Sitta spp. \\
Osprey & Pandion haliaetus \\
Peregrine falcon & Falco peregrinus \\
Phoebe & Sayornis spp. \\
Raven & Corvus corax \\
Red-tail hawk & Buteo jamaicensis \\
\hline & Mammals \\
\hline Bighorn sheep & Ovis canadensis \\
Bobcat & Lynx rufus \\
Coyote & Canis latrans \\
Deer & Odocoileus spp. \\
Elk & Cervus elaphus \\
Gunnison's prairie dog & Cynomys gunnisoni \\
Long-tailed weasel & Mustela frenata \\
Mountain lion & Puma concolor \\
Mule deer & Odocoileus hemionus \\
Raccoon & Procyon lotor \\
Ringtail cat & Bassariscus astutus \\
Pronghorn & Antilocapra americana \\
\hline & \\
\hline
\end{tabular}





\section{Uranium Resource Availability in Breccia Pipes in Northern Arizona}

By James K. Otton and Bradley S. Van Gosen

Chapter A of

Hydrological, Geological, and Biological Site Characterization

of Breccia Pipe Uranium Deposits in Northern Arizona

Edited by Andrea E. Alpine

Scientific Investigations Report 2010-5025

U.S. Department of the Interior

U.S. Geological Survey 


\section{Contents}

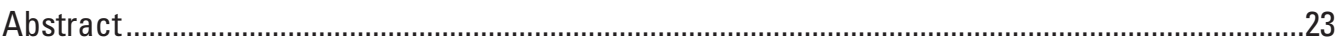

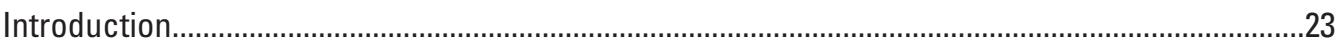

Previous Mineral Appraisals in the Grand Canyon Area .....................................................................26

Uranium Production and Inferred Resources from Pipes in and near the

Three Segregation Areas...................................................................................................28

Characteristics of Breccia Pipes, Related Circular Features, and Resultant

Uncertainties in Resource Estimation ..................................................................................29

The 1990 Finch and Others Estimate ............................................................................................31

Differences in the Surface Area Calculation between the 1990 Finch and

Others Report and the Present Study ..................................................................................34

Estimated Resources Associated with Pre-2009 Mineral Withdrawal Lands

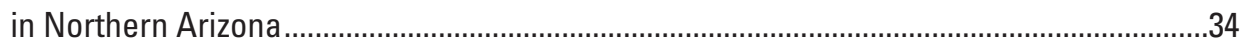

Estimates of the Uranium Resources in the Three Segregation Areas ..............................................35

Pre-Existing Mining Claims and Estimated Undiscovered Uranium Endowment .............................36

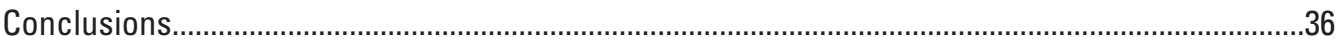

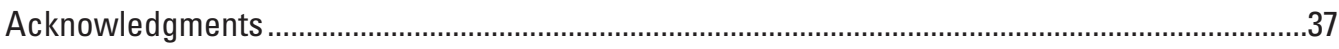

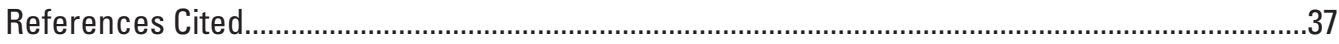

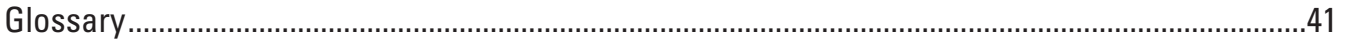

\section{Figures}

1. Map showing northern Arizona and the three segregation areas

2. Map showing mining claims in and near the North, East, and South Segregation Areas.

3. Favorable $(A-D)$ and unfavorable $(E)$ areas for breccia pipe uranium deposits in northern Arizona

4. Simplified geologic cross section of a typical breccia pipe showing maximum known vertical stratigraphic extension and location of ore

5. Map of the Hack-Pinenut control area for uranium-bearing solutioncollapse breccia pipes. 


\section{Tables}

1. Production and inferred reserve amounts of $\mathrm{U}_{3} \mathrm{O}_{8}$ reported for nine mines

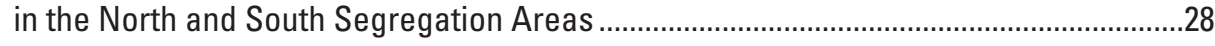

2. Surface areas reported for favorable area A by Finch and others .................................34

3. Comparison of surface areas calculated during this study compared to

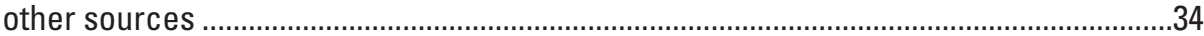

4. Calculated surface areas of previously withdrawn lands that lie within

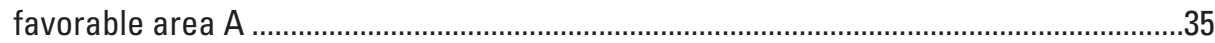

5. Estimated undiscovered uranium endowment for previously withdrawn

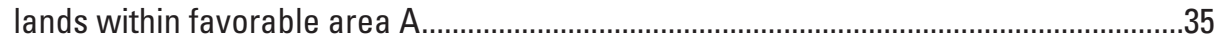

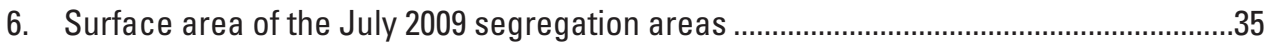

7. Estimated undiscovered uranium endowment in the July 2009 segregation areas.

8. Estimated undiscovered uranium endowment in the July 2009 segregation areas under pre-existing mining claim and not under pre-existing mining claim.

\section{Conversion Factors}

Inch/Pound to SI

\begin{tabular}{lcl}
\hline Multiply & By & To obtain \\
\hline foot $(\mathrm{ft})$ & Length & \\
mile $(\mathrm{mi})$ & 0.3048 & meter $(\mathrm{m})$ \\
\hline & 1.609 & kilometer $(\mathrm{km})$ \\
\hline acre & Area & \\
square mile $\left(\mathrm{mi}^{2}\right)$ & 4,047 & square meter $\left(\mathrm{m}^{2}\right)$ \\
& 2.590 & square kilometer $\left(\mathrm{km}^{2}\right)$ \\
\hline pound, avoirdupois $(\mathrm{lb})$ & Mass & \\
ton, short $(2,000 \mathrm{lb})$ & 0.4536 & kilogram $(\mathrm{kg})$ \\
& 0.9072 & megagram $(\mathrm{Mg})$ \\
\hline
\end{tabular}





\title{
Chapter A \\ Uranium Resource Availability in Breccia Pipes in Northern Arizona
}

\author{
By James K. Otton and Bradley S. Van Gosen
}

\section{Abstract}

In 1990, the U.S. Geological Survey estimated that a mean undiscovered uranium endowment of 1.3 million tons (2.6 billion pounds) $\mathrm{U}_{3} \mathrm{O}_{8}$ is present in breccia pipe deposits in northern Arizona. This estimate exceeds the December 31, 2003, U.S. uranium reserves estimate of 445 thousand tons (890 million pounds) $\mathrm{U}_{3} \mathrm{O}_{8}$ for developed deposits elsewhere in the United States. This chapter examines what part of that undiscovered uranium endowment in northern Arizona is not available for exploration, development, or mining because of previous withdrawals of Federally owned land from mineral entry and the newly proposed withdrawals in the Grand Canyon area, announced July 21, 2009.

The estimated mean undiscovered uranium endowment for the areas in northern Arizona withdrawn from mineral entry prior to July 21, 2009 — which include the national park, two national monuments, the game preserve on forest lands, and tribal lands - is 466,384 tons (about 933.6 million pounds) $\mathrm{U}_{3} \mathrm{O}_{8}$, or 35 percent of the 1990 estimate of 1,315,383 total estimated tons (about 2.63 billion pounds) $\mathrm{U}_{3} \mathrm{O}_{8}$ in all favorable areas in northern Arizona. The estimated mean undiscovered uranium endowment for the three segregation areas proposed for withdrawal in the July 21, 2009, announcement is 162,964 tons (about 326 million pounds) $\mathrm{U}_{3} \mathrm{O}_{8}$, or 12 percent of the total. Combined, the three segregation areas and previously withdrawn areas would contain about 48 percent of the total estimated undiscovered uranium endowment in all favorable areas for northern Arizona. However, these segregation areas and previously withdrawn areas are all within favorable area A, the most prospective area according to the 1990 estimate. The combined existing and proposed withdrawal lands would represent 69 percent of the 910,350 tons ( 1.82 billion pounds) $\mathrm{U}_{3} \mathrm{O}_{8}$ previously estimated to occur in favorable area A.

\section{Introduction}

On July 21, 2009, U.S. Department of the Interior Secretary Ken Salazar proposed the withdrawal of two parcels of Bureau of Land Management (BLM) land north of Grand Canyon National Park from further mineral entry for a period of two years. A few days later, U.S. Secretary of Agriculture Thomas Vilsack proposed the withdrawal of the Tusayan Ranger District of the Kaibab National Forest south of Grand Canyon National Park. Existing mining claims in the three areas with valid existing rights are not affected.

These three parcels of land (fig. 1) total 1,075,384 acres (R. Cox, U.S. Bureau of Land Management, oral commun., 2010). Underlying these parcels of land are numerous breccia pipes, a few of which contain uranium mineralization. Some of these breccias pipes contain sufficient uranium mineralization to have been mined from the early 1950s to about 1992 . These uranium resources are the focus of this chapter.

Following BLM terminology, these parcels of land that have been proposed for withdrawal are referred to as the North, East, and South Segregation Areas (fig. 1). The North Segregation Area is mostly BLM land in the Kanab Creek drainage north of Grand Canyon National Park and west of North Kaibab National Forest. The East Segregation Area is also mostly BLM land in the House Rock Valley area east of North Kaibab National Forest, south of the Vermilion Cliffs National Monument, and northwest of the Colorado River. The South Segregation Area is U.S. Forest Service land, the Tusayan Ranger District of the Kaibab National Forest.

The Grand Canyon area has been the location of modest mining activity since the late 1800s. During the 1950s, five breccia pipe deposits were mined for uranium. From 1952 until 1969, the Orphan Mine produced a significant quantity of uranium, about 2,150 tons (4.3 million pounds) $\mathrm{U}_{3} \mathrm{O}_{8}$ (Chenoweth, 1986). In the 1970s, exploration for uranium in the Grand Canyon area became very active and thousands of mining claims were filed on Federal and other lands across the region. Much of this activity was focused on the Kanab Creek drainage area (North Segregation Area) because of the excellent exposures of several breccia pipes along canyon walls and other surface indications in aerial photos away from canyons. Figure 2 shows the distribution of mining claims in and near the three segregated areas; note the dense mining claim coverage in the North Segregation Area, the lesser amount of mining claims in the South Segregation Area, and the very few mining claims in the East Segregation Area. The mine claim coverage reflects the varied intensity of past exploration among these three land parcels. 


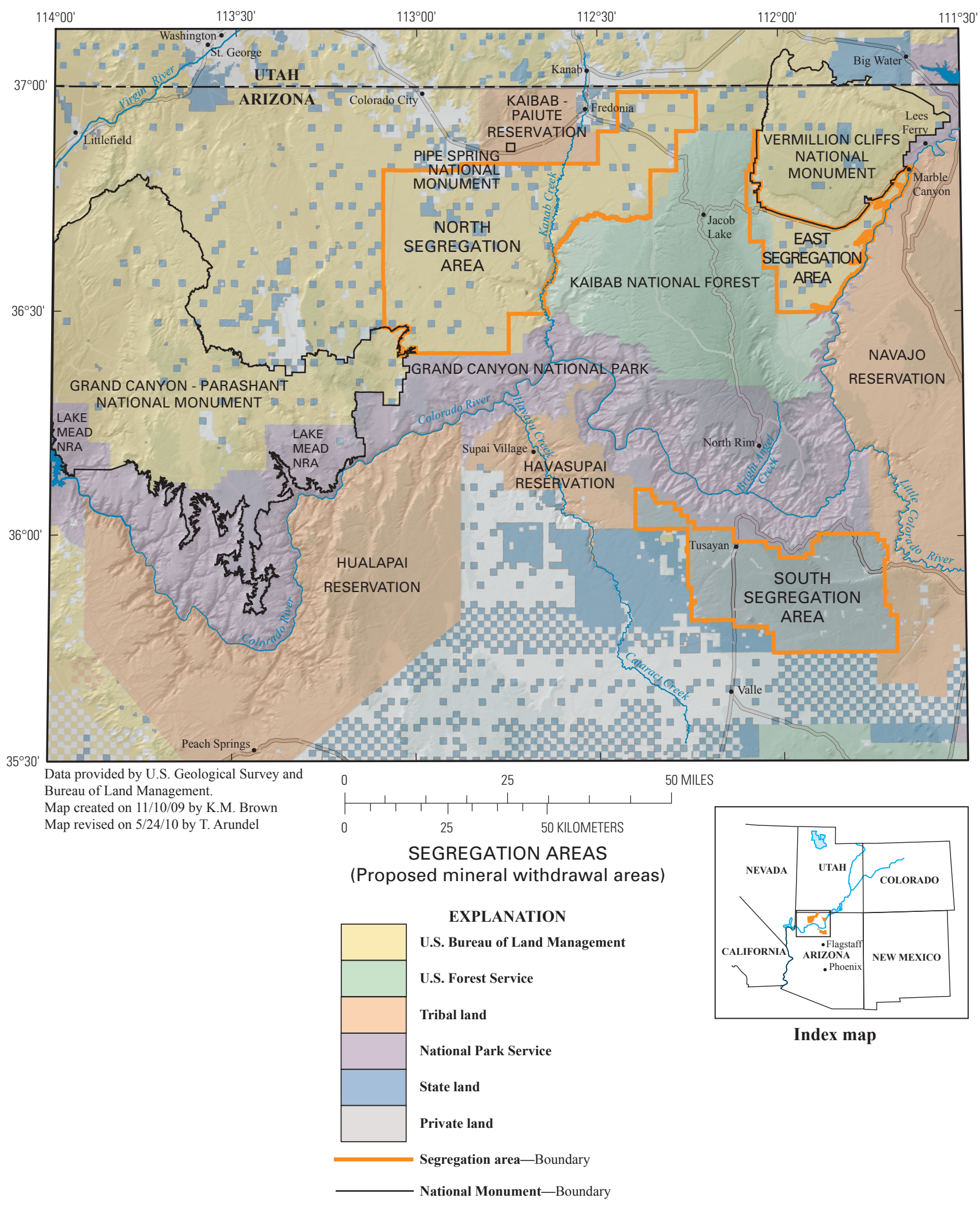

Figure 1. Map showing northern Arizona and the three segregation areas, parcels of Federal land removed from further mineral entry for a two-year period beginning July 21, 2009, pending a longer withdrawal. Boundaries for other major land holdings are shown. From U.S. Bureau of Land Management, 2009. NRA, National Recreation Area. 


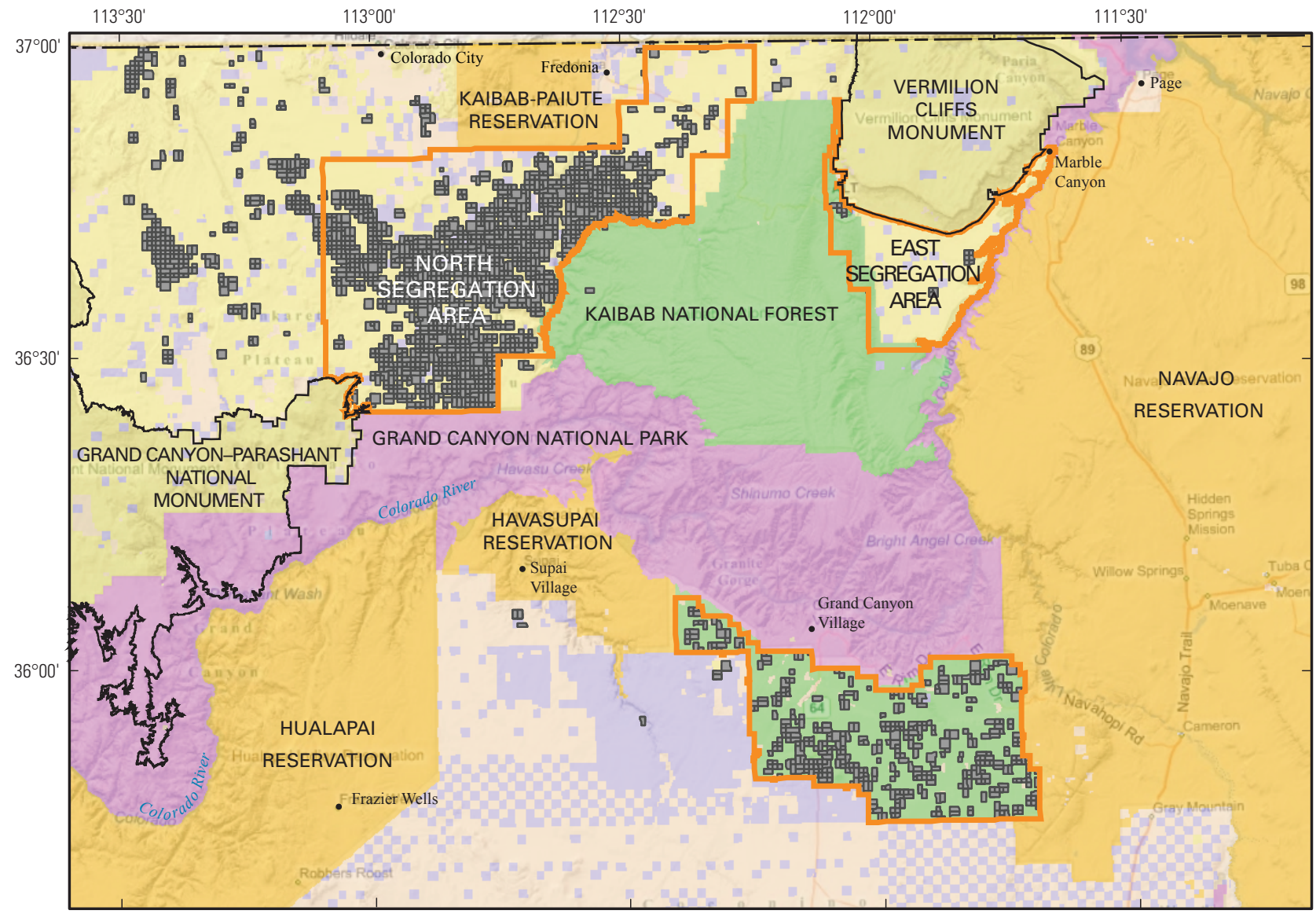

Base from Microsoft Virtual Earth, 2009: Microsoft Corporation, ArcGIS Online Premium Map Service, Bing Maps Roads. Copyrights: (c)2009 ESRI, (c)2009 Microsoft Corporation, (c)2008 NAVTEQ, (c) AND, (c) MapData Sciences Pty Ltd., (c)2007 Zenrin, (c)2007 Intermap. See http://maps.live.com for a complete list of data suppliers.
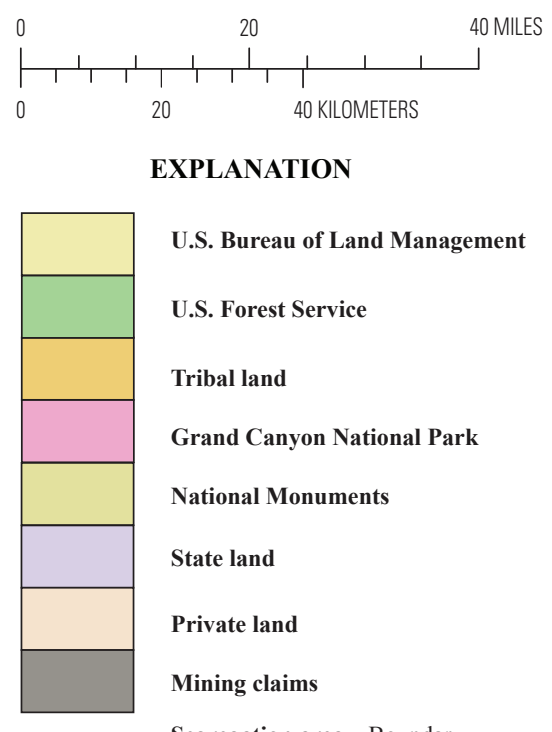

U.S. Bureau of Land Management

U.S. Forest Service

Tribal land

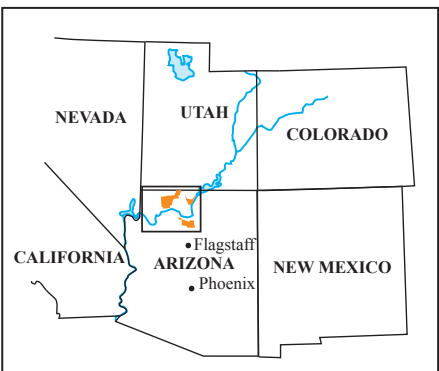

Index map

Grand Canyon National Park

National Monuments

State land

Private land

Mining claims

Segregation area-Boundary

National Monument-Boundary

Figure 2. Map showing mining claims in and near the North, East, and South Segregation Areas. Leases on State lands (blue areas) are not shown. Digital files for mining claims provided by Rody Cox, U.S. Bureau of Land Management, September 2009, and plotted by Laura Biewick, U.S. Geological Survey. 
During the 1970s, the U.S. Department of Energy (DOE) assessed the uranium resources of the United States, including the area of breccia pipes in northern Arizona, and published the assessments in 1980 (Baillieul and Zollinger, 1980; U.S. Department of Energy, 1980). Subsequently, during the 1980s, Karen Wenrich and colleagues of the U.S. Geological Survey (USGS) conducted several studies of breccia pipes across northern Arizona. Information from mining companies in the area, notably Energy Fuels Nuclear, Inc. (EFN), was made available for Wenrich's studies. The USGS used this new information to re-evaluate the uranium resource potential, completing their study in 1987 (Finch and others, 1990). This resource assessment work was part of an agreement with DOE to update undiscovered uranium resources in specific areas of the United States where new information became available (Finch and McCammon, 1987).

The area of northern Arizona considered favorable for the occurrence of breccia pipe uranium deposits (fig. 3) was defined by Finch and others (1990). They estimated that a mean undiscovered uranium endowment of 1.3 million tons ( 2.6 billion pounds) $\mathrm{U}_{3} \mathrm{O}_{8}$ is present in breccia pipes in northern Arizona. ("Uranium endowment" is the uranium that is estimated to occur in rock with a grade of at least 0.01 percent $\mathrm{U}_{3} \mathrm{O}_{8}$.) This mean undiscovered uranium endowment is the average of a range of estimates from 338,948 tons (about 678 million pounds) $\mathrm{U}_{3} \mathrm{O}_{8}$ with a high probability of occurrence to $2,757,230$ tons (about 5.5 billion pounds) $\mathrm{U}_{3} \mathrm{O}_{8}$ with a low probability of occurrence. The estimated mean undiscovered uranium endowment in northern Arizona exceeds the December 31, 2003, uranium reserves estimate of 445,000 tons (890 million pounds) $\mathrm{U}_{3} \mathrm{O}_{8}$ for the entire United States by the U.S. Energy Information Administration (2004). For comparison, the 104 U.S. nuclear reactors consume about 27,500 tons (55 million pounds) $\mathrm{U}_{3} \mathrm{O}_{8} / \mathrm{yr}$. About $1,750-2,250$ tons ( $3.5-4.5$ million pounds) $\mathrm{U}_{3} \mathrm{O}_{8}$ are produced from U.S. uranium mines each year, and the remainder of the U.S. uranium needs is supplied from foreign sources and U.S. utility inventory.

This chapter addresses four primary topics:

1. Review of previous mineral resource studies in the Grand Canyon area and deposit-specific breccia pipe uranium production and resource estimates developed from company data;

2. Discussion of uncertainties in uranium resource estimates for breccia pipes;

3. Evaluation of the Finch and others (1990) undiscovered uranium resource estimate of 1987; and

4. Evaluation of the availability of uranium resources defined by Finch and others (1990) through an estimate of the resource in lands withdrawn from mineral entry prior to July 21, 2009, and an estimate of the undiscovered uranium resource that may be present in the three segregation areas (currently proposed for withdrawal).

\section{Previous Mineral Appraisals in the Grand Canyon Area}

During the 1980s, prior to the Finch and others (1990) study, several areas of northern Arizona had mineral resource appraisals completed that included areas with potential for breccia pipe deposits. None of these studies provided quantitative resource estimates. Areas covered in these studies include:

- Kanab Creek Roadless Area (Billingsley and Ellis, 1983; Billingsley and others, 1983; Hopkins and others, 1984). This roadless area is a narrow, 14- $\mathrm{mi}^{2}$ tract that follows Snake Gulch, a major eastern tributary to Kanab Creek. It lies along the boundary between the section of the Kaibab National Forest north of the Grand Canyon and the North Segregation Area (fig. 1).

- Pigeon Canyon, Nevershine Mesa, and Snap Point Wilderness Study Areas in the western part of what is now the Grand Canyon-Parashant National Monument (Lane, 1984; Billingsley and others, 1986). These three contiguous study areas are in the Grand Wash Cliffs area along the western edge of the favorable area $\mathrm{A}$ (fig. 3) outlined by Finch and others (1990).

- Vermilion Cliffs-Paria Canyon area, now the Vermilion Cliffs National Monument (Bush and Lane 1982 a, b; Bush 1983). This area lies immediately north of the East Segregation Area (fig. 1).

- Mt. Trumbull Wilderness Study Area (McDonnell, 1984), now part of the Grand Canyon-Parashant National Monument (fig. 3).

The USGS conducted extensive geologic studies of breccia pipes on the Hualapai Reservation (Wenrich and others, 1986; Verbeek and others, 1988; Wenrich and Sutphin, 1988; Van Gosen and Wenrich, 1989; Wenrich and others, 1990; Wenrich and others, 1996; Wenrich and others, 1997; Wenrich and Huntoon, 2000). Sutphin and Wenrich (1989) also mapped 1,296 breccia pipes for the entire Grand Canyon area.

Wenrich (1992) studied breccia pipe deposits in an area of four 7.5' quadrangles near Red Butte in the Tusayan Ranger District. The intent was to establish a control area for evaluating the uranium mineral potential of the remainder of Kaibab National Forest. During a joint USGS and U.S. Bureau of Mines study, Bliss and Pierson (1993) and Scott (1992) evaluated the mineral resources of the Kaibab National Forest. Bliss and Pierson (1993) provided quantitative resource estimates for uranium resources using the Finch and others (1990) methodology. The Kaibab National Forest districts evaluated include the North Kaibab Ranger District, a large, previously withdrawn forested area between the North and East Segregation Areas, and the Tusayan Ranger District (South Segregation Area). 


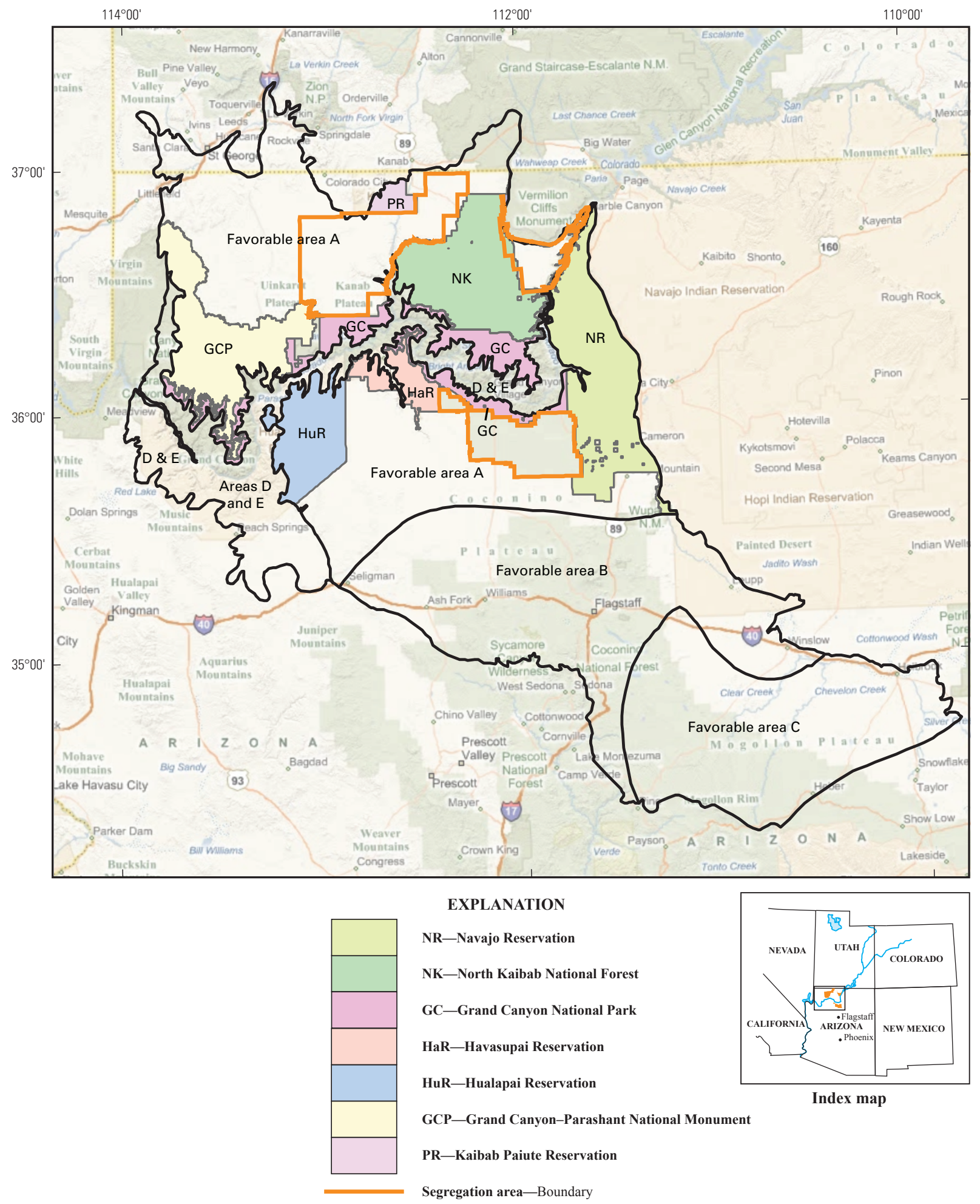

Figure 3. Favorable $(A-D)$ and unfavorable $(E)$ areas for breccia pipe uranium deposits in northern Arizona. Boundaries for favorable areas digitized from Finch and others $(1990$, fig. 2). Previously withdrawn areas are shown where they occur within favorable area A only. The North, East, and South Segregation Areas are also shown. 


\section{Uranium Production and Inferred Resources from Pipes in and near the Three Segregation Areas}

From 1951 to 1969 , uranium production in the Grand Canyon region occurred at five breccia pipes: the Hacks (or Hack Canyon), Ridenour, Orphan Lode (or Orphan), Riverview, and Chapel Mines (Chenoweth, 1986, 1988). Except for the Orphan Mine, all production was modest. Only the Hack Canyon Mine lies within an area proposed for withdrawal, the North Segregation Area. The Hack Canyon Mine produced about 2.5 tons (5,000 pounds) $\mathrm{U}_{3} \mathrm{O}_{8}$ from 1951 to 1954 and in 1961. The Orphan Mine produced about 2,150 tons (4.3 million pounds) $\mathrm{U}_{3} \mathrm{O}_{8}$ from 1956 to 1969 from a breccia pipe located about 1 mi northwest of Grand Canyon Village (Chenoweth, 1986). The average grade was 0.43 percent $\mathrm{U}_{3} \mathrm{O}_{8}$. The Orphan Mine is within the Grand Canyon National Park, about 3.5 mi north of the South Segregation Area northern boundary. The Ridenour, Riverview, and Chapel Mines are within other lands previously withdrawn from mineral entry.

Exploration for breccia pipe uranium deposits occurred in the Grand Canyon region through much of the 1970s, but mining did not resume until 1980. Although the price of uranium dropped dramatically in the early 1980 s, existing purchase contracts and the high grade of the breccia pipe ores allowed for profitable mining. During the 1980s and early 1990s, nine breccia pipe deposits were mined or developed: eight breccia pipes were in the North Segregation AreaHack 1, Hack 2, Hack 3, Pigeon, Hermit, Kanab-North, Arizona 1, and Pinenut - and one breccia pipe was in the South Segregation Area - the Canyon Mine. Mining at the first five of these pipes has been completed and the sites have been reclaimed. Reclamation at the Hack 1, 2, and 3 Mines included the older Hack Canyon operations. The Kanab-North breccia pipe has been mined, but minor amounts of uranium ore remain in the workings and the mine has been on standby status since 1992. The Pinenut breccia pipe was also mined with an estimated 15 percent of the uranium ore removed; it has been on standby status since 1989. The Arizona 1 breccia pipe was developed by a shaft and nearly completed by 1992 , but operations ceased without any uranium ore having been produced. Surface operations at the Canyon Mine breccia pipe were developed and a shaft collared to a depth of $50 \mathrm{ft}$ (Pool and Ross, 2007). The Arizona 1 Mine and the Canyon Mine are also on standby status.

Production and inferred reserves reported for these nine mines are given in table 1. All data are from NI 43-101 independent technical reports for Denison Mines by Pool and Ross (2007) and Moreton and Ross (2009) and are herein considered the best information available. Energy Fuels Nuclear
Table 1. Production and inferred reserve amounts of $\mathrm{U}_{3} \mathrm{O}_{8}$ reported for nine mines in the North and South Segregation Areas.

\begin{tabular}{|c|c|c|}
\hline \multicolumn{3}{|c|}{ North Segregation Area-production } \\
\hline Mine & Production amounts & $\begin{array}{c}\text { Average grade } \\
\qquad\left(\% \mathrm{U}_{3} \mathrm{O}_{8}\right)\end{array}$ \\
\hline Hack 1 & 1.42 million pounds & 0.53 \\
\hline Hack 2 & 7.00 million pounds & 0.70 \\
\hline Hack 3 & 1.12 million pounds & 0.50 \\
\hline Pigeon & 5.7 million pounds & 0.65 \\
\hline Hermit & 550,000 pounds & 0.76 \\
\hline Kanab-North & 2.77 million pounds & 0.53 \\
\hline Pinenut & 526,000 pounds & 1.02 \\
\hline \multicolumn{3}{|c|}{ North and South Segregation Areas-inferred reserves ${ }^{1}$} \\
\hline Mine & Production amounts & $\begin{array}{c}\text { Average grade } \\
\left(\% \mathrm{eU}_{3} \mathrm{O}_{8}\right)^{2}\end{array}$ \\
\hline Arizona 1 & 956,000 pounds & 0.68 \\
\hline Canyon & 1.5 million pounds & 1.08 \\
\hline Pinenut & 873,000 pounds & 0.44 \\
\hline Kanab-North & \multicolumn{2}{|c|}{ minor reserves remain } \\
\hline EZ1 & 436,404 pounds & $0.54^{3}$ \\
\hline EZ2 & 428,252 pounds & $0.42^{4}$ \\
\hline
\end{tabular}

${ }^{1}$ Six properties only; Pool and Ross, 2007; Moreton and Ross, 2009.

2“"e" refers to reliance on gamma logging of deep drill holes for the reserve measurement.

${ }^{3}$ Reported as proven, probable, and potential mineral reserves by EFN, February 1988. Pathfinder Mines Corp. reported indicated mineral reserves at 1.4 million pounds $\mathrm{U}$ at $0.66 \% \mathrm{eU}_{3} \mathrm{O}_{8}$ in 2004 .

${ }^{4}$ Reported as proven, probable, and potential mineral reserves by EFN, February 1988. Pathfinder Mines Corp. reported indicated mineral reserves at 1.9 million pounds $\mathrm{U}$ at $0.44 \% \mathrm{eU}_{3} \mathrm{O}_{8}$ in 2004 .

(EFN) developed and mined these nine breccia pipes in the North Segregation Area from 1980 through 1994, producing 9,550 tons (19.1 million pounds) $\mathrm{U}_{3} \mathrm{O}_{8}$.

Combined uranium production from the mines in the North Segregation Area plus production from the Orphan Mine near the South Segregation Area total 11,650 tons (23.3 million pounds). No production or reserves have been reported for the East Segregation Area.

McMurray Geological Consulting (2003) has independently evaluated the uranium reserve potential of the Grand Canyon area by studying exploration and development drilling information from several companies for the pipes discussed here as well as for other breccia pipe deposits drilled but not developed. The report concludes that "proven, probable, and potential reserves" of 24 million pounds $\mathrm{U}_{3} \mathrm{O}_{8}$ are present in 11 breccia pipes in the area north and south of the Grand Canyon (in the North and South Segregation Areas) and in State and private lands west of the South Segregation Area, which includes the 6 pipes listed above (McMurray Geological Consulting, 2003, table 3, p. 13). The report further states that, in the breccia pipes mined in the North Segregation Area, inferred reserves based on surface drilling can be expanded 
significantly when the company in question completes a shaft and drifts and conducts more detailed development drilling underground. The individual orebodies in these pipes are typically very narrow, vertically oriented, and difficult to intercept during surface drilling. Using data reported for the 6 mined pipes (McMurray Geological Consulting, 2003, table 4), the report concludes that the ratio of actual measured reserves to surface-indicated reserves is $3.65: 1$. Based on his analysis, which found increases in uranium reserves based on the past underground development of pipes, McMurray (2003, table 5, p. 17) concluded that, in his terms, "adjusted reserves" of 87.5 million pounds $\mathrm{U}_{3} \mathrm{O}_{8}$ exist in breccia pipes drilled at the time of the analysis. This value, combined with known production cited above, exceeds 100 million pounds $\mathrm{U}_{3} \mathrm{O}_{8}$.

Companies known to have recently conducted exploration in and near the three segregation areas include Denison Mines, Quaterra Resources Inc., VANE Minerals Group, Tournigan Energy Ltd. (Tournigan USA Inc.), Liberty Star Uranium \& Metals Corp., Energy Fuels Resources Corp., DIR Exploration, Inc., and Uranium One Exploration, U.S.A. (R. Cox, U.S. Bureau of Land Management, written commun., 2009).

\section{Characteristics of Breccia Pipes, Related Circular Features, and Resultant Uncertainties in Resource Estimation}

The principal question in resource estimation is how many deposits of what size are present in a particular area. For the Grand Canyon region, the question is not only how many breccia pipes are present, but also how many of them are mineralized with uranium. A description of the breccia pipes and their geologic setting helps geologists understand the difficulties in exploring for them.

Breccia pipes in the Grand Canyon region typically extend vertically from the Mississippian Redwall Limestone as much as a few thousand feet, locally reaching the Petrified Forest Member of the Triassic Chinle Formation (fig. 4). The breccia pipes are roughly circular in shape, about $200-400 \mathrm{ft}$ in diameter, and have a solution-collapse origin. The breccia pipes are often characterized by inward-dipping beds along the margins and internal ring-shaped fracture zones. The width of the collapsed zone in the overlying beds can be many times larger than the largest diameter of the pipe itself. The solution collapse has generated abundant breccia derived from overlying strata. The breccias may have abundant voids or openings or may be tightly cemented by a variety of minerals, including uranium minerals.
Where it occurs, uranium mineralization is usually located in the pipe adjacent to the upper part of the Supai Group, the Hermit Formation, or the Coconino Sandstone, but can also extend much higher or lower stratigraphically. Weak uranium mineralization may extend several hundred feet to over 1,000 feet within a pipe. A sulfide cap may be present in the upper part of the mineralized portion of a pipe. A wide variety of other trace elements accompany the uranium; copper and silver are present in many breccia pipes in sufficient quantities to have been mined in years past. Bleaching of nearby wallrock, weakly uraniferous iron-cemented zones in permeable wallrock, and a weak geochemical signature in soils, springs, and stream sediments may be present. The breccia pipe deposits formed 200-260 million years ago (Wenrich and Sutphin, 1989).

Several plateaus formed in the areas north and south of the Grand Canyon, mostly during erosion that predates the canyon. Each of the plateaus is capped by resistant rocks, from varying formations in the stratigraphic section. Examples of plateau-capping units include the Redwall Limestone in the western part of the Grand Canyon area and the lower Permian Kaibab Formation in the east. The level of erosion controls the degree of preservation of uranium deposits in the Grand Canyon area. Where the Redwall Limestone caps a plateau, many breccia pipes are exposed, but there is little remnant oxidized mineralization preserved in the pipes because the mineralization primarily occurs adjacent to formations well above the Redwall Limestone. Where the Kaibab Formation forms the plateau surface, the pipes are only occasionally exposed in deeper canyons. In the Vermilion Cliffs area, formations that postdate the Chinle Formation cap the plateau and there is no known exposure of breccia pipes, although they may be present beneath the plateau.

The ease of investigating breccia pipes exposed on canyon walls throughout the region led to the mining of copper and silver in the late 1800s and more recently for the mining of uranium. However, detection of the presence of unexposed breccia pipes on plateaus is more difficult. On plateau surface areas, features that suggest a breccia pipe may be present include roughly circular grassy outlines in vegetation, inward dipping beds, zones of alteration in the center, oval to circular depressions with radial drainage, and depressions with surrounding raised ridges (Wenrich and Sutphin, 1988; Wenrich and others, 1990). However, many of these features can have other origins, including:

- sinkholes derived from the dissolution of limestone in the Kaibab Formation;

- collapse features caused by dissolution of gypsum beds in the Harrisburg Gypsiferous Member of the Kaibab Formation and Woods Ranch Member of the Toroweap Formation; and

- zones of stratabound, oxidized copper-mineralized breccias in the Kaibab Formation. 


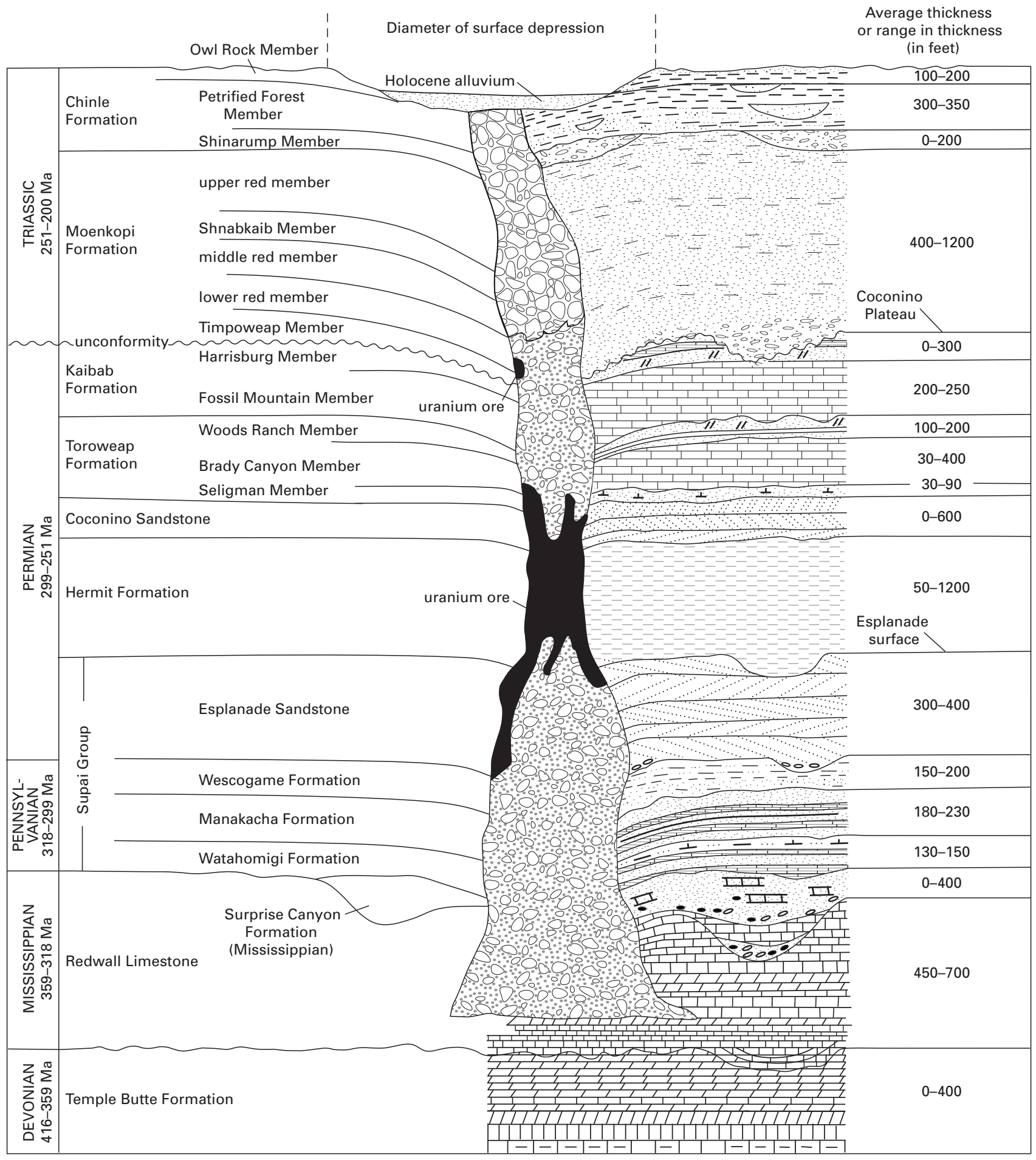

Figure 4. Simplified geologic cross section of a typical breccia pipe showing maximum known vertical stratigraphic extension (about 3,000 feet) and location of ore. Internal structure of the pipe is not shown. The width across a pipe is typically 200-400 feet and is often narrowest in the "throat" where it passes through the Hermit Formation.. 
Once a feature is evaluated for geologic, geochemical, and geophysical characteristics, further exploration would involve drilling. Pool and Ross (2007, p. 11-1) report:

Shallow drilling was often conducted to locate the centre of the collapse feature as a guide to the throat of the underlying breccia pipe. The basic tool for exploring breccia pipes in northern Arizona is deep rotary drilling supplemented by core drilling, to a depth of 2,000 ft. or more from surface. Prospective pipes were usually first tested with three drill holes. If no showing of mineralization was present, the effort was abandoned.

Drilling of breccia pipes is a difficult process. Substantial depths, approximately 2,000 ft., small targets, approximately $200 \mathrm{ft}$. in diameter, and nonhomogeneous rock formations combine to limit the accuracy of the drilling process. The presence of cavernous and brecciated sediments near the present land surface can result in loss of circulation of drilling fluid; as a result, much drilling is conducted "blind". Periodic "spot cores" are taken to determine whether or not holes are within the target structure or have drifted away from the pipe. Indeed, most pipes cannot be completely drilled out from the surface due to deviation from desired targets. All drill holes are surveyed for deviation and logged with gamma logging equipment.

If surface drilling provides sufficient encouragement that a mine can be developed on that basis, a vertical shaft is sunk or drilled to its ultimate depth and underground drill stations are established at various levels to provide platforms for further exploration and delineation drilling. Drilling from underground stations typically utilized large-bore percussion drills. The resulting drill holes, out to as much as approximately $200 \mathrm{ft}$., were then gamma logged and surveyed as a supplement to surface drilling.

As previously discussed, many breccia pipes may have little or no surface expression and are thus hidden. The Hack 2 pipe was recognized only by some surface bleaching in an outcrop of Hermit Shale along a canyon wall. The presence of the breccia pipe was confirmed by subsequent drilling (G. Billingsley, oral commun., 2009). Without the canyon incision, the breccia pipe would not have had any surface expression. Quaterra Resources Inc. has used airborne variable time-domain electromagnetic (VTEM) geophysical surveys to identify possible hidden breccia pipes (Spiering, 2009). The company announced a significant drilling intercept of $57 \mathrm{ft}$ averaging 0.33 percent $\mathrm{U}$ on their A-1 VTEM anomaly. Upward stoping by solution collapse at the A-1 pipe had stopped about $400 \mathrm{ft}$ below the present land surface. The company reports that another hidden pipe, A-20, has been confirmed as having significant uranium intercepts. In their surface holdings of $85 \mathrm{mi}^{2}$ within and near the North Segregation Area, Quaterra reports over 200 geophysical anomalies, only a few of which have been drilled.

These factors make it difficult to use estimates of numbers of pipes or density of pipes per square mile, percentage of mineralized pipes, and the average size of orebodies to estimate undiscovered uranium resources. This is especially true for gently rolling plateau surfaces with very limited dissection, which do not provide three-dimensional exposure necessary to recognize breccia pipes. The East and South Segregation Areas occupy such topography, whereas the North Segregation Area has substantial dissection along Kanab Creek and its tributaries. Work by Scott (1992) on the South Segregation Area illustrates the difficulty. Using simple drainage, topography, color, and vegetation criteria developed by Wenrich and Sutphin (1988) and from analyses of aerial photos, Scott lists 495 "circular features" (Scott, 1992, table 4, p. 121-126). Of these, 104 circular features were field checked for evidence of concentric, inward-dipping beds and visible alteration. Only 9 of the 104 features had both of these criteria (Scott, 1992, table 5) and are thus more likely to be breccia pipes. Even with these two criteria at a site, only drilling can determine with certainty whether a breccia pipe is present and if it contains uranium mineralization. Wenrich (1992) reports nine documented mineralized breccia pipes in the Tusayan Ranger District.

\section{The 1990 Finch and Others Estimate}

In 1987, Finch and others (1990) prepared a quantitative estimate of the undiscovered uranium "endowment" in breccia pipes in the Grand Canyon region of northern Arizona. This estimate did not consider whether the deposits are economically recoverable. The estimate was based on studies that established the criteria that appear to control the presence of breccia pipes, regional geologic mapping, detailed investigation of a well-characterized area, and the depositsize-frequency (DSF) method (Finch and McCammon, 1987). The DSF method is a modified version of the DOE's National Uranium Resource Evaluation method used to assess undiscovered uranium resources for the entire United States. Based on geologic criteria related to formation and preservation of the deposits, the northern Arizona region was divided into four favorable areas (A-D) and one unfavorable area (E) (fig. 3). Unfavorable area $\mathrm{E}$ is underlain by the Redwall Limestone, but none of the pipes in the Redwall Limestone contain significant uranium mineralization in that area. The method evaluates the undiscovered uranium endowment of the various favorable areas by comparing the favorable areas to a reasonably well-exposed and explored "control area." 
The formula used to assess undiscovered uranium endowment (Finch and McCammon, 1987; Finch and others, 1990, p. 5) is as follows:

$$
U=A\left(\sum_{i=1}^{k}\left(\frac{n_{i c}}{A_{c}}\right) T_{i}\right) G \times L
$$

where

$U$ is the unconditional uranium endowment in tons of $\mathrm{U}_{3} \mathrm{O}_{8}$ above a cutoff of 0.01 percent $\mathrm{U}_{3} \mathrm{O}_{8}$,

$A$ is the favorable area in square miles,

$k$ is the number of deposit-size classes (four for the Grand Canyon area),

$n_{i c} / A_{c}$ is the spatial density (number of deposits/unit area) of deposits of size $T_{i}$ within a control area $A_{c}$,

$T_{i}$ is the tons of endowed rock in the $i^{\text {th }}$ depositsize class,

$A_{c}$ is the control area from which estimates of $n_{i c} / A_{c}$ are taken,

$G$ is the grade distribution of endowment, in decimal fraction form,

and

$L \quad$ is the optional scaling factor that expresses the relation between the endowment in the favorable area to either the control area or some designated subarea for which estimates of the number of deposits in different size classes have been made.

Note that the factor within the parentheses when multiplied by $G$ has the unit of tons $\mathrm{U}_{3} \mathrm{O}_{8}$ per square mile and therefore can be considered as an endowment density.

Grade distributions, size-frequency distributions, L-factors, and associated probabilities of occurrence were established by elicitation from the principal scientist, H.B. Sutphin, on April 19 and 20, 1987. The surface areas of all favorable area subdivisions were calculated. The Finch and others (1990) study also subdivided favorable areas by the presence of volcanic rocks or younger age sedimentary formations. The eight National Topographic Mapping System (NTMS) $1^{\circ} \times 2^{\circ}$ quadrangles that cover the region were also used to subdivide the region. The TENDOWG software developed by DOE and modified by the USGS (McCammon and others, 1988) was used to calculate the undiscovered uranium endowment in 17 favorable subareas. The calculated undiscovered uranium endowments for each subarea were ranked according to probability of occurrence from 0.05 to
0.95 and a mean probability value was calculated. The sum of the mean probabilities for the entire Grand Canyon region is the most likely endowment value for undiscovered uranium according to the method.

The North Segregation Area includes the Hack-Pinenut control area used in the Finch and others (1990) resource estimate, a 141- $\mathrm{mi}^{2}$ area within favorable area A covering almost all of four townships centered on the Hack and Pinenut Mines (fig. 5). Characterization of the Hack-Pinenut control area by Finch and others (1990) was based on a USGS review of exploration and development drillhole logs and calculations of $\mathrm{U}_{3} \mathrm{O}_{8}$ reserves provided by EFN for its entire drilling program. EFN was the primary mining claim owner and the only producer of uranium in the area during the 1980s.

Finch and others (1990) show that most of the undiscovered uranium endowment (910,350 tons [1.82 billion pounds] of $\mathrm{U}_{3} \mathrm{O}_{8}$ out of a total 1.315 million tons [2.6 billion pounds $\mathrm{U}_{3} \mathrm{O}_{8}$ ) lies within the highest ranked favorable area A. As mentioned earlier, all three segregation areas fall within favorable area A (fig. 3). Favorable area A is limited on the west by outcrops of the base of the Hermit Formation where it is exposed in cliffs along the western margin of the Colorado Plateau and in the canyon of the Colorado River. On the north and east, it is bounded by outcrops of the top of the Petrified Forest Member of the Chinle Formation. Breccia pipes have not been observed in rocks younger than this member. The southernmost limit is a line drawn arbitrarily about $10 \mathrm{mi}$ south of the southernmost known breccia pipes. Favorable area $\mathrm{A}$ includes many areas underlain by volcanic and young sedimentary rocks of varying thickness that would make it very difficult to explore for and develop deposits. The endowment of those areas was calculated but considered separately as a secondary group in Finch and others (1990). Volcanic and young sedimentary rocks do not occur in any of the three segregation areas.

The calculated results for the mean endowment of the Hack-Pinenut control area is 16,429 tons $\mathrm{U}_{3} \mathrm{O}_{8}$ (Finch and others, 1990) or 32.8 million pound $\mathrm{U}_{3} \mathrm{O}_{8}$ in the $141-\mathrm{mi}^{2}$ area. The range of values (probability $0.05-0.95$ ) was from 4,337 to 34,063 tons ( 8.7 to 68 million pounds) $\mathrm{U}_{3} \mathrm{O}_{8}$. The mean endowment figure yields an average density of 116.5 tons (233,000 pounds) $\mathrm{U}_{3} \mathrm{O}_{8} / \mathrm{mi}^{2}$. To date, known production (Hack 1, 2, 3, Pinenut) and inferred reserves (Pinenut, Arizona 1) in the Hack-Pinenut control area total 5,950 tons $\mathrm{U}_{3} \mathrm{O}_{8}\left(11.9\right.$ million pounds $\left.\mathrm{U}_{3} \mathrm{O}_{8}\right)$. Several additional mineralized breccia pipes (10), known breccia pipes (12), and possible breccia pipes (9) (fig. 5) are in the Hack-Pinenut control area and hidden pipes may be present (Finch and others, 1990, map on p. 9; McMurray Geological Consulting, 2003; Spiering, 2009). These pipes would contain the balance of the uranium resource estimate. 


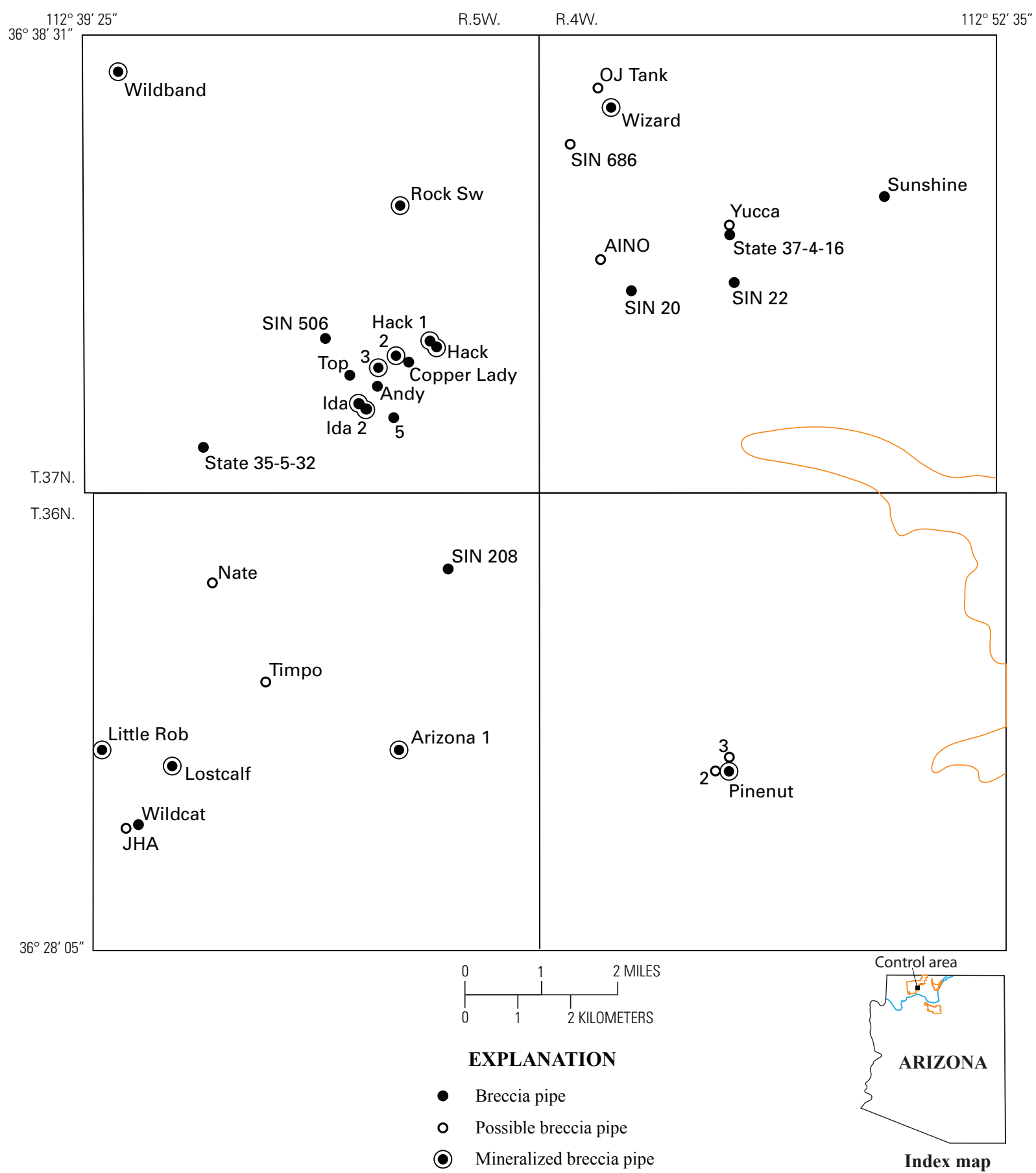

Figure 5. Map of the Hack-Pinenut control area for uranium-bearing solution-collapse breccia pipes. From Finch and others (1990). East side shows boundary between favorable area A and favorable area D. 


\section{Differences in the Surface Area Calculation between the 1990 Finch and Others Report and the Present Study}

During GIS analysis of surface areas for the areas withdrawn before July 21, 2009, the authors noted that calculated surface areas for the present report were higher than those cited by Finch and others (1990). The surface area for favorable area A derived from Finch and others (1990) is shown in table 2. Note that not all of the surface area of certain Federal units (Grand Canyon National Park, Grand Canyon-Parashant National Monument), tribal land (the Hualapai and Havasupai Reservations), and other entities are in favorable area A. The surface areas of those land units are split between favorable area A away from the Colorado River and favorable area $\mathrm{D}$ and unfavorable area $\mathrm{E}$ along the river where erosion has removed the most favorable rock units. The surface of the Hack-Pinenut control area is included in the total because Finch and others (1990) excluded it from their resource appraisal and the endowment was calculated separately.

The surface area calculated by the present study for favorable area $\mathrm{A}, 10,750 \mathrm{mi}^{2}$, is 16.3 percent larger than that calculated by Finch and others (1990). The Finch and others map (1990, fig. 2) included longitude and latitude lines that permitted georeferencing and facilitated a recalculation of the area for this study. As the exact surface area affects the endowment density calculation, the surface areas calculated for this study for two Forest Service units of land and two reservations were also compared to those reported from official sources (table 3 ). The comparisons show that the surface areas determined in the present study for tribal, park, monument, and forest entities are reasonably accurate representations. Differences may reflect differences in delineation of boundaries, exclusion or inclusion of inholdings and water bodies, and the type of projection used to calculate

Table 2. Surface areas reported for favorable area A by Finch and others (1990, table 2).

$\left[\mathrm{A}_{\mathrm{b}}\right.$, areas with basalt cover; $\mathrm{A}_{\mathrm{s}}$, areas with young sediment cover; NTMS, National Topographic Mapping System]

\begin{tabular}{ccr}
\hline $\begin{array}{c}\text { NTMS } \mathbf{1}^{\mathbf{0}} \times \mathbf{2}^{\mathbf{0}} \\
\text { quadrangle name }\end{array}$ & Subarea & $\begin{array}{c}\text { Surface area } \\
\left(\mathbf{m i}^{\mathbf{2}}\right)\end{array}$ \\
\hline Grand Canyon & $\mathrm{A}_{\mathrm{A}}$ & 4,290 \\
Cedar City & $\mathrm{A}_{\mathrm{b}}$ & 399 \\
Williams & $\mathrm{A}$ & 207 \\
& $\mathrm{~A}$ & 1,665 \\
Marble Canyon & $\mathrm{A}_{\mathrm{s}}$ & 201 \\
& $\mathrm{~A}_{\mathrm{b}}$ & 232 \\
Flagstaff & $\mathrm{A}$ & 1,095 \\
& $\mathrm{~A}_{\mathrm{b}}$ & 1 \\
Subtotal & $\mathrm{A}$ & 843 \\
Hack-Pinenut & $\mathrm{A}_{\mathrm{b}}$ & 173 \\
control area & Partly in area A & 9,106 \\
Total & & 141 \\
\hline
\end{tabular}

Table 3. Comparison of surface areas calculated during this study compared to other sources.

\begin{tabular}{|c|c|c|}
\hline $\begin{array}{c}\text { Name of } \\
\text { withdrawn area }\end{array}$ & $\begin{array}{c}\text { Surface area of } \\
\text { unit calculated } \\
\text { during this study } \\
\left(\mathrm{mi}^{2}\right)\end{array}$ & $\begin{array}{c}\text { Published } \\
\text { surface area from } \\
\text { official sources } \\
\left(\mathrm{mi}^{2}\right)\end{array}$ \\
\hline Tusayan Ranger District & 520 & $518^{1}$ \\
\hline Havasupai Reservation & 269 & $294^{2}$ \\
\hline $\begin{array}{l}\text { Hualapai Reservation } \\
\text { (main section) }\end{array}$ & 1,590 & $1,551^{3}$ \\
\hline North Kaibab Ranger District & 1,022 & $1,010^{4}$ \\
\hline \multicolumn{3}{|c|}{$\begin{array}{l}\text { 'U.S. Forest Service, 2009a; M. Porter, Kaibab National Forest, written } \\
\text { commun., October } 2009 .\end{array}$} \\
\hline \multicolumn{3}{|c|}{${ }^{2}$ Center for American Indian Economic Development, 2009a. } \\
\hline \multicolumn{3}{|c|}{${ }^{3}$ Center for American Indian Economic Development, 2009b. } \\
\hline${ }^{4}$ U.S. For & & \\
\hline
\end{tabular}

surface areas. If the higher values for surface areas are accepted, then the endowment densities determined during the Finch and others (1990) study need to be adjusted downward from 112.4 tons $\mathrm{U}_{3} \mathrm{O}_{8} / \mathrm{mi}^{2}$ to 96.6 tons $\mathrm{U}_{3} \mathrm{O}_{8} / \mathrm{mi}^{2}$ (from 224,800 pounds to 193,200 pounds). Note that the lower, corrected undiscovered uranium endowment density $\left(96.6\right.$ tons $\left.\mathrm{U}_{3} \mathrm{O}_{8} / \mathrm{mi}^{2}\right)$ is compensated for by the increased surface area for all favorable areas; therefore, the Finch and others (1990) endowment numbers are the same.

\section{Estimated Resources Associated with Pre-2009 Mineral Withdrawal Lands in Northern Arizona}

Prior to July 2009, several tracts of land in favorable area A were withdrawn from mineral entry in the Grand Canyon area. An estimate of the surface areas of these withdrawn lands within favorable area $\mathrm{A}$ was made using a digitized version of the Finch and others map (1990, fig. 2), boundary files for the withdrawn lands, and GIS techniques for calculating surface areas of intersecting polygons using the Albers equal area projection. The calculated surface areas of specific lands is given in table 4 .

Using the corrected average of the endowment density for favorable area A of 96.6 tons (193,200 pounds) $\mathrm{U}_{3} \mathrm{O}_{8} / \mathrm{mi}^{2}$, the endowment for the areas withdrawn before July 2009 can be calculated as in table 5 .

Bliss and Pierson (1993, p. 33) also evaluated the undiscovered uranium endowment of the Kaibab National Forest (KNF), based on the Finch and others (1990) assessment:

The total mean unconditional endowment of 233,000 short tons (st) (211,000 metric tons (mt)) $\mathrm{U}_{3} \mathrm{O}_{8}$ for the KNF is 18 percent of the total mean endowment of 1,320,000 st $(1,200,000 \mathrm{mt})$ estimated for solutioncollapse breccia pipes in the Grand Canyon Region of Northern Arizona and adjacent Utah (Finch and others, 1990). Most of the undiscovered $\mathrm{U}_{3} \mathrm{O}_{8}$ endowment in this region for this deposit type is expected to be found 
in areas outside of the KNF. Of the three units evaluated (North Kaibab District, Tusayan District, and the combined Chalendar-Williams districts), the North Kaibab district is expected to contain approximately half of the undiscovered uranium endowment (mean of 112,000 st $\left.(102,000 \mathrm{mt}) \mathrm{U}_{3} \mathrm{O}_{8}\right)$ predicted in the $\mathrm{KNF}$. The remaining undiscovered uranium endowment is almost equally divided between the other two units - 57,800 st (52,400 mt) in the Tusayan District and 63,400 st (57,500 $\mathrm{mt})$ in the combined ChalendarWilliams districts. [A short ton, "st" in Bliss and Pierson (1993), is equivalent to a ton.]

Pierson was one of the authors of the Finch and others (1990) report; in their report, Bliss and Pierson (1993) appear to have used the 112.4 tons (224,800 pounds) $\mathrm{U}_{3} \mathrm{O}_{8} / \mathrm{mi}^{2}$ endowment density and a surface area very similar to that determined here for the North Kaibab Ranger District to calculate the reported 112,000 tons (224 million pounds) $\mathrm{U}_{3} \mathrm{O}_{8}$, as that number is identical to the number calculated here using the uncorrected endowment density.

\section{Estimates of the Uranium Resources in the Three Segregation Areas}

The three proposed withdrawal areas are the North Segregation Area (BLM lands mostly in the Kanab Creek watershed), the East Segregation Area (BLM lands in the House Rock Valley area), and the South Segregation Area (Forest Service lands in the Tusayan Ranger District). Table 6 gives the surface area of these lands based on digital boundary files provided by Rody Cox (BLM, written commun., 2009).

Again using the corrected endowment density for favorable area $\mathrm{A}$ of 96.6 tons $\left(193,200\right.$ pounds) $\mathrm{U}_{3} \mathrm{O}_{8} / \mathrm{mi}^{2}$, the endowment for the three proposed withdrawal areas can be calculated as in table 7.

The undiscovered uranium endowment estimate calculated for the South Segregation Area is less than the estimate calculated by Bliss and Pierson (1993), apparently because they used the higher, uncorrected endowment density and an accurate surface area. If the original endowment density is used, then the calculated values would be about 1 percent greater than Bliss and Pierson's calculation.

In testimony to The Subcommittee on National Parks, Forests, and Public Lands of the Committee on Natural Resources on July 21, 2009, Madan Singh of the Arizona Department of Mines and Mineral Resources stated that 375 million pounds (187,500 tons) $\mathrm{U}_{3} \mathrm{O}_{8}$ occur within the three segregation areas (Singh, 2009). This estimate is also based on the Finch and others (1990) resource analysis and used the surface areas of the three proposed withdrawal areas as originally found in the bill by Representative Grijalva and the uncorrected endowment density at 112.4 tons (224,800 pounds) $\mathrm{U}_{3} \mathrm{O}_{8} / \mathrm{mi}^{2}$ (M. Singh, written commun., 2009).
Table 4. Calculated surface areas of previously withdrawn lands that lie within favorable area $A$ (see fig. 3).

[Note that differences may exist between the surface areas shown here and other sources. For Grand Canyon National Park, Grand Canyon-Parashant National Monument, the Hualapai and Havasupai Reservations, and other entities, the surface areas are split between favorable area $\mathrm{A}$ and favorable area $\mathrm{D}$ and unfavorable area $\mathrm{E}$ along the canyon of the Colorado River and its tributaries]

\begin{tabular}{lc}
\hline \multicolumn{1}{c}{$\begin{array}{c}\text { Withdrawn } \\
\text { land designation }\end{array}$} & $\begin{array}{c}\text { Surface area } \\
\left(\mathbf{m i}^{2}\right)\end{array}$ \\
\hline Grand Canyon National Park & 762 \\
Grand Canyon-Parashant National Monument & 976 \\
Havasupai Reservation & 234 \\
Hualapai Reservation & 557 \\
North Kaibab National Forest & 997 \\
Navajo Reservation & 1,194 \\
Kaibab Paiute Reservation & 90 \\
Vermilion Cliffs National Monument & 18 \\
Total for withdrawn areas & $\mathbf{4 , 8 2 8}$ \\
\hline
\end{tabular}

Table 5. Estimated undiscovered uranium endowment for previously withdrawn lands within favorable area $\mathrm{A}$.

\begin{tabular}{lc}
\hline \multicolumn{1}{c}{$\begin{array}{c}\text { Withdrawn } \\
\text { land designation }\end{array}$} & $\begin{array}{c}\text { Endowment } \\
\text { in tons } \mathbf{U}_{\mathbf{3}} \mathbf{0}_{\mathbf{8}}\end{array}$ \\
\hline Grand Canyon National Park & 73,609 \\
Grand Canyon-Parashant National Monument & 94,282 \\
Havasupai Reservation & 22,604 \\
Hualapai Reservation & 53,806 \\
North Kaibab National Forest & 96,310 \\
Navajo Reservation & 115,340 \\
Kaibab Paiute Reservation & 8,694 \\
Vermilion Cliffs National Monument & 1,739 \\
Total for withdrawn areas & $\mathbf{4 6 6 , 3 8 4}$ \\
\hline
\end{tabular}

Table 6. Surface area of the July 2009 segregation areas.

\begin{tabular}{cc}
\hline $\begin{array}{c}\text { Segregation } \\
\text { area }\end{array}$ & $\begin{array}{c}\text { Surface area } \\
\left(\mathbf{m i}^{\mathbf{2}}\right)\end{array}$ \\
\hline North & 952 \\
East & 226 \\
South & 509 \\
Total & $\mathbf{1 , 6 8 7}$ \\
\hline
\end{tabular}

Table 7. Estimated undiscovered uranium endowment in the July 2009 segregation areas.

\begin{tabular}{cc}
\hline $\begin{array}{c}\text { Segregation } \\
\text { area }\end{array}$ & $\begin{array}{c}\text { Endowment } \\
\text { in tons } \mathbf{U}_{\mathbf{3}} \mathbf{0}_{\mathbf{8}}\end{array}$ \\
\hline North & 91,963 \\
East & 21,832 \\
South & 49,169 \\
Total & $\mathbf{1 6 2 , 9 6 4}$ \\
\hline
\end{tabular}




\section{Pre-Existing Mining Claims and Estimated Undiscovered Uranium Endowment}

Under the withdrawal proposal, mining claims filed before the proposal date will not be withdrawn from further development, but the validity of existing rights will need to be established during the segregation period. These pre-existing mining claims occupy varying percentages of each of the proposed withdrawal areas (fig. 2): for the North Segregation Area, $474 \mathrm{mi}^{2}$, or 49.8 percent of the area; for the East Segregation Area, $4.4 \mathrm{mi}^{2}$, or 1.9 percent of the area; and for the South Segregation Area, $149 \mathrm{mi}^{2}$, or 29 percent of the area.

Although it seems probable that pre-existing mining claims were filed in areas with a higher potential for finding breccia pipes with significant uranium resources, an analysis of this effect on resource availability was not possible for this study. Table 8 , based on the corrected endowment density and the surface area of pre-existing mining claims and areas outside of pre-existing mining claims, gives the uranium endowment within each segregation area that underlies existing mining claims and the endowment that does not.

Table 8. Estimated undiscovered uranium endowment in the July 2009 segregation areas under pre-existing mining claim and not under pre-existing mining claim (in tons $\mathrm{U}_{3} \mathrm{O}_{8}$ ). Differences between the total endowment in this table $\left(163,380\right.$ tons $\left.\mathrm{U}_{3} \mathrm{O}_{8}\right)$ and that in table $7\left(162,964\right.$ tons $\left.\mathrm{U}_{3} \mathrm{O}_{8}\right)$ are due to rounding errors.

\begin{tabular}{ccc}
\hline $\begin{array}{c}\text { Segregation } \\
\text { area }\end{array}$ & $\begin{array}{c}\text { Endowment- } \\
\text { existing claims }\end{array}$ & $\begin{array}{c}\text { Endowment- } \\
\text { not in } \\
\text { existing claims }\end{array}$ \\
\hline North & 45,808 & 46,136 \\
East & 425 & 21,832 \\
South & 14,403 & 34,776 \\
Total & $\mathbf{6 0 , 6 3 6}$ & $\mathbf{1 0 2 , 7 4 4}$ \\
\hline
\end{tabular}

\section{Conclusions}

The Finch and others (1990) uranium resource estimate compares the well-exposed, reasonably well-explored and developed Hack-Pinenut control area to other areas where there is much less exposure and much less exploratory and development drilling. For favorable area A, the assumption was that the endowment in all of favorable area A closely resembles that of the Hack-Pinenut control area. The L-factors (see equation 1) used for all the favorable area A sectors throughout northern Arizona were 0.90 (lower), 0.99 (most likely), and 1.00 (upper), suggesting close resemblance to the Hack-Pinenut control area (Finch and others, 1990, table 2). $\mathrm{L}$-factors for the other favorable areas are lower. Most likely L-factors for favorable areas B, C, and D were $0.55,0.10$, and 0.13 , respectively. The estimate does not rely on counts of circular features, assumptions about the number of breccia pipes and mineralized breccia pipes represented by those circular features, or the tons of uranium in an average uranium mineralized breccia pipe. The key uncertainty is how well the Hack-Pinenut control area represents the remainder of favorable area $\mathrm{A}$ where most of the endowment occurs. This cannot be known with a greater degree of certainty without further exploration and development drilling in other areas, including further exploration for hidden breccia pipes suggested by geophysical techniques. The possibility of hidden breccia pipes was not considered explicitly in the Finch and others (1990) assessment. Further development of genetic models for the formation of the breccia pipe uranium ore deposits could aid a new assessment by allowing additional favorable and unfavorable factors to be developed and applied.

The estimated mean undiscovered uranium endowment for the areas withdrawn from mineral entry prior to July 21, 2009 , is 466,384 tons (about 933.6 million pounds) $\mathrm{U}_{3} \mathrm{O}_{8}$ or 35 percent of the 1,315,383 total estimated tons (about 2.6 billion pounds) $\mathrm{U}_{3} \mathrm{O}_{8}$ in all favorable areas in northern Arizona (Finch and others, 1990, tables 3 and 4). The estimated mean undiscovered uranium endowment for the three segregation areas proposed in the July 21, 2009, announcement is 162,964 tons (326 million pounds) $\mathrm{U}_{3} \mathrm{O}_{8}$ or 12 percent. Combined, the three segregation areas and previously withdrawn areas would contain about 48 percent of the total estimated undiscovered uranium endowment in all favorable areas for northern Arizona (Finch and others, 1990, fig. 2). However, all three areas under consideration are within favorable area $\mathrm{A}$, the most prospective area. The combined withdrawal would represent 69 percent of the 910,350 tons (1.82 billion pounds) $\mathrm{U}_{3} \mathrm{O}_{8}$ estimated to occur in favorable area $\mathrm{A}$.

If the endowment under pre-existing mining claims is excluded from withdrawal in each of the three segregation areas, the estimated mean uranium endowment for the three segregation areas proposed in the July 21, 2009, announcement is 102,744 tons (205 million pounds) $\mathrm{U}_{3} \mathrm{O}_{8}$ or 7.8 percent of the endowment in all favorable areas. Combined, the three segregation areas and previously withdrawn areas would contain about 43 percent of the total estimated uranium endowment in all favorable areas for northern Arizona. As noted above, all three segregation areas are within favorable area A, the most prospective area. Thus the combined withdrawal would represent 62.5 percent of the 910,350 tons (1.82 billion pounds) $\mathrm{U}_{3} \mathrm{O}_{8}$ estimated to occur in favorable area $\mathrm{A}$.

Because of the difficulties in exploring for breccia pipes, assessing them, and proving that a breccia pipe uranium ore deposit can be mined economically, it seems likely that development of the resource would occur slowly. Nine breccia pipes were mined (Pigeon, Hermit, Hack 1, 2, 3), partly mined (Kanab North, Pinenut), or partially developed without mining (Arizona 1, Canyon) over a period of 12 to 14 years. The rate of development is sensitive to the price received for the produced uranium, a factor that has varied substantially in the past ten years; higher prices would encourage development. 


\section{Acknowledgments}

We thank Laura Biewick (USGS) for creating maps from GIS databases to display location information and for extracting surface area data from GIS files provided by Rody Cox (BLM) for the various features described in this report. Rody Cox, Madan Singh (Arizona Department of Mines and Mineral Resources), Cindy Woodward (Denison Mines), and David Scott (USGS) provided useful discussion and copies of documents related to uranium resources in breccia pipes in northern Arizona. Thomas M. Roesch (Newmont Mining Corporation) granted permission to use the McMurray Geological Consulting, Inc. report. We thank Warren Finch (USGS, emeritus) and David Scott (USGS) for reviewing an early version of this paper.

\section{References Cited}

Baillieul, T.A., and Zollinger, R.C., 1980, National uranium resource evaluation, Grand Canyon Quadrangle, Arizona: Bendix Field Engineering Corporation, U.S. Department of Energy Contract no. DE-ACI3-76GJOI664, 43 p.

Billingsley, G.H., Antweiler, J.C., Beard, L.S., and Lucchitta, Ivo, 1986, Mineral resource potential map of the Pigeon Canyon, Nevershine Mesa, and Snap Point Wilderness Study Areas, Mohave County, Arizona: U.S. Geological Survey Miscellaneous Field Studies Map 1860-A, scale 1:50,000, $10 \mathrm{p}$. text.

Billingsley, G.H., Antweiler, J.C., and Ellis, C.E., 1983, Mineral resource potential map of the Kanab Creek Roadless Area, Coconino and Mohave counties, Arizona: U.S. Geological Survey Miscellaneous Field Studies Map 1627-A, scale 1:48,000, 10 p. text.

Billingsley, G.H., and Ellis, C.E., 1983, Kanab Creek Roadless Area, Arizona, in Marsh, S.P., Kropschot, S.J., and Dickinson, R.G., eds., Wilderness mineral potential, assessment of mineral-resource potential in U.S. Forest Service lands studied 1964-1984: U.S. Geological Survey Professional Paper 1300, p. 76-78.

Bliss, J.D., and Pierson, C.T., 1993, Mineral resource assessment of solution-collapse breccia pipe uranium deposits, in Bliss, J.D., ed., Mineral resource assessment of undiscovered mineral deposits for selected mineral deposit types in the Kaibab National Forest, Arizona: U.S. Geological Survey Open-File Report 93-329, p. 30-33.

Bush, A.L., 1983, Geologic map of the Vermilion CliffsParia Canyon instant study area and adjacent wilderness study areas, Coconino County, Arizona, and Kane County, Utah: U.S. Geological Survey Miscellaneous Field Studies Map MF-1475-A, scale 1:62,500, 1 plate.
Bush, A.L., and Lane, M.E., 1982a, Mineral resource potential map of the Vermilion Cliffs-Paria Canyon instant study area, Coconino County, Arizona, and Kane County, Utah: U.S. Geological Survey Miscellaneous Field Studies Map 1475-D, scale 1:62,500, 11 p. text.

Bush, A.L., and Lane, M.E., 1982b, Geochemical data and sample locality map of the Vermilion Cliffs-Paria Canyon instant study areas and adjacent wilderness study areas, Coconino County, Arizona, and Kane County, Utah: U.S. Geological Survey Miscellaneous Field Studies Map 1475-B, scale 1:62,500, 1 plate.

Canadian Institute of Mining, Metallurgy and Petroleum (CIM) Standing Committee on Reserve Definitions, 2005, CIM definition standards for mineral resources and mineral reserves: Canadian Institute of Mining, Metallurgy and Petroleum, accessed January 14, 2010, at http://www.cim.org/committees/ CIMDefStds_Dec11_05.pdf.

Center for American Indian Economic Development, [2009]a, Havasupai Reservation, Havasupai Tribe: Northern Arizona University, Center for American Indian Economic Development, accessed October 2009 at http://www.cba.nau.edu/caied/tribepages/Havasupai.asp.

Center for American Indian Economic Development, [2009] b, Hualapai Reservation, Hualapai Tribe: Northern Arizona University, Center for American Indian Economic Development, accessed October 2009 at http://www.cba.nau.edu/caied/tribepages/Hualapai.asp.

Chenoweth, W.L., 1986, The Orphan Lode Mine, Grand Canyon, Arizona - A case history of a mineralized, collapse-breccia pipe: U.S. Geological Survey Open-File Report 86-510, 91 p. [With a 35-page appendix.]

Chenoweth, W.L., 1988, The production history and geology of the Hacks, Ridenour, Riverview and Chapel breccia pipes, northwestern Arizona: U.S. Geological Survey OpenFile Report 88-648, 60 p.

Finch, W.I., and McCammon, R.B., 1987, Uranium resource assessment by the Geological Survey-Methodology and plan to update the national resource base: U.S. Geological Survey Circular 994, 31 p.

Finch, W.I., Sutphin, H.B., Pierson, C.T., McCammon, R.B., and Wenrich, K.J., 1990, The 1987 estimate of undiscovered uranium endowment in solution-collapse breccia pipes in the Grand Canyon region of northern Arizona and adjacent Utah: U.S. Geological Survey Circular 1051, 19 p.

Hopkins, R.T., Fox, J.P., Campbell, W.L., and Antweiler, J.C., 1984, Analytical results and sample locality map of streamsediment, panned concentrate, soil, and rock samples from the Kanab Creek (B3060) Roadless Area, Coconino and Mohave Counties, Arizona: U.S. Geological Survey OpenFile Report 84-291, 18 p., 1 map. 
Lane, M.E., 1984, Mineral investigation of the Pigeon Canyon, Nevershine Mesa, Snap Point, and Last Chance Wilderness Study Areas (BLM), Mohave County, Arizona: U.S. Bureau of Mines Mineral Land Assessment MLA 84-8, 61 pages, accessed October 2009, at http://www.admmr.state.az.us/ DigitalLibrary/USBM_MLA/USBM_MLA_008-84.pdf.

McCammon, R.B., Finch, W.I., Pierson, C.T., and Birdges, M.W., 1988, The micro-computer program TENDOWG for estimating undiscovered uranium endowment: U.S. Geological Survey Open-File Report 88-653, 11 p., 1 diskette.

McDonnell, J.R., Jr., 1984, Mineral investigation of the Mount Trumbull Wilderness Study Area, Mohave County, Arizona: U.S. Bureau of Mines Mineral Land Assessment MLA 31-84, $11 \mathrm{p}$.

McMurray Geological Consulting, Inc., 2003, Analysis of breccia pipe-related uranium potential on the Arizona Strip: Englewood, Colo., McMurray Geological Consulting, Inc., 22 p. [Prepared for Newmont Mining Corporation, used with permission.]

Moreton, Christopher, and Ross, David, 2009, Technical report on the EZ1 and EZ2 breccia pipes, Arizona Strip District, U.S.A.: Scott Wilson Roscoe Postle Associates Inc., [variously paged], accessed October 2009, at http://sec.edgar-online.com/denison-mines-corp/ 6-k-report-of-foreign-issuer/2009/08/18/section24.aspx. [Prepared for Denison Mines Corporation.]

Pool, T.C., and Ross, D.A., 2007, Technical report on the Arizona strip uranium project, U.S.A.: Scott Wilson Roscoe Postle Associates Inc., 116 p., accessed October 2009, at http://www.denisonmines.com/SiteResources/data/ MediaArchive/pdfs/reserves/43-101\%20arizona\%20strip. $p d f$. [Prepared for Denison Mines Corporation.]

Scott, D.C., 1992, Mineral appraisal of the Kaibab National Forest, Arizona: U.S. Bureau of Mines Mineral Land Assessment Report MLA 6-92, 128 p., accessed October 2009, at http://www.admmr.state.az.us/DigitalLibrary/ USBM_MLA/USBM_MLA_006-92.pdf.

Singh, M.M., 2009, Testimony for the Subcommittee on National Parks, Forests and Public Lands of the Committee on Natural Resources, July 21, 2009: State of Arizona, Department of Mines and Mineral Resources, 8 p., accessed October 2009, at http://resourcescommittee.house.gov/ images/Documents/20090721/parks/testimony_singh.pdf.
Spiering, E.D., 2009, Exploration and discovery of blind breccia pipes - The potential significance to the uranium endowment of the Arizona Strip District, northern Arizona, in U2009 International Uranium Conference, Keystone, Colo., May 9-13, 2009, Proceedings: Keystone, Colo., Quaterra Resources, Inc., 33 p., accessed October 2009, at http://www.quaterraresources.com/uploads/projects/ presentation_global_uranium_symposium_09_05.pdf.

Sutphin, H.B., and Wenrich, K.J., 1989, Map locations of collapse-breccia pipes in the Grand Canyon of Arizona: U.S. Geological Survey Open-File Report 89-550, 1 plate.

U.S. Bureau of Land Management, 2009, Proposed mineral withdrawal environmental impact statement: Bureau of Land Management fact sheet, 6 p. (also available online at http://www.blm.gov/pgdata/etc/medialib/blm/az/pdfs. Par.53235.File.dat/Mining-Withdrawal-EIS-Fact-Sheet.pdf).

U.S. Bureau of Mines, 1996, Dictionary of mining, mineral, and related terms CD-ROM: U.S. Bureau of Mines, accessed January 14, 2010, at http://www.maden.hacettepe.edu.tr/dmmrt/.

U.S. Department of Energy, 1980, An assessment report on uranium in the United States of America: U.S. Department of Energy GJO-111(80), 150 p., 6 microfiche.

U.S. Energy Information Administration, 2004, U.S. uranium reserves estimates by state: U.S. Energy Information Administration, accessed October 2009, at http://www.eia.doe.gov/cneaf/nuclear/page/reserves/ uresst.html.

U.S. Forest Service, 2009a, Final environmental assessmentTusayan Ranger District travel management project: U.S. Forest Service, Southwestern Region, 169 p., accessed October 2009 at http://www.fs.fed.us/r3/kai/travelmanagement/ documents/tus-tmr-ea-final-0416-2009.pdf.

U.S. Forest Service, 2009b, Kaibab National Forest-About us: U.S. Forest Service, Southwestern Region, accessed December 2009 at http://www.fs.fed.us/r3/kai/about/.

Van Gosen, B.S., and Wenrich, K.J., 1989, Ground magnetometer surveys over known and suspected breccia pipes on the Coconino Plateau, northwestern Arizona: U.S. Geological Survey Bulletin 1683-C, 31 p.

Verbeek, E.R., Grout, M.A., and Van Gosen, B.S., 1988, Structural evolution of a Grand Canyon breccia pipe-The Ridenour copper-vanadium-uranium mine, Hualapai Indian Reservation, Coconino County, Arizona: U.S. Geological Survey Open-File Report 88-006, 75 p. 
Wenrich, K.J., 1992, Breccia pipes in the Red Butte area of Kaibab National Forest: U.S. Geological Survey Open-File Report 92-219, 13 p.

Wenrich, K.J., Billingsley, G.H., and Huntoon, P.W., 1996, Breccia-pipe and geologic map of the northwest part of the Hualapai Indian Reservation and vicinity, Arizona: U.S. Geological Survey Miscellaneous Investigations Map I-2522, scale 1:48,000, 1 plate.

Wenrich, K.J., Billingsley, G.H., and Huntoon, P.W., 1997, Breccia-pipe and geologic map of the northeastern part of the Hualapai Indian Reservation and vicinity, Arizona: U.S. Geological Survey Miscellaneous Investigations Map I-2440, scale 1:48,000, 2 plates, 19 p. text.

Wenrich, K.J., Billingsley, G.H., and Van Gosen, B.S., 1986, The potential for breccia pipes in the National Tank Area, Hualapai Indian Reservation, Arizona: U.S. Geological Survey Open-File Report 86-592-A, 45 p.
Wenrich, K.J., and Huntoon, P.W., 2000, Breccia-pipe and geologic map of the southeastern part of the Hualapai Indian Reservation and vicinity, Arizona: U.S. Geological Survey Miscellaneous Investigations Map I-2643, scale 1:48,000, 2 plates, 18 p. text.

Wenrich, K.J., and Sutphin, H.B., 1988, Recognition of breccia pipes in northern Arizona: Field Notes, v. 18, no. 1, p. $1-5$.

Wenrich, K.J., and Sutphin, H.B., 1989, Lithotectonic setting necessary for formation of a uranium-rich, solution-collapse breccia-pipe province, Grand Canyon Region, Arizona: U.S. Geological Survey Open-File Report 89-173, 33 p.

Wenrich, K.J., Verbeek, E.R., Sutphin, H.B., Modreski, P.J., Van Gosen, B.S., and Detra, D.E., 1990, Geology, geochemistry, and mineralogy of the Ridenour Mine breccia pipe, Arizona: U.S. Geological Survey Open-File Report 90-0504, 66 p. 



\section{Glossary}

\section{E}

Endowment The physical aggregate of mineral occurrences in a region above some lower cutoff (U.S. Bureau of Mines, 1996). As used in this report, "uranium endowment" is the uranium that is estimated to occur in rock with a grade of at least 0.01 percent $\mathrm{U}_{3} \mathrm{O}_{8}$ (Finch and others, 1990).

\section{M}

Mineral entry The filing of a claim for public land to obtain the right to any minerals it may contain (U.S. Bureau of Mines, 1996).

Mineralization The process or processes by which a mineral or minerals are introduced into a rock, resulting in a valuable or potentially valuable deposit (U.S. Bureau of Mines, 1996).

\section{0}

Ore The naturally occurring material from which a mineral or minerals of economic value can be extracted profitably (U.S. Bureau of Mines, 1996).

Orebody A continuous, well-defined mass of material of sufficient ore content to make extraction economically feasible (U.S. Bureau of Mines, 1996).

Ore deposit A mineral deposit that has been tested and is known to be of sufficient size, grade, and accessibility to be producible to yield a profit (U.S. Bureau of Mines, 1996).

\section{R}

Reserves "Reserves" as used by U.S. Energy Information Administration (2004, p. 1) refers to "the sums of quantities estimated to occur in known deposits on properties where data about the ore grade, configuration, and depth indicate that the quantities estimated could be recovered at or less than the stated costs given current mining and milling technology and regulations." The "stated costs" are forward cost estimates at $\$ 30$ per pound and $\$ 50$ per pound. The term "reserves" is qualified by various authors cited in this report by words such as proven, indicated, probable, potential, and adjusted. The reader is referred to these cited reports for further information.

Resource "Resource" or "uranium resource" as used in this report closely follows the Canadian Institute of Mining, Metallurgy and Petroleum (CIM) definition:

A Mineral Resource is a concentration or occurrence of...natural solid inorganic material...in or on the Earth's crust in such form and quantity and of such a grade or quality that it has reasonable prospects for economic extraction. The location, quantity, grade, geological characteristics and continuity of a Mineral Resource are known, estimated or interpreted from specific geological evidence and knowledge (CIM Standing Committee on Reserve Definitions, 2005).

\section{U}

Undiscovered uranium resource As used in this report refers to a uranium resource not presently known to exist but which can be inferred to exist by using geologic information and resource estimation methods. 



\section{Effects of 1980s Uranium Mining in the Kanab Creek Area of Northern Arizona}

By James K. Otton, Tanya J. Gallegos, Bradley S. Van Gosen, Raymond H. Johnson, Robert A. Zielinski, Susan M. Hall, L. Rick Arnold, and Douglas B. Yager

Chapter B of

Hydrological, Geological, and Biological Site Characterization

of Breccia Pipe Uranium Deposits in Northern Arizona

Edited by Andrea E. Alpine

Scientific Investigations Report 2010-5025 


\section{Contents}

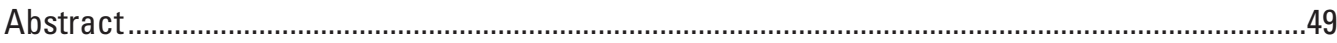

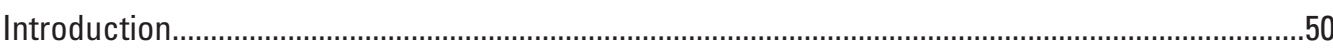

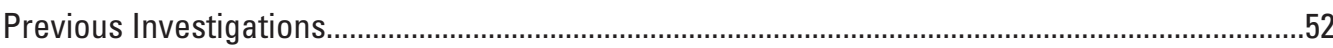

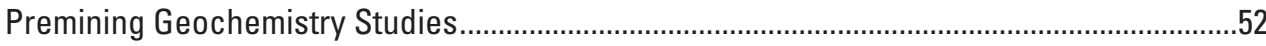

National Uranium Resource Evaluation Soil Sampling ...................................................52

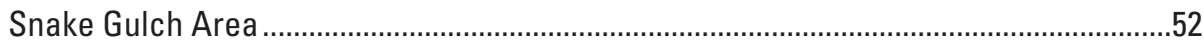

Soils over Grand Canyon Breccia Pipes ......................................................................54

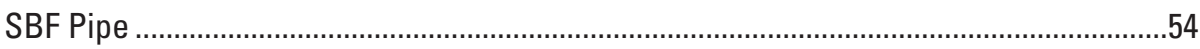

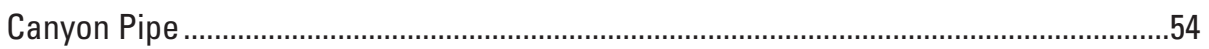

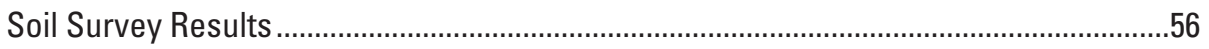

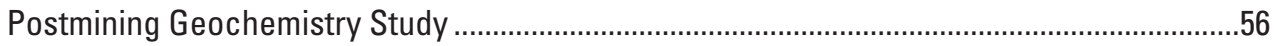

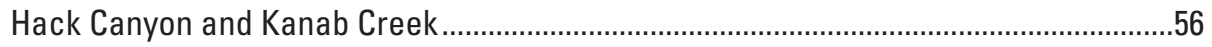

Kanab Creek Water Samples ...........................................................................................60

Sampling, Sample Processing, and Analytical Methods .................................................................60

Soil, Stream Sediment, and Mine Waste Sampling .............................................................60

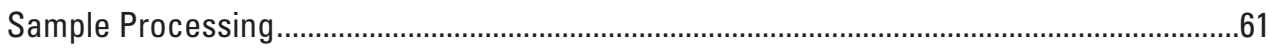

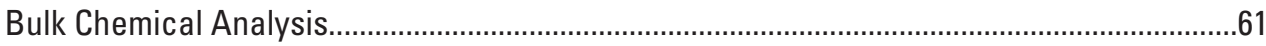

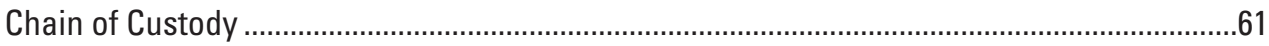

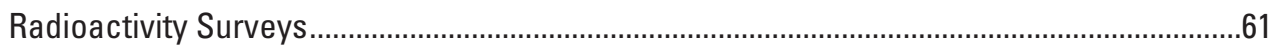

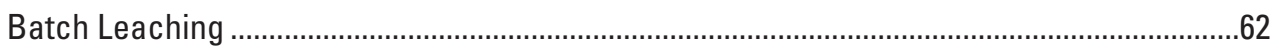

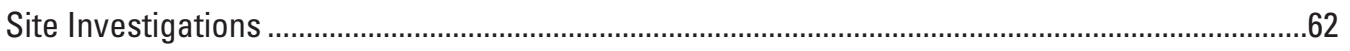

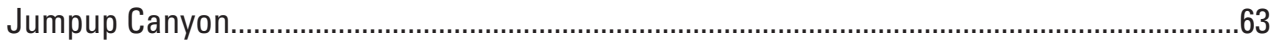

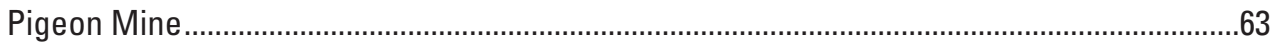

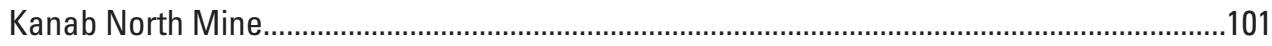

Kanab South Pipe ....................................................................................................... 110

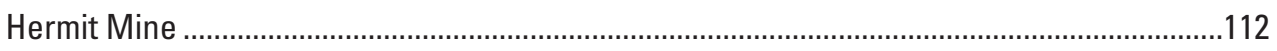

Hack Mines ..................................................................................................................... 116

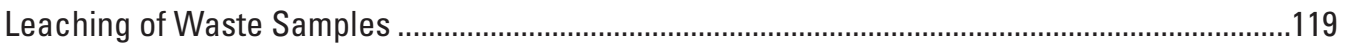

Pigeon Mine Samples ........................................................................................................ 121

Kanab North Mine Samples ............................................................................................... 122

Hack Canyon Mines Samples ......................................................................................... 122

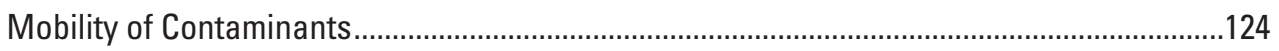

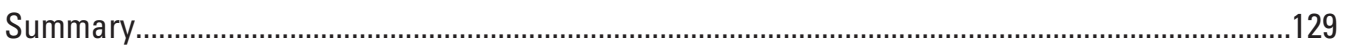

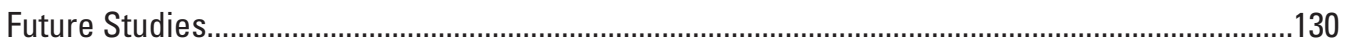

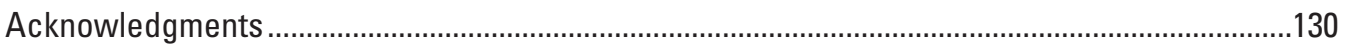

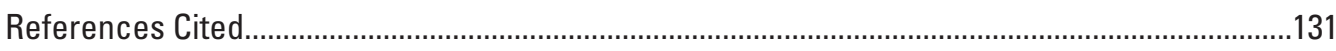

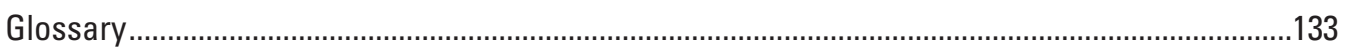

\section{Figures}

1-2. Index maps showing location of sites studied in the:

1. Kanab Creek area for this report ...............................................................................51

2. Kanab Creek area studied during previous investigations.........................................53 
3-4. Maps showing location of:

3. Stream-sediment sample sites in Snake Gulch and adjacent Kanab Creek area

4. SBF breccia pipe and Canyon breccia pipe..........................................................

5-6. Photographs of:

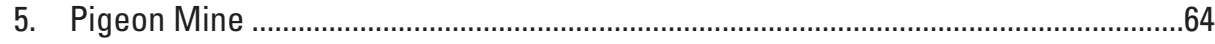

6. Pigeon Mine during operation..................................................................................64

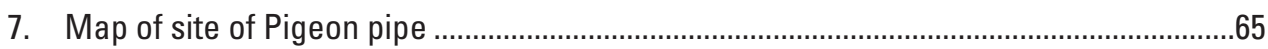

8-10. Aerial photographs showing:

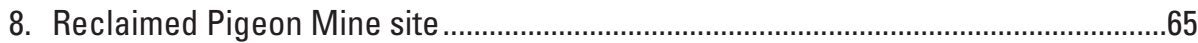

9. Concentration of selected elements at sample sites on Pigeon Mine site ...............66

10. Radioactivity measurements at sample sites on Pigeon Mine site .........................100

11. Photographs of Kanab North Mine .............................................................................101

12. Diagram of Kanab North Mine site, and aerial image used as base for the map..........102

13. Photograph of wastewater pond at the Kanab North Mine .........................................103

14-18. Aerial photographs showing:

14. Concentration of selected elements at sample sites on the Kanab North

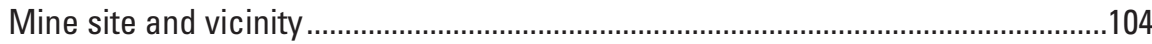

15. Radioactivity measurements at sample sites on the Kanab North Mine site .............110

16. Kanab South breccia pipe..................................................................................111

17. Uranium concentration at sample sites on the Kanab South breccia pipe site............. 111

18. Reclaimed Hermit Mine ............................................................................................112

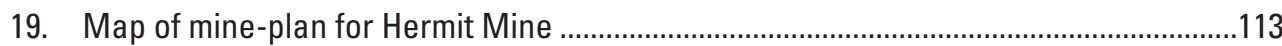

20-23. Aerial photographs showing:

20. Concentrations of selected elements at sample sites at Hermit Mine ....................114

21. Radioactivity measurements at sample sites on the Hermit Mine site ....................116

22. Hack Canyon, Robinson Canyon, and unnamed tributary canyon; Hack Canyon Mines approximately located ...................................................................117

23. Uranium concentration in stream sediment and in ore and waste-rock samples at sample sites in Hack Canyon Wash area..

24. Diagram showing concentration of 12 elements in stream sediments

downstream from the Hack 1 Mine as a ratio of concentration in background

stream sediments ......

25-28. Photographs showing:

25. Ore and waste rock in the wash bottom of Hack Canyon

26. Bottom of tributary canyon and Hack Canyon showing waste-rock terrace and mining operations

27. Eroded terrace downstream of former Hack 1 Mine at confluence of tributary canyon and Hack Canyon

28. Large waste-rock boulder in streambed approximately $10 \mathrm{ft}$ west of low terrace shown in figure 27

29. Schematic diagram of processes expected to disperse trace elements in stored ore and mined waste rock at a mine site

30-31. Diagrams showing:

30. Concentration of seven elements in ore from Hack Mine leached into simulated rainwater and following equilibration

31. Percentage of uranium leached from five types of material during three experiments 


\section{Tables}

1. Summary of geochemical analyses of 31 stream sediment samples collected in the northern Kanab Creek and Snake Gulch area.

2. Summary of analyses of three soil samples collected from the Pigeon breccia pipe prior to mining.

3. Average trace element concentrations in soil samples collected in the surface expression of two uranium-ore-bearing breccia pipes exposed on the Coconino Plateau

4. Summary of elemental concentrations determined by premining and other previous studies.

5. Summary of trace element content of bulk stream sediment samples from 10 sites in Hack Canyon

6. Summary of trace metal content in samples of stream sediment and waters from Kanab Creek

7. Trace element concentrations in stream sediment samples from Jumpup Canyon

8. Chemical analyses of soil, sediment, rock, and mine waste samples collected by this study.

9. Trace element concentrations of soil samples inside and outside the reclaimed area

10. Whole-rock trace-element composition of samples selected for leaching compared with crustal abundance and average trace-element composition of the crust and of western soils.

11. Concentrations of uranium and other trace elements in 1- and 24-hour leachates of Pigeon samples.

12. Concentrations of uranium and other trace elements in 1- and 24-hour leachates of Kanab North samples

13. Whole-rock composition of ore and rock from Hack Canyon and concentrations of uranium and trace elements in 1- and 24-hour leachates of ore collected in Hack Canyon. 


\title{
Conversion Factors
}

\author{
Inch/Pound to SI
}

\begin{tabular}{|c|c|c|}
\hline Multiply & By & To obtain \\
\hline \multicolumn{3}{|c|}{ Length } \\
\hline inch (in.) & 2.54 & centimeter $(\mathrm{cm})$ \\
\hline foot $(\mathrm{ft})$ & 0.3048 & $\operatorname{meter}(\mathrm{m})$ \\
\hline mile (mi) & 1.609 & kilometer $(\mathrm{km})$ \\
\hline yard (yd) & 0.9144 & $\operatorname{meter}(\mathrm{m})$ \\
\hline \multicolumn{3}{|c|}{ Area } \\
\hline square foot $\left(\mathrm{ft}^{2}\right)$ & 0.09290 & square meter $\left(\mathrm{m}^{2}\right)$ \\
\hline gallon (gal) & 3.785 & liter $(\mathrm{L})$ \\
\hline cubic foot $\left(\mathrm{ft}^{3}\right)$ & 0.02832 & cubic meter $\left(\mathrm{m}^{3}\right)$ \\
\hline \multicolumn{3}{|c|}{ Mass } \\
\hline ounce, avoirdupois (oz) & 28.35 & $\operatorname{gram}(\mathrm{g})$ \\
\hline pound, avoirdupois (lb) & 0.4536 & kilogram (kg) \\
\hline ton, short $(2,000 \mathrm{lb})$ & 0.9072 & megagram $(\mathrm{Mg})$ \\
\hline \multicolumn{3}{|c|}{ Concentration } \\
\hline Part per billion (ppb) & 1.0 & microgram per liter $(\mu \mathrm{g} / \mathrm{L})$ \\
\hline part per million (ppm) & 1.0 & milligram per liter $(\mathrm{mg} / \mathrm{L})$ \\
\hline ton per year (ton/yr) & 0.9072 & metric ton per year \\
\hline
\end{tabular}

Temperature in degrees Celsius $\left({ }^{\circ} \mathrm{C}\right)$ may be converted to degrees Fahrenheit $\left({ }^{\circ} \mathrm{F}\right)$ as follows:

$$
{ }^{\circ} \mathrm{F}=\left(1.8 \times^{\circ} \mathrm{C}\right)+32
$$

Temperature in degrees Fahrenheit $\left({ }^{\circ} \mathrm{F}\right)$ may be converted to degrees Celsius $\left({ }^{\circ} \mathrm{C}\right)$ as follows:

$$
{ }^{\circ} \mathrm{C}=\left({ }^{\circ} \mathrm{F}-32\right) / 1.8
$$

Vertical coordinate information is referenced to the North American Vertical Datum of 1988

(NAVD 88).

Horizontal coordinate information is referenced to the World Geodetic System of 1984 (WGS 84).

Altitude, as used in this report, refers to distance above the vertical datum. 


\section{Abbreviations Used in This Report}

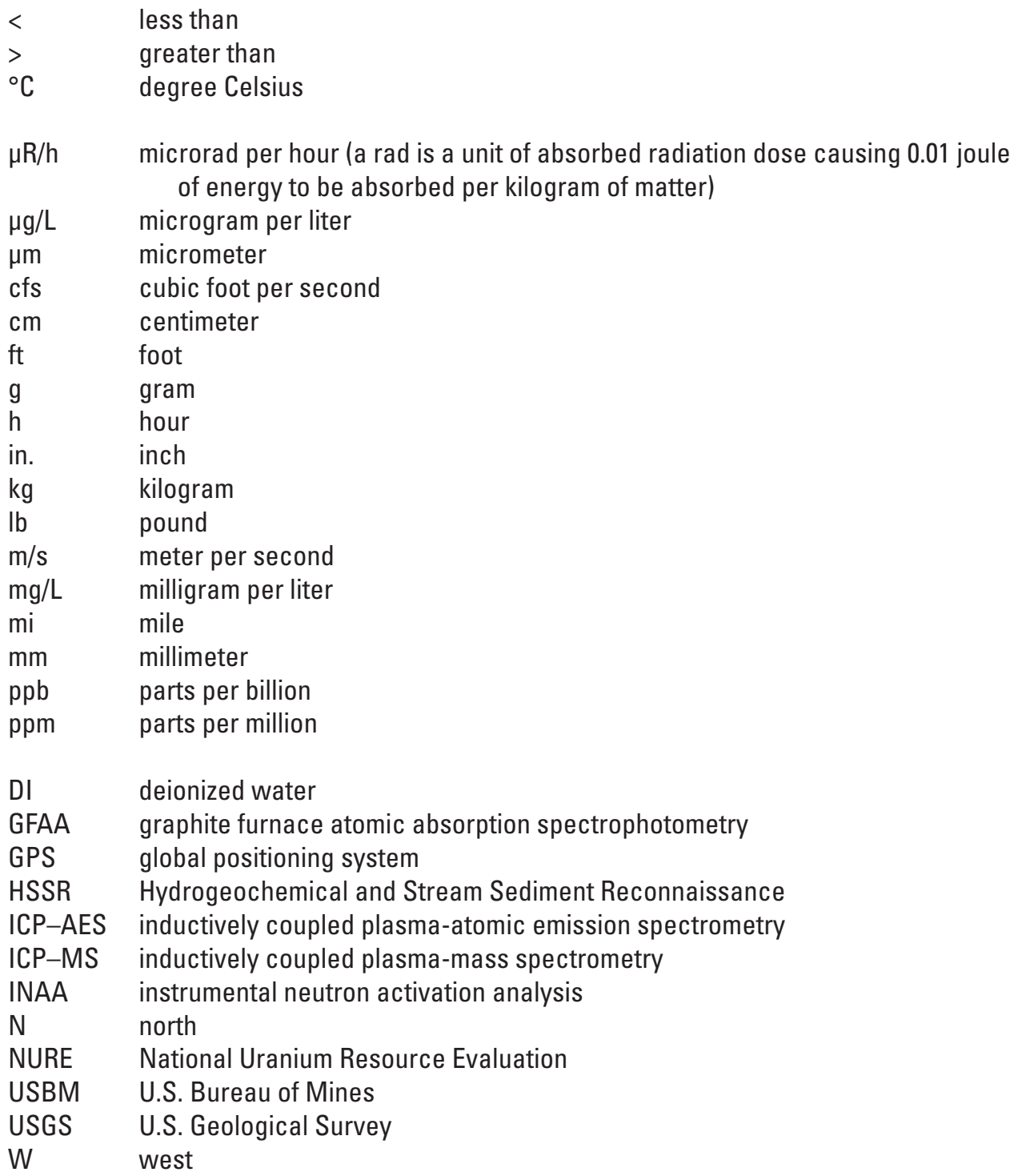




\title{
Chapter $B$
}

\section{Effects of 1980s Uranium Mining in the Kanab Creek Area of Northern Arizona}

\author{
By James K. Otton, Tanya J. Gallegos, Bradley S. Van Gosen, Raymond H. Johnson, Robert A. Zielinski, \\ Susan M. Hall, L. Rick Arnold, Douglas B. Yager
}

\section{Abstract}

In August and October of 2009, the U.S. Geological Survey conducted a field assessment of the geochemistry of surface soils, waste rock, and sediments in and around several reclaimed or inactive breccia-pipe uranium mines; these mines are located on Bureau of Land Management lands in the Kanab Creek area north of Grand Canyon National Park. Surface soil, stream sediment, and mined waste-rock samples were collected at six sites that represent various stages of mining: mined and reclaimed (Hermit, Pigeon, and the Hack mine complex); partially mined and on hold (Kanab North); and mineralized and explored by drilling, but not mined (Kanab South). Previous studies on undisturbed sites in the study area suggest that soil and sediment can naturally contain as much as 5.6 parts per million uranium and 39 parts per million arsenic. The average soil uranium concentration in a region bounded by the surrounding twelve 7.5 minute quadrangles is 2.4 parts per million. Stream sediments were also collected in a canyon with no mining history or known uranium deposits - Jumpup Canyon - to provide geochemical data for comparison with data in the mined areas. Samples at breccia-pipe mine sites were analyzed to determine historic dispersion (by wind and water) of uranium and trace elements. Some samples were leached to simulate the potential mobility of uranium and other trace elements during weathering. Radioactivity was measured with a microR meter to determine the degree of exposure to radioactivity at each site. Findings show the following:

- Uranium and arsenic: These two elements were consistently the most abundant trace elements of concern at mined sites.

- Jumpup Canyon: Concentrations of uranium and other trace elements in stream sediments in this background area were lower than in regional soil levels. The Jumpup Canyon sediment samples $(n=9)$ had average concentrations of 1.7 parts per million uranium and 4.6 parts per million arsenic.

- Pigeon Mine: Fewer than 10 weathered uranium ore and waste-rock fragments were found at Pigeon reclaimed sites. Wind dispersed some wastes offsite. Soils collected inside the disturbed and reclaimed mine area $(n=26)$ had median concentrations of 4.4 parts per million uranium and 41 parts per million arsenic, reflecting the geochemistry of the cover materials used to reclaim the site. Soils collected outside of the disturbed area $(n=16)$ had median concentrations of 6.3 parts per million uranium and 25 parts per million arsenic. Stream sediments below the mine contained elevated uranium and arsenic concentrations, but dispersion from the mine site and weakly mineralized rock outside the mine site may both be responsible.

- Kanab North Mine: Mined waste rock, uranium ore, pond sludge, and local wind- and water-dispersed fine particles on the unreclaimed mine site (all of which contained high concentrations of uranium and other trace element constituents such as arsenic) were exposed to the ambient environment for about 20 years at the Kanab North partially mined site. Offsite, only one soil sample approximated background uranium concentrations, suggesting that dispersion extends beyond the limit of sampling, about 420 feet. Soil samples $(n=20)$ collected within about 420 feet outside of the fenced mine site had an average uranium concentration of 27.8 parts per million (more than 10 times background concentration) and arsenic concentration of 12 parts per million. Wind appears to be the dominant process dispersing material offsite.

- Kanab South drill site: Although uranium has not been mined at this breccia pipe site (only exploratory drilling has taken place), elevated concentrations of uranium and other trace elements are found at this site and in its vicinity as compared with concentrations in Jumpup Canyon and with regional concentrations in soils of the western United States. In six soils sampled around the drilled area, uranium concentrations ranged from 1.3 to 2.7 parts per million and arsenic concentrations ranged from 5 to 23 parts per million. In six stream sediments from the Kanab South area, uranium concentrations ranged from 1.5 to 3.6 parts per million and arsenic concentrations ranged from 4 to 20 parts per million. Several trace elements in stream sediment samples collected downstream from the pipe location were anomalously high by a small amount. 
- Hermit Mine: The reclaimed Hermit Mine site, active for less than one year, contains very little evidence of elevated concentrations of uranium either onsite or offsite. The 22 soils sampled inside of the disturbed area averaged 4.6 parts per million uranium (median, 3.1 parts per million) and 7.5 parts per million arsenic (median 6.0 parts per million); 35 soils and stream sediments collected outside of the disturbed area averaged 1.9 parts per million uranium (less than the regional background average of $2.4 \mathrm{ppm}$ ) (median 1.6 parts per million), and 4.6 parts per million arsenic (median 4.0 parts per million).

- Hack 1 Mine: During mining, ore and waste-rock piles were eroded by a flash flood. Since the cessation of mining and completion of reclamation, reclaimed mined waste rock were eroded by floods that exposed covered uranium-enriched mined waste-rock and ore fragments in a terrace adjacent to the stream channel that runs through Hack Canyon. Fragments of material from these floods were found in the channel and on the floodplain for as much as a half mile downstream from the reclaimed site. Downstream from Hack 1, concentrations of uranium and arsenic in stream sediments ranged from 2.4 to 10.2 parts per million for uranium and from 9 to 17 parts per million for arsenic. The highest concentrations were found about a half mile downstream near the low end of the eroded terrace. Most trace elements in stream sediments were at background concentrations at a sample site about $1.7 \mathrm{mi}$ east of the Hack 1 reclaimed mine site.

- Hack 2 and 3 Mines: In a reconnaissance radiometric survey, two anomalously radioactive areas (of less than 1 square foot) and one uranium waste-rock or ore fragment were found downstream of the reclaimed Hack 2 and 3 Mine area but above the location of the Hack 1 Mine. A single stream-sediment sample downstream from the Hack 2 and 3 Mine area had concentrations of 5 parts per million uranium and 10 parts per million arsenic. However, the waste-rock fragment along the channel contained 7,760 parts per million uranium.

- Elevated radioactivity is evident at all sites (except the Jumpup Canyon background area). The highest microR measurements were found at the Kanab North Mine (a partially mined site with abundant mined waste rock at the surface inside a fenced site perimeter), followed by the Pigeon site and then the Hack Mine complex (within a half mile downstream of Hack 1 Mine). Much lower microR measurements were recorded at the Hermit site. Very little radiation above background concentrations was found at the unmined Kanab South site, except at a weakly uraniferous limonite-stained outcrop. Radioactivity rapidly decreases within 400 feet outside of the fenced area of the Kanab North site. Similarly, radioactivity notably decreased within a few feet of anomalous point sources (ore and waste-rock fragments) at reclaimed Pigeon, and Hack 1, 2, and 3 sites.
- Uranium in mine wastes that were leached with synthetic rainwater and simulated river water increased in solubility with increased weathering. This increased solubility was reflected in the percentages of uranium leached from solids during 24-hour contact with the synthetic rainwater: unweathered ore ( $0.2-0.33$ percent), wind-transported fines $(0.5-1.66$ percent), weathered ore and waste rock (0.89-2.76 percent), and chemically redistributed uranium redeposited on waste ( $0.57-17.06$ percent); backgroundarea samples leached $0.16-0.19$ percent.

- Although experimental data indicate that concentrations of leached trace-elements derived from waste rock or ore under experimental conditions can be very high, the dilution factors during floods are also very high. The resultant contribution to trace element concentrations in the passing water is less than one part per billion. Projection of site-specific future mobilization of uranium and trace elements contained in contaminated soils and mined waste rock and the efficiency of natural attenuation processes cannot be determined from these results and should be considered for future study.

\section{Introduction}

Lands containing substantial uranium resources in northern Arizona region (Finch and others, 1990; Otton and Van Gosen, this report) have been proposed for withdrawal from mineral entry. Previous uranium mining in northern Arizona began in the early 1950s, although most uranium mining occurred in the 1980s in the Kanab Creek drainage on Bureau of Land Management lands north of Grand Canyon National Park. The effect of past mining is here evaluated to provide a factual basis for understanding possible future effects and for suggesting new remedial approaches. This report reviews existing information and presents new data that examines the remnant effects of uranium mining and reclamation on soils and stream sediments in and near selected mine sites, and it evaluates the effects of long-term exposure of materials exposed at a standby mine site to environmental conditions. Companion reports in this volume discuss potential effects on water and ecosystems.

Sites of this investigation represent the variety of geologic and topographic settings of uranium mines in the Kanab Creek area (North Segregation Area). The sites selected are the reclaimed Pigeon, Hermit, and Hack (1, 2, and 3) Mines and the Kanab North Mine, currently on standby status (fig. 1). The Kanab South pipe, drilled but not developed, and Jumpup Creek, a drainage in the North Kaibab National Forest that is remote from mining, were also studied.

This report summarizes previous investigations whose results can be compared with geochemical data gathered during this study and provides background information for the sites, and it describes the site geochemical and radiometric investigations conducted during this study, leaching experiments conducted on ore and waste-rock samples, and the results of these investigations. 


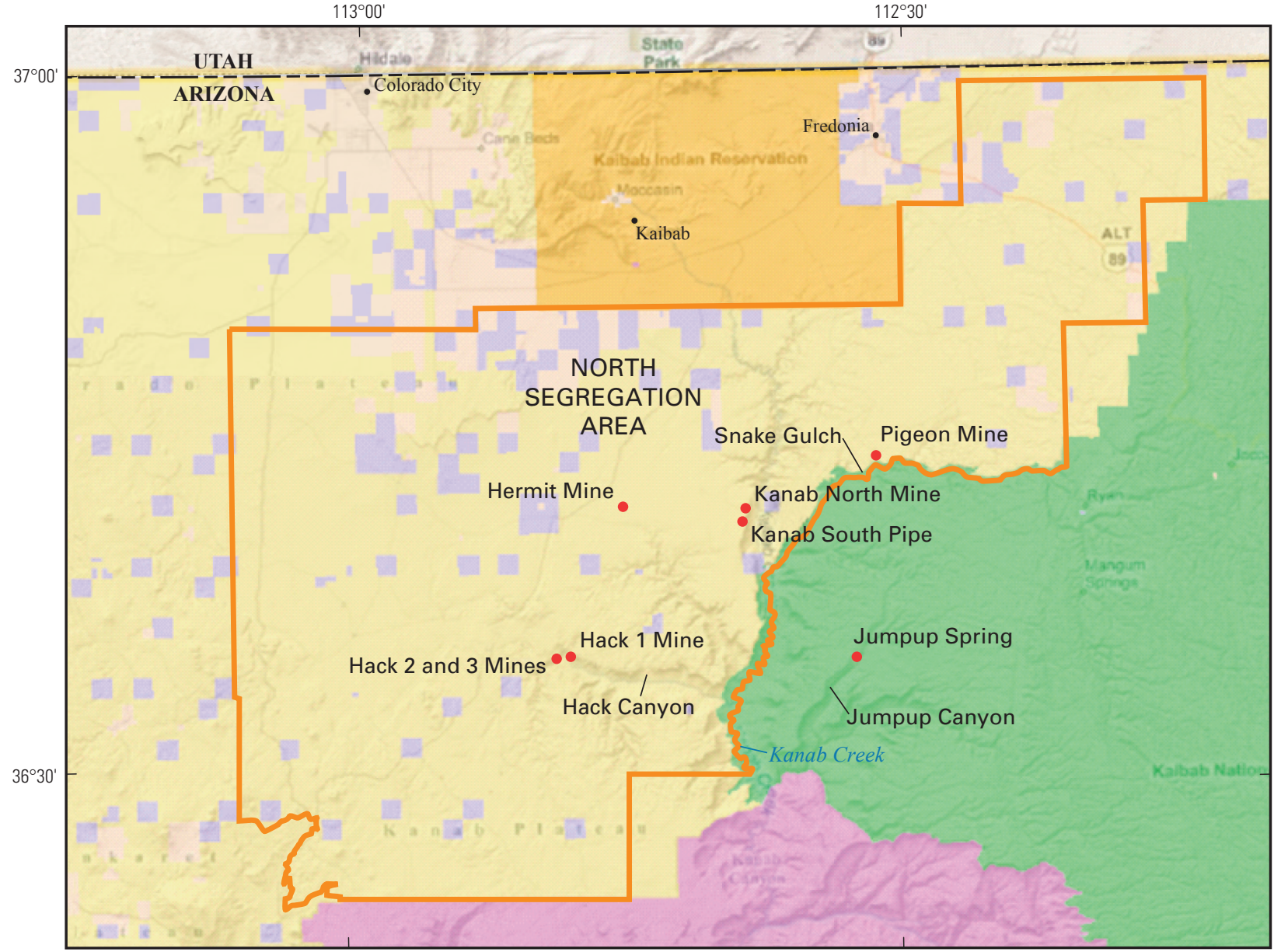

Base from Microsoft Virtual Earth, 2009: Microsoft Corporation, ArcGIS Online Premium Map Service, Bing Maps Roads. Copyrights: (c)2009 ESRI, (c)2009 Microsoft Corporation, (c)2008 NAVTEQ, (c) AND, (c) MapData Sciences Pty Ltd., (c)2007 Zenrin, (c)2007 Intermap.See http://maps.live.com

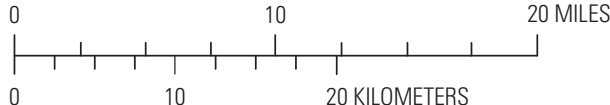
for a complete list of data suppliers.

\section{EXPLANATION}

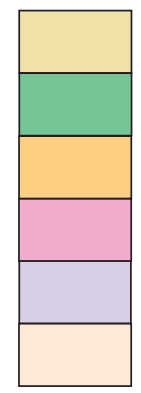

U.S. Bureau of Land Management

U.S. Forest Service

Tribal land

National Park Service

State land

Private land

Segregation area-Boundary

- Sample site

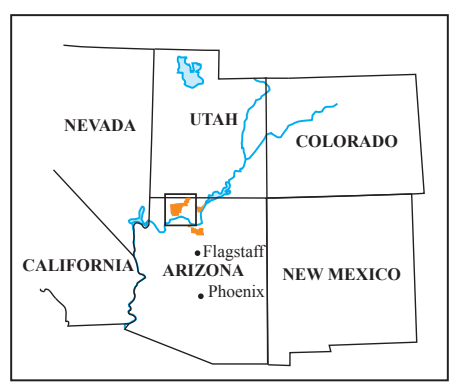

Index map

Figure 1. Location of sites (mines and stream segments) studied for this report in North Segregation Area (Kanab Creek area), northern Arizona. 


\section{Previous Investigations}

\section{Premining Geochemistry Studies}

Geochemical results of analyses of soil and stream sediment samples collected as part of this study are compared with the results of previous studies. Defining premining traceelement geochemistry is important for distinguishing concentrations that are due to natural processes from those related to uranium mining. This section summarizes previous studies that will be used in later sections to aid in establishing natural background concentrations in the study area. Previous investigations of the geochemistry of soils, stream sediments, and rocks of the Kanab Creek and the South Rim areas (fig. 2) include (1) soil samples collected during the U.S. Department of Energy's National Uranium Resource Evaluation (NURE) program of the 1970s (Smith, 1997), (2) stream sediments and soils collected during study of the geochemistry of the Snake Gulch area near the Pigeon Mine (Hopkins and others, 1984), and (3) geochemistry of soils formed on two solution-collapse features (breccia pipes) in the South Rim of the Grand Canyon area (Van Gosen and Wenrich, 1991). These three studies are discussed below.

\section{National Uranium Resource Evaluation Soil Sampling}

The NURE Hydrogeochemical and Stream Sediment Reconnaissance (HSSR) program sampled and chemically analyzed surface waters and groundwaters from streams, springs, wells and ponds, and stream sediments, soils, and rocks across the United States. Resulting data were released in a series of reports. In 1984, under an agreement with the Department of Energy, the U.S. Geological Survey (USGS) took over management of the HSSR dataset and prepared the data for release online (Smith, 1997). In the NURE regional geochemical survey of the western United States (conducted by Savannah River Laboratory), samples were taken as close to random grid points as possible (Price and Jones, 1981). The sample medium depended on regional conditions that would allow uniform collection throughout a broad area. In the northern Grand Canyon area, soil was the primary medium sampled, and soil sample sites were located on plateau surfaces probably because of ease of access. Samples were taken without regard to the location of the many solution-collapse features in the area. No waters, stream sediments, or rocks were sampled in the northern Grand Canyon area. Delayed neutron activation and instrumental neutron activation analysis were used to analyze the soil samples for uranium and for other trace elements commonly associated with uranium-bearing minerals in some geologic settings. The fraction passing a 100 -mesh sieve (0.149 millimeter ( $\mathrm{mm}$ ) opening) was analyzed. At each site, 10 or more samples collected within a 25-yard radius were composited. Plastic scoops or stainless steel "bag" samplers were used and samples were collected in either cloth or paper bags. Detailed location and data sheets were filled out for each site (appendix C of Price and Jones, 1981).
An area in northern Arizona extending through twelve 7.5 minute quadrangles was selected for soil geochemistry characterization from the larger HSSR dataset (fig. 2). This area contains the southern Kanab Creek drainage basin from just north of the Kanab North Mine to its confluence with the Colorado River. Of the 120 HSSR samples in this area, all but 17 were collected in mid-May 1979 and those 17 were collected in late October 1979. This sampling thus predated uranium mining in the area, with the exception of minor production (about 5,000 pounds (lb) $\mathrm{U}_{3} \mathrm{O}_{8}$ ) at the Hack Canyon Mine (adjacent to Hack 1 Mine). Concentrations of uranium, aluminum, cerium, dysprosium, europium, iron, hafnium, lanthanum, lutetium, manganese, samarium, scandium, sodium, thorium, titanium, vanadium, and ytterbium were reported. In this analytical suite, only uranium and vanadium are noted as markedly anomalous in the breccia-pipe ores of the Grand Canyon region (Wenrich and others, 1995). Therefore, comparisons of our current data with HSSR data are limited to these two elements.

Most of the 120 samples were taken from soils on upland surfaces formed on sandstone or carbonate rocks or alluvium derived from them. However, 14 soil sample sites were located on mafic volcanic rocks (basalt). Because basalt does not host breccia-pipe uranium deposits nor does it occur in mined areas, these samples would not provide background soil geochemical data suitable for this study; thus they were excluded. Uranium concentrations in the remaining 106 soil samples ranged from 1.4 to 3.4 parts per million (ppm). The average and median of the 106 samples is $2.4 \mathrm{ppm}$ uranium and the mode is $2.3 \mathrm{ppm}$ uranium. The value of $2.4 \mathrm{ppm}$ uranium is considered the background concentration for soils on the upland surfaces in the Kanab Creek area. Vanadium concentrations ranged from 9 to $75 \mathrm{ppm}$ with 6 nondetect concentrations (the lower reporting limit for these samples ranged from 7 to $13 \mathrm{ppm})$. The average of the reported and censored concentrations (using one half of the lower reporting limit for the censored data) is $37 \mathrm{ppm}$ vanadium. The median was $35.5 \mathrm{ppm}$ vanadium and the mode $35 \mathrm{ppm}$ vanadium. The background for vanadium in soils in the study area is defined as $37 \mathrm{ppm}$.

\section{Snake Gulch Area}

In the early 1980s, the USGS and the U.S. Bureau of Mines assessed the mineral resource potential of the northern Kanab Creek and Snake Gulch area (Billingsley and others, 1983). This work was performed as part of the evaluation and planning process for the Kanab Creek Roadless Area. A reconnaissance geochemical survey collected and analyzed bulk stream sediment; panned concentrate of stream sediment; and rock, soil, and clay samples. Samples were collected in March 1982 (Billingsley and others, 1983; Hopkins and others, 1984). The stream sediment and soil sample data are relevant to this study. In addition to providing stream sediment geochemical data, the March 1982 date of sampling provides premining soil-sample data for the Pigeon Mine site. Billingsley and others (1983) note that in March 1982 the 


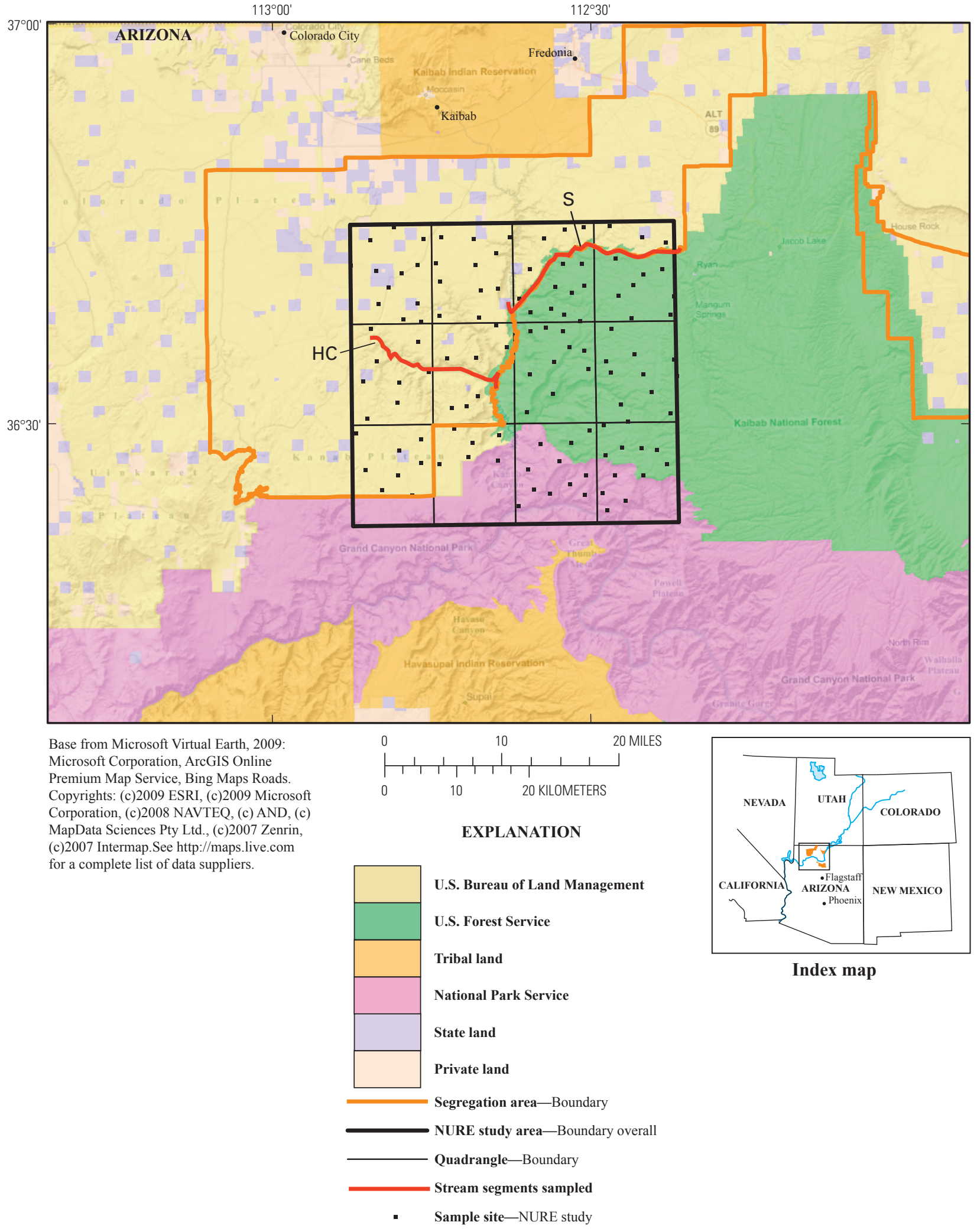

Figure 2. Location of sites in the North Segregation Area (Kanab Creek area) studied during previous investigations. NURE, National Uranium Resource Evaluation, Hydrogeochemical Stream-Sediment Reconnaissance soil sample locations (Smith, 1997); S, Snake Gulch-Kanab Creek area; red line, stream segments sampled (Hopkins and others, 1984); HC, Hack Canyon-Kanab Creek area, red line, stream segments studied (Carver, 1999). 
Pigeon Mine site was being cleared by Energy Fuels Nuclear, Inc., but mining did not begin until 1984. Eighteen miles to the southwest, mines in Hack Canyon were actively producing uranium ore during the early 1980s.

Features that could influence the stream-sediment geochemistry in the Snake Gulch-Kanab Creek drainage basins include 19 mapped solution-collapse features (fig. 3) and stratabound copper deposits of the historic Jacob Lake-Warm Springs mining district, which lies east of a roadless area near Jacob Lake. This district contains thinly layered coppergold-silver-lead deposits, which were mined on a small scale between the early 1900s and about 1942 (Tainter, 1947). The copper deposit closest to the roadless area lies 4 miles (mi) to the east of the head of Snake Gulch. Mills that processed the ores were built in 1901 and 1928 at Ryan, about 2.5 mi southeast of the head of Snake Gulch (Tainter, 1947).

Analytical results from the March 1982 geochemical survey are tabulated in Hopkins and others (1984). This tabulation contains analyses of 31 composite stream sediment samples, 2 of which were collected at sites near the confluence of Kanab Creek and Snake Gulch and 29 of which were from sites within Snake Gulch and canyons tributary to Snake Gulch (fig. 3). These samples provide a snapshot of the composition of sediments carried by Snake Gulch and northern Kanab Creek. Uranium-mineralized breccia pipes of northern Arizona (Wenrich, 1985, 1986) typically are enriched in certain metals; analysis of these stream sediments focused on those metals (table 1).

The highest base metal concentrations in stream sediment from Snake Gulch were measured in samples located downstream of the Pigeon pipe. Specifically, sample site $10 \mathrm{~S}$ (fig. 3) had the highest concentration of nickel (30 ppm), lead (44 ppm), and vanadium (100 ppm); sample site $11 \mathrm{~S}$ had the highest concentration of barium (700 ppm) and chromium $(100 \mathrm{ppm})$ and high concentrations of nickel (30 ppm) and vanadium (100 ppm).

All 31 stream sediment samples contain less than $2 \mathrm{ppm}$ uranium. The low uranium and generally low base metal concentrations may indicate that the dispersed metals are diluted by much larger volumes of sediment derived from the unmineralized rock that also is carried downstream by the braided stream systems of Snake Gulch and northern Kanab Creek.

Billingsley and others (1983) note slight enrichments in arsenic, barium, copper, and molybdenum in stream sediments in the eastern reaches of Snake Gulch. They attribute these geochemical anomalies to the mining of the Jacob Lake-Warm Springs copper deposits and to ore processing in the mills at Ryan.

Through the courtesy of Energy Fuels Nuclear, Inc., the USGS was able to collect three samples of fresh-cut soil from the surface of the Pigeon pipe during the mining company's surface excavation in March 1982. Analytical results of these soils are summarized in table 2 . The three soils have uranium concentrations of 2.2, 2.2, and $5.6 \mathrm{ppm}$ and modest enrichments in base metals (Hopkins and others, 1984, their fig. 3).

\section{Soils over Grand Canyon Breccia Pipes}

Van Gosen and Wenrich (1991) sampled the soils on 50 solution-collapse features exposed on the Coconino Plateau, which is the extensive plateau surface south of the central Grand Canyon (fig. 4). The subsurface character of the majority of these 50 collapse features is unknown, because most have not been drilled. Two of the sampled solution-collapse features are breccia pipes that host uranium orebodies - the SBF pipe and the Canyon pipe. The soil composition overlying these breccia pipes is thus useful in evaluating the results of the current study.

The soil samples of Van Gosen and Wenrich (1991) were collected from 3 to 4 inches (in.) depth. A pilot sampling study during 1984 compared the analyses of soils collected at 3-4 in. depth with those of soils collected at 7-8 in. depth. No difference in metal concentrations was found at the two depths. Thus, the 3-4 in. depth was used in the subsequent larger soil sampling program. A shallower $0-2$ in. $(0-5$ centimeter $(\mathrm{cm}))$ depth was used in the current study. The soil samples in the study of Van Gosen and Wenrich (1991) were sieved through an 80 mesh screen opening ( 0.0067 in. or 177 micrometers $(\mu \mathrm{m})$ ). The $<80$ mesh material was then pulverized to $<100$ mesh, and this $<100$ mesh material was submitted for geochemical analysis. The same sieving and processing method was used in the current study.

\section{SBF Pipe}

The SBF breccia pipe is located just southeast of the Hualapai Indian Reservation (fig. 4). It is exposed on the surface of the Coconino Plateau (fig. 4) as a 7-foot (ft)high raised rim composed of Harrisburg Member of the Kaibab Formation (Wenrich and Aumente-Modreski, 1994). This rim encloses a soil-covered, circular basin filled with Moenkopi Formation sandstone and siltstone. Intermittent drilling by Union Pacific Resources from 1984 to 1987 confirmed a breccia pipe structure at depth that contains a uranium deposit. The soil survey of Van Gosen and Wenrich (1991, their fig. 32) collected 20 soil samples within the structural basin and 16 background soil samples outside of the basin.

\section{Canyon Pipe}

The surface expression of the Canyon breccia pipe is a sage-covered, elliptical clearing in a ponderosa pine forest, located about $6.5 \mathrm{mi}$ southeast of Tusayan (fig. 4). The bounds of the clearing define a shallow basin that overlies the collapse structure; the clearing is about 2,000 ft long (northsouth) by 1,600 ft wide (east-west) (Wenrich, 1992, her fig. 2; Wenrich and Aumente-Modreski, 1994, their fig. 3). The underlying breccia pipe averages less than $200 \mathrm{ft}$ in diameter 


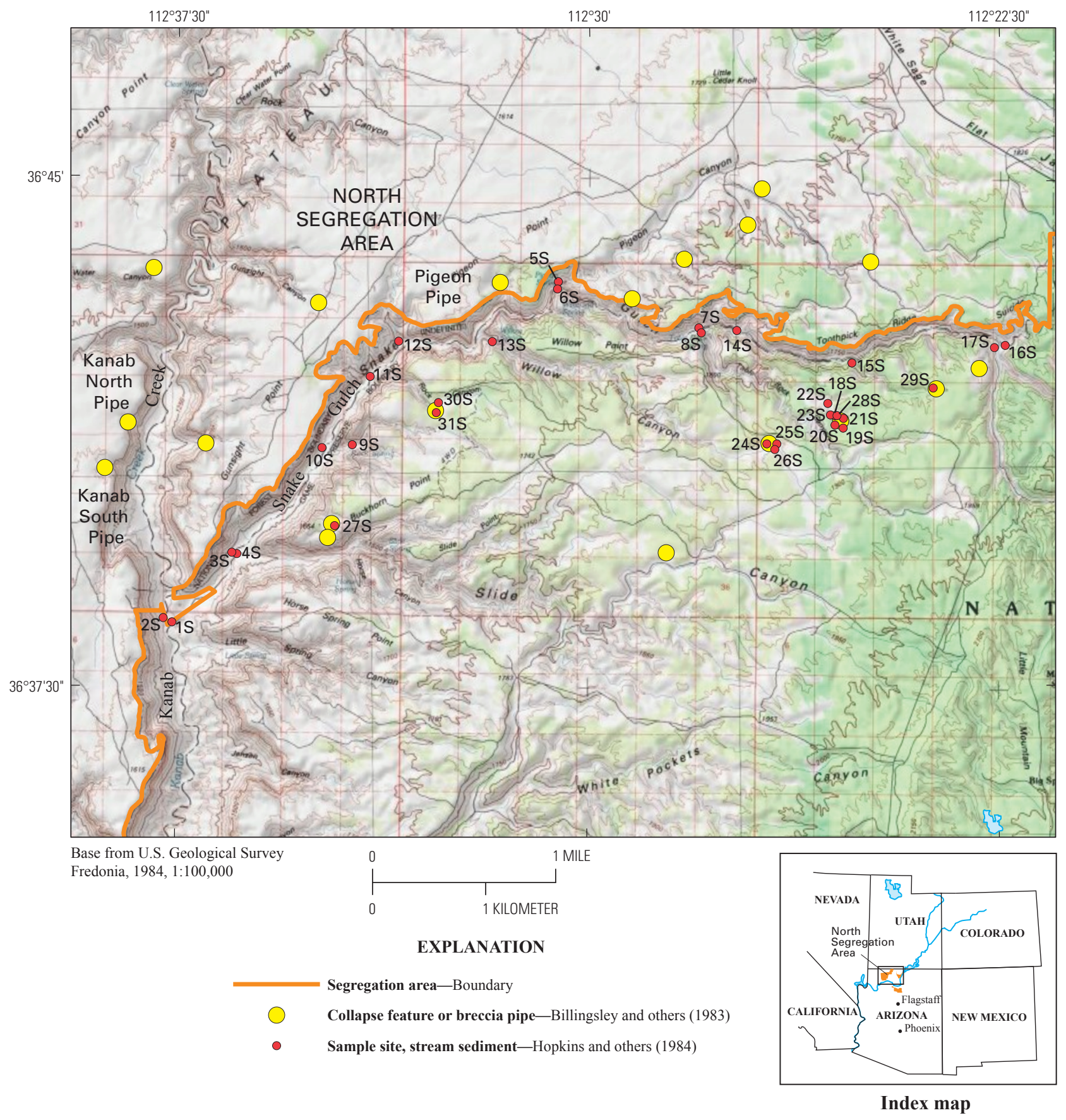

Figure 3. Snake Gulch-Kanab Creek area, showing locations of 31 sites where composite stream sediment samples were collected by the U.S. Geological Survey in March 1982 (Hopkins and others, 1984) and of 19 solution-collapse features and breccia pipes (Billinglsey and others, 1983, sheet 1). 
Table 1. Summary of geochemical analyses of 31 stream sediment samples collected in March 1982, northern Kanab Creek and Snake Gulch area, northern Arizona.

[Data from Hopkins and others (1984); sample site locations shown in figure 3; ppm, parts per million; <, less than; --, not available]

\begin{tabular}{lcc}
\hline \multicolumn{1}{c}{ Element } & $\begin{array}{c}\text { Range } \\
\text { in values } \\
\text { (ppm) }\end{array}$ & $\begin{array}{c}\text { Sample site } \\
\text { with highest } \\
\text { concentration }\end{array}$ \\
\hline Silver & $<0.5$ & -- \\
Arsenic & $<200$ & -- \\
Barium & $300-700$ & $2,11,15,18$ \\
Cadmium & $<20$ & -- \\
Cobalt & $5-7$ & numerous sites \\
Chromium & $20-100$ & $3,5,7,11,14,15,16$ \\
Copper & $3-11$ & 31 \\
Molybdenum & $<5$ & -- \\
Nickel & $10-30$ & 10,11 \\
Lead & $5-44$ & 10 \\
Antimony & $<100$ & -- \\
Strontium & $<100-1,500$ & 9 \\
Uranium & $0.2-2.0$ & 9 \\
Vanadium & $30-100$ & $4,10,11,15$ \\
Zinc & $11-29$ & 24 \\
\hline
\end{tabular}

Table 2. Summary of analyses of three soil samples collected in March 1982 (prior to mining) from the surface of the Pigeon breccia pipe.

[Data from Hopkins and others, 1984; <, less than; ppm, parts per million]

\begin{tabular}{lc}
\hline Element & $\begin{array}{c}\text { Range in } \\
\text { concentration, } \\
\text { (ppm) }\end{array}$ \\
\hline Silver & $<0.5$ \\
Arsenic & $<200$ \\
Barium & $1,000-3,000$ \\
Cadmium & $<20$ \\
Cobalt & $7-20$ \\
Chromium & $100-100$ \\
Copper & $11-29$ \\
Molybdenum & $<5-7$ \\
Nickel & $30-50$ \\
Lead & $13-20$ \\
Antimony & $<100$ \\
Strontium & $19-300$ \\
Uranium & $2.2-5.6$ \\
Vanadium & $100-150$ \\
Zinc & $17-85$ \\
\hline
\end{tabular}

and it narrows within Coconino Sandstone and Hermit Formation horizons (Casadevall, 1989). Drilling by Energy Fuels Nuclear, Inc., passed through a zone of abundant sulfide minerals near the contact of the Coconino Sandstone and Toroweap Formation (Casadevall, 1989). The drilling showed that uranium minerals extend for more than $1,600 \mathrm{ft}$ vertically through the breccia pipe, from the lower Toroweap Formation to the upper Redwall Limestone. Uranium ore averages
0.74 percent $\mathrm{U}_{3} \mathrm{O}_{8}$ and occurs mainly in the Coconino, Hermit, and Esplanade horizons of the pipe (Casadevall, 1989). The soil survey of Van Gosen and Wenrich (1991, their fig. 58) collected 18 soil samples inside the structural basin and 14 background soil samples outside of the basin. After the 1986 soil sampling survey, a head frame was built on the site in preparation for underground mining (Wenrich, 1992, her fig. 2). However, owing to a subsequent steep drop in uranium prices, the mine was never developed.

\section{Soil Survey Results}

Wenrich (1985) indicated that breccia pipe orebodies typically are enriched in silver (Ag), arsenic (As), barium $(\mathrm{Ba})$, cadmium $(\mathrm{Cd})$, cobalt $(\mathrm{Co})$, chromium $(\mathrm{Cr})$, copper $(\mathrm{Cu})$, molybdenum $(\mathrm{Mo})$, nickel $(\mathrm{Ni})$, lead $(\mathrm{Pb})$, strontium $(\mathrm{Sr})$, uranium $(\mathrm{U})$, vanadium $(\mathrm{V})$, and zinc $(\mathrm{Zn})$. See table 3 for average concentrations of these elements in soils collected over the SBF and Canyon breccia pipes (Van Gosen and Wenrich, 1991). These data are considered representative (average) concentrations in soils that formed above undisturbed breccia pipes that contain uranium deposits at depth. Soil samples that were collected outside of the collapse features provide additional information about metal concentrations typical of soils of the Kaibab Limestone ("background concentrations"). The concentrations over and outside of the breccia pipes are similar, which suggests that uranium deposits at depth has only limited effects on the surface soil geochemistry. In soils inside the projected boundary of the SBF pipe, only arsenic concentrations appear to be elevated with respect to soils outside the projected boundary of the pipe (average $33 \mathrm{ppm}$ as compared with $<10 \mathrm{ppm}$ ).

The results of these three studies and additional crustal abundance data and composition of average western U.S. soils are summarized in table 4.

\section{Postmining Geochemistry Study}

\section{Hack Canyon and Kanab Creek}

Carver (1999) examined the concentration of trace elements in stream sediments in Hack Canyon. Carver collected stream sediments at 10 locations on the floor of Hack Canyon Wash - at 5 sites each upstream and downstream of the Hack Mine complex (Hack Mine 1, 2, and 3) (fig. 1). Water and stream-sediment samples were also collected at 3 sites in Kanab Creek: 1 site above, 1 site below, and 1 site at the confluence of Hack Canyon and Kanab Creek. The intent of Carver's study was to evaluate whether trace elements had migrated within Hack Canyon Wash downstream from the former Hack Mine complex toward Kanab Creek. In addition to the bulk sediment sampling, Carver (1999) sieved the sediment samples into gravel ( $>2 \mathrm{~mm})$, sand ( $2 \mathrm{~mm}$ to $63 \mu \mathrm{m})$, silt $(63 \mu \mathrm{m}$ to $53 \mu \mathrm{m})$, 


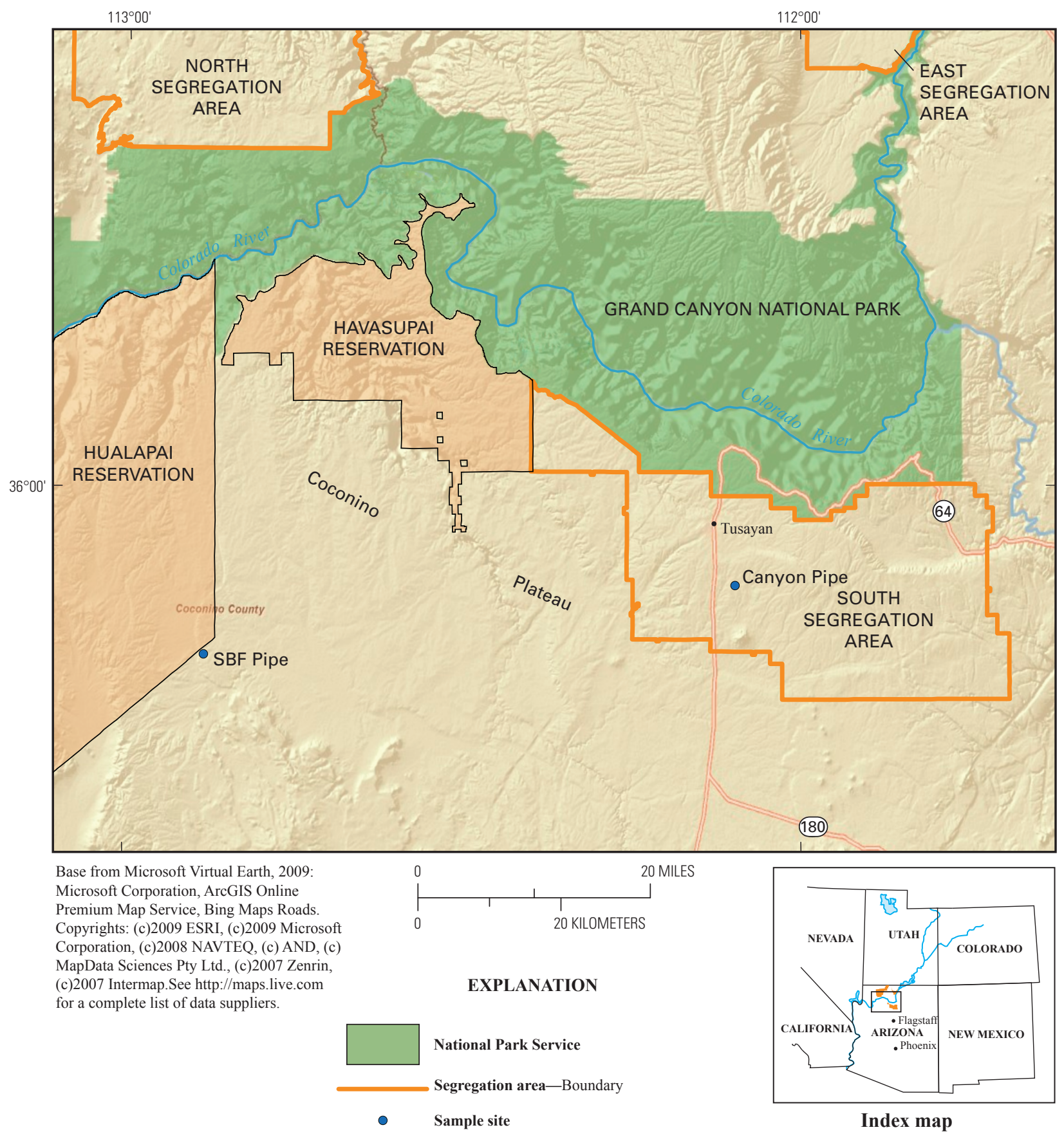

Figure 4. Location of SBF (breccia) pipe and Canyon (breccia) pipe, solution-collapse features whose soil geochemistry is discussed in this report. 

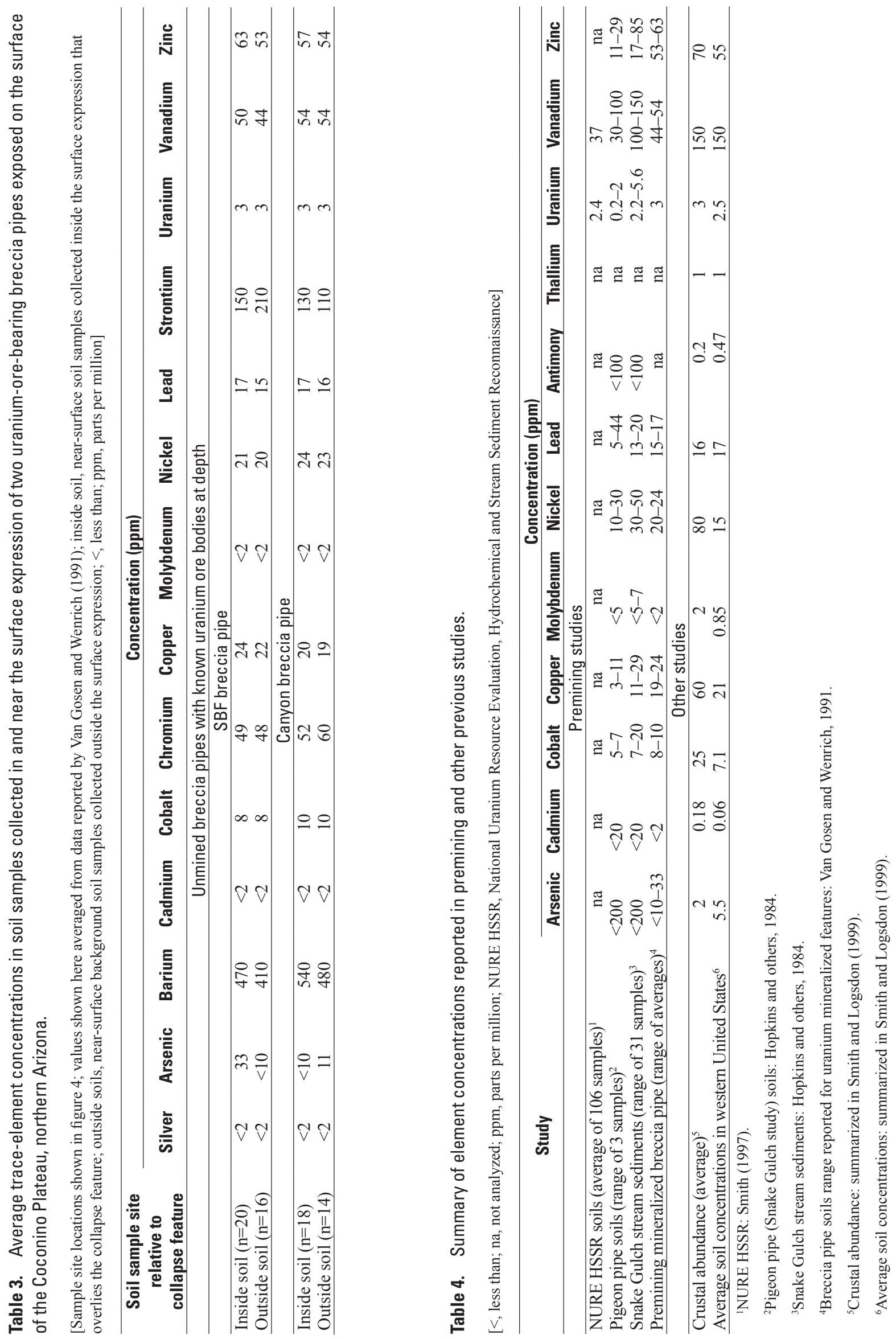
and clay $(<53 \mu \mathrm{m})$ size particles and then separately analyzed each fraction. Concentrations of arsenic, cadmium, chromium, cobalt, copper, iron, manganese, molybdenum, lead, nickel, silver, thorium, tungsten, uranium, vanadium, and zinc were measured in sediment and water samples by using graphite furnace atomic absorption spectrophotometry (GFAA), flame atomic absorption spectrophotometry, and inductively coupled plasma-mass spectrometry (ICP-MS). Carver (1999) then applied statistical tests to the geochemical results in order to test the normality of the data distribution and to compare the element concentrations in stream sediments above and below the Hack Canyon Mine. Carver concluded (1999, p. 51) that "mean concentrations above the mine are equal to the mean concentrations below the mine" in the elements in which the mineralized breccia pipes of this region are typically enriched (table 5).

Some stream sediments collected upstream of the Hack Canyon Mine have copper, nickel, and zinc concentrations that exceed those in sediments sampled below the mine (table 5) and in sediments from Snake Gulch. In particular, high copper concentrations were found in some stream sediments several miles upstream of the mine. These anomalies may indicate that undiscovered, mineralized breccia pipes or stratabound copper deposits lie in the western, upper reaches of Hack Canyon. The lack of corresponding high uranium values may indicate a source other than a breccia pipe.

Two sediment samples collected at one site in the wash just below the Hack 1 Mine contained consistently elevated amounts of the elements in which the ore-bearing Grand Canyon breccia pipes are typically enriched (table 5). For example, these sediments contain as much as 2,000 ppm arsenic, 5,300 ppm copper, 276 ppm molybdenum, 1,200 ppm lead, 154 ppm uranium, and 89 ppm zinc. These high element concentrations are consistent with the geochemistry of ore and waste rock from Hack Mine operations. In contrast, stream sediments collected less than a quarter of a mile downstream from the mine contain much lower concentrations: 20.8 ppm arsenic, 43 ppm copper, $<1 \mathrm{ppm}$ molybdenum, $10.1 \mathrm{ppm}$ lead, $3.6 \mathrm{ppm}$ uranium, and $66.5 \mathrm{ppm}$ zinc. The lower concentrations are interpreted to be due to dilution by detritus derived from unmineralized rock within the drainage.

Carver (1999, p. iv) noted that "trace metal concentrations were found to increase with decreasing particle size for chromium, cobalt, copper, iron, lead, manganese, thorium, vanadium, and zinc." She noted that a large fraction of the clay particles are likely to remain suspended in water during floods. Carver (1999, p. 54) further concluded that: "Clays and sediments, as opposed to dissolved species, are therefore the primary carriers for moving trace metals downstream to the Colorado River." Carver (1999, p. 49) also tested the ability of microbial organisms to capture trace elements and concluded that "the results of this experiment suggest a physicalchemical transport of trace metals rather than a biological mechanism."

The precise location of sediment samples collected from Kanab Creek does not appear to be provided in Carver (1999). A summary of Carver's results is presented in table 6. The trace element concentrations in these sediments are similar to the concentrations found both in the upper reaches of Hack Canyon and at sites several miles downstream of the Hack Mines, except for the highest concentrations of copper, nickel, and zinc above the mines.

Table 5. Summary of trace element concentrations in bulk stream sediment samples from 10 sites in Hack Canyon.

[Samples collected and analyzed by Carver (1999); sediments collected at 5 sites upstream of Hack Canyon mine complex, 4 sites downstream of the mine, and 1 site in the wash just below the mine; <, less than; ppm, parts per million; GFAA, graphite furnace atomic absorption; ICP-MS, inductively coupled plasma mass spectrometry]

\begin{tabular}{|c|c|c|c|c|}
\hline Element & $\begin{array}{l}\text { Analytical } \\
\text { method }\end{array}$ & $\begin{array}{l}\text { Upstream }{ }^{1} \\
\text { (ppm) }\end{array}$ & $\begin{array}{c}\text { Downstream² } \\
\text { (ppm) }\end{array}$ & $\begin{array}{c}\text { Wash just below } \\
\text { Hack } 1 \text { Mine }^{3} \\
\text { (ppm) }\end{array}$ \\
\hline Arsenic & GFAA & $0.8-19.5$ & $2.1-20.8$ & 1,400 and 1,780 \\
\hline Cobalt & ICP-MS & $1.7-8.9$ & $2.0-7.7$ & 5.7 and 4.4 \\
\hline Copper & GFAA & $3.8-534$ & $0.85-97.6$ & 162 and 24.6 \\
\hline Copper & ICP-MS & $4.5-234$ & $<19.5-87.9$ & 166 and 5,320 \\
\hline Lead & GFAA & $<6.7-9.9$ & $1.3-10.1$ & 1,200 and 670 \\
\hline Uranium & ICP-MS & $0.6-1.5$ & $0.6-3.6$ & 11.3 and 154 \\
\hline Vanadium & ICP-MS & $3.8-35.1$ & $6.1-24.9$ & 10.6 and 6.8 \\
\hline Zinc & ICP-MS & $0.5-86.8$ & $13.7-82.8$ & 64.6 and 89 \\
\hline
\end{tabular}

${ }^{1}$ Five sites, many samples.

${ }^{2}$ Four sites, many samples.

${ }^{3}$ One site, two samples. 
Table 6. Summary of Carver (1999) concentration ranges in trace elements in stream-sediment and water samples, collected at three sites near the confluence of Hack Canyon and Kanab Creek.

[ppm, parts per million; $\mu \mathrm{g} / \mathrm{L}$, micrograms per liter; GFAA, graphite furnace atomic absorption; ICP-MS, inductively coupled plasma mass spectrometry; n.d., element not detected (below detection limit)]

\begin{tabular}{lccc}
\hline Element & $\begin{array}{c}\text { Analytical } \\
\text { method }\end{array}$ & $\begin{array}{c}\text { Stream sediment } \\
\text { concentrations } \\
(\mathbf{p p m})\end{array}$ & $\begin{array}{c}\text { Kanab Creek water } \\
\text { concentrations }^{\mathbf{2}} \\
(\boldsymbol{\mu g} / \mathbf{L})\end{array}$ \\
\hline Arsenic & GFAA & $7.2-20.8$ & n.d. \\
Arsenic & ICP-MS & $4.3-7.1$ & n.d.-1.0 \\
Cobalt & ICP-MS & $4.8-8.9$ & $1.65-1.8$ \\
Copper & GFAA & $7.9-22.6$ & n.d. \\
Copper & ICP-MS & $8.6-19.6$ & n.d. \\
Molybdenum & ICP-MS & $0.3-0.4$ & n.d. \\
Nickel & ICP-MS & $30.2-37.5$ & $32.5-37.5$ \\
Lead & GFAA & $7.0-16.9$ & n.d. \\
Uranium & ICP-MS & $1.1-1.8$ & $6.25-7.2$ \\
Vanadium & ICP-MS & $13.2-30.2$ & n.d. \\
Zinc & ICP-MS & $38.3-81.3$ & n.d. \\
\hline
\end{tabular}

${ }^{1}$ Six samples.

${ }^{2}$ Three samples.

\section{Kanab Creek Water Samples}

Three samples of Kanab Creek water showed low traceelement concentrations, and concentrations of most elements were below the detection limits of the analytical methods used (table 6). The waters had measurable concentrations of cobalt, nickel, and uranium. Uranium concentrations of the Kanab Creek water samples ranged narrowly from 6.25 to $7.2 \mathrm{ppm}$. Concentration of these elements differed little among the sampled sites (table 6).

\section{Sampling, Sample Processing, and Analytical Methods}

\section{Soil, Stream Sediment, and Mine Waste Sampling}

Between August 24 and October 7, 2009, soil, stream sediment, mined-rock waste, and rock samples were collected at six sites within the North Segregation Area, an area proposed for withdrawal in the Kanab Creek area north of Grand Canyon National Park (fig. 1). Stream sediment samples were also collected along Jumpup Canyon near Jumpup Spring (fig. 1). Procedures for collecting each of these media are described below.

Sample locations were selected before we arrived at each site on the basis of topographic maps and aerial images. The sampling plan was designed to characterize (1) compositions of material unaffected by mining (background); (2) mined rock presently on the ground surface that contains concentrations of trace elements substantially above background concentrations; (3) trace-element-enriched materials derived from mined rock that were transported by wind or water subsequent to the onset of uranium mining or reclamation. Soil samples were collected from $0-2$ in. $(0-5 \mathrm{~cm})$ depth along traverses that crossed each site and continued beyond the extent of mining disturbance into areas that are presumed to contain materials that show background traceelement concentrations. At the time of sampling, all stream drainages crossing the mine sites were dry. Alluvial sediments from channels in these dry streams constituted the stream-sediment samples. The Pigeon Mine, Hack Mine complex, and Kanab North Mine sites contained additional surface features such as waste-rock piles, former waste-rock-pile sites identified by scattered waste rock at the surface, and current or former wastewaterpond sites. These features required additional description, mapping, and sampling beyond that employed for the background and undeveloped-mine sites.

At each soil and stream sediment sampling location, any surface litter of structured organic matter (such as leaves, needles, or twigs) or of pebbles or cobbles larger than about 1 in. $(2.5 \mathrm{~cm})$ in diameter were carefully removed so that the uppermost surface contained only mineral matter and sparse organic matter. Stainless steel sampling tools and sieve were "conditioned" by digging and sieving adjacent soil before collecting the samples of interest. A stainless steel trowel was used to carefully excavate the $0-5 \mathrm{~cm}$ depth interval and collect a composite sample of 1-2 kg in a plastic 1-gallon bucket. Stream sediments were sampled from a locality that generally included a stream reach of 50-100 ft, depending on an onsite evaluation of the availability of about 5-10 sites of sediment accumulation suitable for sampling. As we moved from site to site, subequal amounts of sediment from each site were passed through the $2 \mathrm{~mm}$ stainless steel sieve (after conditioning the sieve) until a sample containing at least $1 \mathrm{~kg}$ of $<2 \mathrm{~mm}$ material was obtained. A second pass through each sample site was necessary at some localities to accumulate sufficient material. At mine sites, composite samples (consisting of no less than five subsamples) of near-surface ( $0-5 \mathrm{~cm}$ depth) materials from some mined waste-rock piles and from pond sediments were also collected; these composite samples were not sieved. 
Each soil and stream sediment sample was placed into a clean plastic sample bag, labeled with a permanent marker, and sealed with duct tape. Dry rags and a plastic brush were used to clean sampling tools. At each sampling location, all required site and material characterization data were recorded on a sampling sheet. Careful notes, such as sketches of the sampled areas and photographs, were made to thoroughly document the area around each sample collected. An entire duplicate sample at about 1 sampling location in 10 was collected to check the reproducibility of the sampling procedure. At soil sampling sites, duplicate samples were collected from contiguous 2-in. (5-cm) -deep excavations. Duplicates at stream sediment sampling localities were collected by revisiting each of the 5-10 sampling sites and collecting materials adjacent to previous sampling points. Because mine-site material was expected to contain, relative to background materials, high concentrations of uranium and other ore-signature trace elements, mine site materials were collected separately from other less-contaminated samples. When we sampled along traverses, less-contaminated outlying areas were sampled first. All equipment was cleaned between sites that were likely to have very different concentrations of trace elements.

\section{Sample Processing}

Soil, stream sediment, and rock samples were prepared for analysis according to procedures outlined in chapter A3 (Peacock, 2002), chapter A2 (Peacock, Taylor, and Theodorakos, 2002), and chapter A1 (Taylor and Theodorakos, 2002) in "Analytical methods for chemical analysis of geologic and other materials, U.S. Geological Survey" (Taggert, 2002). Upon reaching the laboratory, the samples (as received) were air dried at $40^{\circ} \mathrm{C}$, as needed. Subsequent preparation procedures took place inside a dust hood to minimize dispersion of dusts. Stream sediment samples were sieved through an 80-mesh sieve (opening equal to $177 \mu \mathrm{m}$ ). The fraction that passed through the 80-mesh sieve was split into two parts. One part was preserved for archiving and the other was pulverized to $<100$-mesh $(<150 \mu \mathrm{m})$ and mixed to insure homogeneity for subsequent analysis. Soil samples, as received, were immediately split and pulverized to $<100$-mesh. The mine wastes and rock samples were crushed to reduce the particle size and split into two parts; one part was preserved for reference or future use, and the other was pulverized to $<100$-mesh. The $<100$-mesh fractions of soils, stream sediments, mined-rock waste, and rock were further split into two parts, one of which was archived. The other split was sent to a contract laboratory for whole-rock analysis to determine total elemental composition.

\section{Bulk Chemical Analysis}

All solid samples were analyzed by inductively coupled plasma-atomic emission spectrometry (ICP-AES) and inductively coupled plasma-mass spectrometry (ICP-MS) after acid digestion. This method is described at http://minerals.cr.usgs.gov/projects/analytical_chem/ references.html\#M19 and is summarized here. Forty-two major, minor, and trace elements (reporting limits listed on the website shown above) are determined in geological materials. Each sample is digested using a mixture of hydrochloric, nitric, perchloric, and hydrofluoric acids, heated to $110^{\circ} \mathrm{C}$ to dryness and redissolved in nitric acid. Aliquots of the resulting solution were aspirated into the ICP-AES and the ICP-MS spectrometers. The ICP-AES is calibrated by standardizing with digested rock reference materials and a series of multielement solution standards. The ICP-MS was calibrated with aqueous standards, and internal standards were used to compensate for matrix affects and internal drift. Data are deemed acceptable if measured concentrations of all 42 elements are within \pm 15 percent at five times the lower limits of determination (LOD), and the calculated relative standard deviation of duplicate samples is no greater than 15 percent.

\section{Chain of Custody}

Chain-of-custody procedures were followed for sample collection, transport, processing, and analysis. After collection, individual plastic bags containing each sample, previously sealed with duct tape, were placed into shipping containers. Shipping containers were locked and placed inside a secured vehicle or locked room that could be accessed only by USGS field personnel. Once shipping containers were filled to capacity, they were locked and prepared for transport, either by a vehicle driven by USGS field personnel or by commercial overnight delivery service. For each shipment, a chain-of-custody form was filled out that summarized the total number of samples collected of each sample medium (such as soil, surface sediment, or rock) in each shipment. Accompanying this form was a sample inventory. The individuals who shipped and received the samples signed the form as a designation of responsibility for the samples. Before shipment by the commercial overnight delivery service, boxes containing the samples were sealed with evidence tape to assure that the containers remained secure during shipment. Samples transported by the commercial overnight delivery service were hand-delivered directly to project personnel at USGS offices on the Denver Federal Center, who then verified that they received all samples listed on the inventory and then signed for the receipt of those samples. Subsequently, of all samples were processed in a secure area. Each sample was photographed as received. Processed samples were shipped to various analytical laboratories using a similar chain-of-custody shipping procedure for transport and receipt by the laboratory.

\section{Radioactivity Surveys}

Virtually all sample sites were measured with one of two Ludlum Model 19 MicroR exposure meters. Additional parts of some mine sites were surveyed without sampling. These extremely sensitive NaI scintilometers are used by health physicists to assess radiation exposure and absorbed dose (in rads) from gamma-ray and x-ray emissions. Reported gamma-ray activities in microrads $(\mu \mathrm{R}) /$ hour (h) can be 
compared with the average gamma-ray dose from terrestrial sources of radioactivity (rocks or soil) of approximately $3.2 \mu \mathrm{R} / \mathrm{h}$, or $28,000 \mu \mathrm{R} /$ year (National Council on Radiation Protection Measurements, 1987). These instruments were calibrated at the U.S. Geological Survey reactor facility at the Denver Federal Center approximately one week prior to the start of field studies on August 24, 2009.

In the natural environment, these instruments measure total gamma-ray activities derived from radioactive decay products of the uranium and thorium series and of potassium- $40\left({ }^{40} \mathrm{~K}\right)$. In most natural environments, variations in the total activity can be attributed, for the most part, to variations in the uranium, thorium, and potassium content of soils and rocks. In the vicinity of uranium ore deposits, total gamma-ray activity is predominantly attributed to emissions from uranium and its decay products.

The radioactivity of the immediate vicinity (within a 1-3 m radius) was measured around each soil, stream sediment, and rock sampling site by using a microR meter placed on the ground surface at the sampled point. Additional walking surveys with continuous scans measured radioactivity along stream beds between the sampled stream reaches. Measurements were observed at waist height or, in a few instances, by placing the instrument on the ground. Similar walking radioactivity surveys along linear soil sample traverses radiating outward from sampled mine site perimeters were also performed. These walking surveys provided some estimates of the expected microR readings at measured and recorded sites and aided in the search for ore or waste rock exposed at the surface. Detailed microR surveys (without collection of soil samples) were conducted at the Pigeon and Kanab North sites. For each measurement site with or without media sampling, global positioning system (GPS) latitude, longitude, and elevation readings were recorded along with the microR measurements. Traverse lines and specific sites for soil sampling were selected using aerial photographs to avoid being influenced by soil features or changes in microR readings.

\section{Batch Leaching}

A few samples were selected for batch leaching experiments. Samples selected for leaching included unprocessed uranium ore, mined waste-rock, surface sediments thought to contain fines or salts transported by runoff from a waste pile, and background samples. The purpose of the leaching experiments was to evaluate the solubility of trace elements in these sources. In this method, two leaching solutions were used: deionized (DI) water equilibrated with the atmosphere to produce a simulatedrainwater solution $\left(\mathrm{pH}=5.6,-\log \mathrm{pCO}_{3}{ }^{2-}=3.5\right)$, and water containing 300 milligrams per liter $(\mathrm{mg} / \mathrm{L})\left[\mathrm{HCO}_{3}^{-}\right]$, which is consistent with the bicarbonate concentration of the Colorado River and other surface waters and groundwaters. Two time periods ( $1 \mathrm{~h}$ and $24 \mathrm{~h}$ ) were used in the rainwater experiments to determine the differences in trace element solubility during a short and a long rain event and to determine the soluble components of weathered mine waste.
Samples were processed by grinding and crushing, as necessary, to a size less than $2 \mathrm{~mm}$; they then were mixed and split using a stainless-steel splitter to obtain a homogenous $50 \mathrm{~g}$ sample. Samples were then processed according to the Hageman and Briggs Field Leach Test (Hageman and Briggs, 2000), which is a modification of Environmental Protection Agency Method 1312 (Synthetic Precipitation Leaching Procedure). In summary, $50 \mathrm{~g}$ of a solid sample were extracted in 1,000 milliliters $(\mathrm{mL})$ of deionized $(18 \mathrm{M} \Omega \mathrm{cm})$ water (20:1 liquid/solid ratio). New extraction vessels (Nalgene high density polyethylene $1 \mathrm{~L}$ bottles) were rinsed with DI water. Fifty grams of each sample was weighed and placed into the extraction vessel. One liter of DI water was slowly added to the vessel, and each vessel was capped. The extractor vessels were secured in an Analytical Testing Rotary Agitator (Model DC-20B) and rotated end-over-end at 28 revolutions per minute (rpm) for $1 \mathrm{~h}$ and $24 \mathrm{~h}$. One replicate sample and a blank sample containing only DI water were processed with every 10 samples. At the end of the initial 24-h agitation period, a $250 \mathrm{~mL}$ aliquot of the mixture was poured into a centrifuge bottle and centrifuged at 5,000 rpm for 30 minutes $(\mathrm{min})$ to remove mineral particles larger than approximately 0.4 micrometers $(\mu \mathrm{m})$ from suspension. This mixture was then processed as described for the 24-h extraction with DI water.

After centrifugation, an aliquot of the supernatant liquid was taken for measurement of $\mathrm{pH}$, alkalinity, and specific conductivity. The remainder of the $250-\mathrm{mL}$ aliquot of sample was filtered through a $0.7-\mu \mathrm{m}$ glass-fiber syringe filter (Nalgene PN 189-2000) in series with a $0.45-\mu \mathrm{m}$ surfactant-free cellulose acetate syringe filter (Cameo DDE04025S0) pressurized through a 60-mL plastic sterile Luer-Lok syringe (BD P/N 309653). Filtrates were split into four 50-mL samples for chemical analysis. The $50-\mathrm{mL}$ aliquot was acidified to $\mathrm{pH} 1.5$ with Ultrex II Ultrapure nitric acid. One of the samples was submitted for trace element analysis using ICP-MS (Lamothe and others, 2002).

\section{Site Investigations}

Five sites were selected for study (fig. 1): Pigeon Mine, Kanab North Mine, Kanab South drill site, Hermit Mine, and Hack Mine complex (Hack Canyon and Hack 1, 2, 3 Mines). A stream-sediment survey was conducted along Jumpup Canyon near Jumpup Spring in an unmined area of the North Kaibab Ranger District to estimate background concentrations of trace elements in stream sediments. The Pigeon Mine is a fully reclaimed site in a small unnamed canyon that is a tributary of Snake Gulch. The Kanab North Mine is a mine site on standby with substantial quantities of mined waste rock stored on the ground surface. The site lies on a plateau within a few hundred feet of the cliff on the west side of Kanab Creek. The Kanab South pipe is located along a drainage tributary to Kanab Creek and is a few hundred yards from the cliff on the west side of Kanab Creek. The amount of ore identified by drilling the deposit was insufficient to support mine development. The drilling roads and pads were reclaimed. The Hermit 
Mine is a completely reclaimed site on a gently rolling plateau surface. The Hack Mine complex is in the upper part of Hack Canyon 8 to 9 mi west of Kanab Creek. Each of these sites is distinct and has different exposure to wind and floods, volume and grade of mined ore, and length of time that ore and waste materials have been exposed at the surface.

The trace elements considered during this study are arsenic (As), cadmium ( $\mathrm{Ca}$ ), cobalt $(\mathrm{Co})$, copper $(\mathrm{Cu})$, molybdenum (Mo), nickel $(\mathrm{Ni})$, lead $(\mathrm{Pb})$, antimony $(\mathrm{Sb})$, thallium $(\mathrm{Tl})$, uranium $(\mathrm{U})$, vanadium $(\mathrm{V})$, and zinc $(\mathrm{Zn})$. These elements include those of significant environmental concern and elements known to be present in breccia-pipe uranium ores at concentrations substantially greater than in the surrounding rock.

\section{Jumpup Canyon}

Jumpup Canyon is a major eastern tributary to Kanab Creek (fig. 1). It drains much of the west-central part of the Forest Service land in which it is located. This area was withdrawn as a wildlife refuge in the early 1900s and, although early prospectors likely investigated the area, there has been no reported exploration and mineral development for 100 years. Billingsley and others (2008) mapped a few collapse structures and one breccia pipe in areas around the lower part of Jumpup Canyon.

The geology along the sampled part of the canyon consists of a flat-lying Permian section with the plateau capped by the Harrisburg Member of the Kaibab Formation. Exposed in the canyon wall below the Harrisburg Member are, in order, the Fossil Mountain Member of the Kaibab Formation; the Woods Ranch, Brady Canyon, and Seligman Members of the Toroweap Formation; and the Hermit Formation. Above the Hermit Formation, the Coconino Sandstone is mostly absent, but it is found as a thin unit in a few locations along the canyon wall. The Hermit Formation is mostly covered by talus and colluvium on the canyon slopes. The Coconino Sandstone and Hermit Formation are common hosts for uranium in breccia pipes (Billingsley and others, 2008). Above and near Jumpup Spring, terrace gravels are deposited along the east canyon wall.

Nine stream sediments were sampled along Jumpup Canyon from a point about 5,800 $\mathrm{ft}$ upstream from Jumpup Spring to a point about $6,300 \mathrm{ft}$ downstream (fig. 1). A tenth sample was taken in the lower part of Pine Hollow, which joins Jumpup Canyon at the spring. Water from Jumpup Spring was sampled during the companion study led by Don Bills and others (this volume). One sediment sample, taken just downstream from Jumpup Spring, consists of black, organic muck from the downstream end of a small pool of water fed by Jumpup Spring. The uranium concentration in stream sediment samples along Jumpup Canyon and its tributary ranged from 1.6 to $1.9 \mathrm{ppm}$, and the uranium concentration in the black organic-muck sample was $2.9 \mathrm{ppm}$.

The average, median, and range for trace element concentrations in 9 of the 10 Jumpup Canyon stream sediment samples (excluding the muck sample) are given in table 7 . The median concentrations are considered background concentrations for stream sediments in this study. The tenth sample, the organic muck below Jumpup Spring, was slightly enriched in uranium $(2.9 \mathrm{ppm})$ and contained anomalously high concentrations of copper (66.6 ppm), nickel (23 ppm), and zinc (362 ppm). MicroR measurements for all sample sites along Jumpup Canyon ranged narrowly from 4 to $5 \mu \mathrm{R} / \mathrm{h}$.

\section{Pigeon Mine}

Pigeon Mine lies in a small wash north of Snake Gulch, an eastern tributary to Kanab Creek (figs. 1, 5). The center of the mine site is located at $36^{\circ} 43^{\prime} 27.35^{\prime \prime} \mathrm{N}$. latitude and $112^{\circ} 31^{\prime} 40.80^{\prime \prime} \mathrm{W}$. longitude at an altitude of $5,210 \mathrm{ft}$ above sea level (asl). The center is about 165-200 ft below the adjacent plateau surface to the west, north, and south. Gullies feed radially towards the center of the collapse feature from three sides, and a narrow ridge to the southeast separates the pipe from an adjacent wash. A wash exits the pipe area to the south then turns sharply east to join the adjacent wash (fig. 5). The geologic unit at the surface is the Harrisburg Member of the Kaibab Formation (Billingsley and others, 2008).

The pipe was discovered in 1980 . The site was prepared and developed from 1982 to 1984, and mining began in December 1984. The pipe was mined out in late 1989 and reclamation begun. Production totaled 5.7 million pounds $\mathrm{U}_{3} \mathrm{O}_{8}$ at an average grade of 0.65 percent from 439,400 tons of ore (Pool and Ross, 2007). During mining operations a shaft was dug into the pipe (fig. 6) on the slopes of the small wash, and a mine-site pad was established adjacent to the shaft. Two areas were cleared for site operations on the plateau to the north (fig. 6). One, centered at $36^{\circ} 43^{\prime} 43.82^{\prime \prime} N$. latitude and $112^{\circ} 31^{\prime} 47.90^{\prime \prime} \mathrm{W}$. longitude, was the location of mine operation buildings and ore and mined waste-rock piles. This area, here referred to as the operations site, is about $480 \times 340 \mathrm{ft}$; the long dimension is oriented northeast. Waste-rock and ore piles were at the surface of the operations site for a maximum of 5 years. The second area, centered at $36^{\circ} 43^{\prime} 52.21$ " N. latitude and $112^{\circ} 31^{\prime} 45.07 \mathrm{l} \mathrm{W}$. longitude, is a $400 \times 400 \mathrm{ft}$ square that contained wastewater ponds.

Table 7. Range, average, and median concentrations of trace elements in stream sediment from Jumpup Canyon.

[ppm, parts per million]

\begin{tabular}{lccc}
\hline \multicolumn{1}{c}{ Element } & $\begin{array}{c}\text { Range } \\
(\mathbf{p p m})\end{array}$ & $\begin{array}{c}\text { Average } \\
(\mathbf{p p m})\end{array}$ & $\begin{array}{c}\text { Median } \\
(\mathbf{p p m})\end{array}$ \\
\hline Arsenic & $4-5$ & 4.6 & 5 \\
Cadmium & $0.2-0.4$ & 0.3 & 0.3 \\
Cobalt & $3.3-5.0$ & 4.2 & 4.4 \\
Copper & $9.3-18.7$ & 12.9 & 12.5 \\
Molybdenum & $0.61-1.0$ & 0.78 & 0.74 \\
Nickel & $7.9-12.5$ & 10.3 & 10.9 \\
Lead & $10.1-14.6$ & 12.4 & 12.5 \\
Antimony & $0.38-0.56$ & 0.47 & 0.47 \\
Thallium & $0.3-0.4$ & 0.31 & 0.3 \\
Uranium & $1.6-1.9$ & 1.7 & 1.7 \\
Vanadium & $23-32$ & 29 & 29 \\
Zinc & $32-53$ & 42 & 41 \\
\hline
\end{tabular}




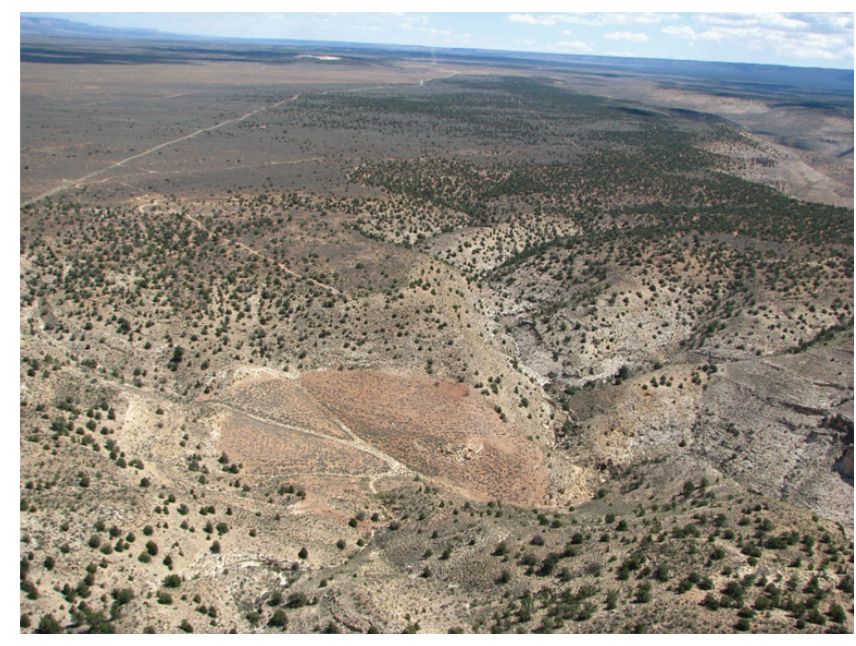

Figure 5. Pigeon Mine site (in small wash); view to northeast. Surface of Pigeon breccia pipe is pale reddish-brown, a color derived from material used to cover mined waste rock throughout the site. Boulders mantle reconstructed drainages in the pipe. (Photograph courtesy of Don Bills, U.S. Geological Survey, Flagstaff, Arizona. Taken August 25, 2009.)

Reclamation has been completed. Within the wash, land surface that was altered during mining was recontoured and is covered with a mix of local soil and rock and gravel from the local county gravel pit (fig. 7). The surface was revegetated, but a few areas support little new growth. Breccia crops out in the covered area. A small gully has eroded the surface of the covered area, but it does not appear to have penetrated buried waste rock (if any is present). The principal gullies draining the site were reconstructed, and large boulders were placed along the channels to control erosion. The haul road was regraded within the wash; it is covered with boulders, here and on the adjacent plateau, to discourage travel. The operations and wastewater pond sites on the nearby plateau were cleared, regraded, and revegetated (fig. 8).

Pigeon Mine was the site of the following USGS studies:

- Soil and mined waste-rock sampling of the cover area within the mine site;

- Soil sampling on the adjacent plateau and hillslope areas;

- Stream sediment sampling within the pipe area and along the wash immediately to the east;

- Soil and waste-rock sampling along two traverses across the former mine operations and mined wasterock storage pile site;

- MicroR readings at each of the soil and stream sediment sites listed above;

- MicroR readings across the site of the former wastewater ponds; and

- Detailed microR readings and sampling on the east slope of the narrow ridge separating the mine site from the adjacent wash. This area contains exposed, mined waste rock that has been transported downslope (fig. 7).
Geochemical data for soil, stream sediment, rock, and mined waste-rock samples are shown on separate map series for the mine site and for the operations site; data for uranium, arsenic, cadmium, antimony, cobalt, copper, lead, molybdenum, nickel, vanadium, zinc, and thallium is presented (figs. 9A-X). No samples were collected across the waste pond site, but radioactivity was measured in that area.

Soil samples collected across the surface of the reclaimed area of the pipe have uranium concentrations that range from 2.2 to $8.1 \mathrm{ppm}$, except for two samples that contain 68 and 79.1 ppm uranium (fig. 9A, n=26; samples GC09PS50-75a). The average and median concentrations of 9.6 and 4.4 ppm uranium, respectively, show the effect of two high-concentration samples. These latter samples likely represent soil contaminated by partly exposed waste material. The uranium content of the cover material is thus about $4.4 \mathrm{ppm}$. Along the reclaimed area's southeast margin, the edge of the gravel cover allows underlying mined waste rock to be exposed along a short section of the crest of the ridge (fig. 7). Owing to distinctive reddish to yellowish colors of slope wash derived from the mined waste rock, which are distinct from the pale reddish-brown

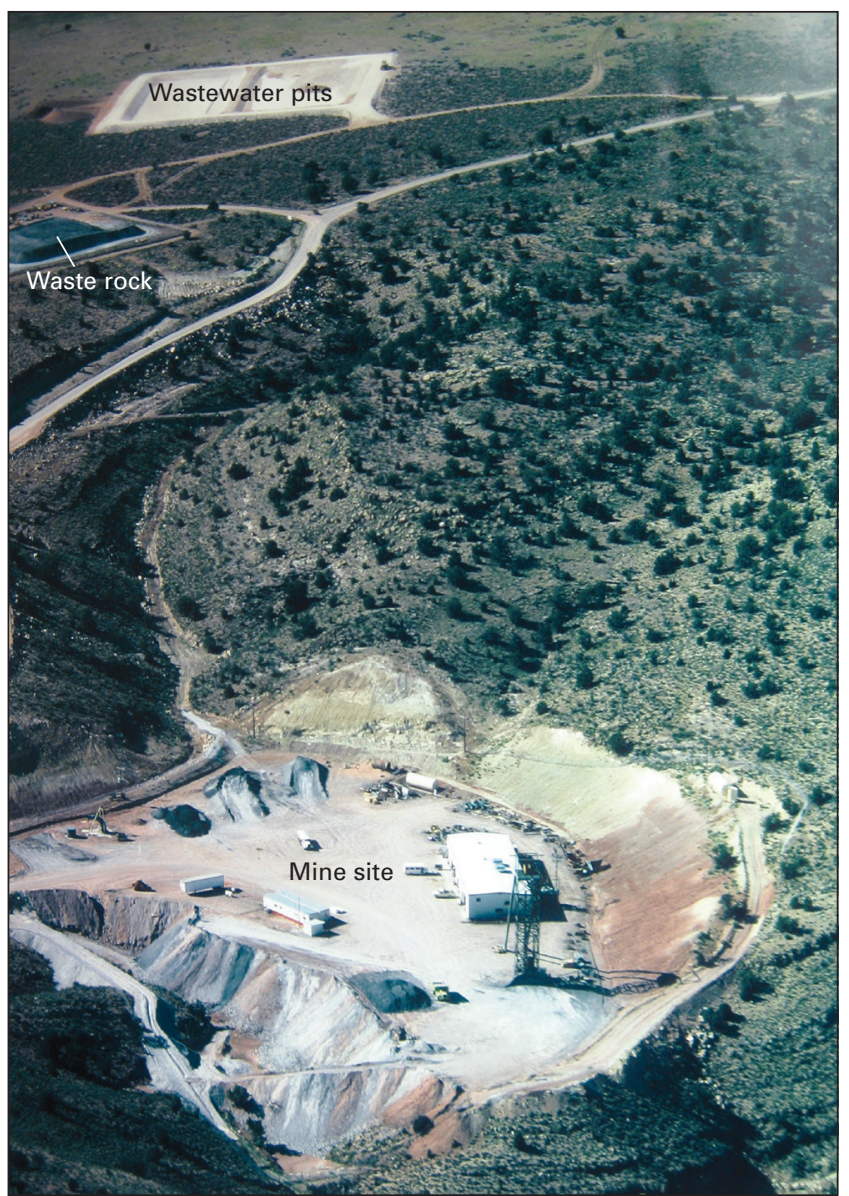

Figure 6. Pigeon Mine during operation; waste-rock piles and wastewater ponds placed on plateau surface. Operations offices were to the left of waste-rock pile. (Photograph courtesy of Denison Mines, Fredonia, Arizona.) 


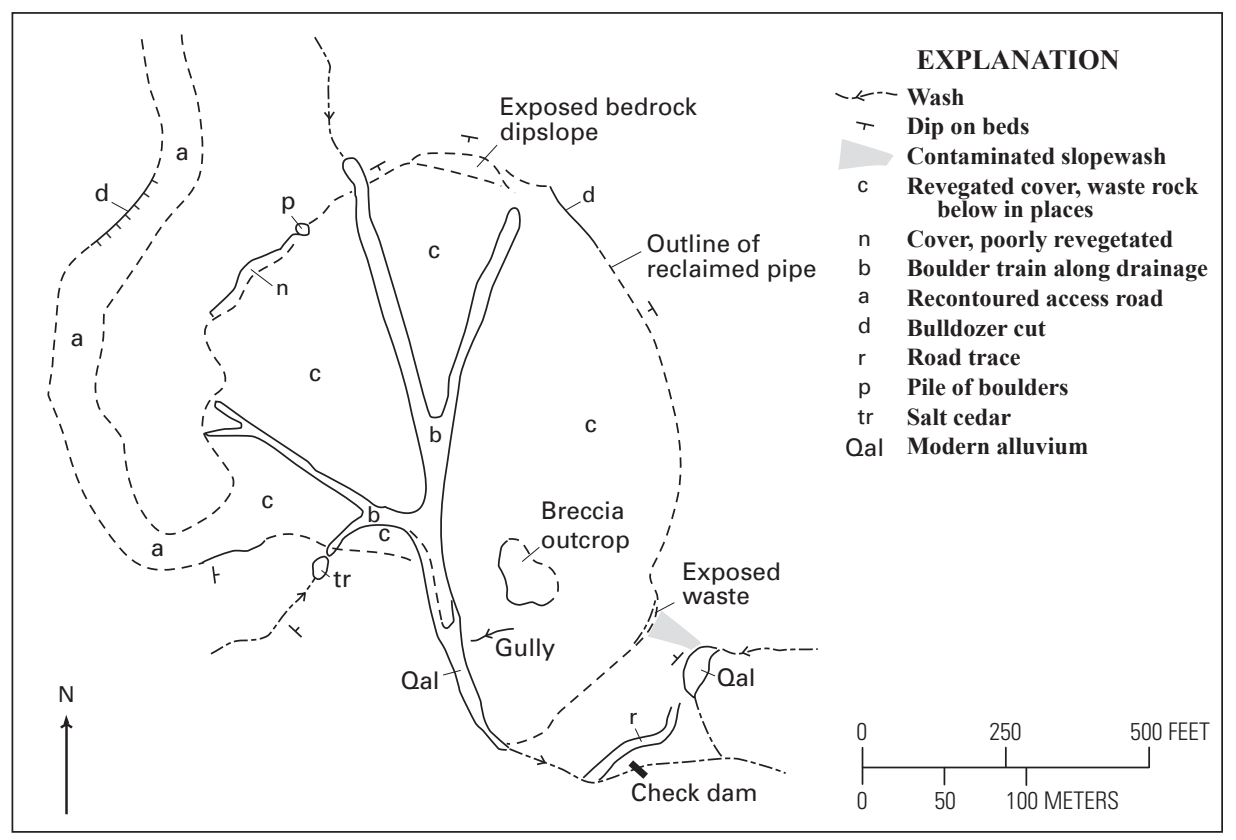

Figure 7. Pigeon pipe showing reclaimed pipe area and related features.

color of the natural soils, this material can be traced downslope from the ridge crest to the edge of the stream channel. One sample of the slope wash contained 20.4 ppm uranium, and a sample of the exposed waste rock contained $171 \mathrm{ppm}$ uranium (fig. $9 A$, table 8 ).

Concentrations of uranium in soil samples on adjacent hilltops and slopes outside of the reclaimed pipe area range from 3.2 to $36.6 \mathrm{ppm}$ and average $9.5 \mathrm{ppm}$ (median, $6.3 \mathrm{ppm}$ ) (fig. $9 \mathrm{~A}$, $\mathrm{n}=16$; table 8, samples GC09PS01-16). All soil samples that contained uranium concentrations exceeding $7 \mathrm{ppm}$ were collected on the east side of the pipe. The two highest uranium concentrations (26.5 and 36.6 ppm) (fig. 9A; table 8, samples GC09PS06-7) were found on the hillslope close to the eastern edge of the pipe. These two sites are downslope from the ridge crest where it is several tens of feet to the east of the bedrock contact with the pipe and the reclaimed area. Slope wash derived from mined waste rock could not have contributed to the uranium content of these soils because of their physical location relative to mine operations. These concentrations are clearly anomalous when compared with regional soil samples from the 12-quadrangle part of the NURE HSSR study (mean 2.4 ppm uranium) and the median concentration of the present-day soil cover (4.4 ppm). These data suggest that windblown dusts from the site may have contributed uranium to soils during mine operations. The ratio of arsenic to uranium in these two soil samples is about 2:1, similar to the average ratio of arsenic to uranium in mine waste samples collected from the site (table 8, samples GC09PW01, -W02, -W03, -W101, -R75 and -R76). A single soil sample taken from a hillslope across the stream to the east contained $11.1 \mathrm{ppm}$ uranium (fig. 9A; table 8, sample GC09PS08,). This sample may also be contaminated by windblown dust, but other highly anomalous trace elements are present in this sample - arsenic (393 ppm), silver (2 ppm), molybdenum (96.7 ppm), and zinc
(254 ppm). The arsenic/uranium ratio is much higher in this soil sample (35:1) than in the two samples discussed previously. This soil sample also contained 3.62 percent iron, three times the average of the other 15 soil samples (1.21 percent). Examination of bedrock exposed in the small drainage revealed several irregularly shaped, crosscutting zones of resistant, limonite-cemented sandstone, some of which have radioactivity levels above background. Similar limonite-cemented sandstone occurs near the Kanab South pipe. These zones may have been formed by fluids circulating near the pipe during ore formation; they occur along the ridge where this soil sample was collected and are the most likely source of iron.

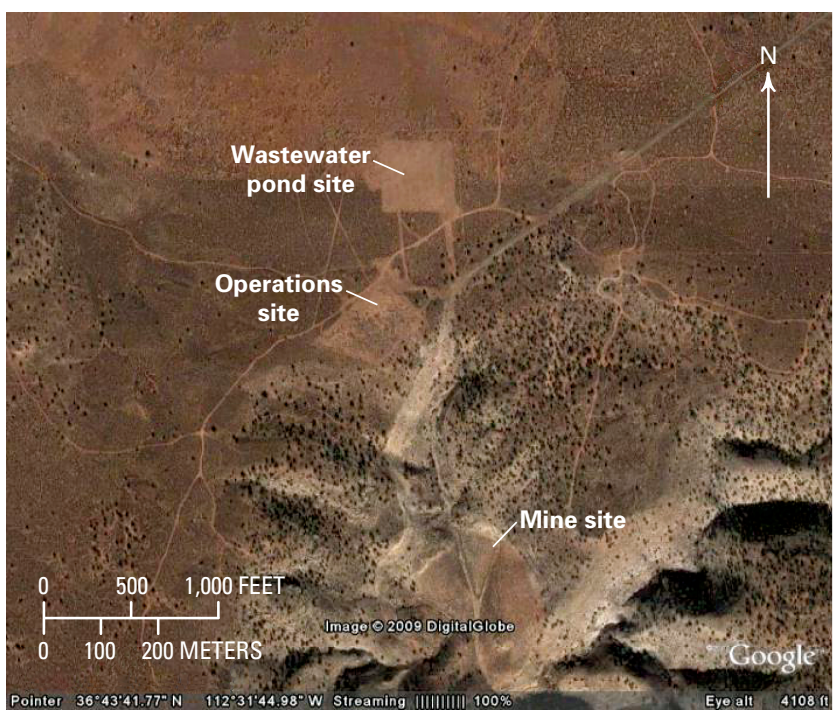

Figure 8. Former Pigeon Mine site, showing reclaimed operations area, waste-water ponds, and mine area. 

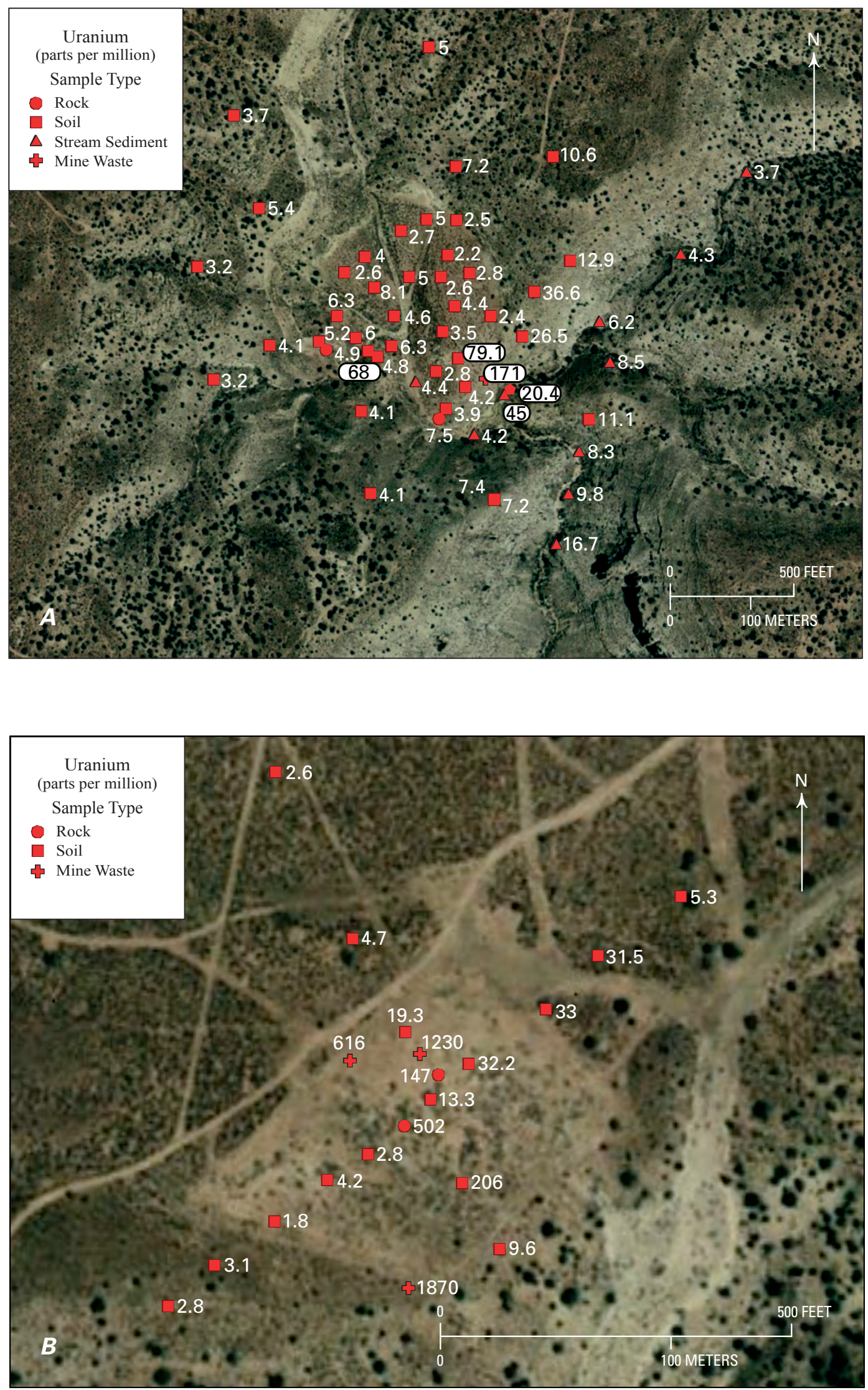

Figure 9. Concentration of selected elements in soils, stream sediments, waste rock, and rock samples at Pigeon Mine site. Uranium concentration at mine site $(A)$ and operations site $(B)$. 

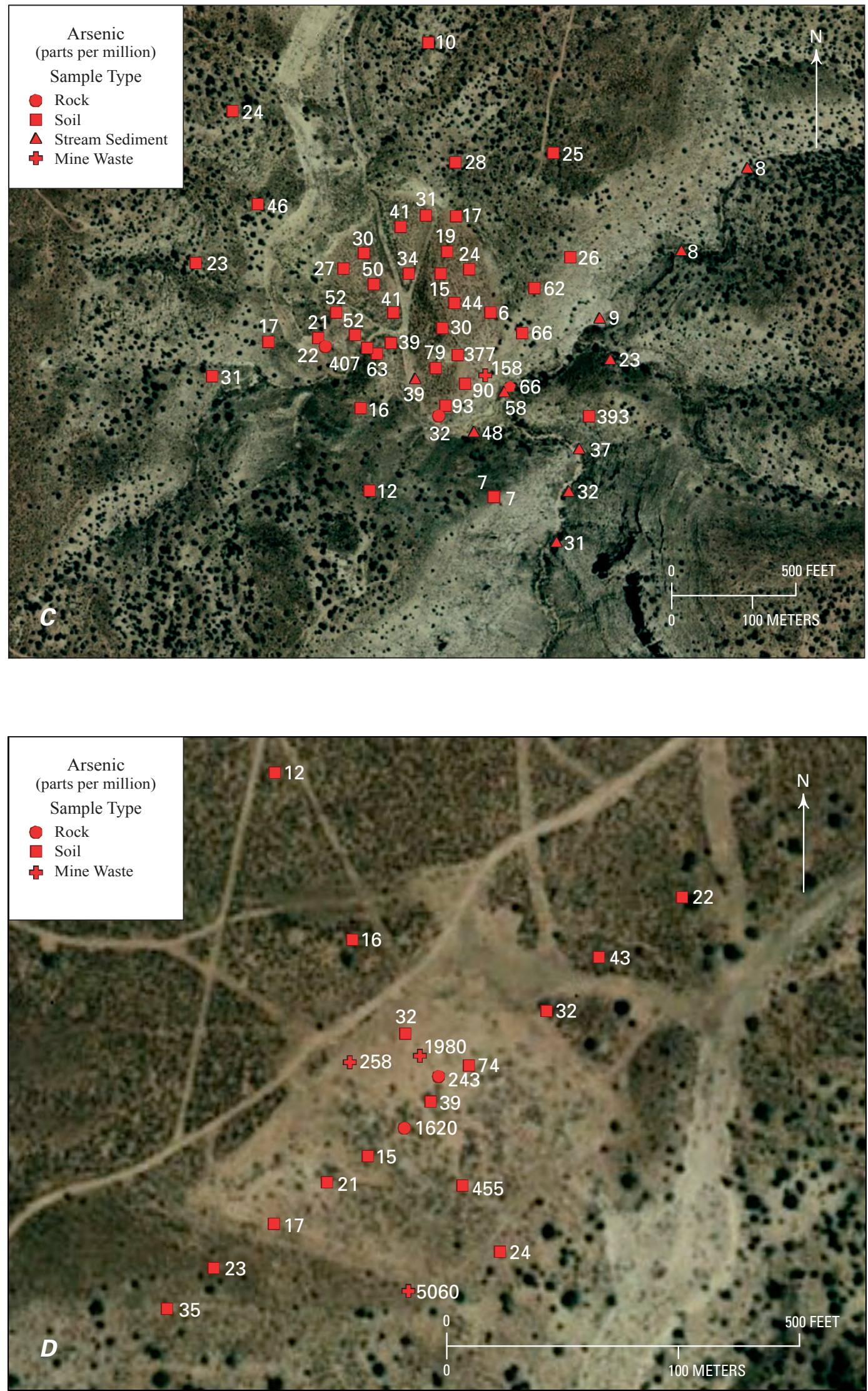

Figure 9-Continued. Concentration of selected elements in soils, stream sediments, waste rock, and rock samples at Pigeon Mine site. Arsenic concentration at mine site $(C)$ and operations site $(D)$. 

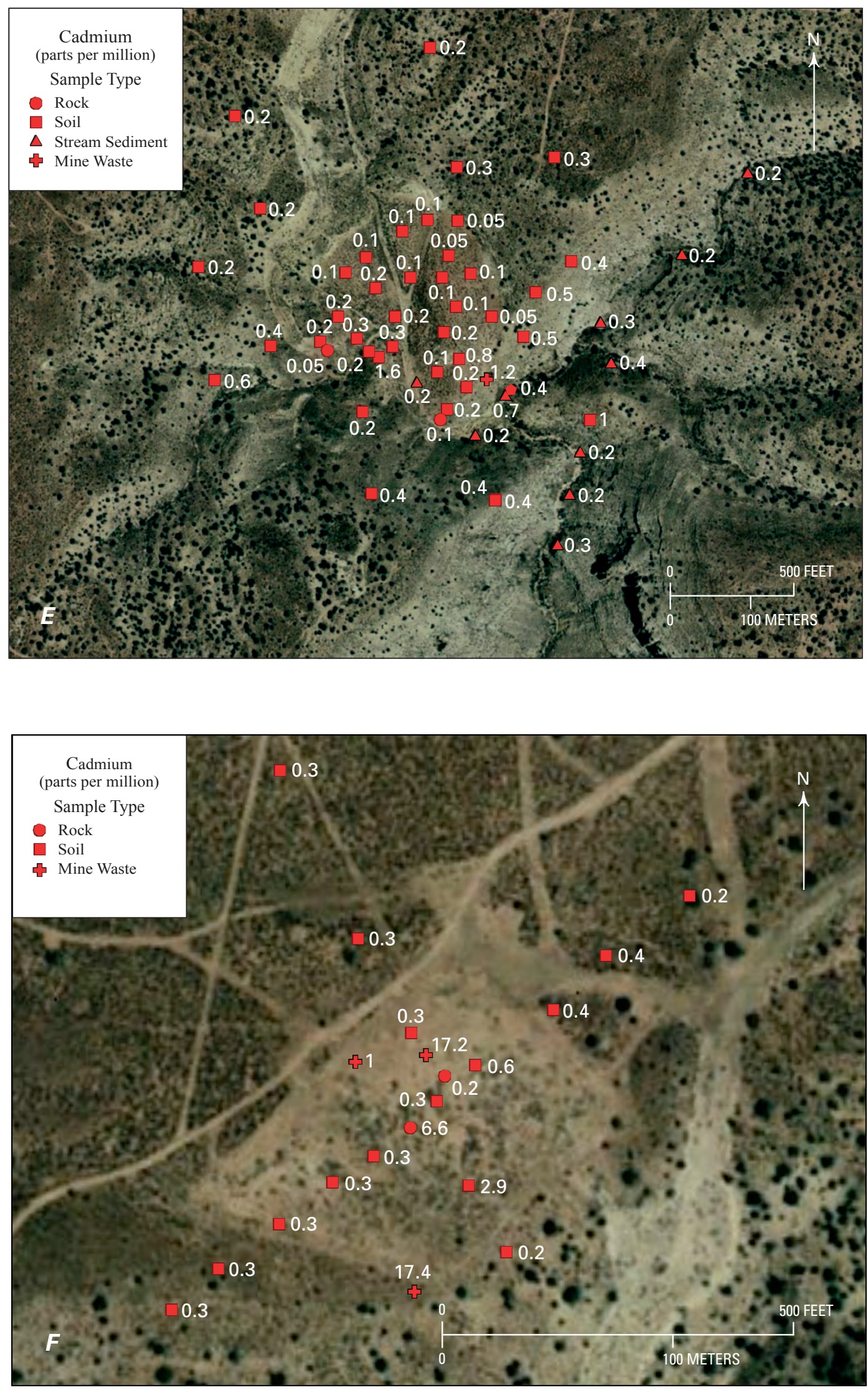

Figure 9-Continued. Concentration of selected elements in soils, stream sediments, waste rock, and rock samples at Pigeon Mine site. Cadmium concentration at mine site $(E)$ and operations site $(F)$. 

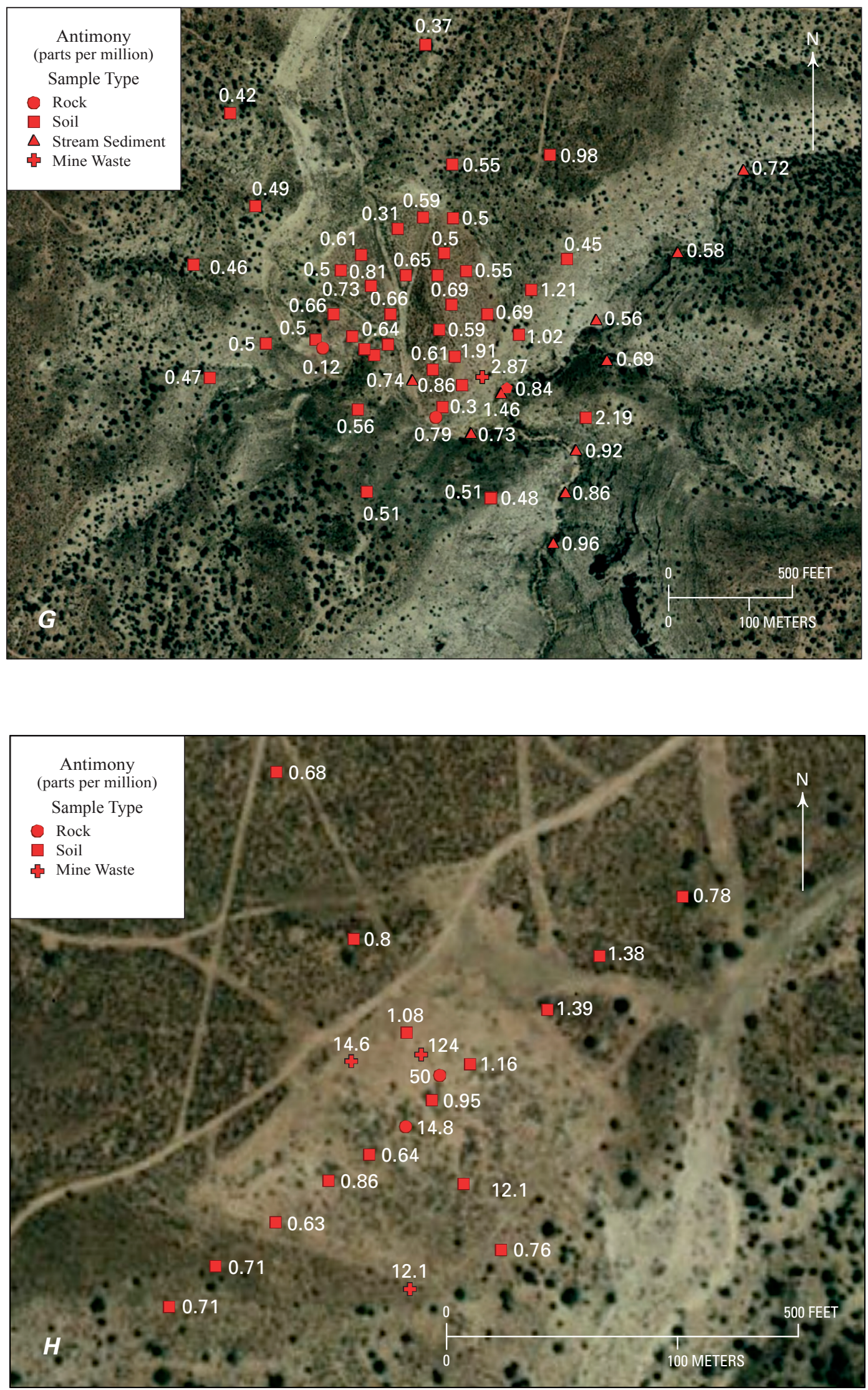

Figure 9-Continued. Concentration of selected elements in soils, stream sediments, waste rock, and rock samples at Pigeon Mine site. Antimony concentration at mine site $(G)$ and operations site $(H)$. 

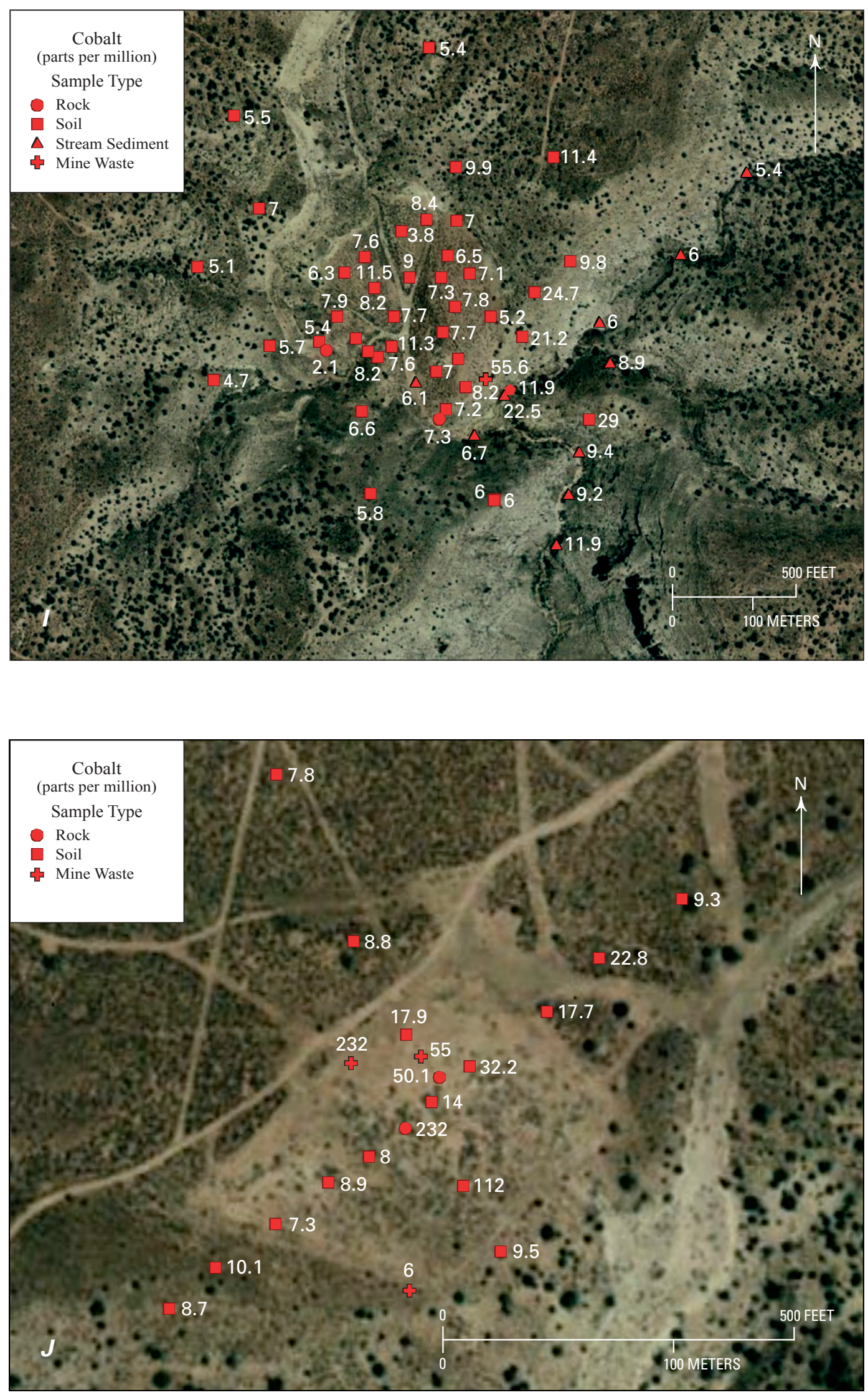

Figure 9-Continued. Concentration of selected elements in soils, stream sediments, waste rock, and rock samples at Pigeon Mine site. Cobalt concentration at mine site ( $/$ ) and operations site (J). 

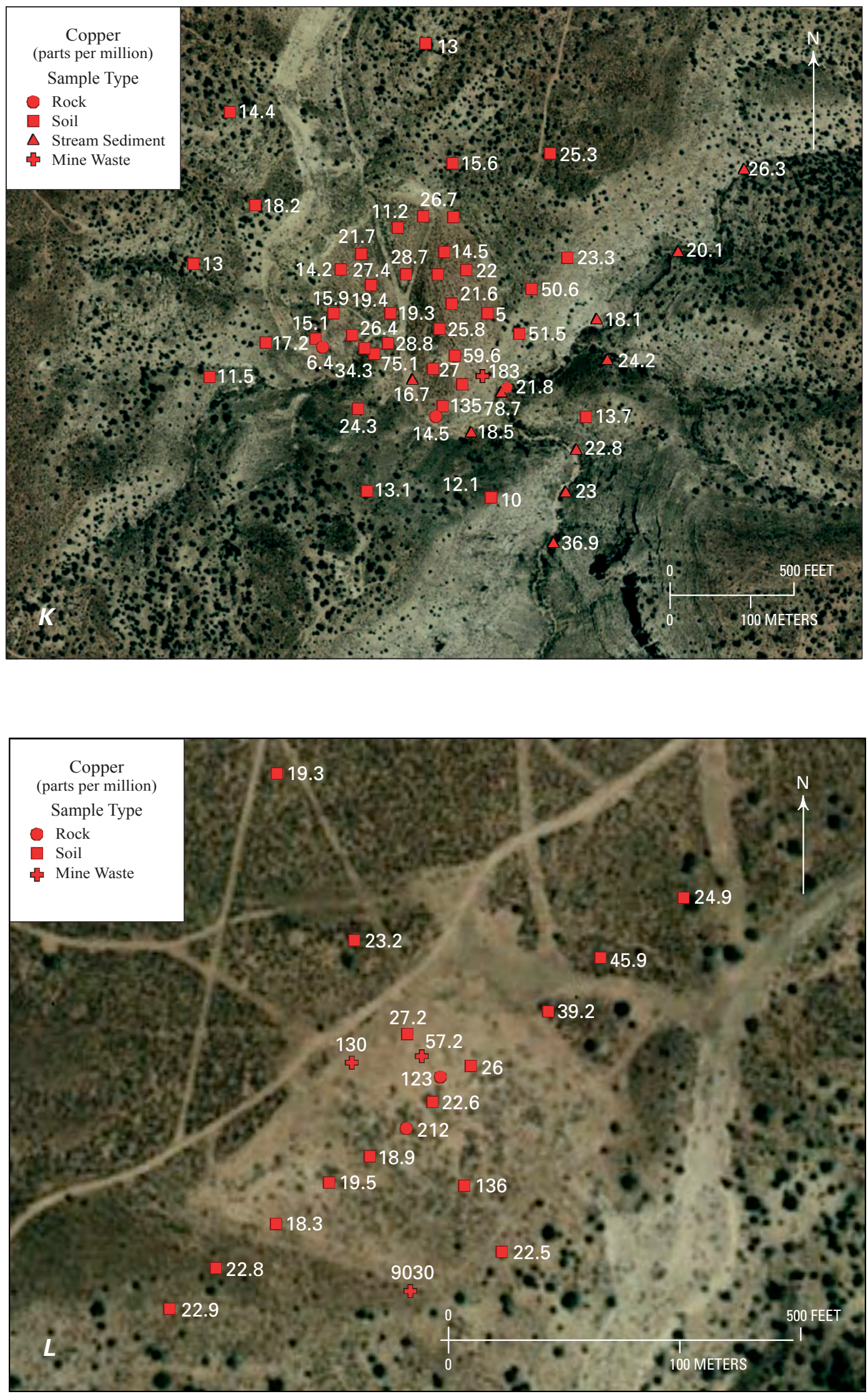

Figure 9-Continued. Concentration of selected elements in soils, stream sediments, waste rock, and rock samples at Pigeon Mine site. Copper concentration at mine site $(K)$ and operations site $(L)$. 

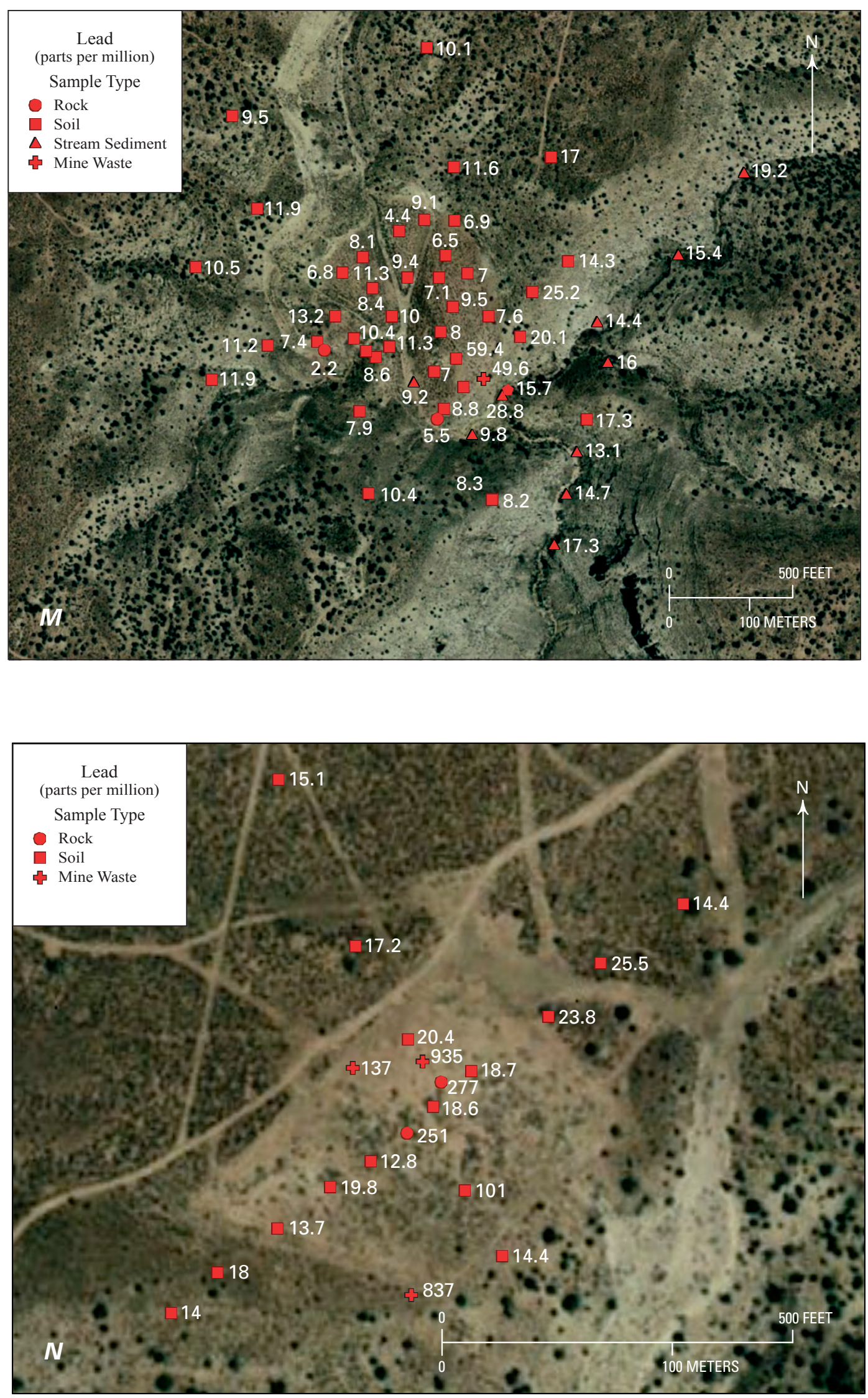

Figure 9-Continued. Concentration of selected elements in soils, stream sediments, waste rock, and rock samples at Pigeon Mine site. Lead concentration at mine site $(M)$ and operations site $(M)$. 

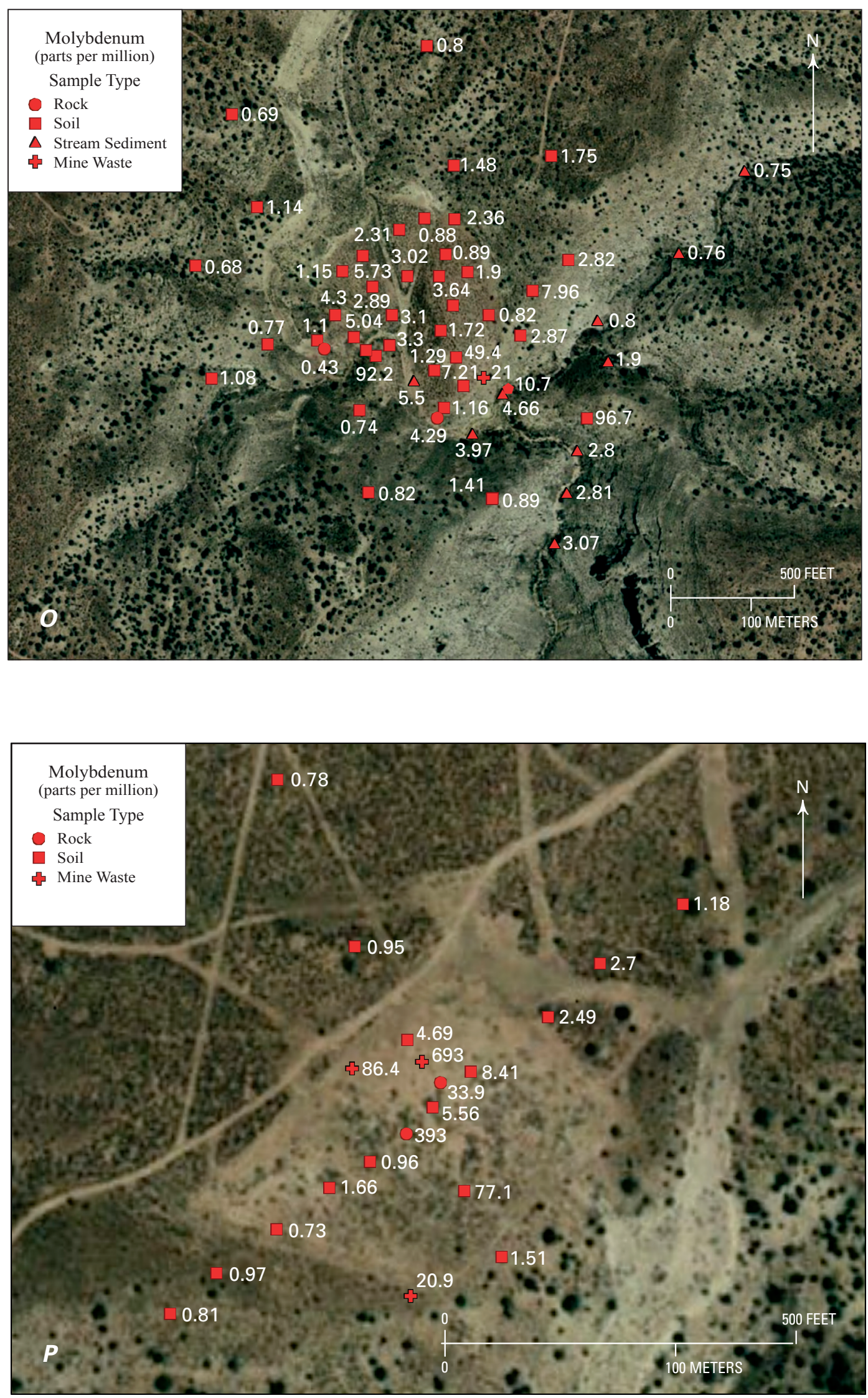

Figure 9-Continued. Concentration of selected elements in soils, stream sediments, waste rock, and rock samples at Pigeon Mine site. Molybdenum concentration at mine site $(0)$ and operations site $(P)$. 

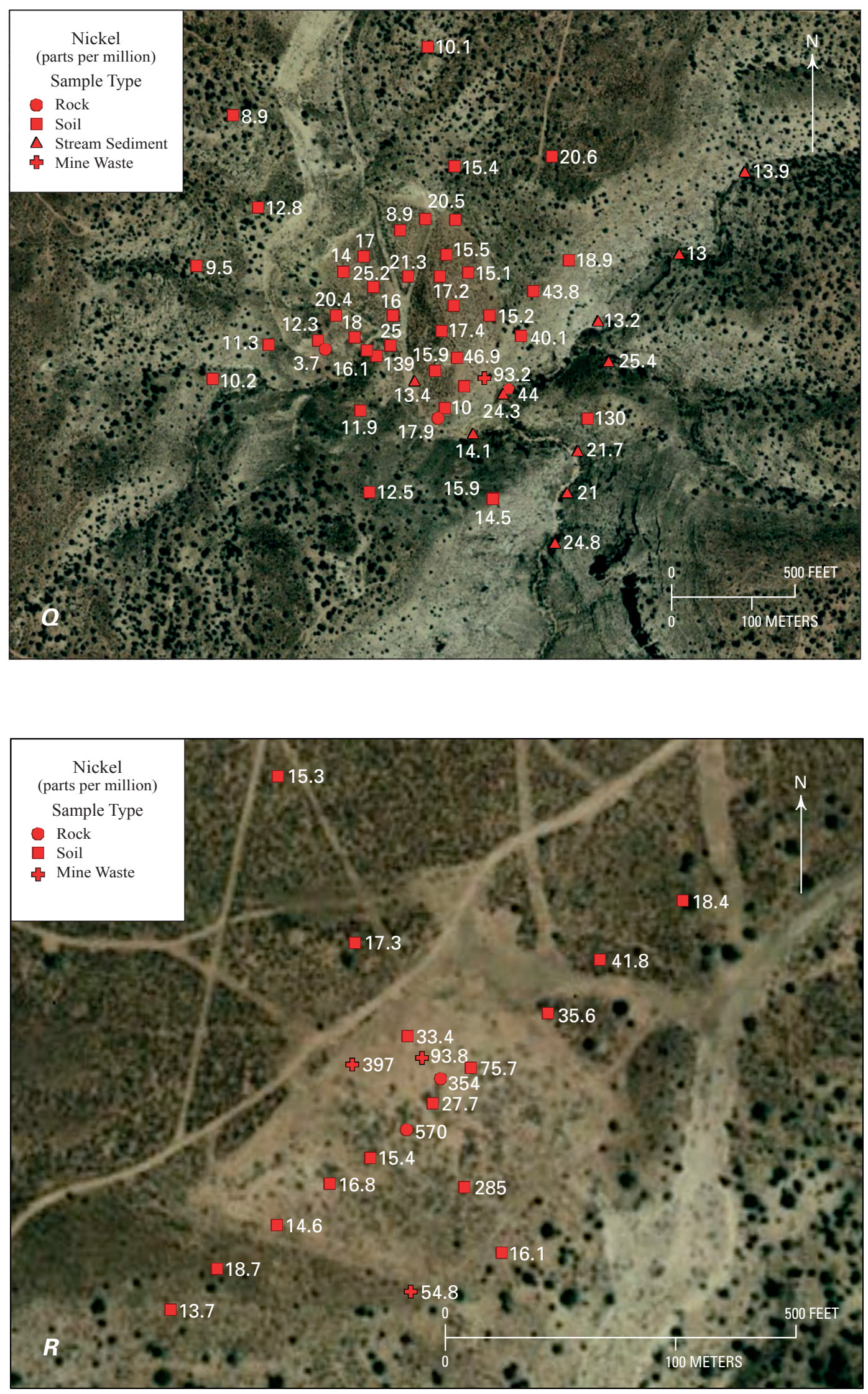

Figure 9-Continued. Concentration of selected elements in soils, stream sediments, waste rock, and rock samples at Pigeon Mine site. Nickel concentration at mine site $(Q)$ and operations site $(R)$. 

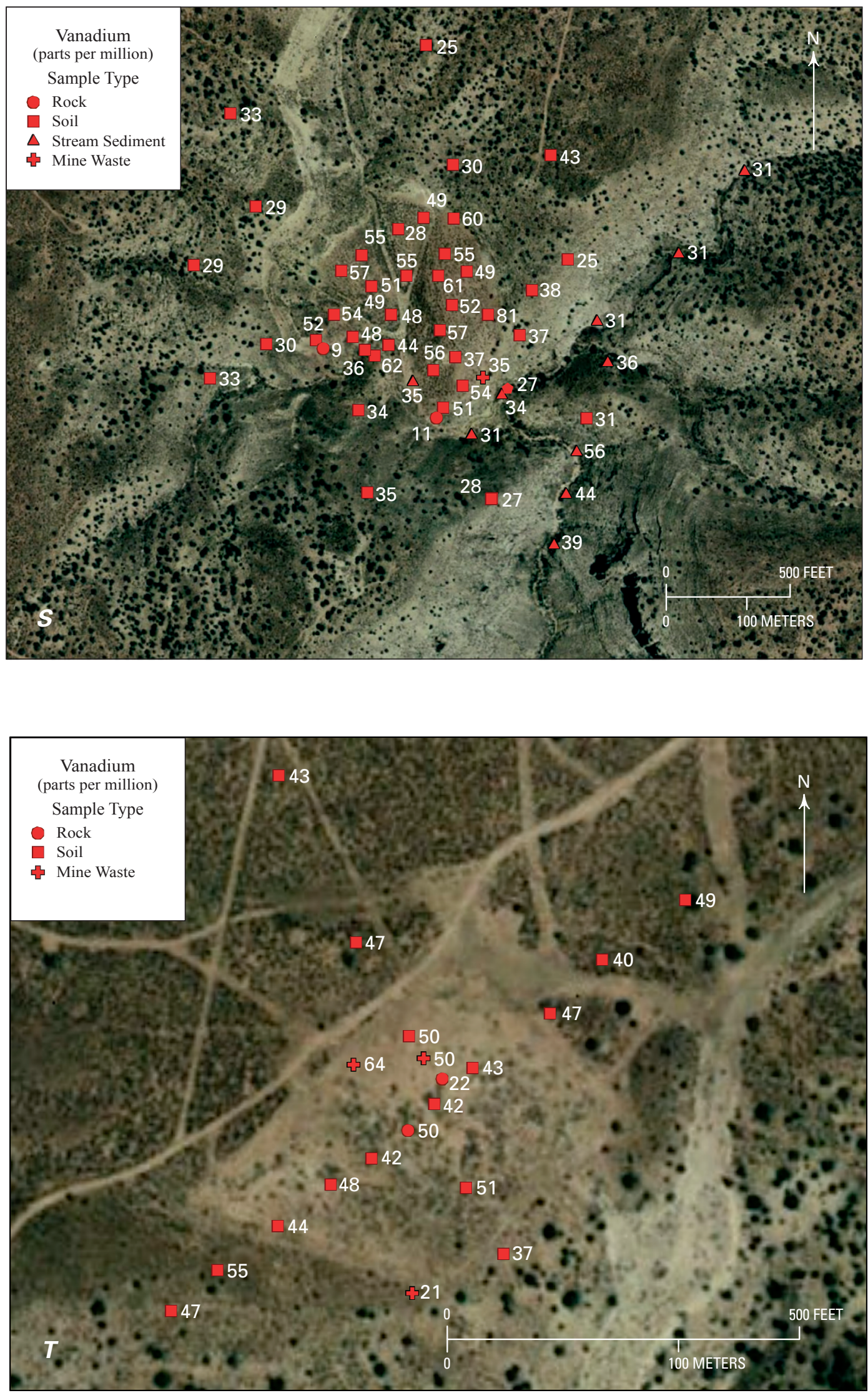

Figure 9-Continued. Concentration of selected elements in soils, stream sediments, waste rock, and rock samples at Pigeon Mine site. Vanadium concentration at mine site $(S)$ and operations site $(T)$. 

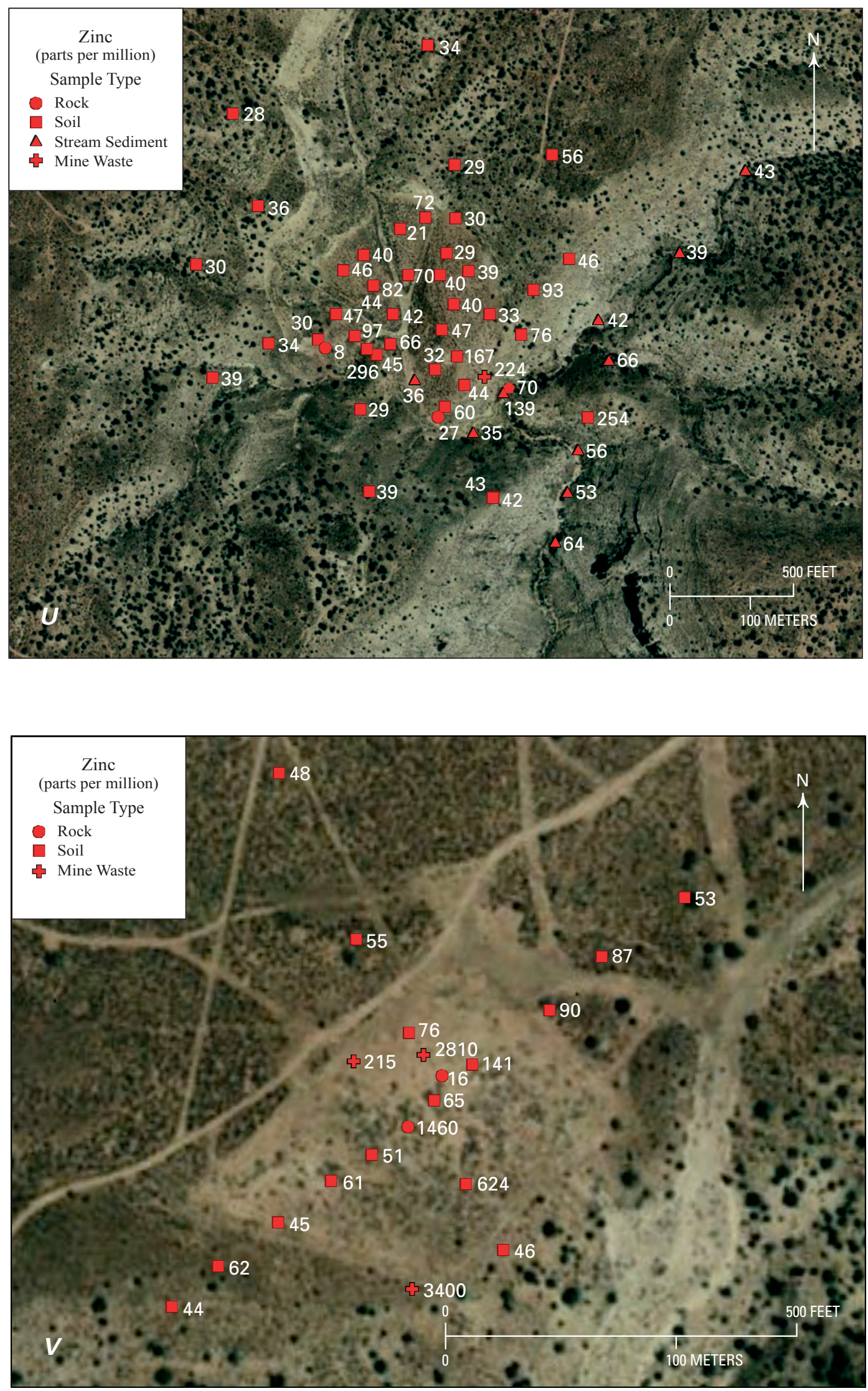

Figure 9-Continued. Concentration of selected elements in soils, stream sediments, waste rock, and rock samples at Pigeon Mine site. Zinc concentration at mine site $(U)$ and operations site ( $V$. 

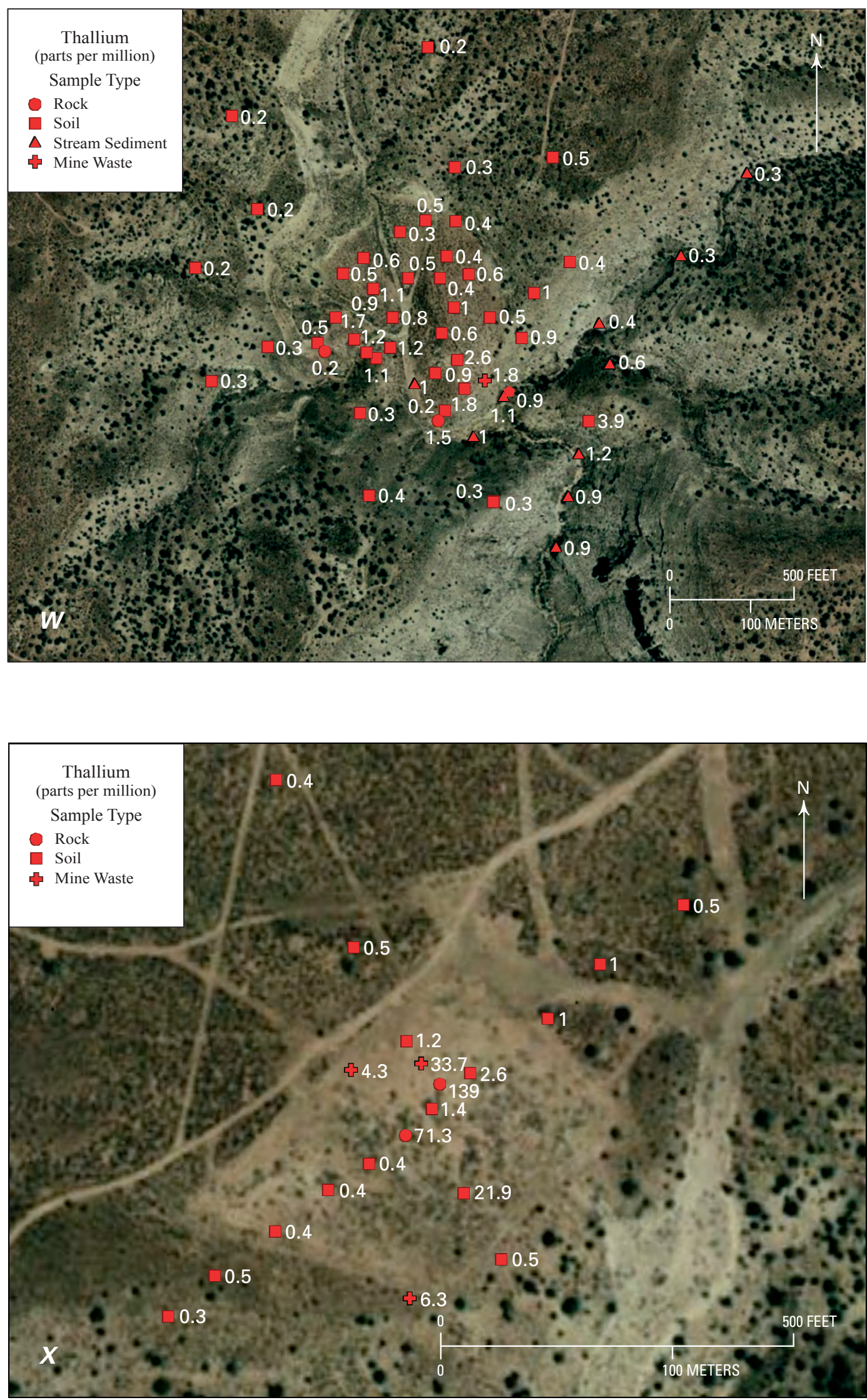

Figure 9-Continued. Concentration of selected elements in soils, stream sediments, waste rock, and rock samples at Pigeon Mine site. Thallium concentration at mine site $(W)$ and operations site $(X)$. 
Table 8. Chemical analyses of soil, sediment, rock, and mine waste samples collected by this study. Description of major, minor, and trace element data from samples collected at Jumpup Canyon, Pigeon, Kanab North, Kanab South, Hermit, and Hack Canyon sample sites.

[Datum for all latitude and longitude values is WGS 1984; ppm, parts per million; wt. \%, weight percent; see text for description of sample processing and analytical procedures; no., number]

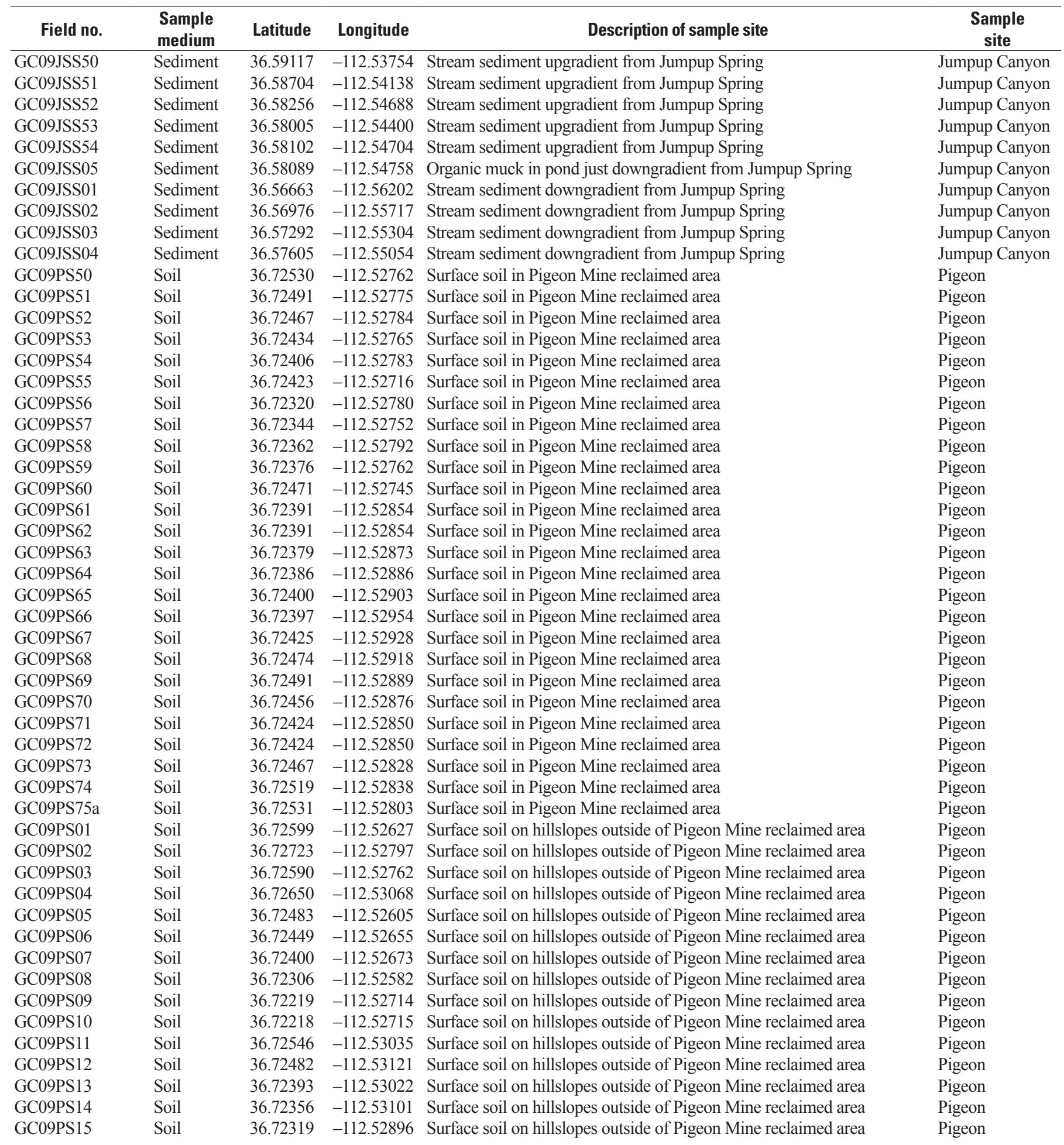


Table 8. Chemical analyses of soil, sediment, rock, and mine waste samples collected by this study. Description of major, minor, and trace element data from samples collected at Jumpup Canyon, Pigeon, Kanab North, Kanab South, Hermit, and Hack Canyon sample sites.-Continued

[Datum for all latitude and longitude values is WGS 1984; ppm, parts per million; wt. \%, weight percent; see text for description of sample processing and analytical procedures; no., number]

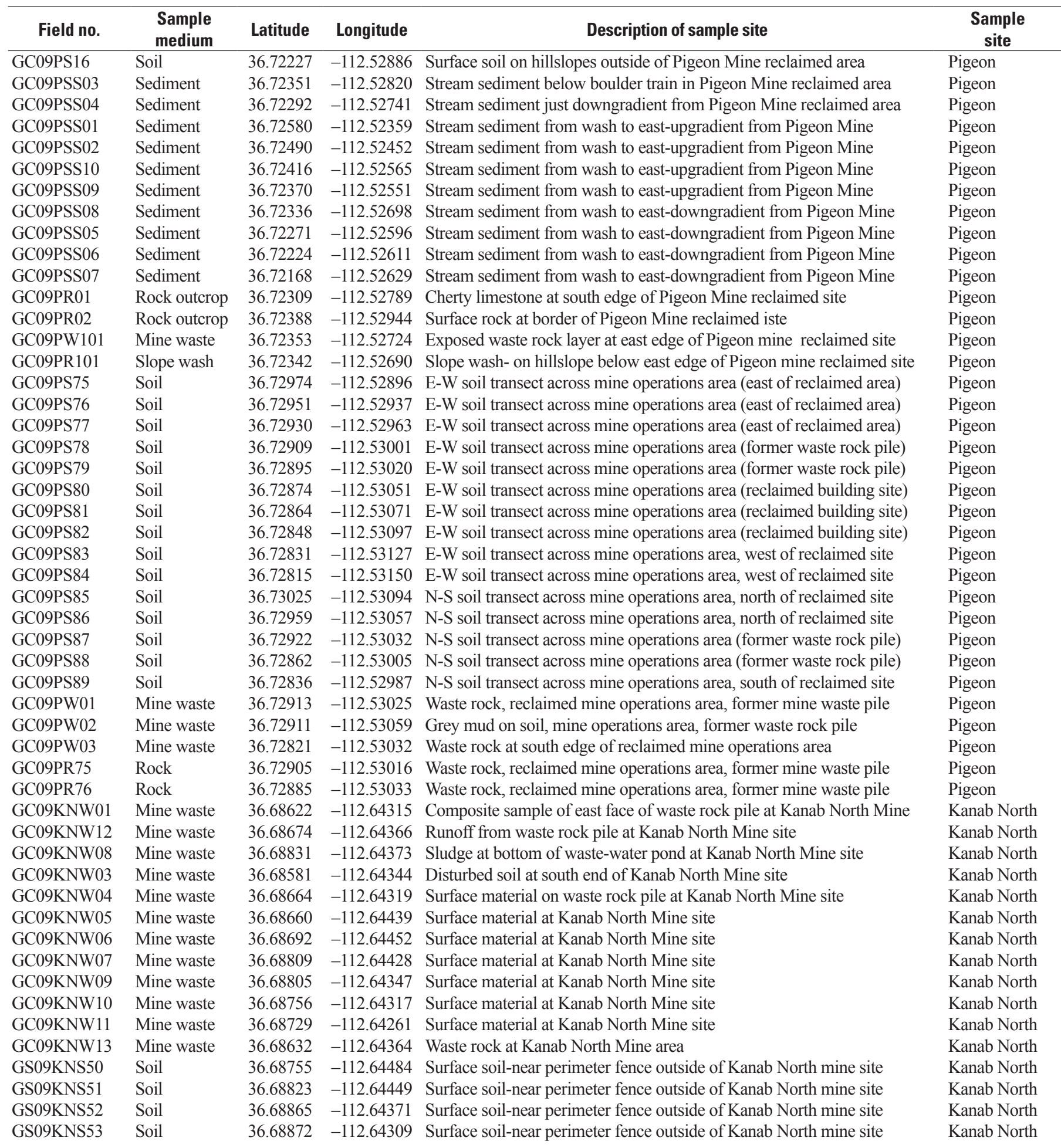


Table 8. Chemical analyses of soil, sediment, rock, and mine waste samples collected by this study. Description of major, minor, and trace element data from samples collected at Jumpup Canyon, Pigeon, Kanab North, Kanab South, Hermit, and Hack Canyon sample sites.-Continued

[Datum for all latitude and longitude values is WGS 1984; ppm, parts per million; wt. \%, weight percent; see text for description of sample processing and analytical procedures; no., number]

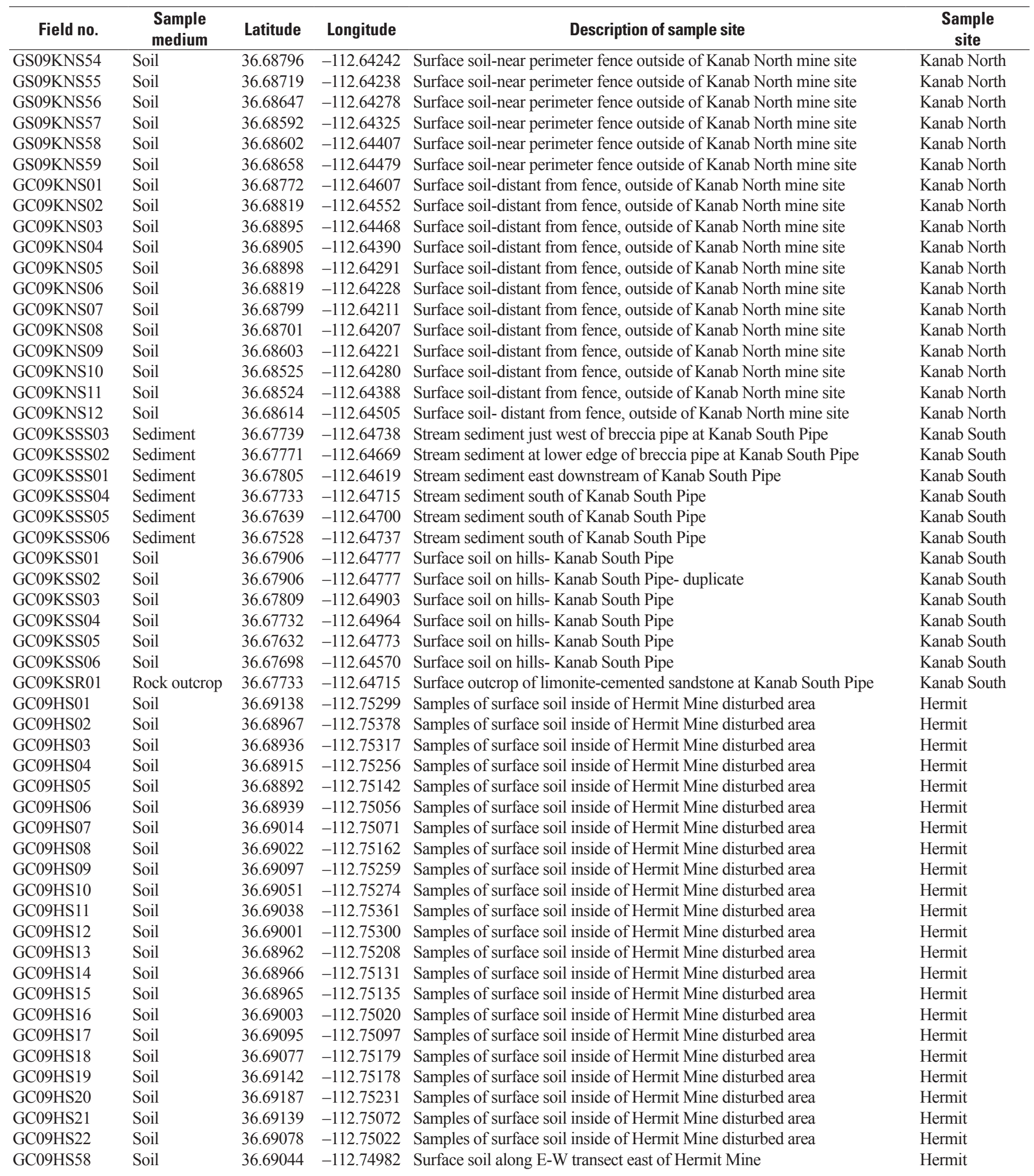


Table 8. Chemical analyses of soil, sediment, rock, and mine waste samples collected by this study. Description of major, minor, and trace element data from samples collected at Jumpup Canyon, Pigeon, Kanab North, Kanab South, Hermit, and Hack Canyon sample sites.-Continued

[Datum for all latitude and longitude values is WGS 1984; ppm, parts per million; wt. \%, weight percent; see text for description of sample processing and analytical procedures; no., number]

\begin{tabular}{|c|c|c|c|c|c|}
\hline Field no. & $\begin{array}{l}\text { Sample } \\
\text { medium }\end{array}$ & Latitude & Longitude & Description of sample site & $\begin{array}{l}\text { Sample } \\
\text { site }\end{array}$ \\
\hline GC09HS60 & Soil & 36.69000 & -112.74759 & Surface soil along E-W transect east of Hermit Mine & Hermit \\
\hline GC09HS62 & Soil & 36.68988 & -112.74539 & Surface soil along E-W transect east of Hermit Mine & Hermit \\
\hline GC09HS63 & Soil & 36.68977 & -112.74416 & Surface soil along E-W transect east of Hermit Mine & Hermit \\
\hline GC09HS64 & Soil & 36.68973 & -112.74311 & Surface soil along E-W transect east of Hermit Mine & Hermit \\
\hline GC09HS67 & Soil & 36.68747 & -112.75234 & Surface soil along N-S transect south of Hermit Mine & Hermit \\
\hline GC09HS68 & Soil & 36.68665 & -112.75265 & Surface soil along N-S transect south of Hermit Mine & Hermit \\
\hline GC09HS69 & Soil & 36.68578 & -112.75303 & Surface soil along N-S transect south of Hermit Mine & Hermit \\
\hline GC09HS70 & Soil & 36.68492 & -112.75335 & Surface soil along N-S transect south of Hermit Mine & Hermit \\
\hline GC09HS71 & Soil & 36.68405 & -112.75365 & Surface soil along N-S transect south of Hermit Mine & Hermit \\
\hline GC09HS50 & Soil & 36.69033 & -112.76189 & Surface soil along E-W transect west of Hermit Mine & Hermit \\
\hline GC09HS55 & Soil & 36.68940 & -112.75633 & Surface soil along E-W transect west of Hermit Mine & Hermit \\
\hline GC09HS56 & Soil & 36.68923 & -112.75514 & Surface soil along E-W transect west of Hermit Mine & Hermit \\
\hline GC09HS57 & Soil & 36.68915 & -112.75404 & Surface soil along E-W transect west of Hermit Mine & Hermit \\
\hline GC09HS76 & Soil & 36.69260 & -112.75355 & Surface soil along road transect NW of Hermit Mine & Hermit \\
\hline GC09HS77 & Soil & 36.69260 & -112.75355 & Surface soil along road transect NW of Hermit Mine & Hermit \\
\hline GC09HS78 & Soil & 36.69332 & -112.75419 & Surface soil along road transect NW of Hermit Mine & Hermit \\
\hline GC09HS79 & Soil & 36.69407 & -112.75485 & Surface soil along road transect NW of Hermit Mine & Hermit \\
\hline GC09HS80 & Soil & 36.69480 & -112.75551 & Surface soil along road transect NW of Hermit Mine & Hermit \\
\hline GC09HS81 & Soil & 36.69560 & -112.75618 & Surface soil along road transect NW of Hermit Mine & Hermit \\
\hline GC09HS75 & Soil & 36.69182 & -112.75292 & Surface soil along road transect NW of Hermit Mine & Hermit \\
\hline GC09HS105 & Soil & 36.70274 & -112.74909 & Surface soil in drainage downgradient north from Hermit Mine & Hermit \\
\hline GC09HS106 & Soil & 36.70029 & -112.75101 & Surface soil in drainage downgradient north from Hermit Mine & Hermit \\
\hline GC09HSS104 & Sediment & 36.70450 & -112.74723 & Stream sediment at mouth of stock tank downgradient from Hermit Mine & Hermit \\
\hline GC09HKSS01 & Sediment & 36.58881 & -112.81559 & Hack Canyon upstream from mines & Hack Canyon \\
\hline GC09HKSS02 & Sediment & 36.57991 & -112.81502 & Robinson Canyon upstream from mines & Hack Canyon \\
\hline GC09HKSS04 & Sediment & 36.58588 & -112.79572 & Tributary canyon upstream from Hack 1 mine & Hack Canyon \\
\hline GC09HKSS05 & Sediment & 36.58615 & -112.79644 & Tributary canyon upstream from Hack 1 mine & Hack Canyon \\
\hline GC09HKSS03 & Sediment & 36.58423 & -112.80953 & Hack Canyon downstream from Hack $2 \& 3$ mines & Hack Canyon \\
\hline GC09HKSS06 & Sediment & 36.58224 & -112.79949 & Hack Canyon downstream from Hack 1 mine & Hack Canyon \\
\hline GC09HKSS07 & Sediment & 36.57947 & -112.79886 & Hack Canyon downstream from mines & Hack Canyon \\
\hline GC09HKSS08 & Sediment & 36.57842 & -112.79243 & Hack Canyon downstream from mines & Hack Canyon \\
\hline GC09HKSS09 & Sediment & 36.57306 & -112.78210 & Hack Canyon downstream from mines & Hack Canyon \\
\hline GC09HKSS10 & Sediment & 36.56619 & -112.74516 & Hack Canyon downstream from mines & Hack Canyon \\
\hline GC09HKRK01 & Mine waste & 36.58534 & -112.80902 & Waste on alluvial surface-Hack Canyon downstream from mines & Hack Canyon \\
\hline GC09HKRK02 & Mine waste & 36.58297 & -112.79952 & Waste on alluvial surface- Hack Canyon downstream from mines & Hack Canyon \\
\hline GC09HKRK03 & Mine waste & 36.58120 & -112.79947 & Waste on alluvial surface-Hack Canyon downstream from mines & Hack Canyon \\
\hline GC09HKRK04 & Mine waste & 36.58120 & -112.79947 & Waste on alluvial surface- Hack Canyon downstream from mines & Hack Canyon \\
\hline GC09HKRK05 & Mine waste & 36.57924 & -112.79874 & Waste on alluvial surface-Hack Canyon downstream from mines & Hack Canyon \\
\hline
\end{tabular}


Table 8. Chemical analyses of soil, sediment, rock, and mine waste samples collected by this study.-Continued

[Datum for all latitude and longitude values is WGS 1984; ppm, parts per million; wt. \%, weight percent; see text for description of sample processing and analytical procedures; no., number]

\begin{tabular}{|c|c|c|c|c|c|c|c|c|c|}
\hline Field no. & $\begin{array}{c}\text { Aluminun } \\
\text { wt. } \%\end{array}$ & $\begin{array}{c}\text { Calcium } \\
\text { wt. } \%\end{array}$ & $\begin{array}{c}\text { Iron } \\
\text { wt. \% }\end{array}$ & $\begin{array}{c}\text { Potassium } \\
\text { wt. } \%\end{array}$ & $\begin{array}{l}\text { Magnesium } \\
\text { wt. \% }\end{array}$ & $\begin{array}{c}\text { Sodium } \\
\text { wt. } \%\end{array}$ & $\begin{array}{l}\text { Sulfur } \\
\text { wt. } \%\end{array}$ & $\begin{array}{c}\text { Titanium } \\
\text { wt. } \%\end{array}$ & $\begin{array}{c}\text { Silver } \\
\text { ppm }\end{array}$ \\
\hline GC09JSS51 & 2.77 & 4.73 & 1.22 & 1.08 & 1.26 & 0.26 & 0.03 & 0.15 & $<1$ \\
\hline GC09JSS53 & 2.72 & 6.67 & 1.09 & 1.17 & 1.24 & 0.28 & 0.23 & 0.15 & $<1$ \\
\hline GC09JSS54 & 2.92 & 5.73 & 1.21 & 1.1 & 1.35 & 0.26 & 0.08 & 0.15 & $<1$ \\
\hline GC09JSS05 & 1.29 & 6.63 & 0.87 & 0.59 & 0.99 & 0.13 & 0.27 & 0.07 & $<1$ \\
\hline GC09JSS03 & 2.1 & 5.58 & 0.9 & 1.15 & 1.27 & 0.18 & 0.02 & 0.12 & $<1$ \\
\hline GC09JSS04 & 2.24 & 5.02 & 0.94 & 1.29 & 1.2 & 0.2 & 0.02 & 0.12 & $<1$ \\
\hline GC09PS50 & 4.53 & 8.04 & 1.79 & 2.19 & 4.9 & 0.06 & 0.04 & 0.23 & $<1$ \\
\hline GC09PS51 & 4.29 & 8.05 & 1.74 & 1.9 & 4.86 & 0.06 & 0.04 & 0.22 & $<1$ \\
\hline GC09PS52 & 4.79 & 7.51 & 2.02 & 2.56 & 4.57 & 0.06 & 0.04 & 0.23 & $<1$ \\
\hline GC09PS53 & 4.07 & 6.98 & 1.8 & 2 & 4.1 & 0.06 & 0.17 & 0.21 & $<1$ \\
\hline GC09PS58 & 4.13 & 8.1 & 1.7 & 1.89 & 4.94 & 0.06 & 0.07 & 0.21 & $<1$ \\
\hline GC09PS59 & 2.8 & 4.91 & 2.88 & 1.58 & 2.79 & 0.04 & 1.43 & 0.14 & $<1$ \\
\hline GC09PS60 & 3.73 & 7.8 & 1.68 & 1.74 & 4.5 & 0.06 & 0.09 & 0.2 & $<1$ \\
\hline GC09PS61 & 3.85 & 7.49 & 1.69 & 2.09 & 4.05 & 0.07 & 0.15 & 0.2 & $<1$ \\
\hline GC09PS62 & 3.56 & 7.26 & 1.58 & 1.97 & 3.96 & 0.06 & 0.15 & 0.18 & $<1$ \\
\hline GC09PS63 & 2.71 & 8.79 & 1.46 & 1.44 & 3.61 & 0.08 & 0.15 & 0.14 & $<1$ \\
\hline GC09PS64 & 3.71 & 3.71 & 2.43 & 1.86 & 1.92 & 0.05 & 1.38 & 0.2 & $<1$ \\
\hline GC09PS65 & 3.43 & 8.36 & 1.59 & 1.84 & 4.56 & 0.09 & 0.15 & 0.18 & $<1$ \\
\hline GC09PS66 & 4.01 & 8.84 & 1.6 & 2.28 & 4.45 & 0.07 & 0.05 & 0.19 & $<1$ \\
\hline GC09PS67 & 4.1 & 8.7 & 1.83 & 2.3 & 5.29 & 0.06 & 0.15 & 0.2 & $<1$ \\
\hline GC09PS68 & 4.3 & 8.56 & 1.72 & 2.39 & 5.16 & 0.06 & 0.04 & 0.22 & $<1$ \\
\hline GC09PS02 & 1.97 & 4.73 & 0.93 & 0.64 & 1.76 & 0.16 & 0.04 & 0.12 & $<1$ \\
\hline GC09PS03 & 2.27 & 9.15 & 1.02 & 1.04 & 2.54 & 0.07 & 0.04 & 0.12 & $<1$ \\
\hline GC09PS04 & 2.37 & 4.85 & 1.16 & 0.88 & 2.05 & 0.14 & 0.03 & 0.16 & $<1$ \\
\hline GC09PS05 & 1.97 & 4.86 & 0.95 & 0.88 & 2.17 & 0.14 & 0.04 & 0.1 & $<1$ \\
\hline GC09PS06 & 3.08 & 7.87 & 1.8 & 1.3 & 2.02 & 0.23 & 0.08 & 0.16 & $<1$ \\
\hline GC09PS07 & 3.19 & 6.88 & 1.16 & 1.64 & 3.86 & 0.08 & 0.07 & 0.17 & $<1$ \\
\hline GC09PS08 & 1.94 & 11.1 & 3.62 & 0.87 & 3.78 & 0.19 & 0.11 & 0.11 & 2 \\
\hline GC09PS09 & 1.78 & 14.9 & 0.91 & 0.82 & 7.31 & 0.19 & 0.05 & 0.1 & $<1$ \\
\hline GC09PS10 & 1.68 & $>15$ & 0.89 & 0.8 & 7.51 & 0.17 & 0.04 & 0.1 & $<1$ \\
\hline GC09PS11 & 1.82 & 4.14 & 1.28 & 0.73 & 1.71 & 0.13 & 0.03 & 0.11 & $<1$ \\
\hline GC09PS12 & 2.2 & 3.7 & 1.27 & 0.92 & 1.49 & 0.17 & 0.03 & 0.13 & $<1$ \\
\hline GC09PS13 & 2.67 & 7.69 & 1.13 & 1.39 & 1.76 & 0.17 & 0.03 & 0.14 & $<1$ \\
\hline GC09PS14 & 2.9 & 5.18 & 1.22 & 1.72 & 2.36 & 0.15 & 0.02 & 0.14 & $<1$ \\
\hline GC09PS15 & 2.72 & 12 & 1.31 & 1.52 & 4.53 & 0.15 & 0.03 & 0.15 & $<1$ \\
\hline GC09PS16 & 3.24 & 5.99 & 1.32 & 1.4 & 2.4 & 0.23 & 0.03 & 0.18 & $<1$ \\
\hline GC09PSS03 & 2.64 & 6.79 & 1.26 & 1.23 & 3.86 & 0.05 & 0.19 & 0.16 & $<1$ \\
\hline
\end{tabular}


Table 8. Chemical analyses of soil, sediment, rock, and mine waste samples collected by this study.-Continued

[Datum for all latitude and longitude values is WGS 1984; ppm, parts per million; wt. \%, weight percent; see text for description of sample processing and analytical procedures; no., number]

\begin{tabular}{|c|c|c|c|c|c|c|c|c|c|}
\hline Field no. & $\begin{array}{c}\text { Aluminun } \\
\text { wt. } \%\end{array}$ & $\begin{array}{c}\text { Calcium } \\
\text { wt. } \%\end{array}$ & $\begin{array}{c}\text { Iron } \\
\text { wt. \% }\end{array}$ & $\begin{array}{c}\text { Potassium } \\
\text { wt. } \%\end{array}$ & $\begin{array}{c}\text { Magnesium } \\
\text { wt. } \%\end{array}$ & $\begin{array}{c}\begin{array}{c}\text { Sodium } \\
\text { wt. } \%\end{array} \\
\end{array}$ & $\begin{array}{l}\text { Sulfur } \\
\text { wt. \% }\end{array}$ & $\begin{array}{c}\text { Titanium } \\
\text { wt. } \%\end{array}$ & $\begin{array}{c}\text { Silver } \\
\text { ppm }\end{array}$ \\
\hline GC09PSS01 & 2.73 & 4.92 & 1.19 & 1.27 & 1.81 & 0.2 & 0.04 & 0.15 & $<1$ \\
\hline GC09PSS10 & 3.01 & 5.17 & 1.3 & 1.55 & 1.83 & 0.24 & 0.03 & 0.17 & $<1$ \\
\hline GC09PSS09 & 3.16 & 6.13 & 1.39 & 1.53 & 2.45 & 0.24 & 0.05 & 0.17 & $<1$ \\
\hline GC09PSS08 & 2.91 & 6.51 & 1.26 & 1.55 & 3.33 & 0.12 & 0.14 & 0.17 & $<1$ \\
\hline GC09PSS07 & 3.31 & 6.05 & 1.4 & 1.64 & 2.83 & 0.18 & 0.12 & 0.18 & $<1$ \\
\hline GC09PR01 & 0.47 & 13 & 0.43 & 0.2 & 7.82 & 0.02 & 0.07 & 0.03 & $<1$ \\
\hline GC09PR02 & 0.57 & 2.56 & 0.23 & 0.27 & 0.89 & 0.01 & 0.06 & 0.03 & $<1$ \\
\hline GC09PW101 & 2.87 & 6.29 & 1.14 & 1.23 & 3.66 & 0.04 & 0.19 & 0.15 & $<1$ \\
\hline GC09PR101 & 0.97 & 13.9 & 0.82 & 0.52 & 7.32 & 0.03 & 0.09 & 0.05 & $<1$ \\
\hline GC09PS75 & 3.88 & 4.31 & 2 & 2.04 & 1.4 & 0.34 & 0.03 & 0.21 & $<1$ \\
\hline GC09PS80 & 3.89 & 8.09 & 1.88 & 2.14 & 1.86 & 0.32 & 0.03 & 0.21 & $<1$ \\
\hline GC09PS81 & 4.16 & 8.7 & 2 & 2.12 & 1.75 & 0.32 & 0.04 & 0.21 & $<1$ \\
\hline GC09PS82 & 4.03 & 8.22 & 1.93 & 2.21 & 1.56 & 0.36 & 0.03 & 0.21 & $<1$ \\
\hline GC09PS83 & 4.9 & 3.76 & 2.45 & 2.47 & 2.16 & 0.5 & 0.03 & 0.28 & $<1$ \\
\hline GC09PS84 & 3.46 & 10 & 2.01 & 1.68 & 5.01 & 0.3 & 0.03 & 0.19 & $<1$ \\
\hline GC09PS85 & 3.97 & 7.79 & 1.79 & 2.21 & 1.58 & 0.39 & 0.03 & 0.23 & $<1$ \\
\hline GC09PS86 & 4.35 & 3.67 & 2.09 & 2.33 & 0.9 & 0.41 & 0.03 & 0.25 & $<1$ \\
\hline GC09PS87 & 4.28 & 5.45 & 2.1 & 2.19 & 1.52 & 0.39 & 0.09 & 0.23 & $<1$ \\
\hline GC09PS88 & 3.53 & 5.28 & 3.09 & 1.78 & 1.89 & 0.29 & 1.63 & 0.19 & $<1$ \\
\hline GC09PS89 & 2.89 & 10.8 & 1.52 & 1.5 & 4.58 & 0.25 & 0.05 & 0.17 & $<1$ \\
\hline GC09PW01 & 1.52 & 1.57 & 3.29 & 0.68 & 0.41 & 0.07 & 3 & 0.1 & 4 \\
\hline GC09KNW04 & 2.15 & 3.51 & 2.47 & 1.24 & 1.93 & 0.04 & 2.8 & 0.11 & 3 \\
\hline GC09KNW05 & 3.65 & 4.34 & 1.56 & 2.03 & 2.14 & 0.06 & 0.91 & 0.2 & 2 \\
\hline GC09KNW06 & 3.44 & 4.17 & 1.56 & 1.91 & 2.41 & 0.06 & 1.33 & 0.2 & 3 \\
\hline GC09KNW07 & 1.96 & $>15$ & 0.69 & 0.92 & 2.01 & 0.07 & 0.15 & 0.1 & $<1$ \\
\hline GC09KNW09 & 2.85 & 6.42 & 1.53 & 1.48 & 3.39 & 0.16 & 1.04 & 0.15 & 1 \\
\hline GC09KNW10 & 2.75 & 5 & 2.36 & 1.59 & 2.41 & 0.06 & 2.08 & 0.15 & 2 \\
\hline GC09KNW11 & 3.3 & 4.33 & 1.43 & 1.94 & 2.41 & 0.05 & 0.65 & 0.18 & 2 \\
\hline GC09KNW13 & 1.45 & 6.33 & 12 & 0.86 & 2.84 & 0.09 & $>5$ & 0.06 & $>10$ \\
\hline GS09KNS50 & 2.18 & 15 & 1.04 & 0.81 & 3.16 & 0.1 & 0.08 & 0.13 & $<1$ \\
\hline GS09KNS51 & 3.08 & 11.5 & 1.25 & 1.29 & 2.06 & 0.2 & 0.07 & 0.16 & $<1$ \\
\hline GS09KNS52 & 2.99 & 6.94 & 1.3 & 1.55 & 1.17 & 0.17 & 0.06 & 0.15 & $<1$ \\
\hline GS09KNS53 & 1.93 & 9.67 & 0.86 & 0.97 & 1.25 & 0.07 & 0.05 & 0.09 & $<1$ \\
\hline GS09KNS54 & 2.45 & 5.68 & 1.23 & 1.3 & 1.05 & 0.15 & 0.1 & 0.13 & $<1$ \\
\hline GS09KNS55 & 3 & 5.64 & 1.41 & 1.66 & 1.04 & 0.22 & 0.09 & 0.16 & $<1$ \\
\hline GS09KNS56 & 2.97 & 4.77 & 1.42 & 1.75 & 0.77 & 0.25 & 0.07 & 0.17 & $<1$ \\
\hline GS09KNS57 & 3.03 & 8.1 & 1.36 & 1.71 & 0.77 & 0.25 & 0.03 & 0.17 & $<1$ \\
\hline
\end{tabular}




\section{Site Characterization of Breccia Pipe Uranium Deposits in Northern Arizona}

Table 8. Chemical analyses of soil, sediment, rock, and mine waste samples collected by this study.-Continued

[Datum for all latitude and longitude values is WGS 1984; ppm, parts per million; wt. \%, weight percent; see text for description of sample processing and analytical procedures; no., number]

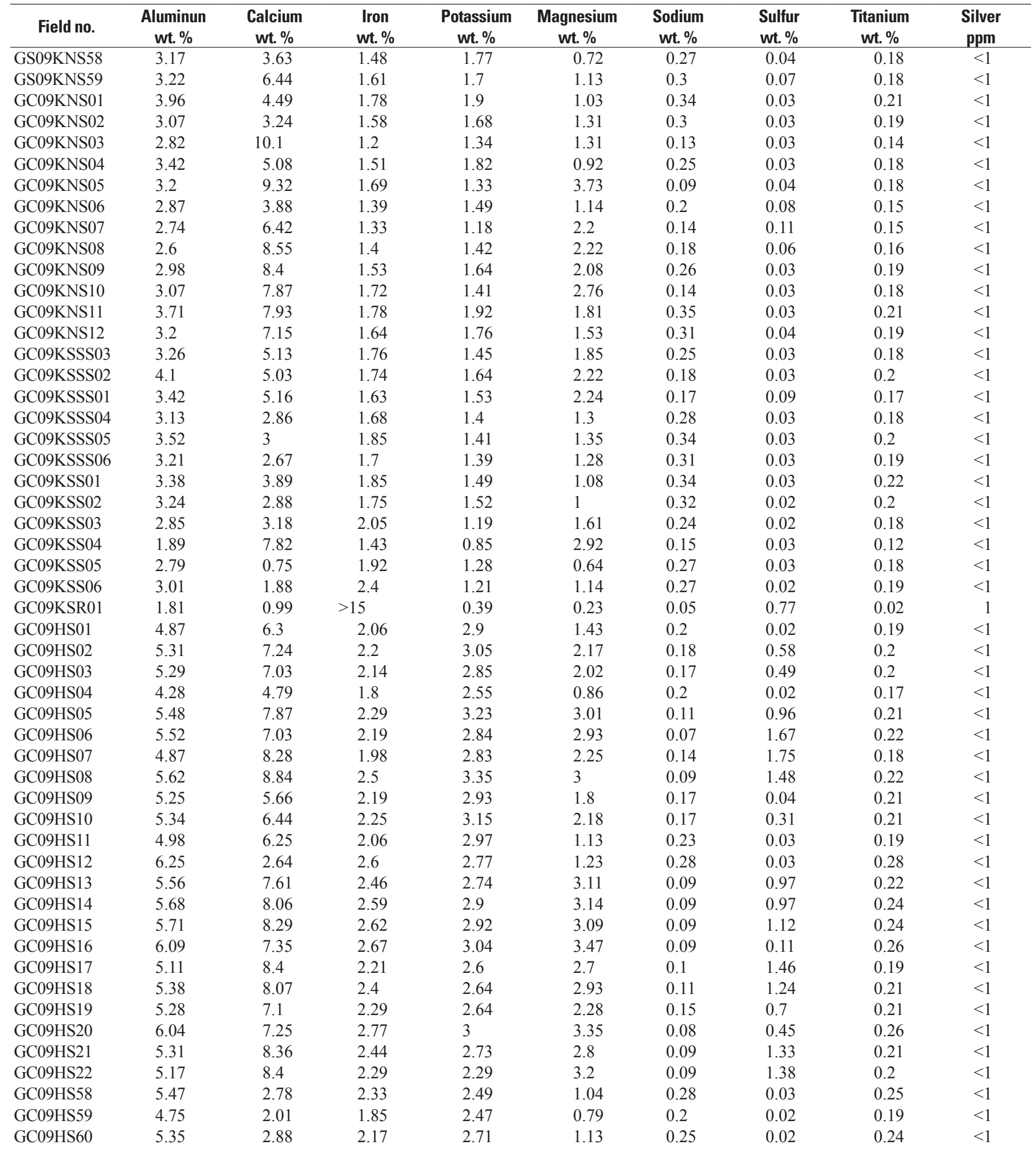


Table 8. Chemical analyses of soil, sediment, rock, and mine waste samples collected by this study.-Continued

[Datum for all latitude and longitude values is WGS 1984; ppm, parts per million; wt. \%, weight percent; see text for description of sample processing and analytical procedures; no., number]

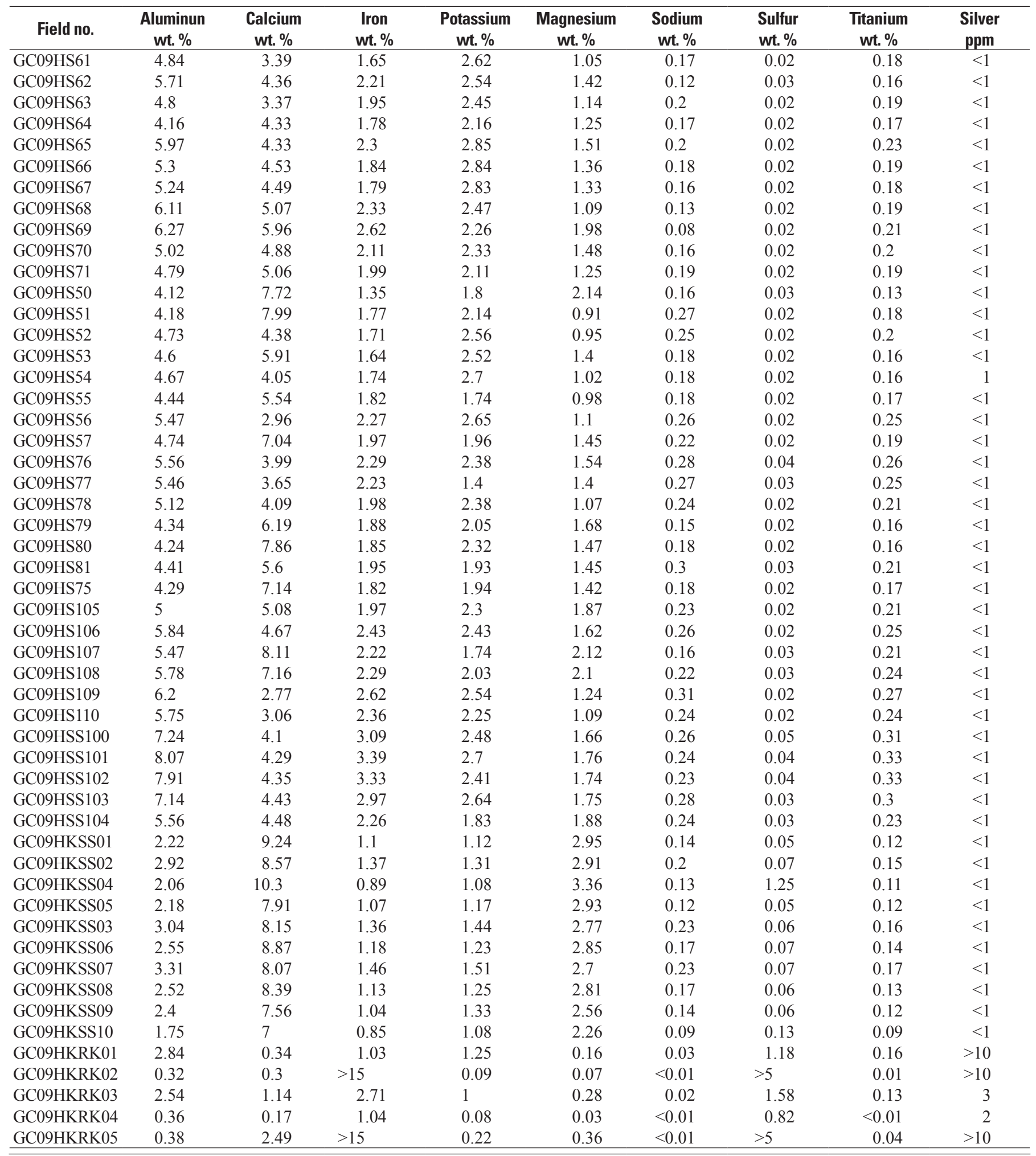


Table 8. Chemical analyses of soil, sediment, rock, and mine waste samples collected by this study.-Continued

[Datum for all latitude and longitude values is WGS 1984; ppm, parts per million; wt. \%, weight percent; see text for description of sample processing and analytical procedures; no., number]

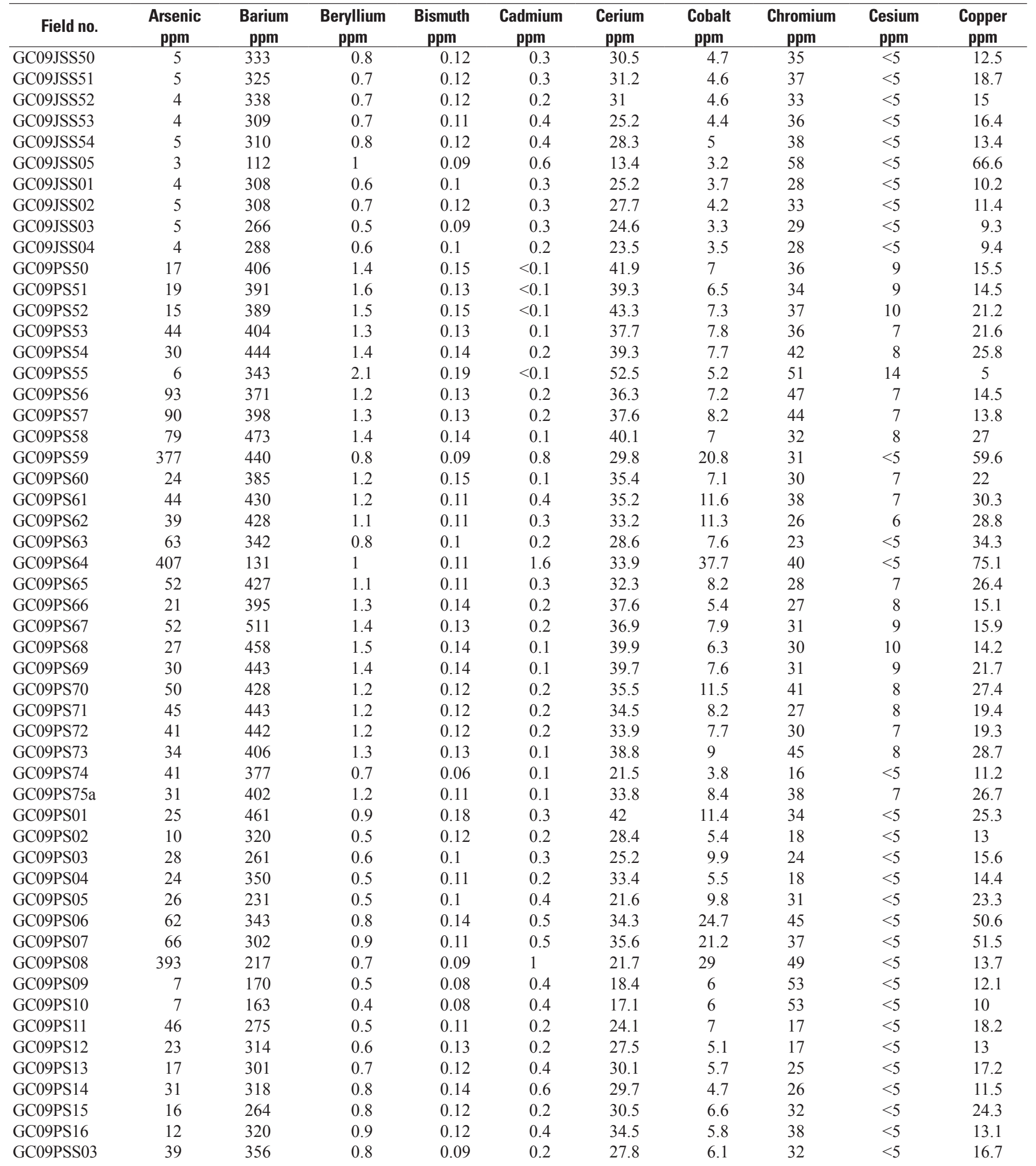


Table 8. Chemical analyses of soil, sediment, rock, and mine waste samples collected by this study.-Continued

[Datum for all latitude and longitude values is WGS 1984; ppm, parts per million; wt. \%, weight percent; see text for description of sample processing and analytical procedures; no., number]

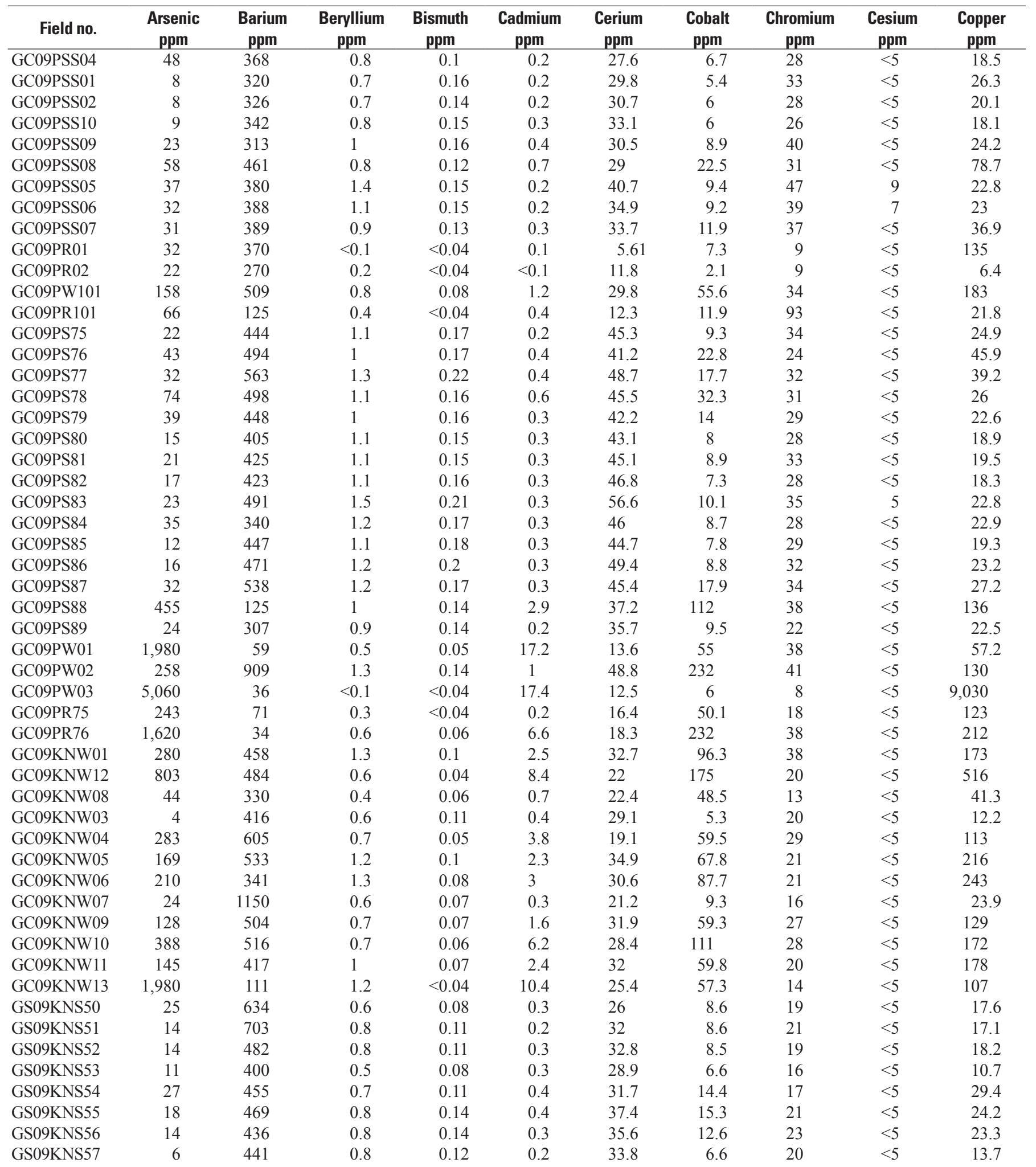


Table 8. Chemical analyses of soil, sediment, rock, and mine waste samples collected by this study.-Continued

[Datum for all latitude and longitude values is WGS 1984; ppm, parts per million; wt. \%, weight percent; see text for description of sample processing and analytical procedures; no., number]

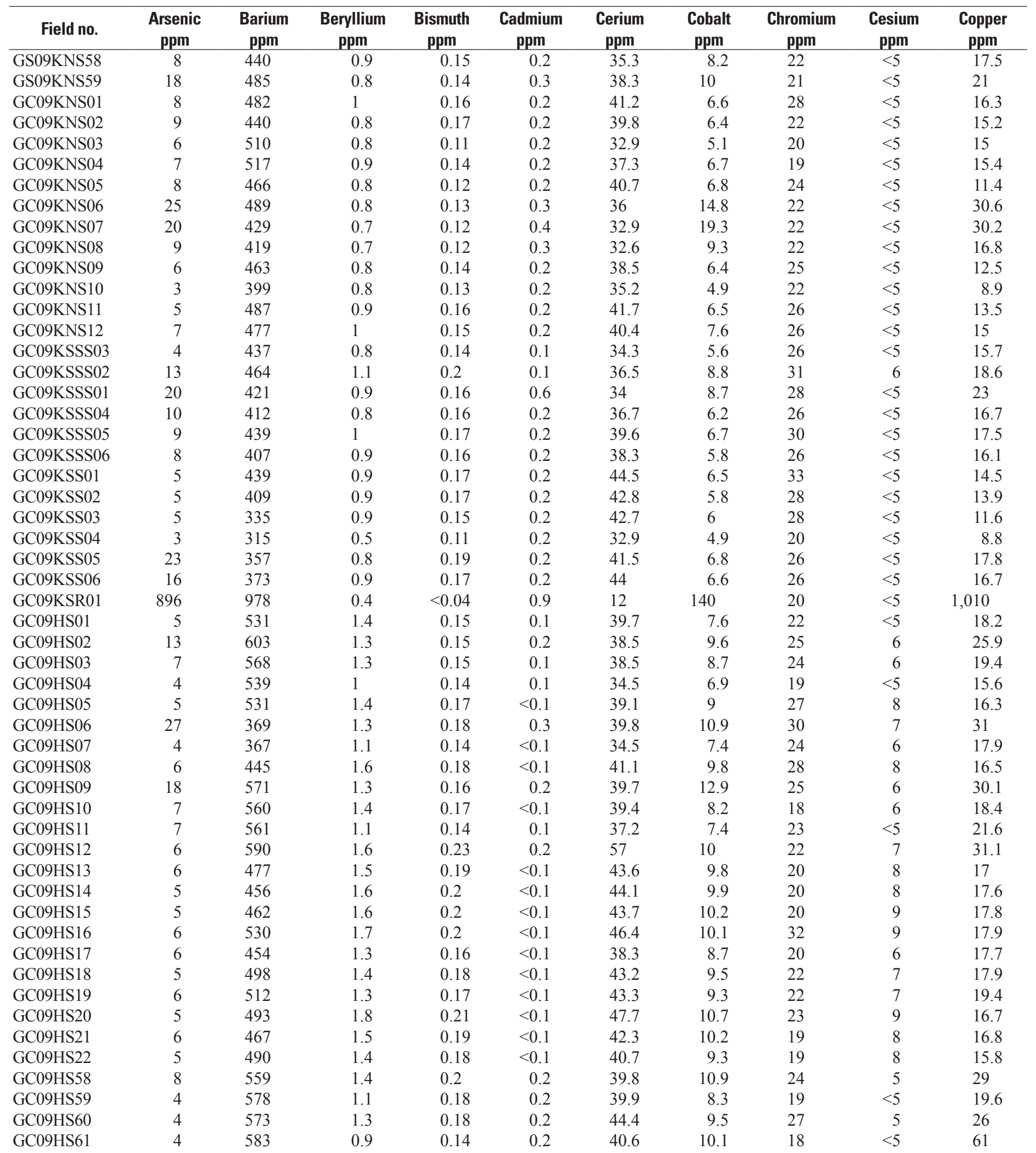


Table 8. Chemical analyses of soil, sediment, rock, and mine waste samples collected by this study.-Continued

[Datum for all latitude and longitude values is WGS 1984; ppm, parts per million; wt. \%, weight percent; see text for description of sample processing and analytical procedures; no., number]

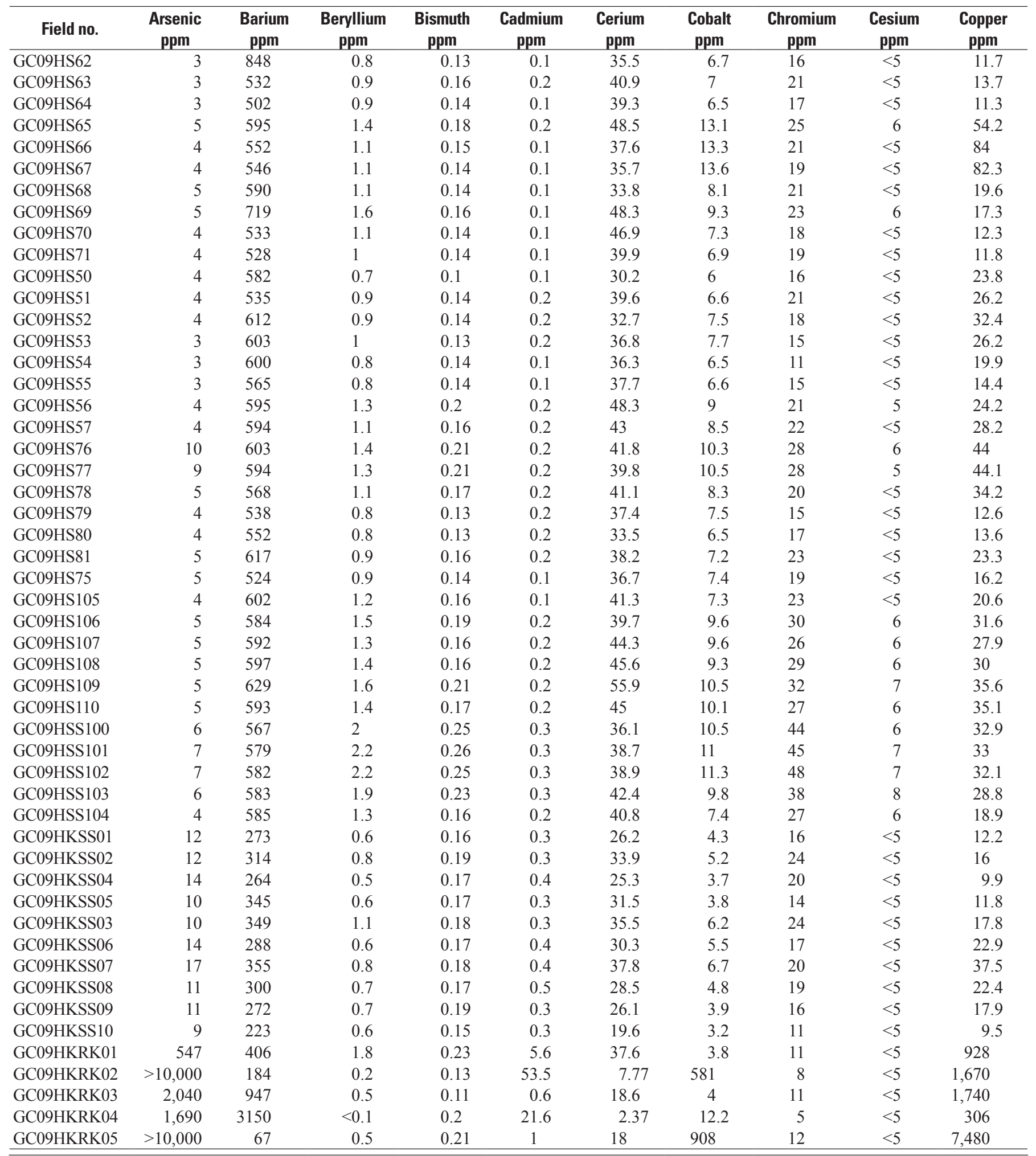


Table 8. Chemical analyses of soil, sediment, rock, and mine waste samples collected by this study.-Continued

[Datum for all latitude and longitude values is WGS 1984; ppm, parts per million; wt. \%, weight percent; see text for description of sample processing and analytical procedures; no., number]

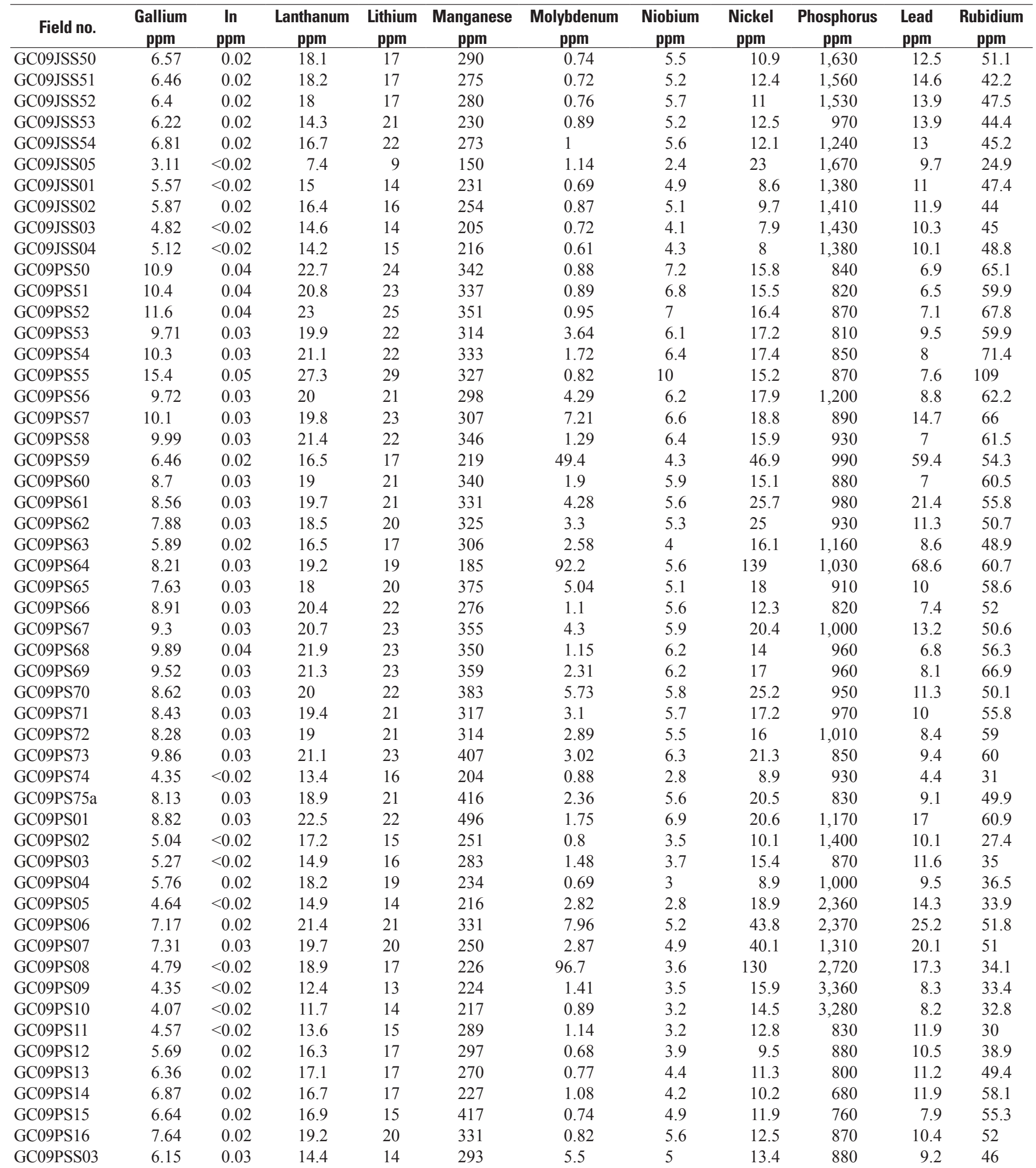


Table 8. Chemical analyses of soil, sediment, rock, and mine waste samples collected by this study.-Continued

[Datum for all latitude and longitude values is WGS 1984; ppm, parts per million; wt. \%, weight percent; see text for description of sample processing and analytical procedures; no., number]

\begin{tabular}{|c|c|c|c|c|c|c|c|c|c|c|c|}
\hline Field no. & $\begin{array}{c}\text { Gallium } \\
\text { ppm }\end{array}$ & $\begin{array}{c}\text { In } \\
\text { ppm }\end{array}$ & $\begin{array}{c}\text { Lanthanum } \\
\text { ppm }\end{array}$ & $\begin{array}{c}\text { Lithium } \\
\text { ppm }\end{array}$ & $\begin{array}{c}\text { Manganese } \\
\text { ppm }\end{array}$ & $\begin{array}{c}\text { Molybdenum } \\
\text { ppm }\end{array}$ & $\begin{array}{c}\text { Niobium } \\
\text { ppm }\end{array}$ & $\begin{array}{c}\text { Nickel } \\
\text { ppm }\end{array}$ & $\begin{array}{c}\text { Phosphorus } \\
\text { ppm }\end{array}$ & $\begin{array}{l}\text { Lead } \\
\text { ppm }\end{array}$ & $\begin{array}{c}\text { Rubidium } \\
\text { ppm }\end{array}$ \\
\hline GC09PSS01 & 6.35 & 0.03 & 16.5 & 16 & 269 & 0.75 & 5.4 & 13.9 & 1,140 & 19.2 & 50.7 \\
\hline GC09PSS10 & 6.68 & 0.03 & 17.7 & 17 & 270 & 0.8 & 5.4 & 13.2 & 1,140 & 14.4 & 59.3 \\
\hline GC09PSS09 & 7.23 & 0.03 & 17.5 & 18 & 282 & 1.9 & 5.8 & 25.4 & 1,650 & 16 & 60.3 \\
\hline GC09PSS08 & 6.5 & 0.03 & 16 & 16 & 282 & 4.66 & 5.2 & 44 & 1,290 & 28.8 & 56.9 \\
\hline GC09PSS07 & 7.49 & 0.03 & 18.2 & 18 & 292 & 3.07 & 6.1 & 24.8 & 1300 & 17.3 & 62.3 \\
\hline GC09PR01 & 1.31 & $<0.02$ & 5.1 & 5 & 478 & 1.16 & 0.9 & 10 & 570 & 5.5 & 6.7 \\
\hline GC09PR02 & 1.71 & $<0.02$ & 7 & 10 & 74 & 0.43 & 0.7 & 3.7 & 950 & 2.2 & 8.8 \\
\hline GC09PW101 & 6.56 & 0.02 & 15.3 & 14 & 185 & 21 & 4.5 & 93.2 & 860 & 49.6 & 40.5 \\
\hline GC09PR101 & 2.51 & $<0.02$ & 11.6 & 9 & 235 & 10.7 & 1.2 & 24.3 & 7540 & 15.7 & 16.7 \\
\hline GC09PS75 & 9.2 & 0.03 & 23.9 & 22 & 642 & 1.18 & 6.7 & 18.4 & 820 & 14.4 & 77.7 \\
\hline GC09PS80 & 8.74 & 0.03 & 22.2 & 22 & 553 & 0.96 & 6.4 & 15.4 & 750 & 12.8 & 64.4 \\
\hline GC09PS81 & 9.29 & 0.03 & 22.9 & 24 & 542 & 1.66 & 6.7 & 16.8 & 660 & 19.8 & 54.1 \\
\hline GC09PS82 & 8.95 & 0.03 & 24.6 & 23 & 567 & 0.73 & 6.6 & 14.6 & 760 & 13.7 & 53.9 \\
\hline GC09PS83 & 11.1 & 0.04 & 27.1 & 28 & 976 & 0.97 & 8.7 & 18.7 & 750 & 18 & 69.7 \\
\hline GC09PS84 & 7.8 & 0.03 & 22.3 & 20 & 991 & 0.81 & 5.9 & 13.7 & 710 & 14 & 61.2 \\
\hline GC09PS85 & 8.64 & 0.03 & 24 & 22 & 515 & 0.78 & 7.2 & 15.3 & 770 & 15.1 & 64.7 \\
\hline GC09PS86 & 9.73 & 0.04 & 25.9 & 25 & 464 & 0.95 & 7.7 & 17.3 & 720 & 17.2 & 84.7 \\
\hline GC09PS87 & 9.48 & 0.03 & 23.1 & 25 & 600 & 4.69 & 7.3 & 33.4 & 710 & 20.4 & 78 \\
\hline GC09PS88 & 7.9 & 0.03 & 19.9 & 20 & 501 & 77.1 & 6 & 285 & 1040 & 101 & 63.4 \\
\hline GC09PS89 & 6.39 & 0.02 & 18.7 & 17 & 712 & 1.51 & 5.2 & 16.1 & 560 & 14.4 & 51 \\
\hline GC09PW01 & 4.72 & $<0.02$ & 9.1 & 11 & 86 & 693 & 3.2 & 93.8 & 1380 & 935 & 25.5 \\
\hline GC09KNW04 & 4.79 & $<0.02$ & 13 & 14 & 123 & 401 & 2.9 & 68.5 & 1610 & 64.3 & 34.8 \\
\hline GC09KNW05 & 8.12 & 0.03 & 17.5 & 22 & 199 & 44.8 & 5.1 & 105 & 530 & 146 & 64.7 \\
\hline GC09KNW06 & 7.24 & 0.02 & 15.4 & 23 & 188 & 75 & 5.5 & 95 & 600 & 196 & 55 \\
\hline GC09KNW07 & 5.25 & $<0.02$ & 11.4 & 14 & 103 & 11.4 & 3.2 & 12.8 & 490 & 17.1 & 31.4 \\
\hline GC09KNW09 & 6.41 & $<0.02$ & 16.6 & 19 & 303 & 118 & 4 & 64 & 840 & 79.6 & 43.9 \\
\hline GC09KNW10 & 6.31 & $<0.02$ & 14.9 & 18 & 209 & 164 & 4.3 & 129 & 830 & 215 & 44.6 \\
\hline GC09KNW11 & 7.42 & 0.02 & 16.1 & 19 & 213 & 37 & 4.7 & 78.5 & 510 & 152 & 58.9 \\
\hline GC09KNW13 & 3.22 & $<0.02$ & 10.5 & 9 & 218 & 102 & 2.2 & 123 & 970 & 1790 & 24.7 \\
\hline GS09KNS50 & 5.27 & $<0.02$ & 14.8 & 18 & 251 & 2.82 & 4 & 12.5 & 590 & 9.8 & 29.1 \\
\hline GS09KNS51 & 7.15 & 0.02 & 18.1 & 20 & 283 & 2 & 5 & 13.4 & 600 & 10.8 & 46.8 \\
\hline GS09KNS52 & 7.03 & 0.02 & 18.5 & 21 & 346 & 2.62 & 4.6 & 13.3 & 560 & 12.2 & 57 \\
\hline GS09KNS53 & 4.67 & $<0.02$ & 17.4 & 17 & 343 & 2.22 & 2.9 & 9.3 & 650 & 9.4 & 35.7 \\
\hline GS09KNS54 & 5.85 & $<0.02$ & 17.3 & 19 & 338 & 4.01 & 3.9 & 21.1 & 530 & 25.4 & 48.3 \\
\hline GS09KNS55 & 7.05 & 0.02 & 19.8 & 19 & 363 & 3.86 & 5 & 20.6 & 580 & 19.1 & 56.9 \\
\hline GS09KNS56 & 6.96 & 0.02 & 19.7 & 19 & 311 & 4.1 & 5.2 & 18.9 & 530 & 18.5 & 58.6 \\
\hline GS09KNS57 & 7.06 & 0.02 & 19.1 & 20 & 310 & 1.13 & 5.3 & 11.6 & 520 & 11.1 & 60.7 \\
\hline
\end{tabular}


Table 8. Chemical analyses of soil, sediment, rock, and mine waste samples collected by this study.-Continued

[Datum for all latitude and longitude values is WGS 1984; ppm, parts per million; wt. \%, weight percent; see text for description of sample processing and analytical procedures; no., number]

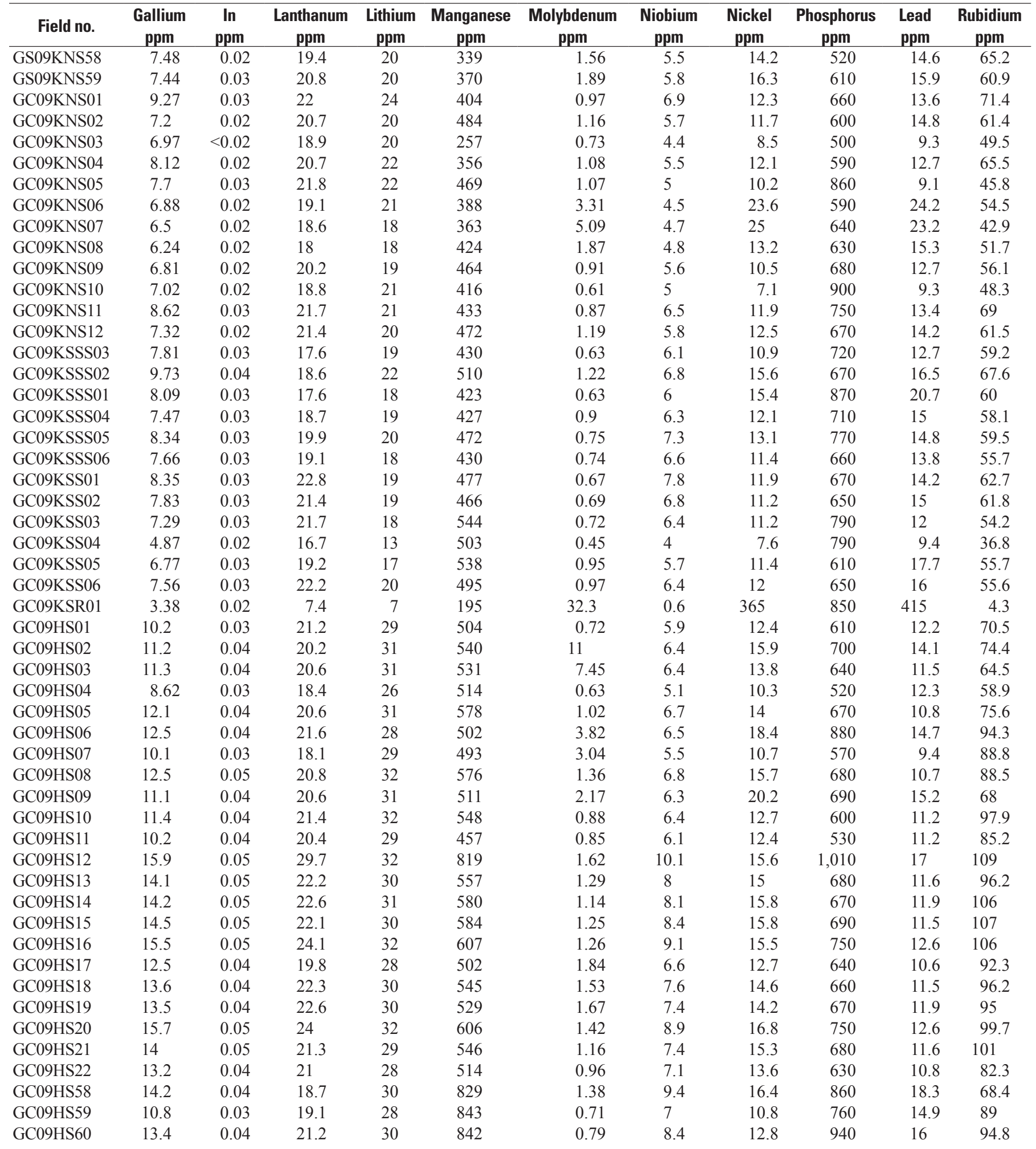


Table 8. Chemical analyses of soil, sediment, rock, and mine waste samples collected by this study.-Continued

[Datum for all latitude and longitude values is WGS 1984; ppm, parts per million; wt. \%, weight percent; see text for description of sample processing and analytical procedures; no., number]

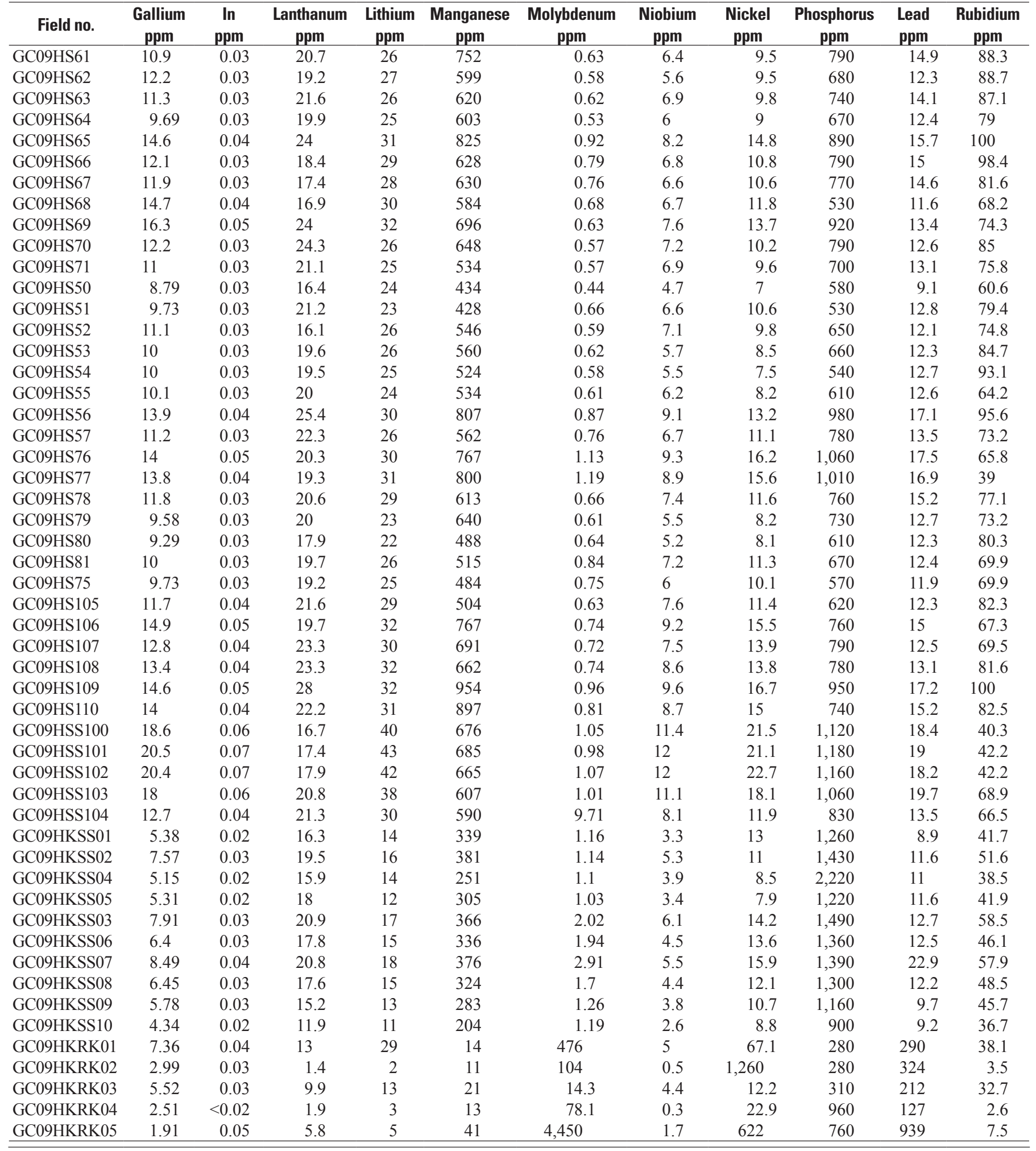




\section{Site Characterization of Breccia Pipe Uranium Deposits in Northern Arizona}

Table 8. Chemical analyses of soil, sediment, rock, and mine waste samples collected by this study.—Continued

[Datum for all latitude and longitude values is WGS 1984; ppm, parts per million; wt. \%, weight percent; see text for description of sample processing and analytical procedures; no., number]

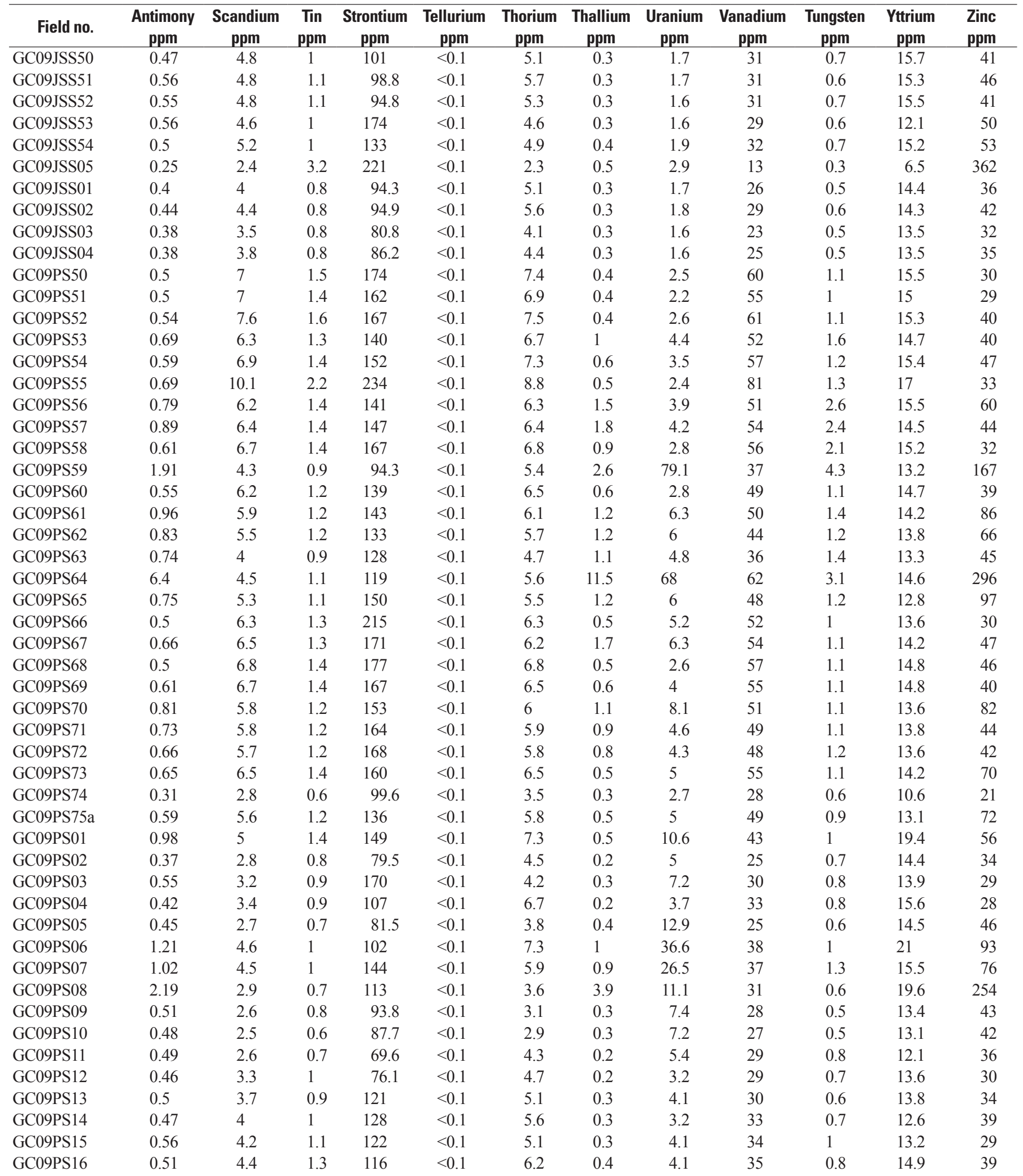


Table 8. Chemical analyses of soil, sediment, rock, and mine waste samples collected by this study.-Continued

[Datum for all latitude and longitude values is WGS 1984; ppm, parts per million; wt. \%, weight percent; see text for description of sample processing and analytical procedures; no., number]

\begin{tabular}{|c|c|c|c|c|c|c|c|c|c|c|c|c|}
\hline Field no. & $\begin{array}{c}\text { Antimony } \\
\text { ppm }\end{array}$ & $\begin{array}{c}\text { Scandium } \\
\text { ppm }\end{array}$ & $\begin{array}{c}\text { Tin } \\
\text { ppm }\end{array}$ & $\begin{array}{c}\text { Strontium } \\
\text { ppm }\end{array}$ & $\begin{array}{c}\text { Tellurium } \\
\text { ppm }\end{array}$ & $\begin{array}{c}\text { Thorium } \\
\text { ppm }\end{array}$ & $\begin{array}{c}\text { Thallium } \\
\text { ppm }\end{array}$ & $\begin{array}{l}\text { Uranium } \\
\text { ppm }\end{array}$ & $\begin{array}{c}\text { Vanadium } \\
\text { ppm }\end{array}$ & $\begin{array}{c}\text { Tungsten } \\
\text { ppm }\end{array}$ & $\begin{array}{c}\text { Yttrium } \\
\text { ppm }\end{array}$ & $\begin{array}{l}\text { Zinc } \\
\text { ppm }\end{array}$ \\
\hline GC09PSS04 & 0.73 & 5.9 & 1 & 103 & $<0.1$ & 5.3 & 1 & 4.2 & 31 & 1.7 & 14.2 & 35 \\
\hline GC09PSS02 & 0.58 & 4.8 & 1.1 & 111 & $<0.1$ & 5.5 & 0.3 & 4.3 & 31 & 0.8 & 12.6 & 39 \\
\hline GC09PSS10 & 0.56 & 5.1 & 1.2 & 117 & $<0.1$ & 5.6 & 0.4 & 6.2 & 31 & 0.8 & 13.5 & 42 \\
\hline GC09PSS09 & 0.69 & 5.8 & 1.3 & 129 & $<0.1$ & 5.2 & 0.6 & 8.5 & 36 & 0.8 & 14.8 & 66 \\
\hline GC09PSS06 & 0.86 & 7.4 & 1.5 & 148 & $<0.1$ & 5.9 & 0.9 & 9.8 & 44 & 1.8 & 14.8 & 53 \\
\hline GC09PSS07 & 0.96 & 6.1 & 1.2 & 131 & $<0.1$ & 5.7 & 0.9 & 16.7 & 39 & 1.4 & 14.7 & 64 \\
\hline GC09PR01 & 0.3 & 0.9 & 0.2 & 58.3 & $<0.1$ & 1 & 0.2 & 7.5 & 11 & $<0.1$ & 5.7 & 27 \\
\hline GC09PR02 & 0.12 & 0.7 & 0.1 & 53.7 & $<0.1$ & 1.6 & 0.2 & 4.9 & 9 & $<0.1$ & 8.6 & 8 \\
\hline GC09PW101 & 2.87 & 4.2 & 1 & 122 & $<0.1$ & 5 & 1.8 & 171 & 35 & 1.7 & 12.1 & 224 \\
\hline GC09PS78 & 1.16 & 5.3 & 1.2 & 134 & $<0.1$ & 7.8 & 2.6 & 32.2 & 43 & 1.1 & 17.2 & 141 \\
\hline GC09PS79 & 0.95 & 5 & 1.1 & 145 & $<0.1$ & 7.4 & 1.4 & 13.3 & 42 & 1 & 15.2 & 65 \\
\hline GC09PS80 & 0.64 & 5.3 & 1.1 & 139 & $<0.1$ & 7.3 & 0.4 & 2.8 & 42 & 1 & 16.4 & 51 \\
\hline GC09PS81 & 0.86 & 5.7 & 1.3 & 165 & $<0.1$ & 7.8 & 0.4 & 4.2 & 48 & 1.1 & 16 & 61 \\
\hline GC09PS82 & 0.63 & 5.5 & 1.2 & 155 & $<0.1$ & 8.1 & 0.4 & 1.8 & 44 & 1 & 16 & 45 \\
\hline GC09PS83 & 0.84 & 6.9 & 1.4 & 126 & $<0.1$ & 9.3 & 0.5 & 3.1 & 55 & 1.2 & 17.5 & 62 \\
\hline GC09PS84 & 0.71 & 5 & 1.2 & 136 & $<0.1$ & 7.3 & 0.3 & 2.8 & 47 & 1.1 & 15 & 44 \\
\hline GC09PS85 & 0.68 & 5.4 & 1.3 & 148 & $<0.1$ & 7.7 & 0.4 & 2.6 & 43 & 0.9 & 18.3 & 48 \\
\hline GC09PS86 & 0.8 & 5.9 & 1.4 & 107 & $<0.1$ & 8.7 & 0.5 & 4.7 & 47 & 1 & 16.7 & 55 \\
\hline GC09PS87 & 1.08 & 5.9 & 1.3 & 131 & $<0.1$ & 8 & 1.2 & 19.3 & 50 & 1.2 & 16.1 & 76 \\
\hline GC09PS88 & 6.2 & 4.8 & 1.1 & 152 & $<0.1$ & 6 & 21.9 & 206 & 51 & 2.2 & 16.9 & 624 \\
\hline GC09KNW08 & 0.66 & 2.7 & 2.5 & 250 & $<0.1$ & 3.4 & 1.8 & 1,800 & 24 & 0.3 & 7.8 & 165 \\
\hline GC09KNW03 & 0.45 & 3.7 & 0.7 & 210 & $<0.1$ & 4.6 & 0.3 & 6.4 & 24 & 0.6 & 14.8 & 33 \\
\hline GC09KNW04 & 0.97 & 3.3 & 0.6 & 99.5 & $<0.1$ & 2.9 & 9.5 & 295 & 50 & 0.5 & 14.8 & 528 \\
\hline GC09KNW05 & 1.28 & 5.8 & 1.1 & 101 & $<0.1$ & 5.7 & 3.2 & 1,350 & 50 & 0.9 & 16.7 & 503 \\
\hline GC09KNW06 & 1.59 & 5.3 & 1.1 & 96.9 & $<0.1$ & 5.2 & 4 & 2,190 & 49 & 0.9 & 17.5 & 621 \\
\hline GC09KNW07 & 0.45 & 3.1 & 0.8 & 626 & $<0.1$ & 3.3 & 0.7 & 50.2 & 30 & 0.9 & 6.8 & 51 \\
\hline GC09KNW09 & 1.16 & 3.6 & 0.9 & 149 & $<0.1$ & 5 & 2.7 & 700 & 49 & 0.7 & 13.9 & 429 \\
\hline GC09KNW10 & 1.62 & 3.5 & 0.8 & 112 & $<0.1$ & 4.1 & 10.7 & 2,840 & 47 & 0.8 & 16 & 1,350 \\
\hline GC09KNW11 & 1.12 & 4.2 & 0.9 & 87.6 & $<0.1$ & 4.9 & 2.8 & 1,050 & 44 & 0.5 & 13.6 & 600 \\
\hline GC09KNW13 & 3.07 & 1 & 0.4 & 64.7 & $<0.1$ & 1.7 & 30.2 & 488 & 51 & 1.4 & 28.4 & 1,400 \\
\hline GS09KNS50 & 0.45 & 3 & 0.7 & 379 & $<0.1$ & 4.1 & 0.4 & 27 & 36 & 1 & 10 & 54 \\
\hline GS09KNS51 & 0.52 & 4 & 1 & 284 & $<0.1$ & 5.2 & 0.4 & 23.5 & 39 & 0.9 & 11.9 & 53 \\
\hline GS09KNS52 & 0.5 & 3.9 & 1.8 & 160 & $<0.1$ & 5.1 & 0.5 & 29.1 & 35 & 0.8 & 13.8 & 54 \\
\hline GS09KNS53 & 0.36 & 2.5 & 0.6 & 161 & $<0.1$ & 3.8 & 0.3 & 22.6 & 24 & 0.6 & 15.7 & 36 \\
\hline GS09KNS54 & 0.63 & 3.1 & 0.8 & 115 & $<0.1$ & 4.8 & 0.6 & 69.5 & 33 & 0.7 & 13.3 & 86 \\
\hline GS09KNS55 & 0.58 & 3.9 & 1 & 121 & $<0.1$ & 6.3 & 0.7 & 69.5 & 36 & 0.7 & 14.9 & 89 \\
\hline
\end{tabular}


Table 8. Chemical analyses of soil, sediment, rock, and mine waste samples collected by this study.-Continued

[Datum for all latitude and longitude values is WGS 1984; ppm, parts per million; wt. \%, weight percent; see text for description of sample processing and analytical procedures; no., number]

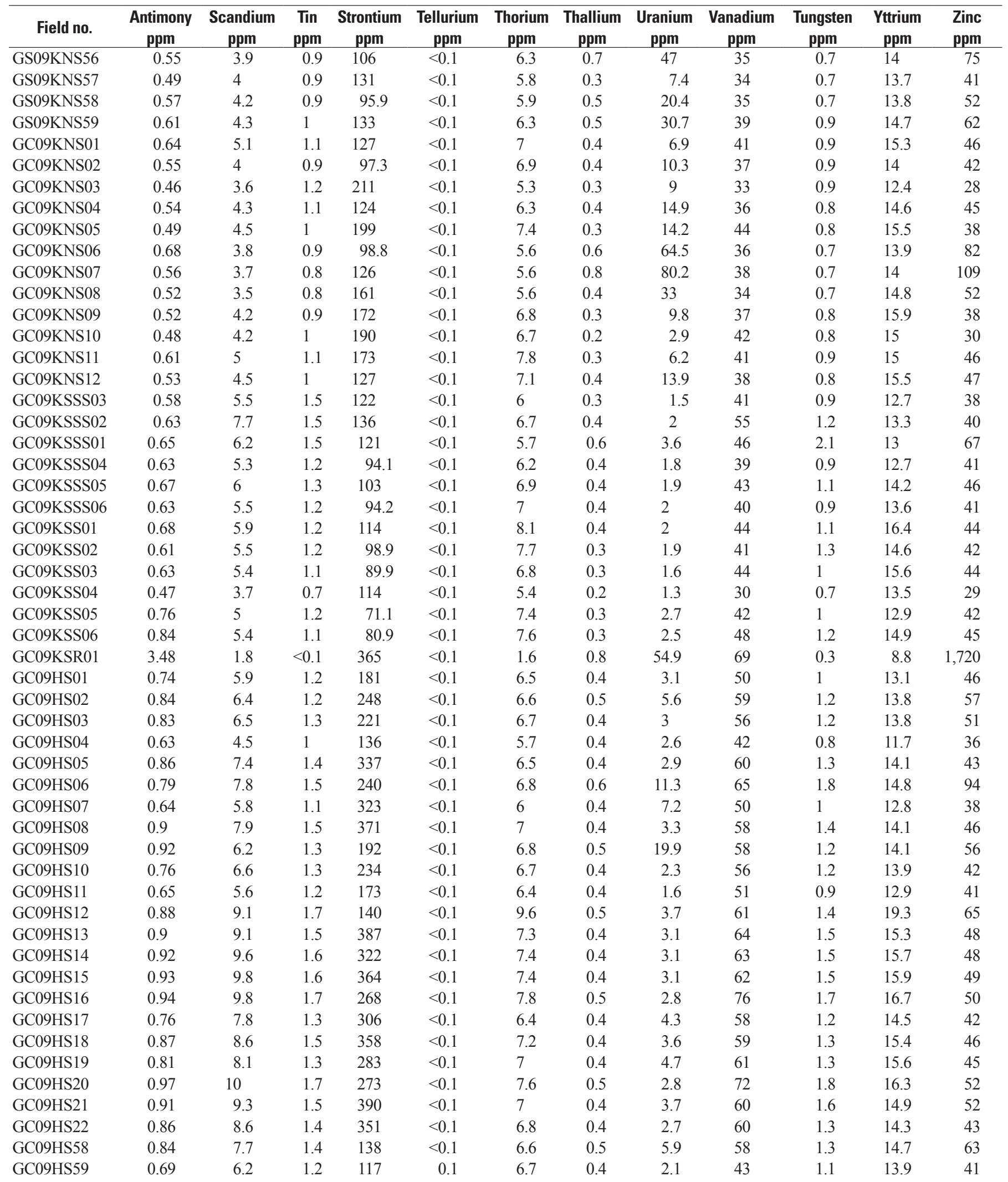


Table 8. Chemical analyses of soil, sediment, rock, and mine waste samples collected by this study.-Continued

[Datum for all latitude and longitude values is WGS 1984; ppm, parts per million; wt. \%, weight percent; see text for description of sample processing and analytical procedures; no., number]

\begin{tabular}{|c|c|c|c|c|c|c|c|c|c|c|c|c|}
\hline Field no. & $\begin{array}{c}\text { Antimony } \\
\text { ppm }\end{array}$ & $\begin{array}{c}\text { Scandium } \\
\text { ppm }\end{array}$ & $\begin{array}{c}\text { Tin } \\
\text { ppm }\end{array}$ & $\begin{array}{l}\text { Strontium } \\
\text { ppm }\end{array}$ & $\begin{array}{c}\text { Tellurium } \\
\text { ppm }\end{array}$ & $\begin{array}{c}\text { Thorium } \\
\text { ppm }\end{array}$ & $\begin{array}{c}\text { Thallium } \\
\text { ppm }\end{array}$ & $\begin{array}{c}\text { Uranium } \\
\text { ppm }\end{array}$ & $\begin{array}{c}\text { Vanadium } \\
\text { ppm }\end{array}$ & $\begin{array}{c}\text { Tungsten } \\
\text { ppm }\end{array}$ & $\begin{array}{c}\text { Yttrium } \\
\text { ppm }\end{array}$ & $\begin{array}{l}\text { Zinc } \\
\text { ppm }\end{array}$ \\
\hline GC09HS61 & 0.59 & 5.5 & 1 & 130 & $<0.1$ & 6.2 & 0.4 & 1.8 & 43 & 0.9 & 14.8 & 39 \\
\hline GC09HS63 & 0.63 & 5.9 & 1.2 & 125 & $<0.1$ & 6.7 & 0.4 & 1.5 & 47 & 0.9 & 14.9 & 42 \\
\hline GC09HS64 & 0.56 & 5.3 & 1 & 126 & $<0.1$ & 5.9 & 0.4 & 1.4 & 42 & 0.8 & 14.1 & 38 \\
\hline GC09HS65 & 0.8 & 8 & 1.4 & 156 & $<0.1$ & 7.8 & 0.5 & 1.9 & 57 & 1.3 & 17.1 & 53 \\
\hline GC09HS68 & 0.63 & 6.9 & 1.2 & 125 & $<0.1$ & 6.3 & 0.4 & 1.2 & 58 & 0.9 & 13.1 & 50 \\
\hline GC09HS69 & 0.68 & 8.3 & 1.5 & 133 & $<0.1$ & 8 & 0.4 & 1.5 & 62 & 1.1 & 17.2 & 61 \\
\hline GC09HS70 & 0.64 & 6.5 & 1.2 & 133 & $<0.1$ & 7.2 & 0.4 & 1.6 & 50 & 1 & 16.3 & 42 \\
\hline GC09HS71 & 0.62 & 6.2 & 1.2 & 131 & $<0.1$ & 6.6 & 0.4 & 1.4 & 48 & 0.9 & 15 & 41 \\
\hline GC09HS50 & 0.47 & 5 & 1.3 & 297 & $<0.1$ & 4.9 & 0.3 & 1.2 & 38 & 0.7 & 12.1 & 30 \\
\hline GC09HS55 & 0.63 & 5.3 & 1 & 157 & $<0.1$ & 6.2 & 0.4 & 1.3 & 43 & 0.9 & 14 & 36 \\
\hline GC09HS56 & 0.77 & 7.1 & 1.4 & 133 & $<0.1$ & 7.2 & 0.5 & 1.5 & 55 & 1.2 & 14.8 & 55 \\
\hline GC09HS57 & 0.68 & 6.4 & 1.3 & 191 & $<0.1$ & 7 & 0.4 & 2 & 47 & 1.1 & 15.2 & 42 \\
\hline GC09HS76 & 0.8 & 8.2 & 1.6 & 156 & $<0.1$ & 7.3 & 0.5 & 3.8 & 61 & 1.5 & 16.2 & 61 \\
\hline GC09HS77 & 0.79 & 7.9 & 1.6 & 154 & $<0.1$ & 7 & 0.5 & 3.1 & 58 & 1.4 & 15.4 & 60 \\
\hline GC09HS78 & 0.72 & 6.7 & 1.2 & 151 & $<0.1$ & 7.2 & 0.4 & 1.6 & 48 & 1.1 & 14.9 & 44 \\
\hline GC09HS79 & 0.61 & 5.9 & 1.1 & 162 & $<0.1$ & 6.2 & 0.4 & 1.5 & 43 & 0.8 & 15.1 & 37 \\
\hline GC09HS80 & 0.6 & 5.3 & 1.1 & 217 & $<0.1$ & 5.8 & 0.4 & 1.6 & 44 & 0.8 & 13.8 & 34 \\
\hline GC09HS81 & 0.66 & 6.3 & 1.2 & 220 & $<0.1$ & 6.6 & 0.4 & 1.9 & 51 & 1 & 14.7 & 42 \\
\hline GC09HS75 & 0.69 & 6.1 & 1.1 & 193 & $<0.1$ & 6.5 & 0.4 & 3.1 & 45 & 1 & 13.3 & 36 \\
\hline GC09HS105 & 0.66 & 7.1 & 1.3 & 199 & $<0.1$ & 7.4 & 0.4 & 1.7 & 50 & 1.1 & 15.1 & 45 \\
\hline GC09HSS103 & 0.95 & 10.6 & 2.6 & 176 & $<0.1$ & 7.5 & 0.5 & 1.9 & 71 & 1.6 & 18.1 & 73 \\
\hline GC09HSS104 & 0.69 & 7.7 & 1.5 & 176 & $<0.1$ & 6.9 & 0.5 & 1.6 & 53 & 1.1 & 15.6 & 50 \\
\hline GC09HKSS01 & 0.34 & 3.2 & 1.2 & 110 & $<0.1$ & 4.3 & 0.3 & 3.9 & 26 & 0.5 & 12.5 & 34 \\
\hline GC09HKSS02 & 0.46 & 4.4 & 1.9 & 129 & $<0.1$ & 5.8 & 0.4 & 2.1 & 33 & 0.8 & 14.7 & 39 \\
\hline GC09HKSS04 & 0.36 & 3.2 & 0.8 & 194 & $<0.1$ & 4.2 & 0.3 & 2.9 & 25 & 0.7 & 14.5 & 42 \\
\hline GC09HKSS05 & 0.33 & 3.2 & 0.9 & 101 & $<0.1$ & 5.7 & 0.3 & 2.8 & 26 & 1 & 12.8 & 32 \\
\hline GC09HKSS03 & 0.5 & 4.8 & 1.2 & 126 & $<0.1$ & 6.4 & 0.4 & 5 & 34 & 0.9 & 16.3 & 46 \\
\hline GC09HKSS06 & 0.39 & 3.8 & 0.9 & 114 & $<0.1$ & 5.4 & 0.4 & 6.5 & 29 & 0.7 & 13.2 & 43 \\
\hline GC09HKSS07 & 0.5 & 4.8 & 1.3 & 134 & $<0.1$ & 6 & 0.4 & 10.2 & 37 & 0.8 & 14.8 & 52 \\
\hline GC09HKSS08 & 0.41 & 4.1 & 1 & 111 & $<0.1$ & 4.9 & 0.3 & 4.8 & 28 & 0.6 & 13.7 & 53 \\
\hline GC09HKSS09 & 0.34 & 3.3 & 0.8 & 102 & $<0.1$ & 4.4 & 0.3 & 3.2 & 26 & 0.5 & 11.3 & 37 \\
\hline GC09HKSS10 & 0.29 & 2.6 & 0.9 & 88.5 & $<0.1$ & 3.2 & 0.3 & 2.4 & 19 & 0.4 & 9 & 28 \\
\hline GC09HKRK01 & 8.7 & 3.8 & 0.8 & 101 & 0.3 & 6.1 & 4.8 & 7,760 & 29 & 20.4 & 25.7 & 797 \\
\hline GC09HKRK02 & 8.55 & 0.9 & 0.3 & 400 & 0.1 & $<0.2$ & 349 & 3,630 & 8 & 12.4 & 4 & $>10,000$ \\
\hline GC09HKRK03 & 12.4 & 2.2 & 0.6 & 81.5 & $<0.1$ & 3.7 & 1.7 & 825 & 32 & 3.5 & 8.1 & 92 \\
\hline GC09HKRK04 & 1.99 & 0.3 & 0.3 & 143 & $<0.1$ & 0.6 & 3.2 & 122 & 7 & 0.4 & 0.9 & 5,270 \\
\hline GC09HKRK05 & 12.9 & 2.9 & 0.5 & 128 & 0.4 & 1.4 & 129 & $>10,000$ & 273 & 22.3 & 17.9 & 111 \\
\hline
\end{tabular}


Soil samples and a few rock samples were collected along and near two traverses across the reclaimed operations area that was the site of mine buildings and a waste-rock pile (fig. 9B). One soil traverse started east of the reclaimed zone and went southwest across the trace of the waste pile and the building location to undisturbed soils on the west side (table 8, samples GC09PS75-84). The second traverse started north-northwest of the site and went south-southeast across it (table 8, samples GC09PS85-89). Along the east-to-west traverse, the first five soil samples contained $5.3-33 \mathrm{ppm}$ uranium whereas the next five samples contained 1.8-4.2 ppm uranium. The second group of samples averaged $2.7 \mathrm{ppm}$, slightly above the regional soil concentration. The break in concentrations between the two sample sets corresponds with the west edge of the before-restoration location of the mined waste-rock pile. Dispersion of material from the waste-rock pile to the east is indicated by concentrations above background in the two easternmost samples on this traverse. The proximity of these two samples to traces of roads indicates that dust from trucks may contribute to these elevated uranium concentrations. The north-to-south traverse crossed two sites that yielded modest uranium concentrations (2.6 and $4.7 \mathrm{ppm}$ ) north of the disturbed zone, substantially elevated uranium concentrations (19.3 and $206 \mathrm{ppm}$ ) in disturbed soils of the former mined waste-rock pile, and an elevated uranium concentration (9.6 ppm) south and down slope of the disturbed zone. Five mined waste-rock samples collected from the surface of this area contained from $147 \mathrm{ppm}$ to $1,870 \mathrm{ppm}$ uranium (table 8 , samples GC09PR75-76 and GC09PW01-03). Four of these samples were in the area of the mined waste-rock pile, and one (1,870 ppm uranium) was at the southwest edge of the site.

Stream sediments were collected from two segments of the stream drainage at the reclaimed mine site (fig. 9A). Two samples were taken along the wash that directly drains the site, but below the zone where boulders were placed along the drainage. These samples contain 4.4 and 4.2 ppm uranium, very similar to the median value of soil samples from the reclaimed site, indicating that this sediment is composed of eroded cover and is little affected by local waste (enriched in uranium) that underlies cover within the reclaimed area. The remainder of the samples was collected from the stream drainage east of the site. Samples upstream of the mine site range from 3.7 to $8.5 \mathrm{ppm}$ uranium; highest concentrations are found closest to the site. Sediment sample GC09SS08 was collected where the western side of the stream channel is contaminated with uranium in slope wash derived from exposed waste rock near the top of the slope. It is a composite of sediment from three locations across the wash bottom. This composite contained $45 \mathrm{ppm}$ uranium. The western location measured $54 \mu \mathrm{R} / \mathrm{h}$ whereas the other two locations measured 13 and $14 \mu \mathrm{R} / \mathrm{h}$. Three samples taken downstream from GC09SS08 contain 8.3, 9.8, and $16.7 \mathrm{ppm}$ uranium; concentrations increased downstream. These data indicate that uranium concentrations in stream sediments in this small wash proximal to and below mine operations are greater than background values at Jumpup Canyon (1.9 ppm) and the stream sediments draining the reclaimed site (4.4 and $4.2 \mathrm{ppm}$ ). Stream sediment samples below the mine site contain higher uranium concentrations than the three upstream. The distribution of these increased concentrations is consistent with dispersion by wind and water from materials redistributed by mining operations and restoration activities. However, uranium derived from the abundant limonite-cemented sandstone outcrops in this part of the wash cannot be eliminated as a possible source of elevated uranium.

Arsenic concentration patterns are similar to those of uranium, but concentrations are generally higher (fig. 9C). Soils within the interior of the pipe contain 6-407 ppm arsenic and have average and median concentrations of $68 \mathrm{ppm}$ and $41 \mathrm{ppm}$, respectively. Two samples that contain 68 and $79.1 \mathrm{ppm}$ uranium also have high arsenic concentrations (407 and $377 \mathrm{ppm}$ ). As noted in the uranium discussion, these samples are soils probably contaminated by mined waste rock. Outside of the pipe, arsenic concentrations for the 16 samples range from 7 to $393 \mathrm{ppm}$ and average $50 \mathrm{ppm}$ (median, $25 \mathrm{ppm}$ ). Without the single high value from the anomalous iron-rich soil sample (table 8, GC09PS08), the average and median are essentially identical. Other samples from the east slope that contain high arsenic concentrations (62 and $66 \mathrm{ppm}$ arsenic) are the same as samples with high uranium concentrations (26.5 and $36.6 \mathrm{ppm})$. Stream sediments above the site contain modest arsenic concentrations ( $8-23 \mathrm{ppm})$, whereas stream sediment from site SS08 contained 58 ppm arsenic, and samples downstream range decrease in concentration from 37 to $31 \mathrm{ppm}$. All arsenic concentrations in stream sediments exceed that of the Jumpup Canyon (median, $5 \mathrm{ppm}$ ). Arsenic in the exposed waste rock and the slope wash at the east edge of the reclaimed mine site is elevated similar to uranium concentrations.

In the operations area (fig. 9D), soil arsenic concentrations range from 12 to $455 \mathrm{ppm}$, whereas rock and mine waste samples range from 243 to $5,060 \mathrm{ppm}$. Highest concentrations for soil, rock, and mine waste are within the area once occupied by the mine-waste pile, except for the anomalous rock sample along the southwest edge of the reclaimed area.

The concentration of cadmium in soil within the reclaimed mine site has a narrow range of $0.05-1.6 \mathrm{ppm}$ and has identical average and median concentrations ( $0.4 \mathrm{ppm})$. Highest concentrations occur in samples that are enriched in uranium and arsenic, such as the two samples from within the site, the sample of exposed mined waste rock (1.2 ppm), and the sample on the ridge east of the stream (1 ppm, fig. $9 E)$. Stream sediments above $(0.2-0.4 \mathrm{ppm})$ and below $(0.2-0.3 \mathrm{ppm})$ the site do not differ in cadmium concentrations. In the operations area (fig. $9 F$ ), most soils fall in the narrow range of $0.2-0.4 \mathrm{ppm}$, but one soil sample (2.9 ppm) and the rock and mined waste-rock samples just described remain the highest for the site (1-17.4 ppm). 
Antimony concentration follows a pattern similar to that of cadmium at the mine site (fig. $9 G$ ), but it has a slightly broader range of concentrations $(0.37-2.87 \mathrm{ppm})$. Stream sediments below the site contain greater amounts of antimony than do samples from above the mine. Concentrations of antimony in soil, rock, and mine waste at the operations site also follow a pattern similar to that of cadmium, except for one remarkably high antimony concentration (124 ppm) in a mined waste-rock sample (fig. 9H).

Cobalt concentrations in soils sampled from the reclaimed mine area averaged $9.4 \mathrm{ppm}$ (median, $7.7 \mathrm{ppm}$ ), whereas soils outside of the reclaimed area averaged $10.2 \mathrm{ppm}$ (median, $6.3 \mathrm{ppm}$ ) (fig. 9I, table 8). Soils along the traverses across the operations site contained 7.3-112 ppm cobalt (fig. 9J). Rock and mine waste samples from the same site contained 6-232 ppm cobalt. All samples greater than $25 \mathrm{ppm}$ cobalt were found where the waste-rock pile had been located.

Copper concentrations in soils sampled from the reclaimed mine area ranged from 5.0 to $75.1 \mathrm{ppm}$, averaged $24.4 \mathrm{ppm}$, and had a median value of $21.7 \mathrm{ppm}$. Soils adjacent to the reclaimed area contained 10.0-51.5 ppm copper and averaged 20.4 ppm (fig. $9 K$ ). The median concentration was lower, $15.0 \mathrm{ppm}$. Soils along the traverses across the operations site contained 19.3-136 ppm copper (fig. 9L). Rock and mine waste samples from the same site contained 57-9,030 ppm copper. The very high copper concentration was measured in the same isolated waste-rock sample that also contained 1,870 ppm uranium and 5,060 ppm arsenic.

Lead concentrations in soils sampled from the mine reclaimed area averaged $13.5 \mathrm{ppm}$ (median, $8.7 \mathrm{ppm}$ ), whereas soils adjacent to the reclaimed area averaged $12.8 \mathrm{ppm}$ (median, 11.4 ppm) (fig. 9M, table 8). Lead concentrations in stream sediments above and below the mine site had a narrow range of 13.1 to $19.2 \mathrm{ppm}$. Narrow concentration ranges were also measured for molybdenum (average 8.0 ppm, reclaimed; 7.7 ppm, adjacent) (fig. 9O, table 8); nickel (average 23.4 ppm, reclaimed; $24.2 \mathrm{ppm}$, adjacent) (fig. $9 Q$, table 8); zinc (average $63 \mathrm{ppm}$, reclaimed; 57 ppm, adjacent) (fig. $9 U$, table 8); and thallium (average $1.3 \mathrm{ppm}$, reclaimed; $0.6 \mathrm{ppm}$, adjacent) (fig. $9 \mathrm{~W}$, table 8). In the case of molybdenum, the average value exceeds the median value because of two anomalous soil samples within the reclaimed mine site (median, $2.74 \mathrm{ppm}$ ).

Lead concentrations in soils in the operations area range from 14 to 101 ppm (fig. $9 N$, table 8). Rocks and mine waste range from 137 to $935 \mathrm{ppm}$; most high concentrations were found in the mine waste-pile area. Molybdenum concentrations in most soils in the operations area are low to moderate (0.81-5.56 ppm) (fig. 9P, table 8), and they strongly contrast with a contaminated soil (table 8, $77.1 \mathrm{ppm}$ molybdenum, and elevated concentrations of uranium and arsenic) and with rock and mine-waste samples (20.9-693 ppm molybdenum). Zinc concentrations have a similar contrast (fig. $9 \mathrm{~V}$, table 8 ), as do nickel (fig. $9 R$, table 8 ) and thallium (fig. $9 X$, table 8), but in a less pronounced manner.
Vanadium concentrations in soils sampled from the mine reclaimed area averaged $52 \mathrm{ppm}$ (median, $52 \mathrm{ppm}$ ), whereas soils adjacent to the reclaimed area averaged $32 \mathrm{ppm}$ (median, $31 \mathrm{ppm}$ ) (fig. 9S, table 8). Vanadium concentrations are somewhat higher in stream sediments below the mine. Concentrations decrease with increasing distance downstream. Mined waste rock and soils at the operations site do not contain high vanadium concentrations; vanadium in all soils and rock ranged from 21 to $64 \mathrm{ppm}$.

MicroR measurements were made at the mine site (fig. 10A) and the operations area, including the former position of the mined waste-rock pile (fig. 10B). In addition, measurements were taken across the former site of the wastewater ponds (fig. $10 B$, top). MicroR readings across the surface of the reclaimed pipe range from 5 to $20 \mu \mathrm{R} / \mathrm{h}$, except for one location which measured $55 \mu \mathrm{R} / \mathrm{h}$ (fig. 10A). Outside of the pipe on undisturbed soils, readings ranged from 5 to $15 \mu \mathrm{R} / \mathrm{h}$, except at the exposed waste-rock and slope-wash sites where measurements were $65 \mu \mathrm{R} / \mathrm{h}$ and $19 \mu \mathrm{R} / \mathrm{h}$ (fig. 10A). Stream sediment sites measured 5-7 $\mu \mathrm{R} / \mathrm{h}$ above the mine site, $13 \mu \mathrm{R} / \mathrm{h}$ at site SS08, and 6.5-8.5 $\mu \mathrm{R} / \mathrm{h}$ below the site; this trend is consistent with an increase in uranium concentration downstream from the site. A detailed microradper-hour survey on the hillslope along a traverse line between the stream at the check dam and the crest of the ridge to the north (see unlabeled line of locations, fig. 10A) measured 10 to $85 \mu \mathrm{R} / \mathrm{h}$. Bedrock outcrops produced the lowest part of the range $(10-13 \mu \mathrm{R} / \mathrm{h})$, and local accumulations of fine-grained sediment produced the highest part of the range.

Within the reclaimed operations site, $5-7 \mu \mathrm{R} / \mathrm{h}$ was measured in the southwestern third of the area, where buildings were located, except for a single locality where the uranium-rich waste-rock was found (fig. $10 B, 600 \mu \mathrm{R} / \mathrm{h}$; fig. $9 B, 1,870$ ppm uranium). Throughout the rest of the reclaimed area, radioactivity measurements were highly variable and ranged from 7 to $400 \mu \mathrm{R} / \mathrm{h}$. Measurements greater than $50 \mu \mathrm{R} / \mathrm{h}$ are highlighted in fig. $10 \mathrm{~B}$. These areas of increased radioactivity occupy the position of the former mined waste-rock pile. Around the perimeter of the operations area, concentrations range from $4.5-6 \mu \mathrm{R} / \mathrm{h}$ on the southwest side to $6-17 \mu \mathrm{R} / \mathrm{h}$ on the northeast side. These data support the eastward dispersion of radioactive materials that is indicated by the soil samples enriched in uranium east of the former mined waste-rock pile. Most readings were taken near the trace of roads, and thus both windblown dust from the pile and dust from trucks transporting ore may have contributed. The area formerly occupied by the wastewater ponds registered $4.5-6 \mu \mathrm{R} / \mathrm{h}$, whereas the surrounding area registered $5-7.5 \mu \mathrm{R} / \mathrm{h}$. The lower radioactivity measurements in the reclaimed area may reflect permanent removal of a slightly more radioactive surface layer during pond construction, or it may represent differences between native soils and nonnative cover materials. Both sets of measurements are within the range of background. 

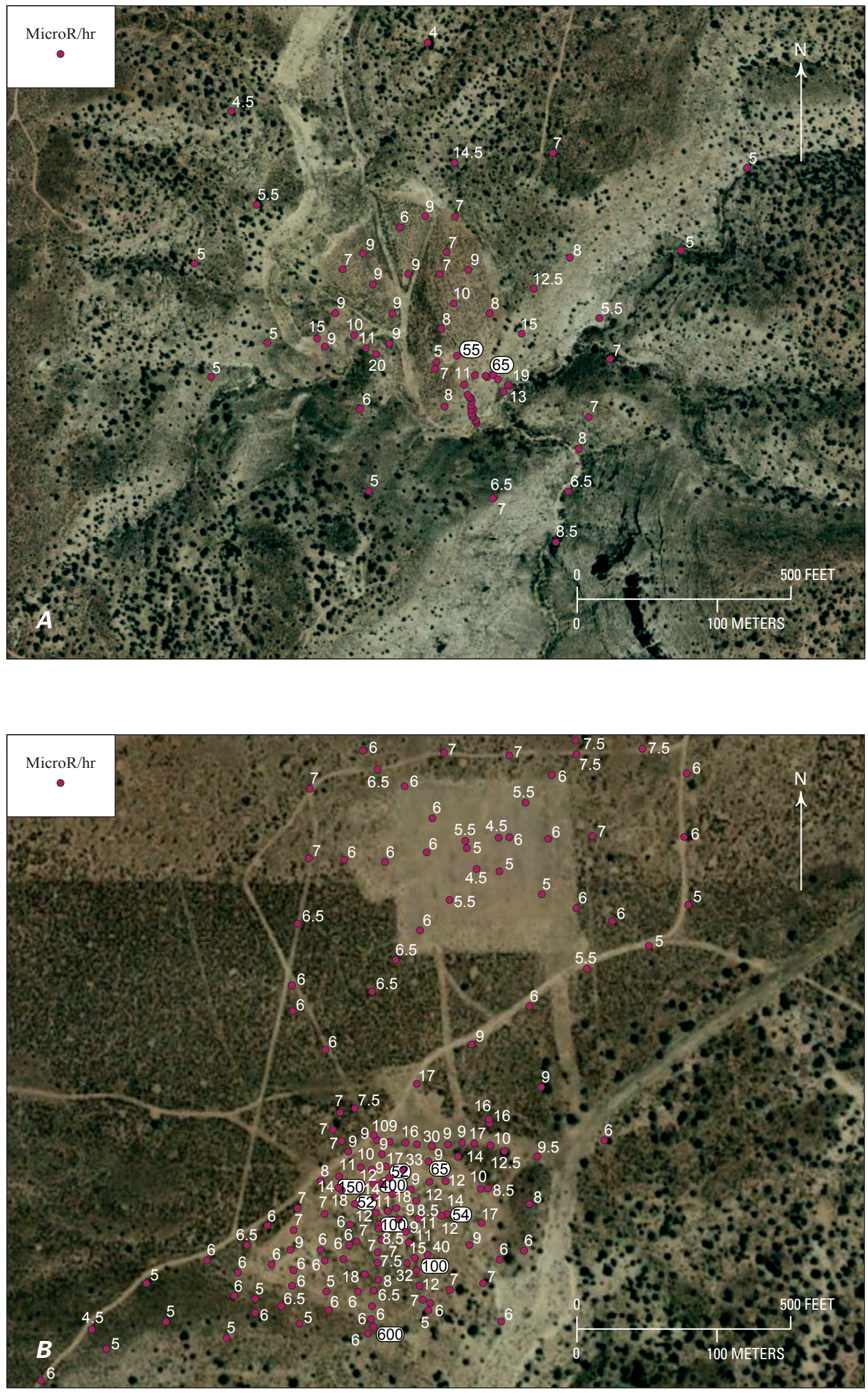

Figure 10. Radioactivity measurements (in $\mu \mathrm{R} / \mathrm{h}$ ) at Pigeon Mine. $A$, mine area; $B$, operations and wastewater-pond site. See also figure 6 ; circled readings, greater than $50 \mu \mathrm{R} / \mathrm{h}$. 


\section{Kanab North Mine}

The Kanab North Mine site lies on the plateau surface on the western side of Kanab Creek at 36 $46^{\prime} 14.42^{\prime \prime}$ N. latitude and $112^{\circ} 38^{\prime} 36.98^{\prime \prime} \mathrm{W}$. longitude (fig. 1). The altitude of the mine site is about 5,020 ft asl, whereas the adjacent section of Kanab Creek is at an altitude of about $3,850 \mathrm{ft}$ asl. The surface lithologic unit at the mine site is the Timpoweap Member of the Triassic Moenkopi Formation (Billingsley and others, 2008). A cliff edge lies about $150 \mathrm{ft}$ east of the east fence at its closest point (fig. 11). The breccia pipe is located on the steep west wall of Kanab Creek just northwest of the mine site, where it is exposed in the Woods Ranch Member of the Toroweap Formation (arrow, fig. 11B). The pipe is accessed by a shaft and drifts from the mine site. A small drainage passes through the mine site from the southwest; it leaves the site as a low swale just north of the fence that turns sharply eastward towards the cliffs just to the east (figs. 11B, 12).

The pipe was discovered in 1981. Development was delayed until 1984 because of the uncertain wilderness land status of the area. It was mined from 1988 to December 1990 and went on standby and maintenance in 1992. Production was 2.77 million pounds $\mathrm{U}_{3} \mathrm{O}_{8}$ at an average grade of 0.53 percent from 260,800 tons of ore (Pool and Ross, 2007). No reclamation work has taken place as of December 2009.

A fenced and bermed perimeter surrounds the site (fig. 12). Within the site, water drains towards a lined wastewater pond (location lp, fig. 12A) located along the trace of the small drainage noted previously. A mined waste-rock pile about $340 \mathrm{ft}(100 \mathrm{~m})$ long occupies the southern part of the site (location wr, fig. 12A).

Kanab North Mine was the site of the following USGS studies:

- Mapping of site features;

- Composite sampling of the east face of the waste-rock pile at the site;

- Sampling of soils within a few feet of fenced perimeter;

- Sampling of soils more distant from the fence line;

- MicroR measurements at each of the sites noted above;

- MicroR measurements of the mine site within the berm;

- MicroR surveys of the perimeter of the site; and

- Sampling of rock at selected microR measurement locations within the fenced perimeter.

Erosion within the site has moved sediment into the lined pond (fig. 13). In a few low spots on the site adjacent to berms, water ponds and allows very fine-grained silt and clay to accumulate. The largest two of these features are indicated on the map (location ps, fig. 12A).

A berm completely surrounds the Kanab North Mine site except at the entry gate on the west side. This berm was examined for evidence of damage and repair. The berm appears intact around the entire perimeter with no evidence of repair. However, at one location along the east side it appears that wet, fine-grained material, possibly water and fine-grained sediment that had accumulated in a low spot or other waste of unknown origin, was pushed over the top of the berm. At this location, the crest of the
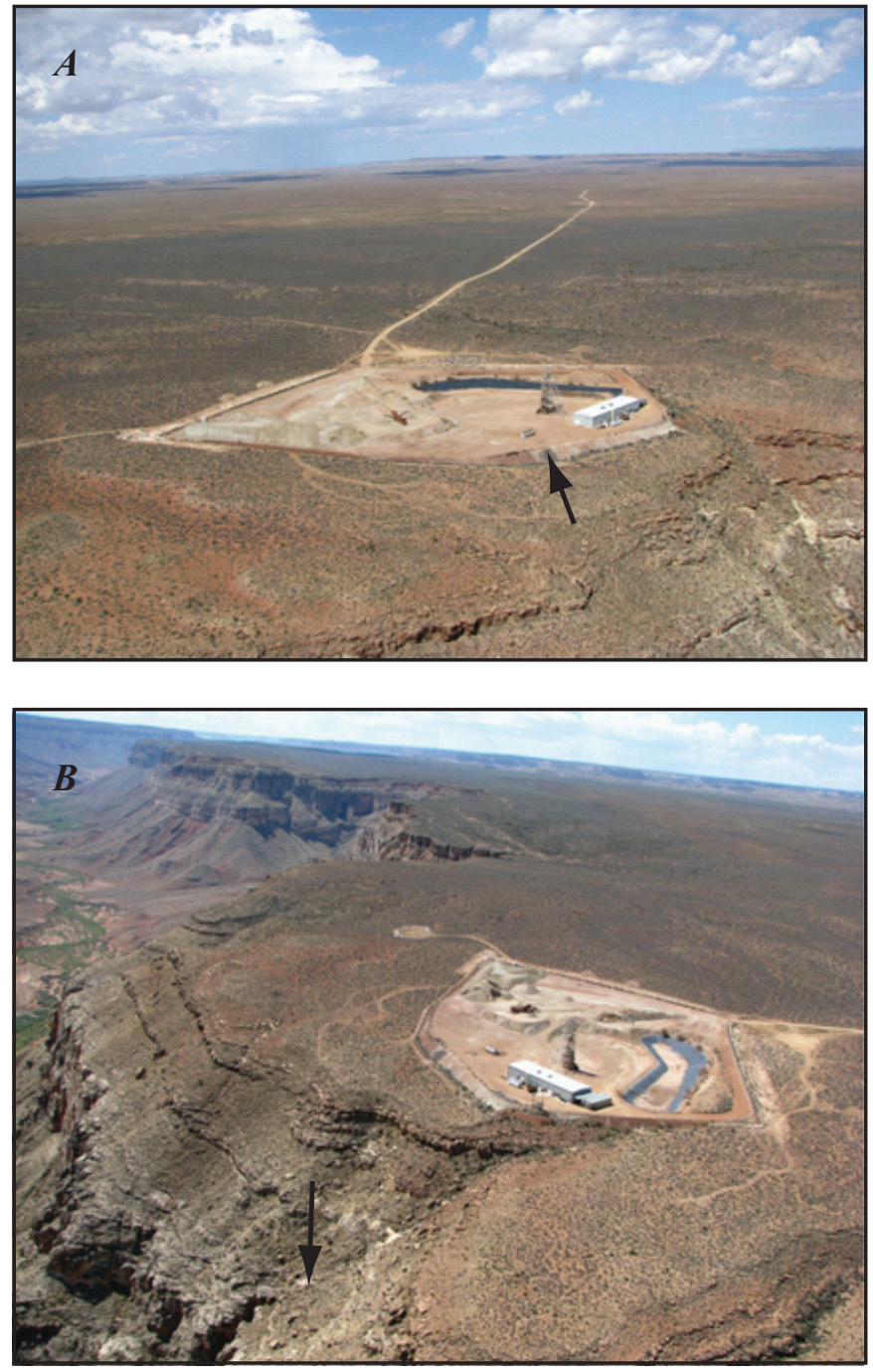

Figure 11. Kanab North Mine site. $A$, View to northwest showing berms (northern and eastern part of site) and trench (south side of site; to the left). Arrow points to brush piled on the berm slope where fine-grained sediment was pushed over the berm. $B$, View to south showing berms (northern and eastern parts of site), trench (west side of site to the right), and sediment in lined pond. Arrow points to approximate location of exposed breccia pipe in a deep gully that drains the site. (Photographs courtesy of Don Bills, U.S. Geological Survey, Flagstaff, Arizona. Taken August 25, 2009.)

berm is slightly lower and discolored with fine-grained, mediumgray to very light reddish-gray sediment in contrast to the moderately red-brown rocky material along the berm crest to the south and the mostly off-white rocky material along the berm crest to the north. This location is further marked by brush piled on the berm slope (arrow, fig. 11A). At the outside toe of the berm below the brush cover, mud-cracked, fine-grained sediment of similar medium-gray to very light reddish-gray has accumulated. It does not appear that this material has moved outside of the fence or into the adjacent low wash, because the adjacent pale-reddishbrown soil is not discolored. A flat bedrock outcrop occurs along the fence at this location. 


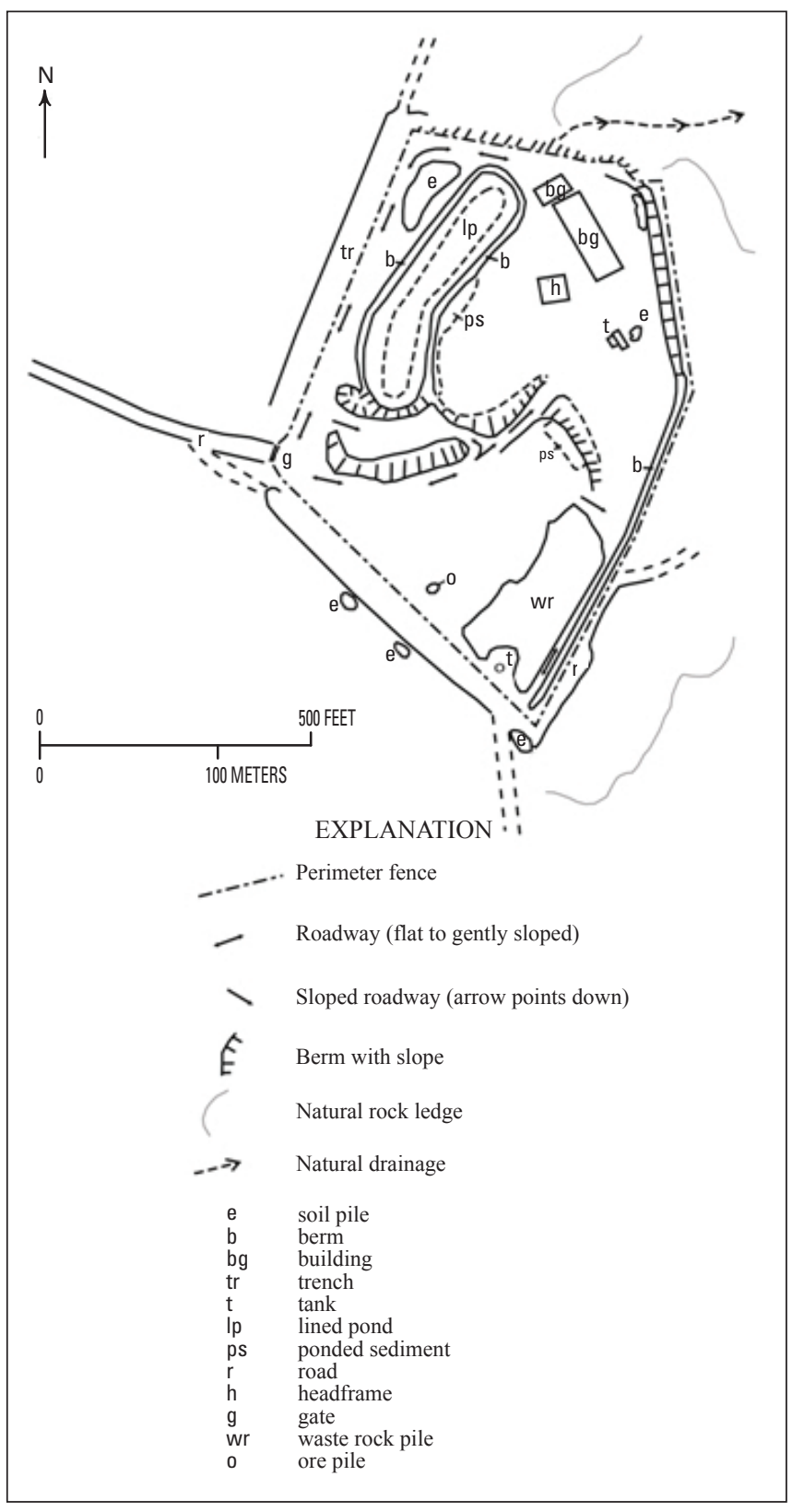

Within the interior of the fenced and bermed mine site, uranium concentrations in samples of surface material (disturbed soils, graded mine operation surfaces, sediment in the pit bottom; $\mathrm{n}=13$ ) range from 6.4 to $2,840 \mathrm{ppm}$ and average 1,135 ppm (median, 1,050 ppm) (fig. 14A; table 8, samples GC09KNW02-13,). A composite of 10 samples collected on the east face of the waste-rock pile contained $679 \mathrm{ppm}$ uranium (sample GC09KNW01, excluded from the reported average; approximate location of midpoint for this composite is shown in fig. 14A). A disturbed soil near the south end of the mined waste-rock pile contained $6.4 \mathrm{ppm}$ uranium. Sludge from the bottom of the pond contained 1,800 ppm uranium. Fine-grained sediment that had washed off the waste pile and accumulated in a low point contained $1,720 \mathrm{ppm}$ uranium. Other samples from the mine operations surface contained 50.2-2,840 ppm uranium.

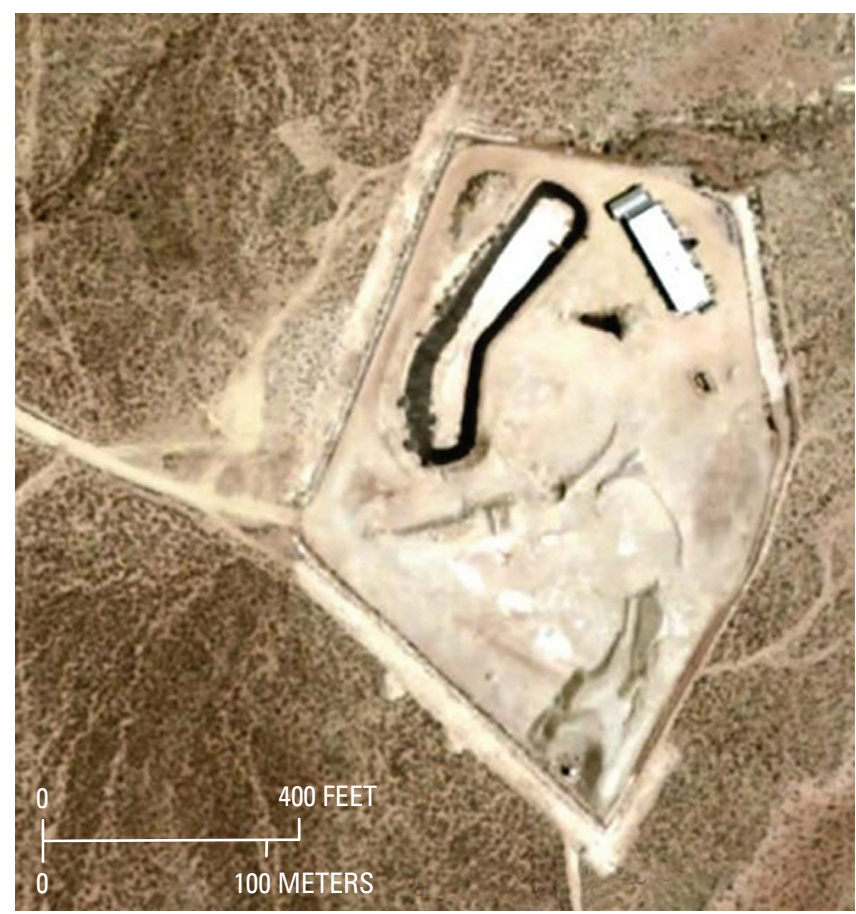

Figure 12. Two views of Kanab North Mine site. A, Diagrammatic map. $B$, Photograph from which map $12 A$ was drawn.

Soil samples beyond the fenced perimeter contained 2.9-80.2 ppm uranium and averaged $27.8 \mathrm{ppm}$ (median, $21.5 \mathrm{ppm}$ ) (fig. 14A; table 8, samples GC09KNS01-12 and $50-59)$. No concentrations in the sampled soils were as low as the average uranium concentrations in area soils, $2.4 \mathrm{ppm}$. All uranium concentrations above $31 \mathrm{ppm}$ (33-80.2 ppm) are in samples collected on the east side of the site between the perimeter fence and the edge of the cliff overlooking Kanab Creek. On the west side of the mine site, concentrations ranged from 6 to $31 \mathrm{ppm}$. No evidence suggests that water moved material offsite. During our mine site visits on two hot days in August, the authors observed wind gusts pick up fine sediment from the surface of the mine site and carry it eastward offsite. Therefore, one explanation of the elevated soil uranium concentrations is windblown dust from the site. An alternative suggested by radioactive limonitecemented sandstone in exposures east of the Pigeon Mine site is that site-wide, anomalously high uranium concentrations are derived from such cemented sandstone present at the Kanab North site. However, such limonite-cemented sandstones were not observed in the sandstone bedrock along the rim of the cliff or in other low outcrops at the site, as would be expected because they are typically more resistant to weathering. In addition, iron concentration in soils beyond the fenced perimeter ranges from 0.86 to 1.78 percent and average 1.43 percent iron (median, 1.42 percent), well below that of iron in the soil formed on iron-cemented sandstone at the Pigeon Mine site. Long-term wind data do not exist for the Kanab North Mine site. However, from March 1983 to March 1984, Energy Fuels Nuclear, Inc., gathered data from a meteorological station on the plateau about $10 \mathrm{mi}$ to the southwest (EnecoTech, Inc., 1987) Although local conditions adjacent to Kanab Creek Canyon likely differ from 
conditions at this station, a wind rose (fig. 1 of EnecoTech, Inc., 1987) shows variable winds dominated by the south-southeast to southwest and west to northwest directions. Highest mean speeds of winds at the station (table 2 of EnecoTech, Inc., 1987) during the reporting period were 4.0 meters per second $(\mathrm{m} / \mathrm{s})$ from the southwest), $4.0 \mathrm{~m} / \mathrm{s}$ from the east-northeast, and $3.7 \mathrm{~m} / \mathrm{s}$ from the west-southwest, but mean wind speeds varied over a narrow range of 3.0 to $4.0 \mathrm{~m} / \mathrm{s}$ for 13 of the 16 directions. Winds from the east, east-southeast, and southeast were the least frequent and had lowest mean speeds $(2.2-2.7 \mathrm{~m} / \mathrm{s})$.

Wind erosion of mill tailings and mine waste has been studied for the past 40 years. A reported threshold speed for dust to move from mine tailings in the southwestern United States is $5.1 \mathrm{~m} / \mathrm{s}$ (table 2.1 of Goudie and Middleton, 2006, citing other sources). Till and Grogan (2008) in summarizing modeling studies of wind suspension from dry, bare surfaces noted that the MILDOS model of Strenge and Bander (1981) yielded fugitive dust emissions (suspension fluxes) at wind speeds of $4.5 \mathrm{~m} / \mathrm{s}$ and greater. The nearby meteorological station showed that wind speeds exceeded $5 \mathrm{~m} / \mathrm{s} 19.2$ percent of the time from all directions, and winds from southsouthwest to north-northwest exceeded $5 \mathrm{~m} / \mathrm{s} 12.6$ percent of the time. The soil geochemical data, wind speed data, our own observations, and the reported wind speed thresholds for dust emissions all indicate that wind is likely to disperse dust from the site frequently, and wind dispersion to the east is favored. Mine-site-specific data, especially chemical analysis of dust collected in traps, could provide additional evidence.

Other trace elements are present in high concentrations that are similar in the degree of soil enrichment and range of variation shown by uranium $(\mathrm{n}=11)$. Within the fenced perimeter, arsenic ranges from 4 to $1,980 \mathrm{ppm}$ and averages $380 \mathrm{ppm}$ (median, $169 \mathrm{ppm}$ ) (fig. 14B, table 8); lead ranges from 11 to $1,790 \mathrm{ppm}$ and averages $266 \mathrm{ppm}$ (median, $146 \mathrm{ppm}$ ) (fig. 14G, table 8); and zinc ranges from 33 to $1,590 \mathrm{ppm}$ and averages
$661 \mathrm{ppm}$ (median, $528 \mathrm{ppm}$ ) (fig. 14K, table 8). Some trace elements have lower to much lower maximum concentrations and more limited ranges: cadmium ranges from 0.3 to $10.4 \mathrm{ppm}$ and averages $3.6 \mathrm{ppm}$ (median, $2.4 \mathrm{ppm}$ ) (fig. 14C, table 8); cobalt ranges from 5.3 to $175 \mathrm{ppm}$ and averages $67 \mathrm{ppm}$ (median, 59.5 ppm) (fig. 14E, table 8); copper ranges from 12.2 to $516 \mathrm{ppm}$ and averages $159 \mathrm{ppm}$ (median, $129 \mathrm{ppm}$ ) (fig. $14 F$, table 8); molybdenum ranges from 1.63 to $401 \mathrm{ppm}$ and averages $138 \mathrm{ppm}$ (median, $102 \mathrm{ppm}$ ) (fig. 14H, table 8); nickel ranges from 9 to $180 \mathrm{ppm}$ and averages $83 \mathrm{ppm}$ (median, $78.5 \mathrm{ppm}$ ) (fig. 14I, table 8); thallium ranges from 0.3 to $30.2 \mathrm{ppm}$ and averages $7.8 \mathrm{ppm}$ (median, $3.2 \mathrm{ppm}$ ) (fig. $14 L$, table 8); and antimony ranges from 0.45 to $3.07 \mathrm{ppm}$ and averages $1.3 \mathrm{ppm}$ (median, $1.16 \mathrm{ppm}$ ) (fig. $14 D$, table 8 ). Vanadium has a very narrow range (24-66 ppm, average 44, median 49 ppm; fig. 14J, table 8). Soils samples from outside the fenced perimeter $(n=22)$ show lower averages and medians for the other trace elements (arsenic, $12 \mathrm{ppm}$ and $9 \mathrm{ppm}$; cadmium, $0.26 \mathrm{ppm}$ and $0.2 \mathrm{ppm}$; cobalt, $9.1 \mathrm{ppm}$ and $7.9 \mathrm{ppm}$; copper, $17.9 \mathrm{ppm}$ and $16.6 \mathrm{ppm}$; molybdenum, $2.05 \mathrm{ppm}$ and $1.72 \mathrm{ppm}$; nickel, $14.5 \mathrm{ppm}$ and $12.5 \mathrm{ppm}$; lead, $14.5 \mathrm{ppm}$ and $13.5 \mathrm{ppm}$; antimony, $0.54 \mathrm{ppm}$ and $0.54 \mathrm{ppm}$; thallium, $0.44 \mathrm{ppm}$ and $0.4 \mathrm{ppm}$; vanadium, $37 \mathrm{ppm}$ and $36 \mathrm{ppm}$; and zinc, $55 \mathrm{ppm}$ and $50 \mathrm{ppm}$, respectively).

MicroR data for the Kanab North Mine site show that radioactivity within the fenced perimeter ranges from 40 to $1,000 \mu \mathrm{R} / \mathrm{h}$; only three measurements were less than $50 \mu \mathrm{R} / \mathrm{h}$ and the average was $361 \mu \mathrm{R} / \mathrm{h}$ (fig. 15). Outside the fence, measurements range from $5 \mu \mathrm{R} / \mathrm{h}$ in the western edge of the study area to $75 \mu \mathrm{R} / \mathrm{h}$ near the fence along the eastern side of the site. The overall average is $19 \mu \mathrm{R} / \mathrm{h}$. Data are insufficient to establish the local background, because the measurements apparently did not extend westward beyond the local effects of mine operations. Although the east side of the site has the highest individual readings, the east-side average of $20.6 \mu \mathrm{R} / \mathrm{h}$ is only slightly higher than the west-side average of $17.7 \mu \mathrm{R} / \mathrm{h}$.

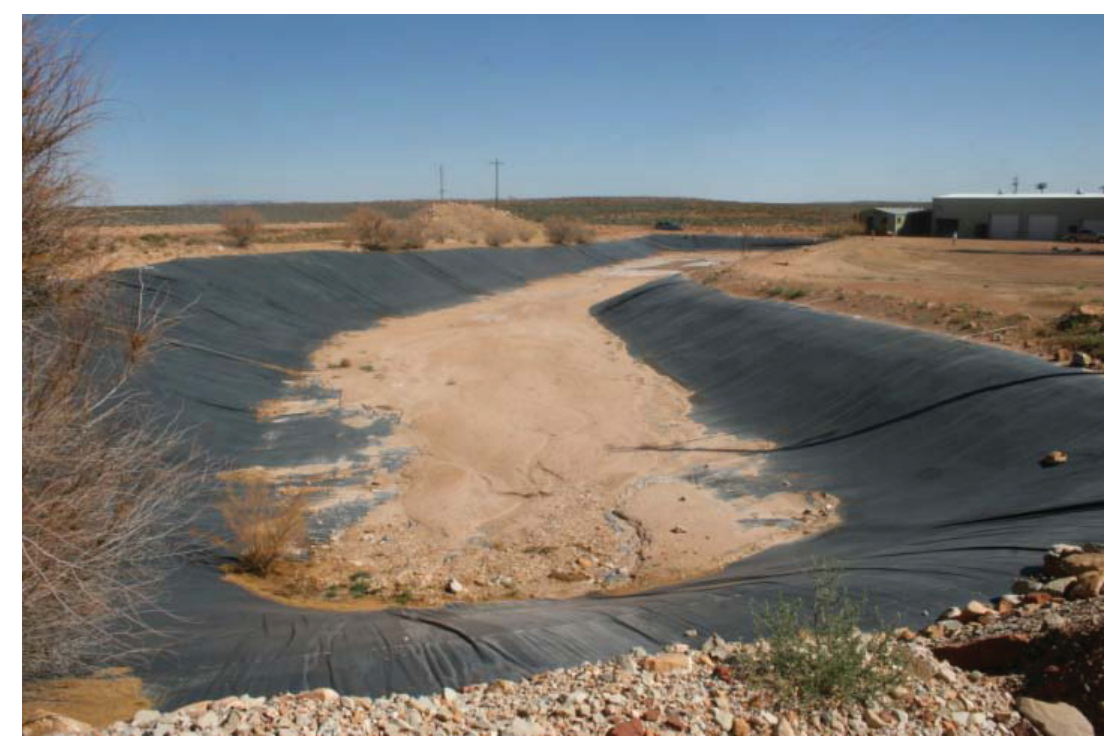

Figure 13. Wastewater pond at Kanab North Mine site showing sediment accumulated in bottom. 

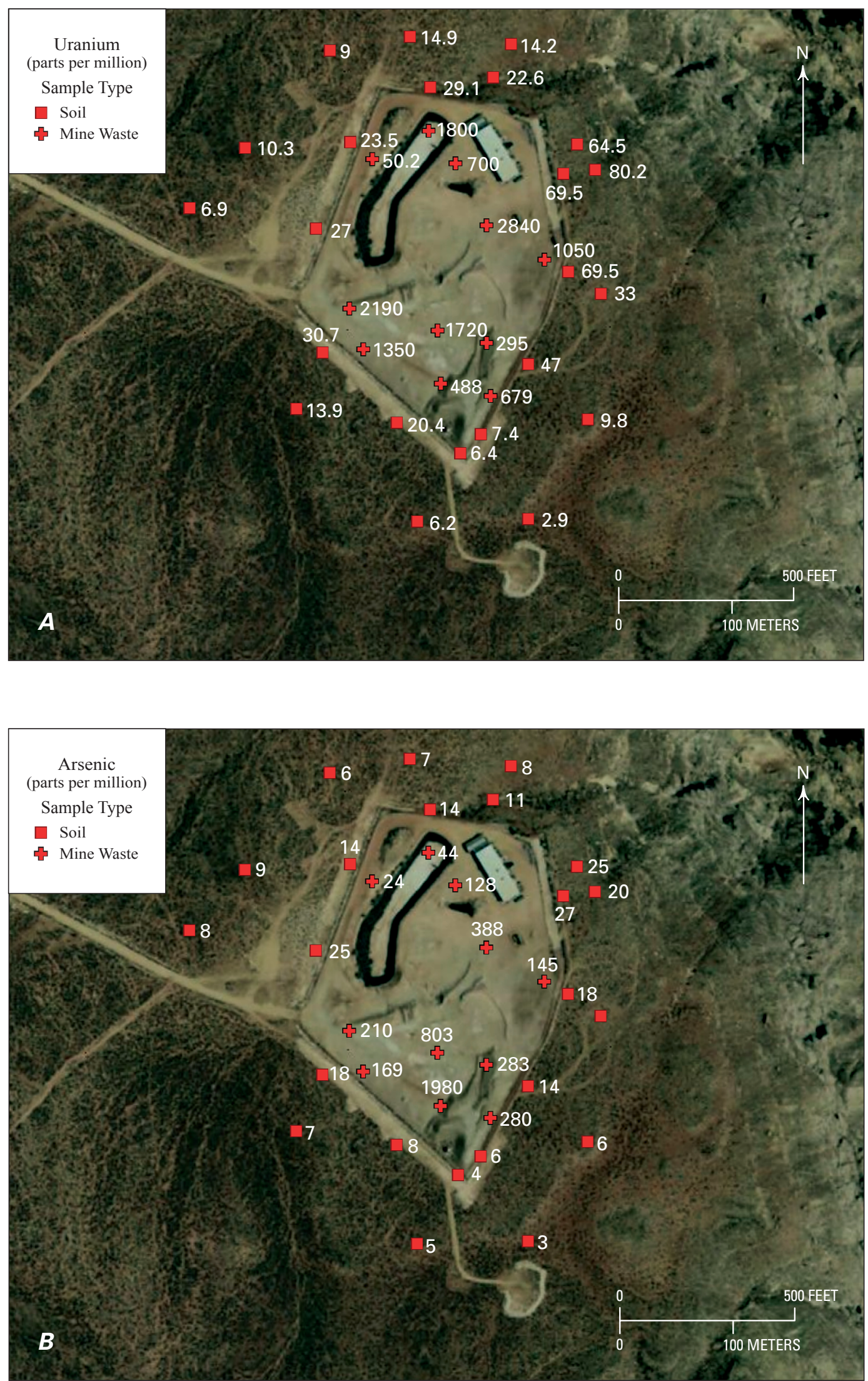

Figures 14. Concentrations of 12 elements at Kanab North Mine site and vicinity. $A$, Uranium; $B$, Arsenic. 

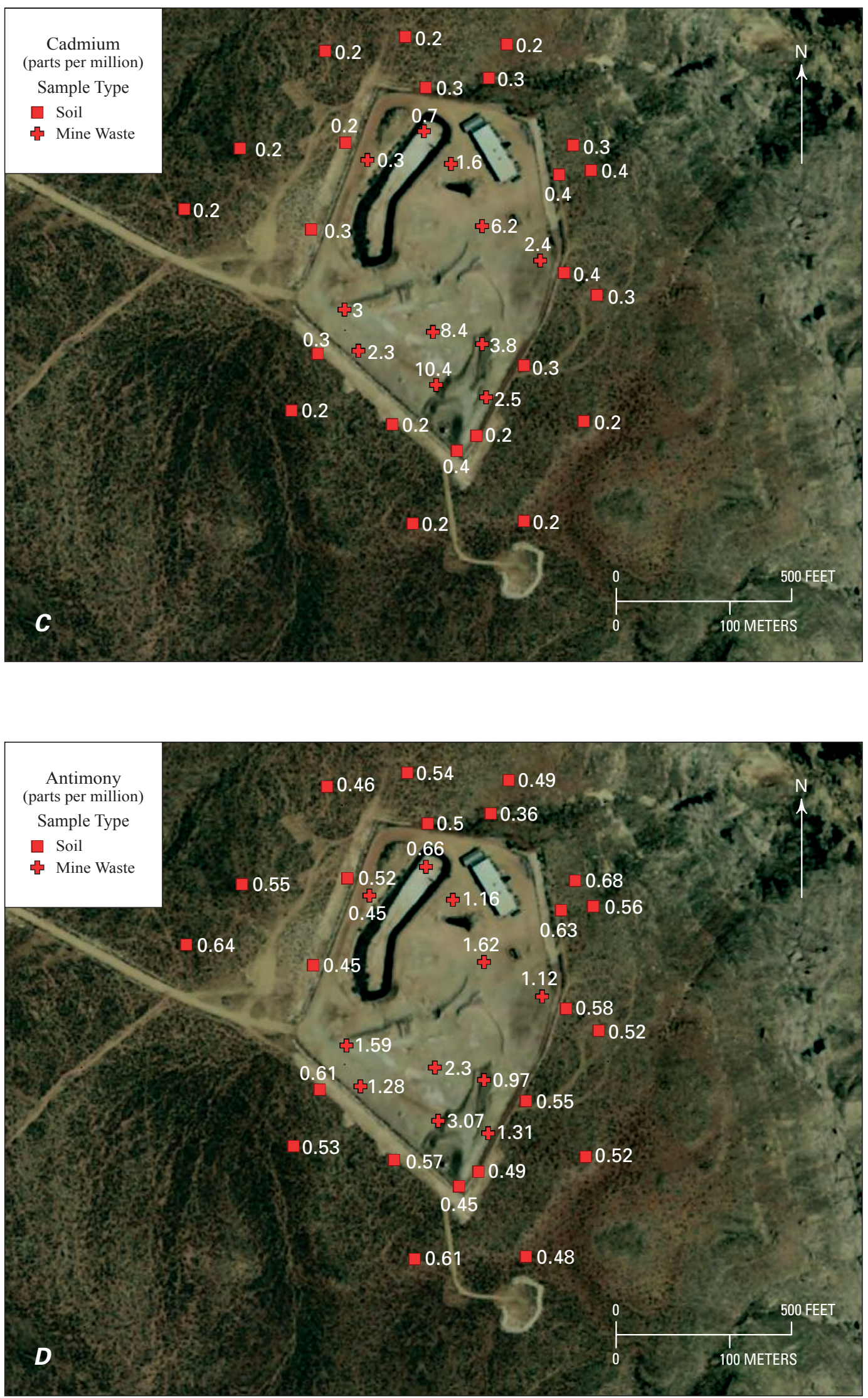

Figures 14-Continued. Concentrations of 12 elements at Kanab North Mine site and vicinity. $C$, Cadmium ; $D$, Antimony. 

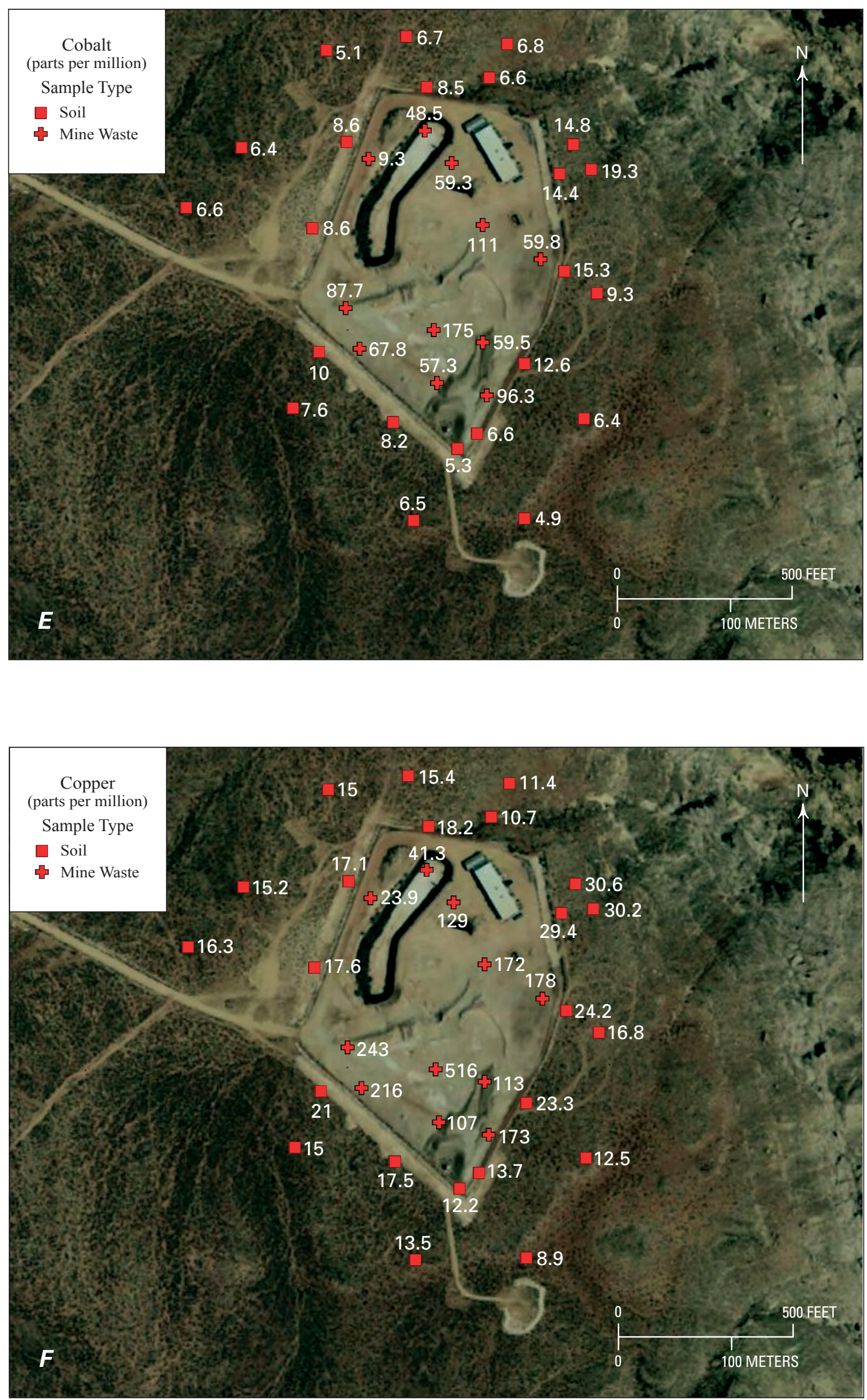

Figures 14-Continued. Concentrations of 12 elements at Kanab North Mine site and vicinity. E, Cobalt; F, Copper. 

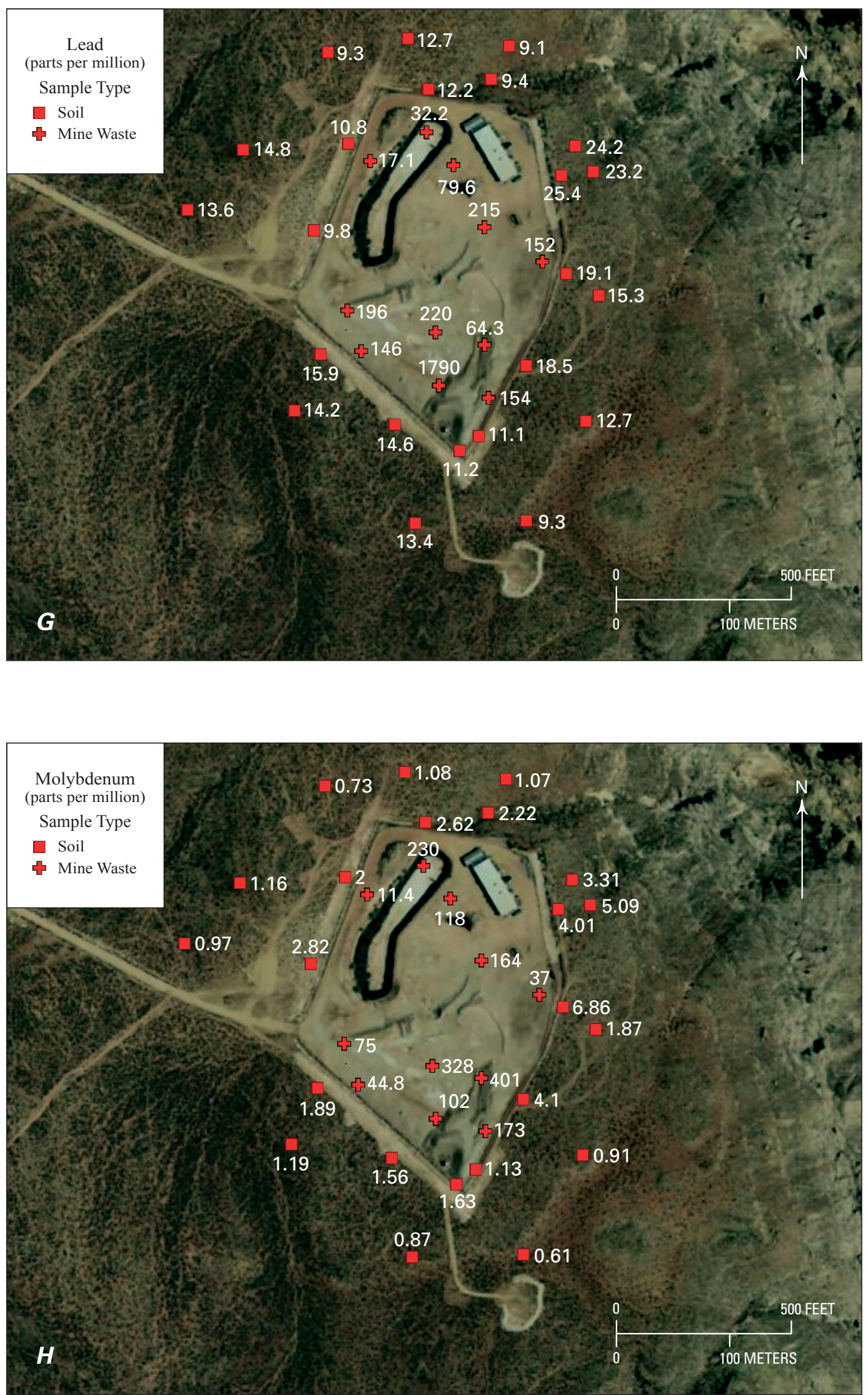

Figures 14-Continued. Concentrations of 12 elements at Kanab North Mine site and vicinity. G, Lead; $H$, Molybdenum. 

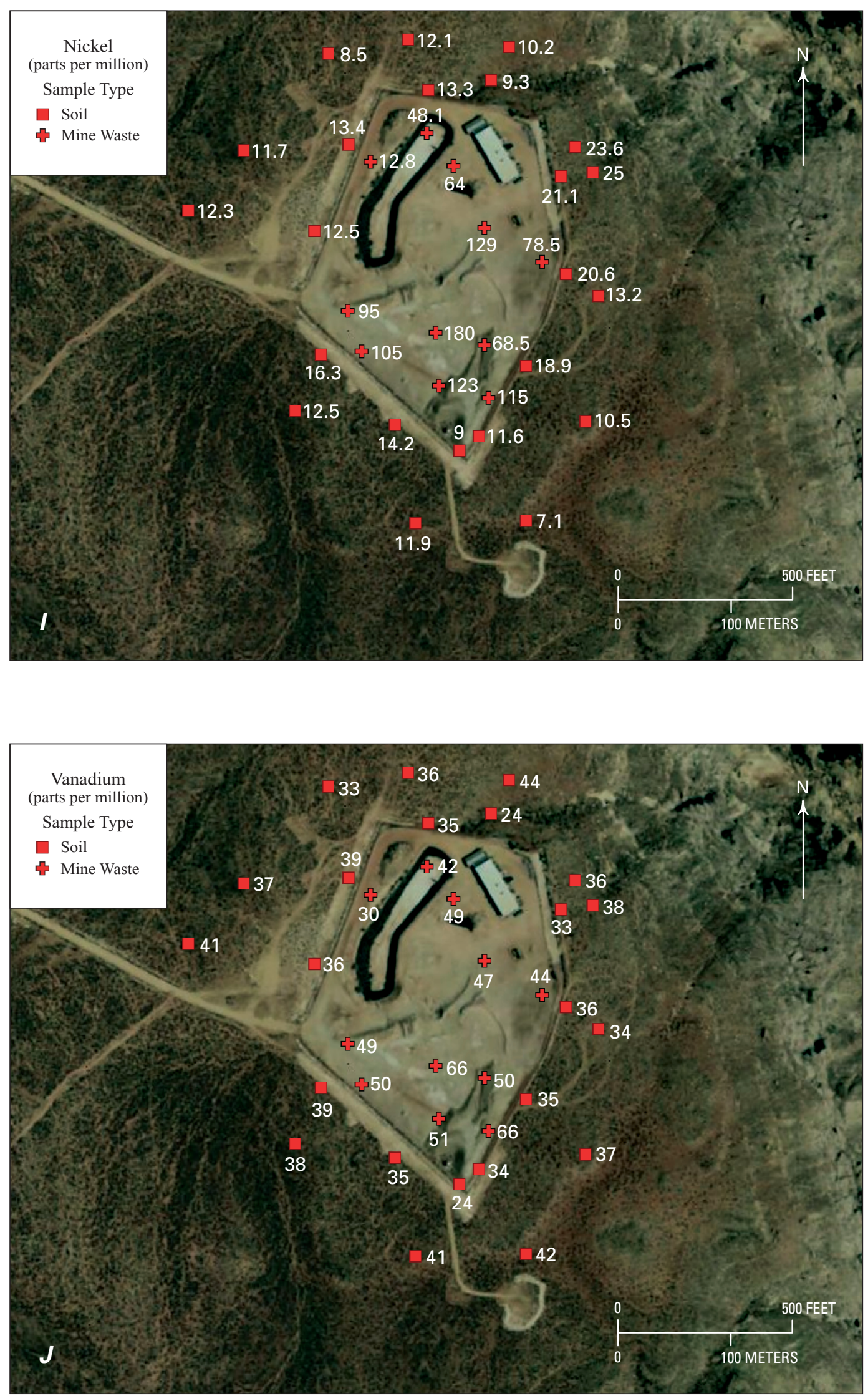

Figures 14-Continued. Concentrations of 12 elements at Kanab North Mine site and vicinity. I, Nickel; $J$, Vanadium. 

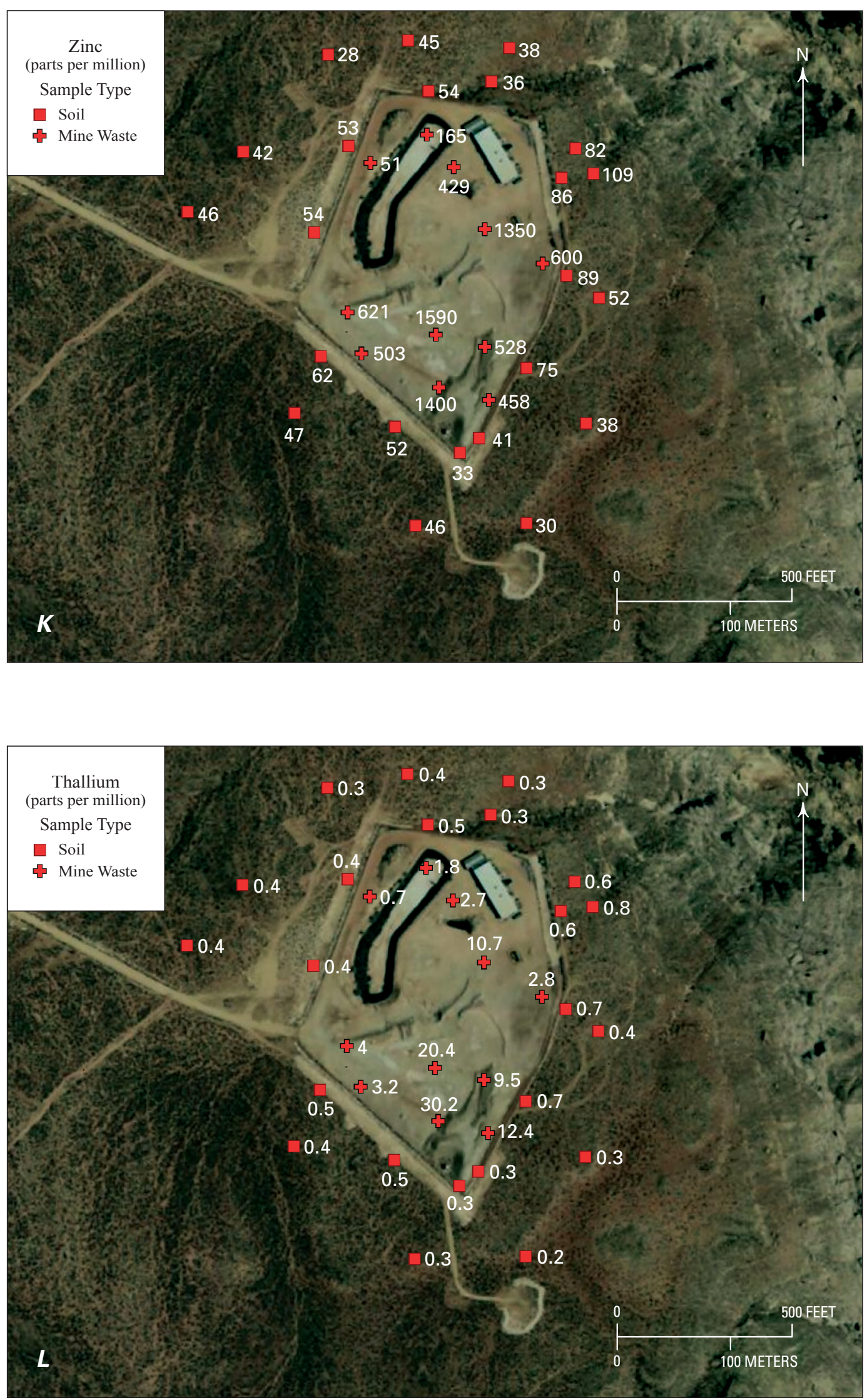

Figures 14-Continued. Concentrations of 12 elements at Kanab North Mine site and vicinity. K, Zinc; L, Thallium. 


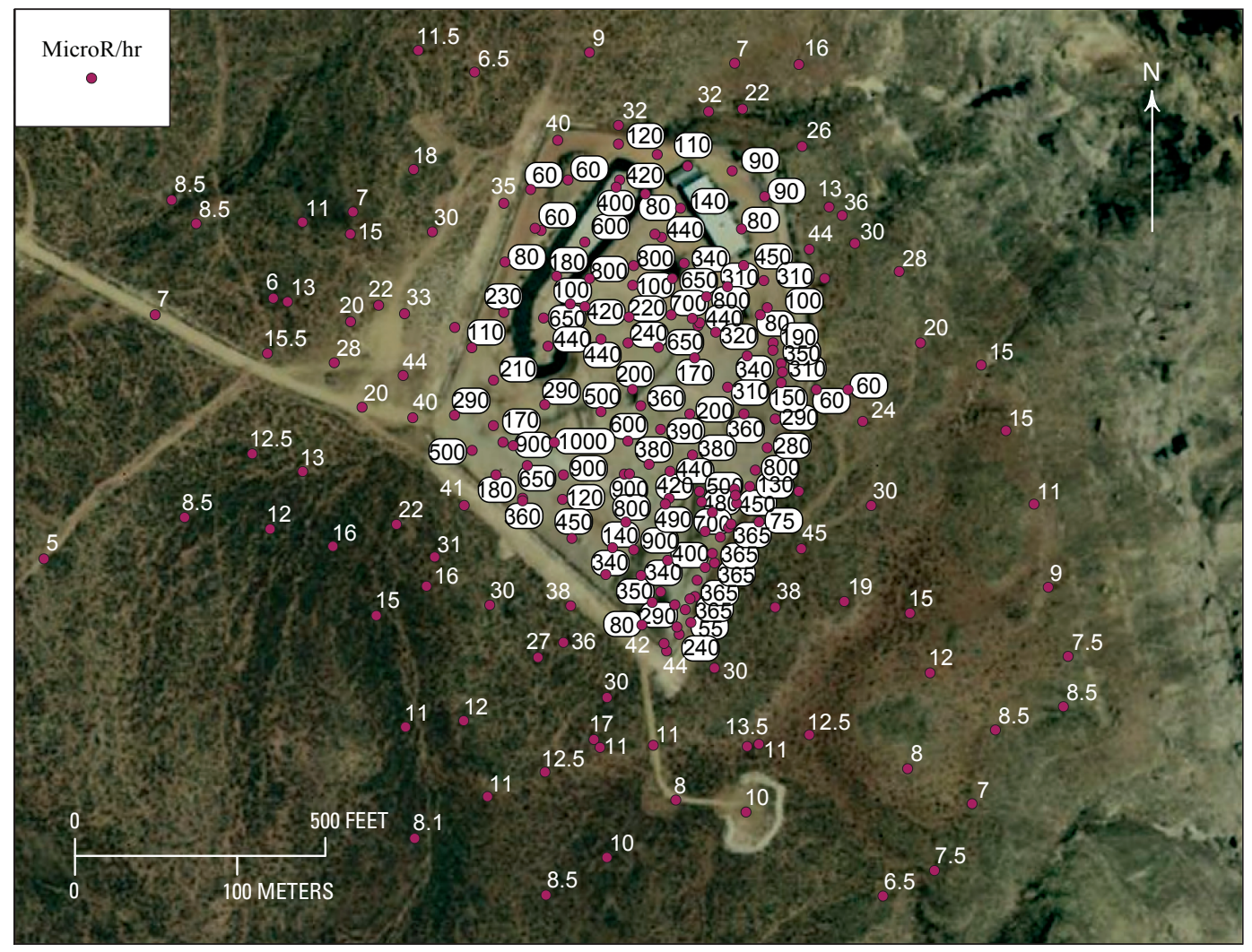

Figure 15. Radioactivity measurements at the Kanab North Mine site. Measurements exceeding $50 \mu R / h$ are circled.

\section{Kanab South Pipe}

The approximate center of the Kanab South pipe is at $36^{\circ} 4^{\prime} 39.81^{\prime \prime} \mathrm{N}$. latitude and $112^{\circ} 38^{\prime} 48.47^{\prime \prime} \mathrm{W}$. longitude (fig. 1). The altitude of the center is about $5,035 \mathrm{ft}$ asl. Similar to the Kanab North Mine site, which is located about 3,700 ft to the north, the surface lithologic unit at the pipe is the Timpoweap Member of the Triassic Moenkopi Formation (Billingsley and others, 2008). Erosion of the pipe created an opening in the small wash that passes through it (fig. 16). About $500 \mathrm{ft}$ northeast of the center of the pipe, the wash drops steeply into the valley of Kanab Creek. Variably dipping beds exposed in the low cliffs along the small wash indicate the presence of a collapse feature, as do the reddish sandstone beds in the center of the pipe that appear to be stratigraphically lower than expected for the surrounding units. Several roads were built to facilitate drilling at the site (fig. 16). The road traces have been recontoured to reestablish the original slopes. Disturbed ground marked by large boulders shows where the roads were located.

The USGS conducted the following studies at this site:

- Stream sediment sampling along the small drainage that passes through the site;

- Soil sampling on the adjacent low hills next to the wash; and

- MicroR measurements at each of the sample sites.
A few irregular, crosscutting masses and layers of limonite-cemented sandstone were observed in the low cliffs along the wash south of the pipe. These features showed variable degrees of anomalous radioactivity that ranged from background to several times background and suggested a relation between these features and the mineralization deeper in the adjacent pipe. One of these layers was sampled and analyzed. It (fig. 17; table 8, sample GC09KSR01) contains $54.9 \mathrm{ppm}$ uranium, $896 \mathrm{ppm}$ arsenic, $0.9 \mathrm{ppm}$ cadmium, $3.48 \mathrm{ppm}$ antimony, $140 \mathrm{ppm}$ molybdenum, $140 \mathrm{ppm}$ cobalt, 1,010 ppm copper, $365 \mathrm{ppm}$ nickel, $69 \mathrm{ppm}$ vanadium, $1,720 \mathrm{ppm}$ zinc, and $0.8 \mathrm{ppm}$ thallium. The high concentrations of several elements support a relation with the nearby uranium mineralization.

Concentrations of uranium in stream sediments in the wash as it crosses the pipe range from 1.5 to $3.6 \mathrm{ppm}$ uranium and average $2.1 \mathrm{ppm}$ (fig. 17; table 8 , sample GC09KSSS01-06), slightly greater than the Jumpup Creek average of $1.9 \mathrm{ppm}$. The highest concentration was in a sample below the pipe in the area of the drill sites. However, information is insufficient to determine whether the pipe mineralization or drilling disturbances contributed to the higher uranium. Uranium concentration in soils on the adjacent low hills ranged from 1.3 to $2.7 \mathrm{ppm}$ and averaged $2.0 \mathrm{ppm}$ uranium (fig. 17; table 8, sample GC09KSS01-06), a little lower than the regional average of $2.4 \mathrm{ppm}$. 


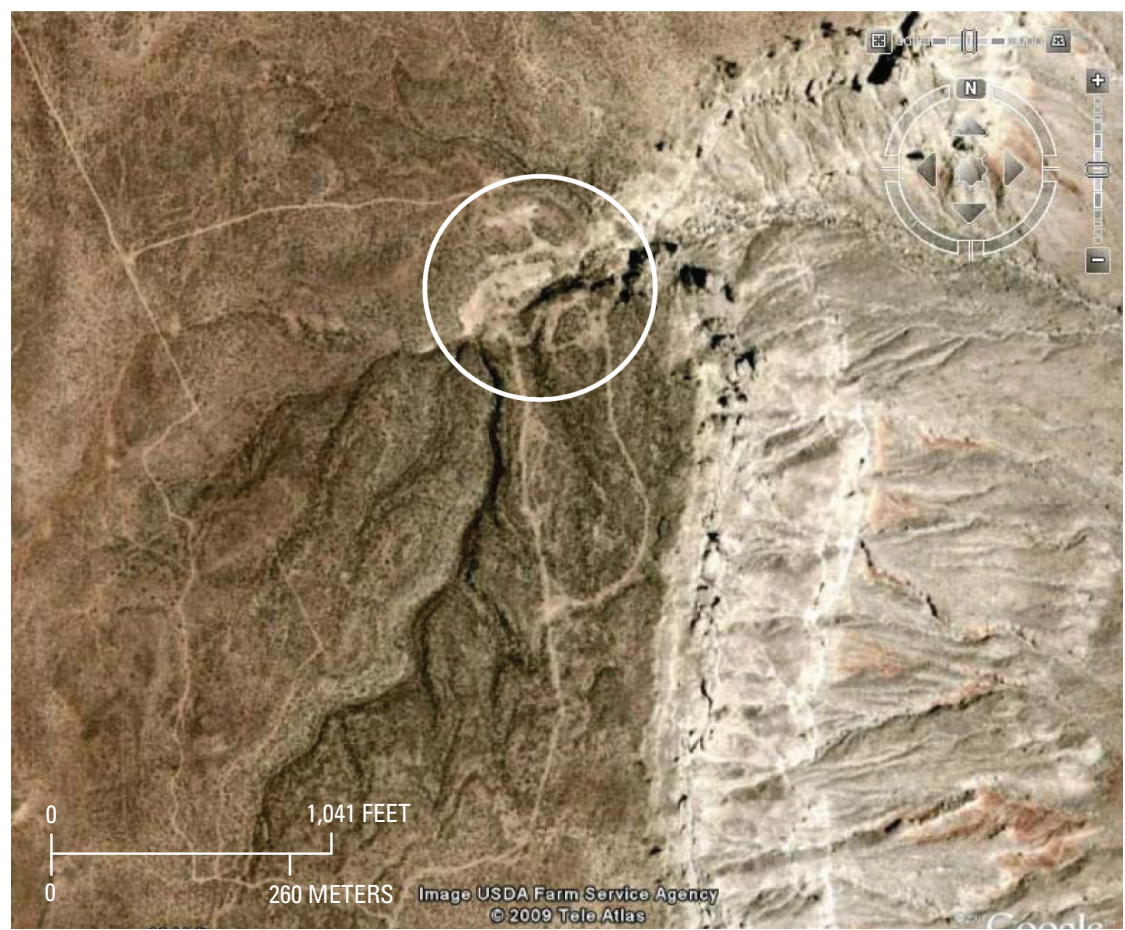

Figure 16. Kanab South pipe (inside white circle) showing drilling roads, small wash that passes through the site, and edge of cliffs on west side of Kanab Creek.

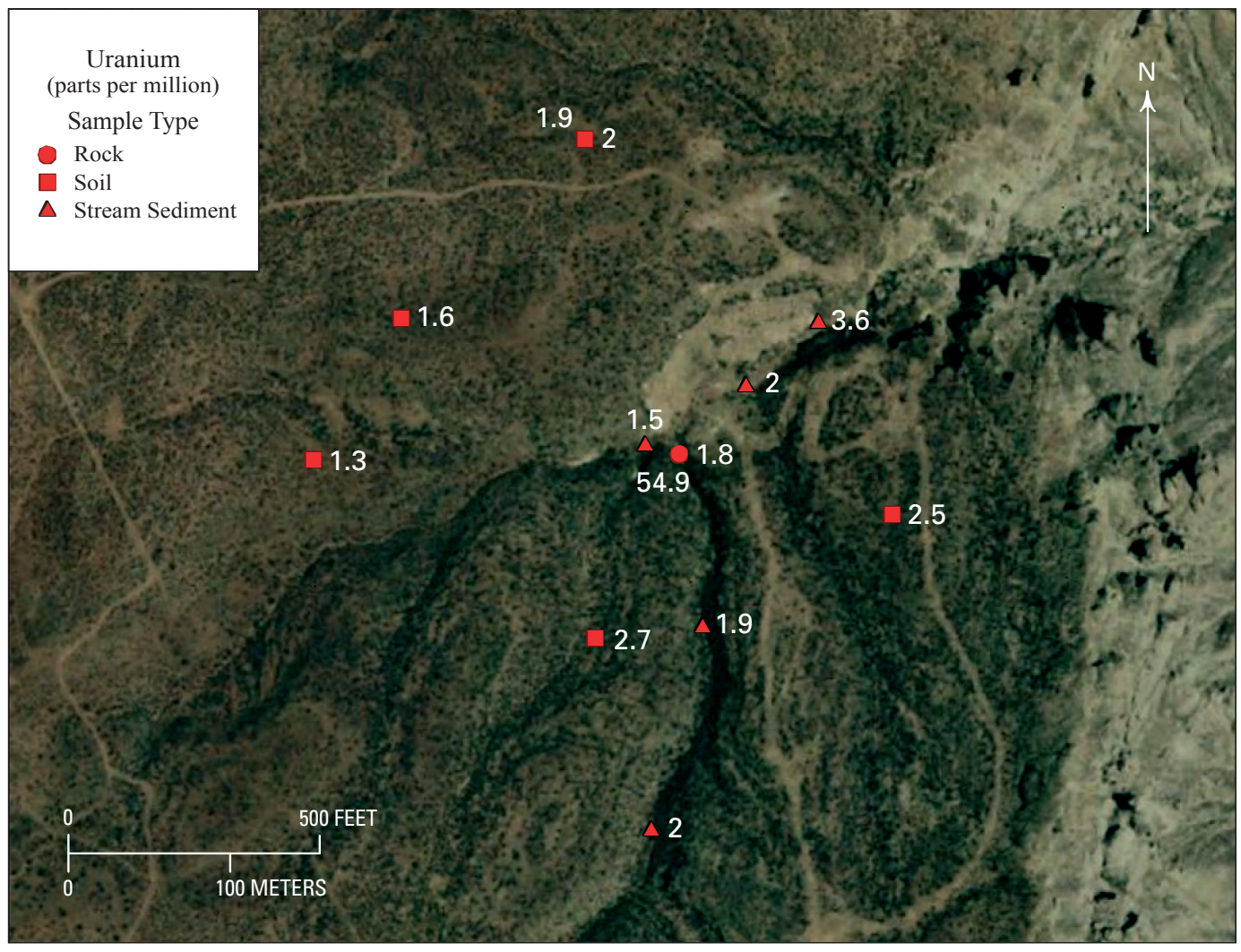

Figure 17. Uranium concentrations at Kanab South pipe site. Duplicate analytical concentrations shown for northernmost sample. A rock sample and a stream-sediment sample were collected at one site (stream sediment, $1.8 \mathrm{ppm}$ uranium; rock, $54.9 \mathrm{ppm}$ uranium). 
Arsenic concentrations in soil samples differed with location. Two samples collected west of the pipe contained 3 and $5 \mathrm{ppm}$ arsenic, whereas samples to the south and east contained 23 and $16 \mathrm{ppm}$, respectively. Stream sediments contained 4-20 ppm arsenic; the lowest concentration was in the stream draining the area that had low soil concentrations, and the highest concentration was just downstream from the pipe.

Other trace elements in soils and stream sediments showed limited variability, although the pipe may have influenced some stream sediment analyses. Cadmium in both soils and stream sediments was low, 0.1 or $0.2 \mathrm{ppm}$, except for the sample downstream from the position of the pipe, which contained $0.6 \mathrm{ppm}$. Antimony was also low in soils and stream sediments $(0.47-0.84 \mathrm{ppm})$ but with no apparent downstream anomaly. Cobalt concentrations in soils and stream sediments ranged narrowly from 4.9 to $8.8 \mathrm{ppm}$; the two highest concentrations were in stream sediment samples at and below the position of the pipe. Copper concentrations in soils and stream sediments ranged narrowly from 8.8 to $23 \mathrm{ppm}$; the two highest concentrations were at and below the position of the pipe. Lead concentrations in soils and stream sediments ranged narrowly from 9.4 to $20.7 \mathrm{ppm}$; the highest concentration was below the position of the pipe. Molybdenum in soils and stream sediments had a narrow range of 4.9 to $8.8 \mathrm{ppm}$; the two highest concentrations were at or below the position of the pipe. Nickel concentrations also had a narrow range of 7.6 to $15.6 \mathrm{ppm}$, highest at or below the pipe. Vanadium concentration in soils and stream sediments ranged from 30 to $55 \mathrm{ppm}$; the highest concentration was over the pipe. Soil samples averaged $41 \mathrm{ppm}$ vanadium, a little greater than the regional soil average in the NURE geochemical data (37 ppm). Zinc in soils and stream sediments ranged from 29 to $67 \mathrm{ppm}$; the highest concentration was at the downstream site. Thallium concentrations ranged from 0.2 to $0.6 \mathrm{ppm}$, and again the highest concentration was downstream. These data consistently suggest that modest geochemical anomalies are measured in the immediate vicinity of the pipe. MicroR measurements show modest levels of radioactivity $(3-7 \mu \mathrm{R} / \mathrm{h})$ associated with the stream sediment and soils at the site. Highest values occur near the pipe and downstream $(5-7 \mu \mathrm{R} / \mathrm{h})$. Because the geologic and physiographic setting of the Kanab South drill site is very similar to that of the Kanab North Mine site, soil and stream sediment geochemical data and the microR measurements for the Kanab South site may approximate local background levels for the Kanab North site.

\section{Hermit Mine}

The Hermit Mine is a reclaimed site centered at $36^{\circ} 41^{\prime} 24.81^{\prime \prime} \mathrm{N}$. latitude and $112^{\circ} 45^{\prime} 06.57^{\prime \prime} \mathrm{W}$. longitude (fig. 1). The surface at the site is part of a gently rolling plateau (fig. 18). It drains towards a stock tank that is located about 5,500 ft to the north-northeast. Aerial photographs show concentric inward-dipping beds that aided discovery of the deposit. The surface lithologic unit at the mine site is the lower red member of the Triassic Moenkopi Formation (Billingsley and others, 2008). The reclaimed area is an irregular shape that extends about $1,300 \mathrm{ft}$ north to south and $1,300 \mathrm{ft}$ east to west. The pipe was drilled in October 1982 and the uranium discovery was announced in August 1986. Production began in January 1989 and the pipe was mined out at the end of 1989 and reclamation begun. Production was 550 thousand pounds $\mathrm{U}_{3} \mathrm{O}_{8}$ at average grade of 0.76 percent from 36,339 tons of ore (Pool and Ross, 2007). No historic photos are available to define where mine operation features were located on the site; however, a mine plan map shows the proposed site operations (fig. 19). A concrete pad remains on the south edge of the site, and a power line leading to the Kanab North Mine site crosses the south part of the site (power poles visible in fig. 18).

The USGS conducted the following studies at this site:

- Soil sampling within the disturbed area of the site;

- Soil sampling along four transects away from the disturbed area;

- Soil and stream sediment sampling along the small drainage that leads to the stock tank north of the site plus three vertical auger samples of the stock tank sediment; and

- MicroR measurements at each of the sample sites.

Soil and stream sediment samples are difficult to distinguish from one another at the Hermit Mine, because the drainage that extends from north of the site to the stock tank has a very poorly developed channel. Soil samples $(n=22)$ within the reclaimed area contained 1.6-19.9 ppm uranium and averaged 4.6 ppm (median, $3.1 \mathrm{ppm}$ ) (table 8, samples GC09HS01-22; fig. 20A). Four samples contained $5 \mathrm{ppm}$ uranium or greater. The four samples are highlighted in figure $20 \mathrm{~A}$ (inset). Soil samples $(\mathrm{n}=25)$ along four transects that extend radially from the site contained 1-5.9 ppm uranium; only two concentrations exceeded 3 ppm uranium (table 8, samples GC09HS50-71, 01-22). The soil sample containing $5.9 \mathrm{ppm}$ uranium was

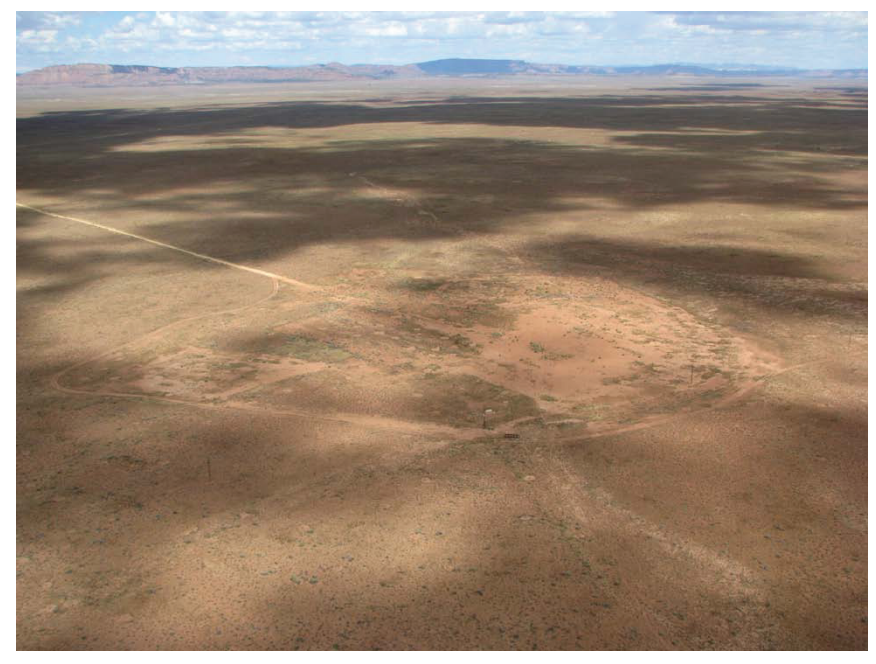

Figure 18. Reclaimed Hermit Mine site; view to northeast. Entry road to north-northwest (left). (Photograph courtesy of Don Bills, U.S. Geological Survey, Flagstaff, Arizona. Taken August 25, 2009.) 


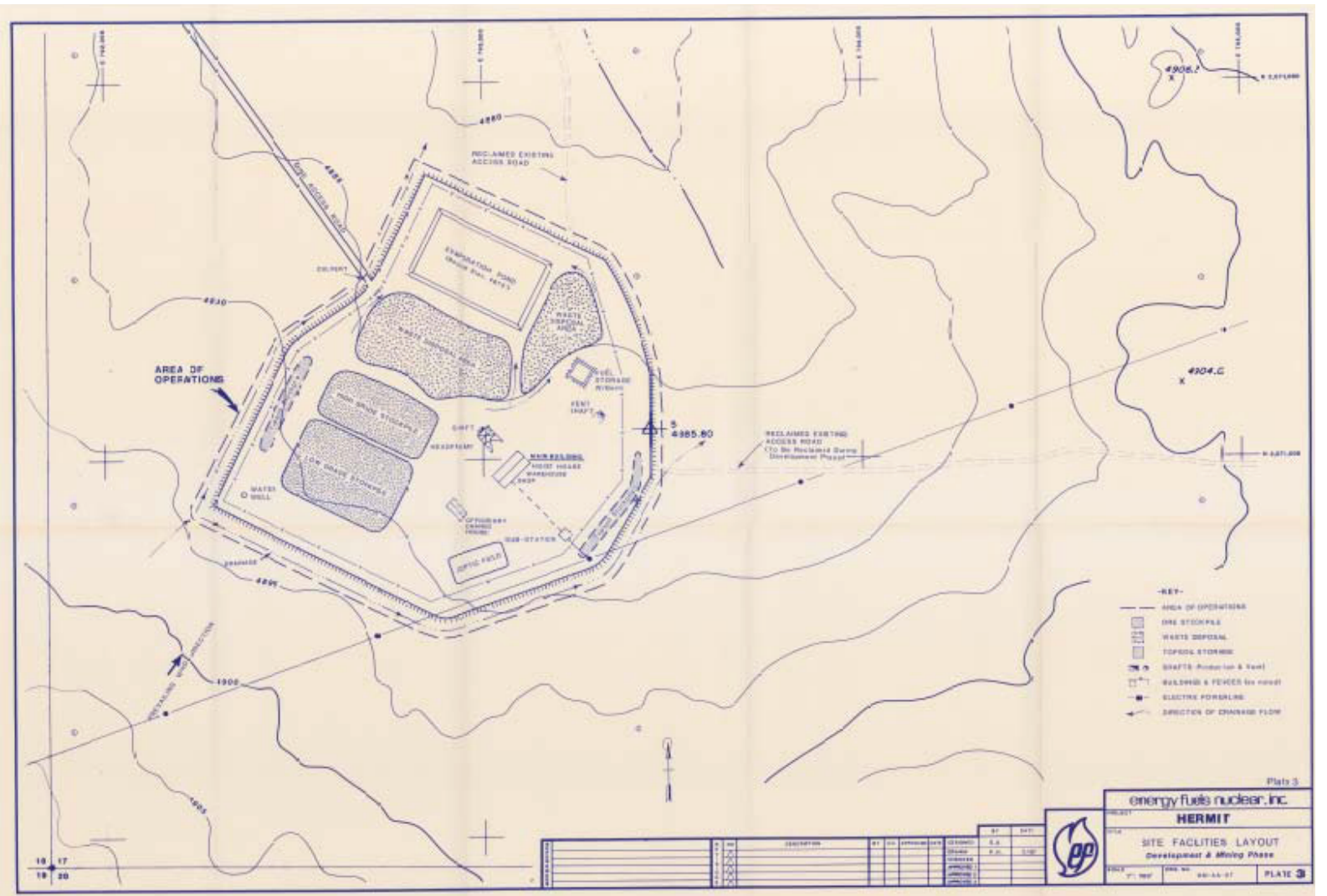

Figure 19. Hermit Mine plan map (EnecoTech Inc., 1987).

collected about $70 \mathrm{ft}$ east of the disturbed area. Along the access road to the northwest of the reclaimed site, samples nearest to the site contained 3.1 and $3.8 \mathrm{ppm}$ uranium. To the west and the south, soil uranium concentrations drop to concentrations below the regional average of $2.4 \mathrm{ppm}$ uranium about $40 \mathrm{ft}$ from the site margin. Samples collected near the ends of the three transects distant from the roads contain 1.1-1.6 ppm uranium. Soils along the drainageway to the north of the site $(\mathrm{n}=6)$ contained 1.4-2.9 ppm uranium; higher concentrations came from samples closer to the former mine site. Five samples were collected at the stock tank, two from the surface and three from a vertical profile hand augered to $19 \mathrm{in}$. depth in sediment accumulated in the stock tank sample (GC09HSS100-104, fig. 20A). The five samples contained 1.6-1.9 ppm uranium, a little less than in samples along the drainage closer to the site.

Other trace elements show similar modest variations. Arsenic in all soil and stream sediment samples ranged from 3 to $27 \mathrm{ppm}$; concentrations greater than $6 \mathrm{ppm}$ are restricted to the reclaimed area (maximum 27 ppm, fig. 20B), at sites along the access road closest to the reclaimed area $(9$ and $10 \mathrm{ppm}$, fig. 20B) and at the stock tank (7 ppm, fig. 20B). Copper in soils and stream sediment samples ranged from 11.8 to $84 \mathrm{ppm}$; highest concentrations are at two sites along the south transect immediately adjacent to the site (fig. 20C). Neither uranium nor arsenic is anomalously high at these two sites (fig. 20A,B). Thus, these elevated levels may be related not to mine waste but to a natural feature or perhaps some other site disturbance such as power-line installation. Cobalt was also highest at these two sites (table 8,13-14 ppm). Molybdenum was consistently highest in the reclaimed part of the site, ranging there from 0.75 to $11 \mathrm{ppm}$, and all external sites contained less than $1 \mathrm{ppm}$ except for two sites along the road (fig. 20D). A surface sample at the stock tank contained $9.71 \mathrm{ppm}$ molybdenum.

All soil and stream sediment concentrations ranged narrowly for other elements: antimony, $0.47-1.06 \mathrm{ppm}$; cadmium, 0.05-0.3 ppm; cobalt, 6.0-13.6 ppm; lead, 9.1-19.7 ppm; nickel, 7-22.7 ppm; thallium, 0.3-0.6 ppm; vanadium, 38-81 ppm; and zinc, 30-87 ppm. Except for cobalt, highest concentrations were either in the reclaimed area or in the stock tank. The stock tank seemed to accumulate most of these elements, possibly because its fine-grained sediment tends to accumulate many trace elements (Carver, 1999). Table 9 compares trace element concentrations inside and outside of the reclaimed area.

MicroR measurements at soil-sample sites within the reclaimed area ranged from 4 to $44 \mu \mathrm{R} / \mathrm{h}$ (fig. 21). On the four soil traverses beyond the perimeter of the disturbed zone most readings were in the $6-7 \mu \mathrm{R} / \mathrm{h}$ range. Some measurements for closer sites ranged from 8 to $10 \mu \mathrm{R} / \mathrm{h}$. Slightly elevated results were obtained for sediments along the wash to the stock tank $(7-9.5 \mu \mathrm{R} / \mathrm{h})$; highest values are closer to the site. At the stock tank, measurements of 7.5 and $10 \mu \mathrm{R} / \mathrm{h}$ were recorded. On the basis of these readings, background for the Hermit Mine site is $6-7 \mu \mathrm{R} / \mathrm{h}$, higher than the background measurements in the Jumpup Canyon stream sediment sites $(4-5 \mu \mathrm{R} / \mathrm{h})$. 

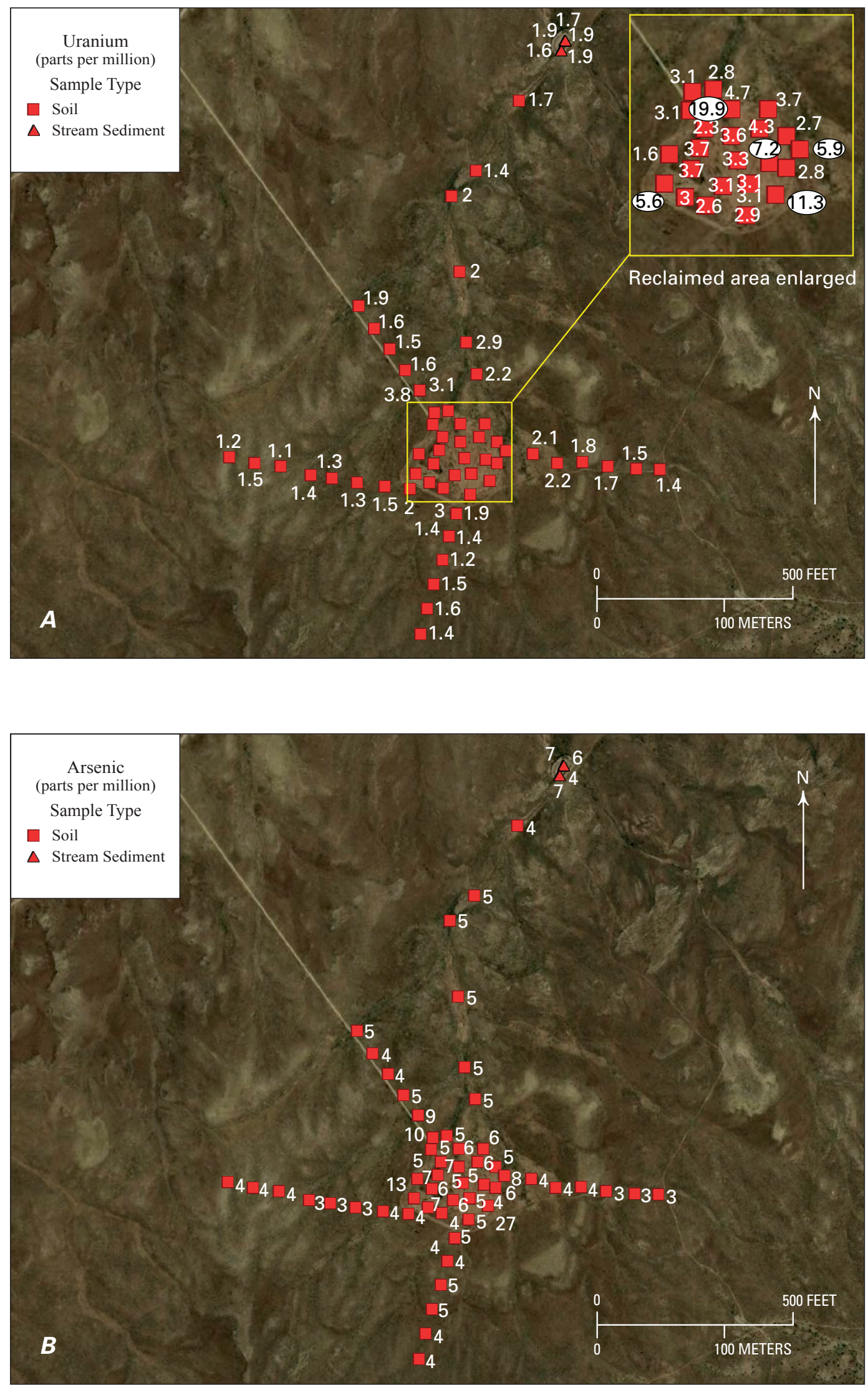

Figure 20. Concentrations of four elements at Hermit Mine. $A$, Uranium; concentrations exceeding $5 \mathrm{mg} / \mathrm{L}$ circled; $B$, Arsenic. 

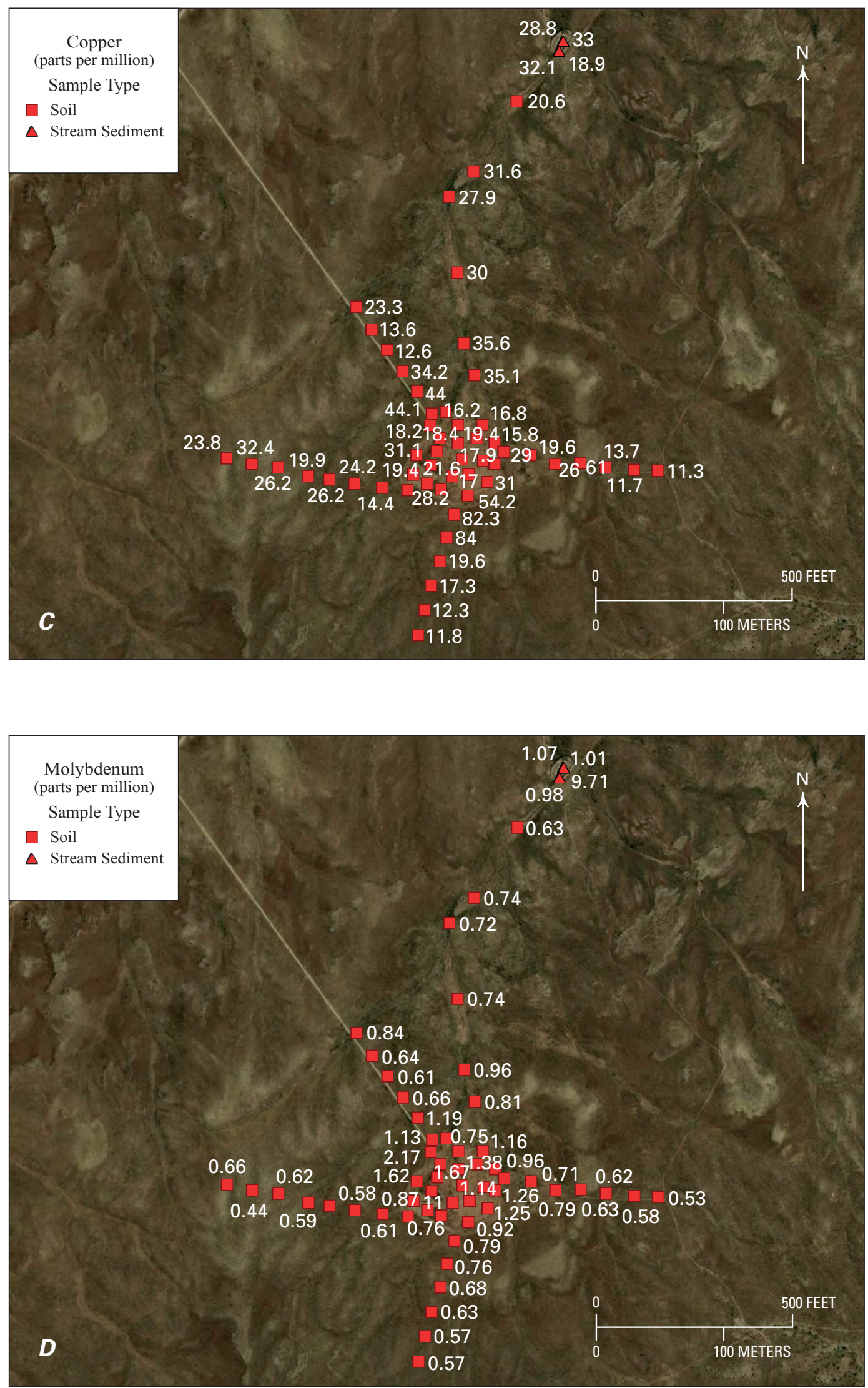

Figure 20-Continued. Concentrations of four elements at Hermit Mine. C, Copper; $D$, Molybdenum. 
Table 9. Trace element concentrations in soil samples inside and outside the Hermit Mine reclaimed area.

[Samples inside reclaimed area, $n=22$; samples outside reclaimed area, $n=35 ; \mathrm{ppm}$, parts per million]

\begin{tabular}{|c|c|c|c|c|c|c|}
\hline \multirow{2}{*}{ Trace element } & \multicolumn{3}{|c|}{ Concentration inside (ppm) } & \multicolumn{3}{|c|}{ Concentration outside (ppm) } \\
\hline & Range & Average & Median & Range & Average & Median \\
\hline Cadmium & $0.05-0.3$ & 0.09 & 0.05 & $0.1-0.2$ & 0.2 & 0.2 \\
\hline Copper & $15.6-31.1$ & 19.8 & 17.9 & $11.3-84$ & 29.1 & 26.0 \\
\hline Molybdenum & $0.63-11.0$ & 2.19 & 1.33 & $0.44-1.38$ & 0.73 & 0.68 \\
\hline Nickel & $10.3-20.2$ & 14.6 & 14.8 & $7.0-16.7$ & 11.5 & 10.8 \\
\hline Thallium & $0.4-0.6$ & 0.43 & 0.4 & $0.3-0.5$ & 0.42 & 0.40 \\
\hline Uranium & $1.6-19.9$ & 4.6 & 3.1 & $1.1-5.9$ & 1.9 & 1.6 \\
\hline Vanadium & $42-76$ & 59 & 60 & $38-63$ & 50 & 48 \\
\hline Zinc & $36-94$ & 50 & 47 & $30-65$ & 46 & 42 \\
\hline
\end{tabular}

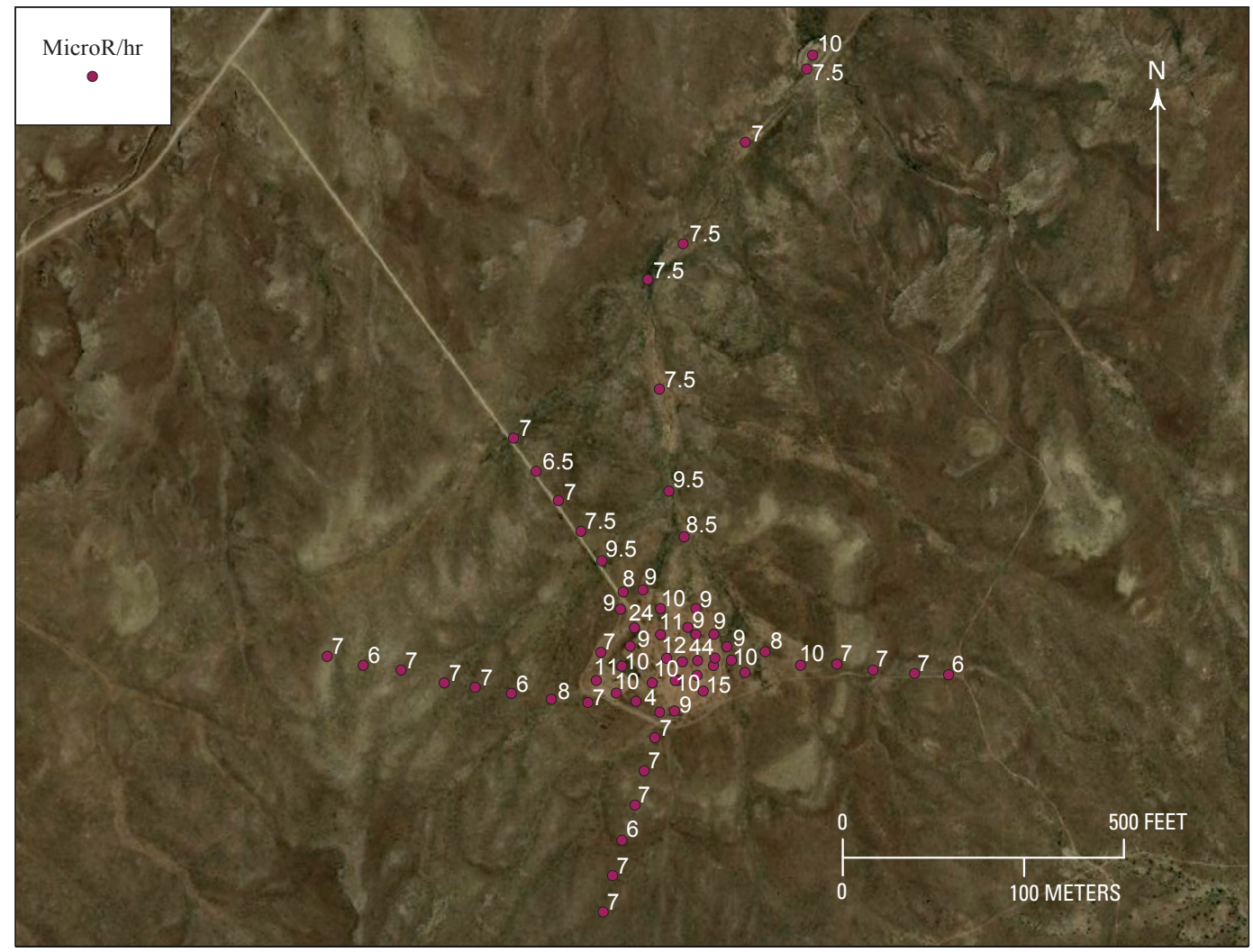

Figure 21. Radioactivity measurements at Hermit Mine site.

A comparison of the uranium and arsenic data and the microR measurements with the mine plan map (fig. 19) shows a few elevated concentrations of uranium in soils and some higher microrad-per-hour measurements at the planned locations of ore and waste-rock piles. However, higher values for both (including the highest radioactivity measurement, $44 \mu \mathrm{R} / \mathrm{h}$ ) also were found on the east side. It cannot be determined if some ore or mine waste piles were located on the east side or if some radioactive material was redistributed to that side during mine operations or reclamation.

\section{Hack Mines}

Four breccia pipes were mined along Hack Canyon near the intersections of Robinson Canyon and Hack Canyon (Hack 2 and 3, fig. 22), and a small unnamed tributary canyon and Hack Canyon (Hack Canyon and Hack 1, fig. 22). The Hack Canyon Mine was discovered in the early 1900 s and mined intermittently for copper and silver until about 1945. From 1950 to 1954 and in 1964 about 5,000 pounds of $\mathrm{U}_{3} \mathrm{O}_{8}$ were produced (Chenoweth, 1988). In the middle 1970s, the Hack 1 pipe was found near the 


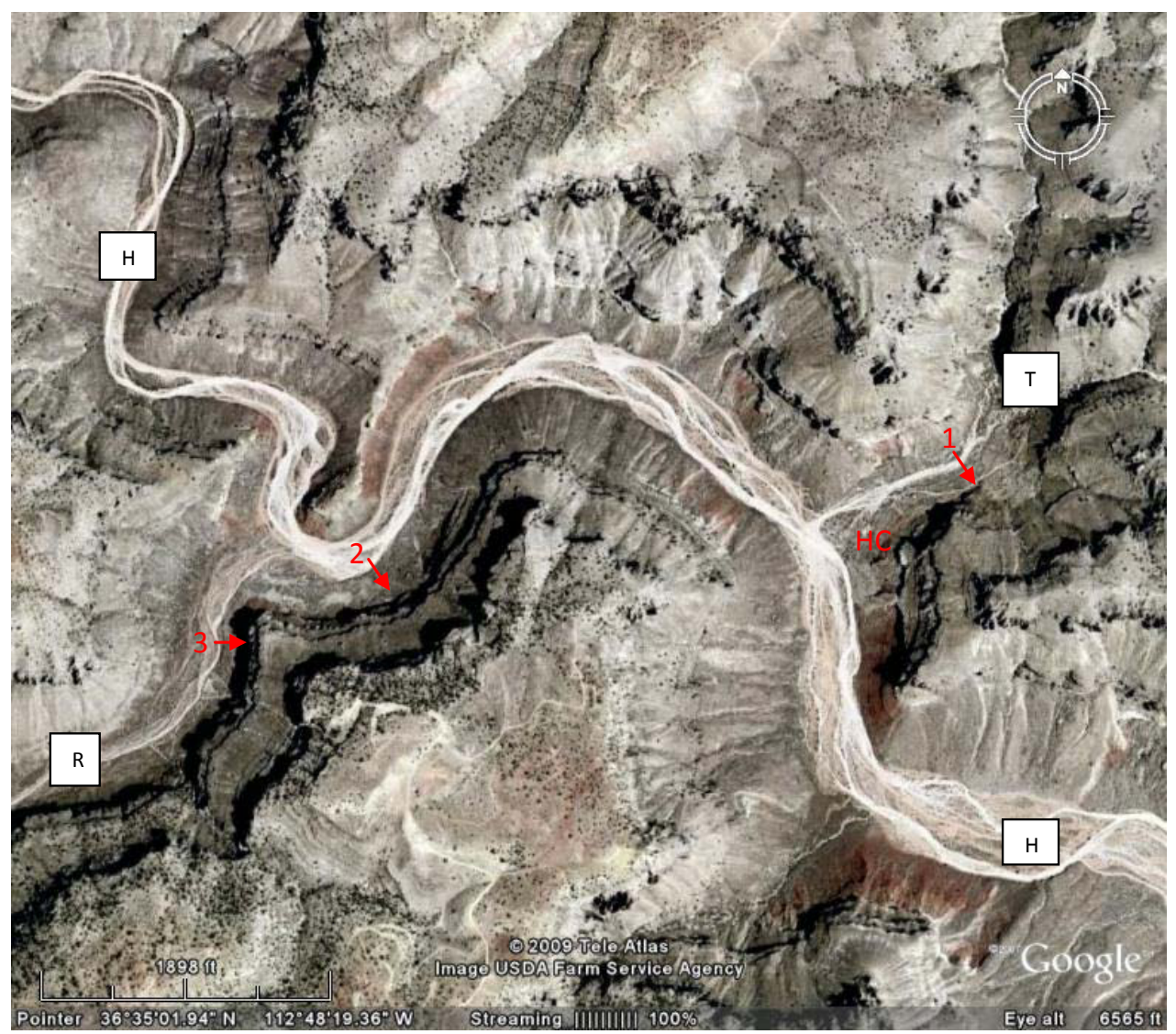

Figure 22. Features near Hack Canyon. H, Hack Canyon; R, Robinson Canyon; T, unnamed tributary canyon. Hack 1 (arrow 1), Hack Canyon (HC), Hack 2 (arrow 2), and Hack 3 (arrow 3) Mines; location of mines approximate.

original mine; mining began in 1981 and ceased in 1987. In the late 1970s the Hack 2 was opened on the opposite side of and farther upstream in Hack Canyon. Mining started in 1981 and ceased in May 1987. Hack 3 was discovered adjacent to Hack 2; development started about 1982 and mining ceased in June 1987. Reclamation of all three Hack Mines plus the older Hack Canyon Mine site was planned and completed from March 1987 to April 1988. On August 19, 1984, a flash flood in the tributary drainage where the Hack 1 Mine was operating (location T, fig. 22) eroded ore and mined waste-rock piles and washed these materials downstream. Energy Fuels Nuclear, Inc., recovered radioactive rock from the stream bed as far downstream as the wilderness boundary fence, which was then about $1 \mathrm{mi}$ down the wash (Roger Smith, formerly with Energy Fuels Nuclear, Inc., oral commun., 2009).

During mining of the three pipes, 9.5 million pounds of $\mathrm{U}_{3} \mathrm{O}_{8}$ were produced from 742,200 tons of ore (fig. 4) (Pool and Ross, 2007). The average grade ranged from 0.50 to 0.70 percent $\mathrm{U}_{3} \mathrm{O}_{8}$. The period of time during which uranium ore and waste-rock piles were at the surface can be estimated at about 6 or 7 years (about 1981 to about December 1987 , Energy Fuels Nuclear, Inc., undated). For the Hack Mines reclamation, alluvium from a gravel pit adjacent to the Hack 2 and 3 Mines was used to cover the recontoured ore and wasterock pile areas (Energy Fuels Nuclear, Inc., undated).
The USGS conducted the following studies at Hack Mine sites:

- Stream sediment sampling at 10 sites along Hack Canyon, Robinson Canyon, and unnamed Hack 1 tributary canyon down to the current wilderness boundary fence;

- Rock sampling and photodocumentation of selected ore or waste-rock fragments in the channel and on the flood plain; and

- MicroR measurements at each of the sample sites listed above and other sites.

Stream sediment samples were taken from four sites above the mining operations: one upstream from the Hack 2 and 3 Mines along Hack Canyon (table 8, sample GC09HKSS01); one upstream from the same mines along Robinson Canyon (table 8, sample GC09HKSS02); and two samples upstream from the Hack 1 and old Hack Canyon Mines on an unnamed tributary canyon to Hack Canyon (table 8, sample GC09HKSS04 and SS05). Six stream sediment samples were taken along Hack Canyon: one between the Hack 2 and 3 Mines and the tributary canyon where Hack 1 Mine was located (table 8, sample GC09HKSS03), and five downstream from all mining operations (table 8, sample GC09HKSS06-SS10). 
During sampling in Hack Canyon, the field party noticed mineralized rock along the wash bottom. Two locations were documented below the Hack 2 and 3 Mines, and multiple sites extended below the Hack 1 Mine tributary canyon for a few hundred feet down valley from the SS07 stream-sediment sample location. Five mineralized rock samples were collected and submitted for analysis (table 8, samples GC09HKRK01-05). The radioactivity of some additional mineralized rock was measured with the microR meter and their locations were determined using a GPS unit.

All stream sediment samples, including those collected upstream of Hack 2 and 3 (samples GC09HKSS01-02) and upstream of Hack 1 (samples GC09HKSS04-05) have high concentrations of trace elements relative to the average Jumpup Canyon concentrations. The relatively high concentrations are apparent for uranium (2.1-10.2 ppm, Jumpup average 1.7 ppm); arsenic (9-17 ppm; Jumpup average $4.6 \mathrm{ppm}$ ), and molybdenum (1.1-1.9 ppm, Jumpup average $0.78 \mathrm{ppm}$ ). However, other elements are present in concentrations that are at or only slightly above background values: cadmium (0.3-0.5 ppm; Jumpup average $0.3 \mathrm{ppm})$; cobalt (3.2-6.7 ppm, Jumpup average 4.2 ppm); copper (9.5-37.5 ppm; Jumpup average $12.9 \mathrm{ppm})$; antimony (0.29-0.5 ppm; Jumpup average $0.47 \mathrm{ppm}$ ); lead (8.9-22.9 ppm; Jumpup average 12.4 ppm); nickel (7.9-15.9 ppm, Jumpup average 10.3 ppm); thallium (0.3-0.4 ppm; Jumpup average $0.31 \mathrm{ppm})$; vanadium (19-37 ppm; Jumpup average 29 ppm); and zinc (32-53 ppm; Jumpup average $42 \mathrm{ppm}$ ).

Uranium concentrations in stream sediments and mineralized rock are summarized in an aerial image of the Hack Canyon site (fig. 23). The four background stream sediment samples range in uranium concentration from 2.1 to $3.9 \mathrm{ppm}$. Concentrations in two samples below the confluence of the tributary canyon with Hack Canyon, which contain $6.5 \mathrm{ppm}$ and $10.2 \mathrm{ppm}$, are higher than these background concentrations. However, these concentrations drop to 4.8 and $3.2 \mathrm{ppm}$ farther downstream (fig. 23) and to $2.4 \mathrm{ppm}$ farther yet downstream near Willow Spring (east of the area of fig. 23). A similar pattern in all trace element concentrations in stream sediment samples is apparent. Figure 24 shows the ratio of stream sediment trace element concentrations to background concentrations as compared with stream channel distance below the Hack 1 Mine location. Sample site SS07, at the lower end of an eroded waste-rock terrace (see following discussion), consistently contained concentrations of trace elements that are higher than concentrations at upstream site SS06. At sample site SS09, most trace elements have dropped to background concentrations or below (a ratio of 1 or less). At sample site SS10, only molybdenum is slightly

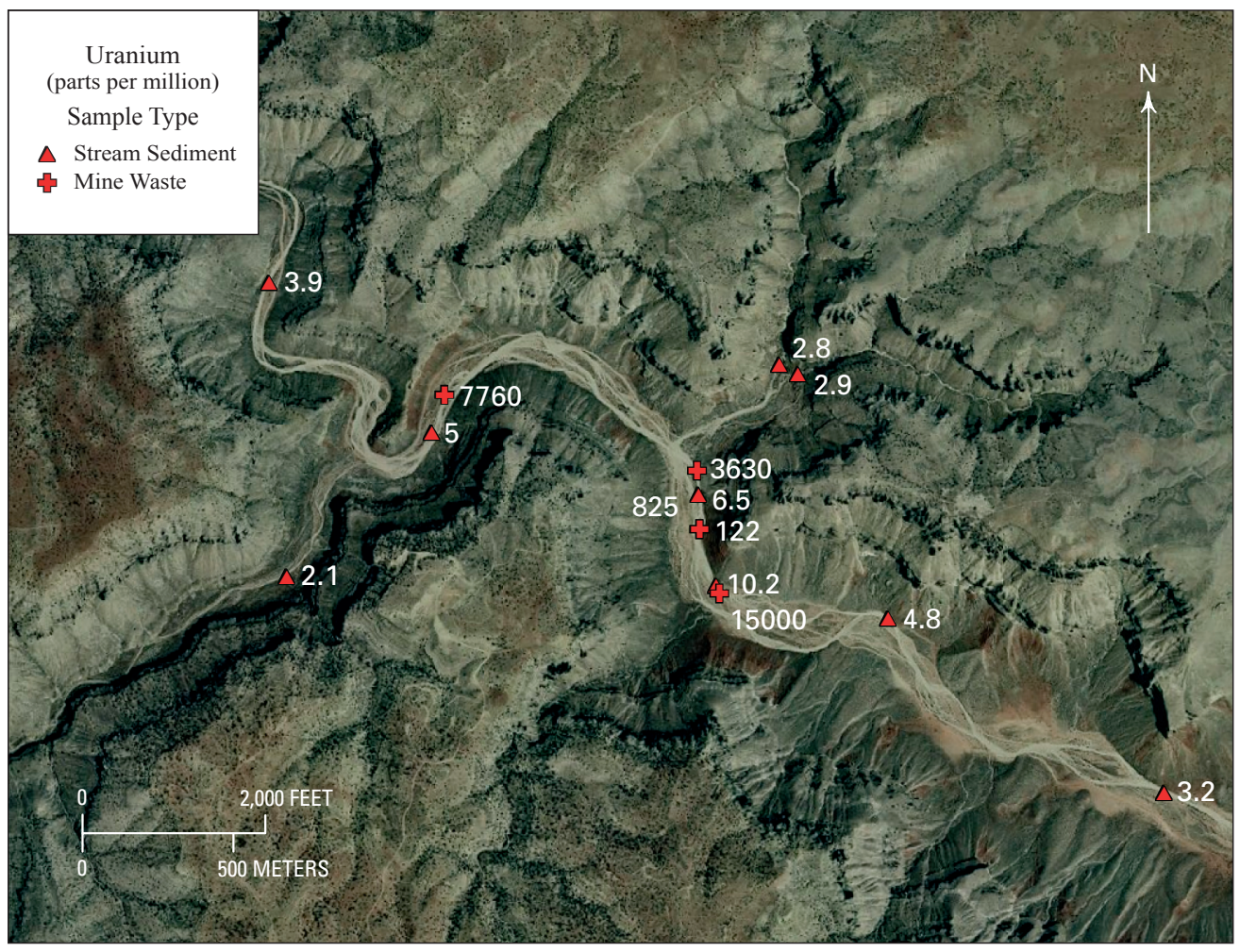

Figure 23. Uranium concentrations in stream sediment and in ore and waste-rock samples. One mine-waste sample (825 ppm uranium) and one stream-sediment sample (6.5 ppm uranium) are from same site. Site for sample GC09HKSS10 (2.4 ppm uranium) lies east of photograph boundary. One mine-waste sample exceeded the 10,000 ppm upper detection limit for the analytical method, and the concentration given here $(15,000 \mathrm{ppm}$ uranium $)$ is an estimate. 


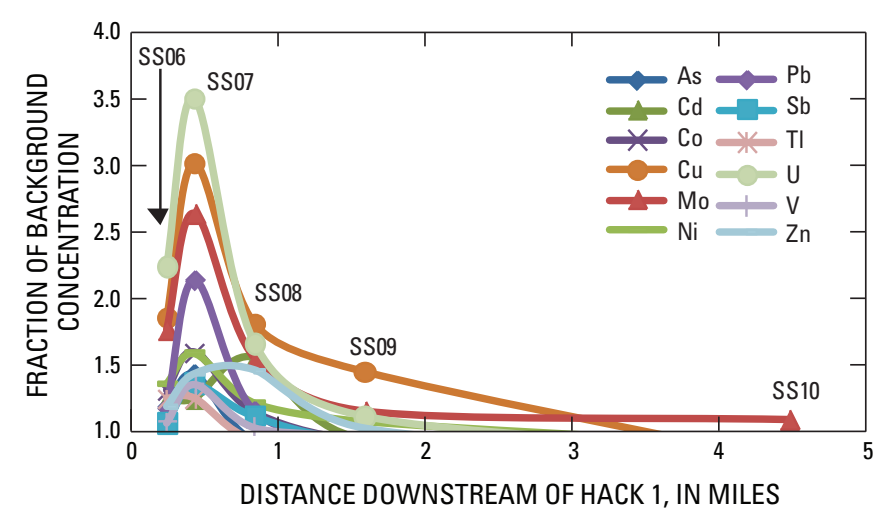

Figure 24. Ratio of concentrations of Arsenic (As), Cadmium (Cd), Cobalt (Co), Copper (Cu), Molybdenum (Mo), Nickel (Ni), Lead (Pb), Antimony (Sb), Thallium (TI), Uranium (U), Vanadium (V), and Zinc $(Z n)$ in stream sediments to their concentrations in background stream sediments as a function of distance downstream from the Hack 1 Mine. Background data are the average of the trace element concentrations in four samples upstream from mining operations. SS06 to SS10, samples GCO9HKSS06-10 (see table 8).

above background concentration. The results of the stream sediment geochemistry in this study are consistent with those of Carver (1999).

Scattered fragments of ore or waste rock, generally 2 to 18 in. in diameter, are found on the wash bottom. MicroR measurements for these samples were quite variable and ranged from 18 to $900 \mu \mathrm{R} / \mathrm{h}$. The mineralized rock samples collected from the wash contained $122 \mathrm{ppm}$ to $>10,000 \mathrm{ppm}$ uranium (the upper detection limit for the analytical method, shown as $15,000 \mathrm{ppm}$ in fig. 23) and are similarly high in several associated trace elements (table 8, samples GC09HKRK01-05). The appearance of these fragments is varied, but commonly they are yellowish orange, dark gray, greenish gray, or reddish brown (fig. 25A-H). The uranium-mineralized rock fragments along the floor of Hack Canyon may be derived from the flood of August 19, 1984, from undocumented floods before or after 1984 during the period of mining, or from one or more postreclamation floods that eroded the edge of the terrace adjacent to the channel.

Adjacent to the stream channel just downstream of the reclaimed Hack 1 Mine and upstream of sample GC09HKSS08 is a terrace which has been eroded by floods, revealing a cross section of uranium-mine waste rock covered by gravel. Figure $26 A$ shows the location of this terrace. Figure $26 B$ shows mining operations on this terrace in June 1985. During reclamation, waste rock from mine operations was spread on the terrace surface, contoured, and then covered with gravel. Four to $10 \mathrm{ft}$ of buried uranium mineralized waste rock and 2 to $3 \mathrm{ft}$ of cover material are now exposed where the edge of the terrace has been eroded by flow down the channel. The microR measurements for the lower, northern length of this terrace range from 200 to $1,900 \mu R / h$; radioactivity decreases along the higher, southern length
$(20-100 \mu \mathrm{R} / \mathrm{h})$. Images of this eroded terrace edge are shown in figure 27. Waste-rock sample GC09HKRK02 (table 8) was collected from the terrace wall. A few large rocks from this terrace edge have been eroded into the channel (fig. 28). In the stream reach from downstream of the reclaimed Hack 1 Mine to just downstream of the old wilderness boundary fence at sample site GC09HKSS07, microR measurements at stream sediment sites ranged from 7 to $9 \mu \mathrm{R} / \mathrm{h}$. At sample location GC09HKSS08, microR readings were at background (4-5 $\mu \mathrm{R} / \mathrm{h}$ ), which correlates well with background uranium concentrations measured in the stream sediments. MicroR measurements at sites along Jumpup Canyon are in the same range, although the average uranium concentrations in the Jumpup Canyon stream sediments are smaller (average $1.9 \mathrm{ppm})$.

\section{Leaching of Waste Samples}

During and after mining operations, ore and uraniferous waste rock are exposed to surface conditions that include episodic wetting events. Wetting is of concern because of the potential dissolution and transport of environmentally sensitive trace elements. Ore and waste rock can be wetted (1) while exposed on the ground surface at mine sites during active operations and standby conditions, (2) while buried in alluvial soils along a drainage where they were covered by clean fill during reclamation, (3) while buried in alluvium after floods have washed them downstream, and (4) in underground mine openings when used as backfill. As part of the USGS investigation of possible effects of mining, samples of ore and waste rock were leached by simulated rainfall for materials left at the surface and by more carbonate-rich solutions that might form as water percolates downward through unsaturated zones towards the saturated zone in stream beds or in backfilled underground mine workings.

Waste materials found at active or standby mine sites differ from site to site but can include (fig. 29) lower grade uranium ore or mineralized waste rock stored in piles or left on the surface of the mine site during storage, transport, site grading, or similar processes (location O, fig. 29); particles displaced from ore or waste rock that were physically transported by gravity, wind or water (location P); particles that were formed by mechanical weathering of rock fragments on surfaces and enriched in trace elements (location M); surface sediments ponded in low places and enriched by trace elements in salts derived from dissolution of nearby ore or waste (location C); and leached trace elements sequestered in the unsaturated zone (location V). In this area, groundwater is not generally a receptor for dispersed trace elements, except where shallow, perched water may be present. Wind disperses dust offsite. The origin and character of these waste sources is important for understanding the potential for future dispersion, bioavailability, and mobility of uranium and other trace element contaminants of concern. 

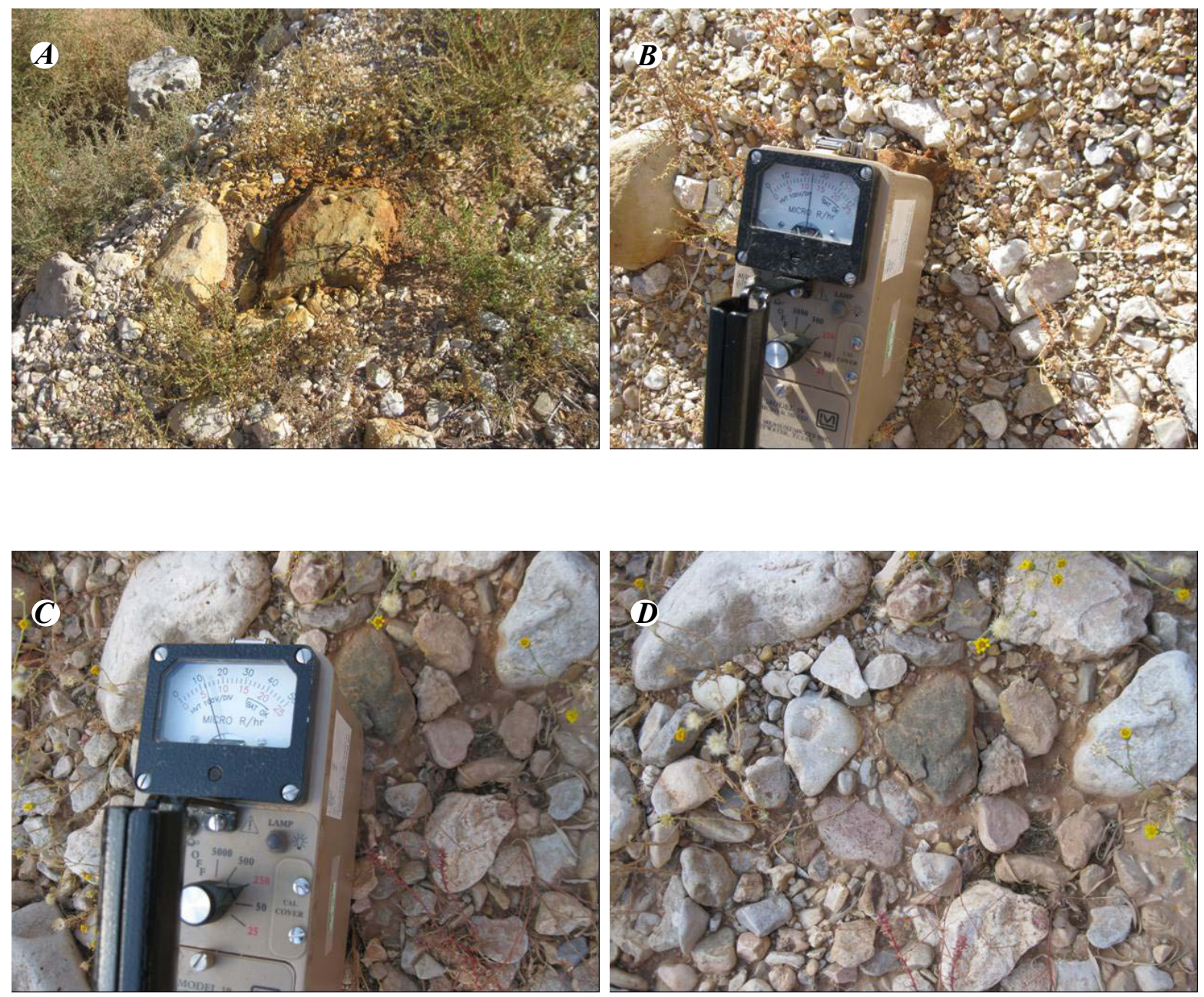

Figure 25. Ore and waste rock on the wash bottom of Hack Canyon. $A$, Sample GC09HKRK03 (weathered, 18 in. across); radioactivity measurement, $900 \mu \mathrm{R} / \mathrm{h}$. $B$, Sample GC09HKRK04 (weathered, 5 in. diameter); radioactivity measurement, $125 \mu \mathrm{R} / \mathrm{h}$. Sites of samples GC09HKRK03 and GC09HKRK04 are within $5 \mathrm{ft}$ of each other. $C, D$, Waste rock and ore between GC09HKSS06 and GC09HKSS07 (microR meter for scale; radioactivity measurement on less weathered rock, $60 \mu \mathrm{R} / \mathrm{h})$.

Because these sites are located in an arid region, the mobilization of contaminants from sources at the mine sites is largely limited to (1) physical dispersion of fines by wind, (2) low-intensity rainfall that locally could mobilize dissolved species by dissolution or desorption processes, and (3) highintensity rainfall that could promote infiltration of dissolved species into the unsaturated zone or cause physical and chemical transport through sheet flow and channel erosion during flooding. In the event of physical dispersion or transport of solids (dust, waste rock, or uranium ore) to a surface water body such as a stream channel with perennial flow (for example, the lower part of Kanab Creek), dissolution of uranium is expected to increase through interaction with bicarbonate dissolved in water (Langmuir, 1978). The study reported here study investigated the potential for lowand high-intensity rainfall to mobilize uranium and other trace element contaminants by leaching representative waste sources present at the Hack, Pigeon, and Kanab North Mines. Background samples from Kanab South and Jumpup Canyon were also leached for comparison. Table 10 describes the whole-rock composition of these samples with respect to the crustal abundance of trace elements of concern that are typically associated with uranium breccia pipes in Arizona.

The whole-rock composition of the samples selected for leaching $(\mathrm{n}=11$; table 10$)$ are generally above crustal abundances for uranium and a number of other elements of environmental concern such as arsenic, barium, cadmium, cobalt, copper, molybdenum, nickel, lead, antimony, thallium, uranium, and zinc (table 10, highlighted in red). However, during leaching with simulated rainwater and groundwater or surface water, not all of these elements are leached into solution. Generally, in these samples synthetic rainwater extracted substantial amounts of uranium, arsenic, and molybdenum, and 

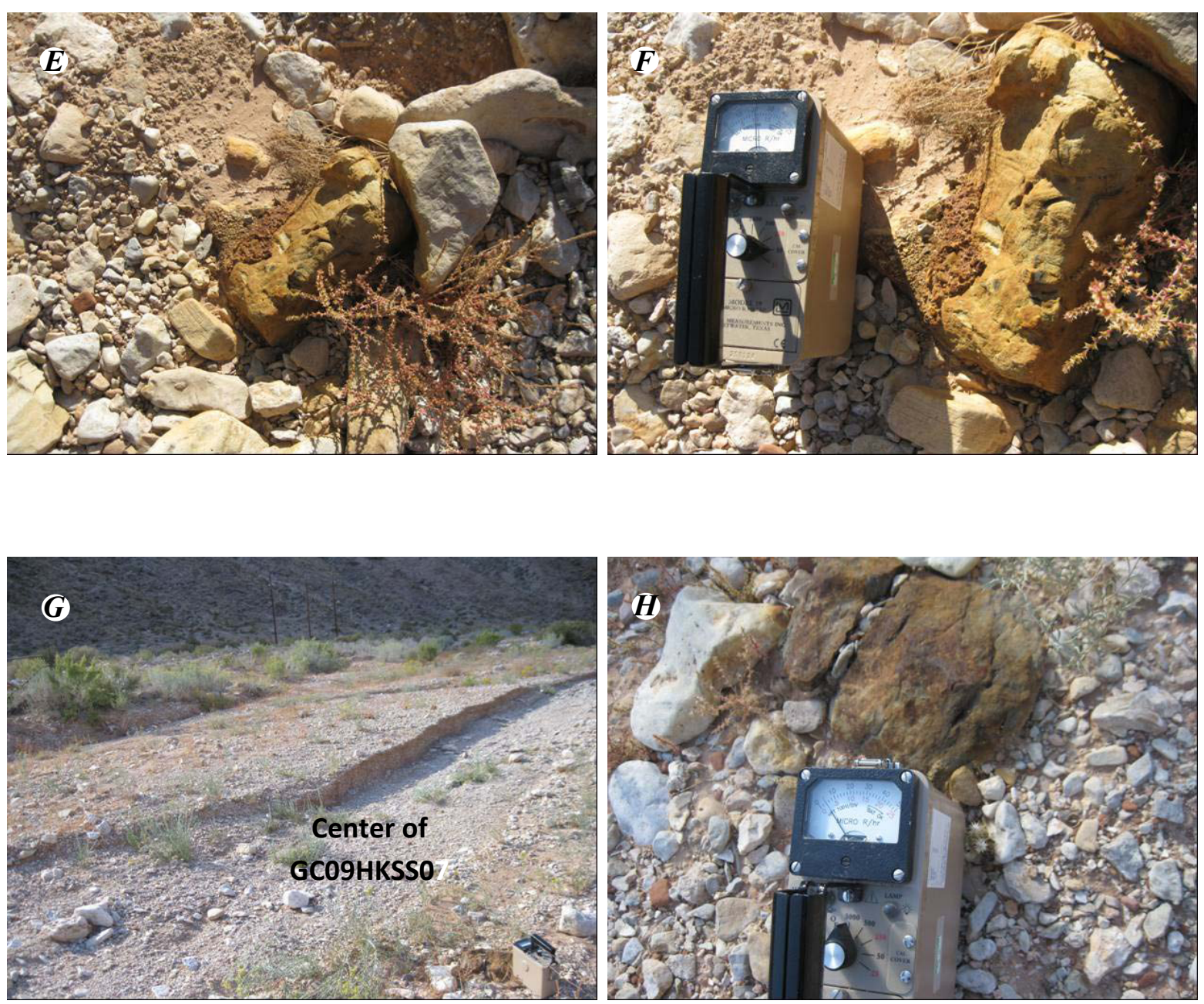

Figure 25-Continued. Ore and waste rock on the wash bottom of Hack Canyon. $E$, $F$, Weathered waste rock and ore between GC09HKSS06 and GC09HKSS07 (microR meter for scale; radioactivity measurement, $25 \mu \mathrm{R} / \mathrm{h}$ ). $G$, Waste rock and ore in overbank area (to lower right) adjacent to locality of GC09HKSS07 stream-sediment sample. $H$, Closeup of waste rock and ore (microR meter for scale; radioactivity measurement, $400 \mu \mathrm{R} / \mathrm{h}$ ).

concentrations increased as the duration of leaching increased (see following sections). Likewise, the addition of bicarbonate to the leaching solution also increased the concentrations of uranium in solution owing to the formation of uranylcarbonate aqueous complexes, which promote the dissolution of uranium minerals (Langmuir, 1978). As extracted uranium concentrations increase, more arsenic and molybdenum are also released. These relationships, as well as site-specific elements, are briefly discussed below.

\section{Pigeon Mine Samples}

At the Pigeon reclaimed mine site and mine operations area, several samples enriched in uranium were identified $(n<10)$ by anomalously high microR measurements. The representative samples collected and selected for leaching (table 10) included weathered uranium ore from the operations area (600 $\mu \mathrm{R} / \mathrm{h}$, sample GC09PW-03), and soil samples enriched in uranium possibly by the addition of salts derived from waste (150 $\mu \mathrm{R} / \mathrm{h}$, sample GC09PW-02) or from fine-grained sediments derived from waste (sample GC09PS-88) at the reclaimed mine site. These samples were leached for $1 \mathrm{~h}$ and for $24 \mathrm{~h}$ with synthetic rainwater. Leaching results for the Pigeon Mine samples are summarized in table 11 .

During the first hour of leaching with the synthetic rainwater, solutions contained $18.2-489 \mathrm{ppb}$ arsenic, $60-401 \mathrm{ppb}$ uranium, and 2.5-106 ppb molybdenum. Leachate from sample GC09PW-02 (which contains readily leachable salts) contained the highest concentrations of all three elements. The weathered ore sample (GC09PW-03) leached higher concentrations of copper (3,870 ppb), manganese (108 ppb), nickel (96 ppb), and zinc $(1,220 \mathrm{ppb})$. After a $24-\mathrm{h}$ leaching period in simulated rainwater, concentrations in solution were higher: $29.7-799 \mathrm{ppb}$ 

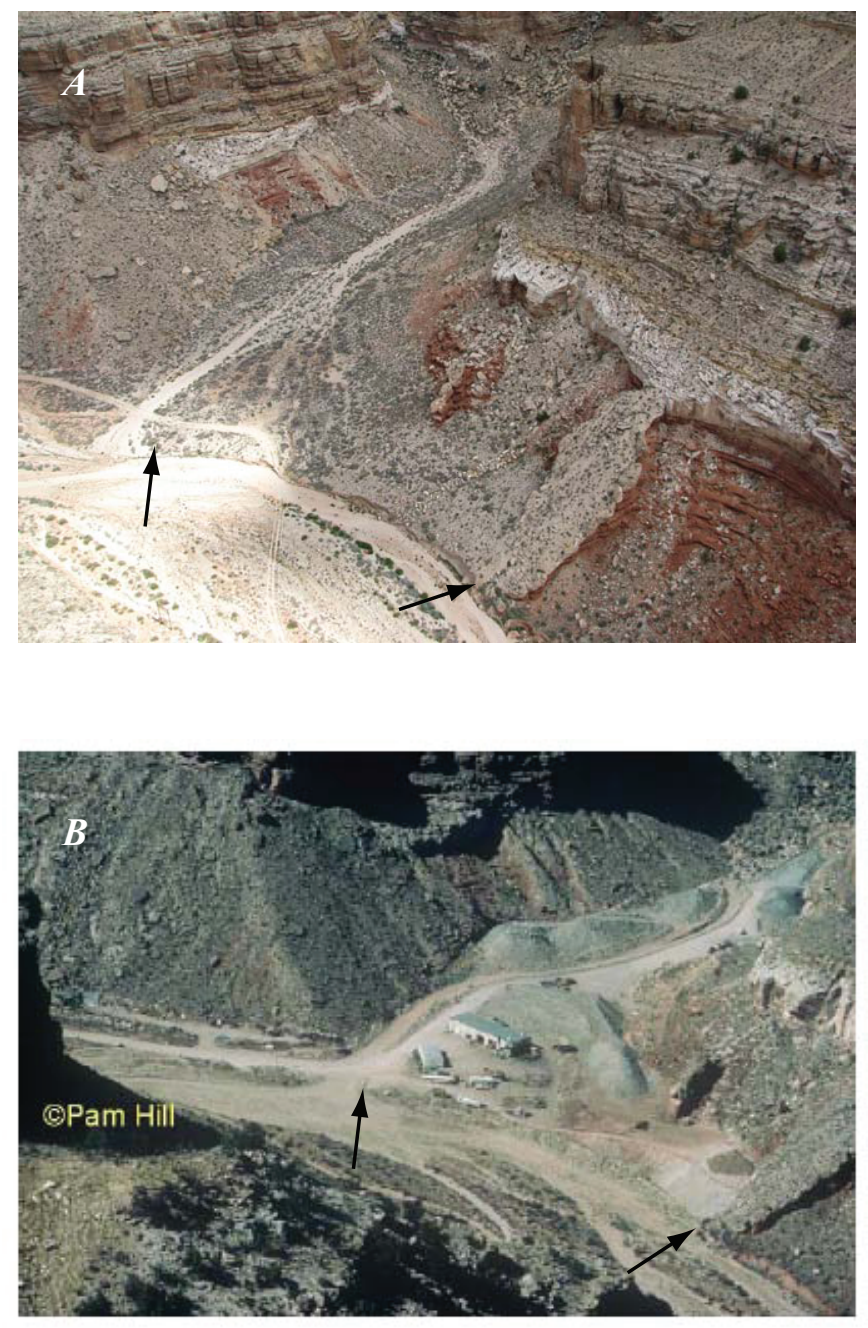

Figure 26. A, Tributary canyon and Hack Canyon bottom showing location of waste-rock terrace (upper and lower extent of terrace marked by arrows). Upstream part of terrace is substantially lower than downstream part. (Photograph courtesy of Don Bills, U.S. Geological Survey, Flagstaff, Arizona. Taken August 25, 2009.) $B$, Tributary canyon and Hack Canyon during mining operations (upper and lower extent of terrace marked by arrows). (Photograph courtesy of Pam Hill, American Clean Energy Resources Trust. Taken June 1985.)

arsenic, 171-1,270 ppb uranium, and 9.3 to 503 ppb molybdenum. Once again, leachate from sample GC09PW-02 contained the highest concentrations of uranium, arsenic, and molybdenum. This result suggests that sample GC09PW-02 is a contaminated soil that contains redistributed secondary salt or a sorbed phase and thus has the most readily leachable uranium, arsenic, and molybdenum. Uranium leached from the weathered ore sample (GC09PW-03) increased substantially to $1,020 \mathrm{ppb}$, and the sample yielded additional trace-element constituents such as $16.3 \mathrm{ppb}$ cadmium, 3,270 ppb copper, and $186 \mathrm{ppb}$ manganese, $182 \mathrm{ppb}$ nickel, in addition to $1,600 \mathrm{ppm}$ sulfate.

\section{Kanab North Mine Samples}

Because the Kanab North site is partially mined and not yet reclaimed, the mine site contained the most obvious sources of uranium waste material, weathered ore fragments, and ponded sediment. Sample leach data reported here include samples from a low-grade ore stock pile (sample GC09KNW-13), surface ponded sediment enriched in uranium (sample GC09KNW-12), weathered ore and waste rock from a large waste-rock pile (sample GC09KNW-01), sludge from the wastewater pond (sample GC09KNW-08), and physically transported waste (sample GC09KNW-10). These samples were leached for $1 \mathrm{~h}$ and for $24 \mathrm{~h}$ with simulated rainwater. Leaching results for Kanab North samples are summarized in table 12 .

During the 1-h leaching with simulated rainwater, more uranium was released from the pond sludge (sample GC09KNW-08) than from the weathered uranium ore (sample GC09KNW-13) - 19,600 ppb as compared with $924 \mathrm{ppb}$ uranium in solution. The pond sludge also yielded $8,820 \mathrm{ppb}$ molybdenum, 4,930 ppb strontium and 2,720 ppm sulfate. These concentrations suggest that the pond sludge contains readily leachable phases that may be mobilized during short rain events. Because the pond is lined, infiltration of dissolved uranium into the unsaturated zone is limited; however, rainwater in the pond may contain very high trace-element concentrations until evaporation to dryness causes them to precipitate into the sludge again. After a $24-\mathrm{h}$ leaching period, uranium in the leachate increased substantially in the remainder of the samples: GC09KNW-13 (21,200 ppb uranium and $347 \mathrm{ppb}$ molybdenum), GC09KNW-12 (487 ppb uranium and 998 ppb molybdenum), GC09KNW-01 (301 ppb uranium and 695 ppb molybdenum), GC09KNW-08 (27,600 ppb uranium and 10,900 ppb molybdenum), and GC09KNW-10 (708 ppb uranium and $592 \mathrm{ppb}$ molybdenum). Unlike leaching of Pigeon Mine samples, leaching of Kanab North Mine waste samples produced very little arsenic (3.8-114 ppb) in solution.

\section{Hack Canyon Mines Samples}

Although a number of uranium-mineralized rock samples were found along Hack Canyon downstream from the Hack 1, 2 , and 3 reclaimed mine sites and from the buried waste rock exposed in the terrace just downstream from Hack 1, these specimens were collected after the leaching experiments so they were not included. A sample of Hack Ore (01-Hack Ore) previously collected and archived by the USGS was used in the leaching study as a representative analog to determine leachability of uranium and other trace elements from ore at this site. Whole-rock compositions of the archived analog sample (01-Hack Ore, analyzed by instrumental neutron activation analysis [INAA]) are compared with the fragments of waste rock and weathered ore collected from the Hack Canyon 

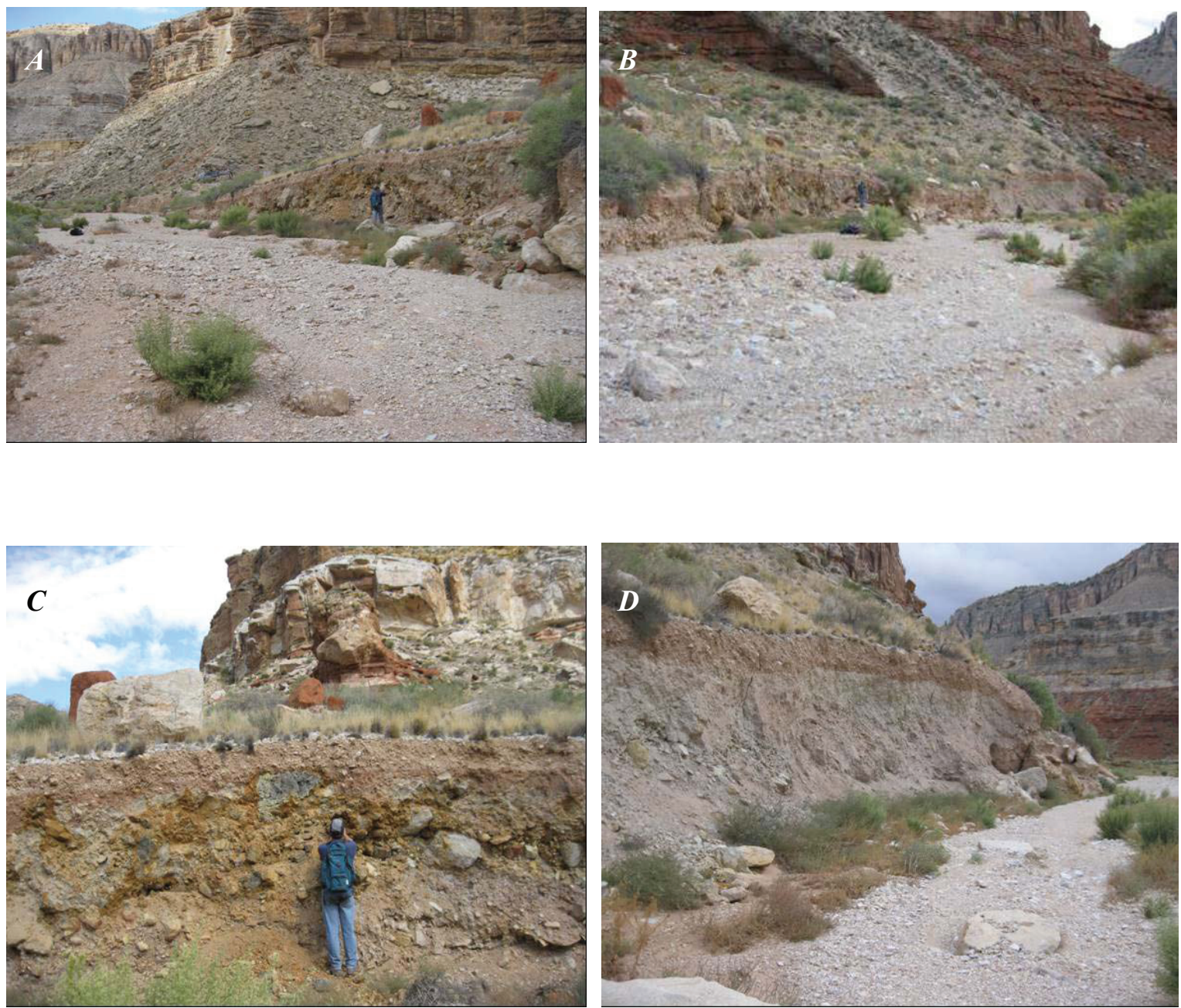

Figure 27. Terrace downstream of the former Hack 1 Mine (see also fig. 26) at confluence of tributary canyon and Hack Canyon. $A$, View upstream (north) along eroded low terrace edge. Person provides scale. $B$, View downstream (south) along low, eroded terrace edge toward higher terrace. $C$, Low part of terrace; view east toward reclaimed Hack 1 Mine at wall of terrace. Radioactivity measurements here, 200-1,900 $\mu \mathrm{R} / \mathrm{h}$. $D$, High downstream end of terrace. Radioactivity measurements here, $100-250 \mu \mathrm{R} / \mathrm{h}$.

Mine (sample GC09HKR01-05, not used in this leaching study, analyzed by ICP-MS and ICP-AES); results are shown in table 13a. Concentration of trace elements commonly associated with breccia pipe ores differ widely (table 13a).

Hack ore and waste rock could migrate in a flash flood to a saturated perennial stream environment. This scenario would involve high-intensity rain followed by burial in the stream bed below the water table. In order to simulate this situation, the Hack Ore sample was leached in synthetic rainwater for a 1-h period and a 24-h period followed by leaching in a solution containing $300 \mathrm{mg} / \mathrm{L}$ bicarbonate. Concentrations of bicarbonate in Colorado River water averaged $162 \mathrm{ppm}$ during the interval 1980 to 2009; its maximum concentration was $186 \mathrm{ppm}$. Data are available through the USGS National Water Information System at http://waterdata.usgs.gov/nwis/ $q w$. A factor of approximately two times this average value was used to account for any higher values that may be present in stream flow at various times and to estimate effects of shallow alluvial groundwater (which can have higher bicarbonate concentrations - at times greater than $300 \mathrm{mg} / \mathrm{L}$ ). Leaching results for the Hack waste-ore analog sample are summarized in table $13 \mathrm{~b}-\mathrm{d}$.

Figure 30 shows the concentration of trace elements as a function of leaching solution for the Hack Ore sample, first with simulated rainwater at various time intervals for the first $24 \mathrm{~h}$, then after $24 \mathrm{~h}$ equilibration with simulated river water. After the first hour (table 13b), trace element concentrations increase in solution for arsenic $(2,020 \mathrm{ppb})$, cadmium (6.9 ppb), cobalt (334 ppb), molybdenum (4,960 ppb), nickel (782 ppb), antimony (12.1 ppb) and uranium (590 ppb). After a 24-h equilibration period, the same elements substantially increased and appeared to be approaching a steady-state 

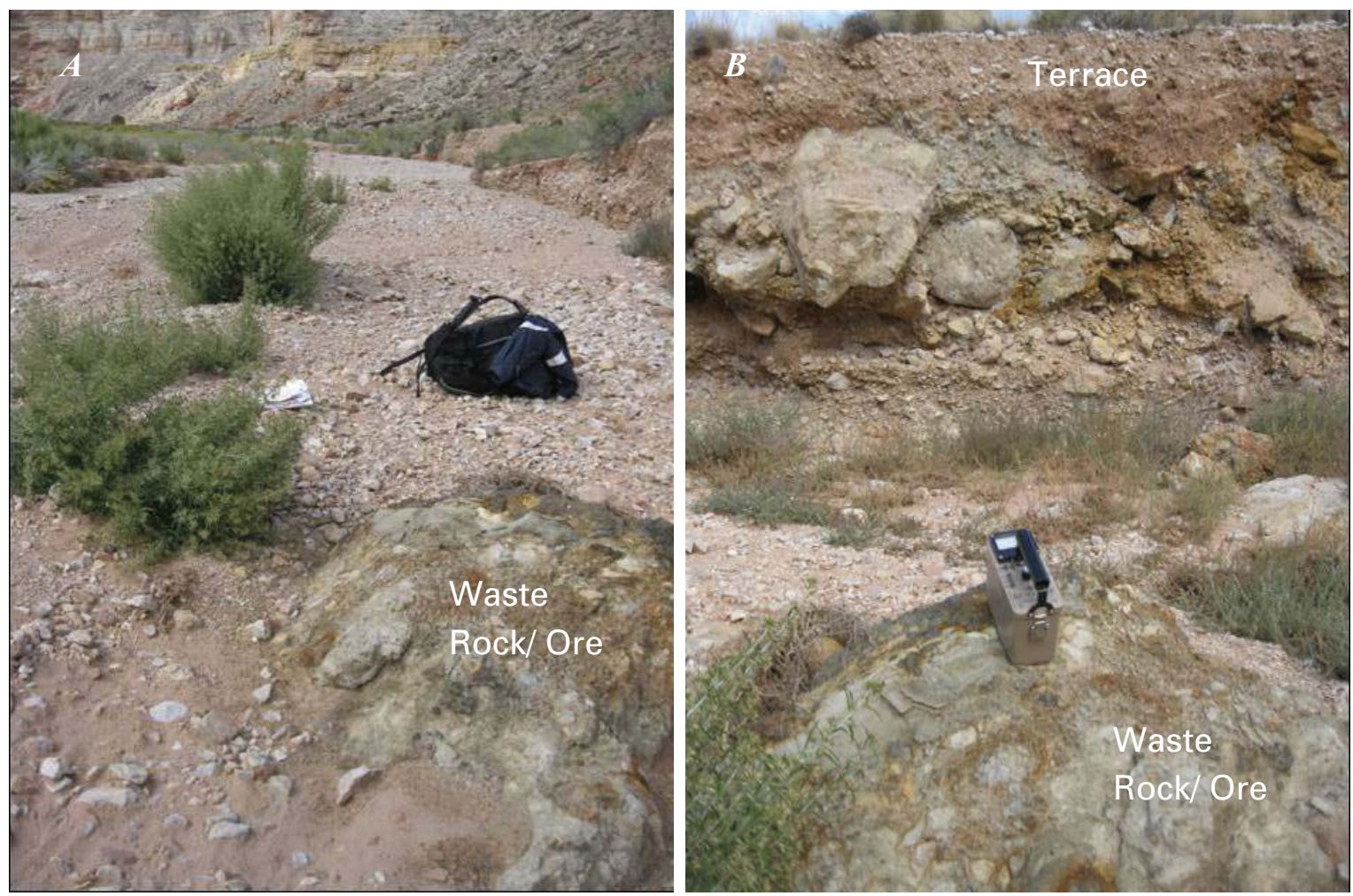

Figure 28. Large waste-rock boulder in streambed approximately $10 \mathrm{ft}$ west of low terrace. $A$, View upstream of terrace and waste-rock boulder. $B$, View east toward eroded terrace wall from waste-rock boulder in streambed (Hack 1 Mine site is beyond terrace). Terrace gravel cover is pale reddish-brown. Radioactivity measurement on waste-rock boulder, $300 \mu \mathrm{R} / \mathrm{h}$.

concentration in solution at $13,800 \mathrm{ppb}$ arsenic, $26.8 \mathrm{ppb}$ cadmium, 1,190 ppb cobalt, 17,400 ppb molybdenum, 3,480 ppb nickel, $75.7 \mathrm{ppb}$ antimony and 4,410 ppb uranium. A major rain event at Hack Canyon that leaches 1 metric ton $(1,000 \mathrm{~kg})$ of ore and waste rock at a liquid/solid weight ratio of 20:1 will produce 20,000 liters of metal-rich leachate solution. In the worst case, all this solution would enter the stream channel as runoff and seepage during the event. Compare this 20,000 liter volume with the 10,477 liters per second (L/s) average flow past the mine site during the 1984 flood in Hack Canyon (370 cubic feet per second (cfs) (Energy Fuels Nuclear, Inc., undated $) \times 28.316$ liters per cubic foot $\left(\mathrm{L} / \mathrm{ft}^{3}\right)$. Clearly, the total volume of floodwater available during the entire duration $\left(9.05 \times 10^{8}\right.$ liters in $\left.24 \mathrm{~h}\right)$ of a flood event allows for extreme dilution of mine-derived leachates of ore and waste rock to concentrations below $1 \mathrm{ppb}$ for all constituents.

After 24-h contact between the Hack Ore and the $300 \mathrm{mg} / \mathrm{L}$ bicarbonate solution (table 13d), dissolved concentrations increased further to $36,400 \mathrm{ppb}$ arsenic, $63,000 \mathrm{ppb}$ uranium, $34.7 \mathrm{ppb}$ cadmium, 1,890 ppb cobalt, 6,380 ppb nickel, $23,800 \mathrm{ppb}$ molybdenum, and $114 \mathrm{ppb}$ antimony. Even if such a solution generated by an assumed 1 metric ton of uranium ore and waste material buried in the stream bed did reach a surface water, such as the Colorado River with a flow rate of 10,780 cfs, then trace element concentrations in the flow would be below $1 \mathrm{ppb}$. (See summary data for USGS streamgage 09402500 on the Colorado River just northeast of Grand Canyon Village at http://waterwatch.usgs.gov/? $m=m v 01 d \& r=a z \& w=$ map.)

\section{Mobility of Contaminants}

The leaching experiments demonstrate that all samples appear to have a small component of uranium in readily water-soluble form. Percentages of uranium leached during 24-h contact with synthetic rainwater were as follows: unweathered ore ( $0.2-0.33$ percent), wind transported fines $(0.5-1.66$ percent), weathered ore and waste rock (0.89-2.76 percent), chemically redistributed uranium waste in some soils and pond sediments (0.57-17.06 percent), and background samples (0.16-0.19 percent). Readily soluble uranium is probably desorbed or derived from surface coatings of sparingly soluble secondary minerals (in weathered waste rocks and ore specimens). The liquid/solid weight ratio of 20:1 used in the batch-leaching experiments simulated water saturation within intergranular pore spaces and excess pore water draining from a saturated ore or waste-rock pile. A liquid/solid weight ratio of 20:1 does not simulate the additional dilution 


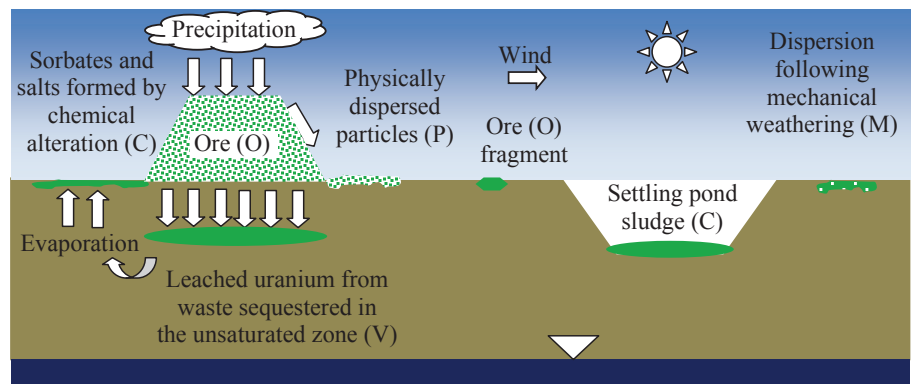

Figure 29. Processes expected to disperse trace elements contained in stored ore and mined waste rock at mine sites within study area. In this area, groundwater is generally not a receptor for dispersed trace elements from mine sites, except where shallow perched water is present.

Table 10. Elements in whole rock composition of samples selected for leaching compared with crustal abundance of those elements.

[Crustal abundance data from Smith and Logsdon (1999); red, concentration exceeds crustal abundance of element; ppm, parts per million; na, not analyzed]

\begin{tabular}{|c|c|c|c|c|c|c|c|c|c|}
\hline \multirow{2}{*}{ Sample } & \multicolumn{9}{|c|}{ Concentration (ppm) } \\
\hline & Arsenic & Barium & Cadmium & Cobalt & Chromium Co & Opper & Manganese & Molybdenum & Nickel \\
\hline 01-Hack Ore & 3,210 & 6,320 & & 205 & 33 & na & na & na & 1,600 \\
\hline GC09PW03 & 5,060 & 36 & 17.40 & 6 & 8 & 9,030 & 18 & 20.9 & 55 \\
\hline GC09PS88 & 455 & 125 & 2.90 & 112 & 38 & 136 & 501 & 77.1 & 285 \\
\hline GC09PW02 & 258 & 909 & 1.00 & 232 & 41 & 130 & 520 & 86.4 & 397 \\
\hline GC09KNW01 & 280 & 458 & 2.50 & 96 & 38 & 173 & 187 & 173.0 & 115 \\
\hline GC09KNW08 & 44 & 330 & 0.70 & 49 & 13 & 41 & 162 & 230.0 & 48 \\
\hline GC09KNW10 & 388 & 516 & 6.20 & 111 & 28 & 172 & 209 & 164.0 & 129 \\
\hline GC09KNW13 & 1,980 & 111 & 10.40 & 57 & 14 & 107 & 218 & 102.0 & 123 \\
\hline GC09KNW12 & 803 & 484 & 8.40 & 175 & 20 & 516 & 182 & 328.0 & 180 \\
\hline GC09KNS12 & 7 & 477 & 0.20 & 8 & 26 & 15 & 472 & 1.2 & 13 \\
\hline Sample & \multicolumn{9}{|c|}{ Hack } \\
\hline \multirow[t]{2}{*}{ 01-Hack Ore } & na & 9.2 & 713 & 2.5 & na & & 26,800 & na & 4,100 \\
\hline & \multicolumn{9}{|c|}{ Pigeon } \\
\hline GC09PW03 & 837 & 12.1 & 436 & 0.3 & 6.30 & & 1,870 & 21 & 3,400 \\
\hline GC09PS88 & 101 & 6.2 & 152 & 6.0 & 21.90 & & 206 & 51 & 624 \\
\hline GC09PW02 & 137 & 14.6 & 210 & 7.6 & 4.30 & & 616 & 64 & 215 \\
\hline \multirow[t]{2}{*}{ GC09PS08 } & 17 & 2.2 & 113 & 3.6 & 3.90 & & 11 & 31 & 254 \\
\hline & \multicolumn{9}{|c|}{ Kanab North } \\
\hline$\overline{\text { GC09KNW01 }}$ & 154 & 1.3 & 107 & 5.7 & 12.40 & & 679 & 66 & 458 \\
\hline GC09KNW08 & 32 & 0.7 & 250 & 3.4 & 1.80 & & 3,236 & 24 & 165 \\
\hline GC09KNW10 & 215 & 1.6 & 112 & 4.1 & 10.70 & & 2,840 & 47 & 1,350 \\
\hline
\end{tabular}


Table 11. Concentrations of uranium and other trace elements in 1- and 24-hour leachates of Pigeon Mine samples.

$[\mu \mathrm{g} / \mathrm{L}$, microgram per liter; $\mathrm{mg} / \mathrm{L}$, milligram per liter $]$

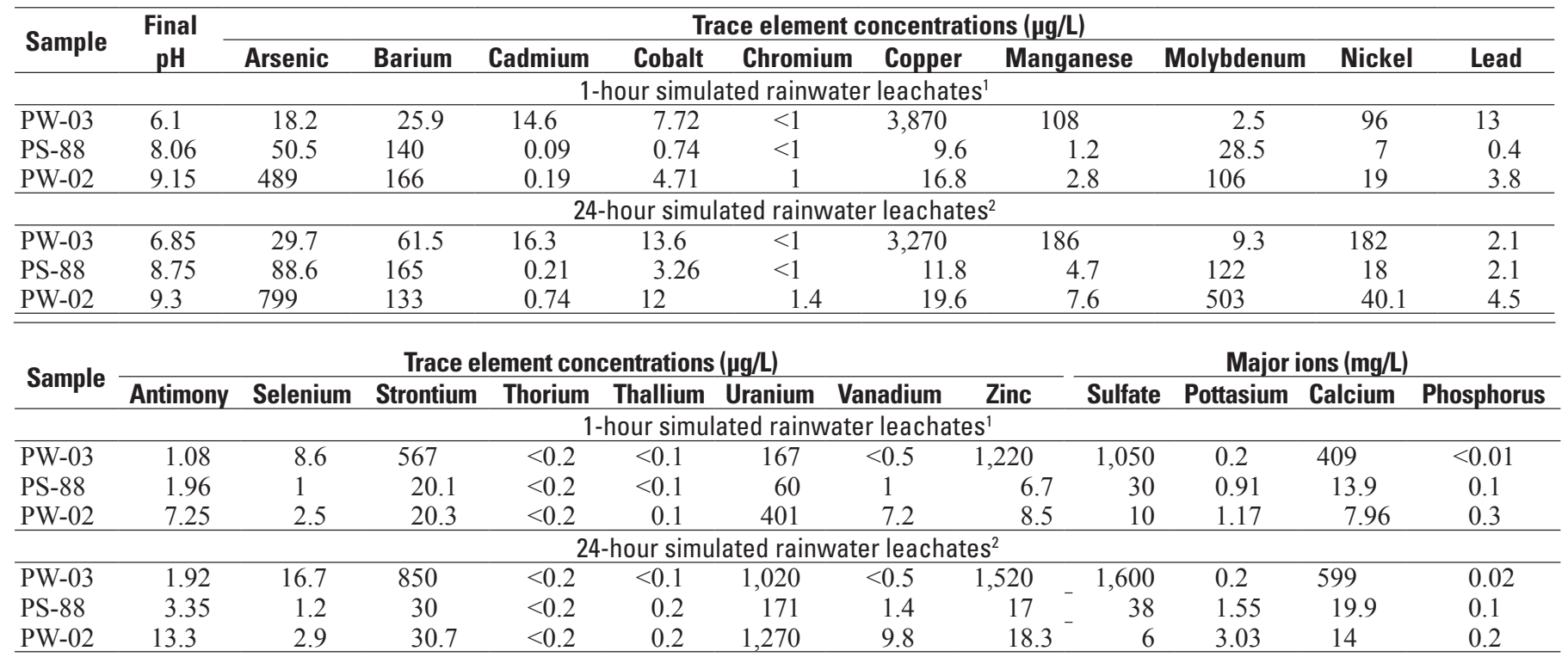

${ }^{1}$ Initial $\mathrm{pH}$ of two blank samples, 5.52 and 5.65 .

${ }^{2}$ Initial pH of two blank samples, 5.7 and 5.6.

Table 12. Concentrations of uranium and other trace elements in 1- and 24-hour simulated-rainwater leachates of Kanab North samples (see also table 8).

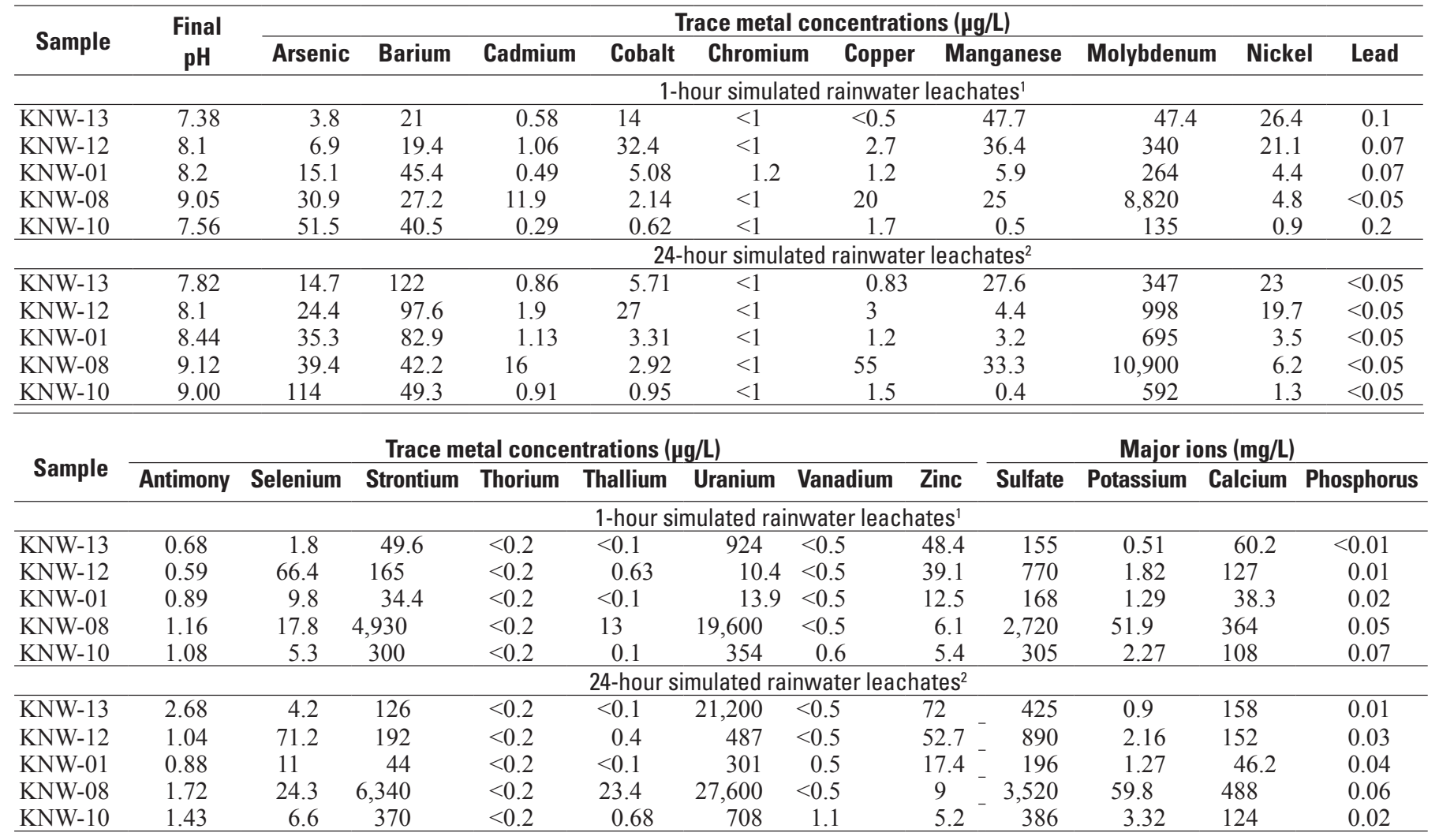

${ }^{1}$ Intial $\mathrm{pH}$ values for two blanks, 5.52 and 5.65.

${ }^{2}$ Initial pH values for two blanks, 5.7 and 5.6. 

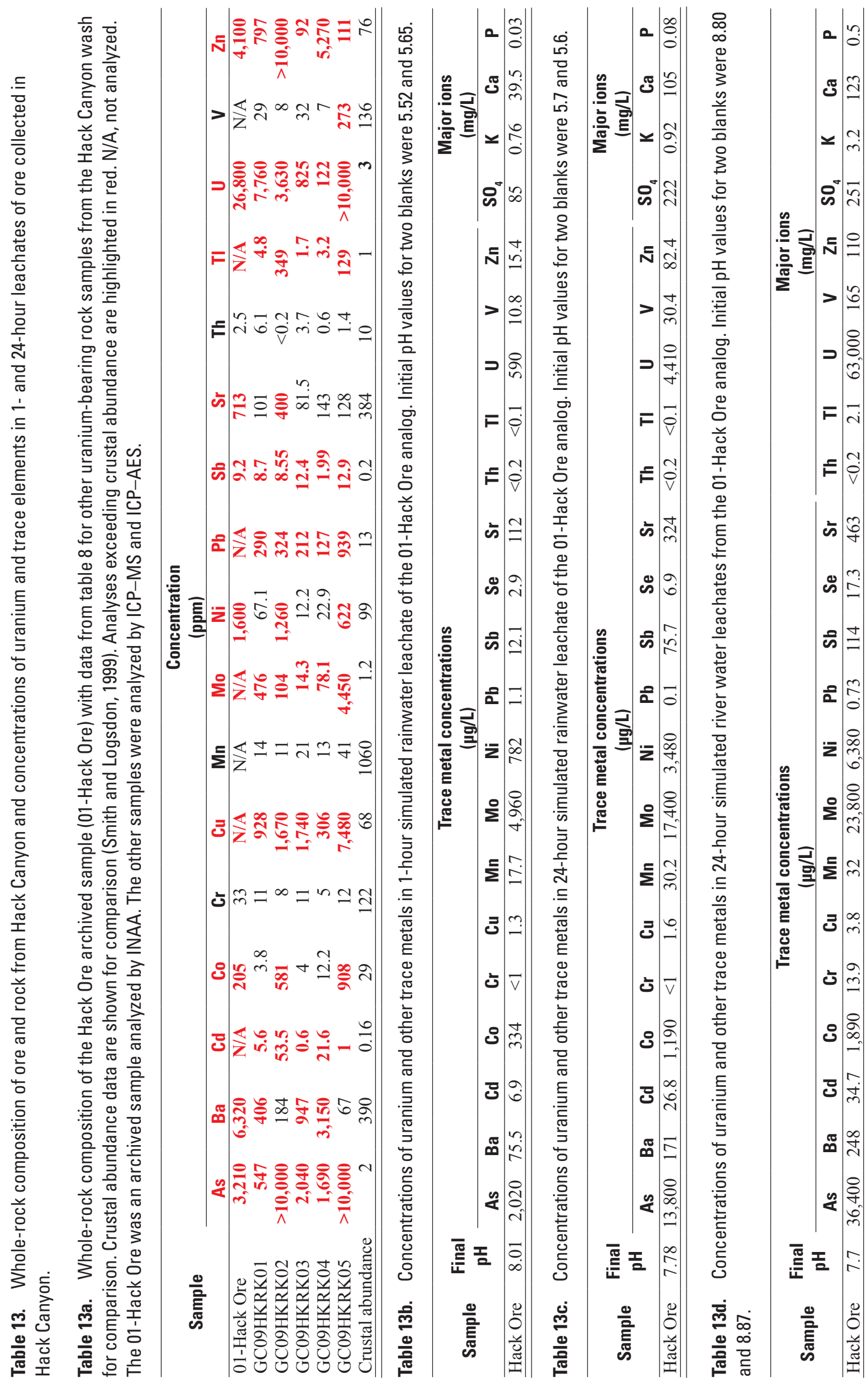

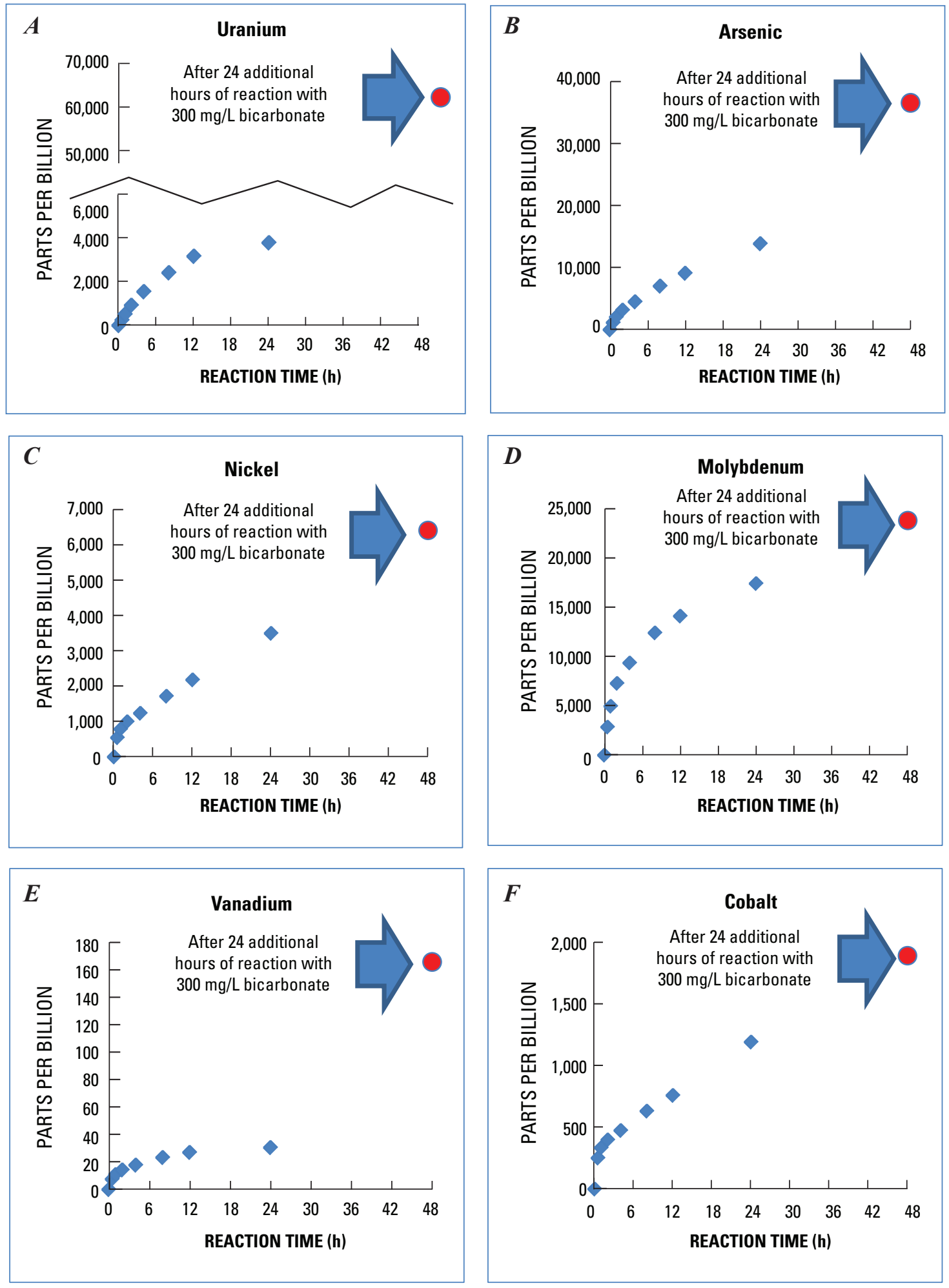

Figure 30. Concentration of seven elements in ore from Hack Mine leached into simulated rainwater during a 24-hour period (blue diamond) followed by equilibration in a $300 \mathrm{mg} / \mathrm{L}$ bicarbonate solution for 24 hours (large red dot). $A$, Uranium; $B$, Arsenic; $C$, Nickel; $D$, Molybdenum; $E$, Vanadium; $F$, Cobalt; $G$, Antimony. Leaching solutions were simulated rainwater (deionized water equilibrated with air, $\mathrm{pH}=5.6$ ) and simulated carbonateenriched river water (deionized water containing $300 \mathrm{mg} / \mathrm{L}$ dissolved sodium bicarbonate, $\mathrm{pH}=8.3$ ). 


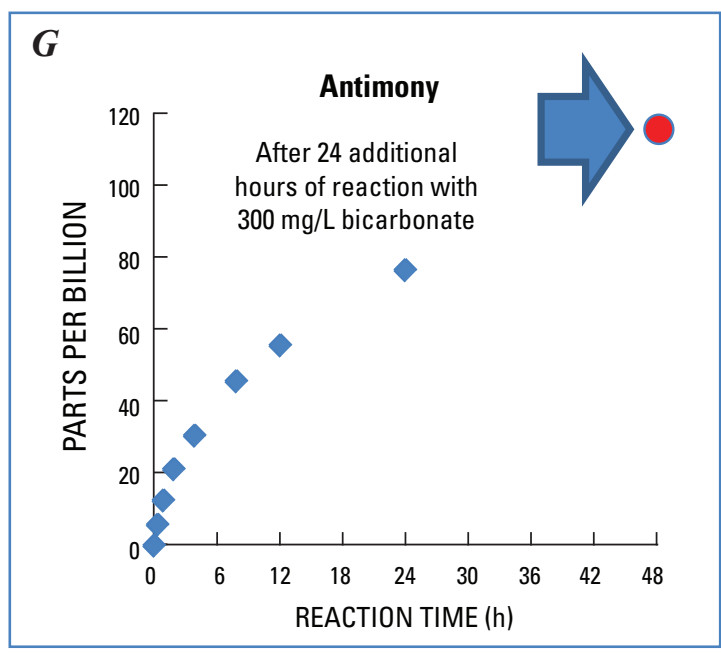

Figure 30-Continued. Concentration of seven elements in ore from Hack Mine leached into simulated rainwater during a 24-hour period (blue diamond) followed by equilibration in a $300 \mathrm{mg} / \mathrm{L}$ bicarbonate solution for 24 hours (large red dot). $A$, Uranium; $B$, Arsenic; $C$, Nickel; $D$, Molybdenum; $E$, Vanadium; $F$, Cobalt; $G$, Antimony. Leaching solutions were simulated rainwater (deionized water equilibrated with air, $\mathrm{pH}=5.6$ ) and simulated carbonate-enriched river water (deionized water containing $300 \mathrm{mg} / \mathrm{L}$ dissolved sodium bicarbonate, $\mathrm{pH}=8.3$ ).

that such waters experience when entering the larger surrounding environment. Projected dilution factors should be defined for specific environments and depend on duration and intensity of rainfall and the extent of mixing of mine-derived runoff with water from other sources.

Carbonate-based leaching, designed to simulate prolonged interaction of rock with surface water or groundwater in an area where carbonate rocks are common, mobilized greater amounts of uranium in unweathered ore (3-5 percent), wind-transported fines (7-13 percent), weathered ore and waste rock (14-20 percent), chemically redistributed uranium on waste (18-91 percent), and background soils (1-2 percent). The most leachable materials were again soil samples and pond sludges previously enriched in uranium and other trace elements through evaporative concentration or sorption. Interestingly, a greater percentage of uranium is leached from weathered waste-rock samples compared with the unweathered high-grade ore specimens (01-Pigeon Ore and 01-Hack Ore). These results are summarized in figure 31 . Although measured concentrations are high at the 20:1 liquid/solid ratio used in the experiments, the extreme dilution in flood waters or after transport into large flowing water bodies will produce much lower concentrations in those waters. (The specific dilution will depend on water volume and flow rate.)

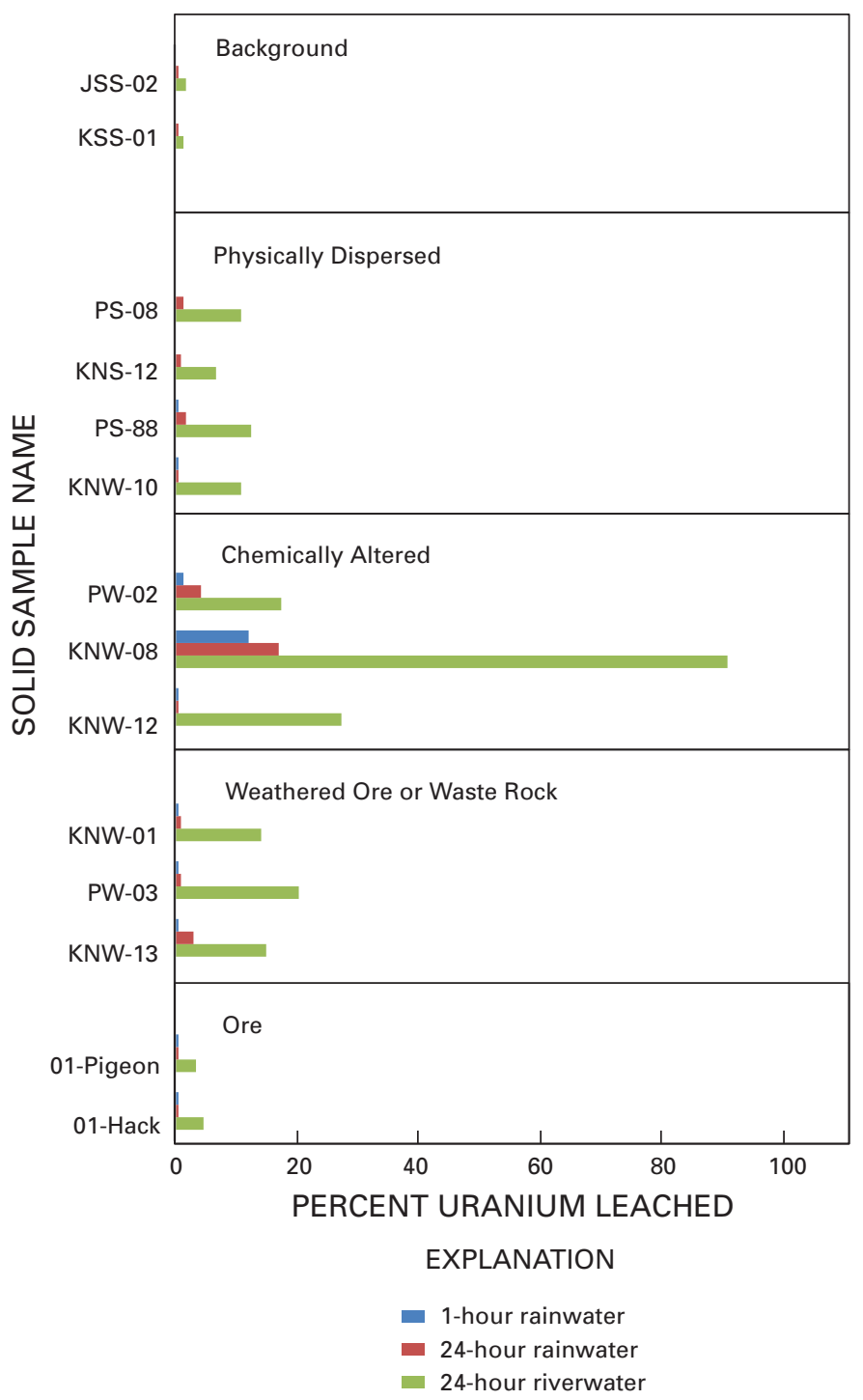

Figure 31. Percentage of uranium leached from five types of material during three experiments.

\section{Summary}

Uranium mining in the Kanab Creek area produced a varied legacy of contamination depending on the physiographic setting of the mining operations, the length of time that mined rock was exposed at the surface, and the effectiveness of reclamation at the site. Our study was designed to examine these effects through collection and geochemical analyses of a limited number of soils, stream sediments, and mine wastes located inside and outside of reclaimed and unreclaimed breccia pipe uranium mine sites. These mine sites were the Pigeon Mine, the Kanab North Mine, the Hermit Mine and the Hack Mine complex (Hack 1, 2, 3).

At the Pigeon Mine site, scattered fragments of uraniferous waste rock remain at the surface after reclamation in the small drainage where the mine was located and in the operations 
area in and near the former waste-rock pile site. Some waste rock remained uncovered after reclamation in the mine area, and slope wash has dispersed uranium and trace elements to the stream channel edge downslope. Dust dispersed contaminants downwind to soils adjacent to the mine and operations sites. In some cases, anomalous soils offsite may be due to soils formed over limonite-cemented sandstone that had been altered by oreforming solutions related to nearby mineralization. In the bed of a small intermittent stream, concentrations of uranium and several trace elements increased down valley towards Snake Gulch, but it is unclear how much of this increase is related to mine operations and how much is derived from the weakly mineralized rock outside of the pipe.

At the Kanab North Mine site, where ore and waste rock have been present at the surface for more than 20 years, wind dispersion of dust has carried contaminants to nearby soils and especially to soils downslope and downwind to the east. Soils outside of the fenced perimeter average 28 ppm uranium compared with the average of $2.4 \mathrm{ppm}$ uranium estimated from NURE data. Although uraniferous sediment has moved within the site during rain events, no waterborne sediment has moved offsite, because a berm surrounding the site has remained intact during the standby period. Ponding of fine-grained sediment within and adjacent to onsite berms may contribute to offsite dispersion by wind.

The Hermit Mine was operational for less than 1 year. The relatively flat reclaimed mine site shows little radioactivity in excess of background levels and minor waste-rock debris. Very limited dispersion of trace elements was found offsite. Uranium and trace element concentrations in soils drop to background concentrations within a few hundred feet outside the reclaimed edge. No stream channel crosses the site, thus limiting the likelihood of flood-related effects.

The Hack Mine complex, operational for about 7 years, has been flooded owing to its deep canyon setting (about $230 \mathrm{~m}$ of local relief). Two or more floods carried ore and waste rock offsite during mining operations and during erosion of a reclaimed terrace area underlain by waste rock adjacent to the main channel of Hack Canyon. Ore and waste-rock fragments are found in the active channel and scattered on the floodplain of the wash for about a half mile downstream from the Hack 1 Mine. Associated finer grained stream sediments show limited dispersion of contaminants downstream. Mine-derived particulates in stream sediments are diluted by the vast quantities of native fine-grained sediment that are incorporated into a flow during a flood, likely limiting the effects of such contaminants.

Ore and waste-rock samples from a variety of mine site settings were leached using simulated rainwater and a simulated surface or shallow ground water rich in dissolved bicarbonate. Results of both studies show varied leaching of uranium and other trace elements. In some instances, uranium concentrations in the experimental leachates were very high — several hundred to several thousand parts per billion - but in natural settings such element-rich waters leached from mine sites are subject to very large dilutions as they mix with runoff. Mine wastes that are covered by fill such as at the Pigeon and Hack Mine sites may have relatively high concentrations of uranium and related trace elements in pore waters during rainfall events.

\section{Future Studies}

Listed below are studies that would improve our understanding of mine-related effects.

1. Studies of the dispersion of mercury, selenium, and radium at the mine sites;

2. Studies of the vertical distribution of trace elements in wind-contaminated soils and biogeochemical uptake by plants;

3. Documentation of the local background geochemistry of soils and stream sediments due to differences in geology and weak mineralization in outcrops outside of pipes;

4. New sampling of stream sediments in Snake Gulch to document changes that may exist owing to the mining of the Pigeon pipe;

5. Detailed mapping of dispersed fragments of ore and waste rock along Hack Canyon and the relation to the braided, aggrading stream;

6. Evaluation of radon emissions in the natural background and at reclaimed mine sites;

7. Evaluation, in greater detail, of the mobilization of dissolved trace elements from ore or waste rock during flood events; and

8. Development of geochemical and aqueous transport models for transport to deep groundwater of any contaminants mobilized from mined waste rock located in back-filled mine openings.

\section{Acknowledgments}

We thank Laura Biewick (USGS) for creating maps from GIS databases to display location information and geochemical data. Rody Cox (USBLM), Roger Smith (formerly with Energy Fuels Nuclear, Inc.), and Cindy Woodward (Denison Mines) provided useful discussion and copies of documents related to mine reclamation. Denison Mines (Fredonia, Arizona) provided access to the Kanab North Mine site. Papillon Grand Canyon Helicopters provided access to reclaimed mine sites in Hack Canyon. We thank George Breit (USGS) and Jon Spencer (Arizona Bureau of Geology and Mineral Technology) for reviewing early versions of this paper. 


\section{References Cited}

Billingsley, G.H., Antweiler, J.C., and Ellis, C.E., 1983, Mineral resource potential of the Kanab Creek Roadless Area, Coconino and Mohave Counties, Arizona: U.S. Geological Survey Miscellaneous Field Studies Map MF-1627-A, 1 sheet, scale 1:48,000, plus 10 p. pamphlet.

Billingsley, G.H., Priest, S.S., and Felger, T.J., 2008, Geologic map of the Fredonia 30' x 60' quadrangle, Mohave and Coconino Counties, northern Arizona: U.S. Geological Survey Scientific Investigations Map 3035, 1 plate with text, accessed October 2009, at http://pubs.usgs.gov/sim/3035/.

Canadian Institute of Mining, Metallurgy and Petroleum (CIM) Standing Committee on Reserve Definitions, 2005, CIM definition standards for mineral resources and mineral reserves: Canadian Institute of Mining, Metallurgy and Petroleum, accessed January 14, 2010, at http://www.cim.org/committees/ CIMDefStds_Dec11_05.pdf.

Carver, N.R., 1999, Trace metal concentrations of Hack Canyon Wash and Kanab Creek, Arizona: Flagstaff, Ariz., Northern Arizona University, M.S. thesis, 190 p.

Casadevall, W.P., 1989, Exploration geology of Canyon breccia pipe south of Grand Canyon, Arizona [abs.]: American Association of Petroleum Geologists Bulletin, v. 73, no. 9, p. 1150.

Chenoweth, W.L., 1988, The production history and geology of the Hacks, Ridenour, Riverview and Chapel breccia pipes, northwestern Arizona: U.S. Geological Survey OpenFile Report 88-648, 60 p.

EnecoTech Inc., 1987, Air quality impact analysis of the Hermit Project, in The Hermit Project, appendix document: U.S. Bureau of Land Management EA AZ-010-87-013, unpaginated.

Energy Fuels Nuclear, Inc., undated, Hack Canyon Mine reclamation summary: Energy Fuels Nuclear, Inc., unpublished company report, 48 p., provided by Denison Mines, 2009.

Finch, W.I., Sutphin, H.B., Pierson, C.T., McCammon, R.B., and Wenrich, K.J., 1990, The 1987 estimate of undiscovered uranium endowment in solution-collapse breccia pipes in the Grand Canyon region of northern Arizona and adjacent Utah: U.S. Geological Survey Circular 1051, 19 p.

Goudie, A.S., and Middleton, N.J., 2006, Desert dust in the global system: Springer Berlin Heidelberg, 287 p.

Hageman, P.L., and Briggs, P.H., 2000, A simple field leach for rapid screening and qualitative characterization of mine waste material on abandoned mine lands, in ICARD 2000, Proceedings from the International Conference on Acid Rock Drainage, 5th, Denver, Colo., May 21-24, 2000: Society for Mining, Metallurgy, and Exploration Inc., p. 1463-1475.
Hopkins, R.T., Fox, J.P., Campbell, W.L., and Antweiler, J.C., 1984, Analytical results and sample locality map of stream sediment, panned-concentrate, soil, and rock samples from the Kanab Creek (B3060) Roadless Area, Coconino and Mohave Counties, Arizona: U.S. Geological Survey OpenFile Report 84-291, 16 p., 1 plate, scale 1:48,000.

Langmuir, Donald, 1978, Uranium solution-mineral equilibrium at low temperatures with applications to sedimentary ore deposits: Geochimica et Cosmochimica Acta, no. 42, p. 547-569.

Lamothe, P.J., Meier, A.L., and Wilson, S.A., 2002, The determination of forty-four elements in aqueous samples by inductively coupled plasma-mass spectrometry, Chapter $\mathrm{H}$, in Taggart, J.E., ed., Analytical methods for chemical analysis of geologic and other materials, U.S. Geological Survey: U.S. Geological Survey Open-File Report 2002-223-H, 11 p., accessed November 2009, at http://pubs.usgs.gov/ of/2002/ofr-02-0223/.

National Council on Radiation Protection and Measurements, 1987, Ionizing radiation exposure of the population of the United States: National Council on Radiation Protection and Measurements, Bethesda Maryland, Report 93, 87 p.

Peacock, T.R., 2002, Soil sample preparation, Chapter A3, in Taggart, J.E., ed., Analytical methods for chemical analysis of geologic and other materials, U.S. Geological Survey: U.S. Geological Survey Open-File Report 2002-223-A3, 6 p., accessed November 2009, at http://pubs.usgs.gov/ of/2002/ofr-02-0223/.

Peacock, T.R., Taylor, C.D., and Theodorakos, P.M., 2002, Stream-sediment sample preparation, Chapter A2, in Taggart, J.E., ed., Analytical methods for chemical analysis of geologic and other materials, U.S. Geological Survey: U.S. Geological Survey Open-File Report 2002-223-A2, 6 p., accessed November 2009, at http://pubs.usgs.gov/ of/2002/ofr-02-0223/.

Pool, T.C., and Ross, D.A., 2007, Technical report on the Arizona strip uranium project, U.S.A., prepared for Denison Mines Corp: Scott Wilson Roscoe Postle Associates Inc, 116 p.

Price, V., and Jones, P.L., 1981, Training manual for water and sediment geochemical reconnaissance: Department of Energy Report GJBX-420 (81), 104 p., accessed November 2009, at http://pubs.usgs.gov/of/1997/ ofr-97-0492/pubs/gjbx_420(81).pdf.

Smith, S.M., 1997, National Geochemical DatabaseReformatted data from the National Uranium Resource Evaluation (NURE) Hydrogeochemical and Stream Sediment Reconnaissance (HSSR) Program, Version 1.40 (2006): U.S. Geological Survey Open-File Report 97-492, accessed September 2009, at http://pubs.usgs.gov/of/1997/ofr-97-0492/ index.html. 
Smith, S.M., and Logsdon, M.J., 1999, An overview of the abundance, relative mobility, bioavailability, and human toxicity of metals, in The environmental geochemistry of mineral deposits, Part A-Processes, techniques and health issues (Plumlee, G.S., and Logsdon, M.J., eds.): Reviews in Economic Geology, v. 6A, p. 29-70.

Strenge, D.L., and Bander, T.J., 1981, MILDOS-A computer program for calculating environmental radiation doses from uranium recovery operations: Richland, Washington, Pacific Northwest Laboratories, NUREG/CR-2011, PNL-3767.

Taggart, J.E., ed., 2002, Analytical methods for chemical analysis of geologic and other materials, U.S. Geological Survey: U.S. Geological Survey Open-File Report 2002-223, version 5.0, accessed November 2009, at http://pubs.usgs.gov/ of $/ 2002 /$ ofr-02-0223/.

Tainter, S.L., 1947, Apex Copper property, Coconino County, Arizona: U.S. Bureau of Mines Report of Investigations RI 4013, 23 p.

Taylor, C.D., and Theodorakos, P.M., 2002, Rock sample preparation, in Taggart, J.E., ed., Analytical methods for chemical analysis of geologic and other materials, U.S. Geological Survey: U.S. Geological Survey Open-File Report 2002-223-A1, 5 p., accessed November 2009, at $h t t p: / / p u b s . u s g s . g o v / o f / 2002 /$ ofr-02-0223/A1RxSampPrep_M.pdf.

Till, J.E., and Grogan, H.A., 2008, Radiological risk assessment and environmental analysis: Oxford University Press, $702 \mathrm{p}$.
U.S. Bureau of Mines, 1996, Dictionary of mining, mineral, and related terms: U.S. Bureau of Mines, CD-ROM and accessed January 14, 2010, at http://www.maden.hacettepe.edu.tr/ dmmrt/.

Van Gosen, B.S., and Wenrich, K.J., 1991, Geochemistry of soil samples from 50 solution-collapse features on the Coconino Plateau, northern Arizona: U.S. Geological Survey Open-File Report 91-0594, 281 p. and 3 diskettes.

Wenrich, K.J., 1985, Mineralization of breccia pipes in northern Arizona: Economic Geology, v. 80, p. 1722-1735.

Wenrich, K.J., 1986, Geochemical exploration for mineralized breccia pipes in northern Arizona, U.S.A.: Applied Geochemistry, v. 1, p. 469-485.

Wenrich, K.J., 1992, Breccia pipes in the Red Butte area of Kaibab National Forest, Arizona: U.S. Geological Survey Open-File Report 92-219, 13 p.

Wenrich, K.J., and Aumente-Modreski, R.M., 1994, Geochemical soil sampling for deeply buried mineralized breccia pipes, northwestern Arizona: Applied Geochemistry, v. 9, p. 431-454.

Wenrich, K.J., Van Gosen, B.S., and Finch, W.I., 1995, Solution-collapse breccia pipe U deposits (Model 32e; Finch, 1992), in du Bray, E.A., ed., Preliminary compilation of descriptive geoenvironmental mineral deposit models: U.S. Geological Survey Open-File Report 95-831, p. 244-251. 


\section{Glossary}

M

Mineral entry The filing of a claim for public land to obtain the right to any minerals it may contain (U.S. Bureau of Mines, 1996).

Mineralization The process or processes by which a mineral or minerals are introduced into a rock, resulting in a valuable or potentially valuable deposit (U.S. Bureau of Mines, 1996).

\section{0}

Ore The naturally occurring material from which a mineral or minerals of economic value can be extracted profitably (U.S. Bureau of Mines, 1996).

Orebody A continuous, well-defined mass of material of sufficient ore content to make extraction economically feasible (U.S. Bureau of Mines, 1996).

Ore deposit A mineral deposit that has been tested and is known to be of sufficient size, grade, and accessibility to be producible to yield a profit (U.S. Bureau of Mines, 1996).

\section{R}

Resource "Resource" or "uranium resource" as used in this report closely follows the Canadian Institute of Mining, Metallurgy and Petroleum (CIM) definition:

A Mineral Resource is a concentration or occurrence of...natural solid inorganic material...in or on the Earth's crust in such form and quantity and of such a grade or quality that it has reasonable prospects for economic extraction. The location, quantity, grade, geological characteristics and continuity of a Mineral Resource are known, estimated or interpreted from specific geological evidence and knowledge (CIM Standing Committee on Reserve Definitions, 2005).

\section{W}

Waste rock Barren or submarginal rock or ore that has been mined, but is not of sufficient value to warrant treatment and is therefore removed ahead of the milling processes (U.S. Bureau of Mines, 1996). 



\section{Historical and 2009 Water Chemistry of Wells, Perennial and Intermittent Streams, and Springs in Northern Arizona}

By Donald J. Bills, Fred D Tillman, David W. Anning, Ronald C. Antweiler, and Thomas F. Kraemer

Chapter $\mathrm{C}$ of

Hydrological, Geological, and Biological Site Characterization

of Breccia Pipe Uranium Deposits in Northern Arizona

Edited by Andrea E. Alpine

Scientific Investigations Report 2010-5025

U.S. Department of the Interior

U.S. Geological Survey 


\section{Contents}

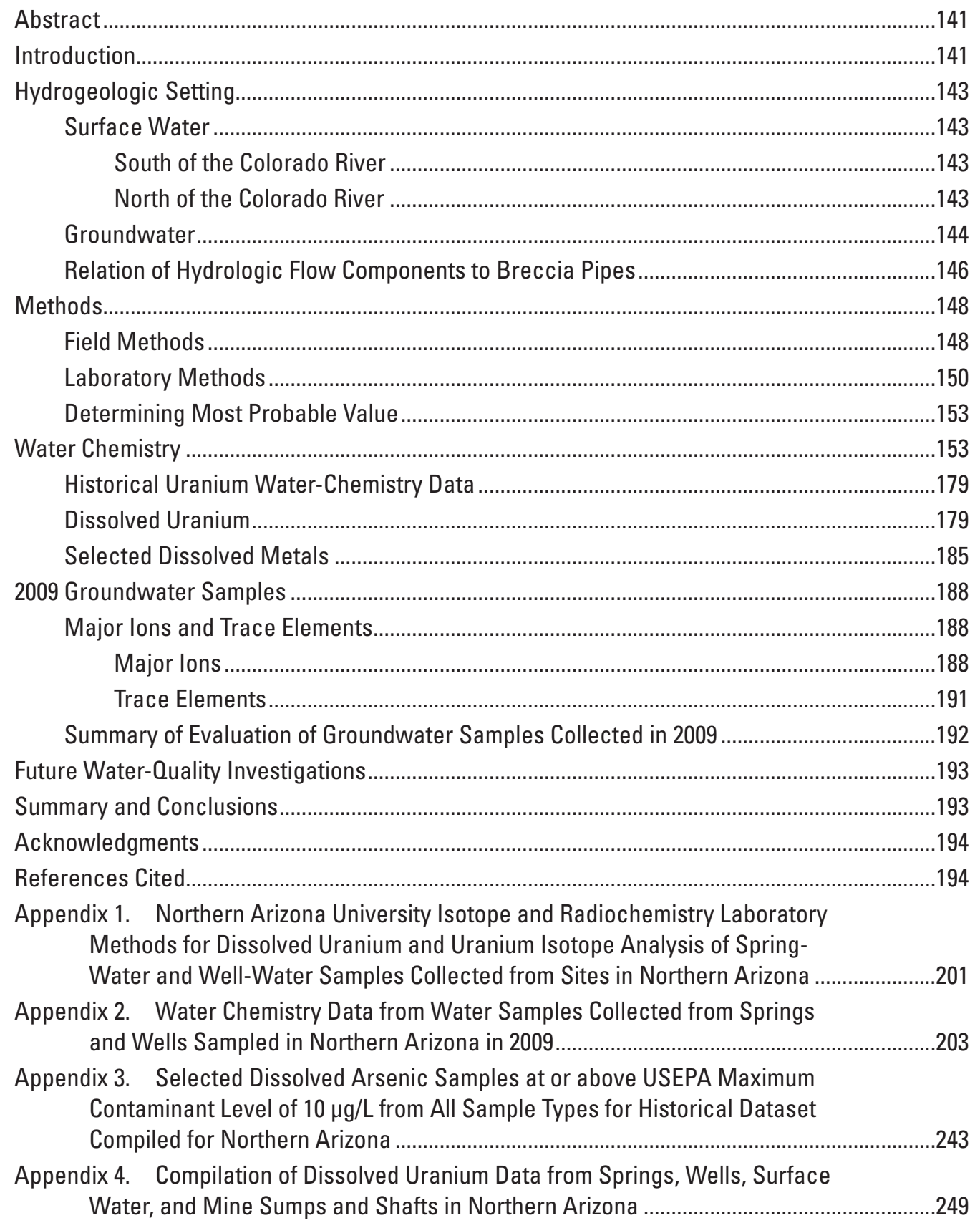

\section{Plate}

[In pocket]

1. Map Showing Geologic Structure, Cultural and Geographic Features, and Geologic Cross Sections of Northwestern Arizona 


\section{Figures}

1. Map showing study area, segregation areas, and land ownership in northern Arizona.

2. Map showing perennial and ephemeral drainages and selected springs

in northern Arizona.

3. Stratigraphic column showing relation of water-bearing zones and aquifers

to mineralized breccia deposits in northern Arizona.

4-9: Maps showing:

4. Hydrogeologic framework of northern Arizona

5. Average annual precipitation and average annual evaporation in northern Arizona.

6. Water chemistry data for selected wells and streams in northern Arizona...............155

7. Water chemistry data for selected springs in northern Arizona .............................156

8. Sites in northern Arizona at which lead, mercury, and molybdenum exceeded U.S. Environmental Protection Agency maximum contaminant or health advisory concentrations, and concentrations of each

9. Average uranium concentration in spring, stream, well, mine shaft, and mine sump water samples in the historical dataset for northern Arizona.

10. Histogram showing number of samples in northern Arizona analyzed for dissolved uranium that were collected during 5-year intervals in northern Arizona ...

11. Histogram showing frequency and cumulative distribution of all uranium concentrations in historical dataset for northern Arizona

12-14. Boxplots showing range in concentration of dissolved uranium in:

12. Water samples in historical dataset from spring, stream, and well locations in northern Arizona.

13. Water samples from mine shafts and sumps in northern Arizona 185

14. Spring and well samples from north and south of the Colorado River in northern Arizona.

15. Line graphs showing variation in uranium concentration with time for selected wells, streams, and springs in historical dataset for northern Arizona.

16. Map showing arsenic concentrations in northern Arizona above

U.S. Environmental Protection Agency maximum contaminant level..

17. Map showing well and spring sites in northern Arizona at which water samples were collected in 2009

18. Piper diagram showing major ions in groundwater samples collected in 2009 from sites in northern Arizona.

\section{Tables}

1. Field protocol used to process spring-water and well-water samples collected in 2009 in northern Arizona

2. Laboratories used and analyte and quality-control sample types for springwater and well-water samples collected in 2009 in northern Arizona

3. Chemical and isotopic analytes and corresponding median detection limits for spring-water and well-water samples collected in 2009 in northern Arizona 
4. Concentrations of elements from the historical dataset and from spring-water and well-water samples collected in 2009 in northern Arizona that exceed U.S. Environmental Protection Agency primary maximum contaminant levels and secondary maximum contaminant levels for selected constituents.

5. Water samples from springs, streams, wells, and mine sumps in the historical dataset of sites in northern Arizona containing mercury, molybdenum, or lead with at least one measurement above U.S. Environmental Protection Agency maximum contaminant level or health advisory level

6-10. Summary information about:

6. Stream-water samples analyzed for dissolved uranium from the historical dataset compiled for northern Arizona

7. Spring-water samples analyzed for dissolved uranium from the historical dataset compiled for northern Arizona

8. Well-water samples analyzed for dissolved uranium from the historical dataset compiled for northern Arizona

9. Water samples from mine shafts and sumps analyzed for dissolved uranium from the historical dataset compiled for northern Arizona

10. Sources of data and types of samples used to compile historical dissolved uranium data for northern Arizona used in this study.

11. Relative rank of concentrations of selected trace elements from springwater and well-water samples collected in 2009 in northern Arizona

\section{Conversion Factors}

Inch/Pound to SI

\begin{tabular}{|c|c|c|}
\hline Multiply & By & To obtain \\
\hline \multicolumn{3}{|c|}{ Length } \\
\hline inch (in.) & 2.54 & centimeter $(\mathrm{cm})$ \\
\hline foot $(\mathrm{ft})$ & 0.3048 & meter $(\mathrm{m})$ \\
\hline mile (mi) & 1.609 & kilometer $(\mathrm{km})$ \\
\hline \multicolumn{3}{|c|}{ Area } \\
\hline square mile $\left(\mathrm{mi}^{2}\right)$ & 2.590 & square kilometer $\left(\mathrm{km}^{2}\right)$ \\
\hline \multicolumn{3}{|c|}{ Volume } \\
\hline gallon (gal) & 3.785 & liter $(\mathrm{L})$ \\
\hline cubic foot $\left(\mathrm{ft}^{3}\right)$ & 0.02832 & cubic meter $\left(\mathrm{m}^{3}\right)$ \\
\hline Fluid ounces (oz) & 0.03 & milliliters (mL) \\
\hline \multicolumn{3}{|c|}{ Flow rate } \\
\hline cubic foot per second $\left(\mathrm{ft}^{3} / \mathrm{s}\right)$ & 0.02832 & cubic meter per second $\left(\mathrm{m}^{3} / \mathrm{s}\right)$ \\
\hline \multicolumn{3}{|c|}{ Concentration } \\
\hline part per billion (ppb) & 1.0 & microgram per liter $(\mu \mathrm{g} / \mathrm{L})$ \\
\hline part per million (ppm) & 1.0 & milligram per liter $(\mathrm{mg} / \mathrm{L})$ \\
\hline \multicolumn{3}{|c|}{ Radioactivity } \\
\hline becquerel per liter $(\mathrm{Bq} / \mathrm{L})$ & 27.027 & picocurie per liter $(\mathrm{pCi} / \mathrm{L})$ \\
\hline tritium unit (TU) & $1{ }^{3} \mathrm{H}$ per 1,018 hydrogen atoms & -- \\
\hline picocurie per liter $(\mathrm{pCi} / \mathrm{L})$ & $\begin{array}{l}4(\mathrm{x} / \mathrm{y}) \text {; where } \mathrm{x} \text { is photon activity } \\
\text { and } \mathrm{y} \text { is conversion rate }\end{array}$ & millirems per year (mrem/y) \\
\hline
\end{tabular}

Temperature in degrees Celsius $\left({ }^{\circ} \mathrm{C}\right)$ may be converted to degrees Fahrenheit $\left({ }^{\circ} \mathrm{F}\right)$ as follows:

$$
{ }^{\circ} \mathrm{F}=\left(1.8 x^{\circ} \mathrm{C}\right)+32
$$

Temperature in degrees Fahrenheit $\left({ }^{\circ} \mathrm{F}\right)$ may be converted to degrees Celsius $\left({ }^{\circ} \mathrm{C}\right)$ as follows:

$$
{ }^{\circ} \mathrm{C}=\left({ }^{\circ} \mathrm{F}-32\right) / 1.8
$$


Vertical coordinate information is referenced to the North American Vertical Datum of 1988

(NAVD 88).

Horizontal coordinate information is referenced to the North American Datum of 1983 (NAD 83).

Altitude, as used in this report, refers to distance above the vertical datum.

Specific conductance is given in microsiemens per centimeter at 25 degrees Celsius $(\mu \mathrm{S} / \mathrm{cm}$ at $25^{\circ} \mathrm{C}$.

Concentrations of chemical constituents in water are given either in milligrams per liter (mg/L) or micrograms per liter $(\mu \mathrm{g} / \mathrm{L})$.

\title{
Abbreviations Used in This Report
}

\author{
ADEO Arizona Department of Environmental Quality \\ ADWR Arizona Department of Water Resources \\ ICP-AES inductively coupled plasma-atomic emission spectroscopy \\ ICP-MS inductively coupled plasma-mass spectrometry \\ INAA instrumental neutron-activation analysis \\ GRCA Grand Canyon National Park \\ MCL maximum contaminant level \\ MPV most-probable value \\ NURE National Uranium Resource Evaluation Program \\ NWOL U.S. Geological Survey National Water Quality Laboratory \\ PMCL primary maximum contaminant level \\ BLM U.S. Bureau of Land Management \\ USEPA United States Environmental Protection Agency \\ USGS United States Geological Survey
}





\title{
Chapter C \\ Historical and 2009 Water Chemistry of Wells, Perennial and Intermittent Streams, and Springs in Northern Arizona
}

\author{
By Donald J. Bills, Fred D Tillman, David W. Anning, Ronald C. Antweiler, and Thomas F. Kraemer
}

\section{Abstract}

This chapter provides an evaluation of selected historical water-chemistry data and recently collected water-chemistry data for wells, springs, and streams in the Grand Canyon region of northern Arizona. Historical data were used to evaluate the effects of legacy mining and recent uranium mining and to provide an historical context for the concentration of dissolved uranium in water in northern Arizona. New data were collected in the three segregation areas, East, North, and South, where recent uranium mining is on standby or is planned. A few springs were sampled along the corridor of the Colorado River in the Marble Canyon reach, which is downgradient from the House Rock area (the East Segregation Area) where mining claims have been filed and very little water-chemistry data exist.

Historical water-quality and water-chemistry data evaluated for 1,014 water samples from 428 sites indicate that about 70 sites exceeded either the primary or secondary maximum contaminant levels (or both) for a few major ions and trace elements such as arsenic, iron, lead, manganese, sulfate, radium, and uranium. These data suggest that water recharged from the surface or from perched water-bearing zones contains dissolved gypsum from overlying rock units or may have been in contact with sulfide-rich ore.

Samples from about 120 springs and 32 streams in the region contained dissolved uranium concentrations greater than $5 \mu \mathrm{g} / \mathrm{L}$ but less than $30 \mu \mathrm{g} / \mathrm{L}$; those concentrations are probably the result of natural dissolution and erosion of mineralized ore deposits. Samples from 15 springs and 5 wells in the region contained dissolved uranium concentrations greater than the U.S. Environmental Protection Agency maximum contaminant level for drinking water. These springs and wells are close by or in direct contact with mineralized orebodies, and those concentrations are related to natural processes, mining, or to both. In 66 percent of natural water samples in the dataset, uranium concentrations were $5 \mu \mathrm{g} / \mathrm{L}$ or less and may be subjectively classified as low concentrations for this study area on the basis of the subjective evaluation of historical data. Samples of surface water from the Colorado River in the Grand Canyon region typically contained less than $5 \mu \mathrm{g} / \mathrm{L}$ dissolved uranium. However, in the northwest corner of the area a sample of Virgin River water contained a dissolved uranium concentration greater than $80 \mu \mathrm{g} / \mathrm{L}$.

Groundwater samples were collected from 24 sites in August and September 2009 in the study area; they augment the historical dataset and allowed variations in groundwater chemistry to be evaluated by geographic region and groundwater source. Major-ion composition, specific conductance, and concentrations of uranium, barium, strontium, and molybdenum appear correlated with geographic region and groundwater source. In addition, arsenic concentrations appear correlated with groundwater source, and zinc concentrations appear correlated with geographic region. Relations of uranium and 13 other trace elements to mining activity were few and inconclusive.

\section{Introduction}

The U.S. Geological Survey (USGS) evaluated historical and recently collected water-chemistry data in northern Arizona in order to understand better the source and distribution of dissolved uranium in the Grand Canyon region. This chapter describes the region's general hydrogeologic setting, investigative methods, and the resultant chemical analyses of historical and recently collected data. The evaluation describes the presence of natural dissolved uranium and other elements in groundwater and the potential for and extent of any release of postmining waste into the region's groundwater. Data on historical and 2009 concentrations of dissolved uranium provide a context that could then be used to evaluate past and current mining activity. Surface water samples were not collected owing to a lack of precipitation and runoff. The evaluation focuses on the East, North, and South Segregation Areas in the Grand Canyon region that are being considered for withdrawal from future mining (fig. 1). 


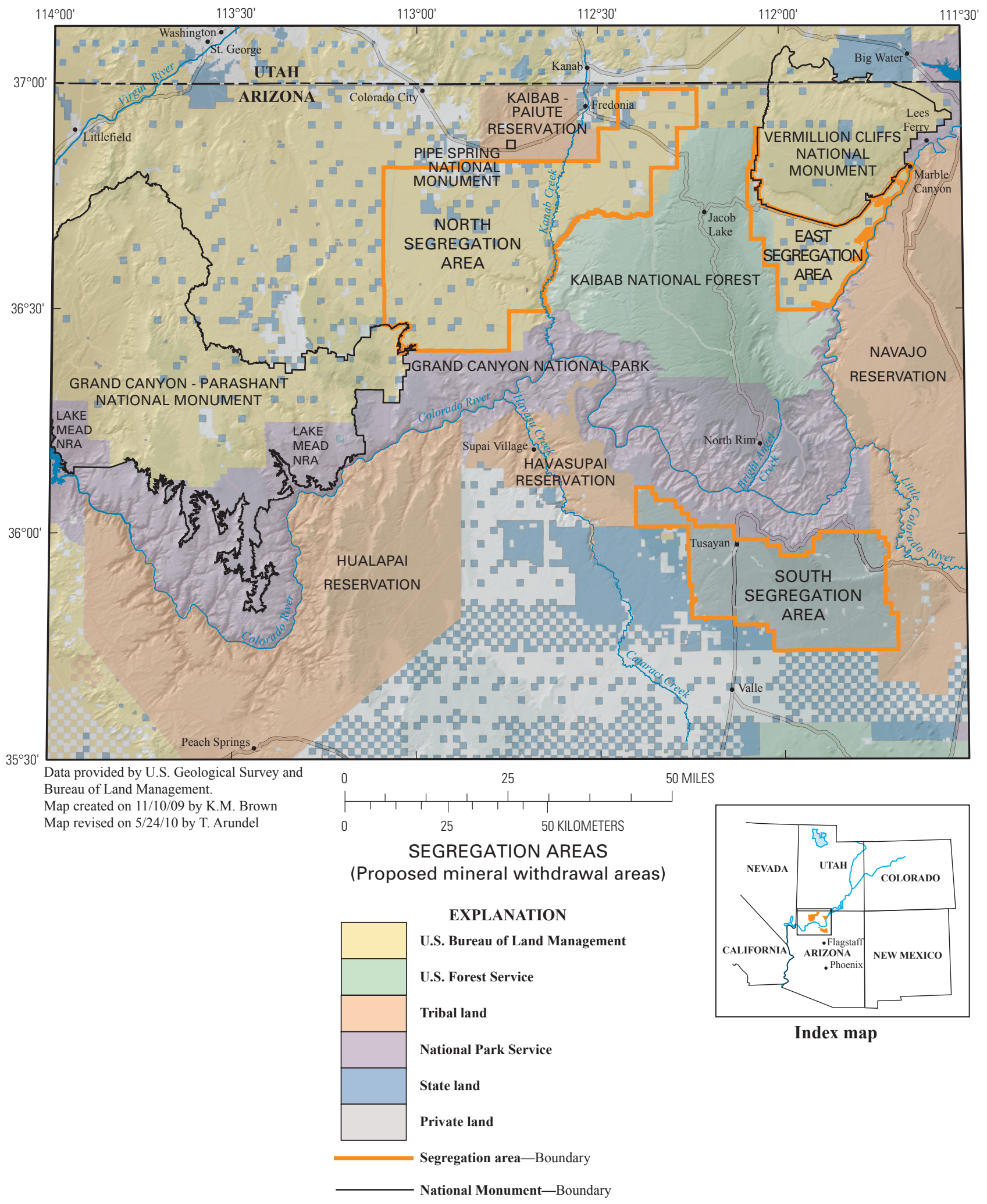

Figure 1. Study area, segregation areas, and land ownership in northern Arizona. NRA, National Recreation Area. 


\section{Hydrogeologic Setting}

The study area is in the Colorado River Basin in northern Arizona on the southern edge of the Colorado Plateau (fig. 1). The Colorado River and its many tributaries have exposed Paleozoic and Mesozoic sedimentary rocks containing mineralized breccia pipes that are enriched in uranium (Finch and others, 1987; Finch, 2003). Past mine development has, in some cases, accelerated the erosion of these mineral deposits (Billingsley, 1997). Regional groundwater flow systems in this part of the Colorado Plateau are largely contained within Paleozoic rocks. Erosion of the Grand Canyon has produced large regional discharge zones (springs) that drain these aquifers to the Colorado River and its tributaries. Surface water and groundwater are natural pathways for migration of trace elements and radionuclides in the environment. Therefore, the water chemistry of streams and springs can provide insight into the sources and directions of groundwater flow as well as the effects of anthropogenic activities, such as mining within the region.

\section{Surface Water}

\section{South of the Colorado River}

South of the Colorado River, all tributaries on the Coconino Plateau are ephemeral except for short perennial reaches supported by groundwater discharge (fig. 2). On the south, the largest tributaries that drain to the Colorado River are the Little Colorado River and Havasu Creek. The Little Colorado River basin drains about 27,000 square miles ( $\mathrm{mi}^{2}$ ) of northeastern Arizona and central New Mexico. Headwater reaches of the Little Colorado River are perennial, supported by groundwater discharge from local and regional aquifers (Hart and others, 2002). The middle reaches of the Little Colorado River are ephemeral and flow only in response to winter and spring runoff and summer thunderstorms. The lower 13 miles (mi) of the Little Colorado River are also perennial and are supported by groundwater discharge from a series of large springs in the Blue Spring area (fig. 2). The Blue Spring area, in the lower Little Colorado River, is the largest single source of spring discharge (220 cubic feet per second $\left[\mathrm{ft}^{3} / \mathrm{s}\right]$ ) in the entire Grand Canyon region and is a primary discharge area for the regional aquifer (Cooley and others, 1969; Hart and others, 2002; and Bills and others, 2007).

Havasu Creek is the second largest tributary south of the Colorado River, draining 3,020 $\mathrm{mi}^{2}$. Havasu Creek is perennial from Havasu Spring, about 2 mi upstream of Supai, to the mouth of its canyon (fig. 2). The base flow of Havasu Creek, about $70 \mathrm{ft}^{3} / \mathrm{s}$ (Bills and others, 2007), comes entirely from the Redwall-Muav aquifer (Bills and Flynn, 2002; Bills and others, 2007). Upstream from Havasu Spring, Havasu Creek is called Cataract Creek; it is ephemeral for its entire length and flows only in response to substantial winter precipitation and summer thunderstorms. The Havasu and Cataract
Creek drainage is subject to periodic, catastrophic floods that transport large sediment loads (Melis and others, 1996). In this drainage, several breccia pipes have been exposed largely by normal erosional processes.

Other tributaries south of the Colorado River are relatively small and mostly ephemeral (fig. 2). The few tributaries that do have perennial flow to their mouths have base flows between about $10 \mathrm{ft}^{3} / \mathrm{s}$ and less than $0.1 \mathrm{ft}^{3} / \mathrm{s}$ (Hualapai Water Resources Department, 1995; Monroe and others, 2005; Bills and others, 2007). The base flow in these drainages is supported by groundwater discharge from the Redwall-Muav aquifer and from waterbearing zones in underlying units. All of the drainages south of the Colorado River are capable of high-volume flash floods and debris flows that can mobilize large amounts of rock and sediment (Melis and others, 1994). These floods can effectively transport trace elements and radionuclides.

\section{North of the Colorado River}

Most of the tributaries that drain the north of the Colorado River are ephemeral except for short perennial reaches supported by groundwater discharge (fig. 2). Paria River and Kanab Creek are the only perennial streams that drain large areas. The Paria River, northeast of the study area, has a drainage area of 1,410 $\mathrm{mi}^{2}$ (fig. 2). Most of the lands drained by the Paria River contain rock units that in turn contain uranium and associated trace elements; these elements augment the trace element or radionuclide content of the both the Paria and Colorado Rivers (Foust and Hope, 1985).

Kanab Creek, the largest tributary north of the Colorado River, drains 2,360 $\mathrm{mi}^{2}$. The Kanab Creek Basin contains many breccia pipes, many mines and prospects for copper and other ore, and six uranium mines. In addition, it drains all of the North Segregation Area (see plate 1). Kanab Creek is perennial at Fredonia, Ariz. (fig. 2), because of spring flow from the Navajo Sandstone in Utah and from irrigation return flows (Levings and Farrar, 1979a; Cordova, 1981). A few miles south of Fredonia the creek is dry, because flow has been lost by evapotranspiration or infiltration into the streambed. The lower $10 \mathrm{mi}$ of Kanab Creek is perennial (fig. 2); a base flow of about $4.0 \mathrm{ft}^{3} / \mathrm{s}$ discharges from the Redwall-Muav aquifer (Rote and others, 1997). Winter storms and intense summer thunderstorms within in the drainage can produce floods, flash floods, and debris flows that could transport substantial volumes of trace elements and radionuclides in dissolved, suspended, and bed loads. Fine-grained particles that have a high cation-exchange capacity are nearly ideal sites for the mobilization of radionuclides (Ames and Dhanpat, 1978). In 1984, a flash flood in Hack Canyon, a tributary of Kanab Creek, washed away parts of waste rock and ore piles of the Hack Canyon mines (J.K. Otton, U.S. Geological Survey, written commun., 2009). Foust and Hoppe (1985) reported that Kanab Creek contained numerous dissolved trace metals in excess of established standards for both domestic supplies and the support of freshwater aquatic and terrestrial wildlife use that warrant further investigation. 


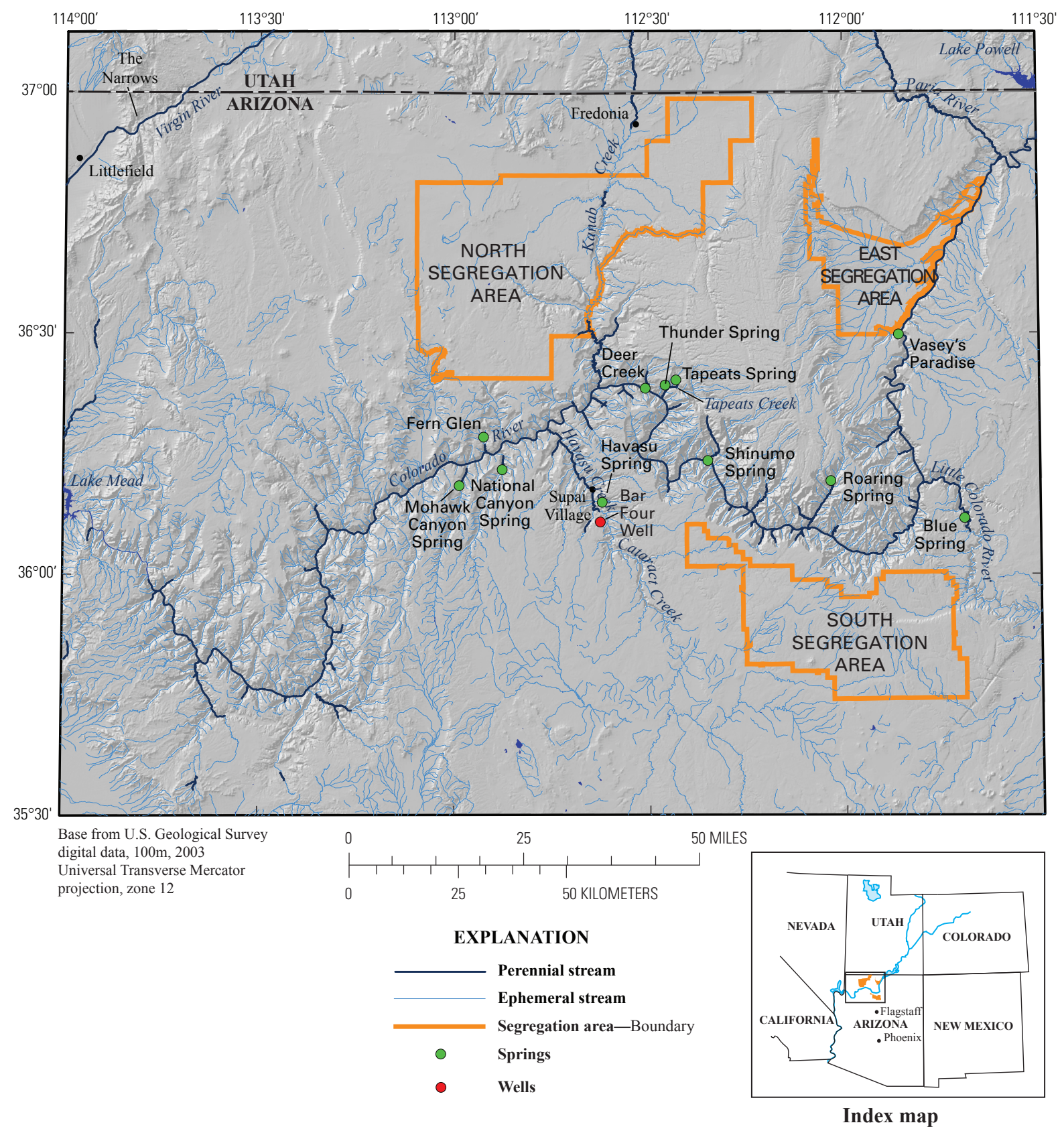

Figure 2. Perennial and ephemeral streams and selected springs in northern Arizona.

Other tributaries north of the Colorado River have relatively small drainage areas but some of the largest baseflow discharge issuing from the Redwall-Muav aquifer, ranging from $75 \mathrm{ft}^{3} / \mathrm{s}$ at Tapeats Creek to less that $1.0 \mathrm{ft}^{3} / \mathrm{s}$ at Fern Glen (fig. 2) (Johnson and Sanderson, 1968; S.E. Rice, Grand Canyon National Park, written commun., 2007; http://waterdata.usgs.gov/az/nwis/sw/, accessed September 2009). All drainages north of the Colorado River are capable of substantial flash floods and debris flows that can mobilize large volumes of rock and sediment (Melis and others, 1994) and represent significant transport mechanism for trace elements and radionuclides.

\section{Groundwater}

The groundwater flow systems in the study area are divided into smaller perched water-bearing zones and larger regional aquifer systems (fig. 3). The perched water-bearing zones are contained in unconsolidated alluvium, volcanic rocks, and consolidated sedimentary rocks located a thousand feet or more above the main regional aquifer systems. These perched zones generally are small and discontinuous in the subsurface. Groundwater flows downgradient and discharges at springs or migrates deeper into the subsurface (Farrar 1979, 1980; Levings and Farrar, 1979a,b; McGavock and others, 1986; Bills and others, 2007; Arizona 


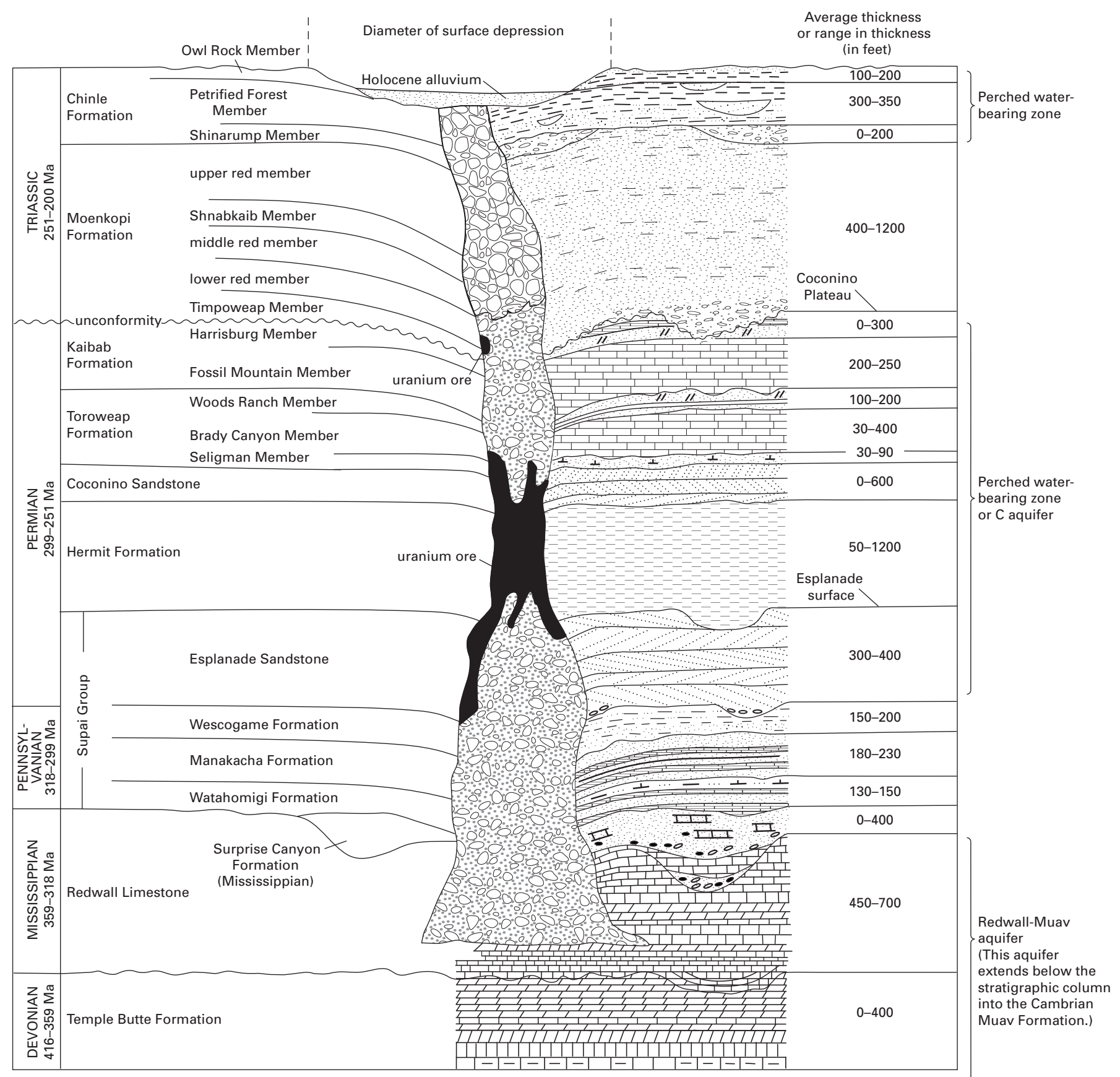

Figure 3. Stratigraphic column showing relation of perched water-bearing zones and aquifers to mineralized breccia deposits in northern Arizona. Modified from Van Gosen and Wenrich, 1989. Ma, million years ago.

Department of Water Resources, 2009). The depth to water ranges from a few feet to more than $300 \mathrm{ft}$ below land surface (Levings and Farrar, 1979; Bills and others, 2007; Arizona Department of Water Resources, 2009). Perched water-bearing zones can be in direct contact with mineralized orebodies in the Chinle Formation, the Coconino Sandstone, or the Supai Group (fig. 3).

The $\mathrm{C}$ aquifer and the Redwall-Muav aquifer (fig. 3) are the two primary regional aquifer systems in the study area (Hart and others, 2002; Bills and others, 2007). These aquifer systems are contained in hydraulically connected Paleozoic sedimentary rocks, typically sandstone and limestone. The relatively simple layered nature of the Paleozoic strata throughout the study area obscures the more complex character of the regional aquifers they contain (plate 1 , fig. 3 ). The complexity is due to variations in stratigraphy, lithology and, most important, geologic structure throughout the southern Colorado Plateau (plate 1). The $\mathrm{C}$ aquifer is present at the southern edge of the study area and in the Little Colorado River Valley east of the Mesa Butte fault (plate 1) where fractures and faults in the rock provide pathways for migration of groundwater from 
this aquifer deeper into the subsurface (Bills and others, 2007). The saturated thickness of the $\mathrm{C}$ aquifer is about $600 \mathrm{ft}$ along the Little Colorado River valley before it drains completely to underlying rock units just east of the study area (Bills and others, 2007). Groundwater in the $\mathrm{C}$ aquifer could be in direct contact with mineralized ore where breccia pipes are present east of the Mesa Butte fault (plate 1, fig. 3). In addition, fractures associated with these collapse features could be pathways that allow dissolved constituents to move deeper into the subsurface. The hydrogeology of the $\mathrm{C}$ aquifer is described in detail by McGavock and others (1986), Bills and others (2000), and Bills and others (2007). The C aquifer is not present west of the Mesa Butte fault or north of the Colorado River (Bills and others, 2007; Arizona Department of Water Resources, 2009). In these areas, perched water-bearing zones in the Kaibab Formation, Coconino Sandstone, or sandstones in the Supai Group are underlain by finer grained sediments (fig. 3).

The Devonian Temple Butte Formation, Mississippian Redwall Limestone, and Cambrian Muav Limestone compose the Redwall-Muav aquifer and are the principal water-bearing rock units underlying the entire study area (fig 4). The RedwallMuav aquifer also underlies the $\mathrm{C}$ aquifer south of the Colorado River; there, 1,500 to 2,500 feet of unsaturated rock separate the two (McGavock and others, 1986; Bills and others, 2000; Bills and others, 2007). The Redwall-Muav aquifer is the ultimate drain for groundwater and for dissolved trace elements and radionuclides migrating downward from overlying ore deposits. The aquifer is confined throughout much of its extent (fig. 4) by very fine grained sediments in the overlying Supai Group (fig. 3) and by underlying Proterozoic granites and schists. It is fully to partly saturated south of the Colorado River. In a few places along the South Rim of Grand Canyon, these limestones may be partly saturated to unsaturated where groundwater migrates into lower units of the aquifer (Bills and others, 2007). The Redwall-Muav aquifer extends north of the Colorado River into Utah and Nevada but is poorly defined there because it is deeply buried and subsurface borehole data is lacking (fig. 4). It is a major aquifer system in central and northern Utah also, where it has been better defined (Taylor and others, 1986). Most information about the extent and flow of groundwater in the Redwall-Muav aquifer north of the Colorado River is derived from studies by Cooley (1976) and Huntoon (1977, 2000a,b), from observation of springs in Marble Canyon and the Grand Canyon, and from a few wells drilled to support mining activity in the Kanab Creek drainage. North of the Colorado River, the Redwall-Muav aquifer can be described as an unconfined to confined, karstified carbonate aquifer. Groundwater flow in the aquifer is controlled by five main features: cave systems developed on joint fractures and faults, large regional faults, lithology and regional dip of the rock matrix, incision of the Colorado River and its tributaries through rock units of the aquifer, and the Bright Angel Shale (plate 1, fig. 4) (Cooley, 1976; Goings, 1985; Zukosky, 1995; Huntoon, 1996, 2000a,b;
Ross, 2005; Arizona Department of Water Resources, 2009). In Marble Canyon, the Colorado River has not fully penetrated the Redwall or Muav Limestones. As result, there is underflow in the Redwall-Muav aquifer in this area (fig. 4) (Huntoon, 1996). The water-level elevation on the Kaibab Plateau, where limited well data exist, is 2,800 to $3,700 \mathrm{ft}$ above sea level (fig. 4).

Groundwater discharges from the Redwall-Muav aquifer as springs supplying water to the Colorado River and its many tributaries, as downward leakage into the Bright Angel Shale and Tapeats Sandstone, as supply to wells, and as evapotranspiration where the water table in the aquifer is at or near land surface (Johnson and Sanderson, 1968; Cooley, 1976; Levings and Farrar, 1978, 1979a,b; Farrar, 1979; Monroe and others 2005; and Bills and others, 2007). Water in the Early to Middle Cambrian Bright Angel Shale and Tapeats Sandstone is believed to be hydraulically connected with the overlying Redwall-Muav aquifer through faults and fractures in the Bright Angel confining unit or where, in the central part of the study area, the Bright Angel Shale is thin or absent (plate 1) (Bills and others, 2007).

\section{Relation of Hydrologic Flow Components to Breccia Pipes}

Fractures, faults, sinkholes, and breccia pipes occur throughout the study area and are pathways for downward migration of surface water and groundwater. Collapse features and breccia pipes in particular can intercept precipitation, runoff, and groundwater in perched water-bearing zones and can direct that water deeper into the subsurface. In areas containing mineralized pipes, this process can dissolve trace elements and radionuclides in the deposits and transport them to groundwater deeper in the subsurface. This process has been occurring naturally for millions of years (Sanford, 1982; Wenrich and Stuphin, 1989; Young, 2008). Uranium mineralization is concentrated in or near the Esplanade Sandstone, Hermit Formation, and Coconino Sandstone (fig. 3) (Van Gosen and Wenrich, 1989). These stratigraphic units typically lie several hundred feet below the plateau surface north and south of the Colorado River. Orebodies range in thickness from a few hundred to more than a thousand feet. Uranium minerals in the Canyon breccia pipe south of the Colorado River extend from the contact between the Coconino Sandstone and Toroweap Formation for more than $1,600 \mathrm{ft}$ vertically down through the breccia pipe to the upper Redwall Limestone (plate 1) (Casadevall, 1989). The depth to perched water in these rock units generally is greater than $1,000 \mathrm{ft}$ below land surface south of the Colorado River and a few hundred to more than 1,000 ft below the surface north of the river (Levings and Farrar, 1979a,b; Farrar, 1980; Bills and others, 2007; Arizona Department of Water Resources, 2009). These water-bearing zones generally are separated by more than $2,000 \mathrm{ft}$ of unsaturated rock above the 


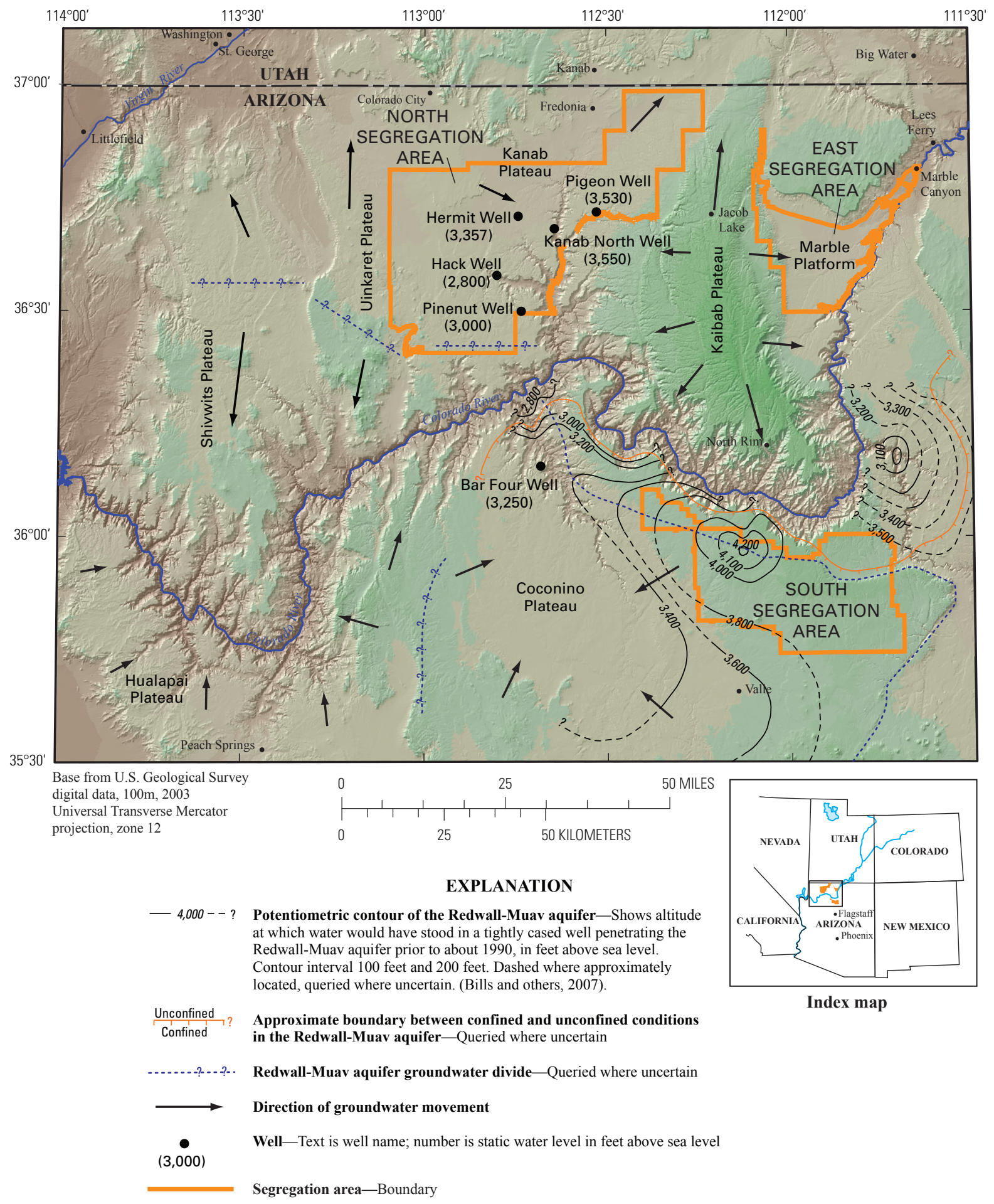

Figure 4. Hydrologic framework of northern Arizona. 
regional aquifer in the Redwall and Muav Limestones (fig. 3) (Bills and others, 2007). The Redwall-Muav aquifer is confined throughout much of its extent by very fine grained sediments at the base of the overlying Supai Group, except where it is faulted or fractured or where breccia pipes have developed (plate 1, fig. 3). The depth to water in the Redwall-Muav aquifer both south and north of the Colorado River is $2,500 \mathrm{ft}$ or more below the surface (fig. 4) (Bills and others, 2007) and typically $1,000 \mathrm{ft}$ or more below the bottom of most ore deposits in breccia pipes (fig. 3). The stratigraphically confined nature of the Redwall-Muav aquifer and other featuresfaults, fractures, and breccia pipes - provide pathways by which dissolved minerals may reach this flow system. Groundwater flow systems south and north of the Colorado River are connected hydraulically with some stream reaches of the many tributaries of the Grand Canyon and possibly to the Virgin River (figs. 2, 4). The interaction of groundwater, surface water, and dissolved minerals in these stream reaches is controlled by the physical properties of the rock units and sediments that make up the stream channels and geologic structure near the spring and base-flow areas.

Short reaches of several streams north of the Colorado River have perennial flow because groundwater discharges where stream channels intersect rock units of the RedwallMuav aquifer (plate 1, fig. 2). Large regional springs-Vasey's Paradise, Roaring Spring, Shinumo Spring, Tapeats Spring, Thunder Spring, and Deer Creek - are the main regional discharge areas for the Redwall-Muav aquifer north of the Colorado River (fig. 2). The lower 10 mi of Kanab Creek are perennial owing to spring flow from the Redwall-Muav aquifer. Spring flow in the creek is controlled by the channel's deep incision that intersects deep-seated fractures and normal faults in the area (plate 1, fig. 2). The spring-fed base flow of Kanab Creek is small because most of the flow to the east has been intercepted by larger springs, the remaining area of the Kanab Creek Basin receives much less annual recharge, and the springs are close to a potential groundwater divide that may further limit recharge to this area (figs. 2, 4). Potential groundwater divides in the central parts of the Uinkaret and Shivwits Plateaus divert groundwater flow north to the Virgin River and south to the Colorado River (fig. 4). Even though these plateaus are large, the low annual precipitation limits recharge potential in these areas (Flint and others, 2004; Flint and Flint, 2007) (fig. 5). Only a few small seeps and springs discharge to tributaries of the Colorado River at the southern ends of these plateaus because of the proximity of groundwater divides to potential recharge areas and regional dip of rock units to the north (plate 1, fig. 4). Several springs discharge large volumes to the Virgin River to the north; this groundwater flows from limestones exposed from the Narrows to Littlefield that may originate on the Uinkaret and Shivwits Plateaus (fig. 4) (Levings and Farrar, 1979a,b; Billingsley and Workman, 2000).

\section{Methods}

Water-chemistry data have been collected by many agencies and by academia for selected springs, streams, wells, and mine sumps that discharge water from the perched waterbearing zones, the $\mathrm{C}$ aquifer, and Redwall-Muav aquifer in northern Arizona; these data were evaluated for this study. New water data were collected by the USGS in August and September 2009 and were primarily used to fill gaps in the limited information. The historical and new data were used in three ways: to conceptualize a hydrogeologic framework for the north side of the Colorado River, to evaluate water chemistry in relation to natural uranium concentrations and concentrations that may be influenced by mining, and to determine the distribution of concentrations of dissolved uranium in the study area.

\section{Field Methods}

New water samples were collected from 20 springs and 3 wells north of the Colorado River in and adjacent to the North and East Segregation Areas, and from one well south of the Colorado River in the South Segregation Area. Most of the springs are $2,000 \mathrm{ft}$ or more below the canyon rim and required access by foot along several miles of unimproved trails or in stream channels. These remote sites and excessive heat necessitated modification of standard water-sampling protocols described in the USGS National Field Manual for the Collection of Water-Quality Data (Wilde and Radtke, 1998). These protocols ensure the quality of the water samples and limit exposure of field personnel to potentially hazardous conditions. In some cases, the modification required completion of sample processing after returning to base camp or to a motel room rather than processing the sample onsite (table 1). Helicopter access was used at seven of the remote spring sites to limit time between collection and processing of the water sample.

At all spring sites, field personnel completed field notes that provided a complete description of the sample site, sample conditions, sample location (including global positioning system coordinates), and any site conditions that might affect the water sample. Field parameters such as spring discharge, air and water temperature, $\mathrm{pH}$, specific conductance, and dissolvedoxygen concentration were measured onsite by using calibrated instruments and USGS protocols (Wilde and others, 1998). Alkalinity was determined at the processing area by incremental titration (Wilde and Radtke, 1998). Spring discharge was measured by using a pygmy meter and Aquacalc, or a Parshall flume, or it was measured volumetrically as physical conditions required (Rantz and others, 1982). Springs were sampled as close as possible to the point of discharge. At sites where discharge locations were inaccessible, water samples were collected from the flowing channel as close as possible to the discharge point. Water 


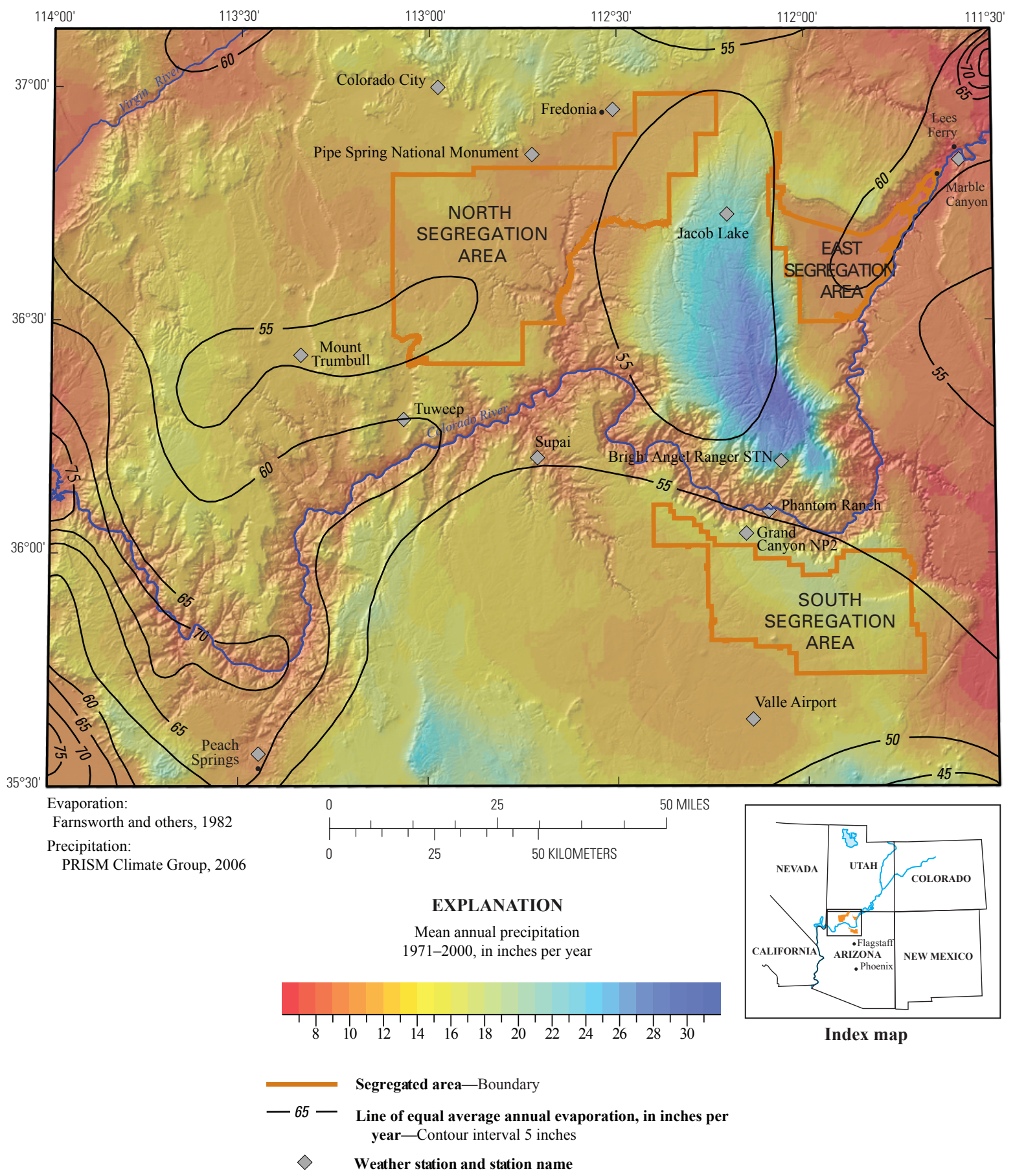

Figure 5. Annual average precipitation and average annual evaporation in northern Arizona.

samples were collected in three cleaned $4 \mathrm{~L}$ Nalgene bottles and then transported to the processing area using a sampling protocol modified for backcountry use as described by Monroe and others (2004) and Bills and others (2007).

At the base camp, field processing was completed in a partially enclosed, tent-like structure constructed of tarps that protected the processing area from precipitation, sun, wind, and dust. Samples were processed immediately after they arrived at the processing site. At all times during processing, polypropylene gloves were worn to ensure that samples were not contaminated. New cleaned, Tygon silicon tubing connected to a peristaltic pump was inserted into each of the 4-L bottles in turn; spring water was sucked through the tubing into a glove-box-like chamber where subsamples were collected according to a set protocol (table 1) (Koterba and others, 1995). All sample bottles for individual subsets were precleaned and individually bagged in zip-lock plastic bags. 
Table 1. Field protocol used to process spring-water and well-water samples collected in 2009 in northern Arizona.

[ $\mu \mathrm{m}$, micrometer; $\mathrm{mL}$, milliliter; DIC, dissolved inorganic carbon; FA, filtered acidified acid-rinsed polyethylene bottle; FAR, filtered acidified with Ultrex (ultrapure distilled water) nitric-acid-rinsed polyethylene bottle; FCC, filtered chilled brown polyethylene bottle; FU, filtered unacidified plain polyethylene bottle; FUS, filtered plastic-coated glass bottle with polyseal cap; L, liter; N, normal; RU, raw unacidified plain polyethylene bottle; RUR, raw unacidified in an acid-rinsed polyethylene bottle; RUS, raw clear glass with baked polyseal cap; WCA, filtered chilled plain polyethylene bottle acidified with sulfuric acid]

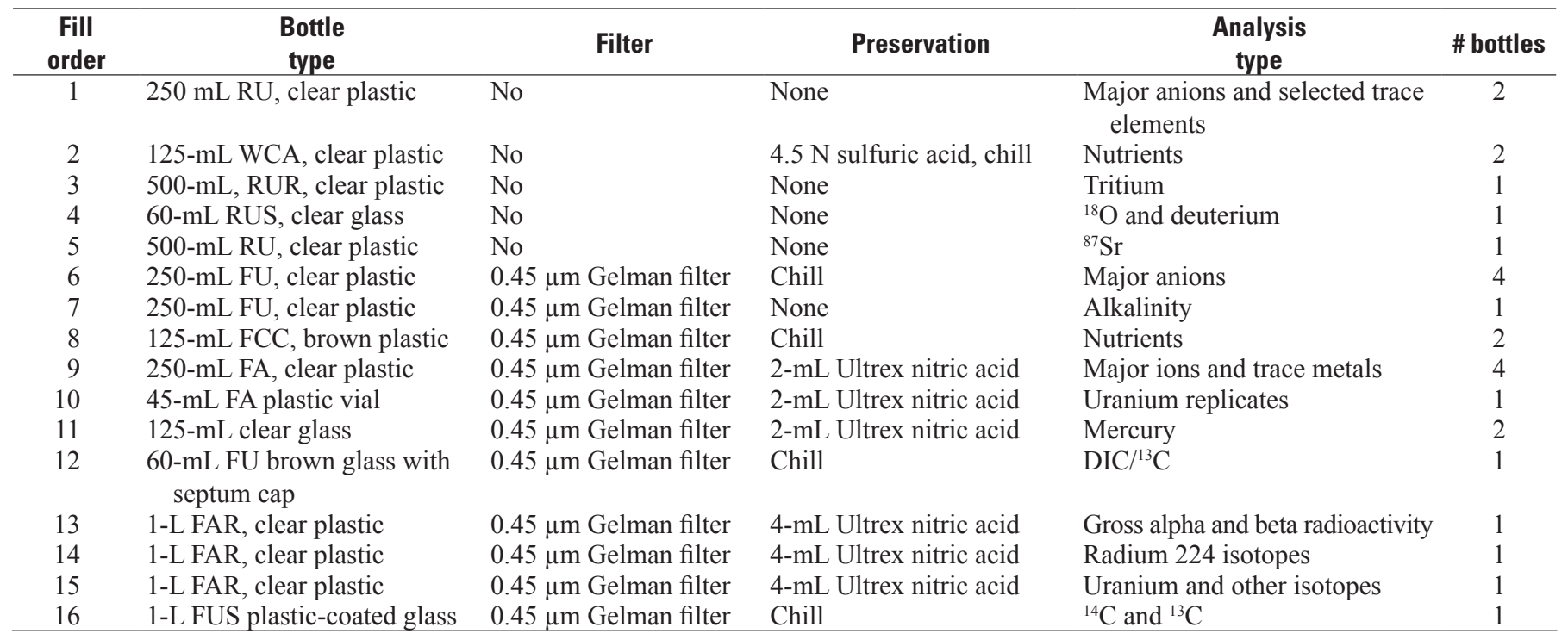

An additional 100 gallons of water was processed through manganese-impregnated acrylic-fiber cartridges at 3 springs and 2 wells in order to produce a quantitative extract of radium that was used for radium isotope analysis (Kramer, 2005). Once the sample was collected, the filters were again sealed in clean zip-lock bags for shipping to a laboratory for analysis; accompanying field notes described the sample site, sample conditions, flow rate, volume of water pumped, and any site conditions that might affect the water sample. Oneliter water samples also were collected at these same sites in order to determine total dissolved radium concentrations.

Groundwater samples from wells were collected as close to the well head as possible and after purging a minimum of three casing volumes of water from each well while temperature, $\mathrm{pH}$, and specific conductance were monitored. Alkalinity was determined at the site by incremental titration (Wilde and Radtke, 1998). All samples were collected according to protocols described in the USGS National Field Manual for the Collection of Water-Quality Data (Wilde and Radtke, 1998) and USGS protocols in effect at the time of sample collection. Well discharge was measured volumetrically using methods described by Rantz and others (1982). Field processing was done onsite directly from the stream discharging from the well. At all times during processing, polypropylene gloves were worn to ensure that samples were not contaminated. New pre-cleaned, Tygon silicon tubing was inserted into a glove-box-like chamber where subsamples were collected according to a set protocol (table 1; Koterba and others, 1995). All sample bottles for individual subsets were pre-cleaned and individually bagged in zip-lock plastic bags.
Duplicates were collected for all subsamples except the stable isotopes. Two field blank samples were collected to ensure that equipment did not become contaminated between samples. These blanks consisted of ultrapure deionized water and were treated in all regards as if they were spring samples; they were processed according to protocol (table 1). After processing and preservation, all subsamples from each spring and well were double-sealed in zip-lock plastic bags and placed into a dedicated cooler already chilled with ice until they could be express mailed to the individual laboratories responsible for analysis.

At all steps in the collection, processing, and transportation of the spring and well samples, chain-of-custody procedures were followed (Driscoll, 2007). A chain-of-custody form accompanied each water sample from collection to the processing laboratory. Once the water samples arrived at individual laboratories and were signed for, chain-of-custody became the responsibility of each laboratory and it followed the laboratory's protocol. Chain-of-custody forms were returned to the Flagstaff Water Science Center office, where they are filed with other forms and information for each sample site.

\section{Laboratory Methods}

Samples were analyzed for selected constituents at several laboratories to compare results of analytical methods from different laboratories and to reduce analysis error (table 2).

Major ions, nutrients, trace elements, dissolved uranium, and stable isotopes were determined by the USGS National Water Quality Laboratory (NWQL) in Denver, Colo. Details of analytical procedures are described by Fishman and others, 
1994; Hoffman and others, 1996; and Garbarino and others, 2006. Chloride and sulfate were determined by ion chromatography by using a modified ion chromatograph (Brinton and others, 1996). Nutrients were determined by using methods described by Wershaw and others (1987). Gross-alpha and gross-beta particle counting, used to provide semiquantitative information on the overall degree of radioactivity in water samples without quantifying individual radionuclides, was completed by use of decay-counting that in turn used a gas-proportional detector (U.S. Environmental Protection Agency, 1976). This method is most often applied for screening purposes. The method has the advantage of being sensitive to activity from a wide range of radionuclides, but it does not inherently provide information about the identity of the radioactive isotopes present. Count rates from the detector are converted to and reported as activities. More details of the methodology can be found in American Public Health Association (1985). Tritium was determined using a liquid-scintillation counting technique (Kendall and Caldwell, 1998) after preconcentration by an electrolytic-enrichment procedure. Results are reported in picocuries per liter $(\mathrm{pCi} / \mathrm{L})$ and tritium units $(\mathrm{TU})$ (Fritz and Fontes, 1980; Clark and Fritz, 1997).

A duplicate set of water samples was sent to USGS National Research Program research analytical laboratory in Boulder, Colo. (Taylor Laboratory) and analyzed for concentrations of major ions, trace elements, and mercury (table 3 ). All analyses of dissolved metals were run in triplicate by two different instruments - inductively coupled plasma-atomic emission spectroscopy (ICP-AES) and inductively coupled plasma-mass spectrometer (ICP-MS). A selected suite of elements (boron, calcium, cobalt, iron, magnesium, manganese, sodium, nickel, potassium, phosphorus, silica, strontium, sulfur, titanium, and zinc) were analyzed by ICP-AES). Trace elements (table 3) were analyzed with a Perkin Elmer Elan Model 6000 ICP-MS using indium, iridium, and rhodium as internal standards to normalize for instrument drift. A general description of the analysis conditions and procedures are reported by Garbarino and Taylor (1979), details of operational conditions are reported in Mitko and Bebek (1999,
2000), and details of specific analytical techniques, procedures, and instrumental settings are described in Garbarino and Taylor (1996) and Taylor (2000). At least 30 percent of the samples analyzed in all batches (by both ICP-AES and ICP-MS) used standard reference waters or other qualitycontrol samples in order to assess accuracy. Samples designated for mercury analyses were further preserved by addition of potassium dichromate in the laboratory ( 3 to 4 days after collection). Total dissolved mercury concentrations were measured in triplicate using an automated cold-vapor atomic fluorescence spectrometric method using a PS Analytical Millennium System mercury analyzer (Roth, 1994; Roth and others, 2001). All analytical batches included at least 20 percent quality-control and standard-reference samples to assess accuracy.

Water samples were analyzed for carbon-13 at USGS Isotope Fractionation Project Laboratory in Reston, Va. An isotope ratio-mass spectrometric technique was used to analyze $\delta^{13} \mathrm{C}$ in water (Clark and Fritz, 1997). Measured ${ }^{13} \mathrm{C} /{ }^{12} \mathrm{C}$ ratios are reported as $\delta^{13} \mathrm{C}$ relative to per mil deviation from values obtained from the Vienna Peedee belemnite standard (Coplen, 1994). The activity of ${ }^{14} \mathrm{C}$ was measured by accelerator mass spectrometry (Beukens, 1992); results are reported as percent modern carbon normalized to the 1950 National Bureau of Standards (National Bureau of Standards, 1984) oxalic acid standard (Stuiver and Polach, 1977; Wigley and Muller, 1981), along with 1-sigma analytical uncertainties.

Isotope compositions of radium and uranium as well as concentrations of radium, uranium, major ions, and trace elements were determined at USGS National Research Program Laboratories in Reston, Va., and Menlo Park, Calif. Uranium concentrations were determined by ICP-MS on a small aliquot $(10 \mathrm{~mL})$ in order to determine amounts of sample required for isotope analysis of ${ }^{234} \mathrm{U} /{ }^{238} \mathrm{U}$ (Kraemer and others, 2002). Uranium was concentrated and purified by using standard ion-chromatographic methods, and the final uranium fraction was eluted into a $30 \mathrm{~mL}$ bottle for liquid aspiration into the ICP-MS. This method measures the ${ }^{234} \mathrm{U}$ and ${ }^{235} \mathrm{U}$ peaks and calculates a ${ }^{234} \mathrm{U} /{ }^{238} \mathrm{U}$ uranium activity ratio on the basis of

Table 2. Laboratories used and analyte and quality-control sample types for spring-water and well-water samples collected in 2009 in northern Arizona.

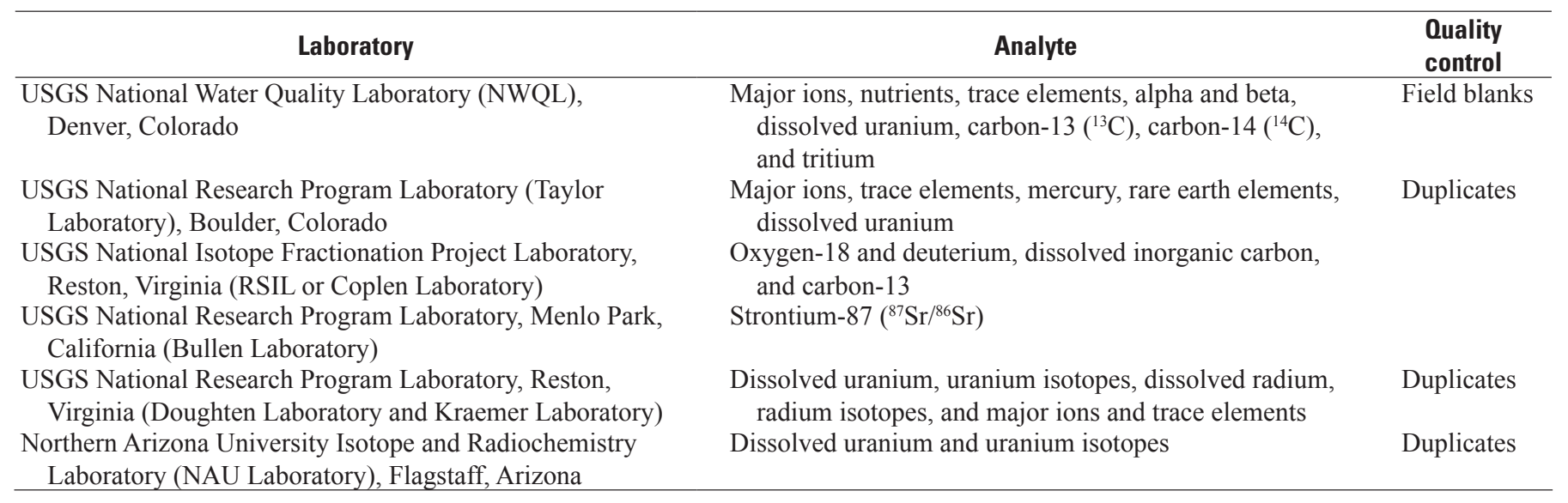


Table 3. Chemical and isotopic analytes and corresponding median detection limits for spring-water and well-water samples collected in 2009 in northern Arizona.

[Elements not footnoted were analyzed by more than one laboratory; $\mu \mathrm{g} / \mathrm{L}$, microgram per liter; $\mathrm{mg} / \mathrm{L}$, milligram per liter; mg N/L, milligram nitrogen per liter; mg P/L, milligram phosphorus per liter; ng/L, nanogram per liter; $\mathrm{pCi} / \mathrm{L}$, picocurie per liter; pmc, percent modern carbon; TU, tritium unit; $\delta$, delta notation; \%, per mil; na, not applicable]

\begin{tabular}{|c|c|c|c|c|c|c|c|}
\hline $\begin{array}{l}\text { Chemical } \\
\text { constituent }\end{array}$ & Symbol & $\begin{array}{c}\text { Median } \\
\text { detection } \\
\text { limit }\end{array}$ & Unit & $\begin{array}{l}\text { Chemical } \\
\text { constituent }\end{array}$ & Symbol & $\begin{array}{c}\text { Median } \\
\text { detection } \\
\text { limit }\end{array}$ & Unit \\
\hline Bicarbonate $^{1}$ & $\mathrm{HCO}_{3}$ & 0.5 & $\mathrm{mg} / \mathrm{L}$ & Lead & $\mathrm{Pb}$ & 0.008 & $\mu \mathrm{g} / \mathrm{L}$ \\
\hline Calcium & $\mathrm{Ca}^{3}$ & 0.001 & $\mathrm{mg} / \mathrm{L}$ & Lutetium $^{2}$ & $\mathrm{Lu}$ & 0.0002 & $\mu \mathrm{g} / \mathrm{L}$ \\
\hline Chloride $^{1}$ & $\mathrm{Cl}$ & 0.02 & $\mathrm{mg} / \mathrm{L}$ & Manganese & $\mathrm{Mn}$ & 0.06 & $\mu \mathrm{g} / \mathrm{L}$ \\
\hline Potassium & $\mathrm{K}$ & 0.005 & $\mathrm{mg} / \mathrm{L}$ & Mercury & $\mathrm{Hg}$ & 0.4 & $\mathrm{ng} / \mathrm{L}$ \\
\hline Sulfate $^{1}$ & $\mathrm{SO}_{4}$ & 0.04 & $\mathrm{mg} / \mathrm{L}$ & Nickel & $\mathrm{Ni}$ & 0.03 & $\mu \mathrm{g} / \mathrm{L}$ \\
\hline Silica & $\mathrm{SiO}_{3}^{4}$ & 0.01 & $\mathrm{mg} / \mathrm{L}$ & Praseodymium $^{2}$ & $\operatorname{Pr}$ & 0.0004 & $\mu \mathrm{g} / \mathrm{L}$ \\
\hline Nitrate $^{1}$ & $\mathrm{NO}_{3}^{3}$ & 0.01 & $\mathrm{mg} \mathrm{N} / \mathrm{L}$ & Radium $^{3,4}$ & $\mathrm{Ra}$ & 0.003 & $\mathrm{pCi} / \mathrm{L}$ \\
\hline Nitrite $^{1}$ & $\mathrm{NO}_{2}^{3}$ & 0.001 & $\mathrm{mg} \mathrm{N} / \mathrm{L}$ & Rhenium $^{2}$ & $\mathrm{Re}$ & 0.001 & $\mu \mathrm{g} / \mathrm{L}$ \\
\hline Ammonium $^{1}$ & $\mathrm{NH}_{4}^{2}$ & 0.03 & $\mathrm{mg} \mathrm{N} / \mathrm{L}$ & Rubidium & $\mathrm{Rb}$ & 0.003 & $\mu \mathrm{g} / \mathrm{L}$ \\
\hline Phosphorus & $\mathrm{P}^{4}$ & 8 & $\mu \mathrm{g} / \mathrm{L}$ & Samarium $^{2}$ & $\mathrm{Sm}$ & 0.002 & $\mu \mathrm{g} / \mathrm{L}$ \\
\hline Phosphate $^{2}$ & $\mathrm{PO}_{4}$ & 0.02 & $\mathrm{mg} \mathrm{P} / \mathrm{L}$ & Selenium & $\mathrm{Se}$ & 0.4 & $\mu \mathrm{g} / \mathrm{L}$ \\
\hline Beryllium & $\mathrm{Be}$ & 0.03 & $\mu \mathrm{g} / \mathrm{L}$ & Thorium & $\mathrm{Th}$ & 0.0006 & $\mu \mathrm{g} / \mathrm{L}$ \\
\hline Bismuth & $\mathrm{Bi}$ & 0.003 & $\mu \mathrm{g} / \mathrm{L}$ & Thulium $^{2}$ & $\mathrm{Tm}$ & 0.0003 & $\mu \mathrm{g} / \mathrm{L}$ \\
\hline Boron & B & 11 & $\mu \mathrm{g} / \mathrm{L}$ & Tungsten & $\mathrm{W}$ & 0.001 & $\mu \mathrm{g} / \mathrm{L}$ \\
\hline Bromine $^{3}$ & $\mathrm{Br}$ & 0.5 & $\mathrm{mg} / \mathrm{L}$ & Uranium $^{1-4}$ and 6 & $\mathrm{U}$ & 0.001 & $\mu \mathrm{g} / \mathrm{L}$ \\
\hline Cadmium & $\mathrm{Cd}$ & 0.009 & $\mu \mathrm{g} / \mathrm{L}$ & Vanadium & V & 0.1 & $\mu \mathrm{g} / \mathrm{L}$ \\
\hline Cerium $^{2}$ & $\mathrm{Ce}$ & 0.0005 & $\mu \mathrm{g} / \mathrm{L}$ & Ytterbium $^{2}$ & $\mathrm{Yb}$ & 0.0007 & $\mu \mathrm{g} / \mathrm{L}$ \\
\hline Cesium & $\mathrm{Cs}$ & 0.01 & $\mu \mathrm{g} / \mathrm{L}$ & Yttrium $^{2}$ & $\mathrm{Y}$ & 0.0008 & $\mu \mathrm{g} / \mathrm{L}$ \\
\hline Chromium & $\mathrm{Cr}$ & 0.3 & $\mu \mathrm{g} / \mathrm{L}$ & Zinc & $\mathrm{Zn}$ & 0.2 & $\mu \mathrm{g} / \mathrm{L}$ \\
\hline Cobalt & $\mathrm{Co}$ & 0.007 & $\mu \mathrm{g} / \mathrm{L}$ & Zirconium & $\mathrm{Zr}$ & 0.003 & $\mu \mathrm{g} / \mathrm{L}$ \\
\hline Copper & $\mathrm{Cu}$ & 0.03 & $\mu \mathrm{g} / \mathrm{L}$ & Gross beta $^{1}$ & na & 4 & $\mathrm{pCi} / \mathrm{L}$ \\
\hline Dysprosium $^{2}$ & Dy & 0.001 & $\mu \mathrm{g} / \mathrm{L}$ & Gross alpha ${ }^{1}$ & na & 3 & $\mathrm{pCi} / \mathrm{L}$ \\
\hline Erbium $^{2}$ & $\mathrm{Er}$ & 0.0009 & $\mu \mathrm{g} / \mathrm{L}$ & Oxygen-18 & $\delta^{18} \mathrm{O}$ & na & $\%$ \\
\hline
\end{tabular}

${ }^{1}$ USGS National Water Quality Laboratory.

${ }^{2}$ USGS National Research Program Taylor Laboratory.

${ }^{3}$ USGS National Research Program Kraemer Laboratory.

${ }^{4}$ USGS National Research Program Bullen Laboratory.

${ }^{5}$ USGS Isotope Fractionation Project Laboratory.

${ }^{6}$ Northern Arizona University Isotope and Radiochemistry Laboratory reported precision.

the assumption that the natural ${ }^{235} \mathrm{U} /{ }^{238} \mathrm{U}$ ratio is constant. The error associated with each uranium activity ratio is estimated from complete duplicate or triplicate analyses of the same sample. Acceptable instrument operation was verified by running standards of known uranium activity ratio value before, between, and after sample sets.

Radium isotope compositions were determined by gammaray spectroscopy on radium extracted from large-volume water samples preconcentrated in the field on manganese-impregnated acrylic-fiber cartridges (Kraemer, 2005). Manganese dioxide, along with adsorbed cations, is removed by circulating a solution of hydroxylamine hydrochloride through the cartridge. Chemical processing includes dissolution and reprecipitation of $\mathrm{Ba}(\mathrm{Ra})$ $\mathrm{SO}_{4}$, which is collected and placed in a high-purity germanium detector for quantitative analysis of ${ }^{228} \mathrm{Ra}$ and ${ }^{226} \mathrm{Ra}$ by gamma-ray spectrometry. Samples are counted for a sufficient length of time to achieve a 1-sigma counting error of 5 percent or less. Analytical error was estimated from counting statistics only. 
Total radium concentrations were determined by adding $\mathrm{Ba}\left(\mathrm{NO}_{3}\right)_{2}$ to a known amount of water until $\mathrm{BaSO}_{4}$ precipitated. Usually, dissolved sulfate in the samples was sufficient such that addition of $\mathrm{H}_{2} \mathrm{SO}_{4}$ was not necessary. The barite precipitate was filtered, dried, and counted in the same manner as in large-volume samples.

A duplicate set of water samples was sent to the Northern Arizona University Isotope and Radiochemistry Laboratory, Flagstaff, Ariz., for analysis of dissolved uranium and uranium isotopes (see appendix 1 for methods). These analyses provide an independent check on USGS analyses of dissolved uranium and uranium isotopes.

Water samples were analyzed for strontium-87 $\left({ }^{87} \mathrm{Sr} /{ }^{86} \mathrm{Sr}\right)$ at USGS National Research Program Laboratory in Menlo Park, California by using thermal ionization mass spectrometry (Bullen and others, 1996; Taylor, 2000). Resulting measurements of ${ }^{87} \mathrm{Sr} /{ }^{86} \mathrm{Sr}$ were normalized for mass-dependent fractionation to a value of 8.37521 for measured ${ }^{88} \mathrm{Sr} /{ }^{86} \mathrm{Sr}$ ratios.

\section{Determining Most Probable Value}

Appendix 2 contains data reported from each laboratory used in this study. Because multiple values were available for many analytes, it was necessary to establish a final (or mostprobable) value (MPV) for each analyte. Calculation of MPVs depended on how many laboratories reported results. If only one laboratory reported an analyte, then that value was used as the MPV. If two laboratories reported results, then the average value was usually taken, although laboratory detection limits were considered. If one laboratory had a much higher detection limit than the other and reported a concentration, whereas the other laboratory reported a "less than detection," then the value was listed rather than the detection limit. If both laboratories reported values less than the detection limit, then the value from the laboratory with the smaller detection limit was reported. If the two laboratories had similar detection limits and reported values greater than and less than this limit, then the MPV was calculated as the average of the greater value and a value of half the detection limit; if this average was greater than the detection limit, then the average value was used; otherwise the parameter was listed as less than detection. Finally, in the rare cases in which values reported by two laboratories were widely discrepant, neither value was accepted and an "na" was reported as the MPV.

For analytes reported from three or four laboratoriesespecially for uranium - a more elaborate method was used to determine an MPV. First, one of the laboratories (typically NWQL) was selected as a temporary control, and results of other laboratories were ratioed to its values. These ratios were then plotted against the control concentrations to verify that no concentration dependencies were present. The median value of the sample and control ratios for a given analyte reported by each laboratory is a measure of interlaboratory bias. Median values were compared, and results from the laboratory having the central-most ratio were selected to represent the MPV for a given analyte. Results were screened to remove spurious or systematically biased results. In these cases, the values reported by the remaining laboratories were averaged. When two or more laboratories had equivalent ratios (typically within 2 percent), the values from those laboratories were averaged and reported as the MPV.

Because uranium is the most important element for this report, it is instructive to outline how the MPV was selected for it. Four laboratories reported uranium data: NWQL, USGS National Research Program Laboratory (Doughten Laboratory), Reston Va., the Taylor Laboratory, and the Northern Arizona University Laboratory (appendix 2). NWQL data were selected as a temporary control and all values were ratioed to them. After first determining that ratios of none of the laboratories were concentration dependent, the median ratio for each lab was determined. NWQL had a ratio of 1.000 (by construction); Doughten Laboratory had a median ratio of 1.052; Taylor Laboratory had a median ratio of 1.042; and Northern Arizona University had a median ratio of 1.238 . These results clearly demonstrate that Northern Arizona University data are strongly biased relative to the other three laboratories, and its data are therefore rejected. Of the remaining three laboratories, the middle ratio, 1.042, corresponds with the ratio of Taylor Laboratory. Thus, the Taylor average value is used as the MPV for uranium except for cases in which the Taylor Laboratory reported a value more than 10 percent different from values reported by the other two laboratories. This event occurred only once, for the Tom Land Well, in which the average Taylor Laboratory value is $17.6 \mu \mathrm{g} / \mathrm{L}$, the (bias-adjusted) NWQL value is $20.8 \mu \mathrm{g} / \mathrm{L}$, and the (biasadjusted) Doughten Laboratory value is $20.4 \mu \mathrm{g} / \mathrm{L}$. In this case, the average value of the NWQL and Doughten Laboratory values is used $(20.6 \mu \mathrm{g} / \mathrm{L})$.

\section{Water Chemistry}

It is not uncommon to find streams and springs in the region that contain high concentrations of dissolved trace elements and radionuclides owing to natural processes of evaporation, weathering, and erosion. In addition, human activities such as mining may further contribute to the dissolved chemical load. Historical mining activity in northern Arizona has left a legacy of abandoned mines, mine waste, and waste rock. Uranium mining of breccia pipes in northern Arizona through 1969 left waste rock and low-grade ore exposed at the surface, allowing subsequent remobilization of minerals and radionuclides and contamination of both surface water and groundwater systems in the region. Beginning in the mid-1970s, the advent of stricter environmental regulations and improvements in mining practices reduced the potential for environmental contamination. However, secondary permeability in fractured rocks provides pathways for dispersing remobilized radionuclides. 
Waters from wells and springs have water chemistries that depend on the chemistry of rock units that contact the water. Therefore, water-chemistry data provide important clues about the origins and flow paths of water in groundwater systems. Major-ion and trace-element data can be used to distinguish groundwater from different sources. Nutrient and selected traceelement data can be used to indicate sources of contamination and secondary groundwater recharge (for example, wastewater). Trace element, isotope, and radiochemistry data can be used to evaluate the presence of and contributions from mineralized orebodies in surface-water drainages. In particular, historical dissolved-uranium data can be used to determine a baseline value for the Grand Canyon region. Dissolved uranium, radium, gross alpha and gross beta particles, and other radionuclides can be used to compare mined and unmined drainages.

Wells and springs that discharge from perched waterbearing zones and aquifers south of the Colorado River contain mostly calcium-magnesium-bicarbonate water (figs. 6, 7). This composition is consistent with groundwater that has spent substantial time in contact with rock units of these groundwater flow systems (Bills and others, 2007). Groundwater discharging from perched water-bearing zones north of the Colorado River is a calcium-magnesium-sulfate water. These springs discharge from either the Coconino Sandstone or sandstones in the Supai Group; these formations are overlain by silty sandstones containing gypsum $\left(\mathrm{CaSO}_{4} \cdot 2 \mathrm{H}_{2} \mathrm{O}\right)$, which dissolves readily in water. Besides creating shallow collapse features that are easily confused with breccia pipes (Billingsley and others, 2006), the dissolved gypsum creates a water type that is easy to recognize.

Groundwater discharging from the Redwall-Muav aquifer south of the Colorado River typically has calcium-magnesiumbicarbonate compositions (Monroe and others, 2004; Bills and others, 2007). Groundwater from the same aquifer has calciummagnesium-sulfate compositions in the western part of Grand Canyon and sodium-chloride compositions to the southeast in the Little Colorado River Canyon (figs. 6, 7) (Cooley, 1976; Hualapai Water Resources Department, 1995; Hart and others, 2004; Bills and others, 2007). North of the Colorado River, groundwater that discharges from the Redwall-Muav aquifer has different chemical compositions in different areas. Groundwater has a calcium-bicarbonate composition with low total dissolved solids in the Marble Canyon reach and to the west of the Kaibab Plateau, but a calcium-magnesium-sulfate composition with high total dissolved solids on the Kanab Plateau and lower Kanab Creek north of the estimated groundwater divide (figs. 4, 6, 7). Groundwater in the Redwall-Muav aquifer south of the groundwater divide still has a calcium-bicarbonate composition. Higher concentrations of magnesium and sulfate in the Redwall-Muav aquifer on the Kanab Plateau could be evidence of recharge through rocks that contain gypsum or sulfide. The increased sulfate concentrations of springs in the Kanab Creek area in proximity to mined sites and unmined ore deposits could also be evidence (subject to further analysis) of this relation (plate 1, fig. 7). Groundwater discharging from the Redwall-Muav aquifer in the central part of Grand Canyon has low major-ion concentrations that suggest greater contributions from local recharge and shorter contact time with the aquifer rock (Monroe and others, 2004). Similar increases in the proportions of calcium and magnesium also are found among sites near the South Rim of Grand Canyon, suggesting recharge from more distant sources and longer contact time with the rock (Monroe and others, 2004; Bills and others, 2007). The low total-dissolved-solid calcium-bicarbonate water of the RedwallMuav aquifer north of the Colorado River is typical of groundwater that has had little contact time with the rock as it flowed through large fracture and solution-channel systems that probably originate on the Kaibab Plateau (Huntoon, 2000a,b; Ross, 2005). The higher total-dissolved-solid content of groundwater from the Redwall-Muav aquifer on the Kanab Plateau indicates that groundwater likely has a much longer residence time in this area (figs. 4, 6, 7). The larger concentrations of dissolved magnesium and sulfate in groundwater in this area are consistent with the accumulation of salts derived from water that contains dissolved sulfate from gypsum or sulfide-rich orebodies, that percolated downward from the perched water-bearing zones in sandstones in the Supai Group, the Coconino Sandstone, or the Chinle Formation.

Water discharging from the perched water-bearing zones and the Redwall-Muav aquifer in northern Arizona are generally of good quality for most intended uses. However, a number of sites were found to have constituent concentrations in excess of selected criteria for drinking water, fish, wildlife, and irrigation uses (table 4). In many cases, the elevated concentrations of these elements are from natural sources (Hualapai Water Resources Department, 1995; Monroe and others, 2005; Bills and others, 2007).

At some sites, high trace-element concentrations and radionuclide activity are known to be associated with legacy mines or uranium-ore deposits in breccia pipes that are near the sample site (Wenrich and others, 1994; Hualapai Water Resources Department, 1995; Billingsley, 1997; Monroe and others, 2005; Bills and others, 2007). High concentrations of trace elements at other locations result from dissolution of certain minerals in secondary ore deposits (table 4; arsenic, iron, lead, uranium, zinc). Some high concentrations of other elements probably are related to other recent human-caused and land-management practices (Hualapai Tribe, 1995; Monroe and others, 2005; Bills and others, 2007). Boron concentrations are high in several areas, and although those concentrations may have natural origins, they could also be related to wildfire suppression, mining, or detergents. Water from the springs on the lower Little Colorado River (for example, Blue Spring, fig. 2) generally had higher concentrations of most trace elements than did other springs and streams south of the Colorado River. The differences in water chemistry of these springs and the geologic setting of their points of discharge suggests that either the water that discharges from these systems has resided longer in the flow system, resulting in greater dissolution of minerals, or that the water has traveled along flow paths originating in different source areas (Hart and others, 2002; Bills and others, 2007). Mohawk Canyon Spring, National Canyon Spring, and Bar Four Well also had higher concentrations of many trace elements 


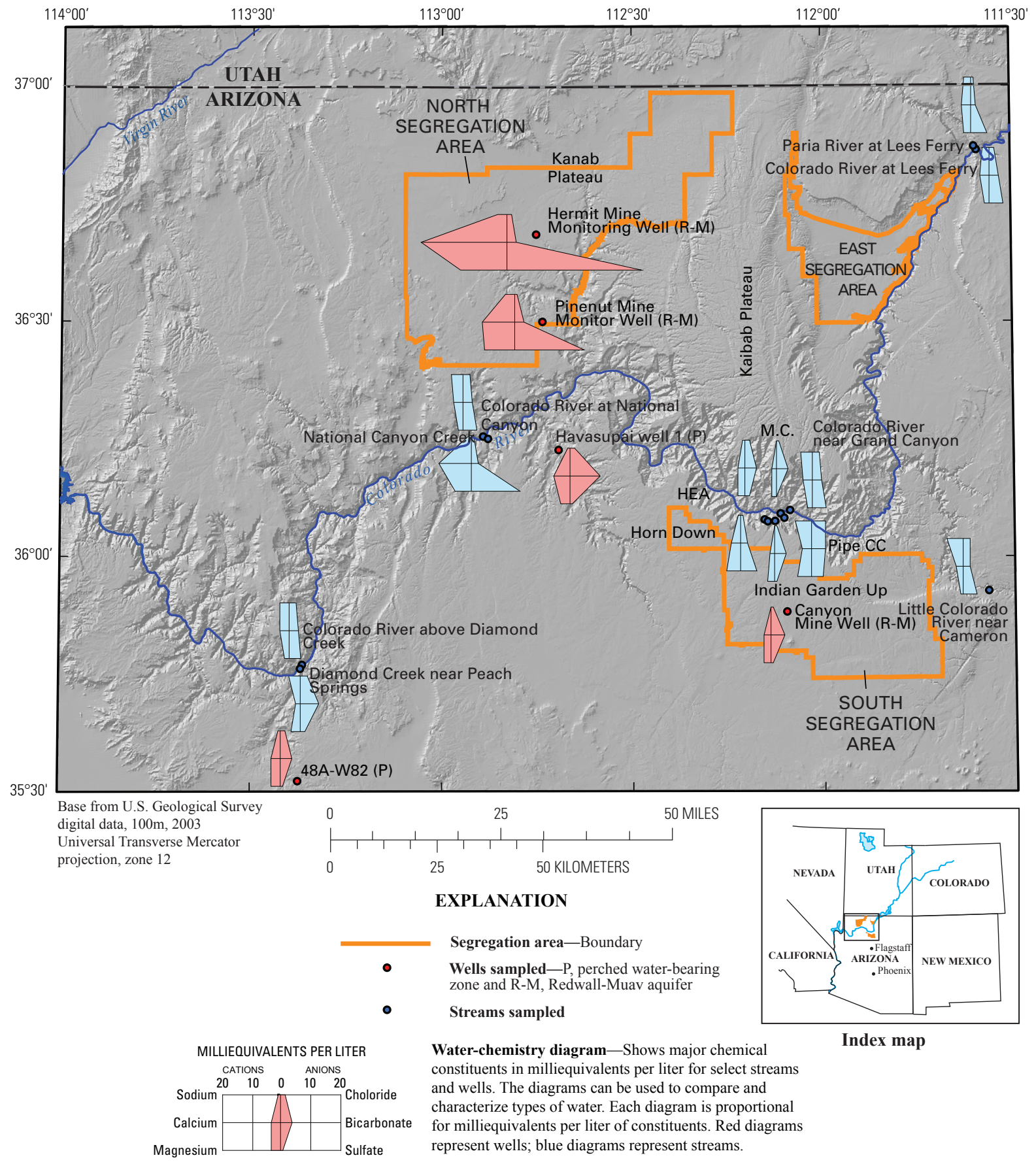

Figure 6. Water chemistry data for selected wells and streams in northern Arizona.

compared with other wells on the Coconino Plateau or springs in Havasu Canyon (figs. 2, 4, 6, 7) (Monroe and others, 2004; Bills and others, 2007). This difference implies that groundwater at Mohawk Canyon Spring, National Canyon Spring, and Bar Four Well have recharge areas and flow paths that differ from those of other groundwater that discharges in areas along the western part of Grand Canyon (fig. 4).

Arsenic and lead are common accessory metals in uranium ore deposits. At 70 sites the average concentrations of arsenic exceeded the primary maximum contaminant level (PMCL) of
$10 \mu \mathrm{g} / \mathrm{L}$, and at 40 sites arsenic concentrations exceeded $100 \mu \mathrm{g} / \mathrm{L}$ (appendix 3; tables 4, 5). Lead concentrations exceeded the PMCL of $15 \mu \mathrm{g} / \mathrm{L}$ at three sites, Havasu Spring, Fern Spring, and Canyon Mine Well (fig. 8) (tables 4, 5) (Bills and others, 2007). High lead concentrations in Kanab Creek and Virgin River water samples that were collected before 1990 - under a less-strict sampling protocol - may reflect contamination (tables 4, 5).

Recent samples collected from sites on Kanab Creek and from the Canyon Mine Well all have lead concentrations less than $0.3 \mu \mathrm{g} / \mathrm{L}$ (appendix 2). 

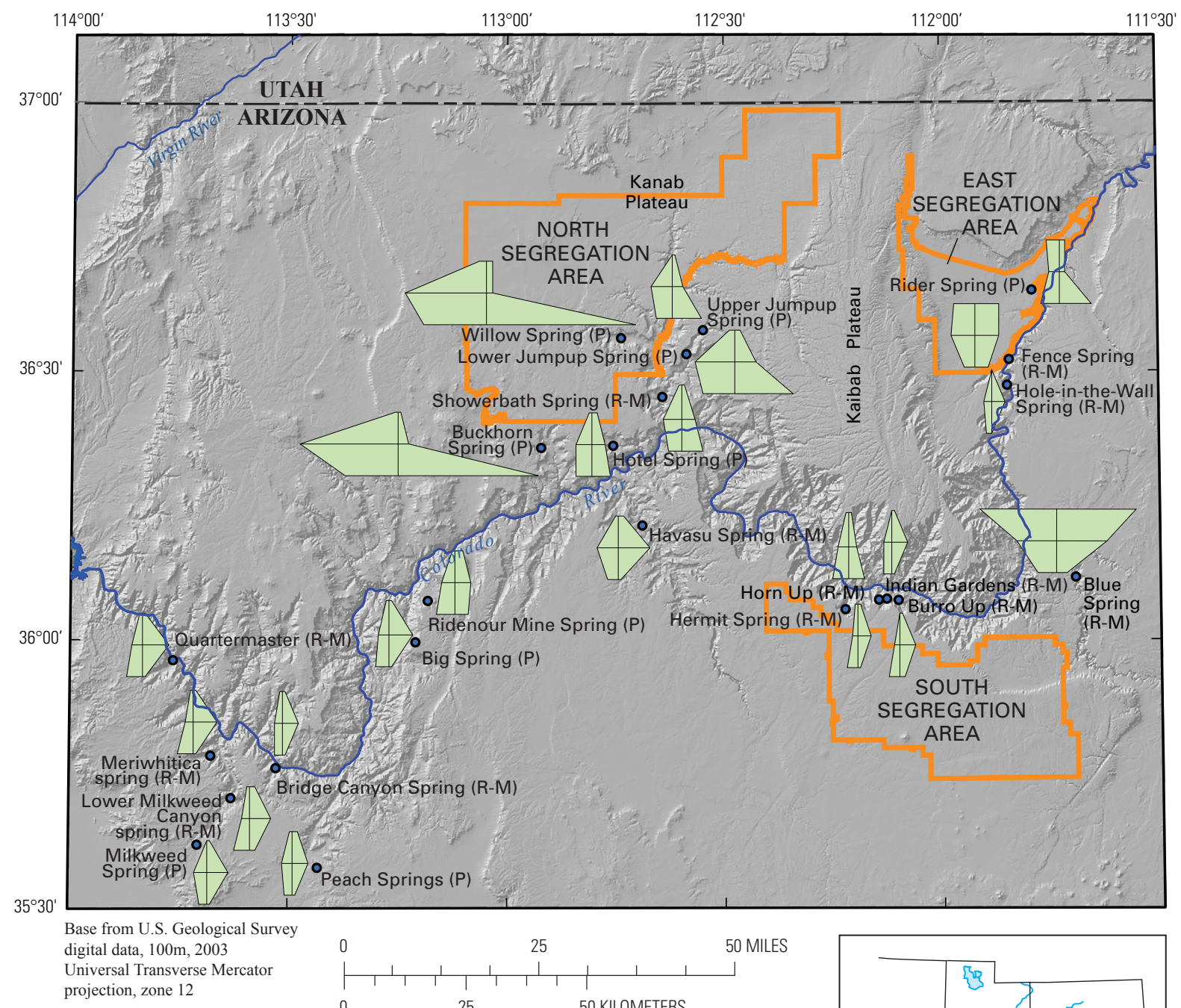

projection, zone $12 \quad 0 \quad 250$ KILOMETERS

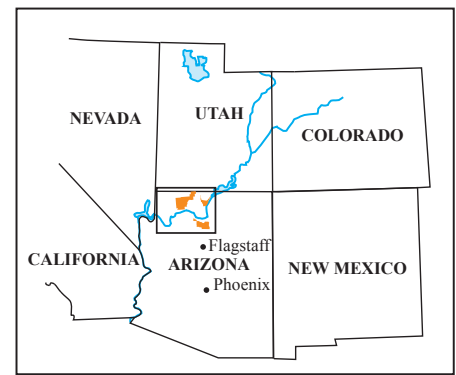

Index map

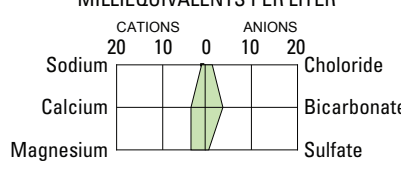

Water-chemistry diagram-Shows major chemical constituents in milliequivalents per liter for select springs. The diagrams can be used to compare and characterize types of water. Each diagram is proportional for milliequivalents
per liter of constituents.

Figure 7. Water chemistry data for selected springs in northern Arizona.

Radioactive constituents were near or above PMCL at a few sites (appendixes 2, 4; tables 4, 6-9). Uranium concentrations in samples from Salt Creek Spring (average, $30.6 \mu \mathrm{g} / \mathrm{L}$ ) exceeded U.S. Environmental Protection Agency (USEPA) PMCL of $30 \mu \mathrm{g} / \mathrm{L}$ (fig. 9). One sample from Horn Creek had a concentration only slightly lower than the PMCL $(29.2 \mu \mathrm{g} / \mathrm{L})$. Previous studies have found high gross-alpha-particle activity in samples from Salt Creek Spring and Horn Creek (Monroe and others, 2005; Bills and others, 2007). Salt Creek and Horn Creek are downgradient from the abandoned Orphan Lode Mine site, a breccia pipe that has been mined for copper and uranium (plate 1). The high gross-alpha-particle activity and uranium concentrations at these sites are likely related to the pipe or to mining activity (Fitzgerald, 1996; Monroe and others, 2005; Bills and others, 2007). Samples from Turquoise Creek, Forster Canyon Spring No. 2, Mohawk Canyon Spring, and the Bar Four Well near the village of Supai all had unadjusted gross-alpha-particle activities greater than $14 \mathrm{pCi} / \mathrm{L}$ (Monroe and others, 2005; Bills and others, 2007). The unadjusted gross-alpha-particle data from a water sample recently collected from Willow Spring in Hack Canyon is also high (appendix 2). These sites are near or downstream from breccia pipes that are known to concentrate uranium ores on this part of the Coconino and Kanab Plateaus (Wenrich and others 1994; Billingsley and others, 1997; Wenrich and others, 1997). 


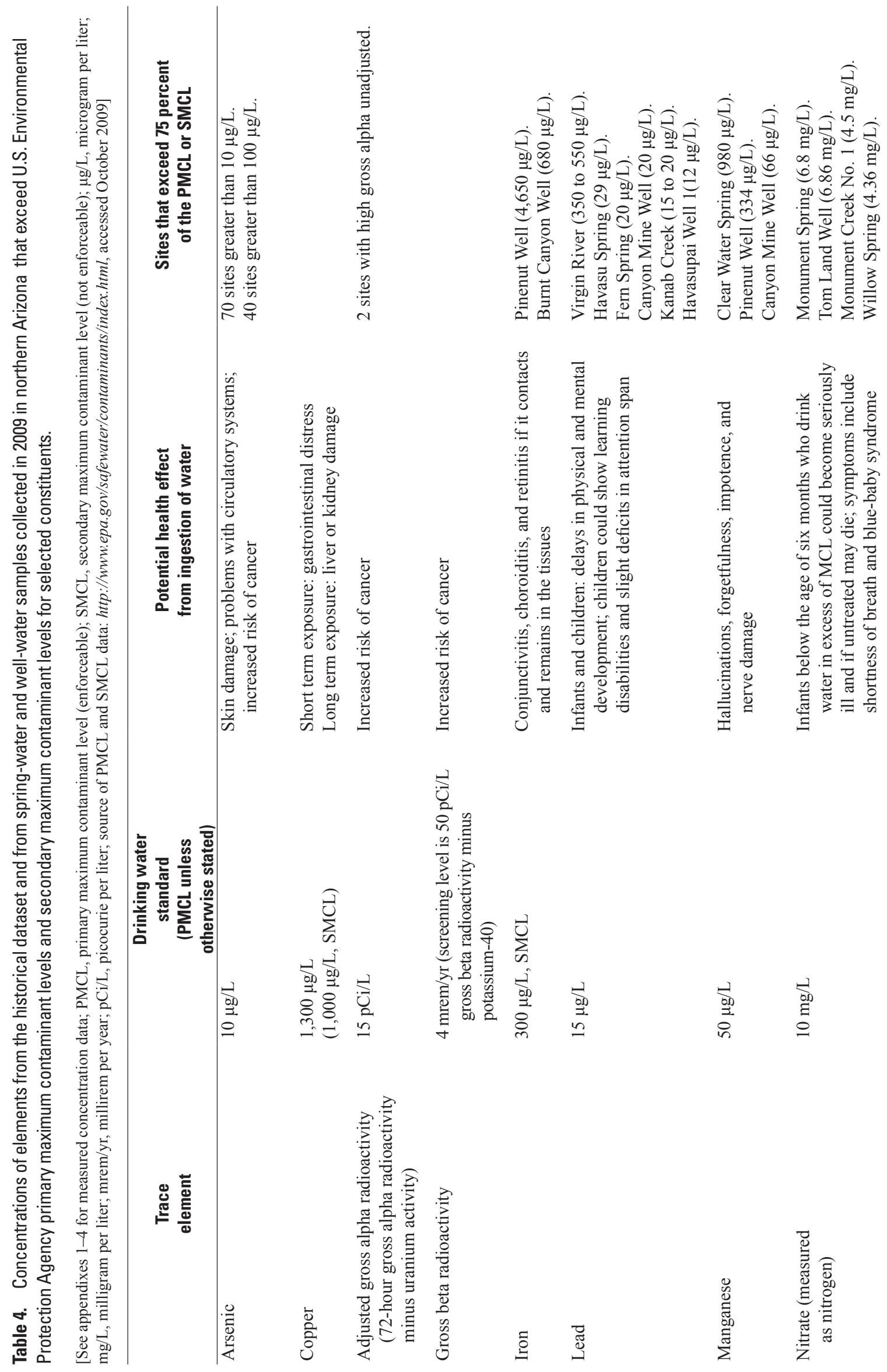




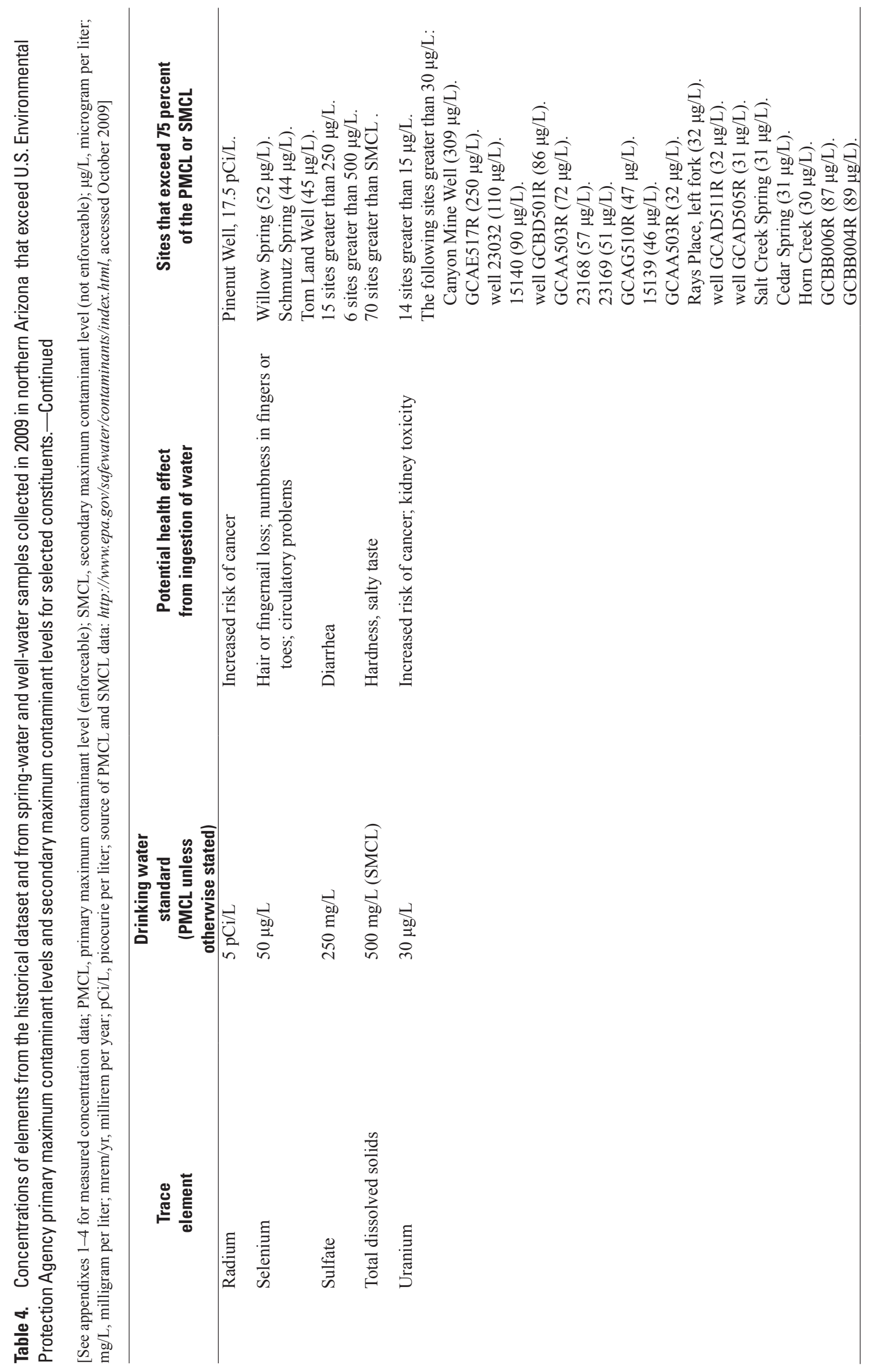




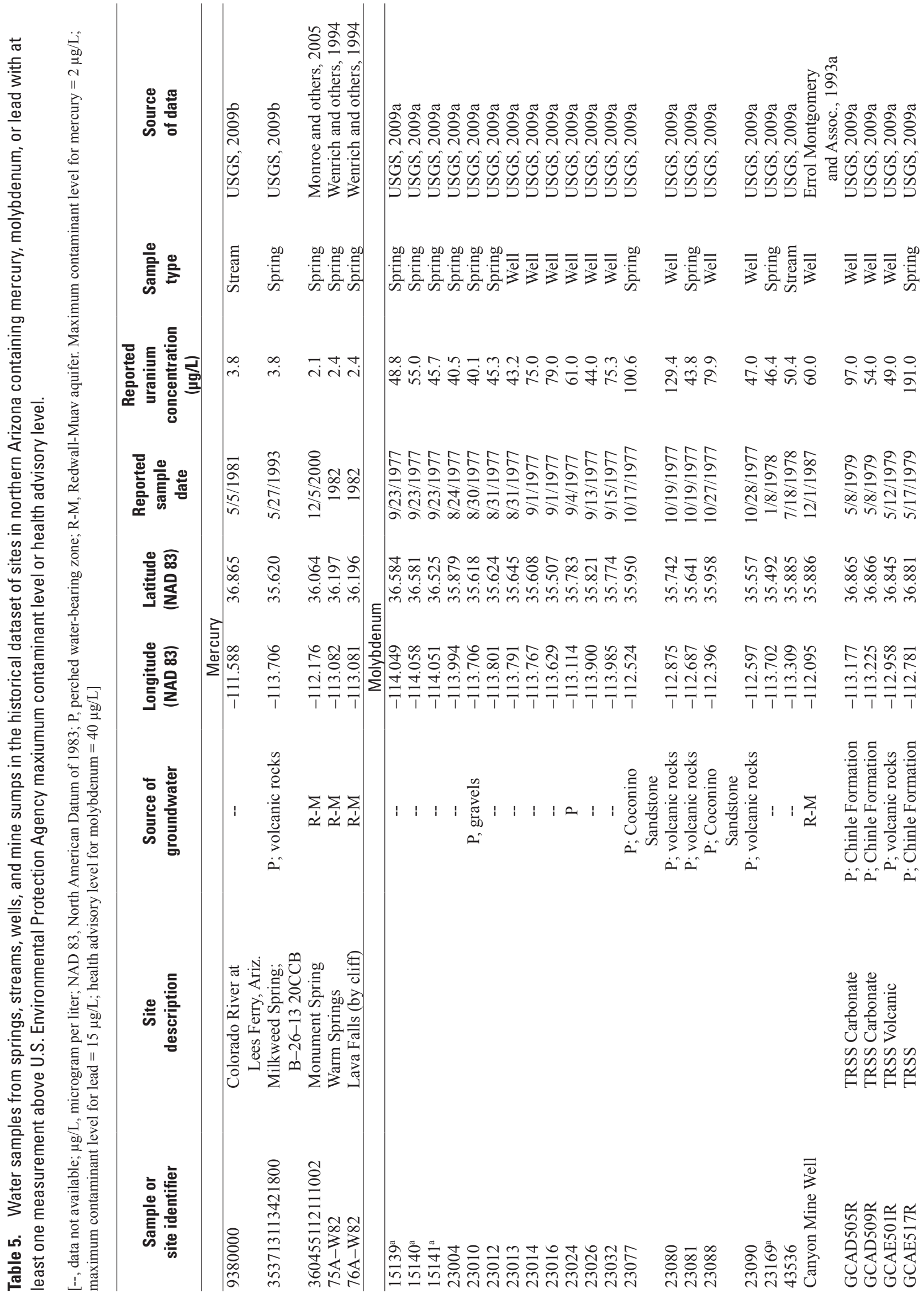




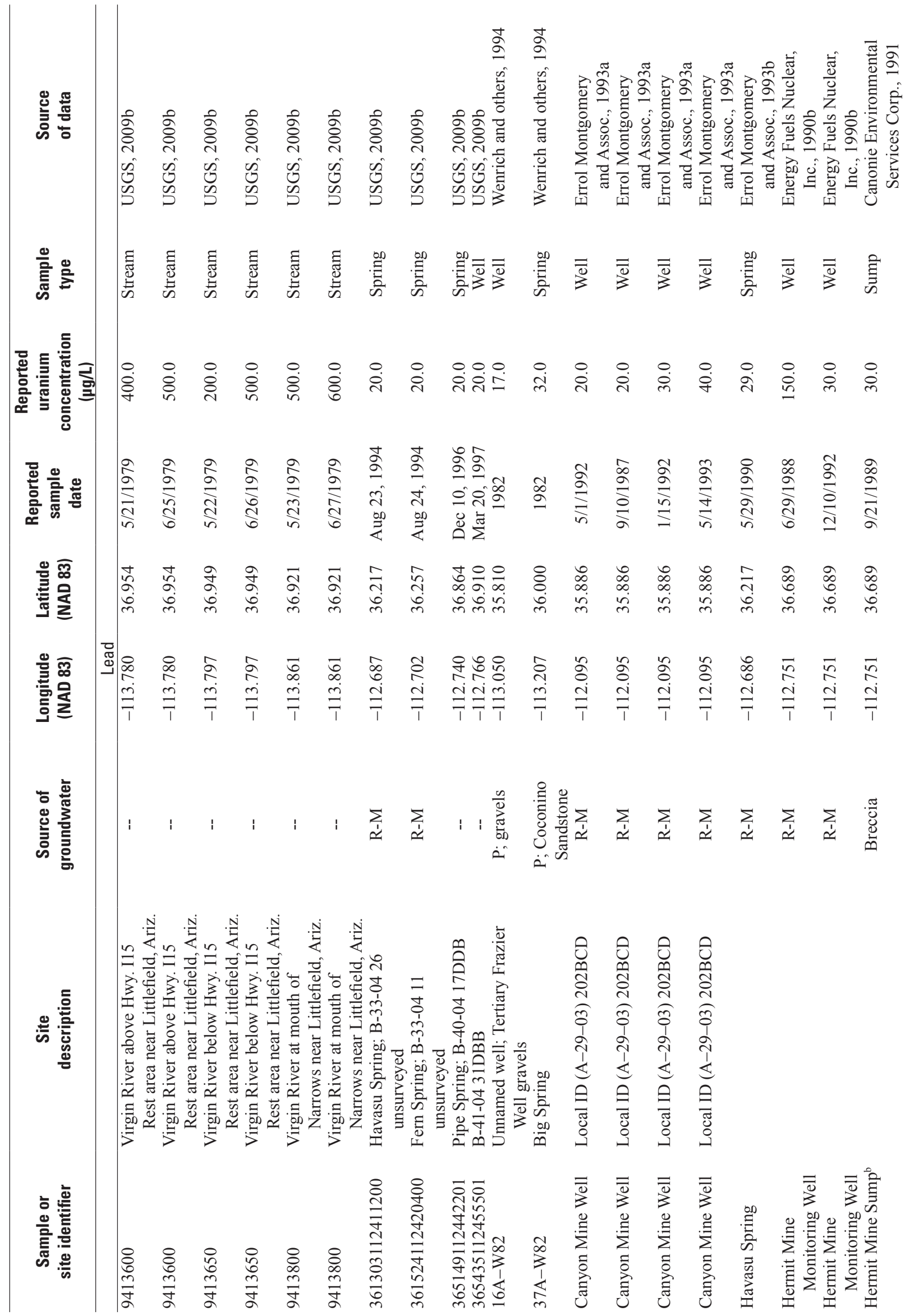




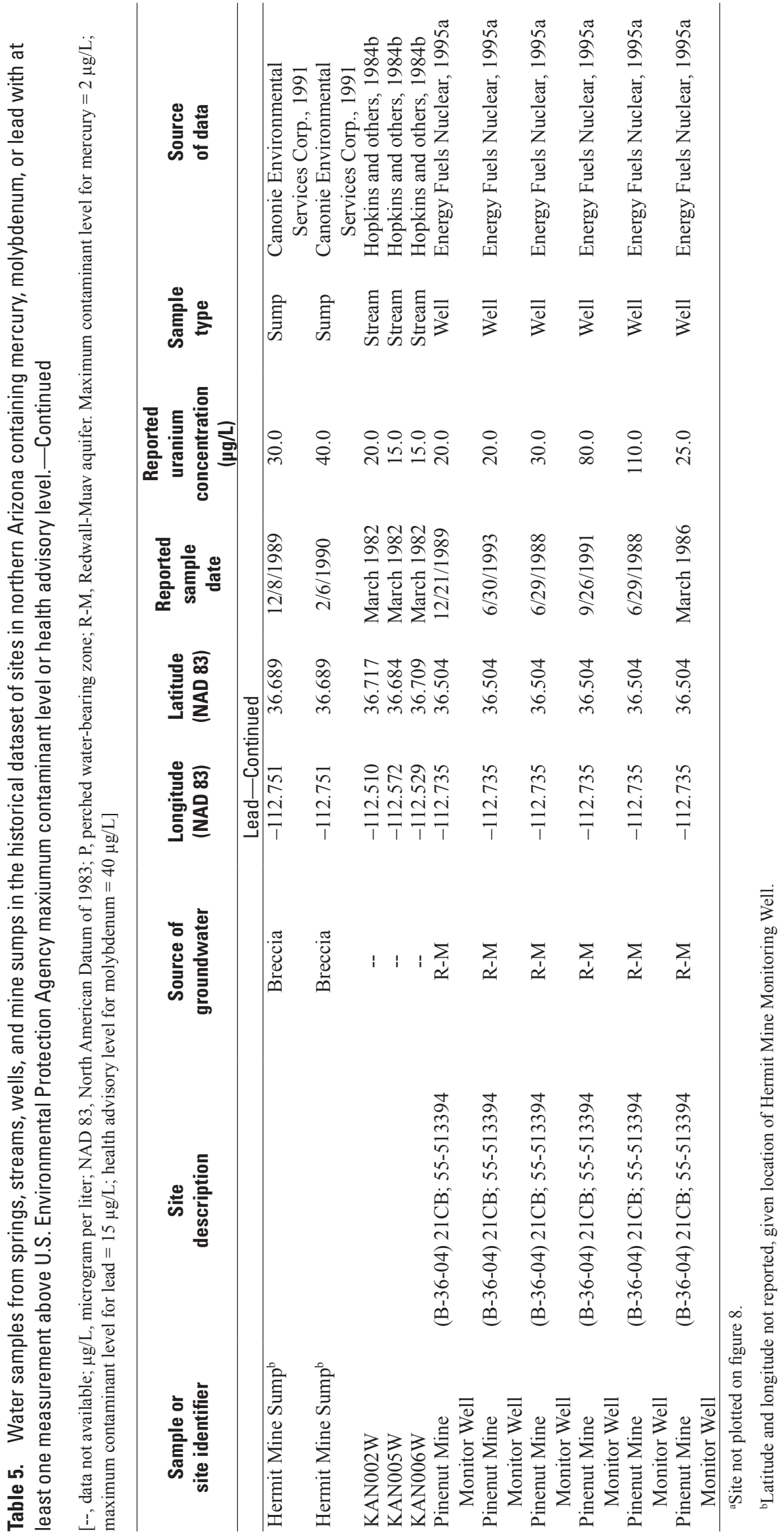




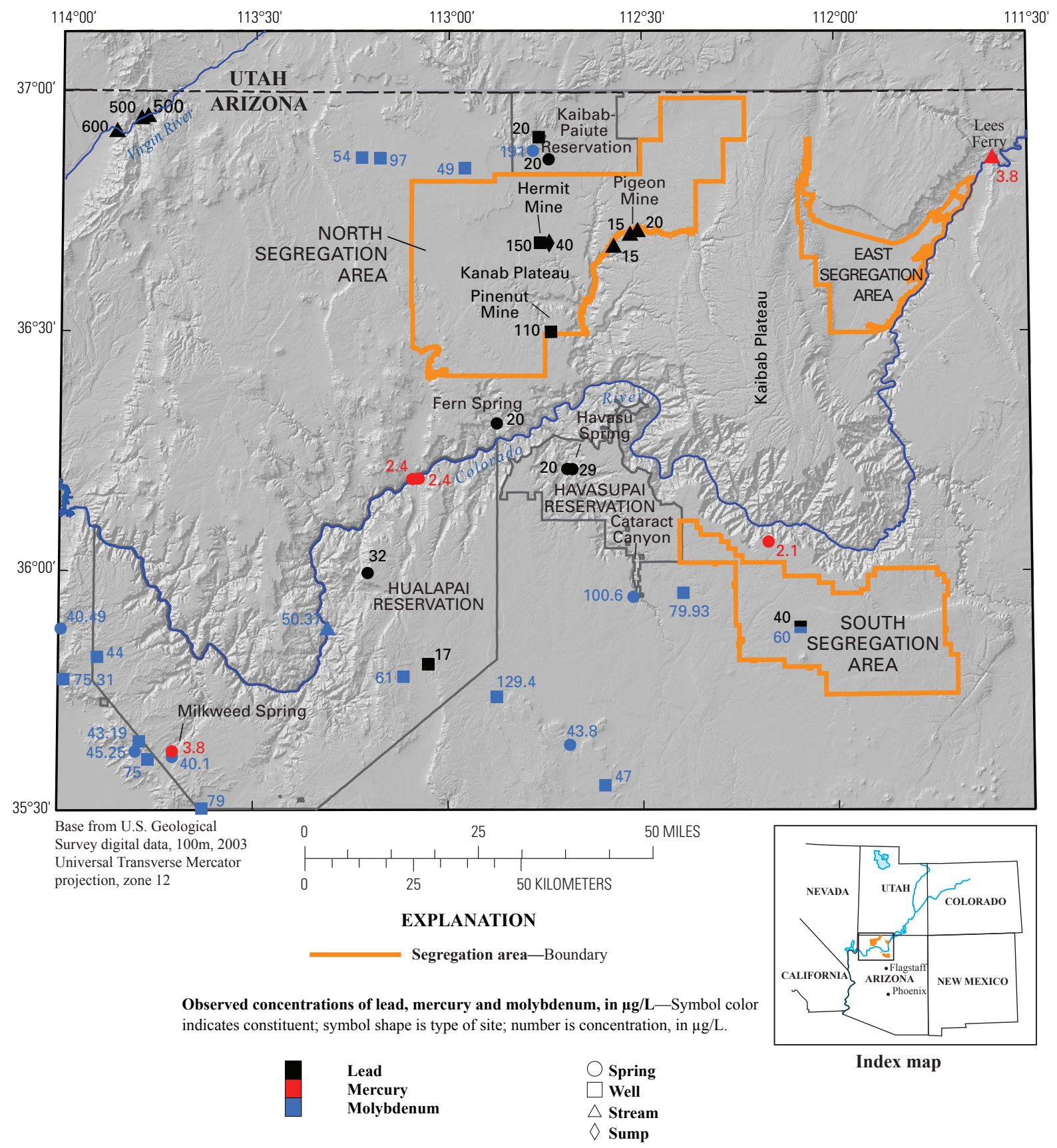

Figure 8. Selected spring, stream, well, and sump sites from the historical dataset for northern Arizona, table 5, at which concentrations of lead and mercury exceed U.S. Environmental Protection Agency maximum contaminant level of 15 and 2 micrograms per liter, respectively, and molybdenum exceeds U.S. Environmental Protection Agency health advisory level of 40 micrograms per liter. 


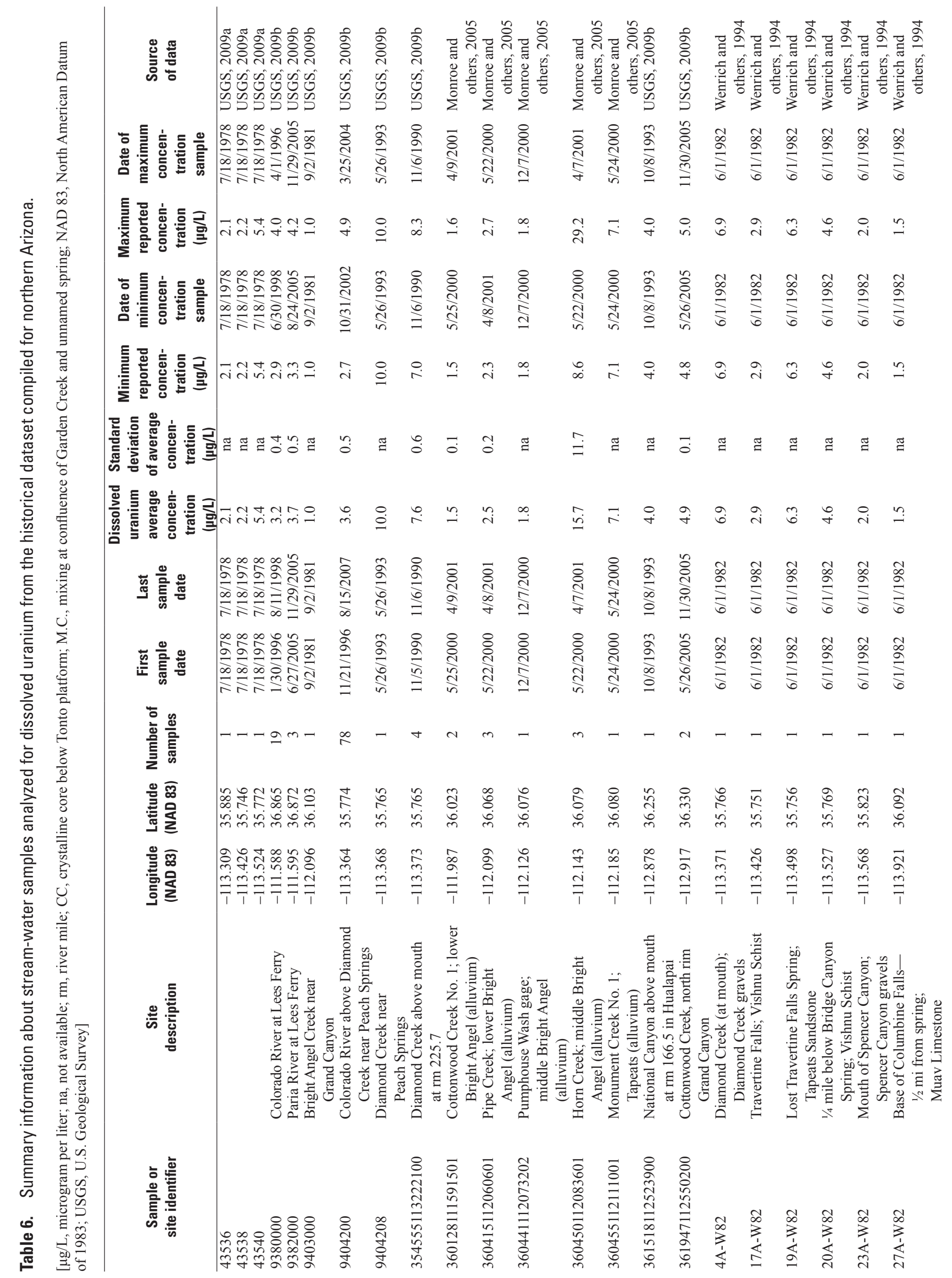




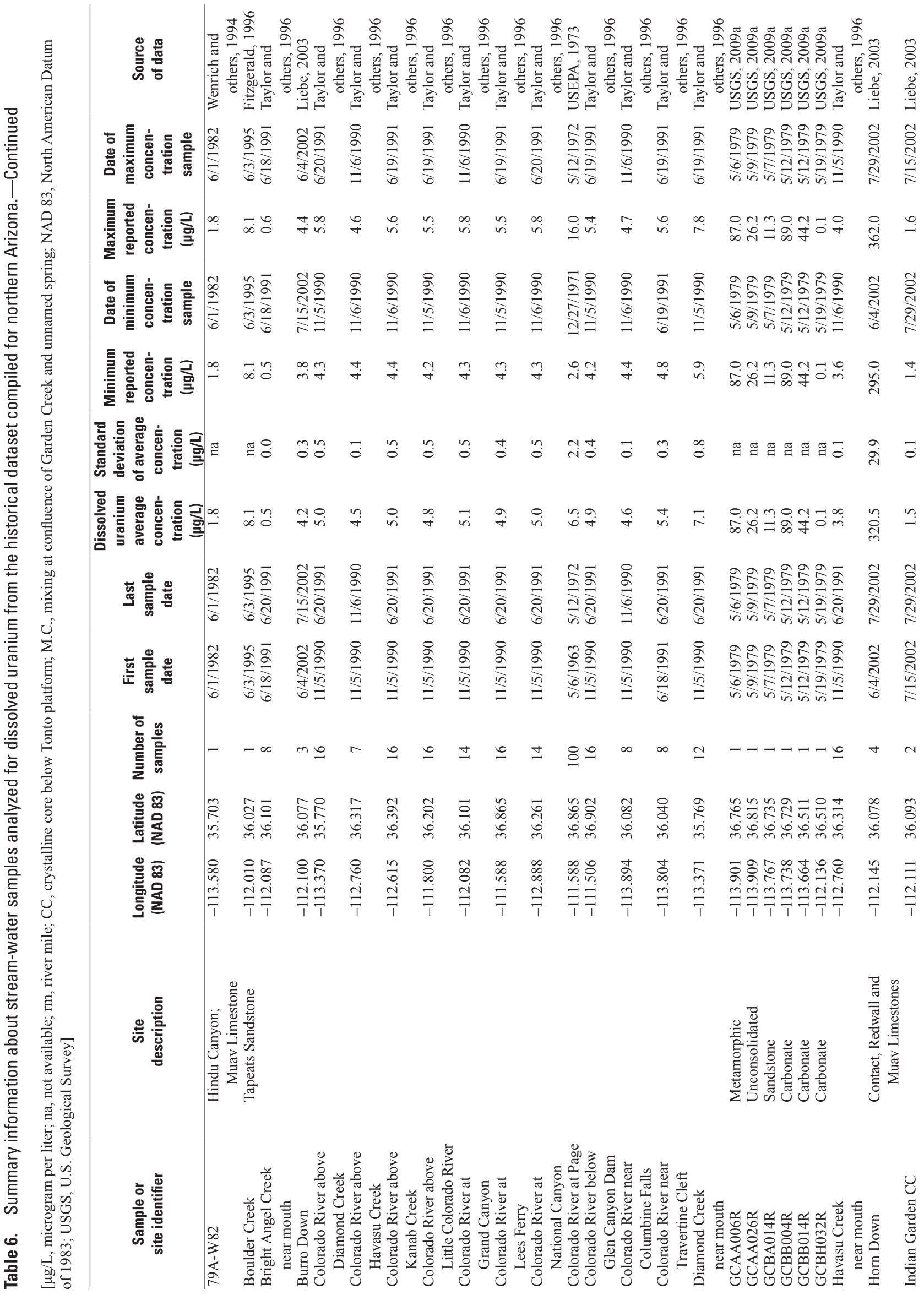




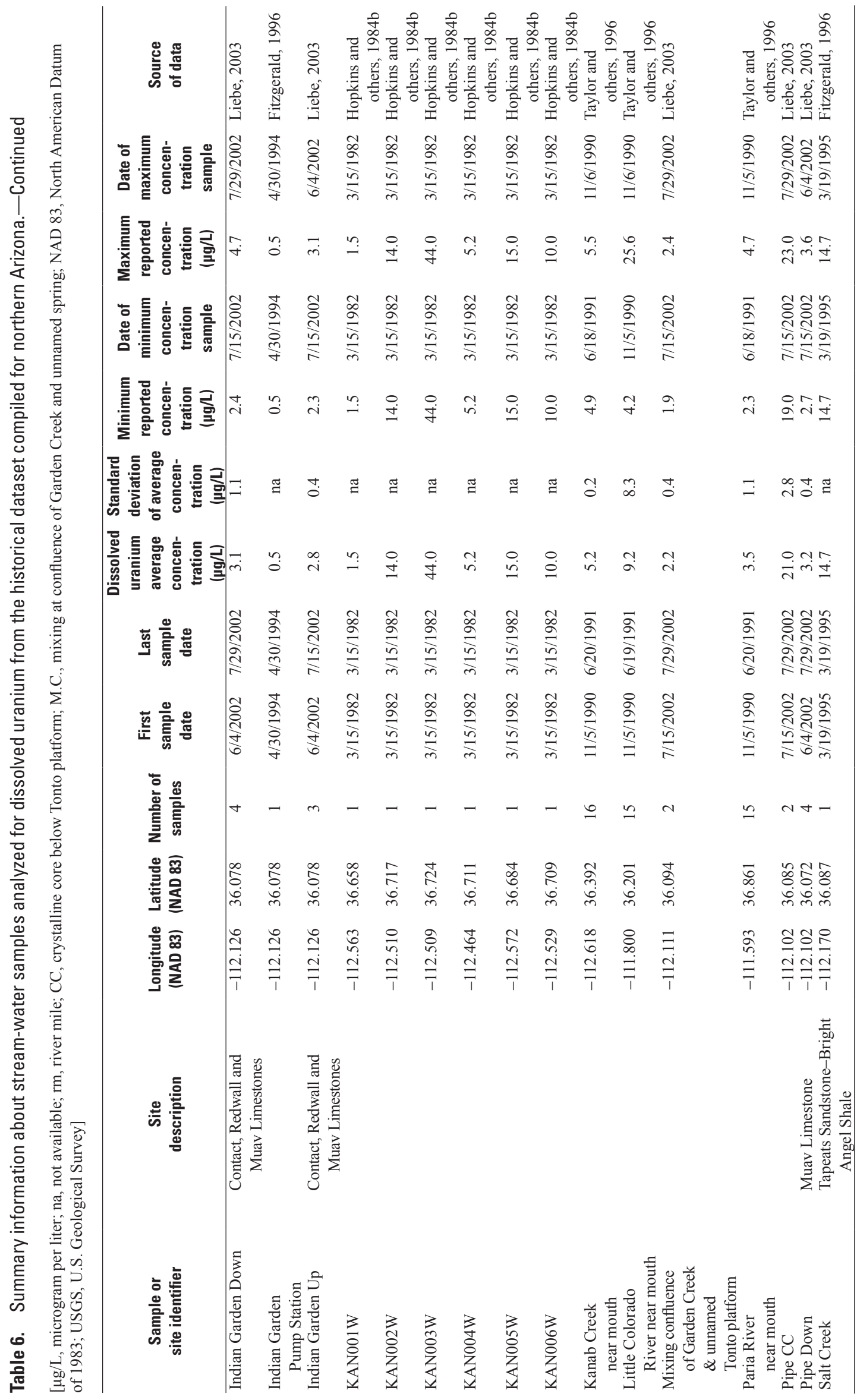




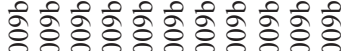

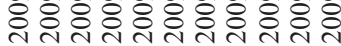
in

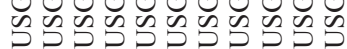

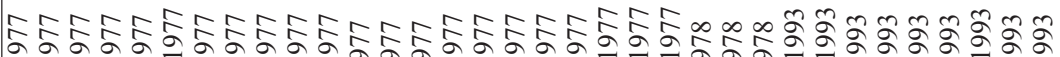

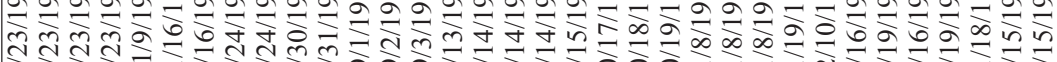

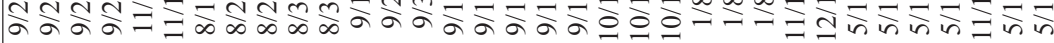

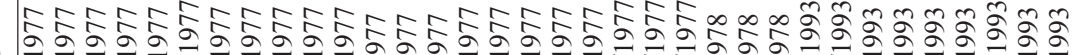

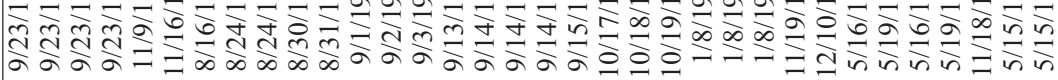

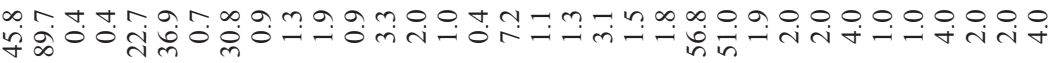

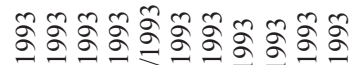

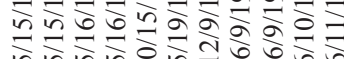

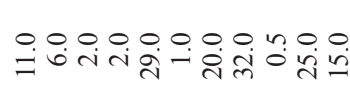

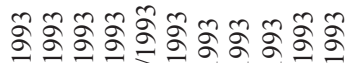

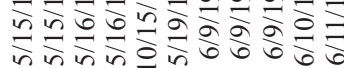

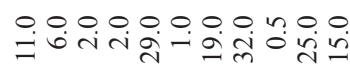
$\dddot{g} \dddot{g} \dddot{g} \mathfrak{\sigma} \cong \dddot{g} \dddot{g}$

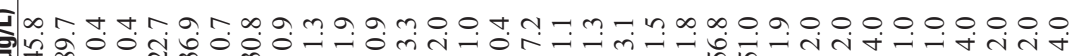

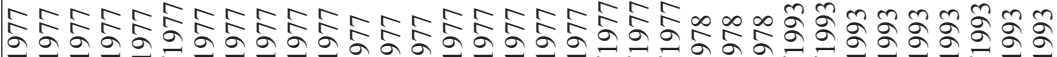
ल ल্য

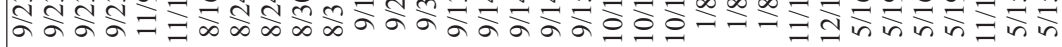

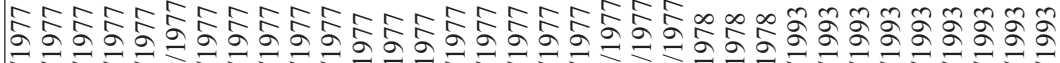

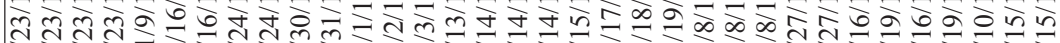
후유

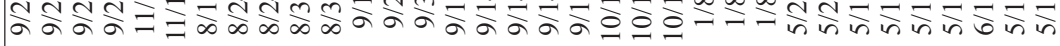

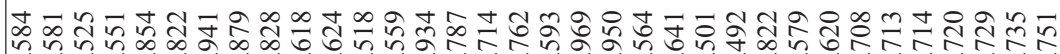

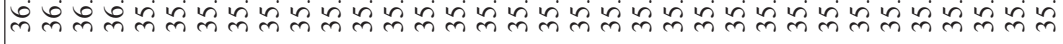

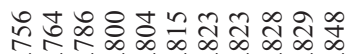

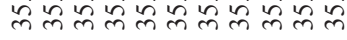

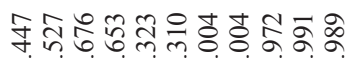

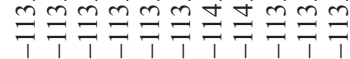

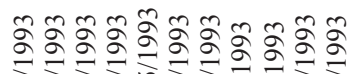
in

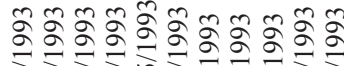

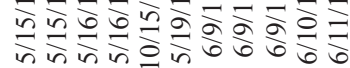
9
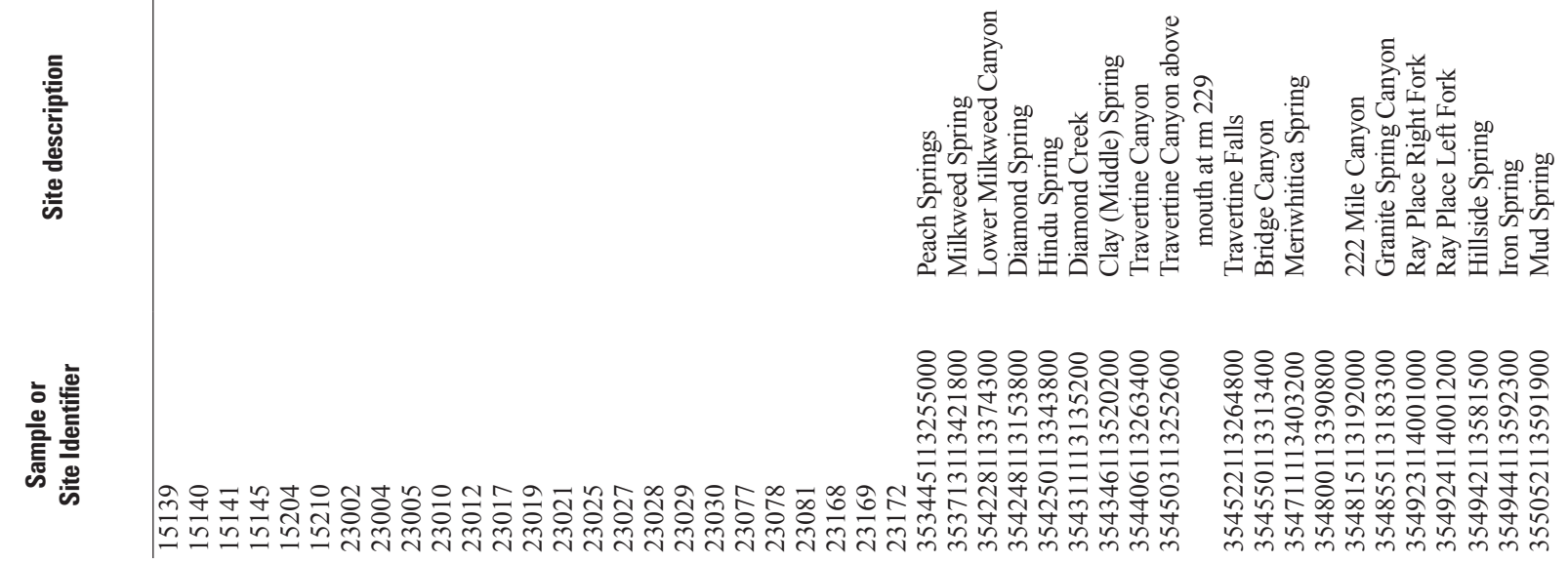
产䌟
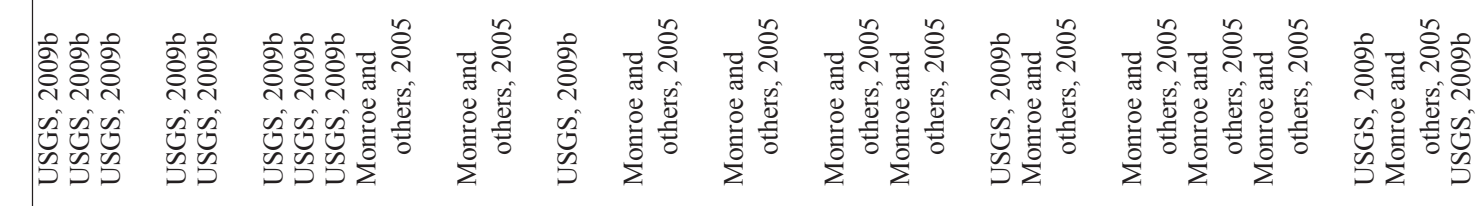

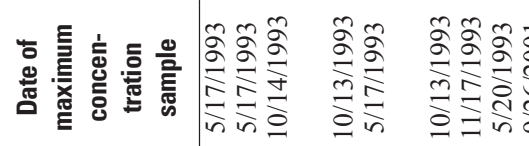

II

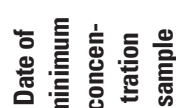

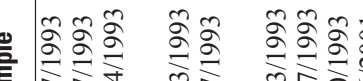

in 要方

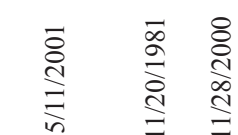

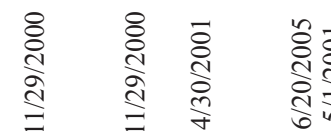

응

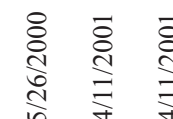

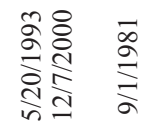

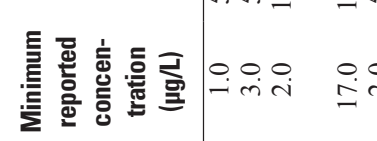

어

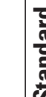

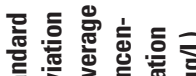

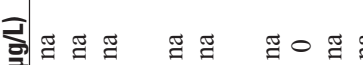

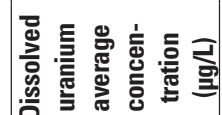

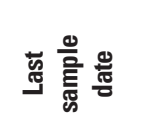

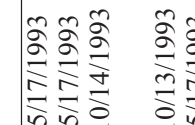

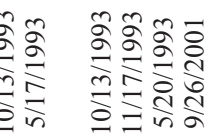

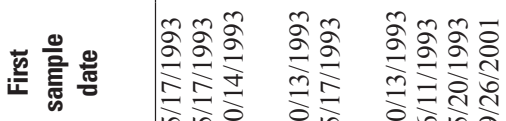

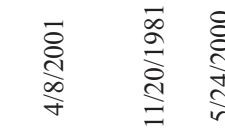

$\stackrel{\infty}{-} \underset{\infty}{\infty}=$

กํํํ.

$\stackrel{9}{i} \vec{i}$

$\stackrel{\infty}{\infty} \stackrel{0}{i}$

就

害

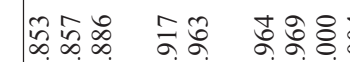

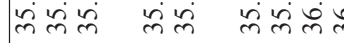

童离

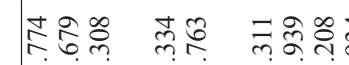

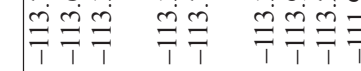

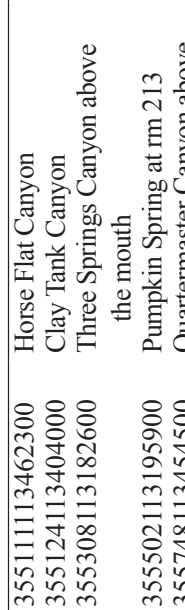

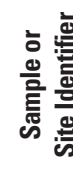

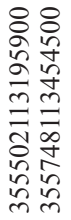

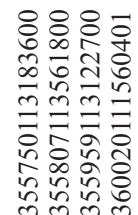

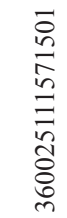

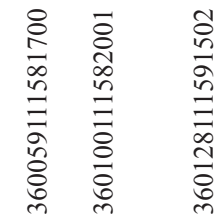

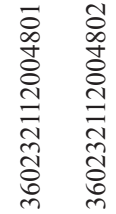

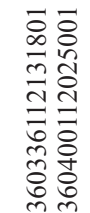

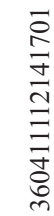

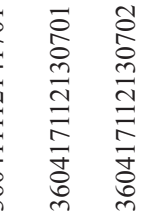

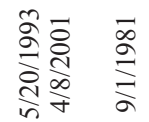

$\stackrel{\infty}{\circ} \stackrel{i}{i} \quad \stackrel{0}{i}$

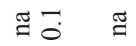

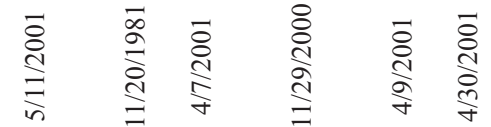

㠃高

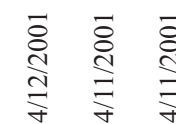

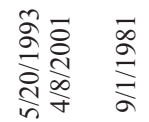

ํํㅇํํ

๕ัญ ๕

๗ूㅇํ

กิ

I

in 


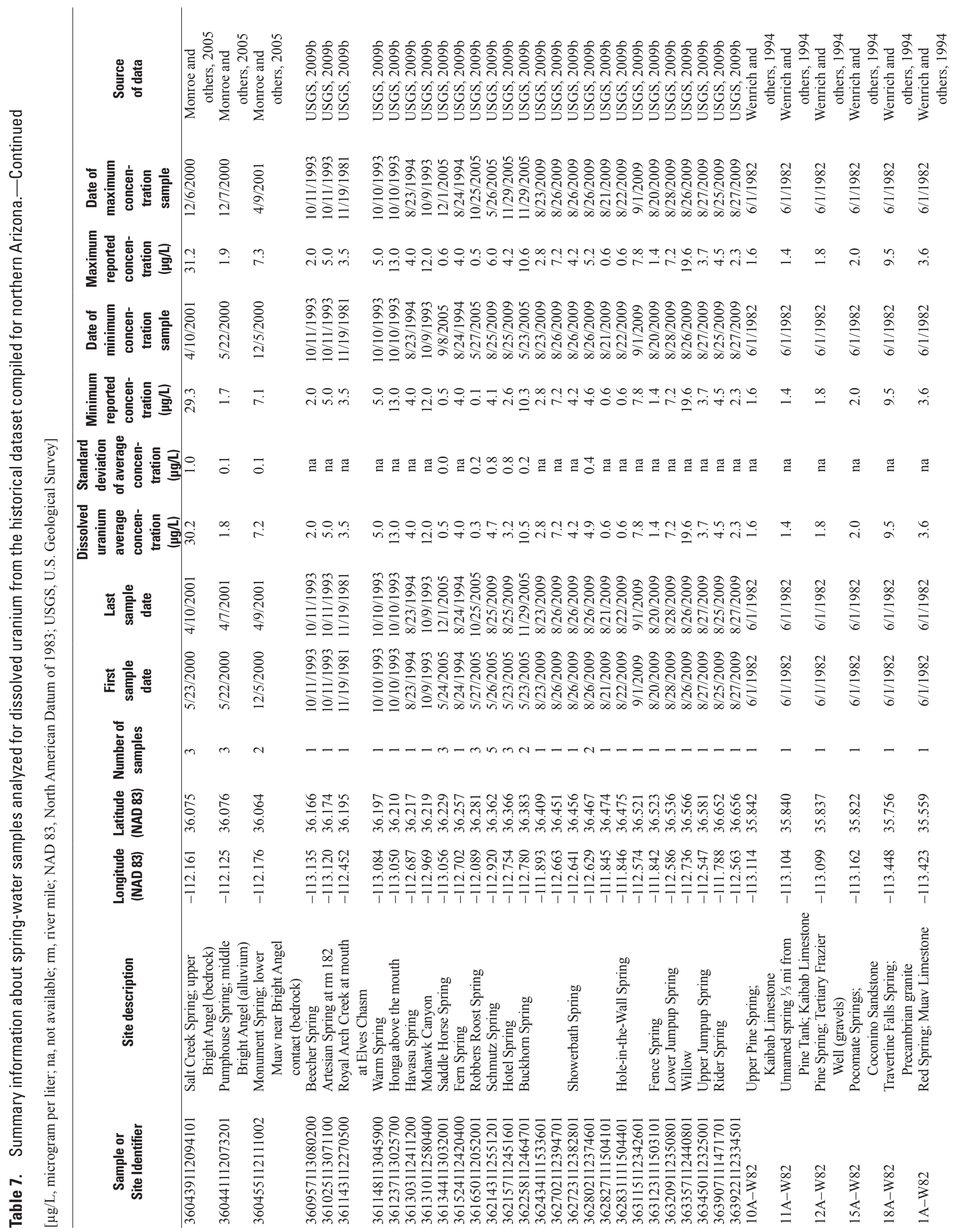




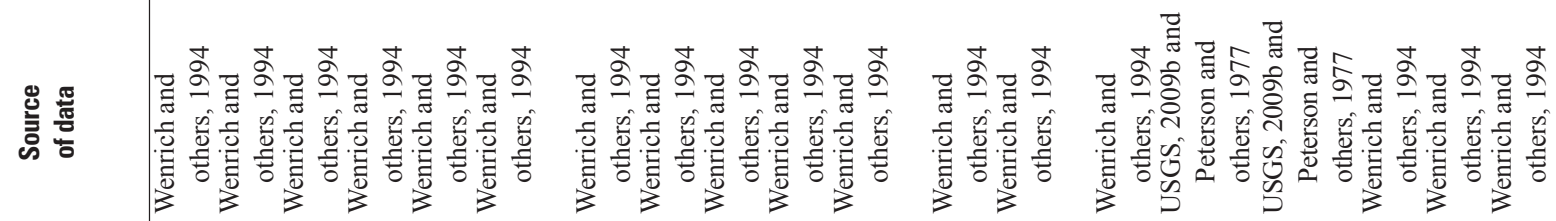

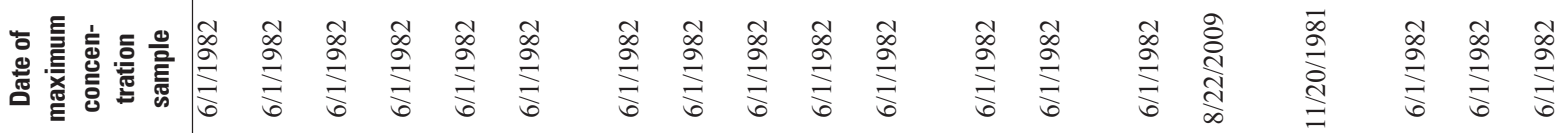

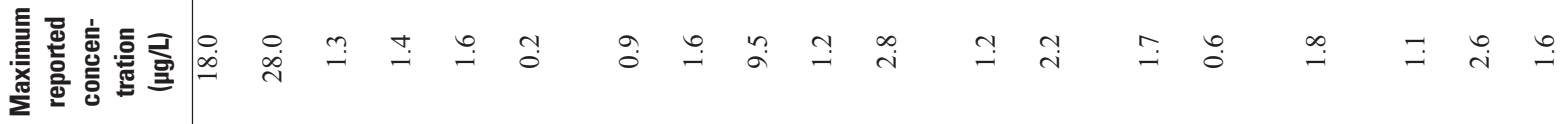

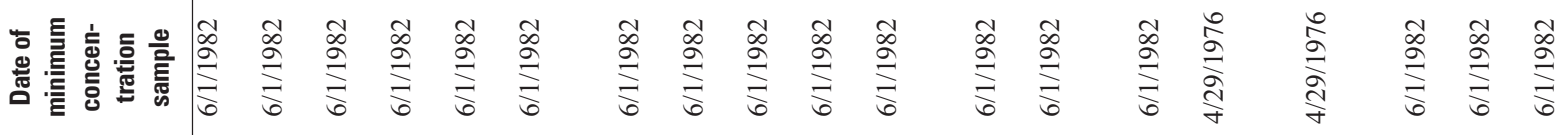

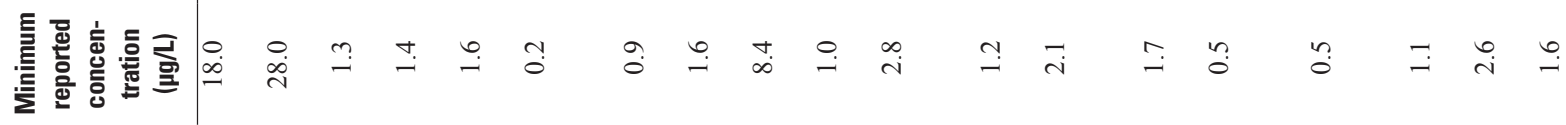

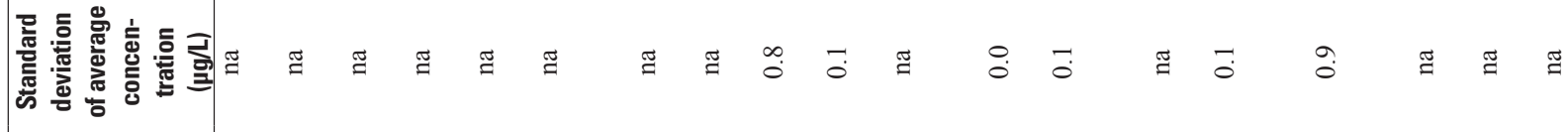

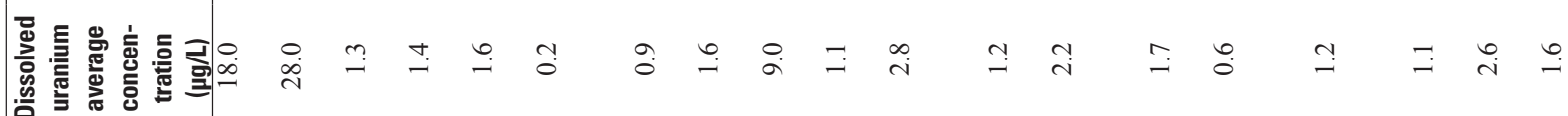

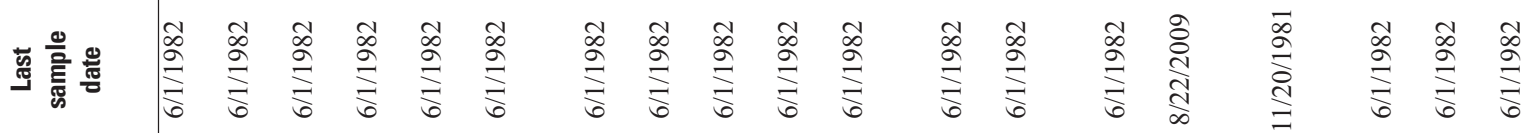

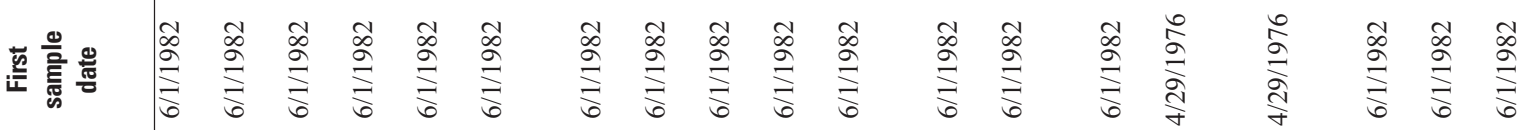

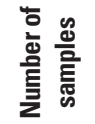

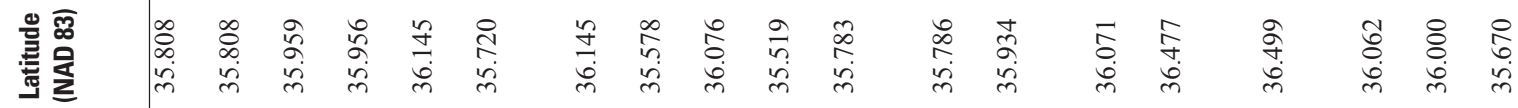

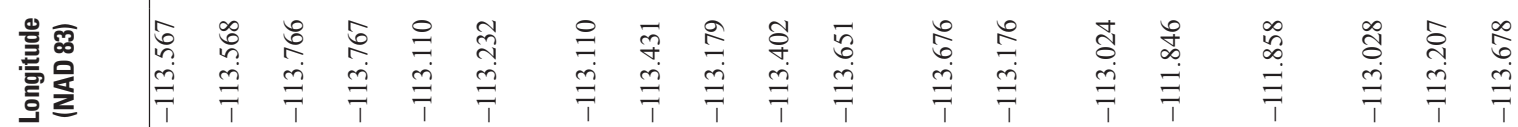

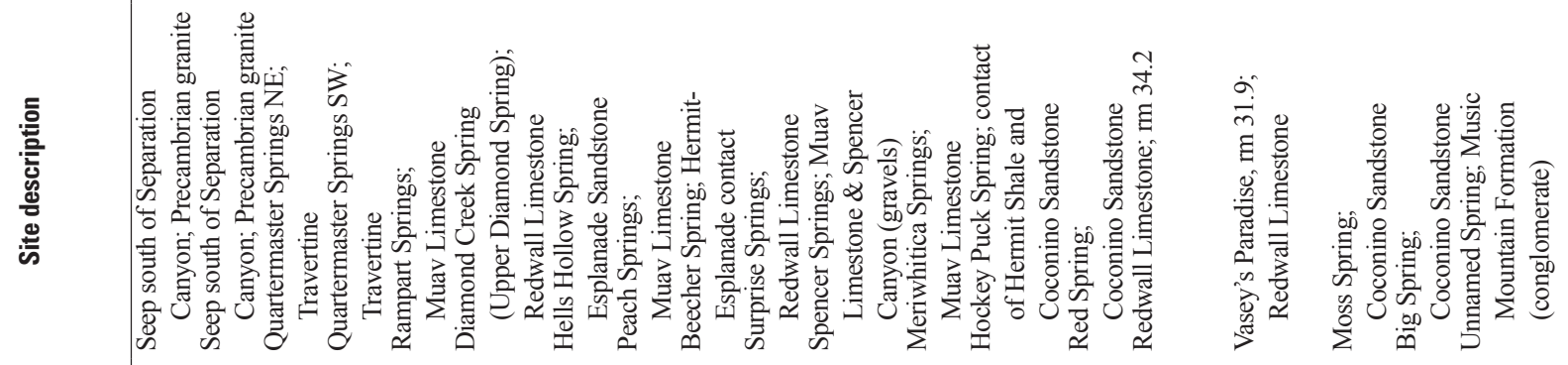

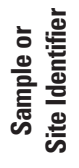

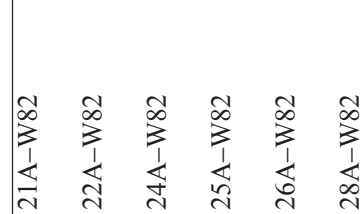

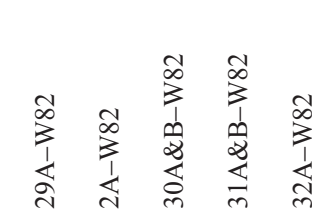

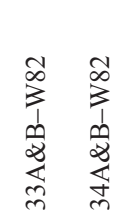

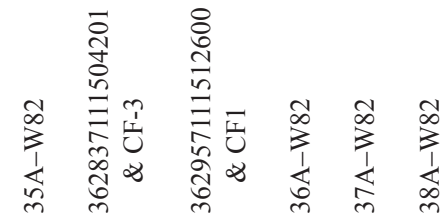




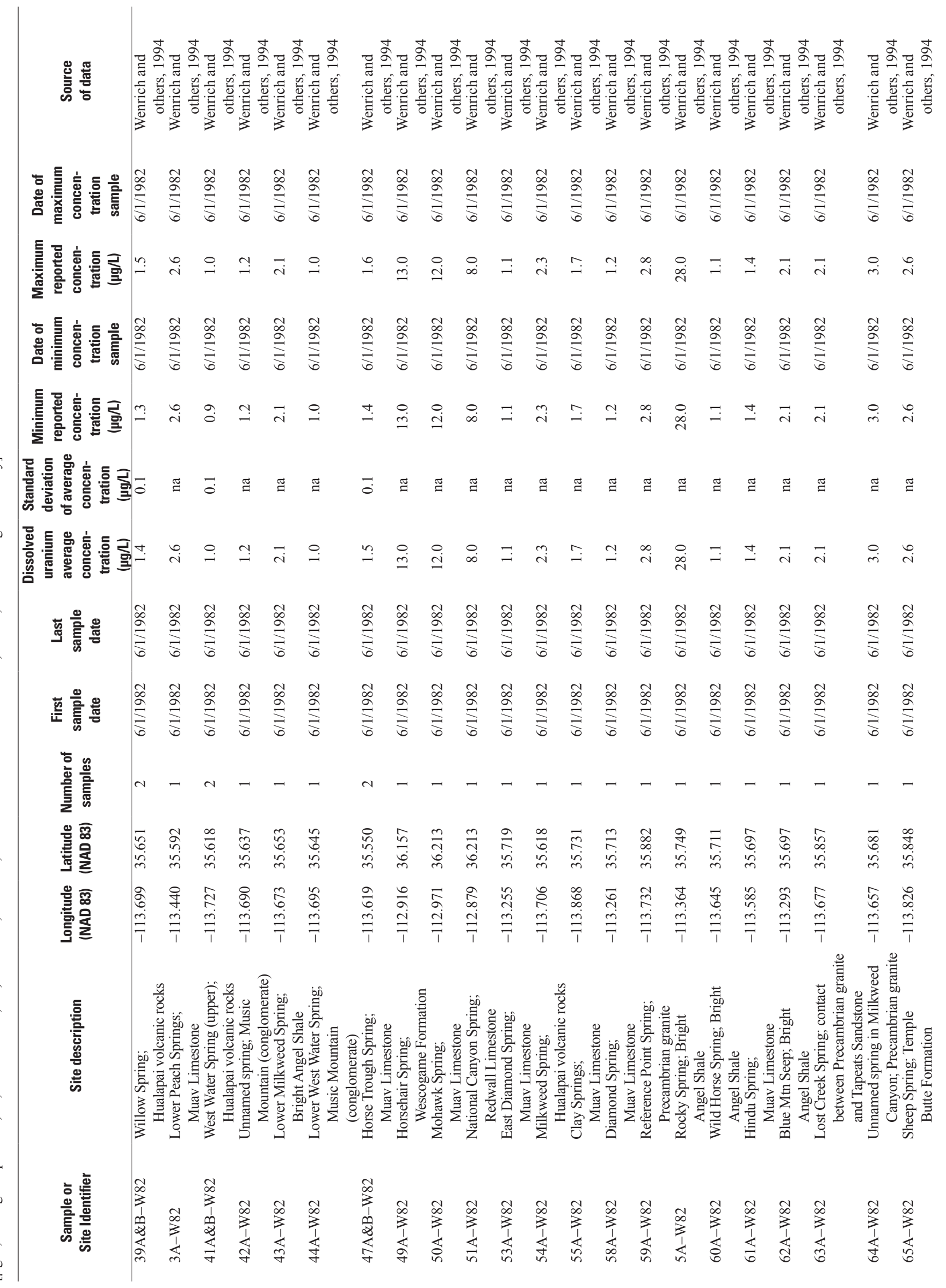




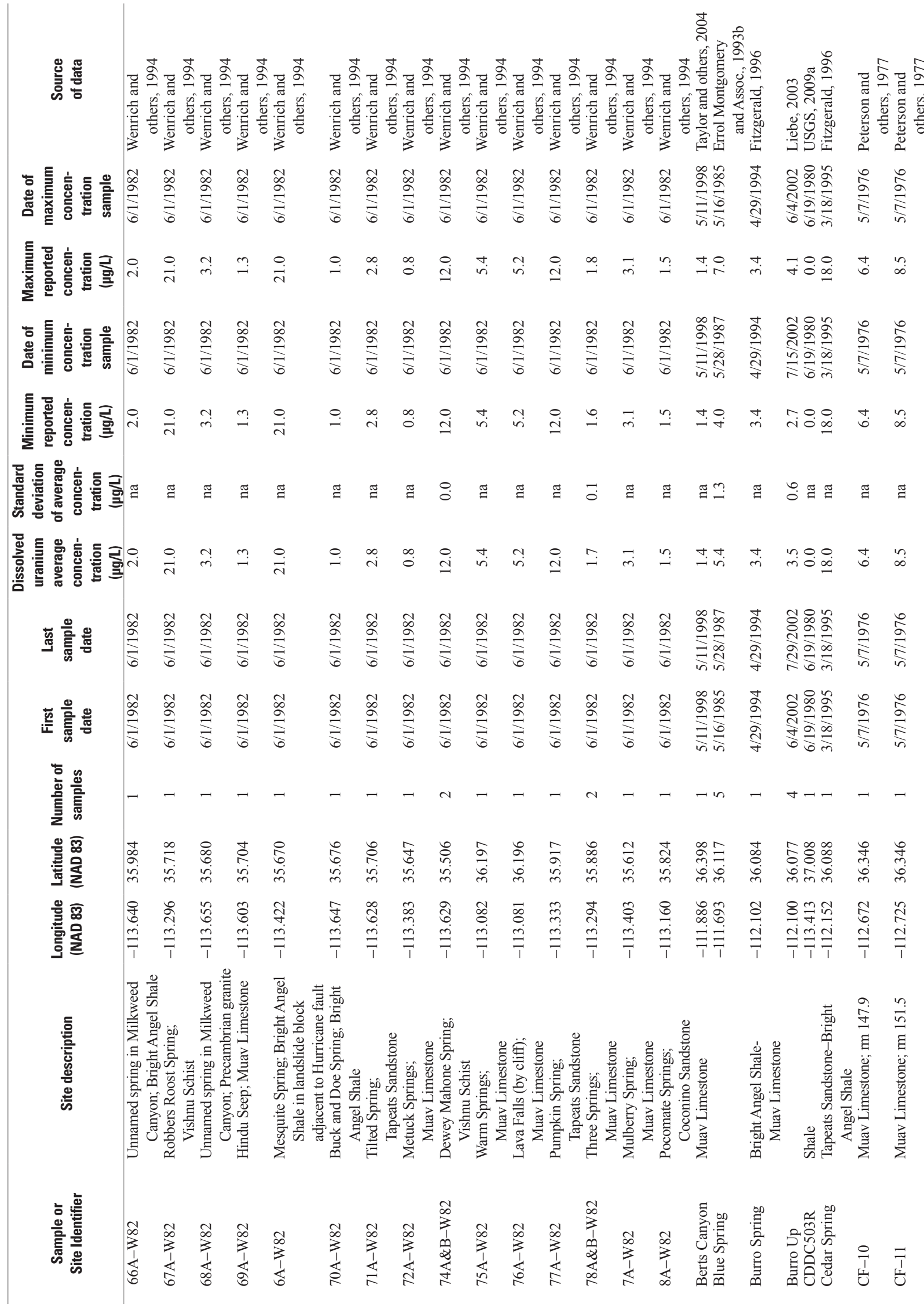




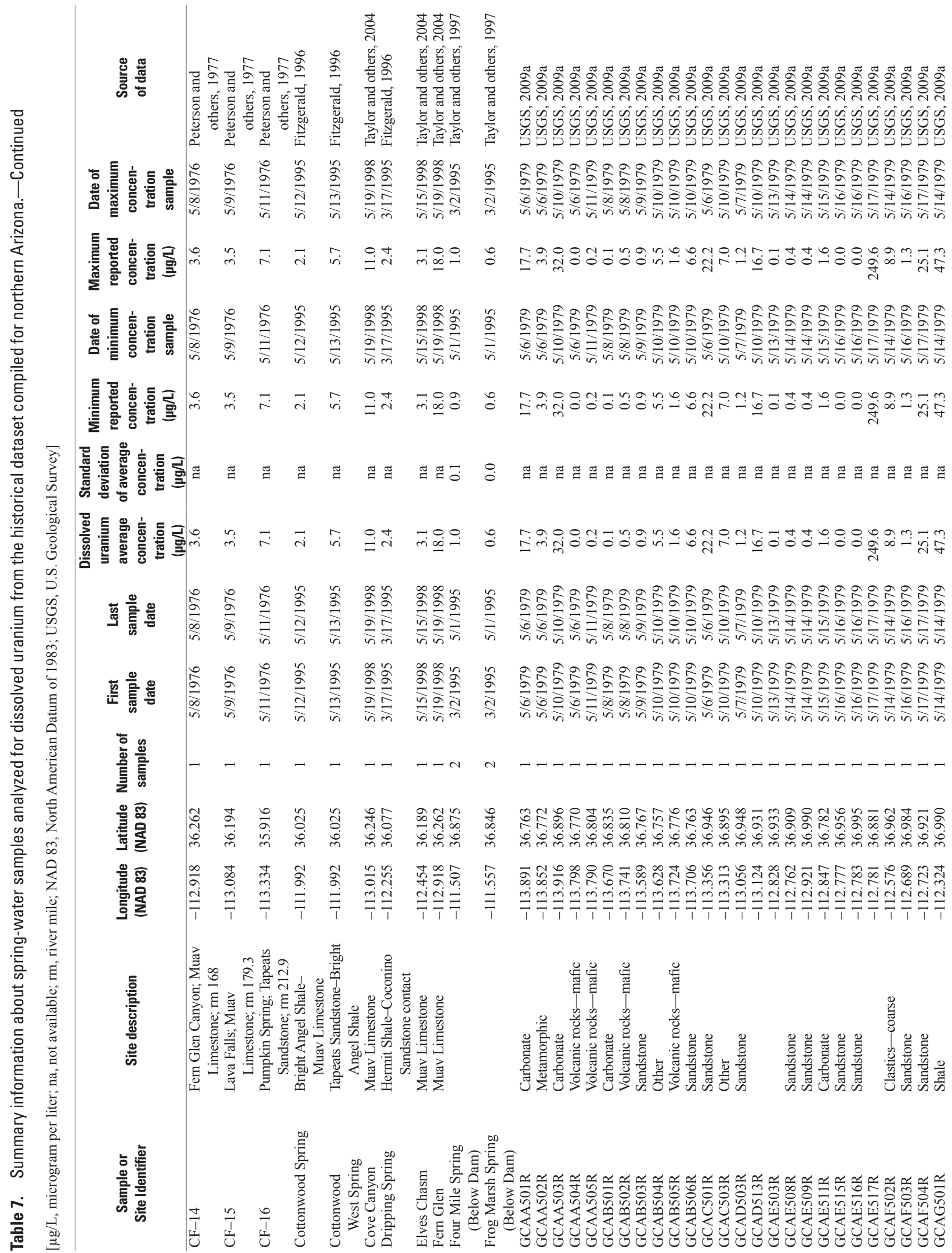




\begin{tabular}{|c|c|c|c|c|c|c|c|c|c|}
\hline 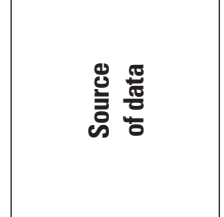 & 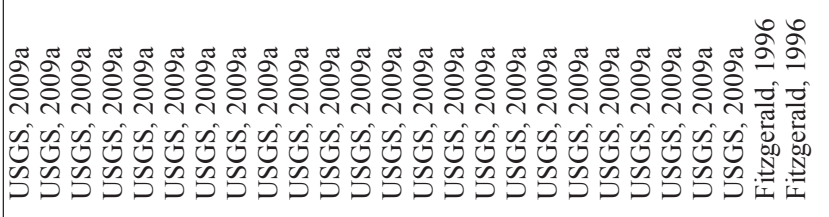 & 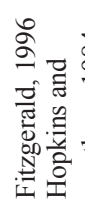 & & & & & & & \\
\hline 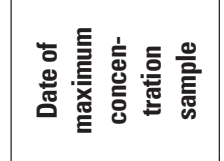 & 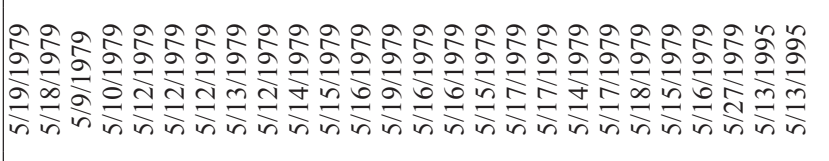 & $\frac{n}{2} \bar{\alpha}$ & $\underset{\infty}{\stackrel{\infty}{n}}$ & $\underset{\infty}{\stackrel{\infty}{m}}$ & $\underset{\infty}{\stackrel{\infty}{\infty}}$ & $\frac{\vec{\infty}}{\stackrel{5}{n}}$ & $\underset{\substack{\infty \\
\frac{\infty}{m}}}{\stackrel{5}{m}}$ & $\frac{\vec{\infty}}{\frac{\infty}{n}}$ & \\
\hline 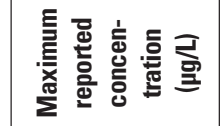 & 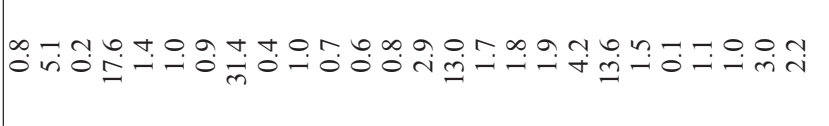 & $\begin{array}{c}m \\
\infty\end{array}$ & $\exists$ & กี & $\stackrel{\text { I }}{-}$ & $\infty$ & $\stackrel{\infty}{+}$ & $\mathrm{N}$ & \\
\hline 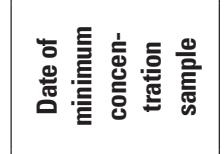 & 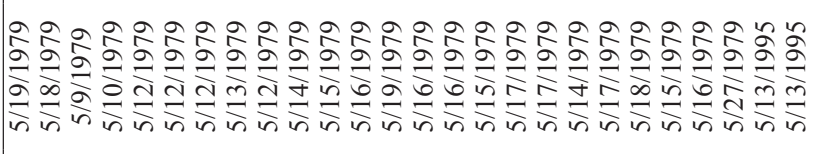 & $\underset{n}{\frac{n}{m}} \frac{\infty}{\infty} \frac{\infty}{m}$ & $\underset{\infty}{\infty}$ & $\frac{\vec{\infty}}{\sum_{m}^{n}}$ & $\frac{\infty}{\sum_{\infty}^{\infty}}$ & $\frac{\infty}{\infty}$ & $\frac{\vec{\infty}}{\sum_{\infty}^{\frac{1}{m}}}$ & $\frac{5}{m}$ & \\
\hline 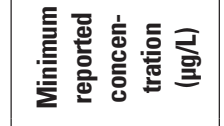 & 車 & $m \stackrel{n}{\infty}$ & $\exists$ & กี & $\stackrel{\Upsilon}{\Im}$ & $\stackrel{\infty}{i}$ & $\stackrel{\infty}{+}$ & 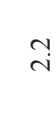 & \\
\hline 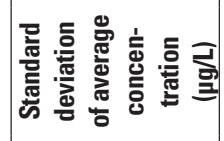 & 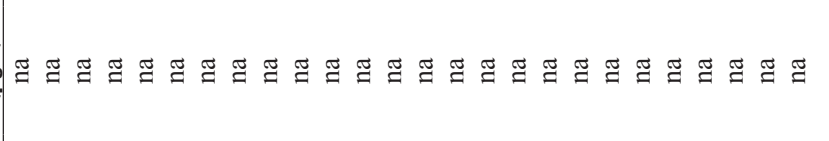 & $\cong \approx$ & 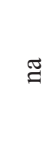 & $\Xi$ & $\cong$ & $\dddot{g}$ & $\dddot{\Xi}$ & & \\
\hline 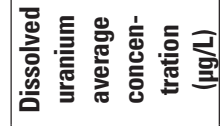 & tontar & $m ?$ & $\exists$ & กุ & $\stackrel{\Upsilon}{\rightrightarrows}$ & $\stackrel{\infty}{i}$ & $\stackrel{\infty}{+}$ & $v$ & \\
\hline 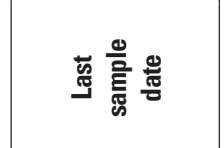 & 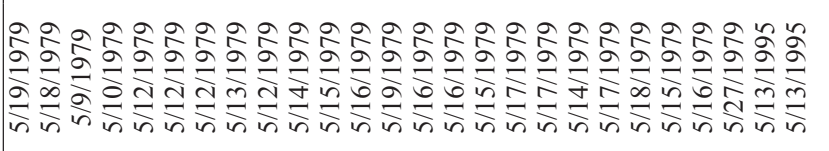 & $\frac{n}{2} \frac{\infty}{\infty} \frac{\infty}{\infty} \frac{2}{m}$ & $\underset{\infty}{\frac{\infty}{\infty}}$ & $\sum_{\infty}^{\infty}$ & $\underset{\infty}{\frac{\infty}{\infty}}$ & $\underset{m}{\frac{\infty}{m}}$ & 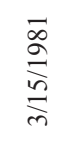 & $\frac{\infty}{\frac{\infty}{2}}$ & \\
\hline 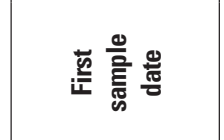 & 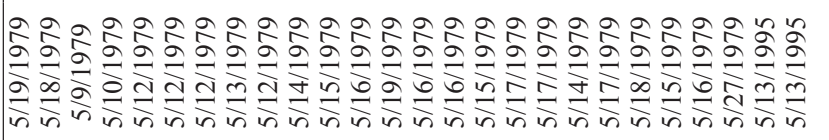 & $\underset{m}{\stackrel{n}{\infty} \frac{\infty}{\infty}} \frac{\vec{\infty}}{\infty}$ & $\underset{\infty}{\stackrel{\infty}{2}}$ & $\underset{\infty}{\infty} \frac{\infty}{\infty}$ & $\underset{m}{\stackrel{\infty}{\infty}}$ & $\underset{\infty}{\frac{\infty}{\infty}}$ & $\underset{\substack{\infty \\
\frac{\infty}{m}}}{\stackrel{5}{\infty}}$ & $\stackrel{\vec{\infty}}{\stackrel{2}{a}}$ & \\
\hline 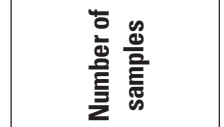 & $\neg-\neg-\neg-\neg-\neg-\neg$ & -- & - & - & - & - & - & - & \\
\hline 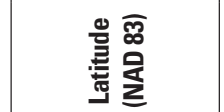 & 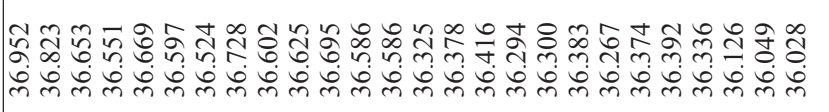 & 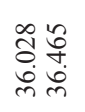 & 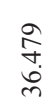 & 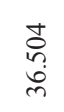 & 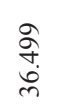 & $\begin{array}{l}\text { त̂ } \\
\text { ర్ల }\end{array}$ & 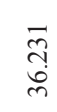 & 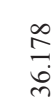 & \\
\hline 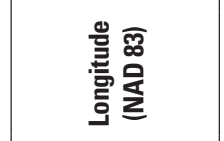 & 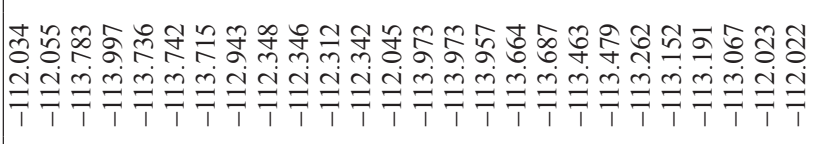 & 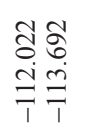 & 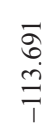 & $\stackrel{\substack{n \\
\stackrel{\leftrightarrow}{\rightleftharpoons}}}{\stackrel{1}{7}}$ & 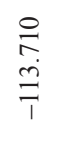 & 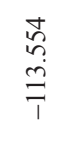 & 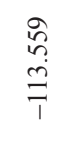 & 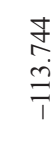 & \\
\hline 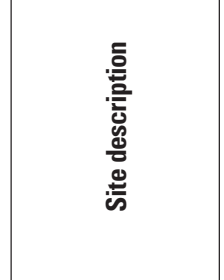 & 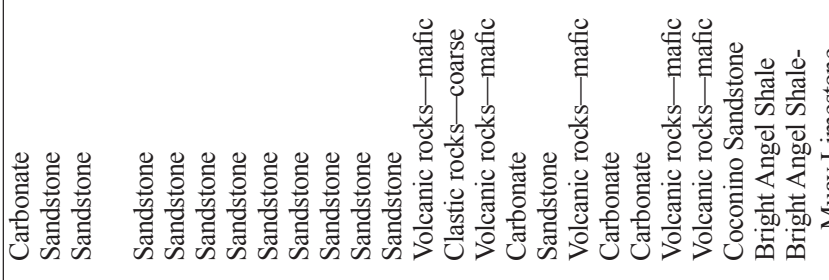 & & & & & & & & \\
\hline 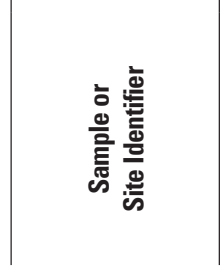 & 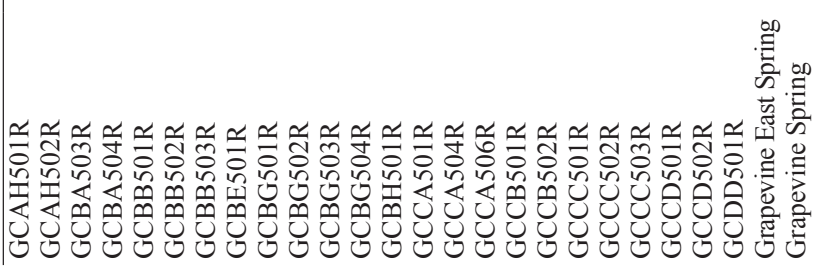 & 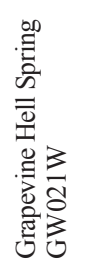 & స్తి & 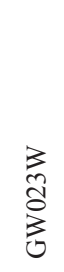 & 勇 & 帘 & 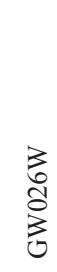 & ลิ & \\
\hline
\end{tabular}




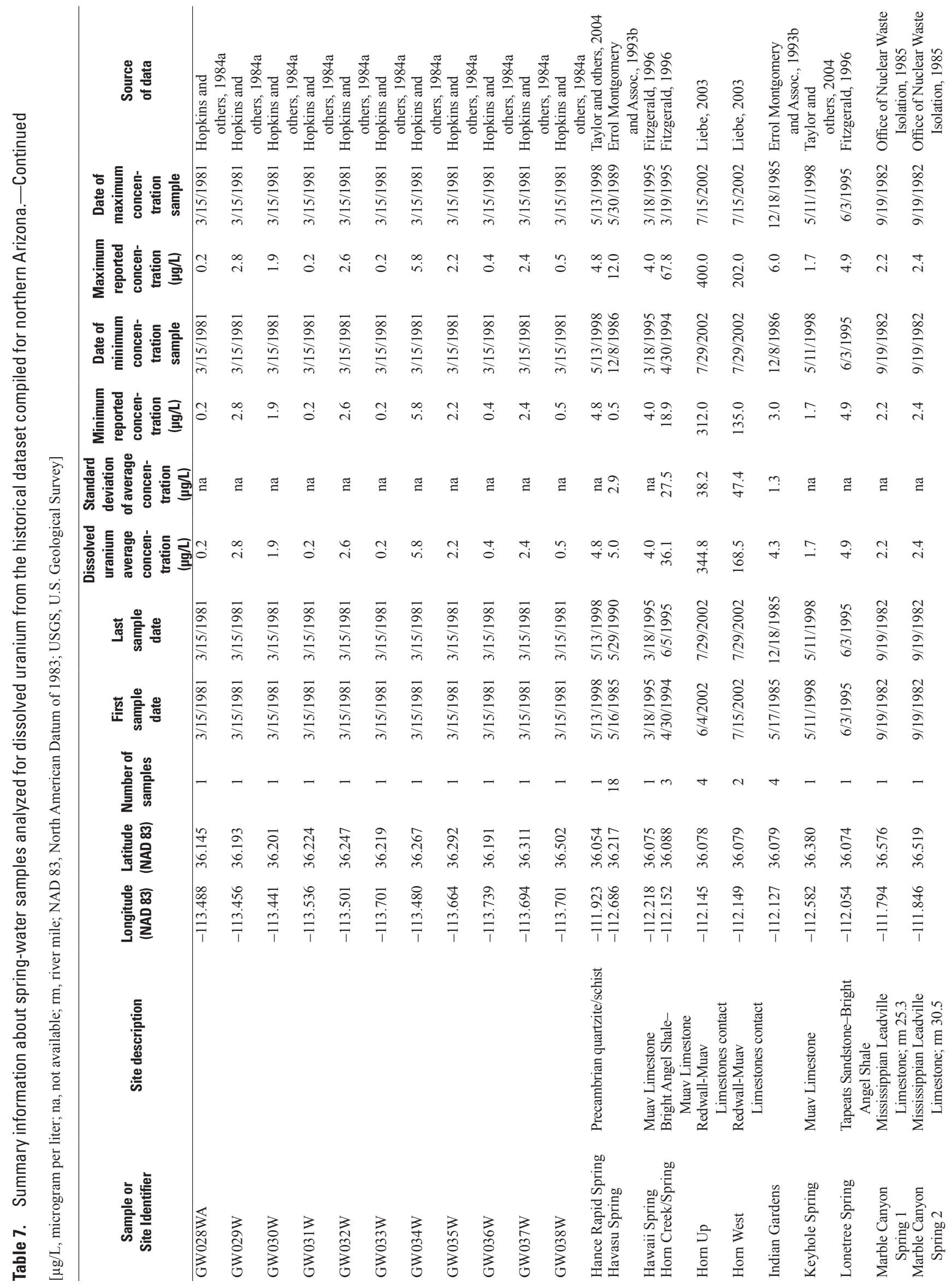




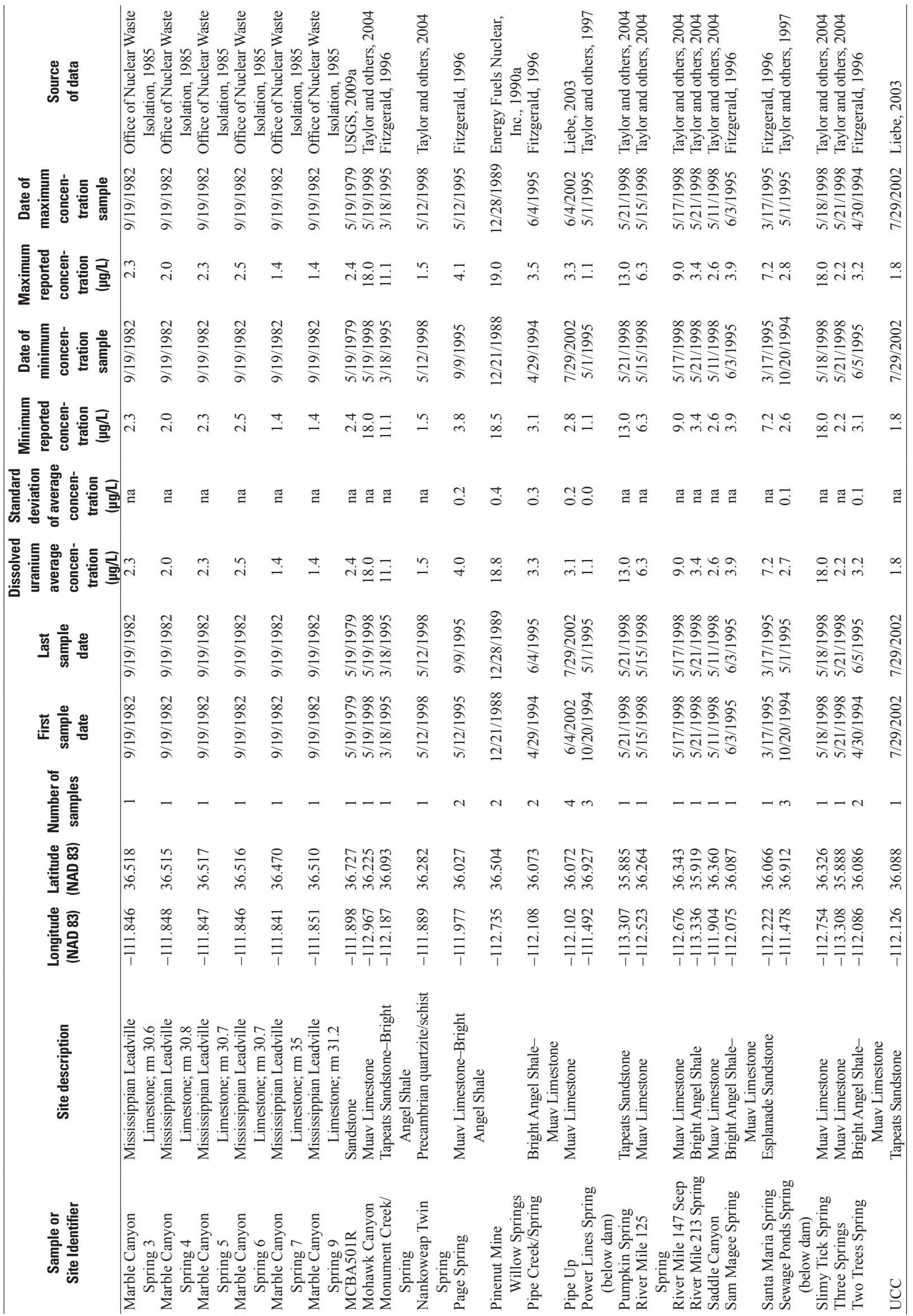




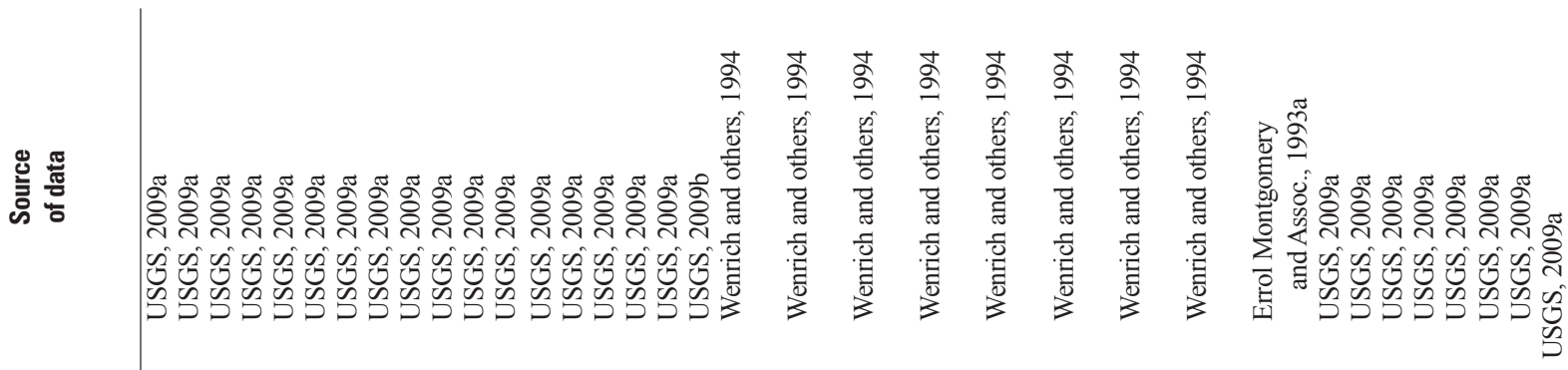

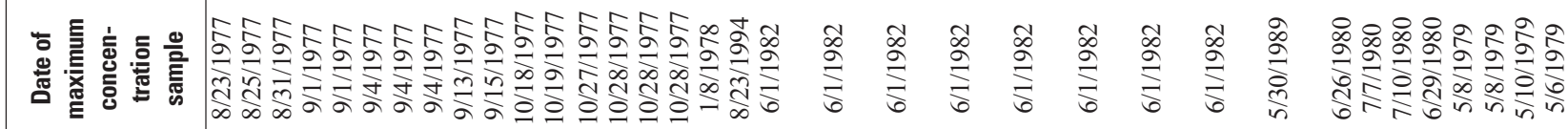

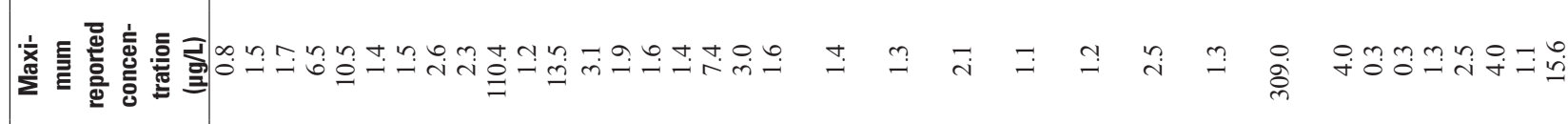

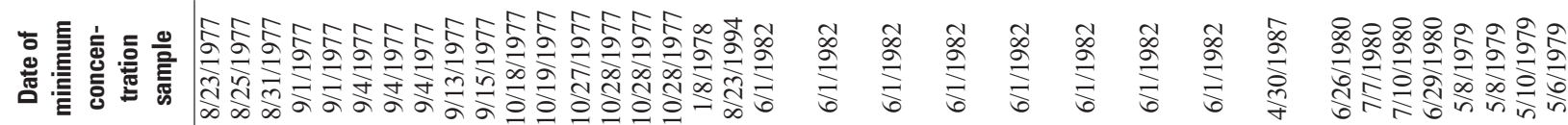

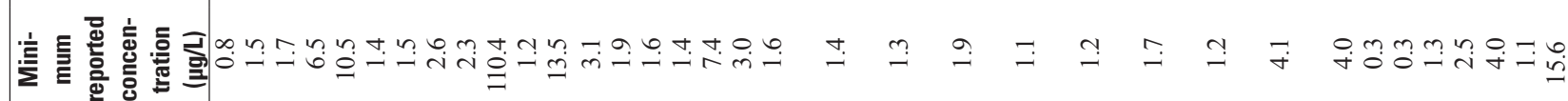

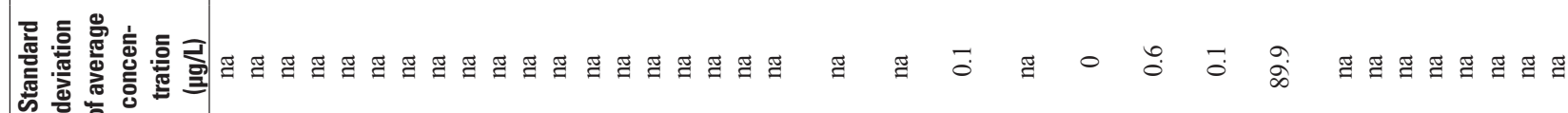

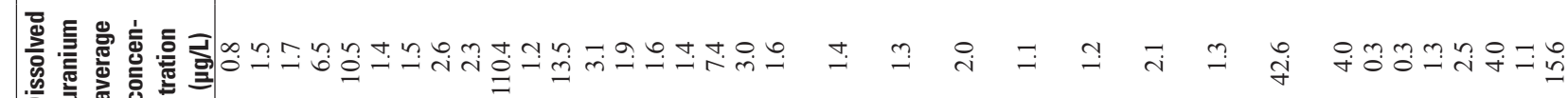

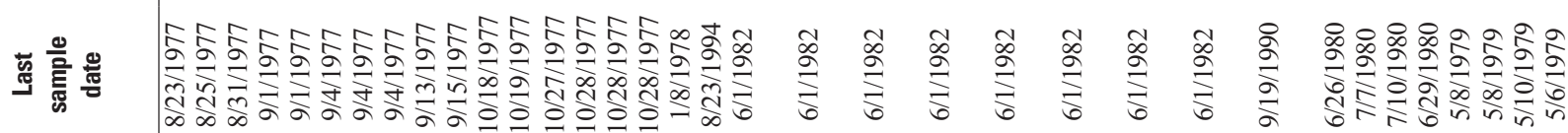

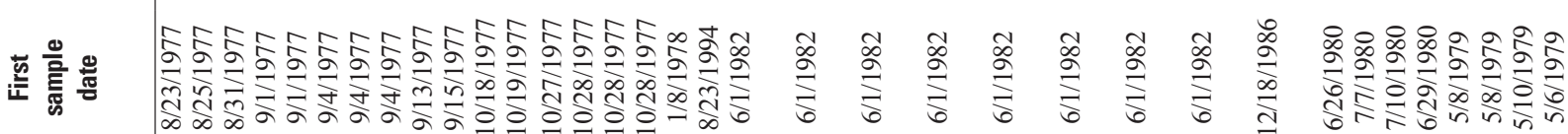

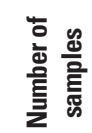

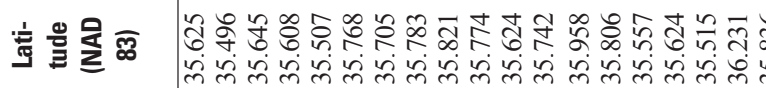

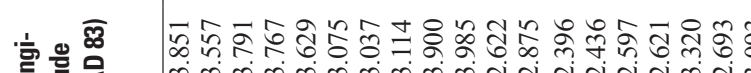

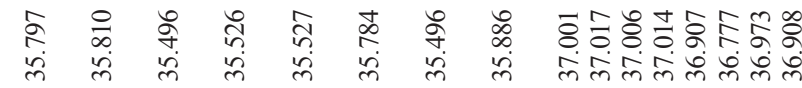

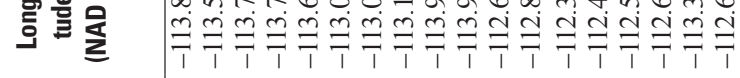
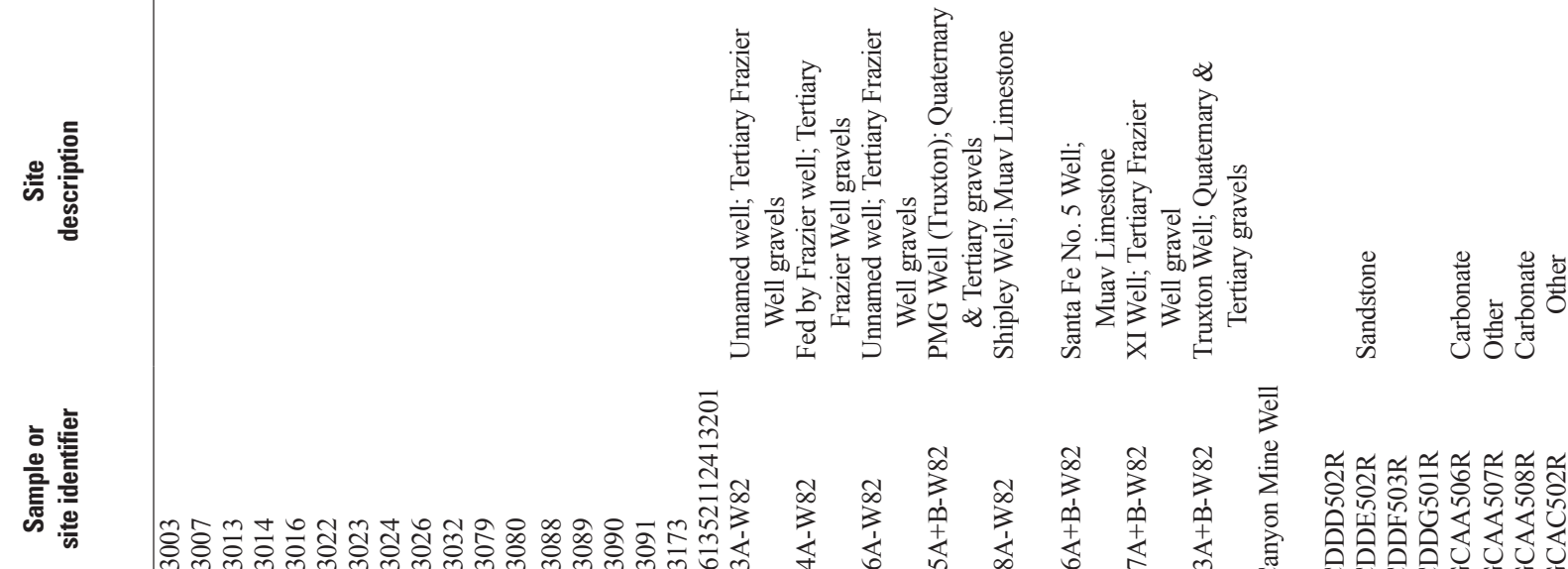

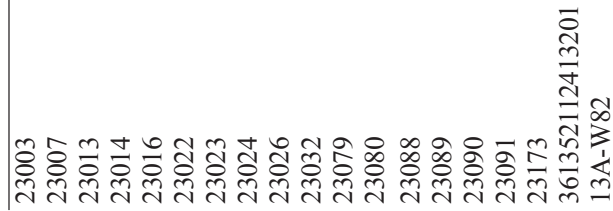
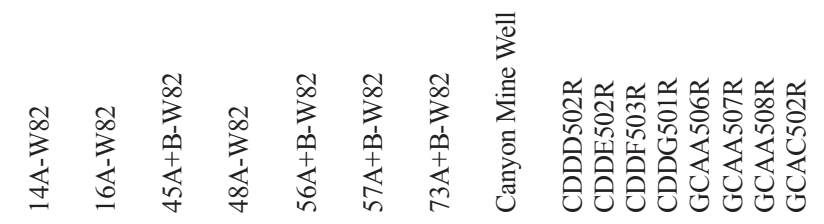


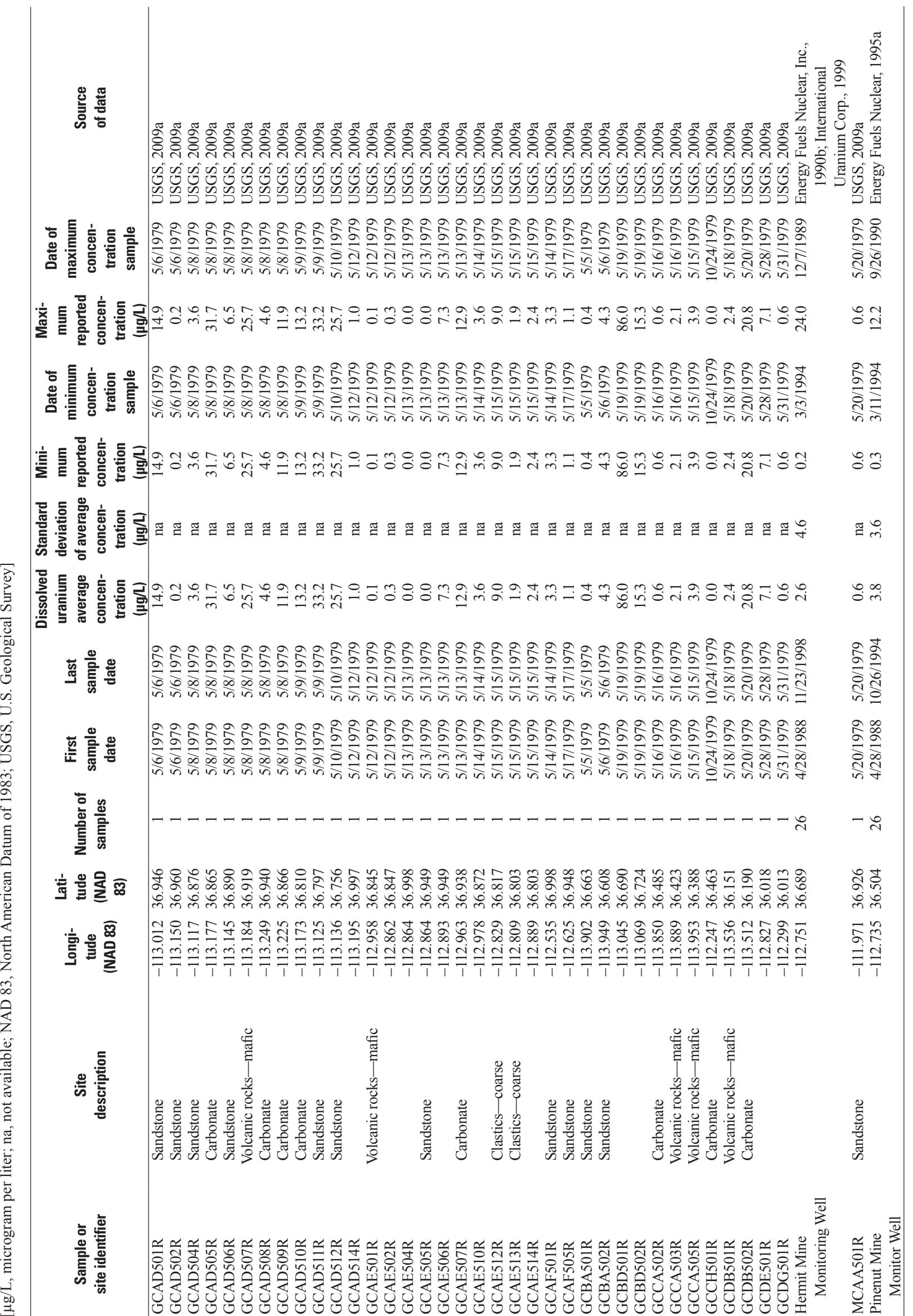




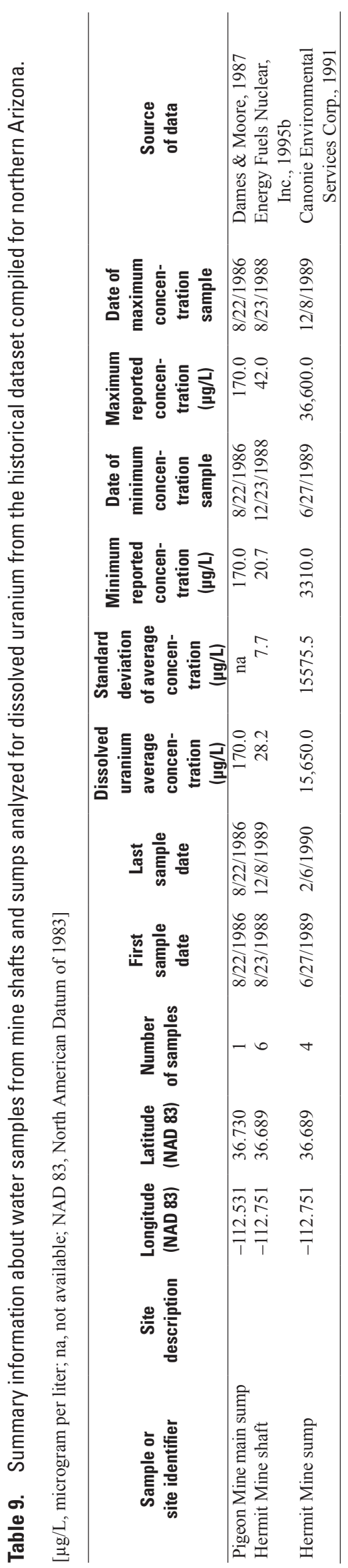




\section{Historical Uranium Water-Chemistry Data}

A dataset of historical water information for the study area was compiled and evaluated with a particular focus on gathering observations of dissolved uranium in water samples. Additional sampling along the Colorado River corridor and in the Kanab Creek drainage was conducted in August and September 2009 to fill in known gaps in data. Information from this combined dataset was evaluated to determine if there are indications that mining affected waters in the study area. The dataset also provides baseline values for comparison during future monitoring activities so that any changes to water quality in the area can be evaluated. Relevant data for locations in and near the study area were compiled from databases, government reports, published scientific literature, graduate theses, and reports and laboratory analyses from environmental consulting firms. Information on a limited number of dissolved metals was included, because they are associated with mineralized breccia pipes in the area. While this dataset is not a verifiably complete set of all data from the study area, it does present a good first-level compilation and evaluation of existing water-quality information for the area and will be amended as new sources of data are located and new samples collected.

Documentation of these data differed in completeness and required some assumptions during compilation and analysis. Differing laboratory methods with differing detection and reporting limits were used for various data sources, making the comparison of data between sources problematic. The limited scope of this study precluded investigation of the quality assurance and quality control methods used either by those collecting and handling the water-quality samples or by the laboratories analyzing the samples, and all data were treated as of equal quality. No statement can be made about the uncertainty associated with the reported data. Field procedures were not documented in some historical studies; therefore, the data compilation used for analyses in this report may combine analytical results from both filtered and unfiltered samples. Additionally, uranium isotope data in two reports (Office of Nuclear Waste Isolation, 1985; Fitzgerald, 1996) were not reported as mass of total uranium but rather in units of activity (pCi). In order to facilitate comparisons with other studies, activities were converted to masses of total uranium by using an activity-to-mass ratio of 0.90 (U.S. Environmental Protection Agency, 2000b). The reader is encouraged to investigate the primary sources of the data used in this report for more information on sample handling, analysis, and reporting (table 10). Uncertainties in sampling locations provided by previous reports may have resulted in this study listing a single site as separate locations. The horizontal datum for sample locations was not always provided. For these cases, the datum was assumed to be NAD27 for all samples collected before 1983 and NAD83 for samples collected in 1983 and afterwards.

Water-quality data were compiled from several sources (table 10) that include dissolved uranium, major ions, and selected metals. Data retrieved from sources listed in table 10 were combined into a single dataset for analyses and presentation. Samples in these datasets were collected from springs, streams, wells, mine shafts, and mine sumps in the area for a variety of purposes, such as water-quality research projects, uranium reconnaissance investigations, surveys for mineralized breccia pipes, and mine permitting documentation. Data from samples collected in the study area were sparse, both spatially and temporally, and time-series data from any site is very limited. The timing and location of water quality information in the area is important, because the potential effects of breccia-pipe uranium mining and other activities may be localized and appear rapidly (for example, a flash flood), or they may be more spatially dispersed during longer timescales (for example, groundwater discharging as springs some distance from mining sites).

\section{Dissolved Uranium}

The aqueous geochemistry of uranium is complicated because of the many forms it can assume depending on factors such as $\mathrm{pH}$, redox conditions, and concentrations of other complexing species (Langmuir, 1978). Hexavalent uranium is soluble under oxidizing conditions, forming the highly stable divalent uranyl ion $\left(\left[\mathrm{UO}_{2}\right]^{2+}\right)$ which readily complexes with other anions in solution (particularly carbonate, hydroxyl, and sulfate). Uranium concentrations in oxidized groundwaters commonly range from 0.1 to $10 \mu \mathrm{g} / \mathrm{L}$ (Osmond and Cowart, 1992; Paces and others, 2002). Under reducing conditions, tetravalent uranium remains highly insoluble and concentrations in groundwater are typically much less than $0.1 \mu \mathrm{g} / \mathrm{L}$. Information on dissolved uranium species is typically unreported in the data sources used in this report. However, the vast majority of uranium concentrations compiled for this study $(1,005$ of 1,014 analyses; appendix 4) are greater than $0.1 \mu \mathrm{g} / \mathrm{L}$. Therefore, it is highly likely that groundwater throughout the study area is oxidized and can readily transport uranium in solution.

Dissolved uranium may be transported away from mining locations or ore deposits by water. The investigation of available dissolved uranium analyses produced 1,014 documented water samples with uranium analyses from 428 sites in and near the study area (appendix 4). Of these 1,014 samples, 480 were from 63 stream locations, 385 were from 288 spring locations, 138 were from 74 wells, 6 were from a single mine shaft, and 5 were from 2 mine sumps (the lowest point in a mine shaft into which water drains). Sampling dates ranged from 1963 (stream samples by the USEPA from the Colorado River at Page, Ariz.) to August and September 2009 (spring samples collected by USGS) (fig. 10). Most uranium samples located were collected during the 1990-95 time period, many as part of USGS studies in the area-such as a synoptic waterquality study on the Colorado River in the Grand Canyon in 1990-91 (Taylor and others, 1996). Two USGS studies during the 1975-85 time period also produced a number of documented uranium samples: the National Uranium Resource Evaluation (NURE) Program (Smith, 2006) and a hydrogeochemical survey for mineralized breccia pipes on the Hualapai Reservation (Wenrich and others, 1994). 


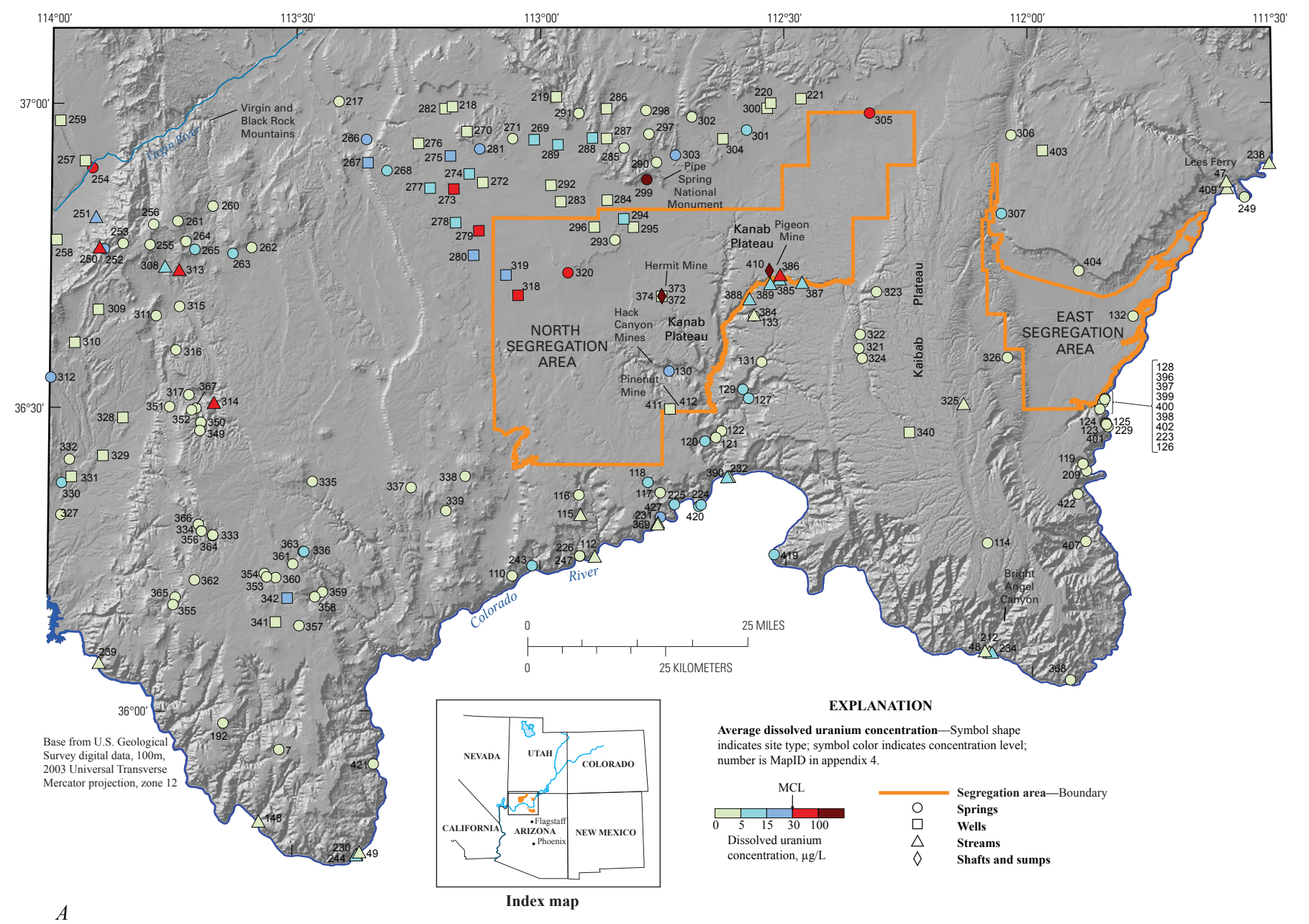

Figure 9. Average uranium concentration in selected spring, stream, well, mine shaft, and mine sump water samples in the historical dataset for northern Arizona. A, Sites located north of the Colorado River. See tables 6-9 and appendix 4 for complete dataset.

In this chapter, if uranium concentrations at a site were reported as less than a reporting limit, then they were assigned a value of one-half the reporting limit for calculation of summary information. This assumption affects observations from 9 wells with reporting limits of $0.002-0.5 \mu \mathrm{g} / \mathrm{L}$ and 3 springs with reporting limits of $0.002-1 \mu \mathrm{g} / \mathrm{L}$. All uranium observations are listed in appendix 4. Concentrations of dissolved uranium in all water samples in the dataset ranged from less than reporting limits in 12 samples to a high of $36,600 \mu \mathrm{g} / \mathrm{L}$ in the Hermit Mine sump. Figure 11 shows the distribution of uranium concentrations in available natural water samples in the Grand Canyon region of Arizona.

The compilation of uranium data in natural waters (tables 6-8) permits two important observations for the study area. First, it compiles sampling sites whose data may be used to try to determine baseline values. As used in this chapter, baseline refers to a set of observations with which future observations may be compared. Because mining and mineral exploration has occurred in the area for many decades, it is probable that some observations in this dataset are already the result of mining activities and therefore should not be considered background values (that is, natural concentrations in local waters, unaffected by human activities). To determine truly background water values for uranium in the study area, all documented and undocumented mining and exploration activities would need to be fully investigated and then water samples in the dataset classified as likely affected or likely unaffected by these activities. This classification of water samples would require a more-complete understanding of the direction and timing of groundwater flow in the area, particularly north of the Colorado River. Two hypothetical examples may serve to illustrate this point. First, depending on groundwater flow paths, springs emanating at great distances from a mine may have water chemistries that were affected by the mine, whereas springs located near mines may have groundwater that is unaffected by those mines. Second, even if a spring is along the downgradient groundwater flow path of a mine, it may take decades for the water chemistry of a spring to show the effects of mining activities, depending on the rate of groundwater flow. Better information on the complex flow system in the area and geochemical investigations of groundwater may provide insight into the connection between source and observation necessary for determining true background values. 


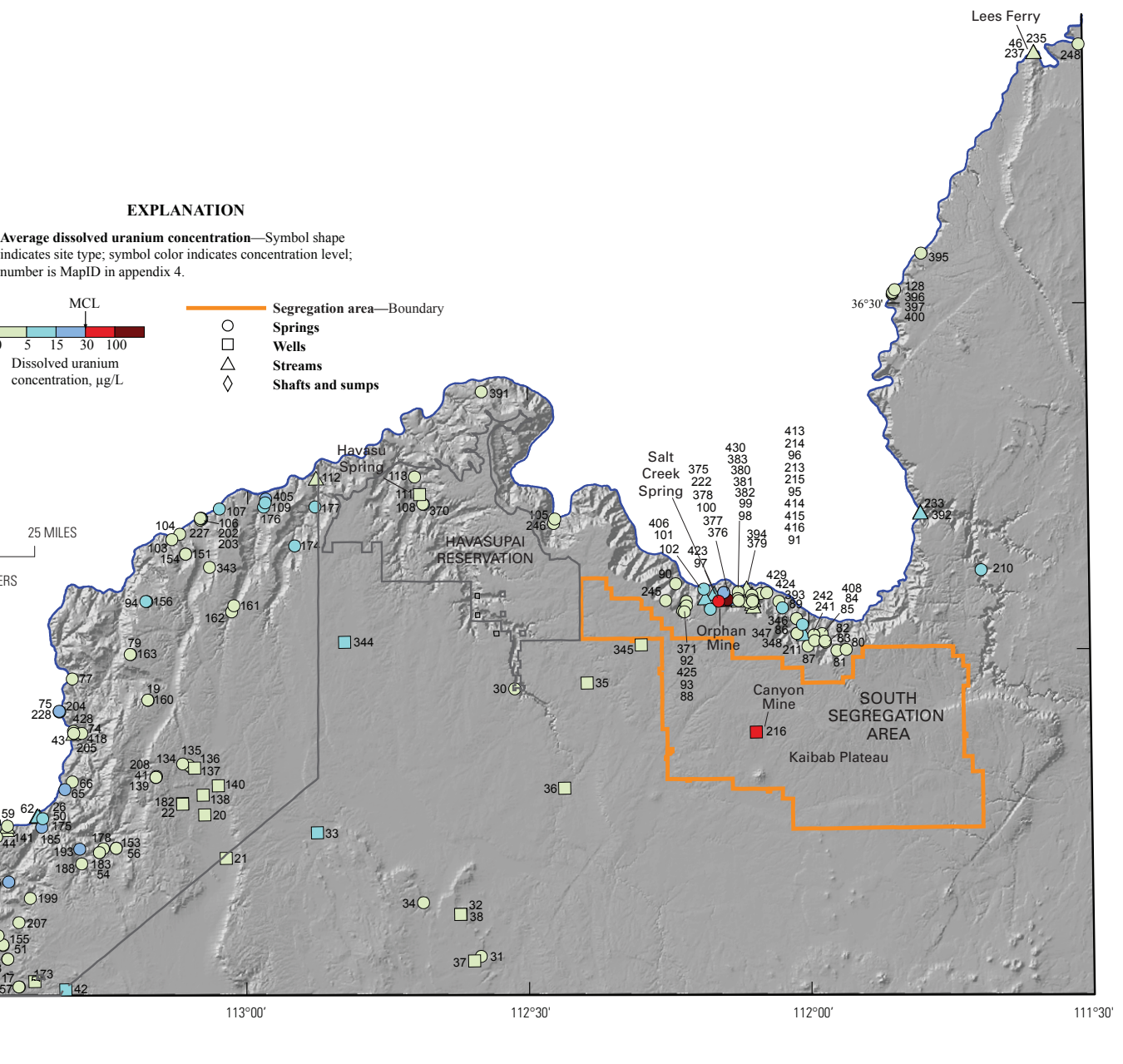

$100 \mathrm{~m}, 2003$ U. Geological Survey digital dat

$100 \mathrm{~m}, 2003$ Univer
projection, zone 12

Figure 9-Continued. Average uranium concentration in selected spring, stream, well, mine shaft, and mine sump water samples in the historical dataset for northern Arizona. B, Sites located south of the Colorado River. See tables 6-9 and appendix 4 for complete dataset.

The second important utility of the compilation of available uranium observations is that it provides subjective definitions of high, medium, and low uranium concentrations in the study area. Future studies on the effect of uranium mining in the area may have as one hypothesis that uranium concentrations in waters affected by mining will have high values and concentrations in unmined areas will have low values. The majority (66 percent) of natural water sample concentrations in the dataset was $5 \mu \mathrm{g} / \mathrm{L}$ or less (fig. 11), and may be subjectively classified as low concentrations in the study area (although quite high for other aquifers in other parts of the country). Nearly 95 percent of the concentrations in the dataset were $20 \mu \mathrm{g} / \mathrm{L}$ or less (fig. 11), allowing a subjective definition of medium concentration values as 5-20 $\mu \mathrm{g} / \mathrm{L}$. High concentrations may be defined as greater than $20 \mu \mathrm{g} / \mathrm{L}$; they compose about 5 percent of the observations in the dataset. Some samples with concentrations above this high threshold may be unaffected by anthropogenic activities and, in fact, reflect natural geochemical conditions favorable to elevated dissolveduranium concentrations.
Quartiles (75th and 25th percentiles) and median uranium concentrations were similar for spring, stream, and well samples in the study area (fig. 12); they have median values of 2.8, 4.6, and $2.4 \mu \mathrm{g} / \mathrm{L}$, respectively. Maximum uranium observations ranged from 309 to $400 \mu \mathrm{g} / \mathrm{L}$ for these sample types. Shaft and sump water, although based on many fewer observations, produced higher ranges of uranium concentrations; medians were 25 and 4,290 $\mu \mathrm{g} / \mathrm{L}$, respectively (fig. 13).

Nearly 95 percent of all spring samples have uranium concentrations less than the USEPA maximum contaminant level (MCL) of $30 \mu \mathrm{g} / \mathrm{L}$; most (72 percent) are less than $5 \mu \mathrm{g} / \mathrm{L}$ (figs. 9, 12, table 7). Notable exceptions include the Horn Creek and Horn Spring samples collected in 1994-95 by Fitzgerald (1996) and the Horn Up and Horn West sites sampled by in 2002 Liebe (2003), all within Grand Canyon National Park. Horn Creek and Horn Spring were sampled three times in 1994-95; concentrations ranged from 18.9 to $67.8 \mu \mathrm{g} / \mathrm{L}$ (appendix 4). The Horn Up site was sampled four times in June and July 2002; concentrations ranged from 312 to $400 \mu \mathrm{g} / \mathrm{L}$ (appendix 4). Two samples from the Horn West site, both collected in July 2002, had uranium 
Table 10. Sources of data and types of samples used to compile historical dissolved uranium data for northern Arizona used in this study.

\begin{tabular}{lc}
\hline \multicolumn{1}{c}{ Data source } & $\begin{array}{c}\text { Type of } \\
\text { sample }\end{array}$ \\
\hline Canonie Environmental Services Corp., 1991, Water Quality Data Evaluation Report, 33 p. & Mine sump \\
Dames \& Moore, 1987, Hermit Mine ground-water conditions Mohave County, Arizona: submitted to Energy Fuels & Mine sump \\
Nuclear, Inc., Denver, Colorado, March 20, 1987. & Spring \\
Energy Fuels Nuclear Inc., 1990a, Hermit Mine groundwater monitoring report mining and post mining phase: &
\end{tabular}

Energy Fuels Nuclear, Inc., 1990b, Hermit Mine groundwater monitoring report mining phase: submitted to Arizona Department of Environmental Quality, Denver, Colorado, February 12, 1990.

Energy Fuels Nuclear, Inc., 1990c, Letter report to Abigail A. Myers, Arizona Department of Environmental Quality, from William J. Almas re: Hermit Mine Groundwater Protection Permit No. G-0035-08: Denver, Colorado, March 7, 1990.

Energy Fuels Nuclear, Inc., 1995a, Arizona aquifer protection permit application Pinenut Mine: Denver, Colorado.

Energy Fuels Nuclear, Inc., 1995b, Arizona aquifer protection permit closure plan Hack Canyon Mine: Denver, Colorado.

Errol L. Montgomery and Assoc., 1993a, Aquifer protection permit application Energy Fuels Nuclear, Inc., Canyon Mine, Coconino County, Arizona: December 1993 Final Report.

Errol L. Montgomery and Assoc., 1993b, Data for Canyon Mine Groundwater Monitoring Program Reference N2219 (GRCA-8213): Annual Letter Report to Grand Canyon National Park, 16 tables.

Fitzgerald, Jim, 1996, Residence time of groundwater issuing from the South Rim Aquifer in the eastern Grand Canyon: Las Vegas, University of Nevada, M.S. thesis, 103 p.

Hopkins, R.T., Fox, J.P., Campbell, W.L., Antweiler, J.C., 1984a, Analytical results and sample locality map of stream-sediment, panned-concentrate, rock, and water samples from the Andrus Canyon, Grassy Mountain, Last Chance Canyon, Mustang Point, Nevershine Mesa, Pigeon Canyon, and Snap Point Wilderness Study Areas, Mohave County, Arizona: U.S. Geological Survey Open-File Report 84-288, 34 p.

Hopkins, R.T., Fox, J.P., Campbell, W.L., Antweiler, J.C., 1984b, Analytical results and sample locality map of stream sediment, panned-concentrate, soil, and rock samples from the Kanab Creek (B3060) Roadless Area, Coconino and Mohave counties, Arizona: U.S. Geological Survey Open-File Report 84-291, 18 p.

International Uranium Corp., 1999, Letter report to Craig Dewalt, Arizona Department of Environmental Quality, from Donn M. Pillmore, January 29, 1999.

Liebe, Dirk, 2003, The use of the ${ }^{234} \mathrm{U} / 238 \mathrm{U}$ activity ratio at the characterization of springs and surface streams in Grand Canyon National Park, Arizona: Dresden, Saxony, Germany, Hochschule fur Technik und Wirtschaft Dresden, M.S. thesis, 105 p.

Monroe, S.A., Antweiler, R.C., Hart, R.J., Taylor, H.E., Truini, Margot, Rihs, J.R., and Felger, T.J., 2005, Chemical characteristics of ground-water discharge along the south rim of Grand Canyon in Grand Canyon National Park, Arizona, 2000-2001: U.S. Geological Survey Scientific Investigations Report 2004-5146, 59 p.

Office of Nuclear Waste Isolation, 1985, Marble Canyon Spring sampling investigation: Technical Report BMI/ONWI-514, 62 p.

Peterson, J.E., Buell, S.E., Cadigan, R.A., Felmlee, J.K., and Sprakis, C.S., 1977, Uranium, radium and selected metallic-element analyses of spring water and travertine samples from the Grand Canyon, Arizona: U.S. Geological Survey Open-File Report 77-36, 7 p.

Taylor, H.E., Peart, D.B., Antweiler, R.C., Brinton, T.I., Campbell, W.L., Garbarino, J.R., Roth, D.A., Hart, R.J., and Averett, R.C., 1996, Data from synoptic water-quality studies on the Colorado River in the Grand canyon, Arizona, November 1990 and June 1991: U.S. Geological Survey Open-File Report 96-614, 175 p.

Taylor, H.E., Berghoff, K., Andrews, E.D., Antweiler, R.C., Brinton, T.I., Miller, C., Peart, D.B., and Roth, D.A., 1997, Water quality of springs and seeps in Glen Canyon National Recreation Area: National Park Service Technical Report NPS/NRWRD/NRTR-97/128, 26 p. 
Table 10. Sources of data and types of samples used to compile historical dissolved uranium data for northern Arizona used in this study.-Continued

$\begin{array}{ll}\text { Data source } & \begin{array}{l}\text { Type of } \\ \text { sample }\end{array}\end{array}$

Taylor, H.E., Spence, J.R., Antweiler, R.C., Berghoff, K., Plowman, T.I., Peart, D.B., and Roth, D.A., 2004, Water quality and quantity of selected springs and seeps along the Colorado River Corridor, Utah and Arizona: Arches National Park, Canyonlands National Park, Glen Canyon National Recreation Area, and Grand Canyon National Park, 1997-98: U.S. Geological Survey Open-File Report 2003-496, 33 p.

U.S. Environmental Protection Agency Region VIII, 1973, Radium-226, uranium and other radiological data from water quality surveillance stations located in the Colorado River Basin of Colorado, Utah, New Mexico and Arizona-January 1961 through June 1972, 155 p.

U.S. Geological Survey, 2009a, Mineral Resources On-Line Spatial Data: Geochemistry of water samples in the U.S. from the NURE-HSSR database, accessed November 4, 2009, at http://tin.er.usgs.gov/nure/water/.

U.S. Geological Survey, 2009b, National Water Information System (NWISWeb): U.S. Geological Survey database, Spring, stream, well accessed October 16, 2009 at http://waterdata.usgs.gov/nwis/.

Wenrich, K.J.; Boundy, S.Q.; Aumente-Modreski, R.M.; Schwarz, S.P.; Sutphin, H.B.; Been, J.M., 1994, A hydrogeochemical survey for mineralized breccia pipes - Data from springs, wells, and streams on the Hualapai Indian Reservation, northwestern Arizona: U.S. Geological Survey Open-File Report 93-619, 66 p.

concentrations of 135 and $202 \mu \mathrm{g} / \mathrm{L}$ (appendix 4). Other spring samples reported by USGS with elevated uranium concentrations include sample GCAE517R collected by the NURE project in 1979 near Pipe Spring National Monument $(250 \mu \mathrm{g} / \mathrm{L})$, and samples 23168 and 23169 collected by the NURE project in 1978 just south of the Hualapai Reservation $(57$ and $51 \mu \mathrm{g} / \mathrm{L}$, respectively; appendix 4, table 7). In all, water collected from 15 of the 288 spring sites had uranium concentrations greater than or equal to $30 \mu \mathrm{g} / \mathrm{L}$, and nearly all observations were in the NURE (U.S. Geological Survey, 2009a), Fitzgerald (1996), and Liebe (2003) studies.

Uranium concentrations were reported for several stream samples from the Colorado River, mostly from locations near Lees Ferry, Grand Canyon National Park near Bright Angel Canyon, and on the Hualapai Reservation (fig. 9; table 6). A few other samples were located on tributaries to Kanab Creek and near the Virgin River in the northwest portion of the study. The Horn Down site (Liebe, 2003) had the highest stream concentration in the dataset at $362 \mu \mathrm{g} / \mathrm{L}$. Presumably, this stream is fed by groundwater discharge from the high-concentration Horn Creek Spring and Horn Up and Horn West springs noted earlier. Most other stream samples near the Colorado River near Bright Angel Canyon in the national park were $5 \mu \mathrm{g} / \mathrm{L}$ or less. All stream samples reported for locations on or near the Hualapai Reservation were $10 \mu \mathrm{g} / \mathrm{L}$ or less. Two other stream samples of note are in the northwest portion of the study area near the Virgin and Black Rock Mountains (plate 1; fig. 9A). These two samples, GCAA006R and GCBB004R, both collected by NURE in 1979, had uranium concentrations of 87 and $88 \mu \mathrm{g} / \mathrm{L}$, respectively (fig. 9A) (U.S. Geological Survey, 2009a).

A small number of water samples from wells also had elevated uranium concentrations. The highest is from the Canyon Mine Well on the Kaibab Plateau (appendix 4, figs. $9 B, 12,14$, table 8). Eleven samples reported from this well had concentrations ranging from $4.1 \mu \mathrm{g} / \mathrm{L}$ in 1987 to
$309 \mu \mathrm{g} / \mathrm{L}$ in 1989. Concentrations in 9 of the 11 Canyon Mine Well samples were less than $20 \mu \mathrm{g} / \mathrm{L}$. Hermit Mine Monitoring Well produced 26 reported observations, all but one less than $7 \mu \mathrm{g} / \mathrm{L}$; the exception was $24.0 \mu \mathrm{g} / \mathrm{L}$ in December, 1989. Twenty-six reported observations from the Pinenut Mine Monitoring Well were all less than $13 \mu \mathrm{g} / \mathrm{L}$ (appendix 4). Four other wells that were sampled between 1977 and 1979 for the NURE investigation had values above $30 \mu \mathrm{g} / \mathrm{L}$ : samples GCAD505R (32 $\mu \mathrm{g} / \mathrm{L})$, GCAD511R (33 $\mu \mathrm{g} / \mathrm{L})$, and GCBD501R (86 $\mu \mathrm{g} / \mathrm{L})$, all from the Kanab Plateau; and sample $23032(110 \mu \mathrm{g} / \mathrm{L})$ from the southwest part of the study area (fig. 9B) (U.S. Geological Survey, 2009a).

Mine shaft and sump samples were located on mining property on the Kanab Plateau and, unsurprisingly, have elevated dissolved-uranium concentrations (appendix 4, table 9). Water samples collected in the Hermit Mine shaft for

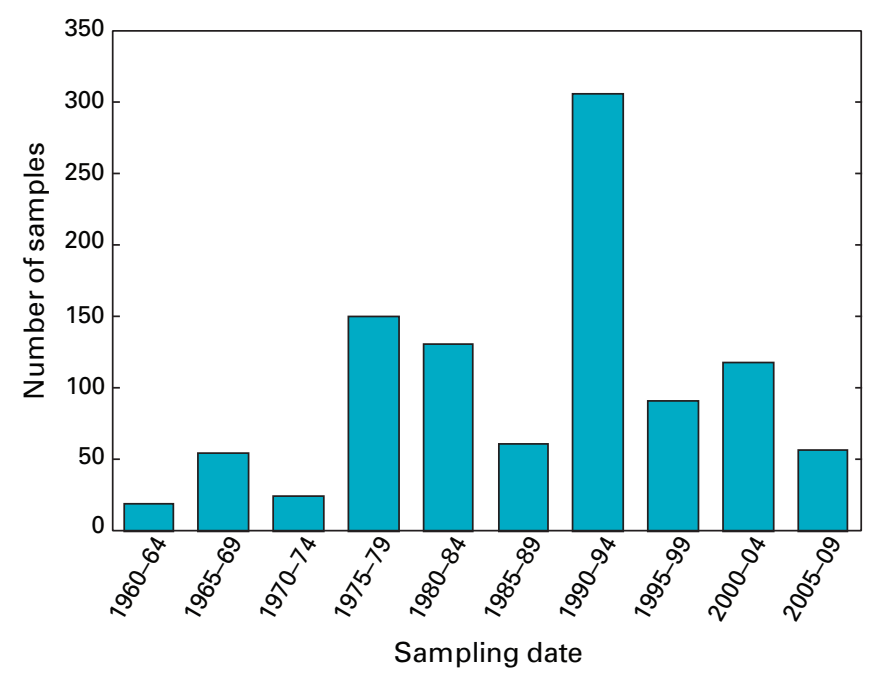

Figure 10. Number of dissolved uranium samples collected during 5-year intervals from 1960 to 2009 in northern Arizona. 


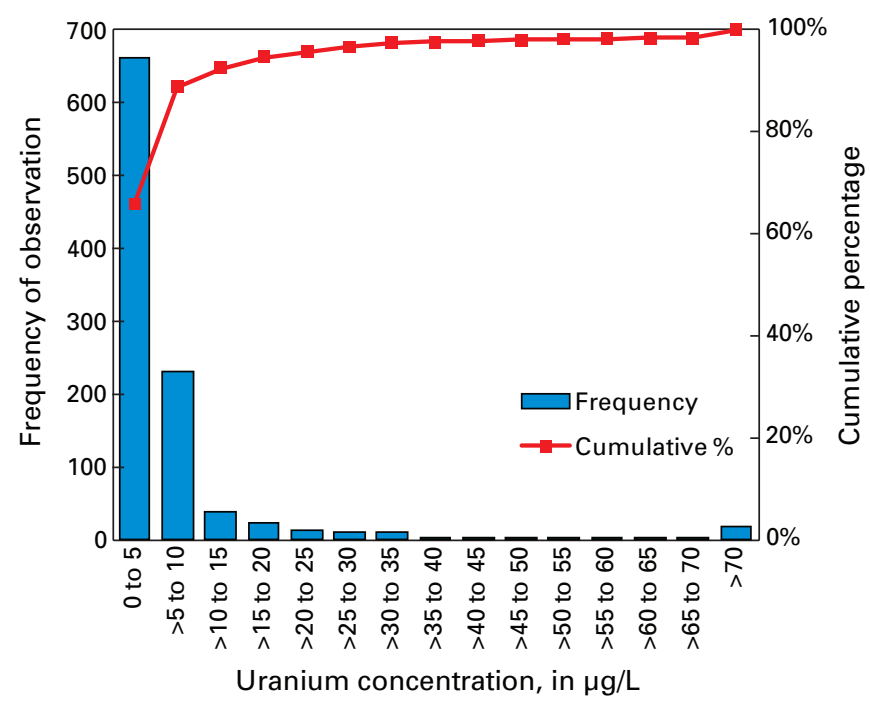

Figure 11. Frequency and cumulative distribution of uranium concentrations in all spring, stream, and well-water analyses from historical dataset for northern Arizona, appendix 4.

the Arizona Department of Environmental Quality in 1988 and 1989 range from 20 to $42 \mu \mathrm{g} / \mathrm{L}$ (Energy Fuels Nuclear, 1995b). Higher uranium concentrations were reported for similar samples from the Hermit and Pigeon Mine sumps. The Pigeon Mine sump had a single reported value of $170 \mu \mathrm{g} / \mathrm{L}$ in 1986, and the Hermit Mine sump concentrations ranged from 3,310 to $36,600 \mu \mathrm{g} / \mathrm{L}$ (the highest reported value of any sample type in this study) in 1989-90 (figs. 9A, 13). These highconcentration mine shaft and sump waters may be sources of dissolved uranium for nearby sites if mine water is capable of entering the regional groundwater flow system.

The large number of historical analyses of both spring and well samples allows for comparison of uranium concentrations from areas north and south of the Colorado River (figs. 9, 14). Maximum observations were greater for springs and wells south of the river compared with observations from north of the river. The 90th and 75th percentiles and median observations for spring data were similar for samples from north $(17.7,5.4$, and $2.1 \mu \mathrm{g} / \mathrm{L}$, respectively) and south $(18.5,6.1$, and $3 \mu \mathrm{g} / \mathrm{L}$, respectively) of the river. Well observations had similar 90th percentiles and means for north (14.2 and $2.4 \mu \mathrm{g} / \mathrm{L}$, respectively) and south (15.5 and $2.3 \mu \mathrm{g} / \mathrm{L}$, respectively) locations, but south wells had a higher 75 th percentile observation at $8.7 \mu \mathrm{g} / \mathrm{L}$ compared with $6.1 \mu \mathrm{g} / \mathrm{L}$ for north wells.

Consistent temporal water sampling is essential for determining trends and observing potential effects on water quality of mining and other activities; however, only very limited temporal data were available for this study. Three wells at Canyon, Hermit, and Pinenut Mines, 6 spring sites, and 3 stream locations had more than two observations that spanned at least one year (fig. 15). Dissolved uranium concentrations in the wells are mostly less than $20 \mu \mathrm{g} / \mathrm{L}$. Three exceptions are a single observation of $24 \mu \mathrm{g} / \mathrm{L}$ from the Hermit Mine Well in December 1989 and observations of $65 \mu \mathrm{g} / \mathrm{L}$ in December 1987 and $309 \mu \mathrm{g} / \mathrm{L}$ in May 1989 at the Canyon Mine Well (fig. 15). Dissolved uranium concentrations at both the Hermit Mine and Canyon Mine Wells returned to less than $20 \mu \mathrm{g} / \mathrm{L}$ after these peak observations. Two stream sampling sites on the Colorado River near Lees Ferry, Ariz., present dissolved uranium data for different time periods. The "Colorado River at Page" line graph (fig. 15) contains observations from May 1963 through May 1972; early observations (through June 1965) were around 9-10 $\mu \mathrm{g} / \mathrm{L}$ and later observations were around 5-6 $\mu \mathrm{g} / \mathrm{L}$, except for a spike of $16 \mu \mathrm{g} / \mathrm{L}$ in May 1972, the last observation in the record (fig. 15). The record for nearby site 09380000 (Colorado River at Lees Ferry; fig. 15) extends from January 1996 through June 1998 and consistently records observations of 3-4 $\mu \mathrm{g} / \mathrm{L}$. The temporal dissolved uranium data from springs are consistently less than $10 \mu \mathrm{g} / \mathrm{L}$ with two exceptions, Horn Creek Spring and Havasu Spring. Horn Creek Spring has values that range from 19 to $67 \mu \mathrm{g} / \mathrm{L}$ (fig. 15). Horn Creek Spring is located in the same drainage and downgradient from the Orphan Mine. Several investigators have linked the elevated dissolved uranium in Horn Creek and Salt Creek with the Orphan breccia pipe or with mining activity in the area (Fitzgerald, 1996; Monroe and others, 2004; Grand Canyon National Park, 2006; Bills and others, 2007). Havasu Spring has dissolved uranium concentrations that are typically $5 \mu \mathrm{g} / \mathrm{L}$ or less; however several samples measured in 1985 and again in 1989-90 may have had values between 7 and $12 \mu \mathrm{g} / \mathrm{L}$ (duplicate data from same-day samples were less than $5 \mu \mathrm{g} / \mathrm{L}$ ).

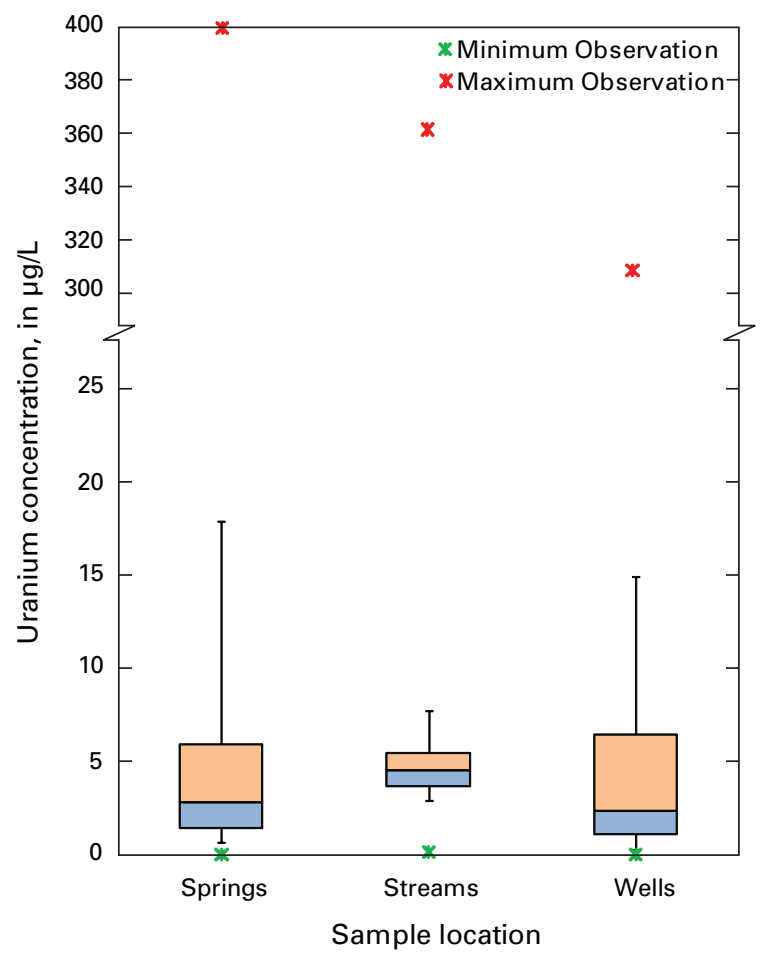

Figure 12. Dissolved uranium concentrations in water samples from springs, streams, wells, and mine shafts from historical dataset for northern Arizona, appendix 4. Upper and lower whiskers represent 90th and 10th percentiles, respectively. Upper, middle, and lower lines on box represent the 75th percentile, median, and 25th percentile, respectively. Note broken concentration axis. 


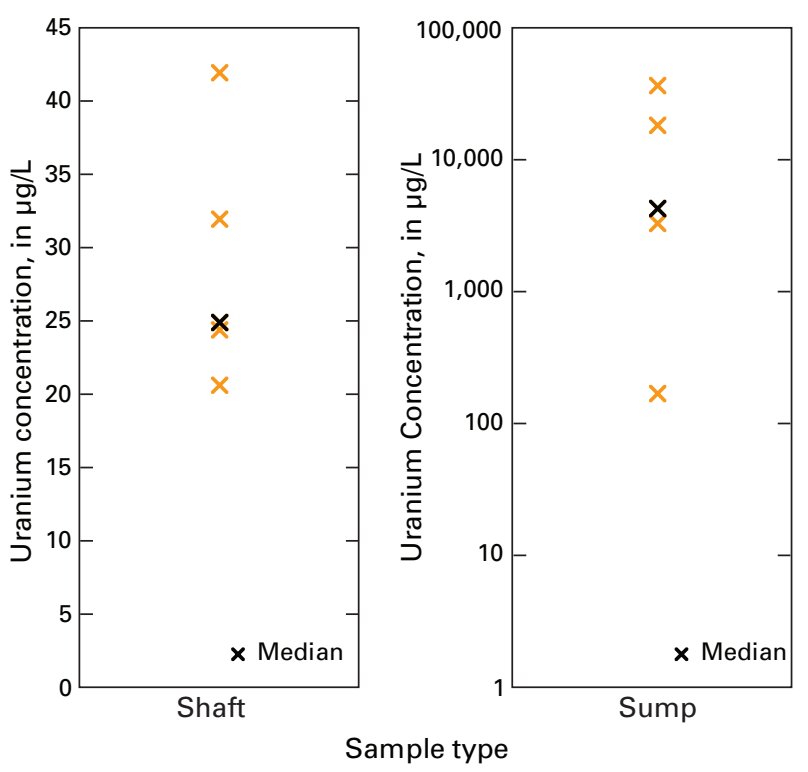

Figure 13. Dissolved uranium concentrations in water samples from mine shafts (left panel) and mine sumps (right panel) in historical dataset for northern Arizona, appendix 4. Note logarithmic scale for concentration axis on mine sump plot.

\section{Selected Dissolved Metals}

Other metals are associated with uranium in mineralized breccia pipes including silver, arsenic, barium, cadmium, cobalt, copper, mercury, molybdenum, nickel, lead, antimony, strontium, vanadium, and zinc. However, these metals do not necessarily correlate with dissolved uranium in groundwater, owing to differences in aqueous solubilities and the possible presence of complexing anions (Wenrich and others, 1994). The historical dataset was evaluated for arsenic, molybdenum, mercury, and silver at concentrations exceeding USEPA maximum contaminant levels or lifetime health advisory level in the case of molybdenum (U.S. Environmental Protection Agency, 2004). Available data for silver $\geq 100 \mu \mathrm{g} / \mathrm{L}$, mercury $\geq 2.0 \mu \mathrm{g} / \mathrm{L}$, molybdenum $\geq 40 \mu \mathrm{g} / \mathrm{L}$, and lead $\geq 15 \mu \mathrm{g} / \mathrm{L}$ indicate that few samples in the study area exceed these concentrations (fig. 8, table 5). Elevated lead concentrations were reported at the Hermit Mine sump and monitoring well (40 and $150 \mu \mathrm{g} / \mathrm{L}$ in 1990 and 1988, respectively) and at the Pinenut Mine monitoring well $(110 \mu \mathrm{g} / \mathrm{L}$ in 1988), all on the Kanab Plateau. The highest lead concentrations were reported in Virgin River samples in the northwestern portion of the study area (fig. 8). Two observations of $500 \mu \mathrm{g} / \mathrm{L}$ and a single observation of $600 \mu \mathrm{g} / \mathrm{L}$ were reported from this area in June 1979. Although these water samples were collected using a pre-1990 USGS sampling protocol that may have resulted in contamination of the water sample, similar results are reported for samples collected days later. Five mercury exceedances were found in the dataset; the reported high is $3.8 \mu \mathrm{g} / \mathrm{L}$ in both a stream sample from site 09380000 (Colorado River at Lees Ferry) and a spring sample from site 353713113421800 (Milkweed Spring) (fig. 8, table 5). Water samples with elevated molybdenum concentrations are more widely distributed in the study area. Higher concentrations were reported in spring sample GCAE517R $(191 \mu \mathrm{g} / \mathrm{L})$ on the Kaibab-Paiute Reservation, in well sample $23080(129.4 \mu \mathrm{g} / \mathrm{L})$ just southeast of the Hualapai Reservation, in spring sample $23077(100 \mu \mathrm{g} / \mathrm{L})$ in Cataract Canyon at the southern end of the Havasupai Reservation, and in well sample GCAD505R $(97 \mu \mathrm{g} / \mathrm{L})$ near the northwest corner of the North Segregation Area (fig. 8, table 5). Although no silver samples were reported above the MCL, a value of $80 \mu \mathrm{g} / \mathrm{L}$ was reported in Havasu Spring (Errol Montgomery and Associates, 1993b).

A number of water samples within the study area contained arsenic concentrations exceeding the EPA MCL of $10 \mu \mathrm{g} / \mathrm{L}$ (fig. 16, appendix 3). Twelve well samples had concentrations above $100 \mu \mathrm{g} / \mathrm{L}$, all along the south rim of the Grand Canyon. The highest was reported from sample $23014(301 \mu \mathrm{g} / \mathrm{L})$; the sample locality is just southwest of the Hualapai Reservation. Twenty-two spring samples had concentrations above $100 \mu \mathrm{g} / \mathrm{L}: 16$ on the south rim of the Grand Canyon and 6 near the Virgin Mountains north of Lake Mead. Spring sample 77A-W82 (Pumpkin Spring) on the Hualapai Reservation had the highest arsenic concentration of $350 \mu \mathrm{g} / \mathrm{L}$ (fig. 16, appendix 3). Elevated arsenic concentrations were also noted in stream samples from the Hualapai Reservation; the three highest concentrations were in samples $43536(175 \mu \mathrm{g} / \mathrm{L})$, $43540(178 \mu \mathrm{g} / \mathrm{L})$ and $43538(310 \mu \mathrm{g} / \mathrm{L})$ (fig. 16, appendix 3).

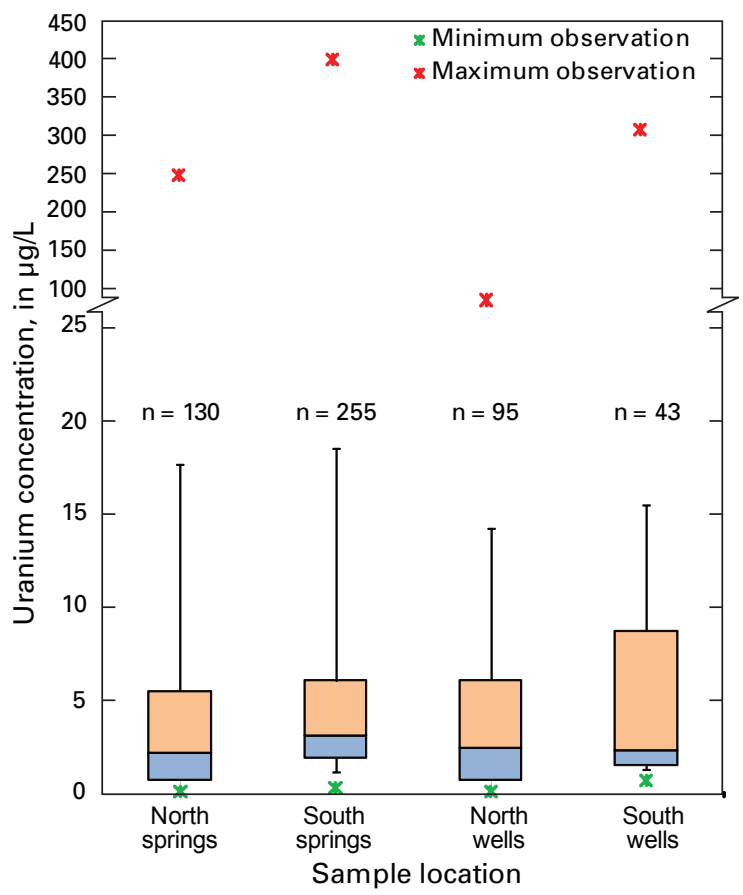

Figure 14. Range of dissolved uranium concentrations in water samples from springs and wells in historical dataset for northern Arizona, appendix 4, in relation to location north and south of Colorado River. Upper and lower whiskers represent 90th and 10th percentiles, respectively. Upper, middle, and lower lines on box represent the 75th percentile, median, and 25th percentile, respectively. Note broken concentration axis. 

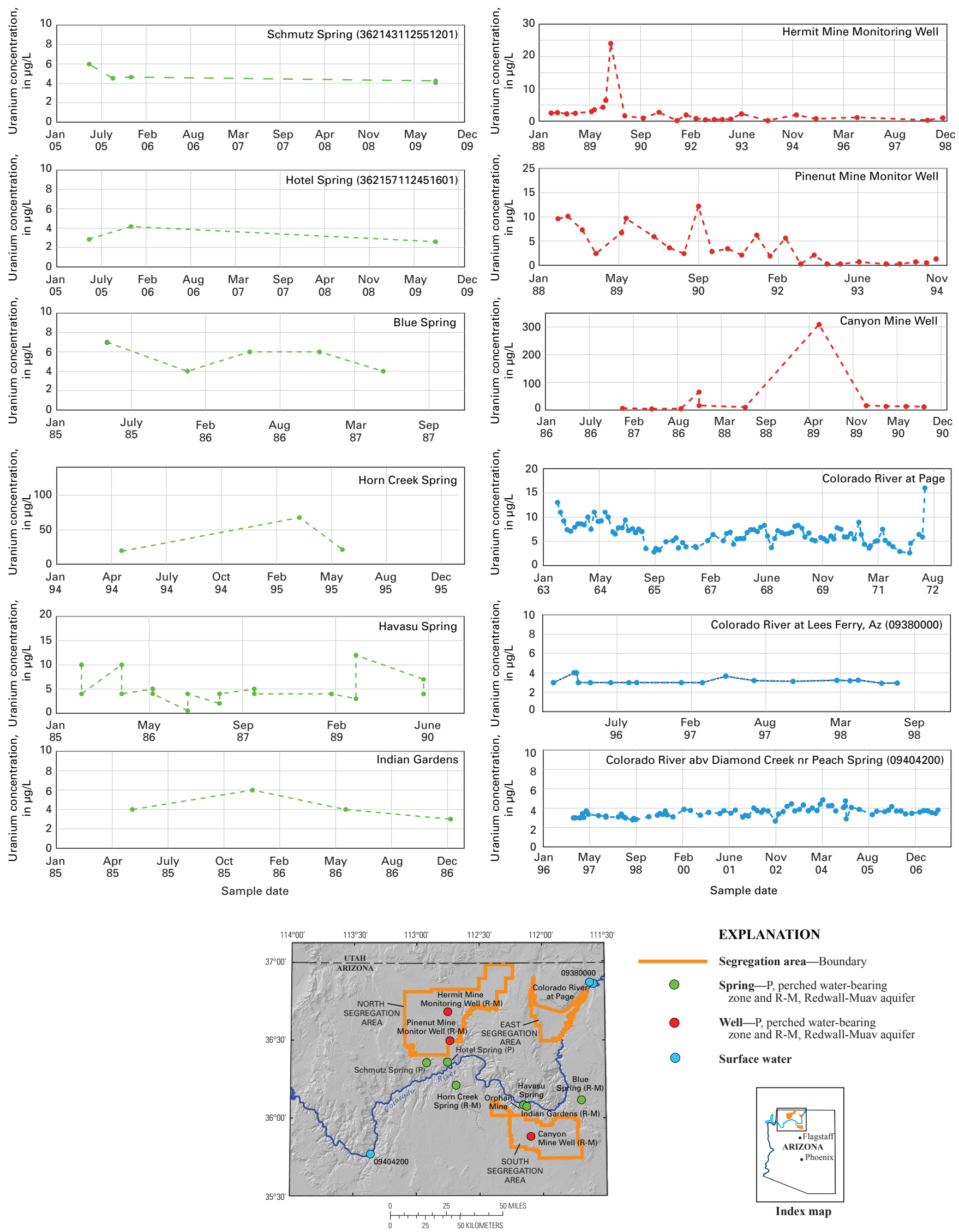

\section{EXPLANATION}
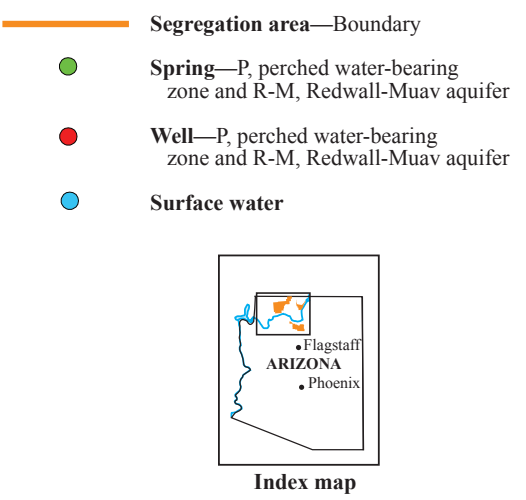

Figure 15. Variation in uranium concentration with time for selected springs, streams, and wells in the historical dataset for northern Arizona, appendix 4. 


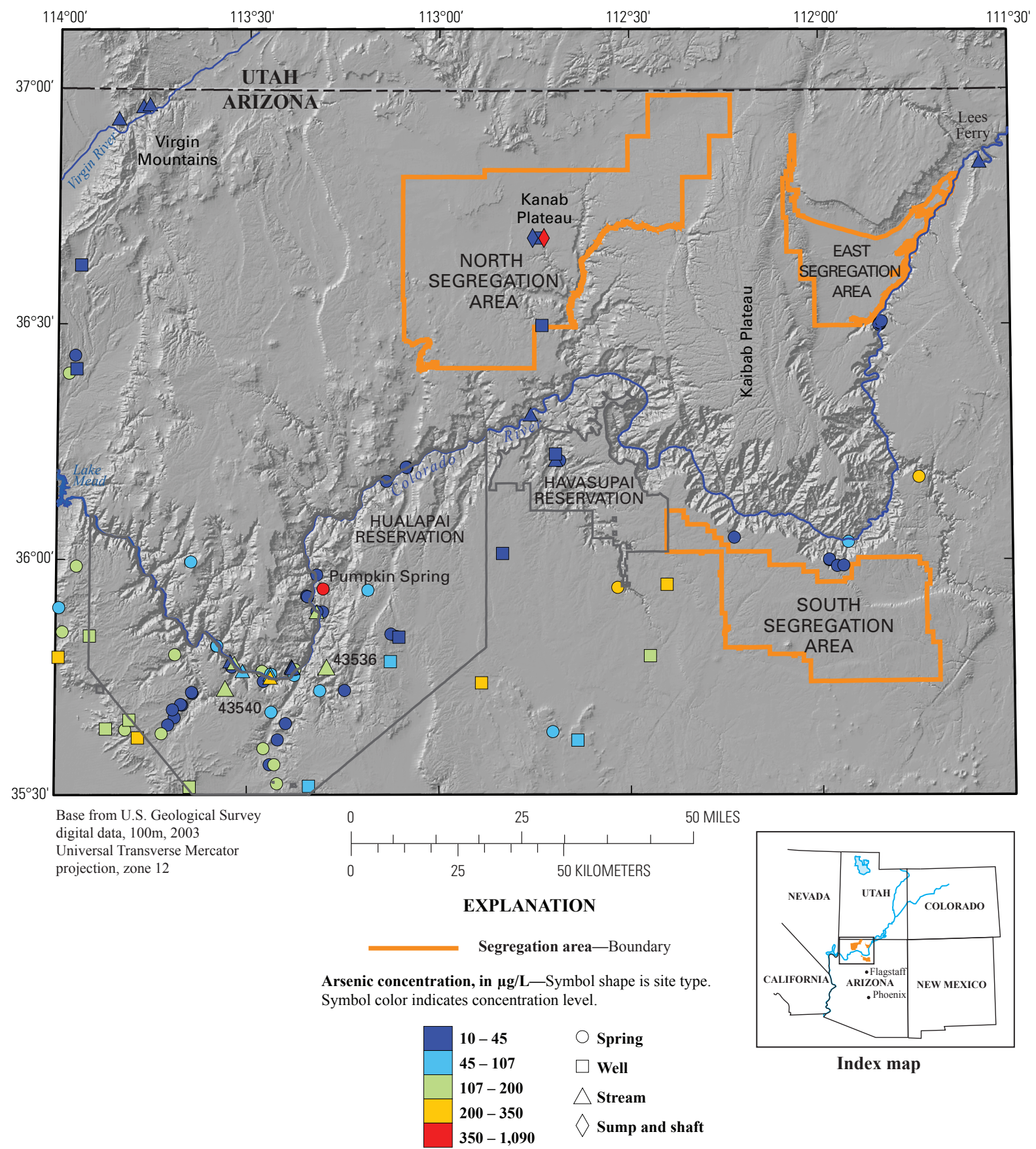

Figure 16. Selected spring, stream, well, and sump sites from the historical dataset, appendix 3 , at which concentrations of arsenic exceed U.S. Environmental Protection Agency maximum contaminant level of $10 \mu \mathrm{g} / \mathrm{L}$. For sites at which more than one sample exceeded $10 \mu \mathrm{g} / \mathrm{L}$, the maximum value is plotted. 


\section{Groundwater Samples}

Groundwater samples were collected at 24 sites in the study area during August-September 2009 (fig. 17) to augment the historical dataset and to provide additional information for evaluation of variations in groundwater chemistry by geographic region, groundwater source, and mining condition (fig. 7, appendix 2). Sample collection sites were geographically located in the northern part of the Marble platform, the lower Kanab Creek drainage, and the Havasu drainage (figs. 4, 17). The samples represent groundwater from either the RedwallMuav aquifer or perched water-bearing zones in the Coconino Sandstone and sandstones of the Supai Group (appendix 2). Sites were also categorized on the basis of mining conditions of the surface drainage basin in which the site is located; the three mining categories were no mines, reclaimed mines, or active mines that are on standby (appendix 2). All sites sampled were in areas that contain uranium orebodies associated with breccia pipes, and for the latter two classes the mines are associated with extracting uranium ore from breccia pipes.

For comparison of groundwater-chemistry data by geographic region and groundwater source, it is necessary to be certain that each site was classified correctly. For sites associated with active or reclaimed mines, however, it not known with certainty that the groundwater sampled at each site actually flowed past and had opportunity to be affected by the mining activity. For this reason it is vital that comparison of groundwater-chemistry data by mining condition be considered strictly an exploratory assessment that needs further sampling and evaluation to determine if there is a relationship.

Table 11 lists the 24 groundwater sites sampled in 2009 and their geographic region, groundwater source, and mining condition (see also fig. 17). To facilitate comparison of the waterchemistry data, the ranks for selected trace-element concentrations reported in appendix 2 are also presented in this table. Only one site was available in the Havasu Creek drainage, the Canyon Mine Well; consequently, comparison of geographic regions is limited to the Marble platform and the Kanab Creek drainage. The three sites in areas with reclaimed mines-Slide, Rock, and Willow Springs (fig. 17) — are potentially downgradient and affected by the reclaimed Pigeon and Hack Mines. Five sites in areas with active mines in the Kanab Creek drainage-Pinenut Well and Hotel, Kanab, Showerbath, and Side Canyon Springs (figs. 9A, 17) - are potentially downgradient and affected by the Kanab North Mine, Arizona 1 Mine, and Pinenut Mine.

In addition to major ion and trace elements, the 2009 samples were analyzed for strontium, uranium, radium, carbon, tritium, and oxygen-deuterium isotopes (appendix 2). These isotopic data provide information on groundwater-recharge sources, rock-water interactions affecting groundwater along the flow path, and the length of time during which groundwater flowed from recharge areas to the point of discharge. The workscope and tight schedule for this report, however, precluded a detailed analysis of and integration of information learned from the isotopes into the analysis of variations in major ions and trace elements. The work-scope and tight schedule also precluded an advanced statistical or geochemical evaluation of the major ion and trace element data.

\section{Major Ions and Trace Elements}

Major ions and trace elements dissolved in water are derived from water-rock interactions during recharge and from flow within the aquifer. Aquifer-rock composition differs on local and regional scales and, therefore, water composition also differs spatially. This section presents major ion and trace metal concentration variations by geographic region, groundwater source, and mining condition.

\section{Major Ions}

The composition of major ions and their total concentration, as measured by specific conductance, differs by geographic region and by groundwater source. Overall, the major ions composing groundwater at the 24 sites sampled in 2009 (fig. 18) had varying proportions of calcium, magnesium, bicarbonate, and sulfate (fig. 18). High concentrations of sulfate were common; the USEPA secondary maximum contaminant level for sulfate in drinking water $(250 \mathrm{mg} / \mathrm{L})$ was exceeded in samples from 15 sites (appendix 2). Specific conductance values ranged from 303 to $3,570 \mu \mathrm{S} / \mathrm{cm}$ (appendix 2).

Groundwater from the Marble platform (fig. 18), which is typically of calcium-magnesium-sulfate composition, tended to have the lowest specific conductance (appendix 2; fig. 18; table 11). Fence Spring and Rider Spring (fig. 17), however, have higher specific conductance and larger contributions to the water composition from sodium and chloride than other sites in the Marble platform. Groundwater from the Kanab Creek drainage tends to have a higher specific conductance than groundwater from the Marble platform, and it is enriched in sulfate (appendix 2, fig. 18, table 11).

The specific conductance and contributions of sulfate to water composition are typically greater in perched water-bearing zones than in the Redwall-Muav aquifer (appendix 2; fig. 18). Groundwater with relatively high amounts of sulfate may result from the dissolution of gypsum from the overlying Moenkopi Formation or from dissolution of sulfides in ore deposits (Wenrich and others, 1994; Billingsley and others, 2006).

Characteristics of major ions differ widely in groundwater samples from sites without mining activities, which indicates that this variation is natural. The highest (Burnt Canyon Well, fig. 17) and lowest (Hole in the Wall Spring) specific conductance values (appendix 2) observed in the 2009 samples were from sites without mining activities. Consequently, specific conductance values for sites in basins with active mines or reclaimed mines fall within the range of values observed for sites in basins without mines. For sites within the Kanab Creek drainage, no systematic change in major ion characteristics was noted for different mining conditions (appendix 2, fig. 18, table 11). 


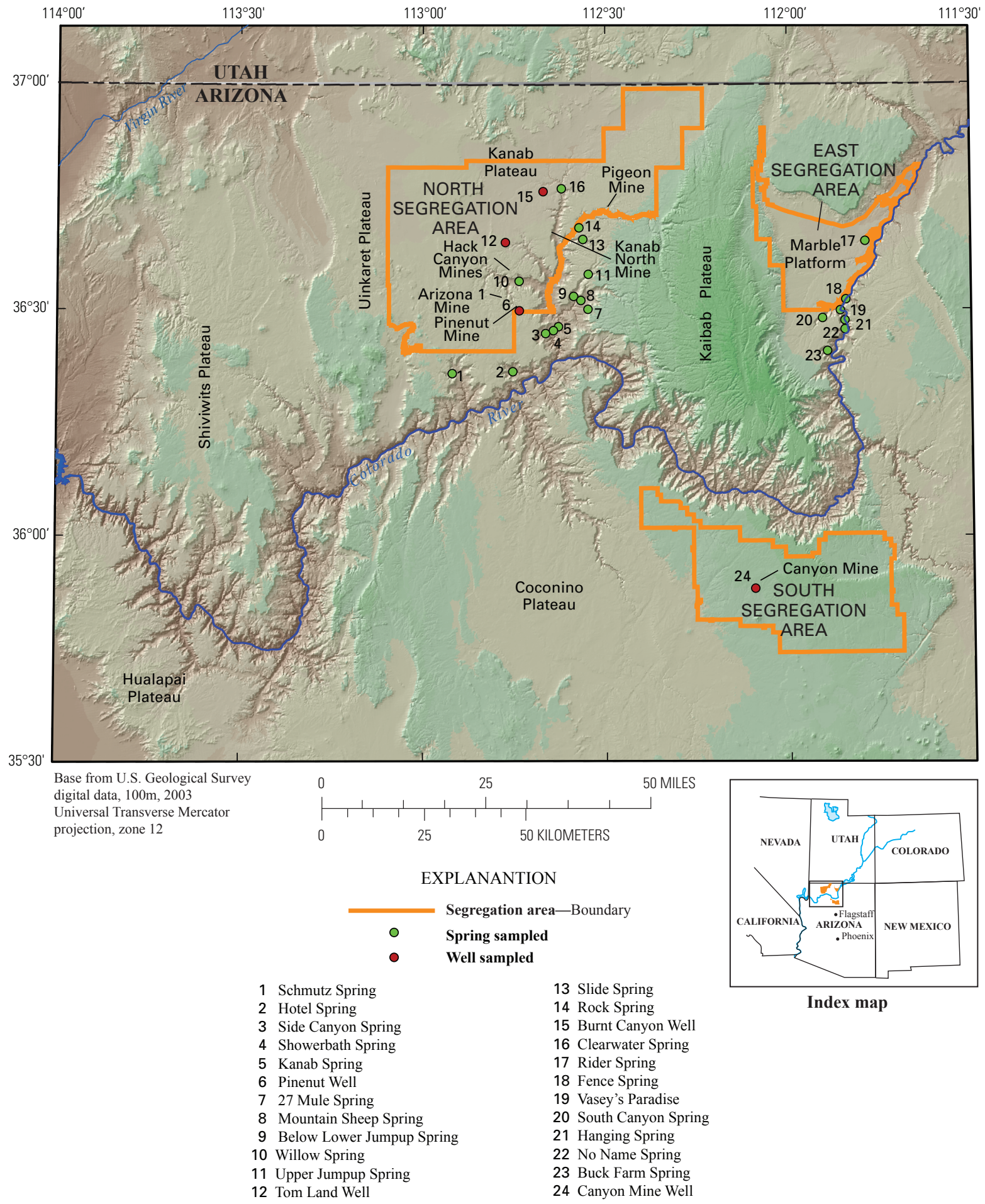

Figure 17. Well and spring sites in or near segregation areas of northern Arizona where water samples were collected in 2009. 


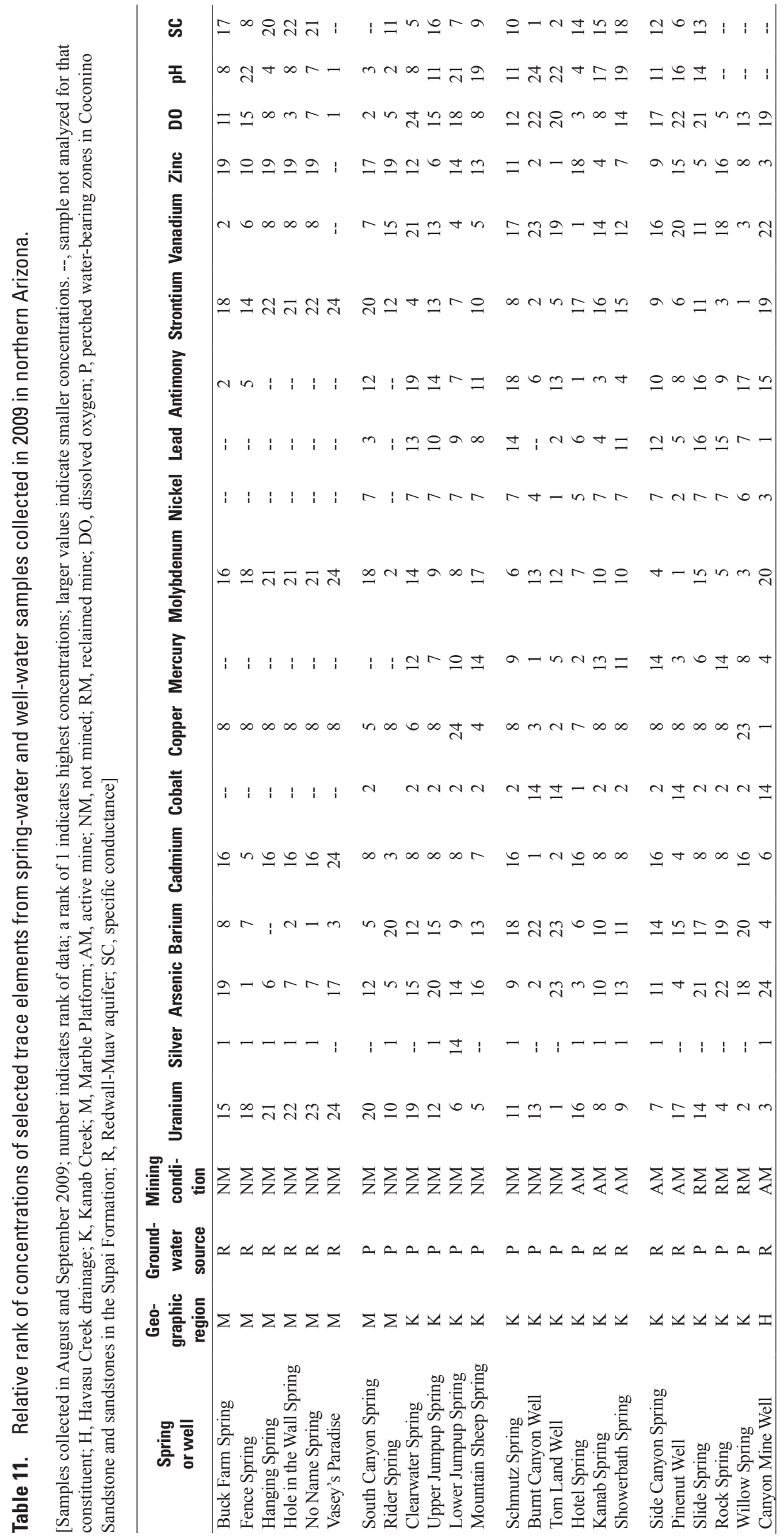




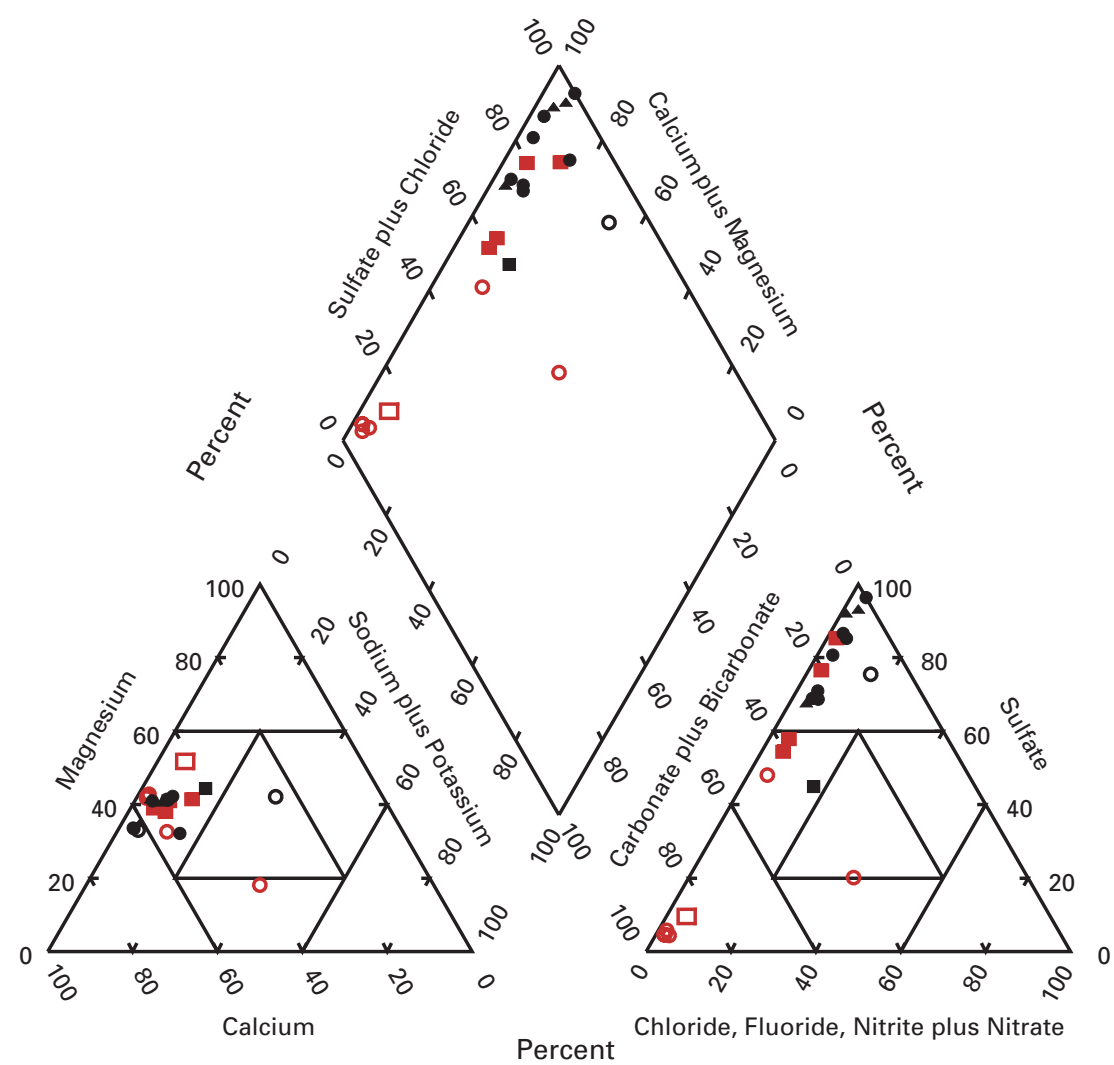

\section{EXPLANATION}

Groundwater source

- Perched water-bearing zones in the Coconino Sandstone and sandstones in the Supai Formation

- Redwall-Muav Aquifer

Geographic region and mining condition

- Marble Platform, no mining

- Kanab Creek drainage, no mining

- Kanab Creek drainage, reclaimed mines

- Kanab Creek drainage, active mines

Havasu Creek drainage, active mines

Figure 18. Major ion composition in groundwater samples collected in 2009 from sites in northern Arizona. Vasey's Paradise and South Canyon Springs samples excluded owing to insufficient data.

\section{Trace Elements}

Several trace elements differ by geographic region and by groundwater source. Although the 2009 groundwater samples were analyzed for many trace elements, this evaluation focuses on those determined by a previous study (Wenrich and others, 1994) to occur with uranium in mineralized breccia-pipe orebodies: antimony, arsenic, barium, cadmium, cobalt, copper, mercury, molybdenum, lead, nickel, silver, strontium, vanadium, and zinc. Some of these elements may not appear in groundwater as a result of differing solubilities and complexing anions. Relations between some trace elements and geographic region were not examined owing to the elements' low concentrations.
Concentrations of cobalt, copper, and silver were less than the minimum reporting limit in nearly all of the wells and springs sampled (appendix 2). Neither nickel nor cadmium was commonly detected, although they were detected at low concentrations in all four wells; however, cadmium was detected at only 3 springs and nickel at only 2 springs (appendix 2, table 11).

Overall concentrations of the examined trace elements were low compared with drinking water standards. Arsenic concentrations at two sites, Fence Spring and Burnt Canyon Well (fig. 17) exceeded the drinking water standard of $10 \mu \mathrm{g} / \mathrm{L}$ (appendix 2). No other trace-element concentrations exceeded primary drinking water standards, including the drinking water standard for uranium of $30 \mu \mathrm{g} / \mathrm{L}$. 
Patterns of trace-element concentrations in groundwater by geographic region were found for uranium, barium, molybdenum, strontium, and zinc. Uranium, molybdenum, strontium, and zinc concentrations were generally higher in groundwater from the Kanab Creek drainage than in groundwater from the Marble platform (appendix 2; table 11). Conversely, barium concentrations were generally higher in groundwater from the Marble platform than in groundwater from the Kanab Creek drainage (appendix 2; table 11). Concentrations of vanadium were not clearly higher or lower in groundwater from either of the two geographic regions. A high minimum reporting limit for lead and tin concentrations at several sites in the Marble platform precluded comparison of those elements in groundwater from the two geographic regions (appendix 2).

Patterns of trace-element concentrations in samples from the two groundwater sources were found for uranium, arsenic, barium, molybdenum, and strontium. Concentrations of uranium, molybdenum, and strontium were generally higher in groundwater from perched water-bearing zones than in groundwater from the Redwall-Muav aquifer (appendix 2; table 11). Conversely, arsenic and barium concentrations are generally higher in the Redwall-Muav aquifer than in the perched water-bearing zones (appendix 2; table 11). No pattern with respect to groundwater source was found for concentrations of lead, mercury, tin, vanadium and zinc.

Only a few patterns were found between of traceelement concentrations in groundwater and the three types of mining activity associated with the sites. Arsenic and barium concentrations appear to be lowest in groundwater associated with reclaimed mines, and molybdenum concentrations appear to be lowest in groundwater from unmined areas (appendix 2; table 11). None of the sites of the three types of mining activity were clearly enriched in dissolved uraniumsites of each type of mining activity produced 2 of the 7 sites with the highest uranium concentrations (table 11). Also, the range in uranium concentrations at sites in areas without mining activities $(0.57-20.6 \mu \mathrm{g} / \mathrm{L})$ was similar to that for sites associated with active or reclaimed mines $(2.14-19.5 \mu \mathrm{g} / \mathrm{L}$; appendix 2). Additionally, neither lead, mercury, strontium, tin, vanadium, nor zinc concentrations appear related to mining conditions. As stated previously for sites associated with active or reclaimed mines, it is assumed but not known with certainty that the groundwater sampled at each site actually flowed past and had opportunity to be affected by the mining activity. The lack of patterns in trace elements observed in this study could have resulted if the groundwater sampled did not flow past the mined areas. Consequently, patterns or lack of patterns in trace-element chemistry with respected to mining conditions noted here must be considered exploratory and inconclusive.

\section{Summary of Evaluation of Groundwater Samples Collected in 2009}

Groundwater samples collected in 2009 augmented the historical dataset compiled in this study and provided additional spatial resolution for the geographic distribution of uranium and trace metals in the Grand Canyon area of northern Arizona. Through evaluation of these water-quality data, the following was learned about the effects of geographic locations, groundwater source, and mining activities on major ion and trace metal concentrations:

- Major ion composition, specific conductance, and concentrations of uranium, barium, strontium, and molybdenum appear correlated with geographic region and groundwater source.

- Arsenic concentrations appear correlated with groundwater source, and zinc concentrations appear correlated with geographic region.

- Relations of uranium and 13 other trace elements with mining activity were few and inconclusive.

Certain limitations of this analysis of major ion and trace element data, many of which were due to programmatic resource and timing constraints, should be recognized. These limitations include the following:

- Information contained in the isotopic data was not incorporated into this analysis, and consideration of these data could affect our conclusions.

- Geochemical factors, such as $\mathrm{pH}$, temperature, and redox state, which are known to affect the fate and transport of trace elements, were not accounted for in this analysis.

- Compositional differences in the breccia pipes throughout the study area were not considered in the analysis, nor were the distances between the pipes and the sampling locations.

- The trace constituents examined in this analysis were limited to those determined by previous studies to be relevant to breccia pipe deposits; other elements not considered could be affected by mining activities.

- Most of the groundwater samples represent conditions at the end of a groundwater flow path from areas of recharge to location of discharge (springs). Affected groundwater, if any, may not have flowed yet to the points sampled in this study.

- This study was based on observational data without benefit of an optimal sampling design. Examination of the groundwater-chemistry data showed that groundwater chemistry appears correlated with groundwater source and location. To fully assess the relation 
between trace-element concentrations and mining conditions, the study needs to fully control for confounding effects of groundwater source and location on water chemistry. An ideal sampling design would have equal numbers of sites in each of the different permutations of the 3 types of mining conditions, the 2 groundwater sources, and the 3 different geographic regions.

- Groundwater samples were used to assess the relation between water chemistry and mining. The relation between surface-water chemistry and mining was not assessed.

\section{Future Water-Quality Investigations}

A more thorough investigation of water chemistry in the Grand Canyon region is required to better understand groundwater flow paths, travel times, and contributions from mining activities, particularly on the north side of the Colorado River. The hydrologic processes that control the distribution and mobilization of natural uranium in this hydrogeologic setting are poorly understood. New investigations of water chemistry can help to provide critical information that will refine our current understanding of the area. Suggested investigations include the following:

1. Collect and analyze additional water-chemistry data from springs and wells in the Redwall-Muav aquifer to determine groundwater flow characteristic north of the Colorado River that affect mobility of radionuclides near ore deposits and mined areas. Such an investigation would require the drilling of new observation wells in this area.

2. Monitoring of water levels in wells developed in the Redwall-Muav aquifer could provide information about the hydraulic connections between mined areas, springs, and seasonal precipitation in the area.

3. Establish a network of surface-water and water-qualitymonitoring sites in Kanab Creek Basin (the North Segregation Area). These sites would allow sampling of runoff that can then be analyzed for total radionuclide flux in this area.

4. Collect water and sediment samples from existing USGS streamflow gages tributary to the Colorado River in the Grand Canyon region (Paria River and the Little Colorado River) and from proposed new or reactivated gage sites on Kanab Creek and Havasu Creek. These data could be used to calculate maximum daily loads of uranium and radium. Such samples would provide net flux of radionuclides from the study area and provide an estimate of the storage of this material in Lake Mead.
5. Evaluate 2009 groundwater samples for isotopic composition, and then use those results to evaluate the recharge source area and water-rock interactions along flow paths that may or may not encounter orebodies.

6. Evaluate sediment samples archived by other USGS programs that were collected from tributaries to the Colorado River for their potential to be analyzed for total uranium and radium. Such analyses of archived samples would provide additional insight into historical radionuclide flux in the Grand Canyon region.

\section{Summary and Conclusions}

During 2009, the U.S. Geological Survey compiled available historical water-chemistry data for wells, springs, and streams in the Grand Canyon region and collected new samples at 24 sample sites for water-chemistry analysis. These data have three uses: evaluating the effects of legacy mining in the region, providing baseline information for dissolved uranium in groundwater, and comparing subbasin mining activities in the Kanab Creek Basin in northern Arizona. The occurrence and movement of groundwater north of the Colorado River has never been fully described owing to the limited population in this part of northern Arizona and to a lack of data needed to complete an analysis. Geologic and available hydrologic data from wells and springs were used to conceptualize the movement of groundwater in this part of northern Arizona.

Historical water-quality and water-chemistry data evaluated for 1,014 water samples from 428 sites indicate that about 70 sites have exceeded either the primary or secondary maximum contaminant levels for certain major ions and trace elements, such as arsenic, iron, lead, manganese, radium, sulfate, and uranium. These data suggest that water recharged from the surface or from perched water-bearing zones may contain dissolved gypsum from overlying rock units or may have been in contact with sulfide-rich ore. A few springs and wells in the region contain concentrations of dissolved uranium greater than the U.S. Environmental Protection Agency maximum contaminant level of $30 \mu \mathrm{g} / \mathrm{L}$. These springs and wells are close by or in direct contact with orebodies. Water samples from a few springs produce gross alpha and gross beta particle values greater than the U.S. Environmental Protection Agency recommended maximum contaminant level of $15 \mathrm{pCi} / \mathrm{L}$ and $4 \mathrm{mrem} / \mathrm{y}$ respectively.

Sixty-six percent of natural water sample concentrations of dissolved uranium in the dataset were $5 \mu \mathrm{g} / \mathrm{L}$ or less, and they may be subjectively be classified as low concentrations for the study area. Dissolved uranium concentrations in about 120 springs and 32 streams in the region in the range $5-30 \mu \mathrm{g} / \mathrm{L}$ result from natural dissolution and erosion 
of ore deposits. Fifteen springs and 5 wells in the region contain concentrations of dissolved uranium that exceed the U.S. Environmental Protection Agency maximum contaminant level for drinking water and are related to mining processes. Surface water in the Colorado River in the Grand Canyon region contains dissolved uranium concentrations typically less than $5 \mu \mathrm{g} / \mathrm{L}$. The Virgin River in the northwest corner of the study area, in contrast, contains dissolved-uranium concentrations greater than $80 \mu \mathrm{g} / \mathrm{L}$ from 1979 . There is no information since then to determine whether the concentrations persist or not.

Observation of groundwater-chemistry relations between concentration and geographic region (Marble platform, Kanab Creek drainage, and Havasu Creek drainage) and groundwater source (Redwall-Muav aquifer or perched water-bearing zone in the Coconino Sandstone and sandstones of the Supai Group) were made for major-ion composition, specific conductance, and concentrations of uranium, arsenic, barium, molybdenum, strontium, and zinc. Observation of groundwater-chemistry relations between concentration and mining condition (no mining activity, active mines on standby, or reclaimed mine areas) were limited and inconclusive. Surface water was not evaluated in this study.

\section{Acknowledgments}

Many agencies and individuals helped to collect and compile data for this study. The Bureau of Land Management (BLM), U.S. Forest Service, Grand Canyon National Park (GRCA), and Arizona Department of Environmental Quality (ADEQ) provided access to water-chemistry data for wells and springs in their databases. The BLM, U.S. Forest Service, and GRCA also expedited sample collection permits, and permits and waivers for access to springs in areas that are not normally visited. Leslie Grazer, Arizona Department of Water Resources (ADWR), compiled well data in the ADWR database for the region. John Stubblefield, Denison Mines, facilitated access to and assistance with the operation of mine wells to collect water samples. Several private owners also provided access to their wells for sampling. Steve Rice, hydrologist, and Brian Healy, biologist, GRCA, provided area knowledge and assistance that was invaluable in the collection of water samples from springs.

Many USGS personnel contributed to the collection, compilation, analysis, and presentation of data used in this report. The professional attitude of hydrologic technicians and hydrologists (Bob Hart, Greg Fisk, Dave Anning, Jamie Macy, Frank Schaffner, Geoff Debenedetto, Kurt Schonauer, Nancy Hornewer, Margot Truini, Cory Sannes, Nick Paretti, and Kim Beisner) who, in the harsh summer environment of the Grand Canyon $\left(105^{\circ} \mathrm{C}\right.$-plus temperatures, wind storms, and long, dry, and hazardous hikes), contributed to the safety of all and the successful collection of most of the planned well and spring samples. The services of camp cook Sarah Clinger were invaluable for keeping us comfortable, fed, and hydrated in primitive conditions. Jessica (and Ada) Gardner, precleaned and organized hundreds of sample bottles, collected sample bottles from the South Rim Heliport every evening for shipping to the laboratories, and maintained tracking sheets and chain-ofcustody for samples transported from the field to the laboratories, organizing the resultant data. Marilyn Flynn produced many of the figures and investigated creative methods of presenting data. Cheryl Partin, Henry Sanger, Claire Bunch, and Naomi Castillo researched numerous reports and databases for water-quality data, verified these data, and compiled them into spreadsheets for the authors' evaluation. George Billingsley, geologist, USGS, with his intimate knowledge of the geology and geologic structure of northern Arizona, provided a much-needed sounding board for discussions and conversation on possible groundwater flow scenarios in northern Arizona.

\section{References Cited}

American Public Health Association, 1985, Standard methods for the examination of water and wastewater (16th ed.): Washington, D.C., American Public Health Association.

Ames, L.L., and Dhanpat, Rai, 1978, Radionuclide interaction with soil and rock, v. 1, Processes influencing radionuclide mobility and retention, element chemistry and geochemistry, and conclusions and evaluation: Las Vegas Nev., U.S. Environmental Protection Agency Report EPA 520/6-78-007-A, 330 p.

Appel, C.L., and Bills, D.J., 1980, Map showing ground-water conditions in the Canyon Diablo area, Coconino and Navajo Counties, Arizona: U.S. Geological Survey Open-File Report 80-747.

Appel, C.L., and Bills, D.J., 1981, Map showing groundwater conditions in the San Francisco Peaks area, Coconino County, Arizona: U.S. Geological Survey Open-File Report 81-914, 2 sheets.

Arizona Department of Water Resources, 2009, Arizona water atlas, v. 6, Western Plateau Planning Region: Phoenix, Ariz., Arizona Department of Water Resources, 308 p.

Beukens, R.P., 1992, Radiocarbon accelerator mass spectrometry-Background, precision and accuracy, in Taylor, R.E., Long, A., and Kra, R.S., eds., Radiocarbon after four decades: New York, Springer-Verlag Publishing, p. 230-239.

Beus, S.S., and Morales, M., 2003, Grand Canyon geology (2d ed.): New York, Oxford University Press, 432 p.

Billingsley, G.H., 2000, Geologic map of the Grand Canyon $30^{\prime} \times 60^{\prime}$ quadrangle, Coconino and Mohave Counties, northwestern Arizona: U.S. Geological Survey Geologic Investigations Series I-2688, version 1.0, 15 p., scale 1:100,000. 
Billingsley, G.H., Block, D.L., and Dyer, H.C., 2006, Geologic map of the Peach Springs $30^{\prime} \times 60^{\prime}$ quadrangle, Mohave and Coconino Counties, northwestern Arizona: U.S. Geological Survey, Scientific Investigations Map SIM-2900, 17 p., $1: 100,000$.

Billingsley, G.H., Felger, T.H., and Priest, S.S., 2006, Geologic map of the Valle $30^{\prime} \times 60^{\prime}$ quadrangle, Coconino County, northern Arizona: U.S. Geological Survey, Scientific Investigations Map SIM-2895, 23 p., 1:100,000.

Billingsley, G.H., and Hendricks, J.D., 1989, Physiographic features of northwestern Arizona, in Elston, D.P., Billingsley, G.H., and Young, R.A., eds., Geology of Grand Canyon, northern Arizona (with a Colorado River guide): Washington, D.C., American Geophysical Union, chap. 4, p. 67-71.

Billingsley, G.H., Priest, S.S., and Felger, T.H., 2006, Geologic map of the Fredonia 30' $\times 60^{\prime}$ quadrangle, Mohave and Coconino Counties, northern Arizona: U.S. Geological Survey, Scientific Investigations Map SIM-3035, 25 p., 1:100,000.

Billingsley, G.H., Priest, S.S., and Felger, T.H., 2007, Geologic map of the Cameron $30^{\prime} \times 60^{\prime}$ quadrangle, Coconino County, northern Arizona: U.S. Geological Survey, Scientific Investigations Map SIM-2977, 33 p., 1:100,000.

Billingsley, G.H., Spamer, E.E., and Menkes, Dove, 1997, Quest for the pillar of gold, the mines and miners of the Grand Canyon: Grand Canyon, Ariz., Grand Canyon Association Monograph 10, $112 \mathrm{p}$.

Billingsley, G.H., and Wellmeyer, J.L., 2006, Geologic Map of the Mount Trumbull 30' $\times 60^{\prime}$ quadrangle, Mohave and Coconino Counties, northwestern Arizona: U.S. Geological Survey, Geologic Investigations Series I-2766, 2003, revised 2006, 36 p., 1:100,000.

Billingsley, G.H., and Workman, J.B., 2000, Geologic map of the Littlefield $30^{\prime} \times 60^{\prime}$ quadrangle, Mohave County, northwestern Arizona: U.S. Geological Survey, Geologic Investigations Series I-2628, 25 p., 1:100,000.

Bills, D.J., and Flynn M.E., 2002, Hydrogeologic data for the Coconino Plateau and adjacent areas, Coconino and Yavapai Counties, Arizona: U.S. Geological Survey Open-File Report 02-265, $29 \mathrm{p}$.

Bills, D.J., Flynn, M.E., and Monroe, S.A., 2007, Hydrogeology of the Coconino Plateau and adjacent areas, Coconino and Yavapai Counties, Arizona: U.S. Geological Survey Scientific Investigations Report 2005-5222, 101 p., 4 plates.

Bills, D.J., Truini, Margot, Flynn, M.E., Pierce, H.E., Catchings, R.D., and Rymer, M.J., 2000, Hydrogeology of the regional aquifer near Flagstaff, Arizona: U.S. Geological Survey Water-Resources Investigations Report 00-4122, 143 p., 4 plates.
Brinton, T.I., Antweiler, R.C., and Taylor, H.E., 1996, Method for the determination of dissolved chloride, nitrate and sulfate in natural water using ion chromatography: U.S. Geological Survey Open-File Report 95-426A, 16 p.

Brown, D., and Lowe, C., 1982, Biotic communities of the southwest United States and Mexico: Special issue of Desert Plants, v. 4, nos. 104, University of Arizona Boyce Tompson Southwest Arboretum.

Buekins, R.P., 1992, Radiocarbon accelerator mass spectrometry: Background, precision and accuracy, in Taylor, R.E., Long, A., and Kra, R.S., eds., Radiocarbon after four decades: New York, Springer-Verlag Publishing, p 230-239

Bullen, T.D., Krabbenhoft, D.P., and Kendall, C., 1996, Kinetic and mineralogic controls on the evolution of groundwater chemistry and ${ }^{87} \mathrm{Sr} /{ }^{86} \mathrm{Sr}$ in a sandy silicate aquifer, northern Wisconsin, USA: Geochimica et Cosmochimica Acta, v. 60, no. 10, p. 1807-1821.

Canonie Environmental Services Corp., 1991, Water quality data evaluation report, $33 \mathrm{p}$.

Casadevall, W.P., 1989, Exploration geology of Canyon breccia pipe south of Grand Canyon, Arizona [abs.]: American Association of Petroleum Geologists Bulletin, v. 73, no. 9, p. 1150.

Cheng, H., Edwards, R.L., Hoff, J., Gallup, C.D., Richards, D.A., and Asmerom Y., 2000, The half-lives of uranium-234 and thorium-230. Chem. Geol. 169, 17-33.

Clark, I.D., and Fritz, P., 1997, Environmental isotopes in hydrogeology: Boca Raton, Fla., Lewis Publishers, 328 p.

Cooley, M.E., 1976, Spring flow from pre-Pennsylvanian rocks in the southwestern part of the Navajo Indian Reservation, Arizona: U.S. Geological Survey Open-File Report 521-F, $15 \mathrm{p}$.

Cooley, M.E., Harshbarger, J.W., Akers, J.P., and Hardt, W.F., 1969, Regional hydrogeology of the Navajo and Hopi Indian Reservations, Arizona, New Mexico, and Utah, with a section on Vegetation by Hicks, O.N.: U.S. Geological Survey Professional Paper 521-A, 61 p., 9 plates.

Coplen, T.B., 1994, Reporting of stable hydrogen, carbon, and oxygen isotopic abundances: Pure and Applied Chemistry, v. 66, p. $273-276$.

Cordova, R.M., 1981, Ground-water conditions in the upper Virgin River and Kanab Creek basins area, Utah, with emphasis on the Navajo Sandstone: Utah Department of Natural Reosurces Technical Publication 70, 87 p., 3 plates.

Crossey, L.J., Fischer, T.B., Patchett, P.J., Karlstrom, K.E., Hilton, D.R., *Newell, D.L., Huntoon, P., and Reynolds, A.C., 2006, Dissected hydrologic system at the Grand Canyon: Interaction between deeply derived fluids and plateau aquifer waters in modern springs and travertine: Geology, v. 34 , p. $25-28$. 
Dames \& Moore, 1987, Hermit Mine ground-water conditions Mohave County, Arizona: submitted to Energy Fuels Nuclear, Inc., Denver, Colo., March 20, 1987.

Darton, N.H., 1910, A reconnaissance of parts of northwestern New Mexico and northern Arizona: U.S. Geological Survey Bulletin 435, $88 \mathrm{p}$.

Driscoll, A., 2007, National Water Quality Laboratory chain of custody: U.S. Geological Survey Administrative Report, 17 p., 4 attachments.

Dutton, C.E., 1882, The Tertiary history of the Grand Canyon district with atlas: U.S. Geological Survey Monograph 2, 264 p., atlas, 23 sheets.

Energy Fuels Nuclear, Inc., 1990a, Hermit Mine groundwater monitoring report mining and post mining phase: Denver, Colo.

Energy Fuels Nuclear, Inc., 1990b, Hermit Mine groundwater monitoring report mining phase, Submitted to Arizona Department of Environmental Quality: Denver, Colo., February $12,1990$.

Energy Fuels Nuclear, Inc., 1990c, Letter report to Abigail A. Myers, ADEQ from William J. Almas re: Hermit Mine Groundwater Protection Permit G-0035-08: Denver, Colo., March 7, 1990.

Energy Fuels Nuclear, Inc., 1995a, Arizona aquifer protection permit application Pinenut Mine: Denver, Colo.

Energy Fuels Nuclear, Inc., 1995b, Arizona aquifer protection permit closure plan Hack Canyon Mine: Denver, Colo.

Errol L. Montgomery and Assoc., 1993a, Aquifer protection permit application Energy Fuels Nuclear, Inc., Canyon Mine, Coconino County, Arizona: December 1993 Final Report.

Errol L. Montgomery and Assoc., 1993b, Data for Canyon Mine Groundwater Monitoring Program Reference N2219 (GRCA-8213): Annual Letter Report to Grand Canyon National Park, 16 tables.

Errol L. Montgomery and Associates, 1999, Supplemental assessment of hydrogeologic conditions and potential effects of proposed groundwater withdrawal Coconino Plateau Groundwater Subbasin, Coconino County, Arizona, June 1999: Williams, Ariz., Appendix of Final Environmental Impact Statement for Tusayan Growth, Kaibab National Forest, July 1999, 256 p.

Finch, W.I., 2003, Uranium-Fuel for nuclear energy 2002: U.S. Geological Survey Bulletin 2179-A, 18 p. Also available at http://pubs.usgs.gov/bul/b2179-a/.

Finch, W.I., Sutphin, H.B., Pierson, C.T., McCammon, R.B., and Wenrich, K.J., 1990, The 1987 estimate of undiscovered uranium endowment in solution-collapse breccia pipes in the Grand Canyon region of northern Arizona and adjacent Utah: U.S. Geological Survey Circular 1051, 19 p.
Farrar, C.D., 1979, Map showing ground-water conditions in the Bodaway Mesa area, Coconino County, Arizona: U.S. Geological Survey Open-File Report 79-1488, scale 1:250,000.

Farrar, C.D., 1980, Map showing ground-water conditions in the Hopi area, Coconino and Navajo Counties, Arizona: U.S. Geological Survey Open-File Report 80-3, 4 sheets, scale 1:250,000.

Farnsworth, R.K., Thompson, E.S., and Peck, E.L., 1982, Evaporation atlas for the contiguous 48 United States: Washington D.C., National Oceanographic and Atmospheric Administration Technical Report NWS 33, 26 p.

Fishman, M.J., Pritt, J.W., and Raese, J.W., 1994, Guideline for method validation and publication: National Water Quality Laboratory Standard Operating Procedure MX0015.0., $11 \mathrm{p}$.

Fitzgerald, J., 1996, Residence time of ground water issuing from the south rim aquifer in the eastern Grand Canyon: Las Vegas, University of Nevada, master's thesis, May 1996, 103 p.

Flint, A.L., Flint, L.E., Hevesi, J.A., and Blainey, J.B., 2004, Fundamental concepts of recharge in the desert southwestA regional modeling perspective, in Hogan, J.F., Phillips, F.M., and Scanlon, B.R., eds., Groundwater recharge in a desert environment-The southwestern United States: American Geophysical Union Water Science and Applications Series, v. 9, p. 159-184, doi:10.1029/0009WSA10.

Flint, A.L., and Flint, L.E., 2007, Application of the basin characterization model to estimate in-place recharge and runoff potential in the Basin and Range carbonate-rock aquifer system, White Pine County, Nevada, and adjacent areas in Nevada and Utah: U.S. Geological Survey Scientific Investigations Report 2007-5099, 20 p.

Foust, Jr., R.D., and Hope, Steve, 1985, Seasonal trends in the chemical composition of Grand Canyon waters: Flagstaff, Ariz., Ralph M. Bilby Research Center, Northern Arizona University, March 1985, 39 p., one appendix.

Fritz, P., and Fontes, Jean-Charles, 1980, Handbook of environmental isotope geochemistry, v. 1-2: Amsterdam, Elsevier Scientific Publishing Company, $557 \mathrm{p}$.

Garbarino, J.R., Kanagy, L.K., and Cree, M.E., 2006, Determination of elements in natural-water, biota, sediment, and soil samples using collision/reaction cell inductively coupled plasma-mass spectrometry: U.S. Geological Survey Techniques and Methods, book 5, sec. B, chap. 1, 88 p.

Garbarino, J.R., and Taylor, H.E., 1979, An inductively coupled plasma atomic-emission spectrometric method for routine water quality testing: Applied Spectroscopy, v. 33, p. 220-225. 
Garbarino, J.R., and Taylor, H.E., 1996, Inductively coupled plasma-mass spectrometric method for the determination of dissolved trace elements in natural water: U.S. Geological Survey Open-File Report 94-358, 88 p.

Goings, D.B., 1985, Spring flow in a portion of Grand Canyon National Park, Arizona: Las Vegas University of Nevada, master's thesis, CPSU/UNLV 033/01, June 1985, 60 p.

Grand Canyon National Park, 2006, Community fact sheetOrphan Mine site: National Park Service, Grand Canyon National Park Fact Sheet, revision2, February 2006. 1 p. http://www.nps.gov/grca/parkmgmt/upload/orphan1.pdf. Accessed Jan. 15, 2010.

Gregory, H.E., 1916, The Navajo country-A geographic and hydrographic reconnaissance of parts of Arizona, New Mexico, and Utah: U.S. Geological Survey Water-Supply Paper 380, 219 p.

Hart, R.J., Ward, J.J., Bills, D.J., and Flynn, M.E., 2002, Generalized hydrogeology and ground-water budget for the $\mathrm{C}$ aquifer, Little Colorado River Basin and parts of the Verde and Salt River Basins, Arizona and New Mexico: U.S. Geological Survey Water-Resources Investigations Report 02-4026, 47 p., 1 plate.

Hoffman, G.L., Fishman, M.J., and Garbarino, J.R., 1996, Methods of analysis by the U.S. Geological Survey National Water Quality Laboratory-In-bottle acid digestion of whole-water samples: U.S. Geological Survey Open-File Report 96-225, 28 p.

Hopkins, R.T., Fox, J.P., Campbell, W.L., and Antweiler, J.C., 1984a, Analytical results and sample locality map of streamsediment, panned-concentrate, rock, and water samples from the Andrus Canyon, Grassy Mountain, Last Chance Canyon, Mustang Point, Nevershine Mesa, Pigeon Canyon, and Snap Point Wilderness Study Areas, Mohave County, Arizona: U.S. Geological Survey Open-File Report 84-288, 34 p.

Hopkins, R.T., Fox, J.P., Campbell, W.L., and Antweiler, J.C., 1984b, Analytical results and sample locality map of stream sediment, panned-concentrates, soil, and rock samples from the Kanab Creek (B3060) Roadless Area, Coconino and Mohave counties, Arizona: U.S. Geological Survey OpenFile Report 84-291, 18 p.

Hualapai Water Resources Department, 1995, Hualapai Reservation water-quality assessment report 305(b), 1995: Hualapai Water Resources Department, Peach Springs, Arizona, with assistance from the U.S. Geological Survey, June 1995, $101 \mathrm{p}$.
Huntoon, P.W., 1974, Synopsis of Laramide and postLaramide structural geology of the eastern Grand Canyon, Arizona, in Karlstrom, T.N.V., Swann, G.A., and Eastwood, R.L., eds., Geology of northern Arizona with notes on archaeology and paleoclimate-Regional studies: Geological Society of America, Rocky Mountain Section Meeting, Flagstaff, Arizona, part 1, p. 317-335.

Huntoon, P.W., 1977, Holocene faulting in the western Grand Canyon, Geological Society of America Bulletin, November 1977, v. 88, p. 1619-1622.

Huntoon, P.W., 2000a, Variability of karstic permeability between unconfined and confined aquifers, Grand Canyon region, Arizona: Environmental and Engineering Geoscience, May 2000, v. VI, no. 2, p. 155-170.

Huntoon, P.W., 2000b, Karstification associated with groundwater circulation through the Redwall artesian aquifer, Grand Canyon, Arizona, U.S.A., in Klimchouk, AB., Ford, D, C., Palmer, A.N., and Dreybrodt, W., eds., SpeleogenesisEvolution of karst aquifers: Huntsville, National Speleological Society, Inc., p. 287-291.

International Uranium Corp., 1999, Letter report to Craig Dewalt, ADEQ from Donn M. Pillmore, January 29, 1999.

Johnson, P.W., and Sanderson, R.B., 1968, Spring flow into the Colorado River - Lees Ferry to Lake Mead, Arizona: Arizona State Land Department Water-Resources Report 34, $26 \mathrm{p}$.

Kendall, C., and Caldwell, E.A., 1998, Fundamentals of isotope geochemistry, in Kendall, C. and McDonnell, J.J., eds., Isotope tracers in catchment hydrology: Amsterdam, Elsevier Scientific Publishing Company, p. 51-86.

Kessler, J.A., 2002, Grand Canyon springs and the RedwallMuav aquifer - Comparison of geologic framework and groundwater flow models: Flagstaff, Northern Arizona University, unpublished master's thesis, $122 \mathrm{p}$.

Koterba, M.T., Wilde, F.D., and Lapham, W.W., 1995, Ground-water data-collection protocols and procedures for the National Water-Quality Assessment ProgramCollection and documentation of water-quality samples and related data: U.S. geological Survey Open-File Report 95-399, 113 p.

Kraemer, T.F., 2005, Radium isotopes in Cayuga Lake, New York-Indicators of inflow and mixing processes: Limnology and Oceanography, v. 50, no. 1, p. 158-168.

Kraemer, T.F., Doughten, M.W., and Bullen, T.D., 2002, Use of ICP/MS with ultrasonic nebulizer for routine determination of uranium activity ratios in natural water: Environmental Science \& Technology, v. 36, p. 4899-4904.

LaRue, E.C., 1925, Water power and flood control of Colorado River below Green River, Utah: U.S. Geological Survey Water-Supply Paper 556, 176 p. 
Langmuir, D., 1978, Uranium solution-mineral equilibria at low temperatures with applications to sedimentary ore deposits: Geochimica et Cosmochimica Acta, 42, pp. 547-569.

Levings, G.W., and Farrar, C.D., 1978, Maps showing groundwater conditions in the House Rock area, Coconino County, Arizona-1976: U.S. Geological Survey Water-Resources Investigations Report 78-15, 17 p., 1 sheet.

Levings, G.W., and Farrar, C.D., 1979a, Map showing groundwater conditions in the Kanab Area, Coconino and Mohave Counties, Arizona-1976: U.S. Geological Survey WaterResources Investigations Open-File Report 79-1070, 32 p. 2 sheets.

Levings, G.W., and Farrar, C.D., 1979b, Map showing groundwater conditions in the Virgin River, Grand Wash, and Shiviwits areas, Mohave County, Arizona-1976: U.S. Geological Survey Water-Resources Investigations Open-File Report 79-57, 24 p., 1 sheet.

Liebe, Dirk, 2003, The use of the ${ }^{234} \mathrm{U} / 238 \mathrm{U}$ activity ratio at the characterization of springs and surface streams in Grand Canyon National Park, Arizona: Dresden, Saxony, Germany, Hochschule fur Technik und Wirtschaft Dresden, M.S. thesis, $105 \mathrm{p}$.

Longsworth, S.A., 1994, Hydrogeology and water chemistry of abandoned uranium mines and radiochemistry of soil leachate, Monument Valley and Cameron areas, Arizona and Utah: U.S. Geological Survey Water Resources Investigations Report 93-4226, 43 p.

McGavock, E.H., 1968, Basic ground-water data for southern Coconino County, Arizona: Phoenix, Arizona State Land Department Water-Resources Report 33, 48 p.

McGavock, E.H., Anderson, T.W., Moosburner, Otto, and Mann, L.J., 1986, Water resources of southern Coconino County, Arizona: Phoenix, Arizona Department of Water Resources Bulletin 4, 53 p.

Melis, T.S., Phillips, W.M., Webb, R.H., and Bills, D.J., 1996, When the blue-green waters turn red-Historical flooding in Havasu Creek, Arizona: U.S. Geological Survey WaterResources Investigations Report 96-4059, 136 p.

Melis, T.S., Webb, R.H., Griffiths, P.G., and Wise, T.J., 1994, Magnitude and frequency data for historic debris flows in the Grand Canyon National Park and vicinity, Arizona: U.S. Geological Survey Water-Reosurces Investigations Report 94-4214, 285 p.

Metzger, D.G., 1961, Geology in relation to availability of water along the south rim, Grand Canyon National Park, Arizona: U.S. Geological Survey Water-Supply Paper 1475-C, 138 p.

Mitko, K., and Bebek, M., 1999, ICP-OES determination of trace elements in salinated water: Atomic Spectroscopy, v. 20, p. 217-223.
Mitko, K., and Bebek, M., 2000, Determination of major elements in saline water samples using a dual-view ICP-OES: Atomic Spectroscopy, v. 21, p. 77-85.

Monroe, S.A., Antweiler, R.C., Hart, R.J., Taylor, H.E., Truini, M., Rihs, J.R., and Felger, T.J., 2005, Chemical characteristics of ground-water discharge at selected springs, south rim Grand Canyon, Arizona: U.S. Geological Survey Scientific Investigations Report 04-5146, 59 p., 1 plate.

National Bureau of Standards (National Institute of Standards and Technology), 1984, Certificate for standard reference material 1643b, trace elements in water: Washington, D.C.

National Water Quality Laboratory, 1998, Determination of elements in whole-water digests using inductively coupled plasma-optical emission spectrometry and inductively coupled plasma-mass spectrometry: U.S. Geological Survey Open-File Report 98-165, 101 p.

Natural Resources Consulting Engineers, Inc., 1999, Field study of springs and other hydrologic features on the Havasupai Reservation, Arizona: Fort Collins, Colo., Natural Resources Consulting Engineers, Inc., 28 p.

Natural Resources Consulting Engineers, Inc., 2000, Field study of springs and Bar Four Well on the Havasupai Reservation, Arizona: Fort Collins, Colo., Natural Resources Consulting Engineers, Inc., Fort Collins, 26 p.

Office of Nuclear Waste Isolation, 1985, Marble canyon spring sampling investigation: Technical Report BMI/ONWI-514, $62 \mathrm{p}$.

Olson, D.M., Dinerstien, E., Wikramanayake, E.D., Burgress, N.D., Powell, G.V.N., Underwood, E.C., D’Amico, J.A., Itoua, I., Strand, H.E., Morrison, J.C., Loucks, C.J., Allnutt, T.F., Ricketts, T.H., Kura, Y., Lamoreux, J.F., Wettengel, W.W., Hedeo, P., and Kassem, K.R., 2001, Terrestrial ecoregions of the world-A new map of life on Earth: Bio Science, v. 51, p. 933-938.

Osmond, J.K., and Cowart, J.B., 1992, Groundwater, in Uraniumseries disequilibrium-Applications to earth, marine, and environmental sciences, Ivanovich, M., and Harmon, R.S., eds.: Oxford, U.K., Clarendon Press, p. 259-289.

Paces, J.B., Ludwig, K.R., Peterman, Z.E., and Neymark, L.A., 2002, 234U/238U evidence for local recharge and patterns of ground-water flow in the vicinity of Yucca Mountain, Nevada, USA: Applied Geochemistry, v. 17, p. 751-779

Peterson, J.E., Buell, S.E., Cadigan, R.A., Felmlee, J.K., and Sprakis, C.S., 1977, Uranium, radium and selected metallicelement analyses of spring water and travertine samples from the Grand Canyon, Arizona: U.S. Geological Survey Open-File Report 77-36, 7 p.

Rantz, S.E., and others, 1982, Measurement and computation of streamflow, v. 1, Measurement of stage and discharge: U.S. Geological Survey Water-Supply Paper 2175, 284 p. 
Ross, L.E.V., 2005, Interpretive three-dimensional numerical groundwater flow modeling, Roaring Springs, Grand Canyon, Arizona: Flagstaff, Master's Thesis, Department of Geology, Northern Arizona University, December 2005, $120 \mathrm{p}$.

Rote, J.J., Flynn, M.E., and Bills, D.J., 1997, Hydrologic data, Colorado River and major tributaries, Glen Canyon Dam to Diamond Creek, Arizona, water years 1990-95: U.S. Geological Survey, Open-File Report 97-250, 474 p.

Roth, D.A., 1994, Ultratrace analysis of mercury and its distribution in some natural waters in the United States: Fort Collins, Colorado State University, Department of Chemistry Ph.D. dissertation, $309 \mathrm{p}$.

Roth, D.A., Taylor, H.E., Domagalski, J., Dileanis, P., Peart, D.B., Antweiler, R.C., and Alpers, C.N., 2001, Distribution of inorganic mercury in Sacramento River water and sediments: Archives of Environmental Contamination and Toxicology, v. 40, p. 161-172.

Sanford, R.F., 1982, Preliminary model of regional Mesozoic groundwater flow and uranium deposition in the Colorado Plateau: Geology, July 1982, v. 10, p., 248-352.

Smith, S.M., 2006, National Geochemical Database reformatted data from the National Uranium Resource Evaluation (NURE) Hydrogeochemical and Stream Sediment Reconnaissance (HSSR) program: U.S. Geological Survey OpenFile Report 97-0492, version 1.40, http://pubs.usgs.gov/ of/1997/ofr-97-0492/, accessed January 13, 2010.

Spamer, E.E., compiler, with G.H. Billingsley, W.J. Breed, R.C. Euler, D.A. House, Grace Keroher, Valerie Meyer, Richard Quartaroli, L.E. Stevens, and L.M. Hinchliffe)1990, Bibliography of the Grand Canyon and the lower Colorado River from 1540: Grand Canyon Natural History Association Monograph 8, $370 \mathrm{p}$.

Steiger, R.H., and Jäger, E., 1977, Subcommission on geochronology - Convention on the use of decay constants in geo- and cosmochronology: Earth and Planetary Science Letters, v. 36, p. 359-362.

Stuiver, Minze, and Polach, H.A., 1977, Discussion of reporting ${ }^{14} \mathrm{C}$ data: Radiocarbon, v. 19 , no. 3, p. 355-363.

Szabo, B.J., Kolesar, P.T., Riggs, A.C., Winograd, I.J., and Ludwig, K.R., 1994. Paleoclimatic inferences from a 120,000-yr calcite record of water-table fluctuation in Browns Room of Devils Hole, Nevada: Quaternary Research v. 41, no. 1, p. 59-69.

Taylor, H.E., 2000, Inorganic substances, mass spectrometric in the analysis of, in Meyers, R.A., ed., Encyclopedia of analytical chemistry: Chichester, England, John Wiley and Sons, Ltd., p. 11761-11773.
Taylor, H.E., Berghoff, K., Andrews, E.D., Antweiler, R.C., Brinton, T.I., Miller, C., Peart, D.B., and Roth, D.A., 1997, Water quality of springs and seeps in Glen Canyon National Recreation Area: National Park Service Technical Report NPS/NRWRD/NRTR-97/128, 19 p.

Taylor, H.E., Peart, D.B., Antweiler, R.C., Brinton, T.I., Campbell, W.L., Garbarino, J.R., Roth, D.A., Hart, R.J., and Averett, R.C., 1996, Data from synoptic water quality studies on the Colorado River in the Grand Canyon, Arizona, November 1990 and June 1991: U.S. Geological Survey Open-File Report 96-614, 176 p.

Taylor, H.E., Spence, J.R., Antweiler, R.C., Berghoff, K., Plowman, T.I., Peart, D.B., and Roth, D.A., 2004, Water quality and quantity of selected springs and seeps along the Colorado River corridor, Utah and Arizona-Arches National Park, Canyonlands National Park, Glen Canyon National Recreation Area, and Grand Canyon National Park, 1997-98: U.S. Geological Survey Open-File Report 2003-496, 33 p.

Taylor, O.J., Hood, J.W., and Zimmerman, E.A., 1986, Hydrogeologic framework of the upper Colorado River basinexcluding the San Juan Basin - Colorado, Utah, Wyoming, and Arizona: U.S. Geological Survey Hydrologic Investigations Atlas HA-687, scale 1:3,000,000, 2 sheets.

The PRISM Group at Oregon State University, 2006, United States monthly or annual precipitation, 1971-2000: PRISM Climate Group, Oregon State University, accessed May 29, 2008, at http://www.prism.oregonstate.edu.

Thomas, B.E., 2003, Water-quality data for Walnut Canyon and Wupatki National Monuments, Arizona, 2001-02: U.S. Geological Survey Open-File Report 03-286, 13 p.

U.S. Environmental Protection Agency Region VIII, 1973, Radium-226, uranium and other radiological data from water quality surveillance stations located in the Colorado River Basin of Colorado, Utah, New Mexico and ArizonaJanuary 1961 through June 1972: 155 p.

U.S. Environmental Protection Agency, 1976, Quality criteria for water 1976 [The Red Book]: U.S. Environmental Agency number 440976023, July 1976, 534 p.

U.S. Environmental Protection Agency, 2000. National primary drinking water regulations-Radionuclides, Final Rule: Federal Register, U.S. Code of Federal Regulations, December 7, 2000, v. 65, no. 236, p. 76708-76753.

U.S. Environmental Protection Agency, 2004, Drinking water standards and health advisories: Washington, D.C., EPA 822-R-04-005, 12 p.

U.S. Environmental Protection Agency, 2009, Drinking water contaminants: http://www.epa.gov/safewater/contaminants/ index.html, accessed October 2009 [from table 5]. 
U.S. Geological Survey, 2009a, Mineral resources on-line spatial data-Geochemistry of water samples in the US from the NURE-HSSR database: http://tin.er.usgs.gov/nure/ water/, accessed November 4, 2009.

U.S. Geological Survey, 2009b, National Water Information System (NWISWeb): U.S. Geological Survey database, accessed October 16, 2009 at http://waterdata.usgs.gov/ nwis/.

Van Gosen, B.S., and Wenrich, K.J., 1989, Ground magnetometer surveys over known and suspected breccia pipes on the Coconino Plateau, northwestern Arizona: U.S. Geological Survey Bulletin 1683-C, 31 p.

Webb, R.H., Smith, S.S., and McCord, V.A.S., 1991, Historic channel change of Kanab Creek, southern Utah and northern Arizona: Grand Canyon Natural History Association monograph 9, $91 \mathrm{p}$.

Wenrich, K.J., Billingsley, G.H., and Huntoon, P.W., 1997; Breccia-pipe and geologic map of the northeastern part of the Hualapai Indian Reservation and vicinity, Arizona: U.S. Geological Survey I-Map 2440.

Wenrich, K.J., Boundy, S.Q., Aumente-Modreski, R., Schwarz, S.P., Sutphin, H.B., and Been, J.M., 1994, A hydrogeochemical survey for mineralized breccia pipes - Data from springs, wells, and streams on the Hualapai Indian Reservation, northwestern Arizona: U.S. Geological Survey OpenFile Report 93-619, 66 p.
Wenrich, K.J., and Sutphin, H.B., 1989, Lithotectonic setting necessary for formation of a uranium-rich, solution-collapse breccia-pipe province, Grand Canyon region, Arizona, U.S. Geological Survey Open-File Report 89-173, 33 p.

Wershaw, R.L., Fishman, M.J., Grabbe, R.R., and Lowe, L.E., eds., 1987, Methods for the determination of organic substances in water and fluvial sediments: U. S. Geological Survey Techniques of Water-Resources Investigations, book 5, chap. A3, p. 6-7.

Wigley, T.M.L., and Muller, A.B., 1981, Fractionation corrections in radiocarbon dating: Radiocarbon, v. 23, no. 2, p. 173-190.

Wilde, F.D., and Radtke, D.B., eds., 1998, National field manual for the collection of water-quality data-Field measurements: U.S. Geological Survey Techniques of WaterResources Investigations, book 9, chap. A6.

Young, R.A., 2008, Pre-Colorado River drainage in the western Grand Canyon-Potential influence on Miocene stratigraphy in Grand Wash trough: Geological Society of America Special Papers 2008, v. 439, p. 319-333

Zukosky, K.A., 1995, An assessment of the potential to use water chemistry parameters to define ground water flow pathways at Grand Canyon National Park, Arizona: Las Vegas, Department of Geoscience, University of Nevada, master's thesis, $105 \mathrm{p}$. 


\section{Appendix 1. Northern Arizona University Isotope and Radiochemistry Laboratory Methods for Dissolved Uranium and Uranium Isotope Analysis of Spring-Water and Well-Water Samples Collected from Sites in Northern Arizona}

A duplicate set of water samples were sent to the Northern Arizona University (NAU) Isotope and Radiochemistry Laboratory, Flagstaff, Ariz., for dissolved uranium and uranium isotopes analysis. The NAU Laboratory used a $20 \mathrm{~mL}$ aliquot for analysis pipetted volumetrically into a precleaned $50 \mathrm{~mL}$ polypropylene test tube along with tracemetal grade nitric acid $(16 \mathrm{M}, 2 \mathrm{~mL})$ and a known amount of purified ${ }^{233} \mathrm{U}$ tracer solution. After sample-spike equilibration, uranium was purified using $50 \mathrm{mg}$ of UTEVA resin beads $(50-100 \mu \mathrm{m})$ added to each sample, agitated for 30 minutes, and retained on an ion-exchange column. Columns were rinsed three times with $1 \mathrm{~mL}$ of $2 \mathrm{M} \mathrm{HNO}_{3}$, followed by elution of uranium using $1.0 \mathrm{~mL}$ water, $1.0 \mathrm{~mL} 0.05 \mathrm{M}$ ammonium oxalate, and $1.0 \mathrm{~mL}$ water. Chemical process blanks $(\mathrm{n}=3)$ were run through the entire sample preparation process along with duplicates of two samples. Inductively coupled plasmamass spectrometer (ICP-MS) analyses were conducted using a Thermo X Series II quadrupole ICP-MS equipped with an APEX HF sample introduction system (ESI Scientific, Omaha, Nebr.) operating in peak-jumping mode (10 millisecond dwell at each of ${ }^{232} \mathrm{Th},{ }^{233} \mathrm{U},{ }^{234} \mathrm{U}$, and ${ }^{235} \mathrm{U}$ peaks with 1,500 sweeps per integration). An analysis consisted of three sequential integrations, each requiring 70 seconds. Resulting data represent the average and standard deviations for these three integrations. The sample introduction system was rinsed between samples with an aqueous solution containing $0.005 \mathrm{M}$ ammonium oxalate and $0.1 \mathrm{M} \mathrm{HNO}_{3}$ while monitoring the ${ }^{235} \mathrm{U}^{+}$ion beam was monitored until the signal reached levels typical of the blanks. Average blank results were used to correct ${ }^{234} \mathrm{U}^{+}$and ${ }^{235} \mathrm{U}^{+}$signals. Corrections to the ${ }^{233} \mathrm{U}^{+}$signal for contributions of $\mathrm{ThH}^{+}$were not necessary because $\mathrm{Th}$ is virtually absent in all samples. Mass bias corrections were applied based on external measurements of ${ }^{238} U \mathrm{U}^{235} \mathrm{U}$ in natural $\mathrm{U}$ solutions. Corrected ${ }^{234} \mathrm{U} /{ }^{235} \mathrm{U}$ atom ratios were converted to ${ }^{234} \mathrm{U} /{ }^{238} \mathrm{U}$ activity ratios as follows:

$$
\text { AR } 234 / 238=\left({ }^{234} \mathrm{U} /{ }^{235} \mathrm{U}\right) \times(1 / 137.88) / 0.00005472
$$

where

\author{
$(1 / 137.88)$ is the ${ }^{235} \mathrm{U} /{ }^{238} \mathrm{U}$ atom ratio in nature (constant \\ within 0.1 percent)
}

and

0.00005472 is the ${ }^{234} \mathrm{U} /{ }^{238} \mathrm{U}$ atom ratio at secular equilibrium. (Steiger and Jäger, 1977; Cheng and others, 2000). Eight blocks of ${ }^{234} U{ }^{235} U$ atom ratios were collected at different times during the analysis of a uranium solution prepared from "modern coral." This material has the activity ratio characteristic of modern seawater (see following table).

Uranium Atomic Ratios in Modern Corals

[The expected atomic ratio in modern seawater is $1.148 \pm 0.002$. AR 234/238, atomic ratio of uranium-234 to uranium-238; SD, standard deviation

\begin{tabular}{ccc}
\hline Block & AR 234/238 & SD \\
\hline 1 & 1.158 & 0.001 \\
2 & 1.154 & 0.004 \\
3 & 1.153 & 0.001 \\
4 & 1.154 & 0.003 \\
5 & 1.150 & 0.002 \\
6 & 1.158 & 0.006 \\
7 & 1.156 & 0.009 \\
8 & 1.155 & 0.006 \\
Average & 1.155 & 0.003 \\
\hline
\end{tabular}

The expected AR in modern seawater is $1.148 \pm 0.002$ (Szabo and others, 1994).

The average NAU value of 1.155 for the atomic ratio of uranium-234 to uranium-238 (AR 234/238) is in close agreement with the expected value for modern seawater (1.148 \pm 0.002$)$. Given the large differences among AR 234/238 values observed for unknown samples, the slight bias between measured and expected seawater AR 234/238 values is insignificant. Uranium concentrations in the water samples were obtained from the correct ${ }^{233} \mathrm{U} /{ }^{235} \mathrm{U}$ and standard isotope dilution calculations. Duplicate analyses of two water samples (Showerbath Spring and Rider Spring) are in excellent agreement for both activity ratios and uranium concentrations. 



\section{Appendix 2. Water Chemistry Data from Water Samples Collected from Springs and Wells Sampled in Northern Arizona in 2009}

Table A. Analysis results from all laboratories.

These terms are used on the following pages in table A:

$[\mathrm{H}$, Havasu Creek drainage;

K, Kanab Creek;

M, Marble Platform;

$\mathrm{P}$, perched water-bearing zones in the Coconino Sandstone and sandstones in the Supai Formation;

$\mathrm{R}$, Redwall-Muav aquifer;

AM, active mines;

NM, not mined;

RM, reclaimed mines;

Bullen, USGS National Research Program Laboratory, Menlo Park, California;

Coplen, USGS National Isotope Fractionation Project Laboratory, Reston, Virginia;

Doughten, USGS National Research Program Laboratory, Reston, Virginia;

Kraemer, USGS National Research Program Laboratory, Reston, Virginia;

Michel, USGS National Research Program Laboratory, Menlo Park, California;

NAU, Northern Arizona University Isotope and Radiochemistry Laboratory, Flagstaff, Arizona;

NWQL, USGS National Water Quality Laboratory, Denver, Colorado;

RSIL, USGS National Isotope Fractionation Project Laboratory, Reston, Virginia;

Taylor, USGS National Research Program Laboratory, Boulder, Colorado;

AASCE, atomic absorption spectrometry-chelation extraction;

AASD, atomic absorption spectrometry direct;

AAS-GF, atomic absorption spectrophotometry-graphite furnace;

AASH, atomic absorption spectrometry hydride;

AES, atomic emission spectroscopy;

AES-DCP, atomic emission spectrometry-direct current plasma;

CCRDSF, colorimetry hydrazine reduction-diazotization segmented flow;

CPBDSF, colorimetry phosphormolydate block digester segmented flow;

$\mathrm{CS}$, colorimetry salicylate-hypochlorite;

CV-AFS, cold vapor-atomic fluorescence spectroscopy;

EISE, electrometry ion-selective electrode;

IC, ion chromatography;

ICP-OES, inductively coupled plasma-optical emission spectroscopy;

ICP-AES, inductively coupled plasma-atomic emission spectroscopy;

ICP-MS, inductively coupled plasma-mass spectrometry;

KDM, Kjeldahl digestion method;

--, not available;

$<$, less than;

${ }^{\circ} \mathrm{C}$, degree Celsius;

$\%$, per mil;

e, estimated;

field, value determined at the site;

$\mathrm{gal} / \mathrm{min}$, gallon per minute;

$\mu \mathrm{g} / \mathrm{L}$, microgram per liter;

$\mu \mathrm{S} / \mathrm{cm}$, microsiemen per centimeter at $25^{\circ} \mathrm{C}$;

$\mathrm{mg} \mathrm{CaCO} 3 / \mathrm{L}$, milligram calcium carbonate per liter;

$\mathrm{mg} \mathrm{N} / \mathrm{L}$, milligram nitrogen per liter;

$\mathrm{mg} \mathrm{P} / \mathrm{L}$, milligram phosphorus per liter;

$\mathrm{mg} / \mathrm{L}$, milligram per liter;

$\mathrm{mm} \mathrm{Hg}$, millimeter of mercury;

$\mathrm{nm}$, not measured;

ns, no sample;

$\mathrm{pC} / \mathrm{L}$, picocurie per liter;

$R$, results less than sample-specific reporting limit;

$\mathrm{SD}$, standard deviation;

$\mathrm{TU}$, tritium unit;

unf, unfiltered] 
Table A. Analysis results from all laboratories.

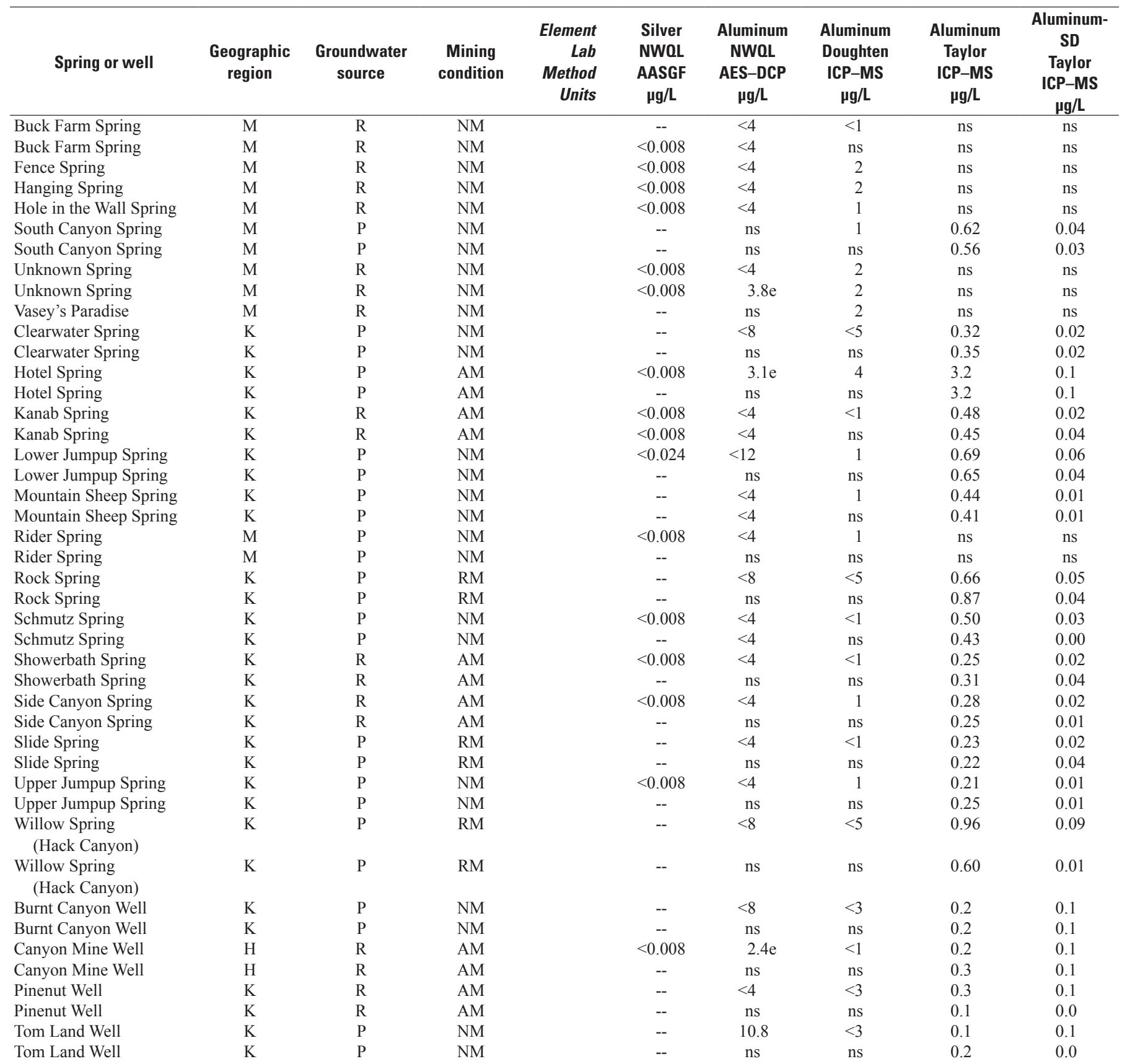


Table A. Analysis results from all laboratories.-Continued

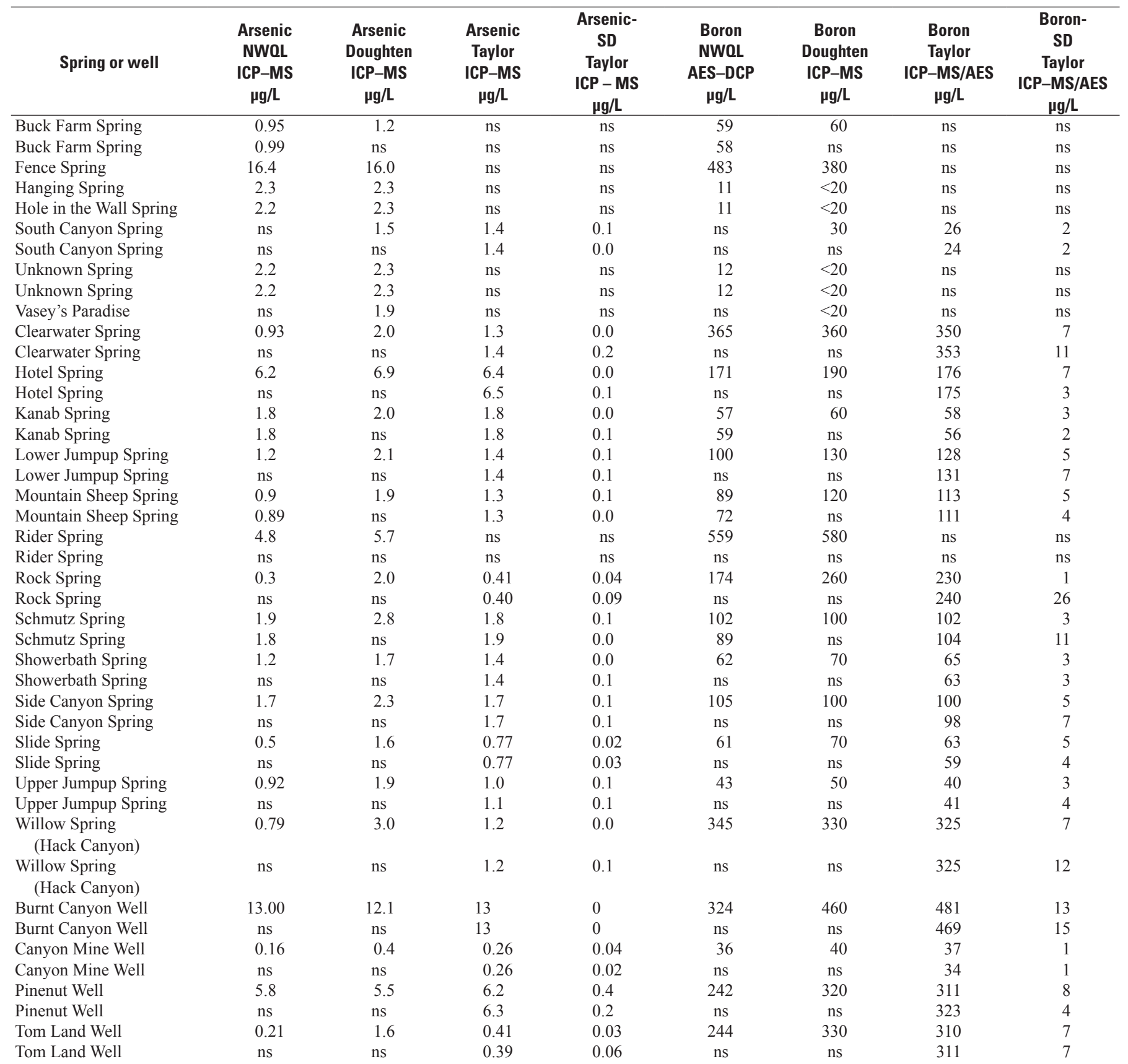


Table A. Analysis results from all laboratories.-Continued

\begin{tabular}{|c|c|c|c|c|c|c|c|c|c|}
\hline Spring or well & $\begin{array}{c}\text { Barium } \\
\text { NWOL } \\
\text { AASD } \\
\mu g / L\end{array}$ & $\begin{array}{c}\text { Barium } \\
\text { Doughten } \\
\text { ICP-MS } \\
\text { pg/L }\end{array}$ & $\begin{array}{c}\text { Barium } \\
\text { Taylor } \\
\text { ICP-MS/AES } \\
\mu \mathrm{g} / \mathrm{L}\end{array}$ & $\begin{array}{c}\text { Barium-SD } \\
\text { Taylor } \\
\text { ICP-MS/AES } \\
\mu \mathrm{g} / \mathrm{L}\end{array}$ & $\begin{array}{c}\text { Beryllium } \\
\text { NWOL } \\
\text { ICP-MS } \\
\mu \mathrm{g} / \mathrm{L}\end{array}$ & $\begin{array}{c}\text { Beryllium } \\
\text { Taylor } \\
\text { ICP-MS } \\
\text { нg/L }\end{array}$ & $\begin{array}{c}\text { Beryllium- } \\
\text { SD } \\
\text { Taylor } \\
\text { ICP-MS } \\
\mu \mathrm{g} / \mathrm{L}\end{array}$ & $\begin{array}{c}\text { Bismuth } \\
\text { Taylor } \\
\text { ICP-MS } \\
\text { нg/L }\end{array}$ & $\begin{array}{c}\text { Bismuth- } \\
\text { SD } \\
\text { Taylor } \\
\text { ICP-MS } \\
\mu \mathrm{g} / \mathrm{L}\end{array}$ \\
\hline Buck Farm Spring & 31 & 30 & ns & $\mathrm{ns}$ & $<0.02$ & ns & $\mathrm{ns}$ & ns & ns \\
\hline Buck Farm Spring & 31 & ns & ns & ns & $<0.02$ & ns & ns & ns & ns \\
\hline Fence Spring & 52 & 54 & ns & ns & 0.04 & ns & ns & ns & ns \\
\hline Hanging Spring & 181 & 65 & ns & ns & $<0.02$ & ns & $\mathrm{ns}$ & ns & ns \\
\hline Hole in the Wall Spring & 178 & 162 & ns & ns & $<0.02$ & ns & ns & ns & ns \\
\hline South Canyon Spring & ns & 72 & 74 & 2 & ns & $<0.02$ & 0.02 & $<0.006$ & 0.001 \\
\hline South Canyon Spring & ns & ns & 73 & 2 & ns & $<0.02$ & 0.01 & $<0.006$ & 0.000 \\
\hline Unknown Spring & 180 & 166 & ns & ns & $<0.02$ & ns & $\mathrm{ns}$ & $\mathrm{ns}$ & ns \\
\hline Unknown Spring & 178 & 165 & ns & ns & $<0.02$ & ns & ns & ns & ns \\
\hline Vasey's Paradise & ns & 134 & ns & ns & ns & ns & ns & ns & ns \\
\hline Clearwater Spring & 22 & 22 & 21 & 1 & $<0.04$ & $<0.02$ & 0.01 & $<0.006$ & 0.000 \\
\hline Clearwater Spring & ns & ns & 21 & 0 & ns & $<0.02$ & 0.00 & $<0.006$ & 0.000 \\
\hline Hotel Spring & 57 & 54 & 56 & 2 & $<0.02$ & $<0.02$ & 0.01 & $<0.006$ & 0.003 \\
\hline Hotel Spring & ns & ns & 57 & 1 & ns & $<0.02$ & 0.01 & $<0.006$ & 0.001 \\
\hline Kanab Spring & 25 & 24 & 25 & 0 & $<0.02$ & $<0.02$ & 0.01 & $<0.006$ & 0.001 \\
\hline Kanab Spring & 26 & ns & 25 & 0 & $<0.02$ & $<0.02$ & 0.02 & $<0.006$ & 0.002 \\
\hline Lower Jumpup Spring & 29 & 29 & 28 & 0 & $<0.06$ & $<0.02$ & 0.01 & $<0.006$ & 0.001 \\
\hline Lower Jumpup Spring & ns & ns & 28 & 1 & ns & $<0.02$ & 0.02 & $<0.006$ & 0.000 \\
\hline Mountain Sheep Spring & 18 & 19 & 18 & 0 & $<0.02$ & 0.009 & 0.005 & $<0.006$ & 0.001 \\
\hline Mountain Sheep Spring & 18 & ns & 18 & 0 & $<0.02$ & 0.010 & 0.006 & $<0.006$ & 0.002 \\
\hline Rider Spring & 8 & 8 & ns & $\mathrm{ns}$ & $<0.02$ & ns & $\mathrm{ns}$ & $\mathrm{ns}$ & ns \\
\hline Rider Spring & ns & ns & ns & $\mathrm{ns}$ & ns & $\mathrm{ns}$ & ns & ns & ns \\
\hline Rock Spring & 9 & 9 & 8.6 & 0.2 & $<0.04$ & 0.007 & 0.002 & $<0.006$ & 0.001 \\
\hline Rock Spring & ns & ns & 6.5 & 0.4 & ns & $<0.006$ & 0.008 & $<0.006$ & 0.001 \\
\hline Schmutz Spring & 7 & 9 & 8.5 & 0.5 & $<0.02$ & $<0.02$ & 0.02 & $<0.006$ & 0.001 \\
\hline Schmutz Spring & 9 & ns & 8.4 & 0.8 & $<0.02$ & $<0.02$ & 0.01 & $<0.006$ & 0.001 \\
\hline Showerbath Spring & 23 & 22 & 23 & 0 & $<0.02$ & $<0.02$ & 0.01 & $<0.006$ & 0.002 \\
\hline Showerbath Spring & ns & ns & 22 & 1 & ns & $<0.02$ & 0.01 & $<0.006$ & 0.001 \\
\hline Side Canyon Spring & 12 & 12 & 12 & 0 & $<0.02$ & $<0.02$ & 0.01 & $<0.006$ & 0.001 \\
\hline Side Canyon Spring & ns & ns & 12 & 0 & ns & $<0.02$ & 0.01 & $<0.006$ & 0.001 \\
\hline Slide Spring & 10 & 10 & 10 & 0 & $<0.02$ & $<0.02$ & 0.01 & $<0.006$ & 0.001 \\
\hline Slide Spring & ns & ns & 10 & 0 & ns & 0.02 & 0.01 & $<0.006$ & 0.001 \\
\hline Upper Jumpup Spring & 11 & 11 & 11 & 0 & $<0.02$ & $<0.02$ & 0.01 & $<0.006$ & 0.001 \\
\hline Upper Jumpup Spring & ns & ns & 11 & 0 & $\mathrm{~ns}$ & $<0.02$ & 0.00 & $<0.006$ & 0.001 \\
\hline $\begin{array}{l}\text { Willow Spring } \\
\text { (Hack Canyon) }\end{array}$ & 8 & 8 & 7.7 & 0.2 & $<0.04$ & $<0.02$ & 0.01 & $<0.006$ & 0.000 \\
\hline $\begin{array}{l}\text { Willow Spring } \\
\text { (Hack Canyon) }\end{array}$ & ns & ns & 8.3 & 0.5 & ns & $<0.02$ & 0.01 & $<0.006$ & 0.002 \\
\hline Burnt Canyon Well & 7 & 8 & 7.7 & 0.5 & 0.06 & 0.04 & 0.01 & $<0.007$ & 0.001 \\
\hline Burnt Canyon Well & ns & ns & 7.6 & 0.9 & ns & 0.04 & 0.01 & $<0.007$ & 0.001 \\
\hline Canyon Mine Well & 78 & 89 & 96 & 1 & $<0.02$ & $<0.02$ & 0.00 & $<0.007$ & 0.001 \\
\hline Canyon Mine Well & ns & ns & 93 & 5 & ns & $<0.02$ & 0.01 & $<0.007$ & 0.000 \\
\hline Pinenut Well & 11 & 10 & 11 & 1 & $<0.02$ & $<0.02$ & 0.01 & $<0.007$ & 0.001 \\
\hline Pinenut Well & ns & ns & 11 & 0 & ns & $<0.02$ & 0.00 & $<0.007$ & 0.001 \\
\hline Tom Land Well & 7 & 7 & 6.6 & 0.6 & $0.02 \mathrm{e}$ & $<0.02$ & 0.01 & $<0.007$ & 0.001 \\
\hline Tom Land Well & ns & ns & 6.8 & 0.8 & ns & $<0.02$ & 0.00 & $<0.007$ & 0.001 \\
\hline
\end{tabular}


Table A. Analysis results from all laboratories.-Continued

\begin{tabular}{|c|c|c|c|c|c|c|c|c|c|}
\hline Spring or well & $\begin{array}{c}\text { Bromine } \\
\text { Doughten } \\
\text { IC } \\
\mathrm{mg} / \mathrm{L}\end{array}$ & $\begin{array}{c}\text { Calcium } \\
\text { NWOL } \\
\text { ICP-MS } \\
\text { mg/L }\end{array}$ & $\begin{array}{c}\text { Calcium } \\
\text { Doughten } \\
\text { ICP-OES } \\
\text { mg/L }\end{array}$ & $\begin{array}{c}\text { Calcium } \\
\text { Taylor } \\
\text { ICP-AES } \\
\text { mg/L }\end{array}$ & $\begin{array}{c}\text { Calcium- } \\
\text { SD } \\
\text { Taylor } \\
\text { ICP-AES } \\
\text { mg/L }\end{array}$ & $\begin{array}{c}\text { Cadmium } \\
\text { NWOL } \\
\text { AASGF } \\
\mu \mathrm{g} / \mathrm{L}\end{array}$ & $\begin{array}{c}\text { Cadmium } \\
\text { Doughten } \\
\text { ICP-MS } \\
\mu \mathrm{g} / \mathrm{L}\end{array}$ & $\begin{array}{c}\text { Cadmium } \\
\text { Taylor } \\
\text { ICP-MS } \\
\text { मg/L }\end{array}$ & $\begin{array}{c}\text { Cadmium- } \\
\text { SD } \\
\text { Taylor } \\
\text { ICP-MS } \\
\mu \mathrm{g} / \mathrm{L}\end{array}$ \\
\hline Buck Farm Spring & 0.07 & 95.1 & 94.4 & ns & ns & $0.01 \mathrm{e}$ & $<0.05$ & ns & ns \\
\hline Buck Farm Spring & ns & ns & ns & ns & ns & $<0.02$ & ns & $\mathrm{ns}$ & $\mathrm{ns}$ \\
\hline Fence Spring & 0.50 & 147 & 145 & ns & ns & 0.03 & $<0.05$ & ns & ns \\
\hline Hanging Spring & 0.03 & 44.9 & 43.5 & ns & ns & $0.01 \mathrm{e}$ & $<0.05$ & ns & ns \\
\hline Hole in the Wall Spring & 0.03 & 45.5 & 45.2 & $\mathrm{~ns}$ & ns & $<0.02$ & $<0.05$ & ns & ns \\
\hline South Canyon Spring & $\mathrm{ns}$ & ns & 55.7 & 55 & 1 & ns & $<0.05$ & $<0.002$ & 0.002 \\
\hline South Canyon Spring & ns & ns & ns & 56 & 2 & ns & ns & $<0.002$ & 0.000 \\
\hline Unknown Spring & 0.02 & 44.2 & 44.3 & $\mathrm{~ns}$ & ns & $<0.02$ & $<0.05$ & $\mathrm{~ns}$ & ns \\
\hline Unknown Spring & 0.02 & & 44.1 & ns & ns & $<0.02$ & $<0.05$ & ns & ns \\
\hline Vasey's Paradise & ns & ns & 43.7 & ns & ns & ns & $<0.05$ & ns & ns \\
\hline Clearwater Spring & 0.52 & 492 & 472 & 464 & 1 & 0.04 & $<0.25$ & $<0.002$ & 0.000 \\
\hline Clearwater Spring & ns & ns & ns & 469 & 6 & ns & ns & $<0.002$ & 0.000 \\
\hline Hotel Spring & 0.53 & 72.6 & 72.8 & 72 & 2 & 0.02 & $<0.05$ & $<0.002$ & 0.002 \\
\hline Hotel Spring & ns & ns & ns & 72 & 1 & ns & ns & $<0.002$ & 0.003 \\
\hline Kanab Spring & 0.12 & 97.6 & 99.3 & 102 & 2 & $0.01 \mathrm{e}$ & $<0.05$ & $<0.002$ & 0.000 \\
\hline Kanab Spring & ns & ns & ns & 97 & 3 & $0.02 \mathrm{e}$ & ns & $<0.002$ & 0.002 \\
\hline Lower Jumpup Spring & 0.46 & 238 & 251 & 254 & 0 & $0.04 \mathrm{e}$ & $<0.05$ & $<0.002$ & 0.003 \\
\hline Lower Jumpup Spring & $\mathrm{ns}$ & ns & ns & 245 & 2 & ns & ns & $<0.002$ & 0.001 \\
\hline Mountain Sheep Spring & 0.13 & 188 & 189 & 184 & 13 & $0.02 \mathrm{e}$ & $<0.05$ & 0.004 & 0.001 \\
\hline Mountain Sheep Spring & $\mathrm{ns}$ & ns & ns & 184 & 12 & $0.02 \mathrm{e}$ & ns & 0.004 & 0.000 \\
\hline Rider Spring & 0.57 & 63.9 & 63.0 & $\mathrm{~ns}$ & ns & 0.04 & $<0.05$ & ns & ns \\
\hline Rider Spring & ns & ns & ns & ns & ns & ns & ns & ns & ns \\
\hline Rock Spring & 0.34 & 447.0 & 437 & 404 & 3 & 0.06 & $<0.25$ & $<0.001$ & 0.001 \\
\hline Rock Spring & ns & ns & ns & 433 & 15 & ns & ns & $<0.001$ & 0.001 \\
\hline Schmutz Spring & 0.18 & 239 & 241 & 241 & 8 & $0.01 \mathrm{e}$ & $<0.05$ & $<0.002$ & 0.002 \\
\hline Schmutz Spring & ns & ns & ns & 230 & 10 & 0.02 & ns & $<0.002$ & 0.001 \\
\hline Showerbath Spring & 0.11 & 113 & 115 & 111 & 2 & $0.01 \mathrm{e}$ & $<0.05$ & $<0.002$ & 0.002 \\
\hline Showerbath Spring & ns & ns & ns & 114 & 3 & ns & ns & $<0.002$ & 0.000 \\
\hline Side Canyon Spring & 0.08 & 176 & 181 & 181 & 2 & 0.03 & $<0.05$ & $<0.002$ & 0.003 \\
\hline Side Canyon Spring & $\mathrm{ns}$ & ns & $\mathrm{ns}$ & 177 & 8 & ns & ns & $<0.002$ & 0.000 \\
\hline Slide Spring & 0.21 & 142 & 149 & 147 & 6 & $<0.02$ & $<0.05$ & $<0.002$ & 0.000 \\
\hline Slide Spring & ns & ns & ns & 144 & 2 & ns & ns & 0.003 & 0.004 \\
\hline Upper Jumpup Spring & 0.20 & 132 & 136 & 137 & 2 & $0.01 \mathrm{e}$ & $<0.05$ & $<0.002$ & 0.002 \\
\hline Upper Jumpup Spring & ns & ns & ns & 138 & 2 & ns & ns & $<0.002$ & 0.002 \\
\hline $\begin{array}{l}\text { Willow Spring } \\
\text { (Hack Canyon) }\end{array}$ & 0.31 & 498 & 488 & 483 & 32 & $0.04 \mathrm{e}$ & $<0.25$ & $<0.002$ & 0.002 \\
\hline $\begin{array}{l}\text { Willow Spring } \\
\text { (Hack Canyon) }\end{array}$ & ns & ns & ns & 493 & 6 & ns & ns & $<0.002$ & 0.001 \\
\hline Burnt Canyon Well & 0.41 & 548 & 525 & 568 & 27 & 0.16 & $<0.15$ & 0.11 & 0.01 \\
\hline Burnt Canyon Well & ns & ns & ns & 565 & 11 & ns & ns & 0.11 & 0.00 \\
\hline Canyon Mine Well & 0.07 & 32.9 & 42.6 & 43 & 1 & $<0.02$ & $<0.05$ & 0.009 & 0.002 \\
\hline Canyon Mine Well & ns & $\mathrm{ns}$ & ns & 41 & 1 & ns & ns & 0.011 & 0.001 \\
\hline Pinenut Well & 0.10 & 238 & 264 & 245 & 9 & 0.05 & $<0.15$ & 0.011 & 0.002 \\
\hline Pinenut Well & ns & $\mathrm{ns}$ & ns & 253 & 10 & ns & ns & 0.013 & 0.005 \\
\hline Tom Land Well & 0.38 & 470 & 466 & 454 & 23 & 0.10 & $<0.15$ & 0.047 & 0.001 \\
\hline Tom Land Well & ns & ns & ns & 464 & 21 & ns & ns & 0.047 & 0.001 \\
\hline
\end{tabular}


Table A. Analysis results from all laboratories.-Continued

\begin{tabular}{|c|c|c|c|c|c|c|c|c|}
\hline Spring or well & $\begin{array}{c}\text { Cerium } \\
\text { Taylor } \\
\text { ICP-MS } \\
\mu \mathrm{g} / \mathrm{L}\end{array}$ & $\begin{array}{c}\text { Cerium-SD } \\
\text { Taylor } \\
\text { ICP-MS } \\
\mu \mathrm{g} / \mathrm{L}\end{array}$ & $\begin{array}{c}\text { Chlorine } \\
\text { NWOL } \\
\text { IC } \\
\text { mg/L }\end{array}$ & $\begin{array}{c}\text { Chlorine } \\
\text { Doughten } \\
\text { IC } \\
\text { mg/L }\end{array}$ & $\begin{array}{c}\text { Cobalt } \\
\text { NWOL } \\
\text { ICP-MS } \\
\mu g / L\end{array}$ & $\begin{array}{c}\text { Cobalt } \\
\text { Doughten } \\
\text { ICP-MS } \\
\mu \mathrm{g} / \mathrm{L}\end{array}$ & $\begin{array}{c}\text { Cobalt } \\
\text { Taylor } \\
\text { ICP-AES } \\
\mu \mathrm{g} / \mathrm{L}\end{array}$ & $\begin{array}{c}\text { Cobalt-SD } \\
\text { Taylor } \\
\text { ICP-AES } \\
\mu \mathrm{g} / \mathrm{L}\end{array}$ \\
\hline Buck Farm Spring & ns & ns & 12.7 & 12.9 & 0.09 & 0.10 & ns & ns \\
\hline Buck Farm Spring & ns & ns & ns & & 0.1 & ns & ns & ns \\
\hline Fence Spring & $\mathrm{ns}$ & ns & 239 & 243 & 0.12 & 0.21 & ns & ns \\
\hline Hanging Spring & ns & ns & 2.0 & 2.03 & 0.07 & 0.08 & ns & $\mathrm{ns}$ \\
\hline Hole in the Wall Spring & ns & ns & 2.0 & 2.02 & 0.04 & 0.05 & ns & $\mathrm{ns}$ \\
\hline South Canyon Spring & 0.0021 & 0.0009 & ns & ns & ns & 0.07 & $<0.2$ & 0.2 \\
\hline South Canyon Spring & 0.0015 & 0.0005 & ns & ns & ns & ns & $<0.2$ & 0.2 \\
\hline Unknown Spring & ns & ns & 2.0 & 2.03 & 0.05 & 0.05 & ns & ns \\
\hline Unknown Spring & ns & ns & & 2.06 & 0.05 & $<0.05$ & ns & ns \\
\hline Vasey's Paradise & $\mathrm{ns}$ & ns & ns & ns & ns & 0.41 & ns & $\mathrm{ns}$ \\
\hline Clearwater Spring & 0.0009 & 0.0005 & 69.8 & 70.9 & 0.6 & 0.42 & $<0.2$ & 0.0 \\
\hline Clearwater Spring & 0.0008 & 0.0003 & ns & ns & ns & ns & $<0.2$ & 0.0 \\
\hline Hotel Spring & 0.0079 & 0.0000 & 48.9 & 52.3 & 0.95 & 1.46 & 1.1 & 0.2 \\
\hline Hotel Spring & 0.0081 & 0.0009 & ns & ns & ns & ns & 0.9 & 0.2 \\
\hline Kanab Spring & 0.0025 & 0.0018 & 16.0 & 16.2 & 0.09 & 0.09 & $<0.2$ & 0.2 \\
\hline Kanab Spring & 0.0020 & 0.0007 & ns & ns & 0.16 & ns & $<0.2$ & 0.2 \\
\hline Lower Jumpup Spring & 0.0072 & 0.0009 & 41.7 & 42.4 & 0.48 & 0.35 & $<0.2$ & 0.1 \\
\hline Lower Jumpup Spring & 0.0072 & 0.0012 & ns & ns & ns & ns & $<0.2$ & 0.2 \\
\hline Mountain Sheep Spring & 0.0010 & 0.0002 & 41.2 & 41.1 & 0.42 & 0.19 & $<0.2$ & 0.0 \\
\hline Mountain Sheep Spring & 0.0008 & 0.0001 & ns & ns & 0.29 & ns & $<0.2$ & 0.1 \\
\hline Rider Spring & ns & ns & 57.4 & 60.5 & 0.09 & 0.15 & ns & ns \\
\hline Rider Spring & ns & ns & ns & $\mathrm{ns}$ & ns & ns & ns & ns \\
\hline Rock Spring & 0.0012 & 0.0000 & 15.2 & 15.4 & 0.58 & 0.43 & $<0.2$ & 0.3 \\
\hline Rock Spring & 0.0010 & 0.0002 & ns & ns & ns & ns & 0.2 & 0.2 \\
\hline Schmutz Spring & 0.0009 & 0.0001 & 18.4 & 18.2 & 0.18 & 0.24 & $<0.2$ & 0.1 \\
\hline Schmutz Spring & 0.0010 & 0.0006 & ns & ns & 0.25 & ns & $<0.2$ & 0.1 \\
\hline Showerbath Spring & $<0.0006$ & 0.0005 & 16.1 & 16.3 & 0.11 & 0.10 & $<0.2$ & 0.1 \\
\hline Showerbath Spring & $<0.0006$ & 0.0003 & $\mathrm{~ns}$ & $\mathrm{~ns}$ & ns & ns & $<0.2$ & 0.1 \\
\hline Side Canyon Spring & $<0.0006$ & 0.0009 & 10.7 & 11.3 & 0.19 & 0.16 & $<0.2$ & 0.1 \\
\hline Side Canyon Spring & $<0.0006$ & 0.0005 & ns & $\mathrm{ns}$ & ns & ns & $<0.2$ & 0.3 \\
\hline Slide Spring & $<0.0006$ & 0.0004 & 15.3 & 15.4 & 0.12 & 0.14 & $<0.2$ & 0.1 \\
\hline Slide Spring & $<0.0006$ & 0.0003 & ns & ns & ns & ns & $<0.2$ & 0.2 \\
\hline Upper Jumpup Spring & 0.0023 & 0.0004 & 16.2 & 16.4 & 0.12 & 0.12 & $<0.2$ & 0.1 \\
\hline Upper Jumpup Spring & 0.0006 & 0.0003 & ns & ns & ns & ns & $<0.2$ & 0.1 \\
\hline $\begin{array}{l}\text { Willow Spring } \\
\text { (Hack Canyon) }\end{array}$ & 0.0088 & 0.0004 & 48.5 & 47.3 & 0.57 & 0.48 & $<0.2$ & 0.1 \\
\hline $\begin{array}{l}\text { Willow Spring } \\
\text { (Hack Canyon) }\end{array}$ & 0.0076 & 0.0003 & ns & ns & ns & ns & $<0.2$ & 0.1 \\
\hline Burnt Canyon Well & 0.0035 & 0.0013 & 55.7 & 53.8 & 0.86 & 0.72 & $<0.3$ & 0.3 \\
\hline Burnt Canyon Well & 0.0031 & 0.0007 & ns & ns & ns & ns & $<0.3$ & 0.1 \\
\hline Canyon Mine Well & 0.0004 & 0.0002 & 6.45 & 6.51 & 1.7 & 0.16 & 0.3 & 0.0 \\
\hline Canyon Mine Well & 0.0008 & 0.0003 & ns & ns & ns & ns & $<0.3$ & 0.3 \\
\hline Pinenut Well & 0.0019 & 0.0001 & 18.9 & 18.8 & 0.60 & 0.52 & $<0.3$ & 0.1 \\
\hline Pinenut Well & 0.0017 & 0.0004 & $\mathrm{~ns}$ & ns & ns & ns & $<0.3$ & 0.1 \\
\hline Tom Land Well & 0.0024 & 0.0004 & 28.5 & 28.0 & 0.73 & 0.51 & $<0.3$ & 0.1 \\
\hline Tom Land Well & 0.0027 & 0.0008 & ns & ns & ns & ns & $<0.3$ & 0.3 \\
\hline
\end{tabular}


Table A. Analysis results from all laboratories.-Continued

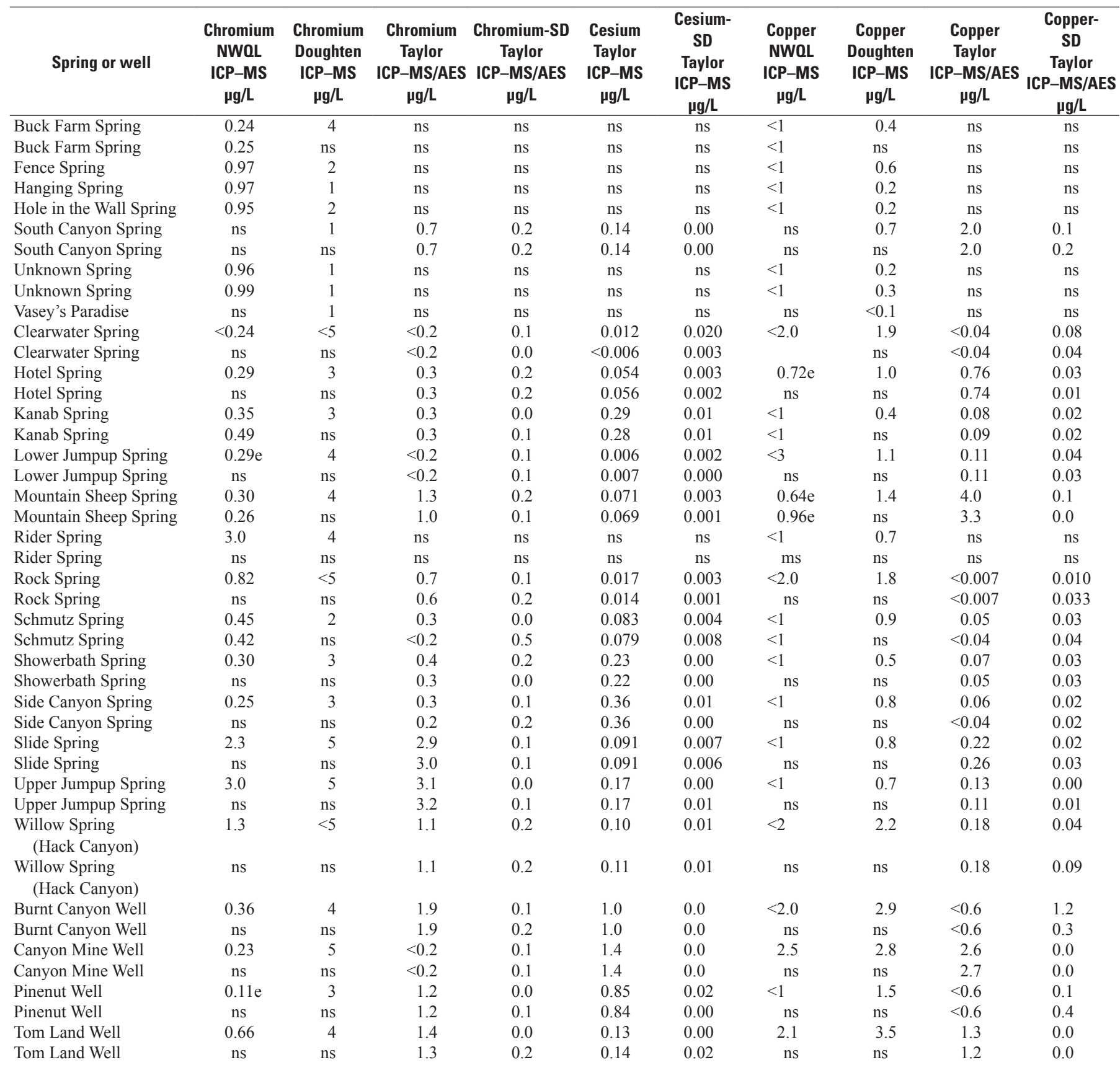


Table A. Analysis results from all laboratories.-Continued

\begin{tabular}{|c|c|c|c|c|c|c|c|c|}
\hline Spring or well & $\begin{array}{c}\text { Dysprosium } \\
\text { Taylor } \\
\text { ICP-MS } \\
\text { Ig/L }\end{array}$ & $\begin{array}{c}\text { Dysprosium- } \\
\text { SD } \\
\text { Taylor } \\
\text { ICP-MS } \\
\mu \mathrm{g} / \mathrm{L} \\
\end{array}$ & $\begin{array}{c}\text { Erbium } \\
\text { Taylor } \\
\text { ICP-MS } \\
\mu g / L\end{array}$ & $\begin{array}{c}\text { Erbium-SD } \\
\text { Taylor } \\
\text { ICP-MS } \\
\text { Ig/L }\end{array}$ & $\begin{array}{c}\text { Europium } \\
\text { Taylor } \\
\text { ICP-MS } \\
\mu g / L\end{array}$ & $\begin{array}{c}\text { Europium- } \\
\text { SD } \\
\text { Taylor } \\
\text { ICP-MS } \\
\text { Hg/L }\end{array}$ & $\begin{array}{c}\text { Fluorine } \\
\text { NWOL } \\
\text { EISE } \\
\text { mg/L }\end{array}$ & $\begin{array}{c}\text { Fluorine } \\
\text { Doughten } \\
\text { IC } \\
\text { mg/L }\end{array}$ \\
\hline Buck Farm Spring & ns & ns & ns & ns & ns & ns & 0.18 & 0.16 \\
\hline Buck Farm Spring & ns & ns & ns & ns & ns & ns & ns & ns \\
\hline Fence Spring & ns & ns & ns & ns & ns & ns & 0.31 & 0.33 \\
\hline Hanging Spring & ns & ns & ns & ns & ns & ns & $0.07 \mathrm{e}$ & 0.07 \\
\hline Hole in the Wall Spring & ns & ns & ns & ns & ns & ns & $0.08 \mathrm{e}$ & 0.07 \\
\hline South Canyon Spring & 0.0008 & 0.0004 & $<0.001$ & 0.001 & 0.002 & 0.001 & ns & ns \\
\hline South Canyon Spring & 0.0004 & 0.0004 & $<0.001$ & 0.001 & $<0.001$ & 0.001 & ns & ns \\
\hline Unknown Spring & ns & ns & ns & ns & ns & ns & $0.08 \mathrm{e}$ & 0.07 \\
\hline Unknown Spring & ns & ns & ns & ns & ns & ns & & 0.07 \\
\hline Vasey's Paradise & ns & ns & ns & ns & ns & ns & ns & ns \\
\hline Clearwater Spring & 0.0005 & 0.0004 & $<0.001$ & 0.000 & $<0.001$ & 0.000 & 0.71 & 0.70 \\
\hline Clearwater Spring & 0.0006 & 0.0002 & $<0.001$ & 0.001 & $<0.001$ & 0.001 & ns & ns \\
\hline Hotel Spring & 0.0028 & 0.0001 & $<0.001$ & 0.001 & $<0.001$ & 0.001 & 0.38 & 0.36 \\
\hline Hotel Spring & 0.0032 & 0.0002 & 0.001 & 0.003 & $<0.001$ & 0.004 & ns & ns \\
\hline Kanab Spring & $<0.0004$ & 0.0005 & $<0.001$ & 0.001 & $<0.001$ & 0.000 & 0.28 & 0.28 \\
\hline Kanab Spring & $<0.0004$ & 0.0008 & $<0.001$ & 0.001 & 0.002 & 0.000 & ns & ns \\
\hline Lower Jumpup Spring & 0.0011 & 0.0005 & $<0.001$ & 0.002 & $<0.001$ & 0.001 & 0.56 & 0.52 \\
\hline Lower Jumpup Spring & 0.0014 & 0.0002 & $<0.001$ & 0.001 & $<0.001$ & 0.001 & ns & ns \\
\hline Mountain Sheep Spring & 0.0006 & 0.0005 & 0.0011 & 0.0004 & $<0.001$ & 0.001 & 0.38 & 0.78 \\
\hline Mountain Sheep Spring & 0.0007 & 0.0006 & 0.0006 & 0.0003 & $<0.001$ & 0.001 & ns & ns \\
\hline Rider Spring & $\mathrm{ns}$ & ns & ns & ns & ns & ns & 1.59 & 1.56 \\
\hline Rider Spring & ns & ns & ns & ns & ns & ns & ns & ns \\
\hline Rock Spring & 0.0007 & 0.0000 & 0.0006 & 0.0002 & $<0.001$ & 0.000 & 0.84 & 0.34 \\
\hline Rock Spring & $<0.0004$ & 0.0002 & $<0.0004$ & 0.0003 & $<0.001$ & 0.001 & ns & ns \\
\hline Schmutz Spring & $<0.0004$ & 0.0001 & $<0.001$ & 0.001 & $<0.001$ & 0.000 & 0.47 & 0.51 \\
\hline Schmutz Spring & $<0.0004$ & 0.0003 & $<0.001$ & 0.002 & $<0.001$ & 0.001 & ns & ns \\
\hline Showerbath Spring & $<0.0004$ & 0.0003 & $<0.001$ & 0.000 & $<0.001$ & 0.001 & 0.30 & 0.29 \\
\hline Showerbath Spring & $<0.0004$ & 0.0002 & $<0.001$ & 0.001 & $<0.001$ & 0.001 & ns & ns \\
\hline Side Canyon Spring & $<0.0004$ & 0.0005 & $<0.001$ & 0.001 & $<0.001$ & 0.001 & 0.55 & 0.46 \\
\hline Side Canyon Spring & $<0.0004$ & 0.0003 & $<0.001$ & 0.000 & $<0.001$ & 0.000 & ns & ns \\
\hline Slide Spring & $<0.0004$ & 0.0002 & $<0.001$ & 0.001 & $<0.001$ & 0.001 & 0.38 & 0.34 \\
\hline Slide Spring & $<0.0004$ & 0.0001 & $<0.001$ & 0.001 & $<0.001$ & 0.001 & ns & ns \\
\hline Upper Jumpup Spring & $<0.0004$ & 0.0001 & $<0.001$ & 0.002 & $<0.001$ & 0.001 & 0.27 & 0.25 \\
\hline Upper Jumpup Spring & $<0.0004$ & 0.0004 & $<0.001$ & 0.000 & $<0.001$ & 0.001 & ns & ns \\
\hline $\begin{array}{l}\text { Willow Spring } \\
\text { (Hack Canyon) }\end{array}$ & 0.0004 & 0.0007 & $<0.001$ & 0.001 & $<0.001$ & 0.001 & 0.94 & 1.04 \\
\hline $\begin{array}{l}\text { Willow Spring } \\
\text { (Hack Canyon) }\end{array}$ & 0.0007 & 0.0004 & $<0.001$ & 0.000 & $<0.001$ & 0.001 & ns & ns \\
\hline Burnt Canyon Well & 0.0007 & 0.0000 & 0.0014 & 0.0009 & $<0.0003$ & 0.0006 & 1.46 & 1.38 \\
\hline Burnt Canyon Well & 0.0012 & 0.0004 & 0.0017 & 0.0008 & $<0.0003$ & 0.0009 & ns & ns \\
\hline Canyon Mine Well & $<0.0007$ & 0.0004 & $<0.0005$ & 0.0003 & $<0.0003$ & 0.0013 & 0.33 & 0.29 \\
\hline Canyon Mine Well & $<0.0007$ & 0.0003 & $<0.0005$ & 0.0002 & $<0.0003$ & 0.0003 & ns & ns \\
\hline Pinenut Well & $<0.0007$ & 0.0005 & $<0.0005$ & 0.0003 & $<0.0003$ & 0.0006 & 0.85 & 0.75 \\
\hline Pinenut Well & $<0.0007$ & 0.0002 & 0.0006 & 0.0002 & $<0.0003$ & 0.0002 & ns & ns \\
\hline Tom Land Well & 0.0012 & 0.0009 & $<0.0005$ & 0.0002 & $<0.0003$ & 0.0007 & 1.0 & 0.90 \\
\hline Tom Land Well & $<0.0007$ & 0.0003 & 0.0006 & 0.0005 & $<0.0003$ & 0.0005 & ns & ns \\
\hline
\end{tabular}


Table A. Analysis results from all laboratories.-Continued

\begin{tabular}{|c|c|c|c|c|c|c|c|c|c|c|}
\hline Spring or well & $\begin{array}{c}\text { Iron } \\
\text { NWQL } \\
\text { ICP-MS } \\
\text { Ig/L }\end{array}$ & $\begin{array}{c}\text { Iron } \\
\text { Doughten } \\
\text { ICP-0ES } \\
\mu \mathrm{g} / \mathrm{L}\end{array}$ & $\begin{array}{c}\text { Iron } \\
\text { Taylor } \\
\text { ICP-AES } \\
\mu \mathrm{g} / \mathrm{L}\end{array}$ & $\begin{array}{c}\text { Iron-SD } \\
\text { Taylor } \\
\text { ICP-AES } \\
\mu \mathrm{g} / \mathrm{L}\end{array}$ & $\begin{array}{c}\text { Gallium } \\
\text { Taylor } \\
\text { ICP-MS } \\
\mu \mathrm{g} / \mathrm{L}\end{array}$ & $\begin{array}{c}\text { Gallium- } \\
\text { SD } \\
\text { Taylor } \\
\text { ICP-MS } \\
\mu \mathrm{g} / \mathrm{L}\end{array}$ & $\begin{array}{c}\text { Gadolinium } \\
\text { Taylor } \\
\text { ICP-MS } \\
\text { Hg/L }\end{array}$ & $\begin{array}{c}\text { Gadolinium- } \\
\text { SD } \\
\text { Taylor } \\
\text { ICP-MS } \\
\text { Ig/L } \\
\end{array}$ & $\begin{array}{c}\text { Mercury } \\
\text { Taylor } \\
\text { CV-AFS } \\
\text { ng/L }\end{array}$ & $\begin{array}{c}\text { Mercury- } \\
\text { SD } \\
\text { Taylor } \\
\text { CV-AFS } \\
\text { ng/L }\end{array}$ \\
\hline Buck Farm Spring & $<4$ & $<20$ & $\mathrm{~ns}$ & $\mathrm{~ns}$ & ns & ns & $\mathrm{ns}$ & ns & na & na \\
\hline Buck Farm Spring & -- & ns & ns & ns & ns & ns & ns & ns & na & na \\
\hline Fence Spring & $<4$ & $<20$ & ns & ns & ns & ns & ns & ns & na & na \\
\hline Hanging Spring & $<4$ & $<20$ & ns & ns & ns & $\mathrm{ns}$ & $\mathrm{ns}$ & ns & na & na \\
\hline Hole in the Wall Spring & $<4$ & $<20$ & ns & ns & ns & ns & ns & ns & na & na \\
\hline South Canyon Spring & ns & $<20$ & 4 & 2 & 0.0032 & 0.0001 & 0.0009 & 0.0003 & na & na \\
\hline South Canyon Spring & ns & $\mathrm{ms}$ & 3 & 1 & 0.0033 & 0.0012 & 0.0010 & 0.0005 & na & na \\
\hline Unknown Spring & $<4$ & $<20$ & ns & ns & ns & ns & ns & ns & na & na \\
\hline Unknown Spring & -- & $<20$ & ns & ns & ns & $\mathrm{ns}$ & ns & ns & na & na \\
\hline Vasey's Paradise & $\mathrm{ns}$ & $<20$ & ns & ns & ns & $\mathrm{ns}$ & ns & ns & na & na \\
\hline Clearwater Spring & 28 & $<100$ & 31 & 0 & 0.020 & 0.002 & $<0.0004$ & 0.0003 & 0.2 & 0.1 \\
\hline Clearwater Spring & ns & ns & 35 & 2 & 0.022 & 0.001 & $<0.0004$ & 0.0002 & na & na \\
\hline Hotel Spring & 5 & $<20$ & 7 & 3 & 0.0044 & 0.0010 & 0.0044 & 0.0001 & 2.0 & 0.1 \\
\hline Hotel Spring & ns & ns & 4 & 1 & 0.0046 & 0.0009 & 0.0040 & 0.0000 & na & na \\
\hline Kanab Spring & $<4$ & $<20$ & $<2$ & 1 & 0.0019 & 0.0003 & 0.0007 & 0.0002 & 0.2 & 0.1 \\
\hline Kanab Spring & -- & ns & $<2$ & 1 & 0.0017 & 0.0009 & $<0.0004$ & 0.0005 & na & na \\
\hline Lower Jumpup Spring & 5 & $<20$ & 4 & 1 & 0.0042 & 0.0021 & 0.0013 & 0.0005 & 0.3 & 0.1 \\
\hline Lower Jumpup Spring & ns & ns & 4 & 0 & 0.0036 & 0.0012 & 0.0016 & 0.0006 & na & na \\
\hline Mountain Sheep Spring & $4 \mathrm{e}$ & $<20$ & 3 & 4 & 0.0028 & 0.0010 & 0.0005 & 0.0001 & $<0.2$ & 0.0 \\
\hline Mountain Sheep Spring & -- & ns & $<3$ & 2 & 0.0032 & 0.0006 & 0.0008 & 0.0004 & na & na \\
\hline Rider Spring & 12 & $<20$ & ns & $\mathrm{ns}$ & ns & ns & ns & $\mathrm{ns}$ & na & na \\
\hline Rider Spring & ns & ns & ns & ns & ns & ns & ns & ns & na & na \\
\hline Rock Spring & $<8$ & $<100$ & 4 & 3 & 0.0023 & 0.0012 & $<0.0004$ & 0.0002 & $<0.2$ & 0.1 \\
\hline Rock Spring & ns & ns & 20 & 4 & 0.0013 & 0.0007 & $<0.0004$ & 0.0003 & na & na \\
\hline Schmutz Spring & $<4$ & $<20$ & $<2$ & 0 & 0.0016 & 0.0002 & $<0.0004$ & 0.0005 & 0.3 & 0.1 \\
\hline Schmutz Spring & -- & $\mathrm{ns}$ & $<2$ & 1 & 0.0025 & 0.0007 & $<0.0004$ & 0.0005 & na & na \\
\hline Showerbath Spring & $2 \mathrm{e}$ & $<20$ & $<2$ & 1 & 0.0019 & 0.0006 & $<0.0004$ & 0.0001 & 0.2 & 0.0 \\
\hline Showerbath Spring & ns & ns & $<2$ & 2 & 0.0035 & 0.0008 & $<0.0004$ & 0.0005 & na & na \\
\hline Side Canyon Spring & $<4$ & 70 & $<2$ & 3 & 0.0012 & 0.0004 & $<0.0004$ & 0.0004 & $<0.2$ & 0.1 \\
\hline Side Canyon Spring & ns & ns & $<2$ & 1 & 0.0014 & 0.0007 & $<0.0004$ & 0.0003 & na & na \\
\hline Slide Spring & $<4$ & $<20$ & $<2$ & 0 & 0.0020 & 0.0007 & $<0.0004$ & 0.0001 & 0.4 & 0.1 \\
\hline Slide Spring & ns & $\mathrm{ns}$ & $<2$ & 1 & 0.0013 & 0.0010 & 0.0005 & 0.0005 & na & na \\
\hline Upper Jumpup Spring & $<4$ & $<20$ & $<2$ & 1 & 0.0017 & 0.0003 & $<0.0004$ & 0.0002 & 0.4 & 0.2 \\
\hline Upper Jumpup Spring & ns & ns & $<2$ & 1 & 0.0021 & 0.0009 & $<0.0004$ & 0.0003 & na & na \\
\hline $\begin{array}{l}\text { Willow Spring } \\
\text { (Hack Canyon) }\end{array}$ & $<12$ & $<100$ & 27 & 4 & 0.0029 & 0.0003 & 0.0012 & 0.0004 & 0.3 & 0.1 \\
\hline $\begin{array}{l}\text { Willow Spring } \\
\text { (Hack Canyon) }\end{array}$ & ns & ns & 7 & 1 & 0.0036 & 0.0006 & 0.0010 & 0.0007 & na & na \\
\hline Burnt Canyon Well & 761 & 680 & 790 & 129 & 0.003 & 0.001 & 0.0011 & 0.0001 & 2.3 & 0.2 \\
\hline Burnt Canyon Well & ns & ns & 590 & 16 & 0.003 & 0.003 & 0.0020 & 0.0005 & na & na \\
\hline Canyon Mine Well & $2 \mathrm{e}$ & $<20$ & $<10$ & 6 & 0.006 & 0.001 & 0.0007 & 0.0005 & 1.6 & 0.4 \\
\hline Canyon Mine Well & ns & $\mathrm{ns}$ & $<10$ & 4 & 0.005 & 0.001 & 0.0006 & 0.0000 & na & na \\
\hline Pinenut Well & 4,170 & 4,650 & 4,860 & 209 & 0.019 & 0.000 & 0.0004 & 0.0000 & 1.7 & 0.2 \\
\hline Pinenut Well & ns & ns & 4,830 & 76 & 0.015 & 0.001 & 0.0004 & 0.0001 & na & na \\
\hline Tom Land Well & 779 & 776 & 721 & 19 & 0.003 & 0.002 & 0.0008 & 0.0000 & 1.4 & 0.2 \\
\hline Tom Land Well & ns & ns & 703 & 27 & 0.005 & 0.000 & 0.0010 & 0.0001 & na & na \\
\hline
\end{tabular}


Table A. Analysis results from all laboratories.-Continued

\begin{tabular}{|c|c|c|c|c|c|c|c|c|c|}
\hline Spring or well & $\begin{array}{c}\text { Holmium } \\
\text { Taylor } \\
\text { ICP-MS } \\
\text { pg/L }\end{array}$ & $\begin{array}{c}\text { Holmium- } \\
\text { SD } \\
\text { Taylor } \\
\text { ICP-MS } \\
\mu \mathrm{g} / \mathrm{L} \\
\end{array}$ & $\begin{array}{c}\text { Potassium } \\
\text { NWOL } \\
\text { ICP-MS } \\
\text { mg/L }\end{array}$ & $\begin{array}{c}\text { Potassium } \\
\text { Doughten } \\
\text { ICP-OES } \\
\text { mg/L }\end{array}$ & $\begin{array}{c}\text { Potassium } \\
\text { Taylor } \\
\text { ICP-MS/AES } \\
\text { mg/L }\end{array}$ & $\begin{array}{c}\text { Potassium- } \\
\text { SD } \\
\text { Taylor } \\
\text { ICP-MS/AES } \\
\text { mg/L } \\
\end{array}$ & $\begin{array}{c}\text { Kjeldahl- } \\
\text { nitrogen, unf } \\
\text { NWOL } \\
\text { KDM } \\
\text { mg N/L }\end{array}$ & $\begin{array}{c}\text { Lanthanum } \\
\text { Taylor } \\
\text { ICP-MS } \\
\text { pg/L }\end{array}$ & $\begin{array}{c}\text { Lanthanum- } \\
\text { SD } \\
\text { Taylor } \\
\text { ICP-MS } \\
\text { Hg/L }\end{array}$ \\
\hline Buck Farm Spring & ns & ns & 7.32 & 7.0 & ns & $\mathrm{ns}$ & $<0.1$ & ns & ns \\
\hline Buck Farm Spring & ns & ns & -- & ns & ns & ns & ns & ns & ns \\
\hline Fence Spring & ns & ns & 15.9 & 15.3 & ns & ns & $<0.1$ & ns & ns \\
\hline Hanging Spring & ns & ns & 0.82 & 0.8 & ns & ns & $<0.1$ & $\mathrm{~ns}$ & ns \\
\hline Hole in the Wall Spring & ns & ns & 0.86 & 0.8 & ns & ns & $<0.1$ & ns & ns \\
\hline South Canyon Spring & 0.0003 & 0.0002 & ns & 1.5 & 1.6 & 0.1 & ns & 0.0027 & 0.0002 \\
\hline South Canyon Spring & $<0.0003$ & 0.0001 & ns & ns & 1.6 & 0.1 & ns & 0.0027 & 0.0004 \\
\hline Unknown Spring & ns & ns & 0.75 & 0.8 & ns & ns & $<0.1$ & ns & ns \\
\hline Unknown Spring & ns & ns & -- & 0.8 & ns & ns & ns & ns & ns \\
\hline Vasey's Paradise & ns & ns & ns & 0.7 & ns & ns & ns & $\mathrm{ns}$ & ns \\
\hline Clearwater Spring & 0.0008 & 0.0002 & 12.8 & 11.4 & 11 & 1 & 0.5 & 0.0007 & 0.0000 \\
\hline Clearwater Spring & 0.0015 & 0.0001 & ns & ns & 11 & 0 & ns & 0.0007 & 0.0005 \\
\hline Hotel Spring & 0.0008 & 0.0004 & 7.26 & 7.1 & 7.0 & 0.2 & 0.5 & 0.0085 & 0.0012 \\
\hline Hotel Spring & 0.0008 & 0.0003 & $\mathrm{~ns}$ & ns & 7.0 & 0.0 & ns & 0.0088 & 0.0016 \\
\hline Kanab Spring & $<0.0003$ & 0.0002 & 4.03 & 3.8 & 3.9 & 0.1 & $<0.1$ & 0.0017 & 0.0007 \\
\hline Kanab Spring & $<0.0003$ & 0.0003 & -- & ns & 3.8 & 0.1 & ns & 0.0015 & 0.0002 \\
\hline Lower Jumpup Spring & 0.0005 & 0.0003 & 8.32 & 8.1 & 8.1 & 0.0 & $0.09 \mathrm{e}$ & 0.0052 & 0.0002 \\
\hline Lower Jumpup Spring & 0.0005 & 0.0002 & ns & ns & 7.8 & 0.3 & ns & 0.0051 & 0.0004 \\
\hline Mountain Sheep Spring & 0.0002 & 0.0000 & 8.09 & 7.6 & 7.7 & 0.1 & $<0.1$ & 0.0021 & 0.0001 \\
\hline Mountain Sheep Spring & 0.0002 & 0.0001 & -- & ns & 7.6 & 0.1 & ns & 0.0017 & 0.0004 \\
\hline Rider Spring & ns & ns & 5.79 & 5.4 & ns & ns & $<0.1$ & ns & ns \\
\hline Rider Spring & ns & ns & ns & ns & ns & ns & ns & ns & ns \\
\hline Rock Spring & 0.0001 & 0.0000 & 5.64 & 5.4 & 4.8 & 0.2 & $<0.1$ & 0.0008 & 0.0001 \\
\hline Rock Spring & $<0.0001$ & 0.0001 & ns & ns & 5.0 & 0.0 & ns & 0.0005 & 0.0002 \\
\hline Schmutz Spring & $<0.0003$ & 0.0003 & 3.05 & 2.9 & 2.7 & 0.0 & $<0.1$ & 0.0006 & 0.0003 \\
\hline Schmutz Spring & $<0.0003$ & 0.0002 & -- & ns & 2.6 & 0.1 & $\mathrm{~ns}$ & 0.0005 & 0.0005 \\
\hline Showerbath Spring & $<0.0003$ & 0.0002 & 4.58 & 4.2 & 4.1 & 0.2 & $0.05 \mathrm{e}$ & 0.0008 & 0.0002 \\
\hline Showerbath Spring & $<0.0003$ & 0.0002 & ns & ns & 4.0 & 0.4 & ns & 0.0006 & 0.0001 \\
\hline Side Canyon Spring & $<0.0003$ & 0.0001 & 5.41 & 5.2 & 4.8 & 0.2 & $<0.1$ & 0.0008 & 0.0001 \\
\hline Side Canyon Spring & $<0.0003$ & 0.0003 & ns & ns & 5.1 & 0.2 & ns & 0.0004 & 0.0001 \\
\hline Slide Spring & $<0.0003$ & 0.0002 & 2.06 & 2.1 & 1.9 & 0.1 & $<0.1$ & 0.0002 & 0.0002 \\
\hline Slide Spring & $<0.0003$ & 0.0002 & ns & ns & 2.0 & 0.0 & ns & 0.0006 & 0.0004 \\
\hline Upper Jumpup Spring & 0.0003 & 0.0002 & 1.78 & 1.8 & 1.6 & 0.2 & $<0.1$ & 0.0008 & 0.0003 \\
\hline Upper Jumpup Spring & $<0.0003$ & 0.0003 & ns & ns & 1.6 & 0.1 & ns & 0.0004 & 0.0001 \\
\hline $\begin{array}{l}\text { Willow Spring } \\
\text { (Hack Canyon) }\end{array}$ & $<0.0003$ & 0.0001 & 12.7 & 12.0 & 11 & 1 & 0.2 & 0.0060 & 0.0001 \\
\hline $\begin{array}{l}\text { Willow Spring } \\
\text { (Hack Canyon) }\end{array}$ & 0.0004 & 0.0002 & ns & ns & 12 & 1 & ns & 0.0053 & 0.0009 \\
\hline Burnt Canyon Well & 0.0006 & 0.0004 & 15.5 & 14.8 & 15 & 0 & $0.08 \mathrm{e}$ & 0.0025 & 0.0002 \\
\hline Burnt Canyon Well & 0.0009 & 0.0001 & ns & ns & 16 & 1 & ns & 0.0032 & 0.0006 \\
\hline Canyon Mine Well & $<0.0003$ & 0.0001 & 1.74 & 2.2 & 2.3 & 0.1 & $<0.1$ & 0.0012 & 0.0004 \\
\hline Canyon Mine Well & $<0.0003$ & 0.0001 & ns & ns & 2.3 & 0.1 & $\mathrm{~ns}$ & 0.0012 & 0.0002 \\
\hline Pinenut Well & $<0.0003$ & 0.0002 & 24.70 & 23.4 & 25 & 1 & $0.06 \mathrm{e}$ & 0.0013 & 0.0003 \\
\hline Pinenut Well & $<0.0003$ & 0.0003 & ns & ns & 26 & 2 & ns & 0.0013 & 0.0005 \\
\hline Tom Land Well & $<0.0003$ & 0.0003 & 7.16 & 6.7 & 7.1 & 0.1 & 0.1 & 0.0023 & 0.0001 \\
\hline Tom Land Well & $<0.0003$ & 0.0002 & ns & ns & 7.3 & 0.2 & ns & 0.0018 & 0.0002 \\
\hline
\end{tabular}


Table A. Analysis results from all laboratories.-Continued

\begin{tabular}{|c|c|c|c|c|c|c|c|c|c|c|}
\hline Spring or well & $\begin{array}{c}\text { Lithium } \\
\text { NWOL } \\
\text { AASD } \\
\text { rg/L }\end{array}$ & $\begin{array}{c}\text { Lithium } \\
\text { Doughten } \\
\text { ICP-MS } \\
\mu \mathrm{g} / \mathrm{L}\end{array}$ & $\begin{array}{c}\text { Lithium } \\
\text { Taylor } \\
\text { ICP-MS } \\
\text { मlg/L }\end{array}$ & $\begin{array}{c}\text { Lithium- } \\
\text { SD } \\
\text { Taylor } \\
\text { ICP-MS } \\
\mu \mathrm{g} / \mathrm{L}\end{array}$ & $\begin{array}{c}\text { Lutetium } \\
\text { Taylor } \\
\text { ICP-MS } \\
\text { pg/L }\end{array}$ & $\begin{array}{c}\text { Lutetium- } \\
\text { SD } \\
\text { Taylor } \\
\text { ICP-MS } \\
\mu \mathrm{g} / \mathrm{L}\end{array}$ & $\begin{array}{c}\text { Magnesium } \\
\text { NWQL } \\
\text { ICP-MS } \\
\text { mg/L }\end{array}$ & $\begin{array}{c}\text { Magnesium } \\
\text { Doughten } \\
\text { ICP-OES } \\
\text { mg/L }\end{array}$ & $\begin{array}{c}\text { Magnesium } \\
\text { Taylor } \\
\text { ICP-AES } \\
\text { mg/L }\end{array}$ & $\begin{array}{c}\text { Magnesium- } \\
\text { SD } \\
\text { Taylor } \\
\text { ICP-AES } \\
\text { mg/L }\end{array}$ \\
\hline Buck Farm Spring & 24.4 & 24 & ns & ns & ns & ns & 33.9 & 33.3 & ns & ns \\
\hline Buck Farm Spring & 22.7 & ns & ns & ns & ns & ns & ns & ns & ns & ns \\
\hline Fence Spring & 355 & 378 & ns & ns & ns & ns & 39.4 & 38.6 & ns & ns \\
\hline Hanging Spring & 1.7 & 2 & ns & ns & ns & ns & 21.0 & 19.8 & ns & ns \\
\hline Hole in the Wall Spring & 1.6 & 2 & $\mathrm{~ns}$ & ns & ns & ns & 21.2 & 20.0 & ns & ns \\
\hline South Canyon Spring & ns & 3 & 4.0 & 0.1 & 0.0001 & 0.0001 & ns & 18.6 & 17 & 1 \\
\hline South Canyon Spring & ns & ns & 4.0 & 0.2 & 0.0002 & 0.0001 & ns & ns & 18 & 1 \\
\hline Unknown Spring & 1.7 & 2 & ns & ns & ns & ns & 20.7 & 20.1 & ns & ns \\
\hline Unknown Spring & 1.7 & 2 & ns & ns & ns & ns & ns & 20.3 & ns & ns \\
\hline Vasey's Paradise & ns & 1 & ns & ns & ns & ns & ns & 20.8 & ns & ns \\
\hline Clearwater Spring & 92.1 & 100 & 82 & 1 & 0.0001 & 0.0001 & 182.0 & 177 & 170 & 3 \\
\hline Clearwater Spring & ns & ns & 84 & 4 & $<0.0001$ & 0.0000 & ns & ns & 172 & 0 \\
\hline Hotel Spring & 18.9 & 18 & 18 & 0 & 0.0003 & 0.0001 & 49.7 & 47.4 & 49 & 1 \\
\hline Hotel Spring & ns & ns & 19 & 1 & 0.0004 & 0.0001 & ns & ns & 47 & 2 \\
\hline Kanab Spring & 18.4 & 18 & 20 & 1 & $<0.0001$ & 0.0001 & 48.8 & 48.4 & 51 & 1 \\
\hline Kanab Spring & 19.4 & ns & 20 & 1 & $<0.0001$ & 0.0001 & ns & ns & 48 & 3 \\
\hline Lower Jumpup Spring & 45.3 & 54 & 53 & 2 & 0.0002 & 0.0001 & 121 & 124 & 117 & 3 \\
\hline Lower Jumpup Spring & ns & ns & 51 & 0 & 0.0002 & 0.0000 & ns & ns & 120 & 2 \\
\hline Mountain Sheep Spring & 33.9 & 40 & 39 & 1 & 0.0003 & 0.0002 & 98.2 & 97.2 & 98 & 6 \\
\hline Mountain Sheep Spring & 32.1 & ns & 39 & 2 & $<0.0001$ & 0.0001 & ns & ns & 95 & 3 \\
\hline Rider Spring & 70.5 & 70 & ns & ns & ns & ns & 65.6 & 62.5 & ns & ns \\
\hline Rider Spring & ns & ns & ns & ns & ns & ns & $\mathrm{ns}$ & ns & ns & ns \\
\hline Rock Spring & 59.3 & 74 & 63 & 0 & $<0.0001$ & 0.0001 & 158.0 & 153 & 150 & 5 \\
\hline Rock Spring & ns & ns & 66 & 2 & $<0.0001$ & 0.0001 & ns & ns & 150 & 2 \\
\hline Schmutz Spring & 21.9 & 24 & 23 & 1 & 0.0002 & 0.0002 & 77.4 & 83.3 & 78 & 0 \\
\hline Schmutz Spring & 21.6 & ns & 26 & 4 & $<0.0001$ & 0.0000 & ns & ns & 76 & 1 \\
\hline Showerbath Spring & 17.8 & 20 & 21 & 0 & $<0.0001$ & 0.0001 & 53.0 & 49.8 & 49 & 3 \\
\hline Showerbath Spring & ns & ns & 21 & 0 & $<0.0001$ & 0.0001 & $\mathrm{~ns}$ & ns & 48 & 3 \\
\hline Side Canyon Spring & 29.5 & 31 & 31 & 0 & $<0.0001$ & 0.0001 & 78.7 & 76.8 & 75 & 2 \\
\hline Side Canyon Spring & $\mathrm{ns}$ & ns & 31 & 1 & $<0.0001$ & 0.0001 & $\mathrm{~ns}$ & ns & 79 & 2 \\
\hline Slide Spring & 9.7 & 13 & 13 & 0 & $<0.0001$ & 0.0000 & 68.8 & 65.9 & 65 & 2 \\
\hline Slide Spring & ns & ns & 13 & 0 & $<0.0001$ & 0.0000 & ns & ns & 65 & 1 \\
\hline Upper Jumpup Spring & 7.5 & 8 & 8.7 & 0.3 & $<0.0001$ & 0.0001 & 63.3 & 61.6 & 59 & 2 \\
\hline Upper Jumpup Spring & ns & ns & 8.8 & 0.1 & 0.0002 & 0.0001 & ns & ns & 59 & 2 \\
\hline $\begin{array}{l}\text { Willow Spring } \\
\text { (Hack Canyon) }\end{array}$ & 87.9 & 89 & 75 & 0 & 0.0002 & 0.0001 & 227 & 234 & 222 & 1 \\
\hline $\begin{array}{l}\text { Willow Spring } \\
\text { (Hack Canyon) }\end{array}$ & ns & ns & 75 & 1 & 0.0002 & 0.0001 & ns & ns & 225 & 10 \\
\hline Burnt Canyon Well & 348.0 & 344 & 342 & 3 & 0.0002 & 0.0001 & 269.0 & 263 & 273 & 21 \\
\hline Burnt Canyon Well & ns & ns & 368 & 45 & 0.0002 & 0.0000 & ns & ns & 279 & 5 \\
\hline Canyon Mine Well & 6.1 & 6 & 8.0 & 0.2 & $<0.0002$ & 0.0001 & 22.9 & 30.2 & 30 & 0 \\
\hline Canyon Mine Well & ns & ns & 7.8 & 0.3 & $<0.0002$ & 0.0000 & $\mathrm{~ns}$ & $\mathrm{~ns}$ & 30 & 1 \\
\hline Pinenut Well & 196 & 154 & 166 & 2 & $<0.0002$ & 0.0000 & 135 & 143 & 138 & 9 \\
\hline Pinenut Well & ns & ns & 168 & 5 & $<0.0002$ & 0.0001 & ns & ns & 143 & 7 \\
\hline Tom Land Well & 51.7 & 54 & 58 & 1 & $<0.0002$ & 0.0001 & 149 & 150 & 155 & 3 \\
\hline Tom Land Well & ns & ns & 58 & 0 & 0.0002 & 0.0001 & ns & ns & 159 & 1 \\
\hline
\end{tabular}


Table A. Analysis results from all laboratories.-Continued

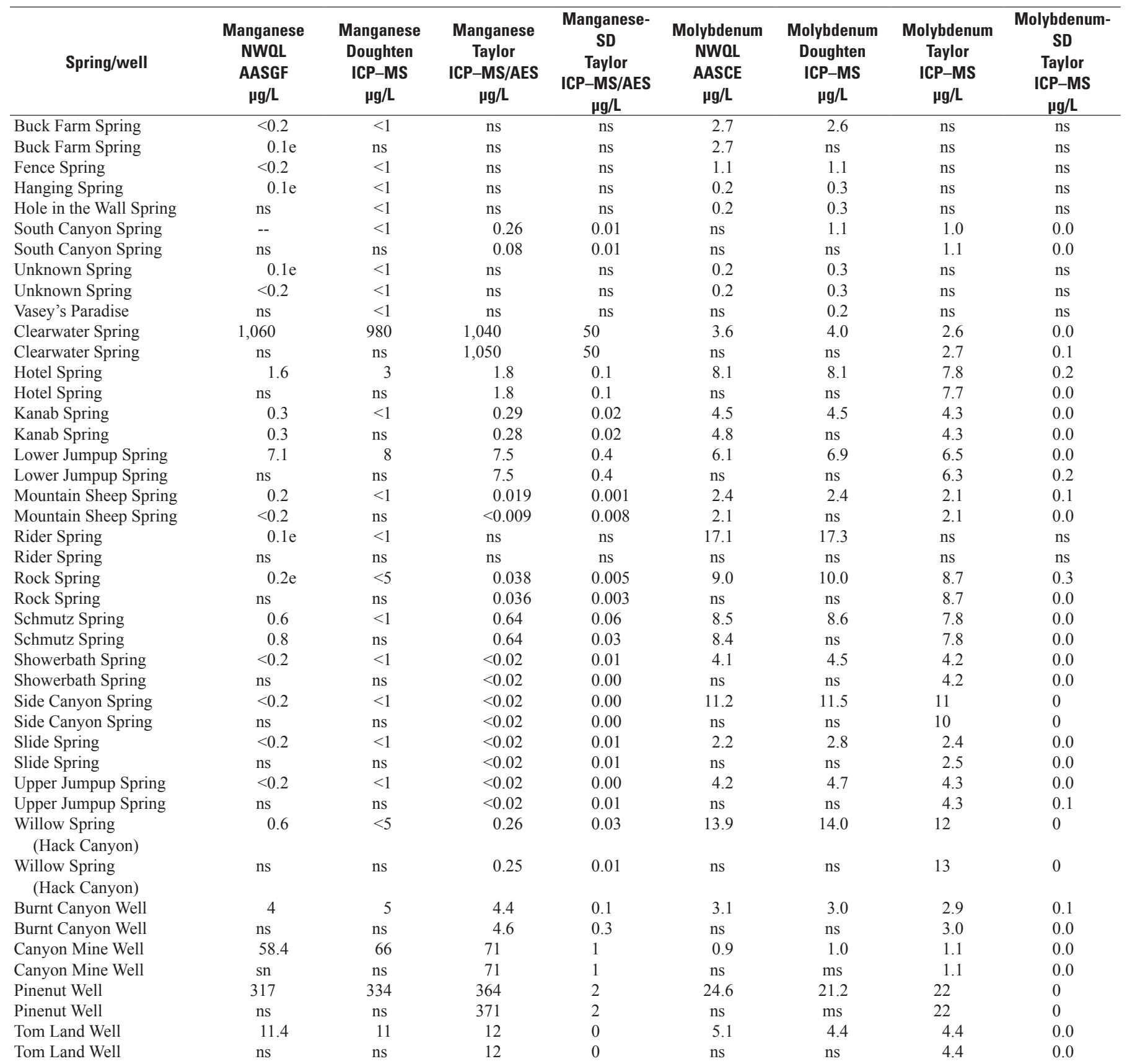


Table A. Analysis results from all laboratories.-Continued

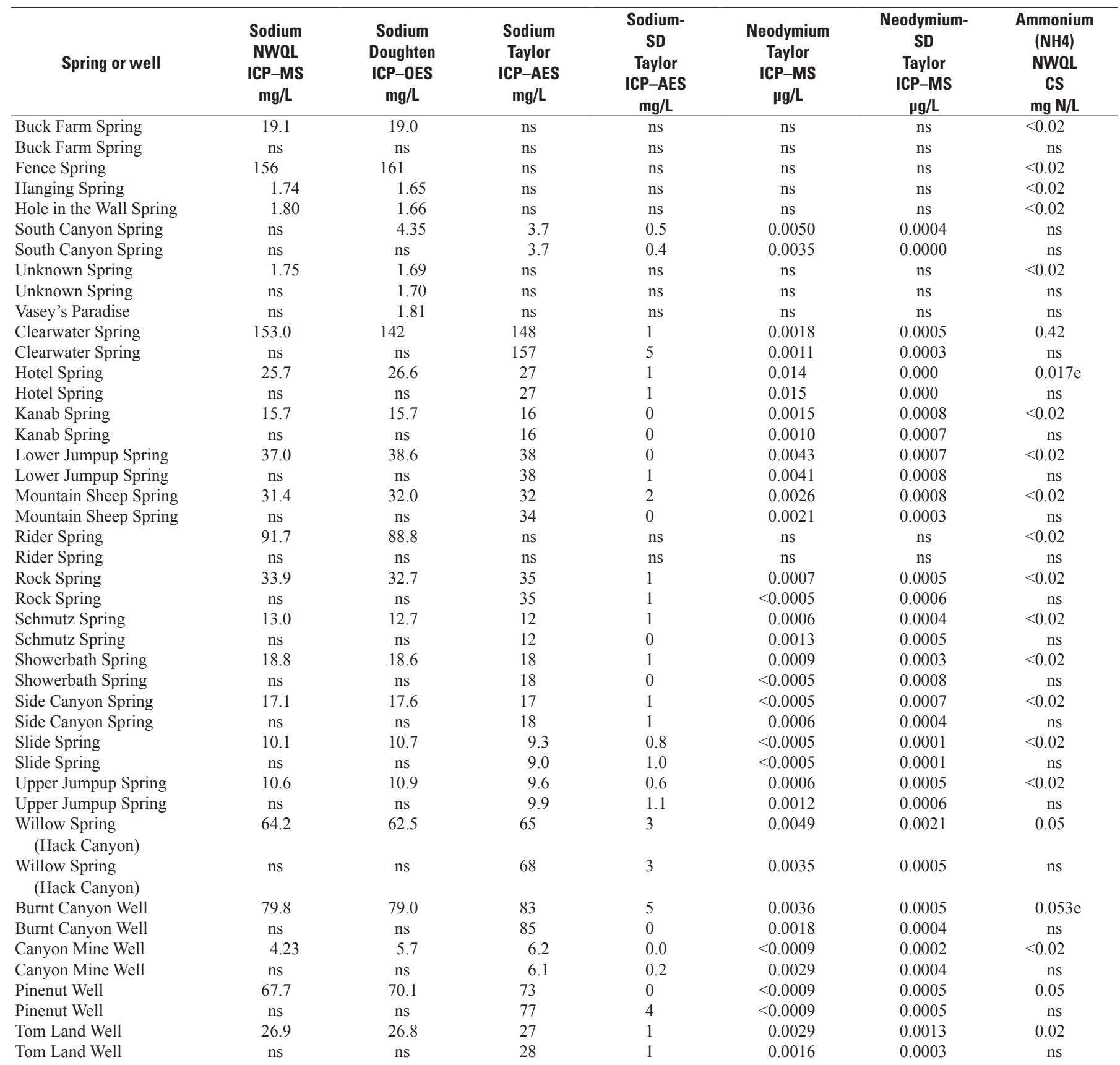


Table A. Analysis results from all laboratories.-Continued

\begin{tabular}{|c|c|c|c|c|c|c|c|c|c|c|c|}
\hline Spring or well & $\begin{array}{c}\text { Nickel } \\
\text { NWOL } \\
\text { ICP-MS } \\
\text { Ig/L }\end{array}$ & $\begin{array}{c}\text { Nickel } \\
\text { Doughten } \\
\text { ICP-MS } \\
\mu \mathrm{g} / \mathrm{L}\end{array}$ & $\begin{array}{c}\text { Nickel } \\
\text { Taylor } \\
\text { ICP-AES } \\
\text { pg/L }\end{array}$ & $\begin{array}{c}\text { Nickel- } \\
\text { SD } \\
\text { Taylor } \\
\text { ICP-AES } \\
\mu \mathrm{g} / \mathrm{L} \\
\end{array}$ & $\begin{array}{l}\text { Nitrate } \\
\text { NWOL } \\
\text { CCRDSF } \\
\text { mg N/L }\end{array}$ & $\begin{array}{c}\text { Nitrate } \\
\text { Doughten } \\
\text { IC } \\
\text { mg N/L }\end{array}$ & $\begin{array}{c}\text { Nitrate + } \\
\text { nitrite } \\
\text { NWOL } \\
\text { CCRDSF } \\
\text { mg N/L }\end{array}$ & $\begin{array}{c}\text { Phosphorus } \\
\text { NWOL } \\
\text { CPBDSF } \\
\text { mg P/L }\end{array}$ & $\begin{array}{c}\text { Phosphorus } \\
\text { Taylor } \\
\text { ICP-MS/AES } \\
\text { mg P/L }\end{array}$ & $\begin{array}{c}\text { Phosphorus- } \\
\text { SD } \\
\text { Taylor } \\
\text { ICP-MS/AES } \\
\text { mg P/L } \\
\end{array}$ & $\begin{array}{c}\text { Phosphorus, } \\
\text { unf } \\
\text { NWOL } \\
\text { CPBDSF } \\
\text { mg P/L }\end{array}$ \\
\hline Buck Farm Spring & 0.42 & 0.2 & ns & ns & $<0.002$ & 0.20 & 0.17 & $<0.04$ & ns & ns & $<0.04$ \\
\hline Buck Farm Spring & 0.45 & $\mathrm{~ns}$ & ns & ns & ns & ns & ns & ns & ns & ns & ns \\
\hline Fence Spring & 1.1 & 1.1 & ns & ns & $<0.002$ & 0.19 & 0.17 & $<0.04$ & ns & ns & $0.02 \mathrm{e}$ \\
\hline Hanging Spring & 0.20 & $<0.1$ & ns & ns & $<0.002$ & 0.20 & 0.19 & $<0.04$ & $\mathrm{~ns}$ & ns & $0.03 \mathrm{e}$ \\
\hline Hole in the Wall Spring & 0.19 & $<0.1$ & ns & ns & $<0.002$ & 0.20 & 0.19 & $<0.04$ & ns & ns & $<0.04$ \\
\hline South Canyon Spring & ns & 0.1 & $<0.3$ & 0.1 & ns & $<0.05$ & ns & ns & $<0.005$ & 0.003 & ns \\
\hline South Canyon Spring & ns & ns & $<0.3$ & 0.3 & ns & ns & ns & ns & 0.010 & 0.008 & ns \\
\hline Unknown Spring & 0.19 & $<0.1$ & ns & ns & $<0.002$ & 0.20 & 0.18 & $<0.04$ & ns & ns & $0.02 \mathrm{e}$ \\
\hline Unknown Spring & 0.20 & $<0.1$ & ns & ns & ns & 0.21 & ns & ns & ns & ns & ns \\
\hline Vasey's Paradise & ns & $<0.1$ & ns & ns & ns & 0.00 & ns & ns & $\mathrm{ns}$ & ns & ns \\
\hline Clearwater Spring & 2.9 & 7.1 & $<0.3$ & 0.2 & $<0.002$ & $<0.05$ & $<0.04$ & $<0.04$ & $<0.005$ & 0.005 & 0.09 \\
\hline Clearwater Spring & ns & ns & $<0.3$ & 0.0 & ns & ns & ns & ns & $<0.005$ & 0.007 & ns \\
\hline Hotel Spring & 0.88 & 0.8 & 0.6 & 0.1 & 0.018 & 0.75 & 0.74 & $<0.04$ & $<0.005$ & 0.009 & $<0.04$ \\
\hline Hotel Spring & ns & $\mathrm{ns}$ & 0.3 & 0.1 & ns & ns & ns & ns & $<0.005$ & 0.001 & ns \\
\hline Kanab Spring & 0.68 & 0.5 & $<0.3$ & 0.3 & $<0.002$ & 0.30 & 0.28 & $<0.04$ & $<0.005$ & 0.008 & $<0.04$ \\
\hline Kanab Spring & 1.2 & ns & $<0.3$ & 0.2 & ns & ns & ns & $\mathrm{ns}$ & $<0.005$ & 0.011 & ns \\
\hline Lower Jumpup Spring & 2.7 & 1.6 & $<0.3$ & 0.3 & $<0.002$ & $<0.05$ & $<0.04$ & $<0.04$ & $<0.005$ & 0.010 & $<0.04$ \\
\hline Lower Jumpup Spring & ns & ns & $<0.3$ & 0.2 & ns & ns & ns & ns & $<0.005$ & 0.006 & ns \\
\hline Mountain Sheep Spring & 2.5 & 1.2 & $<0.3$ & 0.6 & $<0.002$ & 0.49 & 0.48 & $<0.04$ & $<0.008$ & 0.008 & $0.03 \mathrm{e}$ \\
\hline Mountain Sheep Spring & 2.0 & $\mathrm{~ns}$ & $<0.3$ & 0.2 & ns & ns & ns & ns & $<0.008$ & 0.008 & ns \\
\hline Rider Spring & 0.40 & 8.2 & ns & ns & $<0.002$ & 2.16 & 2.12 & $<0.04$ & ns & ns & $<0.04$ \\
\hline Rider Spring & $\mathrm{ns}$ & $\mathrm{ns}$ & ns & ns & $\mathrm{ns}$ & $\mathrm{ns}$ & $\mathrm{ns}$ & $\mathrm{ns}$ & ns & ns & $\mathrm{ns}$ \\
\hline Rock Spring & 3.3 & 1.8 & $<0.3$ & 0.7 & $<0.002$ & $<0.05$ & $<0.04$ & $<0.04$ & $<0.008$ & 0.002 & $<0.04$ \\
\hline Rock Spring & ns & ns & $<0.3$ & 0.4 & ns & ns & ns & ns & $<0.008$ & 0.011 & ns \\
\hline Schmutz Spring & 0.98 & 0.6 & $<0.3$ & 0.3 & $<0.002$ & 0.78 & 0.75 & $<0.04$ & $<0.005$ & 0.006 & $<0.04$ \\
\hline Schmutz Spring & 1.4 & ns & $<0.3$ & 0.3 & ns & ns & ns & $\mathrm{ns}$ & $<0.005$ & 0.001 & ns \\
\hline Showerbath Spring & 0.70 & 0.4 & $<0.3$ & 0.1 & $<0.002$ & 0.25 & 0.23 & $<0.04$ & $<0.005$ & 0.006 & $<0.04$ \\
\hline Showerbath Spring & ns & ns & $<0.3$ & 0.1 & ns & ns & ns & ns & $<0.005$ & 0.008 & ns \\
\hline Side Canyon Spring & 1.4 & 0.7 & $<0.3$ & 0.4 & $<0.002$ & 1.85 & 1.78 & $<0.04$ & $<0.005$ & 0.008 & $<0.04$ \\
\hline Side Canyon Spring & ns & ns & $<0.3$ & 0.2 & ns & ns & ns & ns & $<0.005$ & 0.005 & ns \\
\hline Slide Spring & 1.1 & 0.8 & $<0.3$ & 0.3 & $<0.002$ & 1.31 & 1.29 & $<0.04$ & $<0.005$ & 0.001 & $<0.04$ \\
\hline Slide Spring & ns & $\mathrm{ns}$ & $<0.3$ & 0.0 & ns & ns & ns & ns & $<0.005$ & 0.004 & ns \\
\hline Upper Jumpup Spring & 1.1 & 0.7 & $<0.3$ & 0.2 & $<0.002$ & 1.43 & 1.43 & $<0.04$ & $<0.005$ & 0.005 & $<0.04$ \\
\hline Upper Jumpup Spring & ns & $\mathrm{ns}$ & $<0.3$ & 0.3 & ns & ns & ns & ns & $<0.005$ & 0.004 & ns \\
\hline $\begin{array}{l}\text { Willow Spring } \\
\text { (Hack Canyon) }\end{array}$ & 2.7 & 3.7 & $<0.3$ & 0.2 & $<0.002$ & 4.38 & 4.36 & $<0.04$ & $<0.005$ & 0.005 & $<0.04$ \\
\hline $\begin{array}{l}\text { Willow Spring } \\
\text { (Hack Canyon) }\end{array}$ & ns & ns & 0.5 & 0.2 & ns & ns & ns & ns & $<0.005$ & 0.006 & ns \\
\hline Burnt Canyon Well & 7.6 & 9.6 & 5.2 & 0.4 & $<0.002$ & $<0.05$ & $<0.04$ & $<0.04$ & $<0.007$ & 0.001 & $<0.04$ \\
\hline Burnt Canyon Well & ns & $\mathrm{ns}$ & 5.5 & 0.1 & ns & ns & ns & ns & $<0.007$ & 0.001 & ns \\
\hline Canyon Mine Well & 7.8 & 8.6 & 8.3 & 0.1 & $<0.002$ & 0.15 & 0.12 & $<0.04$ & $<0.007$ & 0.003 & $<0.04$ \\
\hline Canyon Mine Well & $\mathrm{sn}$ & ns & 8.1 & 0.4 & ns & ns & ns & ns & $<0.007$ & 0.002 & ns \\
\hline Pinenut Well & 10.7 & 14.3 & 8.8 & 0.0 & $<0.002$ & 0.00 & $<0.04$ & $<0.04$ & $<0.007$ & 0.000 & $<0.04$ \\
\hline Pinenut Well & ns & ns & 9.6 & 0.2 & ns & ns & ns & ns & $<0.007$ & 0.004 & ns \\
\hline Tom Land Well & 30.7 & 29.3 & 29 & 0 & $<0.006$ & 6.80 & 6.96 & $<0.04$ & $<0.007$ & 0.001 & $<0.04$ \\
\hline Tom Land Well & ns & ns & 29 & 0 & ns & ns & ns & ns & $<0.007$ & 0.001 & ns \\
\hline
\end{tabular}


Table A. Analysis results from all laboratories.-Continued

\begin{tabular}{|c|c|c|c|c|c|c|c|c|c|c|}
\hline Spring or well & $\begin{array}{c}\text { Lead } \\
\text { NWOL } \\
\text { AASGF } \\
\text { Ig/L }\end{array}$ & $\begin{array}{c}\text { Lead } \\
\text { Doughten } \\
\text { ICP-MS } \\
\mu \mathrm{g} / \mathrm{L}\end{array}$ & $\begin{array}{c}\text { Lead } \\
\text { Taylor } \\
\text { ICP-AES } \\
\mu \mathrm{g} / \mathrm{L}\end{array}$ & $\begin{array}{c}\text { Lead-SD } \\
\text { Taylor } \\
\text { ICP-AES } \\
\mu \mathrm{g} / \mathrm{L}\end{array}$ & $\begin{array}{c}\text { Phosphate } \\
\text { PO }_{4} \\
\text { NWOL } \\
\text { not provided } \\
\text { mg P/L }\end{array}$ & $\begin{array}{c}\text { Praseodymium } \\
\text { Taylor } \\
\text { ICP-MS } \\
\mu \mathrm{g} / \mathrm{L}\end{array}$ & $\begin{array}{c}\text { Praseodymium- } \\
\text { SD } \\
\text { Taylor } \\
\text { ICP-MS } \\
\mu \mathrm{g} / \mathrm{L} \\
\end{array}$ & $\begin{array}{c}\text { Rubidium } \\
\text { Doughten } \\
\text { ICP-MS } \\
\mu \mathrm{g} / \mathrm{L}\end{array}$ & $\begin{array}{c}\text { Rubidium } \\
\text { Taylor } \\
\text { ICP-MS } \\
\mu \mathrm{g} / \mathrm{L}\end{array}$ & $\begin{array}{c}\text { Rubidium- } \\
\text { SD } \\
\text { Taylor } \\
\text { ICP-MS } \\
\mu \mathrm{g} / \mathrm{L} \\
\end{array}$ \\
\hline Buck Farm Spring & $<0.06$ & $<0.05$ & $\mathrm{~ns}$ & ns & $0.005 \mathrm{e}$ & ns & ns & 4.2 & ns & ns \\
\hline Buck Farm Spring & $<0.06$ & ns & ns & ns & ns & ns & ns & $\mathrm{ns}$ & ns & ns \\
\hline Fence Spring & $<0.06$ & $<0.05$ & ns & ns & 0.017 & ns & ns & 44.4 & ns & ns \\
\hline Hanging Spring & $<0.06$ & $<0.05$ & $\mathrm{~ns}$ & ns & 0.018 & ns & ns & 1.3 & ns & ns \\
\hline Hole in the Wall Spring & $<0.06$ & $<0.05$ & ns & ns & 0.018 & ns & ns & 1.3 & ns & ns \\
\hline South Canyon Spring & ns & 0.34 & 0.068 & 0.004 & ns & 0.0009 & 0.0001 & 1.5 & 1.6 & 0.0 \\
\hline South Canyon Spring & ns & ns & 0.064 & 0.003 & ns & 0.0004 & 0.0000 & ns & 1.6 & 0.0 \\
\hline Unknown Spring & $<0.06$ & $<0.05$ & ns & ns & 0.018 & ns & ns & 1.3 & ns & ns \\
\hline Unknown Spring & $<0.06$ & $<0.05$ & ns & ns & ns & ns & ns & 1.3 & ns & ns \\
\hline Vasey's Paradise & ns & $<0.05$ & ns & ns & ns & ns & ns & 1.2 & ns & ns \\
\hline Clearwater Spring & $<0.12$ & $<0.25$ & 0.007 & 0.001 & $0.006 \mathrm{e}$ & $<0.0002$ & 0.0002 & 1.4 & 1.4 & 0.1 \\
\hline Clearwater Spring & ns & ns & 0.007 & 0.001 & ns & $<0.0002$ & 0.0002 & ns & 1.4 & 0.0 \\
\hline Hotel Spring & $<0.06$ & $<0.05$ & 0.033 & 0.009 & $0.005 \mathrm{e}$ & 0.0029 & 0.0001 & 3.9 & 4.1 & 0.1 \\
\hline Hotel Spring & ns & ns & 0.025 & 0.003 & ns & 0.0027 & 0.0003 & $\mathrm{~ns}$ & 4.1 & 0.1 \\
\hline Kanab Spring & $0.04 \mathrm{e}$ & $<0.05$ & 0.043 & 0.003 & $0.007 \mathrm{e}$ & $<0.0002$ & 0.0001 & 3.4 & 3.6 & 0.0 \\
\hline Kanab Spring & $0.04 \mathrm{e}$ & $\mathrm{ns}$ & 0.042 & 0.004 & ns & 0.0002 & 0.0002 & ns & 3.4 & 0.0 \\
\hline Lower Jumpup Spring & $<0.18$ & $<0.05$ & 0.008 & 0.001 & 0.012 & 0.0007 & 0.0003 & 2.1 & 2.2 & 0.1 \\
\hline Lower Jumpup Spring & ns & ns & 0.012 & 0.003 & ns & 0.0008 & 0.0003 & ns & 2.2 & 0.0 \\
\hline Mountain Sheep Spring & $<0.06$ & $<0.05$ & 0.012 & 0.002 & 0.011 & 0.0005 & 0.0001 & 4.3 & 4.4 & 0.0 \\
\hline Mountain Sheep Spring & $<0.06$ & ns & 0.010 & 0.000 & ns & 0.0005 & 0.0001 & $\mathrm{~ns}$ & 4.3 & 0.0 \\
\hline Rider Spring & $<0.06$ & $<0.05$ & ns & ns & $<0.008$ & ns & ns & 8.0 & ns & ns \\
\hline Rider Spring & $\mathrm{ns}$ & ns & ns & ns & ns & ns & ns & $\mathrm{ns}$ & ns & ns \\
\hline Rock Spring & $<0.12$ & $<0.25$ & 0.006 & 0.000 & $0.006 \mathrm{e}$ & $<0.0002$ & 0.0002 & 4.3 & 4.0 & 0.0 \\
\hline Rock Spring & ns & ns & 0.004 & 0.002 & ns & $<0.0002$ & 0.0001 & ns & 3.9 & 0.0 \\
\hline Schmutz Spring & $<0.06$ & $<0.05$ & 0.007 & 0.005 & $0.005 \mathrm{e}$ & $<0.0002$ & 0.0001 & 3.1 & 3.1 & 0.1 \\
\hline Schmutz Spring & $<0.06$ & ns & 0.007 & 0.005 & ns & 0.0002 & 0.0002 & ns & 3.1 & 0.1 \\
\hline Showerbath Spring & $<0.06$ & $<0.05$ & 0.007 & 0.002 & $0.005 \mathrm{e}$ & $<0.0002$ & 0.0001 & 3.1 & 3.2 & 0.1 \\
\hline Showerbath Spring & ns & ns & 0.008 & 0.005 & ns & $<0.0002$ & 0.0001 & ns & 3.2 & 0.0 \\
\hline Side Canyon Spring & $<0.06$ & $<0.05$ & 0.009 & 0.006 & $0.005 \mathrm{e}$ & $<0.0002$ & 0.0003 & 6.1 & 6.1 & 0.0 \\
\hline Side Canyon Spring & ns & ns & 0.006 & 0.001 & ns & $<0.0002$ & 0.0001 & ns & 6.1 & 0.0 \\
\hline Slide Spring & $<0.06$ & $<0.05$ & 0.004 & 0.003 & $0.005 \mathrm{e}$ & $<0.0002$ & 0.0000 & 2.0 & 2.0 & 0.0 \\
\hline Slide Spring & ns & ns & 0.005 & 0.001 & ns & $<0.0002$ & 0.0000 & ns & 2.0 & 0.0 \\
\hline Upper Jumpup Spring & $<0.06$ & $<0.05$ & 0.010 & 0.005 & $0.006 \mathrm{e}$ & 0.0005 & 0.0001 & 1.9 & 2.0 & 0.0 \\
\hline Upper Jumpup Spring & ns & ns & 0.009 & 0.002 & ns & $<0.0002$ & 0.0001 & ns & 2.0 & 0.0 \\
\hline $\begin{array}{l}\text { Willow Spring } \\
\text { (Hack Canyon) }\end{array}$ & $<0.12$ & $<0.25$ & 0.021 & 0.011 & $0.007 \mathrm{e}$ & 0.0010 & 0.0001 & 8.3 & 8.0 & 0.3 \\
\hline $\begin{array}{l}\text { Willow Spring } \\
\text { (Hack Canyon) }\end{array}$ & ns & ns & 0.020 & 0.005 & ns & 0.0008 & 0.0002 & ns & 8.0 & 0.4 \\
\hline Burnt Canyon Well & 0.76 & $<0.15$ & 0.75 & 0.01 & $0.008 \mathrm{e}$ & 0.0004 & 0.0001 & 21.9 & 23 & 0 \\
\hline Burnt Canyon Well & ns & ns & 0.75 & 0.00 & ns & 0.0003 & 0.0000 & ns & 23 & 0 \\
\hline Canyon Mine Well & 0.24 & 0.29 & 0.26 & 0.01 & $0.006 \mathrm{e}$ & $<0.0001$ & 0.0001 & 7.9 & 8.4 & 0.0 \\
\hline Canyon Mine Well & ns & ns & 0.28 & 0.01 & ns & $<0.0001$ & 0.0001 & ns & 8.4 & 0.1 \\
\hline Pinenut Well & $<0.06$ & $<0.15$ & 0.050 & 0.003 & $<0.024$ & $<0.0001$ & 0.0001 & 20.7 & 22 & 0 \\
\hline Pinenut Well & ns & ns & 0.013 & 0.003 & ns & 0.0002 & 0.0001 & ns & 22 & 0 \\
\hline Tom Land Well & 0.13 & $<0.15$ & 0.094 & 0.008 & $0.006 \mathrm{e}$ & 0.0004 & 0.0000 & 7.9 & 8.2 & 0.2 \\
\hline Tom Land Well & ns & ns & 0.094 & 0.001 & ns & 0.0003 & 0.0001 & ns & 8.4 & 0.1 \\
\hline
\end{tabular}


Table A. Analysis results from all laboratories.-Continued

\begin{tabular}{|c|c|c|c|c|c|c|c|c|c|c|}
\hline Spring or well & $\begin{array}{c}\text { Rhenium } \\
\text { Taylor } \\
\text { ICP-MS } \\
\text { Hg/L }\end{array}$ & $\begin{array}{c}\text { Rhenium- } \\
\text { SD } \\
\text { Taylor } \\
\text { ICP-MS } \\
\mu \mathrm{g} / \mathrm{L} \\
\end{array}$ & $\begin{array}{c}\text { Sulfur } \\
\text { Taylor } \\
\text { ICP-AES } \\
\text { mg/L }\end{array}$ & $\begin{array}{c}\text { Sulfur-SD } \\
\text { Taylor } \\
\text { ICP-AES } \\
\text { mg/L }\end{array}$ & $\begin{array}{c}\text { Antimony } \\
\text { NWOL } \\
\text { AASH } \\
\mu \mathrm{g} / \mathrm{L}\end{array}$ & $\begin{array}{c}\text { Antimony } \\
\text { Doughten } \\
\text { ICP-MS } \\
\mu \mathrm{g} / \mathrm{L}\end{array}$ & $\begin{array}{c}\text { Antimony } \\
\text { Taylor } \\
\text { ICP-MS } \\
\mu \mathrm{g} / \mathrm{L}\end{array}$ & $\begin{array}{c}\text { Antimony- } \\
\text { SD } \\
\text { Taylor } \\
\text { ICP-MS } \\
\text { Ig/L }\end{array}$ & $\begin{array}{c}\text { Scandium } \\
\text { Taylor } \\
\text { ICP-AES } \\
\text { g/L }\end{array}$ & $\begin{array}{c}\text { Scandium- } \\
\text { SD } \\
\text { Taylor } \\
\text { ICP-AES } \\
\mu \mathrm{g} / \mathrm{L}\end{array}$ \\
\hline Buck Farm Spring & ns & ns & $\mathrm{ns}$ & $\mathrm{ns}$ & 0.12 & $<0.1$ & ns & $\mathrm{ns}$ & ns & ns \\
\hline Buck Farm Spring & ns & ns & ns & ns & 0.12 & ns & ns & ns & ns & ns \\
\hline Fence Spring & ns & ns & ns & ns & 0.06 & $<0.1$ & ns & ns & ns & ns \\
\hline Hanging Spring & ns & ns & ns & ns & $0.03 \mathrm{e}$ & $<0.1$ & ns & ns & ns & ns \\
\hline Hole in the Wall Spring & ns & ns & ns & ns & $0.03 \mathrm{e}$ & $<0.1$ & ns & ns & ns & ns \\
\hline South Canyon Spring & 0.045 & 0.005 & 18 & 0 & ns & $<0.1$ & 0.030 & 0.002 & $<0.4$ & 0.0 \\
\hline South Canyon Spring & 0.039 & 0.005 & 18 & 0 & ns & ns & 0.020 & 0.003 & $<0.4$ & 0.1 \\
\hline Unknown Spring & ns & ns & ns & ns & $0.03 \mathrm{e}$ & $<0.1$ & ns & ns & ns & ns \\
\hline Unknown Spring & ns & ns & ns & ns & $0.03 \mathrm{e}$ & $<0.1$ & ns & ns & ns & ns \\
\hline Vasey's Paradise & ns & ns & ns & ns & ns & $<0.1$ & ns & ns & ns & ns \\
\hline Clearwater Spring & 0.34 & 0.00 & 690 & 5 & 0.93 & $<0.5$ & 0.008 & 0.002 & $<0.4$ & 0.2 \\
\hline Clearwater Spring & 0.33 & 0.00 & 689 & 41 & ns & ns & 0.006 & 0.001 & $<0.4$ & 0.1 \\
\hline Hotel Spring & 0.048 & 0.002 & 73 & 4 & 0.12 & $<0.1$ & 0.13 & 0.01 & $<0.4$ & 0.6 \\
\hline Hotel Spring & 0.048 & 0.005 & 72 & 4 & ns & ns & 0.13 & 0.00 & $<0.4$ & 0.6 \\
\hline Kanab Spring & 0.12 & 0.00 & 100 & 7 & 0.07 & $<0.1$ & 0.072 & 0.000 & $<0.4$ & 0.1 \\
\hline Kanab Spring & 0.12 & 0.01 & 96 & 6 & 0.09 & ns & 0.073 & 0.003 & $<0.4$ & 0.1 \\
\hline Lower Jumpup Spring & 0.31 & 0.00 & 313 & 7 & $<0.12$ & $<0.1$ & 0.043 & 0.006 & $<0.4$ & 0.5 \\
\hline Lower Jumpup Spring & 0.31 & 0.01 & 310 & 5 & ns & ns & 0.045 & 0.004 & $<0.4$ & 0.3 \\
\hline Mountain Sheep Spring & 0.20 & 0.00 & 220 & 25 & 0.04 & $<0.1$ & 0.026 & 0.003 & $<0.4$ & 0.1 \\
\hline Mountain Sheep Spring & 0.20 & 0.00 & 216 & 16 & $0.03 \mathrm{e}$ & ns & 0.024 & 0.002 & $<0.4$ & 0.1 \\
\hline Rider Spring & ns & ns & ns & ns & $0.04 \mathrm{e}$ & $<0.1$ & ns & ns & ns & ns \\
\hline Rider Spring & ns & ns & ns & $\mathrm{ns}$ & ns & ns & ns & $\mathrm{ns}$ & ns & ns \\
\hline Rock Spring & 0.47 & 0.00 & 534 & 14 & $0.06 \mathrm{e}$ & $<0.5$ & 0.030 & 0.003 & $<0.4$ & 0.1 \\
\hline Rock Spring & 0.32 & 0.03 & 557 & 7 & ns & ns & 0.029 & 0.001 & $<0.4$ & 0.1 \\
\hline Schmutz Spring & 0.82 & 0.03 & 302 & 21 & $0.04 \mathrm{e}$ & $<0.1$ & 0.013 & 0.003 & $<0.4$ & 0.5 \\
\hline Schmutz Spring & 0.80 & 0.02 & 293 & 3 & $0.04 \mathrm{e}$ & ns & 0.007 & 0.008 & $<0.4$ & 0.6 \\
\hline Showerbath Spring & 0.12 & 0.00 & 113 & 6 & 0.06 & $<0.1$ & 0.066 & 0.004 & $<0.4$ & 0.2 \\
\hline Showerbath Spring & 0.11 & 0.00 & 117 & 5 & ns & ns & 0.069 & 0.004 & $<0.4$ & 0.5 \\
\hline Side Canyon Spring & 0.18 & 0.00 & 229 & 3 & $0.03 \mathrm{e}$ & $<0.1$ & 0.028 & 0.001 & $<0.4$ & 0.5 \\
\hline Side Canyon Spring & 0.18 & 0.00 & 222 & 14 & ns & ns & 0.031 & 0.003 & $<0.4$ & 0.4 \\
\hline Slide Spring & 0.24 & 0.00 & 165 & 6 & $0.04 \mathrm{e}$ & $<0.1$ & 0.015 & 0.002 & $<0.4$ & 0.4 \\
\hline Slide Spring & 0.25 & 0.00 & 162 & 3 & ns & ns & 0.015 & 0.002 & $<0.4$ & 0.4 \\
\hline Upper Jumpup Spring & 0.22 & 0.00 & 159 & 3 & $0.04 \mathrm{e}$ & $<0.1$ & 0.016 & 0.004 & $<0.4$ & 0.3 \\
\hline Upper Jumpup Spring & 0.22 & 0.01 & 162 & 4 & ns & ns & 0.019 & 0.004 & $<0.4$ & 0.4 \\
\hline $\begin{array}{l}\text { Willow Spring } \\
\text { (Hack Canyon) }\end{array}$ & 1.3 & 0.0 & 768 & 75 & $<0.08$ & $<0.5$ & 0.015 & 0.003 & $<0.4$ & 0.3 \\
\hline $\begin{array}{l}\text { Willow Spring } \\
\text { (Hack Canyon) }\end{array}$ & 1.3 & 0.0 & 761 & 63 & ns & ns & 0.014 & 0.002 & $<0.4$ & 0.9 \\
\hline Burnt Canyon Well & 0.21 & 0.00 & 867 & 67 & 0.09 & $<0.3$ & 0.062 & 0.002 & $<0.5$ & 0.5 \\
\hline Burnt Canyon Well & 0.21 & 0.00 & 874 & 29 & ns & ns & 0.056 & 0.000 & $<0.5$ & 1.7 \\
\hline Canyon Mine Well & 0.015 & 0.000 & 7.6 & 0.5 & 0.05 & $<0.1$ & 0.013 & 0.002 & $<0.5$ & 2.0 \\
\hline Canyon Mine Well & 0.016 & 0.000 & 7.6 & 0.6 & ns & ns & 0.019 & 0.002 & $<0.5$ & 2.0 \\
\hline Pinenut Well & 0.096 & 0.001 & 424 & 29 & 0.05 & $<0.3$ & 0.034 & 0.001 & $<0.5$ & 0.8 \\
\hline Pinenut Well & 0.10 & 0.00 & 442 & 25 & ns & ns & 0.034 & 0.001 & $<0.5$ & 0.6 \\
\hline Tom Land Well & 0.62 & 0.00 & 543 & 31 & $0.05 \mathrm{e}$ & $<0.3$ & 0.024 & 0.004 & $<0.5$ & 0.1 \\
\hline Tom Land Well & 0.60 & 0.00 & 548 & 28 & ns & ns & 0.026 & 0.002 & $<0.5$ & 0.0 \\
\hline
\end{tabular}


Table A. Analysis results from all laboratories.-Continued

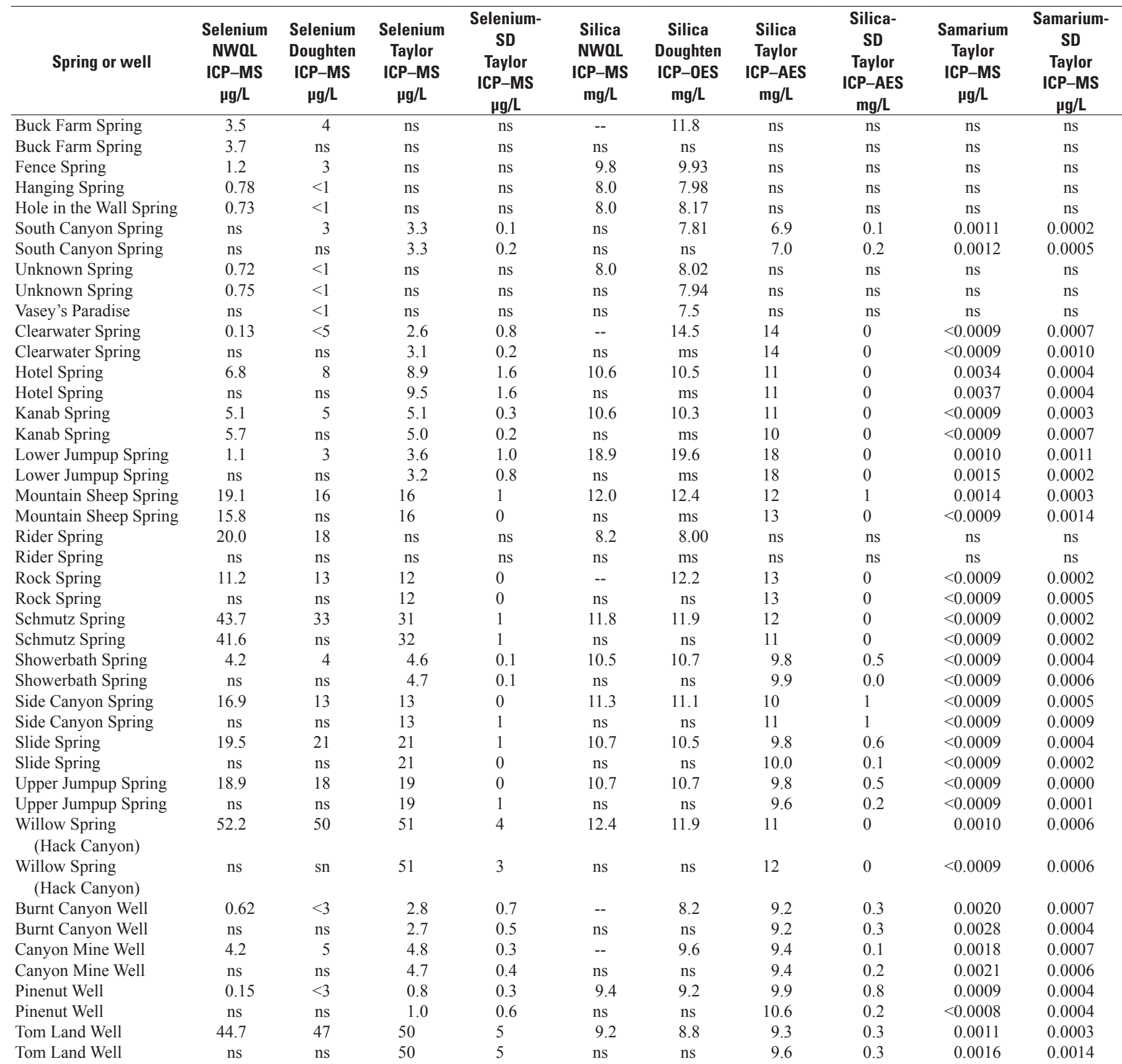


Table A. Analysis results from all laboratories.-Continued

\begin{tabular}{|c|c|c|c|c|c|c|c|c|c|c|}
\hline Spring or well & $\begin{array}{c}\text { Tin } \\
\text { Taylor } \\
\text { ICP-MS } \\
\text { Ig/L }\end{array}$ & $\begin{array}{c}\text { Tin-SD } \\
\text { Taylor } \\
\text { ICP-MS } \\
\text { Hg/L }\end{array}$ & $\begin{array}{c}\text { Sulfate } \\
\text { SO }_{4} \\
\text { NWOL } \\
\text { IC } \\
\text { mg/L }\end{array}$ & $\begin{array}{c}\text { Sulfate } \\
\mathrm{SO}_{4} \\
\text { Doughten } \\
\text { IC } \\
\mathrm{mg} / \mathrm{L} \\
\end{array}$ & $\begin{array}{c}\text { Strontium } \\
\text { NWOL } \\
\text { AASD } \\
\mu \mathrm{g} / \mathrm{L}\end{array}$ & $\begin{array}{c}\text { Strontium } \\
\text { Doughten } \\
\text { ICP-OES } \\
\text { mg/L }\end{array}$ & $\begin{array}{c}\text { Strontium } \\
\text { Taylor } \\
\text { ICP-MS/AES } \\
\mu \mathrm{g} / \mathrm{L}\end{array}$ & $\begin{array}{c}\text { Strontium } \\
\text { Bullen } \\
\text { ICP-MS } \\
\mu \mathrm{g} / \mathrm{L}\end{array}$ & $\begin{array}{c}{ }^{87} \mathrm{Sr} /{ }^{86} \mathrm{Sr} \\
\text { Bullen }\end{array}$ & $\begin{array}{c}\text { Strontium- } \\
\text { SD } \\
\text { Taylor } \\
\text { ICP-MS/AES } \\
\mu \mathrm{g} / \mathrm{L} \\
\end{array}$ \\
\hline Buck Farm Spring & ns & ns & 194 & 189 & 590 & 609 & ns & 1,150 & 0.70946 & ns \\
\hline Buck Farm Spring & ns & ns & ns & ns & 591 & & ns & ns & ns & ns \\
\hline Fence Spring & ns & ns & 170 & 169 & 1,060 & 1,090 & ns & 1,545 & 0.71417 & ns \\
\hline Hanging Spring & ns & ns & 8.21 & 8.39 & 75 & 74 & ns & 103 & 0.71071 & ns \\
\hline Hole in the Wall Spring & ns & ns & 8.27 & 8.37 & 71 & 76 & ns & 122 & 0.71053 & ns \\
\hline South Canyon Spring & $<0.008$ & 0.005 & ns & ns & -- & 248 & 245 & -- & -- & 12 \\
\hline South Canyon Spring & $<0.008$ & 0.002 & ns & ns & -- & & 247 & -- & -- & 15 \\
\hline Unknown Spring & ns & ns & 8.25 & 8.35 & 73 & 74 & ns & 140 & 0.71043 & ns \\
\hline Unknown Spring & ns & ns & ns & 8.34 & 72 & 74 & ns & ns & ns & ns \\
\hline Vasey's Paradise & ns & ns & ns & ns & -- & 68 & ns & 118 & 0.71077 & ns \\
\hline Clearwater Spring & $<0.008$ & 0.002 & 1,870 & 1,810 & & 5,750 & 5,830 & 10,650 & 0.70821 & 40 \\
\hline Clearwater Spring & $<0.008$ & 0.002 & ns & ns & & & 5,830 & ns & ns & 210 \\
\hline Hotel Spring & $<0.008$ & 0.002 & 194 & 186 & 624 & 692 & 681 & 1,360 & 0.70828 & 14 \\
\hline Hotel Spring & $<0.008$ & 0.009 & ns & ns & & & 681 & ns & ns & 10 \\
\hline Kanab Spring & $<0.008$ & 0.008 & 261 & 252 & 802 & 857 & 870 & 1,475 & 0.70849 & 11 \\
\hline Kanab Spring & $<0.008$ & 0.004 & ns & ns & 850 & & 855 & ns & ns & 4 \\
\hline Lower Jumpup Spring & $<0.008$ & 0.003 & 834 & 816 & 2,680 & 2,660 & 2,650 & 4,375 & 0.70817 & 50 \\
\hline Lower Jumpup Spring & $<0.008$ & 0.003 & ns & ns & & & 2,670 & ns & ns & 100 \\
\hline Mountain Sheep Spring & $<0.008$ & 0.001 & 662 & 623 & 1,970 & 1,840 & 1,830 & 3,075 & 0.7083 & 0 \\
\hline Mountain Sheep Spring & $<0.008$ & 0.002 & ns & ns & 1,720 & & 1,770 & ns & ns & 80 \\
\hline Rider Spring & ns & ns & 449 & 451 & 1,280 & 1,300 & ns & 2,140 & 0.70943 & ns \\
\hline Rider Spring & ns & ns & ns & ns & & & ns & ns & ns & ns \\
\hline Rock Spring & $<0.008$ & 0.002 & $1,660.0$ & 1,580 & & 6,060 & 6,130 & 11,360 & 0.70785 & 40 \\
\hline Rock Spring & $<0.008$ & 0.006 & ns & ns & & & 5,880 & ns & ns & 40 \\
\hline Schmutz Spring & $<0.008$ & 0.007 & 826 & 782 & 1,850 & 2,290 & 2,340 & 4,490 & 0.70762 & 60 \\
\hline Schmutz Spring & $<0.008$ & 0.002 & ns & ns & 2,030 & & 2,200 & ns & ns & 80 \\
\hline Showerbath Spring & $<0.008$ & 0.005 & 292 & 298 & 941 & 987 & 997 & 1,630 & 0.70846 & 4 \\
\hline Showerbath Spring & $<0.008$ & 0.000 & ns & ns & & & 1,010 & ns & ns & 30 \\
\hline Side Canyon Spring & $<0.008$ & 0.002 & 596 & 594 & 2,030 & 2,000 & 2,020 & 3,660 & 0.70868 & 50 \\
\hline Side Canyon Spring & $<0.008$ & 0.007 & ns & ns & & & 2,050 & ns & ns & 20 \\
\hline Slide Spring & $<0.008$ & 0.004 & 428 & 430 & 1,570 & 1,770 & 1,640 & 3,875 & 0.70778 & 50 \\
\hline Slide Spring & $<0.008$ & 0.007 & ns & ns & & & 1,610 & ns & ns & 50 \\
\hline Upper Jumpup Spring & 0.011 & 0.002 & 401 & 403 & 1,140 & 1,180 & 1,160 & 1,940 & 0.7079 & 70 \\
\hline Upper Jumpup Spring & $<0.008$ & 0.002 & ns & ns & & & 1,160 & ns & ns & 50 \\
\hline $\begin{array}{l}\text { Willow Spring } \\
\text { (Hack Canyon) }\end{array}$ & 0.011 & 0.000 & 2,100 & 2,050 & 6,500 & 7,720 & 7,360 & 13,160 & 0.70789 & 170 \\
\hline $\begin{array}{l}\text { Willow Spring } \\
\text { (Hack Canyon) }\end{array}$ & $<0.008$ & 0.005 & ns & ns & & & 7,270 & ns & ns & 130 \\
\hline Burnt Canyon Well & $<0.01$ & 0.01 & 2,150 & 2,040 & & 6,330 & 6,300 & 11,800 & 0.70947 & 261 \\
\hline Burnt Canyon Well & $<0.01$ & 0.00 & ns & ns & & & 6,420 & ns & ns & 140 \\
\hline Canyon Mine Well & $<0.01$ & 0.00 & 19.6 & 18.6 & 214 & 275 & 272 & 480 & 0.70971 & 7 \\
\hline Canyon Mine Well & $<0.01$ & 0.00 & ns & ns & & & 262 & ns & ns & 24 \\
\hline Pinenut Well & $<0.01$ & 0.00 & 1,150 & 1,100 & 3,520 & 3,170 & 3,210 & 5,780 & 0.70972 & 77 \\
\hline Pinenut Well & $<0.01$ & 0.00 & ns & ns & & & 3,230 & ns & ns & 185 \\
\hline Tom Land Well & $<0.01$ & 0.01 & 1,440 & 1,380 & 4,490 & 4,540 & 4,460 & 7,175 & 0.70856 & 37 \\
\hline Tom Land Well & $<0.01$ & 0.00 & ns & ns & & & 4,530 & ns & ns & 165 \\
\hline
\end{tabular}


Table A. Analysis results from all laboratories.-Continued

\begin{tabular}{|c|c|c|c|c|c|c|c|c|c|c|}
\hline Spring or well & $\begin{array}{c}\text { Terbium } \\
\text { Taylor } \\
\text { ICP-MS } \\
\text { मg/L }\end{array}$ & $\begin{array}{c}\text { Terbium- } \\
\text { SD } \\
\text { Taylor } \\
\text { ICP-MS } \\
\mu \mathrm{g} / \mathrm{L} \\
\end{array}$ & $\begin{array}{c}\text { Tellurium } \\
\text { Taylor } \\
\text { ICP-MS } \\
\text { } \mathbf{g g} / \mathrm{L}\end{array}$ & $\begin{array}{c}\text { Tellurium- } \\
\text { SD } \\
\text { Taylor } \\
\text { ICP-MS } \\
\mu \mathrm{g} / \mathrm{L}\end{array}$ & $\begin{array}{c}\text { Thorium } \\
\text { Taylor } \\
\text { ICP-MS } \\
\mu \mathrm{g} / \mathrm{L}\end{array}$ & $\begin{array}{c}\text { Thorium- } \\
\text { SD } \\
\text { Taylor } \\
\text { ICP-MS } \\
\mu \mathrm{g} / \mathrm{L} \\
\end{array}$ & $\begin{array}{c}\text { Titanium } \\
\text { Taylor } \\
\text { ICP-AES } \\
\mu \mathrm{g} / \mathrm{L}\end{array}$ & $\begin{array}{c}\text { Titanium- } \\
\text { SD } \\
\text { Taylor } \\
\text { ICP-AES } \\
\mu \mathrm{g} / \mathrm{L} \\
\end{array}$ & $\begin{array}{c}\text { Thallium } \\
\text { NWOL } \\
\text { AASGF } \\
\mu \mathrm{g} / \mathrm{L}\end{array}$ & $\begin{array}{c}\text { Thallium } \\
\text { Taylor } \\
\text { ICP-MS } \\
\text { pg/L }\end{array}$ \\
\hline Buck Farm Spring & $\mathrm{ns}$ & ns & ns & ns & $\mathrm{ns}$ & ns & ns & ns & $0.02 \mathrm{e}$ & ns \\
\hline Buck Farm Spring & ns & ns & ns & ns & $\mathrm{ns}$ & ns & ns & ns & $<0.04$ & ns \\
\hline Fence Spring & ns & ns & ns & ns & ns & ns & ns & ns & 0.05 & $\mathrm{~ns}$ \\
\hline Hanging Spring & ns & ns & ns & ns & ns & ns & ns & ns & $<0.04$ & ns \\
\hline Hole in the Wall Spring & ns & ns & ns & ns & ns & ns & ns & ns & $<0.04$ & $\mathrm{~ns}$ \\
\hline South Canyon Spring & 0.0002 & 0.0001 & $<0.008$ & 0.003 & $<0.001$ & 0.000 & $<0.2$ & 0.1 & $\mathrm{~ns}$ & 0.006 \\
\hline South Canyon Spring & 0.0003 & 0.0001 & $<0.008$ & 0.005 & $<0.001$ & 0.001 & $<0.2$ & 0.1 & ns & 0.006 \\
\hline Unknown Spring & ns & ns & ns & ns & $\mathrm{ns}$ & ns & ns & ns & $<0.04$ & ns \\
\hline Unknown Spring & ns & $\mathrm{ns}$ & ns & ns & $\mathrm{ns}$ & ns & $\mathrm{ns}$ & ns & $<0.04$ & $\mathrm{~ns}$ \\
\hline Vasey's Paradise & ns & ns & ns & ns & ns & ns & ns & ns & ns & ns \\
\hline Clearwater Spring & 0.0010 & 0.0001 & 0.022 & 0.001 & 0.006 & 0.004 & $<0.2$ & 0.1 & $<0.08$ & $<0.005$ \\
\hline Clearwater Spring & 0.0008 & 0.0001 & 0.014 & 0.000 & 0.009 & 0.004 & $<0.2$ & 0.2 & ns & $<0.005$ \\
\hline Hotel Spring & 0.0006 & 0.0002 & $<0.008$ & 0.004 & 0.006 & 0.003 & $<0.2$ & 0.1 & $0.03 \mathrm{e}$ & 0.027 \\
\hline Hotel Spring & 0.0003 & 0.0000 & $<0.008$ & 0.009 & 0.005 & 0.001 & $<0.2$ & 0.1 & $\mathrm{~ns}$ & 0.022 \\
\hline Kanab Spring & $<0.0002$ & 0.0002 & $<0.008$ & 0.003 & 0.002 & 0.002 & $<0.2$ & 0.1 & 0.12 & 0.12 \\
\hline Kanab Spring & $<0.0002$ & 0.0002 & $<0.008$ & 0.006 & 0.002 & 0.002 & $<0.2$ & 0.1 & 0.14 & 0.12 \\
\hline Lower Jumpup Spring & 0.0003 & 0.0001 & $<0.008$ & 0.002 & 0.008 & 0.003 & $<0.2$ & 0.0 & $<0.12$ & 0.012 \\
\hline Lower Jumpup Spring & $<0.0002$ & 0.0001 & 0.022 & 0.006 & 0.005 & 0.000 & $<0.2$ & 0.1 & ns & 0.012 \\
\hline Mountain Sheep Spring & $<0.0002$ & 0.0001 & 0.008 & 0.005 & 0.002 & 0.001 & $<0.2$ & 0.2 & $<0.04$ & 0.012 \\
\hline Mountain Sheep Spring & $<0.0002$ & 0.0000 & 0.011 & 0.003 & 0.003 & 0.001 & $<0.2$ & 0.0 & $<0.04$ & 0.013 \\
\hline Rider Spring & ns & ns & ns & ns & ns & ns & ns & ns & $<0.04$ & ns \\
\hline Rider Spring & ns & ns & ns & ns & ns & ns & ns & ns & $\mathrm{ns}$ & ns \\
\hline Rock Spring & 0.0004 & 0.0002 & 0.009 & 0.005 & 0.007 & 0.003 & $<0.2$ & 0.2 & $0.04 \mathrm{e}$ & 0.020 \\
\hline Rock Spring & $<0.0002$ & 0.0001 & 0.016 & 0.003 & 0.005 & 0.003 & $<0.2$ & 0.3 & ns & 0.014 \\
\hline Schmutz Spring & $<0.0002$ & 0.0001 & $<0.008$ & 0.008 & 0.008 & 0.000 & $<0.2$ & 0.2 & 0.07 & 0.079 \\
\hline Schmutz Spring & $<0.0002$ & 0.0001 & $<0.008$ & 0.004 & 0.007 & 0.003 & $<0.2$ & 0.2 & 0.09 & 0.082 \\
\hline Showerbath Spring & 0.0003 & 0.0001 & 0.009 & 0.008 & 0.005 & 0.005 & $<0.2$ & 0.2 & 0.07 & 0.064 \\
\hline Showerbath Spring & $<0.0002$ & 0.0002 & $<0.008$ & 0.003 & 0.006 & 0.006 & $<0.2$ & 0.1 & ns & 0.065 \\
\hline Side Canyon Spring & $<0.0002$ & 0.0003 & $<0.008$ & 0.005 & 0.005 & 0.004 & $<0.2$ & 0.1 & 0.17 & 0.16 \\
\hline Side Canyon Spring & $<0.0002$ & 0.0000 & $<0.008$ & 0.003 & 0.005 & 0.002 & $<0.2$ & 0.1 & ns & 0.17 \\
\hline Slide Spring & $<0.0002$ & 0.0002 & 0.011 & 0.007 & 0.004 & 0.002 & $<0.2$ & 0.2 & 0.07 & 0.081 \\
\hline Slide Spring & $<0.0002$ & 0.0001 & $<0.008$ & 0.004 & 0.001 & 0.000 & $<0.2$ & 0.1 & $\mathrm{~ns}$ & 0.079 \\
\hline Upper Jumpup Spring & $<0.0002$ & 0.0002 & $<0.008$ & 0.006 & 0.002 & 0.001 & $<0.2$ & 0.1 & 0.10 & 0.095 \\
\hline Upper Jumpup Spring & $<0.0002$ & 0.0001 & $<0.008$ & 0.004 & 0.004 & 0.003 & $<0.2$ & 0.0 & ns & 0.092 \\
\hline $\begin{array}{l}\text { Willow Spring } \\
\text { (Hack Canyon) }\end{array}$ & 0.0006 & 0.0003 & 0.013 & 0.010 & 0.023 & 0.018 & $<0.2$ & 0.1 & $0.06 \mathrm{e}$ & 0.059 \\
\hline $\begin{array}{l}\text { Willow Spring } \\
\text { (Hack Canyon) }\end{array}$ & 0.0006 & 0.0003 & 0.021 & 0.003 & 0.011 & 0.003 & $<0.2$ & 0.1 & ns & 0.058 \\
\hline Burnt Canyon Well & 0.0014 & 0.0001 & 0.059 & 0.013 & 0.016 & 0.006 & $<0.1$ & 0.2 & 0.13 & 0.12 \\
\hline Burnt Canyon Well & 0.0013 & 0.0001 & 0.052 & 0.018 & 0.014 & 0.005 & $<0.1$ & 0.2 & ns & 0.12 \\
\hline Canyon Mine Well & $<0.0002$ & 0.0001 & 0.010 & 0.006 & $<0.003$ & 0.001 & $<0.1$ & 0.1 & $0.02 \mathrm{e}$ & 0.025 \\
\hline Canyon Mine Well & $<0.0002$ & 0.0000 & $<0.008$ & 0.001 & $<0.003$ & 0.002 & $<0.1$ & 0.0 & ns & 0.024 \\
\hline Pinenut Well & 0.0008 & 0.0001 & 0.030 & 0.006 & 0.036 & 0.001 & $<0.1$ & 0.2 & $<0.04$ & 0.015 \\
\hline Pinenut Well & 0.0009 & 0.0001 & 0.029 & 0.005 & 0.031 & 0.003 & $<0.1$ & 0.2 & ns & 0.016 \\
\hline Tom Land Well & 0.0004 & 0.0001 & 0.036 & 0.009 & 0.012 & 0.001 & $<0.1$ & 0.1 & 0.35 & 0.30 \\
\hline Tom Land Well & 0.0003 & 0.0002 & 0.040 & 0.008 & 0.013 & 0.010 & $<0.1$ & 0.2 & ns & 0.31 \\
\hline
\end{tabular}


Table A. Analysis results from all laboratories.-Continued

\begin{tabular}{|c|c|c|c|c|c|c|c|c|c|}
\hline Spring or well & $\begin{array}{l}\text { Thallium- } \\
\text { SD } \\
\text { Taylor } \\
\text { ICP-MS } \\
\mu \mathrm{g} / \mathrm{L}\end{array}$ & $\begin{array}{c}\text { Thulium } \\
\text { Taylor } \\
\text { ICP-MS } \\
\text { pg/L }\end{array}$ & $\begin{array}{l}\text { Thulium- } \\
\text { SD } \\
\text { Taylor } \\
\text { ICP-MS } \\
\mu \mathrm{g} / \mathrm{L}\end{array}$ & $\begin{array}{c}\text { Uranium } \\
\text { NWOL } \\
\text { IC-MS } \\
\text { Ig/L }\end{array}$ & $\begin{array}{c}\text { Uranium } \\
\text { Doughten } \\
\text { ICP-MS } \\
\mu \mathrm{g} / \mathrm{L}\end{array}$ & $\begin{array}{c}\text { Uranium } \\
\text { Taylor } \\
\text { ICP-MS } \\
\text { pg/L }\end{array}$ & $\begin{array}{c}\text { Uranium- } \\
\text { SD } \\
\text { Taylor } \\
\text { ICP-MS } \\
\mu \mathrm{g} / \mathrm{L}\end{array}$ & $\begin{array}{c}\text { Uranium- } \\
\text { NAU } \\
\text { Appendix } 1 \\
\text { pg/L }\end{array}$ & $\begin{array}{c}\text { Uranium- } \\
\text { SD } \\
\text { Appendix } 1 \\
\text { Ig/L }\end{array}$ \\
\hline Buck Farm Spring & ns & $\mathrm{ns}$ & $\mathrm{ns}$ & 2.77 & 2.80 & ns & ns & 3.25 & 0.01 \\
\hline Buck Farm Spring & ns & ns & ns & 2.81 & ns & ns & ns & ns & $\mathrm{ns}$ \\
\hline Fence Spring & ns & ns & ns & 1.44 & 1.50 & ns & ns & 1.70 & 0.01 \\
\hline Hanging Spring & ns & ns & $\mathrm{ns}$ & 0.61 & 0.61 & ns & ns & 0.70 & 0.01 \\
\hline Hole in the Wall Spring & ns & ns & ns & 0.58 & 0.62 & ns & ns & 0.68 & 0.01 \\
\hline South Canyon Spring & 0.002 & 0.0001 & 0.0001 & ns & 0.90 & 0.83 & 0.02 & 0.93 & 0.01 \\
\hline South Canyon Spring & 0.001 & $<0.0001$ & 0.0001 & ns & ns & 0.82 & 0.02 & ns & ns \\
\hline Unknown Spring & ns & ns & ns & 0.58 & 0.61 & $\mathrm{~ns}$ & ns & 0.68 & 0.01 \\
\hline Unknown Spring & ns & ns & ns & 0.57 & 0.61 & ns & ns & $\mathrm{ns}$ & ns \\
\hline Vasey's Paradise & ns & ns & ns & ns & 0.59 & ns & ns & ns & ns \\
\hline Clearwater Spring & 0.007 & 0.0001 & 0.0000 & 1.28 & 1.20 & 1.12 & 0.05 & 1.35 & 0.01 \\
\hline Clearwater Spring & 0.003 & 0.0002 & 0.0001 & ns & ns & 1.11 & 0.04 & $\mathrm{~ns}$ & ns \\
\hline Hotel Spring & 0.001 & 0.0004 & 0.0001 & 2.60 & 2.69 & 2.7 & 0.1 & 3.18 & 0.02 \\
\hline Hotel Spring & 0.001 & 0.0004 & 0.0001 & ns & ns & 2.7 & 0.0 & ns & ns \\
\hline Kanab Spring & 0.00 & $<0.0001$ & 0.0000 & 4.62 & 4.96 & 4.9 & 0.1 & 5.71 & 0.01 \\
\hline Kanab Spring & 0.00 & $<0.0001$ & 0.0001 & 5.17 & $\mathrm{~ns}$ & 4.8 & 0.0 & ns & $\mathrm{ns}$ \\
\hline Lower Jumpup Spring & 0.002 & 0.0002 & 0.0001 & 7.16 & 7.87 & 7.7 & 0.0 & 8.98 & 0.02 \\
\hline Lower Jumpup Spring & 0.001 & 0.0002 & 0.0001 & ns & ns & 7.5 & 0.0 & ns & ns \\
\hline Mountain Sheep Spring & 0.001 & 0.0001 & 0.0000 & 8.83 & 8.76 & 8.4 & 0.1 & 10.2 & 0.0 \\
\hline Mountain Sheep Spring & 0.001 & 0.0001 & 0.0000 & 7.76 & ns & 8.3 & 0.1 & ns & $\mathrm{ns}$ \\
\hline Rider Spring & ns & ns & $\mathrm{ns}$ & 4.50 & 4.70 & ns & ns & 5.56 & 0.01 \\
\hline Rider Spring & ns & ns & $\mathrm{ns}$ & $\mathrm{ns}$ & ns & $\mathrm{ns}$ & ns & 5.66 & 0.01 \\
\hline Rock Spring & 0.001 & $<0.0001$ & 0.0001 & 14.30 & 16.0 & 14.1 & 1.2 & 19.5 & 0.0 \\
\hline Rock Spring & 0.002 & $<0.0001$ & 0.0001 & ns & ns & 11.3 & 0.4 & ns & ns \\
\hline Schmutz Spring & 0.002 & $<0.0001$ & 0.0001 & 4.25 & 4.41 & 4.4 & 0.0 & 5.42 & 0.01 \\
\hline Schmutz Spring & 0.002 & $<0.0001$ & 0.0001 & 4.06 & ns & 4.8 & 0.4 & ns & ns \\
\hline Showerbath Spring & 0.000 & 0.0001 & 0.0001 & 4.19 & 4.91 & 4.8 & 0.1 & 5.71 & 0.01 \\
\hline Showerbath Spring & 0.001 & $<0.0001$ & 0.0001 & ns & ns & 4.7 & 0.2 & 5.76 & 0.01 \\
\hline Side Canyon Spring & 0.00 & $<0.0001$ & 0.0001 & 7.24 & 7.43 & 7.5 & 0.1 & 9.03 & 0.01 \\
\hline Side Canyon Spring & 0.00 & 0.0002 & 0.0001 & ns & ns & 7.4 & 0.1 & ns & ns \\
\hline Slide Spring & 0.001 & $<0.0001$ & 0.0001 & 2.28 & 2.90 & 2.8 & 0.0 & 3.34 & 0.01 \\
\hline Slide Spring & 0.004 & $<0.0001$ & 0.0001 & ns & ns & 2.9 & 0.1 & ns & ns \\
\hline Upper Jumpup Spring & 0.002 & $<0.0001$ & 0.0001 & 3.72 & 4.02 & 3.9 & 0.0 & 4.70 & 0.01 \\
\hline Upper Jumpup Spring & 0.002 & $<0.0001$ & 0.0001 & $\mathrm{~ns}$ & $\mathrm{~ns}$ & 4.0 & 0.1 & ns & $\mathrm{ns}$ \\
\hline $\begin{array}{l}\text { Willow Spring } \\
\text { (Hack Canyon) }\end{array}$ & 0.000 & $<0.0001$ & 0.0000 & 19.6 & 20.0 & 19.3 & 0.6 & 23.9 & 0.0 \\
\hline $\begin{array}{l}\text { Willow Spring } \\
\text { (Hack Canyon) }\end{array}$ & 0.003 & 0.0003 & 0.0002 & ns & ns & 19.6 & 0.8 & ns & ns \\
\hline Burnt Canyon Well & 0.00 & 0.0003 & 0.0001 & 2.77 & 3.20 & 3.0 & 0.1 & 3.70 & 0.01 \\
\hline Burnt Canyon Well & 0.01 & 0.0002 & 0.0001 & ns & ns & 3.0 & 0.1 & ns & ns \\
\hline Canyon Mine Well & 0.001 & $<0.0001$ & 0.0000 & 12.1 & 15.3 & 14.6 & 0.0 & 16.9 & 0.0 \\
\hline Canyon Mine Well & 0.000 & $<0.0001$ & 0.0001 & ns & ns & 14.2 & 0.7 & ns & $\mathrm{ns}$ \\
\hline Pinenut Well & 0.001 & $<0.0001$ & 0.0000 & 2.28 & 2.40 & 2.1 & 0.0 & 2.71 & 0.01 \\
\hline Pinenut Well & 0.001 & $<0.0001$ & 0.0001 & $\mathrm{~ns}$ & ns & 2.1 & 0.1 & ns & ns \\
\hline Tom Land Well & 0.01 & $<0.0001$ & 0.0000 & 19.8 & 21.1 & 17.4 & 1.2 & 23.9 & 0.1 \\
\hline Tom Land Well & 0.00 & 0.0001 & 0.0001 & ns & ns & 17.8 & 0.6 & ns & ns \\
\hline
\end{tabular}


Table A. Analysis results from all laboratories.-Continued

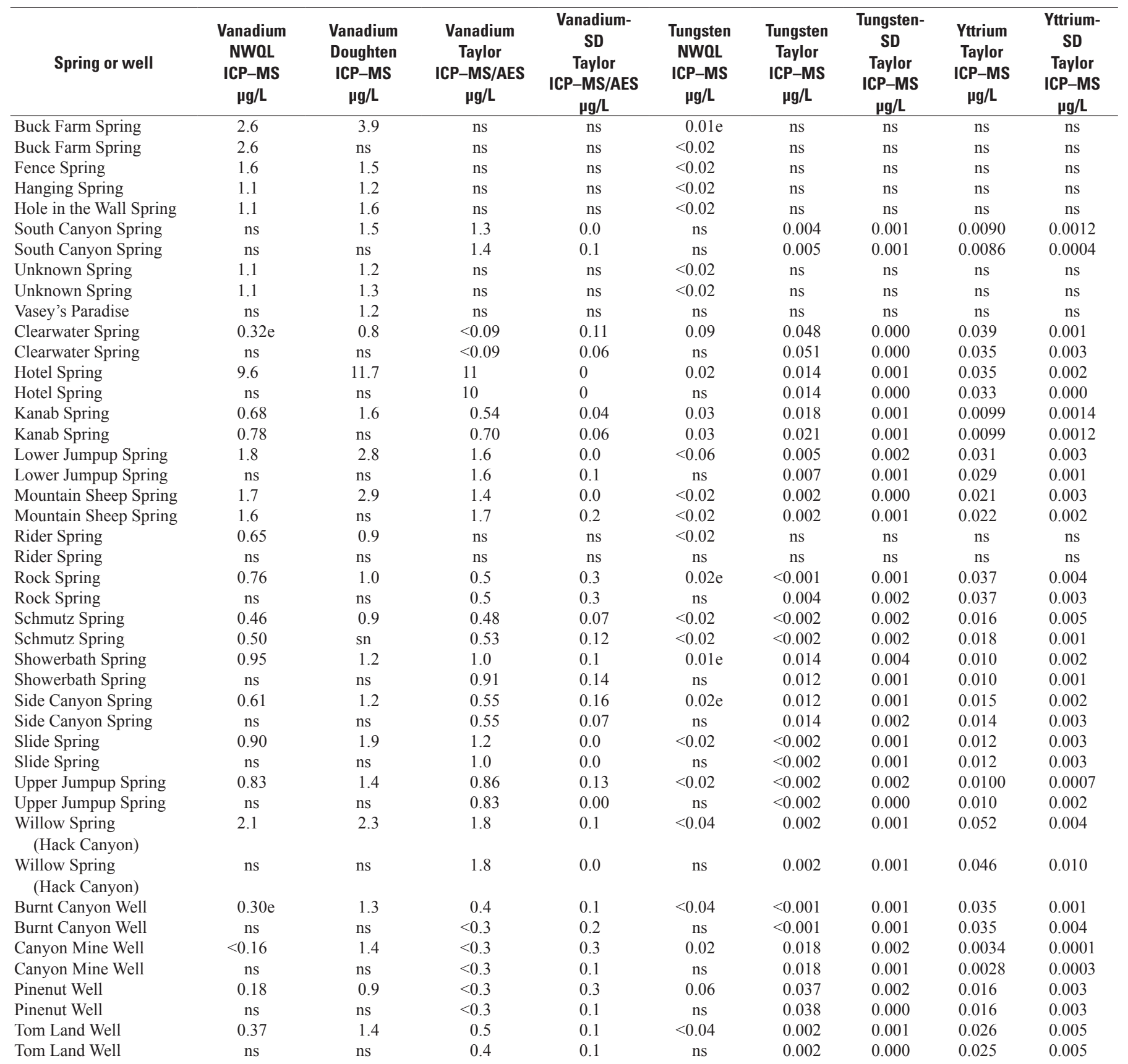


Table A. Analysis results from all laboratories.-Continued

\begin{tabular}{|c|c|c|c|c|c|c|c|c|}
\hline Spring or well & $\begin{array}{c}\text { Ytterbium } \\
\text { Taylor } \\
\text { ICP-MS } \\
\text { Ig/L }\end{array}$ & $\begin{array}{c}\text { Ytterbium- } \\
\text { SD } \\
\text { Taylor } \\
\text { ICP-MS } \\
\mu \mathrm{g} / \mathrm{L}\end{array}$ & $\begin{array}{c}\text { Zinc } \\
\text { NWOL } \\
\text { ICP-MS } \\
\mu \mathrm{g} / \mathrm{L}\end{array}$ & $\begin{array}{c}\text { Zinc } \\
\text { Doughten } \\
\text { ICP-MS } \\
\text { g/L }\end{array}$ & $\begin{array}{c}\text { Zinc } \\
\text { Taylor } \\
\text { ICP-MS/AES } \\
\mu \mathrm{g} / \mathrm{L}\end{array}$ & $\begin{array}{c}\text { Zinc-SD } \\
\text { Taylor } \\
\text { ICP-MS/AES } \\
\mu \mathrm{g} / \mathrm{L}\end{array}$ & $\begin{array}{c}\text { Zirconium } \\
\text { Taylor } \\
\text { ICP-MS } \\
\text { Ig/L }\end{array}$ & $\begin{array}{c}\text { Zirconium- } \\
\text { SD } \\
\text { Taylor } \\
\text { ICP-MS } \\
\mu \mathrm{g} / \mathrm{L}\end{array}$ \\
\hline Buck Farm Spring & ns & ns & $<2$ & 1 & ns & ns & ns & ns \\
\hline Buck Farm Spring & ns & ns & $<2$ & ns & ns & ns & ns & ns \\
\hline Fence Spring & ns & ns & 5.7 & 7 & ns & ns & ns & ns \\
\hline Hanging Spring & ns & ns & $<2$ & 4 & ns & ns & ns & ns \\
\hline Hole in the Wall Spring & ns & ns & $<2$ & 4 & ns & ns & ns & ns \\
\hline South Canyon Spring & $<0.0007$ & 0.0004 & ns & 3 & 1 & 0 & 0.014 & 0.013 \\
\hline South Canyon Spring & $<0.0007$ & 0.0000 & ns & ns & 1 & 0 & 0.008 & 0.009 \\
\hline Unknown Spring & ns & ns & $<2$ & 4 & ns & ns & ns & ns \\
\hline Unknown Spring & ns & ns & $1.1 \mathrm{e}$ & 4 & ns & ns & ns & ns \\
\hline Vasey's Paradise & ns & ns & ns & 4 & ns & ns & ns & ns \\
\hline Clearwater Spring & $<0.0007$ & 0.0002 & $3.9 \mathrm{e}$ & $<5$ & 3 & 0 & 0.22 & 0.13 \\
\hline Clearwater Spring & $<0.0007$ & 0.0006 & ns & ns & 3 & 1 & 0.22 & 0.01 \\
\hline Hotel Spring & 0.0019 & 0.0011 & $1.1 \mathrm{e}$ & 2 & $<1$ & 1 & 0.16 & 0.12 \\
\hline Hotel Spring & 0.0023 & 0.0003 & ns & ns & $<1$ & 1 & 0.32 & 0.27 \\
\hline Kanab Spring & $<0.0007$ & 0.0002 & 20.5 & 17 & 17 & 1 & 0.031 & 0.011 \\
\hline Kanab Spring & $<0.0007$ & 0.0005 & 19.1 & ns & 17 & 0 & 0.037 & 0.017 \\
\hline Lower Jumpup Spring & 0.0008 & 0.0003 & $<6$ & 4 & 3 & 1 & 0.088 & 0.022 \\
\hline Lower Jumpup Spring & 0.0009 & 0.0000 & ns & ns & 3 & 0 & 0.082 & 0.013 \\
\hline Mountain Sheep Spring & 0.0006 & 0.0003 & 14.8 & 6 & 4 & 0 & 0.051 & 0.002 \\
\hline Mountain Sheep Spring & 0.0006 & 0.0000 & 2.7 & ns & 3 & 0 & 0.049 & 0.009 \\
\hline Rider Spring & ns & ns & $1.5 \mathrm{e}$ & 2 & ns & ns & ns & ns \\
\hline Rider Spring & ns & ns & ns & ns & ns & ns & ns & ns \\
\hline Rock Spring & $<0.0005$ & 0.0003 & $<4.0$ & $<5$ & 1 & 0 & 0.10 & 0.00 \\
\hline Rock Spring & $<0.0005$ & 0.0003 & ns & ns & 1 & 1 & 0.084 & 0.005 \\
\hline Schmutz Spring & $<0.0007$ & 0.0000 & 3.7 & 5 & 4 & 1 & 0.22 & 0.20 \\
\hline Schmutz Spring & $<0.0007$ & 0.0004 & 4.1 & $\mathrm{~ns}$ & 4 & 1 & 0.16 & 0.09 \\
\hline Showerbath Spring & $<0.0007$ & 0.0003 & 12.3 & 8 & 9 & 0 & 0.12 & 0.12 \\
\hline Showerbath Spring & $<0.0007$ & 0.0004 & ns & ns & 9 & 0 & 0.031 & 0.034 \\
\hline Side Canyon Spring & $<0.0007$ & 0.0009 & 6.6 & 8 & 7 & 0 & 0.038 & 0.002 \\
\hline Side Canyon Spring & $<0.0007$ & 0.0003 & ns & ns & 7 & 1 & 0.054 & 0.026 \\
\hline Slide Spring & $<0.0007$ & 0.0006 & 13.6 & 16 & 15 & 1 & 0.041 & 0.012 \\
\hline Slide Spring & $<0.0007$ & 0.0001 & ns & ns & 15 & 0 & 0.049 & 0.017 \\
\hline Upper Jumpup Spring & 0.0009 & 0.0005 & 14.2 & 14 & 13 & 2 & 0.026 & 0.019 \\
\hline Upper Jumpup Spring & $<0.0007$ & 0.0003 & ns & ns & 13 & 2 & 0.020 & 0.010 \\
\hline $\begin{array}{l}\text { Willow Spring } \\
\text { (Hack Canyon) }\end{array}$ & 0.0010 & 0.0005 & 9.2 & 9 & 11 & 0 & 0.33 & 0.24 \\
\hline $\begin{array}{l}\text { Willow Spring } \\
\text { (Hack Canyon) }\end{array}$ & $<0.0007$ & 0.0004 & ns & ns & 11 & 0 & 0.23 & 0.04 \\
\hline Burnt Canyon Well & 0.0008 & 0.0003 & 82 & 68 & 95 & 4 & 0.38 & 0.12 \\
\hline Burnt Canyon Well & 0.0009 & 0.0002 & $\mathrm{~ns}$ & ns & 92 & 4 & 0.51 & 0.02 \\
\hline Canyon Mine Well & $<0.0004$ & 0.0003 & 24.4 & 24 & 25 & 3 & 0.04 & 0.03 \\
\hline Canyon Mine Well & $<0.0004$ & 0.0000 & ns & ns & 25 & 1 & 0.04 & 0.06 \\
\hline Pinenut Well & 0.0005 & 0.0003 & 2.1 & 4 & 3 & 2 & 0.16 & 0.05 \\
\hline Pinenut Well & $<0.0004$ & 0.0001 & ns & ns & 2 & 2 & 0.25 & 0.15 \\
\hline Tom Land Well & $<0.0004$ & 0.0002 & 245 & 208 & 264 & 16 & 0.96 & 1.03 \\
\hline Tom Land Well & $<0.0004$ & 0.0001 & ns & $\mathrm{ns}$ & 265 & 18 & 0.22 & 0.13 \\
\hline
\end{tabular}


Table A. Analysis results from all laboratories.-Continued

\begin{tabular}{|c|c|c|c|c|c|c|c|c|c|}
\hline Spring or well & $\begin{array}{c}\text { Alkalinity } \\
\text { NWOL } \\
\text { titration } \\
\text { mg CaCO }_{3} / \mathrm{L}\end{array}$ & $\begin{array}{c}\text { Acid } \\
\text { neutralizing } \\
\text { capacity } \\
\text { NWOL } \\
\text { mg CaCO }_{3} / \mathrm{L}\end{array}$ & $\begin{array}{c}\text { Specific } \\
\text { conductance } \\
\text { field } \\
\text { meter } \\
\mu S / c m \\
\end{array}$ & $\begin{array}{c}\text { Specific } \\
\text { conductance } \\
\text { NWQL } \\
\text { meter } \\
\mu S / c m \\
\end{array}$ & $\begin{array}{c}\mathrm{HCO}_{3} \\
\text { NWOL } \\
\text { titration } \\
\mathrm{mg} / \mathrm{L}\end{array}$ & $\begin{array}{c}\mathrm{HCO}_{3} \\
\text { Doughten } \\
\text { titration } \\
\mathrm{mg} / \mathrm{L}\end{array}$ & $\begin{array}{c}\mathrm{HCO}_{3} \\
\text { field } \\
\text { titration } \\
\mathrm{mg} / \mathrm{L}\end{array}$ & $\begin{array}{c}\text { Discharge } \\
\text { field } \\
\text { meter or } \\
\text { volumetric } \\
\text { gal/min }\end{array}$ & $\begin{array}{c}\text { Barometric } \\
\text { presssure } \\
\text { field } \\
\text { meter } \\
\text { mm Hg }\end{array}$ \\
\hline Buck Farm Spring & 198 & 206 & 708 & 784 & 239 & 265 & 239 & 0.59 & 690 \\
\hline Buck Farm Spring & ns & -- & ns & ns & ns & ns & ns & $\mathrm{nm}$ & ns \\
\hline Fence Spring & 360 & 342 & 1,000 & 1,740 & 439 & 470 & 439 & 732 & 686 \\
\hline Hanging Spring & 177 & 186 & 348 & 362 & 214 & 229 & 214 & $\mathrm{~nm}$ & 690 \\
\hline Hole in the Wall Spring & 173 & 186 & 303 & 364 & 210 & 230 & 210 & 8.8 & 686 \\
\hline South Canyon Spring & 130 & -- & 438 & ns & 156 & ns & 156 & $\mathrm{~nm}$ & 652 \\
\hline South Canyon Spring & ns & -- & ns & ns & ns & $\mathrm{ns}$ & ns & $\mathrm{nm}$ & ns \\
\hline Unknown Spring & 173 & 186 & 330 & 362 & 210 & 228 & 210 & 0.68 & 689 \\
\hline Unknown Spring & ns & & 330 & ns & ns & 228 & ns & $\mathrm{nm}$ & ns \\
\hline Vasey's Paradise & ns & -- & 300 & ns & ns & ns & ns & 260 & $\mathrm{~nm}$ \\
\hline Clearwater Spring & 224 & 222 & 2,250 & 3,230 & 273 & 274 & 273 & 1.4 & $\mathrm{~nm}$ \\
\hline Clearwater Spring & ns & ns & $\mathrm{ns}$ & ns & ns & ns & ns & $\mathrm{nm}$ & $\mathrm{nm}$ \\
\hline Hotel Spring & 169 & 173 & 915 & 852 & 204 & 212 & 204 & $<0.001 \mathrm{e}$ & 754 \\
\hline Hotel Spring & ns & ns & ns & $\mathrm{ns}$ & ns & ns & ns & $\mathrm{nm}$ & $\mathrm{nm}$ \\
\hline Kanab Spring & 199 & 200 & 864 & 869 & 241 & 244 & 241 & 274 & $\mathrm{~nm}$ \\
\hline Kanab Spring & ns & ns & ns & ns & ns & ns & ns & $\mathrm{nm}$ & $\mathrm{nm}$ \\
\hline Lower Jumpup Spring & 294 & 290 & 1,960 & 1,930 & 357 & 371 & 357 & 57.6 & $\mathrm{~nm}$ \\
\hline Lower Jumpup Spring & ns & ns & ns & ns & ns & ns & ns & $\mathrm{nm}$ & $\mathrm{nm}$ \\
\hline Mountain Sheep Spring & 245 & 256 & 1,643 & 1,600 & 298 & 311 & 298 & 41 & 673 \\
\hline Mountain Sheep Spring & ns & ns & $\mathrm{ns}$ & $\mathrm{ns}$ & ns & ns & ns & $\mathrm{nm}$ & ns \\
\hline Rider Spring & 59 & 57 & 1,380 & 1,200 & 71 & 69 & 71 & 0.02 & 665 \\
\hline Rider Spring & ns & & ns & ns & ns & ns & ns & $\mathrm{nm}$ & ns \\
\hline Rock Spring & 128 & 129 & 2,460 & 2,620 & 154 & 159 & 154 & 0.11 & 674 \\
\hline Rock Spring & ns & ns & ns & ns & ns & ns & ns & $\mathrm{nm}$ & ns \\
\hline Schmutz Spring & 100 & 102 & 1,602 & 1,530 & 121 & 126 & 121 & 0 & $\mathrm{~nm}$ \\
\hline Schmutz Spring & ns & ns & ns & ns & ns & ns & ns & $\mathrm{nm}$ & $\mathrm{nm}$ \\
\hline Showerbath Spring & 198 & 187 & 700 & 962 & 241 & 246 & 241 & 202 & $\mathrm{~nm}$ \\
\hline Showerbath Spring & ns & ns & ns & ns & $\mathrm{ms}$ & ns & ns & $\mathrm{nm}$ & $\mathrm{nm}$ \\
\hline Side Canyon Spring & 164 & 170 & 1,316 & 1,370 & 200 & 208 & 200 & 1 & $\mathrm{~nm}$ \\
\hline Side Canyon Spring & ns & ns & ns & $\mathrm{ns}$ & ns & ns & ns & $\mathrm{nm}$ & $\mathrm{nm}$ \\
\hline Slide Spring & 190 & 187 & 1,199 & 1,150 & 232 & 230 & 232 & 89.8 & $\mathrm{~nm}$ \\
\hline Slide Spring & ns & ns & ns & ns & ns & ns & ns & $\mathrm{nm}$ & $\mathrm{nm}$ \\
\hline Upper Jumpup Spring & 160 & 153 & 709 & 1,060 & 195 & 192 & 195 & 1.3 & $\mathrm{~nm}$ \\
\hline Upper Jumpup Spring & ns & ns & ns & ns & ns & ns & ns & $\mathrm{nm}$ & $\mathrm{nm}$ \\
\hline $\begin{array}{l}\text { Willow Spring } \\
\text { (Hack Canyon) }\end{array}$ & 85 & 89 & 2,460 & 3,220 & 102 & 108 & 102 & $\mathrm{~nm}$ & $\mathrm{~nm}$ \\
\hline $\begin{array}{l}\text { Willow Spring } \\
\text { (Hack Canyon) }\end{array}$ & ns & ns & ns & ns & ns & ns & ns & $\mathrm{nm}$ & $\mathrm{nm}$ \\
\hline Burnt Canyon Well & 292 & 307 & 3,570 & 3,520 & 355 & 370 & 355 & 50 & 765 \\
\hline Burnt Canyon Well & ns & ns & ns & ns & ns & ns & ns & $\mathrm{nm}$ & ns \\
\hline Canyon Mine Well & 214 & 218 & 437 & 451 & 260 & 265 & 260 & 70 & 770 \\
\hline Canyon Mine Well & ns & ns & $\mathrm{ns}$ & ns & ns & ns & ns & $\mathrm{nm}$ & ns \\
\hline Pinenut Well & 171 & 184 & 2,170 & 2,160 & 208 & 225 & 208 & 13.6 & 767 \\
\hline Pinenut Well & ns & ns & ns & ns & ns & ns & ns & $\mathrm{nm}$ & ns \\
\hline Tom Land Well & 284 & 293 & 2,666 & 2,670 & 346 & 354 & 346 & 8.2 & 761 \\
\hline Tom Land Well & ns & ns & ns & ns & ns & ns & ns & $\mathrm{nm}$ & ns \\
\hline
\end{tabular}


Table A. Analysis results from all laboratories.-Continued

\begin{tabular}{|c|c|c|c|c|c|c|c|c|}
\hline Spring or well & $\begin{array}{c}\text { Dissolved } \\
\text { oxygen, unf } \\
\text { field } \\
\text { meter } \\
\text { mg/L }\end{array}$ & $\begin{array}{c}\text { pH } \\
\text { field meter } \\
\text { standard units }\end{array}$ & $\begin{array}{c}\text { pH } \\
\text { NWOL } \\
\text { meter } \\
\text { standard units }\end{array}$ & $\begin{array}{c}\text { Air } \\
\text { temperature } \\
\text { field } \\
\text { manual } \\
{ }^{\circ} \mathrm{C}\end{array}$ & $\begin{array}{c}\text { Water } \\
\text { temperature } \\
\text { field } \\
\text { manual } \\
{ }^{\circ} \mathrm{C}\end{array}$ & $\begin{array}{c}\text { Gross alpha } \\
\text { radioactivity, } \\
\text { 30-day } \\
\text { NWOL } \\
\text { pCi/L }\end{array}$ & $\begin{array}{c}\text { Gross alpha } \\
\text { radioactivity, } \\
\text { 30-day- } \\
\text { SD } \\
\text { NWOL } \\
\text { pCi/L }\end{array}$ & $\begin{array}{c}\text { Gross alpha } \\
\text { radioactivity, } \\
30 \text {-day- } \\
\text { sample specific } \\
\text { reporting limit } \\
\text { NWOL } \\
\text { pCi/L }\end{array}$ \\
\hline Buck Farm Spring & 6.8 & 7.5 & 7.8 & 34.7 & 27.3 & 3.9 & 1.1 & 1.2 \\
\hline Buck Farm Spring & $\mathrm{nm}$ & $\mathrm{nm}$ & -- & $\mathrm{nm}$ & $\mathrm{nm}$ & $\mathrm{ns}$ & ns & ns \\
\hline Fence Spring & 5.0 & 6.8 & 7.3 & 31.0 & 21.5 & $0.1 \mathrm{R}$ & 1.5 & 2.3 \\
\hline Hanging Spring & 7.3 & 7.9 & 7.9 & 34.0 & 20.9 & $0.1 \mathrm{R}$ & 0.55 & 0.81 \\
\hline Hole in the Wall Spring & 7.8 & 7.5 & 7.8 & $\mathrm{~nm}$ & 22.4 & 2.2 & 0.64 & 0.63 \\
\hline South Canyon Spring & 8.0 & 8.0 & -- & $\mathrm{nm}$ & 15.5 & ns & ns & ns \\
\hline South Canyon Spring & $\mathrm{nm}$ & $\mathrm{nm}$ & -- & $\mathrm{nm}$ & $\mathrm{nm}$ & ns & ns & ns \\
\hline Unknown Spring & 7.6 & 7.6 & 7.7 & 30.0 & 18.8 & 3.5 & 1.1 & 1.3 \\
\hline Unknown Spring & $\mathrm{nm}$ & $\mathrm{nm}$ & -- & $\mathrm{nm}$ & $\mathrm{nm}$ & ns & ns & ns \\
\hline Vasey's Paradise & 9.1 & 8.6 & -- & 25.9 & 18.6 & 2.1 & 0.59 & 0.53 \\
\hline Clearwater Spring & 0.2 & 7.5 & 7.5 & 28.2 & 17.1 & $-1.0 \mathrm{R}$ & 4.7 & 7.5 \\
\hline Clearwater Spring & $\mathrm{nm}$ & $\mathrm{nm}$ & ns & $\mathrm{nm}$ & $\mathrm{nm}$ & ns & ns & ns \\
\hline Hotel Spring & $7.8 \mathrm{e}$ & 7.9 & 8.1 & 33.0 & 27.8 & 4.4 & 0.96 & 0.76 \\
\hline Hotel Spring & $\mathrm{nm}$ & $\mathrm{nm}$ & ns & $\mathrm{nm}$ & $\mathrm{nm}$ & ns & ns & ns \\
\hline Kanab Spring & 7.3 & 7.1 & 7.6 & 24.5 & 21.8 & 6.7 & 1.6 & 1.5 \\
\hline Kanab Spring & $\mathrm{nm}$ & $\mathrm{nm}$ & ns & $\mathrm{nm}$ & $\mathrm{nm}$ & ns & ns & ns \\
\hline Lower Jumpup Spring & 4.1 & 6.9 & 7.4 & 30.3 & 21.1 & 16.0 & 4.0 & 2.9 \\
\hline Lower Jumpup Spring & $\mathrm{nm}$ & $\mathrm{nm}$ & ns & $\mathrm{nm}$ & $\mathrm{nm}$ & ns & ns & ns \\
\hline Mountain Sheep Spring & 7.3 & 7.0 & 7.2 & 25.8 & 18.3 & 14.5 & 2.6 & 1.6 \\
\hline Mountain Sheep Spring & $\mathrm{nm}$ & $\mathrm{nm}$ & ns & $\mathrm{nm}$ & $\mathrm{nm}$ & ns & ns & ns \\
\hline Rider Spring & 7.7 & 8.3 & 8.0 & 25.5 & 18.9 & 5.0 & 1.5 & 1.7 \\
\hline Rider Spring & $\mathrm{nm}$ & $\mathrm{nm}$ & ns & $\mathrm{nm}$ & $\mathrm{nm}$ & ns & ns & ns \\
\hline Rock Spring & 7.7 & 7.9 & 8.1 & 22.3 & 18.2 & 24.5 & 5.0 & 3.8 \\
\hline Rock Spring & $\mathrm{nm}$ & $\mathrm{nm}$ & ns & $\mathrm{nm}$ & $\mathrm{nm}$ & ns & $\mathrm{ns}$ & ns \\
\hline Schmutz Spring & 6.7 & 7.4 & 7.8 & 23.5 & 19.8 & 5.0 & 1.6 & 1.5 \\
\hline Schmutz Spring & $\mathrm{nm}$ & $\mathrm{nm}$ & ns & $\mathrm{nm}$ & $\mathrm{nm}$ & ns & ns & ns \\
\hline Showerbath Spring & 6.3 & 7.0 & 7.5 & 35.5 & 21.1 & 6.4 & 1.5 & 1.3 \\
\hline Showerbath Spring & $\mathrm{nm}$ & $\mathrm{nm}$ & ns & $\mathrm{nm}$ & $\mathrm{nm}$ & ns & ns & $\mathrm{ns}$ \\
\hline Side Canyon Spring & 4.2 & 7.4 & 7.4 & 28.7 & 23.3 & 9.0 & 3.0 & 3.9 \\
\hline Side Canyon Spring & $\mathrm{nm}$ & $\mathrm{nm}$ & ns & $\mathrm{nm}$ & $\mathrm{nm}$ & ns & ns & ns \\
\hline Slide Spring & 2.6 & 7.3 & 7.6 & 20.9 & 15.6 & 8.0 & 2.0 & 2.0 \\
\hline Slide Spring & $\mathrm{nm}$ & $\mathrm{nm}$ & ns & $\mathrm{nm}$ & $\mathrm{nm}$ & ns & ns & ns \\
\hline Upper Jumpup Spring & 5.0 & 7.4 & 7.8 & 29.3 & 13.4 & 11.2 & 1.9 & 1.1 \\
\hline Upper Jumpup Spring & $\mathrm{nm}$ & $\mathrm{nm}$ & ns & $\mathrm{nm}$ & $\mathrm{nm}$ & ns & ns & $\mathrm{ns}$ \\
\hline $\begin{array}{l}\text { Willow Spring } \\
\text { (Hack Canyon) }\end{array}$ & 6.4 & 7.3 & 7.8 & 31.0 & 18.6 & 12.0 & 5.0 & 6.0 \\
\hline $\begin{array}{l}\text { Willow Spring } \\
\text { (Hack Canyon) }\end{array}$ & $\mathrm{nm}$ & $\mathrm{nm}$ & ns & $\mathrm{nm}$ & $\mathrm{nm}$ & ns & ns & ns \\
\hline Burnt Canyon Well & 0.6 & 6.6 & 6.9 & $\mathrm{~nm}$ & 16.3 & 48 & 8.2 & 4.7 \\
\hline Burnt Canyon Well & $\mathrm{nm}$ & $\mathrm{nm}$ & ns & $\mathrm{nm}$ & $\mathrm{nm}$ & ns & ns & ns \\
\hline Canyon Mine Well & 3.9 & 7.1 & 7.4 & $\mathrm{~nm}$ & 26.7 & 12.4 & 1.6 & 0.43 \\
\hline Canyon Mine Well & $\mathrm{nm}$ & $\mathrm{nm}$ & sn & $\mathrm{nm}$ & $\mathrm{nm}$ & ns & ns & $\mathrm{ns}$ \\
\hline Pinenut Well & 0.6 & 7.2 & 7.2 & $\mathrm{~nm}$ & 26.6 & 142 & 16 & 3.2 \\
\hline Pinenut Well & $\mathrm{nm}$ & $\mathrm{nm}$ & ns & $\mathrm{nm}$ & $\mathrm{nm}$ & ns & ns & ns \\
\hline Tom Land Well & 3.8 & 6.8 & 6.9 & 23.0 & 17.9 & 52.0 & 9.2 & 8.5 \\
\hline Tom Land Well & $\mathrm{nm}$ & -- & ns & $\mathrm{nm}$ & $\mathrm{nm}$ & ns & ns & ns \\
\hline
\end{tabular}


Table A. Analysis results from all laboratories.-Continued

\begin{tabular}{|c|c|c|c|c|c|c|c|c|c|}
\hline Spring or well & $\begin{array}{c}\text { Gross alpha } \\
\text { radioactivity, } \\
\text { 72-hour } \\
\text { NWOL } \\
\text { pCi/L }\end{array}$ & $\begin{array}{l}\text { Gross alpha } \\
\text { radioactivity, } \\
\text { 72-hour- } \\
\text { SD } \\
\text { NWOL } \\
\text { pCi/L }\end{array}$ & $\begin{array}{l}\text { Gross alpha } \\
\text { radioactivity, } \\
\text { 72-hour- } \\
\text { sample specific } \\
\text { reporting limit } \\
\text { NWOL } \\
\text { pCi/L }\end{array}$ & $\begin{array}{c}\text { Gross beta } \\
\text { radioactivity, } \\
\text { 30-day } \\
\text { NWOL } \\
\text { pCi/L }\end{array}$ & $\begin{array}{l}\text { Gross beta } \\
\text { radioactivity, } \\
\text { 30-day- } \\
\text { SD } \\
\text { NWOL } \\
\text { pCi/L }\end{array}$ & $\begin{array}{l}\text { Gross beta } \\
\text { radioactivity, } \\
30 \text {-day, } \\
\text { sample specific } \\
\text { reporting limit } \\
\text { NWOL } \\
\text { pCi/L }\end{array}$ & $\begin{array}{c}\text { Gross beta } \\
\text { radioactivity, } \\
\text { 72-hour } \\
\text { NWOL } \\
\text { pCi/L }\end{array}$ & $\begin{array}{l}\text { Gross beta } \\
\text { radioactivity, } \\
\text { 72-hour- } \\
\text { SD } \\
\text { NWOL } \\
\text { pCi/L }\end{array}$ & $\begin{array}{l}\text { Gross beta } \\
\text { radioactivity, } \\
\text { 72-hour, } \\
\text { sample specific } \\
\text { reporting limit } \\
\text { NWOL } \\
\text { pCi/L }\end{array}$ \\
\hline Buck Farm Spring & 4.3 & 1.7 & 2.3 & 3.9 & 0.92 & 1.2 & 8.1 & 0.87 & 1.0 \\
\hline Buck Farm Spring & $\mathrm{ns}$ & $\mathrm{ns}$ & ns & ns & ns & ns & ns & ns & ns \\
\hline Fence Spring & $0.6 \mathrm{R}$ & 1.6 & 2.4 & 15.4 & 1.3 & 1.2 & 16.7 & 1.4 & 1.2 \\
\hline Hanging Spring & 1.8 & 0.53 & 0.57 & 1.1 & 0.44 & 0.68 & $0.4 \mathrm{R}$ & 0.38 & 0.61 \\
\hline Hole in the Wall Spring & 2.4 & 0.60 & 0.53 & $0.3 \mathrm{R}$ & 0.60 & 0.98 & $0.3 \mathrm{R}$ & 0.45 & 0.71 \\
\hline South Canyon Spring & ns & ns & ns & ns & ns & ns & ns & ns & ns \\
\hline South Canyon Spring & ns & ns & ns & ns & ns & ns & ns & ns & ns \\
\hline Unknown Spring & 1.9 & 0.54 & 0.52 & 2.3 & 0.48 & 0.68 & $0.50 \mathrm{R}$ & 0.40 & 0.63 \\
\hline Unknown Spring & ns & ns & ns & ns & ns & ns & ns & ns & ns \\
\hline Vasey's Paradise & 1.2 & 0.51 & 0.60 & 1.2 & 0.49 & 0.76 & $0.80 \mathrm{R}$ & 0.60 & 0.96 \\
\hline Clearwater Spring & $-3.0 \mathrm{R}$ & 3.0 & 5.2 & 12.0 & 2.2 & 3.1 & 12.2 & 1.6 & 2.1 \\
\hline Clearwater Spring & ns & ns & ns & ns & ns & ns & ns & ns & ns \\
\hline Hotel Spring & 3.3 & 0.92 & 0.89 & 7.9 & 0.82 & 0.95 & 6.0 & 0.77 & 0.94 \\
\hline Hotel Spring & ns & ns & ns & ns & ns & ns & ns & ns & ns \\
\hline Kanab Spring & 4.1 & 1.2 & 1.2 & 6.1 & 0.51 & 0.48 & 6.1 & 0.52 & 0.50 \\
\hline Kanab Spring & ns & $\mathrm{ns}$ & ns & ns & ns & $\mathrm{ns}$ & ns & ns & ns \\
\hline Lower Jumpup Spring & 7.0 & 4.2 & 6.0 & 9.9 & 0.97 & 1.00 & 10.2 & 0.94 & 0.96 \\
\hline Lower Jumpup Spring & ns & ns & ns & $\mathrm{ns}$ & ns & ns & ns & ns & ns \\
\hline Mountain Sheep Spring & 10.6 & 2.3 & 2.0 & 11.4 & 0.90 & 0.75 & 8.8 & 0.77 & 0.79 \\
\hline Mountain Sheep Spring & ns & ns & ns & ns & ns & ns & ns & $\mathrm{ns}$ & ns \\
\hline Rider Spring & 4.7 & 1.4 & 1.4 & 6.3 & 0.53 & 0.49 & 6.6 & 0.66 & 0.80 \\
\hline Rider Spring & ns & ns & ns & ns & ns & ns & ns & ns & ns \\
\hline Rock Spring & 16.6 & 4.6 & 4.9 & 11.7 & 1.2 & 1.4 & 7.8 & 1.1 & 1.5 \\
\hline Rock Spring & ns & ns & ns & ns & ns & ns & ns & ns & $\mathrm{ns}$ \\
\hline Schmutz Spring & 4.3 & 1.6 & 1.6 & 3.8 & 0.53 & 0.68 & 4.6 & 0.61 & 0.80 \\
\hline Schmutz Spring & $\mathrm{ns}$ & ns & ns & $\mathrm{ns}$ & ns & ns & ns & $\mathrm{ns}$ & ns \\
\hline Showerbath Spring & 5.4 & 1.4 & 1.3 & 5.6 & 0.53 & 0.55 & 4.8 & 0.48 & 0.53 \\
\hline Showerbath Spring & ns & ns & ns & ns & $\mathrm{ns}$ & ns & ns & ns & ns \\
\hline Side Canyon Spring & 7.5 & 1.9 & 1.7 & 6.8 & 0.71 & 0.87 & 6.6 & 0.62 & 0.67 \\
\hline Side Canyon Spring & ns & ns & ns & ns & ns & ns & ns & ns & ns \\
\hline Slide Spring & 8.5 & 1.8 & 1.3 & 3.4 & 0.47 & 0.60 & 2.0 & 0.56 & 0.73 \\
\hline Slide Spring & ns & ns & ns & ns & ns & ns & ns & ns & ns \\
\hline Upper Jumpup Spring & 10.3 & 1.9 & 1.2 & 0.7 & 0.45 & 0.62 & 2.1 & 0.46 & 0.66 \\
\hline Upper Jumpup Spring & ns & ns & ns & ns & ns & ns & ns & ns & ns \\
\hline $\begin{array}{l}\text { Willow Spring } \\
\text { (Hack Canyon) }\end{array}$ & 18 & 5 & 5 & 15.5 & 1.7 & 1.9 & 15.8 & 1.6 & 1.8 \\
\hline $\begin{array}{l}\text { Willow Spring } \\
\text { (Hack Canyon) }\end{array}$ & ns & ns & ns & ns & ns & ns & ns & ns & ns \\
\hline Burnt Canyon Well & 22.0 & 5.4 & 4.8 & 31.0 & 2.5 & 2.2 & 18.0 & 2.1 & 2.7 \\
\hline Burnt Canyon Well & ns & ns & ns & ns & ns & ns & ns & ns & ns \\
\hline Canyon Mine Well & 13.0 & 2.0 & 1.0 & 6.3 & 0.52 & 0.48 & 3.0 & 0.50 & 0.62 \\
\hline Canyon Mine Well & ns & ns & ns & ns & ns & ns & ns & ns & ns \\
\hline Pinenut Well & 39.0 & 7.2 & 7.2 & 55.0 & 3.3 & 1.0 & 31.0 & 2.0 & 1.0 \\
\hline Pinenut Well & ns & ns & ns & ns & ns & ns & ns & ns & ns \\
\hline Tom Land Well & 28.0 & 5.1 & 3.4 & 19.4 & 1.7 & 1.7 & 9.7 & 1.5 & 2.2 \\
\hline Tom Land Well & ns & ns & ns & ns & ns & ns & ns & ns & ns \\
\hline
\end{tabular}


Table A. Analysis results from all laboratories.-Continued

\begin{tabular}{|c|c|c|c|c|c|c|c|c|c|}
\hline Spring or well & $\begin{array}{c}\delta^{13} \mathbf{C} \\
\text { RSIL } \\
\% 0\end{array}$ & $\begin{array}{c}\delta^{18} 0 \\
\text { Coplen } \\
\%\end{array}$ & $\begin{array}{c}\delta^{2} \mathrm{H} \\
\text { Coplen } \\
\%\end{array}$ & $\begin{array}{c}\text { Tritium } \\
\text { Michel } \\
\text { TU }\end{array}$ & $\begin{array}{c}\text { Trit-SD } \\
\text { Michel } \\
\text { TU }\end{array}$ & $\begin{array}{c}{ }^{234} \mathrm{U} /{ }^{238} \mathrm{U} \\
\text { activity ratio } \\
\text { NAU }\end{array}$ & $\begin{array}{c}{ }^{234} \mathrm{U} /{ }^{238} \mathrm{U} \\
\text { activity } \\
\text { ratio-SD } \\
\mathrm{NAU}\end{array}$ & $\begin{array}{c}{ }^{234} \mathrm{U} /{ }^{238} \mathrm{U} \\
\text { activity ratio } \\
\text { Kraemer/Bullen }\end{array}$ & $\begin{array}{c}{ }^{234} \mathrm{U} /{ }^{238} \mathrm{U} \\
\text { error, } 1 \text { sigma } \\
\text { Kraemer/Bullen }\end{array}$ \\
\hline Buck Farm Spring & -11.20 & -12.22 & -91.38 & 1.33 & 0.18 & 1.837 & 0.009 & ns & ns \\
\hline Buck Farm Spring & $\mathrm{ns}$ & ns & ns & ns & ns & ns & ns & ns & ns \\
\hline Fence Spring & -4.74 & -13.83 & -101.27 & 0.80 & 0.50 & 2.623 & 0.021 & ns & ns \\
\hline Hanging Spring & -11.40 & -13.78 & -98.52 & 1.76 & 0.19 & 4.054 & 0.018 & 3.924 & 0.014 \\
\hline Hole in the Wall Spring & -10.85 & -13.74 & -99.07 & 1.61 & 0.20 & 4.124 & 0.094 & 3.911 & 0.006 \\
\hline South Canyon Spring & ns & -11.57 & -83.06 & ns & ns & 3.365 & 0.016 & 3.272 & 0.017 \\
\hline South Canyon Spring & ns & ns & ns & ns & ns & ns & ns & ns & ns \\
\hline Unknown Spring & -10.97 & -13.78 & -99.48 & 1.93 & 0.20 & 4.071 & 0.020 & 3.936 & 0.022 \\
\hline Unknown Spring & ns & sn & ns & ns & ns & ns & ns & 3.921 & 0.013 \\
\hline Vasey's Paradise & ns & ns & ns & ns & ns & ns & ns & 4.339 & 0.005 \\
\hline Clearwater Spring & -7.91 & -11.35 & -86.10 & 2.03 & 0.28 & 1.523 & 0.048 & 1.505 & 0.008 \\
\hline Clearwater Spring & ns & ns & ns & ns & ns & ns & ns & ns & ns \\
\hline Hotel Spring & -9.35 & -7.71 & -65.45 & 2.30 & 0.30 & 1.935 & 0.022 & 1.951 & 0.021 \\
\hline Hotel Spring & ns & ns & ns & ns & ns & ns & ns & ns & ns \\
\hline Kanab Spring & -8.89 & -12.40 & -91.56 & 0.69 & 0.29 & 1.966 & 0.007 & 1.980 & 0.018 \\
\hline Kanab Spring & ns & ns & ns & ns & ns & ns & ns & ns & ns \\
\hline Lower Jumpup Spring & -12.44 & -11.93 & -89.77 & 0.13 & 0.28 & 2.634 & 0.024 & 2.594 & 0.010 \\
\hline Lower Jumpup Spring & ns & $\mathrm{ns}$ & ns & ns & ns & ns & ns & ns & ns \\
\hline Mountain Sheep Spring & -11.79 & -12.08 & -90.64 & 0.91 & 0.27 & 2.851 & 0.009 & 2.816 & 0.011 \\
\hline Mountain Sheep Spring & ns & ns & ns & ns & ns & ns & ns & ns & ns \\
\hline Rider Spring & -0.60 & -15.61 & -124.55 & 0.20 & 0.30 & 2.632 & 0.018 & 2.627 & 0.010 \\
\hline Rider Spring & ns & ns & ns & ns & ns & 2.618 & 0.008 & $\mathrm{~ns}$ & ns \\
\hline Rock Spring & -5.02 & -11.87 & -90.91 & 0.42 & 0.29 & 2.459 & 0.007 & 2.434 & 0.007 \\
\hline Rock Spring & ns & $\mathrm{ns}$ & ns & ns & ns & ns & ns & $\mathrm{ns}$ & ns \\
\hline Schmutz Spring & -6.02 & -11.17 & -81.20 & 0.50 & 0.30 & 1.883 & 0.005 & 1.858 & 0.008 \\
\hline Schmutz Spring & ns & ns & ns & ns & ns & ns & ns & ns & ns \\
\hline Showerbath Spring & -10.21 & -12.20 & -90.41 & 1.60 & 0.30 & 1.881 & 0.003 & 1.890 & 0.002 \\
\hline Showerbath Spring & ns & $\mathrm{ns}$ & ns & ns & ns & 1.906 & 0.005 & ns & ns \\
\hline Side Canyon Spring & -7.15 & -12.50 & -91.41 & 0.43 & 0.28 & 1.856 & 0.010 & 1.857 & 0.014 \\
\hline Side Canyon Spring & $\mathrm{ns}$ & ns & ns & ns & ns & ns & ns & ns & ns \\
\hline Slide Spring & -7.22 & -11.67 & -88.69 & 0.00 & 0.28 & 5.626 & 0.023 & 5.590 & 0.005 \\
\hline Slide Spring & ns & ns & ns & ns & ns & ns & ns & ns & ns \\
\hline Upper Jumpup Spring & -6.18 & -12.23 & -90.34 & -0.29 & 0.28 & 4.671 & 0.019 & 4.584 & 0.010 \\
\hline Upper Jumpup Spring & ns & ns & ns & ns & ns & ns & ns & ns & ns \\
\hline $\begin{array}{l}\text { Willow Spring } \\
\text { (Hack Canyon) }\end{array}$ & -5.18 & -10.58 & -76.11 & 2.00 & 0.30 & 1.658 & 0.005 & 1.646 & 0.005 \\
\hline $\begin{array}{l}\text { Willow Spring } \\
\text { (Hack Canyon) }\end{array}$ & ns & ns & ns & ns & ns & ns & ns & $\mathrm{ns}$ & ns \\
\hline Burnt Canyon Well & -4.04 & -13.48 & -105.09 & 5.20 & 0.3 & 2.674 & 0.021 & 2.657 & 0.013 \\
\hline Burnt Canyon Well & sn & ns & ns & ns & ns & ns & ns & 2.666 & 0.011 \\
\hline Canyon Mine Well & -8.69 & -12.08 & -89.16 & 7.20 & 0.4 & 2.017 & 0.008 & 2.026 & 0.013 \\
\hline Canyon Mine Well & sn & ns & ns & ns & ns & ns & ns & 2.024 & 0.004 \\
\hline Pinenut Well & -4.63 & -14.38 & -110.70 & -- & -- & 2.285 & 0.014 & 2.260 & 0.008 \\
\hline Pinenut Well & ns & ns & $\mathrm{ms}$ & ns & ns & ns & ns & 2.264 & 0.012 \\
\hline Tom Land Well & -4.42 & -7.22 & -55.85 & 0.17 & 0.25 & 1.749 & 0.010 & 1.777 & 0.001 \\
\hline Tom Land Well & ns & ns & ns & ns & ns & ns & ns & 1.763 & 0.013 \\
\hline
\end{tabular}


Table A. Analysis results from all laboratories.-Continued

\begin{tabular}{|c|c|c|c|c|c|c|c|c|}
\hline Spring or well & $\begin{array}{c}\text { Large volume } \\
{ }^{226} \mathrm{Ra} \\
\text { Doughten } \\
\text { pCi/L }\end{array}$ & $\begin{array}{c}\text { Large volume } \\
\text { error, } 1 \text { sigma } \\
\text { Doughten } \\
\text { pCi/L }\end{array}$ & $\begin{array}{c}\text { Large volume } \\
{ }^{228} \mathrm{Ra} \\
\text { Doughten } \\
\text { pCi/L }\end{array}$ & $\begin{array}{c}\text { Large volume } \\
\text { error, } 1 \text { sigma } \\
\text { Doughten } \\
\text { pCi/L }\end{array}$ & $\begin{array}{c}\text { Large volume } \\
{ }^{228} \mathrm{Ra} /{ }^{226} \mathrm{Ra} \\
\text { activity ratio } \\
\text { Doughten }\end{array}$ & $\begin{array}{c}\text { Large volume } \\
\text { error, } 1 \text { sigma } \\
\text { Doughten }\end{array}$ & $\begin{array}{c}\text { Small volume } \\
{ }^{226} \mathrm{Ra} \\
\text { Doughten } \\
\text { pCi/L }\end{array}$ & $\begin{array}{c}\text { Small volume } \\
{ }^{228} \mathrm{Ra} \\
\text { Doughten } \\
\text { pCi/L }\end{array}$ \\
\hline Buck Farm Spring & ns & ns & ns & ns & ns & ns & ns & ns \\
\hline Buck Farm Spring & ns & ns & $\mathrm{ns}$ & ns & ns & ns & ns & ns \\
\hline Fence Spring & ns & ns & ns & ns & ns & ns & ns & ns \\
\hline Hanging Spring & ns & ns & ns & ns & ns & ns & $<4$ & $<4$ \\
\hline Hole in the Wall Spring & ns & ns & ns & ns & ns & ns & ns & ns \\
\hline South Canyon Spring & ns & ns & ns & ns & ns & ns & ns & ns \\
\hline South Canyon Spring & ns & ns & ns & ns & ns & ns & ns & ns \\
\hline Unknown Spring & ns & ns & ns & ns & ns & ns & ns & ns \\
\hline Unknown Spring & ns & ns & ns & ns & ns & ns & ns & ns \\
\hline Vasey's Paradise & ns & ns & ns & ns & ns & ns & ns & ns \\
\hline Clearwater Spring & 0.730 & 0.007 & 0.239 & 0.010 & 0.327 & 0.010 & $<4$ & $<4$ \\
\hline Clearwater Spring & ns & ns & $\mathrm{ns}$ & $\mathrm{ns}$ & ns & ns & $\mathrm{ns}$ & ns \\
\hline Hotel Spring & ns & ns & ns & ns & ns & ns & $<4$ & $<4$ \\
\hline Hotel Spring & ns & ns & ns & ns & ns & ns & ns & ns \\
\hline Kanab Spring & 0.245 & 0.003 & 0.016 & 0.002 & 0.071 & 0.009 & -- & -- \\
\hline Kanab Spring & ns & ns & ns & ns & ns & ns & ns & ns \\
\hline Lower Jumpup Spring & ns & ns & ns & ns & ns & ns & $<4$ & $<4$ \\
\hline Lower Jumpup Spring & ns & ns & ns & ns & ns & ns & ns & ns \\
\hline Mountain Sheep Spring & ns & ns & ns & ns & ns & ns & $<4$ & $<4$ \\
\hline Mountain Sheep Spring & ns & ns & ns & ns & ns & ns & ns & ns \\
\hline Rider Spring & ns & ns & ns & ns & ns & ns & $<4$ & $<4$ \\
\hline Rider Spring & ns & ns & ns & ns & ns & ns & ns & ns \\
\hline Rock Spring & ns & ns & ns & ns & ns & ns & $<4$ & $<4$ \\
\hline Rock Spring & ns & ns & ns & ns & ns & ns & ns & ns \\
\hline Schmutz Spring & ns & ns & ns & ns & ns & ns & $<4$ & $<4$ \\
\hline Schmutz Spring & ns & ns & ns & ns & ns & ns & ns & ns \\
\hline Showerbath Spring & ns & ns & $\mathrm{ns}$ & ns & ns & ns & $<4$ & $<4$ \\
\hline Showerbath Spring & ns & ns & ns & ns & ns & ns & ns & ns \\
\hline Side Canyon Spring & ns & ns & ns & ns & ns & ns & $<4$ & $<4$ \\
\hline Side Canyon Spring & ns & ns & ns & ns & ns & ns & ns & ns \\
\hline Slide Spring & ns & ns & ns & ns & ns & ns & ns & ns \\
\hline Slide Spring & ns & ns & ns & ns & ns & ns & ns & ns \\
\hline Upper Jumpup Spring & 0.230 & 0.003 & 0.122 & 0.002 & 0.545 & 0.012 & $<4$ & $<4$ \\
\hline Upper Jumpup Spring & ns & $\mathrm{ns}$ & ns & ns & ns & ns & ns & ns \\
\hline $\begin{array}{l}\text { Willow Spring } \\
\text { (Hack Canyon) }\end{array}$ & ns & ns & ns & ns & ns & ns & $<4$ & $<4$ \\
\hline $\begin{array}{l}\text { Willow Spring } \\
\text { (Hack Canyon) }\end{array}$ & ns & ns & ns & ns & ns & ns & ns & $\mathrm{ns}$ \\
\hline Burnt Canyon Well & ns & ns & ns & ns & ns & ns & ns & ns \\
\hline Burnt Canyon Well & ns & ns & ns & ns & ns & ns & ns & ns \\
\hline Canyon Mine Well & 1.30 & 0.01 & 0.081 & 0.002 & 0.065 & 0.003 & -- & -- \\
\hline Canyon Mine Well & ns & ns & ns & ns & ns & ns & ns & ns \\
\hline Pinenut Well & 17.51 & 0.08 & 0.716 & 0.045 & 0.041 & 0.002 & - & -- \\
\hline Pinenut Well & ns & ns & ns & ns & ns & ns & ns & ns \\
\hline Tom Land Well & 3.01 & 0.02 & 0.266 & 0.009 & 0.089 & 0.003 & -- & -- \\
\hline Tom Land Well & ns & ns & $\mathrm{ns}$ & ns & ns & ns & ns & $\mathrm{ns}$ \\
\hline
\end{tabular}


Table B. Most Probable Value for all elements analyzed.

[*Column heads containing an asterisk present results of analyses by the laboratory noted; values in all other columns derived by comparing results of analyses by many laboratories.

Bullen, USGS National Research Program Laboratory, Menlo Park, California; Doughten, USGS National Research Program Laboratory, Reston, Virginia; Michel, USGS National Research Program Laboratory, Menlo Park, California; NAU, Northern Arizona University Isotope and Radiochemistry Laboratory, Flagstaff, Arizona; NWQL, USGS National Water Quality Laboratory, Denver, Colorado; RSIL, USGS National Isotope Fractionation Project Laboratory, Reston, Virginia; Taylor, USGS National Research Program Laboratory, Boulder, Colorado; MPV, most probable value for all elements analyzed; Site ID, site identification;

$\delta$, delta notation; <, less than; ${ }^{\circ} \mathrm{C}$, degrees Celsius; \%o, per mil; fil, filtered; unf, unfiltered; gal $/ \mathrm{min}$, gallon per minute; $\mu \mathrm{g} / \mathrm{L}$, microgram per liter; $\mu \mathrm{S} / \mathrm{cm}$, microseimen per centimeter at $25^{\circ} \mathrm{C} ; \mathrm{mg} / \mathrm{L}$, milligram per liter; milligram per liter; $\mathrm{mg} \mathrm{CaCO}_{3} / \mathrm{L}$, milligram calcium carbonate per liter; $\mathrm{mg} \mathrm{N} / \mathrm{L}$, milligram nitrogen per liter; $\mathrm{mg}$ P/L, milligram phosphorus per liter; pC/L, picocurie per liter; TU, tritium unit; pmc, percent modern carbon; na, not available; R, results less than sample specific reporting limit; --, not available]

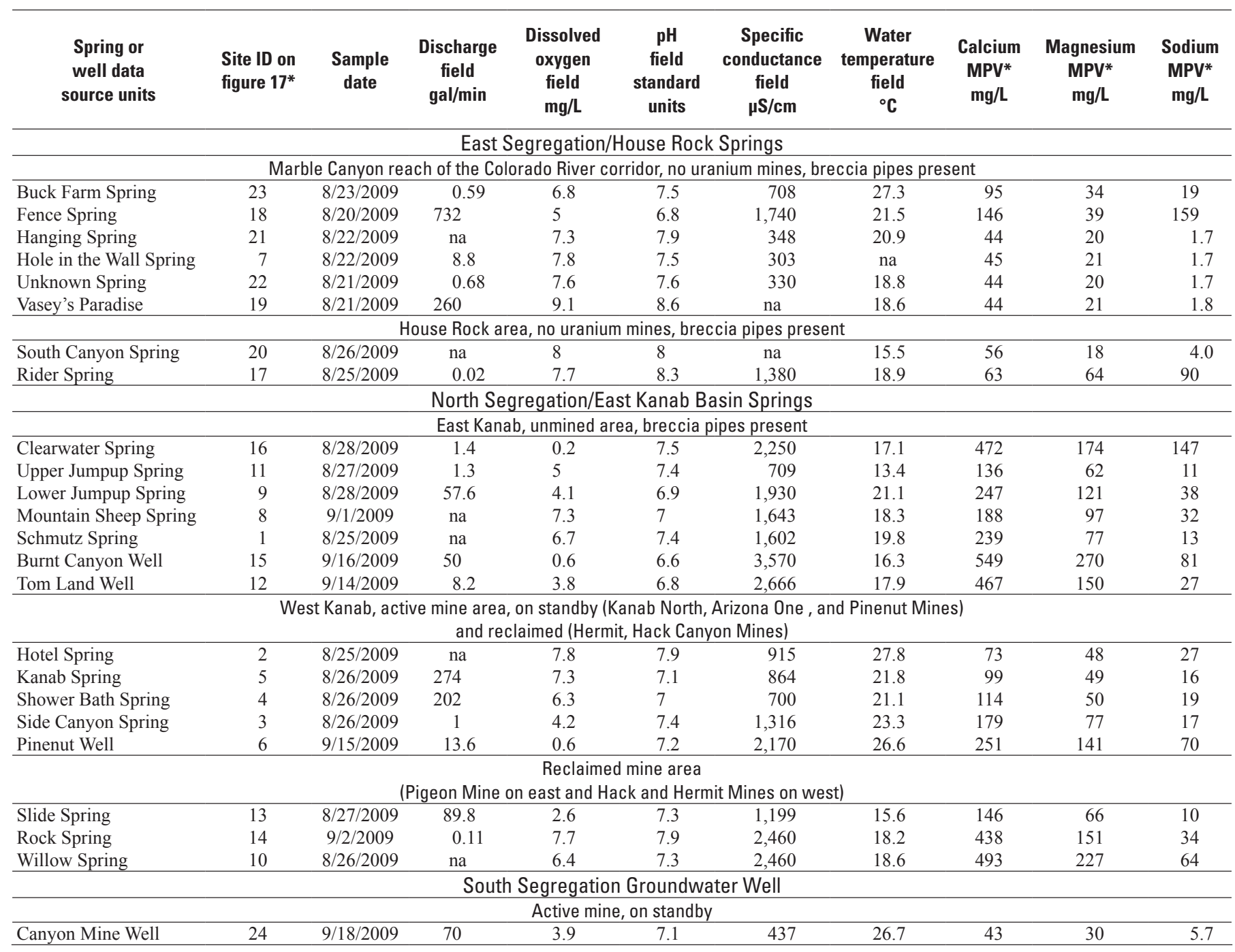


Table B. Most Probable Value for all elements analyzed.-Continued

[*Column heads containing an asterisk present results of analyses by the laboratory noted; values in all other columns derived by comparing results of analyses by many laboratories.

Bullen, USGS National Research Program Laboratory, Menlo Park, California; Doughten, USGS National Research Program Laboratory, Reston, Virginia; Michel, USGS National Research Program Laboratory, Menlo Park, California; NAU, Northern Arizona University Isotope and Radiochemistry Laboratory, Flagstaff, Arizona; NWQL, USGS National Water Quality Laboratory, Denver, Colorado; RSIL, USGS National Isotope Fractionation Project Laboratory, Reston, Virginia; Taylor, USGS National Research Program Laboratory, Boulder, Colorado; MPV, most probable value for all elements analyzed; Site ID, site identification;

$\delta$, delta notation; $<$, less than; ${ }^{\circ} \mathrm{C}$, degrees Celsius; \%, per mil; fil, filtered; unf, unfiltered; gal/min, gallon per minute; $\mu \mathrm{g} / \mathrm{L}$, microgram per liter; $\mu \mathrm{S} / \mathrm{cm}$, microseimen per centimeter at $25^{\circ} \mathrm{C} ; \mathrm{mg} / \mathrm{L}$, milligram per liter; milligram per liter; $\mathrm{mg} \mathrm{CaCO}_{3} / \mathrm{L}$, milligram calcium carbonate per liter; $\mathrm{mg} \mathrm{N} / \mathrm{L}$, milligram nitrogen per liter; $\mathrm{mg}$ P/L, milligram phosphorus per liter; $\mathrm{pC} / \mathrm{L}$, picocurie per liter; $\mathrm{TU}$, tritium unit; pmc, percent modern carbon; na, not available; R, results less than sample specific reporting limit; --, not available]

\begin{tabular}{|c|c|c|c|c|c|c|c|c|}
\hline $\begin{array}{l}\text { Spring or } \\
\text { well data } \\
\text { source units }\end{array}$ & $\begin{array}{c}\text { Potassium } \\
\text { MPV* }^{*} \\
\text { mg/L }\end{array}$ & $\begin{array}{c}\text { Acid } \\
\text { neutralizing } \\
\text { capacity } \\
\text { NWOL } \\
\text { mg CaCO }_{3} / \mathrm{L}\end{array}$ & $\begin{array}{c}\text { Bicarbonate } \\
\text { field } \\
\mathrm{mg} / \mathrm{L}\end{array}$ & $\begin{array}{c}\text { Sulfate } \\
\text { MPV* }^{*} \\
\text { mg/L }\end{array}$ & $\begin{array}{c}\text { Chlorine } \\
\text { MPV* } \\
\text { mg/L }\end{array}$ & $\begin{array}{c}\text { Fluorine } \\
\text { MPV* } \\
\text { mg/L }\end{array}$ & $\begin{array}{c}\text { Silica } \\
\text { MPV* } \\
\text { mg/L }\end{array}$ & $\begin{array}{c}\text { Uranium } \\
\text { MPV* }^{*} \\
\mu g / L\end{array}$ \\
\hline \multicolumn{9}{|c|}{ East Segregation/House Rock Springs } \\
\hline \multicolumn{9}{|c|}{ Marble Canyon reach of the Colorado River corridor, no uranium mines, breccia pipes present } \\
\hline Buck Farm Spring & 7.0 & 206 & 239 & 192 & 12.8 & 0.17 & 11.9 & 2.82 \\
\hline Hole in the Wall Spring & 0.8 & 186 & 210 & 8.3 & 2.0 & 0.08 & 8.1 & 0.60 \\
\hline Unknown Spring & 0.8 & 186 & 210 & 8.3 & 2.0 & 0.08 & 8.0 & 0.60 \\
\hline Vasey's Paradise & 0.7 & na & na & na & na & na & 7.5 & 0.57 \\
\hline \multicolumn{9}{|c|}{ House Rock area, no uranium mines, breccia pipes present } \\
\hline South Canyon Spring & 1.5 & na & 156 & na & na & na & 7.8 & 0.82 \\
\hline Rider Spring & 5.4 & 57 & 71 & 450 & 59.0 & 1.58 & 8.1 & 4.64 \\
\hline \multicolumn{9}{|c|}{ North Segregation/East Kanab Basin Springs } \\
\hline Mountain Sheep Spring & 7.6 & 256 & 298 & 643 & 41.2 & 0.58 & 12.2 & 8.37 \\
\hline Schmutz Spring & 2.9 & 102 & 121 & 804 & 18.3 & 0.49 & 11.8 & 4.59 \\
\hline Burnt Canyon Well & 14.8 & na & $<0.02$ & 2,040 & 53.8 & 1.38 & 8.2 & 3.02 \\
\hline Tom Land Well & 6.7 & 293 & 346 & 1,410 & 28.3 & 0.95 & 9.0 & 20.6 \\
\hline \multicolumn{9}{|c|}{$\begin{array}{c}\text { West Kanab, active mine area, on standby (Kanab North, Arizona One, and Pinenut Mines) } \\
\text { and reclaimed (Hermit, Hack Canyon Mines) }\end{array}$} \\
\hline Hotel Spring & 7.1 & 173 & 204 & 190 & 50.6 & 0.37 & 10.6 & 2.70 \\
\hline Kanab Spring & 3.8 & 200 & 241 & 257 & 16.1 & 0.28 & 10.5 & 4.83 \\
\hline Shower Bath Spring & 4.2 & 187 & 241 & 295 & 16.2 & 0.30 & 10.6 & 4.74 \\
\hline Side Canyon Spring & 5.2 & 170 & 200 & 595 & 11.0 & 0.51 & 11.2 & 7.44 \\
\hline Pinenut Well & 23.4 & 184 & 208 & 1,125 & 18.9 & 0.80 & 9.3 & 2.14 \\
\hline \multicolumn{9}{|c|}{$\begin{array}{l}\text { Reclaimed mine area } \\
\text { east and Hack and Hermit Mines on west) }\end{array}$} \\
\hline
\end{tabular}


Table B. Most Probable Value for all elements analyzed.-Continued

[*Column heads containing an asterisk present results of analyses by the laboratory noted; values in all other columns derived by comparing results of analyses by many laboratories.

Bullen, USGS National Research Program Laboratory, Menlo Park, California; Doughten, USGS National Research Program Laboratory, Reston, Virginia; Michel, USGS National Research Program Laboratory, Menlo Park, California; NAU, Northern Arizona University Isotope and Radiochemistry Laboratory, Flagstaff, Arizona; NWQL, USGS National Water Quality Laboratory, Denver, Colorado; RSIL, USGS National Isotope Fractionation Project Laboratory, Reston, Virginia; Taylor, USGS National Research Program Laboratory, Boulder, Colorado; MPV, most probable value for all elements analyzed; Site ID, site identification;

$\delta$, delta notation; <, less than; ${ }^{\circ} \mathrm{C}$, degrees Celsius; \%o, per mil; fil, filtered; unf, unfiltered; gal $/ \mathrm{min}$, gallon per minute; $\mu \mathrm{g} / \mathrm{L}$, microgram per liter; $\mu \mathrm{S} / \mathrm{cm}$, microseimen per centimeter at $25^{\circ} \mathrm{C} ; \mathrm{mg} / \mathrm{L}$, milligram per liter; milligram per liter; $\mathrm{mg} \mathrm{CaCO}_{3} / \mathrm{L}$, milligram calcium carbonate per liter; $\mathrm{mg} \mathrm{N} / \mathrm{L}$, milligram nitrogen per liter; $\mathrm{mg}$ P/L, milligram phosphorus per liter; pC/L, picocurie per liter; TU, tritium unit; pmc, percent modern carbon; na, not available; R, results less than sample specific reporting limit; --, not available]

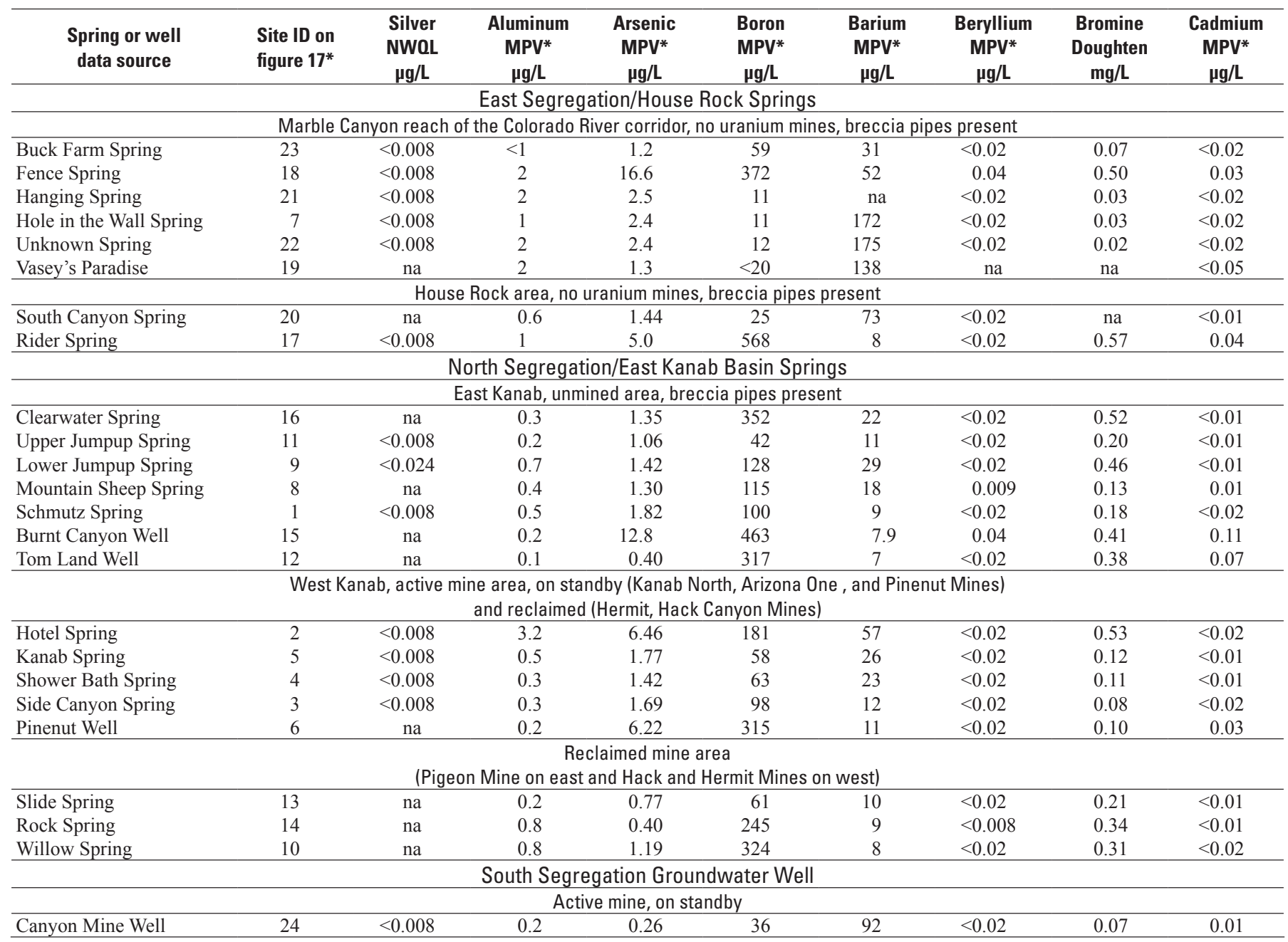


Table B. Most Probable Value for all elements analyzed.-Continued

$[*$ Column heads containing an asterisk present results of analyses by the laboratory noted; values in all other columns derived by comparing results of analyses by many laboratories.

Bullen, USGS National Research Program Laboratory, Menlo Park, California; Doughten, USGS National Research Program Laboratory, Reston, Virginia; Michel, USGS National Research Program Laboratory, Menlo Park, California; NAU, Northern Arizona University Isotope and Radiochemistry Laboratory, Flagstaff, Arizona; NWQL, USGS National Water Quality Laboratory, Denver, Colorado; RSIL, USGS National Isotope Fractionation Project Laboratory, Reston, Virginia; Taylor, USGS National Research Program Laboratory, Boulder, Colorado; MPV, most probable value for all elements analyzed; Site ID, site identification;

$\delta$, delta notation; <, less than; ${ }^{\circ} \mathrm{C}$, degrees Celsius; \%, per mil; fil, filtered; unf, unfiltered; gal $/ \mathrm{min}$, gallon per minute; $\mu \mathrm{g} / \mathrm{L}$, microgram per liter; $\mu \mathrm{S} / \mathrm{cm}$, microseimen per centimeter at $25^{\circ} \mathrm{C} ; \mathrm{mg} / \mathrm{L}$, milligram per liter; milligram per liter; $\mathrm{mg} \mathrm{CaCO}_{3} / \mathrm{L}$, milligram calcium carbonate per liter; $\mathrm{mg} \mathrm{N} / \mathrm{L}$, milligram nitrogen per liter; $\mathrm{mg}$ P/L, milligram phosphorus per liter; pC/L, picocurie per liter; TU, tritium unit; pmc, percent modern carbon; na, not available; R, results less than sample specific reporting limit; --, not available]

\begin{tabular}{|c|c|c|c|c|c|c|c|c|}
\hline $\begin{array}{l}\text { Spring or well } \\
\text { data source }\end{array}$ & $\begin{array}{c}\text { Cerium } \\
\text { Taylor } \\
\mu \mathrm{g} / \mathrm{L}\end{array}$ & $\begin{array}{c}\text { Cobalt } \\
\text { MPV* } \\
\mu \mathrm{g} / \mathrm{L}\end{array}$ & $\begin{array}{c}\text { Chromium } \\
\text { MPV* } \\
\mu \mathrm{g} / \mathrm{L} \\
\end{array}$ & $\begin{array}{c}\text { Cesium } \\
\text { Taylor } \\
\mu \mathrm{g} / \mathrm{L}\end{array}$ & $\begin{array}{c}\text { Copper } \\
\text { MPV* } \\
\mu \mathrm{g} / \mathrm{L} \\
\end{array}$ & $\begin{array}{c}\text { Dysprosium } \\
\text { Taylor } \\
\mu \mathrm{g} / \mathrm{L} \\
\end{array}$ & $\begin{array}{c}\text { Erbium } \\
\text { Taylor } \\
\mu \mathrm{g} / \mathrm{L}\end{array}$ & $\begin{array}{c}\text { Europium } \\
\text { Taylor } \\
\mu \mathrm{g} / \mathrm{L} \\
\end{array}$ \\
\hline \multicolumn{9}{|c|}{ East Segregation/House Rock Springs } \\
\hline Buck Farm Spring & na & na & 0.2 & na & $<1$ & na & na & na \\
\hline Fence Spring & na & na & 1.0 & na & $<1$ & na & na & na \\
\hline Hanging Spring & na & na & 1.0 & na & $<1$ & na & na & na \\
\hline \multicolumn{9}{|c|}{ House Rock area, no uranium mines, breccia pipes present } \\
\hline South Canyon Spring & 0.0018 & $<0.2$ & 0.7 & 0.14 & 1.4 & 0.0006 & $<0.001$ & 0.001 \\
\hline Rider Spring & na & na & 3 & na & $<1$ & na & na & na \\
\hline \multicolumn{9}{|c|}{ North Segregation/East Kanab Basin Springs } \\
\hline \multicolumn{9}{|c|}{ East Kanab, unmined area, breccia pipes present } \\
\hline Clearwater Spring & 0.0009 & $<0.2$ & $<0.2$ & 0.008 & 1 & 0.0005 & $<0.001$ & $<0.001$ \\
\hline Burnt Canyon Well & 0.0033 & $<0.3$ & 1.9 & 1.0 & 2 & 0.0009 & 0.0016 & $<0.0003$ \\
\hline Tom Land Well & 0.0026 & $<0.3$ & 1.0 & 0.14 & 2.1 & 0.0008 & $<0.0005$ & $<0.0003$ \\
\hline \multicolumn{9}{|c|}{$\begin{array}{c}\text { West Kanab, active mine area, on standby (Kanab North, Arizona One, and Pinenut Mines) } \\
\text { and reclaimed (Hermit, Hack Canyon Mines) }\end{array}$} \\
\hline Hotel Spring & 0.0080 & 1.0 & 0.3 & 0.055 & 0.8 & 0.0030 & $<0.001$ & $<0.001$ \\
\hline Kanab Spring & 0.0023 & $<0.2$ & 0.4 & 0.28 & $<1$ & $<0.0004$ & $<0.001$ & 0.001 \\
\hline Shower Bath Spring & $<0.0006$ & $<0.2$ & 0.3 & 0.23 & $<1$ & $<0.0004$ & $<0.001$ & $<0.001$ \\
\hline Side Canyon Spring & $<0.0006$ & $<0.2$ & 0.2 & 0.36 & $<1$ & $<0.0004$ & $<0.001$ & $<0.001$ \\
\hline Pinenut Well & 0.0018 & $<0.3$ & 0.7 & 0.84 & $<1$ & $<0.0007$ & $<0.0005$ & $<0.0003$ \\
\hline \multicolumn{9}{|c|}{$\begin{array}{l}\text { Reclaimed mine area } \\
n \text { east and Hack and Hermit Mines on west) }\end{array}$} \\
\hline Slide Spring & $<0.0006$ & $<0.2$ & 2.6 & 0.091 & $<1$ & $<0.0004$ & $<0.001$ & $<0.001$ \\
\hline Rock Spring & 0.0011 & $<0.2$ & 0.7 & 0.015 & $<1$ & 0.0004 & $<0.0004$ & $<0.001$ \\
\hline \multicolumn{9}{|c|}{ Active mine, on standby } \\
\hline
\end{tabular}


Table B. Most Probable Value for all elements analyzed.-Continued

[*Column heads containing an asterisk present results of analyses by the laboratory noted; values in all other columns derived by comparing results of analyses by many laboratories.

Bullen, USGS National Research Program Laboratory, Menlo Park, California; Doughten, USGS National Research Program Laboratory, Reston, Virginia; Michel, USGS National Research Program Laboratory, Menlo Park, California; NAU, Northern Arizona University Isotope and Radiochemistry Laboratory, Flagstaff, Arizona; NWQL, USGS National Water Quality Laboratory, Denver, Colorado; RSIL, USGS National Isotope Fractionation Project Laboratory, Reston, Virginia; Taylor, USGS National Research Program Laboratory, Boulder, Colorado; MPV, most probable value for all elements analyzed; Site ID, site identification;

$\delta$, delta notation; <, less than; ${ }^{\circ} \mathrm{C}$, degrees Celsius; \%o, per mil; fil, filtered; unf, unfiltered; gal $/ \mathrm{min}$, gallon per minute; $\mu \mathrm{g} / \mathrm{L}$, microgram per liter; $\mu \mathrm{S} / \mathrm{cm}$, microseimen per centimeter at $25^{\circ} \mathrm{C} ; \mathrm{mg} / \mathrm{L}$, milligram per liter; milligram per liter; $\mathrm{mg} \mathrm{CaCO}_{3} / \mathrm{L}$, milligram calcium carbonate per liter; $\mathrm{mg} \mathrm{N} / \mathrm{L}$, milligram nitrogen per liter; $\mathrm{mg}$ P/L, milligram phosphorus per liter; pC/L, picocurie per liter; TU, tritium unit; pmc, percent modern carbon; na, not available; R, results less than sample specific reporting limit; --, not available]

\begin{tabular}{|c|c|c|c|c|c|c|c|c|c|}
\hline $\begin{array}{l}\text { Spring or well } \\
\text { data source }\end{array}$ & $\begin{array}{l}\text { Site ID on } \\
\text { figure } 17^{*}\end{array}$ & $\begin{array}{c}\text { Iron } \\
\text { MPV* } \\
\mu g / L \\
\end{array}$ & $\begin{array}{c}\text { Gallium } \\
\text { Taylor } \\
\mu \mathrm{g} / \mathrm{L} \\
\end{array}$ & $\begin{array}{c}\text { Gadolinium } \\
\text { Taylor } \\
\mu \mathrm{g} / \mathrm{L} \\
\end{array}$ & $\begin{array}{c}\text { Mercury } \\
\text { Taylor } \\
\text { ng/L } \\
\end{array}$ & $\begin{array}{c}\text { Holmium } \\
\text { Taylor } \\
\mu \mathrm{g} / \mathrm{L} \\
\end{array}$ & $\begin{array}{c}\text { Lanthanum } \\
\text { Taylor } \\
\mu \mathrm{g} / \mathrm{L}\end{array}$ & $\begin{array}{c}\text { Lithium } \\
\mathrm{MPV}^{*} \\
\mu \mathrm{g} / \mathrm{L} \\
\end{array}$ & $\begin{array}{c}\text { Lutetium } \\
\text { Taylor } \\
\mu \mathrm{g} / \mathrm{L}\end{array}$ \\
\hline \multicolumn{10}{|c|}{ East Segregation/House Rock Springs } \\
\hline \multicolumn{10}{|c|}{ Marble Canyon reach of the Colorado River corridor, no uranium mines, breccia pipes present } \\
\hline Buck Farm Spring & 23 & $<4$ & na & na & na & na & na & 24 & na \\
\hline Fence Spring & 18 & $<4$ & na & na & na & na & na & 378 & na \\
\hline Hanging Spring & 21 & $<4$ & na & na & na & na & na & 2 & na \\
\hline \multicolumn{10}{|c|}{ House Rock area, no uranium mines, breccia pipes present } \\
\hline South Canyon Spring & 20 & 3 & 0.0032 & 0.0009 & na & $<0.0003$ & 0.0027 & 3 & 0.0002 \\
\hline Rider Spring & 17 & 12 & na & na & na & na & na & 70 & na \\
\hline \multicolumn{10}{|c|}{ North Segregation/East Kanab Basin Springs } \\
\hline \multicolumn{10}{|c|}{ East Kanab, unmined area, breccia pipes present } \\
\hline Clearwater Spring & 16 & 33 & 0.021 & $<0.0004$ & 0.2 & 0.0011 & 0.0007 & 100 & $<0.0001$ \\
\hline Burnt Canyon Well & 15 & 680 & 0.003 & 0.0016 & 2.3 & 0.0008 & 0.0029 & 344 & 0.0002 \\
\hline Tom Land Well & 12 & 776 & 0.004 & 0.0009 & 1.4 & $<0.0003$ & 0.0021 & 54 & $<0.0002$ \\
\hline \multicolumn{10}{|c|}{$\begin{array}{l}\text { West Kanab, active mine area, on standby (Kanab North, Arizona One, and Pinenut Mines) } \\
\text { and reclaimed (Hermit, Hack Canyon Mines) }\end{array}$} \\
\hline Hotel Spring & 2 & 5 & 0.0045 & 0.0042 & 2.0 & 0.0008 & 0.0087 & 18 & 0.0003 \\
\hline Kanab Spring & 5 & $<2$ & 0.0018 & 0.0004 & 0.2 & $<0.0003$ & 0.0016 & 18 & $<0.0001$ \\
\hline Shower Bath Spring & 4 & $<2$ & 0.0027 & $<0.0004$ & 0.2 & $<0.0003$ & 0.0007 & 20 & $<0.0001$ \\
\hline Side Canyon Spring & 3 & $<2$ & 0.0013 & $<0.0004$ & $<0.2$ & $<0.0003$ & 0.0006 & 31 & $<0.0001$ \\
\hline Pinenut Well & 6 & 4,650 & 0.017 & 0.0004 & 1.7 & $<0.0003$ & 0.0013 & 163 & $<0.0002$ \\
\hline \multicolumn{10}{|c|}{$\begin{array}{c}\text { Reclaimed mine area } \\
\text { (Pigeon Mine on east and Hack and Hermit Mines on west) }\end{array}$} \\
\hline Slide Spring & 13 & $<2$ & 0.0016 & $<0.0004$ & 0.4 & $<0.0003$ & 0.0004 & 13 & $<0.0001$ \\
\hline Rock Spring & 14 & 12 & 0.0018 & $<0.0004$ & $<0.2$ & $<0.0001$ & 0.0006 & 74 & $<0.0001$ \\
\hline
\end{tabular}


Table B. Most Probable Value for all elements analyzed.-Continued

$\left[{ }^{*}\right.$ Column heads containing an asterisk present results of analyses by the laboratory noted; values in all other columns derived by comparing results of analyses by many laboratories.

Bullen, USGS National Research Program Laboratory, Menlo Park, California; Doughten, USGS National Research Program Laboratory, Reston, Virginia; Michel, USGS National Research Program Laboratory, Menlo Park, California; NAU, Northern Arizona University Isotope and Radiochemistry Laboratory, Flagstaff, Arizona; NWQL, USGS National Water Quality Laboratory, Denver, Colorado; RSIL, USGS National Isotope Fractionation Project Laboratory, Reston, Virginia; Taylor, USGS National Research Program Laboratory, Boulder, Colorado; MPV, most probable value for all elements analyzed; Site ID, site identification;

$\delta$, delta notation; <, less than; ${ }^{\circ} \mathrm{C}$, degrees Celsius; \%o, per mil; fil, filtered; unf, unfiltered; gal $/$ min, gallon per minute; $\mu \mathrm{g} / \mathrm{L}$, microgram per liter; $\mu \mathrm{S} / \mathrm{cm}$, microseimen per centimeter at $25^{\circ} \mathrm{C} ; \mathrm{mg} / \mathrm{L}$, milligram per liter; milligram per liter; $\mathrm{mg} \mathrm{CaCO}_{3} / \mathrm{L}$, milligram calcium carbonate per liter; $\mathrm{mg} \mathrm{N} / \mathrm{L}$, milligram nitrogen per liter; $\mathrm{mg}$ P/L, milligram phosphorus per liter; $\mathrm{pC} / \mathrm{L}$, picocurie per liter; $\mathrm{TU}$, tritium unit; pmc, percent modern carbon; na, not available; R, results less than sample specific reporting limit; --, not available]

\begin{tabular}{|c|c|c|c|c|c|c|c|c|}
\hline $\begin{array}{l}\text { Spring or well } \\
\text { data source }\end{array}$ & $\begin{array}{c}\text { Manganese } \\
\mathrm{MPV}^{*} \\
\mu \mathrm{g} / \mathrm{L} \\
\end{array}$ & $\begin{array}{c}\text { Molybdenum } \\
\text { MPV* }^{*} \\
\mu \mathrm{g} / \mathrm{L} \\
\end{array}$ & $\begin{array}{c}\text { Neodymium } \\
\text { Taylor } \\
\mu \mathrm{g} / \mathrm{L} \\
\end{array}$ & $\begin{array}{c}\text { Nickel } \\
\text { MPV* }^{*} \\
\mu g / L \\
\end{array}$ & $\begin{array}{c}\text { Lead } \\
\mathrm{MPV}^{*} \\
\mu \mathrm{g} / \mathrm{L} \\
\end{array}$ & $\begin{array}{c}\text { Praseodymium } \\
\text { Taylor } \\
\mu \mathrm{g} / \mathrm{L} \\
\end{array}$ & $\begin{array}{c}\text { Rubidium } \\
\text { MPV* } \\
\mu \mathrm{g} / \mathrm{L} \\
\end{array}$ & $\begin{array}{c}\text { Rhenium } \\
\text { Taylor } \\
\mu \mathrm{g} / \mathrm{L}\end{array}$ \\
\hline \multicolumn{9}{|c|}{ East Segregation/House Rock Springs } \\
\hline Buck Farm Spring & $<0.2$ & 2.6 & na & na & $<0.05$ & na & 4.2 & na \\
\hline Fence Spring & $<0.2$ & 1.1 & na & na & $<0.05$ & na & 44.4 & na \\
\hline Hanging Spring & $<0.2$ & 0.3 & na & na & $<0.05$ & na & 1.3 & na \\
\hline Hole in the Wall Spring & $<0.2$ & 0.3 & na & na & $<0.05$ & na & 1.3 & na \\
\hline \multicolumn{9}{|c|}{ House Rock area, no uranium mines, breccia pipes present } \\
\hline South Canyon Spring & 0.17 & 1.1 & 0.0042 & $<0.3$ & 0.066 & 0.0006 & 1.5 & 0.042 \\
\hline Rider Spring & $<0.2$ & 17 & na & na & $<0.05$ & na & 8.0 & na \\
\hline \multicolumn{9}{|c|}{ North Segregation/East Kanab Basin Springs } \\
\hline \multicolumn{9}{|c|}{ East Kanab, unmined area, breccia pipes present } \\
\hline Clearwater Spring & 980 & 2.8 & 0.0015 & $<0.3$ & 0.007 & $<0.0002$ & 1.4 & 0.33 \\
\hline Burnt Canyon Well & 4.7 & 3.0 & 0.0027 & 5.3 & na & 0.0003 & 22.3 & 0.21 \\
\hline Tom Land Well & 11.4 & 4.4 & 0.0023 & 29 & 0.094 & 0.0004 & 8.1 & 0.61 \\
\hline \multicolumn{9}{|c|}{$\begin{array}{c}\text { West Kanab, active mine area, on standby (Kanab North, Arizona One, and Pinenut Mines) } \\
\text { and reclaimed (Hermit, Hack Canyon Mines) }\end{array}$} \\
\hline Hotel Spring & 1.8 & 8.1 & 0.015 & 0.5 & 0.029 & 0.0028 & 4.0 & 0.048 \\
\hline Kanab Spring & 0.29 & 4.5 & 0.0013 & $<0.3$ & 0.043 & $<0.0002$ & 3.4 & 0.12 \\
\hline Shower Bath Spring & $<0.02$ & 4.5 & 0.0006 & $<0.3$ & 0.008 & $<0.0002$ & 3.1 & 0.11 \\
\hline Side Canyon Spring & $<0.02$ & 12 & $<0.0005$ & $<0.3$ & 0.008 & $<0.0002$ & 6.1 & 0.18 \\
\hline Pinenut Well & 334 & 24 & $<0.0009$ & 9.2 & 0.031 & 0.0001 & 21.3 & 0.098 \\
\hline \multicolumn{9}{|c|}{$\begin{array}{l}\text { Reclaimed mine area } \\
\text { e on east and Hack and Hermit Mines on west) }\end{array}$} \\
\hline Slide Spring & $<0.02$ & 2.8 & $<0.0005$ & $<0.3$ & 0.004 & $<0.0002$ & 2.0 & 0.25 \\
\hline Rock Spring & 0.04 & 10 & $<0.0005$ & $<0.3$ & 0.005 & $<0.0002$ & 4.1 & 0.39 \\
\hline
\end{tabular}


Table B. Most Probable Value for all elements analyzed.-Continued

[*Column heads containing an asterisk present results of analyses by the laboratory noted; values in all other columns derived by comparing results of analyses by many laboratories.

Bullen, USGS National Research Program Laboratory, Menlo Park, California; Doughten, USGS National Research Program Laboratory, Reston, Virginia; Michel, USGS National Research Program Laboratory, Menlo Park, California; NAU, Northern Arizona University Isotope and Radiochemistry Laboratory, Flagstaff, Arizona; NWQL, USGS National Water Quality Laboratory, Denver, Colorado; RSIL, USGS National Isotope Fractionation Project Laboratory, Reston, Virginia; Taylor, USGS National Research Program Laboratory, Boulder, Colorado; MPV, most probable value for all elements analyzed; Site ID, site identification;

$\delta$, delta notation; <, less than; ${ }^{\circ} \mathrm{C}$, degrees Celsius; \%o, per mil; fil, filtered; unf, unfiltered; gal $/ \mathrm{min}$, gallon per minute; $\mu \mathrm{g} / \mathrm{L}$, microgram per liter; $\mu \mathrm{S} / \mathrm{cm}$, microseimen per centimeter at $25^{\circ} \mathrm{C} ; \mathrm{mg} / \mathrm{L}$, milligram per liter; milligram per liter; $\mathrm{mg} \mathrm{CaCO}_{3} / \mathrm{L}$, milligram calcium carbonate per liter; $\mathrm{mg} \mathrm{N} / \mathrm{L}$, milligram nitrogen per liter; mg P/L, milligram phosphorus per liter; pC/L, picocurie per liter; TU, tritium unit; pmc, percent modern carbon; na, not available; R, results less than sample specific reporting limit; --, not available]

\begin{tabular}{|c|c|c|c|c|c|c|c|c|}
\hline $\begin{array}{l}\text { Spring or well } \\
\text { data source }\end{array}$ & $\begin{array}{l}\text { Site ID on } \\
\text { figure } 17^{*}\end{array}$ & $\begin{array}{c}\text { Sulfur } \\
\text { Taylor } \\
\text { mg/L }\end{array}$ & $\begin{array}{c}\text { Antimony } \\
\mathrm{MPV}^{*} \\
\mu \mathrm{g} / \mathrm{L}\end{array}$ & $\begin{array}{c}\text { Scandium } \\
\text { Taylor } \\
\mu \mathrm{g} / \mathrm{L} \\
\end{array}$ & $\begin{array}{c}\text { Selenium } \\
\text { MPV* }^{*} \\
\mu \mathrm{g} / \mathrm{L}\end{array}$ & $\begin{array}{c}\text { Samarium } \\
\text { Taylor } \\
\mu \mathrm{g} / \mathrm{L}\end{array}$ & $\begin{array}{c}\text { Tin } \\
\text { Taylor } \\
\mu \mathrm{g} / \mathrm{L}\end{array}$ & $\begin{array}{c}\text { Strontium } \\
\mathrm{MPV}^{*} \\
\mu \mathrm{g} / \mathrm{L}\end{array}$ \\
\hline \multicolumn{9}{|c|}{ East Segregation/House Rock Springs } \\
\hline Buck Farm Spring & 23 & na & 0.12 & na & 3.3 & na & na & 609 \\
\hline Fence Spring & 18 & na & 0.06 & na & 1.3 & na & na & 1,090 \\
\hline Hanging Spring & 21 & na & $<0.04$ & na & 0.9 & na & na & 74 \\
\hline \multicolumn{9}{|c|}{ House Rock area, no uranium mines, breccia pipes present } \\
\hline South Canyon Spring & 20 & 18 & 0.025 & $<0.4$ & 3.3 & 0.0011 & $<0.008$ & 247 \\
\hline Rider Spring & 17 & na & $<0.04$ & na & 18 & na & na & 1,300 \\
\hline \multicolumn{9}{|c|}{ North Segregation/East Kanab Basin Springs } \\
\hline \multicolumn{9}{|c|}{ East Kanab, unmined area, breccia pipes present } \\
\hline $\begin{array}{l}\text { Clearwater Spring } \\
\end{array}$ & 16 & 689 & 0.007 & $<0.4$ & 2.8 & $<0.0009$ & $<0.008$ & 5,790 \\
\hline Burnt Canyon Well & 15 & 871 & 0.059 & $<0.5$ & 2.8 & 0.0024 & $<0.01$ & 6,330 \\
\hline Tom Land Well & 12 & 545 & 0.025 & $<0.5$ & 49 & 0.0014 & $<0.01$ & 4,530 \\
\hline \multicolumn{9}{|c|}{$\begin{array}{c}\text { West Kanab, active mine area, on standby (Kanab North, Arizona One, and Pinenut Mines) } \\
\text { and reclaimed (Hermit, Hack Canyon Mines) }\end{array}$} \\
\hline Hotel Spring & 2 & 72 & 0.13 & $<0.4$ & 9.2 & 0.0035 & $<0.008$ & 686 \\
\hline Kanab Spring & 5 & 98 & 0.073 & $<0.4$ & 5.0 & $<0.0009$ & $<0.008$ & 857 \\
\hline Shower Bath Spring & 4 & 115 & 0.068 & $<0.4$ & 4.7 & $<0.0009$ & $<0.008$ & 997 \\
\hline Side Canyon Spring & 3 & 226 & 0.029 & $<0.4$ & 13 & $<0.0009$ & $<0.008$ & 2,020 \\
\hline Pinenut Well & 6 & 433 & 0.034 & $<0.5$ & 0.9 & $<0.0008$ & $<0.01$ & 3,210 \\
\hline \multicolumn{9}{|c|}{$\begin{array}{c}\text { Reclaimed mine area } \\
\text { (Pigeon Mine on east and Hack and Hermit Mines on west) }\end{array}$} \\
\hline Slide Spring & 13 & 163 & 0.015 & $<0.4$ & 21 & $<0.0009$ & $<0.008$ & 1,640 \\
\hline Rock Spring & 14 & 545 & 0.030 & $<0.4$ & 13 & $<0.0009$ & $<0.008$ & 6,060 \\
\hline
\end{tabular}


Table B. Most Probable Value for all elements analyzed._Continued

[*Column heads containing an asterisk present results of analyses by the laboratory noted; values in all other columns derived by comparing results of analyses by many laboratories.

Bullen, USGS National Research Program Laboratory, Menlo Park, California; Doughten, USGS National Research Program Laboratory, Reston, Virginia; Michel, USGS National Research Program Laboratory, Menlo Park, California; NAU, Northern Arizona University Isotope and Radiochemistry Laboratory, Flagstaff, Arizona; NWQL, USGS National Water Quality Laboratory, Denver, Colorado; RSIL, USGS National Isotope Fractionation Project Laboratory, Reston, Virginia; Taylor, USGS National Research Program Laboratory, Boulder, Colorado; MPV, most probable value for all elements analyzed; Site ID, site identification;

$\delta$, delta notation; $<$, less than; ${ }^{\circ} \mathrm{C}$, degrees Celsius; \%, per mil; fil, filtered; unf, unfiltered; gal/min, gallon per minute; $\mu \mathrm{g} / \mathrm{L}$, microgram per liter; $\mu \mathrm{S} / \mathrm{cm}$, microseimen per centimeter at $25^{\circ} \mathrm{C} ; \mathrm{mg} / \mathrm{L}$, milligram per liter; milligram per liter; $\mathrm{mg} \mathrm{CaCO}_{3} / \mathrm{L}$, milligram calcium carbonate per liter; $\mathrm{mg} \mathrm{N} / \mathrm{L}$, milligram nitrogen per liter; $\mathrm{mg}$ P/L, milligram phosphorus per liter; pC/L, picocurie per liter; TU, tritium unit; pmc, percent modern carbon; na, not available; R, results less than sample specific reporting limit; --, not available]

\begin{tabular}{|c|c|c|c|c|c|c|c|c|c|}
\hline $\begin{array}{l}\text { Spring or well } \\
\text { data source }\end{array}$ & $\begin{array}{c}\text { Terbium } \\
\text { Taylor } \\
\text { pg/L }\end{array}$ & $\begin{array}{c}\text { Tellurium } \\
\text { Taylor } \\
\mu \mathrm{g} / \mathrm{L}\end{array}$ & $\begin{array}{c}\text { Thorium } \\
\text { Taylor } \\
\text { rg/L }\end{array}$ & $\begin{array}{c}\text { Titanium } \\
\text { Taylor } \\
\mu \mathrm{g} / \mathrm{L}\end{array}$ & $\begin{array}{c}\text { Thallium } \\
\text { MPV* } \\
\mu g / L\end{array}$ & $\begin{array}{c}\text { Thulium } \\
\text { Taylor } \\
\mu \mathrm{g} / \mathrm{L}\end{array}$ & $\begin{array}{c}\text { Vanadium } \\
\text { MPV* }^{*} \\
\mu \mathrm{g} / \mathrm{L}\end{array}$ & $\begin{array}{c}\text { Tungsten } \\
\text { MPV* }^{*} \\
\mu g / L\end{array}$ & $\begin{array}{c}\text { Ytterbium } \\
\text { Taylor } \\
\mu \mathrm{g} / \mathrm{L}\end{array}$ \\
\hline \multicolumn{10}{|c|}{ East Segregation/House Rock Springs } \\
\hline Buck Farm Spring & na & na & na & na & $<0.04$ & na & 2.6 & $<0.01$ & na \\
\hline Fence Spring & na & na & na & na & 0.05 & na & 1.6 & $<0.01$ & na \\
\hline Hanging Spring & na & na & na & na & $<0.04$ & na & 1.1 & $<0.01$ & na \\
\hline Hole in the Wall Spring & na & na & na & na & $<0.04$ & na & 1.1 & $<0.01$ & na \\
\hline \multicolumn{10}{|c|}{ House Rock area, no uranium mines, breccia pipes present } \\
\hline South Canyon Spring & 0.0003 & $<0.008$ & $<0.001$ & $<0.2$ & 0.006 & $<0.0001$ & 1.4 & 0.004 & 0.0088 \\
\hline Rider Spring & na & na & na & na & $<0.04$ & na & 0.7 & $<0.01$ & na \\
\hline \multicolumn{10}{|c|}{ North Segregation/East Kanab Basin Springs } \\
\hline \multicolumn{10}{|c|}{ East Kanab, unmined area, breccia pipes present } \\
\hline Clearwater Spring & 0.0009 & 0.018 & 0.008 & $<0.2$ & $<0.005$ & 0.0001 & $<0.1$ & 0.050 & 0.037 \\
\hline Burnt Canyon Well & 0.0013 & 0.055 & 0.015 & $<0.1$ & 0.12 & 0.0003 & $<0.3$ & $<0.001$ & 0.035 \\
\hline Tom Land Well & 0.0004 & 0.038 & 0.012 & $<0.1$ & 0.33 & $<0.0001$ & 0.4 & 0.002 & 0.025 \\
\hline \multicolumn{10}{|c|}{$\begin{array}{c}\text { West Kanab, active mine area, on standby (Kanab North, Arizona One, and Pinenut Mines) } \\
\text { and reclaimed (Hermit, Hack Canyon Mines) }\end{array}$} \\
\hline Hotel Spring & 0.0004 & $<0.008$ & 0.006 & $<0.2$ & 0.025 & 0.0004 & 9.9 & 0.014 & 0.034 \\
\hline Kanab Spring & $<0.0002$ & $<0.008$ & 0.002 & $<0.2$ & 0.12 & $<0.0001$ & 0.7 & 0.020 & 0.0099 \\
\hline Shower Bath Spring & $<0.0002$ & -0.008 & 0.005 & $<0.2$ & 0.066 & $<0.0001$ & 1.0 & 0.013 & 0.010 \\
\hline Side Canyon Spring & $<0.0002$ & $<0.008$ & 0.005 & $<0.2$ & 0.17 & 0.0001 & 0.6 & 0.013 & 0.015 \\
\hline Pinenut Well & 0.0008 & 0.029 & 0.033 & $<0.1$ & 0.016 & $<0.0001$ & 0.2 & 0.037 & 0.016 \\
\hline \multicolumn{10}{|c|}{$\begin{array}{c}\text { Reclaimed mine area } \\
\text { (Pigeon Mine on east and Hack and Hermit Mines on west) }\end{array}$} \\
\hline Slide Spring & $<0.0002$ & $<0.008$ & 0.003 & $<0.2$ & 0.075 & $<0.0001$ & 1.0 & $<0.002$ & 0.012 \\
\hline Rock Spring & 0.0002 & 0.012 & 0.006 & $<0.2$ & 0.017 & $<0.0001$ & 0.5 & 0.002 & 0.037 \\
\hline
\end{tabular}


Table B. Most Probable Value for all elements analyzed.-Continued

$[*$ Column heads containing an asterisk present results of analyses by the laboratory noted; values in all other columns derived by comparing results of analyses by many laboratories.

Bullen, USGS National Research Program Laboratory, Menlo Park, California; Doughten, USGS National Research Program Laboratory, Reston, Virginia; Michel, USGS National Research Program Laboratory, Menlo Park, California; NAU, Northern Arizona University Isotope and Radiochemistry Laboratory, Flagstaff, Arizona; NWQL, USGS National Water Quality Laboratory, Denver, Colorado; RSIL, USGS National Isotope Fractionation Project Laboratory, Reston, Virginia; Taylor, USGS National Research Program Laboratory, Boulder, Colorado; MPV, most probable value for all elements analyzed; Site ID, site identification;

$\delta$, delta notation; <, less than; ${ }^{\circ} \mathrm{C}$, degrees Celsius; \%o, per mil; fil, filtered; unf, unfiltered; gal $/ \mathrm{min}$, gallon per minute; $\mu \mathrm{g} / \mathrm{L}$, microgram per liter; $\mu \mathrm{S} / \mathrm{cm}$, microseimen per centimeter at $25^{\circ} \mathrm{C} ; \mathrm{mg} / \mathrm{L}$, milligram per liter; milligram per liter; $\mathrm{mg} \mathrm{CaCO}_{3} / \mathrm{L}$, milligram calcium carbonate per liter; $\mathrm{mg} \mathrm{N} / \mathrm{L}$, milligram nitrogen per liter; $\mathrm{mg}$ P/L, milligram phosphorus per liter; pC/L, picocurie per liter; TU, tritium unit; pmc, percent modern carbon; na, not available; R, results less than sample specific reporting limit; --, not available]

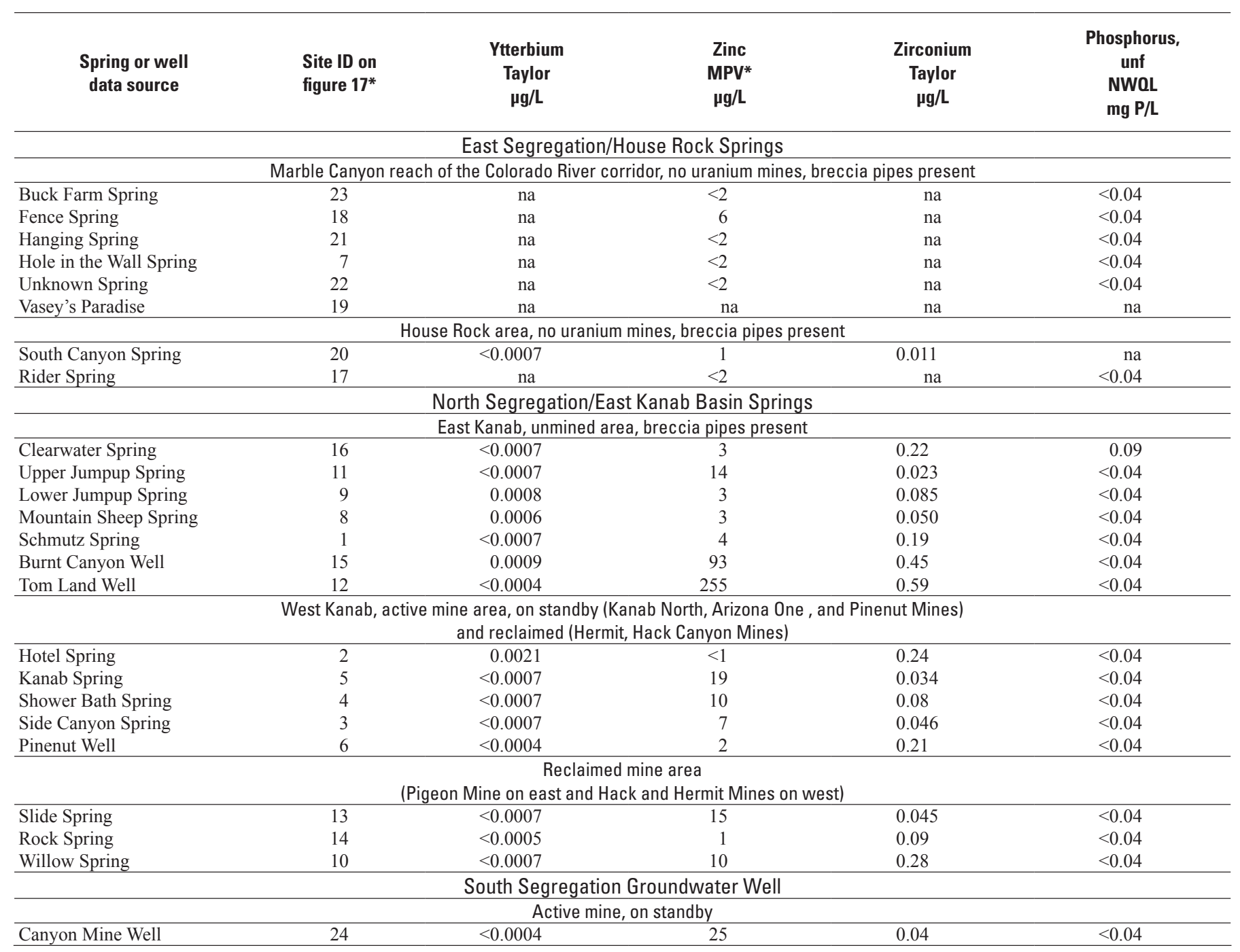


Table B. Most Probable Value for all elements analyzed.-Continued

[*Column heads containing an asterisk present results of analyses by the laboratory noted; values in all other columns derived by comparing results of analyses by many laboratories.

Bullen, USGS National Research Program Laboratory, Menlo Park, California; Doughten, USGS National Research Program Laboratory, Reston, Virginia; Michel, USGS National Research Program Laboratory, Menlo Park, California; NAU, Northern Arizona University Isotope and Radiochemistry Laboratory, Flagstaff, Arizona; NWQL, USGS National Water Quality Laboratory, Denver, Colorado; RSIL, USGS National Isotope Fractionation Project Laboratory, Reston, Virginia; Taylor, USGS National Research Program Laboratory, Boulder, Colorado; MPV, most probable value for all elements analyzed; Site ID, site identification;

$\delta$, delta notation; $<$, less than; ${ }^{\circ} \mathrm{C}$, degrees Celsius; \%, per mil; fil, filtered; unf, unfiltered; gal/min, gallon per minute; $\mu \mathrm{g} / \mathrm{L}$, microgram per liter; $\mu \mathrm{S} / \mathrm{cm}$, microseimen per centimeter at $25^{\circ} \mathrm{C} ; \mathrm{mg} / \mathrm{L}$, milligram per liter; milligram per liter; $\mathrm{mg} \mathrm{CaCO}_{3} / \mathrm{L}$, milligram calcium carbonate per liter; $\mathrm{mg} \mathrm{N} / \mathrm{L}$, milligram nitrogen per liter; $\mathrm{mg}$ P/L, milligram phosphorus per liter; $\mathrm{pC} / \mathrm{L}$, picocurie per liter; $\mathrm{TU}$, tritium unit; pmc, percent modern carbon; na, not available; R, results less than sample specific reporting limit; --, not available]

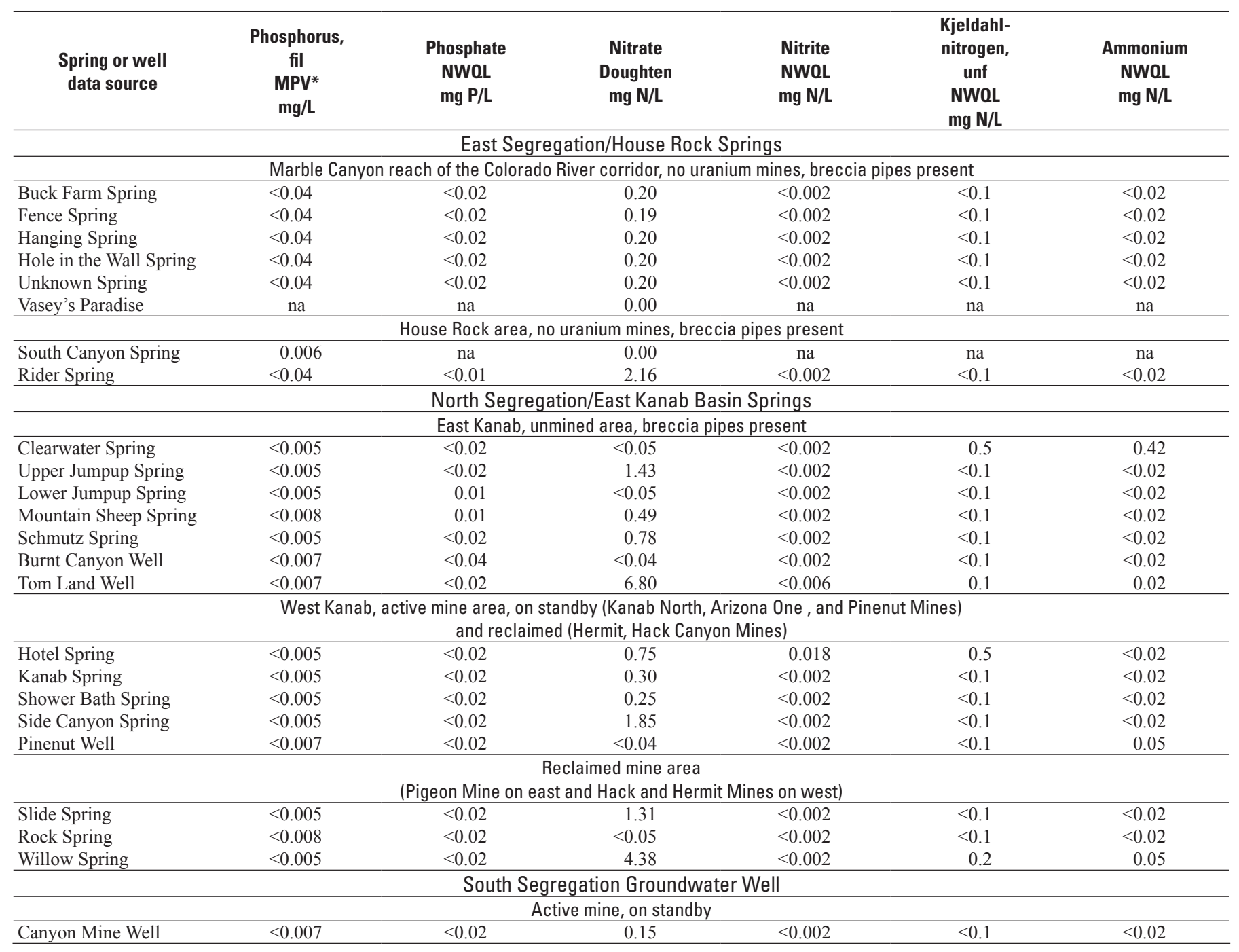


Table B. Most Probable Value for all elements analyzed.-Continued

$[*$ Column heads containing an asterisk present results of analyses by the laboratory noted; values in all other columns derived by comparing results of analyses by many laboratories.

Bullen, USGS National Research Program Laboratory, Menlo Park, California; Doughten, USGS National Research Program Laboratory, Reston, Virginia; Michel, USGS National Research Program Laboratory, Menlo Park, California; NAU, Northern Arizona University Isotope and Radiochemistry Laboratory, Flagstaff, Arizona; NWQL, USGS National Water Quality Laboratory, Denver, Colorado; RSIL, USGS National Isotope Fractionation Project Laboratory, Reston, Virginia; Taylor, USGS National Research Program Laboratory, Boulder, Colorado; MPV, most probable value for all elements analyzed; Site ID, site identification;

$\delta$, delta notation; <, less than; ${ }^{\circ} \mathrm{C}$, degrees Celsius; \%o, per mil; fil, filtered; unf, unfiltered; gal $/ \mathrm{min}$, gallon per minute; $\mu \mathrm{g} / \mathrm{L}$, microgram per liter; $\mu \mathrm{S} / \mathrm{cm}$, microseimen per centimeter at $25^{\circ} \mathrm{C} ; \mathrm{mg} / \mathrm{L}$, milligram per liter; milligram per liter; $\mathrm{mg} \mathrm{CaCO}_{3} / \mathrm{L}$, milligram calcium carbonate per liter; $\mathrm{mg} \mathrm{N} / \mathrm{L}$, milligram nitrogen per liter; $\mathrm{mg}$ P/L, milligram phosphorus per liter; pC/L, picocurie per liter; TU, tritium unit; pmc, percent modern carbon; na, not available; R, results less than sample specific reporting limit; --, not available]

\begin{tabular}{|c|c|c|c|c|c|}
\hline $\begin{array}{l}\text { Spring or well } \\
\text { data source }\end{array}$ & $\begin{array}{l}\text { Site ID on } \\
\text { figure } 17^{*}\end{array}$ & $\begin{array}{c}\text { Gross alpha } \\
\text { radioactivity, } \\
\text { 72-hour } \\
\text { NWOL } \\
\text { pC/L }\end{array}$ & $\begin{array}{c}\text { Gross alpha } \\
\text { radioactivity, } \\
\text { 30-day } \\
\text { NWQL } \\
\text { pC/L }\end{array}$ & $\begin{array}{c}\text { Gross beta } \\
\text { radioactivity, } \\
\text { 72-hour } \\
\text { NWOL } \\
\text { pC/L }\end{array}$ & $\begin{array}{c}\text { Gross beta } \\
\text { radioactivity, } \\
\text { 30-day } \\
\text { NWOL } \\
\text { pC/L }\end{array}$ \\
\hline \multicolumn{6}{|c|}{ East Segregation/House Rock Springs } \\
\hline \multicolumn{6}{|c|}{ Marble Canyon reach of the Colorado River corridor, no uranium mines, breccia pipes present } \\
\hline Buck Farm Spring & 23 & 4.3 & 3.9 & 8.1 & 3.9 \\
\hline Fence Spring & 18 & R.6 & R.1 & 16.7 & 15.4 \\
\hline Unknown Spring & 22 & 1.9 & 3.5 & $0.5 \mathrm{R}$ & 2.3 \\
\hline Vasey's Paradise & 19 & 1.2 & 2.1 & $0.8 \mathrm{R}$ & 1.2 \\
\hline \multicolumn{6}{|c|}{ House Rock area, no uranium mines, breccia pipes present } \\
\hline South Canyon Spring & 20 & na & na & na & na \\
\hline Rider Spring & 17 & 4.7 & 5 & 6.6 & 6.3 \\
\hline \multicolumn{6}{|c|}{ North Segregation/East Kanab Basin Springs } \\
\hline Mountain Sheep Spring & 8 & na & na & na & na \\
\hline Schmutz Spring & 1 & 4.3 & 5 & 4.6 & 3.8 \\
\hline Burnt Canyon Well & 15 & na & na & na & na \\
\hline Tom Land Well & 12 & na & na & na & na \\
\hline \multicolumn{6}{|c|}{$\begin{array}{l}\text { West Kanab, active mine area, on standby (Kanab North, Arizona One, and Pinenut Mines) } \\
\text { and reclaimed (Hermit, Hack Canyon Mines) }\end{array}$} \\
\hline Hotel Spring & 2 & 3.3 & 4.4 & 6 & 7.9 \\
\hline Kanab Spring & 5 & 4.1 & 6.7 & 6.1 & 6.1 \\
\hline Shower Bath Spring & 4 & 5.4 & 6.4 & 4.8 & 5.6 \\
\hline Side Canyon Spring & 3 & 7.5 & 9 & 6.6 & 6.8 \\
\hline Pinenut Well & 6 & na & na & na & na \\
\hline \multicolumn{6}{|c|}{$\begin{array}{c}\text { Reclaimed mine area } \\
\text { (Pigeon Mine on east and Hack and Hermit Mines on west) }\end{array}$} \\
\hline
\end{tabular}


Table B. Most Probable Value for all elements analyzed.-Continued

[*Column heads containing an asterisk present results of analyses by the laboratory noted; values in all other columns derived by comparing results of analyses by many laboratories.

Bullen, USGS National Research Program Laboratory, Menlo Park, California; Doughten, USGS National Research Program Laboratory, Reston, Virginia; Michel, USGS National Research Program Laboratory, Menlo Park, California; NAU, Northern Arizona University Isotope and Radiochemistry Laboratory, Flagstaff, Arizona; NWQL, USGS National Water Quality Laboratory, Denver, Colorado; RSIL, USGS National Isotope Fractionation Project Laboratory, Reston, Virginia; Taylor, USGS National Research Program Laboratory, Boulder, Colorado; MPV, most probable value for all elements analyzed; Site ID, site identification;

$\delta$, delta notation; <, less than; ${ }^{\circ} \mathrm{C}$, degrees Celsius; \%o, per mil; fil, filtered; unf, unfiltered; gal $/ \mathrm{min}$, gallon per minute; $\mu \mathrm{g} / \mathrm{L}$, microgram per liter; $\mu \mathrm{S} / \mathrm{cm}$, microseimen per centimeter at $25^{\circ} \mathrm{C} ; \mathrm{mg} / \mathrm{L}$, milligram per liter; milligram per liter; $\mathrm{mg} \mathrm{CaCO}_{3} / \mathrm{L}$, milligram calcium carbonate per liter; $\mathrm{mg} \mathrm{N} / \mathrm{L}$, milligram nitrogen per liter; $\mathrm{mg}$ P/L, milligram phosphorus per liter; $\mathrm{pC} / \mathrm{L}$, picocurie per liter; $\mathrm{TU}$, tritium unit; pmc, percent modern carbon; na, not available; R, results less than sample specific reporting limit; --, not available]

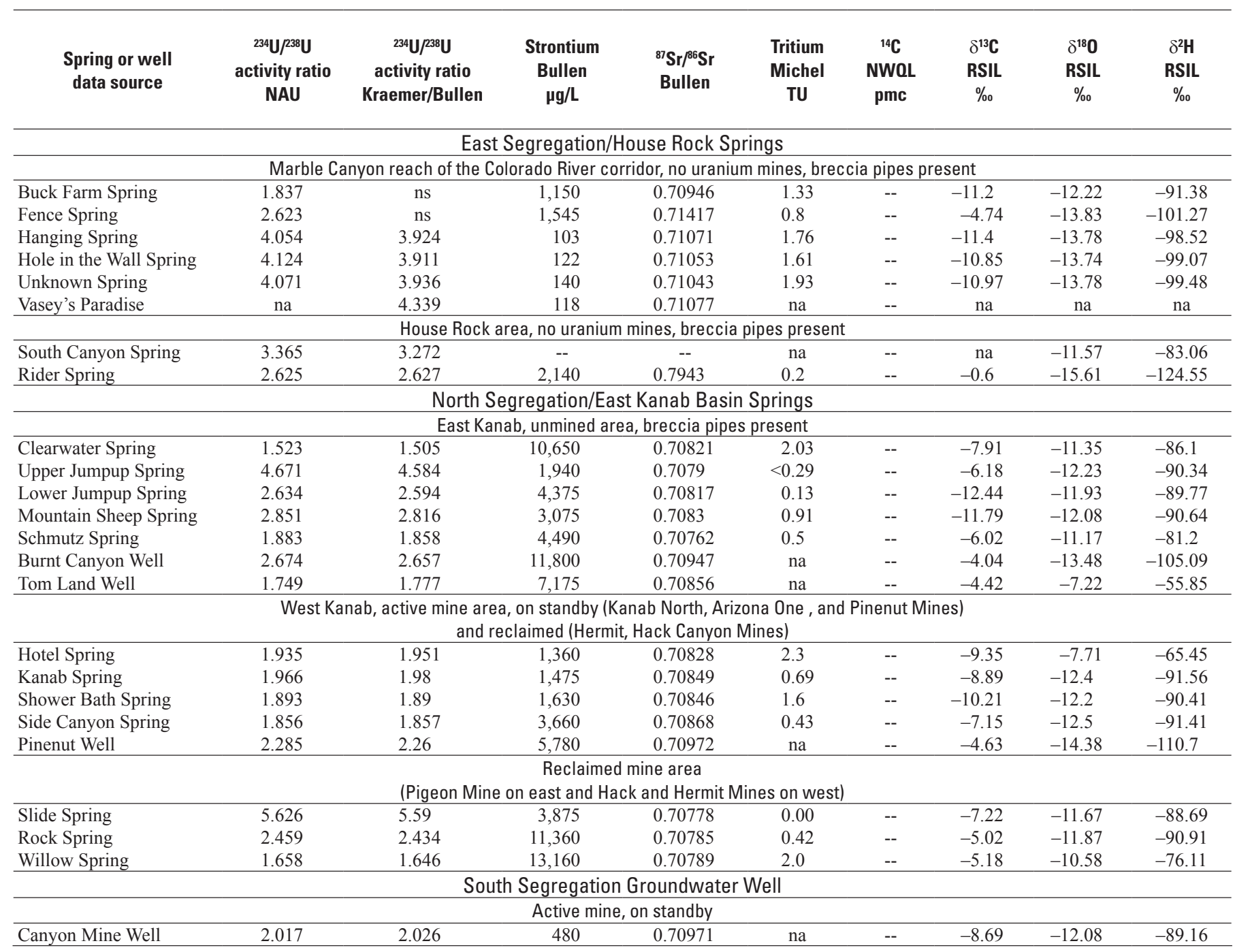





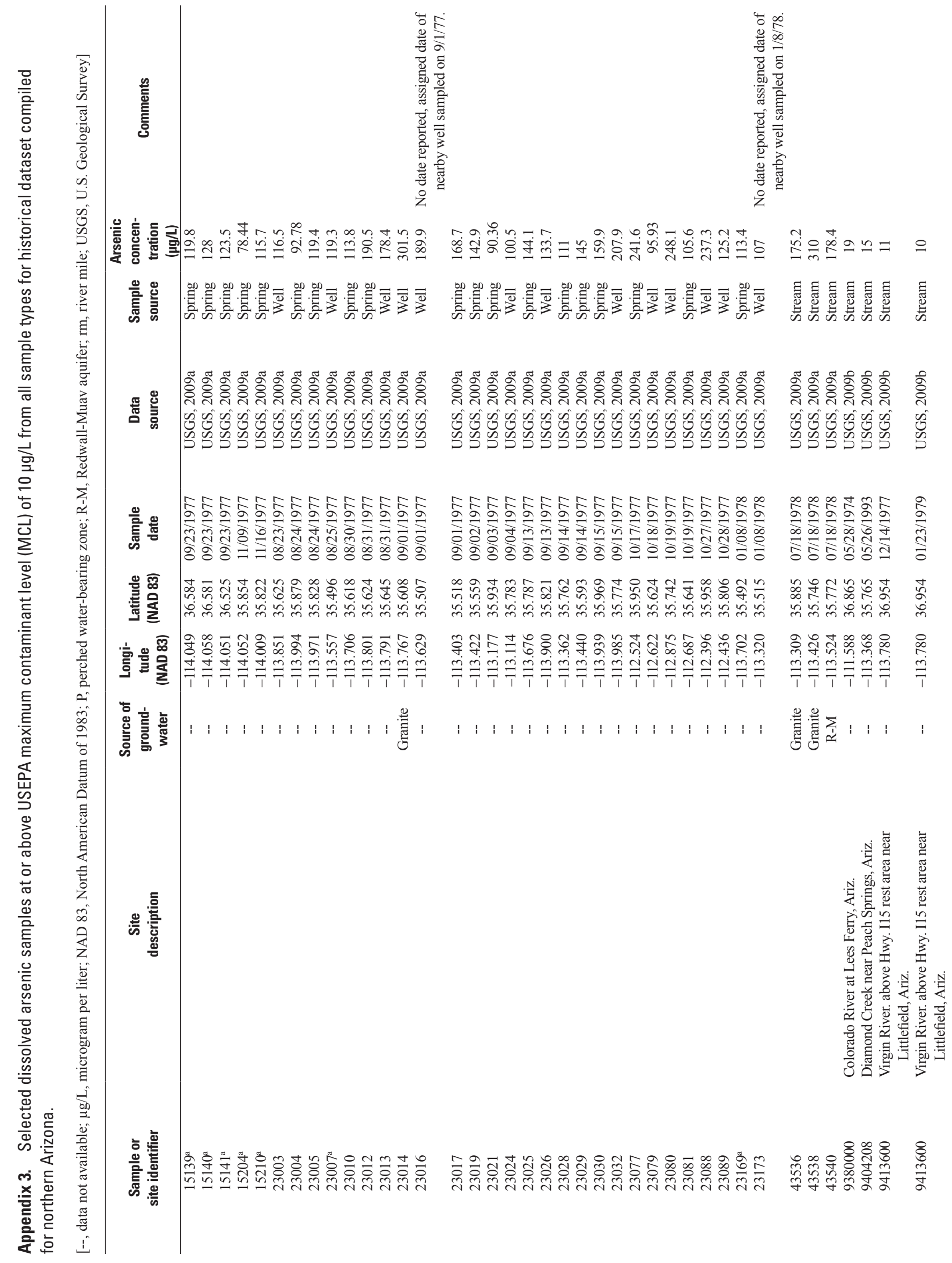




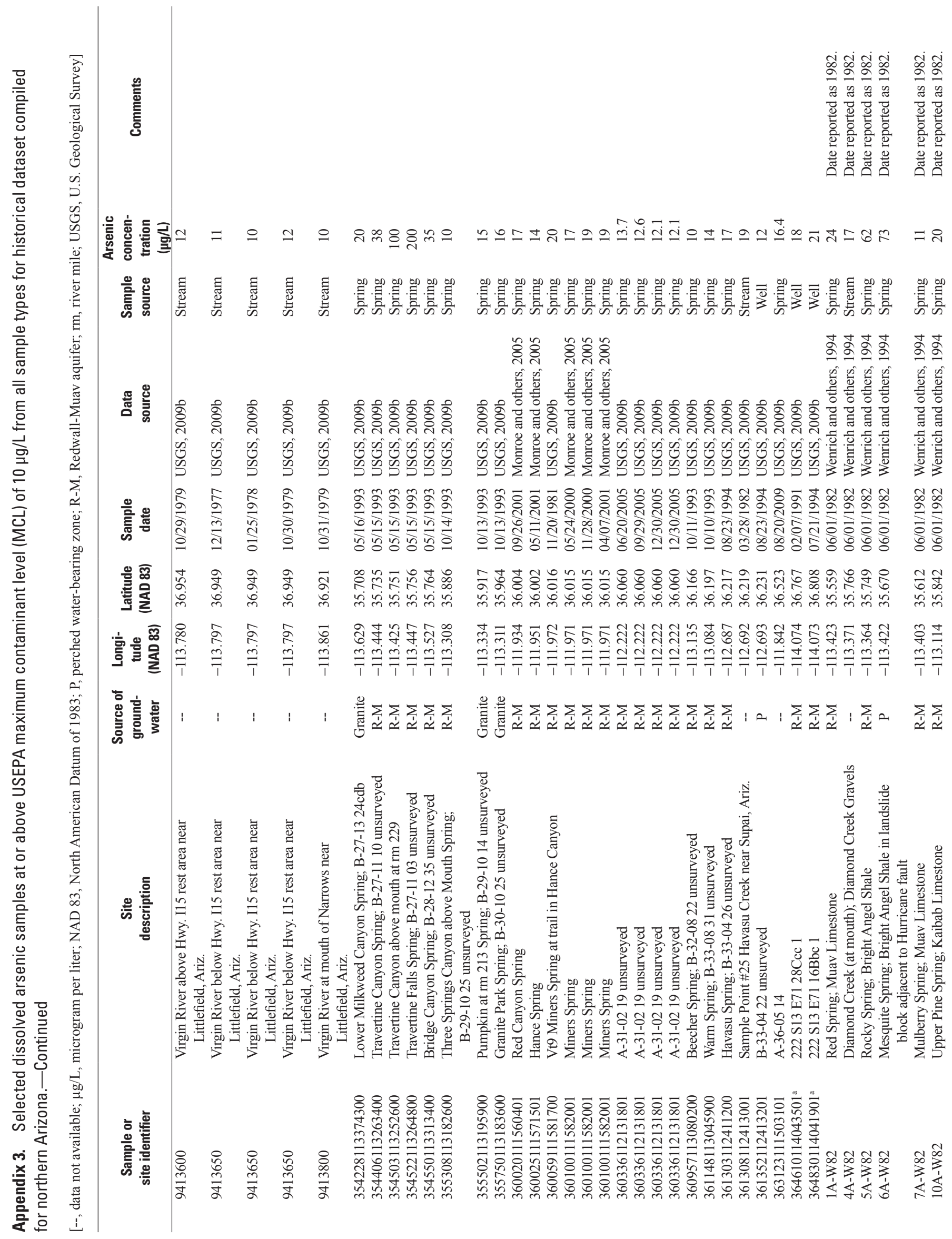




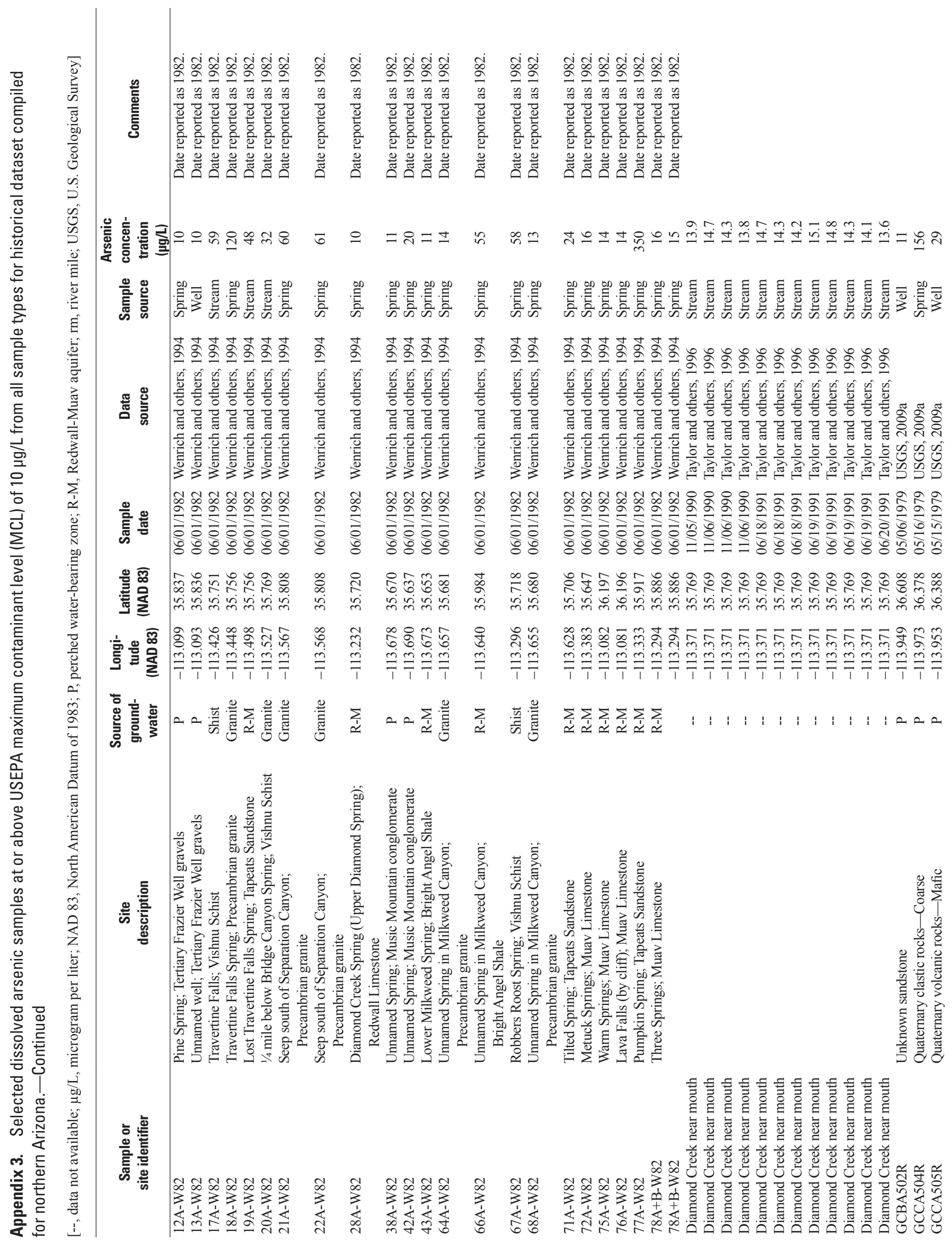




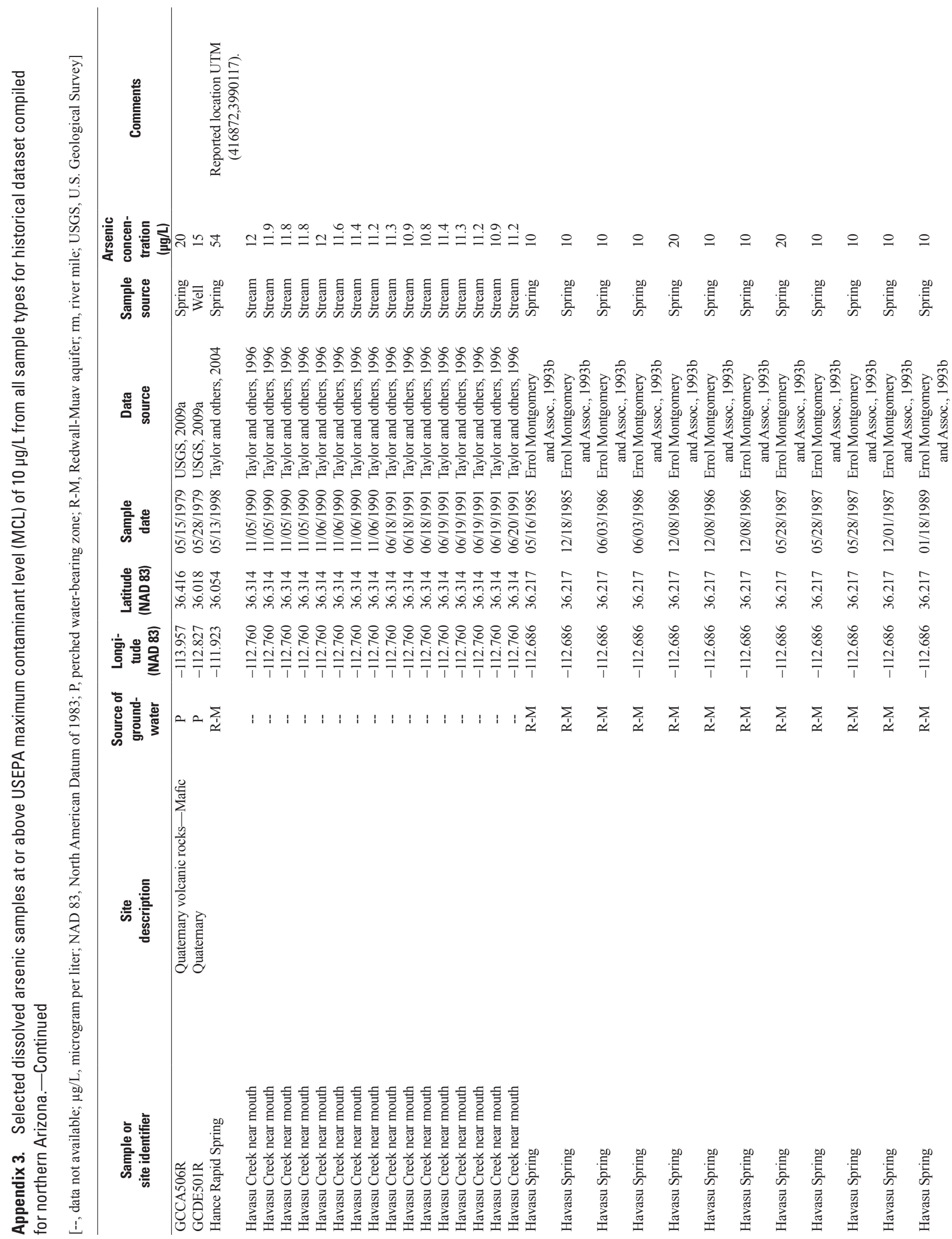




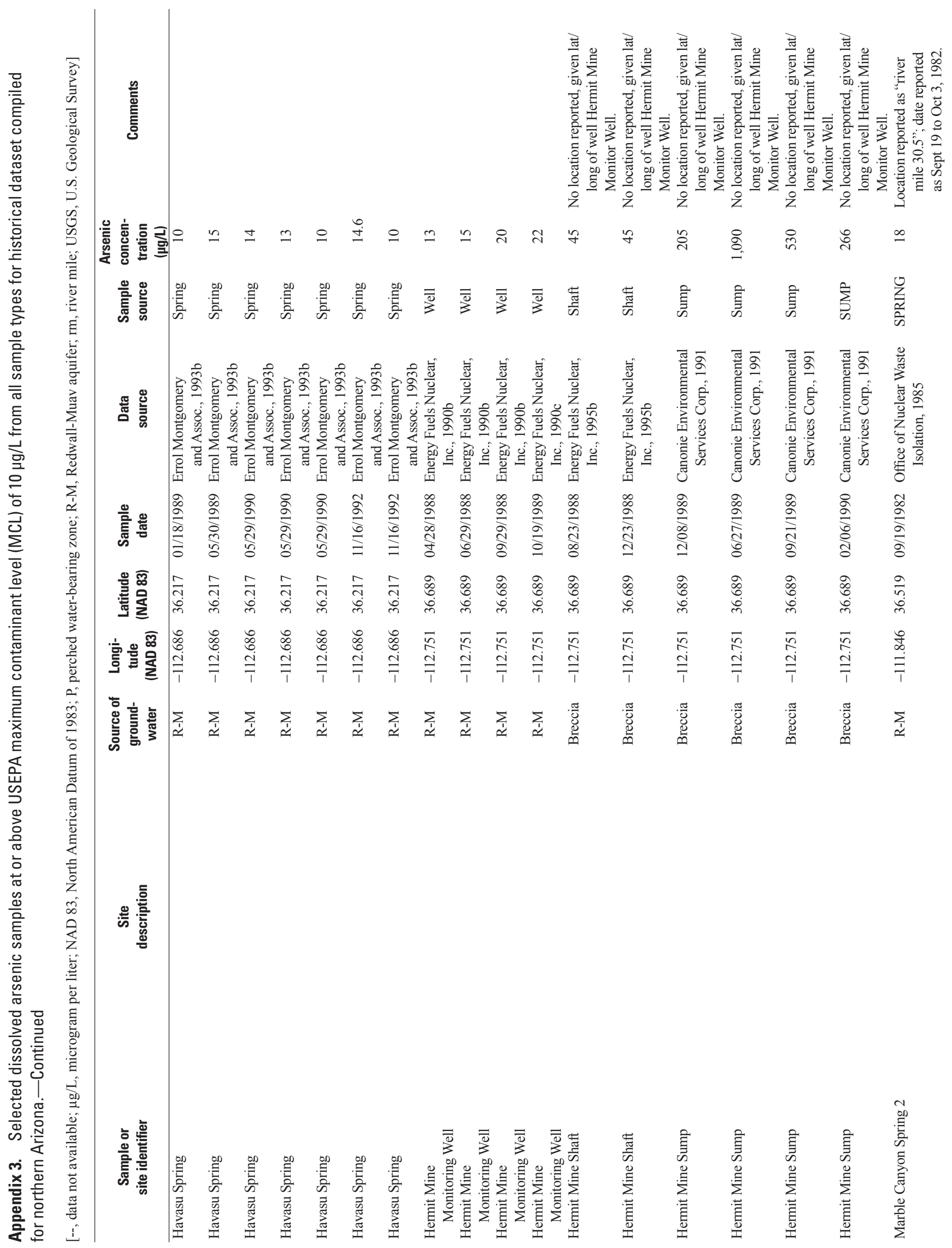




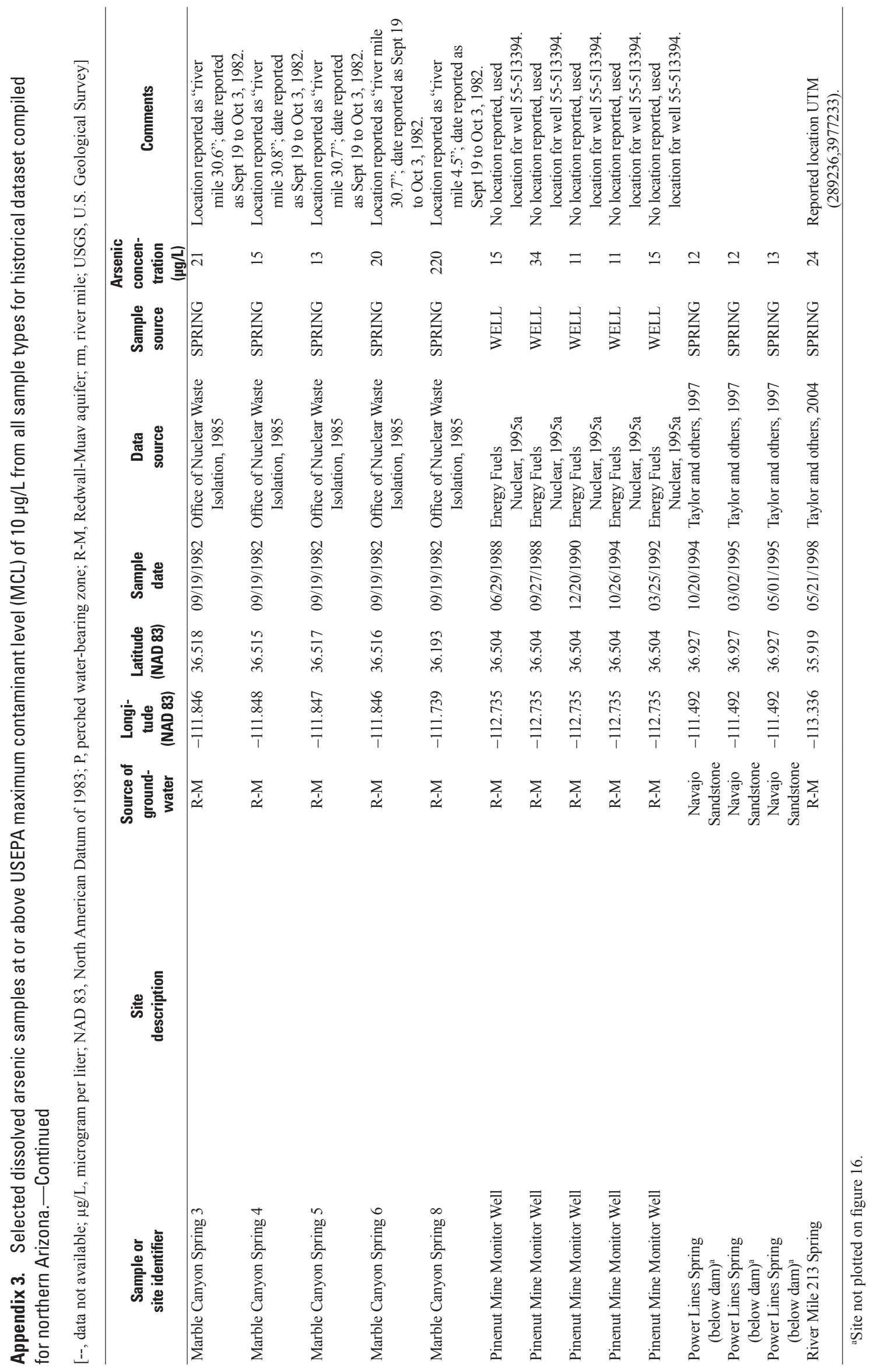




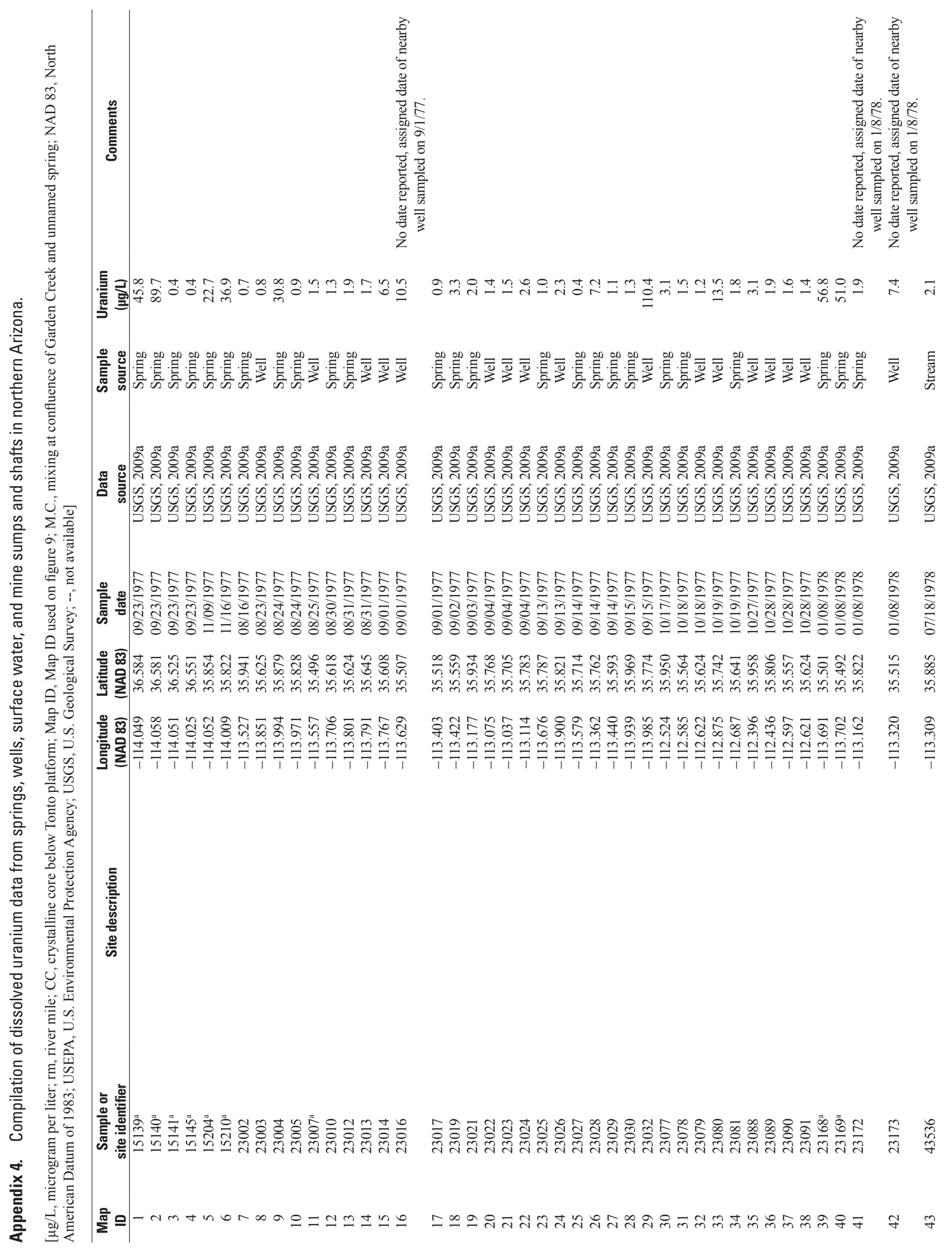




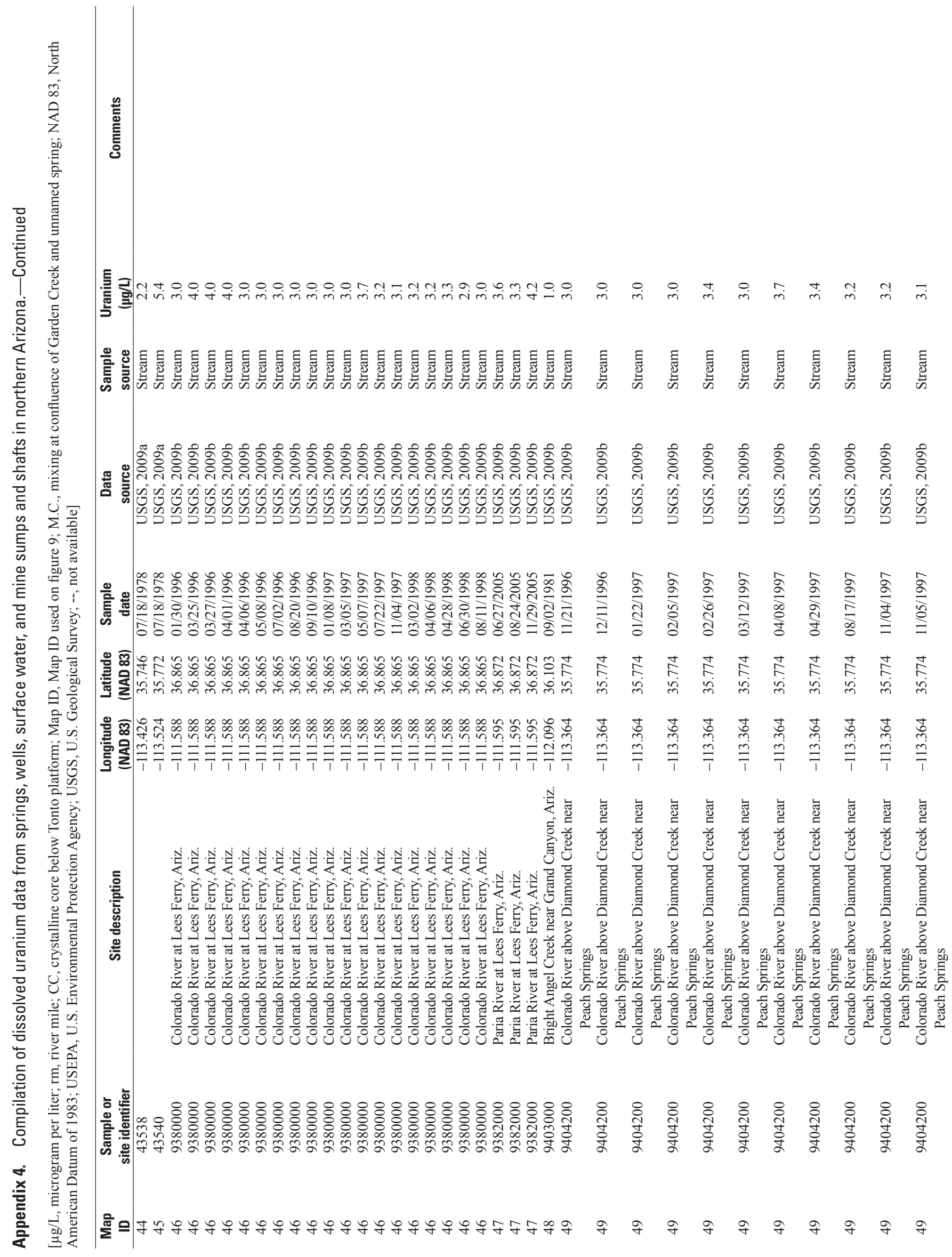




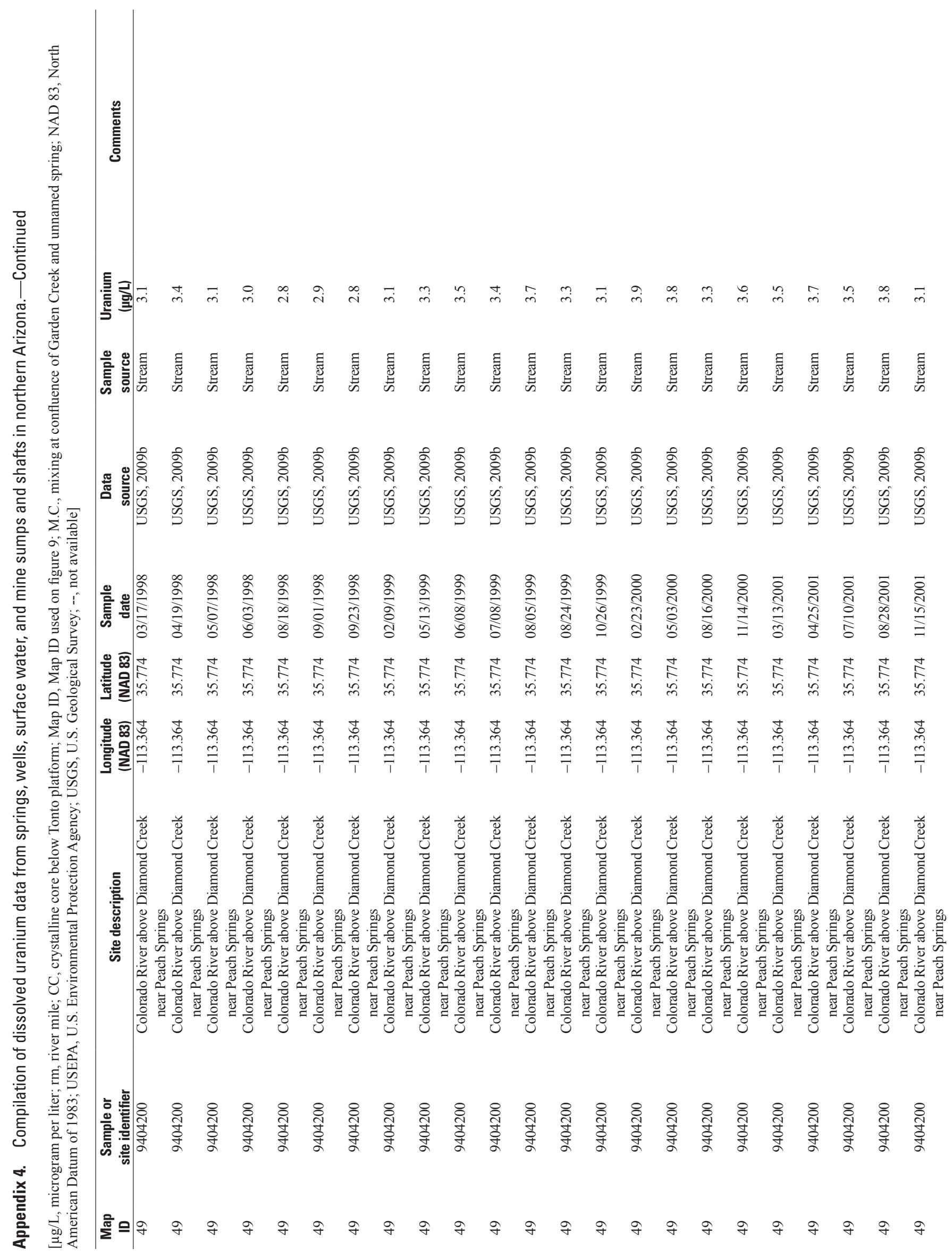




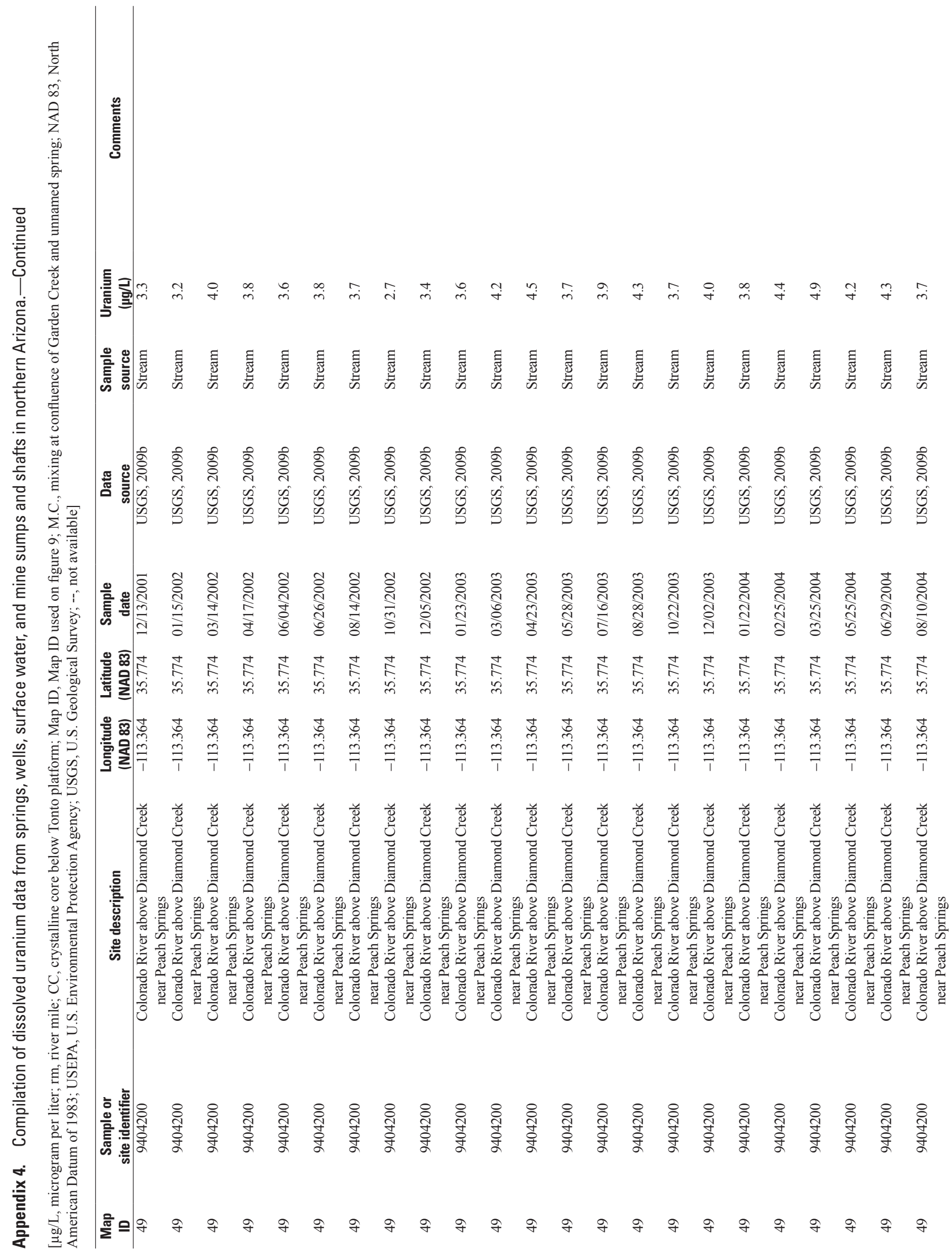




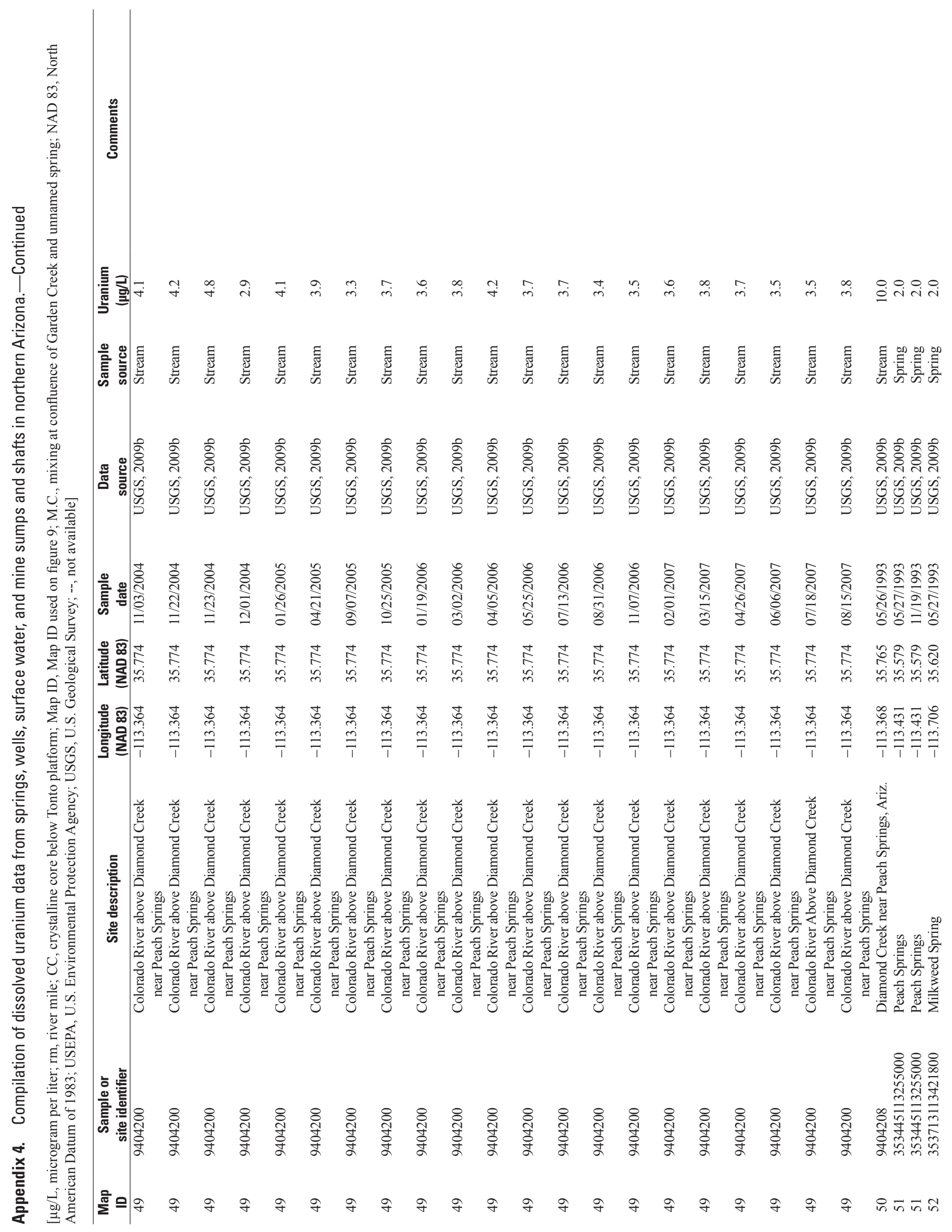




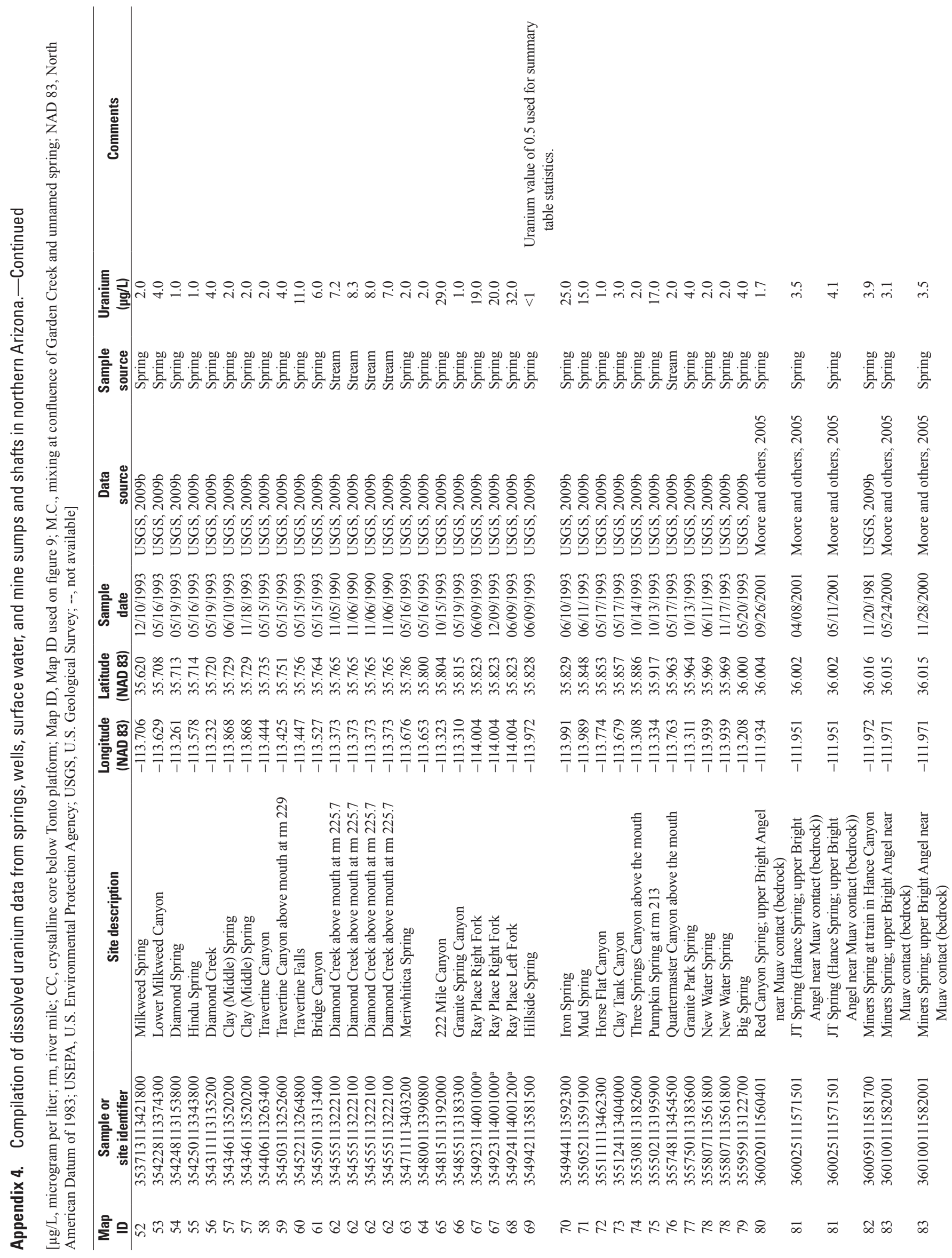




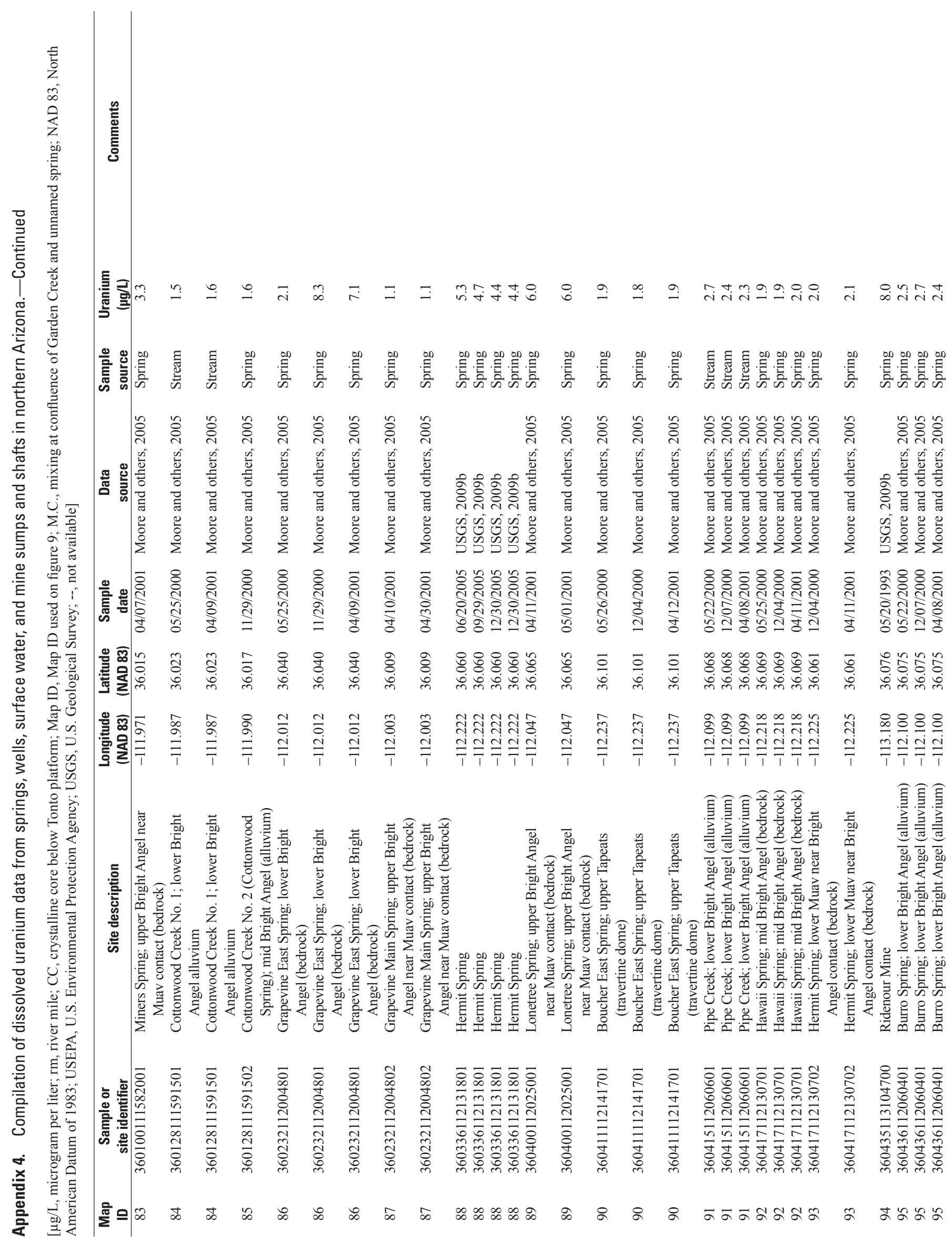




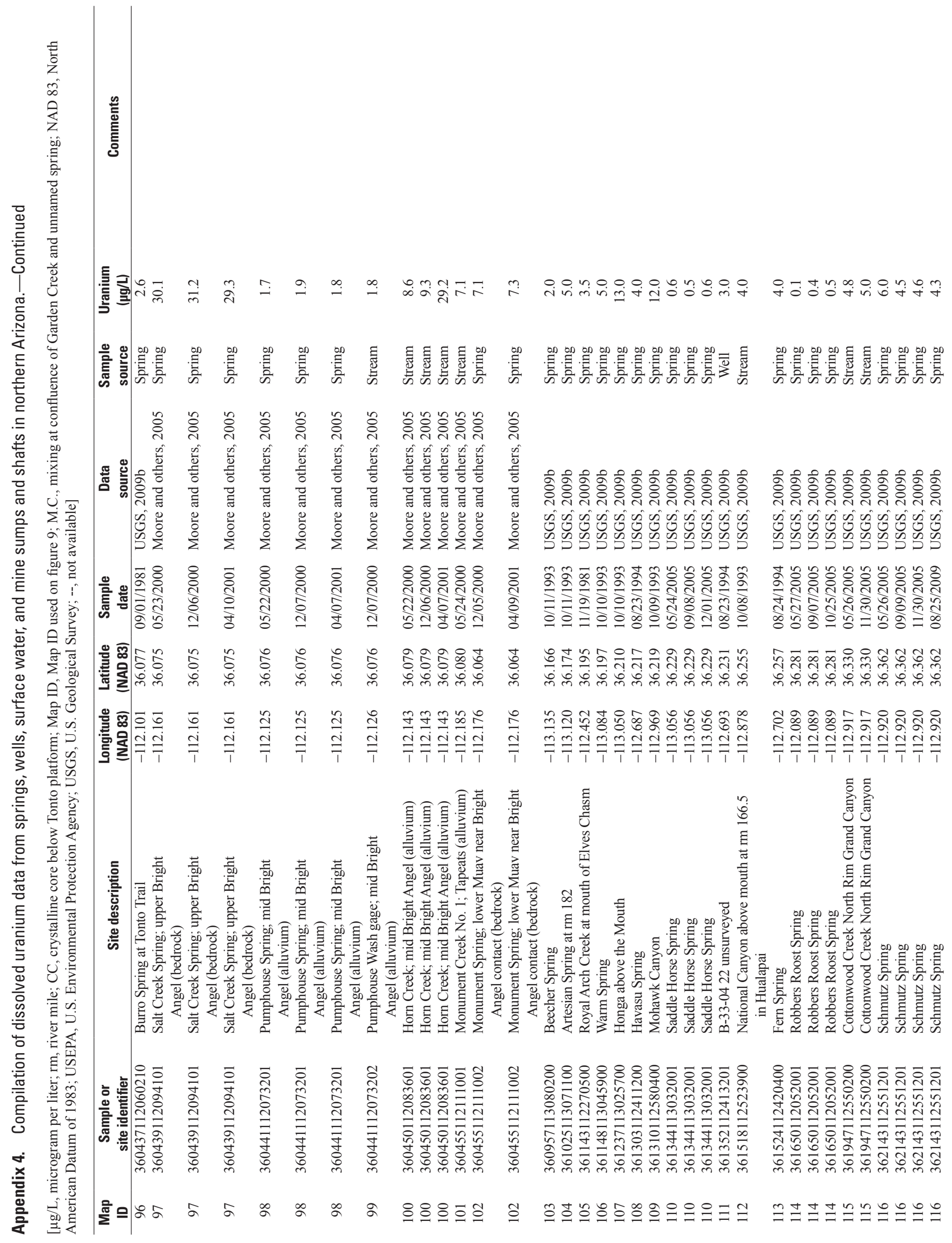




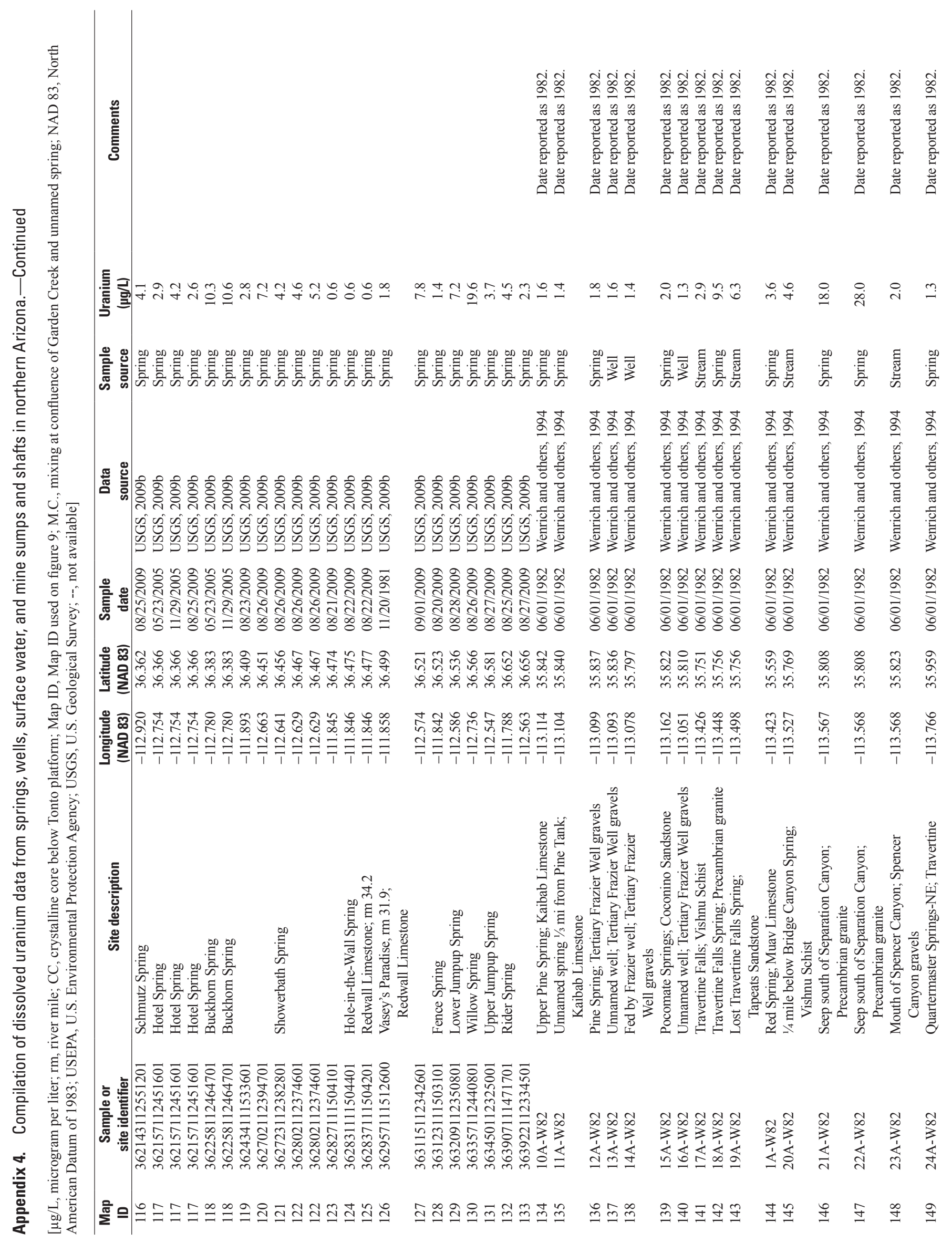




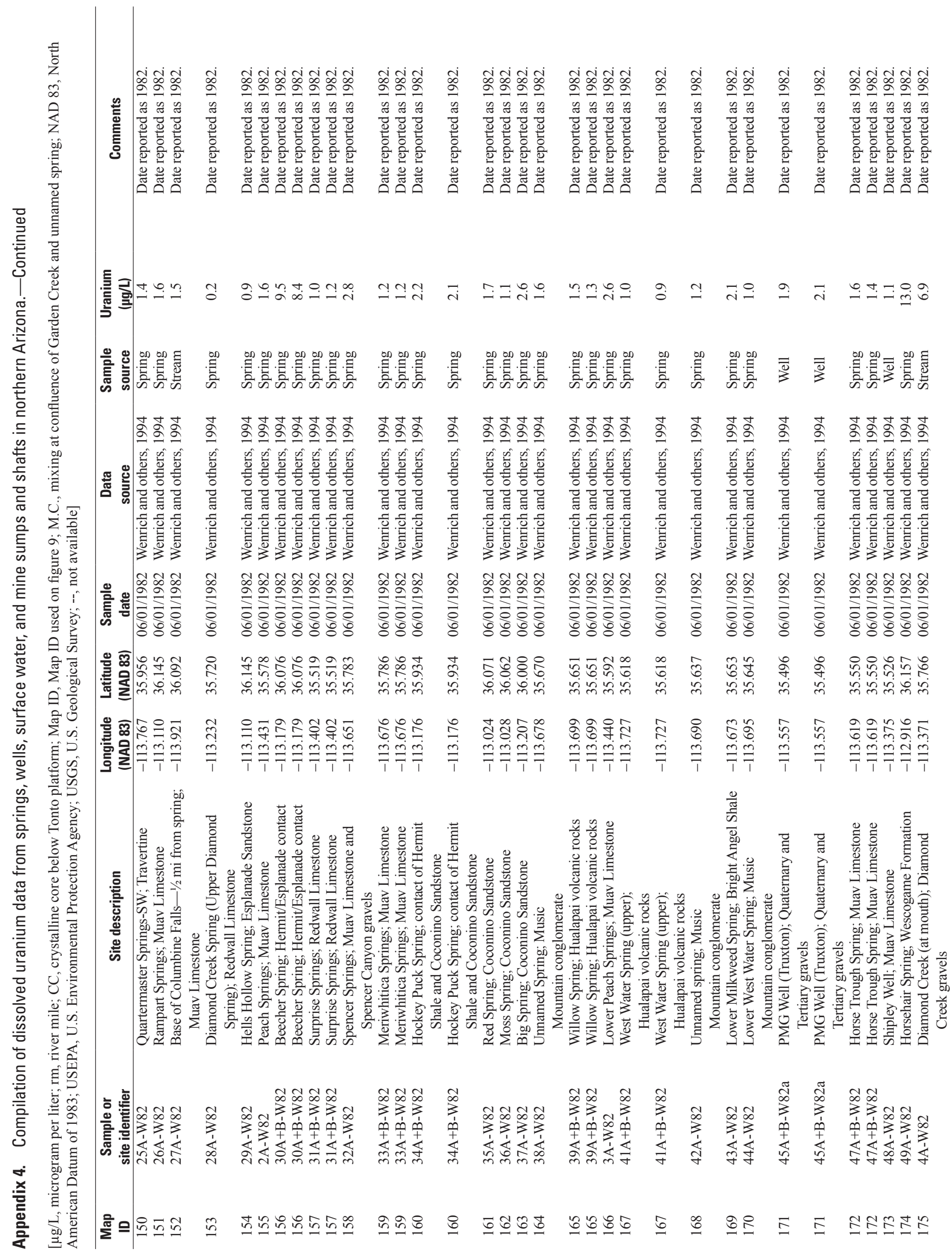




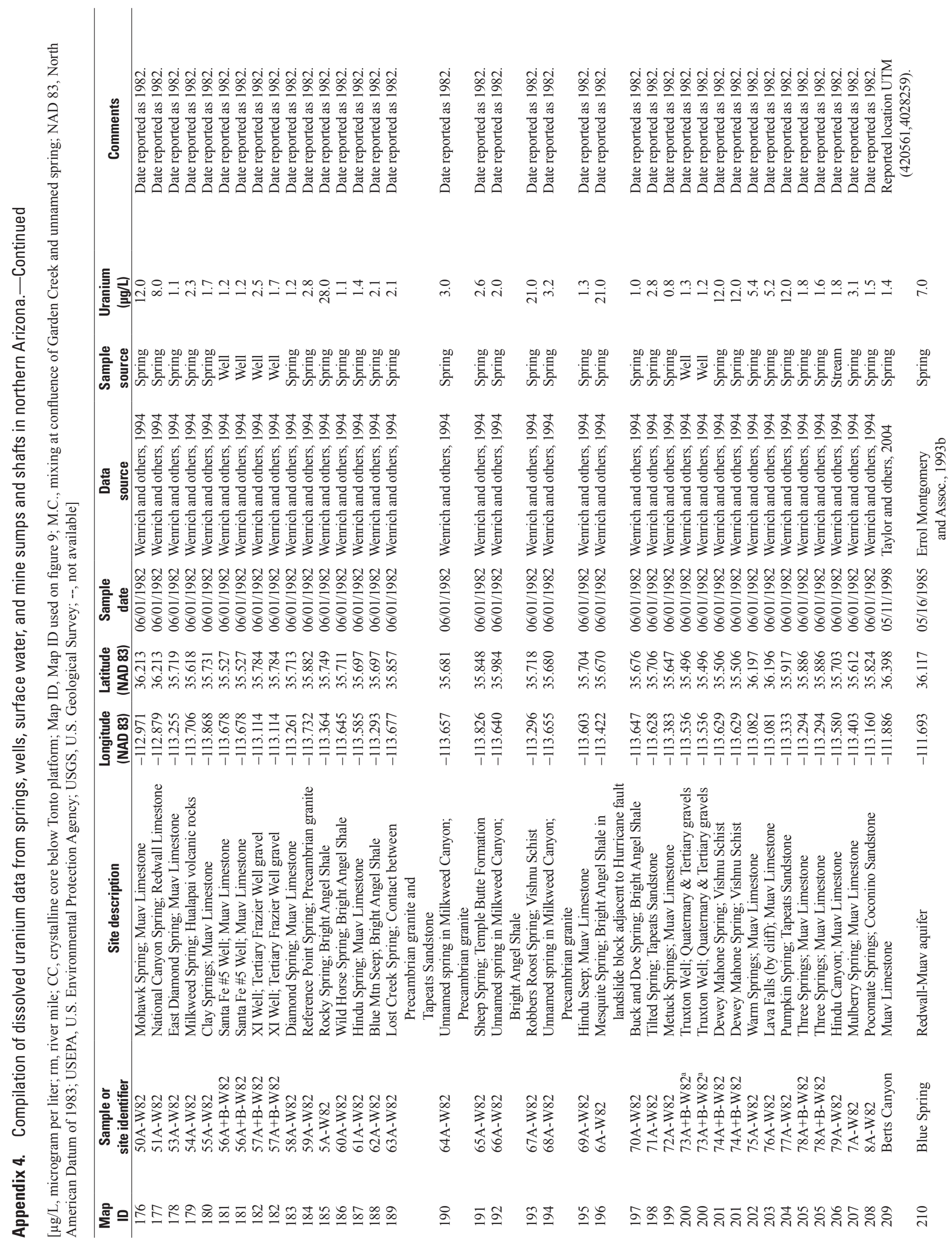




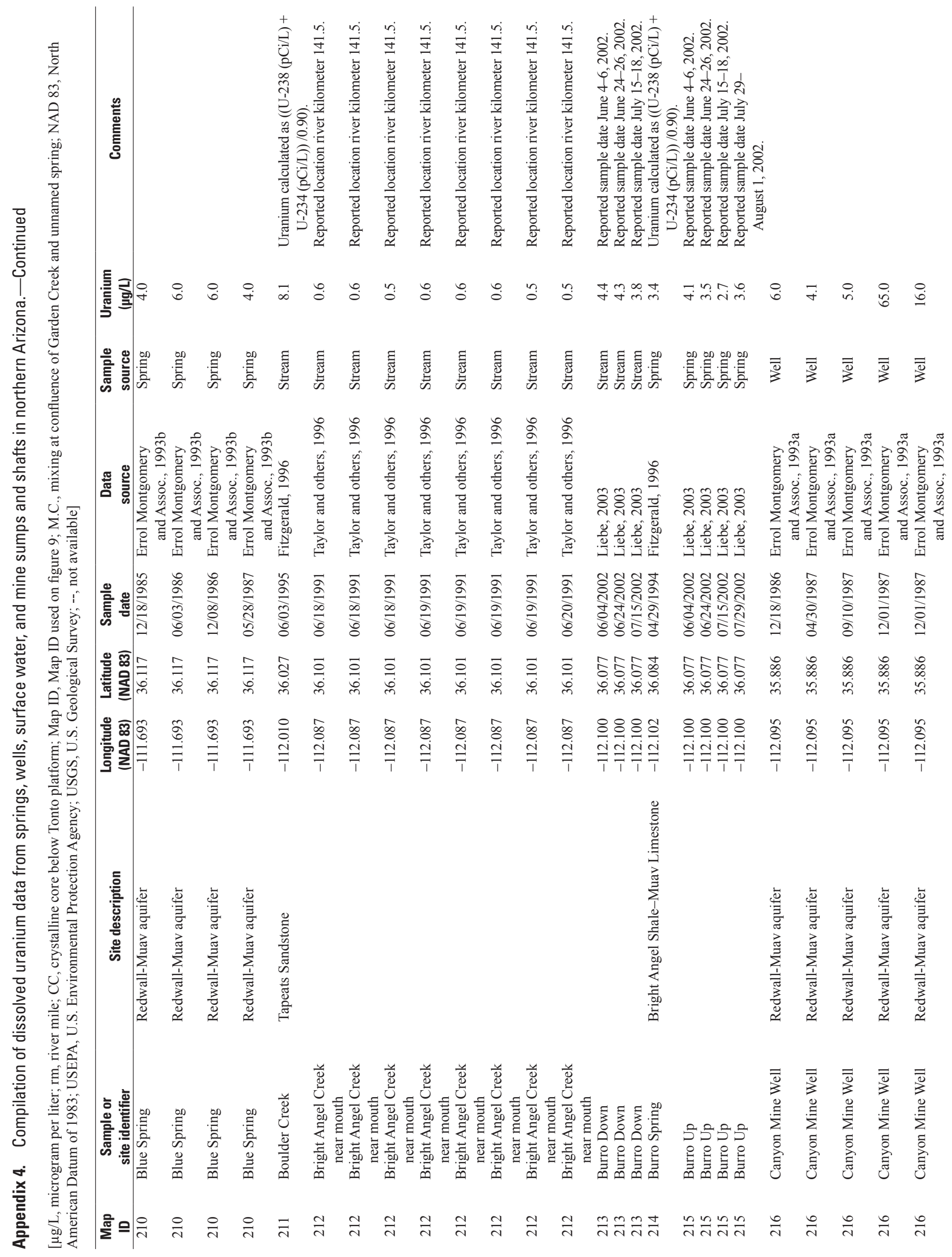




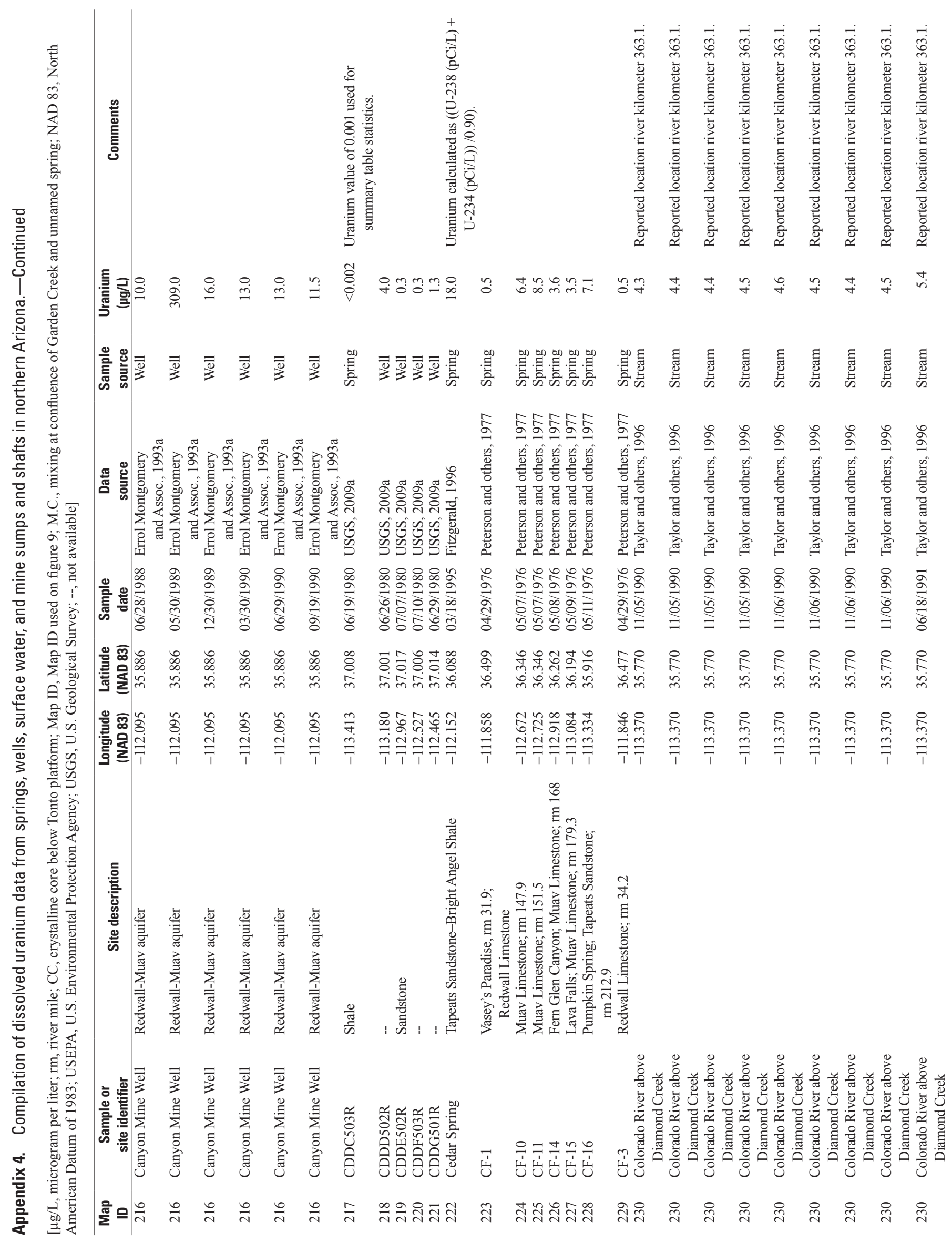




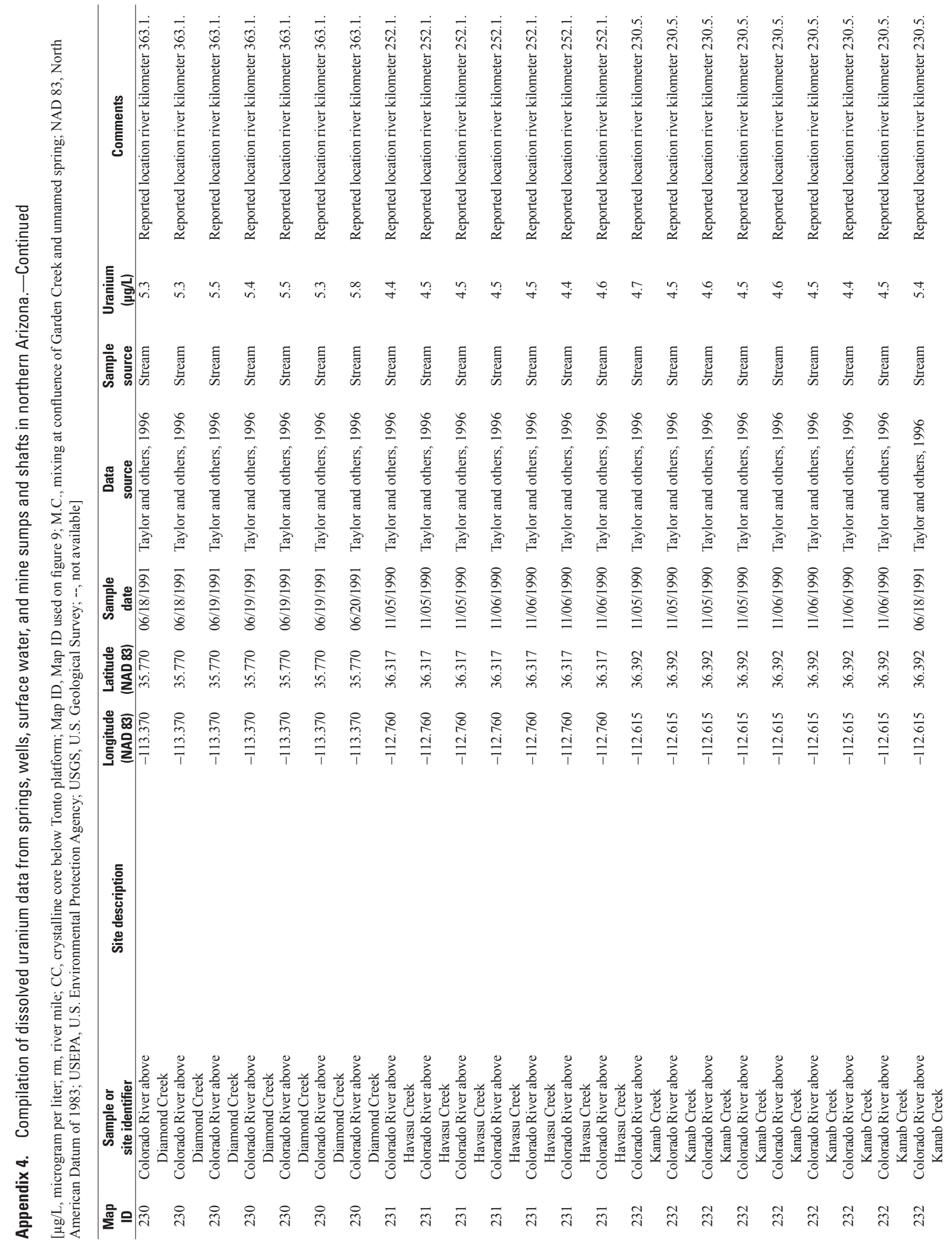




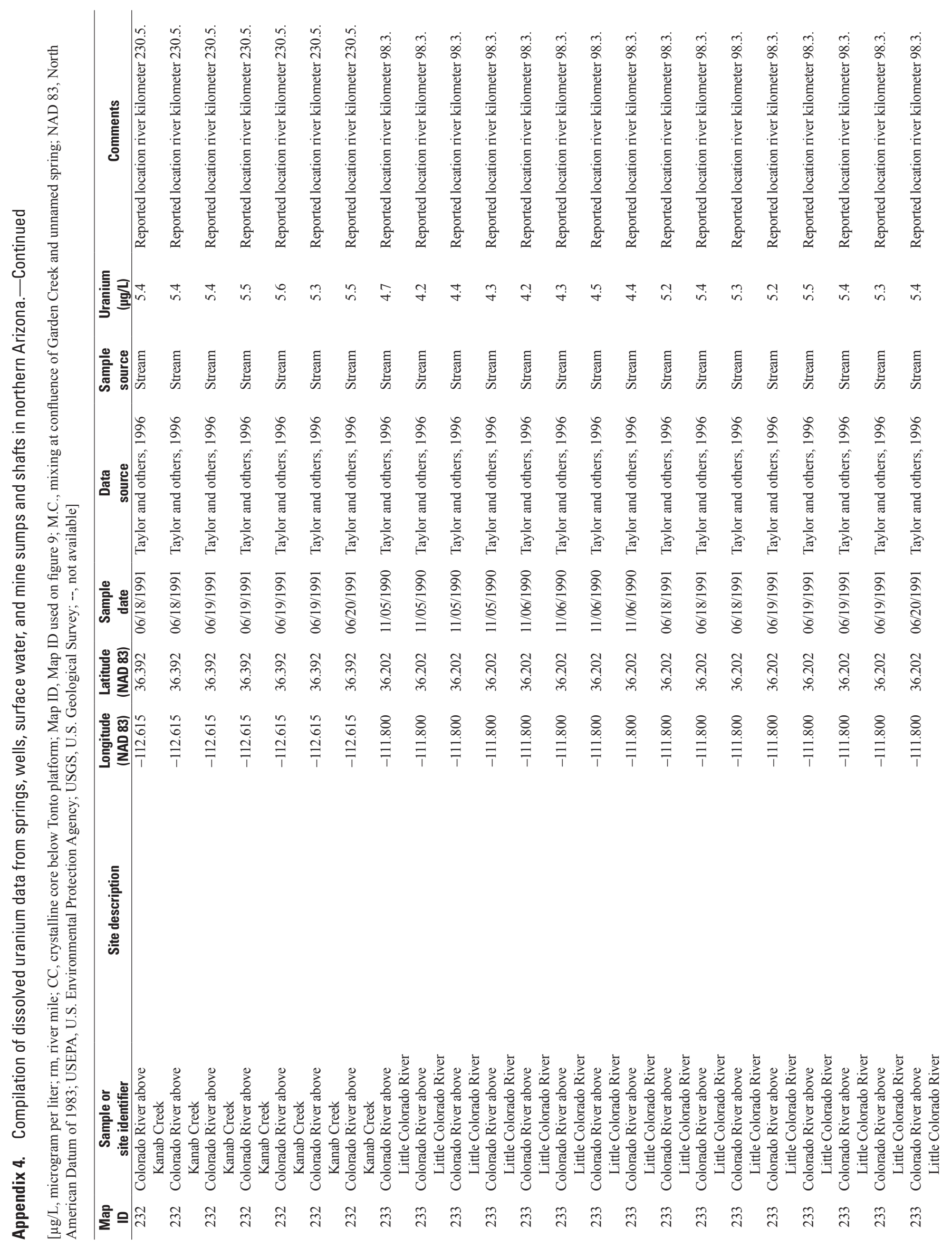




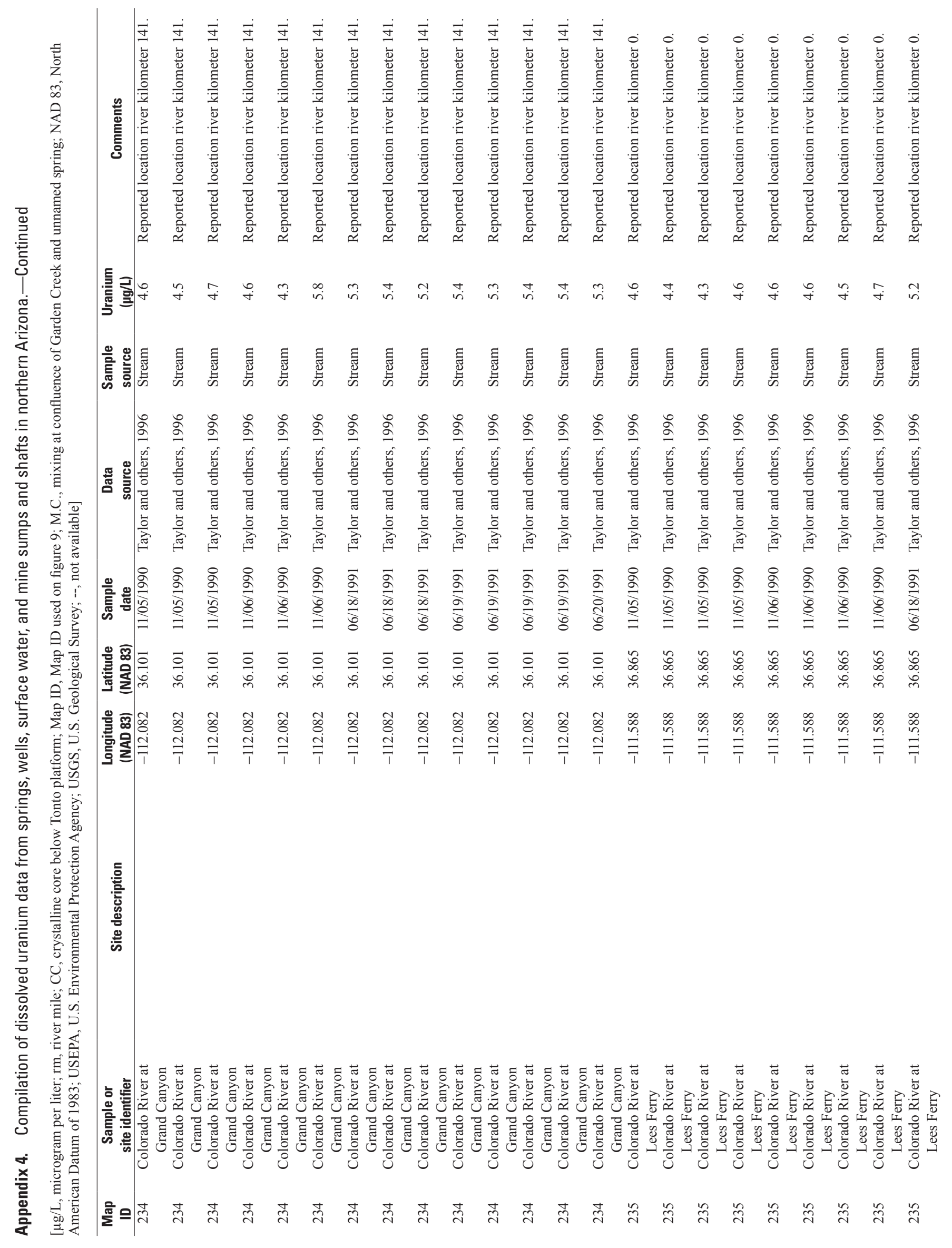




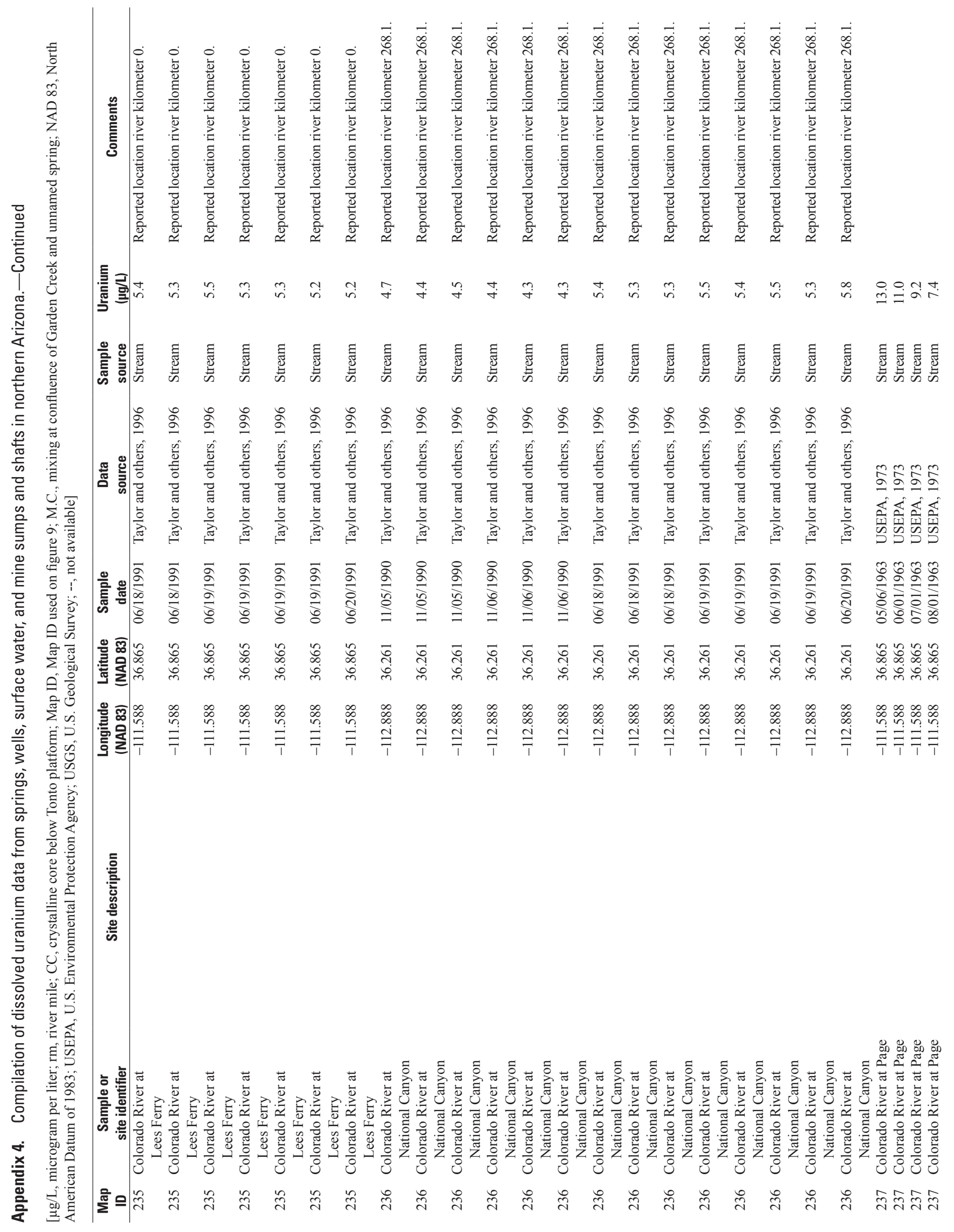




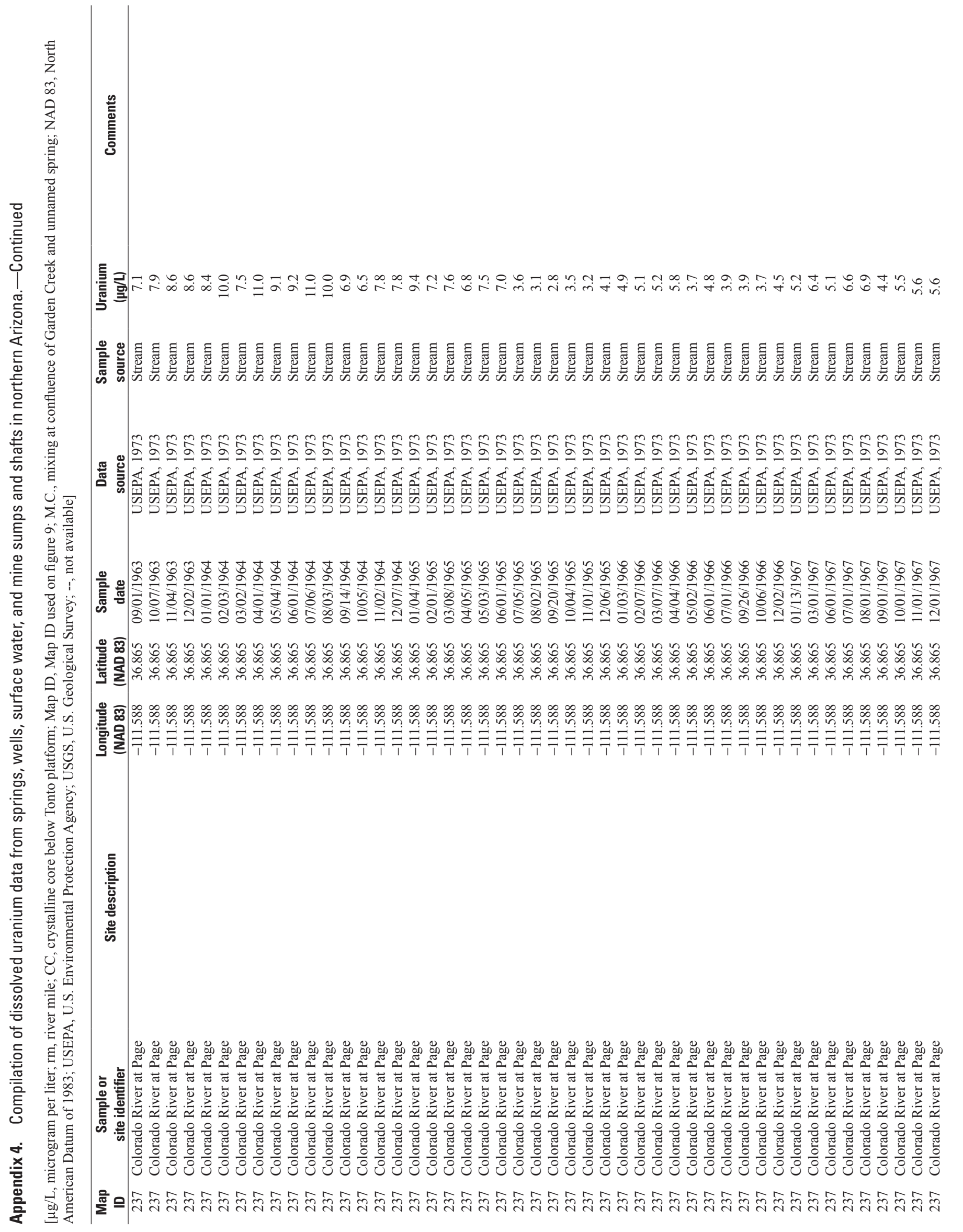




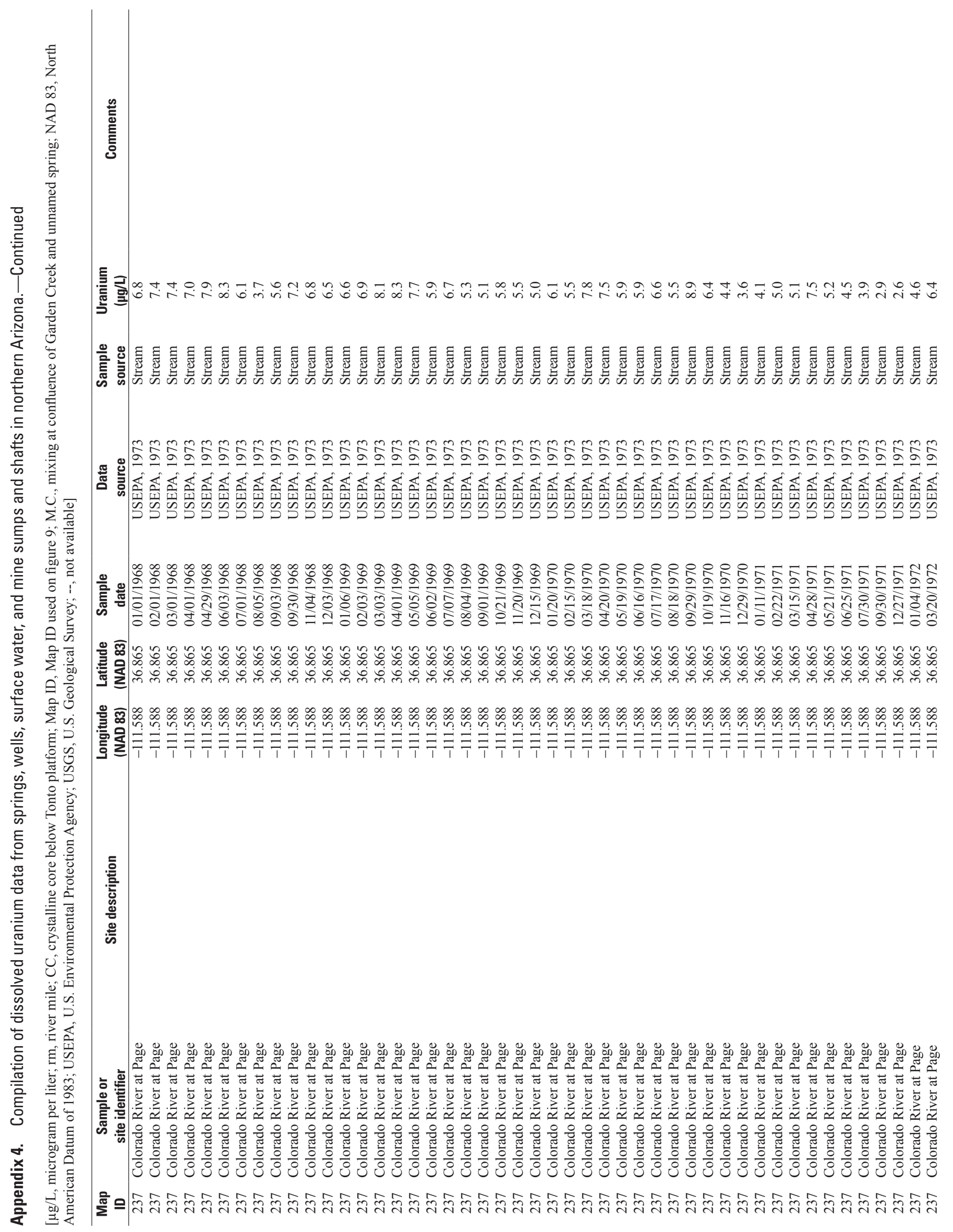




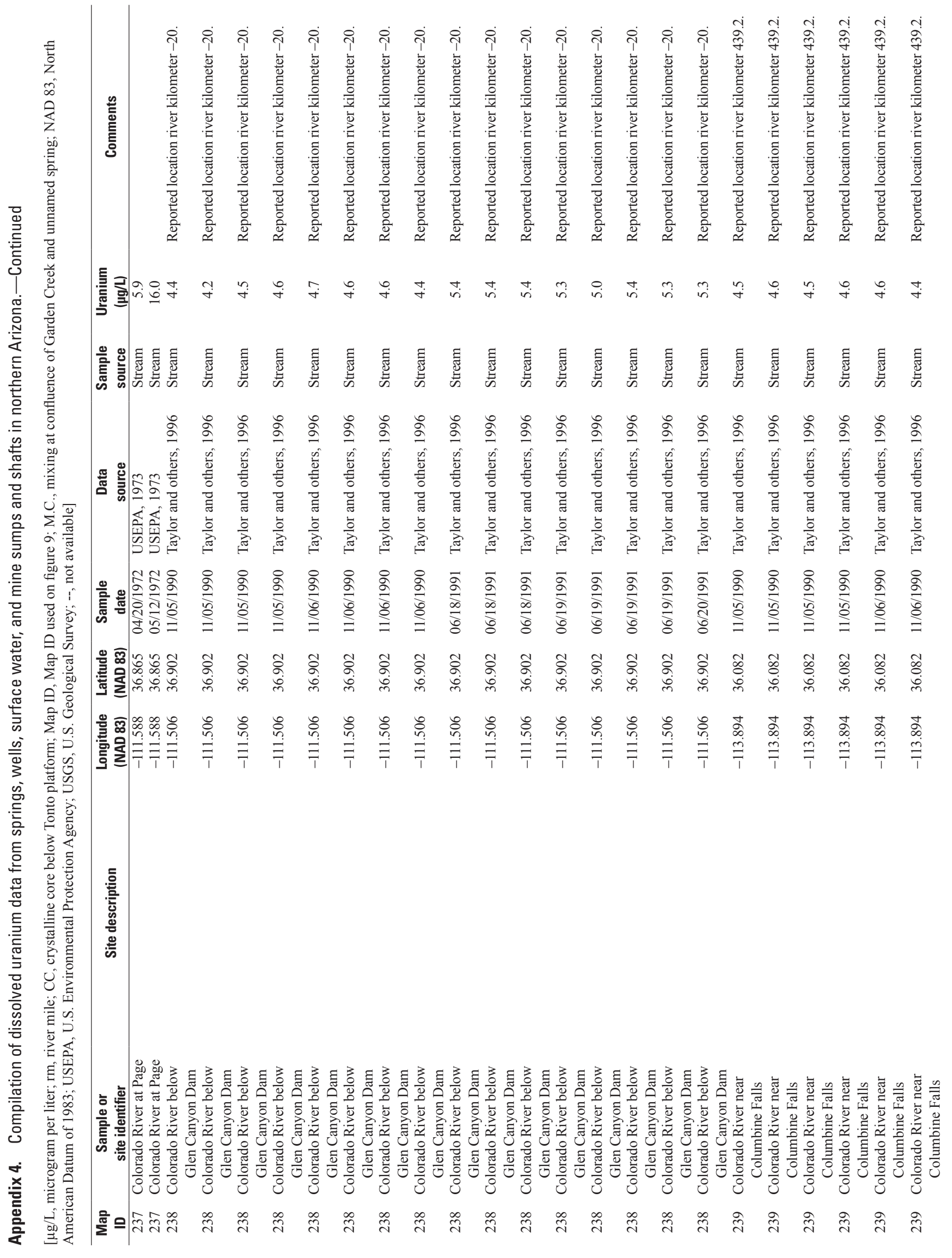




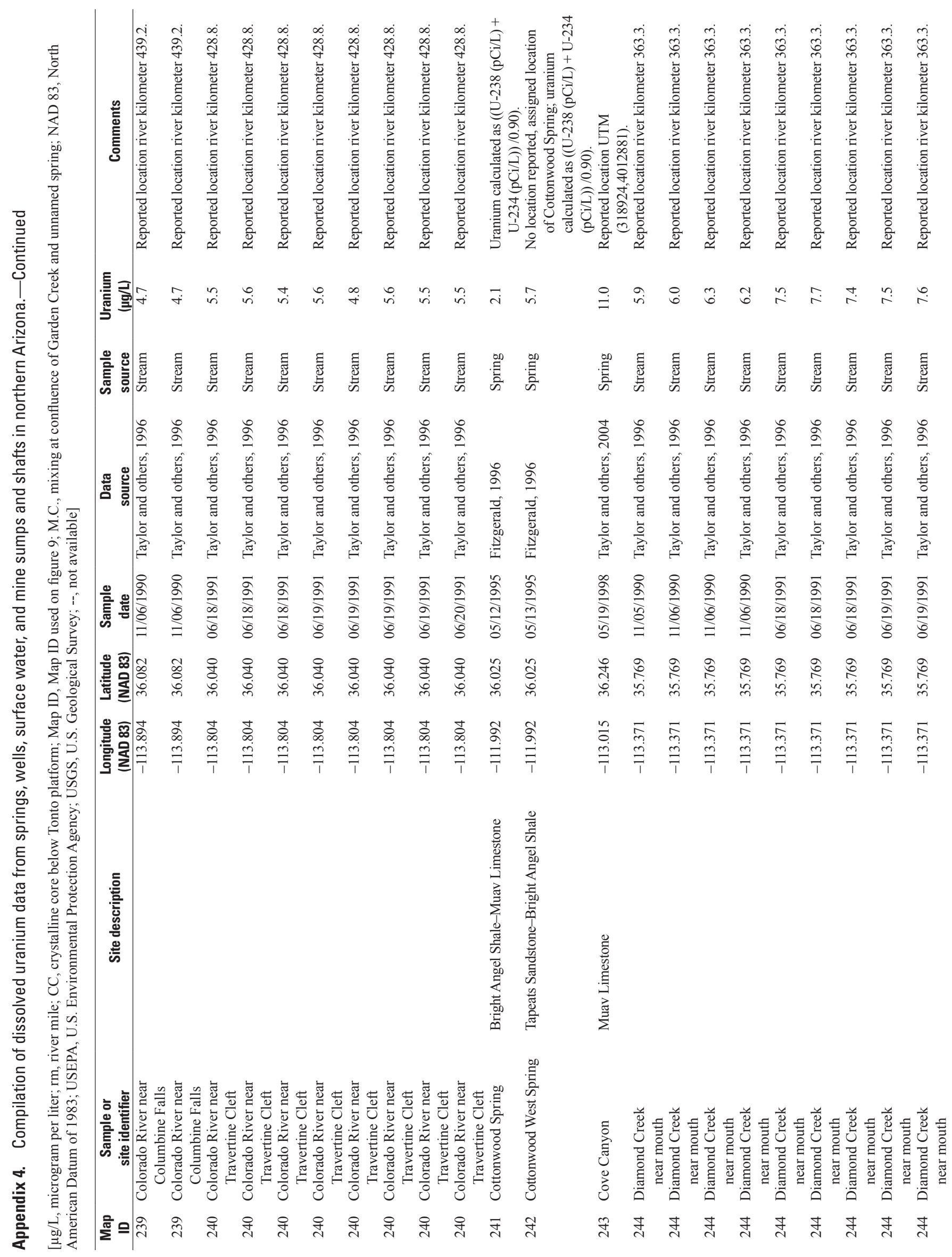




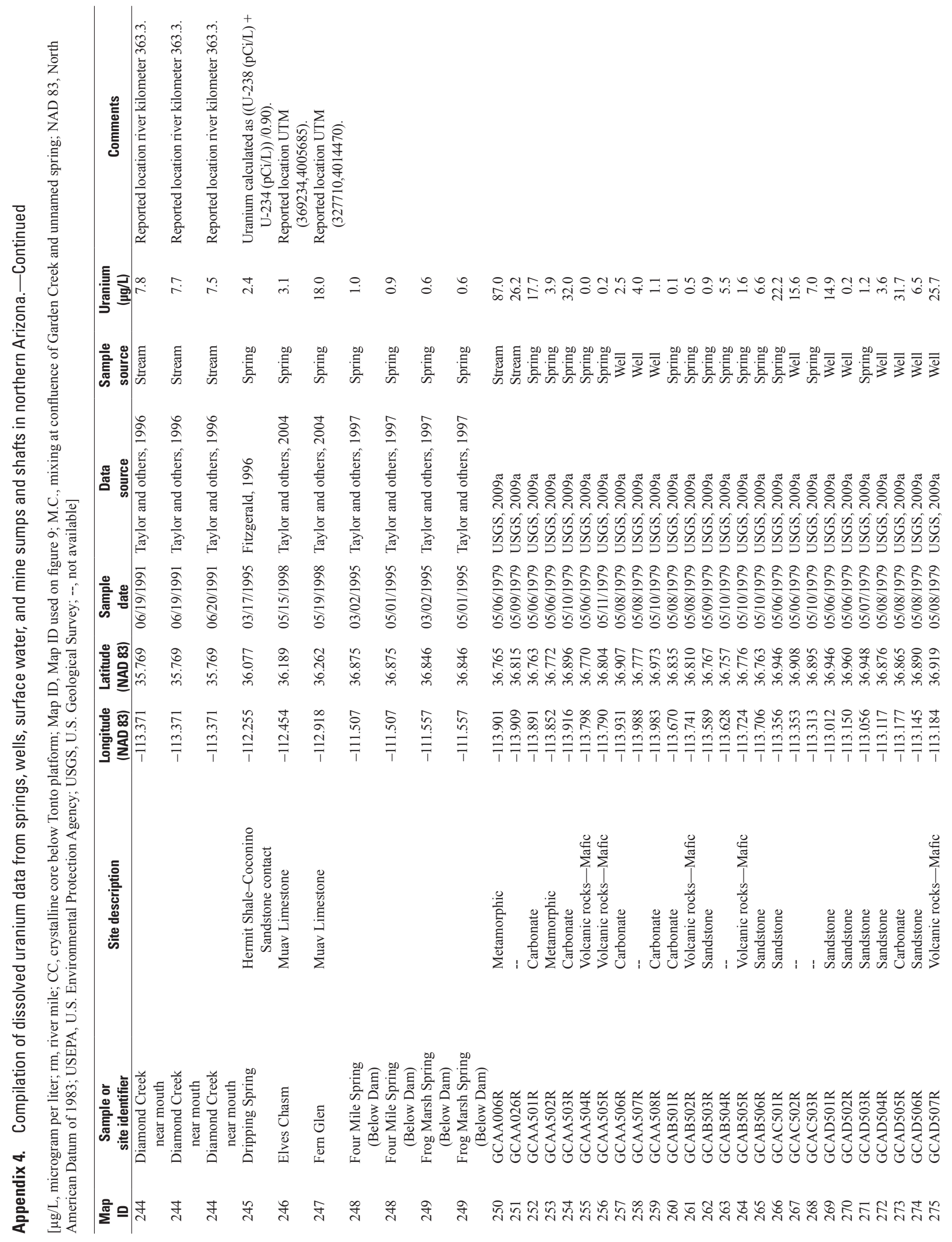




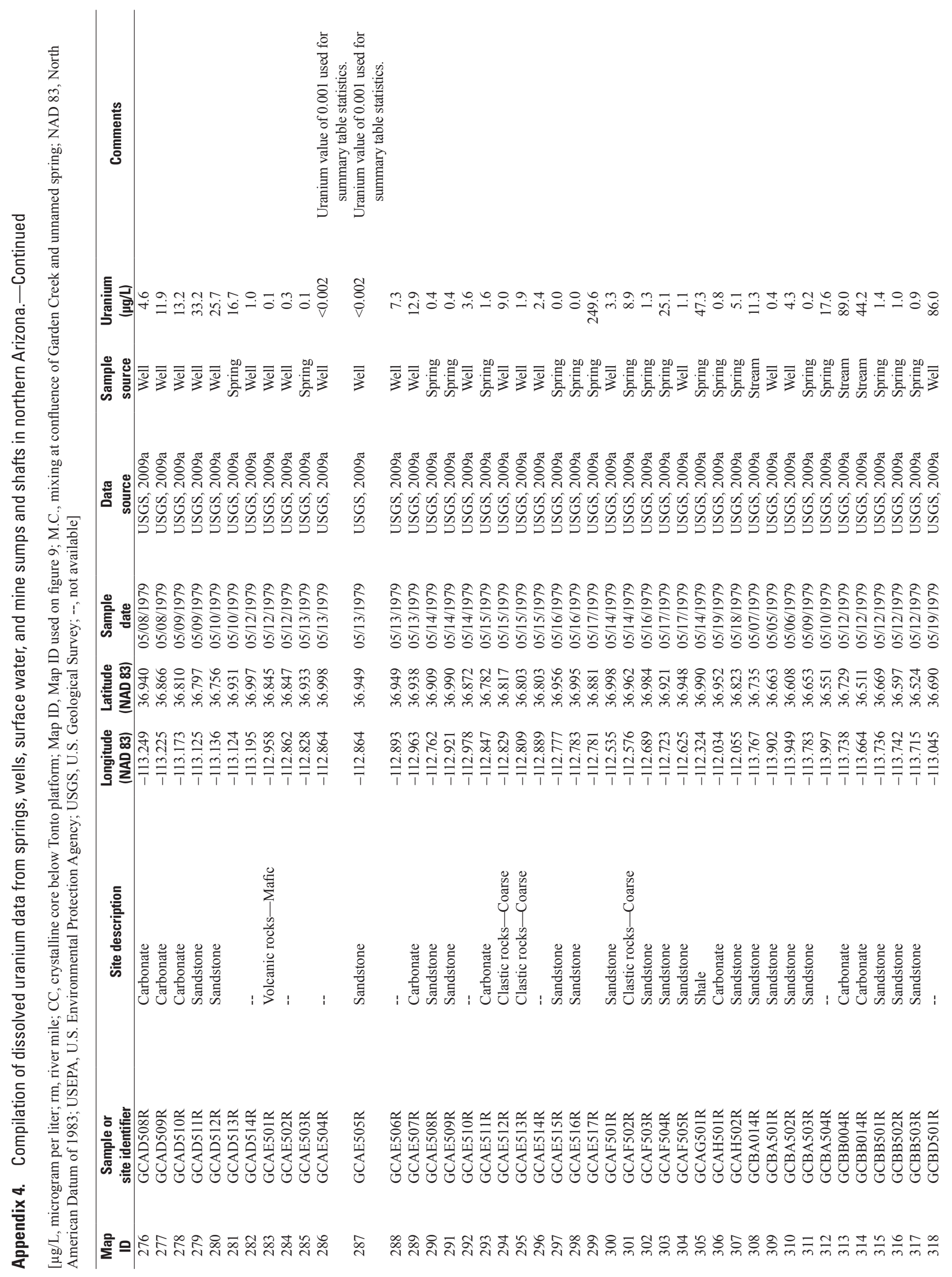




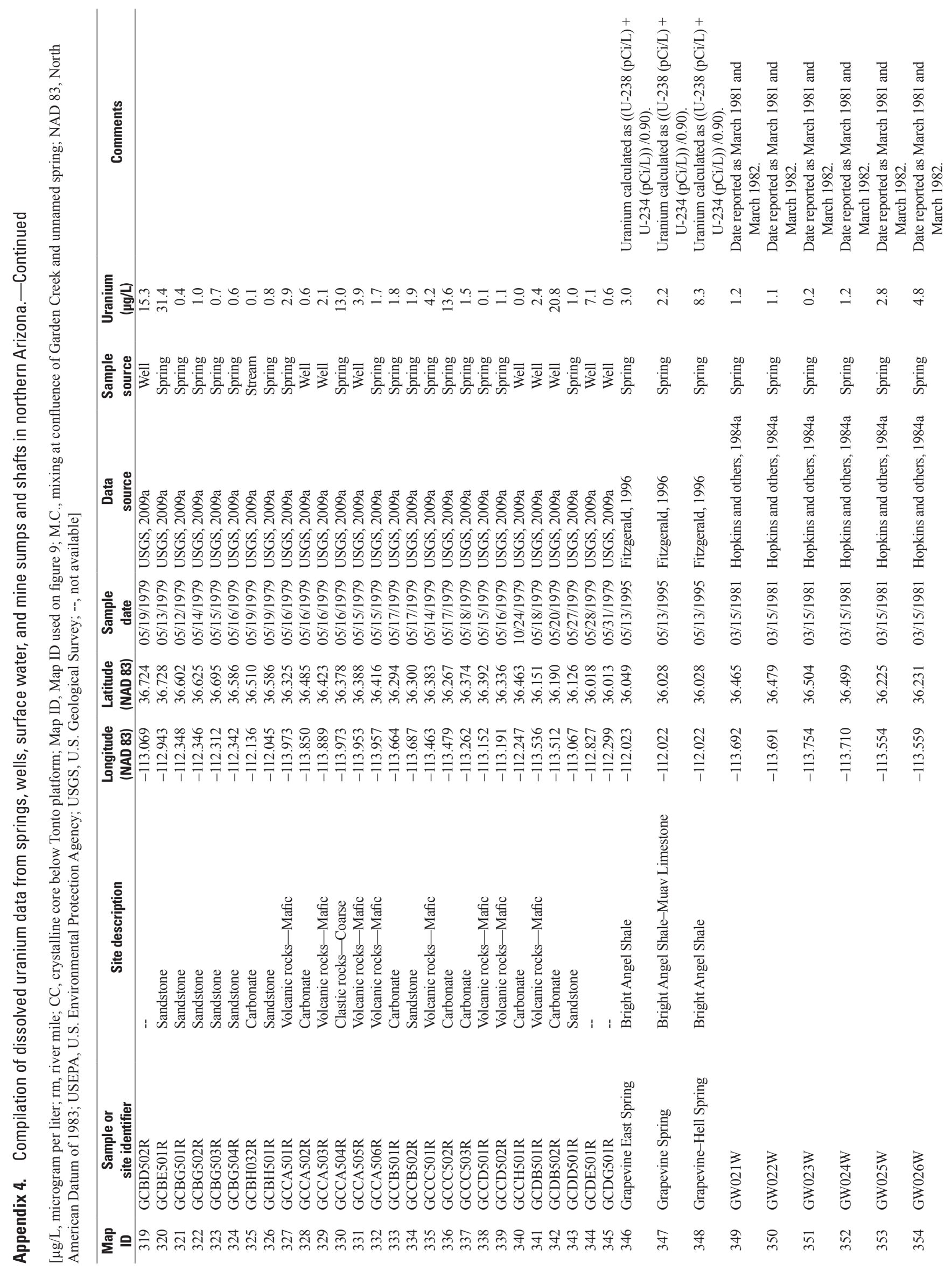




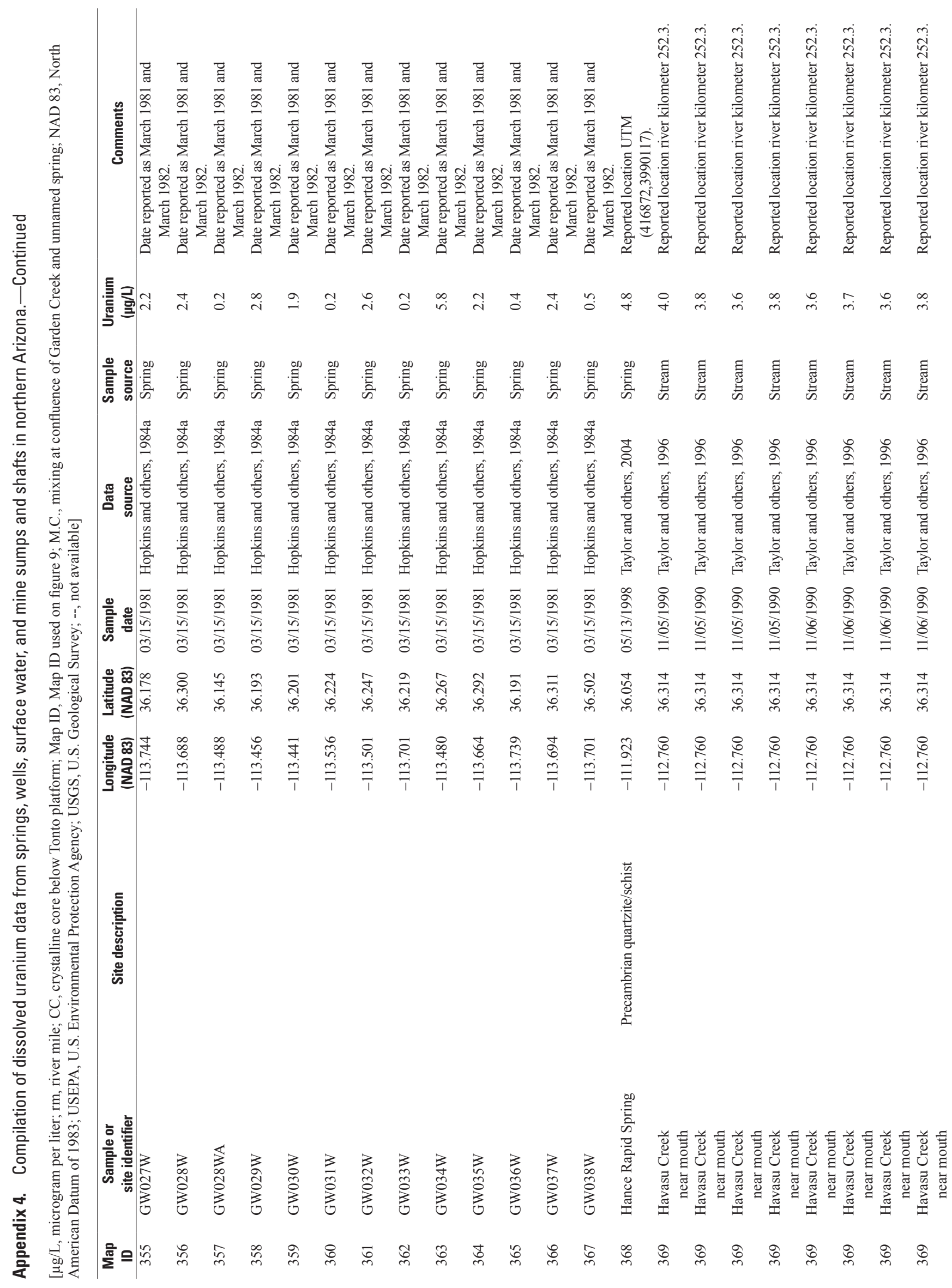




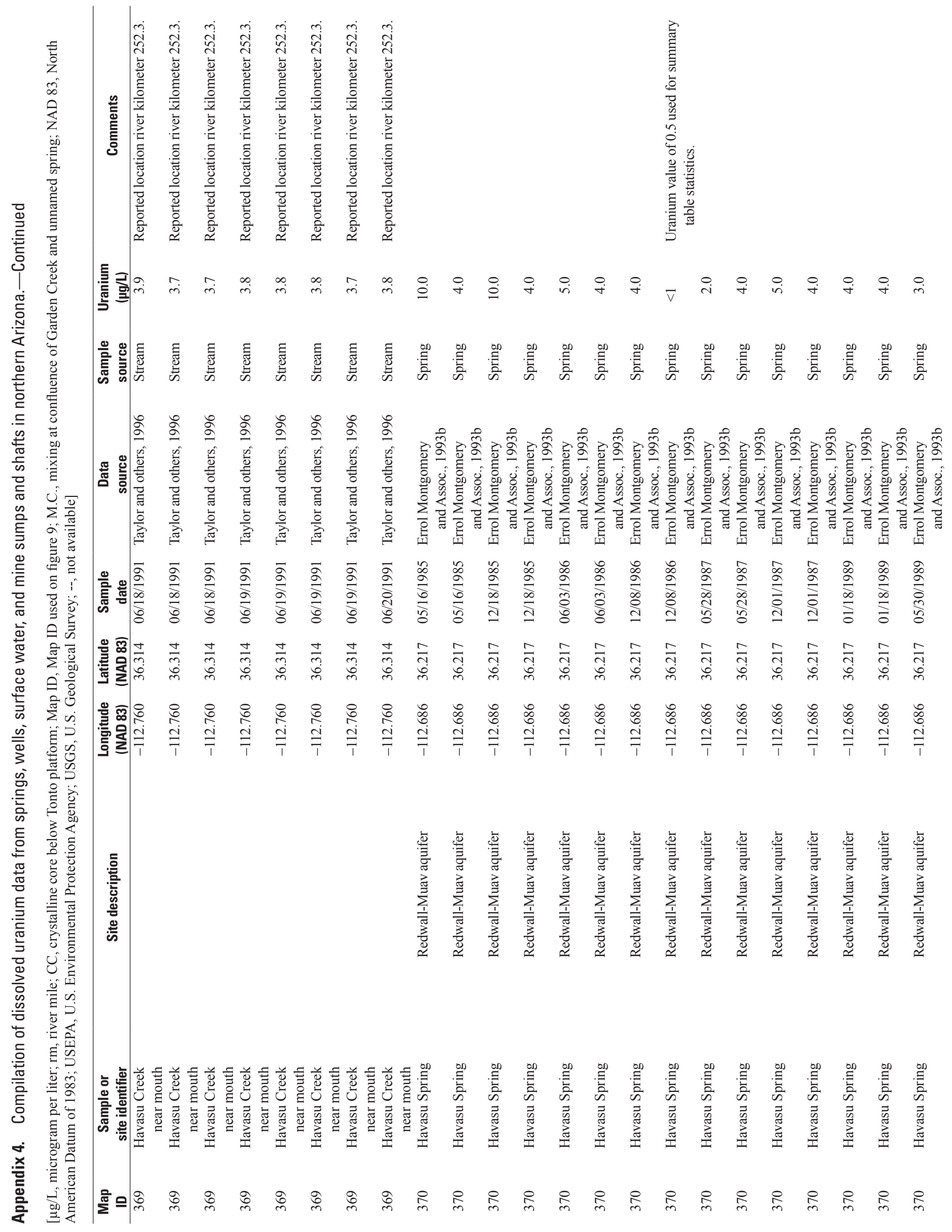




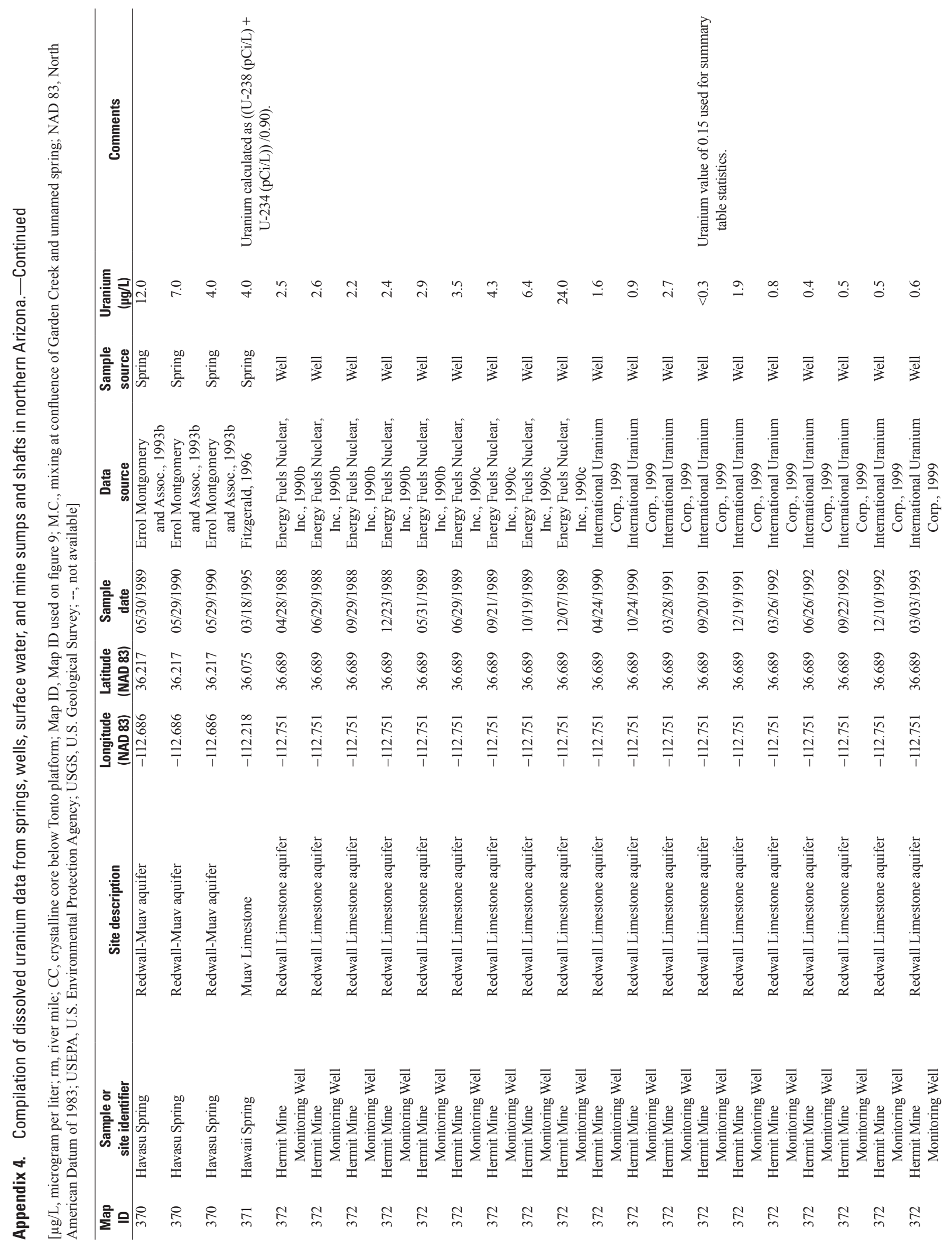




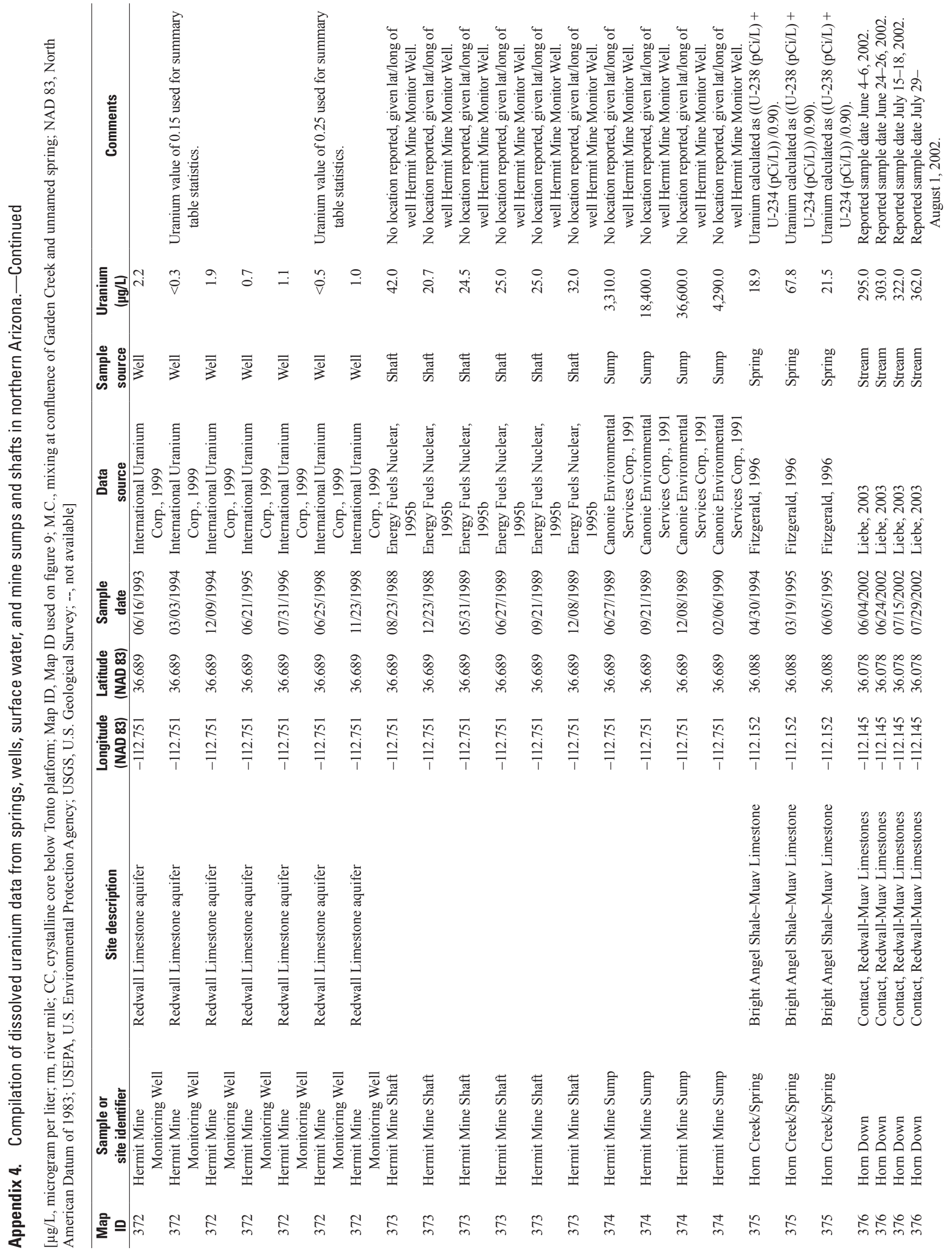




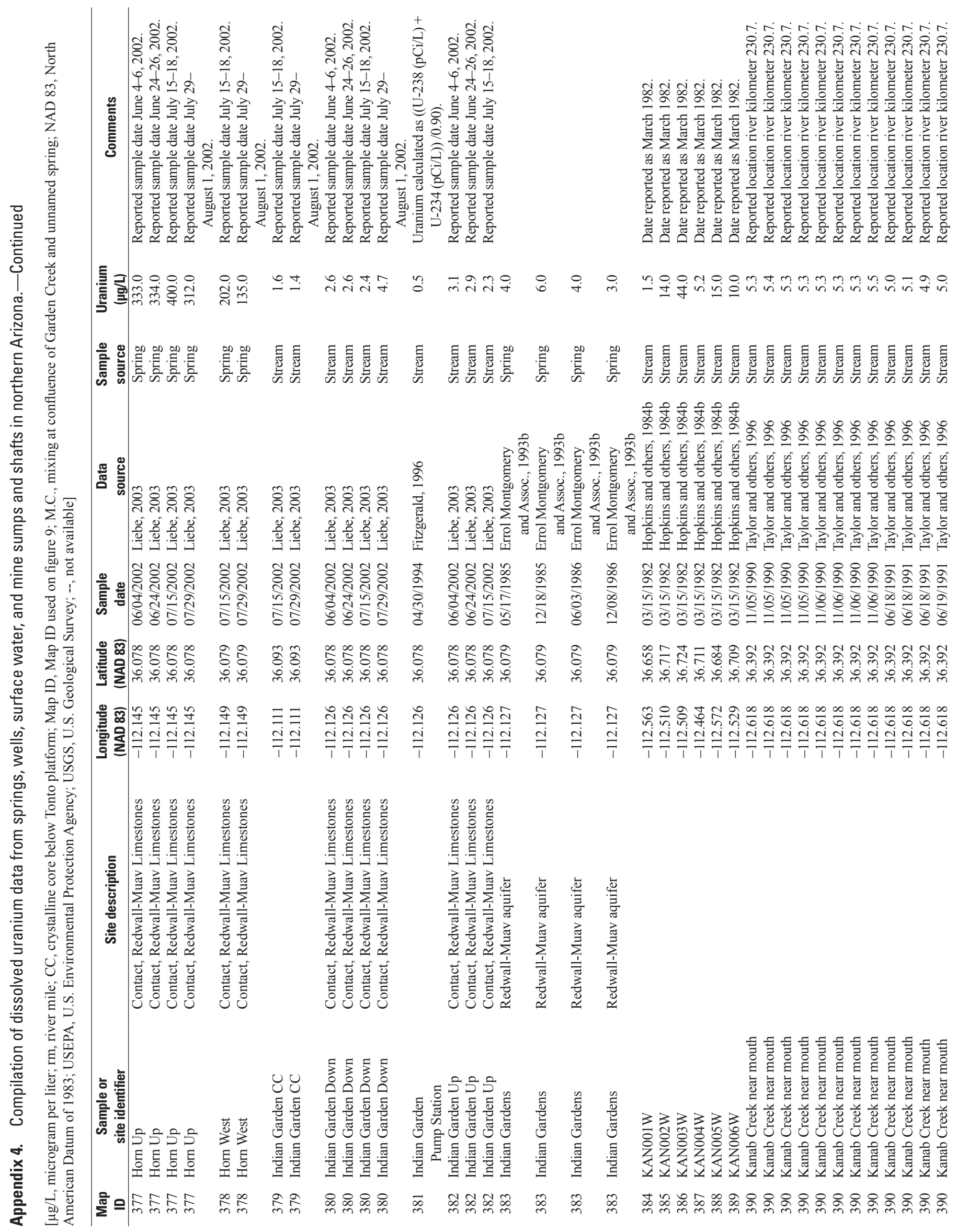




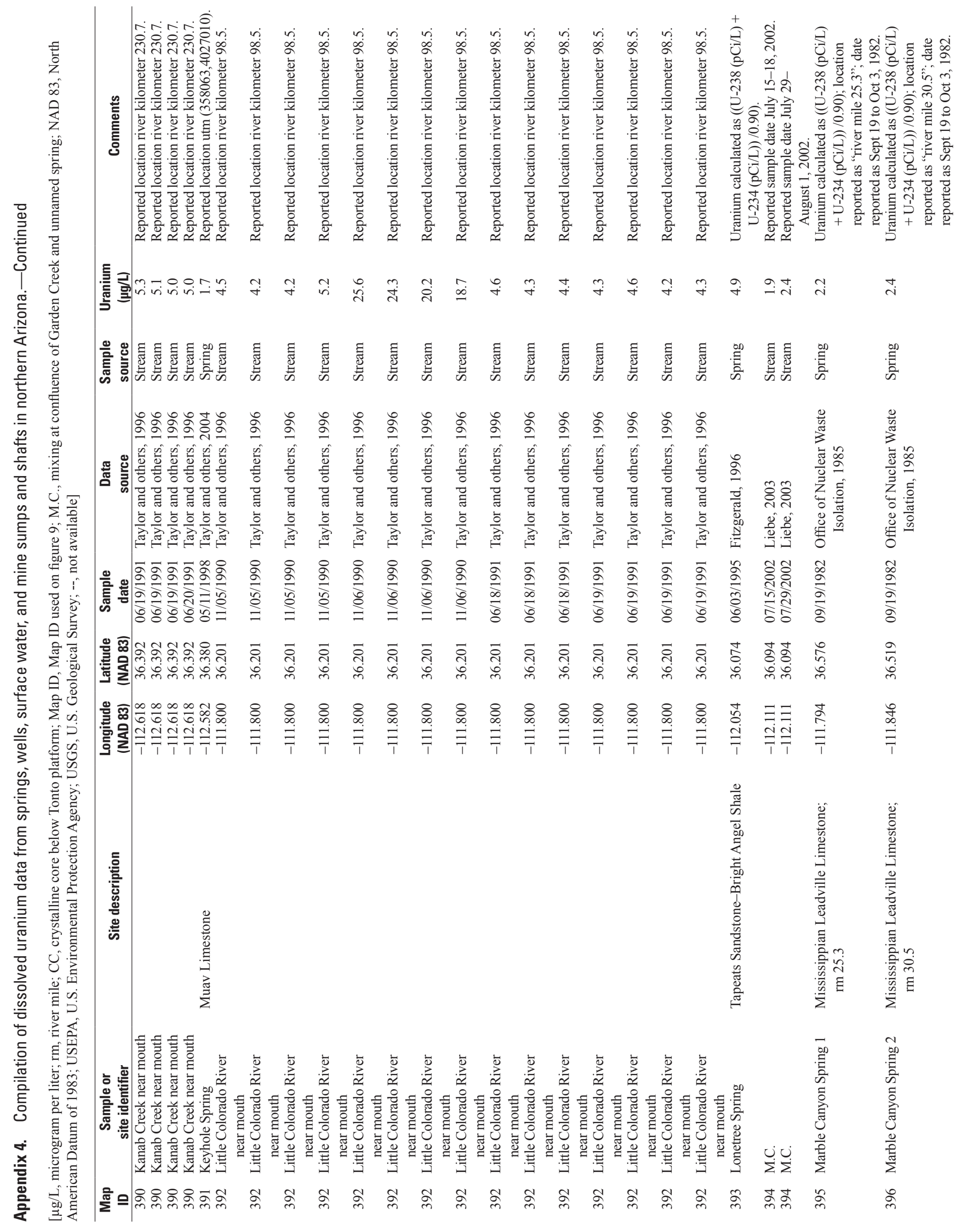




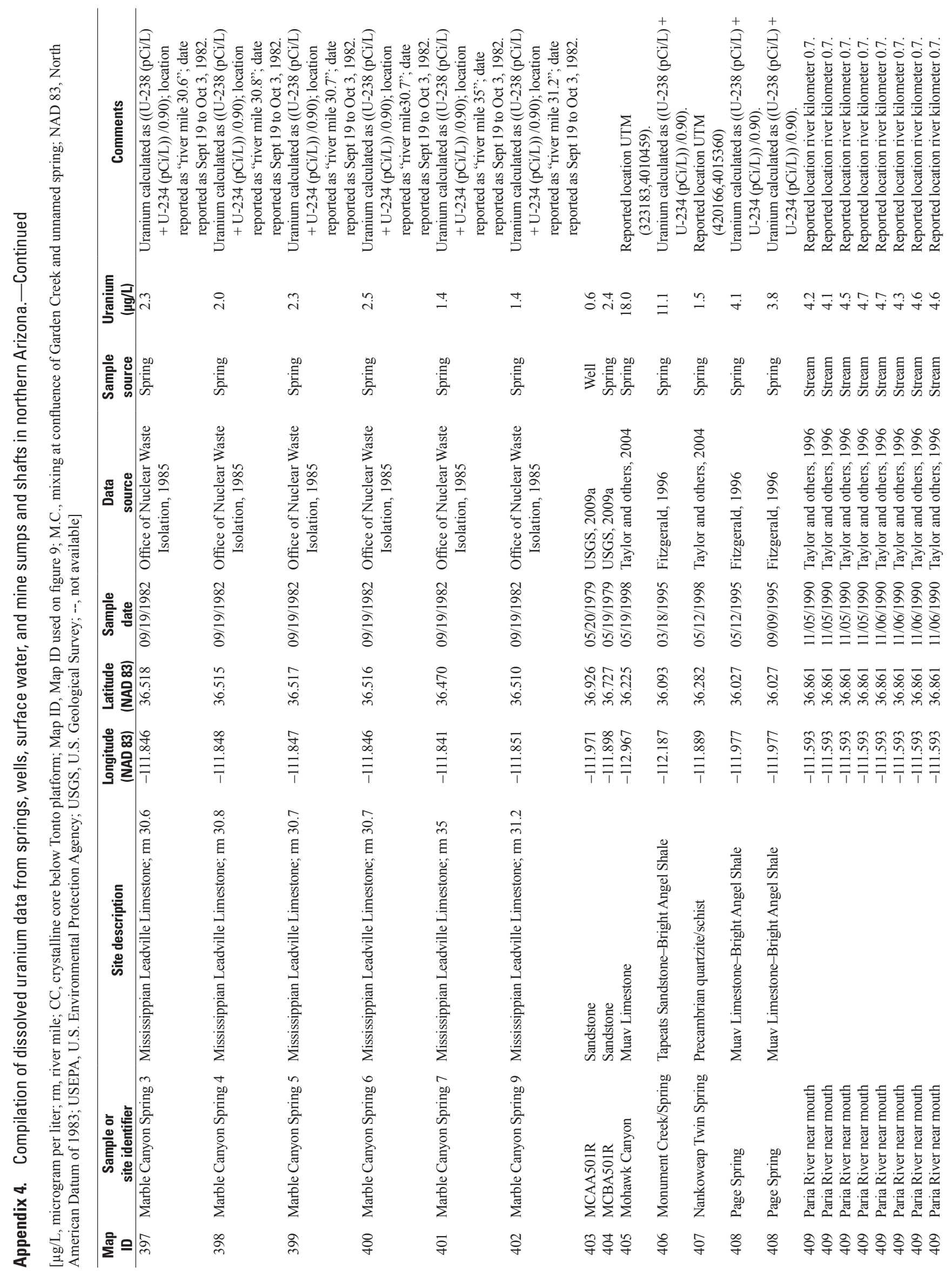




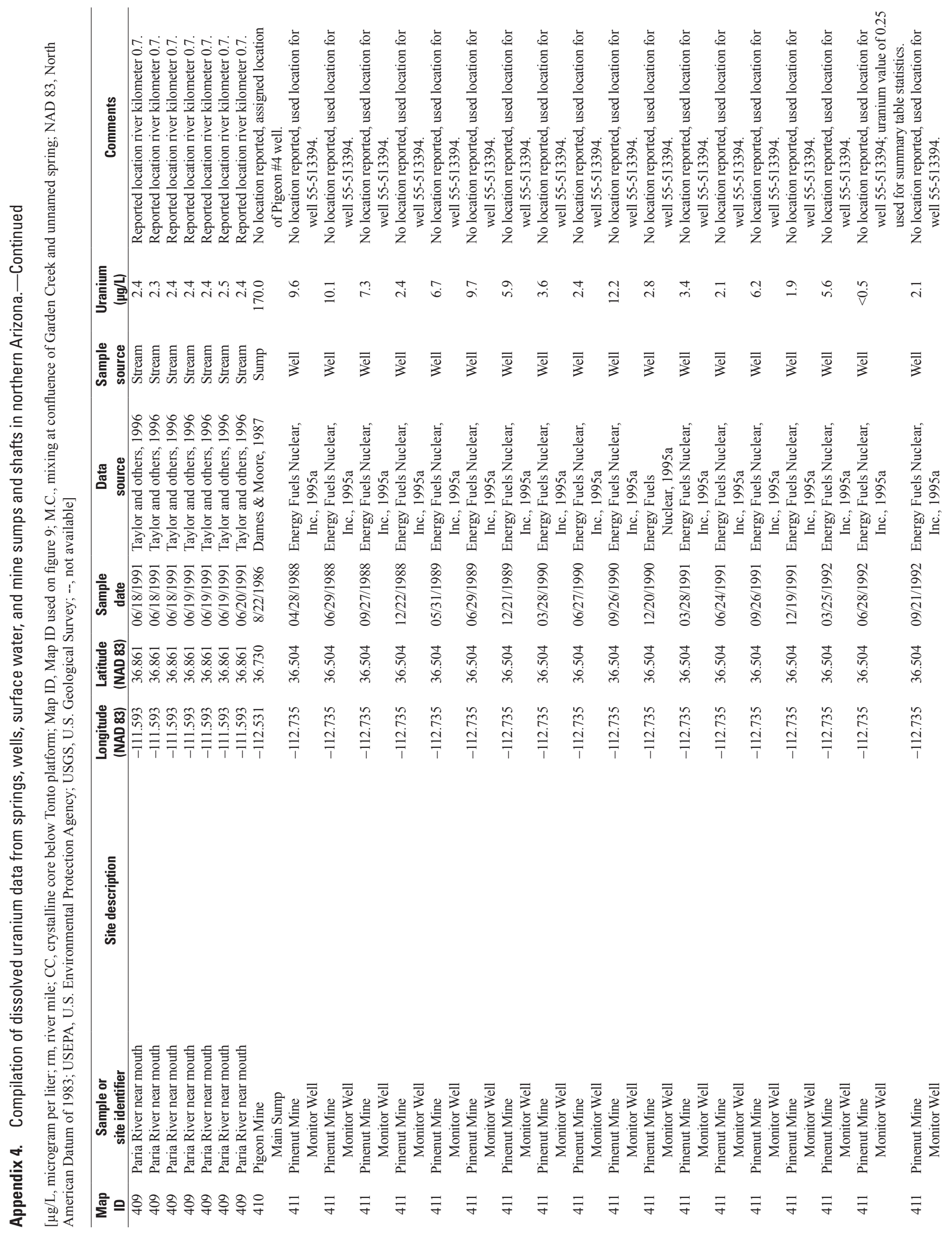




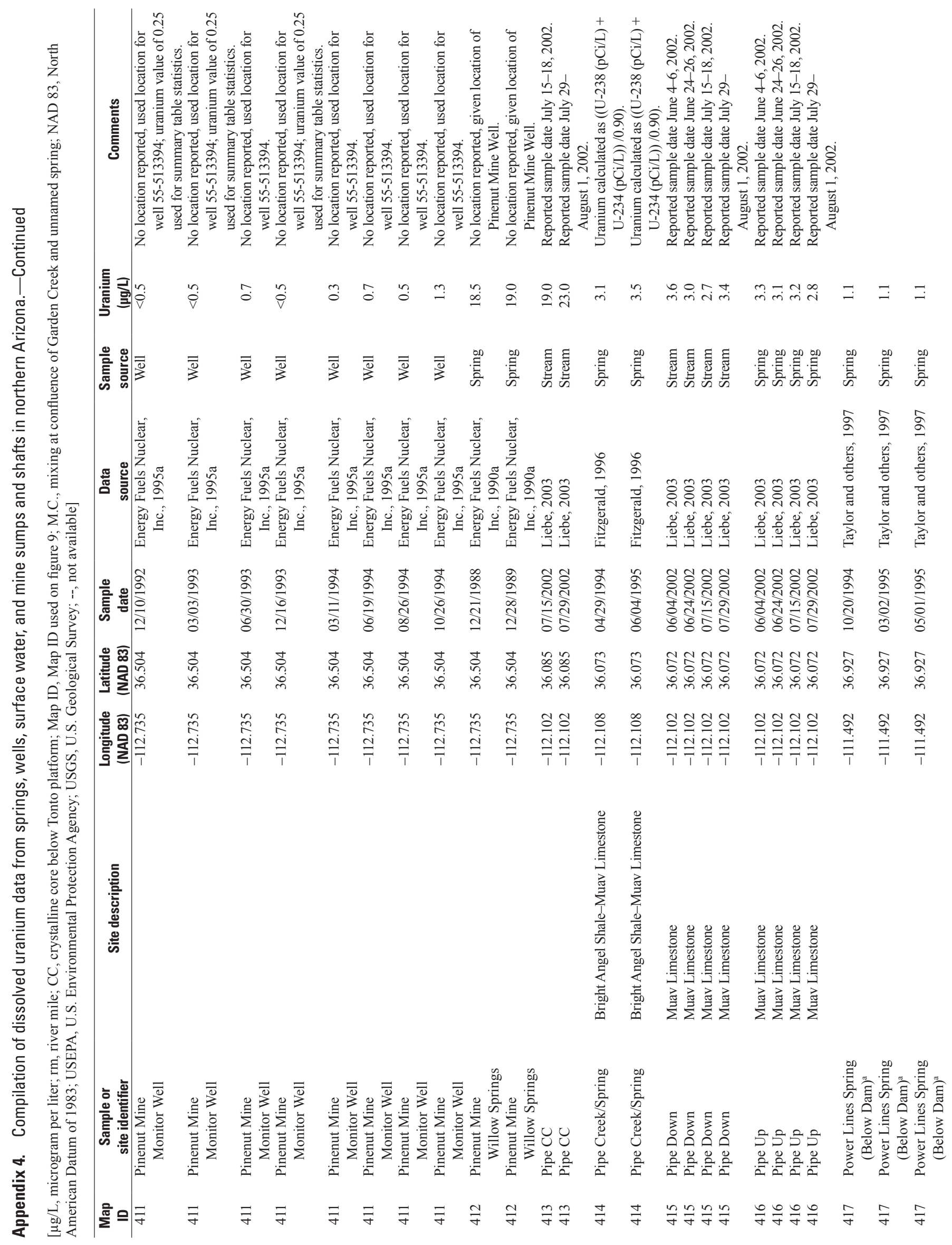




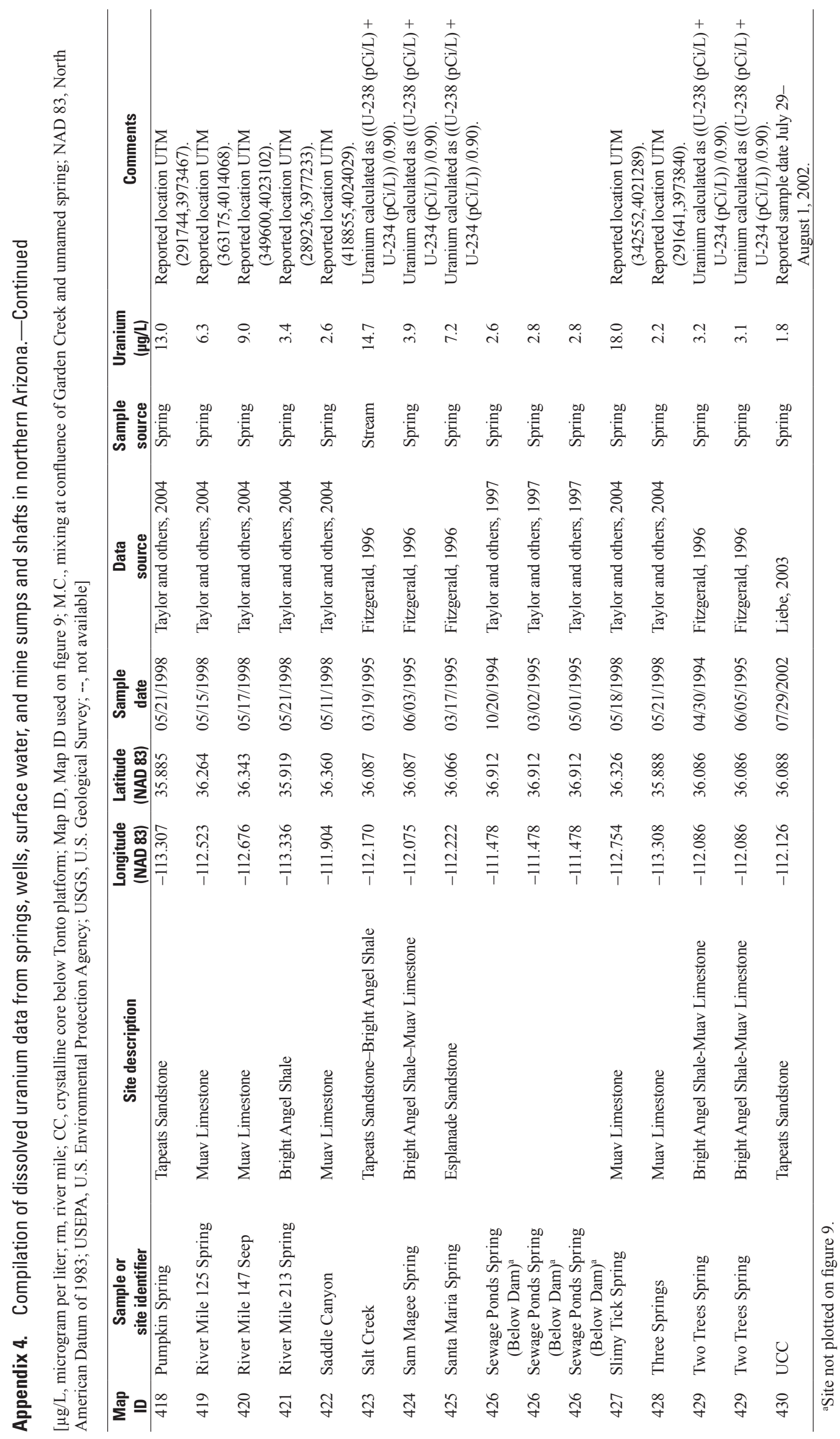




\section{Biological Pathways of Exposure and Ecotoxicity Values for Uranium and Associated Radionuclides}

By Jo Ellen Hinck, Greg Linder, Susan Finger, Edward Little, Donald Tillitt, and Wendy Kuhne

Chapter D of

Hydrological, Geological, and Biological Site Characterization

of Breccia Pipe Uranium Deposits in Northern Arizona

Edited by Andrea E. Alpine

Scientific Investigations Report 2010-5025 


\section{Contents}

Abstract

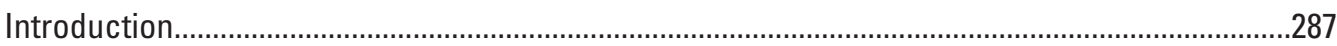

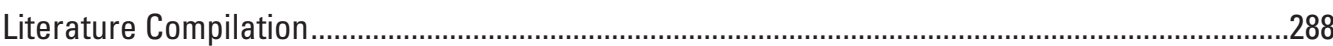

Sources of Uranium in Northern Arizona ..................................................................................28

Chemical Speciation of Uranium as It Relates to Biota ..............................................................28

Biological Receptors for Exposure Effects Associated with Uranium Mining ..............................294

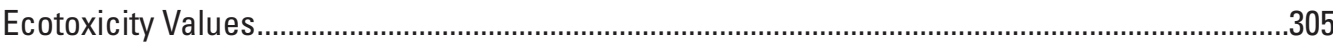

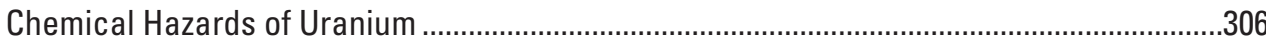

Biological Receptors in the Aquatic Food Chain ........................................................306

Algae, Cyanobacteria, and Aquatic Microorganisms ………………………......306

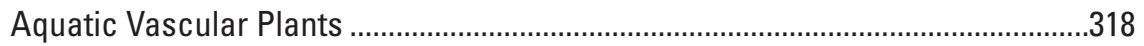

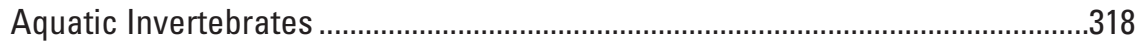

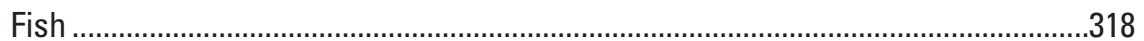

Biological Receptors in the Terrestrial Food Chain ...................................................318

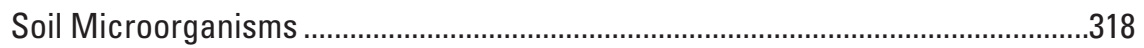

Terrestrial Nonvascular and Vascular Plants .......................................................318

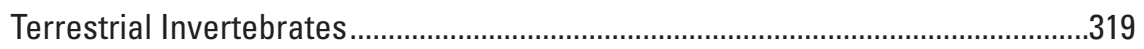

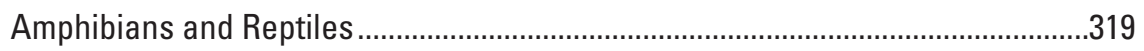

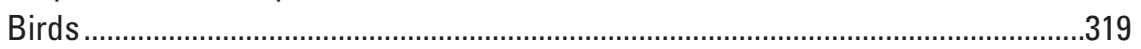

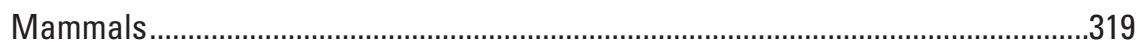

Bioconcentration Factors and Trophic Transfers........................................................320

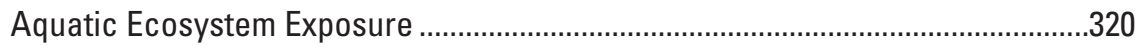

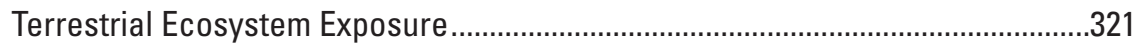

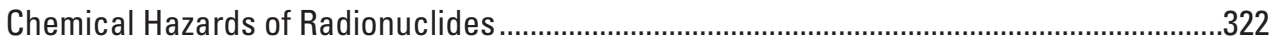

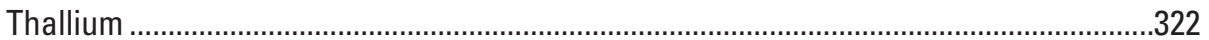

Algae, Cyanobacteria, and Aquatic Microorganisms ............................................323

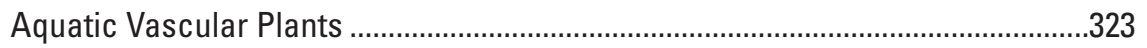

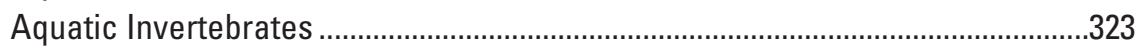

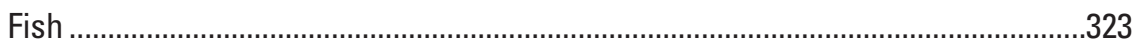

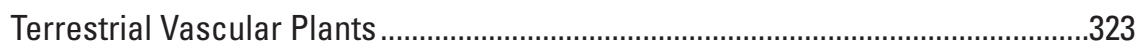

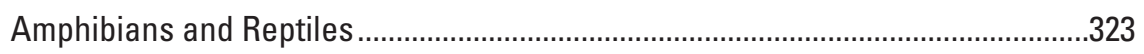

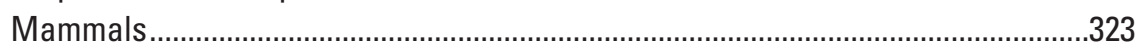

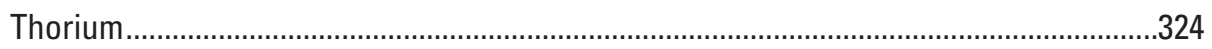

Algae, Cyanobacteria, and Aquatic Microorganisms ...........................................325

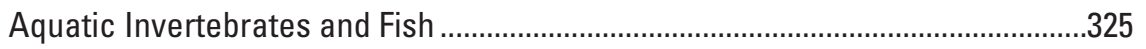

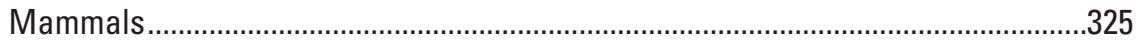

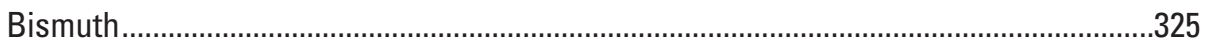

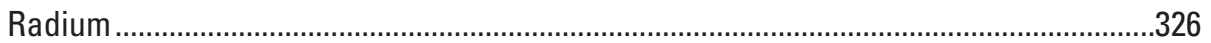

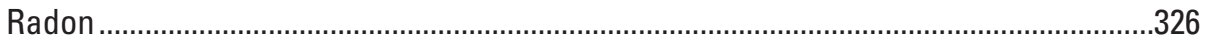

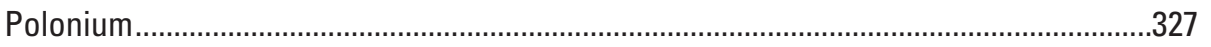

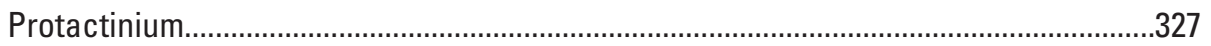

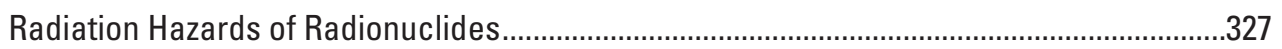

Biological Receptors in the Aquatic Food Chain ........................................................330

Algae, Cyanobacteria, and Aquatic Vascular Plants...............................................330

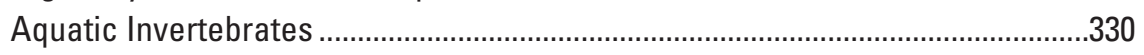

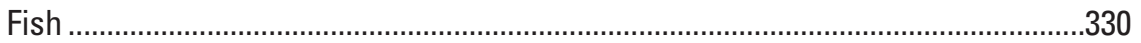


Biological Receptors in the Terrestrial Food Chain..........................................................333

Terrestrial Nonvascular and Vascular Plants ..........................................................333

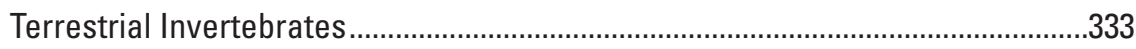

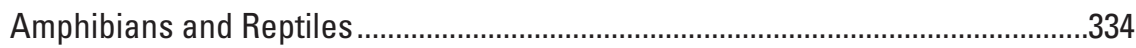

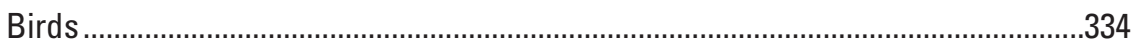

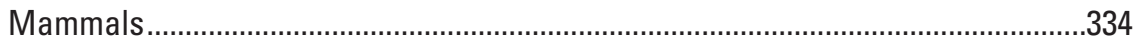

Radionuclide and Radiation Transfers in Aquatic and Terrestrial Ecosystems ............335

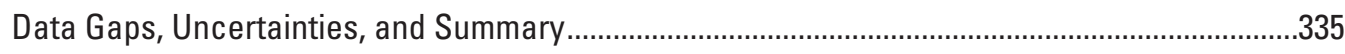

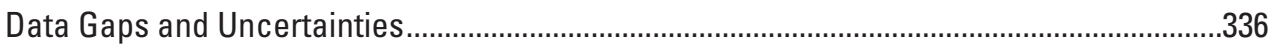

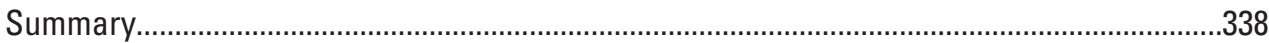

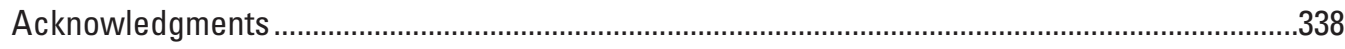

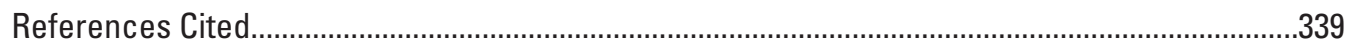

Appendix 1. ${ }^{235}$ Uranium and ${ }^{232}$ Thorium Decay Series .........................................................351

Appendix 2. Radiation Measurement........................................................................................353

\section{Figures}

1. Uranium provinces in the western United States ..........................................................290

2. Segregation areas, mine sites, and sample collection locations...................................291

3. Schematic cross section of a solution-collapse breccia pipe in northern Arizona .............292

4. Diagrammatic representation of generalized food web for the segregation areas.............295

5. Range distributions of threatened and endangered fish, amphibians, and reptiles

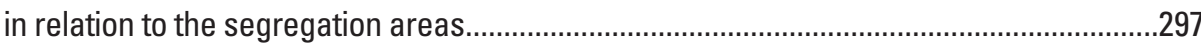

6. Range distributions of threatened and endangered birds in relation to the

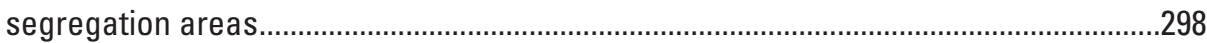

7. Range distributions of threatened and endangered plants in relation to the

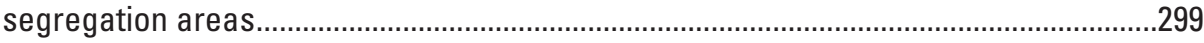

8. Exposure pathways among generalized terrestrial and aquatic habitats .......................304

9. Comparative radiosensitivity of different organisms .....................................................329

\section{Tables}

1. Radiation and half-life for constituent elements of ${ }^{238} \mathrm{U}$ decay series ...........................293

2. Threatened and endangered species occurring within the segregation areas .............296

3. Examples of species of concern documented within the segregation areas ................300

4. Exposure pathway matrix for aquatic and terrestrial biological receptors.....................303

5. Amount of chemical toxicity data available for biological receptors ..............................306

6. Guidance values for chemical and radiation toxicity .....................................................307

7. Biological effects thresholds related to uranium chemical toxicity .................................310

8. Biological effects thresholds related to thallium chemical toxicity................................316

9. Biological effects thresholds related to radiation toxicity..............................................331 


\section{Conversion Factors}

Inch/Pound to SI

\begin{tabular}{lcl}
\hline Multiply & By & To obtain \\
\hline ton, short $(2,000 \mathrm{lb})$ & Mass & \\
\hline
\end{tabular}

SI to Inch/Pound

\begin{tabular}{lcl}
\hline Multiply & By & To obtain \\
\hline millimeter $(\mathrm{mm})$ & Length & \\
\hline & 0.03937 & inch (in.) \\
\hline liter per kilogram $(\mathrm{L} / \mathrm{kg})$ & Specific volume & \\
\hline & 27.68 & cubic inch per pound $\left(\mathrm{in}^{3} / \mathrm{lb}\right)$ \\
\hline milligram per cubic meter $\left(\mathrm{mg} / \mathrm{m}^{3}\right)$ & Density & \\
microgram per cubic centimeter $\left(\mu \mathrm{g} / \mathrm{cm}^{3}\right)$ & 0.00000006242 & pound per cubic foot $\left(\mathrm{lb} / \mathrm{ft}^{3}\right)$ \\
& 0.0000624220 & pound per cubic foot $\left(\mathrm{lb} / \mathrm{ft}^{3}\right)$ \\
\hline microgram per square centimeter $\left(\mu \mathrm{g} / \mathrm{cm}^{2}\right)$ & Surface density & \\
\hline & 0.0000002276 & ounce per square inch $\left(\mathrm{oz} / \mathrm{in}^{2}\right)$ \\
\hline milligram per liter $(\mathrm{mg} / \mathrm{L})$ & Concentration & \\
microgram per liter $(\mu \mathrm{g} / \mathrm{L})$ & 1.0 & parts per million $(\mathrm{ppm})$ \\
milligram per kilogram $(\mathrm{mg} / \mathrm{kg})$ & 1.0 & parts per billion $(\mathrm{ppb})$ \\
nanomole per cubic centimeter $\left(\mathrm{nmol} / \mathrm{cm}^{3}\right)$ & 0.000016 & ounce per pound $(\mathrm{oz} / \mathrm{lb})$ \\
& 1,000 & nanomole per liter $(\mathrm{nmol} / \mathrm{L})$ \\
\hline becquerel $(\mathrm{Bq})$ & Radioactivity & \\
becquerel per kilogram $(\mathrm{Bq} / \mathrm{kg})$ & $3.7 \times 10^{10}$ & curie $(\mathrm{Ci})$ \\
gray $(\mathrm{Gy})$ & 37 & picocurie per gram $(\mathrm{pCi} / \mathrm{g})$ \\
sievert $(\mathrm{Si})$ & 0.01 & rad $(\mathrm{rad})$ \\
coulomb/kg in air & 0.01 & rem (rem) \\
\hline
\end{tabular}




\title{
Chapter D \\ Biological Pathways of Exposure and Ecotoxicity Values for Uranium and Associated Radionuclides
}

\author{
By Jo Ellen Hinck, Greg Linder, Susan Finger, Edward Little, Donald Tillitt, and Wendy Kuhne
}

\section{Abstract}

This chapter compiles available chemical and radiation toxicity information for plants and animals from the scientific literature on naturally occurring uranium and associated radionuclides. Specifically, chemical and radiation hazards associated with radionuclides in the uranium decay series including uranium, thallium, thorium, bismuth, radium, radon, protactinium, polonium, actinium, and francium were the focus of the literature compilation. In addition, exposure pathways and a food web specific to the segregation areas were developed. Major biological exposure pathways considered were ingestion, inhalation, absorption, and bioaccumulation, and biota categories included microbes, invertebrates, plants, fishes, amphibians, reptiles, birds, and mammals. These data were developed for incorporation into a risk assessment to be conducted as part of an environmental impact statement for the Bureau of Land Management, which would identify representative plants and animals and their relative sensitivities to exposure of uranium and associated radionuclides. This chapter provides pertinent information to aid in the development of such an ecological risk assessment but does not estimate or derive guidance thresholds for radionuclides associated with uranium.

Previous studies have not attempted to quantify the risks to biota caused directly by the chemical or radiation releases at uranium mining sites, although some information is available for uranium mill tailings and uranium mine closure activities. Research into the biological impacts of uranium exposure is strongly biased towards human health and exposure related to enriched or depleted uranium associated with the nuclear energy industry rather than naturally occurring uranium associated with uranium mining. Nevertheless, studies have reported that uranium and other radionuclides can affect the survival, growth, and reproduction of plants and animals.

Exposure to chemical and radiation hazards is influenced by a plant's or an animal's life history and surrounding environment. Various species of plants, invertebrates, fishes, amphibians, reptiles, birds, and mammals found in the segregation areas that are considered species of concern by State and Federal agencies were included in the development of the site-specific food web. The utilization of subterranean habitats (burrows in uranium-rich areas, burrows in waste rock piles or reclaimed mining areas, mine tunnels) in the seasonally variable but consistently hot, arid environment is of particular concern in the segregation areas. Certain species of reptiles, amphibians, birds, and mammals in the segregation areas spend significant amounts of time in burrows where they can inhale or ingest uranium and other radionuclides through digging, eating, preening, and hibernating. Herbivores may also be exposed though the ingestion of radionuclides that have been aerially deposited on vegetation. Measured tissues concentrations of uranium and other radionuclides are not available for any species of concern in the segregation areas. The sensitivity of these animals to uranium exposure is unknown based on the existing scientific literature, and species-specific uranium presumptive effects levels were only available for two endangered fish species known to inhabit the segregation areas.

Overall, the chemical toxicity data available for biological receptors of concern were limited, although chemical and radiation toxicity guidance values are available from several sources. However, caution should be used when directly applying these values to northern Arizona given the unique habitat and life history strategies of biological receptors in the segregation areas and the fact that some guidance values are based on models rather than empirical (laboratory or field) data. No chemical toxicity information based on empirical data is available for reptiles, birds, or wild mammals; therefore, the risks associated with uranium and other radionuclides are unknown for these biota.

\section{Introduction}

Proposed uranium mining in areas adjacent to the Grand Canyon National Park, Ariz., has prompted the U.S. Department of the Interior (DOI) to investigate physical, chemical, and biological issues potentially affected by mining. On July 21, 2009, U.S. Secretary of the Interior Ken Salazar proposed that about 1 million acres of Federal lands near the Grand Canyon be withdrawn from consideration for future mining activity. The land under consideration is contained in three parcels: two Bureau of Land Management (BLM) parcels on the North Rim of the Grand Canyon and one U.S. Forest Service (USFS) parcel on the South Rim. The Secretary's action prompted the U.S. Geological Survey (USGS) to design a series of studies to evaluate the 
environmental impacts of uranium mining in this area. This investigation is in response to that action. Habitats in the Grand Canyon and its environs support diverse flora and fauna that include culturally significant, threatened, and endangered species. Mining activity can result in changes to this habitat that may increase exposure of the biological resources to chemical elements including uranium, thallium, radium, and other radioactive decay products. This chapter will identify biological pathways of exposure for these radionuclides and consolidate information from the scientific literature on concentrations of these chemical elements known to adversely affect biological resources.

The goal of this chapter is to compile available toxicological and radiological information necessary to evaluate the potential effects of uranium and associated compounds on biological resources and affected habitat in the three segregation areas in northern Arizona. This chapter addresses chemical and radiation effects associated with radionuclides in the uranium-238 $\left({ }^{238} \mathrm{U}\right)$ decay series including uranium, thallium, thorium, bismuth, radium, radon, protactinium, polonium, actinium, and francium. Specific objectives are:

- to identify possible routes of exposure linked to atmospheric dispersion (including wind-borne dusts) and aqueous (surface water and groundwater), soil, sediment, and food-chain pathways;

- to identify species and habitats vulnerable to chemical and radiation effects potentially associated with uranium decay series products that are linked to exposures that result from uranium mining activities; and

- to compile relevant scientific information on toxicity threshold effects levels for uranium and associated radionuclides for aquatic and terrestrial flora and fauna.

Our approach included three interrelated steps. First, a literature search and compilation was conducted to provide a foundation for identifying the underlying biological and ecological issues that should be considered related to mining activities near the segregation areas. The second step was to characterize natural sources of uranium, other elements in the uranium decay series, and radiation (alpha, beta, or gamma) released during the uranium decay process. Because biological resources may be exposed to chemical and physical hazards associated with mining activities, the third step was the identification of ecological receptors in the area and the associated pathways of chemical and radiation exposure. Available data on culturally significant, threatened, and endangered species and associated habitats were compiled. These data were then used to develop a preliminary conceptual model.

\section{Literature Compilation}

The literature compilation was directed to collect existing chemical toxicity and radiation effects data associated with chemicals of potential concern, primarily uranium, thallium, radium, and other elements in the uranium decay series, commonly characterized in uranium ores of breccia pipe formations typical of the segregation areas. Nested literature searches and acquisitions of existing peer-reviewed data and literature were completed through:

- Cambridge Scientific Abstracts (Aquatic Sciences and Fisheries Abstracts, Biological Sciences, Environmental Sciences and Pollution Management databases; to a lesser extent, Aqualine, Water Resources Abstracts, GeoRef, Biology Digest, Conference Papers Index, Medline, and Toxline databases);

- OCLC FirstSearch (Agricola, ArticleFirst, BasicBiosis, Dissertations, GeoBase, WorldCat, BioAgIndex, Electronic Collections Online, PapersFirst, and Proceedings databases);

- ECOTOX database (in particular, combined AQUIRE and TERRATOX databases), for chemical toxicity values to characterize acute and chronic threshold effects;

- Frederica Radiation Effects Database (FREDERICA, previously known as FRED; http://87.84.223.229/fred/ mainpage.asp, accessed October 30, 2009) to confirm published effects-based radiation exposure values;

- PubMed-NLM (U.S. National Library of Medicine), Synergy, and ScienceDirect databases; and

- Focused manual searches reliant on networked citations derived from data and literature sources encountered in directed computer-aided data mining searches.

Searches were primarily conducted for chemical name, but additional searches for species of concern used scientific name (at genus or species level) and common names. Additional search terms were added depending on the number of citations found. Terms also included keywords related to the distribution of the species, its life history and habitat, and its interaction with other species.

\section{Sources of Uranium in Northern Arizona}

The uranium province situated in the Colorado Plateau is typically characterized as being semiarid and sparsely vegetated and having a terrain of broad plateaus, ancient volcanic mountains, and deeply dissected canyons. The region contains substantial amounts of oil, gas, coal, oil shale, and uranium resources. In general, the uranium provinces throughout the western United States occur across a wide range of physiographic and ecological regions (fig. 1). Within these provinces, uranium ores occur in various geologic deposits. The spatial distribution of uranium reserves serves as a frame of reference for identifying sources of chemical and radiation hazards potentially released to the environment as a result of mining activities. Uranium in the segregation areas (fig. 2) occurs in collapse-breccia pipe deposits as an Orphan Lodetype deposit, with clusters of pipes found in proximity to one another (Weinrich, 1985; Finch, 1992). The deposits occur 
as uraninite (uranium oxide) and associated sulfide, arsenide, sulfate, and arsenic-sulfosalt minerals as disseminated replacements and minor fracture fillings in near-vertical cylindrical solution-collapse breccia pipes (fig. 3). Economically recoverable quantities of copper, gold, molybdenum, nickel, silver, thorium, and vanadium can also occur with the uranium deposits. As a naturally occurring source of uranium, the pipe materials leach uranium with subsequent enrichment of copper and vanadium, among other metals, particularly in those pipes that have been deeply weathered. A massive sulfide cap prevents oxidation if there is no erosion or mining; therefore, deposits of antimony, arsenic, barium, cadmium, cobalt, chromium, cesium, copper, mercury, molybdenum, nickel, lead, selenium, silver, strontium, uranium, vanadium, yttrium, zinc, zirconium, and rare earth elements are present in the pipes (Weinrich, 1985).

Uranium can be mined by open pit, underground tunnels, and solution. Methods used depend on the type of deposit being mined, environmental conditions associated with the mining site (for example, depth to groundwater), and the economics of the mining operations (Hartman and Mutmansky, 2002; Moon and others, 2006). Heap leach mining has been phased out in the United States in favor of alternatives that reduce environmental impacts (http://www.epa.gov/radtown/ uranium-mines.html, accessed October, 30 2009), such as in situ leaching (ISL) and in situ recovery (ISR), which have been used increasingly in mining operations throughout the world (Bartlett, 1998). However, ISL is not used for mining operations associated with breccia pipes because of their porous nature; fluids from this method have the potential to leak out of the pipe and contaminate nearby water sources (for example, aquifers and springs). Accordingly, current proposals do not include ISL or ISR in the segregation areas in northern Arizona. In addition, onsite milling of the uranium in the segregation areas is not anticipated as established uranium mills located nearby in Utah have historically been used. Nevertheless, technical literature focused on geological and mining engineering should be reviewed for a detailed analysis of extraction and recovery of uranium ores from the segregation areas. The chemicals released to the surrounding environment during uranium mining operations can only be evaluated based on an understanding of which of the mining techniques are to be used.

Conventional mining methods employed in the uranium industry and used previously in the segregation areas are associated with hazardous chemical and physical effects on the surrounding ecosystem. Deposits occurring at greater depths require underground extraction - rock is crushed to fist-sized pieces underground, which creates substantial amounts of particulates (friable sand and silt sized materials), and is brought to the surface by vertical shaft mines. Mined materials are then transported to milling operations for extraction and recovery. Uranium ore grades range from tenths of a percent to singledigit percentages, indicating that the ratio of usable uranium to mined rock is low. Therefore, conventional mining creates relatively large quantities of waste materials characterized by low-level radiation, heavy metals, and other inorganic and organic materials, which are potential sources of chemical and radiation exposure to biota.

Chemical and radiation hazards caused by source materials and waste products of uranium mining must be considered when conducting biological assessments. The number of chemical and radiation hazards potentially released to the environment can be identified and characterized with respect to their potential links to adverse effects to biota. For example, deposition of particulates above ground on soils, plants, and surface water, as well as runoff or erosion to surface water, create pathways to expose a variety of biota to uranium and its decay products. In addition, the physical habitat of biological receptors may be affected by mining activities - for example, mine shafts can become habitats for bats and birds, plant communities can be destroyed by road and building construction, and water sources for amphibians, birds, and mammals can be contaminated.

\section{Chemical Speciation of Uranium as It Relates to Biota}

Uranium naturally occurs as a major constituent in more than 150 different minerals and is a minor constituent in at least 50 other minerals (Burns and Finch, 1999). Naturally occurring uranium consists of three isotopes $-{ }^{238} \mathrm{U},{ }^{235} \mathrm{U}$, and ${ }^{234} \mathrm{U}$ - with each isotope characteristically contributing to total uranium within an isotope-specific range: ${ }^{238} \mathrm{U}$ dominates naturally occurring sources of uranium (99.28 percent expressed with regard to the mass versus 49 percent by radioactivity for natural uranium), followed by ${ }^{235} \mathrm{U}$ ( 0.72 percent by mass versus 2 percent by radioactivity for natural uranium) and ${ }^{234} \mathrm{U}$ ( 0.0050 percent by mass versus 49 percent by radioactivity for natural uranium). All three uranium isotopes yield decay products that, along with parent uranium and radiation releases typical of the decay series, present chemical hazards, radioactive hazards, or both to biological receptors. Geochemical properties of these isotopes vary among source materials. The ${ }^{238} \mathrm{U}$ decay series will be considered the primary source of chemical and radiological hazards, considering the isotope composition of naturally occurring uranium ( $>99$ percent by mass). Constituents in the ${ }^{238} \mathrm{U}$ decay series include very shortlived elements, with half-lives on the order of minutes to days, and long-lived elements, with half-lives up to $4 \times 10^{9}$ years. The short-lived radionuclides are considered to have a limited potential for mediating adverse biological effects linked to chemical exposure because of reduced duration of exposure (table 1, appendix 1). Literature evaluating the chemical toxicity of these elements is limited but does indicate that exposure to these radionuclides can affect the survival, growth, reproduction, and renal function of biota. Radiation emitted during uranium decay contributes to radioactivity encountered in the environment. Therefore, radiation hazards of all daughter products are considered in evaluating radiation exposure. 


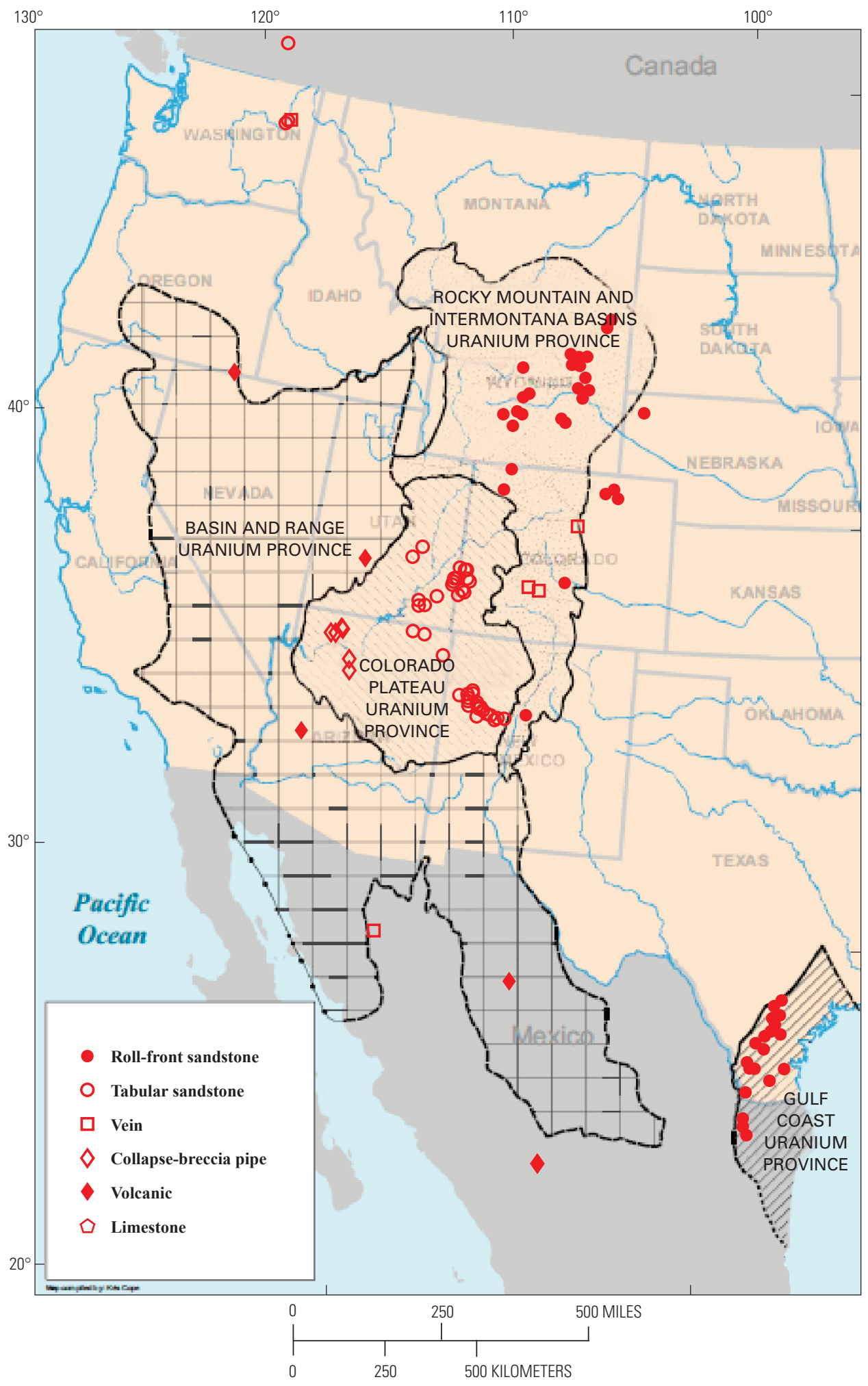

Figure 1. Uranium provinces in the western United States (Finch, 1996). 


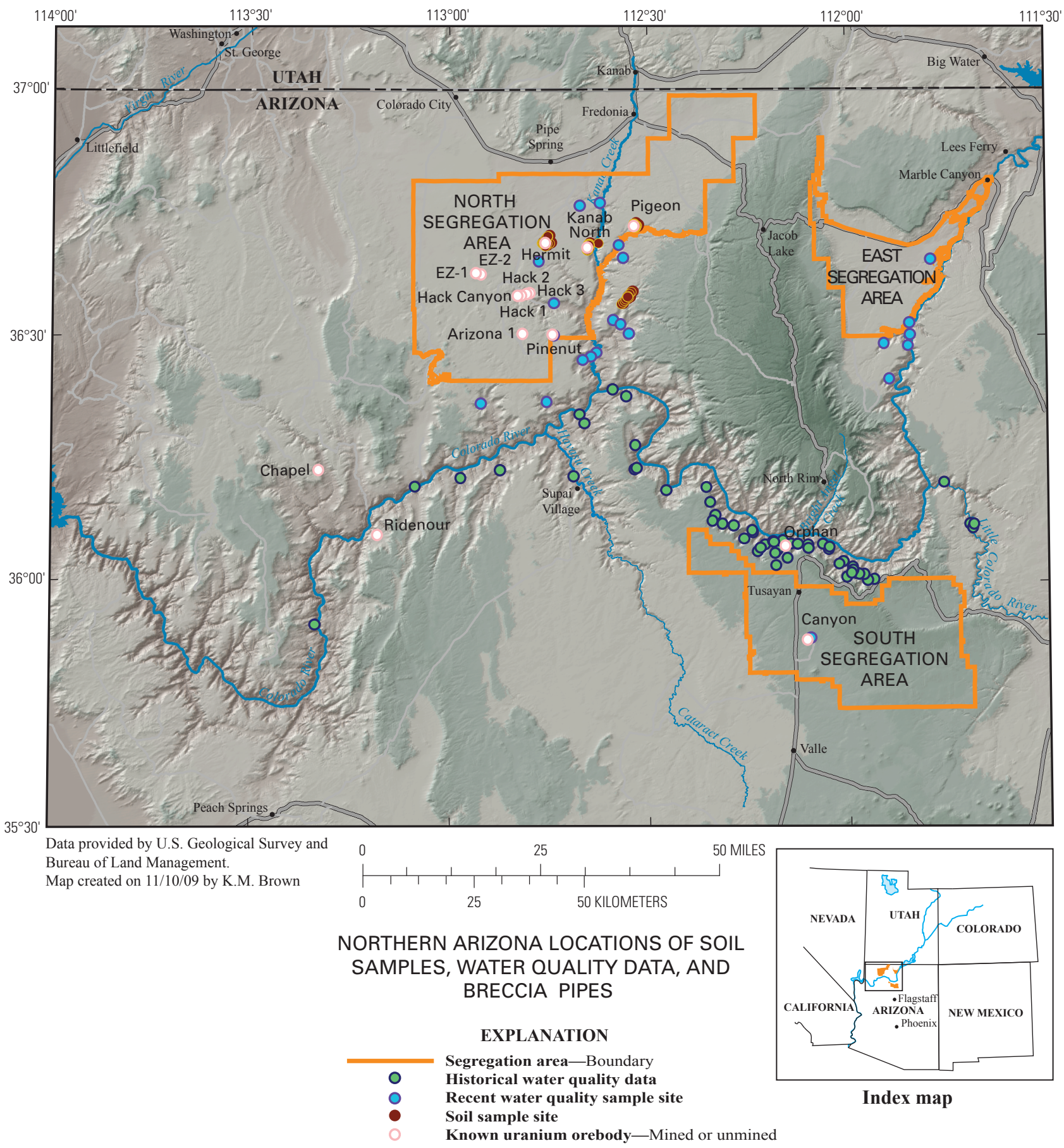

Figure 2. Segregation areas, mine sites, and sample collection locations. 


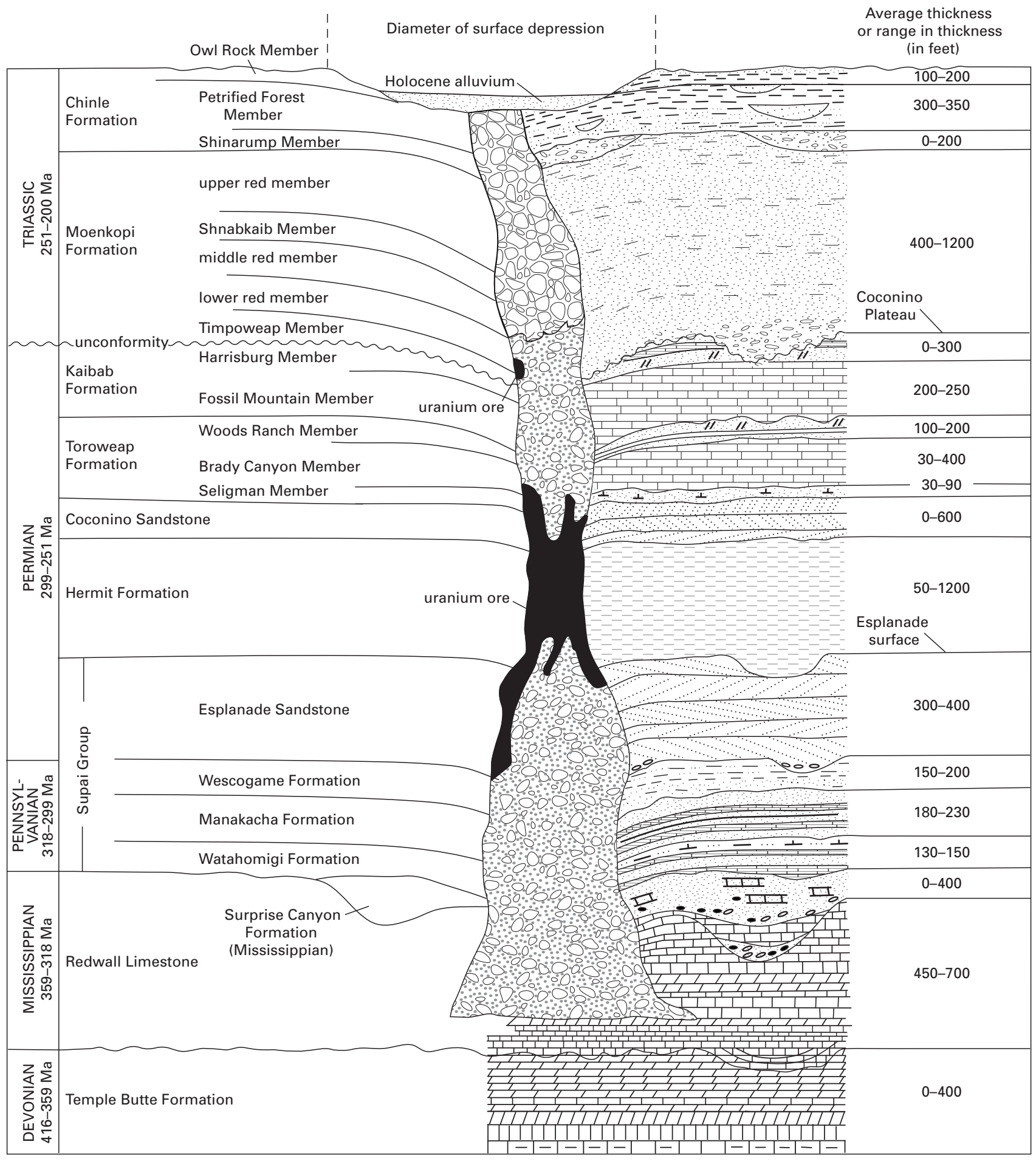

Figure 3. Schematic cross section of a solution-collapse breccia pipe in northern Arizona showing the general distribution of uranium ore within the pipe. 
Table 1. Radiation and half-life for constituent elements of ${ }^{238} \mathrm{U}$ decay series.

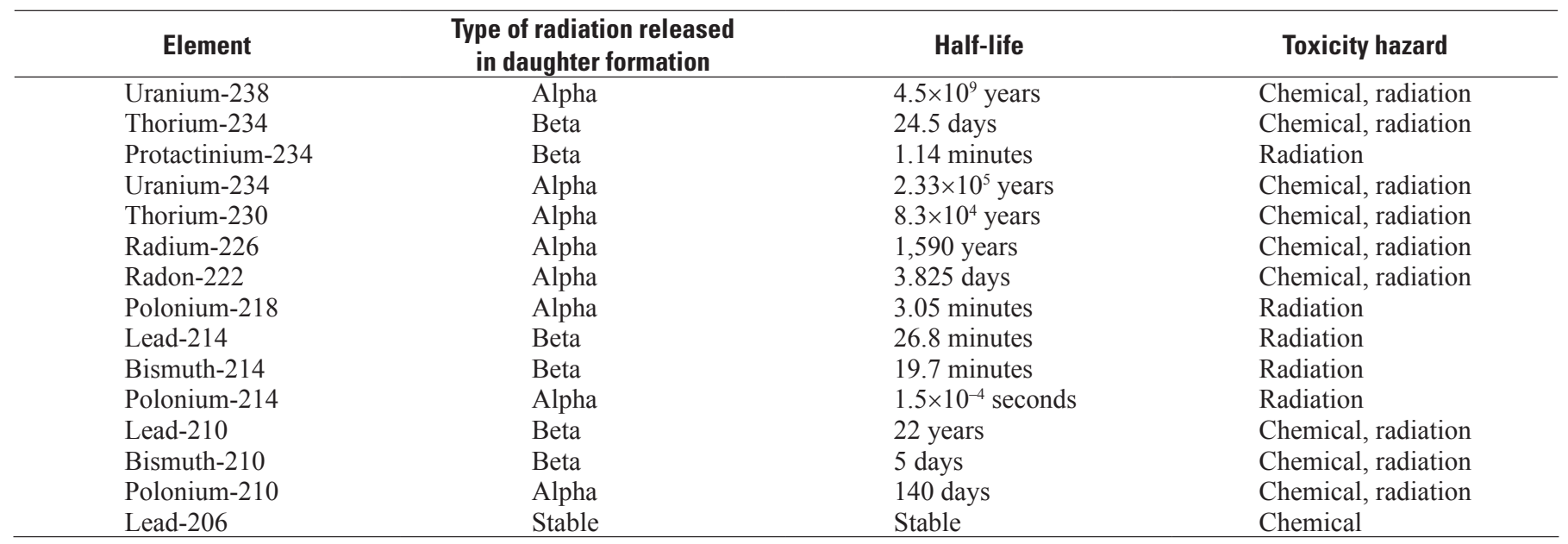

Within the context of radiation exposures to ${ }^{238} \mathrm{U}$ decay products (including ${ }^{234} \mathrm{U}$ ) in the field, an initial data filter was applied to distinguish between constituents that present significant chemical hazards relative to radiation hazards and those that do not. Radionuclides with half-lives of less than one day were removed from consideration as a chemical hazard; their short lives prevent them from participating in pathways or in reaching significant concentrations to pose a chemical risk. However, they can significantly contribute to radiological doses and are considered from that perspective. These radionuclides, or chemicals of potential ecological concern (COPECs), were sorted to expedite compilation of ecotoxicity data for uranium exposures in the field. Those radionuclides with a half-life of less than one day include ${ }^{214} \mathrm{Bi}$ (bismuth), ${ }^{214} \mathrm{~Pb}$ (lead), ${ }^{214} \mathrm{Po}$ (polonium), ${ }^{218} \mathrm{Po}$, and ${ }^{234} \mathrm{~Pa}$ (protactinium). Their radiation hazard is largely a function of their alpha particle or beta particle emissions in the ${ }^{238} \mathrm{U}$ decay series. In contrast, those longer-lived radionuclides (half-life greater than or equal to one day) were considered for both radiation and chemical hazards. These COPECs include ${ }^{230} \mathrm{Th}$ (thorium), ${ }^{234} \mathrm{Th},{ }^{226} \mathrm{Ra}$ (radium), ${ }^{222} \mathrm{Rn}$ (radon), ${ }^{210} \mathrm{Bi},{ }^{210} \mathrm{Po},{ }^{210} \mathrm{~Pb},{ }^{234} \mathrm{U}$, and ${ }^{238} \mathrm{U}$. A stable isotope of lead $\left({ }^{206} \mathrm{~Pb}\right)$ is the end-state of the ${ }^{238} \mathrm{U}$ decay series.

The bioavailability of metals (radionuclides) in water, sediment, and soil must be characterized to estimate effects on biota associated with exposure to uranium concentrations that result from natural weathering of mineral deposits or from mining activities. Bioavailability is the fractional uptake of metals (radionuclides) within the tissues of biota and is considered when examining the incorporation of metals (radionuclides) into biotic tissues. It is very context-specific to the metal (radionuclide), environmental conditions, and the biota of interest. Bioavailability alters the assimilation efficiencies of metals (radionuclides) by biota and therefore can reduce the effective exposure and resultant dose. Uptake of metals (radionuclides) may occur directly through water exposure (aquatic organisms), soil solution exposure (terrestrial plants or soil fauna), dermal or foliar contamination, inhalation (terrestrial biota), or through intentional or coincidental dietary ingestion of water, food, soils, or sediments.

Chemical speciation of uranium has been summarized previously (Gunther and others, 2002; Markich, 2002; Salbu and Skipperud, 2009). In general, speciation of uranium influences the chemical's transport (or mobility) within specific environments, as well as the bioavailability in aquatic and terrestrial systems. The metal's chemical toxicity will vary depending on the matrix in which it occurs. The speciation of uranium in aquatic systems (fresh waters and sediments) can be characterized by potential oxidation states. Uranium(VI) is the major form of uranium in oxic surface waters, whereas $\mathrm{U}(\mathrm{IV})$ is the major form in anoxic waters. The relationship between uranium speciation and bioavailability is complex and incompletely understood (Gunther and others, 2002; Markich, 2002). Uranium in surface waters occurs as various physicochemical forms depending on the environmental conditions. Uranium complexes with organic ligands, inorganic complexes of U(VI) as phosphate or humic substances, or metal-bound particulates or colloidals yield lower bioavailability by reducing activities of $\mathrm{UO}_{2}^{(2+)}$ and $\mathrm{UO}_{2} \mathrm{OH}^{+}$. The uranyl ion $\left(\mathrm{UO}_{2}^{(2+)}\right)$ and the uranyl hydroxyl complex $\mathrm{UO}_{2} \mathrm{OH}^{+}$are the major forms of $\mathrm{U}(\mathrm{VI})$ available to organisms. In contrast to other metals, characterization of uranium bioavailability is highly dependent on geochemical speciation models, and data from empirical studies using natural waters and aquatic biota are limited. Data are not available to characterize uranium speciation and its bioavailability in sediments.

Uranium in rocks and minerals generally occurs in low concentrations or grade in terrestrial systems, although uranium distribution in sedimentary rocks varies widely with high uranium contents in black shales, phosphate rocks, and coal. The natural background uranium concentration is $2.3 \mathrm{mg} / \mathrm{kg}$ for soils in the segregation areas (Smith, 1997). Uranium may be a 
major element in a mineral (for example, uraninite, $\mathrm{UO}_{2+}$ ) or an accessory mineral (for example, uranothorite, $\left.(\mathrm{Th}, \mathrm{U}) \mathrm{SiO}_{4}\right)$. The redox state of uranium, in particular the ratio of $\mathrm{U}(\mathrm{VI})$ to $\mathrm{U}(\mathrm{IV})$, governs its solubility and subsequent movements in undisturbed materials and its release to the environment through various anthropogenic activities (Hem, 1992; Roh and others, 2000; Zhang and Brady, 2002; Stewart, 2008). The biogeochemistry of uranium under field conditions is incompletely characterized with respect to its physicochemical behavior in complex chemical mixtures with dissolved metals, organic ligands, and mineralogical matrices (Alloway, 1990; Hem, 1992; Zhang and Brady, 2002; Cooper and others, 2003; Stewart, 2008). The environmental fate and movement of uranium in near-surface and subsurface environments is strongly influenced by oxygen. For example, $\mathrm{UO}_{2}$ displays decreased solubility and movement in soil under anaerobic conditions and increased solubility and movement in aerobic soils. The physicochemical behavior of uranium affects adsorption and desorption processes that occur over a wide range of mineral substrates and soil types and influence concentrations in soil solution. These surface-mediated processes are strongly influenced by the geochemical composition of soils. For example, soil calcium promotes the formation of ternary uranyl-calcium-carbonato complexes, which decreases the extent and rate of $\mathrm{U}(\mathrm{VI})$ reduction and therefore reduces the amount of $\mathrm{U}(\mathrm{VI})$ adsorption to mineral surfaces (Stewart, 2008).

The bioavailability of uranium depends on its speciation in the environment. Metals including uranium partition between solid and liquid phases and may occur as dissolved, exchangeable, carbonate, iron-manganese oxide, organic, or crystalline species. Partitioning or speciation is influenced to varying degrees by $\mathrm{pH}$, redox state, organic content, and other environmental factors such as temperature, flow rates, and periodic events (such as storms). Hydrogen ion activity $(\mathrm{pH})$ is likely one of the more critical factors governing metal speciation, solubility from mineral surfaces, transport, and eventually bioavailability (Zhang and Brady, 2002). Particulate size and total surface area available for adsorption affect metal speciation and metal bioavailability. For example, finely milled ore may release smaller particles that are likely more widely dispersed by water and wind and enhance metal adsorption (Jones and others, 1990; Hem, 1992; Zhang and Brady, 2002).

Radioisotopes of interest in uranium mill tailings include ${ }^{230} \mathrm{Th},{ }^{226} \mathrm{Ra},{ }^{222} \mathrm{Rn}$, and its daughter products. With its long half-life, ${ }^{230} \mathrm{Th}$ is the parent and a constant source of ${ }^{226} \mathrm{Ra}$ (see Esienbud and Gesell, 1997; Burns and Finch, 1999). Thorium and radium migrate slowly in the soil but can move via groundwater into sediments and surface waters. Radium isotopes ${ }^{226} \mathrm{Ra}$ (from the ${ }^{238} \mathrm{U}$ decay chain) and ${ }^{224} \mathrm{Ra}$ (from the ${ }^{232} \mathrm{Th}$ decay chain) are chemically similar to calcium. Radium is assimilated from the soil by plants and passed up the food

'The species distribution map for Kanab ambersnail (Oxyloma haydeni kanabensia) does not include a translocated population at Elves Chasm, at River Mile 117 (Sorenson and Nelson, 2000). chain to terrestrial biota including humans. In vertebrates, radium can enter the body through ingestion or inhalation pathways. The radium isotopes are alpha emitters and the parents of radon gas $\left({ }^{226} \mathrm{Ra}\right.$ decays to ${ }^{222} \mathrm{Rn} ;{ }^{224} \mathrm{Ra}$ decays to ${ }^{220} \mathrm{Rn}$ ). All radon isotopes are noble gases and inert with relatively short half-lives. Radon progeny are electrically charged when formed and attach to naturally occurring dust particles within the atmosphere. The inhalation of minute dust particles laden with radon progeny is a major contributor to the annual dose of natural radioactivity received by humans (National Council on Radiation Protection and Measurements, 1987). Radiation dose associated with inhalation of larger sized particulates carrying radon particles is less important because larger particulates are less likely to enter vertebrate lungs. Inhalation of aerosols and particulates by miners working in the confined spaces of the uranium mines was critical to occupational exposures; however, in natural settings the release of the radionuclides is often dispersed into the atmosphere and diluted, thus decreasing the radiogenic effects on surrounding biota (International Atomic Energy Agency, 1997).

\section{Biological Receptors for Exposure Effects Associated with Uranium Mining}

Habitats in northern Arizona support diverse flora and fauna that include culturally significant, threatened, and endangered species. The wide range of elevation and slope aspect creates a variety of habitats including desert scrub, ponderosa and pinyon pine forests (Pinus spp.), and seeps and springs in which species can thrive. A diagrammatic sketch of the system at risk was developed to identify potential linkages between chemical and radiation hazards associated with mining operations and biota present in the segregation areas (fig. 4). Biological receptors co-occur with environmental hazards that are associated with proposed uranium mining activities. Direct effects associated with radiochemicals and associated radiation released in the decay process are the primary focus of this chapter, but inorganic chemicals, physical and biological stressors, and indirect effects also warrant attention. These potentially confounding factors likely operate at landscape levels (such as ecoregion and watershed) and should be considered as contributing factors in an ecological risk assessment.

Biota of concern, based on the food web, were identified as soil microorganisms (including soil crust and microbial communities), aquatic microorganisms, terrestrial and aquatic vascular plants, terrestrial and aquatic invertebrates, fish, amphibians and reptiles, birds, and mammals. Threatened and endangered species including aquatic invertebrates, birds, fishes, and terrestrial plants occur within or near the segregation areas (table 2, figs. 5-7). ${ }^{1}$ Distribution maps are 


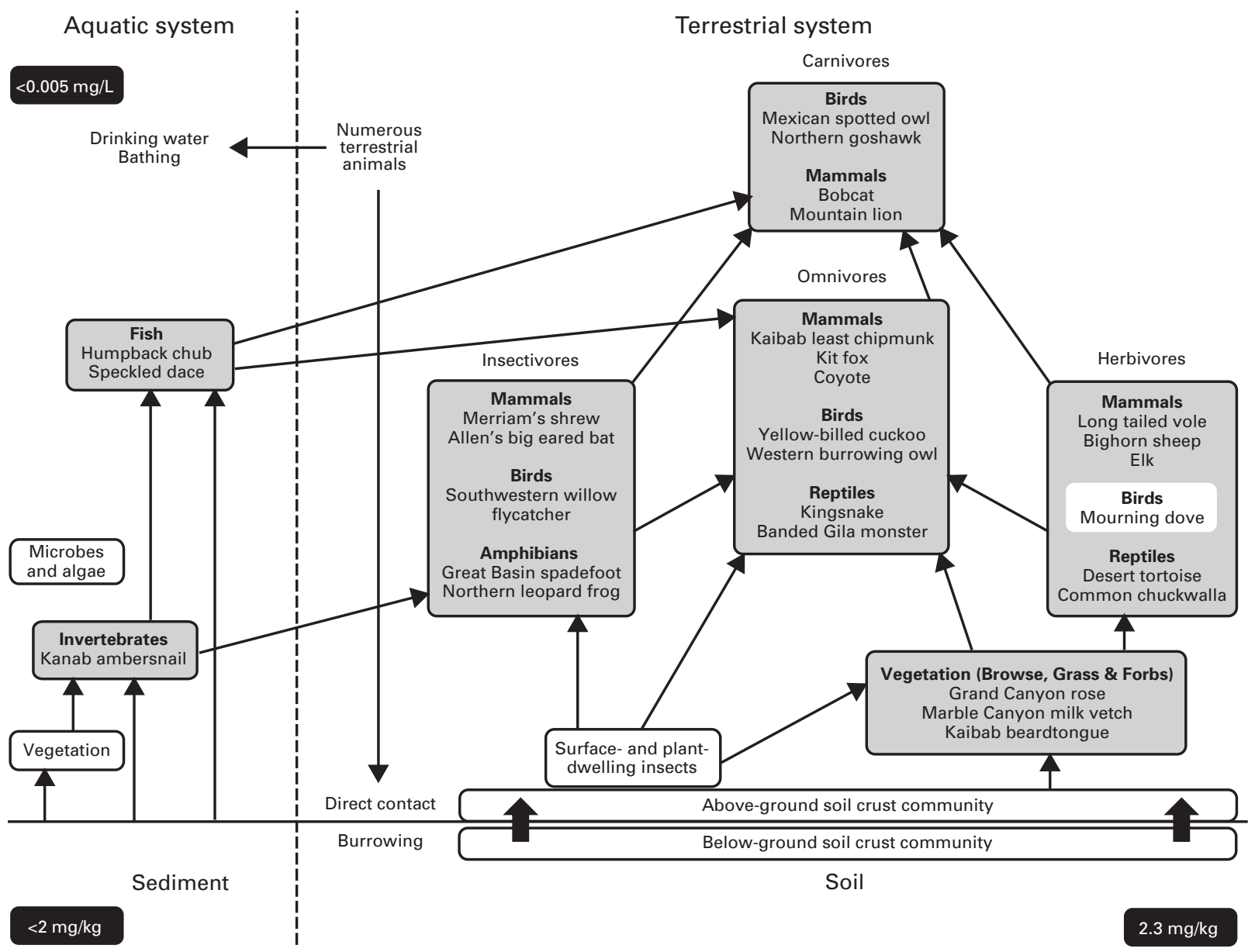

Figure 4. Diagrammatic representation of a generalized food web for the segregation areas. Gray shading indicates receptor groups for which sensitive species have been identified by State and Federal agencies (see tables 2 and 3 for species-specific information). Example species for each receptor group are provided. Black boxes are regional background concentrations of uranium in water, sediment, and soil.

not available for all species, but documentation from State and Federal agencies indicate that appropriate habitat for these species is available within or near the segregation areas (table 2). Species of concern (as identified by State and Federal agencies) occur in most compartments of the food web within the segregation areas (table 3, fig. 4).

Uranium and other radionuclides can be transported through the environment and contribute to exposure of biological receptors via atmospheric deposition, dust, runoff, erosion and deposition, groundwater and surface water, and the food chain. As a result, biological receptors can be exposed to radionuclides through various pathways including ingestion (soil, food, or water), inhalation, cell membrane-mediated uptake, cutaneous absorption, and biotic uptake/trophic transfer (table 4, fig. 8). Chemical and radiological exposure of burrowing or subterranean invertebrates such as tiger beetles and desert centipedes, amphibians such as the Great Basin spadefoot (Spea intermontana), reptiles such as the northern sagebrush lizard (Sceloporus graciosus graciosus) and common kingsnake (Lampropeltis getulus), mammals such as
House Rock Valley chisel-toothed kangaroo rat (Dipodomys microps leucotis), Kaibab northern pocket gopher (Thomomys talpoides kaibabensis), and kit fox (Vulpes macrotis), and birds such as the western burrowing owl (Athene cunicularia hypugea) are of particular concern. In addition, a variety of species of scorpions, birds, and bats use cave-like mine shafts for habitat. For example, several bat species listed as species of concern-Allen's big-eared bat (Idionycteris phyllotis), Pale Townsend big-eared bat (Corynorhinus townsendii), fringed myotis (Myotis thysanodes), long-eared myotis (M. evotis), and western small-footed myotis (M. ciliolabrum) - hibernate in mine shafts where these animals are exposed to prolonged radiation and chemical hazards associated with uranium mining (table 3). Herbivores listed as species of concern, such as the desert tortoise (Gopherus agassizii), common chuckwalla (Sauromalus obesus), Kaibab northern pocket gopher, Navajo Mexican vole (Microtus mexicanus navaho), elk (Cervus elaphus), and bighorn sheep (Ovis canadensis), can be exposed to radionuclides through the aerial deposition of uranium or its decay products onto vegetation. 
Table 2. Threatened and endangered species occurring within the segregation areas. Habitat data from the State of Arizona's Natural Heritage Program-Heritage Data Management System (http://www.azgfd.gov/w_c/edits/species_concern.shtml, accessed Octber 2009).

[NA, not applicable]

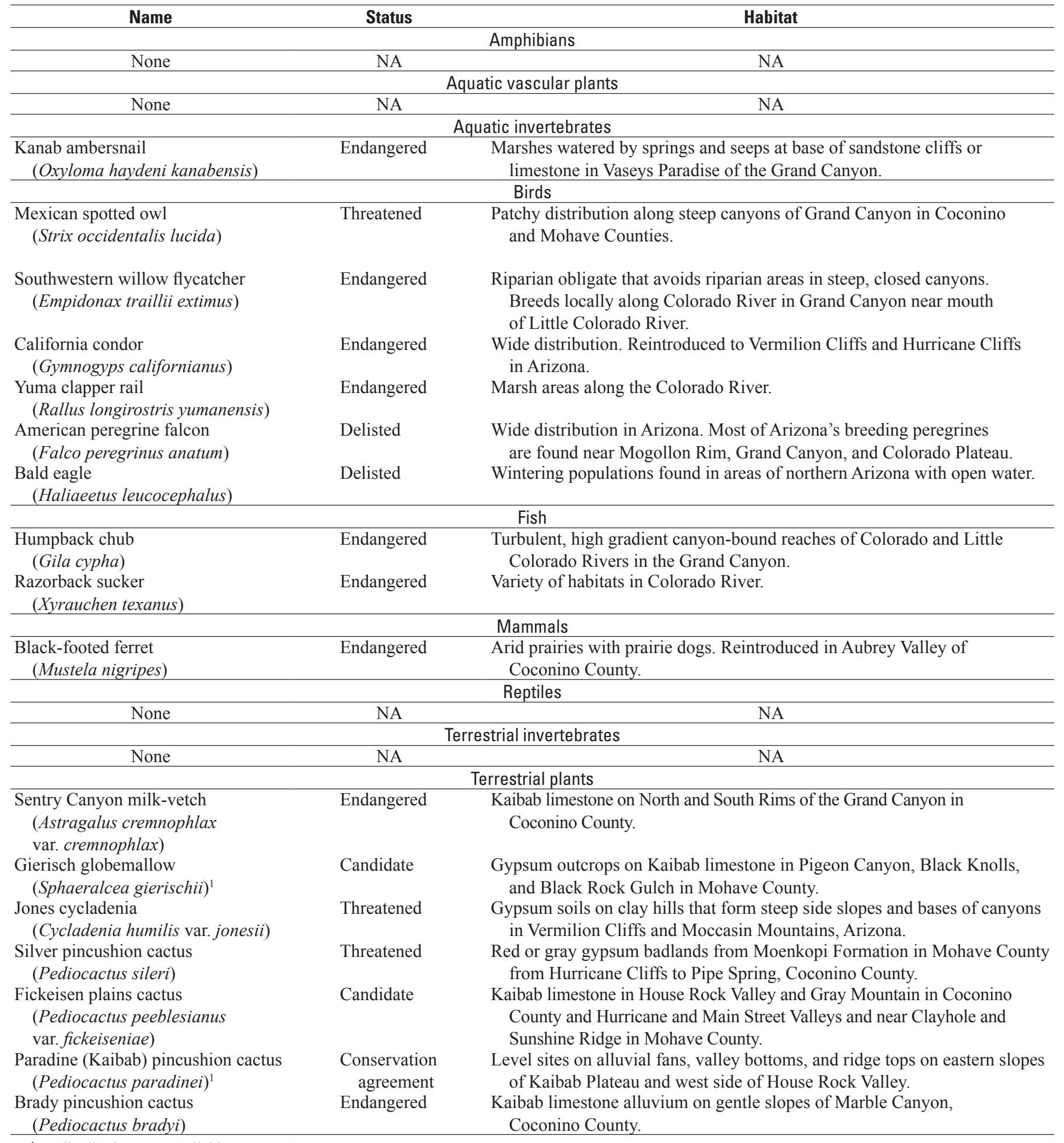

${ }^{1}$ No distribution map available. 


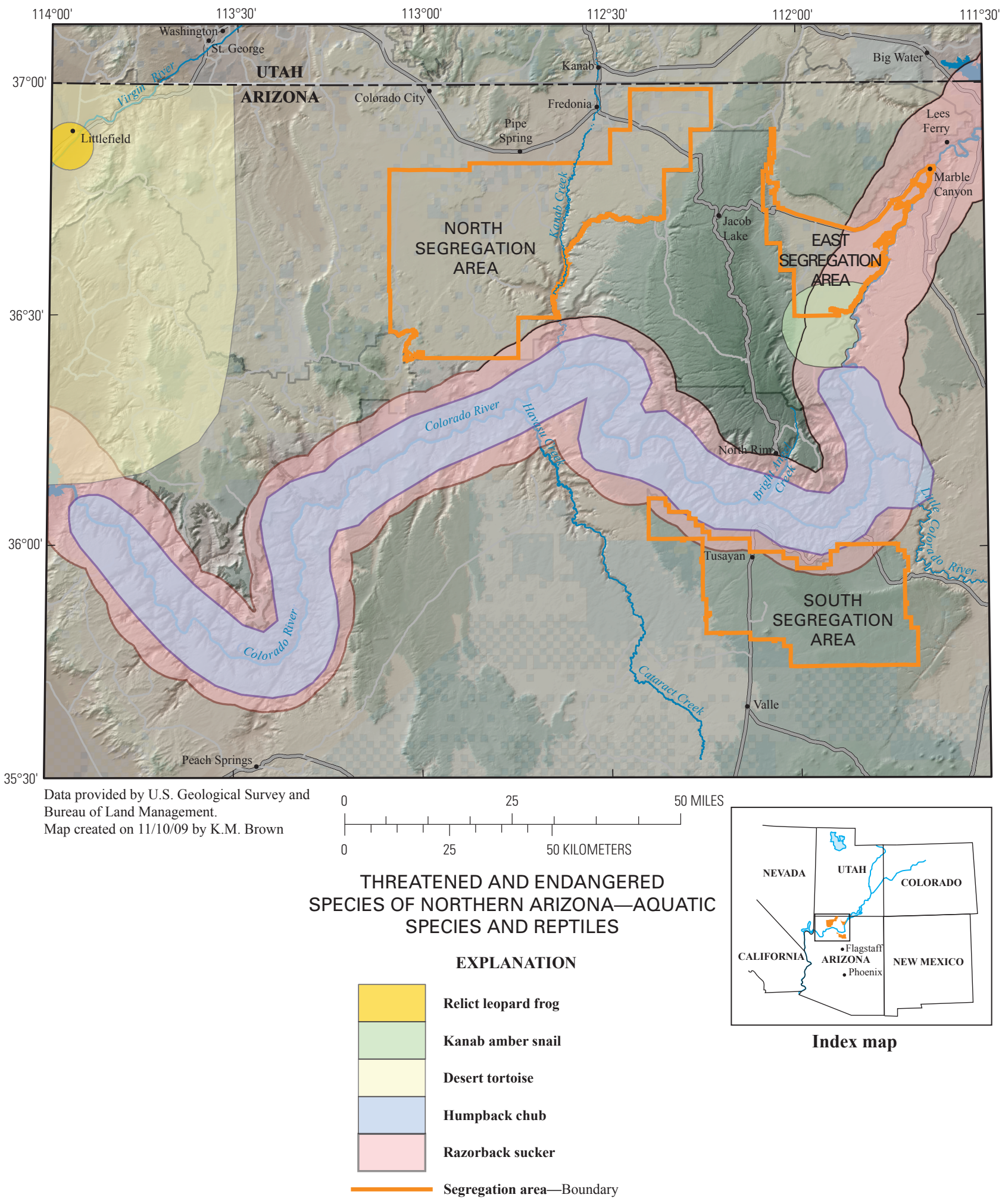

Figure 5. Range distributions of threatened and endangered fish, amphibians, and reptiles in relation to the segregation areas. The species distribution map for Kanab ambersnail does not include a translocated population at Elves Chasm, at River Mile 117 (Sorenson and Nelson, 2000). (Geospatial data provided by Mary Richardson, U.S. Fish and Wildlife Service, Phoenix, Ariz.) 


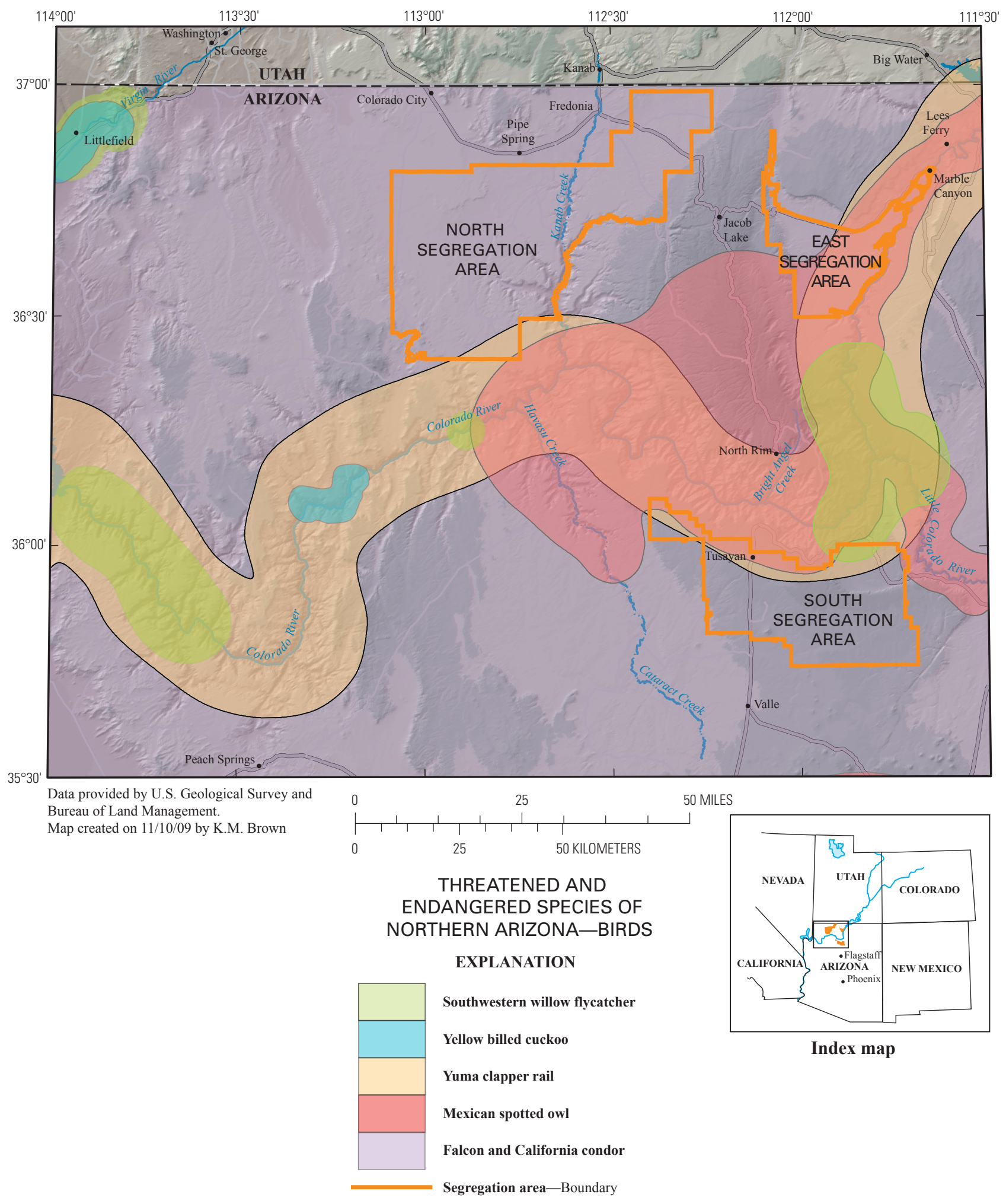

Figure 6. Range distributions of threatened and endangered birds in relation to the segregation areas. (Geospatial data provided by Mary Richardson, U.S. Fish and Wildlife Service, Phoenix, Ariz.) 


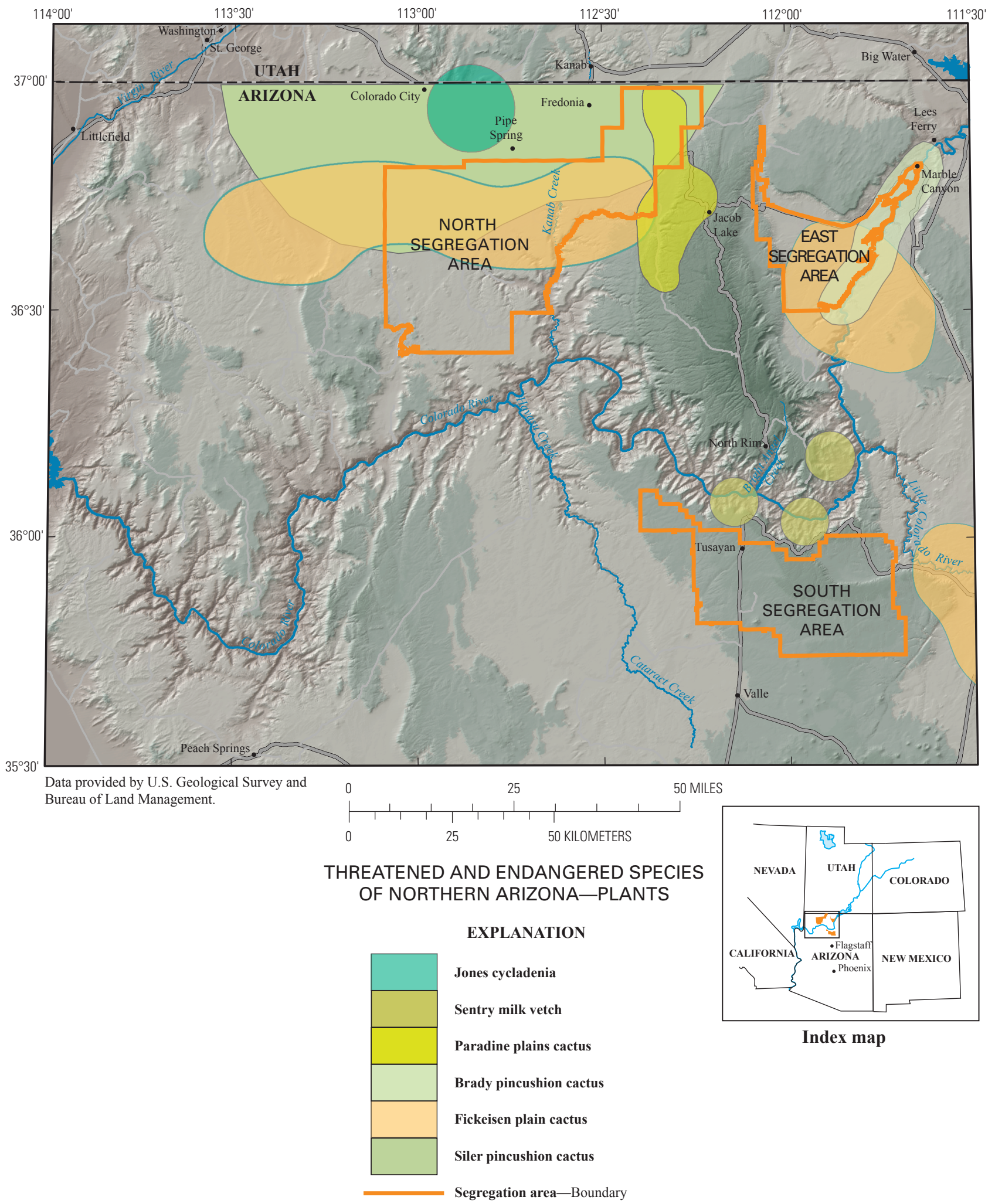

Figure 7. Range distributions of threatened and endangered plants in relation to the segregation areas. (Geospatial data provided by Mary Richardson, U.S. Fish and Wildlife Service, Phoenix, Ariz.) 
Table 3. Examples of species of concern documented within the segregation areas based on data from the State of Arizona's Natural Heritage Program-Heritage Data Management System (http://www.azgfd.gov/w_c/edits/species_concern.shtml, accessed October 2009), the U.S. Bureau of Land Management, the U.S. Forest Service, and the National Park Service.

\begin{tabular}{|c|c|c|}
\hline Name & Habitat & Diet \\
\hline \multicolumn{3}{|c|}{ Amphibians } \\
\hline $\begin{array}{l}\text { Relict leopard frog } \\
\quad(\text { Lithobates }[\text { Rana }] \text { onca })\end{array}$ & Springs and wetlands with open shorelines. & $\begin{array}{l}\text { Adults are invertivores. Larvae eat } \\
\text { algae, organic debris, plant tissue, } \\
\text { and microorganisms. }\end{array}$ \\
\hline $\begin{array}{l}\text { Red spotted toad } \\
\quad(\text { Bufo punctatus })\end{array}$ & Riparian area of rocky streams and arroyos. & Insectivorous. \\
\hline
\end{tabular}

(Bufo punctatus)

Roaring Springs prickly-poppy
(Argemone arizonica) $)^{3}$
Welsh's milkweed
(Asclepias welshii)
Atwood's catseye
(Cryptantha atwoodii)

Bigelow onion (Allium bigelovii)

Ditch evening-primrose (Camissonia ssp. abyssa) Grand Canyon rose

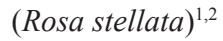

Gumbo milk-vetch (Astragalus ampullarius

Cliff milk-vetch (Astragalus cremnophlax var. myriorrhaphis $)^{1,2}$

Marble Canyon milk-vetch (Astragalus cremnophlax var. hevronii) $)^{1,2}$

North Rim vetch (Astragalus septentriorema) $^{3}$

Sentry Canyon milk-vetch (Astragalus cremnophylax)

Kaibab beardtongue (Penstemon pseudoputus)

Flagstaff penstemon (Penstemon nudiflorus) $^{2}$

House Rock fishhook cactus (Sclerocactus sileri $)^{1}$

Kaibab bladderpod (Lesquerella kaibabensis)

Kaibab paintbrush (Castilleja kaibabensis)

Grand Canyon catchfly (Silene rectiramea $)^{3}$
Steep, south-facing slopes; rockslides in pinyon juniper/desertscrub.

Open, sparsely vegetated semi-stabilized sand dunes in desert scrub.

Sandy to clayey soils with sagebrush and pinyon juniper. West rim of Marble Canyon on Kaibab limestone.

Dry rocky soil in grassland, open chaparral, and desertscrub communities.

Debris slides and crevices of broken Redwall Limestone.

Known populations are on or near canyon rims or cliff tops at edges of mesas or plateaus, along low ledges at depressions caused by breccia pipes. Kanab Canyon: rim on low limestone breaks and in small, shallow drainages. Twin Point: on deeper soils along west edge, Kaibab limestone bedrock outcropping in places.

Gumbo clay knolls.

Crevices and depressions with shallow or no soil on Kaibab limestone on rim-rock benches, cliff ledges, and pinnacles.

Desertscrub on rim-rock benches on canyon edge in crevices and depressions with shallow soils on Kaibab limestone.

Not well defined.

Kaibab limestone with mat rockspirea (Petrophytum caespitosum) in pinion-juniper-cliffrose plant community.

Kaibab limestone and sandstone in grassland meadows; disturbed areas.

Dry ponderosa pine forests.

Pinyon-juniper mesa tops in House Rock Valley and Paria Plateau.

Limestone-clay knolls with exposed rock; meadows of Kaibab Plateau.

Fine silts and clays to rocky meadow soils from Kaibab limestone on low rounded ridge tops and small knolls.

North-facing in gravel loam to clay soils in limestone and calcareous sandstone.
Not applicable.

Not applicable.

Not applicable. Note: Potentially at risk from grazing sheep, goats, and insects.

Not applicable. Note: Species considered edible and bulbs sought after by Native Americans for food and seasoning.

Not applicable.

Not applicable. Note: Wildlife may browse on this plant, especially rabbits; grows in breccia pipes where uranium prospects have been concentrated.

Not applicable. Note: Potentially threatened by mineral exploration and livestock grazing.

Not applicable.

Not applicable.

Not applicable.

Not applicable.

Not applicable. Note: Browsed upon by deer and rodents.

Not applicable.

Not applicable.

Not applicable.

Not applicable. Note: Grazing is the most significant risk.

Not applicable. 
Table 3. Examples of species of concern documented within the segregation areas based on data from the State of Arizona's Natural Heritage Program-Heritage Data Management System (http://www.azgfd.gov/w_c/edits/species_concern.shtml, accessed October 2009), the U.S. Bureau of Land Management, the U.S. Forest Service, and the National Park Service.-Continued

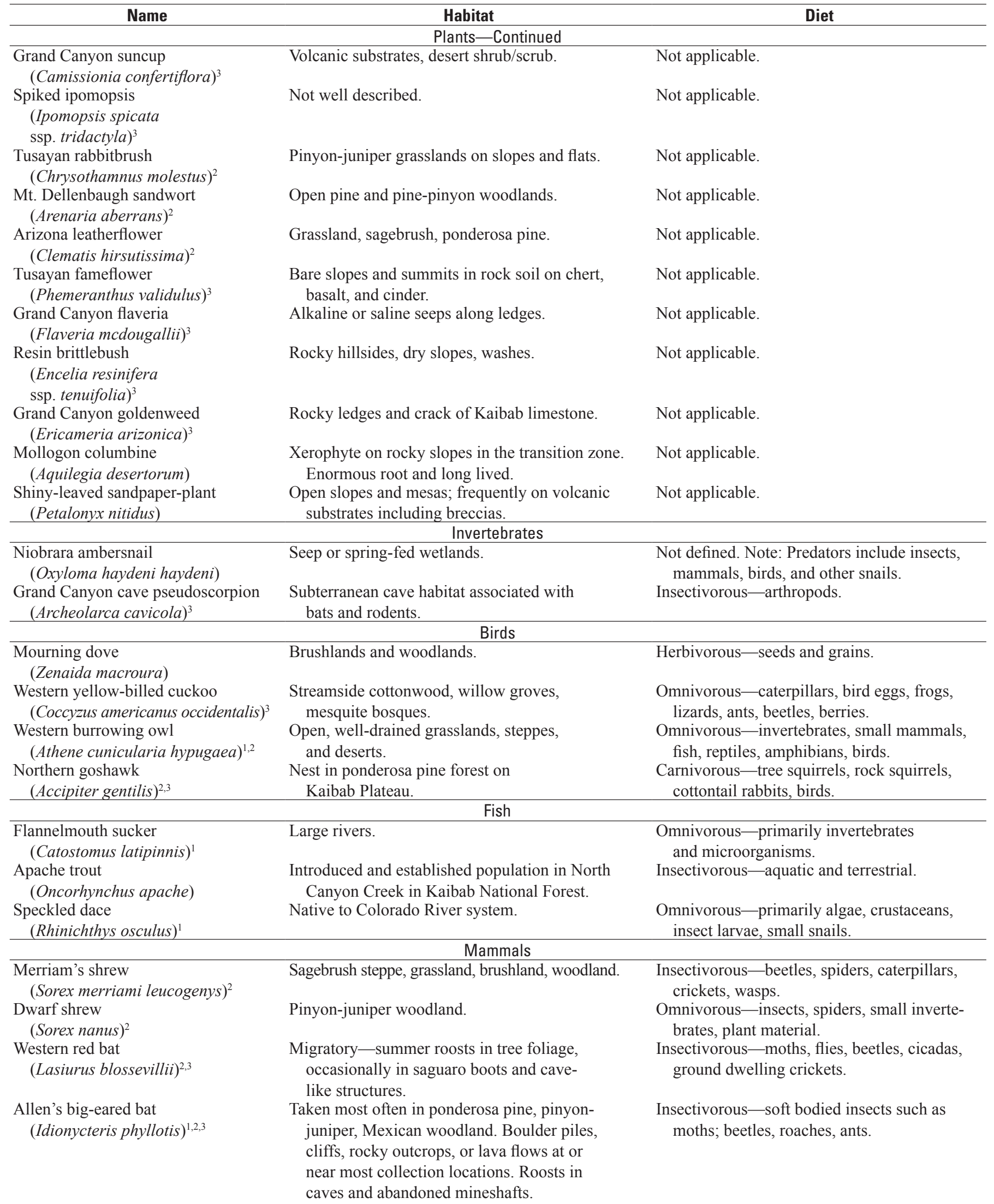


Table 3. Examples of species of concern documented within the segregation areas based on data from the State of Arizona's Natural Heritage Program-Heritage Data Management System (http://www.azgfd.gov/w_c/edits/species_concern.shtml, accessed October 2009), the U.S. Bureau of Land Management, the U.S. Forest Service, and the National Park Service.-Continued

\begin{tabular}{|c|c|c|}
\hline Name & Habitat & Diet \\
\hline $\begin{array}{l}\text { Big free-tailed bat } \\
\qquad(\text { Nyctinomops macrotis })^{1}\end{array}$ & $\begin{array}{l}\text { Inhabit rugged, rocky country and riparian areas. } \\
\text { Roost in caves and holes in trees. }\end{array}$ & $\begin{array}{l}\text { Insectivorous - moths, crickets, grasshoppers, } \\
\text { flying ants, stinkbugs, leafhoppers. }\end{array}$ \\
\hline $\begin{array}{l}\text { Fringed myotis } \\
\qquad(\text { Myotis thysanodes })^{1}\end{array}$ & $\begin{array}{l}\text { Oak-pinyon woodlands and other open, coniferous, } \\
\text { middle-elevation forests. Roost sites have been } \\
\text { found in caves, mine tunnels, in large snags, under } \\
\text { exfoliating bark, and in buildings. May use lower } \\
\text { elevation caves and mines as hibernation sites. }\end{array}$ & Insectivorous - beetles, moths. \\
\hline $\begin{array}{l}\text { Long-eared myotis } \\
\qquad(\text { Myotis evotis })^{1}\end{array}$ & $\begin{array}{l}\text { Inhabit ponderosa pine or spruce-fir forests of } \\
\text { Arizona. Summer roosts in rock outcroppings, } \\
\text { tree cavities, under peeling bark, in stumps, } \\
\text { caves, mines, sink holes, lava tubes, or in } \\
\text { abandoned buildings. Likely use caves and } \\
\text { abandoned mines during hibernation. }\end{array}$ & Insectivorous_primarily Lepidopterans. \\
\hline $\begin{array}{l}\text { Long-legged myotis } \\
\qquad(\text { Myotis volans })^{1,3}\end{array}$ & $\begin{array}{l}\text { Primarily coniferous forest; also riparian and } \\
\text { desert habitats. Roosts including cracks in } \\
\text { the ground, crevices in cliff faces, and spaces } \\
\text { behind exfoliating tree bark. Use caves and } \\
\text { mine tunnels for hibernation. }\end{array}$ & $\begin{array}{l}\text { Insectivorous-flies, termites, lacewings, } \\
\text { wasps, beetles. }\end{array}$ \\
\hline $\begin{array}{l}\text { Spotted bat } \\
\quad(\text { Euderma maculatum })^{2,3}\end{array}$ & Dry, rough desertscrub. & Insectivorous-primarily moths. \\
\hline $\begin{array}{l}\text { Western small-footed myotis } \\
\qquad(\text { Myotis ciliolabrum })^{1}\end{array}$ & $\begin{array}{l}\text { Deserts, chaparral, riparian areas, and oak-juniper } \\
\text { forests. Hibernates in caves and old mines; } \\
\text { summers in crevices, cracks, holes, snags, } \\
\text { hollow trees, under rocks, and in buildings. }\end{array}$ & Insectivorous - flying insects. \\
\hline $\begin{array}{l}\text { Kaibab least chipmunk } \\
\quad(\text { Neotamias minimus consobrinus })^{2}\end{array}$ & Rock cliffs, river bluffs, and forest edges. & $\begin{array}{l}\text { Omnivorous - plants, fungi, invertebrates, } \\
\text { small mammals and birds. }\end{array}$ \\
\hline $\begin{array}{l}\text { Kaibab northern pocket gopher } \\
\quad(\text { Thomomys talpoides kaibabensis) })^{2}\end{array}$ & $\begin{array}{l}\text { Live underground (fossorial) in sagebrush steppe } \\
\text { and valley grasslands. }\end{array}$ & $\begin{array}{l}\text { Herbivorous-roots and stems of forbs } \\
\text { and herbs. }\end{array}$ \\
\hline $\begin{array}{l}\text { House Rock Valley chisel- } \\
\text { toothed kangaroo rat } \\
\text { (Dipodomys microps leucotis) }^{2}\end{array}$ & $\begin{array}{l}\text { Burrow in desertscrub communities with high } \\
\text { shrub cover and sparse grass cover. }\end{array}$ & Herbivorous_-saltbush leaves. \\
\hline $\begin{array}{l}\text { Navajo Mexican vole } \\
\quad(\text { Microtus mexicanus navaho })^{3}\end{array}$ & $\begin{array}{l}\text { Burrow in dense shrub thickets; dry grassy areas } \\
\text { adjacent to ponderosa pine forests. }\end{array}$ & Herbivorous-grasses, forbs. \\
\hline $\begin{array}{l}\text { Navajo Mogollon vole } \\
\quad\left(\text { Microtus mogollonensis navaho) }{ }^{2}\right.\end{array}$ & $\begin{array}{l}\text { Burrow in dense shrub patches in ponderosa pine } \\
\text { forests, sagebrush stands, thick grasses. }\end{array}$ & Herbivorous - grasses, forbs, other vegetation. \\
\hline $\begin{array}{l}\text { Long-tailed vole } \\
\qquad(\text { Microtus longicaudus })^{2}\end{array}$ & $\begin{array}{l}\text { Scrubby and grassy meadows; high elevations } \\
(>2,400 \mathrm{~m}) \text {. }\end{array}$ & Herbivorous - fruit, seeds, bark, leaves. \\
\hline
\end{tabular}


Table 3. Examples of species of concern documented within the segregation areas based on data from the State of Arizona's Natural Heritage Program-Heritage Data Management System (http://www.azgfd.gov/w_c/edits/species_concern.shtml, accessed October 2009), the U.S. Bureau of Land Management, the U.S. Forest Service, and the National Park Service.-Continued

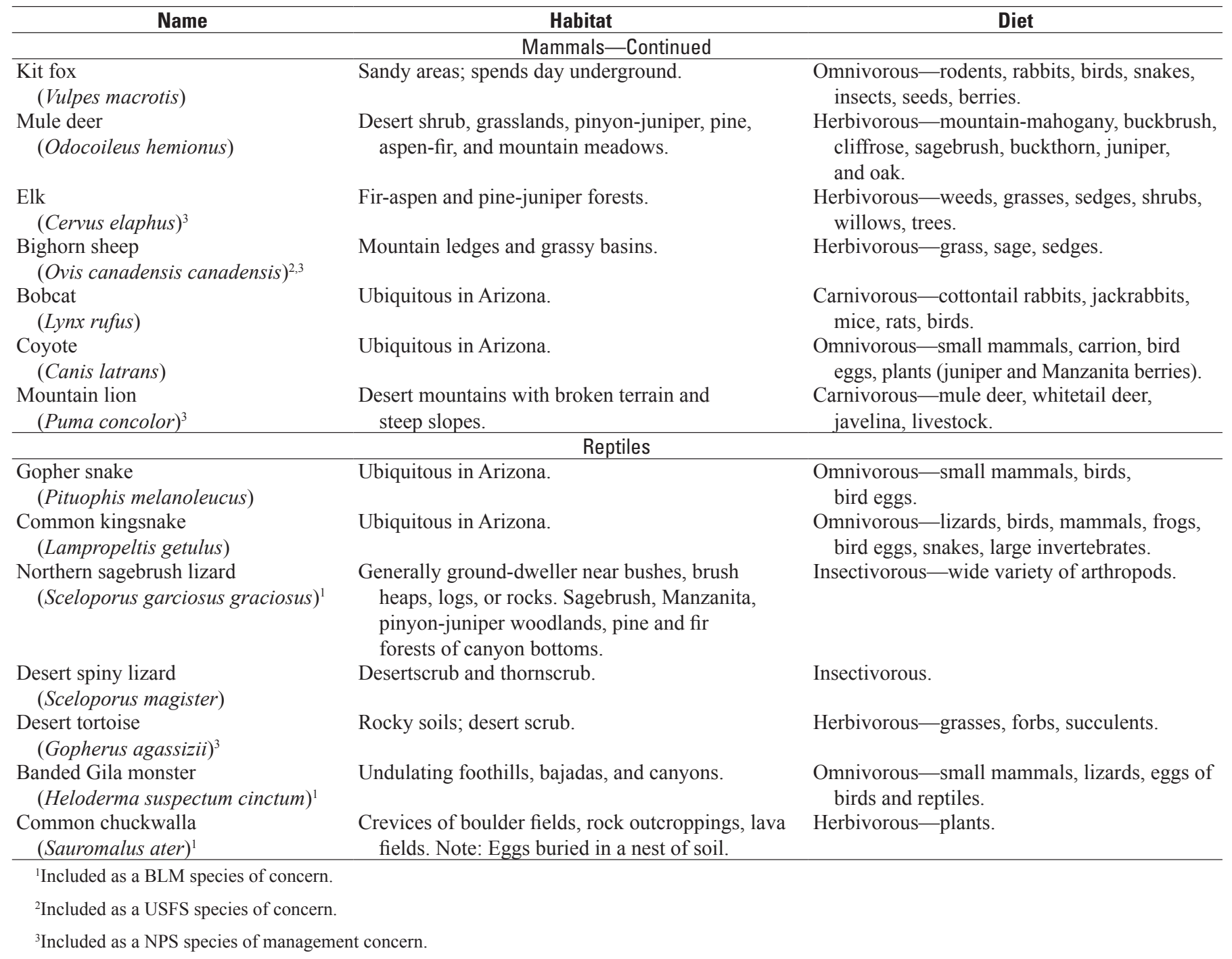

Table 4. Exposure pathway matrix for aquatic and terrestrial biological receptors.

\begin{tabular}{|c|c|c|c|c|c|}
\hline Receptor & Ingestion & Inhalation & $\begin{array}{l}\text { Cell membrane- } \\
\text { mediated uptake }\end{array}$ & $\begin{array}{l}\text { Cutaneous } \\
\text { absorption }\end{array}$ & $\begin{array}{l}\text { Biotic uptake or } \\
\text { trophic transfer }\end{array}$ \\
\hline \multicolumn{6}{|c|}{ Aquatic habitats: Lentic, lotic, and wetland systems } \\
\hline Algae, cyanobacteria, and microorganisms & & & $\bullet$ & & $\bullet$ \\
\hline Aquatic invertebrates & $\bullet$ & & $\bullet$ & $\bullet$ & $\bullet$ \\
\hline Fish & $\bullet$ & & $\bullet$ & $\bullet$ & $\bullet$ \\
\hline \multicolumn{6}{|c|}{ Terrestrial habitats: Upland and riparian systems } \\
\hline Terrestrial invertebrates & $\bullet$ & $\bullet$ & $\bullet$ & $\bullet$ & $\bullet$ \\
\hline Amphibians & • & $\bullet$ & - & • & • \\
\hline Reptiles & - & $\bullet$ & • & $\bullet$ & - \\
\hline Birds & - & - & $\bullet$ & $\bullet$ & $\bullet$ \\
\hline Mammals & - & $\bullet$ & $\bullet$ & $\bullet$ & - \\
\hline
\end{tabular}




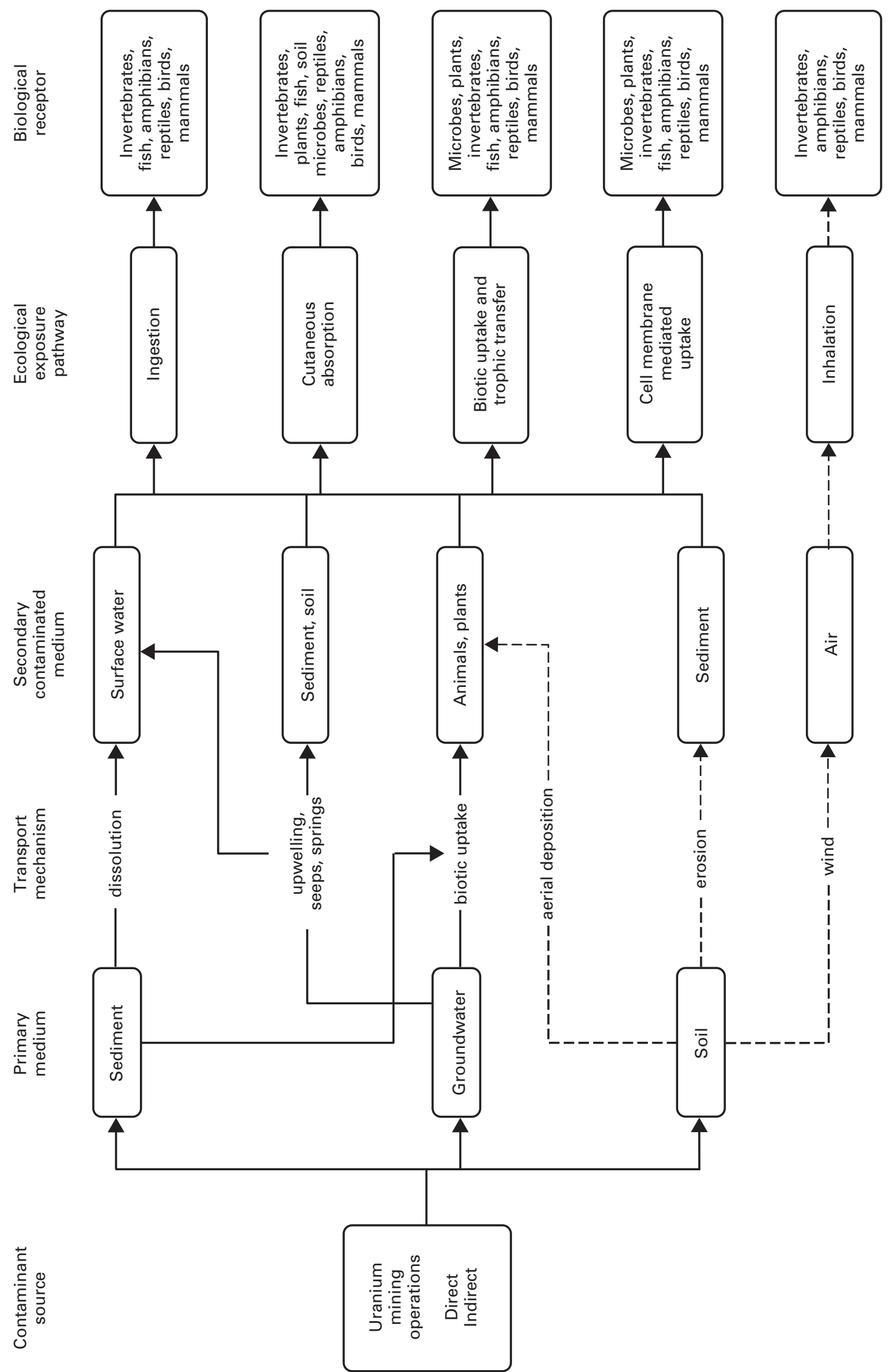

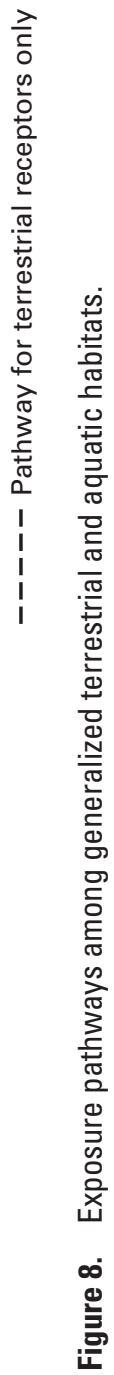


Biological data related to uranium that is specific to the segregation areas are limited. Concentrations of uranium in biota within the segregation areas have not been reported by USFS (Angela Gatto and Jeff Waters, personal commun., October 2009), BLM (Elroy Masters, personal commun., October 2009), Arizona Game and Fish Department (Sabra Schwartz, personal commun., October 2009), U.S. Fish and Wildlife Service (USFWS; Carrie Marr, personal commun., September 2009), or National Park Service (NPS; Martha Hahn, personal commun., October 2009). The only information identified for uranium concentrations in biota is from a study east of the segregation areas. Uranium concentrations were less than $0.09 \mathrm{mg} / \mathrm{kg}$ dry weight in invertebrates (aquatic beetles, water boatmen, and annelids), $0.27 \mathrm{mg} / \mathrm{kg}$ dry weight in whole-body fish (plains killifish, Fundulus zebrinus; Lower Colorado River sucker, Catostomus sp.; common carp, Cyprinus carpio; fathead minnow, Pimephales promelas; and green sunfish, Lepomis cyanellus), and $0.02 \mathrm{mg} / \mathrm{kg}$ dry weight in bird carcasses (killdeer, Charadrius vociferus; least sandpiper, Calidris minutilla; semipalmated plover, Charadrius semipalmatus; and spotted sandpiper, Actitis macularia) in the Rio Puerco and Little Colorado River drainages in Arizona (Andrews and others, 1995).

\section{Ecotoxicity Values}

The ecotoxicity data that follow are intended to provide overviews of biological responses potentially associated with uranium exposure in the environment. This information is best presented in two major categories: chemical hazards and radiation hazards. Within these two categories, biological receptor groups are further subdivided into aquatic and terrestrial environments. This chapter will also distinguish between two types of effects endpoints available in the scientific literature: effects thresholds and guidance values. Effects thresholds are acute and chronic values derived from empirical data based on a primary study. Guidance values are consensus values commonly derived from effect thresholds (acute and chronic empirical data) from multiple sources that establish benchmark values for the protection of biota or based on expert judgment. These two types of data will be presented separately in this document. While it is important to recognize that guidance values exist, the application of such toxicity benchmarks to any study should not be done without understanding how they were derived.

Biological receptors (fish and wildlife, aquatic and terrestrial invertebrates, vascular and nonvascular plants, a wide array of soil microorganisms) are potentially exposed to elements of the ${ }^{238} \mathrm{U}$ decay series, particularly as those elements occur within minerals and ores in deposits such as breccia pipes. These chemicals may attain concentrations that are toxic to biota in the segregation areas when encountered through the ingestion of prey and water, incidental ingestion of soil, inhalation of airborne contaminants, and dermal uptake. These radionuclides also present radiation hazards if exposure pathways are complete and exposure is sufficient to yield adverse effects in receptors. Therefore, radiation hazards were summarized separately from chemical hazards for each radionuclide.

Radionuclides from the ${ }^{238} \mathrm{U}$ decay series were the focus of this chapter, although toxicity data for radionuclides from other actinide decay series (for example, thallium) were included when available. Existing scientific literature provided the basis for the synoptic data compilation, which represents the status of the current literature and identifies data gaps in toxicity data. Available information was compiled on microbial, plant, and animal species and on effects linked to exposures to uranium and other radionuclides, including an overview of transfer of the contaminants from water and soil to biota. To help identify data gaps for receptor groups, the chemical toxicity data from the literature compilation were subjectively categorized by biological receptor as none (no chemical toxicity data available), minimal (chemical toxicity data available for $<5$ species and from $<3$ individual studies), low (chemical toxicity data available for $5-10$ species and from 3-5 individual studies), or moderate (chemical toxicity data available for $>10$ species and from $>5$ individual studies) (table 5). Existing guidance values from the scientific literature were also included, although the methodologies for deriving these values were not critiqued. Data regarding biota sensitivity to radionuclides were also included when available. Data for special status and nonstatus species occurring within the segregation areas were not available except for several fish species. Tabulations of chemical exposure concentrations and radiation dose based on available guidance are also included as a linkage to the pathway analysis (tables 6-8). Derivation of radiation dose is detailed in Turner (2007) and Bréchignac and Desmet (2005), and exposure units used to characterize radiation toxicity are detailed in appendix 2 .

Ecotoxicity data were compiled to provide relevant information on chemical hazards to aquatic and terrestrial biota of concern; data were limited to radionuclides of the ${ }^{238} \mathrm{U}$ decay series including uranium, thallium, thorium, radium, and radon because they are relatively long-lived (table 7). Availability of ecotoxicological data varies among those radionuclides likely encountered in field exposures, but was most abundant for uranium and thallium (tables 7-8). As a radionuclide of ${ }^{234} \mathrm{U}$ and ${ }^{235} \mathrm{U}$ decay series, thallium has a short half life $(<5$ minutes), but in field settings it occurs predominately in its stable isotopes $\left({ }^{203} \mathrm{Tl}\right.$ and $\left.{ }^{205} \mathrm{Tl}\right)$. As a result, ecotoxicological data for the chemical toxicity of thallium are available for multiple receptors (table 8). The ecotoxicological data consist of a compilation of existing acute and chronic guidance values and effects thresholds. Information-such as exposure route, exposure duration, exposure compound, life stage exposed, and endpoint evaluated - that is relevant to characterizing benchmarks was included in the summary (tables 6-8). There were no selection criteria for including or excluding any guidance value or effects threshold into the summary of the 
Table 5. Amount of chemical toxicity data available for biological receptors exposed to radionuclides in the uranium decay series considered in this summary.

[None, no chemical toxicity data; Minimal, chemical toxicity data available for $<5$ species and $<3$ primary studies; Low, chemical toxicity data available for 5-10 species and 3-5 primary studies; Moderate, chemical toxicity data available for $>10$ species and $>5$ primary studies]

\begin{tabular}{|c|c|c|c|c|c|c|c|c|}
\hline Receptor & Uranium & Thallium & Thorium & Bismuth & Radium & Radon* & Protactinium* & Polonium* \\
\hline Algae & Minimal & Minimal & Minimal & Minimal & None & None & None & None \\
\hline Microorganisms & Minimal & Minimal & None & None & None & None & None & None \\
\hline Aquatic invertebrates & Moderate & Moderate & Minimal & Minimal & None & None & None & None \\
\hline Fish & Moderate & Low & Minimal & None & None & None & None & None \\
\hline Soil microorganisms & Minimal & None & None & None & None & None & None & None \\
\hline Amphibians & Minimal & Minimal & None & None & None & None & None & None \\
\hline Reptiles & None & None & None & None & None & None & None & None \\
\hline Birds & None & None & None & None & None & None & None & None \\
\hline Mammals, wild & None & None & None & None & None & None & None & None \\
\hline $\begin{array}{l}\text { Mammals, standard } \\
\text { laboratory species }\end{array}$ & Moderate & Low & Minimal & None & None & None & None & None \\
\hline
\end{tabular}

"Primarily a radiation hazard.

literature compilation because (1) the objective was to compile as much uranium toxicity literature possible, and (2) the toxicity data available was expected to be limited for certain biological receptors. Also, because available data were limited for some receptors, the toxicity tables include dose and dose rates. Guidance values from the scientific literature are presented (table 6). The derivations of these benchmark toxicity values need to be understood before they can be incorporated into risk assessments for the segregation areas, but information on how these benchmarks were derived is beyond the scope of this document. Chronic endpoints such as no observed effect concentrations (NOECs) and lowest observed effect concentrations (LOECs) were reported instead of acute endpoints such as LC50s and EC50s (lethal and effect concentrations for 50 percent of the organisms tested) from the same study in order to provide the most conservative effects data available and to minimize the length of summary tables. However, acute data (LC50s and EC50s) would be important to consider when deriving or estimating benchmark or guidance values (Crane and Newman, 2000; Scholze and others, 2001; European Commission, 2003; Lepper, 2005; Canadian Council of Ministers of the Environment, 2007). In addition, NOECs presented may have included bounded (both NOEC and LOEC determined) and unbounded (no effect at the highest exposure evaluated) values. Such information should be indentified when guidance values are being derived because unbounded NOECs from studies that did not evaluate very high exposures can imply a potential sensitivity that is unfounded. Ecotoxicity data was not provided for lead, the stable end-state of the uranium decay series; the chemical toxicity of lead is well characterized for aquatic and terrestrial biota (for example, U.S. Environmental Protection Agency, 2005). Similarly, benchmark values are available for many metals co-occurring in uranium deposits characteristic of field settings (for example, see $h$ ttp://www.epa.gov/ecotox/ecossl/).

\section{Chemical Hazards of Uranium}

The chemical toxicity of uranium presents a variety of concerns for biota and ecosystem, particularly in areas where ore deposits are associated with mining operations. Driver (1994) and Eisler (1994) provided early compilations of chemical hazards associated with uranium. Data on the chemical toxicity, bioconcentration, and bioaccumulation of uranium for terrestrial systems are less developed compared to aquatic systems. The range of reported toxicity values for uranium varies widely, presumably because its toxicity is heavily influenced by the chemistry of the associated matrix (water, sediment, soil). For example, uranium tends to be more toxic to aquatic biota in soft water than in hard water (Paquin and others, 2003; Meyer and others, 2007).

\section{Biological Receptors in the Aquatic Food Chain}

\section{Algae, Cyanobacteria, and Aquatic Microorganisms}

Chemical toxicity data for algae, cyanobacteria, and aquatic microorganisms are limited, and responses to uranium exposure varies among receptors (table 7). Gus'Kova and others (1966, cited in Driver, 1994) reported that uranium (specifically the uranyl ion) inhibited the growth of aquatic microflora at about $1.0 \mathrm{mg} / \mathrm{L}$ in freshwater systems and was bactericidal at $100 \mathrm{mg} / \mathrm{L}$. Diatom survival was reduced at an exposure of $1.0 \mathrm{mg} / \mathrm{L}$ (Gross and Koczy, 1946, cited in Driver, 1994), whereas a field study (Ruggles and others, 1979, cited in Driver, 1994) reported abundant diatom populations in tailing waters with $17 \mathrm{mg} / \mathrm{L}$ of uranium. Algae (Scenedesmus) experienced growth inhibition at $22 \mathrm{mg} / \mathrm{L}$, and a protozoan (Microregma) had reduced food intake at $28 \mathrm{mg} / \mathrm{L}$ of uranium (Bringman and Kuhn, 1959, cited in Driver, 1994). 


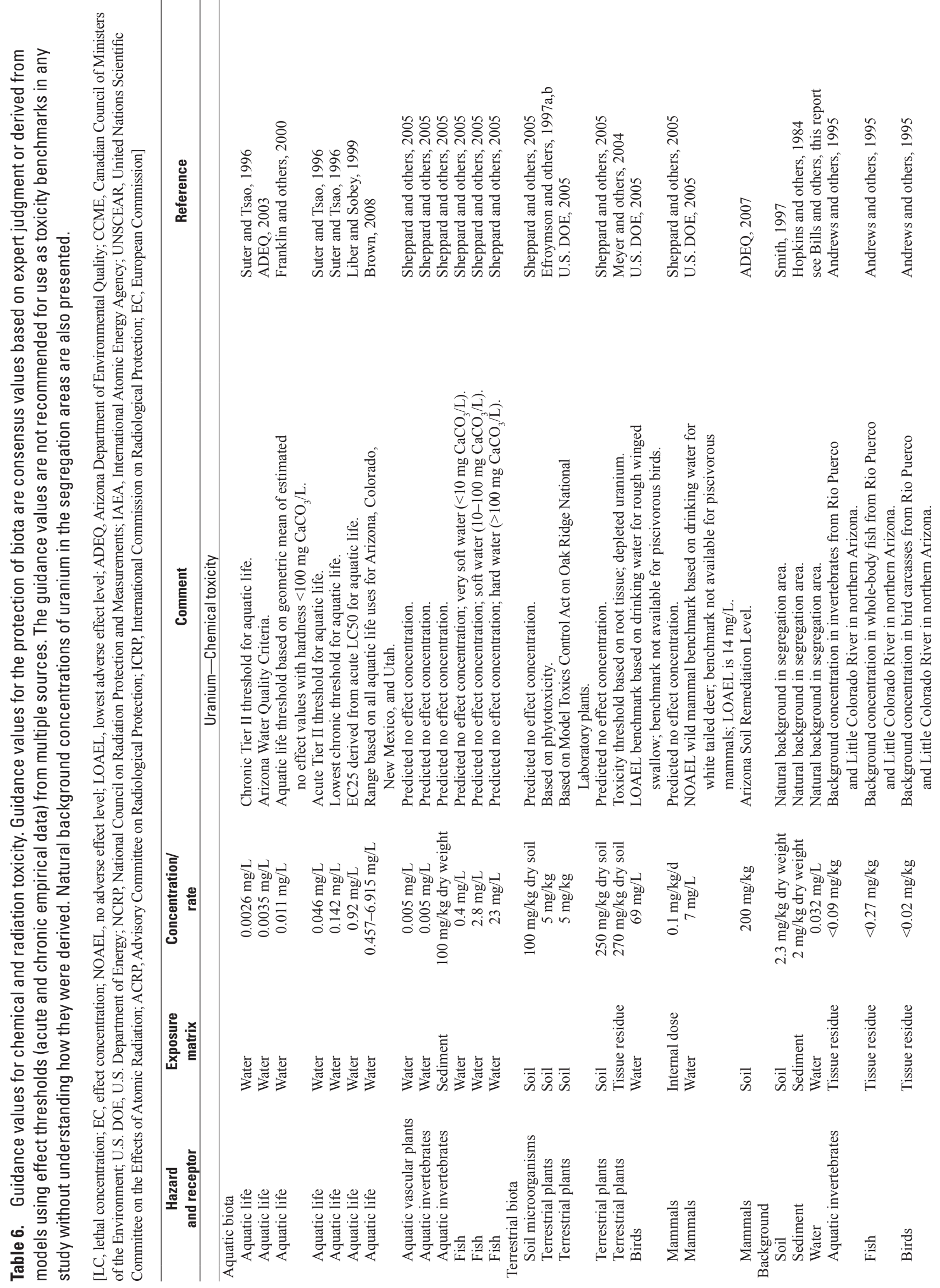




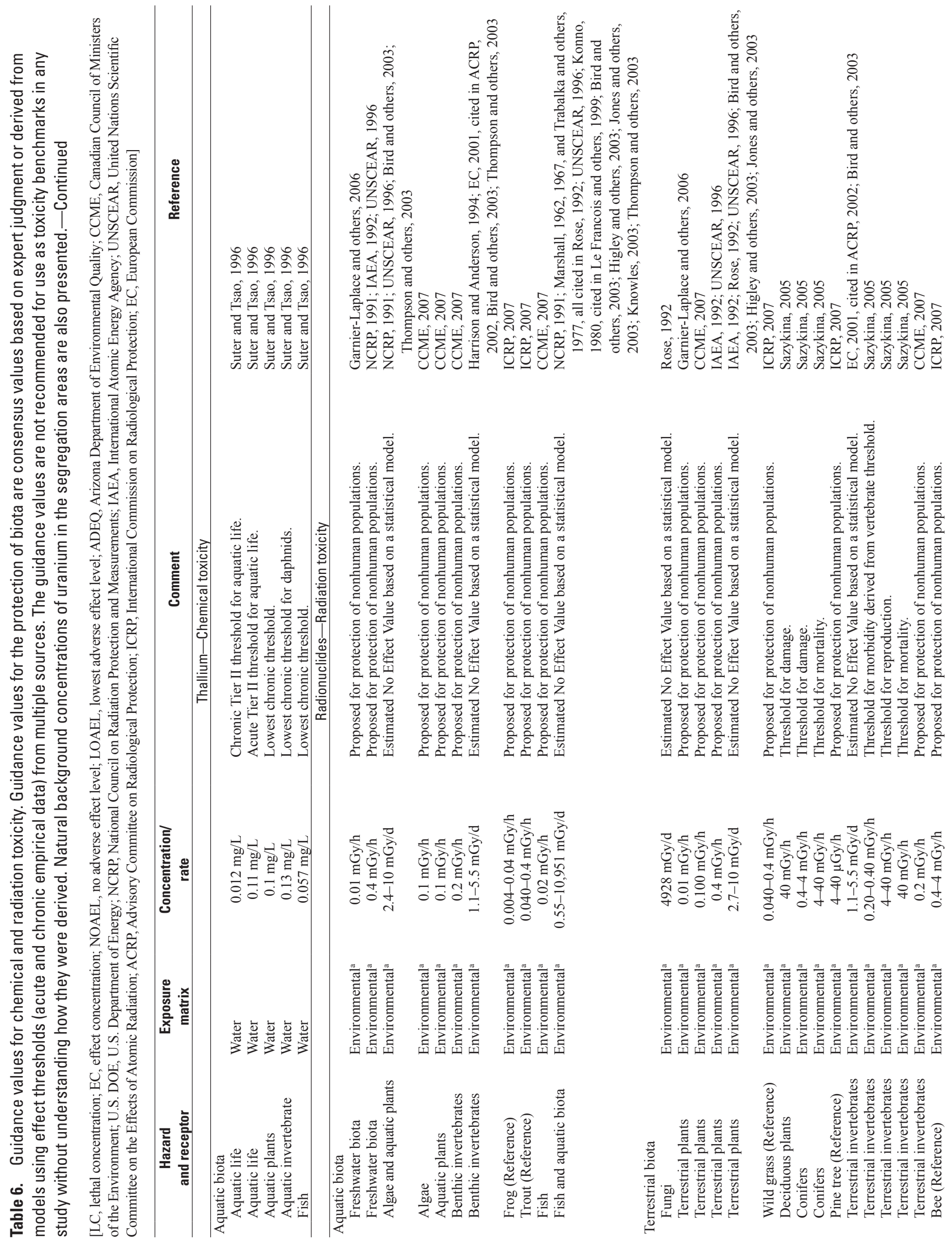




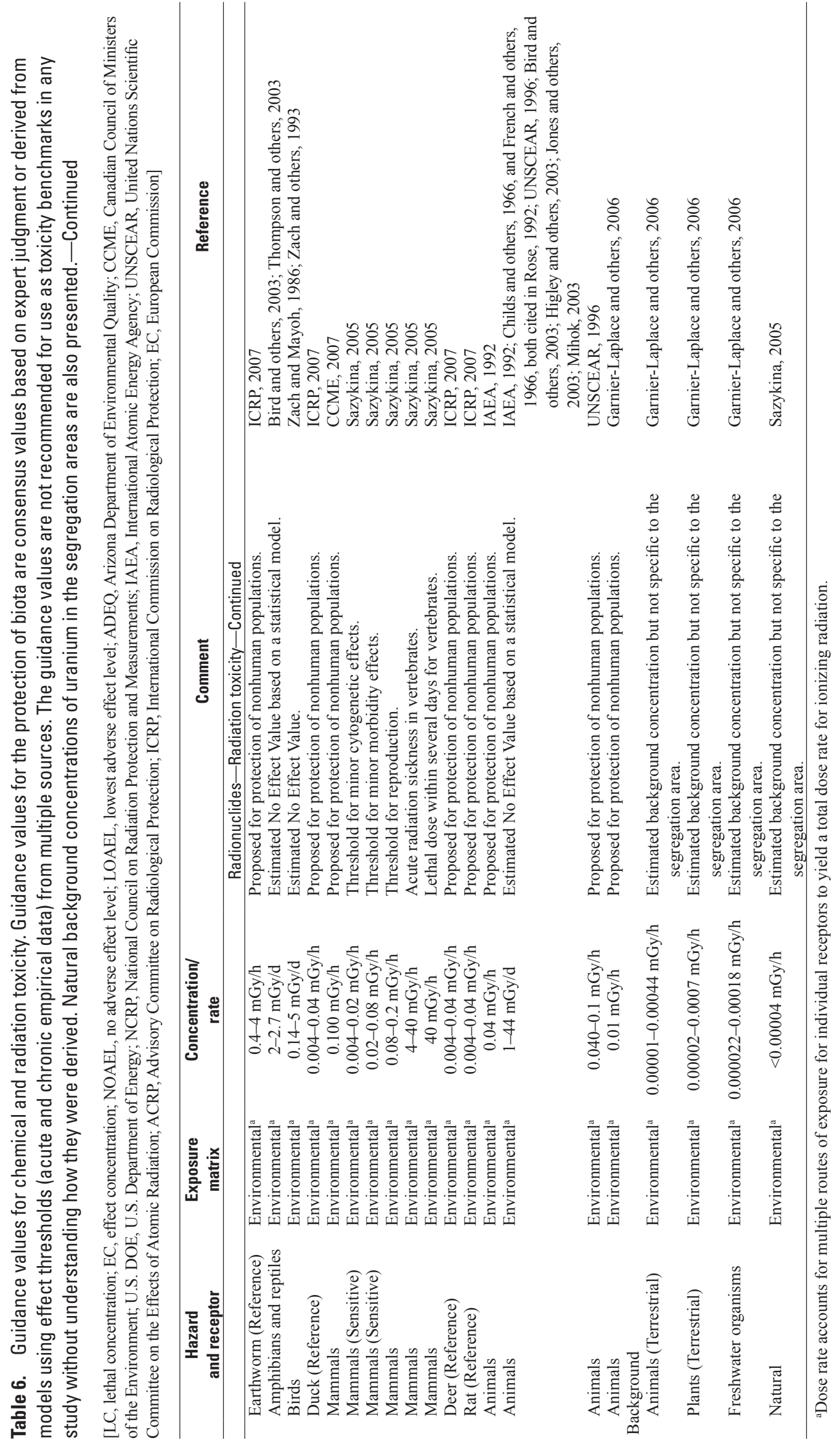




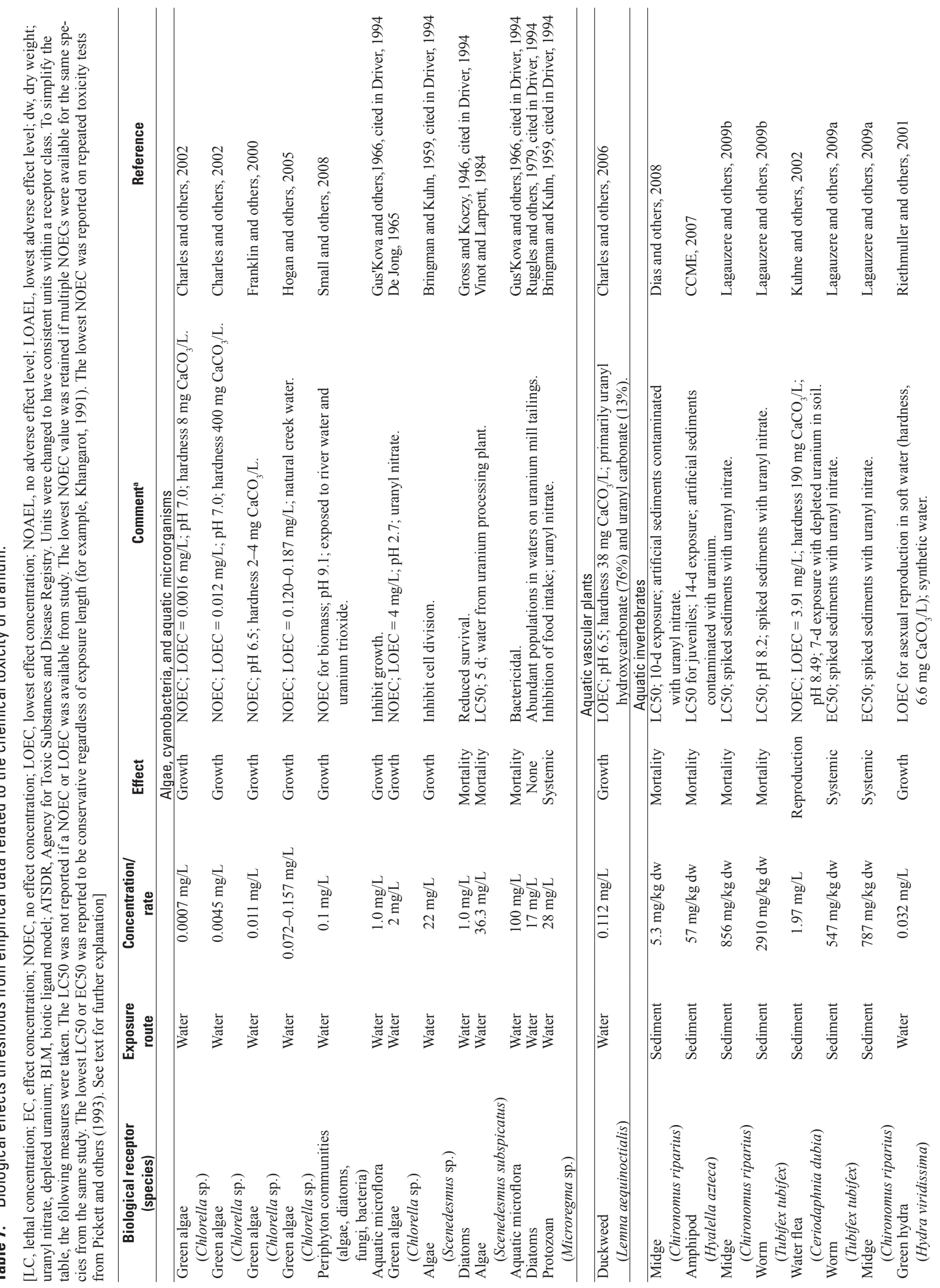




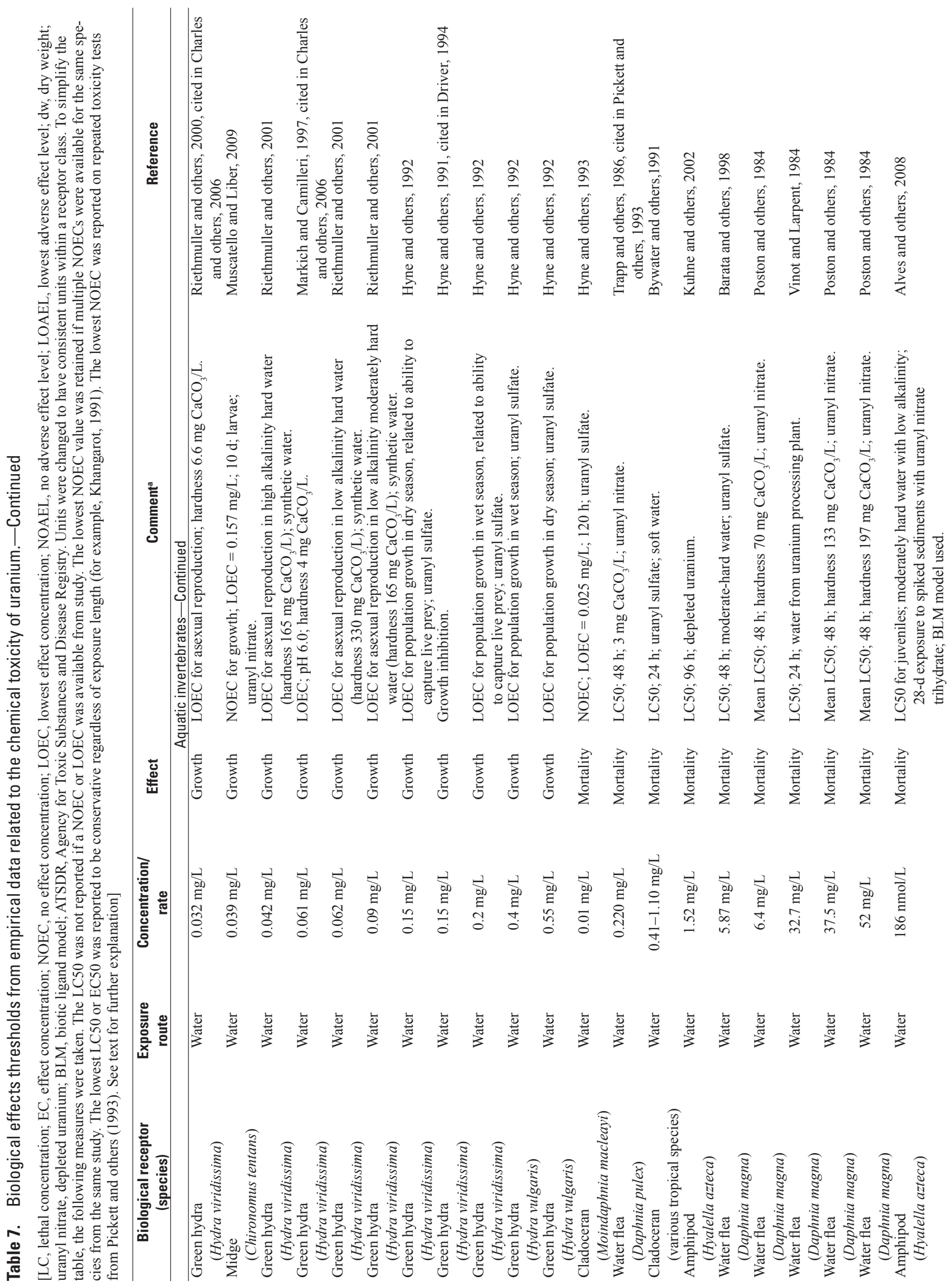




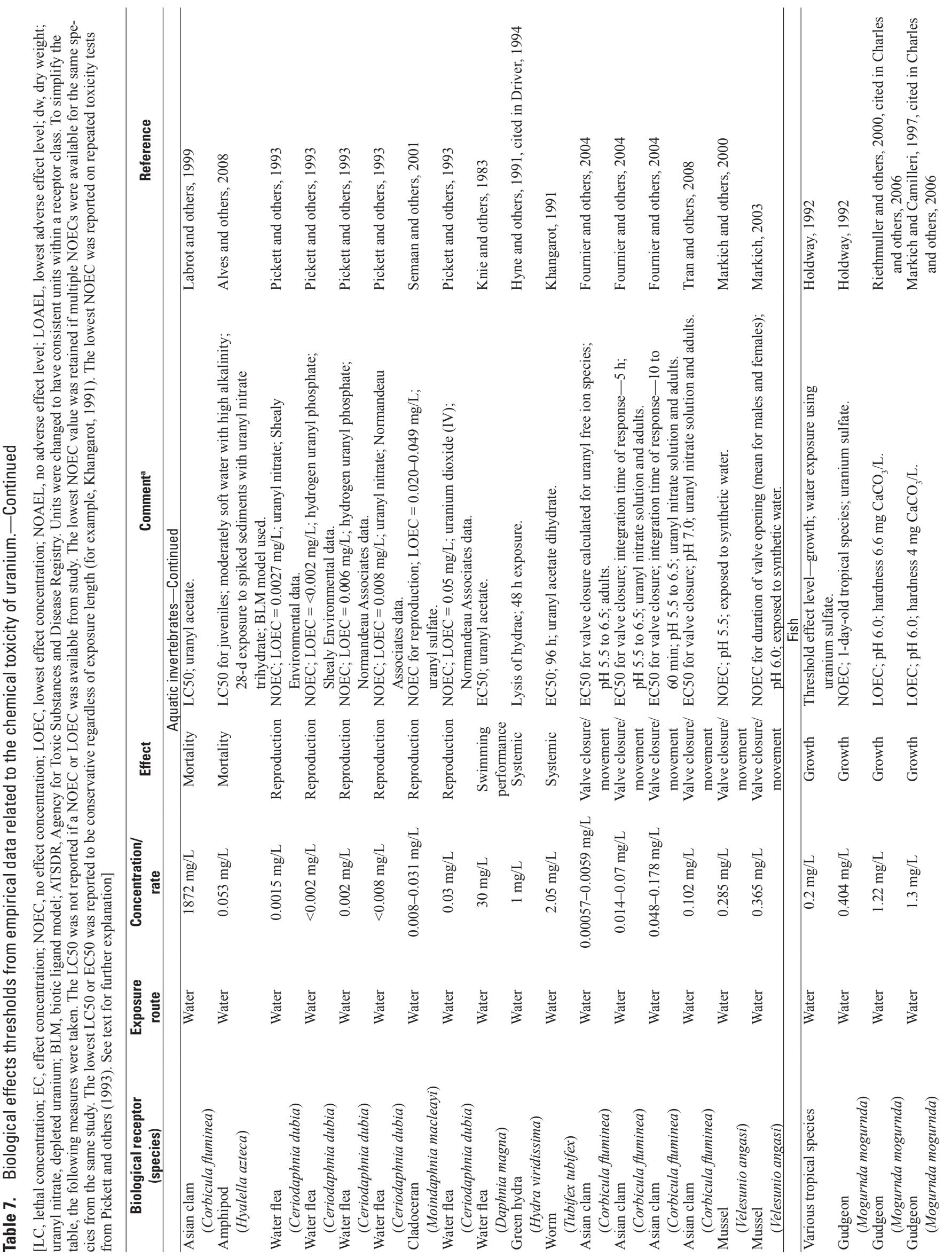




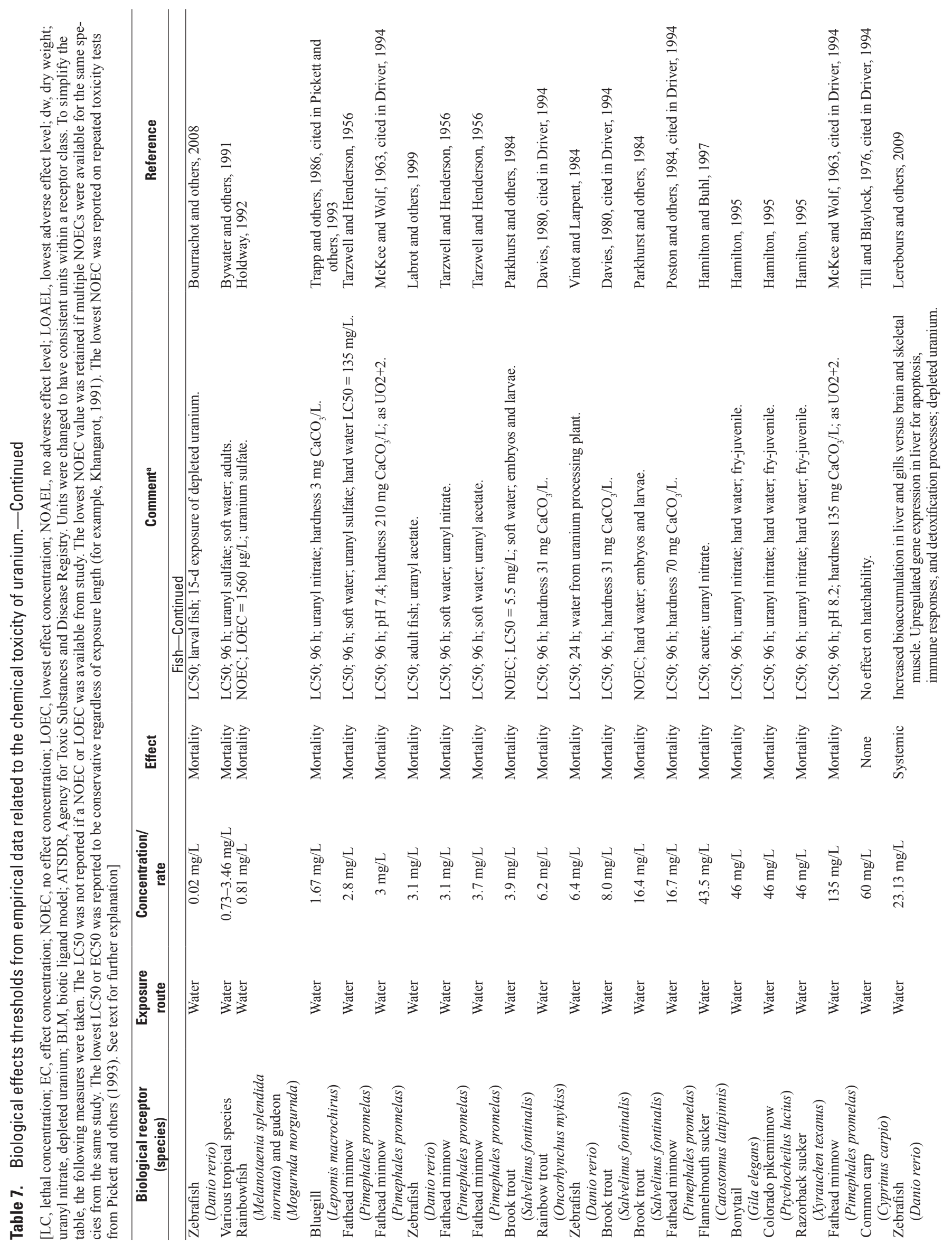




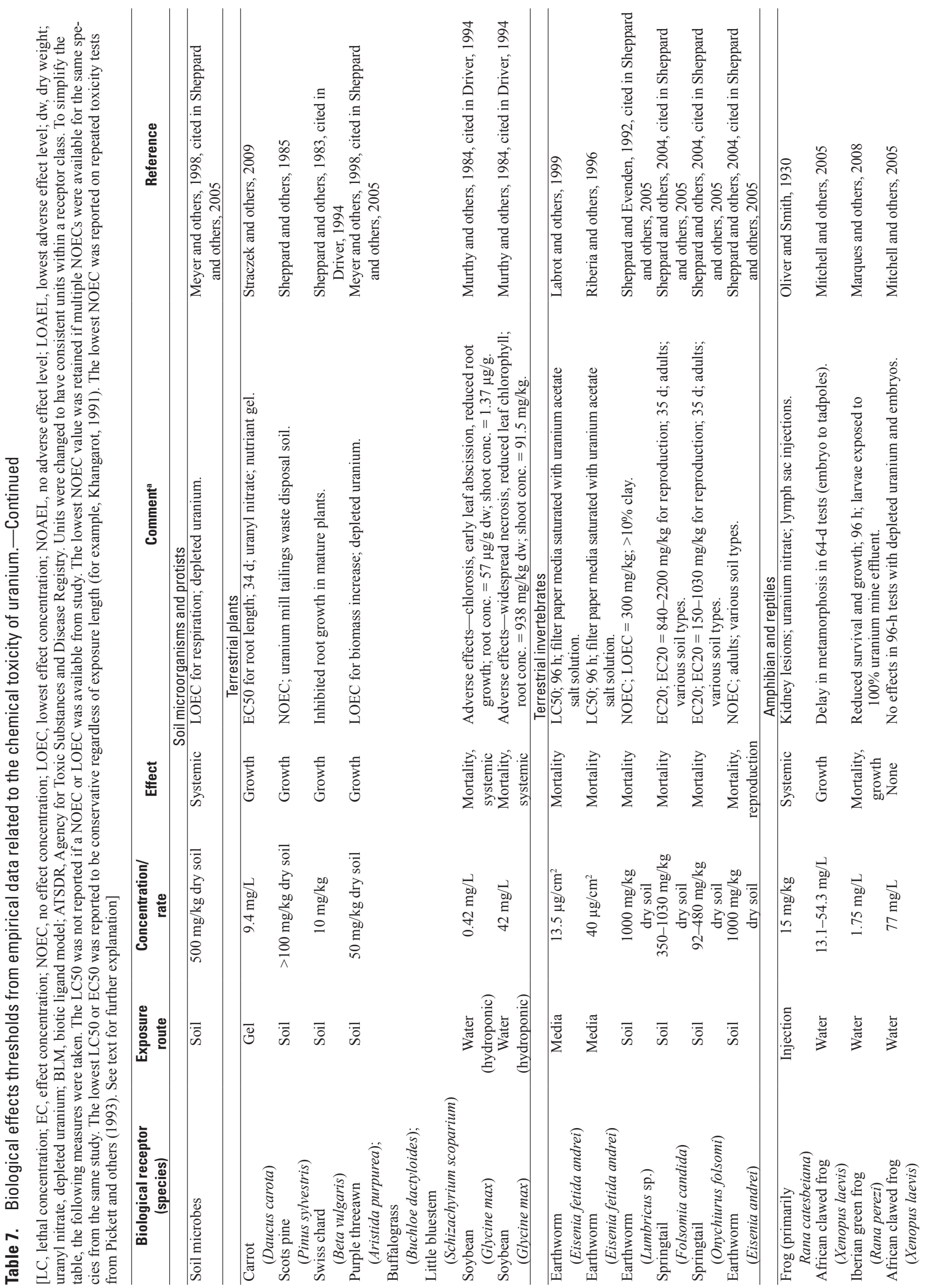




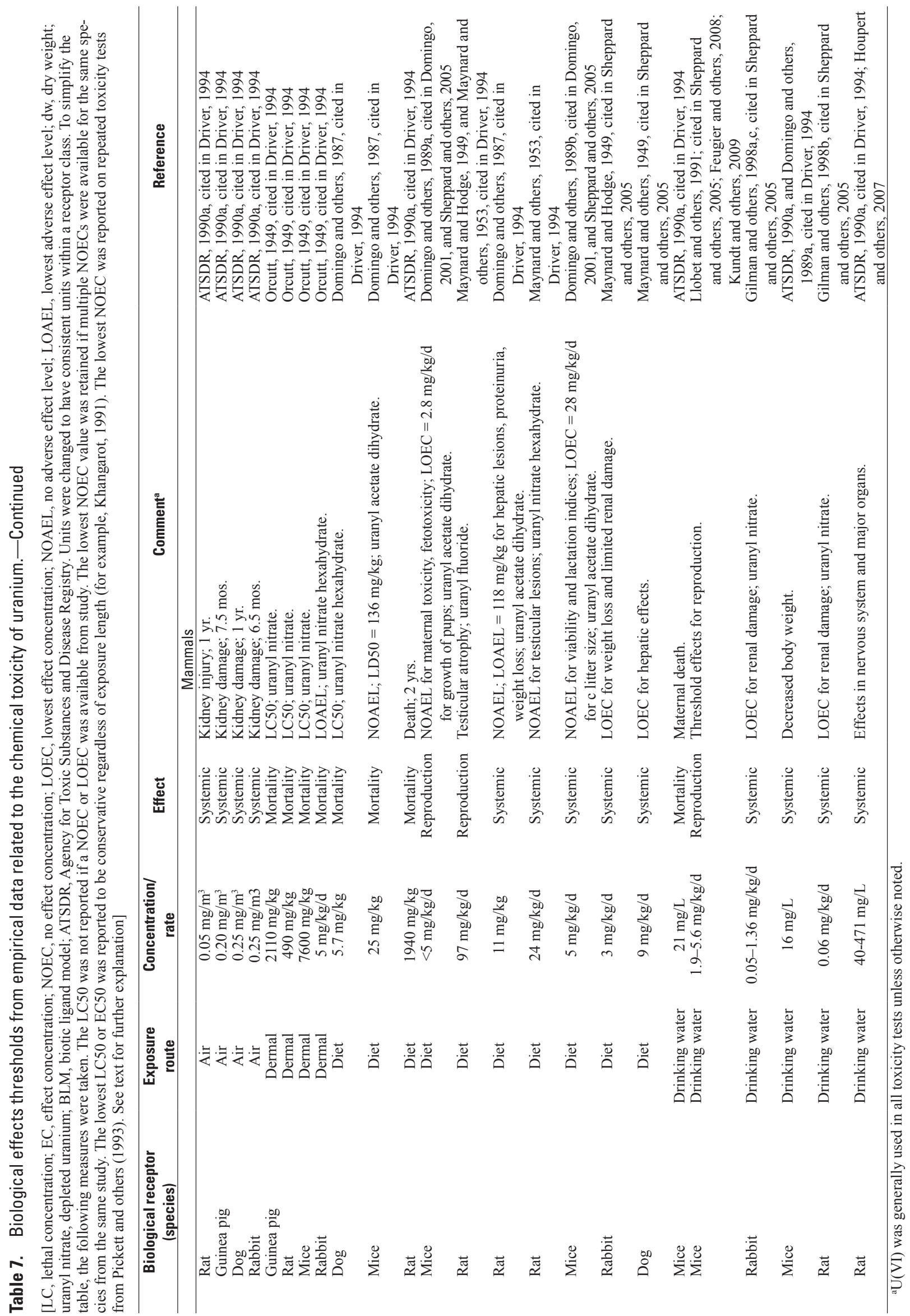




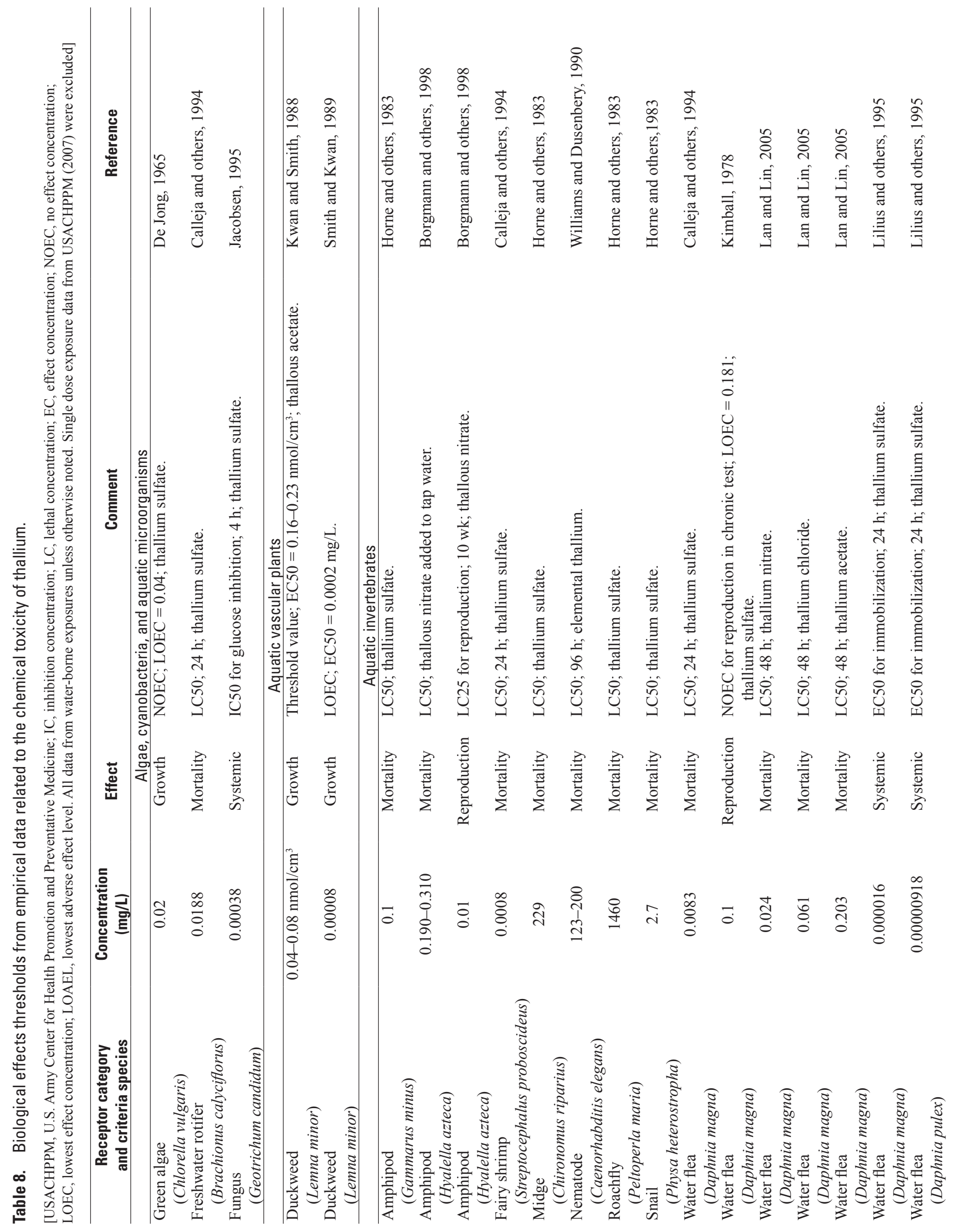




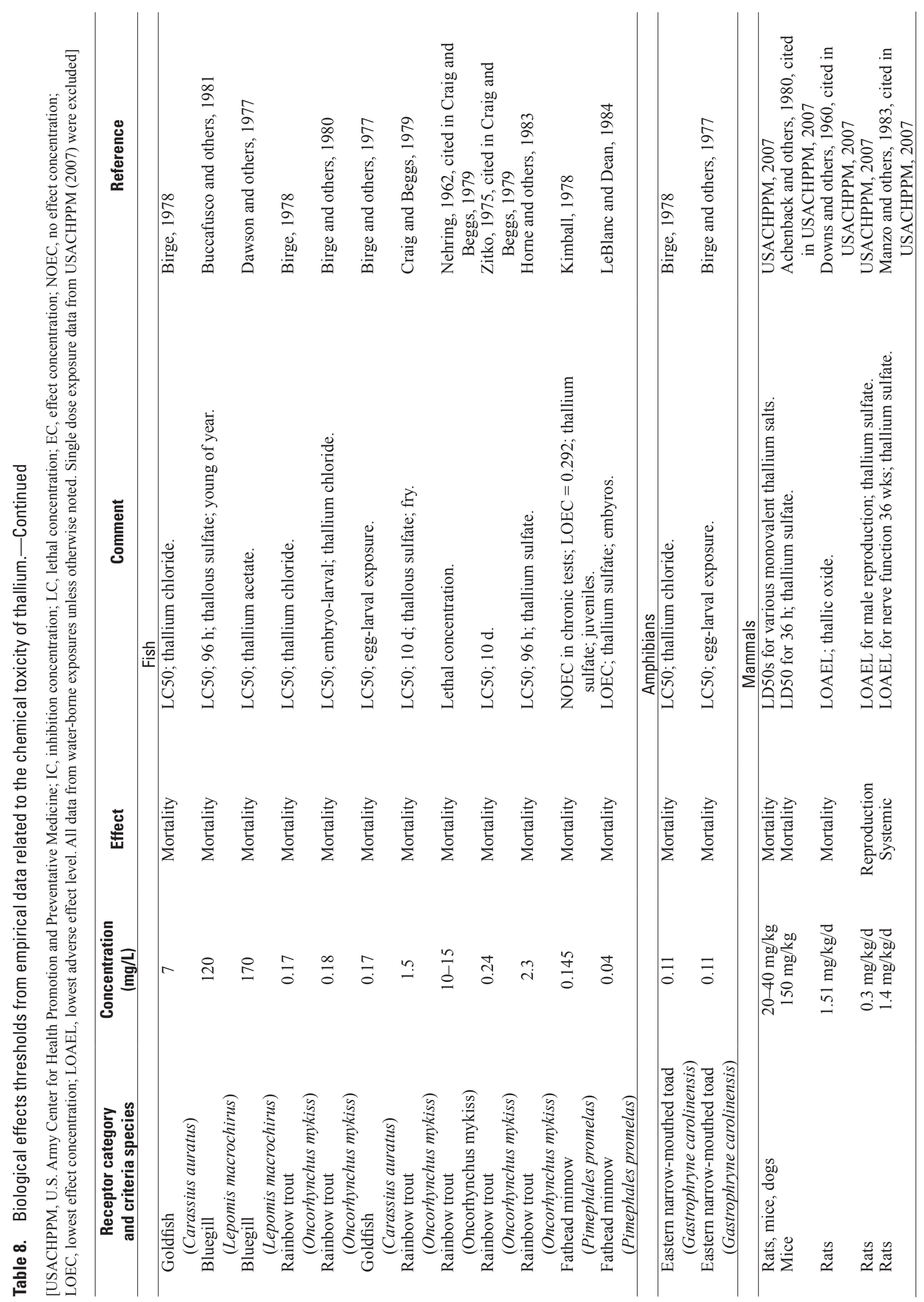


Few studies focused on the toxicity of uranium to aquatic microorganisms have been published since the review by Driver (1994). Studies have reported microbe activity in soils and sediments related to uranium exposures, but threshold effects levels for mortality, growth, and reproduction are minimally reported in the literature. Most research has focused on establishing benchmark concentrations for aquatic bacteria exposed to uranium, although studies for freshwater algae and periphyton have also been published. For example, Small and others (2008) observed no adverse effects on periphyton communities exposed to river water having $0.1 \mathrm{mg} / \mathrm{L}$ of uranium. Water quality conditions, particularly $\mathrm{pH}$, dissolved organic carbon, and differential chemical speciation, affect uranium toxicity to green algae (Franklin and others, 2000; Charles and others, 2002; Fortin and others, 2004, 2007; Hogan and others, 2005). The bioavailability of uranium to aquatic microorganisms and algae remains a critical issue for aquatic habitats potentially exposed to uranium releases from ore deposits. Guidance values to protect aquatic life (which includes algae and aquatic microorganisms) have been estimated by various organizations (table 6).

\section{Aquatic Vascular Plants}

Toxicity data for aquatic vascular plants are limited (table 7). The uptake and incorporation of uranium from water to plant tissues yield relatively low tissue residues (Pettersson and others, 1993). Translocation of uranium from root to foliage is low; therefore, foliage generally has lower uranium concentrations than roots (Pettersson and others, 1993). Mkandawire and others $(2005,2007)$ noted that water quality characteristics, such as phosphate concentration, affected the uranium toxicity to duckweed (Lemna aequinoctialis) under field conditions. Charles and others (2006) reported that joint exposures to copper and uranium reduced growth inhibition relative to singlecompound exposures. Charles and others (2006) also reported a LOEC of $0.112 \mathrm{mg} / \mathrm{L}$ for growth. Sheppard and others (2005) have suggested a predicted no effect concentration for uranium toxicity to freshwater plants (table 6).

\section{Aquatic Invertebrates}

A moderate amount of chemical toxicity data is available for aquatic invertebrates including midges, cladocerans, hydrae, amphipods, worms, and molluscs (table 7). Similar to other metals, the toxicity of uranium varied with total hardness and alkalinity for aquatic invertebrates. For example, Poston and others (1984) reported greater mean acute values (as LC50s) for cladocerans in hard water $(37.5 \mathrm{mg} / \mathrm{L})$ than in soft water $(6.4 \mathrm{mg} / \mathrm{L}$ ) (table 7). Chronic values (as NOECs) were available for the water flea Ceriodaphnia dubia $(<0.002-0.03$ $\mathrm{mg} / \mathrm{L})$, the cladoceran Moindaphnia macleayi $(0.008-0.031$ $\mathrm{mg} / \mathrm{L})$, the midge Chironomus tentans $(0.039 \mathrm{mg} / \mathrm{L})$, and the mussel Velesunio angasi $(0.280-0.388 \mathrm{mg} / \mathrm{L})$, some of which are lower than guidance thresholds available for aquatic invertebrates (table 6). Uranium toxicity data for freshwater green hydra (Hydra viridissima) was also available from multiple studies (table 7).
Fish

A moderate amount of chemical toxicity data is available for fish (table 7). Uranium toxicity varies widely in fishes and is dependent on water quality conditions such as total hardness and alkalinity. For example, acute values (as LC50s) for fathead minnow were $3 \mathrm{mg} / \mathrm{L}$ with a water hardness of $210 \mathrm{mg}$ $\mathrm{CaCO}_{3} / \mathrm{L}$ and $\mathrm{pH}$ of 7.4 , and $135 \mathrm{mg} / \mathrm{L}$ with a water hardness of $400 \mathrm{mg} \mathrm{CaCO} / \mathrm{L}$ and $\mathrm{pH}$ of 8.2 (McKee and Wolf, 1963, cited in Driver, 1994). Some estimated guidance values to protect fish have also included hardness in their recommendations (table 6).

Toxicity data for uranium were available for threatened and endangered species of the Colorado River system. Hamilton (1995) examined the acute toxicity of uranium on swimup fry and juvenile Colorado pikeminnow (Ptychocheilus lucius), razorback sucker (Xyrauchen texanus), and bonytail (Gila elegans). Acute values for were $46 \mathrm{mg} / \mathrm{L}$ (96-hr LC50s) for each species, which indicated uranium sensitivity did not differ between species. Common carp, a nonstatus species in the Colorado River system, were not affected by uranium exposures of $60 \mathrm{mg} / \mathrm{L}$ in areas of high water hardness (Till and Blaylock, 1976). Chronic values (as NOECs) for uranium toxicity were available for the gudgeon Mogurnda mogurnda $(0.404 \mathrm{mg} / \mathrm{L})$, the rainbowfish Melanotaenia splendida inornata $(0.81 \mathrm{mg} / \mathrm{L})$, and brook trout (Salvelinus fontinalis) (3.9 $\mathrm{mg} / \mathrm{L}$ soft water and $16.4 \mathrm{mg} / \mathrm{L}$ hard water) (table 7).

\section{Biological Receptors in the Terrestrial Food Chain}

\section{Soil Microorganisms}

Although the soil crust community in arid ecosystems typical of the segregation areas are critical to the system's structure and function, existing uranium toxicity data for soil microorganisms and other soil-dwelling biota are limited (table 7). Biological soil crusts are assemblages of lichens, fungi, cyanobacteria, and mosses that colonize soil surfaces and represent up to 70 percent of the living groundcover in arid land environments (Belnap and Lange, 2001; Belnap and others, 2005). Biological soil crusts are critical to the transfer of nutrients from seasonal surface runoff (Ludwig and others, 1997, 2005). Empirical data related to the uranium toxicity for soil microbes was found in one study. Meyer and others (1998) indicated that an LOEC of $500 \mathrm{mg} / \mathrm{kg}$ dry soil for soil microbe respiration may also be applicable for some terrestrial systems. Characterization of effects cannot be developed for soil microbes in the absence of chemical toxicity data. Nevertheless, guidance values for soil microbes have been estimated (table 6).

\section{Terrestrial Nonvascular and Vascular Plants}

Chemical toxicity data for uranium were available for terrestrial plants (table 7). Uranium concentrations as low as $0.42 \mathrm{mg} / \mathrm{L}$ reduced seedling survival based on measures of 
chlorosis, early leaf abscission, and reduction in root growth in hydroponically-grown soybean plants (Glycine max) (Murthy and others, 1984). Chronic values available for uranium concentrations in soil include a NOEC of $>100 \mathrm{mg} / \mathrm{kg}$ for Scots pine (Pinus sylvestris) and a LOEC of $50 \mathrm{mg} / \mathrm{kg}$ dry soil for a variety of grasses (Sheppard and others, 1985; Meyer and others, 1998). Sheppard and Evenden (1992) suggested that sublethal effects may occur in plants grown in soils containing between 10 to $100 \mathrm{mg} / \mathrm{kg}$ of uranium. In this exposure range, reduced root growth in test plants was observed at soil concentrations of $10 \mathrm{mg} / \mathrm{kg}$ in both sand and peat soils, but aboveground growth was not affected (Sheppard and others, 1983). Several guidance thresholds for the protection of terrestrial plants have been estimated by various organizations (table 6).

Other factors should be considered when evaluating the toxicity of uranium to terrestrial plants. The mycorrhizae (fungus-plant root relationships) are critical to soil structure and function, and biological processes acting within the rhizosphere (the zone surrounding the roots of plants) complement the physicochemical factors influencing uranium solubility and control uranium uptake into plant tissues. Rufyikiri and others (2004) observed that mycorrhizal fungi may limit uranium accumulation by mycorrhizae-dependent plants exposed to high uranium concentrations in soil. Mechanisms explaining these observations are numerous, including the interactions of soil $\mathrm{pH}$, calcium, and phosphorus. Such confounding factors encourage caution in interpretations of soil guidance values for metals in soils and threshold effects concentrations of uranium and other radionuclides.

\section{Terrestrial Invertebrates}

Chemical toxicity data for uranium were limited to earthworms and springtails for terrestrial invertebrates (table 7); guidance values specific to terrestrial invertebrates have not been estimated (table 6). Sheppard and Evenden (1992) observed reduced survival in earthworms (Lumbricus spp.) exposed to $1,000 \mathrm{mg} / \mathrm{kg}$ dry weight soil, a concentration associated with adverse effects to other organisms in different soil types. Following these earlier studies, Sheppard and others (2004, cited in Sheppard and others, 2005) evaluated the toxicity of uranium to the earthworm Eisenia andrei using three different soil types as exposure matrices and reported NOECs of $1,000 \mathrm{mg} / \mathrm{kg}$ dry weight soil for survival and reproduction in each soil type. Effects levels observed for two species of springtail (Onychiurus folsomi and Folsomia candida) were similar to those for earthworms following 35-day exposures (Sheppard and others, 2004). In a similar study, adult $O$. folsomi were more sensitive to uranium than $F$. candida as measured by mortality and reproduction (Sheppard and others, 2004, cited in Sheppard and others, 2005).

Alternative test methods have also been used to evaluate chemical toxicity to earthworms (table 7). Ribera and others (1996) exposed the earthworm Eisenia fetida andrei to filter paper media saturated with a uranium acetate salt solution and reported a 96-hour LC50 of $40 \mu \mathrm{g} / \mathrm{cm}^{2}$, whereas Labrot and others (1999) using a similar test method reported a 96-hour LC50 of $13.5 \mu \mathrm{g} / \mathrm{cm}^{2}$. Labrot and others (1996) also examined various biomarkers in E. fetida andrei exposed to a uranyl acetate solution and observed decreased levels of malondialdehyde at $1.0 \mu \mathrm{g} / \mathrm{cm}^{2}$. These studies relied on exposures of individuals to filter paper saturated with uranium solutions and should not be compared directly with exposure on bulk soils. Regardless of that methodological difference, the findings of Labrot and others $(1996,1999)$ indicate that toxicity and bioconcentration may be mediated by uranium concentrations occurring in soil solution.

\section{Amphibians and Reptiles}

Amphibians and reptiles are key components of the food web in the segregation areas; however, data for the chemical toxicity of naturally occurring uranium in amphibians was minimal and no data was found for reptilian species (table 7). Decreased survival and reduced growth in survivors was observed in larvae of the frog Rana perezi exposed to 100 percent uranium mine effluent (uranium concentration, $1.75 \mathrm{mg} / \mathrm{L}$ ), although effects could not be specifically associated with uranium (Marques and others, 2008). Marques and others (2008) also noted that other adverse effects related to growth and malformations were observed at effluent exposures $>50$ percent, but mortality was not significant relative to controls. Mitchell and others (2005) observed no effects in exposures of the African clawed frog (Xenopus laevis) to concentrations of depleted uranium greater than $77 \mathrm{mg} / \mathrm{L}$ in 96-hour tests, but delayed metamorphosis was observed at concentrations greater than $13.1 \mathrm{mg} / \mathrm{L}$ in 64-day exposures. However, no mortality or malformations were observed in these longerterm exposures (Mitchell and others, 2005). Kidney lesions developed in various frog species after the lymph sacs were injected with $15 \mathrm{mg} / \mathrm{kg}$ of uranium nitrate (Oliver and Smith, 1930). Guidance values for the protection of amphibians and reptiles have not been estimated (table 6).

\section{Birds}

Chemical toxicity data for effects of uranium in birds were not found, which is consistent with previous uranium reviews (Driver, 1994; Eisler, 1994). Despite the lack of empirical chemical toxicity data, a guidance value for uranium in drinking water has recommended for non-piscivorous birds in southern Utah (table 6) (U.S. Department of Energy, 2005).

\section{Mammals}

Chemical toxicity data for uranium in mammalian wildlife were not found; however, mammalian wildlife receptors and animal models used to evaluate human health share common pathways of uranium exposure. Laboratory mammals provide a starting point for evaluating effects levels in wild mammals, which undoubtedly have a range of sensitivities to uranium (table 7). Rabbits, dogs, and guinea pigs were more sensitive to uranium exposure than rats (Driver, 1994), and 
rabbits were most sensitive to uranium in laboratory tests (Morrow and others, 1981, 1982, and Leach and others, 1984, all cited in Driver, 1994). As with other biological receptors, the increased solubility of uranium in U(VI) makes the hexavalent form more toxic to mammals than U(IV). More recent studies (for example, Domingo, 2001; Sheppard and others, 2005) indicate that mammalian toxicity values for uranium remain consistent with those of previous reviews (Driver, 1994; Eisler, 1994). Field observations (for example, tissue concentrations) related to uranium mining activities and releases of radionuclides from energy-generating facilities dominate the recent literature for mammals, particularly with respect to exposures and bioaccumulation. Most effects data available were associated with kidney function (table 7). Guidance values for the protection of mammals have been estimated by various organizations (table 6).

\section{Bioconcentration Factors and Trophic Transfers}

The bioavailability of uranium depends on its speciation in the environment. Metals, including uranium, partition between solid and liquid phases and may occur as dissolved, exchangeable, carbonate, iron-manganese oxide, organic, or crystalline species. Partitioning or speciation of metals in the environment is influenced to varying degrees by $\mathrm{pH}$, redox state, organic content, and other environmental factors such as temperature, precipitation, and periodic events (for example, storms). Hydrogen ion activity $(\mathrm{pH})$ is likely one of the more critical factors governing metal speciation, solubility from mineral surfaces, transport, and eventually bioavailability to plants or animals. Factors such as particulate size, mineral properties, and total surface area available for adsorption or desorption processes affect metal speciation and metal bioavailability. For example, finely milled ore may release smaller particles that are likely more widely dispersed by water and wind, and thus can enhance metal transport and availability to biological receptors. Therefore, the form of the uranium and the nature of the environment can strongly influence the transport (movement) and bioavailability of uranium and the uranium decay series products in the segregation areas. In particular, interception rates are strongly influenced by the amount of precipitation (Pröhl, 2009). Interception is the fractional rate of adsorption of radionuclides from atmospheric sources (both dry and wet deposition). Rates of interception are inversely proportional to precipitation on a logarithmic scale (Pröhl, 2009). The greatest rates of interception (that is, fractional adsorption to plants) occur in arid regions like the segregation areas. The transport of radionuclides into a plant is measured by a transfer factor (TF) that is specific to the plant (Leclerc and others, 2009) and in general is defined by the amount of radionuclide taken up into the edible portions relative to the amount on the foliar areas of the plant. Therefore, when environmental pathways are considered for transport of uranium to biological receptors, such coefficients must be evaluated separately. Databases of plant-specific TFs for uranium and other radionuclides have been developed (Leclerc and others, 2009) and will be important for quantitative modeling of exposure pathways of species of interest within the segregation areas.

The uptake of uranium and uranium decay series products into animals is similar to that of other metals. The uptake of metals can be regulated or nonregulated, depending on the size (atomic radius) and valence (charge) of the metal species (Gray and others, 2006; Nordberg and others, 2007). Metals that have a similar size and charge to essential trace metal nutrients can be taken up across biological membranes through specific transport mechanisms (for example, sodium/ potassium exchange pumps). These same properties of atomic size and charge regulate binding once metals are inside an animal. These physical properties of the metals, along with the physiological characteristics of an animal, determine the internal dose and pharmacokinetics of metals, including uranium. In general, the liver and kidney are the primary sites of uranium accumulation, with bones, scales, gonads, gills, and gastrointestinal tract variously contributing to the accumulated uranium load (Colley and Thomson, 1991; Holdway, 1992). As with other non-essential metals, semi-metals, and non-essential metalloids, uranium tissue residues tend to be inversely related to body size. For example, higher mass-specific tissue residues are observed in small-bodied organisms provided uptake and depuration kinetics are similar across species of varying masses. Thus, target organ dose metrics of uranium and the decay series products will be determined by the speciation of each radionuclide and species-specific factors of the animals of interest.

\section{Aquatic Ecosystem Exposure}

Metal uptake by aquatic organisms is associated with two major pathways: (1) ingestion of metal-enriched sediment or particles and metal-enriched food items, and (2) uptake directly from water across biological membranes (generally respiratory membranes). Therefore, reactions of metals in water and sediment influence the bioavailability of metals in natural waters, and biological food webs influence the ultimate uptake of metals in aquatic ecosystems. However, detailed quantitative models that incorporate both biotic and abiotic factors which control uranium uptake in aquatic organisms are incompletely characterized. Therefore, empirical values for bioconcentration or bioaccumulation of uranium (and decay products) into aquatic organisms are used to derive estimates of exposure (Driver, 1994).

Linkages among aquatic and terrestrial habitats assure transfers across environmental compartments. Uranium in ore deposits accumulates in soils and reaches surface waters and sediments through physical processes mediated by natural or human-aided mechanisms, or the two combined. Uranium behaves similarly to other metals upon its entry in food 
chains (Meyer and others, 2005); uranium is adsorbed onto the surfaces of plants and animals and can then be ingested by consumers and predators through their diets. Coincidental ingestion of suspended or bed sediments may also contribute significantly to uranium exposure for some species of aquatic vertebrates; therefore, bottom-feeding fishes tend to accumulate greater uranium concentrations than piscivorous fish (see Swanson, 1983, 1985, and Waite and others, 1988, all cited in Driver, 1994).

Uranium tends to adsorb to surfaces in sediment systems, and its interactions depend on the physicochemical properties of these solid matrices. Sediments act as a sink for uranium with concentrations consistently exceeding that in overlying water. Uptake of uranium from water to organisms occurs primarily through sources in sediment (Swanson, 1985, and Brunskill and Wilkinson, 1987, both cited in Driver, 1994) or through equilibriums established among sediment, water column, and fish. Early studies (Swanson, 1985) observed that organisms feeding on or near stream and lake sediments receiving drainage from uranium mill tailings contained higher concentrations of uranium than pelagic or predatory species. Transfer pathways and effects of uranium-series radionuclides in surface waters are poorly characterized quantitatively because there are few data available for uranium under field or laboratory conditions. Overall, sediment-to-fish transfer coefficients were $0.02-0.05$ for sediment-to-fish and 5.7-11.0 for water-to-fish (Swanson, 1985). Driver (1994) postulated that a decline of about one order of magnitude in bioconcentration factors (BCFs) or bioaccumulation factors (BAFs) occurred at each step in an aquatic food chain and that biomagnification of uranium would not occur in aquatic or semi-aquatic food chains with species such as amphibians, fish-eating birds or waterfowl, and mammals such as muskrats (Ondatra zibethicus) or otters (Lontra canadensis).

Bioconcentration factors for uranium vary across aquatic species and were available for a limited number of species. For aquatic microbes, BCFs for uranium ranged from 2,794 to 354,200 (Driver, 1994). High BCFs for uranium by algae results from the relatively high adsorption of radionuclides on cell surfaces rather than actual uptake by the organisms (Atkins, 1977, and Horikoshi and others, 1981, both cited in Driver, 1994). For example, cell-bound uranium may account for only 10-15 percent of the total uranium on a dry weight basis in green algae and other aquatic microorganisms (Strandberg and others, 1981, cited in Driver, 1994). Physicochemical interactions among water quality factors and biological interactions can affect the binding of uranium to cell walls (for example, in phytoplankton) or cell membranes (for example, in zooplankton) and in solution.

The transfer of uranium in aquatic-sediment systems to rooted or floating aquatic vascular plants has been characterized in some species. A water-to-plant BCF of 0.55 was reported for uranium in aquatic macrophytes (Thompson and others, 1972, cited in Driver, 1994), which was lower than
BCFs for the pondweed Potamogeton sp. (1.13) and the water milfoil Myriophyllum sp. (1.15) in a lake receiving uranium mine tailings (Waite and others, 1988, cited in Driver, 1994). Sediment-to-plant BCFs were lower for Potamogeton sp. (0.16) and Myriophyllum sp. (0.20) than water-to-plant BCFs (Waite and others, 1988). Water-to-invertebrate BCFs for uranium are highly variable, ranging from 1 to 10,000 (Thompson and others, 1972; Mahon, 1982; Driver, 1994), which reflects greater variation in trophic and spatial niches among invertebrates collected under field conditions (Swanson, 1985, cited in Driver, 1994).

Numerous field studies demonstrate that uranium concentrates in fish. Values derived from field-collected individuals reflect bioaccumulation factors (BAFs), which capture all potential routes of exposure beyond the uptake of material solely from ambient waters. Uranium BAFs in fish were less than 10 when exposed to contaminated surface waters (Thompson and others, 1972). The greatest reported BAFs for uranium in rainbow trout (Oncorhynchus mykiss), longnose suckers (Catostomus catostomus), and lake whitefish (Coregonus clupeaformis) were less than 38 (Mahon, 1982; Poston, 1982; Swanson, 1985, cited in Driver, 1994). BAFs reported in the literature for early life stage fish are consistently less than 20 (Driver, 1994; Yankovich, 2009). For example, BCFs for uranium ranged from 1.9 to 4.3 in hard water $(210 \mathrm{mg} / \mathrm{L}$ as $\mathrm{CaCO}_{3}$ ) in brook trout eggs and fry (Parkhurst and others, 1984) and 3.3 in eyed carp eggs (Till and Blaylock, 1976). Till and Blaylock (1976) also noted that uranium accumulated in yolk material more than in developing embryo. Driver (1994) suggested that in lieu of species or site-specific data, default values for concentration factors (BCFs or BAFs) should be 10 for the flesh of freshwater fish, 20 for whole body piscivorous or planktivorous fish, and 50 for benthic species that might have greater exposures through incidental ingestion of sediments.

\section{Terrestrial Ecosystem Exposure}

Partitioning of dissolved metals including uranium in soils is primarily affected by $\mathrm{pH}$, and acidic soils are characterized by free metal ions in soil solution. Routine characterization of physicochemical properties of soils such as $\mathrm{pH}$, cation exchange capacity, organic carbon, and soil texture (particle size distribution) are key attributes that govern uranium speciation. Uranium is poorly bioconcentrated in terrestrial plants through direct uptake because of the reduced bioavailability of insoluble compounds formed under naturally occurring conditions.

Factors that influence bioavailability of uranium in soil are similar to those physicochemical properties that influence its bioavailability in aquatic and sediment systems (International Atomic Energy Agency, 2009). For example, for terrestrial plants, uptake of uranium and other trace elements depends on (1) movement of elements from the soil to the 
plant root, (2) movement of elements across the membrane of epidermal cells of the root, (3) transport of elements from the epidermal cells to the xylem, in which a solution of elements is transported from roots to shoots, and (4) possible mobilization, from leaves to storage tissues used as food (seeds, tubers, and fruit), in the phloem transport system (Sansharova and others, 2009a, cited in International Atomic Energy Agency, 2009). Metals including uranium are made available to terrestrial wildlife directly through plant uptake and the food chain, but the limiting step for elemental entry into the food chain is usually passage from the soil to the root, which depends on element concentrations in soil pore solutions. Climate strongly influences metal speciation, primarily because of climate's role in developing soil types. These local- and regional-scale factors ultimately control elemental — metals and metalloidsmobility and availability. For example, in the arid climates of the western United States, soils are commonly characterized by small abundances of soil organic matter and large abundances of salt and carbonate, the latter phases often containing metals in varying states of solution.

Uranium bioavailability in terrestrial food chains is strongly influenced by the nature of soils and their complex interactions with metals (Driver, 1994; Bohn and others, 2001). In general, uranium enters food chains via adsorption on plant surfaces (known as interception) or as tissue residues in prey. Natural history attributes related to feeding strategy can influence exposure of herbivores (Meyer and others, 2005). Coincidental ingestion of particles of sediment or soils also contributes to dietary exposures (Beyer and others, 1994). For plants, uranium exposures occur primarily in the rhizosphere where the soil directly interacts with the root (Ross, 1994). However, uranium uptake across root membranes is limited and little translocation to aboveground structures has been observed (Sheppard and others, 1983, and Van Netten and Morley, 1983, both cited in Driver, 1994; Vandenhove and others, 2009). Plant accumulations of uranium are limited, as reflected in low soil-to-plant concentration factors, while the greatest concentration ratios are associated with dusty conditions (Garten and others, 1987, cited in Driver, 1994). Concentration ratios for a variety of plants (food crops, pasture grass, fruits, and vegetables) were generally reported to be below 1 (Driver, 1994; Sansharova and others, 2009b, cited in International Atomic Energy Agency, 2009).

Bioaccumulation of uranium is also relatively low into herbivorous vertebrates, although multiple exposure routes (ingestion, inhalation, dermal contact, etc.) enhance the likelihood that uranium will be accumulated in tissues of exposed biota. Biomagnification of uranium does not occur through food-chain transfers, with transfer coefficients less than 1 from plants to foraging grazers in terrestrial environments (Driver, 1994). In addition, Mahon (1982) reported that vertebrate (bird and mammal) tissue concentrations of uranium in terrestrial food chains decreased by an order of magnitude at each trophic level. More information on soil-to-biota BCFs for uranium is available and should be consulted for detail (for example, Driver, 1994; see also Calmon and Fesenko, 2009).

\section{Chemical Hazards of Radionuclides}

Data on the chemical hazards of other radionuclides in the ${ }^{238} \mathrm{U}$ decay series are much more limited. Chemical toxicity data is available for thallium to terrestrial and aquatic receptors, but toxicity data for thorium, bismuth, radium, radon, polonium, and protactinium are limited. Brief characterizations of each element's toxicity and capacity for bioconcentration or bioaccumulation under field conditions are presented.

\section{Thallium}

Thallium is highly reactive, and concentrations range from 0.3 to $0.6 \mathrm{mg} / \mathrm{kg}$ in the environment. Elemental thallium occurs as relatively short-lived radionuclides, such as those encountered in the uranium decay series, and as stable isotopes, ${ }^{203} \mathrm{Tl}$ and ${ }^{205} \mathrm{Tl}$. Stable isotopes of thallium occur as Tl(I) and Tl(III) in minerals (potassium and sulfur-containing ores), as thallium salts, and as alloys and amalgams with mercury (World Health Organization, 1996). Atmospheric releases of thallium from coal burning plants and the smelting of zinc, copper, and lead ores contribute to wet and (or) dry deposition from these industrial or mining sources. Thallium can also be released to surface waters through erosional processes during mining operations of other economically important minerals. Such releases of thallium through atmospheric deposition or erosional processes in undisturbed or disturbed source areas have the potential to contaminate surface waters, sediments, or soils, creating an exposure pathway to biological receptors (Peter and Viraraghavan, 2005).

Thallium in the aquatic environment exists in inorganic forms and as the stable organic dimethylthallium $\left(\left(\mathrm{CH}_{3}\right)_{2} \mathrm{Tl}^{+}\right)$. Dimethylthallium is produced by oxidative methylation of $\mathrm{Tl}(\mathrm{I})$ in anaerobic freshwater sediment, but no measurement of dimethylthallium in the freshwater column has yet been made (Huber and Kirchmann, 1978). The mobility of thallium in soil varies as a function of its physiochemical properties (for example, oxidation state) and the nature and properties of the soils in which it occurs. The concentration of thallium in soil interstitial water may enable its uptake by terrestrial plants, and the release to groundwater may occur as a function of soil $\mathrm{pH}$ in soils where thallium is highly mobile. Thallium adsorbs to clays, organic matter, and iron oxides (World Health Organization, 1996). Deposited thallium may be resuspended as dust in terrestrial habitats or solubilized in aquatic habitats (Peter and Viraraghavan, 2005). The bioavailability of Tl(III) in freshwater is less than that of $\mathrm{Tl}(\mathrm{I})$ because of the oxidation of Tl(I) to $\mathrm{Tl}(\mathrm{III})$ by biota, despite $\mathrm{Tl}(\mathrm{III})$ being the dominant form of dissolved thallium in the water column of the Great Lakes (Canada/United States) (Ralph and Twiss, 2002; Twining and others, 2003). Potassium is important in determining the aquatic toxicity of thallium. Thallium and potassium are interchangeable in mineral crystal lattices and membrane transport because of similar atomic radii and ionic mobility (Hassler and others, 2007). Therefore, potassium has been used to help establish water quality guidelines and predicting the fate of thallium in the aquatic environment. 
Chemical toxicity data for thallium are available (table 8), although much of the literature for terrestrial and aquatic biota reflects an emphasis on human health implications of environmental exposures (Agency for Toxic Substances and Disease Registry, 1992). Toxicity data for biota was limited to algae, aquatic microorganisms, aquatic vascular plants, aquatic invertebrates, fish, amphibians, and mammals; studies on the chemical toxicity of thallium were not available for cyanobacteria, soil microorganisms, terrestrial invertebrates, reptiles, or birds. The following sections briefly characterize toxicity data from the literature compilation. A wildlife toxicity assessment on the potential toxicity, bioconcentration, and bioaccumulation hazards associated with thallium exposure most often encountered in the environment is available (U.S. Army Center for Health Promotion and Preventive Medicine, 2007). In general, thallium bioaccumulates but does not biomagnify in terrestrial and aquatic food chains (Zitko and Carson, 1975, Zitko and others, 1975, Sharma and others, 1986, and Ewers, 1988, all cited in U.S. Army Center for Health Promotion and Preventive Medicine, 2007). Field experiments have measured thallium content of various food crops because terrestrial plants can absorb thallium from soil (Cataldo and Wildung, 1983, cited in Agency for Toxic Substances and Disease Registry, 1992), but limited uptake data are available. Characterization of food-chain transfer of the metal is lacking, despite observations that thallium is bioconcentrated (Bunzl and others, 2001). Bioconcentration and bioaccumulation is incompletely characterized for thallium, primarily because of insufficient data. The bioconcentration of thallium appears to be greater in aquatic vascular plants and aquatic macroinvertebrates than in fishes. For example, BCFs were 27-1,430 for Atlantic salmon (Salmo salar) (Zitko and others, 1975) and 34 for bluegill (Lepomis macrochirus) (Barrows and others, 1978). BCF values varied widely from 6,000 to 88,000 for duckweed (Kwan and Smith, 1988) and 5,500 to 26,000 for the amphipod Hyalella azteca (Borgmann and others, 1998).

\section{Algae, Cyanobacteria, and Aquatic Microorganisms}

Chemical toxicity data for thallium are limited for algae, and no toxicity data were found for cyanobacteria or aquatic microorganisms (table 8). Acute toxicity values (as EC50s) for algae ranged from 0.13 to $0.43 \mathrm{mg} / \mathrm{L}$, whereas a chronic NOEC of $0.02 \mathrm{mg} / \mathrm{L}$ was reported for the green alga Chlorella vulgaris (De Jong, 1965). Acute toxicity data were also available for the freshwater rotifer Brachionus calyciflorus (EC50 $=18.8 \mu \mathrm{g} / \mathrm{L}$ ) and the fungus Geotrichum candidum (IC50 = $0.38 \mu \mathrm{g} / \mathrm{L}$ ) (table 8 ). Guidance values to protect aquatic life have been estimated for thallium (table 6).

\section{Aquatic Vascular Plants}

Chemical toxicity data for thallium were limited to two studies for aquatic vascular plants (table 8 ). Chronic effects data (LOEC) were available for duckweed (Lemna minor) (Smith and Kwan, 1989). Despite the lack of empirical chemical toxicity data, a guidance threshold to protect aquatic plants has been estimated (table 6).

\section{Aquatic Invertebrates}

Chemical toxicity data for thallium were available for aquatic invertebrates including amphipods, shrimp, snails, daphnids, midges, nematodes, and roachflies (table 8). Chronic toxicity values (NOECs) have been reported for daphnids by Kimball (1978); they are lower than the guidance thresholds for daphnids proposed by Suter and Tsao (1996).

\section{Fish}

Chemical toxicity data for thallium were available for fish (table 8). Acute toxicity (as LC50s) ranged over three orders of magnitude for various fish species (table 8), and a chronic value (NOECs) has been reported for fathead minnows (Kimball, 1978). Guidance thresholds for chronic toxicity of thallium have been suggested for fish (table 6).

\section{Terrestrial Vascular Plants}

Thallium is not essential for plant growth, but terrestrial vascular plants will take up and translocate thallium to aboveground vegetation when soluble species are present in the soil. Toxic effects of thallium in terrestrial plants includes impaired chlorophyll synthesis, seed germination, reduced transpiration due to interference in stomatal processes, growth reduction, stunting of roots, and leaf chlorosis (Adriano, 1986). Kabata-Pendias and Pendias (1984) reported toxic effects on plants grown in a surface soil having $1.0 \mathrm{mg} / \mathrm{kg}$ thallium; this served as the basis for a guidance value developed by Efroymson and others (1997a, b) for thallium released to soils. Efroymson and others (1997a, b) noted that other studies focusing on thallium relied on hydroponic studies.

\section{Amphibians and Reptiles}

Chemical toxicity data for thallium were minimal for amphibians, and no toxicity data were found for reptiles (table 8). An acute toxicity value (as LC50) of $0.11 \mathrm{mg} / \mathrm{L}$ was reported for the eastern narrow-mouthed toad (Gastrophryne carolinensis) (Birge and others, 1977; Birge, 1978). Guidance thresholds for chronic toxicity of thallium have not been suggested for amphibians or reptiles (table 6).

\section{Mammals}

Toxicity data were available for laboratory animal studies related to human health but not wild mammals (table 8) (U.S. Army Center for Health Promotion and Preventive Medicine, 2007). Acute toxicity data (as LD50s) were consistently $20-150 \mathrm{mg} / \mathrm{kg}$ for thallium in rats, mice, and dogs (U.S. Army Center for Health Promotion and Preventive Medicine, 2007). Chronic dose rates (as lowest observed adverse effect levels (LOAELs)) for thallium in rats ranged from 0.3 to $1.51 \mathrm{mg} / \mathrm{kg} / \mathrm{d}$ (U.S. Army Center for Health Promotion and Preventive Medicine, 2007). All of these data were exposures through drinking water; toxicity data for ingestion (soil or prey items) were not available. Guidance thresholds for chronic toxicity of thallium have not been estimated for mammals (table 6). 


\section{Thorium}

Thorium generally occurs at concentrations three times greater than uranium (Zhang and Brady, 2002) as a rare earth phosphate (monazite) that is found in igneous rocks and placer deposits. Thorium also occurs as a relatively common silicate mineral thorite $\left(\mathrm{ThSiO}_{4}\right)$, which occurs in ore-grade deposits in North America (for example, in Idaho; see Mackin and Schmidt, 1957; Staatz, 1972) and as a trace constituent in phosphates (simple and multiple oxides; Gascoyne, 1992). The thorium isotope ${ }^{232} \mathrm{Th}$ has a very long half-life compared to other thorium isotopes, is more likely to be a radiation hazard, and contributes little to thorium occurrence in the lithosphere (Underhill, 1996; Zhang and Brady, 2002).

Releases of thorium to the atmosphere can occur from natural and anthropogenic sources, but pathways linking sources with biological receptors are lacking. Movement and partitioning of thorium in the environment, particularly from naturally occurring sources, involve ${ }^{232} \mathrm{Th}$ as particulates in the atmosphere that can subsequently reach terrestrial and aquatic habitats through wet and dry deposition (Jiang and Kuroda, 1987, cited in Agency for Toxic Substances and Disease Registry, 1990). Wet and dry deposition are the chief removal processes for atmospheric thorium, with deposition rates dependent on weather conditions and the physicochemical properties of particulates (for example, particle size and density, and chemical form; see Agency for Toxic Substances and Disease Registry, 1990). Natural hazards such as volcanic eruptions release thorium, resulting in increased concentrations in rain water (Fruchter and others, 1980; Kuroda and others, 1987, cited in Agency for Toxic Substances and Disease Registry, 1990). Thorium concentrations in soils vary regionally, with windblown dusts as likely natural sources of thorium in the atmosphere. From an exposure perspective, established background concentrations (Agency for Toxic Substances and Disease Registry, 1990) are applicable to biological receptors whether releases of thorium are linked to natural or anthropogenic (for example, uranium mining and ore processing) sources.

Thorium enters surface waters as $\mathrm{ThO}_{2}$ in suspended particles or deposited into sediments because of low water solubility (Hem, 1992); colloids can dominate the concentrations of thorium in waters (Orlandini and others, 1990). Thorium concentrations in solution may be greater in waters with soluble complexes of carbonate, humic materials, or other ligands (Hem, 1992; LaFlamme and Murray, 1987). Dissolved thorium levels in most surface waters will be very low, but they will be higher in naturally occurring alkaline waters (Hem, 1992). In freshwater environments, thorium is relatively unavailable for biological uptake because it adsorbs strongly to inorganic sediments (Whicker and Schultz, 1982; Cowart and Burnett, 1994). Most environmental transport of thorium is through physical processes where thorium adheres to particulate matter; direct accumulation in aquatic plants is very low (approx. $1 \times 10^{-3}$; Pettersson and others, 1993). However, bottom-feeding aquatic organisms ingest thorium through inadvertent consumption of sediments while foraging (Whicker and Schultz, 1982). Although most thorium passes through the digestive tract, some is deposited in and strongly bound to bone, where it is removed only very slowly. Thorium BCFs (57.6-465) were available for rainbow trout (Oncorhynchus mykiss) (Poston, 1982). Poston (1982) also noted that the majority of thorium in fish was associated with the gastrointestinal tract, which may indicate that thorium incorporation into biological matrices was limited or predominately an adsorption process in the absence of assimilation. Based on very few studies, BCFs decrease as the trophic levels of aquatic animals increase (Poston, 1982; Fisher and others, 1987, cited in Agency for Toxic Substances and Disease Registry, 1990). Pyle and Clulow (1998) gives a BCF of 286-1,180 on white sucker (Catostomus commersoni).

Altered physicochemical characteristics of soils associated with uranium mining processes may be linked to thorium releases to surface water and groundwater (for example, acid-leaching of uranium tailing piles; see Moffett and Tellier, 1978, and Platford and Joshi, 1988, both cited in Agency for Toxic Substances and Disease Registry, 1990). The mobility of thorium in soils is determined by geochemical processes, and thorium will generally remain strongly adsorbed onto soil and be relatively immobile (Torstenfelt, 1986).

Thorium binds preferentially to donor atoms of oxygen and strong bases. The sorption of thorium on iron oxides is fast at low $\mathrm{pH}$, which indicates the formation of strong complexes with surface sites (Murphy and others, 1999). Thorium also binds with the oxy-hydroxides, like goethite. Conversely, the presence of sulfates decreases adsorption by the means of competition (Syed, 1999). Thorium(IV) forms strong complexes with humic and fulvic acids (Olofsson and Allard, 1983). Adsorption with organic matter, clays, and oxides, which limits the mobility and bioavailability of thorium, increases with $\mathrm{pH}$ (Syed, 1999). The various isotopes of thorium do not have the same apparent behavior in soils because of their mode of genesis (primary radionuclide or daughter product), the differences in chemical solubility of the minerals which contain them, and their radioactive half-lives (Leslie and others, 1999). The mobility of the thorium isotopes goes in the direction ${ }^{228} \mathrm{Th}>{ }^{230} \mathrm{Th}>{ }^{232} \mathrm{Th}$.

As in aquatic systems, the presence of ions or ligands (for example, $\mathrm{CO}_{3}^{-2}$, humic matter) will increase the formation of soluble complexes of thorium and increase its mobility in soil. Leaching into groundwater may be increased in soils having low sorption capacity and capacity to form soluble complexes (for example, hydroxylated forms). Plant-to-soil transfer ratios for thorium are consistently less than 0.01 (Garten, 1978; Vandenhove and others, 2009), indicating poor bioconcentration in plants from soil. Partitioning of thorium between soil matrix (for example, as an adsorbed fraction) and soil interstitial water also indicates that thorium BCFs in plants will be very low (Vandenhove and others, 2009). Plants grown in highly disturbed soils or waste materials (for example, uranium tailings containing elevated levels of thorium) will have increased BCFs (Ibrahim and Whicker, 1988). 
Characterization of thorium exposure is relatively incomplete for human populations outside of occupational and hazardous waste site settings (Agency for Toxic Substances and Disease Registry, 1990), and data for exposure of biological receptors are even more limited. The following sections summarize the existing data related to the toxicity, bioconcentration, and bioaccumulation of thorium. Chemical toxicity data for thorium were not found for aquatic vascular plants, soil microorganisms, terrestrial plants, terrestrial invertebrates, amphibians, reptiles, or birds. However, recent publications indicate an increased focus on thorium's environmental fate relative to its availability to and incorporation into biological receptors exposed in the field (for example, Calmon and others, 2009).

\section{Algae, Cyanobacteria, and Aquatic Microorganisms}

Chemical toxicity data of thorium were limited to one study of freshwater algae. De Jong (1965) reported that the alga Chlorella vulgaris presented an NOEC for growth of $0.8 \mathrm{mg} / \mathrm{L}$ and an LOEC of $1.2 \mathrm{mg} / \mathrm{L}$ for thorium.

\section{Aquatic Invertebrates and Fish}

Thorium accumulates in the organs, skin, and gastrointestinal tract of fish, indicating that a significant portion of this radionuclide remains adsorbed (Poston, 1982). Chemical toxicity data of thorium in aquatic invertebrates and fish were limited. Acute toxicity of thorium to the amphipod Hyalella azteca varied as a function of water hardness in studies reported by Borgmann and others (2005); LC50s were $0.0052 \mathrm{mg} / \mathrm{L}$ in soft water (approx. $18 \mathrm{mg} \mathrm{CaCO}_{3} / \mathrm{L}$ ) and $3.15 \mathrm{mg} / \mathrm{L}$ in hard water (approx. $124 \mathrm{mg} \mathrm{CaCO}_{3} / \mathrm{L}$ ). In the catfish Rhamdia quelen, Borgmann and others (2005) reported that thorium exposure to $70-210 \mu \mathrm{g} / \mathrm{L}$ could stimulate enzyme activities related to oxidative stress in adults and was cytogenotoxic in juveniles. Data from field studies reported that releases of thorium from uranium mining and milling operations and radium and uranium recovery plants to surface waters have contributed to the exposure of benthic organisms (Hart and others, 1986, and McKee and others, 1987, both cited in Agency for Toxic Substances and Disease Registry, 1990).

\section{Mammals}

Thorium toxicity data for mammals is available for rodents from laboratory toxicity evaluations, but data for wild mammals are lacking. Exposure differences among laboratory studies using traditional biomedical test species yield pertinent data for human health (Agency for Toxic Substances and Disease Registry, 1990), but may be of limited use in identifying threshold effects levels for wild mammals. Nevertheless, these data identify pathways of concern for biota exposed in field settings. Thorium exposures to wild mammals may occur via inhalation, ingestion of food and water, and dermal/cutaneous uptake. Bone is the target organ for thorium; laboratory rodents deposit thorium into bone (70 percent), other organs and tissues (16 percent), urine (10 percent), liver (4 percent), and intestines $(<0.05$ percent) (Agency for Toxic Substances and Disease Registry, 1990). Thorium is excreted via renal mechanisms in mammalian species used in biomedical testing (National Research Council, 1988; Agency for Toxic Substances and Disease Registry, 1990), and that method would presumably apply to wild mammals as well. However, the natural history and life history attributes of wild mammals exposed in the field are different from laboratory rodents, which may affect exposure.

\section{Bismuth}

Bismuth is rare in the Earth's crust and is in the same elemental family as phosphorus, arsenic, and antimony. Bismuth is used as a cooling agent and fuel support in high-power nuclear plants. Bismuth is present at valences +3 and +5 , with +3 being the most stable form. The isotopes of bismuth have atomic masses from 195 to 215 , but only ${ }^{209} \mathrm{Bi}$ is stable. In the natural state, bismuth is in the form of bismuthine $\left(\mathrm{Bi}_{2} \mathrm{~S}_{3}\right)$, whose principal ores are associated with lead, silver, and tin (Li and Thornton, 1993). Bismuth is used as indicator of volcanic activity in connection with sulfide emissions because the contribution of anthropogenic sources (primarily mining extraction) to the total distribution of bismuth remains very limited (Ferrari and others, 2000). The use of fungicides and certain natural or synthetic manures that contain bismuth increase the content of this element in soils; however, the increase is negligible compared to the geochemical background of the majority of the cultivated soils (Senesi and others, 1979). Data relative to the behavior of bismuth in soils and plant transfer are very limited. In soils, bismuth is often oxidized and is found in the carbonate form. The element can accumulate in horizons rich in organic matter or oxidized iron (Kabata-Pendias, 2001), and its mobility can be affected by the $\mathrm{pH}$.

Bismuth is one of the least toxic metals and is often used for the treatment of stomach ulcers and intestinal affections. Bismuth(III) is particularly used with a therapeutic aim as an antacid, astringent, disinfectant, antiprotozoaires, and radiocontrastant $(\mathrm{Bi}(\mathrm{V})$ mainly). However, it presents relatively greater radiation hazards. Bismuth is poorly characterized with respect to its environmental fate and effects on aquatic and terrestrial biota, although some data is available for maximum mineral tolerance in diets of domestic and laboratory animals (National Research Council, 2005). The National Research Council (2005) recommended maximum tolerable levels for bismuth of $500 \mathrm{mg} / \mathrm{kg}$ for rodents, swine, and horses and $1,000 \mathrm{mg} / \mathrm{kg}$ for poultry, based on animal health.

Data for the chemical toxicity of bismuth to biota were limited. De Jong (1965) reported chronic effects endpoints from laboratory exposures of bismuth to alga Chlorella vulgaris, which included an LOEC of $7.2 \mathrm{mg} / \mathrm{L}$ and a NOEC of $3.6 \mathrm{mg} / \mathrm{L}$. Two studies regarding effect levels related to the 
chemical toxicity of bismuth in aquatic invertebrates were identified. For the amphipod Hyalella azteca, the LC50s were $0.025 \mathrm{mg} / \mathrm{L}$ in soft water (approx. $18 \mathrm{mg} \mathrm{CaCO}_{3} / \mathrm{L}$ ) and 2.543 $\mathrm{mg} / \mathrm{L}$ in hard water (approx. $124 \mathrm{mg} \mathrm{CaCO} / \mathrm{L}$ ) (Borgmann and others, 2005). Median effective concentrations (EC50s) for bismuth ranged from 0.662 to $14.79 \mathrm{mg} / \mathrm{L}$ for Tubifex tubifex (Khangarot, 1991). Chemical toxicity data for bismuth were not found for aquatic vascular plants, soil microorganisms, terrestrial plants, terrestrial invertebrates, fish, amphibians, reptiles, birds, or mammals. The effects of bismuth on terrestrial animals is not known, except for humans, for whom the toxic effects are not related to exposure time or dose (Martin and others, 1980, cited in Pamphlett and others, 2000). However, the increasing use of shotgun pellets containing bismuth (91 percent) for hunting may be a hazard to biota that survive after being shot. Pamphlett and others (2000) found significant amounts of bismuth in the cytoplasm within nervous system cells, the tubular cells of the kidneys, the dendritic cells of the liver, and the macrophages of the lungs of exposed mice in a laboratory study. However, the consequences of such a long-term accumulation over the life of the animal are not known (Pamphlett and others, 2000). Studies reporting bioconcentration and bioaccumulation were also not found for aquatic or terrestrial habitats. Additional investigations are necessary to better characterize the ecotoxicity of bismuth.

\section{Radium}

As a decay product of uranium and thorium, radium commonly occurs in all rock, soil, and water at very low concentrations. As an alkaline earth metal, radium behaves environmentally and physiologically like calcium (Whicker and Schultz, 1982; Cowart and Burnett, 1994). Environmental migration of radium is facilitated by its ability to form soluble sulfates, carbonates, and chlorides. Radium readily deposits in bone tissue once taken up by aquatic organisms. Concentrations of radium in the groundwater are typically elevated when high concentrations occur in bedrock (Selinus and others, 2005). All isotopes of radium $\left({ }^{224} \mathrm{Ra},{ }^{226} \mathrm{Ra},{ }^{228} \mathrm{Ra}\right)$ are radioactive. The most common isotope, ${ }^{226} \mathrm{Ra}$, is an alpha emitter with accompanying gamma radiation; ${ }^{228} \mathrm{Ra}$ is principally a beta emitter and ${ }^{224} \mathrm{Ra}$ is an alpha emitter. Radium decays to form radioactive radon gas isotopes, which are not chemically reactive. Radiation hazards dominate exposure in field settings, and radon chemical hazards are limited.

The ecotoxicology of radium is incompletely characterized, particularly with respect to its chemical toxicity. Data are not sufficient to characterize threshold effects levels for the chemical toxicity of radium to biota, but radiation hazards likely outweigh concerns for chemical toxicity of radium. Routes of exposure to terrestrial vertebrates are dominated by inhalation, ingestion, and dermal or cutaneous exposures (Agency for Toxic Substances and Disease Registry, 1990). Radium from inhalation or ingestion is partitioned into fecal material ( 80 percent) and the gastrointestinal tract (20 percent), where radium enters the bloodstream and preferentially accumulates in bone tissues (Agency for Toxic Substances and Disease Registry, 1990). This fraction of the radium dose may be excreted through the feces and urine in time, but a portion will remain in the bones as part of the tissue matrix (Agency for Toxic Substances and Disease Registry, 1990; Casarett and others, 2007).

Chemical toxicity data for radium were not found for algae, cyanobacteria, aquatic microorganisms, aquatic vascular plants, aquatic invertebrates, soil microorganisms, terrestrial plants, terrestrial invertebrates, fish, amphibians, reptiles, birds, or mammals. As noted above, nearly all naturally occurring radium is present as ${ }^{226} \mathrm{Ra}$, which occurs in plants, animals, soil, rocks, surface water, and groundwater. Radium generally occurs at very low concentrations in plants and animals. Higher concentrations of radium in plants are associated with uranium ores and other geologic materials, with estimates of 3 percent of that in soil (Rayno, 1983; Tracy and others, 1983; Watson and others, 1984). Plant BCFs for radium across all plants species and soil types have been summarized by Vandenhove and others (2009). Transfer coefficients summarized for feedstuff-to-domestic animals could potentially be used to evaluate dietary exposures in wild mammals, particularly for herbivores and for preliminary estimates for maternal transfer of nuclides based on milk consumption in offspring (Howard and others, 2009).

\section{Radon}

Radon is a noble gas that has limited data available to characterize its ecotoxicity (Cothern and Smith, 1988; Vincolli, 1996). Radon naturally occurs as a gas and is highly mobile in the earth's crust (Corbett and others, 1997); its presence in the atmosphere results from the transfer of the gas from near-surface soils and rocks to the surface. Numerous isotopes occur, but ${ }^{220} \mathrm{Rn}$ and ${ }^{222} \mathrm{Rn}$ are the most common. The geochemistry of nuclides in the natural decay series and links to release of radon are complex. For example, uranium concentrations vary with rock type, which affects the transport and emission of the gas. Highly permeable rocks, such as limestone, or rocks that are fractured or faulted provide more spaces for radon gas to pass through the material; radon may be released at the surface if these rock types occur within breccia pipes. Furthermore, radon dissolves in water and may be transported through permeable and fractured rocks for long distances, where the gas may be released when groundwater reaches the surface. Radon readily enters the gas phase because of its low vapor pressure (Cothern, 1988). Therefore, radon does not persist in the water and has an aqueous half-life of 2 days (Vincolli, 1996). Given this brief summary of the environmental fate and transfer of radon, the primary hazards associated with exposures to ecological receptors in the field will be radiation toxicity, primarily via inhalation routes of exposure. 


\section{Polonium}

Polonium occurs in the earth's crust at about one part in $10^{15}$. All 25 isotopes are radioactive, but only three have appreciable half-lives (>140 days: $\left.{ }^{208} \mathrm{Po},{ }^{209} \mathrm{Po},{ }^{210} \mathrm{Po}\right)$. From an ecological perspective, polonium occurs naturally at concentrations that preclude chemical toxicity as a primary hazard. The isotope ${ }^{210} \mathrm{Po}$ is produced during the decay of ${ }^{238} \mathrm{U}$, is widely distributed in small amounts in the earth's crust, and occurs in uranium ores at less than $0.1 \mathrm{mg}{ }^{210} \mathrm{Po}$ per ton. Radiation hazards cannot be dismissed given the specific activities of the three most frequently encountered isotopes.

In terrestrial ecosystems, foliar transfer is the dominant pathway for contamination of vegetation by ${ }^{210} \mathrm{Po}$ (Francis and others, 1968; Pietrzak-Flis and Skowronska-Smolak, 1995; Skwarzec and others, 2001). The relative weakness of root transfer of ${ }^{210} \mathrm{Po}$ (because of its strong retention by soils), as well as an almost negligible translocation among plant tissues, results in ${ }^{210} \mathrm{Po}$ mainly being concentrated in the leaves of plants. For animals, specific activities of ${ }^{210} \mathrm{Po}$ vary by four orders of magnitude, depending on the species selected and organs examined. For example, ${ }^{210}$ Po concentrations range from $0.037 \mathrm{~Bq} / \mathrm{kg}$ wet weight for ox muscle (Globel and Muth, 1980, cited in Beaugelin-Seiller and others, 2004) to $332 \mathrm{~Bq} / \mathrm{kg}$ for caribou liver (Thomas and Gates, 1999). This broad interval is related to the quantity of ${ }^{210} \mathrm{Po}$ ingested by the animal (including incidental ingestion of soil particles) and to the lifespan of the animal. In addition, ${ }^{210} \mathrm{Po}$ transfer to animals is proportionally weaker at sites close to uranium mines than at undisturbed sites because the larger particle sizes associated with mining activities reduce the ${ }^{210}$ Po bioavailability for plants and animals (Thomas, 2000).

In lakes, the specific activities of ${ }^{210} \mathrm{Po}$ are much higher in sediments than in water (Haridasan and others, 2001). The specific activities measured in aquatic plants are relatively high, particularly in phytoplankton (approximately $20 \mathrm{~Bq} / \mathrm{kg}$ wet weight) with concentration factors of approximately $10^{3}$ to $10^{4}$ (Hameed and others, 1997; Shaheed and others, 1997, cited in Beaugelin-Seiller and others, 2004). In aquatic animals, specific activity of ${ }^{210} \mathrm{Po}$ is more important in invertebrates than fish. Polonium concentrates in the soft tissues of molluscs. Moreover, the carapaces (chitinous) of shellfish accumulate more ${ }^{210} \mathrm{Po}$ than the shells (calcium carbonates) of bivalves because of a strong affinity of ${ }^{210} \mathrm{Po}$ to organic matter (Cherry and Heyraud, 1981). In fish, soft tissues in contact with the digestive system and the gills have an activity of ${ }^{210} \mathrm{Po}$ that is greater than the muscles and skin. Fish incorporate ${ }^{210} \mathrm{Po}$ from ingestion of food and filtration of water by the gills. The concentration factors in molluscs and fish are very high, from 1 to $1,000 \mathrm{~L} / \mathrm{kg}$ wet weight.

\section{Protactinium}

Protactinium is a radioactive metal that does not readily oxidize when exposed to air. Three isotopes $\left({ }^{231} \mathrm{~Pa},{ }^{234} \mathrm{~Pa}\right.$, ${ }^{234 \mathrm{~m}} \mathrm{~Pa}$ ) naturally occur, but ${ }^{231} \mathrm{~Pa}$ is the most abundant. As a decay product of ${ }^{235} \mathrm{U}$, protactinium is naturally present in soil, rocks, surface water, groundwater, plants, and animals in very low concentrations. Greater concentrations are present in uranium ores and other geologic materials. Protactinium occurs in uranium ores at a concentration of about 1 part protactinium to 3 million parts uranium. Protactinium preferentially adsorbs to soil, with concentrations in sandy soil particles 550 times greater than in interstitial water; concentration ratios are even higher (2,000 and above) for loam and clay soils. Protactinium is generally not a concern for groundwater. Few data specific to protactinium behavior in terrestrial ecosystems are available. The rare data that does exist indicate that protactinium has low mobility in soils and low transfers in the food chains of terrestrial origin (see Colle and Mourlon, 2003).

These radionuclides present little chemical hazards based on their short half-lives but may contribute significantly to radiation hazards for ecological receptors exposed in the field. For example, Thomas and Liber (2001) showed that external beta radiation from ${ }^{234} \mathrm{~Pa}$ and alpha radiation from uranium contributed most of the dose at the affected sites, whereas ${ }^{210} \mathrm{Po}$ was most important at the control site in a study on benthic invertebrates. Polonium ( $\mathrm{Po}$ ) and protactinium $(\mathrm{Pa})$ present the greatest hazards when ingested or inhaled. For example, studies have demonstrated that ${ }^{210} \mathrm{Po}$ is accumulated to exceptionally high levels in tissues of a variety of marine organisms, well above levels of the parent radionuclide ${ }^{210} \mathrm{~Pb}$ (Carvalho and Fowler, 1994; Stepnowski and Skwarzec, 2000). The behavior of ${ }^{210} \mathrm{Po}$ differs from that of ${ }^{210} \mathrm{~Pb}$, especially because of the higher affinity of ${ }^{210} \mathrm{Po}$ for organic matter. The hazards are mediated by adverse effects linked to internal dose of radiation. External radiation dose may be associated with gamma rays emitted by ${ }^{231} \mathrm{Po}$ and a number of short-lived decay products of ${ }^{227} \mathrm{Ac}$ (actinium).

\section{Radiation Hazards of Radionuclides}

Biological receptors may be exposed to radiation from undisturbed and disturbed naturally occurring radioactive materials. Undisturbed natural radiation sources have not been manipulated through human activities such as mineral extraction. Disturbed natural radiation sources have been modified through human interventions and include mining, collateral events associated with the use of fossil fuels, production and use of fertilizers (for example, phosphate fertilizers), and use of natural material for construction activities (for example, granite countertops). Radiation exposure can also occur through the release of technologically enhanced, naturally occurring radioactive materials or refined sources associated with nuclear fuel cycles, but natural radiation remains a significant contributor to radiation dose in the environment (United Nations Scientific Committee on the Effects of Atomic Radiation, 2000). A person in the United States is estimated to receive a natural background radiation dose of approximately 360 mrem per year (3.6 mGy/yr) (United Nations Scientific Committee on the Effects of Atomic Radiation, 2000). Naturally occurring radionuclides, including ${ }^{238} \mathrm{U}$ and its daughter 
products, contribute 63 percent of the overall total dose received; nearly 50 percent of that dose is from inhaled radionuclides such as radon. The remaining 37 percent comes from exposure to cosmic radiation and radionuclides internally present within the human body (United Nations Scientific Committee on the Effects of Atomic Radiation, 2000). The background radiation dose for nonhuman biota will differ because life history and feeding strategies can influence exposure.

Ionizing radiation is produced when naturally occurring radioactive materials decay - the nuclei of unstable atoms or radionuclides release energy in the form of radioactivity to increase their nuclear stability. This process is characterized by emissions of subatomic particles and high-energy photons (gamma rays). Radioactive decay of uranium produces daughter products such as radium, radon, and thorium and releases alpha particles, beta particles, or gamma rays. All daughters and radiation emissions are naturally occurring in the ${ }^{238} \mathrm{U}$ decay process. Emissions of the ${ }^{238} \mathrm{U}$ decay series (alpha and beta particles and gamma rays) are the primary focus of this overview of radiation effects.

Collisions between ionizing radiation and molecules in cells and tissues of exposed organisms can cause adverse effects to biological receptors in field and laboratory settings. An alpha $(\alpha)$ particle has a relatively short range in air, generally no more than several centimeters (and approximately several micrometers in water), and does not penetrate deeply into biological structures such as the epidermis or cuticle of biota. Beta $(\beta)$ particles can travel up to one meter in the air and can penetrate several centimeters into biological tissues. Gamma $(\gamma)$ rays can travel relatively long distances through air, environmental materials, and biological tissues. These emission species are highly energetic and have the capacity to pass through biota; consequently, they pose a great risk to biota.

Gross alpha and beta radiation are measures of all alpha and beta activity, respectively, present in a sample regardless of the specific radionuclide source. As an assessment and monitoring tool, gross alpha and beta are often used to screen samples for relative levels of radioactivity (Underhill, 1996; Cooper and others, 2003). Measurements of exposures to natural radiation associated with elemental uranium, which emits alpha particles, is more problematic for pathways contributing to internal dose (for example, ingestion and inhalation in terrestrial vertebrates) than for those contributing to external dose. Adverse effects of internal alpha emission in biota could be significant (Blaylock and others, 1993; United Nations Scientific Committee on the Effects of Atomic Radiation, 1996; Sample and others, 1997). Effects of chemical toxicity and radiation toxicity may be jointly expressed in field settings.

Exposure to ionizing radiation may lead to adverse biological effects. Alpha particles released during radionuclide decay can cause adverse effects during radiation exposures through ingestion or inhalation in animals or uptake and translocation in plants (Sample and others, 1997). Early developmental stages or life stages with rapid growth are generally more sensitive to radiation exposure than older, relatively mature organisms of the same species. Embryos and fetuses are typically more sensitive to ionizing radiation because these early life stages are dominated by rapidly dividing cells (Huettermann and Koehnlein, 1978; Riley, 1994; Brenner and others, 2003). Cells undergoing division though mitosis are more susceptible than cells that are not proliferating, and damage to the cellular DNA often results in cell death (Wolff, 1998; Shackelford and others, 1999; Pawlik and Keyomarsi, 2004). The sensitivity of biota to radiation and chemical exposures is also influenced by body size. For example, largebodied species are typically more vulnerable to high levels of radiation exposure than small-bodied species because of the greater collision potential (for example, larger target) between the ionizing radiation and biota (Bytwerk, 2006; Higley and Bytwerk, 2007). A species life history may also affect its sensitivity to radiation. Alonzo and others (2008) reported that fast growing invertebrates were more sensitive to reproductive effects than slow growing invertebrates. Life history strategies may not account for all differences in species sensitivity to radiation exposure, but they should be considered when characterizing pathways that link sources to receptors. Invertebrates (for example, herbivorous insects or filter-feeding aquatic invertebrates), vascular plants, unicellular plants and animals, bacteria, and viruses are generally more resistant to the acute effects of radiation (Whicker and Schultz, 1982). However, smaller burrowing mammals will tend to receive larger doses through external exposures to contaminated soils containing radionuclides because of their close and prolonged contact with the soil and their occupation of confined spaces such as burrow habitats wherein soil gases such as radon may accumulate (Macdonald and Laverock, 1998). Burrowing animals have the highest potential for external exposures because they are exposed to a 4-pi geometry (that is, 360 degrees) versus a 2-pi geometry (180 degrees) for animals that only nest or sleep on the soil surface. Fish and other aquatic organisms are typically less sensitive to radiation exposure than terrestrial wildlife (vertebrates). This radioresistance could be due to a smaller DNA content per cell as well as to longer and more variable cell cycle times as compared to mammals. Differences in exposure matrix (atmospheric versus aquatic) also influence dose, given the relative differences in radiation penetration in these media (Martin, 2006).

Exposures to high levels of ionizing radiation produce adverse biological effects, such as increased cell death, decreased life expectancy, reduced growth, and altered behavior. Much of the literature focused on adverse biological effects is related to external gamma acute exposure and associated observed effects (see reviews by Driver, 1994; Eisler, 1994) rather than naturally occurring radioactive materials such as those of the uranium decay series. Previous studies provide information on the biological effects associated with uranium mining operations, altered routes of exposure to radiation from decay series elements, and biological effects thresholds (U.S. Environmental Protection Agency, $2005,2008)$. Species sensitivity to radiation is highly variable (Rose, 1992), and beneficial responses have been observed in 
biota commonly used in evaluating human health effects and radiation safety (for example, see Luckey, 1991, regarding hormesis associated with exposures to low levels of radiation). Single-celled organisms and invertebrates tend to be more resistant to acute radiation exposures than vertebrates (fig. 9) (Eisler, 1994). Extrinsic factors (type of radiation and its associated energy, rate and length of exposure, and dose rate and absorbed dose) will be influenced by environmental factors such as spatial characteristics of exposure, physical stressors (for example, temperature and season), and chemicals occurring as part of the exposure matrix (Cooper and others, 2003). Biological responses to radiation exposure will also be affected by intrinsic factors such as species, age, sex, nutritional status, and biological and ecological interactions (Alpen, 1997; Van der Stricht and Kirchmann, 2001).

Literature on the environmental effects of radiation characteristic of the uranium decay series for microbial, plant, and animal species were reviewed and summarized (for example, see International Atomic Energy Agency, 1976, 1988, 1992; Woodhead, 1984; National Council on Radiation Protection and Measurements, 1991; Driver, 1994; Eisler, 1994; United Nations Scientific Committee on the Effects of Atomic Radiation, 1996; Thompson and Bird, 2003; Woodhead and Zinger, 2003; Andersson and others, 2009). Data available for the effects of ionizing radiation is primarily related to nuclear energy and weapons production rather than naturally occurring radionuclides and mining activities. Nevertheless, radiation effects associated with gross alpha, gross beta, or gamma rays are highly dose-dependent regardless of source. Radiation data, including toxicity and fate data, for species in the segregation areas were not found; therefore, data from other species reported in the literature are presented. Factors influencing uptake, loss, and toxicity of radionuclides in the uranium decay series are considered for aquatic and terrestrial biota. The biota's potential for being an emission source through bioconcentration or bioaccumulation is also considered. Dose and dose rates used to characterize radiation toxicity are detailed in appendix 2.

A brief summary of the transfer coefficients of these radiohazards from water or soil to biota are also presented. Physicochemical characteristics of water-column or watersediment interface or sediments alone influence radionuclide uptake in fish, aquatic invertebrates, and sediment-dwelling invertebrates. For example, radiation uptake by fishes and aquatic invertebrates in water-column dominated exposures is dependent on the ionic chemical species, which interacts with external organs (for example, gills and skin) that provide surfaces for exposure or influences bioaccumulation via dietary exposures. In addition, radionuclide accumulation in biota can differ within organs (for example, preferential partitioning) and by feeding habits.

Biota are potentially exposed to external radiation through radionuclides in parent ore material, water, sediment, soil, and other biota such as vegetation. Sources of internal

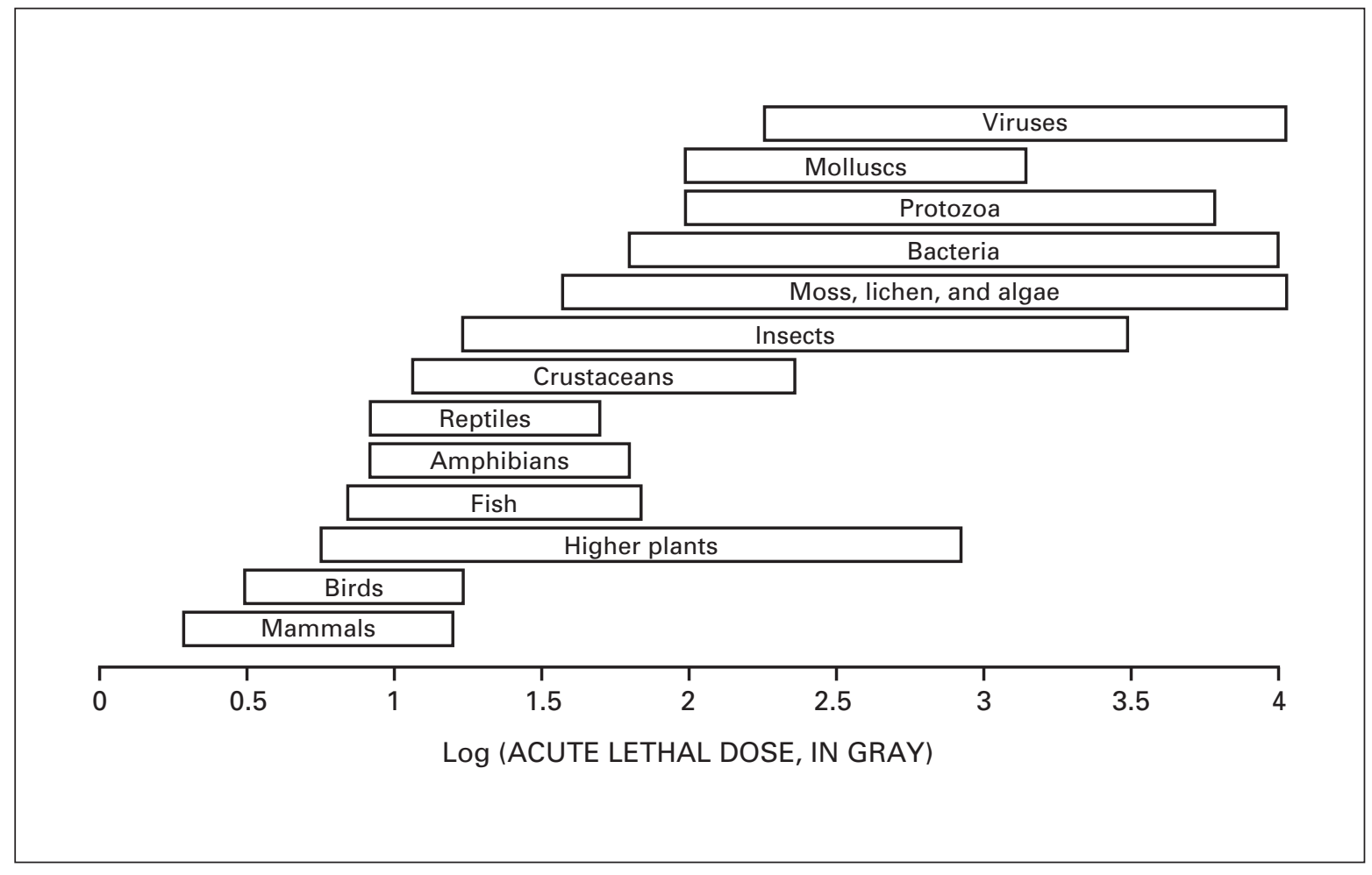

Figure 9. Comparative radiosensitivity of different organisms represented by the acute lethal dose ranges (Woodhead and Zinger, 2003; United Nations Scientific Committee on the Effects of Atomic Radiation, 1996, after Whicker and Schultz, 1982). 
radiation exposure from radionuclides include ingestion via food and water and absorption through the epithelium of the skin or respiratory tissues. Effects thresholds from empirical data and consensus-based guidance values for biota associated with radiation exposures from published literature are presented in the following sections by receptor category. The majority of the toxicity data was from reviews by Driver (1994), Eisler (1994), and Woodhead and Zinger (2003). In the most recent review, Woodhead and Zinger (2003) used a database (FREDERICA) to identify publications containing effects information sufficient to estimate the dose rate for chronic exposures; however, most of these publications provided data for acute rather than chronic radiation exposures. Data from Woodhead and Zinger (2003) was expansive and complex; therefore, data from FREDERICA are presented only in the text to minimize the length and complexity of table 9. Woodhead and Zinger (2003) was the primary reference used to draw radiation toxicity data in the following sections. Woodhead and Zinger (2003) should be reviewed for additional risk assessment for radiological effects. In addition, the United Nations Scientific Committee on the Effects of Atomic Radiation (UNSCEAR) is developing a document that summarizes the effects of ionizing radiation on nonhuman biota that would be useful to consult for risk assessment purposes (Tom Hinton, French Institute of Radiation Protection and Nuclear Safety, personal commun., 2009; see also www.unscear.org, accessed December 1, 2009).

\section{Biological Receptors in the Aquatic Food Chain}

\section{Algae, Cyanobacteria, and Aquatic Vascular Plants}

Empirical data for radiation toxicity to algae, cyanobacteria, and aquatic plants were limited (table 9) (Woodhead and Zinger, 2003). References that describe morphological changes or survival of green algae indicate high acute doses ranging from 100 to 1,000 Gy (Woodhead and Zinger, 2003). Data on low doses and chronic irradiation experiments are limited, although low doses (1-5 Gy) resulted in chromosome aberrations for green algae. Woodhead and Zinger (2003) observed that acutely toxic doses for cyanobacteria and green algae ranged from 1 to several thousand Gy, with most threshold effects occurring at doses greater than 5 Gy. Woodhead and Zinger (2003) reported that aquatic plants were less radiosensitive to radiation exposure than higher trophic levels, although this observation was limited to five references. Dose rates of $1.3-8.5 \mu \mathrm{Gy} / \mathrm{h}$ inhibiting growth in a cyanobacteria (Syenechococcus lividus) have been reported (Woodhead and Zinger, 2003). Guidance values for the protection of algae and aquatic plants have been estimated by various organizations (table 6).

\section{Aquatic Invertebrates}

Radionuclides accumulate in the gut of filter-feeding aquatic and sediment-dwelling invertebrates. Data for radiation effects in aquatic invertebrates are available (table 9) (Woodhead and Zinger, 2003). Hormetic effects have been noted; ionizing radiation increased growth rates at dose rates of $760 \mathrm{mGy} / \mathrm{d}$ for blue crab (Callinectes sapidus), 2,400-5,500 mGy/d for water snail (Assiminea infima), and 8,200-17,800 mGy/d for daphnids (table 9). Historically, data for ionizing radiation effects on crustaceans and molluscs focused on acute exposures with low linear energy transfer radiation (for example, $x$-rays and gamma rays; Woodhead and Zinger, 2003). Significant effects on invertebrate reproductive capacity have been observed for chronic irradiation at dose rates as low as $0.19 \mathrm{mGy} / \mathrm{h}$ (Woodhead and Zinger, 2003). More recently, Alonzo and others (2008) reported that exposures to dose rates of $0.11 \mathrm{mGy} / \mathrm{h}$ or higher resulted in a significant reduction in body mass and egg and neonate masses. Gilbin and others (2008) reported lower fecundity and decreases in egg mass for cladoceran Daphnia magna at 4.2 and $31 \mathrm{mGy} / \mathrm{h}$, respectively. Overall, molluscs were less radiosensitive than crustaceans with expected chronic dose rates greater than $10 \mathrm{mGy} / \mathrm{h}$ (Woodhead and Zinger, 2003). Guidance values for the protection of aquatic invertebrates have been estimated by various organizations (table 6).

Fish

The literature for radiation effects on fishes is relatively well developed (table 9) (Woodhead and Zinger, 2003). More data are available for acute radiation exposures than for chronic irradiation in bony fish. For both irradiation durations, reproductive capacity was the most frequently studied endpoint, and eggs were identified as the most radiosensitive life stage, but it was noted that the most recent acute study was from 1999 (Woodhead and Zinger, 2003). The majority of acute irradiation data are for freshwater species such as medaka (Oryzias latipes) and salmonids (Oncorhynchus mykiss, O. kisutch, and O. tshawytscsha) (Woodhead and Zinger, 2003). Woodhead and Zinger (2003) reported that acute doses less than 1 Gy are unlikely to cause morbidity in irradiated fish, but acute exposure can affect reproduction by altering spermatogenesis, oogenesis, and embryo development. Life stage considerations were also found to be important. Woodhead and Zinger (2003) noted that acute exposures of $0.16 \mathrm{~Gy}$ in the single-cell stage of development could affect mortality, but radiation doses less than 0.5 Gy in later life stages would not likely affect reproduction in adults. Chronic endpoints commonly included growth data as body weight and length and reproductive effects as fertility of the irradiated parents, the viability of the resulting embryos, embryo development, and the fertility of offspring irradiated as developing embryos (Woodhead and Zinger, 2003). Woodhead and Zinger (2003) reported that chronic dose rates less than $12 \mathrm{mGy} / \mathrm{h}$ during embryonic development or less than $4 \mathrm{mGy} / \mathrm{h}$ during post-hatch life were unlikely to affect survival based on irradiation of external sources. Protective guidance values derived for fish by various organizations range over several orders of magnitude (table 6). Literature reviews to establish guidance values of ionizing radiation exposure must be used with caution because biological effects differ from one form of radiation to another. 


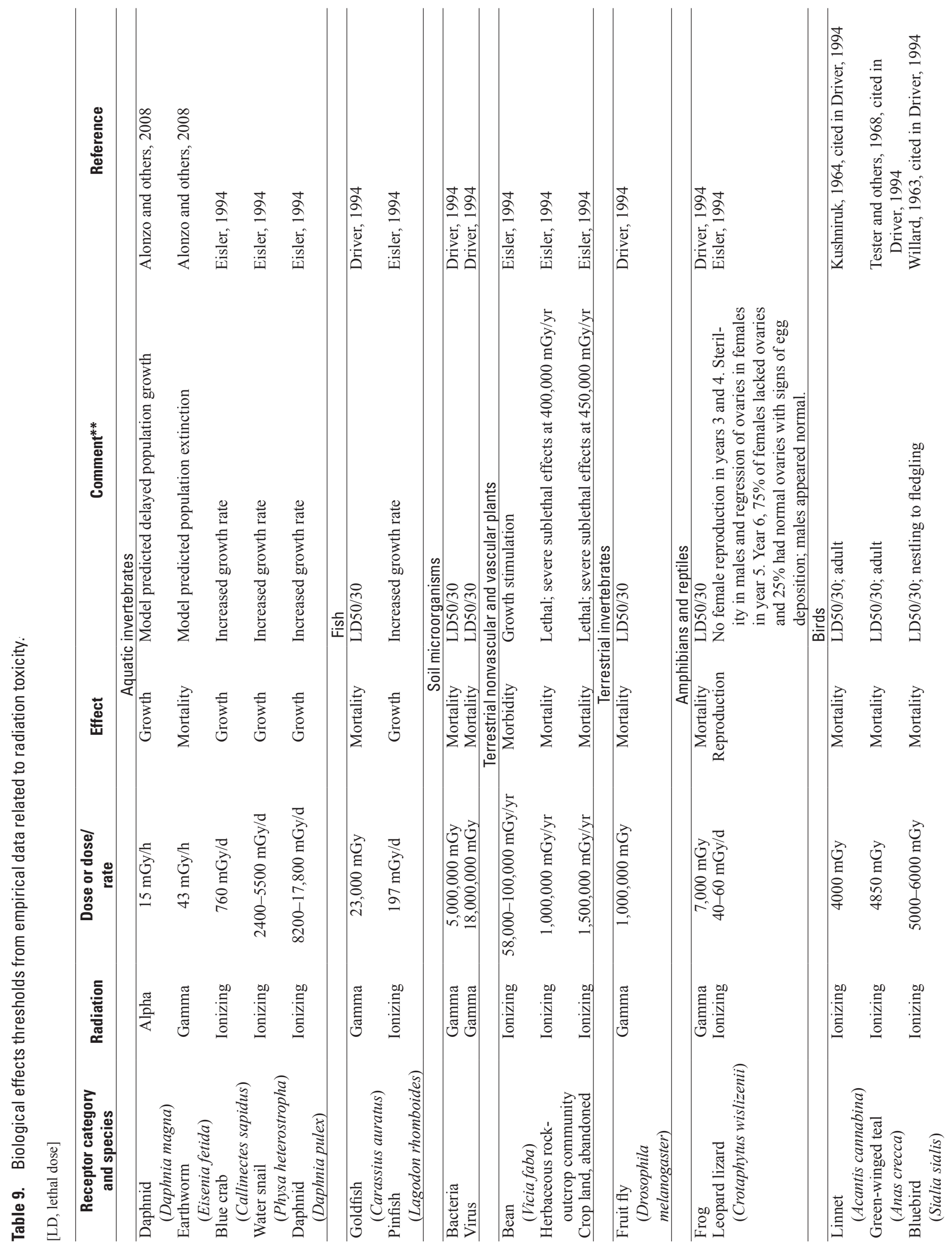




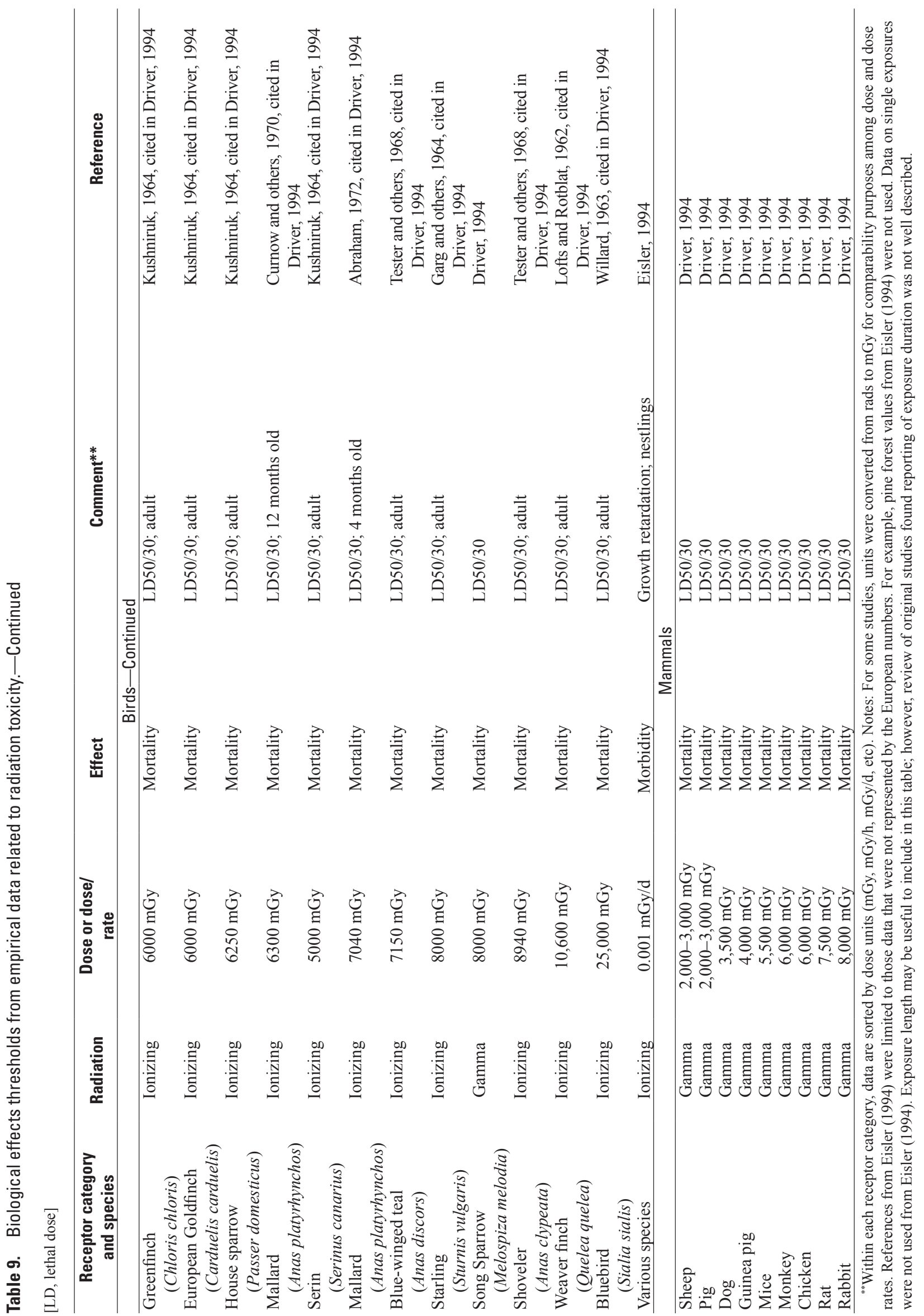




\section{Biological Receptors in the Terrestrial Food Chain}

Radiation effects data for soil biota, terrestrial plants, and terrestrial animals include more acute studies than chronic studies and were generally too limited to establish presumptive no-effects levels (table 9) (Woodhead and Zinger, 2003). Reproductive capacity was the most frequently studied effect of acute radiation exposure in all biota; however, data on morbidity, mortality, and mutation were also available. Morbidity, or the general health of biota, was the most common effect reported for chronic exposures, although survival and effects on reproduction were also found. Radiation dose rates rarely exceeded $10 \mathrm{mGy} / \mathrm{h}$, and threshold effects levels were generally $0.10 \mathrm{mGy} / \mathrm{h}$. Responses to acute irradiation, particularly in terms of the LD50s, differed between taxonomic groups, but these differences became less pronounced in studies focused on continuous, low-dose rate radiation exposure measuring non-mortality endpoints (Woodhead and Zinger, 2003). Woodhead and Zinger (2003) also noted that increased responses were positively related to dose rate, which became unequivocal at dose rates greater than $10 \mathrm{mGy} / \mathrm{h}$ when conferred over a large fraction of the life span.

\section{Terrestrial Nonvascular and Vascular Plants}

Most studies of radiation effects on terrestrial plants were limited to field crops and woody species (table 9) (Woodhead and Zinger, 2003). Very few data were available from references derived from studies focused on mosses, lichens, and fungi, and there are few citations regarding radiation damage to plants resulting from the experimental incorporation of radioactive material into soil in field conditions. However, studies with enhanced natural radiation background at sites were available. Studies reporting the effects of high external radiation dose rate on forests in field conditions are also reported (for example, Sazykina, 2005).

The radiosensitivity of plants is commonly characterized by growth inhibition, reduced reproductive capacity, and reduced survival. The radiation exposure a plant receives is influenced by its morphology (for example, size, shape, density), age, and natural history attributes at the time of exposure (for example, differentiation of flowers). Seasonality also affects radiosensitivity, most often as a function of morphological or physiological changes (Woodhead and Zinger, 2003). Polyploid species, in which reproduction is achieved by vegetative growth, are generally more radioresistant and are typical of extreme environments such as the desert southwest of the United States. Abiotic (for example, light, temperature) and biotic (for example, interactions with neighboring plants) factors influence responses to ionizing radiation exposure (Sazykina, 2005).

Acute radiation effects data, primarily related to reduced growth, morphological changes, alteration in productivity, and abnormal shape and appearance, were available for seeds, seedlings, buds, meristamic tissues, and trees (table 9) (Woodhead and Zinger, 2003). Woodhead and Zinger (2003) noted that acute irradiation effects of coniferous trees in the spring varied (0.7-1.0 Gy), and the timing of irradiation of vegetative plants was critical. For example, survival endpoints (reported as LD50s) for pine trees ranged between 6 and 30 Gy after 2 years of exposure. Among agricultural crops, cereals such as wheat, barley, and oats were radiosensitive (LD50s of 16-22 Gy) (Woodhead and Zinger, 2003). Effects of chronic irradiation were generally related to morbidity, reproductive capacity, and mutation, but few were completed using low LET radiation (linear energy transfer; Woodhead and Zinger, 2003). Woodhead and Zinger (2003) noted threshold dose rates for morbidity $(>0.10 \mathrm{mGy} / \mathrm{h})$, reproduction $(0.05 \mathrm{mGy} / \mathrm{hr})$, and mutation $(0.04 \mathrm{mGy} / \mathrm{h})$ in terrestrial plants from a radiation database (table 9). Guidance values and estimated thresholds for the protection of terrestrial plants have been derived by various organizations (table 6).

\section{Terrestrial Invertebrates}

Soil fauna consist of a large variety of species ranging from protozoa to earthworms and arthropods. Chronic and acute radiation effects data, primarily related to mortality, are available but limited for these receptors (table 9) (Woodhead and Zinger, 2003). For example, effects data for low acute doses (less than $5 \mathrm{~Gy}$ ) were rarely reported, and chronic exposure data relied predominantly on survival. Similar to fish, the acute sensitivity of soil fauna to radiation exposure is dependent on the developmental stage of organism considered. Woodhead and Zinger (2003) reported that a greater dose caused mortality (100-1,000 Gy) compared to morbidity and reproduction effects (5-20 Gy). Relatively sedentary animals, such as earthworms, are vulnerable to internal exposure by alpha radiation by directly foraging in the soil and can experience decreases in population sizes after chronic exposure (Woodhead and Zinger, 2003). Acute effects data less than 5 Gy were not reported for soil fauna including earthworms, springtails, and terrestrial isopods. Susceptibility to acute radiation exposure varies greatly between and within soil invertebrate groups (Woodhead and Zinger, 2003).

Data for chronic effects or radiation on soil fauna was limited. Woodhead and Zinger (2003) reported that soils with elevated natural background levels of radiation (0.001-0.002 mGy/h) contained fewer earthworms (Eisenia nordenskioldi, Dendrobaena octaedra, and Octolasium lacteum) and insect larvae (Dipterea, Elateridae) compared with reference areas; earthworms were particularly sensitive, possibly because of their close contact with soil. In a more recent study, Hertel-Aas and others (2007) reported that chronic gamma external radiation dose rates of $11 \mathrm{mGy} / \mathrm{h}$ reduced cocoon hatchability of the earthworm Eisenia fetida and concluded that dose rates of $43 \mathrm{mGy} / \mathrm{h}$ could collapse a population. Overall, Woodhead and Zinger (2003) observed there were too few data to draw conclusions on dose-effect relationships for terrestrial invertebrates in acute or chronic exposures. However, other studies have estimated a variety of dose rates as guidance values or thresholds for the protection of terrestrial invertebrates (table 6). 


\section{Amphibians and Reptiles}

Amphibians and reptiles represent a significant portion of the vertebrate species in the segregation areas that may be exposed to fugitive radiation, but relatively few studies exist on their radiosensitivity (table 9) (Woodhead and Zinger, 2003). Amphibians are dependent on water for their reproduction and early life stages and shift from an herbivorous to carnivorous diet and to nocturnal activities as adults. Natural history is widely variable for each of the classes, and life span is species dependent. Too few data are available to estimate effects of chronic irradiation. Woodhead and Zinger (2003) noted that acute data are predominately focused on LD50s, which range between 2 and 22 Gy for a number of species of reptiles and amphibians, and that juvenile stages are more sensitive to radiation than other life stages.

The most common species with radiation data were the rough-skinned newt (Taricha granulosa), eastern newt (Notophthalmus viridescens), northern dusky salamander (Desmognathus fuscus), dwarf waterdog (Necturus punctatus), spotted grass frog (Limnodynastes tasmaniensis), northern leopard frog (Rana pipiens), squirrel treefrog (Hyla squirella), and toads (Bufo spp.). Estimated guidance values for the protection of amphibians and reptiles are also limited (table 6).

\section{Birds}

Acute and chronic irradiation data for birds are limited and dated (table 9) (Woodhead and Zinger, 2003). Woodhead and Zinger (2003) observed that data were not sufficient to draw conclusions on dose-effects relationships. However, lethal doses of radiation, regardless of their form, induce a wide range of pathologies because of disruptions in hemostasis and chromosome damage or breakage. For example, LD50/30s (radionuclide dose required to kill 50 percent of the animals in 30 days) for wild bird species exposed to ionizing radiation range from 4,000 to 25,000 mGy (Driver, 1994). Driver (1994) also characterized additional observational studies focused on birds, most in association with nuclear fuel production facilities or waste management operations.

For internal exposures to radiation, particularly alpha particles, vertebrates typically display hemorrhage in respiratory and gastrointestinal tracts in response to inhalation or ingestion of radioactive source materials. Birds may be at greater risk to radiation exposure than other wild vertebrates because of their natural history related to foraging and ingestion of grit, which effectively increases radiation dose (Bellamy and others, 1949, cited in Driver, 1994). Radiation dose will vary depending on food source, behavior, and habitat; therefore, these abiotic and biotic factors influence the accumulation of radionuclides in tissues. Despite the lack of empirical data, guidance values for the protection of birds have been estimated by various organizations (table 6 ).

\section{Mammals}

Biological effects of ionizing radiation in mammals have been extensively studied (table 9) (Woodhead and Zinger, 2003); however, nearly all the data detailing effects of acute or chronic irradiation in mammals are related to human health. These data provide a starting point for characterizing threshold-effects levels in wild mammals, but interspecies differences and field settings will affect radiation effects. Many studies focus on effects of acute exposure to high doses of low LET ionizing radiation administered to rodents (Woodhead and Zinger, 2003).

Data for acute radiation exposures typically measure survival, hematological measures (for example, cell counts, hemoglobin, piruvic acid content), and body and organ weights (for example, kidney, gonads, liver) in a variety of species and different life stages (for example, embryos, young, and adult) (Woodhead and Zinger, 2003). Exposure data on the effects of alpha emitters via inhalation or ingestion are limited compared to beta and gamma emitters; therefore, little data are available related to mortality, morbidity, or reproductive capacity for naturally occurring radioactive materials of the uranium decay series. However, the United Nations Scientific Committee on the Effects of Atomic Radiation (1993) provided a comprehensive review of effects of chronic exposure to low LET radiations on the mutation rate in the mouse. In addition, guidance values for the protection of mammals have been proposed by various organizations (table 6).

Radiation data for wildlife receptors other than mammals are relatively limited as suggested by the previous sections. The reliance on traditional laboratory animal data for extrapolation to terrestrial wildlife may encourage the continued comparative analysis of radiation dose for biota considered in ecological risk assessments. The inability to characterize the interspecies variability as a function of natural histories of wild mammals relative to laboratory mammals, principally rodents, is problematic. Biota concentration guides (BCGs) for radiation exposures to ecological receptors have been developed to help address these uncertainties (for example, Higley and others, 2003). Higley and others (2003) based BCGs on habitats rather than species, which are intended as conservative estimates of values protective of biota living in such habitats. For example, levels of radiation exposure associated with adverse effects to aquatic biota have been calculated as a doserate limit of $0.4 \mathrm{mGy} / \mathrm{h}$. At a dose rate of less than $0.4 \mathrm{mGy} / \mathrm{h}$, populations of the most sensitive aquatic organisms should be protected (National Council on Radiation Protection and Measurements, 1991). The National Council on Radiation Protection and Measurements (1991) developed their guidance values following a review of published literature on the effects of radiation on aquatic biota. Their findings indicated that the developing eggs and young of some fish are the most radiosensitive aquatic organisms. Similarly, the U.S. Department of Energy (2002) recommends that if the results of radiological models or dosimetric measurements exceed a radiation 
dose rate of $0.1 \mathrm{mGy} / \mathrm{h}$, then a more detailed evaluation of the effects of radiation exposure should be conducted. More recent studies should also be considered in future risk evaluations. For example, data related to external gamma irradiation effects (chronic and acute) are available, and the knowledge of relative biological effectiveness (RBE) values could be used to weight the biological effectiveness for other types of radiation (Chambers and others, 2006).

\section{Radionuclide and Radiation Transfers in Aquatic and Terrestrial Ecosystems}

Radionuclide trophic transfer has been discussed in previous sections of this document. In that section, bioconcentration and bioaccumulation processes of metals, including radionuclides, in ecotoxicological studies were evaluated. Bioconcentration or bioaccumulation factors and transfer coefficients have been characterized for a variety of environmental chemicals, yet empirical data detailing the movement and fate of radionuclides are relatively sparse. Driver (1994) had noted that there appeared to be discrimination against the movement of radionuclides of high atomic number from lower to higher trophic levels. Biotic factors influence the extent that a chemical is bioconcentrated. For example, aquatic invertebrates lose up to half of their body burden of adsorbed and absorbed radionuclides at each molt; hence, total accumulation over their entire life cycle is reduced (Wilhm, 1970). Additionally, life histories of animals dictate exposure pathways and scenarios (for example, exposures to burrow-dwelling vertebrates may be dominated by resuspended dusts or gases in their subterranean habitats). Moreover, abiotic factors, such as geochemical composition and specific activity, are also critical for anticipating which pathways may dominate exposure. For example, inhalation routes and dermal exposures will be increasingly critical in determining radiation dose when a physicochemical form suggests that atmospheric exposures (for example, dust) may dominate pathways linking radionuclides with biota. In addition, weathering will affect fate and transport of radionuclides, primarily by altering the matrix with respect to particle size distribution, crystallographic structures, porosity, and oxidation states.

These environmental factors strongly affect long-term processes that influence ecosystem transfers of radionuclides. The physicochemical form of nuclides in naturally occurring radioactive materials will influence biological uptake, accumulation, radiation doses, and biological effects differently in biota exposed to source materials. Sediments and soils act as sinks for radionuclides, particularly when these naturally occurring radioactive materials are present as particles and colloids. Radionuclide speciation is critical to biological uptake, regardless of whether that process results from a relatively simple pathway linking the abiotic environment to biota through direct uptake mediated by membranes in direct contact with the exposure medium (bioconcentration) or from a more complex pathway linking biota not only to the abiotic environment but also to biological sources such as dietary inputs that are manifested as bioaccumulation of radionuclides. As such, radionuclides may occur in various physicochemical forms, such as low molecular mass species (LMM), colloids, pseudocolloids, or particles (Salbu and others, 2004). In addition, each of these physicochemical forms will vary with respect to their mobility and fate in areas potentially open to disturbance linked to mining activities. For example, LMM species and colloids are relatively mobile, whereas smaller physicochemical species, such as particles, may be more likely to be entrapped in the soil or sediment matrix (Zhang and Brady, 2002). Within the context of physicochemical forms of radionuclides, LMM-species can cross biological membranes directly or indirectly following physicochemical interactions with low molecular weight ligands, whereas radionuclides interacting with high molecular weight ligands will display decreased uptake across membrane surfaces. Hence, high molecular weight forms are less bioavailable, and LMM species are more mobile (lower apparent dissociation constant $[\mathrm{Kd}]$ ) and bioavailable (for example, higher apparent BAF) than colloids and particles.

Naturally occurring radioactive materials such as those characteristic of decay chains of ${ }^{238} \mathrm{U},{ }^{235} \mathrm{U}$, and ${ }^{232} \mathrm{Th}$ produce a group of radionuclides with a wide range of half-lives. Most of these radionuclides are predominately alpha emitters, so internal exposures contribute significantly to the radiation dose. However, considering that uranium and thorium are always present in soils, particularly in areas identified as potentially of interest for mining, gamma radiation may become more prominent when characterizing external exposures and their associated absorbed doses in biota occupying habitats in these areas. Thus, exposure to the radioactivity hazards associated with the radionuclides uranium and thorium will be evaluated differently than the chemical hazards associated with these same chemicals. The hazards associated with external doses of ionizing radiation that can affect biota without actually being taken up require a different exposure paradigm for these types of radionuclides.

\section{Data Gaps, Uncertainties, and Summary}

Our overview of biological pathways and ecotoxicity values for radionuclides in the uranium decay series anticipates future studies focused on evaluations of risk or effects potentially associated with possible mining in northern Arizona. Given that anticipation, we (1) briefly identify data gaps and uncertainties we encountered that will likely be addressed in those future efforts, and (2) summarize our technical findings focused on pathways critical to linking sources with receptors that co-occur in the segregation areas. 


\section{Data Gaps and Uncertainties}

The current distribution of uranium to the habitat surrounding segregation areas is not well defined. Other chapters of this assessment measured uranium in soil, sediment, and water, but biological samples were not collected. Therefore, site-specific uranium concentrations in biota inhabiting the segregation areas are not available, nor are they readily available from other sources. This type of information would provide baseline concentrations for various biological receptors that may be exposed to uranium and other inorganic chemicals associated with uranium mining activities. Information on wind dispersal (dust) of uranium also needs to be characterized for the mining areas. The use of dispersion models (for example, dust and particulates) would be useful to identify vulnerable habitats within the segregation areas. The physiochemical properties of water, soil, and sediment collected from the segregation areas will help to further characterize the potential exposure to biota. In addition, other elements present in breccia pipes, including silver, arsenic, cobalt, copper, molybdenum, nickel, lead, selenium, and zinc, may also pose a risk to biota utilizing the area (Weinrich, 1985), but they were not considered in this document. Selenium is of particular concern because elevated concentrations have been reported in biota in the Colorado River Basin (Radtke and others, 1988; Hinck and others, 2008), and adverse biological effects are well documented in aquatic and terrestrial organisms (see reviews by Jarvenin and Ankley, 1999; Ohlendorf, 2003).

Little biological information was found regarding habitat utilization in and near the segregation areas. Therefore, it is unclear where Federal and State species of concern inhabit the segregation areas and where habitat may be lost, degraded, or fragmented if mining operations are allowed. The physical habitat could be altered by the mine itself (for example, old, abandoned, and new tunnels if conventional mining is reinitiated), accessory buildings, waste rock disposal areas, roads, and traffic. Mining activities and roads may also influence infiltration rates, overland flow, and sediment movement important to the aquatic habitat. Site assessments of habitat utilization would help to better define exposure pathways. For example, some plant species of concern, such as the Grand Canyon rose (Rosa stellata), have been documented as growing in breccia pipes (Arizona Game and Fish Department, 2005). Such assessments would need to examine aquatic and terrestrial ecosystems and include microbes, plants, and animals. Assessments would also need to address if active and remediated mining sites could become attractive nuisances to species of concern (for example, bats utilizing refilled breccia pipes, talussnail [Sonorella spp.] using waste rock). Ingestion (water, diet, and incidental), inhalation, and dermal uptake rates of species of concern would further add to the exposure characterization.

The literature compilation was comprehensive, but it is unlikely that every pertinent reference on uranium decay series toxicity was obtained. However, extensive efforts were made to obtain data related to uranium mining operations in the region; uranium data related to depleted uranium from nuclear energy was included because information specific to uranium mining operations was sparse for some biological receptors. In addition, although literature compiled for this report was taken from peer-reviewed publications and Government-reviewed technical reports, our intent was to simply compile and report data and make them available to future studies focused on risks and effects. In future work, data inclusion and exclusion criteria would have to be developed, and the studies would necessarily undergo rigorous data quality analysis or validation required before using these effects data to establish benchmarks or guidance values. The empirical effects data compiled in tables 7-9 represent NOECs, LOECs, LC50s, and EC50s for a variety of endpoints (for example, survival, growth, reproduction), and they may contribute to the development of benchmarks or guidance values, but they were not intended to be applied to that end in our evaluation. Various resources on deriving or estimating guidance values (see Crane and Newman, 2000; Scholze and others, 2001; European Commission, 2003; Lepper, 2005; Canadian Council of Ministers of the Environment, 2007) should be consulted if site-specific benchmark or guidance values are to be developed. Moreover, existing guidance values to protect nonhuman biota (table 6) should not be applied to a risk assessment in the segregation areas unless the bases of these benchmarks are fully understood and are found to be appropriate to the site.

Uranium likely does not biomagnify in the aquatic or terrestrial food chain, and the toxicity, bioconcentration, and bioaccumulation of uranium are better characterized in aquatic systems than terrestrial systems. However, the absence of data should not be considered an indication that uranium is not a concern in seasonally variable terrestrial ecosystems such as those of the arid southwest United States. Precipitation in Arizona varies spatially, which affects exposure pathways that link aquatic biota to source materials potentially released from mining. The average annual precipitation is less than $250 \mathrm{~mm}$ (10 in) in much of the segregation areas, although wetter regions occurring at higher elevations (for example, the Kaibab Plateau) can have an annual precipitation of $635 \mathrm{~mm}$ (25 in) or more. Throughout the region, precipitation typically occurs during two rainy seasons: short, isolated, and intense summer rains and longer, widespread, and less intense winter rains (Peterson, 1994). Aquatic biota may be affected by releases of uranium or co-occurring constituents of mined ores in arid habitats like northern Arizona during rain events. However, little information is available regarding fate and environmental transport of these materials and their potential effects in desert flora and fauna in arid areas. Furthermore, these seasonal patterns in aquatic habitats (for example, ephemeral streams) and concern over climate change suggest that reduced water resources in the segregation areas are not cause to dismiss risk to aquatic species, as indicated by the occurrence of species of concern such as the Kanab ambersnail (Oxyloma haydeni kanabensia) in the area. As future risk or effect evaluations may detail, precipitation events will likely influence risk characterizations for aquatic species, particularly those species reliant on ephemeral aquatic habitats unique to arid landscapes such as that of the southwest United States. For example, the flash flooding typical to the area can cause increased runoff 
and erosion that can erode weathered soils from waste rock or dry gullies and expose unweathered materials. Biota drinking from seasonal streams and ponds after flood events may experience increased exposure to radionuclides because of ingestion after flood events; such water may include runoff from contaminated soils that are relied upon heavily by wildlife when water becomes available after precipitation events. Wind dispersion is also a concern and should be considered when evaluating risks to biota.

Chemical and radiation effects thresholds for radionuclides were consistently limited to only a few species for most biological receptors, and limited data were available for wildlife species. Those species tested were few in number, generally traditional aquatic toxicity test species, and relatively undeveloped with respect to developing benchmark toxicity values. Minimal chemical toxicity data was available for microbes, aquatic vascular plants, terrestrial invertebrates, and amphibians, and no data were found for reptiles, birds, or mammalian wildlife. Toxicity data was most abundant, but still limited, for aquatic invertebrates, fish, and laboratory test mammals. The availability of only certain kinds of data creates extensive gaps in data on the effects of uranium exposure on the food web indicative of the segregation areas. We relied predominately on measures that captured effects based on gross alpha and gross beta exposures, in part because biota in field settings are exposed to a mixture of radiation sources. Nonetheless, data gaps were evident. No chemical or radiation toxicity data were available for species of snakes, lizards, birds, or mammals that are dependent on subterranean habitats such as burrows or caves. Furthermore, studies that focus on effects related to depleted uranium exposure may exclude important subterranean habitats like those found in the segregation areas because dispersed depleted uranium remains near the surface of the soil (Ribera and others, 1996). It is also unknown if these burrow-dwelling species are subject to increased exposures. We can say little, if anything, regarding the sensitivity of wildlife receptors to chemical and radiation exposure encountered in the field. For example, biota in burrow habitats may approach continuous exposure, as compared to surface-dwelling biota whose exposure to radionuclideladen dust would vary relative to daily and seasonal patterns in wind direction and magnitude. In addition, State and Federal species of concern were found in most compartments of the generalized food web. Given the lack of toxicity data available for most biological receptors and the abundance of species of concern in the food web, the risk of uranium and its decay products to biological receptors using the segregation areas should not be underestimated. Future analysis of risks or effects would need to fully establish the comparative basis for evaluating exposure in the field. Specifically, given the geographic setting captured in this pathway analysis, future work must address the data gaps for characterizing "reference" versus "mined" lands in addition to ecotoxicity data; baseline conditions, such as uranium concentrations in materials collected from terrestrial habitats like soils and vegetation, would need to be determined. Similarly, a more completely characterized radiation survey would need to be completed.
Data related to the chemical toxicity of radionuclides, stable end-state constituents associated with uranium decay series, and other inorganic constituents of mined ores vary from absent to sufficient, but empirical data characterizing the radiation toxicity are consistently lacking. Radiation data were available for a limited number of species within each receptor category in our summary, and few data were found for desert flora and fauna. Radiation exposure is of specific concern for biota that spend prolonged periods of time (for example, hibernation, avoiding heat of the day) in the subterranean environment. Most radiation data available are for laboratory test species and are intended to address radiation safety concerns for humans; they may not include important exposure pathways like incidental ingestion of radionuclides through burrowing, preening, or caching food of wild mammals. More infrequently, wildlife have been considered in regulatory contexts related to nuclear energy development and waste management rather than uranium mining and processing. Few studies have attempted to quantify the risk to biota directly caused by the chemical or radiation released by means other than those linked to uranium mill tailings. Research into the biological effects is strongly biased towards human health, yet attention focused on the biological effects of the uranium production of nuclear energy development has increased. For example, plants and fish residing near mill tailings can take up radionuclides and introduce a health risks to individuals, communities, and ecosystems in the food chain, including humans (International Atomic Energy Agency, 2004).

A compilation of the existing literature has indicated that acute exposures to mill tailings often result in sublethal effects to the biota; however, effects resulting from chronic exposures are greatly unknown. The long term risks of chronic exposure are not understood, particularly in terms of potential genetic effects on species populations, density, ecosystem dynamics, and biodiversity. Additionally, the possible synergistic effects of radiation dose and chemical exposure on other metals, semi-metals, and other toxic compounds common at uranium mining and processing facilities also need to be considered.

Given the data gaps we encountered, monitoring and surveillance of radionuclide exposure to biological resources would be appropriate if the segregation areas are opened to mining activities. Research needs will vary among uranium ore deposits throughout the United States. For example, ecological studies or monitoring activities associated with uranium mining activities will likely identify and define stressor exposures to biological resources in areas of concern that are unlike those identified in this evaluation. As indicated by this report, initial evaluations of system vulnerabilities should focus on resources captured in the preliminary conceptual model. In part, the identification of activities associated with the development of energy resources (such as those linked to uranium mining - infrastructure, related surface and subsurface disturbance) would allow connections to be made that shape the pathways between mineral sources such as uranium deposits in breccia pipes and biological resources that risk hazardous exposure to those minerals. 


\section{Summary}

This chapter focused on sources of and exposure to naturally occurring uranium and other radionuclides associated with uranium mining in northern Arizona, particularly in those segregation areas adjacent to Grand Canyon National Park. Federal and State species of concern for the area were identified in order to develop exposure pathways between biological receptors and uranium mining activities. Relevant scientific literature on toxicity threshold effects levels for uranium and associated radionuclides was then compiled for aquatic and terrestrial biota.

Our literature compilation included various biological receptor categories, including microbes, plants, invertebrates, fishes, amphibians, reptiles, birds, and mammals, that are integral parts of the food web in the segregation areas. Species of concern from all of these categories except microbes, identified by State and Federal agencies primarily based on their small home range and limited population size, inhabit the segregation areas. Certain biological receptors are potentially more susceptible to uranium exposure; herbivores, aquatic species, and burrowing animals are of particular concern given the likely exposure pathways and available toxicity data. For example, certain species of reptiles, amphibians, birds, and mammals in the segregation areas spend significant amounts of time in burrows or mine tunnels where they can inhale or ingest uranium and other radionuclides through digging, eating, preening, and hibernating. Toxicity data for the sensitivity of burrowing animals to radionuclides is not available in the existing scientific literature. Herbivores may also be exposed to radionuclides though the ingestion of radionuclides that have been aerially deposited on vegetation. Other receptors such as carnivorous birds and mammals that do not utilize subterranean habitats may be less sensitive to exposure in the segregation areas because uranium does not bioaccumulate or biomagnify in food chains. Microbes and other lower organisms may also be less sensitive to the chemical and radiation hazards of uranium and associated radionuclides, but certain invertebrates including the Kanab ambersnail need additional consideration given their endangered status.

Results of this literature compilation highlight that toxicity data for many radionuclides and biological receptors are lacking. Other authors have developed chemical and radiation toxicity guidance values for uranium decay products (for example, Suter and Tsao, 1996; Woodhead and Zinger, 2003; Sheppard and others, 2005; U.S. Department of Energy, 2005; United Nations Scientific Committee on the Effects of Atomic Radiation, 2008). However, directly applying these values to biota in the segregation areas may be inappropriate. The presumptive values are not limited to naturally occurring uranium at mining areas, which may have chronic exposures at low concentrations. In addition, some guidance values are based on little or no empirical data but rather are driven by mathematical models, the biological relevance of which cannot be determined. Empirical data for the toxicity of uranium and associated radionuclides is limited for the species of concern, specifically reptiles, birds, and mammalian wildlife, that represent essential components of the food web in the segregation areas and have unique habitats and life history strategies. Nevertheless, these existing guidance values were included in this chapter (tables 6-8) to highlight that guidance values for radionuclides have been recommended by various committees. Such recommendations could be useful in the environmental impact statement to be developed, as long as the derivations of the guidance values are clearly understood. Future evaluations of risks or effects may consider developing site-specific benchmarks related to uranium mining in the segregation areas.

Other inorganic constituents (for example, selenium) that are characteristic of uranium ores typical of breccia pipes were not considered in this evaluation of pathways. Whereas these constituents may not present radiation hazards in field exposures, some of these elements are potentially as toxic, if not more toxic, than uranium. Available toxicity data for these inorganic chemicals vary, but toxicity thresholds are available for some. The pathways linking sources with receptors are likely identical regardless of the chemical and radiation hazards associated with breccia pipes. Future studies focused on risks of uranium mining need to develop empirical data to characterize the ore materials included in the exposure mixtures that are potentially released consequent to mining operations. Radiation toxicity data are highly limited for biological receptors likely to be exposed in the field, and little empirical data are available to develop support needed for radiation measurements in biota in natural settings. In our present evaluation, effect thresholds for chemicals of concern and radiation hazards were not available for biological receptors essential to the food web in the segregation areas, including the soil crust community, vascular plants, terrestrial invertebrates, amphibians, reptiles, birds, and mammals.

\section{Acknowledgments}

We thank Julia Towns-Campbell (USGS) for conducting the literature queries and creating the bibliographic database. Kristin Brown (USGS) created the species distribution maps using data provided by Mary Richardson (U.S. Fish and Wildlife Service). Martha Hahn and R.V. Ward (National Park Service), Carrie Marr (U.S. Fish and Wildlife Service), Elroy Masters (BLM), Sabra Schwartz (Arizona Game and Fish Department), and Angela Gatto, Karlynn Huling, and Jeff Waters (U.S. Forest Service) provided information on species of concern and available radionuclide data in biota from their respective agencies. We would like to also thank Karine Beaugelin-Seiller (French Institute of Radiation Protection and Nuclear Safety, IRSN), Nelson Beyer (USGS), Jacqueline Garnier-Laplace (IRSN), Rodolphe Gilbin (IRSN), Tom Hinton (IRSN), and David Mount (USEPA) for reviewing early versions of this chapter. 


\section{References Cited}

Adriano, D.C., 1986, Trace elements in the terrestrial environment: New York, Springer-Verlag, 533 p.

Advisory Committee on Radiological Protection, 2002, Protection of non-human biota from ionizing radiation: Canadian Nuclear Safety Commission INFO-7030, 77 p.

Agency for Toxic Substances and Disease Registry, 1990, Toxicological profile for thorium: U.S. Public Health Service, U.S. Environmental Protection Agency, 186 p.

Agency for Toxic Substances and Disease Registry, 1992, Toxicological profile for thallium: U.S. Department of Health and Human Services, Public Health Services, 99 p.

Alloway, B.J, ed., 1990, Heavy metals in soil: New York, Blackie/John Wiley \& Sons, Inc., 339 p.

Alpen, E.L., 1997, Radiation biophysics (2d ed.): New York, Academic Press, 484 p.

Alonzo, F., Hertel-Aas, T., Gilek, M., Gilbin, R., Oughton, D.H., and Garnier-Laplace, J., 2008, Modelling the propagation of effects of chronic exposure to ionising radiation from individuals to populations: Journal of Environmental Radioactivity, v. 99, no. 9, p. 1464-1473.

Alves, L.C., Borgmann, U., and Dixon, D.G., 2008, Watersediment interactions for Hyalella azteca exposed to uranium-spiked sediment: Aquatic Toxicology, v. 87, no. 3, p. 187-199.

Andersson, P., Garnier-Laplace, J., Beresford, N.A., Copplestone, D., Howard, B.J., Howe, P., Oughton, D., and Whitehouse, P., 2009, Protection of the environment from ionising radiation in a regulatory context (protect)Proposed numerical benchmark values: Journal of Environmental Radioactivity, v. 100, no. 12, p. 1100-1108.

Andrews, B.J., Kirke, K.A., and Baker, D.L., 1995, Radionuclides and trace elements in fish and wildlife of the Puerco and Little Colorado Rivers, Arizona: U.S. Fish and Wildlife Service, Arizona Ecological Services Field Office, 20 p.

Arizona Department of Environmental Quality, 2003, Arizona Administrative Code Title 18, Chapter 11. Department of Environmental Quality - Water Quality Standards: Phoenix, Ariz., Arizona Department of Environmental Quality, 85 p.

Arizona Department of Environmental Quality, 2007, Arizona Administrative Code Title 18, Chapter 7. Department of Environmental Quality-Remedial Action: Phoenix, Ariz., Arizona Department of Environmental Quality, 40 p.

Arizona Game and Fish Department, 2005, Grand Canyon rose-Unpublished abstract compiled and edited by the Heritage Data Management System: Phoenix, Ariz., Arizona Game and Fish Department, 5 p.
Barata, C., Baird, D.J., and Markich, S.J., 1998, Influence of genetic and environmental factors on the tolerance of Daphnia magna Straus to essential and non-essential metals: Aquatic Toxicology, v. 42, no. 2, p. 115-137.

Barrows, M.E., Petrocelli, S.R., Macek, K.J., and Carrol, J.J., 1978, Bioconcentration and elimination of selected water pollutants by bluegill sunfish (Lepomis macrochirus), in Haque, R., ed., Dynamics of exposure, hazard assessment, toxicity, and chemistry: Ann Arbor, Mich., Ann Arbor Science, p. 379-392.

Bartlett, R., 1998, Solution Mining (2d ed.): Boca Raton, Fla., Routledge-Taylor \& Francis, 472 p.

Beaugelin-Seiller, K., Connan, O., Germain, P., and Roussel-Debet, S., 2004, Fiche radionucléide-Polonium 210 et environnement: Fontenay-aux-Roses, France, Institut de Radioprotection et de Sûreté Nucléaire, 24 p.

Belnap, J., and Lange, O.L., eds., 2001, Biological soil crustsStructure, function, and management (1st ed.): Berlin, Springer-Verlag, 503 p. [Revised second printing 2003.]

Belnap, J., Welter, J.R., Grimm, N.B., Barger, N., and Ludwig, J.A., 2005, Linkages between microbial and hydrologic processes in arid and semiarid watersheds: Ecology, v. 86, no. 2, p. 298-307.

Beyer, W.N., Connor, E.E., and Gerould, S., 1994, Estimates of soil ingestion by wildlife: Journal of Wildlife Management, v. 58, no. 2, p. 375-382.

Bird, G.A., Thompson, P.A., Macdonald, C.R., Sheppard, S.C., 2003, Assessment of the impact of radionuclide releases from Canadian nuclear facilities on non-human biota, in Proceedings of the Third International Symposium on the Protection of the Environment from Ionizing Radiation (SPEIR 3), Darwin, Australia, July 22-26, 2002, Proceedings: Vienna, Austria, International Atomic Energy Agency, p. 241-247.

Birge, W.J., 1978, Aquatic toxicology of trace elements of coal and fly ash, in Environmental stress in aquatic systemsSelected papers from a symposium held at Augusta, Georgia, November 2-4, 1977: Augusta, Ga., U.S. Department of Energy, Technical Information Center, p. 219-240.

Birge, W.J., Black, J.A., and Westerman, A.G., 1977, Evaluation of aquatic pollutants using fish and amphibian eggs as bioassay organisms, in Nielsen, S.W., Migaki, G., and Scarpelli, D.G., eds., Animals as Monitors of Environmental Pollutants: Washington, D.C., National Academy of Sciences, p. 108-118. 
Birge, W.J., Black, J.A., Westerman, A.G., and Hudson, J.E., 1980, Aquatic toxicity tests on inorganic elements occurring in oil shale, in Oil Shale Symposium - Sampling, analysis, and quality assurance, March 1979: Cincinnati, Ohio, U.S. Environmental Protection Agency, Office of Research and Development, Industrial Environmental Research Laboratory, p. 519-534.

Blaylock, B.G., Frank, M.L., and O`Neal, B.R., 1993, Methodology for estimating radiation dose rates to freshwater biota exposed to radionuclides in the environment. U.S. Department of Energy ES/ER/TM-78, 39 p.

Bohn, H.L., McNeal, B.L., and O’Connor, G.A., eds., 2001, Soil chemistry ( $3 \mathrm{~d}$ ed.): New York, John Wiley \& Sons, Inc., $307 \mathrm{p}$.

Borgmann, U., Cheam, V., Norwood, W.P., and Lechner, J., 1998, Toxicity and bioaccumulation of thallium in Hyalella azteca, with comparison to other metals and prediction of environmental impact: Environmental Pollution, v. 99, no. 1, p. 105-114.

Borgmann, U., Couillard, Y., Doyle, P., and Dixon, D.G., 2005, Toxicity of sixty-three metals and metalloids to Hyalella azteca at two levels of water hardness: Environmental Toxicology and Chemistry, v. 24, no. 3, p. 641-652.

Bourrachot, S., Simon, O., and Gilbin, R., 2008, The effects of waterborne uranium on the hatching success, development, and survival of early life stages of zebrafish (Danio rerio): Aquatic Toxicology, v. 90, no. 1, p. 29-36.

Bréchignac, F., and Desmet, G., eds., 2005, EquidosimetryEcological standardization and equidosimetry for radioecology and environmental ecology: New York, Springer, $436 \mathrm{p}$.

Brenner, D.J., Doll, R., Goodhead, D.T., Hall, E.J., Land, C.E., Little, J.B., Lubin, J.H., Preston, D.L., Preston, R.J., Puskin, J.S., Ron, E., Sachs, R.K., Samet, J.M., Setlow, R.B., and Zaider, M., 2003, Cancer risks attributable to low doses of ionizing radiation-Assessing what we really know: Proceedings of the National Academy of Sciences of the United States of America, v. 100, no. 24, p. 13761-13766.

Brown, J.B., 2008, Review of available water-quality data for the Southern Colorado Plateau Network and characterization of water quality in five selected park units in Arizona, Colorado, New Mexico, and Utah, 1925 to 2004: U.S. Geological Survey Scientific Investigations Report 2008-5130, $118 \mathrm{p}$.

Buccafusco, R.J., Ells, S.J., and LeBlanc, G.A., 1981, Acute toxicity of priority pollutants to bluegill (Lepomis macrochirus): Bulletin of Environmental Contamination and Toxicology, v. 26, no. 1, p. 446-452.
Bunzl, K., Trautmannsheimer, M., Schramel, P., and Reifenhäuser, W., 2001, Availability of arsenic, copper, lead, thallium, and zinc to various vegetables grown in slagcontaminated soils: Journal of Environmental Quality, v. 30, no. 3, p. 934-939.

Burns, P.C., and Finch, R., eds., 1999, Uranium-Mineralogy, geochemistry, and the environment: Washington, D.C., Mineralogical Society of America, $679 \mathrm{p}$.

Bytwerk, D.P., 2006, An allometric examination of the relationship between radiosensitivity and mass: Corvallis, Oreg., Oregon State University, 70 p.

Bywater, J.F., Banaczkowski, R., and Bailey, M., 1991, Sensitivity to uranium of six species of tropical freshwater fishes and four species of cladocerans from northern Australia: Environmental Toxicology and Chemistry, v. 10, no. 11, p. 1449-1458.

Calleja, M.C., Persoone, G., and Geladi, P., 1994, Comparative acute toxicity of the first 50 Multicentre Evaluation of In Vitro Cytotoxicity chemicals to aquatic non-vertebrates: Archives of Environmental Contamination and Toxicology, v. 26 , no. 1 , p. $69-78$.

Calmon, P., and Fesenko, S., eds., 2009, Quantification of radionuclide transfer in terrestrial and freshwater environments: Journal of Environmental Radioactivity special issue, v. 100 , no. 9 .

Calmon, P., Fesenko, S., Voigt, G., and Linsley, G., 2009, Quantification of radionuclide transfer in terrestrial and freshwater environments: Journal of Environmental Radioactivity, v. 100, no. 9, p. 671-674.

Canadian Council of Ministers of the Environment, 2007, Canadian soil quality guidelines for uraniumEnvironmental and human health: Canadian Council of Ministers of the Environment, Scientific Supporting Document, accessed December 9, 2009, at http://www.ccme.cal assets/pdf/uranium_ssd_soil_1.2.pdf.

Carvalho, F.P., and Fowler, S.W., 1994, A double-tracer technique to determine the relative importance of water and food as sources of polonium-210 to marine prawns and fish: Marine Ecology Progress Series, v. 103, no. 3, p. 251-264.

Casarett, L.J., Klaassen, C.D., and Doull, J., eds., 2007, Casarett and Doull's toxicology (7th ed.): New York, McGraw-Hill Professional, $1280 \mathrm{p}$.

Chambers, D.B., Osborne, R.V., and Garva, A.L., 2006, Choosing an alpha radiation weighting factor for doses to non-human biota: Journal of Environmental Radioactivity, v. 87 , no. 1 , p. $1-14$.

Charles, A.L., Markich, S.J., and Ralph, P., 2006, Toxicity of uranium and copper individually, and in combination, to a tropical freshwater macrophyte (Lemna aequinoctialis): Chemosphere, v. 62, no. 8, p. 1224-1233. 
Charles, A.L., Markich, S.J., Stauber, J.L., and De Filippis, L.F., 2002, The effect of water hardness on the toxicity of uranium to a tropical freshwater alga (Chlorella sp.): Aquatic Toxicology, v. 60, no. 1-2, p. 61-73.

Cherry, R.D., and Heyraud, M., 1981, Polonium-210 content of marine shrimp - Variation with biological and environmental factors: Marine Biology, v. 65, no. 2, p. 165-175.

Colle, C., and Mourlon, C., 2003, Fiche radionucléideProtactinium 231 et environnement: Fontenay-aux-Roses, France, Institut de Radioprotection et de Sûreté Nucléaire, 9 p., accessed December 1, 2009, at http://www.irsn.fr/ FR/larecherche/Information_scientifique/Publications_ Documentation/fiches-techniques-radionucleides/ environnement/Documents/Protactinium_Pa231_v1.pdf.

Colley, S., and Thomson, J., 1991, Migration of uranium daughter radionuclides in natural sediments: Luxemburg, Centre Européen des Consommateurs [European Consumer Center] Nuclear Science and Technology Report EUR 13182, 89 p.

Cooper, J.R., Randle, K., and Sokhi, R.S., 2003, Radioactive releases in the environment-Impact and assessment: West Sussex, England, John Wiley \& Sons, Ltd, 473 p.

Corbett, D.R., Burnett, W.C., Cable, P.H., and Clark, S.B., 1997, Radon tracing of groundwater input into Par Pond, Savannah River Site: Journal of Hydrology, v. 203, no. 1-4, p. 209-227.

Cothern, C.R., 1988, Properties, in Cothern, C.R., and Smith, J.E., II, eds., Environmental radon: New York, Springer, p. 1-29.

Cothern, C.R., and Smith, J.E., II, eds., Environmental radon: New York, Springer.

Cowart, J.B., and Burnett, W.C., 1994, The distribution of uranium and thorium decay-series radionuclides in the environment - A review: Journal of Environmental Quality, v. 23 , no. 4 , p. 651-662.

Craig, G.R., and Beggs, G.L., 1979, Evaluation of fish loading rates in regulatory static bioassays, in Proceedings of the fifth annual Aquatic Toxicity Workshop, Hamilton, Ontario, November 7-9, 1978: Burlington, Ontario, Great Lakes Biolimnology Laboratory, Canada Centre for Inland Waters, p. 145-160.

Crane, M., and Newman, M.C., 2000, What level effect is a no observed effect?: Environmental Toxicology and Chemistry, v. 19 , no. 2 , p. 561-519.

Dawson, G.W., Jennings, A.L., Drozdowski, D., and Rider, E., 1977, The acute toxicity of 47 industrial chemicals to fresh and saltwater fishes: Journal of Hazardous Materials, v. 1, no. 4, p. 303-318.
De Jong, L.E.D., 1965, Tolerance of Chlorella vulgaris for metallic and non-metallic ions: Antonie van Leeuwenhoek, v. 31, p. 301-313.

Dias, V., Vasseur, C., and Bonzom, J.-M., 2008, Exposure of Chironomus riparius larvae to uranium-Effects on survival, development time, growth, and mouthpart deformities: Chemosphere, v. 71, no. 3, p. 574-581.

Domingo, J.L., 2001, Reproductive and developmental toxicity of natural and depleted uranium - A review: Reproductive Toxicology, v. 15, no. 6, p. 603-609.

Driver, C.J., 1994, Ecotoxicity literature review of selected Hanford Site contaminants: U.S. Department of Energy, Pacific Northwest Laboratory, PNL-9394, 141p.

Efroymson, R.A., Suter, G.W., II, Sample, B.E., and Jones, D.S., 1997a, Preliminary remediation goals for ecological endpoints: U.S. Department of Energy ES/ER/TM-162/R2, $26 \mathrm{p}$.

Efroymson, R.A., Will, M.E., Suter, G.W., II, and Wooten, A.C., 1997b, Toxicological benchmarks for screening contaminants of potential concern for effects on terrestrial plants (1997 revision): U.S. Department of Energy ES/ER/TM-85/R3, 123 p.

Eisenbud, M., and Gesell, T., 1997, Environmental radioactivity from natural, industrial, and military sources: San Diego, Calif., Academic Press, 656 p.

Eisler, R., 1994, Radiation hazards to fish, wildlife, and invertebrates - A synoptic review: Patuxent Environmental Science Center, U.S. National Biological Service Contaminant Hazard Reviews Report 29,U.S. Fish \& Wildlife Service Biological Report 26, 147p.

European Commission, 2003, Technical guidance document on risk assessment - In support of Commission Directive 93/67/EEC on risk assessment for new notified substances, Commission Regulation (EC) No 1488/94 on risk assessment for existing substances, and Directive 98/8/EC of the European Parliament and of the Council concerning the placing of biocidal products on the market. Part II: European Commission, Joint Research Centre, Institute for Health and Consumer Protection, European Chemicals Bureau, 328 p.

Ferrari, C.P., Hong, S., Van de Velde, K., Boutron, C.F., Rudniev, S.N., Bolshov, M., Chisholm, W., and Rosman, K.J.R., 2000, Natural and anthropogenic bismuth in Central Greenland: Atmospheric Environment, v. 34, no. 6, p. 941-948.

Feugier, A., Frelon, S., Gourmelon, P., and Claraz, M., 2008, Alteration of mouse oocyte quality after a subchronic exposure to depleted uranium: Reproductive Toxicology, v. 26, no. 3-4, p. 273-277. 
Finch, W.I., 1992, Descriptive model of solution-collapse breccia pipe uranium deposits, in Bliss, J.D., ed., Developments in mineral deposit modeling: U.S. Geological Survey Bulletin 2004, accessed October 1, 2009, at http://pubs.usgs.gov/bul/ b2004/html/bull2004breccia_pipe_uranium_deposits.htm.

Finch, W.I., 1996, Uranium provinces of North AmericaTheir definition, distribution, and models: U.S. Geological Survey Bulletin 2141, 18 p.

Fortin, C., Denison, F.H., and Garnier-Laplace, J., 2007, Metal-phytoplankton interactions-Modeling the effect of competing ions $(\mathrm{H}+, \mathrm{Ca} 2+$, and $\mathrm{Mg} 2+)$ on uranium uptake: Environmental Toxicology and Chemistry, v. 26, no. 2, p. 242-248.

Fortin, C., Dutel, L., and Garnier-Laplace, J., 2004, Uranium complexation and uptake by a green alga in relation to chemical speciation-The importance of the free uranyl ion: Environmental Toxicology and Chemistry, v. 23, no. 4, p. 974-981.

Fournier, E., Tran, D., Denison, F., Massabuau, J.-C., and Garnier-Laplace, J., 2004, Valve closure response to uranium exposure for a freshwater bivalve (Corbicula fluminea) - Quantification of the influence of $\mathrm{pH}$ : Environmental Toxicology and Chemistry, v. 23, no. 5, p. 1108-1114.

Francis, C.W., Chesters, G., and Erhardt, W.H., 1968, Polonium-210 entry into plants: Environmental Science \& Technology, v. 2, no. 9, p. 690-695.

Franklin, N.M., Stauber, J.L., Markich, S.J., and Lim, R.P., 2000, pH-dependent toxicity of copper and uranium to a tropical freshwater alga (Chlorella sp.): Aquatic Toxicology, v. 48 , no. $2-3$, p. $275-289$.

Fruchter, J.S., Robertson, D.E., Evans, J.C., and others, 1980, Mount St. Helens ash from the 18 May 1980 eruptionChemical, physical, mineralogical, and biological properties: Science, v. 29, p. 1116-1125.

Garnier-Laplace, J., Della-Vedova, C., Gilbin, R., Copplestone, D., Hingston, J., and Ciffroy, P., 2006, First derivation of predicted-no-effect values for freshwater and terrestrial ecosystems exposed to radioactive substances: Environmental Science \& Technology, v. 40, no. 20, p. 6498-6505.

Garten, C.T., 1978, A review of parameter values used to assess the transport of plutonium, uranium, and thorium in terrestrial food chains: Environmental Research, v. 17, no. 3, p. 437-452.

Gascoyne, M., 1992, Geochemistry of the actinides and their daughters, in Ivanovich, M., and Harmon, R.S., eds., Uranium-series disequilibrium-Applications to earth, marine and environmental sciences ( $2 \mathrm{~d}$ ed.): Oxford, Clarendon Press, p. 34-61.
Gilbin, R., Alonzo, F., and Garnier-Laplace, J., 2008, Effects of chronic external gamma irradiation on growth and reproductive success of Daphnia magna: Journal of Environmental Radioactivity, v. 99 , no. 1, p. 134-145.

Gray, H.B., Stiefel, E.I., Valentine, J.S., and Bertini, I., eds., 2006, Biological inorganic chemistry-Structure and reactivity: Herndon, Vir., University Science Books, 739 p.

Gunther, A., Berhard, G., Geipel, G., Rossberg, A., and Reich, T., 2002, Uranium speciation in plants, in Merkel, B.J., Planer-Friedrich, B., and Wolkersdorfer, C., eds., Uranium in the aquatic environment-Proceedings of the 3rd International Conference on Uranium Mining and Hydrogeology and the International Mine Water Association Symposium, September 15-21, 2002: Freiberg, Germany, SpringerVerlag, p. 517-524.

Hameed, P.S., Shaheed, K., and Somasundaram, S.S.N., 1997, A study on distribution of natural radionuclide polonium-210 in a pond ecosystem: Journal of Biosciences, v. 22 , no. 5 , p. 627-634.

Hamilton, S.J., 1995, Hazard assessment of inorganics to three endangered fish in the Green River, Utah: Ecotoxicology and Environmental Safety, v. 30, no. 2, p. 134-142.

Hamilton, S.J., and Buhl, K.J., 1997, Hazard evaluation of inorganics, singly and in mixtures, to flannelmouth sucker Catostomus latipinnisin the San Juan River, New Mexico: Ecotoxicology and Environmental Safety, v. 38, no. 3, p. 296-308.

Haridasan, P.P., Paul, A.C., and Desai, M.V.M., 2001, Natural radionuclides in the aquatic environment of a phosphogypsum disposal area: Journal of Environmental Radioactivity, v. 53, no. 2, p. 155-165.

Harrison, F.L., and Anderson, S.L., 1994, Effects of acute irradiation on reproductive success of the polychaete worm, Neanthes arenaceodentata: Radiation Research, v. 137, no. 1, p. 59-66.

Hartman, H.L., and Mutmansky, J.M., 2002, Introductory Mining Engineering (2d ed.): New York, Wiley \& Sons, Inc., $584 \mathrm{p}$.

Hassler, C.S., Chafin, R.D., Klinger, M.B., and Twiss, M.R., 2007, Application of the Biotic Ligand Model to explain potassium interaction with thallium uptake and toxicity to plankton: Environmental Toxicology and Chemistry, v. 26, no. 6, p. 1139-1145.

Hem, J.D., 1992, Study and interpretation of the chemical characteristics of natural water ( $3 \mathrm{~d}$ ed.): U.S. Geological Survey Water-Supply Paper 2254, 263 p. 
Hertel-Aas, T., Oughton, D.H., Jaworska, A., Bjerke, H., Salbu, B., and Brunborg, G., 2007, Effects of chronic gamma irradiation on reproduction in the earthworm Eisenia fetida (Oligochaeta): Radiation Research, v. 168, no. 5 , p. $515-526$.

Higley, K.A., and Bytwerk, D.P., 2007, Generic approaches to transfer: Journal of Environmental Radioactivity, v. 98, no. $1-2$, p. 4-23.

Higley, K.A., Domotor, S.L., Antonio, E.J., and Kocher, D.C., 2003, Derivation of a screening methodology for evaluating radiation dose to aquatic and terrestrial biota: Journal of Environmental Radioactivity, v. 66, no. 1-2, p. 41-59.

Hinck, J.E., Blazer, V.B., Denslow, N.D., Echols, K.E., Gross, T.S., May, T.W., Anderson, P.J., Coyle, J.J., and Tillitt, D.E., 2008, Chemical contaminants, health indicators, and reproductive biomarker responses in fish from the Colorado River and its tributaries: Science of the Total Environment, v. 378 , p. $376-402$.

Hogan, A.C., van Dam, R.A., Markich, S.J., and Camilleri, C., 2005, Chronic toxicity of uranium to a tropical green alga (Chlorella sp.) in natural waters and the influence of dissolved organic carbon: Aquatic Toxicology, v. 75, no. 4, p. 343-353.

Holdway, D.A., 1992, Uranium toxicity to two species of Australian tropical fish, in Batley, G.E., ed., Trace metals in the aquatic environment: Shannon, Ireland, Elsevier Science, p. $137-158$.

Hopkins, R.T., Fox, J.P., Campbell, W.L., and Antweiler, J.C., 1984, Analytical results and sample locality map of stream sediment, panned-concentrate, soil, and rock samples from the Kanab Creek (B3060) Roadless Area, Coconino and Mohave Counties, Arizona: U.S. Geological Survey OpenFile Report 84-291, 16 p., 1 plate, scale 1:48,000.

Horne, J.D., Swirsky, M.A., Hollister, T.A., Oblad, B.R., and Kennedy, J.H., 1983, Aquatic toxicity studies of five priority pollutants-Final report: Nuclear Utility Services Corporation Report no. 4398, U.S. Environmental Protection Agency Contract no. 68-01-6201, 196 p.

Houpert, P., Frelon, S., Monleau, M., Bussy, C., Chazel, V., and Paquet, F., 2007, Heterogeneous accumulation of uranium in the brain of rats: Radiation Protection Dosimetry, v. 27 , no. $1-4$, p. $86-89$.

Howard, B.J., Beresford, N.A., Barnett, C.L., and Fesenko, S., 2009, Quantifying the transfer of radionuclides to food products from domestic farm animals: Journal of Environmental Radioactivity, v. 100, no. 9, p. 767-773.

Huber, F., and Kirchmann, H., 1978, Biomethylation of Tl(1) compounds: Inorganica Chemica Acta, v. 29, p. L249-L250.
Huettermann, J., and Koehnlein, W., 1978, Effects of ionizing radiation on DNA, in Hüttermann, J., Köhnlein, W., Téoule, R., and Bertinchamps, A.J., eds., Effects of ionizing radiation on DNA-Physical, chemical and biological aspects: New York, Springer, p. 261-268.

Hyne, R.V., Padovan, A., Parry, D.L., and Renaud, S.M., 1993, Increased fecundity of the cladoceran Moinodaphnia macleayi on a diet supplemented with a green alga, and its use in uranium toxicity tests: Marine and Freshwater Research, v. 44, no. 3, p. 389-399.

Hyne, R.V., Rippon, G.D., and Ellender, G., 1992, pHDependent uranium toxicity to freshwater hydra: Science of The Total Environment, v. 125, p. 159-173.

Ibrahim, S.A., and Whicker, F.W., 1988, Comparative uptake of $\mathrm{U}$ and $\mathrm{Th}$ by native plants at a $\mathrm{U}$ production site: Health Physics, v. 54, no. 4, p. 413-419.

International Atomic Energy Agency, 1976, Effects of ionizing radiation on aquatic organisms and ecosystems: International Atomic Energy Agency Technical Report Series no. $172,131 \mathrm{p}$.

International Atomic Energy Agency, 1988, Assessing the impact of deep sea disposal of low level radioactive waste on living marine resources: International Atomic Energy Agency Technical Reports Series no. 288, 127 p.

International Atomic Energy Agency, 1992, Effects of ionizing radiation on plants and animals at levels implied by current radiation protection standards: International Atomic Energy Agency Technical Reports Series no. 332, 74 p.

International Atomic Energy Agency, 1997, Closeout of uranium mines and mills - A review of current practices: International Atomic Energy Agency IAEA-TECDOC-939, 105 p.

International Atomic Energy Agency, 2004, The long term stabilization of uranium mill tailings - Final report of a coordinated research project 2000-2004: International Atomic Energy Agency IAEA-TECDOC-140, 311 p.

International Atomic Energy Agency, 2009, Quantification of radionuclide transfer in terrestrial and freshwater environments for radiological assessments: International Atomic Energy Agency IAEA-TECDOC-1616, 616 p.

International Commission on Radiological Protection, 2007, The 2007 Recommendations of the International Commission on Radiological Protection: International Commission on Radiological Protection Publication 103, 332 p.

International Commission on Radiological Protection, 2009, Environmental protection-The concept and use of reference animals and plants: International Commission on Radiological Protection Publication 108, 242 p. 
Jacobsen, T., 1995, Acute toxicity of 16 water-soluble chemicals to the fungus Geotrichum candidum measured by reduction in glucose uptake: Toxicology in Vitro, v. 9, no. 2 , p. 169-173.

Jarvinen, A.W., and Ankley, G.T., 1999, Linkage of effects to tissue residues-Development of a comprehensive database for aquatic organisms exposed to inorganic and organic chemicals: Pensacola, Fla., Society of Environmental Toxicology and Chemistry Press, $358 \mathrm{p}$.

Jones, D., Domotor, S., Higley, K., Kocher, D., and Bilyard, G., 2003, Principles and issues in radiological ecological risk assessment: Journal of Environmental Radioactivity, v. 66 , no. $1-2$, p. $19-39$.

Jones, K.C., Lepp, N.W., and Obbard, J.P., 1990, Other metals and metalloids, in Alloway, B.J., ed., Heavy metals in soils: New York, Blackie/John Wiley \& Sons, Inc., p. 280-321.

Kabata-Pendias, A., 2001, Trace elements in soils and plants (3d ed.): Boca Raton, Fla., CRC Press, 432 p.

Kabata-Pendias, A., and Pendias, H., 1984, Trace elements in soils and plants: Boca Raton, Fla., CRC Press, Inc, 315 p.

Khangarot, B.S., 1991, Toxicity of metals to a freshwater tubificid worm, Tubifex tubifex (Muller): Bulletin of Environmental Contamination and Toxicology, v. 46, no. 6, p. 906-912.

Kimball, G., 1978, The effects of lesser known metals and one organic to fathead minnows (Pimephales promelas) and Daphnia magna: Minneapolis, Minn., University of Minnesota, Department of Entomology, Fish and Wildlife, 88 p.

Knie, J., Haelke, A., Juhnke, I., and Schiller, W., 1983, Results of studies on chemical substances with four biotests:

Deutsche Gewasserkundliche Mitteilungen. Koblenz, v. 27, no. 3, p. 77-79.

Knowles, I.F., 2003, Experimental long-term exposures of fish to low dose rate gamma or alpha radiation, in Protection of the Environment from the Effects of Ionizing RadiationProceedings of an International Conference, Stockholm, 6-10 October 2003, CD-ROM: International Atomic Energy Agency, Paper no. IAEA-CN-109/116.

Kuhne, W.W., Caldwell, C.A., Gould, W.R., Fresquez, P.R., and Finger, S., 2002, Effects of depleted uranium on the health and survival of Ceriodaphnia dubia and Hyalella azteca: Environmental Toxicology and Chemistry, v. 21, no. 10 , p. 2198-2203.

Kundt, M.S., Martinez-Taibo, C., Muhlmann, M.C., and Furnari, J.C., 2009, Uranium in drinking water-Effects on mouse oocyte quality: Health Physics, v. 96, no. 5, p. $568-574$.
Kwan, K.H.M., and Smith, S., 1988, The effect of thallium on the growth of Lemna minor and plant tissue concentrations in relation to both exposure and toxicity: Environmental Pollution, v. 52, no. 3, p. 203-219.

Labrot, F., Narbonne, J.F., Ville, P., Saint Denis, M., and Ribera, D., 1999, Acute toxicity, toxicokinetics, and tissue target of lead and uranium in the clam Corbicula fluminea and the worm Eisenia fetida - Comparison with the fish Brachydanio rerio: Archives of Environmental Contamination and Toxicology, v. 36, no. 2, p. 167-178.

Labrot, F., Ribera, D., SaintDenis, M., and Narbonne, J.F., 1996, In vitro and in vivo studies of potential biomarkers of lead and uranium contamination-Lipid peroxidation, acetylcholinesterase, catalase and glutathione peroxidase activities in three non-mammalian species: Biomarkers, v. 1, no. 1, p. 21-28.

LaFlamme, B.D., and Murray, J.W., 1987, Solid/solution interaction-The effect of carbonate alkalinity on adsorbed thorium: Geochimica Cosmochimica Acta, v. 51, no. 2 , p. $243-250$.

Lagauzere, S., Boyer, P., Stora, G., and Bonzom, J.M., 2009a, Effects of uranium-contaminated sediments on the bioturbation activity of Chironomus riparius larvae (Insecta, Diptera) and Tubifex tubifex worms (Annelida, Tubificidae): Chemosphere, v. 76, no. 3, p. 324-334.

Lagauzere, S., Terrail, R., and Bonzom, J.-M., 2009b, Ecotoxicity of uranium to Tubifex tubifex worms (Annelida, Clitellata, Tubificidae) exposed to contaminated sediment: Ecotoxicology and Environmental Safety, v. 72, no. 2, p. 527-537.

Lan, C.-H., and Lin, T.-S., 2005, Acute toxicity of trivalent thallium compounds to Daphnia magna: Ecotoxicology and Environmental Safety, v. 61, no. 3, p. 432-435.

LeBlanc, G.A., and Dean, J.W., 1984, Antimony and thallium toxicity to embryos and larvae of fathead minnows (Pimephales promelas): Bulletin of Environmental Contamination and Toxicology, v. 32, no. 1, p. 565-569.

Leclerc, E., Tagami, K., Uchida, S., and Varga, B., 2009, Use of analogues, in Quantification of radionuclide transfer in terrestrial and freshwater environments for radiological assessments: International Atomic Energy Agency IAEA-TECDOC-1616, p. 605-614.

Le Francois, N.R., Blier, P.U., Adambounou, L.T., and Lacroix, M., 1999, Exposures to low-level ionizing radiation-Effects on biochemical and whole-body indices of growth in juvenile brook charr (Salvelinus fontinalis): Journal of Experimental Zoology, v. 283, no. 3, p. 315-325. 
Lepper, P., 2005, Manual on the methodological framework to derive environmental quality standards for priority substances in accordance with Article 16 of the Water Framework Directive (2000/60/EC): Schmallenberg, Germany, Fraunhofer-Institute Molecular Biology and Applied Ecology, 51 p.

Lerebours, A., Gonzalez, P., Adam, C., Camilleri, V., Bourdineaud, J.-P., and Garnier-Laplace, J., 2009, Comparative analysis of gene expression in brain, liver, skeletal muscles, and gills of zebrafish (Danio rerio) exposed to environmentally relevant waterborne uranium concentrations: Environmental Toxicology and Chemistry, v. 28, no. 6 , p. 1271-1278.

Leslie, B.W., Pickett, D.A., and Pearcy, E.C., 1999, Vegetation-derived insights on the mobilization and potential transport of radionuclides from the Nopal I natural analog site, Mexico, in Wronkiewicz, D.J., and Lee, J.H., eds., Scientific Basis for Nuclear Waste Management XXII. Materials Research Society Symposium Proceedings 556: Warrendale, Pa., Materials Research Society, p. 833-842

Li, X., and Thornton, I., 1993, Multi-element contamination of soils and plants in old mining areas, U.K.: Applied Geochemistry, v. 8, supplement 2, p. 51-56.

Liber, K., and Sobey, S., 1999, Toxicity of uranium, nickel, and arsenic to Hyalella azteca in spiked-sediment toxicity tests [abs.], in Baddaloo, E.G., Mah-Paulson, M.H., Verbeek, A.G., and Niimi, A.J., eds., Proceedings of the 26th Annual Aquatic Toxicity Workshop, Edmonton, Alberta, Canada, October 4-6, 1999: Canadian Technical Report of Fisheries and Aquatic Sciences 2293, p. 107.

Lilius, H., Hästbacka, T., and Isomaa, B., 1995, A comparison of the toxicity of 30 reference chemicals to Daphnia magna and Daphnia pulex: Environmental Toxicology and Chemistry, v. 14 , no. 12 , p. 2085-2088.

Luckey, T.D., 1991, Radiation hormesis: Boca Raton, Fla., CRC Press, 320 p.

Ludwig, J.A., Wilcox, B.P., Breshears, D.D., Tongway, D.J., and Imeson, A.C., 2005, Vegetation patches and runofferosion as interacting ecohydrological processes in semiarid landscapes: Ecology, v. 86, no. 2, p. 288-297.

Ludwig, J.T., Freudenberger, D., Noble, J., and Hodgkinson, K., eds., 1997, Landscape ecology_-Function and management. Principles from Australia's rangelands: Collingwood, Australia, CSIRO, 158 p.

Macdonald, C.R., and Laverock, M.J., 1998, Radiation exposure and dose to small mammals in radon-rich soils: Archives of Environmental Contamination and Toxicology, v. 35 , no. 1 , p. 109-120.

Mackin, J.H., and Schmidt, D.L., 1957, Uranium and thoriumbearing minerals in placer deposits in Idaho: Idaho Bureau of Mines and Geology Mineral Resources Report no. 7, 9 p.
Mahon, D.C., 1982, Uptake and translocation of naturallyoccurring radionuclides of the uranium series: Bulletin of Environmental Contamination and Toxicology, v. 29, no. 6, p. 697-703.

Markich, S.J., 2002, Uranium speciation and bioavailability in aquatic systems-An overview: Scientific World Journal, v. 2, p. 707-729.

Markich, S.J., 2003, Influence of body size and gender on valve movement responses of a freshwater bivalve to uranium: Environmental Toxicology, v. 18, no. 2, p. 126-136.

Markich, S.J., Brown, P.L., Jeffree, R.A., and Lim, R.P., 2000, Valve movement responses of Velesunio angasi (Bivalvia: Hyriidae) to manganese and uranium-An exception to the free ion activity model: Aquatic Toxicology, v. 51, no. 2, p. $155-175$.

Marques, S.M., Gonçalves, F., and Pereira, R., 2008, Effects of a uranium mine effluent in the early-life stages of Rana perezi Seoane: Science of the Total Environment, v. 402, no. 1, p. 29-35.

Martin, J.E., 2006, Physics for radiation protection: A handbook (2d ed.): New York, Wiley-VCH, 844 p.

Meyer, J.S., Adams, W.J., Brix, K.V., Luoma, S.N., Mount, D.R., Stubblefield, W.A., and Wood, C.M., eds., 2005, Toxicity of dietborne metals to aquatic organisms: Pensacola, Fla., Society of Environmental Toxicology and Chemistry Press, 303 p.

Meyer, J.S., Clearwater, S.J., Doser, T.A., Rogaczewski, M.J., and Hansen, J.A., eds., 2007, Effects of water chemistry on bioavailability and toxicity of waterborne cadmium, copper, nickel, lead, and zinc to freshwater organisms: Pensacola, Fla., Society of Environmental Toxicology and Chemistry Press, $352 \mathrm{p}$.

Meyer, M., McLendon, T., Price, D., Fleckenstein, J., and Schnug, E., 2004, Uptake of munitions-derived depleted uranium by three grass species: Journal of Plant Nutrition, v. 27 , no. 8 , p. $1415-1429$.

Meyer, M.C., Paschke, M.W., McLendon, T., and Price, D., 1998, Decreases in soil microbial function and functional diversity in response to depleted uranium: Journal of Environmental Quality, v. 27, no. 6, p. 1306-1311.

Mihok, S., 2003, Suitability of individual biological effects benchmarks for the protection of wild populations of mammals, in Protection of the Environment from the Effects of Ionizing Radiation-Proceedings of an International Conference, Stockholm, 6-10 October 2003, CD-ROM: International Atomic Energy Agency, Paper no. IAEA-CN-109/87. 
Mitchell, S.E., Caldwell, C.A., Gonzales, G., Gould, W.R., and Arimoto, R., 2005, Effects of depleted uranium on survival, growth, and metamorphosis in the African clawed frog: Journal of Toxicology and Environmental Health, Part A, v. 68, no. 11-12, p. 951-965.

Mkandawire, M., Taubert, B., and Dudel, E.G., 2005, Resource manipulation in uranium and arsenic attenuation by Lemna gibba L. (duckweed) in tailing water of a former uranium mine: Water, Air, and Soil Pollution, v. 166, no. $1-4$, p. $83-101$.

Mkandawire, M., Vogel, K., Taubert, B., and Dudel, E.G., 2007, Phosphate regulates uranium (VI) toxicity to Lemna gibba L. G3: Environmental Toxicology and Chemistry, v. 22, no. 1, p. 9-16.

Moon, C., Wateley, M., and Evans, A.M., eds., 2006, Introduction to Mineral Exploration (2d ed.): New York, WileyBlackwell, $496 \mathrm{p}$.

Murphy, R.J., Lenhart, J.J., and Honeyman, B.D., 1999, The sorption of thorium (IV) and uranium (VI) to hematite in the presence of natural organic matter: Colloids and Surfaces A-Physicochemical and Engineering Aspects, v. 157, no. $1-3$, p. 47-62.

Murthy, T.C.S., Weinberger, P., and Measures, M.P., 1984, Uranium effects on the growth of soybean (Glycine max (L.) Merr.): Bulletin of Environmental Contamination and Toxicology, v. 32, no. 1, p. 580-586.

Muscatello, J., and Liber, K., 2009, Accumulation and chronic toxicity of uranium over different life stages of the aquatic invertebrate Chironomus tentans: Archives of Environmental Contamination and Toxicology, v. 57, no. 3, p. 531-539.

National Council on Radiation Protection and Measurements, 1987, Exposure of the population in the United States and Canada from natural background radiation: Betheseda, Md., National Council on Radiation Protection and Measurements report no. 094, 209 p.

National Council on Radiation Protection and Measurements, 1991, Effects of ionizing radiation on aquatic organisms: Bethesda, Md., National Council on Radiation Protection and Measurements report no. 109, 115 p.

National Research Council, 1988, Health risks of radon and other internally deposited alpha-emitters-BEIR IV: Report of the Committee on the Biological Effects of Ionizing Radiations, Washington, D.C., National Academy Press, $624 \mathrm{p}$.

National Research Council , 2005, Mineral tolerances of animals ( $2 \mathrm{~d}$ ed.): Report of the Committee on Minerals and Toxic Substances in Diets and Water for Animals, Washington, D.C., National Academies Press, 510 p.
Nordberg, G., Fowler, B., Nordberg, M., and Friberg, L., 2007, Handbook on the toxicology of metals: New York, Academic Press, $1024 \mathrm{p}$.

Ohlendorf, H.M., 2003, Ecotoxicology of selenium, in Hoffman, D.J., Rattner, B.A., Burton, G.A., Jr., and Cairns, J., Jr., eds., Handbook of ecotoxicology: Boca Raton, Fla., Lewis Publishers, p. 465-500.

Oliver, J., and Smith, P., 1930, Experimental nephritis in the frog- - I. The anatomical evidence of damage: Journal of Experimental Medicine, v. 52, no. 2, p. 181-193.

Olofsson, U., and Allard, B., 1983, Complexes of actinides with naturally occuring organic substances-Literature survey: Stockholm, Svensk Kärnbränsleförsörjning, Avdeling KBS, SKBF/KBS Teknisk Rapport 83-09, 34 p.

Orlandini, K.A., Penrose, W.R., Harvey, B.R., Lovett, M.B., and Findlay, M.W., 1990, Colloidal behavior of actinides in an oligotrophic lake: Environmental Science and Technology, v. 24, no. 5, p. 706-712.

Pamphlett, R., Danscher, G., Rungby, J., and Stoltenbergy, M., 2000, Tissue uptake of bismuth from shotgun pellets: Environmental Research, v. 82, no. 3, p. 258-262.

Paquin, P.R., Santore, R.C., Farley, K., Di Toro, D.M., Wu, K.B., Mooney, K.G., and Winfield, R.P., eds., 2003, Metals in aquatic systems - A review of exposure, bioaccumulation, and toxicity models: Pensacola, Fla., Society of Environmental Toxicology and Chemistry Press, $160 \mathrm{p}$.

Parkhurst, B.R., Elder, R.G., Meyer, J.S., Sanchez, D.A., Pennak, R.W., and Waller, W.T., 1984, An environmental hazard evaluation of uranium in a Rocky Mountain stream: Environmental Toxicology and Chemistry, v. 3, no. 1, p. 113-124.

Pawlik, T.M., and Keyomarsi, K., 2004, Role of cell cycle in mediating sensitivity to radiotherapy: International Journal of Radiation Oncology*Biology*Physics, v. 59, no. 4, p. $928-942$.

Peter, A.L.J., and Viraraghavan, T., 2005, Thallium-A review of public health and environmental concerns: Environment International, v. 31, no. 4, p. 493-501.

Peterson, K.L., 1994, Modern and Pleistocene climatic patterns in the west, in Harper, K., Clair, L.L.S., Thorne, K.H., and Hess, W.M., eds., Natural history of the Colorado Plateau and Great Basin: Niwot, Colo., University Press of Colorado, p. 27-54.

Peterson, J., MacDonell, M., Haroun, L., and Monette, F., 2005, Radiological and chemical fact sheets to support health risk analyses for contaminated areas: Argonne National Laboratory, Environmental Science Division, $133 \mathrm{p}$. 
Pettersson, H.B.L., Hancock, G., Johnston, A., and Murray, A.S., 1993, Uptake of uranium and thorium series radionuclides by the waterlily, Nymphaea violacea: Journal of Environmental Radioactivity, v. 19, no. 2, p. 85-108.

Pickett, J.B., Specht, W.L., and Keyes, J.L., 1993, Acute and chronic toxicity of uranium compounds to CeriodaphniaDaphnia dubia: Westinghouse Savannah River Company WSRC-RP-92-995, U.S. Department of Energy Contract no. DE-AC09-89SR18035, 403 p.

Piestrzynski, A., Pieczonka, J., Brachanski, B., Grabas, K., and Koszela, J., 2000, Impact of uranium mining on the local environment - Lower Silesia Poland, in International Conference on Mine Remediation, Schlema, Germany, July 11-14, 2000, Proceedings: Chemnitz, Germany, Wismut, p. 1-8.

Pietrzak-Flis, Z., and Skowroska-Smolak, M., 1995, Transfer of $210 \mathrm{~Pb}$ and $210 \mathrm{Po}$ to plants via root system and aboveground interception: Science of The Total Environment, v. 162 , no. $2-3$, p. $139-147$.

Poston, T.M., 1982, Observations on the bioaccumulation potential of thorium and uranium in rainbow trout (Salmo gairdneri): Bulletin of Environmental Contamination and Toxicology, v. 28, no. 6, p. 682-690.

Poston, T.M., Hanf, R., and Simmons, M.A., 1984, Toxicity of uranium to Daphnia magna: Water, Air and Soil Pollution, v. 22, no. 3, p. 289-298.

Pröhl, G., 2009, Interception of dry and wet deposited radionuclides by vegetation: Journal of Environmental Radioactivity, v. 100, no. 9, p. 675-682.

Pyle, G.G., and Clulow, F.V., 1998, Radionuclide equilibria between the aquatic environment and fish tissues: Journal of Environmental Radioactivity, v. 40, no. 1, p. 59-74.

Radtke, D., Kepner, W., and Effertz, R., 1988, Reconnaissance investigation of water quality, bottom sediment, and biota associated with irrigation drainage in the lower Colorado River valley, Arizona, California, and Nevada, 1986-87: U.S. Geological Survey Water-Resources Investigation Report 88-4002, 77 p.

Ralph, L., and Twiss, M.R., 2002, Comparative toxicity of thallium(I), thallium(III), and cadmium(II) to the unicellular Alga chlorella isolated from Lake Erie: Bulletin of Environmental Contamination and Toxicology, v. 68, no. 2, p. 261-268.

Rayno, D.R., 1983, Estimated dose to man from uranium milling via the beef/milk food-chain pathway: Science of the Total Environment, v. 31, p. 219-241.
Ribera, D., Labrot, F., Tisnerat, G., and Narbonne, J.F., 1996, Uranium in the environment-Occurrence, transfer and biological effects, in Ware, G.W., ed., Reviews of Environmental Contamination and Toxicology, v. 146.: New York, Springer-Verlag, p. 53-83.

Riethmuller, N., Markich, S.J., Van dam, R.A., and Parry, D., 2001, Effects of water hardness and alkalinity on the toxicity of uranium to a tropical freshwater hydra (Hydra viridissima): Biomarkers, v. 6, no. 1, p. 45-51.

Riley, P.A., 1994, Free radicals in biology_Oxidative stress and the effects of ionizing radiation: International Journal of Radiation Biology, v. 65, no. 1, p. 27-33.

Roh, Y., Lee, S.R., Choi, S.K., Elless, M.P., and Lee, S.Y., 2000, Physicochemical and mineralogical characterization of uranium-contaminated soils: Soil \& Sediment Contamination, v. 9, no. 5, p. 463-486.

Rose, K.S.B., 1992, Lower limits of radiosensitivity in organisms, excluding man: Journal of Environmental Radioactivity, v. 15, no. 2, p. 113-133.

Ross, S.M., 1994, Toxic metals in soil-plant systems: West Sussex, England, John Wiley \& Sons, Ltd., 469 p.

Rufyikiri, G., Huysmans, L., Wannijn, J., Van Hees, M., Leyval, C., and Jakobsen, I., 2004, Arbuscular mycorrhizal fungi can decrease the uptake of uranium by subterranean clover grown at high levels of uranium in soil: Environmental Pollution, v. 130, no. 3, p. 427-436.

Salbu, B., Lind, O.C., and Skipperud, L., 2004, Radionuclide speciation and its relevance in environmental impact assessments: Journal of Environmental Radioactivity, v. 74, no. 1-3, p. 233-242.

Salbu, B., and Skipperud, L., 2009, Speciation of radionuclides in the environment: Journal of Environmental Radioactivity, v. 100 , no. 4 , p. $281-282$.

Sample, B.E., Aplin, M.S., Efroymson, R.A., Suter II, G.W., and Welsh, C.J.E., 1997, Methods and tools for estimation of the exposure of terrestrial wildlife to contaminants: Oak Ridge National Laboratory, Environmental Sciences Division Publication no. 4650, U.S. Department of Energy ORNL/TM-13391, [variously paged].

Sazykina, T.G., 2005, A system of dose-effects relationships for the northern wildlife-Radiation protection criteria: Radioprotection, v. 40, no. Supplement 1, p. S889-S892.

Scholze, M., Boedeker, W., Faust, M., Backhaus, T., Altenburger, R., and Horst Grimme, L., 2001, A general best-fit method for concentration-response curves and the estimation of low-effect concentrations: Environmental Toxicology and Chemistry, v. 20, no. 2, p. 448-457. 
Selinus, O., Alloway, B.J., Centeno, J.A., Finkelman, R.B., Fuge, R., Lindh, U., and Smedley, P., 2005, Essentials of medical geology - Impacts of the natural environment on public health: Burlington, Mass., Elsevier Academic Press, $812 \mathrm{p}$.

Semaan, M., Holdway, D.A., and Van Dam, R.A., 2001, Comparative sensitivity of three populations of the cladoceran Moinodaphnia macleayi to acute and chronic uranium exposure: Environmental Toxicology, v. 16, no. 5, p. 365-376.

Senesi, N., Polemio, M., and Lorusso, L., 1979, Content and distribution of As, $\mathrm{Li}, \mathrm{Bi}$ and $\mathrm{Se}$ in mineral and synthetic fertilizers and their contribution to soil: Communications in Soil Science and Plant Analysis, v. 10, no. 8, p. 1109-1126.

Shackelford, R.E., Kaufman, W.K., and Paules, R.S., 1999, Cell cycle control, checkpoint mechanisms, and genotoxic stress: Environmental Health Perspectives, v. 107, supplement 1, p. 5-24.

Sheppard, M.I., Thibault, D.H., and Sheppard, S.C., 1985, Concentrations and concentration ratios of $\mathrm{U}, \mathrm{As}$ and $\mathrm{Co}$ in Scots Pine grown in a waste-site soil and an experimentally contaminated soil: Water, Air, and Soil Pollution, v. 26, no. 1, p. 85-94.

Sheppard, M.I., Vandergraaf, T.T., Thibault, D.H., and Reid, J.A.K., 1983, Technetium and uranium-Sorption by and plant uptake from peat and sand: Health Physics, v. 44, no. 6 , p. 635-643.

Sheppard, S.C., and Evenden, W.G., 1992, Bioavailability indexes for uranium-Effect of concentration in 11 soils: Archives of Environmental Contamination and Toxicology, v. 23, no. 1, p. 117-124.

Sheppard, S.C., Sheppard, M.I., Gallerand, M.-O., and Sanipelli, B., 2005, Derivation of ecotoxicity thresholds for uranium: Journal of Environmental Radioactivity, v. 79, no. 1, p. 55-83.

Sheppard, S.C., Sheppard, M.I., Sanipelli, B., Dowsley, B., Stephenson, G., Feisthauer, N., Rowland, R., and Gilbertson, M.K., 2004, Uranium concentrations in Port Hope soils and vegetation and toxicological effect on soil organisms: Canadian Nuclear Safety Commission Contract Report 87055-01-0266-R161.1.

Skwarzec, B., Strumiska, D.I., Ulatowski, J., and Golebiowski, M., 2001, Determination and distribution of 210Po in tobacco plants from Poland: Journal of Radioanalytical and Nuclear Chemistry, v. 250, no. 2, p. 319-322.

Small, J.A., Bunn, A., McKinstry, C., Peacock, A., and Miracle, A.L., 2008, Investigating freshwater periphyton community response to uranium with phospholipid fatty acid and denaturing gradient gel electrophoresis analyses: Journal of Environmental Radioactivity, v. 99, no. 4, p. 730-738.
Smith, S., and Kwan, M.K.H., 1989, Use of aquatic macrophytes as a bioassay method to assess relative toxicity, uptake kinetics and accumulated forms of trace metals: Hydrobiologia, v. 188-189, no. 1, p. 345-351.

Smith, S.M., 1997, National Geochemical DatabaseReformatted data from the National Uranium Resource Evaluation (NURE) Hydrogeochemical and Stream Sediment Reconnaissance (HSSR) program: U.S. Geological Survey Open-File Report 97-492, [variously paged].

Sorensen, J.A., and Nelson, C.B., 2000, Translocation of Kanab ambersnails to establish a new population in Grand Canyon, Arizona: Arizona Game and Fish Department, Nongame and Endangered Wildlife Program Technical Report 153.

Staatz, M.H., 1972, Thorium-rich veins of Hall Mountain in northernmost Idaho: Economic Geology, v. 67, no. 2, p. $240-248$.

Stepnowski, P., and Skwarzec, B., 2000, Tissue and subcellular distributions of 210Po in the crustacean Saduria entomon inhabiting the southern Baltic Sea: Journal of Environmental Radioactivity, v. 49, no. 2, p. 195-199.

Stewart, B.D., 2008, The dominating influence of calcium on the biogeochemical fate of uranium: Palo Alto, Cali., Stanford University, $121 \mathrm{p}$.

Straczek, A., Wannijn, J., Van Hees, M., Thijs, H., and Thiry, Y., 2009, Tolerance of hairy roots of carrots to $U$ chronic exposure in a standardized in vitro device: Environmental and Experimental Botany, v. 65, no. 1, p. 82-89.

Strandberg, G.W., Shumate, S.E., II, and Parrott, J.R., Jr., 1981, Microbial cells as biosorbents for heavy metalsAccumulation of uranium by Saccharomyces cerevisiae and Pseudomonas aeruginosa: Applied and Environmental Microbiology, v. 41, no. 1, p. 237-245.

Suter, G.W., II, and Tsao, C.L., 1996, Toxicological benchmarks for screening potential contaminants of concern for effects on aquatic biota-1996 Revision: U.S. Department of Energy ES/ER/TM-96/R2, 151 p.

Swanson, S.M., 1985, Food-chain transfer of U-series radionuclides in a Northern Saskatchewan aquatic system: Health Physics, v. 49, no. 5, p. 747-770.

Syed, H.S., 1999, Comparison studies adsorption of thorium and uranium on pure clay minerals and local Malaysian soil sediments: Journal of Radioanalytical Nuclear Chemistry v. 241, no. 1 , p. 11-14. 
Tarzwell, C.M., and Henderson, C., 1956, The toxicity of some of the less common metals to fish, in Sanitary engineering aspects of the atomic energy industry — A seminar sponsored by the AEC and the Public Health Service, held at the Robert A. Taft Engineering Center, Cincinnati, Ohio, December 6-9, 1955: Oak Ridge, Tenn., Technical Information Service Extension, U.S. Atomic Energy Commission, U.S. Public Health Service, p. 286-289.

Thomas, P., and Gates, T., 1999, Radionuclides in the lichencaribou-human food chain near uranium mining operations in northern Saskatchewan, Canada: Environmental Health Perspectives, v. 107 , p. 527-537.

Thomas, P., and Liber, K., 2001, An estimation of radiation doses to benthic invertebrates from sediments collected near a Canadian uranium mine: Environment International, v. 27, no. 4 , p. 341-353.

Thomas, P.A., 2000, Radionuclides in the terrestrial ecosystem near a Canadian uranium mill-Part II. Small mammal food chains and bioavailability: Health Physics, v. 78, no. 6, p. 625-632.

Thompson, P., and Bird, G., 2003, Biological effects benchmarks for the protection of aquatic organisms against radiation in Protection of the Environment from the Effects of Ionizing Radiation-Proceedings of an International Conference, Stockholm, 6-10 October 2003, CD-ROM: International Atomic Energy Agency, Paper no. IAEA-CN-109/88.

Thompson, P.A., Macdonald, C.R., and Harrison, F., 2003, Recommended RBE weighting factor for the ecological risk assessment of alpha-emitting radionuclides, in Protection of the Environment from Ionising Radiation-The development and application of a system of radiation protection for the environment. Proceedings of the Third International Symposium, Darwin, Australia, 22-26 July 2002: International Atomic Energy Agency IAEA-CSP-17, p. 93-100.

Thompson, S.E., Burton, C.A., Quinn, D.J., and Ng, Y.C., 1972, Concentration factors of chemical elements in edible aquatic organisms: California University, Lawrence Livermore Laboratory UCRL--50564(Rev.1), 77 p.

Till, J.E., and Blaylock, B.G., 1976, The chemical and radiological toxicity of plutonium to developing embryos of fish: Radiation Research, v. 67, no. 3, p. 626-627.

Torstenfelt, B., 1986, Migration of the actinides, thorium, protactinium, uranium, neptunium, plutonium and americium in clay: Radiochemica Acta, v. 39, p. 105-112.

Tracy, B.L., Prantl, F.A., and Quinn, J.M., 1983, Transfer of 226Ra, $210 \mathrm{~Pb}$ and Uranium from soil to garden produceAssessment of risk: Health Physics, v. 44, no. 5, p. 469-477.

Tran, D., Massabuau, J.C., and Garnier-Laplace, J., 2008, Impact of hypoxia on hemolymph contamination by uranium in an aquatic animal, the freshwater clam Corbicula fluminea: Environmental Pollution, v. 156, no. 3, p. 821-826.
Turner, J.E., 2007, Atoms, radiation, and radiation protection (3d ed.): New York, Wiley-VCH, 606 p.

Twining, B.S., Twiss, M.R., and Fisher, N.S., 2003, Oxidation of thallium by Great Lakes plankton communities: Environmental Science and Technology, v. 37, no. 12, p. 2720-2726.

Underhill, P.T., 1996, Naturally occurring radioactive material: Delray Beach, Fla., St. Lucie Press, 145 p.

United Nations Scientific Committee on the Effects of Atomic Radiation, 1993, Sources and effects of ionizing radiationReport to the General Assembly, with scientific annexes: New York, United Nations, 922 p.

United Nations Scientific Committee on the Effects of Atomic Radiation, 1996, Scientific annex, in Sources and effects of ionizing radiation - Report to the General Assembly, with scientific annex: New York, United Nations, p. 5-86.

United Nations Scientific Committee on the Effects of Atomic Radiation, 2000, Sources and effects of ionizing radiationReport to the General Assembly, with scientific annexes. Volume 1, Sources: New York, United Nations.

United Nations Scientific Committee on the Effects of Atomic Radiation, 2008, Effects of ionizing radiation on non-human biota: United Nations General Assembly A/AC.82/R.672 Draft, $144 \mathrm{p}$.

U.S. Army Center for Health Promotion and Preventive Medicine, 2007, Wildlife toxicity assessment for thallium: U.S. Army Center for Health Promotion and Preventive Medicine, Health Effects Research Program, Environmental Risk Assessment Program, Project no. 39-EJ1138-01O, $19 \mathrm{p}$.

U.S. Department of Energy, 2002, A graded approach for evaluating radiation doses to aquatic and terrestrial biota: U.S. Department of Energy DOE-STD-1153-2002, 234 p.

U.S. Department of Energy, 2005, Biological assessment/ Screening level risk assessment/Biological opinionAppendix A of Remediation of the Moab uranium mill tailings, Grand and San Juan Counties, Utah-Final environmental impact statement: U.S. Department of Energy DOE/EIS-0355, p. A1-103. [Three sub-appendixes each with individual pagination.]

U.S. Environmental Protection Agency, 2005, Guidance for developing ecological soil screening levels - OSWER Directive 9285.7-55: Washington, D.C., U.S. Environmental Protection Agency, Office of Solid Waste and Emergency Response, $85 \mathrm{p}$. 
U.S. Environmental Protection Agency, 2008, Technologically enhanced naturally occurring radioactive materials from uranium mining. Volume 2-Investigation of potential health, geographic, and environmental issues of abandoned uranium mines: U.S. Environmental Protection Agency EPA 402-R-08-005.

Vandenhove, H., Gil-García, C., Rigol, A., and Vidal, M., 2009, New best estimates for radionuclide solid-liquid distribution coefficients in soils. Part 2. Naturally occurring radionuclides: Journal of Environmental Radioactivity, v. 100 , no. 9 , p. 697-703.

Van der Stricht, E., and Kirchmann, R., eds., 2001, Radioecology_Radioactivity and ecosystems: Saint-Paullez-Durance, France, International Union of Radioecology, $624 \mathrm{p}$.

Van Gosen, B.S., and Wenrich, K.J., 1989, Ground magnetometer surveys over known and suspected breccia pipes on the Coconino Plateau, northwestern Arizona: U.S. Geological Survey Bulletin 1683-C, 31 p.

Vincolli, J.W., 1996, Risk management for hazardous chemicals, v. 2: Boca Raton, Fla., CRC Press, p, 2677-2682.

Vinot, H., and Larpent, J.P., 1984, Water pollution by uranium ore treatment works: Hydrobiologia, v. 112, no. 2, p. 125-129.

Waite, D.T., Joshi, S.R., and Sommerstad, H., 1988, The effect of uranium mine tailings on radionuclide concentrations in Langley Bay, Saskatchewan, Canada: Archives of Environmental Contamination and Toxicology, v. 17, no. 3, p. 373-380.

Watson, A.P., Etnier, E.L., and McDowell-Boyer, L.M., 1984, Radium-226 in drinking water and terrestrial food chains: transfer parameters and normal exposure and dose: Nuclear Safety, v. 25, no. 6, p. 815-829.

Wenrich, K.J., 1985, Mineralization of breccia pipes in northern Arizona: Economic Geology, v. 80, no. 6, p. 1722-1735.

Whicker, F.W., and Schultz, V., 1982, Radioecology-Nuclear energy and the environment ( 2 v.): Boca Raton, Fla., CRC Press, $440 \mathrm{p}$.

Wilhm, J.L., 1970, Transfer of radioisotopes between detritus and benthic macroinvertebrates in laboratory microecosystems: Health Physics, v. 18, no. 3, p. 277-284.
Williams, P.L., and Dusenbery, D.B., 1990, Aquatic toxicity testing using the nematode, Caenorhabditis elegans: Environmental Toxicology and Chemistry, v. 9, no. 10, p. 1285-1290.

Wolff, S., 1998, The adaptive response in radiobiologyEvolving insights and implications: Environmental Health Perspectives, v. 106, supplement 1, p. 277-283.

Woodhead, D.S., 1984, Contamination due to radioactive materials, in Kinne, O., ed., Pollution and Protection of the seas-Radioactive materials, heavy metals and oil, pt. 3 of Marine Ecology (v. 5): New York, John Wiley and Sons, p. 1111-1287.

Woodhead, D., and Zinger, I., 2003, Radiation effects on plants and animals: Swedish Radiation Protection Authority, FASSET Deliverable 4, Contract no. FIGE-CT-2000-00102, $196 \mathrm{p}$.

World Health Organization, 1996, Thallium: Geneva, Switzerland, World Health Organization, International Programme on Chemical Safety, Environmental Health Criteria 182, $116 \mathrm{p}$.

Yankovich, T.L., 2009, Mass balance approach to estimating radionuclide loads and concentrations in edible fish tissues using stable analogues: Journal of Environmental Radioactivity, v. 100, p. 795-801.

Zach, R., Hawkins, J.L., and Sheppard, S.C., 1993, Effects of ionizing radiation on breeding swallows at current radiation protection standards: Environmental Toxicology and Chemistry, v. 12, no. 4, p. 779-786.

Zach, R., and Mayoh, K.R., 1986, Gamma irradiation of tree swallow embryos and subsequent growth and survival: The Condor, v. 88 , no. 1, p. 1-10.

Zhang, P.C., and Brady, P.V., 2002, Geochemistry of soil radionuclides: Madison, Wis., Soil Science Society of America, $252 \mathrm{p}$.

Zitko, V., Carson, W.V., and Carson, W.G., 1975, ThalliumOccurrence in the environment and toxicity to fish: Bulletin of Environmental Contamination and Toxicology, v. 13, no. 1, p. 23-30. 


\section{Appendix 1. ${ }^{235}$ Uranium and ${ }^{232}$ Thorium Decay Series}

[Decay series information taken from Peterson and others, 2005]

Table 1.1. Half-life for constituent elements of $235 \mathrm{U}$ decay series.

\begin{tabular}{lcc}
\hline Element & $\begin{array}{c}\text { Type of radiation released } \\
\text { in daughter formation }\end{array}$ & Half-life \\
\hline Uranium-235 & Alpha & $7.0 \times 10^{9}$ years \\
Thorium-231 & Beta & 26 hours \\
Protactinium-231 & Alpha & 33,000 years \\
Actinium-227 & Alpha & 22 years \\
Thorium-227 & Beta & 19 years \\
Francium-223 & Beta & 22 minutes \\
Radon-223 & Alpha & 11 days \\
Radon-219 & Alpha & 4.0 seconds \\
Polonium-215 & Beta & 1.8 milliseconds \\
Lead-211 & Beta & 36 minutes \\
Bismuth-211 & Alpha & 2.1 minutes \\
Thallium-207 & Beta & 4.8 minutes \\
Lead-207 & & Stable \\
\hline
\end{tabular}

Table 1.2. Half-life for constituent elements of ${ }^{232}$ Th decay series.

\begin{tabular}{lcl}
\hline Element & $\begin{array}{c}\text { Type of radiation released } \\
\text { in daughter formation }\end{array}$ & Half-life \\
\hline Thorium-232 & Alpha & $1.405 \times 10^{10}$ years \\
Radium-228 & Beta & 6.7 years \\
Actinium-228 & Beta & 6.13 hours \\
Thorium-228 & Alpha & 1.91 years \\
Radium-224 & Alpha & 3.64 days \\
Radon-220 & Alpha & 55 seconds \\
Polonium-216 & Alpha & 0.15 seconds \\
Lead-212 & Beta & 10.64 hours \\
Bismuth-212 & Alpha & 60.6 minutes \\
Polonium-212 & Beta & 304 nanoseconds \\
Thallium-208 & Alpha & 3.1 minutes \\
Lead-208 & & Stable \\
\hline
\end{tabular}





\section{Appendix 2. Radiation Measurement}

This appendix briefly describes terms related to radiation exposure and dose, as a means to provide the reader with a background for interpreting the numeric values used to characterize radiation effects discussed in this report. For more in depth descriptions of the concepts and terms used to measure radiation (especially as related to exposure) and the total absorbed dose received by a receptor, see Blaylock and others (1993), Brechignac and Desmet (2005), and Turner (2007).

Not unlike other units of measure, units of measurement for radiation have been standardized by the International System of Units (SI), which can trace its lineage to the metric system. A second set of units of measurements, however, are commonly encountered in the United States and serve as a "conventional system" that remains in wide use today throughout the country.

Depending on the properties of radiation being characterized, different units of measure are applied. For characterizing exposure, the amount of radiation being emitted by a radioactive source is measured by the curie $(\mathrm{Ci})$ in the conventional system or by the becquerel (Bq) in SI units. Because of an excess of energy and stability, energy is released from radioactive elements primarily in the form of alpha particles, beta particles, or gamma rays. The units $\mathrm{Ci}$ or $\mathrm{Bq}$ express the number of disintegrations of these radioactive atoms during an interval of time. One Ci equals 37 billion $\left(3.7 \times 10^{10}\right)$ disintegrations per second; one $\mathrm{Bq}$ equals one disintegration per second; hence, one Ci equals 37 billion $\left(3.7 \times 10^{10}\right) \mathrm{Bq}$. Standard prefixes common in scientific nomenclature are applied to alter the quantity expressed by the base units (for example, $\mathrm{mCi}=0.001 \mathrm{Ci}$; $\mathrm{kBq}=1,000 \mathrm{~Bq}$ ).

Radiation dose refers to the energy absorbed per mass of biological tissues (for example, joules per kilogram, $\mathrm{J} / \mathrm{kg}$ ) from radioactive decay. Following conventional nomenclature, radiation dose is measured by the rad, which stands for radiation absorbed dose; the SI unit is the gray (Gy). The rad is a unit of absorbed dose for any ionizing radiation and equals $100 \mathrm{ergs}$ absorbed per gram of material, or $0.01 \mathrm{~J} / \mathrm{kg} ; 1$ Gy equals $100 \mathrm{rad}$, or $1 \mathrm{~J} / \mathrm{kg}$. In the United States, radiation exposures were historically measured in roentgens/hour $(\mathrm{R} / \mathrm{h})$; the roentgen is equivalent to $2.58 \times 10^{-4}$ coulomb $/ \mathrm{kg}(\mathrm{C} / \mathrm{kg})$ in air in SI units. For water and soft tissues the absorbed dose per roentgen is between 0.93 and $0.98 \mathrm{rad}$; hence, the roentgen and rad are nearly equivalent numerically. Regardless of the units being used to characterize absorbed dose, the amount of energy intercepted by the receptor is expressed per unit of weight.

Roentgens were initially developed to address issues related to human radiation safety, particularly those risks associated with exposure to $\mathrm{x}$-rays or gamma rays, and the derivative unit for radiation dose in humans was the roentgen equivalent in man, or rem. A rem is the product of the absorbed dose in roentgens $(\mathrm{R})$ and the biological efficiency or dose equivalent (DE) of the radiation. DE may be regarded as an expression of dose in terms of its biological effect, which accounts for the variation in absorbed dose of radiation for different forms of radiation (for example, alpha, beta, or gamma). More specifically, each form of radiation is characterized by different energies; hence, each form of radiation may give rise to a greater biological effect at the same absorbed dose based on the Quality Factor (Q) characteristic of that type of radiation:

$$
\mathrm{DE}=\text { Absorbed Dose } \times \text { Quality Factor }(\mathrm{Q})
$$

where

and

$\mathrm{Q}=1$ for gamma, $\mathrm{x}$-ray, and beta radiation,

$$
\mathrm{Q}=10 \quad \text { for alpha radiation. }
$$

Adverse effects associated with absorbed dose, then, vary as a function of $\mathrm{Q}$, which is related to the energy loss of radiation per unit path length, or its linear energy transfer (LET). Generally, the greater the LET in tissue, the greater the biological effect (adverse). The SI equivalent of the rem is the sievert $(\mathrm{Sv})$, where $1 \mathrm{~Sv}=100 \mathrm{rem}$ when a radiation weighting factor finds $1 \mathrm{rem}=1.07185 \mathrm{R}$. The official units for radiation measurement are the SI units: the gray (Gy) for absorbed dose and the sievert (Sv) for equivalent dose.

Table 2.1. Equivalent units of radiation measurement.

\begin{tabular}{llll}
\hline & $\begin{array}{c}\text { International } \\
\text { System } \\
\text { (SI) }\end{array}$ & & \multicolumn{1}{c}{$\begin{array}{c}\text { Conventional } \\
\text { (US) }\end{array}$} \\
& \multicolumn{1}{c}{$\begin{array}{c}\text { Multiply } \\
\text { (U) }\end{array}$} & \multicolumn{1}{c}{$\boldsymbol{B y}$} & \multicolumn{1}{c}{ To obtain } \\
\hline Exposure (activity of source) & becquerel (Bq) & $3.7 \times 10^{10}$ & curie (Ci) \\
Absorbed dose & gray (Gy) & 0.01 & rad (rad) \\
Biologically effective dose & sievert (Si) & 0.01 & rem (rem) \\
Intensity & coulomb/kg & $2.58 \times 10^{-4}$ & roentgen (R) \\
& in air & & \\
\hline
\end{tabular}


Publishing support provided by:

Denver Publishing Service Center

For more information concerning this publication, contact:

Pacific Southwest Regional Executive Office, USGS

3020 State University Drive East

Modoc Hall, Suite 3005

Sacramento, CA 95819-2632

Phone: 916-278-9551 